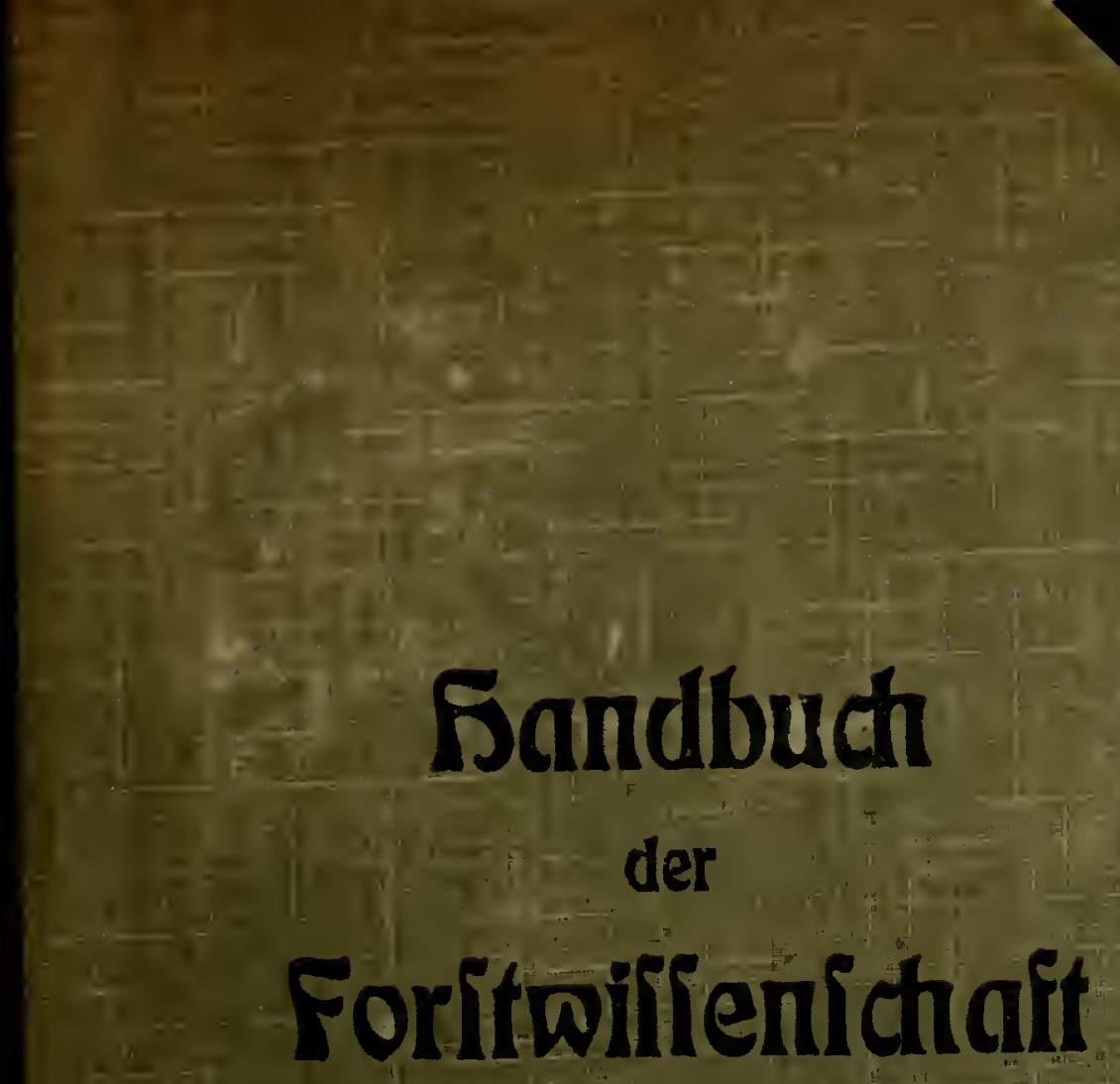


b. E. Hiley

felern of freatiny.

1q21. $\quad x+\infty$. 
THIS BOOK BELONGED TO WILFRID E. WILEY 

Digitized by the Internet Archive in 2009 with funding from

NCSU Libraries 


\section{Fandbuch der Forstwissenschait}

begründet von Professor Dr. Cuisco Lorey

Drifte, verbesserte und erweiterte Huflage

in Verbindung mit

Proieilor Dr. F. von B a u e r in Wien (Ausgabe B) - Profelfor R. B e dz in Charandt - Profelior Dr.

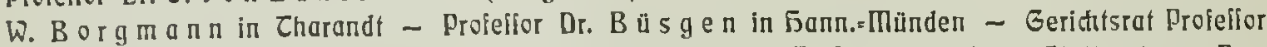
Dr. E. Didzel in Berlin (Ausgabe A) Foritamtmann Dr. D. Dieferidh in Stuftgart - Pro feifor Dr. K. E dz fi e i $n$ in Eberswalde Profefior Dr. In. Endres in Illüntien - Geh. Fofraf

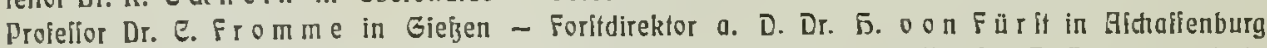
Eofrat Profefior Dr. G. Ritter Don Euttenberg in Wien - Profefior Dr. 5. 5 a us rath in Karlsruhe - Profelfor Dr. In. 5 elb i g in Karlsruhe - Foritmeilter Dr. G. F a nk a in Mariabrun - Geh. Eofrat Proielfor Dr. L. Kle i $\pi$ in Karlsruhe - Profelior Dr. U. In üller in Karlsruhe -

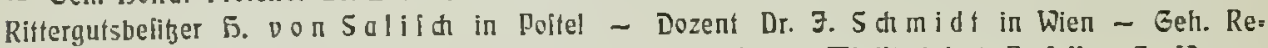
gierungsrat Profelior Dr. H. $S$ d wappad in Eberswalde - Minilterialrat Profeilor F. Wang in Wien - Regierungsdirektor Dr. L. Wappes in Speyer - Proiefior Dr. 5. We ber in Eiejen

herausgegeben von

\section{Dr. Christof Wagner,}

o. Professor der Forsfwissenschaft an der Universitāt Tübingen.

Jn vier $B$ änden.

\section{Zweiter Band.}

\section{Produktionslehre.}

Mit 49 gbbildungen im Zext und zwei farbigen Zaieln.

\section{Cübingen}

Verlag der 5. Laupp'ichen Buthandlung 


\section{Produktionslehre.}

In Verbindung mit

R. Beck, 5. Fürit, F. Wang, G. Janka, V. Dieterith, 3. Sthmidt

herausgegebe $n$

von

Chrìstof Wagner.

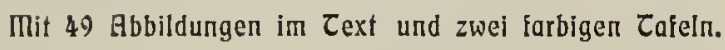

$\tau$ ü b i ng e r

Verlag der 5. Ls a u p p' itten Bucthandlung 1912. 
Copyright 1912 by H. Laupp'sche Buchhandlung, Tübingen. 


\title{
Inhaltsübersicht des zweiten Bandes
}

\author{
(Abschnitt VI-IX).
}

\section{W a Id b a u.}

\author{
Von
}

Tuisko Lorey.

Für die dritte Auflage bearbeitet von R. Beck.

Literatur

Einleitung: Begriff, Zwecke und Ziele, Hilfsfächer, Einteilung . . . 2

Erster Abschnit: Das Bestandesmaterial . . . 4

Holzarten

Valdbauliche Eigenschaften der Holzarten

J. Standortsans pr ü he.

A. Lage und lilima. Allgemeines Iílima; örtliches Kilima 5. Neereshöhe 7. Neigungsrichtung 7. Neigungswinkcl 8. Oberflächengestaltung 8.

B. Boden, insbes. physikalische Eigenschaften desselben 8. Feuchtiglieit 10. Gründigkeit 10. Bindigkeit 10.

I1. EntwickeIungs- und Vuchsverhältnisse des ein$z$ e ln en B a mes

Keimung 11. Wurzelsystem 11. HöhenentwickIung 12. Verhalten gegen Beschädigungen 13. Fruktifikation 13.

11I. Verhaltender Holzarten im Bestand

A. Einfluß der Holzarten auf den Boden

B. Verhalten der Holzarten unter einander. Gemischte Bestände Allgemeines 19. Allgemeine Regeln für die Anlage gemischter Bestände 22. Spezielle Regeln 24. (Schattenhölzer untereinander 24. Schatten- und Lich thölzer 25. Lichthölzer untereinander 26.)

C. Holzartenwechsel Einführung ausländischer Holzarten 28.

IV. Wirtschaftliche Bedeutung der Holzarten. . Massen- und Werterzeugung 32. Arbeitsgelegenheit 35. Verhalten gegen den Standort 35. Wirtschaftseinrichtung 35 . Nebennutzungen 35. Widerstandsfăhigkeit gegen Gefahren 36 . besondere örtliche Anforderungen 36.

Zweiter Abschnitt: Die Betriebsarten . . . . . . 36

Vorbemerkungen der Grund formen

I. Uebersicht an Grundiormen

A. Hochwaldformen

Vorverjūngungsbetriebe: Plenterbetrieb 38 . Plenterschlagbetrieb 39 . Schirmschlagbetrieb 40 . Saumschlagbetrieb 40 . - Nachverjüngungsbetriebe: Kahlschlagbetrieb 41. Kahlschlag mit Randbesamung 41.

B. Ausschlagholzbetriebe

G. Nittelwaldbetrieb

11. Würdigung der Grund formen

Vorbenerkungen

A. Hochwald

Plenterbetrieb 45. Plenterschlagbetrieb 46. Schirmschlagbetrieb 47. Saumschlaghetrieb 47. Kahlschlagbetrieb 48. Kahlschlag mit Randbesamung 49. 
B. Ausschtagwald (Niederwald, Kopfhotzhetrieb, Schneitelholzbetrieb). C. Mtittelwald

Zweites liapitel: Modifikationen der Grundformen, Zw ischen-und Ueburgangsformen. Besondere Fan 11 e.

A. Hochwald (Femelartiger Hochwaldbetrieb, Ueberhattbetrieb, zweihiebiger Hochwałdbetrieb, Unterbau- und Lichtwuchsbetrieb)

B. Nieder- und Mittelwald

C. Haupt- und Nebennutzungsbetriebe (Waldfeldbau, Hackwaldwirtschaft)

Drittes kapitel: Betriebsumwand lungen

i. Atlgemeines

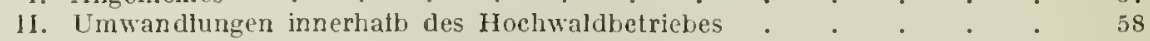

111. Hochwald in Nieder- oder Hittetwald

IV. Nieder-oder Mittetwald in Hochwald

Dritter Abschnitt: Die Bestandesbegründung . . . $\quad 61$

Erstes liapitel: At tgemeine Gesiehtspunkte . . . 61

1. Arten der Begründung und ihre wirtschaftliche Bedeutung . . . . 61

A. Arten

B. Waht der Art der Bestandesbegründung

C. Historisches

11. Reihenfotge der Iivituren

Z weites Kapitet: Natürliche Bestandesbegründung A. durch Samen

1. Isahlschtag mit Randbesamun

II. Mutterbäume auf der Verjüngungsftäche

Algemeines 68. Verjungung im Schirmsehlagbetrieh 71:

(Vorbereitungsstadium 71. Samenschlag 73. Austichtungs. stadium 74 ). Femelschlagbetrieb 75. Saumschlagbetrieb 77 . Femelbetrieb 78 .

B. Durch Ausschtag

I. Niederwatd

(Eichenniederwatd 80. Kastanienniederwatd, Robinienniederwatd 81. Erlenniederwatd, Weidenniederwatd 82)

II. Iiopfholzbetrieb

III. Schneitetholzbetrieb

Drittes Kapite t: Ii ün t tiche Bestan fluegründung. Vorbemerkungen, Arten der Begründung und Wahl zwischen Saat und Pftanzung Erster Te il: Herstellung eines kulturfähigen Watdbo dens. Urbarmachung

I. Behandlung von Sümpfen

11. Flugsand (Biunensand 90, Dünensand 91)

II. Basencisenstein und Ortstein

IV. Heideböden

V. Unfruchtbarer Humus

Vi. Moore

Z weiter Teil: Sa a t

I. Atlgemeines (A. Verschiedene Arten der Saat;

Bedeutung der Saatarten)

11. Das Saatmateriat

A. Beschaffung des Samens (Setbstgewinnung, Naturalabgabe)

B. Ernte und Aufbewahrung

C. Prüfung der Samengüte (Echtheit, Reinheit, Größe und Beschaffenheit, Keinzahl und Keimungsenergie, Keimprobe)

111. Das lieimbett .

Vorbemerkungen

Herstellung cines guten Lieimbettes (Entfernung eines hinderlichen Bodenüberzuges, Bodentockerung 110. Vollsaat 110. Stellenweise saat 111. Herbeischaffen von Iiliturerde)

1V. Die Aussaat
A. Saatzeit
B. Erforderliche Samenmenge
C. Beförderung der Keinung
D. Die einzelnen Saatmethoden
E. Unterbringen und Bedecken des Samens
F. Pflege der Saatkulturen 
Dritter Teil: P f l an zung

I. Allgemeines

A. Arten der Pflanzung

B. Wirtschaftliche Bedeutung

I1. Das Pflanzenmaterial
A. Erforderliche Eigenschaften
B. Arten der Pflanzenbeschaffung
C. Forstgartenbetrieb, insbes.:

1. Arten der Forstgärten 121. 2. Wahl des Platzes 122.

3. Bodenbearbeitung und Verbesserung 123. 4. Einteilung und innere Einriehtung 126. 5. Aussaat in Forstgarten 126. 6. PIlanzbeete im Forstgarten. Verschulen 127. 7. Sehutz und Pflege der Saat- und Pflanzbeete 129.

D. Pflanzenbeschaffung bei den einzelnen Holzarten

E. Ausheben, Beschneiden, Transport, Aufbewahren d. Pftanzen

III. Herrichtung der Küulturfläche

IV. Vollzug der Pflanzung

A. Pflanzzeit .

B. Herstellung geregelter Pflanzverbānde

C. Pflanzenmenge und Pflanzweite

D. Pllanzverfahren

Ballenpflanzen, ballenlose Pflanzen (gewöhnliche Hackpflanzungen, Spalt- oder Kilemmpflanzungen, Obenaufpftanzungen), Stecklinge, Setzstangen.

I. Schutz und Pllege der Pflanzkulturen

Viertes Kapite 1: Betriebsarten und Bestandesbegrändung beiden einzelnen Holzarten

I. L a u b o $1 \mathrm{z} e \mathrm{r}$

Buche 140. Eiche 143. Hornbaum 145. Esche, Ahorn, Ulme 146. Erle,

Linde, Birke 147. Robinie, Edelkastanie, Pappel, Weiden 148. Prunus-,

Pirus-, Sorbus-Arten, Unterhölzer 149.

II. $\mathrm{N}$ a de $l \mathrm{~h} \ddot{0} \mathrm{l} \mathrm{z}$ e

Tanne 149. Fichte 152. Kiefer 154. Sehwarzkiefer, Weymouthskiefer, Berg-, Pech- und Bankskiefer 156. Lärche 157.

IJ. Gemisehte $\mathrm{B}$ estände

Vierter Abschnitt: Die Bestandeserziehung . . . 158

Vorbemerkungen

Erstes Kípite l: A uszugshaungen Räumung von U eber* hältern

Zweites hapitel: Reinigungsthiebe (A usläuterungen)

I. Aushieb von Vorwüchsen

II. Ausjātungen (Auslāuterungen)

Drittes KapiteI: Durehforstungen

I. Begrilf

II. Zweek

III. Grundsătze bei der Ausführung

A. Beginn 169. B. Stürke des Eingriffes und Wiederholung 170 C. Besondere Arten 176. (Hecks freie Durchforstung, dänische Durchforstung, Hochdurchforstung, Tiulissendurchforstung, Borgmanns Lichtwuchsdurchforstung, Borggreves Plenterdurchforstung.)

IV. Durchfūhrung im Vlalce .
Veransehlagung, Holzauszeichnung, Hiebsführung

Viertes Kapitel: Unterbau und Liehtwuehsbetrieb. Vorbemerkungen

1. Unterbau insbesondere

A. Altgemeine Gesichtspunkte

B. Bedingende llomente (die zu unterbauende Holzart, die einzubringende Holzart, die spezielte Aufgabe des Unterstandes, der Boden, die Zeit des Unterbaues, Ausfuhrung)

C. Besondere Fälle des Unterbaues

II. Liehtungsbetrieh inshesondere
A. Allgemeine Gesichtspunkte
B. Bedingende Momente (der Bestand, der besondere Wirtsehaftszweek, Beginn, Maß der Lichtung, wiederholte Liclıtung, Unterbau) 
C. Spezielle Fälle des Lichtungsbetriebes 188 (der zweialterige Hochwald Burckhardts, der modifizierte Buchenhochwaldbetrieb von v. Seebach, die Homburgsche Nutzholzwirtsehaft, Wageners Lichtwuchsbetrieb, Mayrs Kleinbestandswald mit Erziehungsverjüngung, Vogls Lichtwuchsbetrieb)

D. Würdigung der Lichtungsbelriebe

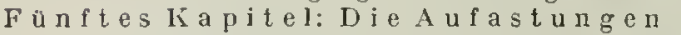

1. Zweck (Erziehung guter Nutzstämme, Förderung des Unterwuchses, Materialanfall)

II. Erfolg

A. Art der Ausführung (Ort der Abtrennung der Aeste, Instrumente, Ausführung, Behandlung der Wundfläche)

B. Zeit der Aufastung

C. Ausdehnung der Astung

D. Kosten

Sechstes Kapite l: Die Boden flege

Erhaltung des Bodens, Erhaltung der Bodenlockerheit, Erhaltung der Bodenfrisehe (1. Bewässerung, 2. Entwässerung), Erhaltung bezw. Verbesserung des Humusvorrates und des Nährstoffgehaltes (Forstdüngung) 197.

\section{For stsehutz.}

\section{Von}

\section{Hermann Fürst.}

Mit 2 farbigen Tafeln.

\section{Einleitung: Begriff, Begrenzung, Einteilung}

Erster Abschnitt: Gefährdung durch menschliche H a n d l u n ge n

1. Sicherung der Waldgrenzen, Vermarkung . . . . . . . . . 20.

2. Schutz der Waldprodukte, Forstfrevel und deren Verhütung . . . .

3. Waldbrände, Entstehung, Art des Auftretens, Vorbeugungsmaßregeln 209. Lösehung 210

4. Sehutz gegen Rauchschäden

Z weiter Abschnitt: Gefährdung durch die organisclue $\mathrm{Natur}$

1. G e fährdung durch Tierc. Bezeichnung dieser

A. S c häd li che $S$ ä ug e t i e re

a) Haustiere; Weidetiere 213. Schweine 216

b) Jagdbares Wild. Rotwild 216. Dam- und Rehwild 219. Schwarzwild 219. Hasen und Kaninchen 219

c) Die lileinen Nagetiere: Näuse 220. Eichhörnchen und Schläfer 221 .

B. Se hã d liche Vögel.

C. $S c h a ̈ d ~ l i c h e l n s e k t e n$. Die Forstinsekten im allgemeinen. Lebensweise 224. Verbreitung und Vermehrung 225. Die nützlichen Forstinsekten 226. Mittel der Abwehr 227. Größe des Schadens 228. Einteilung 228.

a) Nadelholz-lnsekten. Käfer. Die Borkenkäfer im allgemeinen. Vorbeugung und Vertilgung 231. Einteilung 232. Fichtenborkenkäfer 232. Kiefernborkenkäfer 234. Sechszähnige Fichtenborkenkäfer 234. Tannenborkenkäfer 234. Zweizälnige Kiefernborkenkäfer 235. Nutzholzborkenkäfer 235. İ̈iefernnırkkäfer 236. Sonstige Bastkäfer 238 Rüsselkåfer. Große braune Rüsselkãfer 239. Weißpunktierter Rüsselkăfer 242. Sonstige Rüsselkäfer 243

Maikäfer

$\mathrm{Sc} \mathrm{l} \mathrm{me} t \mathrm{t}$ e r l ing e. Kiefernspinner 246. Nonne 249. Föhren-

Eule 251. Föhrenspanner 252. Kieferntriebwiekler 253. Harzgallenwickler 254. Fichtenrindenwiclier 254. Fichtennestwickler 254. Lärchenmotte 255

Sonstige $s c h$ ä di clie $\ln s e k t e \dot{n}$. Kiefernblattwespe 255. Gespinstblattwespen 257. Maulwurfsgrille 257 
b) L a u h h I z - I n sekten. In f er. Laubholzborkenkäfer 258 . Bockkảfer 259. Russelkîfer 259. Praclıtkäfer 210. Blattkäfer 260. Spanische Fliege 261

S c h m e t t e rling e. Buclienspinner 261. Prozessionsspinner 262. Sonstige Spinner 263. Frostspanner 264. Eichenwickler 265

c) D c formita ten-Erze $\Perp \mathrm{ger}$. Auf Nadeholz 266. Auf Laubholz 266

2. Gefahrdung durch Ge wa chse

Forstunkrảuter. Auftreten, Nacisteile 267. Arten 268. Abwehr 268. Schmarotzergewäclise 269 .

Dritter Abschnitt: Gefährdung durch die anorganische $\mathrm{N}$ atur

a) Frost. Winterfrost, Frostreis 270. Spätfrost 271 . Frủhfrost 272 . Barfrost 272

b) $\mathrm{H}$ i $\mathrm{z}$ e. Wirkung, Vorbeugung 273 . Rindenbrand 274 . . . .

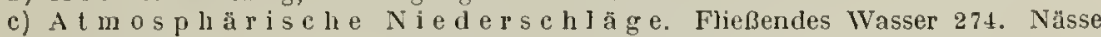
275. Schnee 276. Beschädigung und Vorbeugung 277. Duft und Rauhreif 278. Hagel 279

d) Blitzsch lag

e) Winde und $S$ t ürme. Scluaden durch diese 280. Größe der Gefahr 281. Vorbeugung 282. Loshiebe 282 . . . . . . . . . . . . . . . . . . . .

Vierter Abschnitt: Ir ankheiten der Holzgewächse Begriff, Ursachen 283. Wundfäule 284. Gipfeldürre 285. Schütte 286. Erkrankungen durch Pilze 287. Buchenkeimlingspilz 287. Eichenmehltau 288. Fichtennadelrost 288. Hallimasch 288. Wurzelschwamm 289. Eichenwurzeltöter 289. Löcherpilze 289. Lärchenkrebs 290. Tannenpilz 290. Kiefernbaumschwaunm 290

\title{
VIII. Die Wildbach- und Lawiuenverbauug.
}

\section{Von}

\section{Ferdinand Wang.}

\author{
Mit 41 Abbildungen.
}

\section{$\S 1$. Einleitung}

A. Die Wild bachverbaung

$\S$ 2. Die Charakteristik und Einteilung der Wildbäche

$\S$ 3. Die Einteilung des Bachverlaufes

\$ 4. Das Herkommen des Geschiebes

$\$ 5$. Die Ursachen der Wildbachverheerungen

$\S 6$. Die Systeme der Wildbachverbaunng

$\S$ 7. Die allgemeinen Regeln für den Bau und die Erhaltung der Wildbachverbauungen

§ 8. Die technischen Mittel der Wildbachverbaung

1. Die Querbauten a. Die Talsperren . b. Die Grundschwellen

2. Die Parallelbauten

3. Die Schalenbauten

4. Die Entwässerungsanlagen

5. Die Lehnenbindungen

6. Die Schuttkegelsicherungen

§ 9. Die Berasung und Aufforstung

$\S 10$. Die besonderen Verbauungssysteme

1. Das System nach Jenny

2. Das System nach Sclindter.

3. Das Regulierungssystem nach Wolf

4. Das System nach Seeling

5. Das System nach Serrazanetti

$\$$ 11. Die wirtschaftlichen Maßrahmen. 
$\cdot 333$

$\S$ 14. Mittel zum Abbaue der Lawinen im Anbruchgebiete . . . . . . . . 333

1. Allgemeines

2. Die Verpfāhlungen

\$ 15. Die Lawinenbauten, die eine Ableituing der Lawinen bezwecken oder ausschließ. lich zum Schutze einzelner Objekte errichtet werden . . . . . 340

\$16. Die Lawinenstatistik . . . . . . . . . . . . . . . $\quad . \quad 311$

\section{Die Forstbenutzung.}

\section{A. Die technischen Eigenschaften der Hölzer.}

Von

\section{Wilhelm Franz Exner.}

Fūr die 3. Auflage bearbeitet von G. J a $\mathrm{n} \mathrm{k}$ a.

Mit 3 Abbildungen.

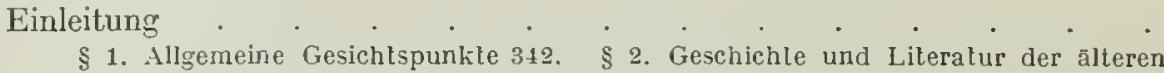
Holzuntersuchungen 343. \$ 3. Holzuntersuchungen von $\mathrm{Ch}$ e va $\mathrm{n}$ d $\mathrm{i}$ er und We r the im 348. § 1 . Holzuntersuchungen von Dr. H. N ör d linger 350. $\S 5$. Holzuntersuchungen des letzten halben Jahrhunderts 351 . \& 6. Holzuntersuchungen in technologischer, botanischer und anatomischer Richtung 353 . \$ 7 . Vorbemerkungen zu den technischen Holzuntersuchungen 356. § 8. Gliederung des Stoffes 356.

I. A eu $B$ ere Ersehe in ung

1. $\S$ 9. Farbe des Holzes

2. \$10. Glanz des Holzes

3. $\S 11$. Feinheit

4. § 12. Textur, Zeichnung, Flader, Maser :

5. $\S 13$. Geruch des Holzes

II. I a terieller Zustand des Holzos

$\$$ 14. Substanz des Holzes nach den physikalischen Eigenschaften 370.

1. $\$ 15$. Dichte oder spezifisches Gewicht (Raungewicht) des Holzes

2. $\$$ 16. Der Wassergehalt

3. $\$ 1$. Volumsveränderlichkeil

4. § 18. Folgen der Hygroskopizität und Volumsveränderlichkeit

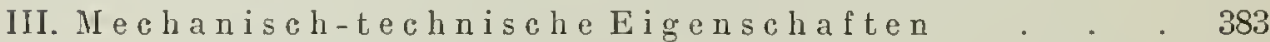

1. § 19. Elastizität und Festigkeit

$\S 20$. Definitionen der Elastizitāts- und Festigkeitslehre 384. $\S 21$. Die verschiedenen Arten der Elastizitāt und Festigkeit 385. \$ 22. Formeln zur Berechnung der Elastizitāts- und Festigkeitskoeffizienten 386. § 23. MaterialPrüfungsmaschinen 387. \$ 24. Allgemeiner inlernationaler Arbeitsplan für Holzuntersuchungen 359. \$25. Uebersicht der neueren Holzuntersuchungen 391. \$ 26. Versuchsresultate von $\mathrm{M} \mathrm{i} \mathrm{k} \mathrm{o} \mathrm{l} \mathrm{a} \mathrm{s} \mathrm{c} \mathrm{h} \mathrm{e} \mathrm{k} 391 . \$ 27$. Versuchsresultate von $\mathrm{J}$ e $\mathrm{n} \mathrm{n}$ y 395 . \$ 28 . Versuchsresultate über Rotbuchenholz von $\mathbf{E} \mathrm{x} \mathbf{n}$ e r 397. § 29. Versuchsresultate über Ailanthusholz von $L$ a u b a c c k 399. $\S 30$. Versuchsresultate über den Einfluß der Fällungszeit auf die Dauer des Fichtenholzes von E. $\mathrm{Har}$ ig 400 . \$ 31. Versuchsresultate von $\mathrm{T}$ e $\mathrm{t}$ m a jer 402. \$ 32. Versuchsresultate über den Einfluß des Standortes und der Fāllzeit auf die Elaslizität und Fesligkeit des Fichten- und Fiefernholzes von $\mathrm{B}$ a us ching e r 407. § 33. Versuchsresultate ūber die Veränderung der Festigkeit des Nadelholzes nach dem Fällen von B a u ching e r 411. $\S 34$. Versuchsresultate über die Elastizität und Festigkeit verschiedener Nadelhölzer von $\mathrm{B}$ a u s c h ing e r 112. § 35. Veısuchsresultate von $\mathrm{R} u \mathrm{del}$ of f 414. § 36. Versuchsresultate von $\mathrm{S} \mathrm{h} \mathrm{h} \mathrm{a} \mathrm{p} \mathrm{p} \mathrm{a} \mathrm{c} \mathrm{h} \mathrm{416.} \mathrm{§} 37$. Versuchsresultate über die Elastizităt und Festigheit des Fichtenholzes von $\mathrm{J}$ a $\mathrm{n}$ k a 418 . $\S 38$. Untersuchungen über die Qualität des Eschenholzes von J a n k a 425 . $\S 39$. Untersuchungen ūber die Druckfestigkeit von im Wasser ausgelaugten Hölzern von $\mathrm{J}$ a $\mathrm{n}$ k a 427 . 
2. $\$ 40$. Biegsamkeit und Zähigkeit

$\S$ 41. Bestimmung der Biegsamkeit, Zähigkeit und Sprōdigkeit und Brucherscheinungen bei der Biegeprobe 429.

3. $\$ 42$. Warnfähigheit 431. \$ 43. Erfahrungen uber Zähiglieit des Holzes 432.

4. $\$ 44$. Spaltbarkeit

5. $\$ 45$. Härte des Holzes

$\mathrm{Sch}$ I $\mathrm{u}$ b e merku $\mathrm{ng}$

\section{B. Die Hauptnutzung.}

(Ernte, Verwertung und Aufbewahrung von Holzund Rinde.)

$$
\text { Von }
$$

\section{Hermann Stoetzer.}

Fūr die 3. Auflage bearbeitet von C. Wa $g$ ne $r$.

Ilit 5 Abbildungen.

\section{Einleitung}

I. Verwendung des Holzes und der Rinde (\$ I-15).

Nutzholz und Brennholz, Verwendungsarten des Nutzholzes 445 . Bauholz 445 . Holzarten des Hochbaus 44. Buche als Bauholz 449. Schiffsbauholz 450. Grubenholz 452. Erd-, Brücken- und Wasserbau 454. Spaltholz 458. Verwendung in Schreinerei, Glaser- und Wagnergewerbe 460. Schnitzerei und Spielwarenfabrikation 463. Papierfabrikation 463. Holzverbrauch in der Landwirtschaft 465. Brennholz 466 . Holzverwendung nach Holzarten und Sortimenten 467 . Vermendung der Rinde 469 . Eichenschälbetrieb 470 .

II. Gewinnung des Holzes und der Rinde ( $16-21)$.

Der Făllungsplan 472. Die Fâllungszeit 473. Art des Holzhauereibetriebs und Anweisung der Holzhauer 475. Der Fällungsbetrieb 478. (Rodung 478. Rodewerkzeuge 479. Făllung mit Axt und Sāge 482. Konstruktion der Waldsägen 482. Fällaxt und Spaltaxt 484. Fallrichtung 485.) Ausformung und Sortierung der Hōlzer 486. Stackholzgewinnung 490. Nutzung der Rinde 492.

III. Verwertung der Fällungsergebnisse (\$22-26)

Schlagaufnahme 496. Numerierung 497. IKubierung 498. Verkaufsarten 500. Bildung von Holztaxen j03. Ausführung der Forstproduktenverkāufe 50خ. Befōrderung des Holzabsatzes 510 .

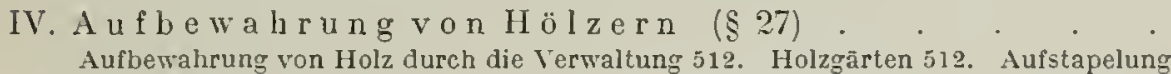
Aufbewahrung von
von Holzern 513 .

\section{Die Nebennutzungen im Walde.}

Von

\section{Viktor Dieterich.}

Einleitung

I. Die $N$ utzung der Nebenerzeugnissevom stehenden $\mathrm{Holz}$

1. Di e $\mathrm{B}$ a u m f $\mathrm{r} \tilde{\mathrm{c}} \mathrm{h} \mathrm{t}$ e (Holzsämereien).

a) Die ökonomischen Gesichtspunkte

b) Die Technik der Samenernte usf. Die Ernte der Baumfruchte im allgemeinen j17. Die Gewinnung der Nadelholzsamen 520. Kilengergebnisse 523. Aufbewahrung der Holzsamen 524.

2. Sonstige Bestandteiledesstehenden Holzes 
3. Die Abfallstoffedes stehenden Holzes.

Raff- und Leseholz

Laub- und Nadelstreunutzung

Bedeutung und Wert der...528. Slalik der ...532. Maß und Art der zulässigen Nutzung 537.

II. Die Nutzung der Nebenerzeugnisse des WV I d bod ens

1. Diepflanzlichen Nebenerzeugnisse.

Allgemeines

Streustoffe (Moosstreu, Unkräuterstreu) .

Futterst offe (Grasnutzung, Waldweide)

Sonstige Gewäclıse (Seegras, Beeren und Pilze)

Der Waldfeldbau

2. Il ineralise he Nebennutzungen

\section{Forstlich-Chemische Technologie. \\ Von}

\section{Franz Schwackhöfer.}

Für die 3. Auflage bearbeitet von $J . S c h \mathrm{mid} t$.

I. Die chemische Zusammensetzung des Holzes, der Rindeund des liorkes, sowieder Gallen . . . 55?

a) $1 \mathrm{Holz}$ Chemischer Bestand desselben 552. Lignil 553. Zellulose, Eigenschaften, Umwandlungsprodukte derselben etc. 553. Holzsaft 556. Wassergehalt des Holzes 557. Organische Bestandteile des Holzsaftes 558. Mineralstoffe desselhen 560 .

b) Ri n d e ${ }^{\circ}$ Gerbrinden 562 . Findenbestandteile 563 .

c) Ko $\mathrm{rk}$ (Gewinnung, Eigenschaften und Verwendung) . . . . . . 56

d) Gallen und Iinoppern . . . . . . . . . . . . . 565

II. Konservierung des $\mathrm{Holzes}$. . . . . . . . . . . . 566

Allgemeines 566. Konservierungsmethoden 567. Das Trocknen 567. Das Auslaugen 569. Das Dämpfen 569. Die Umhällung 570. (Das Polieren 570. Der Anstrieh 570. Das Ankolılen 572.) Imprägnierungsmiltel 572. Imprägnierungsmethoden 576 . Sehlußbenerkungen zur Jmprägnierung 581.

III. Zellulose-und II olzstoff-Fabrikation

Allgemeines 582. Rohmaterial 583. Prozeduren der Zellulosefabrikation 583. Nalronverfahren 584. Sulfitverfahren 586. Elektrochemisches Verfahren 589. Abwässer der Zellulosefabrikation 589. Ausbeule, Beschaffenheit und Verwendung der Zellulose 591. Holzstoffgewinnung 592.

IV. Trockene Destillation des Holzes... . . Allgemeines 594. Verkohlungsmethoden 595. Meilerköhlerei 596. Beurteilung derselben 604. Verkohlung in Oefen 606. Verkohlung in Retorten 607. Produkte der Holzdestillalion 609. (Holzkohle 609. Holzessig 611. Holzteer 613.) Verkohlung von Holzabfällen 615 .

V. Holz als Heizinaterial

Allgeneines ubber den Heizwert der Brennmalerialien 616. Heizwert des Holzes im Vergleich mit den fossilen Brennstoffen 618 .

VI. Die Pottasche-Fabrikation

VII. Die Harze, deren Gewinnung und Verarbeitung Vorkommen, Entslehung und allgemeine Charakteristik der Harze 621. Harzgewinnung 624. (Allgemeines 624. Schwarzfören-Harzung 625. StrandkieferHarzung 627. Fichten-Harzung 628. Harzung nach Dr. Mayr 628. Lärchen-Harzung 629.) Verarbeitung der Harze 629. Harzprodukte 631. (Terpentino̊l 631. liolophoniuın 631. Brauerpech 631. Harzöle 632.)

$\mathrm{Sachregister} \mathrm{zum} \mathrm{II.} \mathrm{B} \mathrm{a} \mathrm{n} \mathrm{d}$ 


\title{
VI. \\ IV a l d b a u.
}

\author{
Von \\ Tuisko Lorey.
}

Für die 3. Auflage bearbeitet von $R$. B e ck.

Literalur: a) Das ganze Gebiet belandelnde Werke: Hartig, G. L., Anweisung zur Holzzucint für Förster, 1. Aufl. 1791, 7. Aufl. 1818. — C o t t a, H., Anweisung zun Waldbau, 1. Anfl. 1817, 9. Aufl. (ed. H. ․ Cotta) 1865. - P.f e il, Die deutsche Holzzucht, 1860. - G w i n e r, H. W., Der Waldbau, 1. Aufl. 1834, 4. Autl. (ed. Dengler) 1858. - St u m p f, C., Anleitung zum Waldbau, 1. Aufl. 1849, 4. Aufl. 1870. - H e yer, C., Der Waldbau, 1. Aufl. 1854, 5. Aufl. (ed. R. HeB) 2 Tle. 1906/09. - B u r e k h a r d, H., Säen und Pllanzen, 1. Aufl. 1855, 6. Aufl. (ed. A. Burckhardt) 1893. - G a y e r, İ́., Der Waldbau, 1. Aufl. 1880, 4. Aufl. 1898. - P e r o n a, Selvicoltura, 1880. - F is c h b a c h, Praktische Forstwirtschaft 1880. - Wa g e $\mathrm{c} r$, G., Der Waldbau und seine Foribildung, 1884. - N e y, C., Die Lehre vom Waldbau, 1885. - B o r g greve, B., Die IJolzzucht, 1. Aufl. 1885, 2. Aufl. 1891. - We i s e, W., Leilfaden für den Waldbau, 1. Aufl. 1888, 3. Aufl. 1903. - M a y r, H., Waldbau auf naturgesetzlicher Grundlage, 1909. - D i t t m a r, Waldbau, 1910. - Schli c h. W., Sylviculture, 3. ed. 1904. - W a g n e r, C., Die Grundlagen der räumlichen Ordnung im Walde, Tübingen 1907, 2. Aufl. 1911. - b) S p e z a l s c li r if$t$ e n, u. a.: H $\mathrm{H}$ y e r, G., Verhalten der Waldbäume gegen Liclıt und Schatten, 1852. - H e $B$, R., Eigenschaften und Verhalten der Holzarten, 1. Aufl. 1883, 3. Aufl. 1905. - B e il, A., Forsiwirlschaftl. Kulturwerkzeuge, 1846. - J äge r, J. P. E. L., Das Forstkulturwesen, 1. Aull. 1850, 3. Aufl. 1874. - v. B u t t l a r, R., Forstkultur-Verfahren, 1853. - v. Ml a nt e 1 f $f$ el, 1I. E., Hügelpflanzung der Laub- und Nadelhōlzer, 1. Aufl. 1855, 3. Aufl. 1865. -. A le m a n n, F. A., Ueber Forstkulturwesen, 1. Aufl. 1851, 3. Aufl. 1881. - U r f Leber Forsthulturen, 1885. - F ü r st, H. Die Pflanzenzucht im Walde, 1882, 4. Aufl. 1907. - Homburg, Die Nulzholzwirtschaft in geregelten Hochwald-Ueberhaltbetrieb, 1878, 2. Aufl. 1890. - B r ün jng s, Der Anbau der Hochmoore, 1881. — Fürst, H., I'länterwald oder scblagweiser Hochwald, 1885. - G a y e r, K. Der gemischte Wald, 1886. - Ir r a he, Rationelle Rorhweidenkultur, 5. Aut. 1897. - B r e c h e r, Aus dem Auen-Mittelwalde, 1886. - Ii r a I t, G., Beitrāge zur Lehre von den Durchforstungen, Schlagstellungen und Liclitungslicten, 1884. - D e rsel b e, Beiträge zur Durchforstungs- und Lichtungsfrage, 1889. IF a u $\mathbf{s}$ c h, Beiträge zur Frage der WeiBtannenwirtschaft, 1895. - H a m ni, T., Der AusEchlagwald, 1896. - B o d e n, Die Lārche, 1899. — G e r h a r d t, P., Handbueli des deut. schen Dünenbaus, 1900. - $\mathrm{S} \mathrm{ch} \mathrm{w}$ a p a c b, A., Anbauversuche mil fremdländischen Holzarten, 1901. - B o o th J., Die Einführung ausländischer Holzarten in Preußen, 1903. Ml a y, H., Fremdländische Wald- und Parkbäume für Europa, 1906. - G o d bersen, Kiefer, 1904. - Ke r n, E., Erfalirungen in liorbweidenbau, 1904. - J a n k w $\mathrm{k}$ y, R., Begründung naturgemăßer Hochwaldbestande, 3. Aufl. 1904. - F r o m bling, C., Buchenhachwaldbetritb, 1908. - E r d m a n n, l:, Die Heideaufrorslung, 1904. - R e u B, H., Die forstliche Bestandsbegründung, 1907. - I e $\mathrm{tz}$ g e $r$, Dänisclie Geräte zur Bodenbearbeitung, 1906 und 1908 . - G. K. S p il z e n b e r g, Die Spitzenberg'sehen Iiullurinstrumente, 2. . Iufl. 1898. - C. R. H e ck, Freie Durchforstung, 1904. - M i c li a elis, Gute Bestandspllege und Starhholzzucht, 190\%. - D ü e s b e r g, R., Der Wald als Erzieher, 1910.

Handb. d. Forstwiss. 3. Auf. II. 


\section{Einleitung: Begriff, Zwecke und Ziele, Hilfsfächer, Einteilung.}

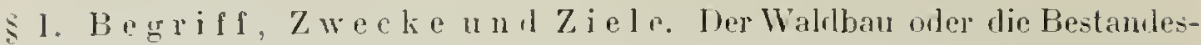
zucht befabt sich nit der Begründung und Erzielıung der Bestände. Alle walrlbaulichen Jaßnalunen lrezwecken die Schaffung von solchen Ilolzbeständen, welche rlen Wirtschaftszweek möglichst vollkommen entsprechen. I'iesen bezeichnet der Waldbesitzer, sein Wille ist maßgebend; in der Regel wird tunlichst hoher Wert der Holzbestände ancrestrebt, gegeben in der Ertragsleislung. Der Wert und damit das Ziel rer Wirtschaft kann dabei in verschiedener Weise bestimmt werden, nämlich entweder als absolut lı̈̈lıstmöglicher Ernteertrag auf gegebener Waldborlenfläclıe uder als relativ, d. l., in Vergleich zu dem Aufwanıl, höchst nö̈gliche Prorluktionsleistung. Welcher Gesichtspunkt maßgebend sein soll, ist von Fall zu Fall zu bestimmen. Im allgeneinen ist die hör hste Rentabilität das Ziel jeder rationellen Wirtschaft; jene zu lomessen, ist Saehe der forstlichen statik. Da der Ertrag und somit jede Entscleidung, welehe die Statik treffen kann, in erster Linie vom Preise der Proululite abhängt, so rlarf im Wirtschaftswalde unter allon Lmstänrlen nur marktfälige Ware erzogen werden.

Von anderen als wirlschaflichen Wicten wird hier abgeschen, weil die Fälle, in welchen stchr, wie z. 13. Gewährung ästletischer (ientuses. (Parkanlagen elc.), erstrebt werden, doch nur als Ausnahmen zu betrachten sind. Von besonderen waldbanlichen Forkelnrungen aus Rückichten les Schutzes (Ǩlima, Boden etc.) wird gelegentljel die Retle sein. - Die Definierung des Waldbaus als "Forstproduktenzucht" (C. IIeyer) oder "Holzzucht" (G. L. 1lartig,

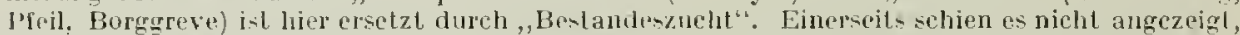
lie Aufgale los Waldbaus auf die Anzucht sĭmtlichrr Jebennulzungen, insbesondere derjenigen au-zudıhnen, welele, wie Wild, Torf, Wiesengras, lantwirtsehaftiche Gewächse unw., nicht Teile des Bestandes sind, währent ander'rseits dip Jeschränkung auf daa Hotz einte zu enge Lingrenzung darslelt, da solehe Nebinnutzungen, welcle, wie Lohrinde, Futterlaub, Ma-i, event. Gras auf Mähplatten usw., an die betreffenden Bestände gebunden sinel, dann in Wathlban cine slelle finden sollten, wenn sie irgendwclche besondere, die Bestande-begrünlung vter -erzielıung beeinflusende wirtschaftliche Vorkeluungen veranlamen.

In der Waldbaulehre sind alle Operationen vorzutragen, welehe, je nacl Lage ler lomkreten l’mstände, zum Ziel führen können; labei sind die allgemeinen Grünıle, welche für oder gegen die einzelnen Möglichkeiten sprechen, zu entwickeln. Der waldlaulichen Praxis bleibt es dann überlassen, unter den jeweils gegebenen besonderen Verhältnissen zur Errejchung des erstrebten Zieles aus der Zalı] der möglichen Wege denjenigen auszuwällen, welcher in bezug auf clie Faktoren: liaschheit und Sirherieit des Erfolgs und liostenaufwand die günstigste liombination darbietet. Die Morlifikationen dor dem Waldbau gestellten Aufgahen unıl der zu ihurer Lösung verfügharen llittel sind änßerst mannigfaltig. Dieser Vielgestaltigkeit der Fälle gegenüber gibt es keine unberlingt liesten waldbaulichen MaBregeln, sondern jede der letzteren kann unter bestimnt ungrenzten Voraussetzungen ilure Berechtigung haben. WVas an cinen Orte lewälırt jst, kamn unter veränderten Berlingungen an einem andern Orte weniger gut, ja sclilerht sein und darum durrh eine abweichende Behandlung ersetzt werden müssen. Jie fast unbescluänkte Vielleit der Verschiebungen, welche sirlı in dem Zusammenwirken der hei der Benrteilung der Fälle hauptsärhlich entscheilemlen Elemente, wie Standort, Ilolzart, Alsatzverlältnisse usw. ergeben, schließt die einseitige Bevorzugung einer bestimmten Richtung von vornherein aus. Man kann die \%ahl „lè als wirtschaftlich berechtigh anzuerkennenden Möglichlieiten verlkemem, dinf jedocl niemals so weit gelien, dals in dem derart verengerten lialumen niclit melı alle in Walde wirklirh vorkonmenden Fälle Platz finden.

Verbietrt nun auch jene Mannigfaltiglinit ire Imstände die strikte Anwendundr jeder Schablone in Wablbau, so müssen doeh, wic sehon uben angerleutet wurde, 
gewise, allgemein leitende Ziele für die forstliche Produktion anfgestellt werden. Ausgangspunlit für alle Erwägung ist hierbei zunächst der Standort. Durch diesen ist - wenn man von absolut hesten Böılen und Lagen absieht, welche auch kaum je in großer Ausdelumugg dem Forstwirtschaftsbetrieb überwiesen sind - immer nur eiue beschüülite Reilıe von waldbalulichen Möglichkeiten bedingt, unter denen man 211 willlen hat. Die Entscheidung wird dureh die im übrigen zu beachtenden Monente (Wert der Produlite, Absatzgelegenheit, Gewähung gewisser Nebenuutzungen, Arbeitsgelegenheit usw.) begründet. So kann z. B. für viele Standorte als waldbaulicl nöglich, bezw. nit gleicher Aussicht auf Erfolg ausführbar, die Anzucht der Buche mit eingesprengten Eichen, Eschen, Ahornen und andererseits etwa der Fichte oder Tanne, beides unter mehrfacher Mlodifikation bezüglich des Verfalırens in einzelneı (Art der Bestandsbegründung, des Durchforstungsbetriebs usw.) in Frage kommen. Die Entscheidung liegt dann auBerlatb des Waldbaus. Der letztere zeigt, zunächst unabhängig von anderen Rücksichten, wie man auf einer Waldbodenfläclıe, eventuell in verschiedener Weise, Bestände schaffen liann. Auf Grund statischer Untersu- Lungen, welche alle konkurrierenden Momente, insbesondere anch die volkswirtschaftlichen, bei der Begutachtung einbeziehen müssen, erhalten dann die waldbaulichen Operationen jeweils ein örtlich und zeitlich morlifiziertes Gejräge. Je nachdem der spezielle Wirtschaftszweck ein verschiedener ist, erstehen in der Folge, Inrch die Kunst des Wirtschafters, auch unter gleichen äußeren Berlingungen ganz verschiedene Bestandesbilder.

Daß alles, was erreicht werden soll, mit möglichst geringen Aufwand erreicht werde, ist oberster Wirtschaftsgrundsatz. Daraus folgt, daß nicht nur die direliten Ausgaben, natürlich immer unter der Voraussetzung eines genügenden Erfolgs, auf ein geringstes Maß beschränkt werden müssen, sondern namentlieh auch, daß an Zeit möglichst zu sparen ist. Jede Abliüzung der Untriebszeit ist im allgemeinen ein Gewinn in dem Sinne, daß alle wirtschaftlichen Maßnahmen, welche uns ohne unverItältnismäßige liostenmehrung gestatten, die erforderliche Ilenge an Produkten von hestinmer Beschaffenheit (z. B. Nutzholzstämme einer gewissen Stärke) in k ü rz est er Zeit zu erziehen, vor anderen den Vorzug verdienen, un so mehr, als daIureh auch die für das Einzeljahr des Untriebs verfügbare Fläche entsprechend größer ausfällt.

Das Bestreben, den Produktionsaufwand in ganzen und im einzelnen tunlichst herabzumindern, schließt überdies auclı die Forderung sorgfältigster Schonung des Bodenkapitals ein. Unsere waldbauliche Arbeit muB die Erhaltung und womöglich Melurung derjenigen Eigenschaften des Bodens, von welchen dessen Leistungsfähiglieit abhängt, gewährleisten. In dieser Erwägung bietet sich für die Beurteilung der einzelnen wirtschaftichen Operationen sowie ganzer Betriebsarten em bisher nicht lierührter, überaus wichtiger Maßstab dar: die Nachhaltigkeit der Waldwirtsehaft ist wesentlich davon abhängig, daß der einzelne Bestand keinenfalls mehr als die Zinsen des Bodenkapitals, nicht aber Teile des letzteren selbst für sich heansprucht. Ja man sieht sich sehr häufig vor die Aufgabe gestellt, vor allem eine Besserung des Budenproduktionsvermögens durch richtig gewähIte und durchgefülırte waldbauliche Operationen zu bewirken, auch wenu dadurch unter Unständen erhebliche Ausgaben veranlaßt werden. Immerhin ist die Bodenpflege stets nur Vittel zum Zweck, und Aufwendungen in dieser Richtung sind nur so lange zu rechtfertigen, als sie sich in den höheren Wert der demnärhst und in der Zukunft erwachsenden Bestände belohut marhen.

\$. 2. H ilfs fä $\mathrm{cl}$ e r, Einteilung: Diejenigen Disziplinen, deren Kenntnis 
der Waldbau voraussetzen muß, dic also füglich als Hilfsfächer desselben bezcichnet werden kömmen, sind Standortslehre, bezw. Bodenkunde und Kilinatologie, sowie die Forstbotanik, einseliließlich Physiologie und Biologic der Holzgewächse.

Das Gesantgebiet des Waldbaus läßt sich folgendermaßen einteilen:

I. Das Bestandesnaterial; H. die Betricbsarten: H1. die Bestandesbegründung; IV. die Bestandeserziehung.

\section{Erster Abschnitt.}

\section{Das Bestaudesuaterial.}

\$3. In diesem Abselnnitte ist im wesentlichen die Wahl der gecignetsten Holzart zu besprechen und danit eine wichtige Vorfrage für alle waldbanliche Tätigkeit zu erledigen.

Die waldbaulich wichtigeren Holzarten sind:

a) L a u b h ölzer: Rotbuche, Fagus silvatica, - Stieleiche, Quercus pedunculata, - Traubeneiche, Quercus sessiliflora, - Roteiche, Quercus rubra, Kastanie, Castanea resca, - Irainbuche (Weißbuche, Hagebuche, Hornbaum), Carpinus betulus, - Rüster, Rusche oder Ulme, Ulmus (effusa, campestris und montana), - Esche, Fraxinus excelsior, - WeiBesche, Fraxinus alba, - Ahorn, Acer (pseudoplatanus, platanoides, campestre), - Erle, Alnus (glutinosa, incana, viridis), - Birke, Betula (verrucosa, pubescens), - Sorbns-Arten, z. B. die Vogelbeere, S. aucuparia; Elsbeere, S. torminalis; Mehlbeere, S. Aria, - Linde. Tilia (jrarvifolia und grandifolia), - Falsche Akazie, Robinia Pseudacacia, - Zitterpappel (Aspe), Populus tremula, und sonstige Pappeln, wie P. alba, nigra, canadensis, - Weide. Salix (caprea, fragilis, anygdalina, acutifolia, alba, viminalis, daphnoides, purpurea), - WalnuB, Juglans (nigra, cinerea), - Hickory, Carya alba.

b) Nadellö̈lzer: Weißtanne (Edeltanne), Abies pectinata, - Fichte, Picea excelsa, - Sitkafichte, Picea sitchensis, - Weißfichte, Picea alba, - Stechfichte, Picea pungens, - gemeine Kiefer (Föhre, Forle, Forche). Pinus silvestris, - Schwarzkiefer, Pinus Laricio austriaca (syn. nigricans) und Pin. Laricio Poiretiana (syn. corsicana), - Berghiefer (Legföhre), Pinus montana, - Zürbelkiefer (Arve), Pinus Cembra, - Weymouthskiefer. Pinms Strobus, - Bankshiefer, Pinus Banlisiana, -- Pechliefer, Pinus rigida, - Lärche, Larix enropaea, - Japanische Lärche, Larix leptolepis, - Douglasie, Psendotsuga donglasii, und Ps. glauca, - Lawsonszypresse, Chamaecyparis Lawsoniana, - Riesenlebensbaum, Thuja gigantra.

Bestimmend lei der Wahl der Ilolzart sind die wa l d b a u lic he n E i ge uschaften. sowie die wirtschaftliche Bede ut ung der einzelnen Art.

II aldbaulicite Eigenselıaften der Holzar ten.

Sie komnen zun Ausdruck in ren Standortsansprüchen. in den Entwicklungsund Wuchsverhälnisen des einzelnen Baumes und in Verhalten der llolzart im Bestant.

$$
\text { l. standortsansurüelıe. }
$$

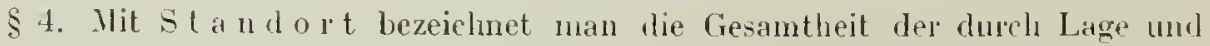
Boden bedingten Einwirkungen, unter denen eine Iolzart lebt. Die Beziehungrn in einzelnen, welche zwischen Standort und Holzart bestehen, sind in diesen Handbuche im wesentlichen in der Standortslehre, sowie zum Teil in der Forstbotanik (s. dort) erörtert. Es handelt sich dabei hinsichtlich del Lage un die allgente ine geographische Lage, suwie num die dureh Jecreshöhe. Yeigungarichtung und Neigungswinkel, 
Budenausformung und L̇mgebung des Waldortes näher unschrichene ö $\mathrm{r}$ t $\mathrm{i}$ c h e Lage. Der Boden wird durch seine Nährliraft, l. L. durch seine chenisehe Zusammensetzung und weiterhin durh seine plysikalischen Eigenschaften nach Wert und Gïte bestimmt.

Vom Standpunkte des Waldbaues aus möclite in Ergänzung der vorausgehenden Abschnitte Standortslelire und Forstbotanik des Handbuchs auf folgendes noch besonders hingewiesen werden.

\section{A. Lage und Klima.}

5. Das Entscheidende für die Existenz von Baum und Wald ist die in ihren Hauptzügen von der geographiselien Breite und Länge, von der Heereshöhe und von der Entfernung zum Meere näher bestimmte Lage, und zwar nicht deshalb, weil hin und wieder auch die Bodeneigenschaften mittelbar oder unmittelbar von ilır beeinflußt werden, sondern weil von ilır die das Pflanzenleben in erster Linie bedingenJen klimatischen Verhältnisse abhängen. Der Boden kommt, sofern es sich nicht nuı Börlen handelt, die aus geognostisehen oder anderen Gründen an der unteren Grenze der Ertragsfähigkeit stehen, erst in zweiter Linie, namentlich bei Kilinagleichleit, als bestimmender Falitor in Betracht.

So erkiärt es sich, daß manche Holzarten, eben weil sie an bestimmte Lagen, I. I. an bestimmte klimatische Verhältnisse gebunden sind, in Waldban eine weit weniger ausgedehnte Verwendung finden, als sie ihnen zugestanden werden könnte und wegen ihres wirtschaftlichen Wertes auch gern eingeräumt werden würde, wenn allein die Bodenansprüche maßgebend wären.

Die mit der Lage wechselnden, die Verteilung und Ausformung der Waldregiouen regelnden Klimafaktoren sind Wärme (mittlere Jahrestemperatur), Luftfeuchtigkeit, Niederschlagsmenge, sowie Länge und Intensität der Frostperiode (Eintreten des ersten und letzten Frostes, tiefster Kältegrad). Von ihnen hängen zunächst Dasein und Cliaraliter des Waldes, in gegebenen Waldgebiete aber auch der Erfolg der wirtschaftlichen Tätigkeit in Walde ab.

Wird als Maßstab für die IV ä $\mathrm{l}$ m e a $\mathrm{n}$ s p r ü c h e der Holzarten der Durchschnittswert der Hauptvegetationszeit unserer nördlichen Halbkugel, d. i. Mai bis August, benutzt, so ist nach II a y r eine Durelisehnittstemperatur (Viermonatstemperatur $=$ Tetratherme) von mindestens $10^{\circ}$ Bedingung für Ansiedelung und Entwicklung von Wald, d. h. von Bäumen, die höher als $8 \mathrm{~m}$ werden.

In bezug auf deı zweiten, füs die Waldbildung unbedingt notwendigen Faktor,

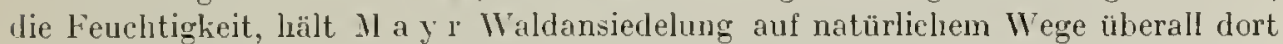
für ausgeschlossen, wo während der Ilauptvegetationszeit weniger als $50 \mathrm{~mm}$ Regen fallen, gleichgültig, ob der Feuchtigkeitsgehalt der Luft hier hoch oder niedrig ist. Die Luftfeuchtigkeit spielt erst in jenen Länderstrichen eine Rolle, wo während der 4 Sommermonate zwischen 50 und 100 mm Regen fallen, insofern hier Waldbildung unterbleibt, wenn die Luftfeuclıtigkeit wälı'end der Hauptvegetationszeit unter $50 \%$ lierabsinkt. In Gebieten mit ıelır als 100 mm Regen ninmıt der Einfluß der Luftfeuchtiglieit in dem Maße wieder ab, in dem die Niedersehlagsmenge zunimmt. Bei $70 \%$ Lufteuchtigkeit und $100 \mathrm{~mm}$ Regenmenge kann jede Holzart gedeihen; ein Mehr von Feuchtigheit sichert nur die natürliche und künstliche Verjüngung.

Je luftfeuchter und reiclıer an Niederschlägen ein Waldgebiet ist, un so müheloser und erfolgreicher sind alle unsere auf Verjüngung und Erziehung gerichteten waldbaulichen Maßnahmen. Feuchte Luft stumpft die extremen Tenueraturgrade ab und verringert damit die Frostgefahı, während ungekehrt trockne Luft zu rasche- 
rer Abkühlıng und größeren Temperaturschwantiungen linneigt. Das niederschlagsreiche und in bezug auf Lufteuchtigkeit gleichuäBigere Krüsten-orler insulare Kilima erleichtert cleshalh, sofern nicht der Wind hier als störender Faktor auftritt, die Waldbildung und Waldbehandlung weit mehr als das Inlandsklina mit seinen Extremen in Temperatur und Lufteuchtigkeit. Die gegen Frost und Dürre empfindlichen Holzarten gedeihen z. B. in Deutschland im Osten weniger gut als im Westen, weil Lufteuchtigheit und Wärme hier in westöstlicher Pichtung abnehmen. Je weiter der Einfluß der durch Winde von der See aus landeinwärts getragenen Feuchtigkeit reicht, um so günstiger gestalten sich die Verlältnisse für den Pflanzenwuchs im Innern der Kontinente. Sonst finden sich hier dem lïüstenklima analoge Verhältnisse nur in den mit Wald bedeckten Gebirgen, wo vermehrte Niederschläge und eine lionstante löhere Luftfeuchtigkeit der Waldbildung gleirl förterlich sind wie im Kïustengelände.

In ihrer Gesantheit bestimnen die klimatischen Standortsfaktoren das nach Norden bezw, oben von der Kältegrenze, nach Süden bezw, unten von der Wärmegrenze umschlossene natürliche Verbreitungsgebiet einer jeden Holzart. Je nach den Ansprüchen an das Klima gruppieren sich rlie Holzgewächse nach Gattung und Art. so zwar, daf gleichen Kilimazonen Bäume mit gleichen oder ähnlichen biologischen Eigenschaften entsprechen. Da mit der sürlicheren Lage der einzelnen Kilimazone die von ihr gebotene mittlere Wärmemenge zunimmt, sehen wir hier melır Baungattungen an der Waldbildung beteiligt als in den nördlicheren Zonen. Die Zalıl der Gattungen und Arten nimmt ron Süden nach Norden z.11 ab. Infolgedessen werden die Wahlbilder nach Norden zu einheitlicher und einfömiger, während der Süden Holzarten mit weiter auseinander liegenden Ansprüchen und fermeren verwandtschaftlichen Beziehungen zun Nebeneinanderleben hefähigt. Die in lıorizontaler Hinsicht, gewissermaßen im Grundriß, beim Durclwandern verschiedener Kilimazonen von Süden nach Norden benerkbare Erscheinung des Zurücktretens und allınähliehen Verschwindens der einzelnen wärmebedürftigeren Holzarten wielerholt sich im Kleinen, im Aufriß, beim Besteigen jedes löheren Gebirges. Die Walıltyen, die uns im Süulen in den löheren Erhebungen entgegentreten, finden wir in um so tieferen Lagen, schließlich in der Ebene, je melu wir uns nach Norden bewegen.

Nach der vom Kilima bedingten Anordnung der Baumarten unterscheidet 11 a y r 6 Waldzonen: rie tropische Zone (Palnetum), die sultropische der immergrünen Eichen und Lorbeerbänme (Lauretum), die gemäljigt warme des winterkahlen Laubwaldes in ilırer wärmeren und kühleren Hälfte (Castanetum und Fagetum), die gemäßigt külıle der Fichten. Tannen uml Lärchen (Picetum, Abictum oder Laricetum) und die külıle Zone der lírummlı̈̆zer und Halbbäume (Alpinetun oder Polaretun). Vom deutschen bezw. mitteleuropäischen Waldgeliete gehört der größte Teil dem Fagetum und iler Region der Nadellölzer an.

Es ist ohue weiteres hlar, daß die Einreihung einer jeden Holzart in die ihr zulommende Waluzone diejenige Grundlage für Anbau und Erzichung aller Ilolzarten ist, ohne deren Beachtung eine erfolgreiche Waldwirtschaft nicht denkbar ist. In= nerlaalb ihrer Waldzone und zwar im mittleren Teile ihres ursprünglichen natürlichen Verbreitungsgebietes muf die einzelne Holzart die ilu zusagendsten limatischen Verhältnisse und damit die Vorhedingungen zu höchsten Massen-und Wertsleishungen finden.

Sowoll in diesem Teile, dem klimatischen Optimum, wie überlaupt in gesanten natürlichen Verhreitungsgehiet einer Holzart sind nun aber die wichtigsten Kilimafaktoren: Wärme, Lufteuclıligkeit, Licht-Wind u. s. f. nicht überall gleiche. 


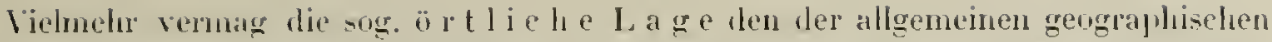
Lage eigentünlichen lilimacharakter wesentlich zu beeinflussen. Dies führt dann zum Entstehen eines auf gröBerem orler lieiuerem Gebiete herrschenden sog. ö r tlic lı e n If l i m as. Ind dieses wiederum hat zur Folge, daß ras Auftreten einer Ilolzart innerhalb ilures Verbreitungsgebietes kein einheitliches und gleichmäßiges ist, sondern um so verschiedenartiger sich gestaltet, je größer die ron der Gelämleausformung ges haffenen Lnterschiede in der Veereshöhe, der Exjositim, Mbdachung und Oberflächengestaltung der einzelnen Standorte simu.

1. Die Ule e eslı̈ he beeinflußt zunächst die Temperatur, die Feurhligkeit der Luft und die Niederschlagsmenge und fülurt in den höheren Lagen zu einer Verstärkung der dureh Frost, Schnee und Winde der Baunvegetation zugefügten Schäden. Diese schärligenden klimatischen Einflüsse werden in Forstsehutz (s. dort) näher besprochen. Hier sei nur ergänzend nochmals darauf hingewiesen, daß das verschiedene IVärmebedürfnis die Holzarten verantaßt, verschiedene Regrionen der absoluten Höle aufzusuchen. Daß die oleren Grenzen des Vorkommens der einzelnen Holzarten in den versehiedenen Gebirgen lierbei nicht immer die gleichen sind, sondern mehr oder weniger auffällige Versehiebungen in den Hölıenzonen derselben Holzarl vorkommen, wird angesichts der Versehiedenartigkeit in der llassenerhebung und Ausformung der Gelirge leicht verständlich.

In den oberen Regionen der höheren Gebirge ist eine geregelte Forstwirtscliaft nicht mehr möglich. Kälte, Schnee, Sturm und Abnahme der Feuchtigkeit verlindern hier die Bildung gesehlossener Bestände und halten den Baumwuehs melır und melı auf, sodaß schlieBlich nur Friech-und Krüppelformen den Wald an seine rertikale Grenze hegleiten.

2. Neigungsrichtung. Exposition, 1. H. Neigung eines Bodens gegen die Himmelsgegend. Da cet. par. der Einflul. der Sonne auf eine Waldbodenfläche durclı sie bedingt ist, so kommt die Verschiedenlıeit der Exposition zunächst in entsprechender Yersehiedenheit der Erwärmungsverhältnisse zum Ausdruck. Tatsächlich macht sich aber in den mittleren Höhenlagen der Unterschied der einzelnen Expositionen besonders hinsichtlich des Feuchtigkeitsgrades bemerklich. Infolge der direkten, intensiveren Erwärmmug durch die Sonne sind die Süd- und Südwestlagen in allgemeinen weniger feuclit als lie Nord-und Nordostseiten. Die Böden in ersteren sind trockener; die Jolzpflanzen werden überdies zu energiseherer Blattverdunstung gereizt, so daß diejenigen, welche in den genannten Beziehungen anspruchsvoller sind, von den süd- und Südwestlängen fern bleiben.

Recht emplindtich ist in dieser Hinsicht z. IB. die Weißtanne, welche gern die nördJichen und östlichen Lagen pinnimmi, wāhrend das tinsetzen der Exposition nacł Süd und West oft sofort durch das Aufteten der liefer charakterisiert ist ${ }^{1}$ ).

Die Bestandesverjüngung wird, sowohl was 1 ahl der Methode als auch Ausführung in einzehnen anlangt, durch die angedeuteten Wirkungen der Exposition oft wesentlich beeinflust; dazu kommt die Beziehung der Exposition zu Windgefahr, Schneedruck und Frost. In höheren Gebirgslagen muß bezüglieh des Gedeihens der Holzarten, von einer grewissen Grenze an, der meist gröferen Wärme der Sïd- und Westseiten das unmittelbar entselieidende Wort zugestanden werden, während feuchtere Luft, bedeutendere Nieder'schlagsmengen usw, dort den Faktor Feuchtigkeit in seiner Beziehung zur Exposition zurücktreten lassen. So kommt es, chals hier die nach Süden, Südwesten und Südosten geneigten (Sommer-)Hänge höher hinauf

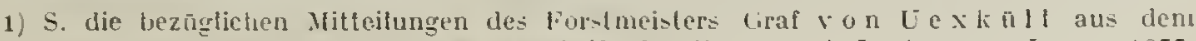

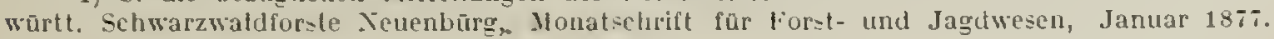


bewaldet sind als die nördlichen, nordöstlichen und nordwestlichen Expositionen (Winterhänge), die ihrerseits wieder in den Vor- und Mittelgebirgen bevorzugt welden. Im höheren Gebirge steigt die einzehne Holzart an den Südseiten unter Unständen 200 bis $500 \mathrm{~m}$ höher als an den Nordseiten.

3. Neigungswinkel, A b d a $\mathrm{c}$ h u ng, In k l i u a tion, d. h. Neigung des Bodens gegen die Horizontale. Im altgemeinen bilden, sofern ein gewisses Maß der Steilheit nicht überschritten wird, auch bedeutendere Neigungen kein Hindernis der Holzkultur, wenn auch Bestandesbegründung und -erziehung, sowie namentlich auch die Ernte und der Transport der Forstprodukte in steileren Lagen oft mit. erhöhten Sehwierigkeiten zu kämpfen haben. Stärker geneigte Hänge sind vielfach trockener und flachgründig, sind Bodenrutschungen ausgesetzt und bedingen dadurch häufig hesondere Aufmerksamkeit bei der IVahl der Betriebsart und der Verjüngungsmethorle. Andererseits treten V'ersumpfungen mehr in ebenen Lagen auf. Die Grenzen der landwirtschaftlichen Bodenbenutzung und der Waldwirtschaft sind an vielen Stellen hauptsächlich durch den Abdachungsgrad gezogen.

4. O berfla c he nges ta I t u n g: Dabei kommt in Betracht der durch die Bodenausformung im großen geschaffene orographische Charakter einer Gegend, sowie die verschiedenartige Gestaltung der Bodenoberfläche im einzelıen. In ersterer Beziehung ist besonders die Verteilung von Land und Wasser, sowje die Gebirgsbildung von Bedeutung: Massengebirge in Gegensatz zu Kettengel,irgen mit zahlreichen Einzelzügen, Anordnung der Täler, Wechsel der Expositionen, isolierte Bergkuppen, Hochplateaus usw. sind zu beachten. Innerhalb dieser, den Gesamtcharakter ausdrückenden Unterschiede, welche die waldbaulichen Vaßregeln oft ganz direkt beeinflussen (z. B. bei der Wahl der Holzart), treten dann bei der Beurteilung von Detailfragen die teihweise sehr greifbaren Verschiedenheiten im einzelnen in liraft, wie insbesondere das Vorkommen von Mulden, welche meist infolge größerer Feuehtigkeit und Tiefgründigkeit wesentlich hesseren Holzwuchs erzeugen, aber als Tieflagen auch zu Frösten Anlaß geben können, ferner von Steilıängen, flacheı Rücken usw. Die meisten dieser großen und kleinen Unterschiede in der Oberflächengestaltung werden auch insofern wichtig, als von ihnen der größere oder geringere Schutz eines Waldortes durch seine Ungebung abhängt. Es ist klar, wie der Verlauf der Höhenzüge, wie cinzelne Berge die Wirkung der Winde auf hinterliegendes Gelände modifizieren, wie die Sturmgefahr durch die lichtung der Täler und Höhen beeinflußt wird, wie größere Wasserflächen bei dem Auftreten von Frösten, Duftund Eisbruch mitwirken können. Zu allen solchen Unständen, die sich teils aus größerer Entfernung, teils aus der Nälıe fühlbar machen, tritt dann der Einfluß des unmittelbar benachbarten Geländes mit seiner Bestockung (vorliegende höhere Holzbestände oder Kahlfäche - junge Kultur, Wiese, Feld - in ihren Beziehungen zu Winden, Randverdämmung usw.).

\section{B. Boden, insbesondere physikalische Eigensehaften desselben.}

$\S 6$. Als solche gelten Feuchtigkeit, Gründigkeit und Bindigkeit.

Fast alle unsere Holzarten zeigen da das beste Gedeihen, wo keine jener Eigenschaften in einem ihuer Extreme vorhanden ist; weder Nässe, noch Trockenleit, weder Festigkeit noch Lockerheit kann, solıald rin bestimmtes Maß überschritten wird, als zuträglich bezeichnet werden. Hinsichtlich der Gründigkeit ist allerdings in allgemeinen nu das eine Extrem, die Flachgründigkeit einer freudigen Entwickehng oft hinderlich, während Tiefgründiggkeit nur in den seltenen Fällen eimmal nachteilig werden liann, wenn sie, - sej es, weil die atmosphärischen Niederschläge zu rasch in den 
Boden einsinken, sei es, weil ein Herauflringen des Grundwassers aus der Tiefe his zum Wurzelraum nicht mehr stattfindet, - 'Trockenheit zur Folge hat. Eine gewisse mittlere Beschaffenheit des Bodens ist also im großen und ganzen die zuträglichste und bietet, da sie fast alle Holzarten wenigstens zuläßt, in waldbauliclıer Bezichung dem Wirtschafter den weitesten Spielraum. Freilich zeigen nicht entfernt alle oder auch nur eine Mehrheit unserer Holzarten bei der nämlichen mittleren Bodenbeschaffenleit gleich gute Entwickelung; ihre Ans]rüche und demgemäß ihr Gedeihen sind mannigfach abgestuft. Ausgeschlossen aber ist auf diesen Böden mittlerer Eigenschaften im allgemeinen keine Holzart. In solchem Falle wird dan die Auswahl einer bestimmten Holzart wesentlich durch ihr Verhalten im Bestand, sowic durch ilıre wirtschaftliche Bedeutung bedingt, während ïberall, wo irgend welche Extreme der Bodenbeschaffenheit vorliegen, diese bei der Entscheidıng über die anzubauende Holzart in erster Linie maßgebend werden. Die Zahl der Möglichkeiten ist dann meist eine sehr beschränkte.

Es ist bekannt, daß und inwieweit der Humus geeignet ist, die physikalischen Eigenschaften des Bodens zu modifizieren, indem er zwischen den Extremen vermittelt, insbesondere einem lockeren Boden melı Bindigkeit, cinem festen größere Lockerheit gewährt, durch bedeutende Wasseraufnahme und wasserhaltencle liraft die Feuchtigheit reguliert, als schlechter Wärmeleiter ausgleichend wirkt und durch liohlensäure-Entwickelung den mineralischen Boden aufschließt. Als absolute Berlingung für die Waldvegetation kann er, sofern im übrigen der Boden die nötigen mineralischen Nährstoffe sowie die erforderlichen physikalischen Eigenschaften besitzt, nicht angesehen werden. Immerhin leuchtet ein, da $B$ die waldbauliche Tätigkeit auf ununterbrochene, reichliche Humusbildung abheben muß. Dabei handelt es sich aber durchaus nicht um Anhäufung größerer Streumassen, sondern vor allem um einen regelmäßigen normalen Fortgang der Streuzersetzung und der Nengung der Zersetzungsstoffe unit dem mineralischen Boden.

In einzelnen sind die Ansprüche der Holzarten an den Boden außerordentlich verschieden. Erwägt man überdies, daß auch für das Gedeihen einer b e s $t$ i m mt e n Holzart nicht ein durchweg gleichbleibendes $\triangle \mathrm{Ia}$ der verschiedenen Bodeneigenschaften gefordert wird, sondern, namentlich durch verschiedene Lage bedingte Schwankungen zulässig sind, so erhellt, daß eine Charakteristik der Holzarten nach ihren Bodenansprüchen nur ganz im allgemeinen und in großem Zuge mögliclı ist. Sie kann auch mehr nur in der Weise erfolgen, da $B$ die Grenze angedeutet wird, unter welche bezüglich der einzelnen Bodeneigenschaft nicht herunter-, bezw. über welche nicht hinaufgegangen werden dari, nicht aber kann man etwa innerhalb dieser Grenzen ein bestimmtes Maß als jeweilig absolut bestes bezeichnen. Dies ist schon durch die große Zahl zusammenwirkender Fahtoren ausgeschlossen. Es gilt hier das gleiche wie bei der vorerwälınten Lage. Die spezielle Einwirkung der einen oder der anderen Gruppe von Produktionsfaktoren läBt sich um so weniger leicht feststellen, als in vielen Fällen Lngunst der Lage durch vorteilhafte Bodenbeschaffenheit, wenn nicht ausgeglichen, so doch in ihrem ertragsmindernden Einfluß abgeschwächt wird. Zu beachten ist, daß aus dem tatsächlichen Vorkommen einer Holzart nicht ohne weiteres auf deren Wohlbefinden Schlüsse gezogen werden können. Anbaufähigkeit und Anbauwürdigkeit sind sehr zu unterscheiden; für jede Holzart gibt es eben ein Optimum ihres Vorkommens, an welches sich Zonen geringerer Leistung anschließen. Bei der Beurteilung des waldbaulichen Wertes einer Holzart entscheidet überhaupt das Verhalten der Holzart im B estand viel mehr als die Entwickelung des Einzelbaumes. Die besten Standorte werden natürlich zunächst von den begelırlichsten Holzarten in 
Beschlag genommen, so daß sich weniger anspruchsvolle vieffach mit greringeren Bö̀len und schlechteren Lagen begnügen müssen, obwohl auch sie gern an dem Genuß der hesseren Standorte teilnehmen würden (z, B. die gem. Kiefer).

\$7. I) Feuclutiglie it: Ausgehend von der überaus wichtigen liolle, welche den Wasser in der Pflanzen-Ernälırung zukommt, und von der daraus folgenden und durch die 'Tatsachen allseits bestärliten Ueberzeugung, daß jede Holzart unter sonst gleichen Verhältnissen auf frischem Boden besser gedeiht ats auf trockenem, muls man sorgsame Bodenpflege in Sinne der Wassererhaltung als eine unabweistare Forderung hinstellen. Was in dieser Hinsicht zu beachten und vorzuliehren ist, wird späterhin berühırt werden.

Für trorkenen Boden taugen noch die gremeine Viefer und die gemeine Birlie, Bet. verrucosa, die Robinie und eventuell einzelne Pappeln und Weiden. Einen mindestens feuchten, wenn nicht nassen Boden verlangt z. B. die Schwarzerle, rlie Ruchbirke, Bet. pubescens; anf solchem gedeihen ferner vicle Weiden, auch wohl Vogelbeere und Kirumnlıolzkiefer. Stagnierende Nïsse bedingt fast immer eine melı oder minder zweifellafte Entwickelung, während fließendes oder nur vorübergehend stagnierendes Wasser auch im Ueberschuß kem llindernis guten Wachstums ist, wie die Weiden an Bach- und Flußufern und die üpjige Entwickelung bes. der Stieleichen, Eschen, Ulmen in zeitweise überschwemmten Arewaldungen beweisen. Selbst die Rotbuche findet sich da und dort in Inundationsgebieten nicht selten. Fraxiums anerica soll sich (nach Brecher) hier besser bewähren als Frax. excelsior; Carya alba, Rolinie und Lärche haben sich nach Ueberschwemmungen grut gehalten. Zeitpunkt, namentlich Daner etc. der Ueberschwemmung sind dabei aber von Einfluf.

Weitaus die meisten unserer Holzarten meilen die Extreme und befinden sich nur auf frisehen, höchstens feuchıen Böden wohı, mit der Abstufung, daß man cinèn nur frischen Boden für die in der Cebersicht zu Eingang dieses Abschnittes genannten Nadelhölzer, sowie für Eiche, Buche, Ahorn, Linde, einen feuchteren dagegen für Esche, Erle, L'me, Pappeln und Weiden vorziehen wird. Auch von den Ausländern, mit welchen Anbauversuche gemarht werden, scheinen die incisten einen nur frischen Boden zu lieben.

2) Grïndiglieit. Man versteht darunter die Mäelitiglieit der von den Wurzeln durchrlringbaren Borlenschicht. Flachgründige, d. h. nur bis $30 \mathrm{~cm}$ liefe Börlen sind oft, insbesondere an llängen, zugleich trocken, seltener, bei undurehlassendem Untergrund, in ebener Lage, zu naß und in beiden Fällen meist von geringer Ertragsfähiglieit. Hiervon abgesehen aher müssen sie dem Gedeihen derjenigen Holzarten hinderlich sein, welche ein tiefgeliendes Wurzelsystem hahen, namentlich dann, wenn letzteres durch eine stark ausgebildete Pfahlwurzel charakterisiert ist, welche sich, auf einem festen, unzerklüfteten Untergrund aufsitzend, nicht normal entwiclieln kann. Aus diesem Grunde taugen z. B. Eiche, Esche, Vlme, Linde und auch die Tanne nicht auf einen flachgiündigen Boden. während sich die Fichte mit ihren flachstreichenden Wurzeln daselbst noch gut zurechtfindet. Auch Buche, Birlie u. a. sind von einem nielht gründigen Boden keineswegs ganz ausgeschlossen. Immerhin sind auch für Holzarten, welche ihre Wurzeln in der Regel nicht weit in die Tiefe senken, mitleltiefgründige $(30-60 \mathrm{cn}$ liefe) und noch besser tiefgründige, über $60 \mathrm{~cm}$ tiefe Böden wegen ilıres meist besseren Feuchtigkeitszustandes entschieden vorzuziehen. Flachgrünliglieit macht sich fast immer durch geringes Höhenwachstum bemerklich. Man vergleiche hierzu auch die Bemerkungen zu $\$ 8,2, \leq .12$.

3) Bind igkeit: Von dem Grade dersellsen ist rlie Enlwickelung der Holzhestände insofern beeinflußs, als mit ihr die Ausbildung der feinen Saugrurzeln, die 
Standfestigrkeit der Bätme, sowie der Feuchtigkeitstgehalt und die Durchlüftung des Bodens in Bezichung stehen. Die Extreme (emerseits strenger Tonborlen, bahl zu nab. und kalt, bakl zu lart und rissig, wenn trocken, andererseits Flugsand) sind in jedem Falle nachateilig. Zu den Holzarten, für deren nomale Leistung ein lockerer Boden gefordert werden muß, gehören z. P. T'hue, Esche, liastinie, Erte, Rohinie, von den Nadelhölzern Kiefer, Douglasie; die neisten andern zeigen auf einem Borlen von mittlerem Bindigkeitsgrad voll befriedigendes, zum 'Teil sograr ilur bestes Gedeilıen.

I]. Entwiclielungs- und Wuehsverlältnisse les cinzeluen B a $11 \mathrm{mes}$.

S S. Da es sich hier nicht um eine botanische Charakteristik, sondern um dic bei waldbaulichen Jaßnalimen hesonders zu beachtenden, bezw. zu verwertenden Eigenheiten in der Entwickelung der einzehen Holzarten handelt, so sind diese. unter Voraussetzung normaler Verhältnisse, vorab also eines geeigneten Standortes. hauptsächlich nur im llinblick auf folgende Fragen zu untersuchen:

1) Wie vollzieht sich die lieimung? Bleiben die liotyledonen unter der Erile oder werden sie mit heraufgenommen? - ?) Wie sielıt das Wurzelsystem aus? 3) lst die Holzart in der Jugend rasch-orler langsamwüchsig? Welchen Verlauf nimmt überlaupt ihre Höhenentwiclielung absolut und im Vergleich zu derjenigen anderer Holzarten? - 4) Wie verhält sich die Holzart gegen Beschädigungen aller Art? Ist sie insbesondere in ilırer Jugend gegen Frost und Hitze empfindlich? ist sie dem Schneedruck und der Sturmgefahr besonder's ausgesetzt? - i) Wann beginnt sie regelmäBig zu fruktifizieren? in welchem Linfange darf auf Wiederliehr waldbaulich verwendbarer Masten gerechnet werten?

Auf die meisten der vorstehenden Fragen geben die Abschnitte Forstbotanik und Forstschutz des Handbuches Antwort, so daß wir uns hier auf eine Gruplielung der Jauptholzarten nach den vorgenannten Gesichtspunkten, sowie auf einige ergänzende Bemerkungen besclüänken kömnen:

1) Keimung: Wie liotyledonen bleiben unter der Erde bei der Eiche, Fiolikastanie, lastanie, Hasel, Juglans und Carya, wäh'end die übrigen Lauhhölzer, sowie die Nadellı̈lzer oberirdisch (epigäisch) keimen, d. h. ihre lieimblätter über den Boden erheben. Die Durchdringung rler über dem Samen lagemden Boclenschicht hedeutet Leistung einer mechanisrhen Arbeit, die un so gröber ist, je umfangreicher die liotyledonen sind und je dicker. bindiger und schwerer die über dem Samen lagernde Erdschicht ist. Bei den unterirdisch (hypogäisch) lieimenden Holzarten: Eiche, Kastanic usw. kann die Berleckung des Samens entsjucehend stärlier scin. Vergl. hierzu $\$ \pi 7$. E.

2) W ur zelsystem: Holzarten mit weitrerzweigtem Wurzelsystem beanspruclıen damit einen größeren Nalırungsraum, sind aber u. U. auch auf ärmerem, trockenerem Borlen noch zuwachskräftig (Akkommodationsfäligkeit von Weidenarten). Durch Bäune mit flachstrcichenden Wurzeln wird zumächst nur die abere Bodenschicht, von solchen mit tiefgehenden Wurzeln werden entsprechend tiefer liegende Schichten belufs Nahrungsaufnahme in Anspruch genommen; erstere köınen auf flachgründigem Boden, wo letztere versagen, eher noclı gedeihen. Holzarten mit tiefgehender Pfahlwurzel, dann besonders aucli solche nit mehreren starken, tiefeindringenden Wurzelsträngen sind standfester als solehe mit flachstreichenden Wurzeln.

Nach Bau und Jabitus des Wurzelsystems unserer Holzgewächse unterscheidet 11. B ü s ge ${ }^{1}$ ) das langr auslaufende, durch dicke, spärlich verzweigte Würzelchen

1) Studien aber die Wurzelsysteme einiger dikotyler Holzpfanzen. Flora 95. Bd. S. 58. 
ausgezeichnete Extensivsstem und das Intensivsystem, bei welchem die letzten Auszweigungen geringere Ijcke haben, aher mit seh" viel nehr Faserwürzelchen besetzt sind als beim Extensirsystem. Durch diese verschiedene Verteilung der Wurzelsubstanz im Buden werdeu Lnterschiede in der Methode der Ausnutzung desselben, speziell in der Wasserversorgung bedingt. Extensive Wurzelsysteme finden sich bei Iolzgewächsen, die wenigstens zum Teil feuchten Winnaten und Standorten angehören, z. B. hei der Esche, und scheinen mehr für Wirtschaft mit reichlichem Wasservorrat geeignet, Intensivsystenı, wie sie z. B. die Buche zeigt, hingegen sind der Ausuutzung kjeinerer Wassermengen, $d . h$. periodisch trockenen standorten angepaßt.

Als Iolzarten mit tiefgehenden Wurzeln sind zu nennen: Eiche, Llme, Esche, Ahorn (besonders Acel pseudoplatanus), Kastanie, Sehwarzerle, Linde, auch Weißtanne, Kiefer, Weymouthskiefer, Lärche. Ton den genannten lraben manche eine his in lölıeres Alter kräftig entwickelte Pfahlwurzel, wie z. B. Eiche, Iiastanie, wählend bei anderen, wie Erle, Lärche, früher oder später das Wachstum der Pfahlwurzel nachläBt, dagegen melurere schuräg in den Boden eindringende starke seitenwurzeln (,Herzwurzeln“) das Gerüst des Wurzelsystems bilden.

Flachstreichende Wurzehn haben Birke, Robinie, Pappeln und Weiden, sowje Fichte, während andere IIolzarten, wie Buche, Hainbuche, Weißerle, eine Nittelstellung einnehmen. Abgesehen von den unzweideutig ausgeprägten Extremen ist diese, wie überhaupt jede ähnliche Abgrenzung, angesichts der zahlreichen Lebergänge keine sichere, zumal auch bei der gleichen Holzart je nach der Bodenbeschaffenheit oft auffällige Verschiedenheiten und vielfache Uebergänge vorkommen. Namentlichı ist die Bildung einel ausgeprägten Pfahlwurzel nicht bei allen, eine solche von Haus aus aufweisenden Holzarten in gleicher Weise Bedingung einer guten Entwickelung (Ejche), sondern unter Umständen (Tanne auf weniger gründigen Böden) kann eine starke eigentliche Pfahlwurzel durch kräftigere Entwickelung seitlicher Wurzeln elsetzt werden.

3) Höh en entwi c ke l u n $\mathrm{g}^{1}$ ): Für viele waldbauliche Fragen (Erzielung genügenden Bestandesschlusses und damit guter Bodendeckung, Schädigung durch Wild, Weidevielı, Frost usw.) ist namentlich die Jugendentwickelung der Holzartem entscheidend. Einzelne machen schon in den ersten Lebensjahren bedeutende Längstriebe, während andere erst nach einer Reilıe von Jahren mit einer energischeren Höhenentwickelung beginnen. Lnter Zugrundelegung des Jugendwachstums teilt man die Holzarten in rasch- und langsamwüchsige ein und rechnet zu den letzteren: Buche, Hainbuche, Tanne, wogegen man Erle, Birlie, Fobinie, Esche, Ahorn, Kastanie, Pappeln, Weiden, die meisten Pinus-Arten und die Lärche als raschwüchsig bezeichnen und endlich den L'hmen, Linden, Pirus- und Sorbus-Arten, sowie der Fichte eine mittlere Stellung einräumen muß. Doch auch hier finden sich von Fall zu Fall, ı. h. nach Standort, Witterung, Behandlung usw. mancherlei Verschichungen. Nach der Bodenzusammensetzung z. B. kann sich die Skala der Schnellwüchsigheit der Holzarten während der ersten Jugendjahre hiı und wieter geradezu unkehren. Eine ziemlich rasche, wielfach aber batd nachlassende Jugendentwicklung zeigen auch unsere beiden einheimischen Eichenarten. Wie überhaupt in ihrem biologischen Verhalten finden sich aber auch in der Wuchsenergie merkbare Interscliede bei ihnen: der Trauheneiche wird ziemlich allgemein rascherer Wuclıs und längeres An-

1) Lebel dic Alt der Errittchng des Höhenzunachsganges ist die Holzmeßkunde von $\checkmark$ Gut $t$ enber $g$ in diesem Handbuche zu vergleichen. Daselust finden sich ūberdies die Entwickelungsgesetze nach dem dermaligen stand unserer Kenntnis zusammengestellt. - Auf die Frage der Bedeutung des Höhenwachstums bei Anlegung gemischter Bestände wird noch zurückgekommen werdeı. 
dauern kräftiger Höhenentwickelung zuerkanıt. Mit zunehmenden Alter äudert sich bei vielen Holzarten das Höhenwachstum. Die in der Jugend langsam wïchsigen Holzarten, Buche, Tamme, Fichte fangen, zusagende Boden- und Standortsverhältnisse vorausgesetzt. mit Eintritt des Bestandsschlusses an, kräftige Hölentrieke zu schieben, während ungeliehrt das Höhenwachstum der in der Jugend raschwächsigen Arten um so frïher und $\mathbf{m}$ so intensiver naclizulassen pflegt, je weniger der Standort ilıren Ansprüchen grenügt. Der bei den einzelnen Holzarlen verschiedene Zeitpunkt dieses Nachlassens verdient namentlich bein Zusammenordnen derselben im llischbestande sorgfältige Beachtung.

Endlich ist, wenn auch weniger für eigentlich waldbauliche Jaßnalınen, als im Hinblick auf die Rentabilität des Betriebs (Haubarlieitserträge), die absolute Höhe, welche überhaupt erreicht wird, von Bedeutung. In dieser Hinsicht stehen die Nadelhölzer (Tanne und Fichte bis zu 40 Meter und melir) in allgemeinen den Laublölzern voran. Entscheidend ist hierbei nicht sowohl die Höhe einzelner besonders gut entwickelter Exemplare, als vielmehr die mittlere Höhe haubarer Bestände. Es verdient volle Aufmerksamkeit des Wirtschafters, daß der Höhenwuchs zwar in erster Linie eine Funktion der Bodengüte, zum Teil aber auch ein Produkt der Bestandserzielıung ist. Alle im freieren Stand zu baldiger Fironenabwölbung und lironenausbreitung und damit zur Kurzschaftigkeit hinneigenden Holzarten, d. i. die Mehrzahl unserer Laublı̈̈lzer; ganz besonders die Buche und Stieleiche, müssen durch Erziehung in engem Verbande während der Jugend-und schwachen Stangenholzperiode gezwungen werden, dem ihnen zunächst nur von oben gebotenen Lichte entgegenzuwachsen, um auf diese Weise die von der Nutzholzwirtschaft geforderte gröBere astreine Schaftlänge zu erzeugen.

4) Verhalten der Holzarten gegen Beschädigungen. Wild-, Weidevieh-, sowie Insektenschäden kommen insofern in Betracht, als sie (wie Rüsselkäferfraß in Kulturen, Ilaikäferschaden, Auftreten gewisser Schmetterlinge u. a.) auf die waldbaulichen Anordnungen einen bestimmten Einfluß ausüben. Immerhin werden unsere wirtschaftlichen Entschließungen häufiger und stärker durch das Terhalten der Waldbäume gegen Frost und Hitze, gegen Schneeschaden und Sturm bedingt.

Hinsichtlich dieser Gefahren und der sie bedingenden llomente wird auf den Forstschutz verwiesen. Hlier soll nur hervorgehoben werden, daß eine in hezug auf ihre .l]assen- und Wertserträge, sowie ilı Verlalten gegen den Boden usw.. vielleicht weniger geschätzte Holzart gerade durch ilre Lnempfindlichkeit gegen Frost und Hitze für gewisse konkrete Fälle eine besondere Bedeutung erlangen kann, in dem sie empfindlichere Holzarten endweder ganz vertritt oder ilmen als wirksmes Schutzholz (1lischung, Toranbau) beigesellt wirl. Beispiele: Hainbuche statt der Rotbuche zun Lnterbau auf feuchten Stellen, Kiefer als Sclutz- und Treibholz für Eiche, Birkenvoranbau in Frostlöchern. Ebenso können manche Holzarten wegen besonderer Gefährdung (z. B. Fichte in Sturnlagen) örtlich von unseren Erwägungen bezüglich der Wahl der Holzart ausgeschlossen erscheinen.

5) Fruktifikation: Soweil die Bestandesbegründung dureh J'flanzmng stattfindet, ist der Waldhau mit seinen Operationen von dem Eintrill guter Samenjahre nur in mäßigem Lmfange ablängiğ. Eimmal läßt sich, was an Pfläuzlingen nicht aus Schlägen entnommen werlen kann. sondern besondere Anzucht erheischt. aus verhältnismäßig kleinen Ilengen des betreffenden Samens erzielen, so daß aucl in samenarmen Jahren of wenigstens dipses geringe Quantum brauchbaren Samens zu enlangen ist, und zum andern liann im Falle reichlicher llast meist für melırere 
Jahre vorgesorgt werlen, weil man bei der Pflanzung nicht immer gerade auf ein ganz bestimmtes Nlter der Pflänzlinge angewiesen ist. Dagegen ist die Kultur durch Saat in weit erheblicherem Maße, sowie die natürliche Samen-Terjüngung vollständig an die Nasten gebunden, und es ist, nanentlich für das regelmäßige Fortschreiten der Wirlschaft in größeren nachlıaltigen Betriebe, oft von wesentlichem Einfluß, ob und in welehen Zwischenräumen Samenjahre in genügender Art wiederliehren (vergl. den Absehnitt über Bestandeshegründung).

Ilan kann zwar für Saaten (Nadelhölzer) unter Linständen auch noclı einige Jahıe alten Sanıen verwenden, überdies den Samen, wenn den Anforderungen der Zuchtwahl dabei nicht entgegengetreten wird, aus weiter Ferne luerbeischaffen, aber diese Behelfe fehlen bei der Naturbesamung. Wenn nun letztere auch bei allen Holzarten staltfindel, so ist der Wirtseluaftsbetrieb im großen doch neist nur bei 'Tanne und Buche, sowie vielfach bei Fichte, da und dort auch bei Eiche, Esehe, Ahorn und Kiefer auf Naturverjüngung begründet. Irie Benutzung natürlicher Ansamung von Eiche, Esche, Ahorn usw: wird, weil sie vielfach nicht nur als erwünschte Ergänzung der künstlichen Kultur erscheint, sundern letztere greradezu überflüssig machen kann, neuerdings mit Rerlit vielenorts in größeren Umfange angestrebt. In erster Linie konmen für unsere Frage Tanne, Fichte und Buche, event. Liefer und Eiche in Betracht, da Holzarten wie Esche und Ahorn, dann anch Hainbuche und Birke meist sehr regehnäßig Samen tragen oder doch nur selten gänzlich rersagen. Obwolıl selıon vom ausgehenden Stangenholzalter an oft bedeutendere llasten vrkommen, und zwar auf schlechterem Standort gewöhnlich früher als auf besserem, wird ihre regelnäßige Wiederkeln meist erst von einem späteren Entwickelungsstadium an beobachtet, welches dengemäß als volle Mlambarkeit bezeichnet werden kann. Erst wenn diese eingetreten ist, läßt sich rlie Verjüngung mit sicherheit leiten.

Jan liamn rechnen ${ }^{1}$, daß bei der Tanne etwa vom $70 .-80$. Jahre an in mildenk Klina alle 3 , in rauherem alle $5-7$.Jahre eine reichliche 11 ast eintritt; bei der Fichte geschieht dies vom 60. Jahre an (nit entsprechenden, örtlich allgemein, sowie durch die nelı zufälligen Einflüsse der .lahreswitterung bedingten schwankungen aufund abwärts) (lurchschnittlich alle is Jahre. Die gemeine Kiefer fruktifiziert früher

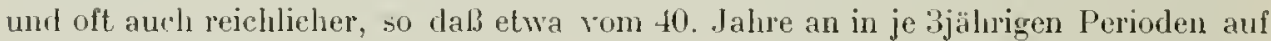
eine genügende Samenmenge zu zählen ist. Buchensanenjahre, wenn auch eigentliche Vollmasten selten sind, doch, je nach Oertlichlieit, vom 70. -50 . Jahre an alle 5-10 Jahre. Aehnlich wie die Buche (in ganzen wohl etwas günstiger) verhalten sielı die Eichen, doch bewegt sich die Buche mehr in Extremen, während bei Eichen Halbund șrengmasten lıäufiger sind.

Von besonderem Einfluß auf die Samenentwickelung sind der allgemeine Charakter des lilimas und die Witterungsverhältnisse des einzehen Jalnes. Die Fruktifikation beginnt, von der nieht unbedeutenden Beeinflussung durch die spezifische Veranlagung des Einzelindividuums al,gesehen, in allgeneinen um so frülıer, je wärmer das Kilima ist. Irie Sanenjahre treten nach Häufigkeit und Ergiebigkeit zurück, je nördlicher bezw. hölıer der in Frage liommende Standort liegt. In der Einflubsphäre der Jahreswitterung spielen naßkalte Sunmer, ganz besonders aber Spätfröste, welche die Blüten vernichten, eine große Rolle. Warme Sommer wirken fördernd und steigern die Frulitifikation bei Eiche im gleichen, bei Buche im folgenden Jahre. Außerden wirkt auch das Licht auf die Anlage und Ausbildung der Blütenknospen anregend ein. Die späte Mambarkeit und greringe Fruktifikation unserer gleichaltrigen

1) V'ejgl. u. a. H e B, ,Die Eigenschaften und las forstliche Verbalten der wichtigeren Holzarten", wosellost in Anmerkungen die spezialliteratur nachgewiesen ist. 
Bestände hängt oft nicht zum wenigsten nit der änersllehen Lirhaltung des vollen Bestandsschlusses zusammen; vergh. Zweck uml Bedeutung der Vorbereitungsschläge. $\$ 10$.

\section{Verlia lten der 110 lzarten ju bestanel.}

ha es der Waldbau fast ausnahmslos nicht mit Ejuzelbäumen, sondern mit Beständen, d. h. mit einer V̈ielheit irgendwie zusammengeordneter Individuen zu tun hat, so ist elie Würdigung der einzehnen Holzarten recht eigentlich dureh rleren Verlatten im Bestande, beim Zusanmenleben mit Individuen der gleichen uder anderer Art bedingt. Dabei jst jenes Verhalten hauptsärhlich nach zwei lichtungen hin zu begutachten; nämlich es fragt sich: 1) welchen Einfluß äußert die Holzart in Bestand auf den Boden, der sie träigt? und ?) was leistet der Bestand als solcher für die Zwecke der Wirtschaft?

\section{A. Einfluß der Holzarten auf den Boden.}

\$. Der Bestand, welcher dem Boden bestimmte Beträge an Nährstoffen entzieht und ihn dadurch äımer macht, soll hierfür durch diejenigen Substanzen, welche die Holzgewächse zur Streudecke und somit demnächst zur Humusbildung beitragen, also in erster Linie durclı den jährlichen Blatt- und Narlelabfall, durelı Blüten- und Fruchtteile, Zweige ete. swreit möglich Ersatz leisten. AuBerdem soll durch das Kironendach des Bestandes die Einwirkung von sonne und IVind in solehem Mlaße vom Boden fern gehalten werden, daß diesem hierdurch das gehörige 1 laß von Feuchtiglieit, sowie vor allem ein normal verlaufencler stetiger Gang der llumusbildung gesichert, die Streudecke in wesentlichen bewahrt und zugleich die Entwickelung zu massenhafter Forstunliräuter hintangehalten werde. Diese Wirkungen sollen vom lironendach ausgehen, d. h. von der Gesantheit aller Baumkronen. welche sich über einer bestimmten Fläche befinden. Wie nach Holzart und Lebensbedingungen überaus verschiedene Ausgestaltung der einzelnen lirone ist - von der gegenseitigen Beeinflussung ler Individuen und der Wirkung wirtschaftlicher Jaßnalunen abgesehen - allgemein bedingt durch die ler Holzart eigene Art der Ast- und Zweigbildung, durch Größe, Gestalt, Anordnung, Menge, Dauer der Blätter und Nadeln. In den weitaus meisten Fällen - außer auf besonders liräftigen bezw. feuchten Böden, deren Erschöpfung in bezug auf Yineralstoffe und Wassergelialt nicht zu fürchten ist - leistet in clen vorangedeuteten Kichtungen nur ein gut geschlossenes kironendach Genügendes, wobei allerdings vielfach das Ideal nicht darin besteht, daB die einzelnen Kronen sich in vrleicher Höhe gewissermaßen zu einer einzigen Etage zusammenfügen. Der Erhaltung und Pflege der Borlentiraft ist es oft weit förderlicher, wemn an Stelle eines gleichmäBig geschlossenen hironendaches Einzelhäune und Gruppen verschiedensten Alters und damit verschielenster Höhe und Ausformung den Raun über dem Boden derart mit . Aesten und Zweigen anfüllen, dab die zur Zersetzung der Streu notwendige Wärme in genügendem llabe dem Buden zugefülnt wird. Jedenfalls aber ist zur Herstellung jenes Schutzdarhes über dem Boden, sowie zur Rücklieferung einer hinreichenden Menge an hunusbildenden Substanzen auf der Flächeneinheit eine gewisse, mit dem Alter des Bestandes wechselnde Anzahl von Holzpflanzen erforderlirh, welehe genügend nahe zusammenstehen und deren Kronen in sich entsprechend dicht sind. Namentlich in höherem Alter, wenn der einzelne Baum cinen gröBeren Standraum einnimmt, ist die Beschaffenheit rer Einzelkrone für die Intensität des Bodenschutzes bedingend. In der .Ingrend fält ja zweifellos die auf gegebener Fläche sich vorfindencle Zahl der Indivirluen an meisten ins Gewirht, aber mit fortsohreitender Ent- 
wickelung (zunchmender natürlicher und künstlicher Bestandesreinigung) tritt diesem Moment der EinfluB der einzelnen Krone mehr und mehr als gleichwertig zur seite. Nun verhalten sich aber unsere Holzarten in Beziehung auf die Ausbildung ihrer Kronen außerordentlich verschieden. Zwar besitzen nicht bloß diejenigen, welehe sich auch in Alter noch durch dichte Kronen auszeichnen, sondern auch viele von denen, bei welchen dies nicht der Fall ist, in der Jugend reichliche Belaubung oder Benadelung; aber nit zunehmenden Alter lichten sich die Kronen mehr und mehr aus. Sie rücken überdies (infolge Alsterbens der unteren Aeste) immer weiter rom Boden in die Höhe. Durch die sowohl im Boden als im Kronenraume stattfindende seitliche Beengung gehen ferner viele Individuen ein, so daß durch dies alles bald früher bald später (nach Holzart, Standortsverhältnissen usw.) eine oft sehr weitgehende Lnterbrechung des Lronenschlusses eintritt, eine Lichtstellung, die sich durch Ueberkleidung des Bodens mit Unkräutern, durch zu rasche oder auch durch unvollionnmene Humuszersetzung, Austrocknung ete. bemerkbar macht. Da im allgemeinen der Waldboden in seiner Produktionsfähigkeit hierdurch geschädigt wird, so muß für dauernden Kronenschirm gesorgt werden. Dies geschieht am einfachsten, indem man überhaupt nur solche Holzarten in die Bestände bringt, deren Kronendach sich bis ins höhere Alter gut geschlossen erhält. Zu diesen gehören T a n n e und Buc h e, dann auch die Fichte. Sie sind vor allen anderen berufen, die Hauptmasse des Waldes zu bilden, und können, richtige Bestandespflege vorausgesetzt, ohne Gefährdung der Bodenkraft in rein en Beständen auftreten, d. h. solchen, die nur aus Exemplaren der nämlichen Holzart zusammengesetzt sind.

Sache einer zweckmäßigen Bestandeserziehung (s. dort vierter Abschnitt) aber ist es, darauf zu halten, daß man mit der Bevorzugung reiner Bestände der genannten Holzarten im Dienste der Bodenpflege nicht aus einem Extrem ins andere fällt. Mit vollem Rechte nämlich beschuldigt man das bis in die neueste Zeit herrschende Dogma von der Erhaltung des dauernden vollen Bestandsschlusses in den Fichten-, Buchenund Tammenbeständen, daß mit ihm nicht in allen Fällen eine Förderung, sondern oft genug eine Verminderung der Bodengüte und eine Erschwerung der Waldbegründung, namentlich der natüslichen, herbeigeführt werde. In den durch liahlschlaghetrieb oder schlagweise Naturverjüngung geschaffenen gleichaltrigen, also gleichwïchsigen und dauernd in Dichtschluß erlaltenen reinen Beständen von Fichte, Buche und Tanne lagern sich, wie die Erfahrung lehrt, beim Vorhandensein ungünstiger Verwesungsbedingungen, d. i. in Lagen mit niederer Temperatur, bei Ueberschuß oder Mangel an Feuchtigkeit oder bei mangelndem Kalkgehalt des Bodens, leicht pflanzliche Reste in Gestalt mehr oder minder mächtiger Streuschichten ab. MIan nennt solche meist dicht gelagerte, wenig oder nicht zersetzte Streumassen Trockentorf (früher Rohhumus). Sie haben sowohl in chemischer wie physikalischer Hinsicht eine ungünstige Veränderung des Walrbodens zur Folge und sind für Boden und Bestand überwiegend schädlich. Wie in vorangehenden Abschnitt, Forstliche Standortslehre" näher ausgeführt ist, verursachen stärkere Trockentorfschichten, zumal auf den Sandböden, das Entstehen von Ortstein, veranlassen Auslaugung der löslichen Mineralstoffe, Tülıren zur V'ersaterung und Verdichtung des Bodens, mindern seine Durchlüftbarkeit und beeinträchtigen das für die normale Verwesung aller organischen Reste auBerordentlich wichtige Tierleben im Boden, sowie die für die Verwesungstorgänge gleich wichtige Baliterienflora, kurz, sie machen den Bodeı, wie man zu sagen pflegt, krank. I)ie sauren Zersetzungsprodukte, die in den reinen Schattenholzbeständeu ïberall dort entstelien, wo infolge Erhaltung dauernden Dichtschlusses die Bodingungen zum raschen Fortgang der Verwesung fehlen, füluren na- 
mentlich bei Buche ${ }^{1}$ ). Fichte und Tanne ${ }^{2}$ ) zum Versagen der Naturverjüngung. Ihrer Bildung kann nur dadurch vorgebeugt werden, daß durch entsprechende und namentlich frühzeitigere Schlußunterbrechung für hinreichenden Wärme- und Luftzutritt zum Boden und damit für Förderung der Verhunstung und Streuzersetzung Vorsorge getroffen wird.

Holzarten, die sich später licht stellen, werden. um der ohen genannten Gefahr der Bodenverunkrautung \% entgelren. entwedes in so niedrigen Umtriehen bewirtscliaftet, daß bei der Aberntung des Bestandes die für den Bodenzustand bedenkiticle Lichtung noch nicht eingetreten ist, oder es muß, wenn man sie älter werden lassen will, in Zeitpunkte der beginnenden Auslichtung durch besondere Maßnahmen (Unterbau) für Bodenschutz gesorgt werden.

Die mehrenwähnten Holzarten Tame, Buche und Fichte werden in Verein mit einigen Nebenholzarten als $s c h$ at $t$ enertragende oder kurz $\mathrm{Sch}$ a t $\mathrm{t}$ e nho Iz a r te n bezeichnet, weil man die Dichtigkeit ilarer lírone, welche wesentlich darauf beruht, daß Blätter bezw. Nadeln im Innern derselben sich noch längere Zeit hindurch lebend erhalten, als einen Beweis hölıeren Schattenerträgnisses ansieht. Im Gegensatz hierzu steht das Verhalten anderer Holzarten, deren líronen sich bald lichten, indem rlie von den äußeren Blatt-bezw. Nadelschichten umschatteten Organe im Kroneninnern nicht mehr lebensfähig bleiben. Diese Holzarten werden deshalb lic lı $\mathrm{tb}$ ed ür f ig oder liurz L i c ht hölzer genannt.

Die schon seil mehr als einem Jahrhundert gebräuchliche Einteilung der Holzarten in Licht- und Schattenhölzer gründet sich auf das eben angedeutete verschiedene Verhalten, das sich zeigt, wenn man Bestände der einzelnen Holzarten wāhrend ihrer Entwicklung sich selbst überläßt. Den Holzarten wohnt in der Tat eine verschiedene Lichtempfindlichlieit inne; sie sind auf einen verschiedenen Lichtgenuß, auf ein verschiedenes Ninimum desselben abgestinmt. Der Lichtbedarf der einzelnen Holzart und die mit ihm zusammenlıängende Fāhigkeit, Beschattung zu ertragen, sind aber keine absolute und unabănderliche Grōßen, sondern wechseln mit den Standortsverhälnissen, der geographischen Breite, der Meereslhöhe, dem Alter, der Jahreszeil und dem Entwicklungsstadiun des Einzelindividuuns. Infolgedessen ist es allerdings nicht angängig, die in einem heranwachsenden Bestande sich abspiclenden Vorgānge der Bestandesausscheidung, d. h. des allmälılichen Unterdrücktwerdens und Absterbens einer größeren oder geringeren Anzalıl von Individuen und das Tempo dicses Vorganges lediglich unter Zugrundelegung der Lichtempfindlichkeit und des wechsclnden Lichtgenusses zu betrachten. Ilierbei spielen vielmehr Filima, Bodengüle und namentlich Bodenfrische als mitwirkicnde Faktoren eine wesentliche Rolle. Der Lichtanspruch einer JIolzart ist um so größer, ilhr Schattenerträgnis mithin um so geringer, je kūhler, schlecliter oder trockiner der Standort isl. Auf gutem, namentlich frischen Boden oder in warmem Lilima vertrăgt eine unter mittleren V'crlıăltnissen auf ein hobes Lichıgenußnininum angewiesene Holzart, d. h. eine Liclitholzarl, so viel Beschattung, daß sie ihren Lichtholzcharakter fast zu leugnen scheint, und ungekehrt verlangt eine Schattenholzart in Standortsverhältnissen, die an der unteren Grenze ihrer Ansprüche liegen, auf trockeneın, armen Boden oder in nördlicheren bezw. höheren, kühlen Lagen so viel Licht, daß sie kaum mehr als Schattenholzart bezeichnet werden kann. Diese noch keineswegs hinreichend geklärten Wechselbezielungen zwichen Lichtgenuß und Standort sind melirfacl, neuerdings wieder für Fricke ${ }^{3}$ ) Veranlassung gewescn, alltägliche Erschcinungen des Waldbaues, wie ungenügende Entwicklung des Jungwuchses im Halbschatten oder unter dem Schirm älterer Băume, Wiederverschwinden des Aufschlages und dergl. nicht auf Lichtmangel, sondem auf mangelnde Bodenfeuchtigkeit infolge lionkurrenz seitens der Wurzeln der älteren Bāume zurüclizuführen. So richtig und wertvoll der von Fricke gelieferte Nachweis der Nitwirkung dieser Wurzelkonkurrenz beim Gedeihen beschatteten Jungwuchses auch is $t$, so wenig berechligt ist die hieraus abgeleitete Folgerung, daß die übliche Einteilung der Holzarten in Licht- und Schattenholzarlen sich nicht halten lasse und wissenschaftlich nicht begründel sei. Die mehr oder minder ausgeprägle Făhigkeit unserer Holzarten, unter sonst gleichen Verlıāltnissen mehr oder weniger Schatten zu ertragen, bleibl als Tatsache bestehen. Sie bedarf aller-

1) Vgl. hierzu: C. F rö m b l ing, Der Buchenlochwaldbetrieb. Berlin 1908.

2) H. S L o ll, Das Versagen ter Weißtanmenverjungung im mittleren llurglale. Nalurwiss. Ztsehr. f. Forst- und Landwirlscliaft 1909, S. 351

3) Fricke, ,Lichl- und schattenholzarten", ein wissesschaftlich nicht begründetes Dogma. Z. f. d. ges. Forstw. 1904, S. 315.

Handb. d. Forstwiss. 3. Auf. II, 
dings noch der Aufhellung hinsichtlich ihrer anscheinend sehr engen und nur selwer zu isolierenden Beziehungen zu den Faktoren der Bodengüte bezw. der Bodenfrische.

Als extreme Repräsentanten der Lichthölzer können Lärche und Birke gelten; sie zeichnen sich vor allen andern durch ihre besonders dünne Krone aus. Zwisehen den beiden genannten Extremen, den absoluten Sehattenhölzern Eibe, Tanne und Buche und den Lichthölzern Birke und Lärche, schalten sich in mannigfacher Abstufung die übrigen Holzarten ein. lieiner unserer Waldbäume liebt oder bedarf den Schatten, abgesehen von der Jugendzeit, in weleher vielen von ilnnen Seluutz gegen Frost und Hitze gewährt werden muß. Das letztere aber kann im großen Forstbetrieb meist nur durch das lironendach eines Schutzbestandes geschehen, ist also mit Beschattung verknüpft. Alle Holzarten entwickeln sich vielmehr kräftiger in der Lichtstellung.

Tanne und Buche brauchen in der Jugend Schutz gegen Frost und Hilze und erlragen die Beschattung, die Tanne aber langer und intensiver als die Buche. Weit weniger schutzbedürftig, zumal gegen Sonnenbeslrahlung, ist die junge Fiehte; ihr Seliattenerträgnis ist. entschieden geringer als dasjenige der Buche. Immerhin muB man die Fichte, so lange nur die zwei großen Gruppen: Schatten- und Lichthölzer gebildet werden, den Schattenhōlzern zuzählen. Mit jhr konkurriert allenfalls in bezug auf die Fähigkeit, i Schatlen zu ertragen, die Weymouthskiefer, von Laubhölzern vielleicht die Hainbuche. Alle anderen Holzarten sind als Jungwüchse sofort selır dankbar für vollen Lichtgenuß und erhalten sich unter dem Schatten von Oberständern im allgemeinen nur dann einige Zeil wuchskräflig, wenn das, was ihnen im Schatten an atmosphärisehen Niederschlägen (Regen, Tau etc.) abgehi, durch Bodenfrische, feuchte Lufi, gule Ernährung reichlich ersetzt wird. Hin und wieder bezeichnet man diejenigen Holzarten, die in der Mitte zwischen ausgesprochenen Lichthölzern und ebensolchen Schattenhölzern stehen, und hinsichtlicl ihres Schattenerlrägnisses in der Jugend oft auch melur den Schatienhölzern nahekommen, als $\mathrm{H}$ a l b s chat $t$ e $\mathrm{n} h$ olz a $\mathrm{t}$ e $\mathrm{n}$. Je nach den Standortsverhältnissen steigert sich das Lichtbedürfnis dieser Holzarten früher oder später bis zu dem der typischen Lichthölzer. - Von dew Verhalten in der ersten Jugend ist dasjenige während der weitern Entwickelung des Besiandes zu unterscheiden. Das lirilische Nlter, in welchem sich die größere oder geringere Fähigkeit einer Holzart, dichte und damil reine Bestände dauernd zu bilden, denllich ausspricht, ist gemeinhin die Zeit des beginnenden Stangenholzes. Außer bej Lärche und Birke tritt die Sorge um den Bodenschulz im reinen Bestande einer Lichtholzarl meisi erst von jenem Zeitpunkte ab an uns heran; ja in Beständen mancher lichlkroniger Nadelhölzer, wie z. B. der Kiefer, kann man sich dieser Sorge oft noch weiterhin, bis ins mittlere, ja höhere Stangenholzalter entschlagen, sofern eine dichte Moosdecke den Boden überkleidel und ihm den erforderliehen Schutz (Feuchtigkeit ete.) gewähri.

Von verschiedenen Schriftslellern sind die Holzarten in bezug auf ihre Fähiglieit, Schatten zu ertragen, bezw. sich im geschlossenen Bestande zu halten, klassifiziert worden $\left.{ }^{\mathbf{1}}\right\rangle$. Die von ilınen aufgestellte Skala slimnt nicht in allen Einzelheiten überein. Dies kann auch nicht ander's sein, denn die Beohachtungsgebiete, welchen die belreffenden Bücluer entstammen, sind sehr verschieden; immerhin treffen die Abweichungen zumeisl nur die eine mithlere Stellung einnehmenden Holzarten. Nanehe Verschiebung isL auch rein lolialer Natur, durch die Eigenart des Standorts bedingt ${ }^{2}$ ). Ueberdies ist, wie oben erwälnt, die exakte komparative Beobachtung äußersi schwierig, weil meist viele Faktoren gleiehzeilig wirksam sind. 7u den Schattenhölzern zählt man allgenein: Eibe, Buehe. Tanne, Fichte, Douglasie, Schierlingstanne, zu den Lichthölzern: Lärche, Birke, Eiche, Kiefer, Pappel, Weide; zu den Halbschaltenhölzern: Ahorn, Esche, Ulme, Erle, Linde, Weymouthskiefer, Robinie. Zu beachten ist, daB zu den ziemlich viel Schatten ertragenden Holzarten die Weymouthskiefer gehört, welche sowohl dadurch wie auch durch ihre Raschwüchsigkeit für manche Spezialfälle waldbaulicher Arbeit, wie z. B. Auspflanzen von Sehneebruchlücken, alten Wegen usw. besonders geeignet erscheinen kann. Ferner sei nochmals betont, daß die Fichte leineswegs der Buche und noch weniger der Tanne gleichgeordnel werden darf.

T'atsächlich kommen auch von andern Holzarten, als der Tanne, Buche und Fichte, ausgedelınte reine Bestände vor; diese sind clann aber entweder Kinder der Not oder in besonders günstigen Verhältnissen, sehr oft auch in eigenartigen wirt-

1) Vergl. u. a. G. H e y e r, Verhalien der Waldbäume gegen Licht und Schatten, 1852. - v. Fi s c h b a c li, ,Forstwissensehafi", 4. Aufl. 1886, S. 5. - K r a $\mathrm{ft}$ in Allg. F.- u. J.-Ztg. von 1878 , S. 164. - G a y e r, "Waldbau", 4. Aufl. S. $31 \mathrm{ff}$.

2) In dieser Beziehung machl z. B. Ga yer auf die erhöhten Lichlansprūche bei kurzer Vegetationsdauer (Gebirg, Norden), dann auf den Einfluß der örtlichen Lichtintensitát, die Wirkung häufiger Nobel usw. aufmerksam. 
sclıaftichen Bedingungen begründet. Alle dicse Umstände können die theoretisch als Ausnahme zu betrachtende Bildung reiner Bestände durch Lichtholzarten gegebenenfalls geradezu als Regel erscheinen lassen. So findet sich, um das prägnanteste Beispiel herauszugreifen, die Kiefer auf weiten Flächen in reinen Beständen, und zwar zumeist auf Böden, welche für andere, anspruchsvollere Holzarten nicht mehr taugen, wo man also, um überhaupt Wald zu haben, mit der Kiefer im reinen Bestand zufrieden sein muß. Man befindet sich hier in einer Zwangslage, aus der man eben niemals herauskommen kann. So lange solche Bestände noch jung und gut geschlossen sind, ist die Leistung der Kiefer auch in Rücksicht auf die Bodenkraft eine befriedigende. Die Fälle, in welchen Lichtholzarten, wie gerade nicht selten die Kiefer, aus wirtschaftlichen (Rentabilitäts-)Gründen rein angebaut werden, sind für unsere Frage zunächst weniger von Interesse. Es mögen nur noch Schwarzkiefer (Wiener Wald), Krummholzkiefer (Hochgebirg, Moore), Erle (nasse Partien), sodann Esche, Eiche (auf kräftigen Böden der Flußniederungen, doch hier meist mit einem Unterholz) als Beispiele dafür aufgeführt werden, daß unter besonderen Umständen Lichthölzer, zumal solche, welche eine mehr mittlere Stellung einnehmen, in reinen Beständen vorkommen. Ueberdies ist der Eichenschälwald als typische Form besonders zu erwähnen, bei welcher der niedrige Umtrieb entscheidend ist. - Anbau von Scluntzbeständen (aus Birke, Kiefer), sowie Anzucht von reinen Beständen (etwa der Eiche) in der Absicht, sie später zu unterbauen, kommen als nicht dauernd beizubehaltende reine Bestände hier nicht weiter in $\mathrm{Be}-$ traclit.

\section{B. Verhalten der Holzarten untereinander. Gemisehte Bestände ${ }^{1}$ ).}

$\S 10$. 1. A llgemeines. "Da, wie wir gesehen haben, nur eine ziemlich kleine Anzahl von Holzarten geeignet ist, für sich allein, d. h. in reinem Bestande, dem Boden den erforderlichen Schutz zu gewähren, da sich aber gerade unter den übrigen, den Lichthölzern, eine Reihe unserer wertvollsten, für die vielseitigsten Verwendungszwecke gesuchten Nutzhölzer befinden, auf deren An- und Nachzucht nicht verzichtet werden kann, so müssen sich den reinen Beständen, gr e m i s c h $t$ e " zugesellen, d. h. solche, welche aus Individuen zweier oder melırerer Holzarten zusammengesetzt sind, wobei dann die Lichthölzer derart mit Schattenhölzern zusammengebracht werden sollen, daß letztere die Sorge für den Bodenschutź in der Hauptsache übernelımen, während jene, in der Minderzahl, ohne besonderen Nachteil für die Bodenkraft mitwachsen. Die Lichthölzer tragen ja auch ihrerseits, wenn auch in mehr ode1 weniger bescheidenen Naße, zum Bodenschutz bei, so daß eine geeignete Zusammenordnung von Licht- und Schattenhölzern volliommen genügt, um die Produktionskraft eines Waldortes dauernd zu sichern. Die zwei großen Gruppen Licht- und Schattenhölzer gestatten folgende drei Arten von Mischungen: a) Schattenhölzer untereinander, b) Schatten- mit Lichthölzern, c) Lichthölzer untereinander. Außerden sind bezüglich der Mischungen Unterschiede dahin zu machen, ob sie bleibend oder vorübergehend sind, ob die einzelnen Holzarten gleichzeitig oder zu verschiedener Zeit auf die Fläche kommen, ob sie demnacl gleichalt oder ungleichaltrig sind, endlich ob eine regelmäßige (reihen-, streifen-, bandweise) oder unregelmäßige, mehr gruppen- oder horstweise Verteilung der einzelnen Holzarten beliebt wird, oder aber ob ein Grundbestand init Exemplaren einer anderen Holzart in einzelständiger Anordnung der letztercn durchstellt ist.

a) Beispiele vorübergehender. II is chungen: 1) Anzucht von Schutz.

1) V'ergl. C a r l H e y e r, „Beitrâge zur Forstwissensehaft" II. Heft, 1847, S. 1 ff. 
beständen: Birke, Lārche oder lïiefer auf Blößen behufs Nachzucht von Tanne, Fichte oder Buche; Kiefer in Untermischung mil Eiche, um lelztere durch Seilensclutz gegen Frost zu sichern; - 2) Mitanzucht einer Holzart, welche i ine frühe Zwischennulzung abwerfen soll, z. B. Fichte (Weihnachlsbāume!) in Pflanzkulturen zwischen ausländischen Hölzern (Douglas-

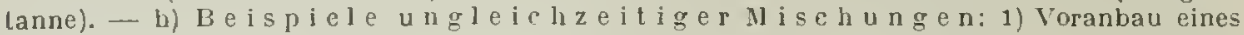
Schutzbestandes, nachfolgendes Einbringen der Hauptholzart; 2) Unterbau von Lichthölzern

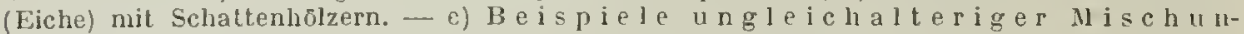
$g e n$ sind unler a und b einbegriffen

Die Entscheidung darüber, ob reine oder gemischte Bestände herangezogen werden sollen, wird, wenn zwingende waldbauliche Momente nicht vorliegen, in letzter Linie von der Rentabilität getroffen. Sofern eine Anzahl kaum entbehrlicher Holzarten im reinen Bestand nicht oder wenigstens nicht in hohem Umtriebe ohne Gefährdung der Bodenkraft erzogen werden liönnen, sind, wie bereits hervolgehohen wurde, Mischbestände eine unabweisbare Notwendigkeit. Es könnte sich aber weiterhin die Erwägung aufdrängen, ob nicht auch solche Holzarten, welche vermöge ihres dichten Kronenschlusses zu reinen Beständen taugen, wegen besonderer Vorzüge der Mischbestände allgemein besser in Untermischung mit andern Holzarten angebaut werden, ob also die Begründung gemischter Bestände nicht ganz allgemein als Regel hingestellt werden soll. Solcher V or z ü g e passend $\mathrm{g}$ e $\mathrm{m}$ is c h te r Bestä $\mathrm{n} d \mathrm{e}$ werden in der Tat mehrere angeführt ${ }^{1}$ ), und zwar wird neben der schon genannten Möglichlieit der Starkholzerziehung von Lichthölzern in der Hauptsache folgendes zugunsten der Mischbestände geltend gemacht: a) Gemischte Bestände gewähren größeren Schutz gegen gewisse Gefalıren, indem die einzelnen Mischholzarten in verschiedenem Maße (manche eventuell gar nicht) bedroht sind und dadurch für den Bestand im ganzen eine hölıere durchschnittliche Widerstandsfähigkeit entstelıt. Wenn letztere auch nicht selten nur mittelbar der Mischung, zunächst jedoch der durch sie ermöglichten liräftigeren lironenentwicklung, besserer Gesundheit in allgemeinen usw. zu verdanken ist, so bedeutet doch in sehr vielen Fällen schon die Terschiedenheit der Holzarten an sich eine größere Sicherheit für den Bestand. Beispiele: Mischung von Laubholz mit Nadelholz als Schutz gegen Feuer, Pilze und Insekten, desgleichen gegen Schneedruck; flach- und tiefwurzelnde Holzarten bilden unter Umständen einen sturmsichereren Bestand als flachwurzelnde allein; frostharte und -empfindliche Holzarten in Mischung zum Schutz der letzteren usw. - b) Gemischte Bestände ,können“ die Holzmássenproduktion steigern. Algemein ließe sich dieser Satz vielleicht aus den verschiedenen Bodenansprüchen der Holzarten, aus der Verschiedenheit ilırer Wurzelbildung (flach-und tiefwurzelnde), ihrer Kronenform, namentlich aber aus den besseren Bodeneigenschaften, welche Lichthölzern im Grundbestande von Schattenhölzern zu gute kommen usw., ableiten. Es wird aber gut sein, wenn man sich solcher allgemeiner Fulgerung gegenüber zunächst skeptisch verhält und das Ergebnis einer größeren Anzahl einwandfreier komparativer Lntersuchungen abwartet. Einige Erhebungen, welche den in Frage stehenden Vorzug gemischter Bestände bestätigen, liegen zwar vor, aber nur in beschränkter Zahll ${ }^{2}$ ). längst noch nicht genügend, um alle einschlagenden Beziehungen mit Bestimmtheit nachzuweisen. Andererseits haben z. B. nenere Untersuchungen, welche die württembergische forstliche Versuchsstation in Fichten-Buchen-Mischbeständen angestellt hat, um deren Wuchsleistung im Vergleich zu derjenigen reiner Fichten- und reiner Buchenbestände zu erfahren, durchaus keine Ueberlegenheit, sondern teihweise sogar ein nicht uner-

1) Vergh. Ca r l li e ye r dasellust $S .32 \mathrm{ff}$.

2) Carl Heyer a. a. O. S. $35 \mathrm{ff}$ - B org m a n , Grundzüge der Geschichte und Wirtschaft der ligl. Oberförsterei Eberswalde, 1905, S. 26. 
hebliches Zurückbleiben der Mischbestände ergeben ${ }^{1}$ ). Zur vollen Klärung der Frage sind noch zahlreiche Aufuahmen nötig. So wäre z. B. auch hinsichtlich einiger, in größerer Ausdehnung vorkommender Nadelholzmischungen, wie Tanne uml K̈̈icfer, Tanne und Fichte, Tame, Fichte und F̈iefer (Schwarzwald, Vogesen), welche offenbar Gules leisten, der zahlenmäBige Vergleich ihrer Massenprodulition mit derjenigen reiner Bestände jener Holzarten auf gleichem Standort noch durch ausgedehnte Untersuchungen zu führen. Nadelhölzer, wie Iijchte, Kiefer, Tanne, bilden, in Buchen einges]rengt, erfahrungsgemäB oft besonders bedeutende Dimensionen heraus. Daß übrigens eine Mehrproduktion, wenn sie insgesamt eintritt, wohl wesentlich auf freiere Kronenentwiekelung einzehner schneller wüchsiger Bäume in Mischbestande zurüclizuführen sein dürfte, während eine Wachstumssteigerung in gleichalterigen, grleichhohen Beständen durch die Mischung allein kaum oder doch nur in beschränktem MaBe verursacht werden möchte, hat Wagener ${ }^{2}$ ) hervorgehoben. Der den Mischbeständen in Verhindung nuit der Jassensteigerung vielfach noch nachgerühmte Vorzug der Wertsteigerung trifft jedenfalls noch weniger zu als der höherer Massenerträge. Der einzelne, in Nischung mit einem Schattenholz astrein und vollholzig erwachsene Lichtholzstamm kann für sich allein betrachtet selır wohl eine Wertssteigerung im Vergleich zum gleichalten Stamm des reinen Lichtholzbestandes erkennen lassen, der Gesantwertsertrag des Mischbestandes bleibt deshalb nach den vorliegenden Erfahrungen hinter dem Gesantwertsertrag des reinen Bestandes zurück. In finanzieller Hinsicht sind die Mischbestände zweifellos minderwertiger als die reinen Bestände. - c) Gemischte Bestände dienen zur Verminderung der Betriebsklassen. Dies geschieht einmal dadurch, daß sie eine einheitliche Schlagordnung (normale Altersstufenfolge) gestatten, wo sonst, weun man von jeder Holzart jälırlich einen Ertrag lıaben möchte, ebensoviele selbständige Schlagordnungen nötig wären, als Holzarten vorhanden sind (bei kłeiner Gesamtfläclie insbesondere ganz undurchführbar); sodann dadurch, daß innerhalb gewisser Grenzen ein Ausgleiclı der Umtriebszeiten im Nischbestande möglich erscheint; Verschiedenheit der Umtriebszeit wäre sonst ein zwingender Grund für Ausscheidung besonderer Betriebsklassen der einzelnen Holzarten. Beispiele: Kiefer, für sich mit S0jälırigem, Buche, für sich mit 120jährigem Umtrieb zu behandeln, lassen sich unter Lmständen in der Mischung, in welcher ein besserer Bodensehutz und Bestandesschluß als in reinen Jiefernbestand bewalut bleibt, zu einem mittleren Umtrieb von I00 Jahren vereinigen. Es kommt hinzu, daß manche Holzarten gar nicht in solcher Masse auf dem Markte begelırt werden, als daß es sich lohnen wörde, durch reine Bestände den Bedarf nachaltig decken zu wollen, während man sie andererseits doch im Handelsverkelır niclıt ganz entbelıren kann (Ahorn, Linde, Elsbeere usw.). - d) Die Mischung versehiedener Holzarten kann ein Nitte] bieten zur IJerbeiführung raselı und regchäßig verlaufender Streuzersetzung, die im Gegensatz zur Anhäufung von mehr oder weniger toten Humusmassen nur erwünscht ist. Denn die Art der Zersetzung (Umfang, Raschheit derselben) ist bein Laub bezw. den Nadeln verschiedener Holzarten eine w esentlich verschiedene, und es leuchtet ein, wie günstig es wirken kann, wenn leicht und rasch zersetzbare Streumengen zu widerstandsfähigeren hinzutreten. Leicht zersetzbar ist z. B. das Laub von Esche, Ahorn, Hainbuche, sind die Nadeln von Weymouthskiefer und Douglasie. Besonders vorteilhaft ist im Hinblick auf die normale Zersetzung der Streu

1) Vergl. L o rey, Mischbestände aus Fichte und Buche. Allg. Forst- und Jagd-Ztg. 1902 , S. 41.

2) Vergl. W a g e n e r, ,Waldbau", S. $141 \mathrm{ff}$. 
die Mischung von Laubholz (Buche) mit Fichte ader Tanne. Die mit der Lockerung des Kronendaches durch das winterliahle Laubholz in Verbindung stehende stärkere Einwirkung der Atmosphärilien auf die Streudecke führt, von den Vorteilen der Mischung der Streu ganz abgesehen, zu rascherer Zersetzung des Pflanzenabfalles. e) Gemischte Bestände tragen unzweifelhaft zur Verschönerung der Gegend bei.

Diesen Vorzügen stehen aber doch manche nicht unerhebliche $\mathrm{B}$ e d e $\mathrm{n} k \mathrm{k} n$ gegenüber: a) Selbst wenn wirklich allgemein die Mischung eine $\mathbf{M}$ a s s e $\mathrm{n}$ produktionssteigerung bedingen würde, müßte von iłr abgeselien werden, falls die Gesamtw e r t s erzeugung des Bestands dadurch eine beschränktere würde, daß geringwertige Holzarten (z. B. Buche) einen Teil der Stellen einnehmen, an welchen lı̈herwertige (Nutzhölzer, wie Fichte, Tanne ete.) stehen könnten. Es ist freilich in vielen Fällen fraglich, ob diejenige Holzart, welche heute die vorteilhafteste ist, dauernd den Vorzug verdienen wird, oder ob ilır nicht eine andere in Zukunft den Rang ablaufen wird. Im allgemeinen wird aber jedenfalls das Nutzholz dem Brennholz überlegen bleiben, so daß es recht wohl verständlich ist, wenn man sich insbesondere gegen eine e $\mathrm{r}$ h e b l i c lı e Beimischung der Buche zu schattenertragenden Nadelhölzern (Tanne, Fichte) ablehnend verlıält. - b) Gemischte Bestände verursachen, in Absicht auf Forsteinrichtung, Bestandesbegründung und -erziehung, Holzernte usw. manche Wirtschaftserschwerung, während umgekehrt reine Bestände sämtliche waldbaulichen Operationen, ganz besonders die in Mischbeständen hochwichtigen Erziehungsmaßnahmen vereinfachen, die Erntearbeiten, die Abgabe und den Transport des Holzes erleichtern und nach der betriebstechnisehen Seite viel bequemer sind. Wohl hauptsächlich aus letzterem Grunde, der aber, selbst wenn die Tatsache an sich richtig ist, niemals für die Wahl des Wirtschaftsverfahrens allein entscheidend sein darf, finden sich gemischte Bestände längst noch nicht oder längst nicht mehr in der für sie von einer Mehrzahl von Forstwirten gewünschten Verbreitung. Daß reine Bestände dann, wenn die e i n e Holzart örtlich unzweifelhaft die tauglichste, bezw: vorteilhafteste ist, den Vorzug verdienen, bedarf keiner nochmaligen Hervorhebung.

In solehen gemischten Beständen, in denen zwei oder mehrere Holzarten nicht zu annähernd gleichen Teilen vertreten sind, sondern eine Holzart entschieden überwiegt, bildet diese, die wohl auch als die herrschende bezeichnet wird, den sog. Grundbestiand, während die anderen Holzarten als beigesellte oder Nebenholzarten erscheinen. Diese Unterscheidung bezieht sich zunächst nur auf Häufigkeit des Vorkommens im Bestande. An Wertsleistung und damit auch an Bedeutung für den Effekt der Wirtschaft ist die beigesellte, in der Minderheit vorhandene Holzart nicht selten der den Grundbestand bildenden überlegen, so daß sie eigentlich zur führenden, zur Hauptlolzart wird. Insbesondere gilt dies von den Mischungen der Rotbuche mit Nutzhölzern.

(6-2) Allgemeine Regeln für die Anlage gemisehter Be$\mathrm{s}$ tän d e.

$\$ 11$. Voraussetzung ist, daß die Holzarten an sich für den betreffenden Standort passen.

a) Den Grundbestand der Mischung nuß eine schattenertragende Holzart bilden, d. h. eine solche, welche in dem in $\$ 9$ angegebenen Sinne die Bodenkraft erhält. - b) Werden Sehattenhölzer miteinander gemischt, so müssen sie entweder gleichen Hölıenwachstumsgang haben, oder es muß die langsaner wüelısige einen Vorsprung besitzen oder durch wirtschaftiche Maßregeln (Freihieb) geschützt werden. Bei allen Mischungen ist natürlich die relative Beteiligung der versehiedenen 
Holzarten von Belang. Es ist z. B. sehr viel leichter, eine geringere Zahl von Exemplaren der rascher wüchsigen Fichte im Buchengrundbestande hoch zu bringen als umgekehrt wenige Buclien im Fichtengrundbestande. - c) Schattenhölzer und Lichthölzer taugen nur dann zu einer Mischung, wenn die letzteren dauernd die ersteren überragen, was dann geschieht, wem sie entweder rascher in die Höhe gehen als die Schattenhölzer oder, im Falle gleicher oder gar geringerer Höhenentwickelung, einen entsprechenden Altersvorsprung vor diesen haben.

Zur Erläuterung der Sätze b unct $\mathrm{c}$ sei darauf hingewiesen, daß keine einzige Holzart - auch die Schattenhölzer nicht - bei andauernder Ueberschirmung sich gut zu entwickeln vermag. Mindestens muß der Gipfel schirmfrei sein, d. h. frei zum Luftraum hinaufschauen, olnne daß die Aeste von Nachbarn über ihn hereinragen. Wenn auch ausgesprochene Schattenhölzer, wie in erster Linie die Tanne, selbst durch eine länger dauernde, mehr oder minder intensive Beschirmung noch nicht geradezu zun Absterben gebraclat werden, so ist ihr Wuchs doch unter solchen Verhältnissen ein kümmerlicher. Dabei finden sich naturgemäß nach Holzart, Beschaffenheit des Jndividuums, Alter, Standörtlichkeit, Maß und Zeitdauer der Ueberschattung usw. die mannigfaltigsten Abstufungen. Lichthölzer sind in dieser Hinsicht sehr viel empfindlicher. Dies liegt sehon im Begriff des Liehtholzes. Bei extremen Lichthōlzern (Lärche) genügt es zur freudigen Entwickelung keineswegs, wenn ihr Gipfel freien Himmelsraum über sich lat, sondern sie verlangen dazu auch, daß ihre lirone, oder doch wenigstens deren oberer Teil, seitlicl nicht beengt ist. $1 \mathrm{~m}$ allgemeinen sind die einzclnen Holzarten in dieser Hinsicht um so anspruchsvoller, je größer jhr Lichtbedürninis ist. Jedenfalls ist dieses versehiedene Verhalten bei der Frage nach der Mischungsmöglichkeit in erster Linie zu beachten. Die Möglichkeit der Mischung ist auch wesentlich von dem relativen Höhenwachs tum der Holzarten abhängig, d. h. davon, wie sich durehschnittlich die Höhenentwickelung einer Holzart zu derjenigen einer anderen Holzart vollzieht. Jede Holzart hat ihre (namentlich durch den Beginn des raschen Ansteigens, sowie durch die Lage des Wendepunktes in der Jugend und dann des Iulminationspunktes im späteren Alter) besonders charaliterisierte Hölıenliurve. Die absoluten Werte der Ordinaten ändern sich innerhalb der nämlichen Holzart nach dem Standort, der WaldbehandJung usw., während das relative Verhalten, trotz der mit wechselnder Standortsgute sich verschiebenden Lagerung der charakteristischen Kurven punkte, namentlich des Maximums, doeh ungefähr das gleiche bleibt (cfr. II. 3 dieses Abschnittes S. 12). Wird eine Holzart von einer anderen überwachsen, so wird sie dadurch meist (Beschattung, Entzug der Niederschläge ete.) geschädigt, kann jedoch auch, vorübergehend wenigstens, (dureh Schutz gegen Frost, Hitze) in ihrer Entwickelung gefördert werden, letzteres aber nur, wenn die überwachsende Holzart nicht zu massenhaft beigemengt und nicht zu dichtkronig ist, weil anderenfalls die schädigenden Einflüsse überwiegen. Ueberdies ist ein solcher Schutz meist nur in der Jugend von Belang. Namentlich wenn gleichzeitige, bezw. gleichalterige Mischungen beliebt werden, ist in erster Linie die Höhenentwickelung im jugendlichen Alter entscheidend. Eine Lichtholzart verträgt, wie schon angeführt wurde, dauernde Ueberwachsung in keinem Falle, am allerwenigsten durch eine Schattenholzart, während umgekehrt der lockere lironenschirm nicht zu zahlreicher Lichthölzer (wie Lärche, Birke) einem Schattenholz die normale Entwickelung nicht notwendig benimmt. Seiten)icht (Bestandesränder, Steilhänge) wirkt modifizierend.

d) Lichtbedürtige Holzarten sind zu dauernden Mischungen nicht zu verbinden. Folgt aus a. Ausnahmen ergeben sich in den nämlichen Fällen, in welchen auch reine Bestände aus Lichthölzerı unbeanstandet bleiben (cfr. S. 19). - e) Die Mischung kann, je nach Umständen, eine gruppen- und horstweise oder eine Einzelmischung sein.

Man spricht von Einzelmischung, wenn Einzelexemplare verschiedener Holzarten in der Zusammenordnung zum Bestand mit einander abwechseln oder die Exemplare einer Holzart einzeln in dem durch eine andere Holzart gehildeten Grundbestande eingesprengt sind. Treten dagegen die einzelnen Holzarten in einer Hehrzahl von Exemplaren zusammen, bilden also für sich Gruppen oder (bei größerer Flächenausdehnung dieser Verbānde) Horste, und setzen dann im wesentlichen solche Verbände je der gleichen IJolzart in Abwechselung die Bestande zusammen, so hat man die gruppen- oder horstweise Mlischung. Gruppe und Horst gehen ineinander über; eine für alle Fälle bestimnte Größe der Flăche als Grenze für beide Jäßt sich nicht angeben. Mlan kőnnte, wenigstens bei Lichthölzern, vielleicht die Gruppe im Gegensatz zum Horste dann noch als gegeben ansehen, wenn im Alter der beginnenden natürlichen Lichtstellung vom umgebenden Bestandesrand her noch eine für den Boden genügende Beeinflussung (Laubahfall, Beschattung) bis zur Mitte der betr. Fläche hin stattfindet, während man einen Horst hat, sobald die bodenschützende Wirkung des Grundbestandes sich nicht mehr auf die ganze Fläche erstreckt. 
Eine allgemein bindende Fegel soll in Beziehung auf die Interscheidung ad e nicht aufgestell werden. Heyers Waldbau verlangt im allgemeinen (5. Aufl. S. 53) Einzelniselsung, während viele neuere Waldbauscliriflen (z. B. G a yer ${ }^{1}$ ) mehr für gruppen- und harstweise Mischung eintrelen. Bei Beantwortung der Frage, ob man reine oder gremischte Bestände vor siclı habe, also bei der Definierung dieser beiden Bestandesarten, muß grundsătzlich daran festgehallen werden, daB ein Mischbestand imstrengen Sinne des Wortes eigenllich nur dann vorliegen würde, wenn durchgängig in obigem Sinne Einzelmischung vorhanden wäre. Bestände, in welchen in der Hauptsache Einzeltäume, bezw. an deren Stelle auch wohl $\mathrm{k} l \mathrm{e}$ i $\mathrm{n}$ e Gruppen (Trupps) der verschiedenen Holzarten in Untermischung stehen, finden sich $\mathrm{z}$. B. bei Tanne und Fichte. So oft eine Lichtholzart mit in Konkurrenz 1rill, ist das Verhalten in der Regel so, daß man einen mehr oder minder zusammenhängenden Grundbesland der Schaltenhölzer hat, in welchem die Lichthölzer verleilt sind, und nun kommt es darauf an, ob diese Verteilung (kunstlich oder durcl dic Natur) so bewirki ist, da $\beta$ dic Individuen der Lichtholzart zumeist in Gruppen und Horsten zusammenstehen oder als Einzelexemplare aufireten. Horste, ja selbst Gruppen (also kleine Horste) einer beigesellten Holzart sind, genau genommen, nichts anderes als reine Bestände, mithin treffen für sie a priori alle die für solche geltenden Sälze zu, nur dadurch modifiziert, daß von den Rändern des Horsts her der Einfluß des umgebenden Holzes sich auf eine gewisco. Erslreckung hin geltend macht. Namenllich wäre ein größerer Horst aus Lichthölzern zunächst ebenso bedenlilich, wie ein reiner Bestand aus solchen. Diese und die weitere Erwägung, daß eine gegenseitige Beeinflussung der Mischhölzer in Sinne der Stammpflege nur dann möglich isl, wenn die Individuen der verschiedenen Arlen miteinander in lionkurrenz Ireten, fuhrtzu Einzelmischung. Aber es ist zu beacliten, daß letzlere die Bestandesrrziehung erschwert, indem man die einzeln eingesprengten Beiholzarten nicht so leichl im Auge behalten kann, als dies bei horstreiser Anordnung derselben möglich ist ${ }^{2}$ ). Die Lichthölzer werden in vorgeschritteneren. Alter von den Schattenhölzern immer mehr oder weniger bedrängt. Hat man Lichtholzgruppen und -Horsle, so haben nur die Randstämme derselben den Kampf zu bestehen, während die Bäume in deren lnnerem sich nur mit ihresgleichen abfinden müssen. Sofort aber isl zu erwägen, ob ter bodenschülzende Einfluß des umgebenden Grundbestandes sich his in die Nitte der belr. Fläche erstreclí, oder ob nicht für letztere noch besondere Mittel zur Bewahrung der Bodenkraft (Unterbau) erforderlich werden. Die kleinere Gruppe kann solcher Maßnalımen wohl entraten; aber sobald man mit Horsten operiert, löst sich das Ganze unzweifelhaft in einen Komplex aus einzelnen reinen Beständen auf, für welche nur an den Rändern die Bedingungen des Mischbestandes noch als vorhanden eingeräumt werden konnen. Die ganze Frage wird eigentlich vom Standort enlschieden. Man sollte — soweil sich dies nit der Lebersichtlichkeit der Wirtschaft, einem Betrieh in großem Zuge, der manchen Vorteil bjetet, vertrāgt - grundsätzlich auf jedem (kleinen oder großen) Waldbodenteil diejenige Holzart erziehen, welche für ihn am besten paßt, bezw. auf ihm am besten rentiert. Freje Wahl lıätte man hiernach also nur auf Böden, welche durchgängig gleichartig sind und melıere Holzarten zulassen. IJier kam man mischen oder (Schattenhölzer) rein anbauen, man kann Einzelmischung oder horstweise Anordung wählen, und hier wäre die Einzelmischung im allgemeinen vorzuziehen. In sehr vielen Fällen, und vorab fasl stets im Hügelland und Gebirg, also wohl auf dem größeren Teil unserer gesanten Waldbodenfläche, wechselt aber die Standortsgüle, oft innerhall, der einzelnen Waldabteilung (Mulden, Rücken etc.). Will man auch nicht jeden einzelnen kleinen Unterschied herüchsichtigen, so muß doch einı sorgfältige Begutachtung der Bodenproduktionsfähigkeit in dem $l$ aße gefordert werden, da $B$ man nicht größere in sich nicht gleichartige Flächenteile gleichwoht mil. Gewalt als einheilliche Ganze bewirtschaftet, sondern bessere Partien den anspruchsvolleren Holzarten (z. B. tiefgründige, frische Böden der Eiche) zuweisl, diese dagegen von geringeren Parlien (sleinigen, trockenen köpfen usw.) fern hält. Wie weit nan bei solcher Ausscheidung ins Delail arbeiten soll, läßt sich nichl allgemein bestimmen. Jedenfalls aber geht dadurch die Einheitlichkeit des Beslandes innerhalb des einzelnen Waldteiles vertoren und der Gesamtbestand gestaltet sich zu einer Anzahl von Einzelbestånden, die in sich gleiclıartig (reine Bestände, event. init Unteruau), aber auch wieder Vischbestände sein können. Es kann sich in einzelnen nalurgemäß eine größere oder geringere Mannigfalligkeit ergeben, je nachdem man der einen oder anderen der dabei auftretenden Erwägungen (sorgsamsle Ausnutzung jeder kleinen Bodenverschiedenheil einerseils, oder Vereinheitlichung der Wirtscliaft und Vereinfachung der Forsteinrichtung andererseils etc.) das grōßere Gewicht beimißı. In den meisten Fällen wird Vermeidung der Exlrene im Inleresse der Wirtschaft (wenigstens hej großem Waldbesitz) gelegen sein.

3) Spezielle Regeln:

S12) a) Seh a t ten hölzer un ter einander:

1) Ta n ne un l Fichle: Dit Tanne, in der Jugend langraner wüclsig, wird von

1) G a y er, "Waldbau" und dessen ,Der gemischle Wald, seine Begründung und P'lege, insbes. durch Horst- und Gruppenwirtschaft", 1886.

2) Durch regelmäßigge V'ertcilung etwa in Reihen oder dergl. läßt sich ubrigens manchmal, wenn auch lieineswegs imner, helfen. 
der Fichle uberholt, komml aber wieder nach, falls dic Fichte nichl zu zahlreich. Schr gute Mischung ${ }^{1}$ ), die bei nalirlicher lirjungung wieder erscheinl, wenn durch lieduklion der Fichlen auf eine geringere Zalıl, sodann durel l)unkellalten des Samenschlags (so daß der Fichtenanflug zunächst wieder vergeht, wảhend sich dir Tanue hảll) dic Tanue vorerst leegünstigt wird. Die lin und wieder angewendele regchuaßige reihenweise Misclung lahrt genein. hin zu keincm befriedigenden lesultat, ebensowenig wie die regelmäBige Einzelmischung. Dic "Tanne wird in solchen Misclungen, nanentlieh dann, wenn der Boden den von ihr gestellen löheren Ansprüchen in bezug auf Nährhaft unl Tiefgründigkeit nicht entsprichl, von der Fichte von Jugend auf uberwachsen und bleibl, wenn ihr nicht ganz energiseh zu llilfe geliontmen wird, sitzen. - 2) Tan $\mathrm{T}$ e $\mathrm{u}$ d $\mathrm{B}$ u c he: Die größere Nutzfähigheil der Tanne verlangt besondere Rücksichtnahmc auf diese llolzart; sie soll herrschende Holzart sein und ist, namentlich auf der Buche behagenden Standort, in der Jugend vor der Buche zu schülzen. Bei der Verjüngung ist zunächst nur auf Tanne zu wirtschaften und ersl, wenn deren Nachwuchs gesichert ist, die für die junge Bnche nötige lichtere Stellung zu gelen. Größere sicherheil der mil Buche durchstellten Tannenbestände gegen Stürme! - 3) B u c ls e m it Fichle: Auch hier ist die Buche an sich dic minderwertige Holzart. Sie wird von der Fichte bald uberholl und bei reichlicher Beimischung derselben in eine mehr untergeordnete Stellung gedrängt. Will man dic Buche gleichwertig erhalten (wozu aber meist kein Grund vorliegen dürfle), so muß sie an Zahl überwicgen. Im allgemeinen wird es, auch mil Rücksiclıt auf den Boden ele., genügen, wenn die Buche in der Zusammenordnung nit Tanne oder Fiehle oder mit beiden elwa $1 / 5-1 / 5$ der Bestandesmasse ausmacht und zwar mehr in Gestalt cines Zwischen- und Fullholzes, weniger als herschender Stamm. Tritt die Buche aber nicht herrschend, sondern mehr nur als bodenpflegendes Füllholz auf, so bereitet die Verjüngung soleher Beslande, vorausgesetzt, daß die Mischung in dem genannten Verhältnis auch in dcn neuen Bestande beibchalten werden soll, meist große Schwierigheiten und endel vielfach mil dem Ergebnis, daß an Slelle des eltemaligen Misclibestandes ein reiner Fichlen- bezw. Tannenbestand lritt, dem nur auf künsllichem Wege (dureh Unterban oder Saat) die gewünschte Durchsprengung mit Buche verschaff werden kann. - 4) T a n n e, Fich t e u $\mathrm{d}$ B uche: Treffliche Nischung, wenn Tanne und Fichle aberwiegen. Wo die Buchenbrennholzpreise besonders hoch stehen, oder sich für Buchennutzholzverwendung ausnahnsweise günstige Gelegenheit bietet, kann man der Buche in der Misclıung selbstredend melır Raum gönnen. Bei cłer lerjüngung entscheidel, falls die Mischung erhalten bleiben soll, zunächst wieder dic für die Tanne geeignete dunkle Schlagrtellung.

b) Schatten-und Lichth ölzer:

1. Ta $\mathrm{n}$ ne als Grundbestand: Charakteristisch ist, daß die Tanne anfänglich von allen Lichlhölzern ïlyerwachsen wird, ihnen (namentlicl den Laubhölzern) aber in Stangenholzaller (früher oder späler) vielfach wieder nachkommt, ja viele von ihnen erheblich überwäehst. Glejchallerige Mischungen der Tanne mit lichtbedürftigen Laubhölzern, wie Eiche, Esche, Alorn finden sich in den Haupltannengebieten von Nalur kaum anders als so, daB diese Holzarten einzeln da und dort eingesprengt sind, oder so, daß die gleichzeitig beigesellte Buche gewissermaßen die Vermitlelung übernimmt. Jene Mischung planmäßjg lierbeizuführen, liegt meis l kein Grund vor. - Dagegen kann sicl wirtschaflliclı sehr empiehlen ${ }^{2}$ ) die Mischung der Tanne mit der lijefer, welch letzlere Iolzarl den höheren Tannenumtrieb meisl trefflich auslaält und dabei besonders wertvolle stämne herausbildet. - Tanne mit Lärche insofern bedenklich, als es im geschlossenen Beslande oft nicht gelingt, der lichtbedürítigen Lärche, welche selbst seilliche Bedrängung übelnimmt, den erforderlichen Vorsprung dauernd zu walıren. Tanne und Birke nur insolange zulässig, als die vorwüchsige Birke die Gipfel der Tanne nicht beschädigt (event. Schneitelung der Birke).

2. F i c h t e als Grundbesland: Die Fichle verhält sich im allgemeinen ähnlich wie die Tanne, geht nur von vornherein rascher in die Höhe und bedarf deshalb in der Jugend nicht in dem Maße, wie die Tanne, der Unterstülzung im liampf mit ancleren Holzarten. Fichte mil Kiefer meist gul. Bei gleichzeitiger Mischung der Fichte und Kiefer muß aber, falls man nichl demnächst einen lijefernbestand nit Fichtenunterwuchs lıben will, die Fichte an Zahl beträchtlich vorherrschen. Je nach dem Slandort isl die Gefahr für die Fichte größer oder geringer (auf trockenen Böden bleibt die Fichle rascher zurück). Die von der liefer nicht völlig unterdruckten Fichten holen auf besseren Böden die lïefer spälel wieder ein, zumal bei erlı̈hten Lichtgenuß, wie z. B. infolge Schneehruchs Bislang völlig zurückgebliebene Fjehten erweisen sich dann oft noch als selır enlwickelungsfähig, indem sie in die entstandenen Lücken einwachsen. Bei reihenweiser oder Einzelnisclung von Fiehle und liefer ist darauf zu achlen, daß auf Böden, die das Hochwerden der Fichte nicht erwarten lassen und ilır von vornherein die Rolle als Bodenschutzholz zuweisen, die Kiefer in hinreichend engen Vuband erzogen wird, da sonst die über die Fichten hinauswachsenden Kiefern ästige Sperıüchse werden. - Fichte nit

1) Z. B. in vielen Revieren des Schwarzwaldes. Die Mischung ist dasclbst meisl eine gruppen- und horstweise, wie dies durch den Gang der Verjüngung bedingt ist.

2) Z. B. Oberforsterei WasseInheim - Elsaß. 
Lārche meisi noch weit zweifelhafter wie Tanne mit Lärche, weil die Fichte der Lärche rascher nachdrängl. Bei räumlicherer Bestandesstellung und im Genusse reichlichen Seitenlichtes (höhere Gebirgslagen, steile Hänge) gelingt es der Lärche eher, ja bisweilen sehr gut, sich zu behaupten, insbesondere, wenn sie der Fichte reichlich beigesellt ist. - Fichte mit Birke, wie Tanne mit Birke. - Desgleichen Fichte mit Eiche, Esche, Ahorn, Ulme etc. Will man, um in einem Fichtengebiet genügende Itengen von Eichenholz zu erziehen, etwa Fichte und Eiche in Mischbeständen haben, so empfiehlt sich Einbringen der Eiche in Horsten bezw. flächenweise Sonderung. Bei reihenweiser oder Einzelmischung wird die Eiche meist früher oder später von der Fichte tolgedrückt. Diese Mischung empfiehlt sich nach vielen übereinstimmenden Erfahrungen gar nicht. Ebensowenig ist der Unterbau älterer Eichenbeslände mit Fichte zu empfehlen: auf nicht sehr frischen Böden führt der Fichtenunterwuchs zur Zopfdüre und Zuwachsrückgang der Eichen.

3. $\mathrm{B} \mathrm{u} \mathrm{c} \mathrm{h} \mathrm{e} \mathrm{als} \mathrm{Grundbestand:} \mathrm{Die} \mathrm{Buche} \mathrm{ist} \mathrm{für} \mathrm{die} \mathrm{meisten} \mathrm{lichtkronigen} \mathrm{Laubhölzer}$ die gegebene, ebenso aber auch für lỉefer und Lärche eine treffliche Mischholzart, welche durch ihre schirmende lírone und ihren Laubabfall auf den Boden in hervorragendem Maße günstig wirkt. Nur muß man sorgen, daß die Lichthölzer, falls sie nichl entschieden rascher wüchsig sind als die Buche, von letzterer nicht bedrängt (seilliche Beengung der lírone ist oft schon verderblich) oder gar überwachsen werden. In Untermischung mit der Buche zieht man die Halbschaltenhölzer Hainbuche, I.inde am besten. Sodann werden Ahorn, Esche, Ulme, Birke, Aspe etc., vor allem aber die Eiche zweckmäBig mit der Buche zusammengebracht. Ahorn kann in der Jugend recht vordringlich werden und isl dann, wenn die Buche nicht zu sehr zurücktrelen soll, zu reduzieren; Esche und Ulme in großer Zahl sind (wegen des besonders werlvollen Holzes) meist nur erwüscht. Der Mischung der Buche mit Esche und Ahorn koinmt örtlich (z. B. in der schwäbischen Alb) besondere Wichligkeit zu. Birke und Aspe dürfen mit Rücksicht auf Bodenschulz und Massenproduktion nicht in größerer Menge und jedenfalls nicht in größeren Gruppen oder gar Horsten vorkommen. - Von hervorragender Bedeulung ist die Mischung der Buche und Eiche, und zwar handelt es sich hier zunächst un (wenigstens annähernd) gleichallerige Mischung (Unterbau der Eiche ist später, § 84 besprochen). Ob Eiche oder Buche vorwüchsig ist, läßt sich zwar nichl ganz allgemein angeben ${ }^{1}$ ), doch ist in dieser Hinsicht der schon S. 13 berührle Unterschied zwischen Sticleiche und Traubeneiche zu beachten; der, ausweislich zahlreicher Beobachtungen ${ }^{2}$ ), mehr Schatlen und Scitendruck ertragenden, anspruchsloseren, schnellwüchsigeren und durch bessere Schaftbildung (vielleicht infolge der kräftigeren Endknospe) gekennzeichneten Traubeneiche wird die Konkurrenz mit der Buche leichter. Nach den Erfahrungen im Solling ${ }^{3}$ ) häll die Trauheneiche im rascheren Wachstum aus und bleibt infolgedessen im gleichalterigen Buchengrundbesi ande nitherrschend, die Stieleiche vermag auf gutem Boden wohl in der ersten Jugend mil der Buche Schritt zu halten, unterliegt aber bald. Immerhin wird, wie auch im Spessart zu beobachten ist, auch die Traubeneiche im Slangenholzalter von der Buche oft eingeholt und so hart bedrängt, da $\beta$ einzeln stehende Exemplare sich in umgebenden Buchenbeslande nur zu halten vermögen, wenn ihnen durch Freihieb seitens der Wirtschaft ausgiebigste Hilfe gewährt wird. Lelztere muB schon im Gertenholzalter einsetzen und durch alle Lebensalter des Bestandes andauern: eine im großen Betrieb sehr weilgehende Forderung, welcher nicht ohne oft beträchtliche Kosten, jedenfalls aber nur hei größter Aufmerksamkeit und Ausdauer des Wirtschaftspersonals genügt werden kann. Horstweises Einbringen der Eiche (Horste von beträchtlicherem Umfang am meisten empfohlen) in Gestalt des Vorbaus (am beslen durch Saat), so daB die Eiche einen entsprechenden Höhenvorsprung hat, sichert deren Heraufwachsen innitten des später sich ringsum einstellenden Buchenaufschlags; man kommt dann aber, wie schon oben S. 24 betont wurde, zu reinen Beständen, welche demnächst unterbaut werden müssen $\left.{ }^{4}\right)$.

\section{c) L i chthölzer un ter e in a nder.}

Besondere Fälle sind z. B. Birke, Eiche elc. eingesprengt in die Kiefernbestände auf Sandbüden, wo man sich, um aberhaupl elwas Laubholz zu erziehen, mit dieser an sich zweifelhaften Mischung begnügen muß. Sodann: Erle mil Esche, auch Birke (bes. Belula pubescens) etc. auf nassen Standorten; Eiche mil Ulme, Esche, Erle, Pappel u. a. auf den fruchtbaren, tiefgründigen Böden der Flußnjederungen usf.

Die ehemals häufigere Mischıng zweier Lichthölzer, die von lïiefer und Eiche, die durch das Vorkommen guler Eichen auf hinreichend frischen und liefgründigen, mineralisch nicht zu armen Kiefernstandorten gewissermaßen legitimiert sind, kann dort, wo der Boden eine befriedigende Entwicklung der Eiche gewährleistet, besser ersetzt werden durch die Mischung

1) E d. H e y e r (cfr. u. a. Zeitschrift f. Forst-u. Jagdwesen, Novbr. 1886) führt das latsăchlich oft raschere in die Höhewachsen der Eichen gegenüber der Buche auf die geringere Emplindlichkeit der Eiche gegen Frost, bezw. das bessere Ueberwinden der Frostschăden zurück; in frostfreier Lage (Nord-, Wrsthänge) sei die Buche in der Jugend vorwüchsig.

2) Cir. u. a. N e y in "Aus deni Walde" Nr. $\$ 9$ von 1899.

3) Verhdlgn. d. Hils-Solling Forslvereins. 27. Vers. 1890, S. $10 \mathrm{ff}$.

4) Vergl. G a y e $\mathbf{r}$, ,Die neue Wirtschaftsrichtung in den Slaatswaldungen des Spessarts", 1884 . 
der Eiche mil einem dann zweifellos auch entwicklungsiuhgen Schattenholz. Auf ausgesprochenem liefernboden aber, wo die Eiche die ihr nötigen Bodenverhåltnisse nicht findet und deshalb von der Kiefer leicht überwachsen wird, lıat diese Mischung ebensowenig Berechtigung wie die auf eine totale Verkennung der Lärchennalur sehließen lassende Mischung der Kiefer mit der Lärche. - Auch die hier und da aus Aushesserungen lückiger Eichenkulturen hervolgegangene Mischung von Eiche und Lärche hal meist $z u$ keinem anderen Ergebnis als zu frühzeilig zurückgehenden und verunkmatenden Bestānden geíürt.

Alle Erfahungen mit Mischungen von Lichtholzarten unter sich weisen darauf hin, daB solche Mischungen nur auf den besten und auf den schlechlesten Böden zulässig sind. Auf den ersteren findet sich der nolwendige Bodenschutz meist von selbst in Gestalt von Slrauchwerk und Unterholz (Auevaldungen) ein oder kann durelı Unterbau eines Schaltenholzes gesehaffen werden; auf den lelzteren, wo meist sowieso nur Lichthölzer, Kiefer und Birke gedeihen, maeht es nichls aus, ob diese rein oder in Mischung auftreten.

Bestände aus Kiefer und Eiehe in der Form abweehselnder breiter Streifen aus den beiden Holzarten sind füglich als entsprechend viele schmale reine Beslände zu belrachten. Die Eichenstreifen, welche meisl höheres Alter erreichen sollen, müssen unlerbaut werden.

\section{Holzartenweehsel.}

§ I3. Ist es für die Erzielung dauernd liöchster Ertragsleistung notwendig, nach Abtrieb eines Bestandes, also etwa von Umtrieb zu Umtrieb, mit der Iolzart zu wechseln? Da die Holzarten verschiedene Ansprüche an die Mineralbestandteile des Bodens machen, so liegt der Gedanke nahe, ob nicht durch regelmäßigen Holzartenwechsel in dem Sinne, wie die Landwirtschaft einen Fruchtwechsel eintreten läßt, von einem bestiminten Boden dauernd die höchstmöglichen Erträge an Forstprodukten erzielt werden können. Vorausgesetzt, daß die hierbei für einen konkreten Fall etwa in Walıl kommenden Holzarten im übrigen wirtschaftlich gleichwertig sind, läßt sich gegen einen solchen Wechsel an sich nichts einwenden, Aber einmal ist diese Voraussetzung in den weitaus meisten Fällen nicht zutreffend, und sodann ist der Weclısel der Holzart als Regel mindestens keine Notwendigkeit, weil - bei einer den Boden sorgsam pflegenden Wirtschaft - durch den relativ sehr geringen und je nur in langen Zeiträumen erfolgenden Entzug an Mineralstoffen keine so weit gehende Schwächung der Bodenkraft stattfindet, daß bei wiederholter Anzucht der gleichen Holzart ein Nachlassen im Ertrag oder gar ein völliges Versagen zu befürchten ist. Wo freilich die nötige Bodenpflege felıt, wo insbesondere rücksichtslose Streunutzung, unbedachte Verlichtung der Bestände usw. das fernere Gedeilien einer irgend anspruclisvollen Holzart zweifelhaft machen, da kann die Vermittelung einer minder begehrliclien Holzart zum Zwecke der Bodenverbesserung angerufen werden müssen (Kiefernanbau auf zurückgegangenen Laubholzböden). Derartige durch eine Notlage herbeigeführte Holzartenwechsel lassen sich vielfach nachweisen (nordwestdeutsches Heidegebiet). Ebenso tritt jetzt in vielen Fällen aus rein wirtschaftlichen Gründen eine wertvollere Holzart an Stelle einer minderwertigen (Umwandlung von Buchenorten in Nadelholz), ein Vorgang, welcher stets gerechtfertigt ist, wenn damit unzweifelliaft eine $\mathrm{d}$ a u e $\mathrm{r} n \mathrm{~d}$ höhere Rentabilität des Waldes herbeigeführt wird. Auch Gründe des Forstschutzes (Wildschaden, Schnee, Inselsten etc.) können da und dort einen Holzartenweclisel, zumal den Uebergang von reinen zu gemischten Beständen, rätlich erscheinen lassen. Solche und ähnliche, durch Rücksichten der Wirtschaftlichkeit und den ungestörten Verlauf des Forstbetriebes gebotene besondere Maßnahmen sind immerhin nicht geeignet, einen Holzartenwechsel als Regel zu empfehlen. Es scheint aber, als legten in unseren in Banne der modernen Betriebsformen stehenden Wirtschaftswäldern die in den gleichalterigen geschlossenen Beständen unserer Hauptholzarten sich ausbildenden ungünstigen Humusverhältnisse dem Wirtschafter nahe, durch Mischung einem wenigstens partiellen Holzartenwechsel naclizugehen, um dem weiteren Fortschreiten des mancherorts bemerkbar 
werdenden Bodenrücliganges (durch Trockentorfbildung) vorzubeugen. Man muß H. J entsch beistimmen, wenn er darauf hinweist ${ }^{1}$ ), daß die immer lauter erlobene Forderung gemischter Bestände ein Zugeständnis an das , Naturgesetz des Fruchtwechsels" ist und daß in den gemischten Beständen ein modifizierter Fruchtwechsel erblickt werden lianm. Nicht unbeachtet darf bleiben, daß Mischbestände nicht nur im Hinblick auf den physikalischen Zustand des Bodens wertvoll sind, sondern auch als geeignetes Mittel gegen einseitige Inanspruchnahme seines Nährstoffgehaltes angesehen werden müssen. In teilweisem Zusammenlang mit dem Streben, der Notwendigkeit eines totalen Holzartenwechsels, einer vollständigen Umwandlung vorzubeugen, steht ferner die Frage, ol, nicht auch in Walde, in analoger Weise wie im Landwirtschaftsbetriebe, mit liünstlicher Düngung nacligeholfen werden sollte. Tatsäclılich ist man dieser Frage in neuester Zeit näher getreten, indem man die Düngung niclıt mehr auf dic Saat- und Pflanzbeete der Forstgärten beschränkte, sondern sie auch, wenigstens versuclisweise, auf Kulturflächen des freien Waldes, in Gerten- und Stangenhölzern angewendet hat. Nur planmäßig eingeleitete Versuche größeren Unfanges und unter verschieclenartigen Verhältnissen liönnen uns die notwendigen Aufschlüsse gewähren (vgl. vierter Abschnitt, Bodenpflege).

$\$ 14$. Ihrer wenn auch nur äußerhichen Verwandtschaft mit der Frage des Holzartenwechsels wegen mögen hier die beachtenswertesten Erfalıungen folgen, die mit der

\section{E inf üh rung a us län discher Holzarten}

in dentsche bezw. mitteleuropäische IValdgebiete gemacht worden sind.

Die seit 1870 wieder aufgegriffene Frage nach dem Werte fremder, namentlich nordamerikanischer Holzarten für unsere heimische Forstwirtschaft hat bereits in den letzten Jahrzehnten des 18. Jahrhunderts die forstlichen Gemüter lebhaft bewegt und würde ihrer Lösung weit näher gebracht sein, wenn sie seinerzeit von den Vertretern der sog. forsthichen Ausländerei (v. Münchhausen, v. Veltheim, du Roi, v. Burgsdorf, v. Wangenheim) auf eine so sichere Basis gestellt worden wäre, wie es in der Neuzeit seitens der forstlichen Versuchsanstalten geschchen ist. Da das nicht der Fall war und da das ehedem treibende Motiv der Anbaurersuclie, die drohende Holznot, seine Wirlisamkeit bald vertor, schlief die Bewegung zugunsten der fremden Holzarten unter dem Drucke der damaligen politischen Verhältnisse um so sclıneller wieder ein, als sich Männer wie Georg Ludw. Hartig und Pfeil angesichts der vielen Mißerfolge der Einführungsversuche berechtigt sahen, die Exotenfrage als Schwärmerei und Torheit hinzustellen. Infolgedessen sind es nur wenige Holzarten, vor allen die Weymouthskiefer, die ilır Heimatsrecht im deutschen Walde aus der Zeit der ersten Anbaubewegung datieren. Wolıl aber ragen in Gärten und Parks steliende stark- und hochstämmige Exemplare einer Reihe anderer nor damerikanischer Laubund Nadelhölzer, meist Platanen, Tulpenbäume, Eichen, Wahnüsse usw. aus dem 18. Jahrhundert in die Gegenwart hinein und künden als lebende Zeugeı, daß der guten Entwickitung dieser Holzarten in unserem Klima Hindernisse nicht entgegenstehen.

Die neuzeitliche Steigerung des Nutzholzbedarfes und die mit ilı in Verbindung stehende Tatsache, daß eine Anzahl frender Holzarten, die unseren heimischen Nutzhölzern auf dem Markte bedenkliche Konkumrenz machen ${ }^{2}$ ), Kilimaten entstanmen, welche den unsrigen gleich oder ähnlich sind, regten die Exotenfrage von neuem an.

1) Fruchtwechsel in der Forstwirtschaft, Berlin 1911, S. 87.

2) Vergl. hierzu Unwin, Die forst- und volkswirtschaftl. Bedeutung der Anbauversuche mit nordamerikanischen Holzarten für Deutschland und Nordamerika. Zbl. r. d. ges. Forstw. 903, S. 8, 56, 153, 207. 
Die Propaganda lür. Wiederaufnalme rler Anbauversurlıe setzte mit dem haufmännisch ganz plausiblen Hinweis ein, daß wir einen großen Teil des jetzt dem Auslande mit teurem Gelde bezahlten Holzes doch viel bequemer im eigenen Lande erzeugen kömten. Der Gedanke ist sicherlieh nicht zu verwerfen: es wird ja, sehon wegen des bescleränkten Areales, das den fremden IJolzarten im deutschen Walde nur zugeviesen werden liann, an ein vollstündiges Hintanlıalten des Importes fremden Holzes nie gedacht werden künnen. Jedenfalls aber gehörte es zu den waldbaulichen Aufgaben des forstlichen Versuchswesens, die Bedingungen festzustellen, unter welchen ein derartiges Unternehmen erfolgversprechend scin möchte. Der Verein deutscher forstlicher Versuchsanstalten hat sich diese Frage auch angenommen und seit etwa 30 Jahren melır oder weniger umfangreiche Anbauversuche mit ausländischen Holzarten eingeleitet ${ }^{1}$ ). Ein ganz hervorragendes Verdienst um die Anbalınung dieser Versuche und um die Wiederbelehung des Einführungsgedankens hat sich der begeisterte Vorkämpfer desselben, J o h n B o th, teils durch seine unverdrossene literarische Tätigkeit ${ }^{2}$ ), teils dadureh erworben, daß er den Fürsten Bismarck für seine Ideen zu interessieren und dessen mächtige Befürwortung zu gewinnen verstand.

Bei der Beurteilung einer ausländischen Holzart hinsichtlich ihrer Einfülırungsmöglichlieit sind A n b a u f äh iglieit und A n b a u w ür diglie it zu unterscheiden. Erste Voraussetzung für die Einführung ist, daß die betreffende Holzart unser Klima verträgt, d. h. aus klimagleichen Verhältnissen stammt. Entseheidend sind dabei sowohl die mittleren Jahrestemperaturen bei uns und in ihrem Ileimatlande als namentlich auch die niedrigsten Wintertemperaturen, auf welehe wir zeitweise rechnen müssen, sowie die Temperatur in der eigentlichen Vegetationsperiode, fernerhin auch insbesondere die Feuchtigkeitsverhältnisse (Seenähe, Luftfeuchtigkeit, Niedersehlagsmengen usw.). Gedeihen die fremden Gehölze im Walde oder außerhalb desselben, im Garten und Park, so ist ihre Anbaufähigkeit unzweifelhaft bewiesen, nicht aber ihre Anbauvürdigkeit im forstlichen Sinne. Um diese zu bejahen, muB die in Frage kommende fremde Holzart auf einem bestimmten Standort im Vergleich zu der für denselben passenden heimisehen Holzart mehr ader doeh mindestens dasselbe leisten. Dekorative Werte und Befriedigung unseres Schönheitsgefühles sind es nicht, die im Walde übel Anbauwürdigkeit entscheirlen. Hier gilt im allgemeinen als anbauwert nur das, was m a t e r i e ll e oder w a l d b a u li c h e Vorteile bietet. Diejenige Jlolzart ist anbauwürdig, die die heimisehen Arten in der Holzmassenerzengung in quanti- oder qualitativer Hinsicht ühertriff, die also in gleicher Zeit mehr und möglichst auch besseres, durch wertvolle technische Eigenschaften bezw. durch gute Formansbildung ausgezeichnetes Holz erzeugt. In bezug auf diesen Punkt ist eine Bemerkung von Prof. M a y r-Wünchen beaclitenswert. M a y r ${ }^{3}$ ) weist darauf hin, daß alle Arten ein und derselben Baumgattung ein in seinem anatomischen Aufbau und damit auch in vielen physiologischen und technischen Eigenschaften gleiches Holz erzeugen, gleichgültig, wo diese Arten wachsen, und daß deshalb dureh Einführung von Holzarter, deren Gattung in unseren Walde schon vertreten ist, d. h. durch Einfülırung frender Fichten, Tannen, Lärchen usf. ein an Güte

1) Arbeitsplan für Anhauversuche mit ausländischen Holzarlen, sowie Arbeilsplan für Unlersuchung des forstlichen Verhaltens ausländischer Holzarten, vergl. Gr a $\mathrm{n} g \mathrm{~h}$ of e r, Das forstl. Versuchswesen. II. Bd, S. 169 und 191.

2) Vergl. John B o oth, Die Douglas-Fichte. Berlin 1877. - D e r s., Die Naturalisation ausländischer Waldbäune in Deutsclıland. Berlin 1882. - D e r s., Die nordamerikanischen Holzarlen und ihre Gegner. Berlin 1896. - D e rs., Die Einfûrung ausländischer Holzarlen in die Preußischen Slaatsforsten unter Bismarek und Inderes. Berlin 1903.

3) 11. Il a ỹ r, Fremdländische Wald- und Parlibäune für Europa. Berlin 1906. \$. 219. 
besseres Holz als das der heimischen Art nicht erzeugt werden kann. Für die hiefern gilt dieser Satz nach $\mathrm{M}$ a y r mit der Einschränkung, daß des Holzes wegen nur jene Arten bei uns in erster Linie anbauwürdig sind, deren Sektion im heimischen Walde noch nicht vertreten ist, cl. h. also die nicht zur Sektion Pinaster gehörigen Arten. Soweit lediglich die Erzeugung hochwertigeren Holzes in Frage kommt, empfiehit es sich am meisten, solche Holzarten einzuführen, deren Gattungen (wie z. B. Douglasie, Chamaecyparis, Thuja, Carya etc.) überhaupt noch nicht im deutschen Walde vertreten sind.

Sind Massen- oder Wertssteigerungen des Nutzungsergebnisses nicht zu erwarten, so muß die fremde Holzart waldbauliche Vorteile gewährleisten, wenn sie Anspruch auf die Bezeichnung ,anbauwürdig" erheben will. Sie muß entweder in der Genügsamkeit hinsichtlich der Bodenansprüche unsere in dieser Richtung bescheidensten einheimischen Holzarten übertreffen, muß also selbst auf den geringsten Böden noch fortkommen und Erfolge in Aussicht stellen, oder aber, sie muß über Eigenschaften verfügen, die ihr im Kampf mit elementaren Gefahren (Frost, Trockenheit, Schnee, Wind) eine größere Widerstandsfähigkeit sichern. Im einzelnen Falle mag dieser oder jener ausländischen Holzart, z. B. Nadelhölzern mit stechenden $\mathrm{Na}-$ deln, auch größere Widerstandsfähigkeit gegen tierische Gefahren (Wildverbiß) als Vorzug angerechnet werden.

Die bisherigen Erfolge der Anbauversuche, die von den forstlichen Versuchsanstalten der verschiedenen deutschen Bundesstaaten, am unfangreichsten von Preußen ${ }^{1}$ ) (1910 auf 417 ha), ferner in Oesterreich und von zahlreichen Privatwaldbesitzern mit hauptsächlich nordamerikanischen und einigen japanischen Holzarten seit rund 3 Jahrzehnten angestellt wurden, sind nicht einheitlich. Neben Mißerfolgen aller Art, die zur Streichung mancher zunächst als anbauwürdig angesehenen Holzart aus der Liste der brauchbaren Fremdländer, vielfach auch zur abfälligen Beurteilung und Verwerfung der ganzen Exotenfrage führten, haben die Anbauversuche auch recht erfreuliche Ergebnisse gezeitigt. Hehrere der eingeführten Holzarten haben sich den einheimischen Arten in bezug auf Massen- oder Wertsleistung überlegen und damit zur Verwendung im forstlichen Großbetrieb geeignet gezeigt, anderen wieder kommt unter besonderen Verhältnissen eine derartige waldbauliche Bedeutung zu, daß sie zum mindesten eine wertvolle Bereicherung der Gehölzflora Deutschlands darstellen.

Es ist selbstverständlich, daß sorgfältiges Studium des Verllaltens der Exoten in ihren Heimatländern und volle Berücksichtigung der Standortsansprüche den Anbauversuchen als Grundlage dienen muß, damit nicht, wie es oft genug geschehen ist, Kulturarbeiten mit fremdländischen Holzarten unternommen werden, die schon in threr ersten Einleitung als verfehlt erscheinen. Es seien hier u. a. nur die in verschiedenen Schriften niedergelegten wertvollen Forschungsergebnisse des Prof. $\mathrm{D}_{i}$. M a y ${ }^{2}$ )-Nünchen erwähnt.

1) Vergl. hierzu die Veröfentlichung von $\mathrm{Dan} \mathrm{ckelm}$ a $\mathrm{n} n$, Anbauversuche mit aus ländischen Holzarten in den preußischen Staatsforsten. Ztschr. f. Forst- u. Jagdw, 1884, S. 289, 345 und die den gleichen Gegenstand behandelnden Arbeiten Sch w p p a c h s: ebendas. 1891, S. $18 ; 1896$, S. $327 ; 1901$, S. $137 ; 1909$, S. $27 ; 1911$, S. 591. - Auch aus Württemberg (Allg. F.- u. J.-Ztg. 1897, S. 14 u. 83), Bayern (forstl.-naturw. Ztschr. 1892), Baden (W i m m e r, Anbauversuche usw. Berlin 1909) und aus Oesterreich (C i e s l a r, Ueber Anbauversuche etc. Zentralbl. f. d. ges. Forstw. 1901) liegen Nachrichten über die bisher erzielten Resultate vor.

2) H. M a y r , Die Waldungen von Nordamerika, ihrc Holzarten usw. München 1890. D e r s, , Aus den Waldungen Japans. München 1891. - D e r s., Monographie der Abietineen des japanischen Reiches. Tokio 1890. - U ers., Fremdlăndische Wald- und Parkbäume für Europa. Berlin 1906. 
Aus der ziemlich langen Reihe von Holzarten, die nach den bisher gesammelten Erfalırungen in melır oder minder hohem Maße anbauwürdig sind, seien nur die wichtigsten hervorgehoben.

A. Na d e l hölzer. 1 D o ugla si e (Pseudotsuga Douglasii Carr.). In der grünen (Küslen-)Form auf frischem Sand und nildem Lehmboden eine ganz hervoragende, dic Fichte weit zurüeklassende Massenerzeugerin (am Sŭdharz laufend-jăhriger Durchsehnit \$zuwachs eines 28jähr. Bestandes $27,2 \mathrm{Fm}$. !). Hin und wieder, namentlich in Saat- und Pflanzensehulen, Frostschaden. Zu engen Verband beim Auspflanzen vermeiden; frühzeitige und kräfligere Durchforstungen erwünseht. Die blaue (Gebirgs-)Form (Ps. glauea Mayr.) zwar frosthārter, aber wegen Langsamwüchsigkeit weniger brauehbar. Die grüne Form ist die wertvollste aller anhauwürdigen Exoten, eignet sich zum Reinanbau und in Misehung (Buche).

2. Si $\mathrm{k}$ a $\mathrm{f}$ i $\mathrm{ch}$ te (Picea sitchensis Trautv. et Meyer). Raschwühsig, auf zusagenden feuchten, moorigen Standorten die heimische Fiehte in der Massenerzeugung ganz wesentlieh übertreffend (lf.-jähriger Zuwachs eines 25 jähr. Beslandes auf einer pommersehen Versuchsfläche (nach Schwappach) $26,5 \mathrm{Fm}$.). Ihrer WViderstandsfähigkeit gegen Seewinde wegen im Füstengebiet brauchbarer als die einheimisehe Fichte; im trockeneren Binnenlande dureh Spätfrosste leidend, buschig werdend und nur dorl der heimischen Arl überlegen, wo es dieser zu feucht ist. Geringerer Verbißschaden infolge ihrer steifen, scharf stechenden Nadeln, hingegen aber gern gefegt.

3. A merika $n$ is c h e Silbertan $n$ e (Abies concolor Gord.). Einzige Tannenart, die auf güstigen frisehen Lehmboden der heimisehen Art durch Rasehwüehsiglieit und Widerstandsfahigkeit gegen extreme Temperalurgrade überlegen ist; lichtbedürftiger als Ab. peetinata.

4. I e y $m$ o $t$ h s $\mathrm{k}$ ie $f$ e $r$ (Pinus Strobus L.). Ihre waldbaulich sehr brauchbaren Eigensehaften: Rasehwüchsigkeit, Schattenerträgnis, Widerstandsfähigkeit gegen Frost, Sturm, Schnee, reicher Nadelabfall) haben ihr seit langen sehon volles Bürgerrecht in den heimischen Valdungen erworben. Gedeiht naehhaltig aber nur auf tiefgründigen, lehmigen, humosen und namentlieh hinreiehend frisehen Böden, sonst nur in der Jugend befriedigend und bald (im Alter von 25-40 Jahren) versagend. Hallimasch und Blasenrost örtlieh sehr gefährlieh.

5. B a n k s k e f er (Pinus Banksiana Lamb.). Anspruchslose, in der Jugend sehr rasehwüehsige Voranbauholzart für ärmste Böden (Flugsand, Dünen, Sumpf- und Mloorpartien), gutes Füllholz für lückige Kiefernkulturen. Kicine Nutzholzerzeugerin.

6. P e c h k i f e r (Pinus rigida Mill.). Ebenfalls lieine für Reinanbau taugliche Nutzholzerzeugerin, aber geeignetes Mischholz für kïefernkulturen auf armen Böden.

7. J a pa $\mathrm{n}$ ise he Lärehe (Larix leptolepis llurr.). Auf zusagendem (kräftigen) Boden der tieferen, höchstens mitlleren Lagen in der Jugend raschwüchsiger als die heimische Art; außerdem widerstandsfähiger gegen Krebs und Motte, bisweilen aber schlechtschaftiger.

8. Law s o n z y p resse (Chamaeeyparis Lawsoniana Parl.). Vorzügliches Holz. Auf gutem Standort (friseher lehmiger Sand-oder sandiger Lehmboden) und bei hinreichender Lufteuchtigkeit nach den ersten Jugendjahren ziemlich raschwüchsig; liebt Seilensehutz, daher für liahlflāehen ungeeignet, tauglich für Löcheranbau in Buche und İiefcr. In der Jugend nicht völlig frosthart, leidel in Frostlagen leicht unter Pilzangriffen (Hallimaseh und Pestalozzia funerea).

9. Ri e sen l ebens b a u m (Thuya gigantea Nutt.). Standortsansprüehe und waldbauliches Verhalten wie bei der vorigen Art; geeignet zum gruppenweisen Einbau in lüekige Buchenverjüngungen.

B. L a u b h $\delta$ lz e r. 1. Rot e ich e (Quercus rubra L.). Raselıwảehsiger und bezüglich der Bodenansprüche genügsamer als unsere deutsehen Eichen; gute Sehaftbildung; Holz infolge größerer Porosität dem der heimischen Eichen nicht ganz gleichwerlig; gehơrt aber dank ihrer guten waldbaulichen Eigenschaflen zu den wertvollsten aller eingefürten ausländischen Holzarten.

2. W e i $B$ esche (Fraxinus alba = americana L.). Waldbauliches Verhallen dem der leimischen Esehe ähnlich; etwas später austreihend als diese, daher etwas weniger durch Spălfröste gefährdel; gegen Stau- und Uebersehwemmungswasser ebenfalls weniger empfindlieh als die heimische Art.

3. Ka na d is e h e Pa p p el (Populus canadensis Moeneh.). Auf güntigem Standort infolge geradezu erstaunlicher Rasehwüchsigkeil größte Holzerzeugerin unscrer Breiten.

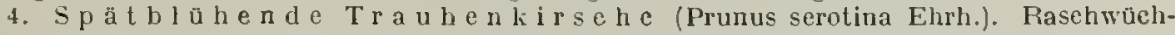
sig, auf Buehenboden geradsehaflig, auf armem und zu feuchtem Boden aber sperrig wachsend; brauchbar als Fülholz in Laubholzverjüngungen.

5. S c h w a rze 11 a 11 n u $\beta$ (Juglans nigra L.). Nur für beste (Aue-)Böden in mildem lilima ohne Spätfőste geeignet, hicr rasehwüchsig, hiehtbedûrftig, Erzeugerin hochwertigen Holzes. Auspflanzung infolge starker Pfallwurzelbildung sehwierig, daher nur Saat mit vorgekeinten Nüssen.

6. Tंe i $\beta$ e H i ck ory (Carya alba Nutt.). Zunăchst langsamwüchsig, spăter in freiem Sland sich gut entwiekelnd; friseher, tiefgründiger Eichenboden beansprueht. 
Die höheren Ansprüche, die vom größeren Teil der wertvollen ausländischen Laubhölze an Klima (Wärme) und Boden gestell werden, bringen es mil sich, daß diesen nicht in dem llaße wie den exotischen Nadelhölzern im deutschen Walde die Bedingungen zu hof fnungsreicher Entwicklung geboten werden können und daß für die Erziehung gerade „ler dem Holzwerl nach hervorragendsten Arten hauptsächlich nur der Süden und Westen unseres Vaterlandes in Belracht kommen. Da wir aber in einzelnen cinheimischen Laubhölzern, wie Eiche und Esche, für bessere Böden Holzarten haben, die den fremden Laubhōlzern in Qualität und V'erwendbarkeit nicht nachstehen, so ist schließlich die Einführung fremder Laubhölzer nicht so bremind.

Ob die in vorstehenden angeführten fremdländischen Holzarten die ihrer forstlichen Verwendbarkeit nach den bisherigen Erfahrungen erteilte günstige Zensur in Zukunft durchlıalten werden, wissen wir noch nicht. Wir urteilen zunächst noch zu sehr nach den in der Kinderstube der Exoten gesammelten Erfahrungen und sind dort, wo waldbauliche Fehles in der Behandlung der Exoten gemacht wurden, und dort, wo der Faktor Wild nicht oder in nicht genügendem Naße bei der Versuchsanordnung ausgeschaltet wurde, wohl oft zu voreilig absprechenden Urteilen gekommen. Auf der anderen Seite aber fehlt es unter Hinweis auf besonders günstige Einzelerfolge ebensowenig an ïbertrieben optimistischen Beurteilungen. Wie alle forstlichen Maßnahmen wird auch die Ausländerfrage von der Zeit gelöst. Die letzte Entscheidung über die Anbauwürdigkeit der einen b e s s e r e n Boden beanspruchenden fremdländischen Holzarten wird jedenfalts unter der Voraussetzung, daß alle waldbaulichen Forderungen durch die eingeführte Holzart erfüllt werden, der Rentabilität. zufallen.

1V. Wirtschaftiche Bedeutung der Holzarten ${ }^{1}$ ).

\$15. Zur Erreichung der in der Einleitung kurz skizzierten Ziele des Waldbaues sind die einzelnen Holzarten in sehr verschiedenem Maße geeignet. Ihre wirtschaftliche Bedeutung beruht hauptsächlich aul der Massen- und Wertserzeugung, letztere bedingt durch die Verhältnisse des Holzmarktes, ferner auf der Arbeitsgelegenheit, welche eine Holzart hietet, auf ihrem Verhalten gegen den Boden, auf der Art der Betriebsführung, bezw. Wirtschaftseinriclıtung, soweit diese durch die Holzart beeinflußt ist, auf der Art und dem Umfang gewisser an sie geknüpfter Nebennutzungen, auf ihrer Widerstandsfähigkeit gegen Gefahren, sowie endlich auf ihrer Tauglichkeit, bestimnten besonderen Anforderungen (Schutzwald u. dergl.) zu genügen.

1. Hassen-und IV ertserzeugunor: Für die auf der Massen-und Wertserzeugung beruhende Wertschätzung einer Holzart entscheidet in erster Linie deren Verbreitungsgebiet. Es gibt Holzarten, welche sclion vermöge ihres ausgedehnten Vorkommens den Markt beherrschen und dadurch anderen, die nur in beschränktem Umfang an der Bestockung unserer Waldungen teilnehmen, an Bedeutung weit überlegen sind. Besonders wertvolle Eigenschaften und dementsprechend hoher Preis werden eben doch immer in Verbindung mil der Masse wirksam; das größte Produkt aus llasse mal durchschnittlicher Preis der Masseneinheit ist ausschlaggebend. Von den in Deutschland heimischen Holzarten sind Iijefer, Fichte, Buche die verbreitetsten. Oertlich (auf größeren oder kleineren Einzelgebieten) sind die Verhältnisse sehr verschieden. Hier und da tritt die Weißtanne, auch wohl die Eiche, stark in den Vordergrund ${ }^{2}$ ).

Ganz Deutschland hat (auf rund 14 Mill. ha Wald = fast $26 \%$ der Gesamtfläche) $67,5 \%$ Nadelholz und $32,5 \%$ Laubholz. Hieraus erhellt die größere Bedeu-

1) Zu vergleichen: W e be $r$, „Die Aufgaben der Forstwirlschaft", $\&$. Handbuch, insbes. „Die Forst wirtschaft vom privatwirtschaftlichen Gesichtspunkle aus betrachtet".

2) Cfr. u. a. die Erörterungen in B o $\mathrm{r} g \mathrm{r} \in \mathrm{ves}$ Holzzucht 2. Aufl. S. $63 \mathrm{ff}$. Im ubrigen gibt die slalistili dor einzelnen Länder die etwa gewünschte spezielle Auskunft. 
tung des Nadelholzes für die deutsche Forstwirtschaft. Erwägt man weiterhin, daß fast $45 \%$ der Gesamtwaldfläche der Kiefer und $23 \%$ der Fichte und Tanne (Tanne gegen die Fichte erheblich zurüchtretend) zufallen, während die sonstigen Nadelhölzer (Lärche, Arve etc.) nur mit verhältnisıäßig kleinen Beträgen beteiligt sind, und beclenkt nian ferner, daß vom Laubholz ca. $14 \%$ den Buchenhochwald, etwa $7 \%$ der Eiche (Hochwald und Schälwald), $5 \%$ dem Mittelwald gehören, so ergibt sich, daß zunächst lediglich der großen Verbreitung und demgemäß Massenerzeugung wegen Kiefer, Fichte, Buche im allgemeinen geradczu als führende, als Hauptholzarten, bezeichnet werden dürfen. Tanne und Eiche schließen sich ihnen an. Dic übrigen Holzarten spielen in der Gesamtheit des deutschen Waldes eine mehr untergeordnete Rolle, obwohl natürlich örtlich, je nach den besonderen Standorts- und sonstigen Verhältnissen, bald dic eine, bald dic andere mch in den Vordergrund tritt, ja die Führung übernimmt.

Besondere Erwähnung verdient an dieser Stelle die örtlich große Verbreitung der Schwarzkiefer, welche in Niederösterreich (bes. in den Kalkbergen des Wiener Waldes) auf etwa 80000 ha bestandbildend auftritt und in diesem Kronland rund 1/8 des Gesamtwaldes ausmacht.

Die Massenerzeugung ist absolut, die Wertshildung stets relativ zu bemessen, d. h. letztere ist abhängig nicht nur von der tatsächlichen Brauchbarkeit einer Holzart für einen gegebenen Verwendungszweck, sondern auch vom Marktpreis, welcher wesentlich durch das Verhältnis von Angebot und Nachfrage bedingt ist. Alle Preisbestimmungsgründe kommen dabei in Betracht, insbesondere wird die Konkurrenz der Surrogate (Kohle, Torf ete. für Brennholz, Eisen, Steine für Bauholz) wirksam ${ }^{\mathbf{1}}$ ). Bekanntlich haben sich die Bedingungen des Holzmarktes in den letzten Jahrzehnten bedeutend verändert: Nutzholzwirtschaft im Gegensatz zur Brennholzerzeugung ist die Losung del waldbaulichen Produktion ${ }^{2}$ ), was gleichbedeutend ist mit der relativ hohen Wertschätzung und dementsprechend inmer weiter schreitenden Ausdehnung des Gebietes der ausgesprochenen Nutzholzarten im Vergleich namentlich zur Buche, welche als spezifische Brennholzart mehr und mehr an Terrain verliert und im raschen Verlauf des Umwandlungsprozesses wohl noch viel weiter zurückgedrängt werden würde, wenn nicht ihre trefflichen waldbaulichen Eigenschaften, vorab in bezug auf die Bewahrung der Bodenkraft, die Einbuße, welche sie am Holzwert erlitten hat, wenigstens zum T zil zu paralysieren berufen wären. Eine Holzart, welche mit der größten Wahrscheinlichkeit dauernd ihren Wert auf dem Holzmarkte bewahren wird, weil ihre Nutzholzqualität unbezweifelt ist und bleiben wird, ist die Eiche. Auch Esche und die sonstigen edlen Laubhölzer, sowie die Lärche berechtigen, wenn auch wohl schon in etwas engeren Grenzen, zu dieser Hoffnung. Die gedeihliche Entwickelung dieser Holzarten ist aber meist an sehr bestimmt umgrenzte Bedingungen (namentlich bezüglich des Standorts) gebunden, so daß durch ihren erweiterten Anbau und intensive Pflege wohl örtlich (z. B. Esche und Ahorn in der schwäb. Alb) eine bemerkbare Veränderung, im allgemeinen jedoch kaum eine besonders weitgehende Umgestaltung der Physiognomie des Waldes herbeigeführt wird. Dagegen müssen einige Nadelhölzer, wie vorab Kiefer und Fichte, als Holzarten bezeichnet werden, welche vermöge ihrer verhältnismäßigen Anspruchslosigkeit und der Leichtigkeit ihres Anbaues im Verein mit einer sehr hohen Nutzfähigkeit allerdings so umfängliche Gebiete teils schon erobert haben, teils noch in Besitz nehmen können, daß der ganze Charakter ausgedehnter. Waldgebiete darlurch verändert wird. Obwohl

1) We ber, Aufgaben der Forstwirtschaft, s. Handbuch I. Bd.

2) Zu vergl. W a g e $n$ e $\mathrm{r}$ in Allg. Forst- u. Jagd-Zeitung von 1877, S. $7 \mathrm{ff}$.

Itandh. d. Forstwiss. 3. Aufl, II. 
auch die Tanne an manchen Orten eine Schmälerung ihres Gebietes zu verzeichnen hat, dic ïbrigens durch erweiterten Anbau an anderen Orten ziemlich ausgeglichen werden dürfte, ist tatsächlich vorzugsweise der Besitzstand der Buche gefälırdet. Sie ist jetzt schon auf weiten Gebieten durch die genannten Nadelhölzer ersetzt worden und wird, wo die augenblicklichen Preisverhältnisse für die Beurteilung der Rentabilität in erster Linie maßgebend sind, unweigerlich auch einen noch weitern Rückgang erfahren. Doch ist es gewiß sehr am Platze, wenn sich gewichtige Stimmen $\left.{ }^{1}\right)$ warnend erheben, um ein zu allgemeines Verdrängen der Buche zu verhüten. Niemand bezweifelt die höhere Nutzfähigkeit der Nadelhölzer; sollten letztere auch schlieBlich (etwa wegen fehlender Absatzgelegenheit zumal für schwächcre Sortimente) zum Teil ins Brennholz geschnitten werden inüssen, so würde ihre in einer gegebenen Zeit pro Flächeneinheit erzeugte größere Masse wohl immer noch das ersetzen, was die Buche an Brennwert pro Masseneinheit vor ilinen voraus hat. Selbst wenn man berücksichtigt, daß die Nadelhölzer von viel größeren und mannigfaltigeren Gefalıren bedroht sind als die Buche und deshalb nicht die gleiche Sicherheit der Ertragsleistung zu bieten vermögen wie diese, nuß ilre Ueberlegenheit im großen und ganzen zugegeben werlen. Inmerlin sollte man keinesfalls in zu weitem Maße ausgedelınte reine Nadelıolzwaldungen schaffen. Ist die Buche auch in reinen Bestand nicht mehr allgemein existenzberechtigt, so sollte man sich doch möglichen V'eränderungen der wirtschaflichen Lage (eventuell gänzlich veränderten Absatz- und Transportbedingungen etc.) gegenüber den Rückweg offen halten, indem man der Buche wenigstens die gebührende Stelle in gemischten Walde gönnt. Sic wird durch ilıre schon mehrfach erwälnte ïheraus günstige Eimwirkung auf deu Boden diese Rüclisichtnahne stets reichlich lohnen. Außerdem ist auch eine gelegentlich gesteigerte Nutzholzverwendumg für die Buche lieineswegs ausgeschlossen. Angesichts der Verwendungsfähigkeit und Dauer der imprägnierten Buchenschwelle, weiterhin angesichts der steigenden Verwertung der Buche zu Holzpflaster und zur Bediclung der Wolıräume ist eine solche Hoffnung nicht unberechtigt. Dem Buchenholz wohnt in der' Tat ein höherer Gebrauchswert inne, als das zu' Zeit noch vorhandene Vorurteil gegen seine Verwendung als Nulzholz ilim zugesteht. Das kann sich aber ändern. Gerade die mangelnde sicherheit bezüglich der Vorausbestinmmung der zukünftigen wirtschaftlichen Verhältnisse in ihrer Gesamtheit kann uns mahnen, gemischte Bestände üherhaupt und insbes. auch solche, in denen die Buche vertreten ist, zu begünstigen ${ }^{2}$ ). Von der Buche, der schon oben genamnten Eiche, die ihres besonderen Wertes wegen olmehin anders zu beurteilen ist, und von den sonstigen sog. edlen Laubhölzern abgesehen, bedürfen die übrigen Laubhölzer, weil sic meist ihre ganz spezifische Nutzbarkeit besitzen (z. B. Birke für Geschirrhölzer, Erle zu Zigarrenkisten, Aspe für die Zündholzfabrikation) und für den großen Betricb kaum irgendwo oder wenigsten: nur auf ganz beschränkten Standörtlichkeiten eimmal als

1) Z. B. G a ye $r$ in seiner mehr zitiorten Scirift: ,Der gemischte Wald".

2) Einen besonders prägnanten Ausdruck hat die Beurteilung des Werts der Rothuche in den Verhandlungen der Versanmlung deutscher Forstmänner zu Stuttgart (1897) und in den daran sich anschließenden literarischen Debatten gefunden. Während von den einen die Buche im Hinblick auf ihre mangelhafte Rentabilität in reinen Beständen geradezu als verlorene Jolzart bezeichnet wurde, lıaben andere dieselbe mehr oder minder energisch in Schutz genonmen. Aus der umfänglichen, zur ,Buchenfrage" erwachsenen Literatur seien u. a. erwälnt die Aufsätze von Endres (Allg. Forst- U. J.-Z. 1898, S. 91), H e i B (ebendas. 1898, 256), Dr. II e e k (ebendas. 1898, 257), N (A. F.- Il. J.-Z. 1898, 383), B in Jrakt. Forstwirt für die Schweiz $(1898,49)$, T r e b e lja h $\mathbf{r}$ (Münlener forstl. Hefte 1898, 14. Heft), Ii u $\mathrm{seh}$, Die Stellnng dis Buehenhochwaldes im leutschen Nationalvermögen, Gießen 1898. - Vgl, auch J uf $\mathrm{nag} \mathbf{J}$, Die Buchenfrage in der osterr. Forstwirtschaft, Wien 1900. 
mitherrschende oder gar herrschende Holzarten, sondern meist nur in untergeordnetem Maße in Frage kommen, der besonderen Fürbitte weit weniger. 2 . A r b e itsgrelegenheit: Hierüber enthält Handbuch I (vgl. Weber, Aufgaben der Forstwirtschaft) die nötigen Angaben. Der Waldbau läßt sich bei Bemessung seiner Maßnahmen in der Regel zwar nicht von der Erwägung leiten, ob eine Iolz- oder Betriebsart mehr oder weniger unfängliche Arbeitsgelegenheit bietet, trotzdem läBt sich dieses Moment doch auch wieder nicht von den übrigen wirtschaftlichen Bezielıungen, von den Rücksichten, welche der Gesamthetrieb zu nehmen hat, einseitig loslösen. Auch der Waldbau sollte vor seinen Entscheidungen über den engen Fireis seiner eigensten Interessen hinaus Umschau halten, um einerseits für seine Arbeiten stets genügende Kräfte verfügbar zu haben und andererseits auch wieder vorłandenen Kräften die erwïnschte Betätigung zu gestatten und sie dadurch dem Walde zu erhalten. Dabei kommen in erster Linje die mit der Begründung, Erziehung, Ernte eines Holzbestandes verknüpften Arbeiten in Betracht; daneben aber auch solche, welche durch die Gewinnung gewisser Nebennutzungen (WValdfeldbau, Hackwald, Harznutzung usw.) bedingt sind, sowie diejenigen, welche sich schließlich nach der vollzogenen Ernte an das Rohprodukt anlehnen, bezw. sich mit dessen Verwendung befassen. Daß die Holz- und Betriebsarten in diesen Beziehungen selu verschieden zu werten sind, erhellt aus den späteren Abschnitten. 3. V erhalten d e r Holzarten gegen den Standort: Die Erörterungen auf S. 15 geben über die einschlägigen Beziehungen Aufschluß. Es sei an dieser Stelle nur wiederholt hervorgehoben, daß bei aller waldbaulichen Tätigkeit die Bodenpflege anch um deswillen vorangestellt werden muß, weil wir im allgemeinen kein Recht haben, etwa zugursten der Gegenwart wirtschaftliche Maßregeln zu ergreifen, infolge deren wir der Zukunft in Gestalt eines geschwächten Bodens einen minder leistungsfähigen Kapitalteil hinterlassen, als wir ihn von der Vergangenheit überkonmen haben. 4. W irts chaftsein rich $t$ ung: Von der absoluten Ertıagsziffer (Etat) abgesehen, bei deren Bemessung natürlich auch die größere oder geringere Sicherheit der Ertragsleistung mit berücksichtigt wird, sind es hauptsächlich zwei Fragen, welche den Zusammenhang der Holzart mit der Forsteinrichtung andeuten, nämlich: 1. für welche Betriebsart (Hochwald, Niederwald, Mittehwald) eignen sich die verschiedenen Holzarten, bezw. wie werden sie verjüngt? und 2. werden sie in reinen oder in gemischten Beständen erzogen? Daß der Femelwald und alle ihm sich nähernden Betriebsformen im Gegensatz zu schlagweiser Behandlung, und daß ebenso gemischte Bestände im Gegensatz zu reinen ${ }^{1}$ ) die Forsteinrichtung erschweren, steht außer allem Zweife]; deı Nachweis dafür ist übrigens an anderer Stelle zu führen. Es wird auch nicht zu beanstanden sein, daß dieser Unstand bei der Würdigung der einzelnen Holzarten mit beachtet wird. Dagegen wäre es verkehrt, wenn bestimnte waldbauliche oder sonstige Vorzüge einer Betriebsform oder Holzartenmischung irgend einer starren Forsteinrichtungsregel zum Opfer gebracht wïrden, da natürlich die waldbaulich höchste Leistung des Forstes stets erste und wichtigste Forderung an die Wirtschaft sein muß. Ein passender Ausgleich zwischen den hier und da sich widerstreitenden Interessen wird in den meisten Fällen unsehwer gefunden werden können. - 5. N e b e n n u $\mathrm{z} u \mathrm{ng}$ e $n$ : An ganz bestimınte Holzarten sind direkt gebunden z. B. Lohrinde, Harz, Mast, Futterlaub u. a. m. Durch Vernittelung der Betriebsart hängen mit der Holzart zusammen z. B. Produkte des Waldfeldbaues, die landwirtschaftlichen Nutzungen in Hackwald, Gräserei in Pflanz-

1) Vergleiche auch 1. Abschn., 111. B., S. 19 ff. dieser Abhandlung. 
kulturen I. dgl. - 6. Widers $t$ and $\mathrm{s} f$ äh igkeit gegen Gefah ren: Die schon mehrfach, erstmals bereits $\S 8$, S. 13 unter 4, angedeuteten Beschädigungen können den wirtschaftlichen Wert einer sonst reeht sclıätzbaren Holzart unter Umständen, bezw. für bestimmte Oertlichlieiten so herunterdrücken, daß man auf ihre Anzucht geradezu verzichten muß. So verbietet sich z. B. in wildreichen Forsten, wenn man nicht besondere Schutzmaßregeln (Eingattern) ergreifen will, zuweilen der Anbaı der Esche, der Eiche, der Weißtanne vollständig, obwohl diese Holzarten ohne die Gefälırdung durch Schälen oder Abäsen hohen Ertrag erwarten ließen. In ausgesprochenen Schneebruchlagen hat man möglichst mit der Kiiefer fern zu bleiben; dem Sturm besonders exponierte Orte taugen nicht für die Fichte usw. Auch hier darf wieder daran erinnert werden, wie vielfache Gelegenheit, solche Gefahren abzuschwächen, dureh geeignete Holzartenmischung gegeben ist. 7. Besondere örtliehe Anforderungen: Dahin gehört $z$. B. eine gewisse Anpassung an die Bewiltsehaftungsweise umgebender Waldungen, sofern es sich um kleinere Enklaven handelt (z. B. ein sturmgefährdeter Fichtenbestand inmitten eines größeren Schälwaldgebietes); ferner die Rücksichtnahme auf Servituten, deren Befriedigung häufig eine bestimmte Holzart fordert; sodann eine Reilıe spezieller wirtschaftlicher Aufgaben, wie die Anzucht von Faschinenhölzern, Böschungsbefestigungen usw.

In allgemeinen kann die tatsächliche Verbreitung der Holzarten als Maßstab derjenigen wirtschaftlichen Bedeutung dienen, welche ilmen beigelegt wird, mit der Einsehränkung natürlich, daß für die Wertschätzung seitens der Gegenwart nur die unter unsern Augen entstehenden Jungbestände beweiskräftig sind, während alle älteren Hölzer nur bezüglich der Anschauung jener Zeit, in welcher sie begründet sind, ein Urteil zulassen. Entscheidend für den Betrieb in großen ist, wie wir rekapitulierend nochmals hervorheben, immer nur dic lileine Zahl von Holzarten, welche ausgedchnte Gebiete (eventuell auch in reinen Beständen) einnehmen, d. h. Kiefer, Fichte, Buche, Tanne. Alle übrigen Ilolzarten, selbst die Eiche, sind, so selır sie auch, örtlich oder allgemein für bestimmte Verhältnisse, unsere Aufmerksamkeit in Anspruch nehmen, doch in ihren Existenzbedingungen jenen herrschenden Holzarten gegenüber meist äußerst beschränkt, so daß an eine den Umfang ihres jetzigen Gebietes weithin überschreitende Verbreitung derselben nie zu denken ist. Um so mehr sollte man ihnen da, wo ihre Anzucht ohne greifbare Benachteiligung anderer Interessen zulässig erscheint, einen Platz anweisen, um dem Walde die in den verschiedensten Beziehungen so schätzenswerte Mannigfaltigkeit zu erhalten, oder, wo sie verloren ist, wieder zu versehaffen.

Zweiter Absclinitt.

\section{Die Betriebsatell.}

$\S 16$. Vorbemerkungen: Ehe wir zum angewandten Teile des Waldbaues, d. h. zur Besprechung und Erörterung aler bei Begründung und Erzielıung der Bestände zu beachtenden Handgriffe und Maßnahmen übergehen, müssen wir uns Kklarheit verschaffen über die bei unserer Wirtsehaftsfülırung innegehaltene zeitliche Aneinanderreihung der von uns jewcils angewendeten waldbaulichen Operationen. Die Erreichung des vorgesteckten Wirtschaftszieles erfordert, daß wir 
unsere Maßnahmen planmäßjg gruppieren und zu einer bestimmten, regelmäßig wiederliehrenden Wechselfolge zeitlich verbinden. Wir nennen eine solche plannäßige Tombination bestimmter, zeitlich aufeinander folgender wirtschaftlicher Operationen $B$ e $t r i c b s$ a $t$ oder $B$ e $t$ rie b f o r m und definieren diesen forstlichen Begriff kurzhin als Art und Weise der Verjüngung und Erzieliung eines Bestandes oder Waldes.

Je nachdem sıclı die zur Veljüngung fülırenden Maßnahmen zeitlich oder wirtschaftlich voneinander unterscheiden und je nachden die spätere Belıandlung und Erzielıung des durch die Verjüngung entstandenen Bestandes in dieser oder jener Weise geregelt und gehandliabt wird, entstelıen verschiedene Betricbsarten, deren

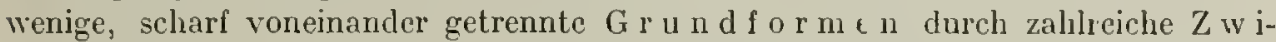
$\mathrm{s}$ ch e $\mathrm{n}$ - und $\mathrm{U}$ e bergan $\mathrm{gs}$ f o $\mathrm{r} \mathrm{m}$ e $\mathrm{n}$ verbunden werden. Als gleichibedeutend mit Betriebsart wird meist das Wort „Bestandesform“ angewendet. Das ist nicht ganz zutreffend, denn die Bestandesform, d. i. das Bild, was ein Bestand als Folge der Bewirtschaftungsweise dem Beschaner darbietet, ist das Resultat der Betriebsart, nicht aber diese selbst.

Angesichts der großen Zahl möglicher Kombinationen (aus Holzart, Bestandesbegründung, bezw. Verjüngung, Bestandespflege, Erziehung usf. mit allen ihren Nodifikationen) ist es begreiflich, daß sich im Walde, sofern anch die feineren Unterscheidungsmerknale beachtet werden, tatsäcllich viele mehr oder weniger voneinander abweichende Betriebsarten vorfinden. Sie alle sind durch menschlichen Eingriff, durch wirtschaftliche liunst (bisweilen auch Krünstelei) herausgebildet, während die Urwaldform überall das in großen ganzen gleiche, wenn auch durch Holzart, Standort usw. modifizierte Gepräge trägt. Zum Verständnis des Wesens der Betriebsarten aber ist es erforderlich, einzelne scharf ausgeprägte Formen als typische herauszugreifen und an ihnen gewissermaßen Schulbegriffe zu entwickeln, die dann als feststehend zu betrachten sind. Zwisclien diese Grundformen lassen sich die übrigen in mannigfaltigster Reihe, oft mit kaum merklichen Uebergängen, einschalten.

Es ist als bedenklich zu bezeichnen, namentlich im Interesse der Anfänger im Studium, die erst in das vielgestaltige Gebiet des Waldbaues eingeführt werden sollen, daß einige Lehrbücher eine verhältnismäßig große Anzahl von Betriebsarten als selbständige Formen aufführen und beschreiben, wälırend man einen Teil derselben recht wohl als Uebergangsformen bezeichnen und sich demgemä $B$ auf eine kleine Anzahl von Grundformen beschränken kann. Das Verständnis wird durch jenes Vorgehen offenbar nicht gefördert. Vielmehr ist dadurch manche irrtümliche Auffassung entstanden, und manche umfängliche Diskussion wäre zu vermeiden gewesen, wenn man sich zunächst nur an wenige, wirlilich wesentliche Unterscheidungsmerkmale gehalten, diese entsprechend scharf betont und dadurch erst aus der reichen Fülle waldbaulicher Fornen einige große Hauptgruppen gebildet hätte. Deren weitere Zerlegung wäre einem vorgeschritteneren Stadium wirtschaftlicher und wissenschaftlicher Erkenntnis vorzubehalten gewesen. Manche Schriftsteller fürchten, wie es scheint, durch eine solche Beschränkung bei dem Lernenden die Meinung zu emvecken, als ob man es im Walde wirklich nur mit einer geringen Zahl bestimmt zu cliarakterisierender Formen zu tun habe. Man scheut die Schablone, die ja sicheslich wenn irgendwo so namentlich in waldbaulichen Dingen zu meiden ist. Und doch kommt man zunächst mit einer kleinen Reihe von Grundformen aus; weitergehende Scheidungen lassen sich jederzeit leicht anschließen. 
Erstes Kapitel.

Uebersieht und allgemeine Würigung der als Grundformenzu betraehtenden Betriebsarten ${ }^{1}$ ).

\$17. I. Uebersicht der Grundformen.

Man unterscheidet:

A. Hoc hwald formen oder $\mathrm{S}$ a men $\mathrm{h}$ ol z betriebe.

Die Verjüngung erfolgt durch Samen; das Bestandesmaterial sind infolgedessen Kernwächse, d. lı. Bäume, die sich aus Samen entwickelt hahen. Die Funlitionsdauer des einzelnen Individuums ist mit dessen Abtrieb zu Ende ${ }^{2}$ ); jedes Individuum wird nur e inmal Gegenstand der Nutzung (Durehforstung oder I Iaubarkeitsnutzung) ${ }^{3}$ ).

B. A usse hl agholzbetriebe.

Die Nutzung erstreckt sich nur auf oberirdische Teile des Individuums. Dessen Funktion ist mit der einmaligen Nutzung nicht zu Ende; an den nicht genützten Teile entstehen vielmehr Ausschläge (Stock-, Wurzel- oder Schaftausschläge), durch welche die Neubegründung des Bestandes erfolgt.

C. Mittel wa l d betriel.

Die Verjüngung erfolgt hier teils durch Samen, teils durch Ausschläge; der Mittelwald stellt eine Kompositionsform von A und B, von Samenholz- und Ausschlagholzbetriel, dar.

\section{A. Die Hoehwaldformen.}

$\S 18$. Die Hochwaldbetriebsarten lassen sich naclı der Zeit der Verjüngung unterseheiden in

1. Vorverjüngung s b e tri e be, d. s. diejenigen Betriebsarten, bei denen die Verjüngung v or der gänzlichen Entfernung des Altholzbestandes erfolgt. Stehenbleibende Teile des Altholzes (Mutterbäume) dienen der Verjüngung, inden sie den zur Neubegründung des Bestandes nötigen Samen tragen und abwerfen. Im Falle des Ausbleibens von Samenjahren kann die Bestandsneubegründung auf kïnstlichem Wege, durch Saat oder Pflanzung (Unterbau) erfolgen.

II. N a c lıver jüng ung s b e tr i e b e, d. s. diejenigen Betriebsarten, bei denen die Verjüngung $\mathrm{n}$ a $\mathrm{e}$ h der gänzlichen Entfernung des Altlolzbestandes erfolgt. Etwaige, zunächıst stehenbleibende Reste des Altholzes (Ueberhälter) dienen nicht oder nur zufällig der Verjüngung.

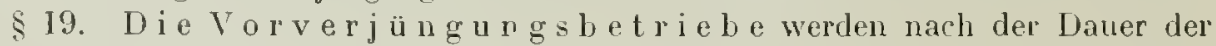
Verjüngung unterschieden:

1. Plente $\mathrm{r}^{\circ}$ oder Femel betrie $\left.\mathrm{b}^{4}\right)$. Die Verjüngung erstreckt sich

1) M a r t i n (Forstl. Statik, 2. Bd. 1911, S. 1) unterscheidut nur 4 Betriebsarten: Niederwaldbetrieb, Mittelwaldbetrieb, Plenterbetrieb und regelmäßigen Jochwaldbetrieb und hält die weitere Ausdehnung des Begrifjes Betriebsart auf andere Formen nicht lür empjehtenswert, wãhrend G a y er (Wallbau, 4. Aufl. 1898, 3. Abschn.) 9 Betriebsarten unterscheidel; Kahlflächenform, Schirmschlagform, Saunschlagform, Femelschlagiorm, femelartige Hochwaldform, Femelform, Ueberhaltform, Unterbauform, Niederwaldformen, Mittehaldformen.

2) Fortvegetieren im Boden verbleibender Stöcke während des falgenden Limtriebs bleibt. insofern unleachte1, als man bei der Begründung des neuen Bestandes die etwa erwachsenden Ausschläge nicht grundsätzlieh einbezieht, wenn ihnen auch da und dort aus lestimmten Gründen (Holzartenmischung, Bodenschutz usw.) eine slelle gegönnt wird.

3) Finden Aufastungen statt, so erfolgt der bezügliche Holzanfall nur im Interesse der Bestandeserziehung, die Wegnahme einzelner Orran geschieht hier nicht zum Zweck einer Reproduktion.

4) Plenter-oder Plänterbetrieb fälschlich abgeleitel von plantare, richtiger nach dem Bejspiel C. Wagners Blenderbetrieb von, Blender" $=$ beschattender Baum. Von den forstliehen 
über die ganze Umtrichszeit und über die ganze Fläche unter Benützung aller eintretenden Samenjahre, sic hört nic auf. Infolgedessen sind im Plenterwalde alle Altersklassen in gruppen- oder horstweiser oler einzelständiger Anordnung vertreten. Inwieweit Repräsentanten jerles einzelnen Jalıres vorhanden sind, hängt von der WViederkehr der Samenjahre bezw, von wirtschaftlichen Eingriffen ab. Da Sanıenjahre nicht von .Jahr zu .Jahı, sondern meist nur in größeren \%eitzwischenräumen kommen, sind mebrjälırige Altersdifferenzen zwischen den im Alter benachbarten Bestandsindividuen die Regel. Je jünger die einzelne Altersstufe ist, um so zahlreicher pflegt sie vertreten zu sein.

Bei 120jähr. Untriebe, d. h. bei Annahme von 120 Jahren als demjenigen Alter, das von der altesten Stammklasse normal erreicht werden soll, sind unter der Vorausselzung, daß alle funf Jahre ein Samenjalır liommt, heispielsweise also 5-, 10-, 15-, 20- . . . 90-, 95-, 100-, 105-, 110-, 115- und 120 jălîr. Individuen vorjanden. Die Intervale können grōßer oder kieiner sein; sie brauchen überdies nicht gleieh groß zu sein: tatsåchlich sind sie auch fast immer verschieden. Clıarakterisliseh ist aber immer, daß Jungwüclıse, mittelalte Stămme, Althölzer in dem nãnlichen Bestande angetroffen werden. Dementspreehend ist das líronendach da und dort unterbrocten, keinenfalls in annähernd gleicher Höhe über den Boden nur e i n e Elage bildend. Bis alle Individuen des jetzt vorhandenen Bestandes genutzt sind, verfließt bei normalem Verlauf der Nutzung die ganze I'mtriebszeit. Erst nach deren Verlauf ist, obwohl die Verjüngung fortwährond im Gang ist, pin in aljen seinen Teilen never Bestand vorhanden.

Bei den übrigen Vorverjüngungshetrieben wie auch bei den Nachverjüngungen erstreckt sich die Verjüngung immer nur auf die mit dem ältesten Holze bestockten Teile der Waldfläche und beansprucht dementsprechend nicht die ganze Umtriebszeit, sondern nur einen mehr oder weniger großen Teil dersellen. Wan bezeichnet die jeweilig zur V'erjüngung bestimmte Fläche als $\mathrm{S} c \mathrm{~b}$ l a g und die weiter zu nennenden Betriebe als $S \mathrm{ch} l \mathrm{ag}$ b e $\mathrm{t}, \mathrm{i}$ e b e. Sie unterscheiden sicl nach der Dauer der Verjüngung. Je schneller die Verjüngung vor sich geht, je kürzer der hieıfür vorgesehene Zeitraum (Verjüngungszeitraum) ist, um so gleichalteriger wird der neue Bestand, während umgekehrt lange Verjüngungszeiträume zu ungleichaltrigen Beständen führen, weil dann die Abkömmlinge einer Reihe aufeinanderfolgender Samenjahre im Bestande vereinigt werden.

2. Plenterschlag- oder Femelschlagbetrieb. Die Ver-

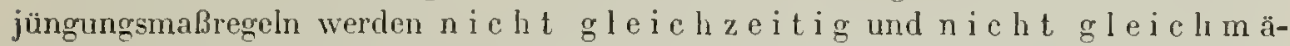
B i g auf der ganzen Fläche eingeleitet, sondern zunächst nur löcher- oder horstweise an bestimmten Stellen (Angrif $\mathrm{fsunkt \circ n})^{l}$ ) und greifen unter Benutzung mehrerer Samenjahre nach und nach auf die noch unberülırten Teile des Bestandes über. Der Verjüngungszeitraum umfaft eine je nach IIolzart, Standort und speziellem Wirtschaftszweck (bezw. Waldbehandlung) bald längere, bald kürzere Reihe von Jahren. Wie schon aus dem allmählichen Fortschreiten der Verjüngung und aus der Zuhilfenahme einer Mehrzahl oft weit genug auseinander liegender Samenjahre hervorgelıt, dauert es aber immer relativ 1 a $\mathrm{n} g \mathrm{e}$, bis ein gröferer Bestand auf diese Weise vollkommen verjüngt ist. Im Zusammenhang damit steht eine mehr oder

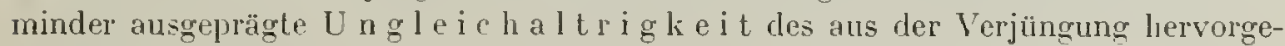
henden Bestandes.

Wie viel Zeit die Verjüngung des ganzen Bestandes erforder't, ist für die Methode an sich ohne Belang, obwohl das entstehende Bestandesbild dadurch natürlich wesentlich beeinflußt wird. Ilan findet lange und kürzeı Verjüngungszeiträume; über

Versuchsanstalten ist aber die Schreibweise ,Plenterbetrieb" angenommen. - Femeltuetrieb von "femella" bezw. von Ausfeneln, d. h. Entfernen der (verneintlietsen) Femellae beim lianf übertragen.

S. 68 fí.

1) Horst- und gruppenweise Verjünung ci a y ers, vgl. dessen, ,Der gemischte Viald" 
die halbe Umtriebszeit wird dabei wohl kaum hinausgegangen; also wird z. B. bei

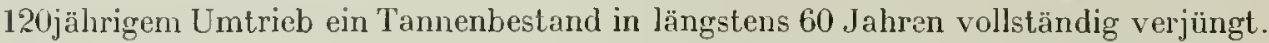
Der Bestand hat ein femelartiges Ansehen, besonders wähỉend der Verjüngungsdauer, insofern stets die der Länge des Verjüngungszeitraumes entsprechenden Altersstufen vorhanden sind. In einem mit 60 jährigem V'erjüngungszeitraum begründeten Tannenbestande werden z. B. 30-90jährige Bäume, oder, so lange die Verjüngung im Gang ist, Altholzgruppen, sowie gleichzeitig wieder Jungwüchse angetroffen. Der Unterschied vom eigentlichen Femelwald springt in die Augen; es fellen die Zwischenglieder der Altersreihe. Ist die Verjüngungsdauer = a Jahre, so ist bei der Umtriebszeit $=u$ in jedem Stadium del Bestandesentwickelung ein Zeitraum von 11-a Jahren nicht durch Stämme vertreten.

3. Sch i r s ch l a g b e trie b. Auch hiel vollzieht sich die Verjüngung in einer längeren oder kürzeren Reihe von Jahren. Die Verjüngungsmaßnahmen aber erstrecken sich, un wenn möglich mit e i n e m e i n z i g e n Samenjahr die ganze Betriebsfläche zu besamen, g l e i c h mä B i g über den ga n z e n Bestand. Das setzt voraus, daß das zu verjüngende Altholz durch seine ganze Erstreckung möglichst $\mathrm{g} l \mathrm{e}$ i c h a r't ig ist, und hat zur Folge, daf der entstehende Junghestand, wenn sonst die Besamung in der gewünschten Weise in kürzester Zeit - tunlichst eben durch ein Samenjahr - gelingt, ganz oder wenigstens annähernd gle ichaltrig wird. Der Verjüngungszeitraum ist mithin bei diesem Betriebe im allgemeinen k ü rz e r als beim Plenterschlagbetriebe. Naneherorts bezeichnet man den Sehirmsehlagbetrieb auch als Dunkelsehlagwirtse ha $\mathrm{t}$.

Während beim Femelschlagbetrieb der Verjüngungszeitraum nicht allein von dem längere oder kürzere Zeit hindurch andauernden Belassen der Mutterbäume im Bestande, sondern namentlich auch von der in Belieben des Wirtschafters liegenden rascheren oder langsameren Ausbreitung des Verjüngungsprozesses über alle Bestandespartien abhängig ist, entscheidet für die Veljüngungsdauer beim Schirmschlagbetrieb nur das Tempo, in welchem man mit den Vorlichtungen und demnächst nach erfolgter Besamung mit Abräumung der Mutterbäume vorgeht, bezw. vorgehen muß. Wie viel Zeit hierfür nötig wird, ist wiederum füı die Methode an sich gleichgültig.

4. S a u m s h l a g b etrieb. Der zu verjüngende Bestand wird von einer Seite, der Angriffsfront (Osten, Nordosten, Norden, Nordwesten) aus auf sclimalen Streifen = Säumen nach den Grundsätzen des Schirmschlag- oder Plenterschlagbetriebes behandelt. In dem Maße die natürliche Ansamung auf dem zuerst in Angriff genommenen Streifen gelurgen ist, schreiten die auf Verjüngung gerichteten 1]aßnahmen aul einem weiteren Streifen nach dem Bestandesinnern vor, während auf dem ersten, bereits besamten Streifen die Bestandspflege für die dem Jungwuchs nötige allmähliche Lichtstellung Sorge trägt. Dieser stufen- oder schrittweise Vordringen der Verjüngung fühıt zu streifenförmigen, dem Alter nach ineinander übergehenden Kíleinbeständen und hat, wenn sonst die Verjüngung eines Bestandes von einem Ende zum andeı en nicht zu lange dauern soll, nur geringe Flächenausdehnung der zu verjüngenden Bestände und öftere Wiederkehı von Samenjahren zur Voraussetzung.

Je breiter die Verjüngungsstreifen werden, umsomehr geht der Saumschlagbetrieb in den reinen Schirmschlag- bezw. Plenterschlagbetrieb über. Die bisher zunächst von Ost oder Nordosl versuchle Saumschlagverjüngung ist neuerdings in der von Prof. W a $g \mathrm{n}$ e $\mathrm{r}^{1}$ ) Tübingen lebhafl empfohlenen und unler dem Namen, ,B l e n d e r s a u $\mathrm{mchl}$ a g geführten Form sehr populär geworden. Das Wesentliche und Neue des Wagner'schen Verfalrens ist die Verlegung dur Angriffsiront auf die Nord-bezw. Nordwestseile des zu verjüngenden Bestandes.

1) Die räumliche Ordnung im Walde, 1907. 
\$20. Die Nachverjü $\mathrm{ng} \mathrm{g} n \mathrm{~g} \mathrm{~s} b \mathrm{etriebe}$ werden nach der Art und Weise der Verjüngung untersehieden.

5. K a h lschl a g b e trie b. Die Verjüngung erfolgt, nachdem der Bestand auf der Fläche hahl abgetrieben ist, dureh Saat oder Pflanzung, also ki in s t l i c li und meist gleiehzeitig auf der ganzen Fläche. Es erwächst infolgedesseı ein gleichaltriger gleichmäßiger Jungbestand.

Wenn tatsiehlich manehmal zwei oder mehrere Jahre bis zur Neubegründung eines Bestandes vergehcu, so tragen sekundäre Umstände, welche mit dem ITesen der Methode in keinem Zusammenhang stehen, wie z. B. Unnöglichlitit raschen Rodens, Inselitengefahr (Rüssclkäfer) u. dergl. die Schuld. Ein einziger Hieb (Kahlabtrieb) räunt den Altholzbestand linweg; danach kann sich die Begründung des neuen Bestandes unmittelbar anreilıen. In kürzester Frist könnte siclı also der Vorgang (Fällung, Abfulır, Saat oder Pflanzung) im Verlaufe etwa eines halben Jahres abspielen, was wirtsehaftlich immerhin als ein einjähriger Zeitraum (eine Zuwachsperiode) aufzufassen wäre.

6. Ii a h $\mathrm{sech} l \mathrm{ag} \mathrm{mit} R$ and bes a m ung. Es handelt sich bei diesem Betriebe um schmale Kalılschläge (Saumschläge), deren Wiederverjüngung den Randbäumen des anstehenden Bestandes, also der Natur überlassen bleibt. Während die Naturverjüngung im allgemeinen Vorverjüngung ist, haben wir es hier mit einem und zwar dem einzigen Fall von natürlicher Nachverjüngung zu tun. Verlauf, Richtung und Breite der Saumschläge wechseln, sind aber für Gelingen und Ergiebigkeit der natürlichen Ansamungen von großer Bedeutung.

Soweit bei den unter 5 und 6 genannten Kahlschlägen Ueberhälter nicht stehen gelassen werden, finden sich beim Kahlschlagbetrieb Altholz und Jungwüchse niemals auf der nämlichen Fläche. Hierin unterscheidet sich der Kahlschlagbetrieb sehr scharf von den Vorverjüngungsbetrieben, bei denen stets während des Verjüngungszeitraumes Teile des alten und neuen Bestandes gleichzeitig vorhanden sind.

Alle übrigen noch vorkommenden Hochwaldformen sind nur als Modifikationen der vorstehend in ihren Hauptmerkmalen charakterisierten Grundformen zu betrachten. Es sind Uebergangsformen mit engerer oder minder enger Anlehnung an diese oder jene Grundform. Zum Teil werden hierbei durch sekundäre Maßnahmen z. B., durch Unterbau, Bestandsbilder geschaffen, die in ilırer Eigenartigkeit den Eindruck neuer selbständiger Formen erwecken.

So ist es z. B. nur eine Modifikation des liahlschlagbetriebes, wenn ein volühergehender Ueberhall zur Beschirmung der nachfolgenden liultur gegen Frost oder Sonnenhitze, vielleicht auch zur Zurūckhaltung von Unkrautwuchs oder von Slockausschlägen belassen wird. Man nennt cine solche Schlagführung hin und wieder ,Schutzschlag“ oder wohl auch ,Schirmschlag". Bei den Vorverjüngungsbetriehen kann man sich an Stelle der unter 1 bis 4 genannten vier Grundformen nur mil deren zwei: Femelbelricb und Schirmschlagbetrich begnügen. Streng genommen lassen sich in der Tat auch nur diese beiden Formen festhalten. Der Saumschlagbetrieb ist ja, wie oben crwähnt, nichls anderes als saunweiser Schirmschlagbetrieb, und der Femelschlagbetrieb zerfällt, sobald man den Horsł oder die Gruppe als wirtschaftliche Einheit betrachtet - was grundsätzlich gewiß zulässig ist - in eine Anzahl von kleineu Schirmschlagbctrieben. Da wir jedoch gewohnt sind, - aus ZwcckinäBigkeitsgrunden und doch auch infolge einer gewissen Berechligung in Sinne der Logik - die von der Waldeinleilung geschaffcnen Wirtschaftsfiguren, wie Abteilnngen und Unterabteilungen ctc., auch in Absicht auf waldbauliche Behandlung als Ganze zn betrachten, so mag hier, wo nicht die Einzeloperation, sondern der Betrieb in Frage steht, jene Trennung durchgeführt und der Femelschlagbelrieb als Grundform der Samenverjüngong durch anf der Fläche stehende llutterbäume bchandelt werden. Bestimmend wirki dabei besonders auch der Wunsch mit, es möchte tunlichste Einheitlichkeit der Definierung erreichl und danit das Verslăndnis gefordert werden. G a y e r luat in seiner Schrift ,Der gemischte Wald" für das, was hicr als ,Femelschlagbetrieb" charakterisiert ist, die Bezeichnung ,horst- und gruppenweise Verjüngung" gewăhlt, weil er sich vor der Verwechselung mit dem Femelschlagbetrieb H e je rs (= unserem Sehirnschlag- 
betrieb) scheut. Es ist dies aber nicht als zwingender Grund anzusehen, die Bezeichnung Femelschlaghetrieb ganz zu meiden, da die Sache, um welche es sich handelt, doch so scharf gehannzeichnet isl, daß Mißverständnisse kaum zu erwarten sind.

\section{B. Die Aussehlagholzbetriebe.}

\$21. Die hierher gehörigen Betriebsarten sind dadurch voneinander verschieden, daß die oberirdische Masse des Einzelindividuums in mehr oder weniger weitgehender Weise Gegenstand der Nutzung ist. Nan unterscheidet:

1. Nied erwald-oder Stockschlagbetrieb: Bei der Ernte wird die gesamte oberirdische Ilolzmasse genutzt, so daf. nichts als der Stock mit den Wurzeln verbleibt. Stockausschläge und eventuell Wurzelbrut bilden den jungen Bestand. Ein in jährlichen Nachıaltbetrieb befindlicher Niederwald hat eine der Umtriebszeit entsprechende Anzahl von einzelnen Flächen bezw. Beständen in Altersabstufung von je 1 Jahr.

2. Ko p f holzbetrieb: Ein Teil des Schaftes bleibt stehen; an seinem oberen Ende entwickeln sich Ausschläge, welche Gegenstand der folgenden Nutzung sind. Bei öfterer Wiederholung derartiger Nutzung bilden sich am Schaftende Wülste und kopfartige Verdickungen.

3. Sc hn e i e l hol z b e $t$ r i e b: Der gauze Schaft bleibt erhalten. Die Nutzung erstreckt sich nur auf die Aeste, an deren Abhiebsstellen Aussclıläge hervortreiben; diese liefern dann die Holzmasse für den nächsten Hieb.

\section{Der Mittelwaldbetrieb.}

$\S 22$. Der Mittelwald ist eine Verbindung von Niederwald mit plenterartigem Hochwald. Auf derselben Fläche wird gleichzeitig ein im wesentlichen Brennholz lieferndes, aus ausschlagsfähigen Holzarten bestelıendes sog. U n t e r h o l z und ein hochstämmig erwachsendes, der Nutzholzerzeugung dienendes $\mathrm{O}$ b e r h o l z erzogen.

Beim jedesmaligen Abtriebe des im 10 bis 20 jälırigen Umtriebe bewirtsclıafteten Unterholzes wird ein Teil der bestwüichsigsten Ausschläge stelıen gelassen, ebenso werden die beim vorllergehenden Abtriebe zur Ausfüllung der Fehlstellen usw. durch Pflanzung eingebrachten Kernwüchse erhalten. Diese stehengelassenen Teile des bisherigen Unterholzes gehen nun in die Oberlıolzklasse über und führen zunächst den Namen $L$ a $B$ r e is e r oder $L$ a $B$ r e i t e l. Beim näclisten Abtriebe des Unterholzes lıaben die Laßreiser das doppelte Alter des Unterholzumtriebes. Ein Teil von ihnen wird gleichzeitig nit dem Unterholz entnommen, der andere Teil bleibt stehen und bildet während des dritten Unterlolzumtriebes die , $\mathrm{O}$ b e r s t ä n d e r" bei den späteren Unterholzabtrieben übergehaltene Teile ab und zu als a $\mathrm{n} g$ e h e $\mathrm{n} d \mathrm{e}$, später als starke oder $\mathrm{H}$ a u p t b ä u m e bezeichnet werden. Die ältesten Oberhölzer werden beim Unterholzschlage = Mittelwaldschlage mit genützt.

Jedem Unterholzabtriehe entspricht somit eine Oberholzklasse. Das Unitriebsalter des Oberholzes ist ein Mehrfaches des Unterholzumtriebes, so daß im normalen Mittelwald der Altersunterschied der verschiedenen Oberholzklassen immer durch ren Unterholzuntrieb oder durch ein Vielfaches desselben angegeben wird.

Ein im jährliclıen Nachlıaltsbetriebe slehender normaler Miltelwald hat, wenı der Unterholzumtrieh $u$, der Oberholzuntrieb $U$ Jahre umfaßt, $\frac{U}{u}-1=n$ Oberholzklassen, da die Laßreiser, die nach Ablrieb des Unterholzes zum Oberholz übertreten, vor dem Ablrieb noch dem Unlerholz angehören. Er bietet dann folgendes Bild:

Vir haben u Flächentcile, bezw. Schläge (im Nornalwald gleichwertig in ihrer Erlragsleistung). Diese sind unnitlelbar vor einem Hieb bestockt mit. 
a) 1-, 2-, 3- ... u jährigem Lnterholz,

b) je init den n Oberholzklassen, welche z. B. für den Schlag mit ujährigem Unterlolz. $2 u_{-}, 3 u-\ldots$ nu-, $(n+1) u=$ Ujährige Stämme und für den Selıtag nit 1 jährigesn Interholz $(u+1)-,(2 u+1)-, \ldots(n u+1)$ jähriqe Stämme enthalten.

Die Zahl der Stảnme in den einzelnen Oberholzklassen bildet eint abnehmende Reihe, sofern sich die urspringlich in befrichtlicher Menge übergehaltenen I.al3reitel stetig veruindern. Denn sowohl die Entwickelung der cinzelnen Oberholzstämme, als die Rucksicht aul kräftiges Erwaelisen genügender Unterholzmengen fordert es, daß bei jedem Hieb des Unterlolzes nicht nur gleichzeitig die a 1 te s $t$ e Oberholzklasse genutzt, sondern auch in die übrigen Oherholzklassen eingegriffen wird, indem man nutzholzlaugliche stamme entfemt und einen zu dichten Stand des Oberholzes ermäßigt. In welchesu Betrage dahei dir Stamnzahlen im einzelnen reduziert werden, ist von einer großen Reihe so sehr wechselnder ['Tmstände (Holzart, Standort, Wirtselaftszweek, bezw. stärkere Betonung bald des Oberholzes, bald iles Lnterholzes usw.) abhängig, daß dafür auch nicht entfernt irgend welche allgemeine Norm aufgestellt werden kann. Ueberhaupt zeigt der Jlittelwald, bedingt durch Art, Menge und Verleilung des Oberholzes, wohl die vielfältigst abgeänderten Formen. Nach dem verschiedenen Maße, in dem Ober- und Unterholz an der Zusantmenselzung des Mittelwaldes teilnehmen, unterscheidet man hochwaldartigen. niederwaldartigen .littelwald und solchen in gewöhnlichen Sinne. Je mehr das Oberholz überwiegt, umsomehr nimmt der Mittelwald naturgemäß hochwaldartigen Charakter an und umsomehr tritt die stammweise Vericilung der Oherholzklassen des niederwaldartigen und gewöhnlicherk Hittelwaldes gegenuber einer netur lıorst- und flächenweisen zurick.

II. Würdjgung de $\mathrm{r}$ Grundfor in en.

$\$ 2:$. Vorbemerkungen. Abgesehen von denjenigen Wäldern, in welchen Schutzwaldeharakter oder besondere vom Waldbesitzer verfolgte Zwecke (Wildpark) die der Wirtschaftsführung zu grunde zu legende Betriebsart vorschreiben, sind bei der Wahl der Betriebsart deren ökonomische und waldbauliche Leistungen ausschlaggebend. Es unterliegt keinem Zweifel, daß in unseren Wirtschaftswäldern die ökonomischen, im Nutzeffekt zum Ausdruck kommenden Leistungen im Laufe der Zeit einen überwiegenden Einfluß auf die Bevorzugung und Ausbreitung der in dieser Richtung vorteilhaftesten Betriebsarten gewonnen und die vom natürlichen Prinzip geforderten Rücksichten hin und wieder in einer zu weit gehenden Weise in den Hintergrund gedrängt haben. Der Einfluß, den die einzelnen Betriebsarten auf den Boden ausüben, ist für ihre Beurteilung zweifellos unbedingt maßgebend, weil die dauernde Erhaltung bezw. Steigerung des Prorluktionsfaktors „Bodenliraft" die wesentlichste Bedingung aller Nachhaltigkeit ist. Die von G a y e r u. a., neuerdings von C. W' a g n ex inaugurierte Bewegung zugunsten schärferer Betonung der waldbaulichen Leistungen der Betriebsarten verdient deslıalb volle Beachtung. Andererseits ist aber auch in dieser Richtung eine einseitige, über die ökonomischen IVerte hinwegsehende Vertschätzung zu vermeiden. Zum mindesten kann es angesichts der Verschiedenartickeit der waldbaukichen und wirtschaftlichen Eigenschaften unserer Holzarten und angesichts der Verschiedenheit der Standortsverhältnisse nicht als richtig bezeichnet werden, in e i n e r Betriebsart ihrer waldbaulichen oder sonstigen Vorzüge wegen die für alle Holzarten und alle Produlitionsgebiete gemeinsame, passendste und beste zu erblicken.

Jede vernünftige Wirtschaft wird diejenige Betriebsart wälılen, die untel den gegebenen Umständen das günstigste Verhältnis zwischen Ertrag und Produktionskosten aufweist und zwar nachhaltig. Diese gebotene Rücksichtnahme auf die Nachhaltigkeit und auf Vermeidung von Augenblickserfolgen umschließt von selbst die Beachtung des waldbaulichen Wertes der zu wählenden Betriebsart. Haßgebend für die Bemessung der ökonomischen Effelite verschiedener Wirtschaftsverfahren ist die Bodenrente bezw. der Bodenertragswert, und dasjenige Wirtschaftsverfahren, das uns bei Wahrung der natürichen, produlitiven Forderungen das Maximum des Bodenertragswertes in Aussiclıt stellt, ist das günstigste. 


\section{A. Hochwald.}

§ 24. In Wesen des Hochwaldbetriebs, wenn auch nicht grundsätzlich dadurch bedingt, liegt es, daß $\mathrm{cr}$ mit höherem Untrieb behandclt wird ${ }^{1}$ ). Aus diesem Umstande hauptsächlich ergeben sich hinsichtlich der wirtschaftlichen Leistung die Unterschiede gegenüber dem Ausschlagswald und den Nittelwald. Bei letzterem steht nur das Oberholz in höherem Umtrieb, während das Unterholz meist in kurzen Zwischenräumen (von 10-20 Jahren) abgetrieben wird; bei den Ausschlagswaldungen kommt überhaupt nur cin niederer Umtrieb (von 1jähıigem bei Flechtweiden bis etwa 30 jährigem bei Eılen) in Betracht.

Jene Unterschiede treten am klarsten zu Tage, wenn man zunächst die beiden extremen Formen: Hochwald und Niederwald vergleicht.

Folge des löheren Umtriebs ist beim Hochwald zunächst die seltenere Sorge für Neubegründung cincs Bestandes auf der nämlichen Fläche. Dagegen muß aber derjenige Waldbesitzer, welcher nicht anders als in aussetzcnden Betrieb wirtschaften kann, länger auf einen Abtriebsertrag warten und empfängt nur in Gestalt der Zwischen- und etwaigen Nebennutzungen mehr oder minder belangreiche Abschlagszahlungen. Soll ein jährlicher Betricb durchgeführt werden, so bedarf es in den meisten Fällen - (beim Plenterbetrieb nicht) - einer relativ (im Verhältnis zur Untriebszeit stehend) großen Fläche, damit der einzelne Jahres- oder Periodenschlag noch eine für dic erfolgreiche wirtschaftliche Behandlung genügende Größe erhält. Unzertrennlich mit dem höheren Umtrieb verbunden ist für den Nachlıaltbetrieb das größere Holzvorratskapital, mit welchem der Hochwald arbeitet, ein Umstand, welcher an sich, d. h. immer dann, wenn er nicht durch andere Nomente paralysiert wird, eine geringere Verzinsung erwarten läßt. Wenn der Ilochwaldbetrieb eine zu hohe Kapitalanhäufung aber vermeidet und durch bessere Ausnützung der das Produktionskapital nicht erhöhenden Naturkräfte (durch Bodenpflege, Ausnützung der Naturverjüngung, intensiven Durchforstungs- und Lichtungsbetrieb) auch auf Kürzung des Produktionszeitraumes bedacht ist, so ist er in bezug auf Rentabilität dem Niederwald immer und dem Mittelwald in den meisten Fällen überlegen. Weniger günstig stellt sich das Verhältnis des Hochwaldes zu Nieder- und Hittchaldbetrieb in bezug auf Sicherheit vor Gefahren: ersterer ist durch Sturm, Schnee, Feuer, Insekten zweifellos mehr gefährdet als jene. Dieser Nachteil ist aber nur zum Tcil auf die Verschiedenheit in der Umtriebshöhe zurückzuführen. In höherem Mlaße wird cr von der Verschiedenheit der Holzart, namentlich von dem mehr oder weniger vollständigen Fehlen der Nadelhölzer im Nieder- und Nittelwaldbetrieb bedingt.

Auf der anderen Seite wiederum ist der Hoclnwald für alle Holzarten tauglich, liefert bei entsprechend hohem Untriebe alle verschiedenen Sortinente, erzeugt Nutzholz in größter Menge und bester Qualität und ist somit diejenige Betriebsart, die den gesteigerten Bedürfnissen des Marktes nach Nutzholz weit mehr gerecht wird als Nieder- und Mittelwald, deren Nutzholzprozente nur ausnahmsweise über 5 bezw. 40 steigen. In zeinem größeren Holzvorrate bietet der Hochwald forner eine oft willkommene Gelegenheit zur Kapitalanlage und gewährleistet, wenn richtig geleitet, wegen der selteneren Wiederkehr der Abtriebsnutzung die vollständigere Erhaltung der Bodenkraft. Daß der Hochwald auch die absolut höclısten Massenerträge liefert, darf als sicher angenommen werden, wenr es auch an Zahlen nicht fehlt, die wenigstens dem Mittelwald die Ucberlegenheit in diesel' Richtung zu sichern scheinen. Diese Zahlen, welche die höheren Massenerträge des Nittehwaldes dartun sollen,

1) Ausnahme z. B. die Anzucht von Weihnachtsbäumchen auf besonderen Flächen. 
berulien entweder darauf, daß ein Ertrag des Mittelwaldes zugrunde liegt, der über den normalen Durchsehnitt hinausgeht, wie es bei Abnutzung ungewöhnlicher Aufspeicherungen von Oberholz leicht vorkommen kanı, oder aber sie stützen sich auf unzulässige Veıgleiche mit zu geringen Zuwacksleistungen oder zu geringen Standortsbonitäten des Hochwaldes. Abgeselven davon, daß in Nieder- und Mittelwalde viele Individuen im jüngeren Alter, in welchem der durchschnittliche Zuwachs noch weit unter seinem Iulminationspunkt steht, abgenutzt werden, weisen schon die natürlichen Faktoren, von denen die Znwachsbildung ablüngt, darauf hin, daß weder der Mittelwald und noch viel weniger der Niederwald den Hochwald in der nachlialtigen Holzmassenerzeugung zu übertreffen vermögen.

Bei den einzelnen Hochwaldformen machen sich die vorstehend angedeuteten Vor- und Nachteile in sehr verschiedenem Maße geltend.

1. Plenter- oder Femelbetrieb ${ }^{\mathbf{1}}$ ):

Als Vorzüge müssen geltend gemacht werden: die Möglichkeit, höhere Abtriebsalter in nachhaltiger Wirtschaft mit jährlichen Erträgen auch auf kleiner Fläche einzuhalten; ferner die weitestgehende Sicherung der Bodenkraft (gegeben namentlich in entspreehender Borlenfrische), weil niemals Bodenstellen in größerem Umfang völlig bloßgelegt werden; sodann die Gewälırung eines bedeutenden Lichtungszuwachses schion in einem verhältnismäßig frühen Stadium der Baumentwiekelung. Dabei werden die Stämme, weil schon bald mehr freiständig erwachsend, widerstandsfähiger gegen Sturm und Selnneebruch, wie denn alle einem ungleichmäßigen Kronendach nachgerühmten Vorteile im Femelwald in besonderem Maße angetroffen werden müssen. Für gefährdete Gebirgslagen, Schutzwaldungen ete. ist der Femelbetrieb die geeignetste, ja oft einzig zulässige IVirtschaftsform.

Dagegen beschränkt sich seine Anwendbarkeit auf nur wenige Holzarten, auf die eigentlichen Schattenhölzer Tanne, Buche, allenfalls Fichte; denn alle Jungwüchse müssen melır oder minder im Druck heraufwachsen, also die Fähigkeit haben, sich mindestens in starkem Seitendruck längere Zeit entwiclielungskräftig zu erhalten. Dem vorerwähnten starken Lichtungszuwachs steht mithin eine (je nach den Umständen versehiedene) Einbuße an Zuwachs in der Jugend gegenüber. Die Wirtschaftsführung hat diese Einbuße möglichst zu reduzieren, kann sie aber begreiflich niemals ganz vermeiden. - Die Fällung und Holzbringung ist ersehwert - (geübte Holzhauer wissen übrigens diesen Nachteil auf ein geringeres $\mathrm{Maß}$ zu beschränken, als der Uneingeweihte meinen sollte!) --; die Bäume werden großenteils weniger astrein und weniger vollholzig als im geschlossenen Bestande, die tiefer angesetzten Kíronen erhöhen zwar den Zuwachs, nehmen aber gleichzeitig den jüngeren Bestandesgliedern mehr Licht weg und vermehren das Reisholzprozent. Für die hin und wieder behauptete Ueberlegenleit des Plenterbetriebes über die schlagweisen Betriebe in bezug auf Massen- und Wertsleistungen fehlen noch hinreiehende Beweise. Der einzelne zutreffende Fall bietet keine Gewähr für die allgemeine Richtigkeit dieser Behauptung. Die im Plenterwald vorliegenden Wachstumsbedingungen, die Sclswierigkeiten der Ernte im allgemeinen und die der rechtzeitigen Nutzung des Einzelstammes machen eher die gegenteilige Annahme wahrseheinlich. Es liommt weiter hinzu, daB der ganze Betrieb, weil er melır zersplittert ist und sich mit seinen Operationen über

1) Vergl. F ü $r \leq t$, ,Plänlerwald oder schlagweiser Hochwald“". Berlin 1885. - S e lt uberg, Sellaglichter zur Streitfrage: ,schlagweiser Hochwaid- oder Femetbetrieb" (Forstw. Zentralbl. v. 1886, S. 129, 193). - V o n h a u s e n, , Der schlagweise Hochwaldbetrieb und der Femelbetrieb" (Allg. F.- u. J.-Z. 1882, S. 289). - D üe s berg, Der Wald als Erzieher, 1910. IV e rn ick. Plenterwatd, eine Studie. Allg. F.- u. J.-Z. 1910, Juli-Olil. 
einen größeren 'Teil des ganzen Waldes erstreckt, weniger übersichtlich ist und der sicheren Ertragshestimmung, der Buclıührung etc. größere Schwieriglieiten bietet.

So wenig aber in der geringesen Uebersichtlichkeit, sowie in der durch den Betrieb etwa geforderten größeren Intelligenz und Arbeitsleistung der Beamten bei der Schlagauszeichnung, Beaufsichtigung des Fällungsbetriebs usw., ein Hindernis für die Durchführung erblickt werden darf, so verfehlt wäre es, wollte man njcht in der größeren Einfachheit anderer Betriebsarten einen immerhin erwälnenswerten Vorzug derselben anerkennen. Es ist kaum anzunelimen, daß der Plenterbetrieb außerhalb der höheren Gebirgslagen, wo er gewiß die beste Betriebsart darstellt, zur ,Bestandsform der Zukunlt' ${ }^{1}$ ) werden oder in der von Düesberg ${ }^{1}$ ) empfohlenen Form in den liiefernbeständen Norddeutschlands viel Feld erobern wird.

2. Plenter-oder Femelsclilagbetrie b ${ }^{2}$ ).

Dem in Bayern, im Scliwarzwald und in den Vogesen in den Buchen-TannenFichten-Nischbeständen bevorzugten horst- und gruppenweisen Betriebe werden Erzielung horstweise gemischter Bestände, bessere Erhaltung der Bodenkraft, Sicherheit der natürlichen Verjüngung und erhöhtere Ausnützung des Lichtungszuwachses nachgerühnt. Es steht fest, daB durch die dem Plenterschlagbetrieb eigentümliche ungleichmäßige Hiebsfülırung und Schlagstellung und die dadurch bedingten Unterschiede im Grade und in der Dauer der Ueberschimung sowohl das Entstehen wie namentlich auch die schnellere oder langsamere Entwicklung von Horsten und Gruppen der verschiedenen Holzarten reguljert werden kann. Soweit der Entwicklungsgang der in Nischung befindlichen IJolzarten es verlangt, kann den einzelnen Horsten ein grundsätzlich verscliedenes Alter gewährt werden dergestalt, daß den langsamwïchsigeren Holzarten ein Vorsprung vor den rasch sich entwickelnden gegelsen wird. Die Altersdifferenz der Horste wird der verschiedenen Wuchsliraft der in Frage kommenden Holzart angepaßt. Auch in reinen Beständen hat die in den einzelnen Verjüngungshorsten von innen nach außen fortschreitende Verjüngung ein wellenfömiges Profil des entstehenden Bestandes zur Folge. Die Verjüngungshorste fallen von ihrer Nitte aus kegelförmig nach den Rändern zu ab und stoßen, wenn der ganze Bestand verjüngt und die letzten llutterbäume geräumt sind, ohne Steilränder aneinander. Man bringt mit der so geschalfenen stufigen Form des Bestandes eine größere Widerstandsfähiglieit gegen Schneeschäden in Zusammenhang und schließt aus dem Vorlıandensein einer in Vergleich zum gleichaltrigen Bestand größeren Kronenoberfläche und größeren Blattmenge auf lebhaftere Wuchsenergie und erhöhten Zuwachs. Ob und in welchem Betrage der Betrieb größere und namentlich wertvollere $\mathrm{Massen}$ erzeugt als ein anderer, insbesondere als ein richtig geleiteter Schirmschlagbetrieb, dessen Bäume frühzeitig aus dem Zustande starlier Kíronen-

1) A. Engle $\mathrm{l}$. Aus Theorie und Praxis des Femelschlagbelriebes. Selweiz. Ztschr. f. Forstw. 1905, S. 123 ff. - D ü s b e r g, Der Wald als Erzieher, S. 93-132.

2) Hier insbes, zu vergleichen G a y e r s: "Der gemisehte Wald", sowie G a y er, "Ueher den Femelscliagbetrieb und seine Ausgestaltung in Bayern" 1895, ferner Bericht über die 19. Versamm] nng deutselier For stmänner in liassel 1890, S. 17. „, Die wirtschaftliche und finanzielle Bedeutung des horst- und gruppenweizen Femelschlagbetriches im Hochwald", sowie Bericht üher die iI. Hauptversammlung des veutschen Forstvereins in Regensburg (1901) S. 106: ,Beruht in dem Fenelschlagverfahren, sowie in der Fombination desselben mit dem Saumsehlagverfahren das vorzüglicliste Mlittel, Mischbestände in sicherster und vollionmenster Weise zu erziehen?" "Wirtschaftsregeln für die Iigl. Bayerisehen Forshümter Iiehlheim-Nord und Süı" herausgegeben von der Iigl. Ministerial-Forstabteilung (den Mitgliedern der Forstversammlung zu Regenshurg gewidmet). - W a p pes, Ueher das Prinzip und die Anwendbarkeit des Femelschlagverfahrens. Zb]. f. d. ges, Forstw. 1904. S. 387; A. E ngler, Aus Theorie und Praxis des Femelschlagbetriebes. Selwweiz. Ztschr. f. Forstw. 1905, S. 29, 61, 99, 123. - B l u m, Aus Theorie und Praxis des Femelschlagbetriebes. Nllg. 1.- u. J.-Ztg. 1906, s. 149. 
spannung befreit werden, ist noch nicht genügend untersucht. Wie allen Naturverjüngungen ist auch dem Plenterschlagletrieb eine gewisse Erschwerung bei der Ernte und heim Transport der Mutterbäıme eigentümlich. Beschädigungen des Jungwuchses und der noch stehenden Althölzer sind unvermeidlich, treten aber um so mehr zurück, je geschickter und vorsichtiger die Arbeiter zu Werlie gehen, und lassen sich wohl bis zur Unschädliclıkeitsgrenze zurückdrängen. Der Gedanke an größere Sturmgefahr der in der Verjüngung stehenden Bestände scheint zwar nach den bayrischen Erfahrungen unberechtigt, bleibt aber für alle exponierteren Lagen und weniger sturmfesten Holzarten naheliegend.

Der Femelschlagbetrieb tritt in Lonkurrenz hauptsächlich mit dem Sehirmschlag- und dem Kahlschlagbetrieb. Er ist im allgemeinen für alle Holzarten zulässig, welche nicht so ausgesprochene Lichthölzer sind, daß sie jeden Schirmdruck oder alle Seitenbeschattung auch in der Jugend verbieten. Die Verbindung mit Kahlabsäumungen und künstlichem Anbau ist nicht ausgeschlossen, vielmehr öfters geboten.

3. Seli irmschlagbetrie b:

Der Betrieb findet ebenfalls in der natürlichen Verjüngung durch Samenabfall (Mutterbäume auf der Fläche) Ziel und Begründung. Der Boden wird niemals bloßgelegt, wohl aber wird dadurch, daß man den ganzen Bestand gleichmäßig durchlichtet, die Entstehung einer leichten Bodenbenarbung eher möglich als bei dem mit einzelnen kleinen, unzusammenhängenden Bestandespartien operierenden Femelschlagbetrieb. Kieineswegs bedeutet dies aber schon eine entschiedene Sclıädigung der Bodenkraft, wenn nur bei den betreffenden Hieben stets mit der nötigen Vorsiclıt verfahren wird. Allerdings entsteht grundsätzlich ein gleichförmiger Bestand. An sich ist ein solcher aber nur dann zu beanstanden, wenn durch ihn den Rücksichten der Bodenpflege nicht genügend entsprochen wird. Ausdehnung des Terjüngungszeitraumes bietet auch bei diesem Betrieb die Möglichkeit länger andauernden Lichtungszuwachses. Das Zusammenfassen mehrerer Jahresschläge in einen Periodensclulag gestattet die Durchfülırung des jährlichen Nachhaltbetriebs auf kleinerer Gesamtfläche als beim Kahlschlagbetrieb; freilich ist der reine Femelbetrieb in dieser Hinsicht nicht zu erreichen. Dagegen ist die Uebersichtlichkeit im Schirmschlagbetrieb größer als im Femelwald und auch als im Femelschlagbetrieb. Die angestrebte Gleichmäßigkeit der Schlagstellung beim Schirmschlaghetrieb spricht für dessen Anwendung in gleichförmigen, hauptsächlich von ein und derselben Holzart gebildeten Beständen.

4. Sa umschlag betricb.

Diese Betriebsweise ist, wie schon S. 41 angedeutet wurde, nur eine Abart des Schirm- bezw. Plenterschlagbetriebes. Die natürliche Verjüngung findet auf schmalen Streifen statt, die man je nach dem gleichmäßigen oder ungleichmäßigen Stande der Samenbäume als Sa unsehirmschläge bezw. Sa u plenter$\mathrm{s} c \mathrm{~h} l$ ä g e bezeichnen darf. Der Wert aller Saumverjüngung beruht in der Erhölıung der für das Gelingen der natürlichen Ansamung selır bedeutsamen Bodenfeuchtigkieit. Auf dem am Bestandesrande liegenden Verjüngungsstreifen kommen die bei günstigem Winde hereingewehten Niederschläge mehr zur Wirkung als auf einer größeren mit Samenbäumen mehr oder weniger gleichmäBig überstellten Fläche, wo sie von den Kronen der Samenbäume um so stärlier abgefangen werden, je größer deren Zahıl ist. Hinsichtlich der von der Saumverjüngung angestrebten besseren Ausnützung der Niederschläge macht es aber einen großen Unterschied, ob der Verjüngungsstreifen am Ost- oder Südrande bezw. am West-oder Nordrande des zu verjüngenden Bestandes gelegen ist. Die der Sturmgefalır wegen zeither zumeist von Osten herein eingeleitete Verjüngung führte infolge der intensiveren Besonnung durch die Vormittags- 
und Nittagssonne, ferner infolge der ungehinderten Einwirkung der trockenen Ostwinde, sowie infolge del stärkeren Abhaltung der von Westen kommenden Regen zu keinem befriedigenden Ergebnis. Vielmehr sind Austrocknung des Bodens, Dürre und Spätfrostschäden die gewöhnlichen Begleiterscheinungen der von Osten, Südosten oder Süden herein versuclıten Verjüngung. Prof. IV a $\mathrm{g} n \mathrm{e} \mathrm{r}$ - Tübingen ist es zu dankien, die infolgedessen stark in Mißkredit gekommene Saumverjüngung dadurch wieder zu Ehren gebracht zu haben, daß er an der Hand praktischer Erfahrungen auf die ganz anders gearteten Verhältnisse der an den West-, Nordwest- und Nordrändern liegenden V'erjüngungsstreifen aufmerksam machte. In dem von $\mathrm{W}$ a gne $\mathrm{r}^{\mathrm{l}}$ ) empfohlenen, ,B le n d e r s a u m s c h l a g ${ }^{\prime}$, einer von Norden, unter Umständen (bei Fehlen von Sturmgefahr) auch von Nordwesten vorrïckenden Saumverjüngung, ist der Saumschlagbetrieb wieder in die Zahl der brauchbaren Betriebsarten aufgenommen worden. Auf den am Nord-oder Nordwestrande liegenden Verjüngungsstreifen bleibt die Bodenfrische besser bewahrt, weil die im Osten und Süden stehende Sonne weniger einwirkt und weil die von Westen liommenden Regen mehr oder weniger vollen Zutritt zum Boden haben. Die Folge ist, wie die Beobachtungen im Walde bestätigen, Gelingen, und zwar teilweis überrasehend gutes Gelingen der Naturverjüngungen.

Die Würdigung des Saumschlagverfahrens kann sich deshalb auf die Bewertung des Wagnerschen Blendersaums beschränken. Dadurch, daß die Verjüngung allmählich streifenweise nach dem Bestandsinnern zu vorrückt und daB auf den bereits angesamten Streifen eine mehr oder wenigel" rasch dırchgeführte Räumung der Samenbäume für Regulierung des Lichtgenusses sorgt, wird, ähnlieh wie beim Plenterschlagbetrieb, dem Wirtschafter die Möglichkeit geboten, Mischungen zu schaffen. Auf dem V'erjüngungsstreifen behauptet sich zunäehst rler Aufschlag der Schattenhölzer Tanne und Buche. Je mehr beim Fortschreiten der Verjüngung auf dem zuerst in Angriff genommenen Streifen die Samenbäume geräumt werden, um so melır sind die Bedingungen für Ansamung der lichtbedürftigen Holzarten, vor allen der Fichte, gegeben. Der Altersvorsjrung, den der Schattenholzjungwuchs hat, sichert vor schnellem Ueberwachsen durch die Fichte und andere natürlich angeflogene oder liünstlich eingebrachte lichtbedürftigere und schnellwüchsigere Holzarten. Dem in Erhaltung des Mischwuchses liegenden Vorzuge treten alle der natürliehen Verjüngung als solcher eigentümlichen Vorteile und Nachteile zur Seite. In sturmgefälırdeten Lagen und gebirgigem Gelände, ferner dort, wo Samenjahre selten sind oder ein Lichtholz, vor allem die Kiefer, die standortsgemäße herrschende Holzart ist, stehen der Anwendbarkeit des Blendersaumschlages Bedenken entgegen. Auch die Notwendiglieit einer großen Anzahl von Anhieben und Transportgelegenheiten (Wegen) bereitet der allgemeinen Durchführung der Blendersaumverjüngung Schwierigkieiten, die in den ausgedehnten Fichtengebieten um so größer erscheinen, je mehr mit der Zahl der Anhiebe von Norden die Sturmgefahr wächst.

5. K a h lse hl a g b e trieb.

Sein wesentlichster Vorzug ist seine Einfachheit und Uebersichtlichkeit, sowohl

1) C. W a g n e r, Die Grundlagen der räumlichen Ordnung im Walde. 2. Aufl. 1911. Derselbe, Der Blendersaumschlag und sein System, 1912. - Vgl. bierzu u. a.: Th a le r, Natur- oder Kunstverjüngung; sowie WVagne rs Erwiderung. Allg. F.- u. J.-Zlg. 1908, S. 8 und 153; Eber hard t, Die răumliche Ordnung im Walde und die Nalurverjungung, ebendas. 1908, S. 113. - Eul e f eld, Die Waldwirtschafl von Prof. Wagner, ebendas. 1908, S. 353. l* ü r t, Slrillige Fragen auf dem Gebiete des Waldbaues. Forstwiss. Zentralbl. 1908, S. 505. - F a b r i c i us, Die Anwendbarkeil des Wagner'schen Verjüngungsverfahrens, ebendas. 1909, S. 401. (Erwiderung von C. Wagner, das. 541); Derselbe, Zu dem Artiliel des Herrn Prof. C. Wagner-Tübingen über die Gaildorfer Waldwirtsehafl, ebendas. 1910, S. 37. - K i e n i l z, Aus dem Gebiete des Blendersaumsehlags. Zlschr. f. F.- u. Jw. 1910, 215. - C i es I a r, Wagners Blendersaumschlag. Zbl. f. d. ges. Fw. 1910, S. 49. 
im Hinblick auf die Operationen des Waldbaues (Lnabhängigkeit von der zufälligen Beschaffenheit des Altbestandes, dem Eintritt von Mastjahren etc.) und der IIolzcrnte einschl. Holzbringung (Hiebslührung zu beliebiger Jabreszeit, olnne Rüclisicht auf Jungwuchs etc.), als auf dic Jaßnalımen der Forsteinrichtung und Wirtschaftskontrolle. Voraussetzung ist aber, daß die Holzart für die Nachzuclıt in Freien (künstlicher Anbau oder Besamung durch Randbäume) geeignct ist, und daß eine Gcfährdung der Bodenkiaft nicht befürchtet werden muß. Der Betricb ist also von voruherein nicht zu wählen für Tanne und Buche, obwohl cr auch für diese Holzarten aushilfsweise da und dort eintreten kann. Bezüglich der Bodenkraft werden dem Kiahlschlag die größten Vomwüre gemacht. Unzweifelhaft ist das zeitweilige Bloßlegen des Bodens kein Gewinn (Verschlechterung inshes. der physikalisehen Bodencigenschaften, Humusverflüchtigung cte.), es sej denn, daß der Nachteil durch die Vorteile nachfolgender Bodenbearbeitung (Roden im Waldfeldbau, Rabattenkultur in nassem Terrain u. dergl.) paralysiert wird. Immerhin aber tritt im Hochwaldhetrieb jenes rollständige Entblößen des Bodens nur in großen Zwischenräumen ein und dürfte kaum als so unbedingt verderblich erachtet werden, wie es ab und zu hingestellt wird, wenn nur durch sofort nachfolgende tüchtige und grïndliche hultur der Boden rasch wieder gedeclit wird. Das ist allerdings eine nicht immer leicht zu erfüllende Bedingung, zumal außer den zunächst entscheidenden Witterungseinflüssen oft auch Insekten (Maikäfer. Rüsselkäfer u. a. m.) auf den Kahlflächen in verderblicher Weise auftreten oder Lnkräuter im Uebermaß sich cinstellen. Die Entstchung eines genügend geschlossenen Jungbestandes kaun dadurch, ganz besonders auch durch Wildschäden, auf Jahre linaus vereitelt werden. Gegen derartig widrige Einflüsse muB man sich möglichst sichern, inden man zu große und nanentlich von Jahr zu Jahr aneinandergereihte Kulturflächen vermeidet, die Art der Kultur richtig wählt und für genügende Pflege derselben sorgt. Ein zweifelloser Nachteil des Kahlsehlagbetriebes ist die durch ihn unaufhaltsam herbeigefühte Lniformierung der Bestände. Die wobltätigen Mischungen verschwinden. Dem gegenüber aber steht das ökonomische Uebergewicht reiner Bestände, wie auch dic trotz aller Jugendkranklıeiten der Kulturen doch immerhin große Erfolgssieherheit des Verjüngungsgeschäftes. Mit dieser Erfolgssicherheit steht allerdings ein oft nicht unbedeutender liulturaufwand, also eine die Rentabilität wesentlich becinflussende Erhöhung des Produktionshapitales in Zusanmenhang. So richtig von den Anbängern der Naturverjüngung hierauf hingewiesen wird, so berchtigt ist der von den Kahlschlagfreunden erhobene Einwand, daB auch die natürlichen Verjüngungen meist nicht kostenlos gelingen und daß der Kahlschlag in viclen Fällen weit schneller zu lüchenlosen Verjüngungen führt als die Naturverjüngung.

Tatsächlich sind mittelst des Kahlschlagbetriebs und nachfolgender künstlicher Kultur auf weiten Strecken vortreffliche Bestände begründet worden (bes. Fichte, Fiefer, Eiche etc.), und obwoh! zweifelsohne da und dort auf großen Flächen auch entschiedene Mißerfolge zu verzeichnen sind, so sind diese doch nicht alle als unvermeidliche Folgen des Betricbs an sich zu charakterisieren, sondern sicherlich teilweise auf wirtschaftliche Felıler oder auf Ungunst des Standsortes zurückzuführcn. Jedenfalls sind die Beweise. welche zugunsten des Betricbs erbracht werden können, mindestens ebcnso zahlreich, als dic gegenteiligen, so dafs es - eine hier und da zu weit gehende Ausdelnung desselben zugegeben - doch nicht gerechtfertigt ist, den Kahlschlag ganz allgemein zu bekämpfen, bezw. auch für diejenjg̣en Fällc zu verwerfen, in welchen er unleugbar guten Erfolg sichert. Man könnte wolıl dic Frage stellen, ob in solchen Fällen nicht durch Schirmschlag oder Femelschlag der gleiche waldbau- 
liche Erfolg erzielt worden wäre? Bejahendenfalls würde dann ein zwingender Grund für den Kahlschlag nicht vorhanden gewesen sein. Aber es blieben dann doch die andern zu seinen Gunsten angeführten Momente in Kraft. Wer freilich überhaupt einen gleichmäßigen Bestand (auch den gleichförmigen Schirmschlag) nicht billigen kann, muß sich gegen Kahlschlag bedingungslos abweisend verhalten, mindestens ihn nur als Ausnahme zulassen. Aber es sind nur wenige, welche so einseitig eine bestimmte waldbauliche Richtung vertreten. Viclmehr begegnen sich mit wenig Ausnahmen alle bedeutenderen neueren Schriftsteller auf dem Gebiete des Waldbaues in dem fortwährenden Hinweis darauf, daß starres Verfolgen von Extremen zu vermeiden und jeder Betriebsart, je nach den örtlichen Bedingungen, ihre Stelle einzuräumen ist. Dies gilt natürlich, wie es jetzt anläßlich der Würdigung verschiedener Hochwaldformen ausgesprochen ist, nicht minder von allen übrigen Betricbsarten. Für die Wahl des einen oder des anderen Verjüngungsverfahrens ist der Standort von ausschlaggebender Bedeutung. Ein Generalisieren zugunsten eines bestimmten Betriebes ist unzulässig.

6. Kahlschlag $\mathrm{mit} R$ and besamung.

Der nur für Holzarten mit leichten flugfähigen Samen in Betracht kommenden Naturverjüngung durch den Seitenstand ist eine größere Bedeutung nicht beizumessen. Die der Windgefahr wegen meist von Osten herein vorrückenden schmalen Kah]schläge sind mit denselben Mängeln behaftet, die oben bei Besprechung der Ostrand-Saumschläge erwähnt wurden. Sie sind namentlicl der Austrocknung ausgesetzt, samen sich meist nur unvollliommen an und bedür fen bei der Verjüngung um so mehr künstlicher Nachhilfe, je breiter und unkrautwüchsiger sie sind.

\section{B. Aussehlagswald.}

$\$ 25$. Charakteristisch sind liurze Umtriebszeit, dementsprechend baldiger Eingang von Abtriebsnutzung, häufige Wiederkchr der Ernte auf der nämlichen Fläche, Kahlabtrieb und damit in Verbindung Bloßlegung des Bodens und Gefährdung der Bodenliraft. Wenn auch in normalen Verhältnissen bei nicht zu alten Stöcken eine rasche Wiederbedeckung des Bodens stattfindet, so ist doch infolge des hohen Mineralstoffbedarfs der Ausschläge das Nährstoffkapital des Bodens mel r als beim Hochwaldbetrieb gefährdet. Die vom Ausschlagswald gelieferten Erträge sind, sowrit es sich lediglich um Holz laandelt, nach Masse und Wert meist gering. Das Nutzholzprozent ist gewöhnlich sehr bescheiden, dic Pentabilität des Betriebes deshalb kine hohe, obgleich infolge des geringen Holzvorrates das Produktionskapital verhältnismäßig klein ist. Vorteilhaft erscheint der Ausschlagswald nur durch die von ihm gebotene Möglichlieit einer jährlichen Nachhaltswirtschaft auf kleiner Fläche und im Hinblick auf die geringe Bedrolıung durch äußere Gefahren. Schnee, Sturm, Insekten, Feuer schaden wenig, nur der Frost wird hin und wieder den Stöcken des Niederwaldes gefälırlich. Es ist selbstverständlich, daß nur ausschlagsfähige Holzarten, also Laublıölzer, für die hier zı nennenden Betriebe sich eignen.

1. $\mathrm{Ni}$ e d e r w a $\mathrm{ld}$.

Er ist diejenige Betricbsart, die unter den Ausschlagswajdungen fast allein im großen angewendet wird. Für ilın gelten alle vorstehend angeführten Momente. Sehr niedrige Umtriebe (Anzucht von Flechtweiden) sind auch auf ganz gutem Standort nur bei entsprechender Bodenbearbeitung, event. Düngung dauernd leistungsfähig, selbst die lı̈heren (z. B. Eichenschälwald) fordern sorgsamste Bestandes- und bezw. Bodenpflege. Der Niederwaldbetrieb zeichnet sich durch grölste Einfachheit und Uebersichtlichkeit aus, vermag aber nur dann einen befriedigenden Ertrag zu liefern, 
wenn seine besonderen Erzeugnisse, z. B. Weidenruten, Rebpfähle, Faschinen usw. günstige Marktverhältnisse finden und infolgedessen relativ loch in Wert stehen. Der nur Brennlıolz erzeugende Niederwald ist im allgemeinen nicht gewinnbringend und daher nur dort gerechtfertigt, wo er durch die Ungunst des Standortes bedingt wird, z. B. an steilen, flachgründigen Hängen oder in Bruch- und Geröllpartien. Vor dem Preisrückgang der Eichenlohrinde war es vielerorts dem Eichenniederwalde (= Eichenschälwalde) möglich, einen im Vergleich zum Durchschnittsertrag des Hochwaldes befriedigenden Reinertrag zu erziclen. Da das heut nicht mehr möglich ist, luat der Eichenschälwald seine Existenzberechtigung auf großen Fläclıen verloren, namentlich dort, wo er sich in Hochwald überführen läßt.

\section{Ko p f holzbetrieb.}

Konımt als forstlicher Betrieb höchstens in Flußniederungen in Frage, wenn Schutz gegen Eisgang und Wasser notwendig ist. Hier sowohl wie auch auf landwirtschaftlichem Gebiete, auf WViesen entlang der Bäche usw., handelt es sich fast durchgängig um Weiden und Pappeln, deren Ausschläge als Futterlaub, meist jedoch zu gröberen Korbflechtereien (Bandweiden) Verwendung finden. Rücksichten der Bodenpflege zugunsten der Holzproduktion werden nicht genommen.

3. Sc lıneitelbetrie b.

Forstlich bedeutungslos. Heist nur in geringem Umfange an Einzelbäumen (Eichen) und außerhalb des Waldes zum Zwecke der Futterlaubgewinnung seitens des Landwirtes ausgeübt.

\section{Mittelwald.}

§ 26. Der Nittelwaldbetrieb ermöglicht die Anzucht sämtlicher Holzarten. Für das Unterholz sind natürlich nur Laubhölzer mit bedeutender Reprodulitionskraft tauglich. Aber als Oberholz lassen sich, obwohl manche und insbesondere dichtkronige Holzarten zu diesem Zwecke wegen zu starker Beschattung des Unterlolzes nur schlecht taugen, wenn es der Waldbesitzer wünscht, sämtliche Holzarten verwenden. Der Mittelwald liefert alle denkbaren Sortimente. Kann er auch, in bezug auf Qualität der Oberholzstämme, mit manchen Leistungen des Hochwaldes (astreines, geradschaftiges $\mathrm{Holz}$ ) nicht konkurrieren, so erzeugt er doch andererseits wieder manche Ware (z. B. Schiffsbauhölzer) in besonderer Güte. Ertragsreich sind die als Mittelwälder behandelten Forste zumeist nur in den Niederungen unserer Flüsse (Auewaldungen), für welche sich diese Betriebsform trefflich eignet. Sie verdient aber auch insofern Beachtung, als sie eine jälırliche Nachhaltwirtschaft auf kleiner Fläche gestattet und dabei doch durch den Oberholzbetrieb auch Nutzholz verschiedenster Art, wenn auch in beschränkter Menge, ergibt (z. B. sehr beliebte Wirtschaftsform für den oft nicht beträchtlichıen Waldbesitz von Gemeinden). Die Gefahren, welche den Iittelwald bedrohen, sind im ganzen ziemlich gering.

Die Wirtschaftsführung erfordert aber viel Fleiß und Umsicht, will man nicht baldigen Rückgang der Erträge erleben ${ }^{1}$ ). Der Kahlhieb im Unterlıolz bedeutet - wenn auch wegen des Oberholzschirmdaclies weniger wie im Niederwald - immerhin eine Gefährdung der Bodenkraft, welcher durch sorgfältige Erhaltung ausschlagskräftiger Holzarten tunlichst begegnet werden muß. Ebenso ist die richtige Auswahl, Menge, Verteilung, Pflege etc. des Oberholzes von größter Wichtiglieit. Die Rekru-

1) Geringwertige Mlittelwaldungen finden sich zahlreich, häufig infolge nicht genūgender Rekrutierung, sowie rūcksichtsloser Ausūbung der Gras- und Weidennutzung, wodurch die etwa sich einstellenden Naturansamungen vernichtel werden. 
tierung erfolgt durch reichliches Einpflanzen von starken Pflänzlingen, namentlich Halbheistern und Heistern (Eiche, Esche, Ulme, Nadelhölzer usw.) naclı jedem Abtrieb des Unterholzes. Besondere Schwierigkeiten entstehen in Mittelwald für die Forsteinrichtung, soweit das Oberholz in Betracht kommt; Ertragsveranschlagungen sind ziemliclı unsicher ${ }^{1}$ ). Die Erträge selbst sind begreiflich außerordentlich versehieden ${ }^{2}$ ).

\section{Zweiles Kapilel.}

\section{Modifikationen derGrundformen, Zwischen- und Uebergangsformen. Besondele Fälle.}

Wie schon in den Vorbemerkungen zum zweiten Abschnitte lervorgehoben worden ist und auclı aus den Erörterungen der späteren Absclınitte, namentliclı aus denen über Bestandeserzichung, näher hervorgehıt, darf die Anzahl der sich zwischen den Grund-Betriebsarten einschaltenden, sie modifizjerenden und in schärferer Ausprägung sich zu gewissen eigenartigen Formen ausbildenden Betriebe füglich als eine unbeschränkte betrachtet werden. Deshalb kann an dieser Stelle auch nur auf e in ige Fälle noch besonders aufmerksam gemaclit werden, rlie, sei es durch ihr häufigeres Auftreten, sei es durch die Art ilırer Merkmale vor anderen Beachtung verdienen dürften.

Dabei können als M o d i f k a $t$ i o n en solche Formen bezeichnel werden, bei welchen die Grundform, der sie zugehören, noch klar erkennbar, bezw. nur in mehr nebensächlichen Punkten versehoben isl; als U e be rga $\mathrm{ngs}$ formen solche, welche sich zwischen zwei Grundformen einschallen und ebensowohl der einen als der anderen zugezîhlt werden können. Als besondere Fälle endlich dürfen gewisse Wirtsehallen namhafl gemachl werden, die sich zwar aus einer bestimmten Grundform herausentwickeln lassen und sich noch mehr oder minder an sie anlehnen, aber doch dureh Einfügung irgend welcher neuer Fakloren ein entschieden abweichendes und entsprechend selbständiges Gepräge zeigen. Scharfe Trennung nach diesen drei Rubriken ist allerdings nichl möglich, viclmehr werden vielfach Zweifol darüber entslehen, ob man eine vorgefundene Wirlschaftsform da oder dort einreihen soll. Doch ist eine solche feinere Rubrizierung auch ziemlich gleichgillig.

A. Hoclowald.

\$27. 1. Femelartiger Hoch w a ld betrie b ${ }^{3}$ ):

Diese Wirtschaftsform würde als eine Vereinigung des Femelbetriebs und Femelschlagbetriebs, auch wohl dieser beiden mit dem Schirmschlagbetrieb im nänlichen Bestand aufgefaßtwerden kömnen. Sie äußert sich - ganz nach dem jeweiligeı Bedürfnis der einzelnen Bestandespartie und frei von allem schablonenmäBigen Gebundensein an ein cinzelnes der in den genannten Grundbetrieben verkörperten Prinzipien - bald in femelweiser, bald in melır schlagweiser Behandlung der Gruppen und Horste und berücksichtigt in gleicher Weise die gesicherle natürliche Verjüngung der Bestände (wo nötig mit liünstlicher Beihilfe in beschränlitem Umfang), wie die Ausformung der Stämme zu möglichst starken, hochwertigen Sor-

1) Vergl. Ilandbuch unter XIII. Forsleinrichlung.

2) Nachweise in den statislischen Veröfentlichungen verschiedener Lïnder. - Vergl. z. B. auch: Vereinshefte des Elsaß-Loth. Forstvereins für 1885; ferner B re he $\mathrm{r}$, Aus dem Auenmillelwalde S. 64 ff., sowie L a u p r e e h l, Aus dem Muhlhäuser Millelwalde, Suppl. zur Allg. F.- u. J.-Z. VIII. Bd., 1. Hefl (S. 54 ff.) von 1871. H a m m, Der \usschlagwald 1896. D e rsel be, "Leitsätze fär den Miltelwaldbetrieb" (Fw. Zbl. 1900, S. 392). Ueber die slatisehe Seite des Miltelwaldbelriebs zu vergleichen $\mathrm{s} t$ o $\mathrm{e} \mathrm{z}$ e r, Die finanzielle seile der Millelwaldwirtschaft (TharandterJahrbueh 1890, S. 75 ); lerner S c li u berg, Zur Belriebsstalik im Millelwalde, 1898. - M a r i n, Forstliche Slatik, 2. Bd. 1911, S. 10 f.

3) Jergl. S e h u b e $\mathrm{g}$ s Schlaglichter zur Streilfrage: schlagweiser IIochwald-oder Femelbetrieb. Forstw. Zentrablatl v. 1886 , S. 129 u. S. 194; siehe auf S. 53 die Bemerkung über diese höchst dankinswerte Arbeil. 
timenten (intensive Auswirkung des Lichtungszuwachses). Ein solcher Betrieb paßt nur für entschiedene Schattenhölzer, hauptsächlich für die Weißtanne, und erscheint in seiner Durchführung zumeist als eine liomzession an die Grundsätze des Femelbetriebs. Das Abweichende von diesen besteht darin, daß nicht ein ganzer Umtrieb zur Schaffung eines neuen Bestandes an Stelle eines jetzt vor'landenen gefordert, sondern die Verjüngung in kürzerer Zeit, jedenfalls aber doch in langem Zeitraum $(30,40$, ja 60 .Jahren) bewerkstelligt wird, und daß sich je nach Imständen gröBere oder kleinere gleichförmig behandelte Gruppen (wie im Femelschlaghetriel,) einschieben. Ob dabei melir durch Aushieb einzehner stämme oder mehr in Gestalt gruppen- und horstweiser Bewirtschaftung vorgegangen wird, hängt in erster Linie von der zufälligen Beschaffenheit des Bestandes (Aushicb a ll es schadhaften Holzes, besonders breitkioniger, hervorragend starker Stämme, Förderung von Vorwuchshorsten usw.) ab. Jedenfalls ist ein ungleichförmiger Bestand das Wirtschaftsziel. Die behaupteten Vorzüge eines solchen kommen in diesem Betrieh voll zur Geltung. In den Alpen werden (nach Engler ${ }^{1}$ ) viele gewöhnlich als Plenterwaldungen bezeichnete Waldungen femelschlagweise bewirtschaftet, indem meistens nur 2 oder 3 Altersklassen miteinander gemengt sind und nach kürzerer oder längerer Zeit auf der einzelnen Bestandsfläche alles ältele $\mathrm{Holz}$ verschwindet.

Die Abhandlung $\mathrm{S}$ e lı u bergs, auf welche S. 52 Ann. 3 verwiesen ist, bringt hinsichtlich der Tanne, welche bes. in badischen Sehwarzwald vielfach in ,femelartigen Betrieb" bewirtschaftet wird, den auf zahlreiche exakte Erhebungen uber die Zuwachsleistung in diesem Betrieb in Gegensatz zun Sehirmschlagbetrieb gestüzten Nachweis, daß der letztere sowohl in der Gesamłmasse als auch namentlieł bezüghich der Verteilung der Einzelstämme auf die versehiedenen Nutzholzklassen erheblieh hinter dem femelartigen Betrieb zuräckbleibt. Bei gleiehem durehschnittlichem Alter liefert dieser einen weit höheren Prozentsałz an Stämmen der ersten Klasse, weil er keine entwickehungsunfähigen Individuen ledigłieh eines gleichmäBigen Bestandesschlusses wegen beläßt und eben infolge der zeitigen Entfermung aller dieser zweifelhaften Glieder den übrigen cinen erhöhten Lichtgenuß gewährt. Immerhin könnte man Iragen, ob nicht bei der Vergleichung ab und zu gegen einen Grundsalz der Statik einigermaßen verstoßen ist, nämlich den, daß man jede der gegeneinander abzuwägenden Wirtschaftsformen in Zustand ihrer höchsten Lcistungsfähigkeil betrachten soll. Dann darf aber auch der Schirnıschlag keine Kiranken aufweisen und muß derart durchlichtet sein, daß auch in ilım cin genugender Lichtungszuwachs zur Geltung kommt. (Ob man dann bei der Tame, insbesondere durch bedingungslosen Aushieb aller lirebsbüune nicht von selbst zu einer fentelartigen Form kommt, ist eine audere Frage.)

2. Ueberhaltbetrieb und zweilı ebiger.Hochualdbetri i e ? $\left.^{2}\right)$ :

a) Wenn von den hiebsreifen Bäunen eines Hochwaldbestandes eine gewisse Anzahl von der Abtriebsnutzung ausgeschlossen wird und im nachgezogenen. Jungwuchse bis in den nächsten Umtrieb hinein stehenbleibt, so entsteht die $\mathrm{U}$ e b e r h a I t f o r m. Zweck derselben ist die Anzucht besonders starker stämme, wie sie der gewölınliche Umtrieb nicht zu erzeugen vermag. Nan will aber nicht für clie ganze Wirtschaft oder für einzelıe ganze Bestände, um solche Starkhölzer zı gewinnen, den Untrieb erhöhen, sondern die übliche Umtriebszeit für die Hauptnısse der Bestände durchweg beibehalten. Der gewünschte Erfolg ist nur zu elreichen, wenn die übergehaltenen stämme (Ueberhälter, Waldrechter, Oberständer) grenügend lange Zeit nach dem Abtrieb des Grundbestandes, möglichst während der ganzen folgenden Umtriebszeit, fortwachsen. Sie müssen also an sich entsprechend wuchsiräftig sein und unter Be-

1) En $\mathrm{g} l$ e $\mathbf{r}$, Aus der Theorie und Praxis des Fenelschlagbetriebes. Schwciz. Zeitschr. f. Forstw. 1905, S. 6t.

2) Vergl. T a g e r, ,Zum zweihiebigen Kielernhochwaldbetrieb" (Festgabe zur Görhizer Forstversammlung 1885). - D e r s c l be, ,Zuı zweihiebigen Kiefernlochwalubetrieb" im Tharandter Jahrb. v. 1887 , S. I ff. - II e $\mathrm{y}$ e r, "Zur Frage des Leberhaltsbetriebs resp. des zweihiebigen Hochwaldes" in Zeitschr. f. F.- U. Jw. 1887, S. 13 ff. 
dingungen belassen werden, die ihre fernere gedeihliche Entwickelung sichern. Man darf deshalb nur durchaus gesunde, gut geformte und gleichmäßig bekronte Stämme zum Ueberhalt bestimmen (nicht etwa die allerstärksten) und muß für Erhaltung der Bodenkraft sorgen.

Mittelhohe Umtriebe eignen sich am meisten; man lıat dann Hoffnung, daß wenigstens ein Teil der Oberständer den vollen zweiten Umtrieb aushält.

Der Betrieb findet sich in den verschiedenartigsten Formen, weil er sich aus jeder beliebigen Grundform herausentwickeln kann. Immer aber sollten die Ueberhaltbäume möglichst allmählich an den freien Stand gewölınt werden, wozu unter Umständen schon lange Zeit (20-40 Jahre) vor ihrer endgültigen Freistellung der Freilieb eingeleitet werden muß, falls nicht die Wirtschaftsform an sich schon (wie im Femelbetrieb oder femelartigen Betrieb) allmähliches Gewöhnen an den Freistand bedingt. Mit dem Uebergang in die Ueberhaltstellung muß jede, wenn auch nur vorübergehende Minderung der Bodentätigkeit vermieden werden.

Ueber die Leistungen des Ueberhaltbetriebes gibt man sich vielfach Täuschungen hin. Sie sind in vielen Fällen keineswegs so befriedigende, wie man namentlich in früherer Zeit annahm. Die Erkenntnis dieser Täuschung hat in der neueren Zeit zu einer wesentlichen Einschränkung des Ueberhaltbetriebes geführt. Auf gutem Boden zeigen gesunde und mittelstarke Ueberhaltstämme in den ersten Jahrzehnten nach der Freistellung allerdings eine lebhafte Zuwachssteigerung, einen erfreulichen Lichtungszuwachs, dem bei Eiche, Kiefer, Lärche und anderen Wertshölzern auch eine mehr oder weniger beträchtliche Wertszunahme zur Seite steht. Je nach der Bodengüte früher oder später, manchmal schon wenige Jahre nach der Freistellung lassen Massen- und damit Wertzuwachs aber nach und vermögen dann oft nicht mehr den Schaden zu paralysieren, den Wurzeln und Krone des Ueberhälters am nachwachsenden Jungwuchse anrichten. Hierzu kommt, daß der einzelne Ueberhaltstamm den doppelten Umtrieb oft nicht aushält, sondern aus Gründen verschiedenster Art (Rindenbrand, Sturmbeschädigung, Insekten, Blitz usw.) vor der Hiebsreife des Hauptbestandes genützt werden muB, wenn der weiteren Holzentwertung vorgebeugt werden soll. Derartige Vorentnahmen (Auszugshauungen) sind ebenso störend, wie für den Hauptbestand gefährlich und hinterlassen meist unbequeme Löcher, die nur schwer sich ausfüllen lassen. Aus allen diesen Gründen empfiehlt sich der Ueberhaltbetrieb nur auf den besten Böden, die einen nachlıaltigen Lichtungszuwachs in Aussicht stellen, und nur für solche Holzarten, deren Massenzuwachs eine erhebliche IVertsteigerung in sich schließt, das sind vor allem Eiche, weiterhin Kiefer, Lärche, Ahorn, Esche. Je lichtbedürftiger dic übergehaltene Holzart und je schattenertragender der Hauptbestand ist, um so mehr treten die Verdämmungsschäden zurück. Ganz besonders rechtfertigt sich das Ueberhalten der Eiche im Buchengrundbestande. $\mathrm{Ob}$ gruppenveiser Ueberhalt dem Einzelüber'halt vorzuzielıen ist, bedarf der Entscheidung von Fall zu Fall; jedenfalls erfordert die Ueberhaltgruppe Unterbau, wenn nicht natiirlicher Unterwuchs sich einstellt. Die Ansichten über die zweckmäßige Anzahl der auf der Flächeneinheit zu belassenden Ueberhälter sind verschieden und müssen es sein, da Bodengüte und Schattenerträgnis des Hauptbestandes bei der Bemessung der Zahl der Uelerhaltstämme entscheidend sind.

Der mehr oder weniger günstige Wirtsehaftserfolg des Ueberhaitbetriebes hängt weiterhin auch von der Betriebsart ab, mit welcher der Ueberhalt verbunden wird. Am mißlichsten sind in dieser llinsieht die Bedingungen in Kahlschlagbelrieh, z. B. beim Ueberhalt einzelner Kiefern beim Abtrieb des Bestandes. Die wünsehenswerte allmähliche Freistellung der Ueberhälter unterbleibt hier oft, der Ueberhaltstamm wird vielfael aus dem vollen BestandssehluB freigestellt und leidet dann unter den Folgen der ungewohnten Wuehsverhältnisse, während an- 
dererseils seine zunachst kleine lirone nicht in der Lage ist, den verstärkten Lichtgenuß in gehơrigem Maße auszunủtzen.

Im Sehirmschlaghetrieb (7. B. Iteberhalt wuchskräftiger Eichen, Eschen, auch einzelner Buchen etc. im gemischten Laubholzhochwald) liegen die Verhältnisse insofern günstiger, als wăhrend des Verjungungszeitraumes allmălıliche Freistellung bewirkt und der Boden nicht entbloßıt wird. - Auch mit den Femelschlagbetricb würde sich ein eigentlieher Ueberhaltbetrieb (stammweise oder vielleicht grundsätzlich mehr gruppenweise) sehr gul verbinden lassen.

b) Der zweihiebige oder zweialtrige Hockwald darf als besonderer Fall des Ueberhaltbetriebs bezeichnet werden. Er entsteht, wenn bei nicht zu holıem Umtrieb verhältnismäßig viele Stänme zum Zwecle der Starkholzerziehung als Ueberhälter belassen werden. Die Oberständer erscheinen dann nicht als eine Zugabe zum Grundbestand, sondern sind der eigentlich entscheidende Bestandesteil, während der naclıuziehende Bestand zwar auch zu nutzholzliefernden Stämmen heranwachsen, nebenbei aber für Schutz und Erhaltung der Bodenkraft sorgen soll. Der zweihiebige Hochwald ist somit nichts anderes als ein Lichtwuchsbetrieb. Er arbeitet am besten, wenn ihm nur mittelhole Umtriebszeiten (70, 80 höchstens 100 Jahre) zu Grunde gelegt, die Ueberhaltstämme in diesem Alter also freigestellt werden. Anderenfalls werden trotz aller Sorgfalt viele Ueberlıälter vor der Zeit abständig ${ }^{1}$ ). Gegenüber einer allgemeinen Erhölung der Umtriebszeit hat man den Vorteil, daß nur die wirklich guten Stämme dem hohen Alter zugeführt werden. Von geringeren Böden ist der Betrieb fernzuhalten ${ }^{2}$ ).

Das frühzeilige Vorbereiten auf die Ueberhaltstellung, d. h. das Freistellen der dazu bestimmten Bäume ist stets nur so allmählich auszuführen, daß eine schädliche Verlichtung des Bestandes dabei nicht eintritt.

Als besondere hierher gehörige Formen sind zu nennen:

der zweialtrige Hochwald Burckhardts,

der modifizierte Buchenhochwaldbetrieb von v. Seebach,

die Homburgsehe Nutzholzwirtsehaft.

Sie sind im vierten Abschnitt besprochen.

Wie sich unter bestimmten Umständen auch einmal ein ,Dreifacher Hochwaldbetrieb" (innerhalb einer Umtriebszeit Nutzung gewissermaßen von drei verschiedenen Beständen auf der nāmlichen Flåche: 20jähriger Kiefernschutzbestand, 110 jăhrige Buchen, 140 jährige Eichen) entwickeln kann, hat Wil b r a d in der Allg. F.- u. J.-Z. (1879, S. 41 ff.) gezeigt. Doch gehört die betr. Wirtschaft mehr nur dem Namen nach bierher; sie ist ein Unterbaubetrieb mit besonderer Modifikation.

3. Unterbau- und Lichtwuehsbetrieb.

Beide sind nicht eigentlich besondere Betriebsarten, sondern mehr nur bestimmte Formen der Bestandeserziehung und werden als solehe im 4. Abschnitt näher besprochen. Sie schließen sich nach Zweck und Form eng an die oben genannten zweialtrigen Betriebe an und können sowohl aus dem Kahlschlagbetrieb wie auch aus den Vorverjüngungsbetrieben heraus entwickelt werden. Von den zweialtrigen Betrieben im engeren Sinne unterscheiden sie sich dadurch, daß zwar das Wirtschaftsziel wie dort auf die Nutzbarmachung des Lichtungszuwachses an freigestellten Stämmen gerichtet, neben diesen Stämmen aber ein natürlich entstandener oder durch Unterbau usw. geschaffener Bestandsteil vorhanden ist, dem ohne Rücksicht auf eigene Werterzeugung in erster Linie der Schutz des Bodens zufällt.

B. Nied erwald und ll it telwald.

$\S 28$. Zwischen beiden Betriebsarten, sowie zwischen diesen und dem Hochwald schieben sich mehrere Uebergangsformen ein, welche sich in verschiedenartiger Weise gegenseitig annälıern können.

1) Auszugshiebe, vergl. vierter Abschnitt, $\$ 72$.

2) T ä g e r a. a. O. will auch noch auf líiefernboden 3., ja 4. Güte mit seinem Betrieb gute Starkhölzer erziehen; auf Boden 2. Bonität soll mit Fichte unterbaut werden. Entsprechende Rentabilität wird ron T. nachgewiesen. 
So kann man im $\mathrm{N}$ i e d e r w a l d einzelne Oberständer überlalten und gewinnt dadurclı, namentlich wenn man einen Teil derselben noch länger als durch den nächstfolgenden Umtrieb stehen läßt, eine mittelwaldartige Foum. Eine solche liann für etwaige Betriebsumwandhungen (z. B. Eichenschälwald in Eichenhochwald, bei rückgängigen Rindenpreisen) von hoher Bedeutung werden.

Oder man läßt im Niederwald an den Wegrändern Hochstämme stehen, bezw. pflanzt daselbst hochstämmig zu erziehende Holzarten (Lärche ete.) an, um wenigstens ein mäBiges Quantum stärkerer Nutzholzsortimente zu erhalten. Durch den Oberstand wird ja im allgemeinen der Ertrag an Ausschlagholz geringer, dafür aber erhält man stärkere, im Nutzwert höher stehende Stangen. In einzelnen Fällen kann auch Beschattung des Bodens oder Schutz der Ausschläge vor Frost Veranlassung zum Ueberhalt sein.

Der $\mathrm{ll} \mathrm{j} \mathrm{t} \mathrm{t} \mathrm{e} \mathrm{l} \mathrm{w} \mathrm{a} \mathrm{I} \mathrm{d} \mathrm{kann} \mathrm{ein} \mathrm{hochwaldartiges} \mathrm{Aussehen} \mathrm{gewinnen} \mathrm{oder} \mathrm{anderer-}$ seits mehr nach Art des Niederwaldes beschaffen sein, je nachdem man dem Oberholz eine mehr oder ninder umfängliche Beteiligung gestattet. Die besonderen Umstände des Wirtschaftsbetriebes können Uebergänge nach der einen oder anderen Seite hin rätlich e’scheinen lassen. Die neuere Zeit neigt dazu, die niederwaldartige, durch Vorherrschen des Ausschlagholzes gekennzeichnete Form, sowie den sog. regulären Mittelwald, in welchem Ober- und Unterholz in annähernd gleichmäBiger Verteilung vertreten sind, zu verlassen und die durch größeren Oberholzreichtum rentabler werdende hochwaldartige Form zu begünstigen. Den Oberholz verschafft man hierbei durch Auspflanzen größerer Löcher eine mehr horstweise Verteilung. In dem Maße die Horste erweitert werden, nähert sich der Vittelwald alsdann der Plenterschlagform und geht in Hocliwald ïber.

C. H a u p - und $\mathrm{Nebennutzungsbetriebe.}$

$\S$ 29. Als besondere Formen des Hoch- bezw. Niederwaldbetriebes seien lier noch die im Abschnitt Forstbenutzung näher geschilderten Verbindungen forstund landwirtschaftlicher Produlition erwälınt, die als $\mathrm{W}$ a $\mathrm{l} \mathrm{d} f \mathrm{e} \mathrm{l} \mathrm{d}$ b a $\mathrm{u}$ bezw. $\mathrm{Hackwald-oder} \mathrm{Ha} \mathrm{ubergswirtschaft}$ in früheren Zeiten eine gröBere Rolle gespielt haben als in der Gegenwart.

1. Wa $\mathrm{ld}$ feld ba ${ }^{1}$ ): stellt eine Verbindung von Hocliwaldbetrieb und landwirtschaftlicher Produktion dar. Erfolgt der Anbau landwirtscluaftlicher Erzeugnisse (Roggen, Buchweizen, Kartoffel) nach der Rodung der ursprünglich mit Holz bestockten Fläche als Vorbau, wechsehn mithin land- und forstwirtschaftliclıe Eunten miteinander $\mathrm{ab}$, so lıaben wir es mit $\mathrm{R} \ddot{o} \mathrm{~d}$ er $\mathrm{l}$ a n d b e $\mathrm{t} \mathbf{r}$ i e b zu tun. Erfolgt hingegen der Anbau land- und forstwirtschaftlicher Nutzpfanzen gleichzeitig auf derselben Fläche, dergestalt, daß zwischen den mehr oder weniger weit voneinander entferuten Holzpflanzenreihen eine Anzahl von Jahren landwirtschaftlicher Zwischenbau getrieben wird, so handelt es sich $u m ~ W$ a $l$ d f e l d b a u im engeren Sinne. Beide zunächst auf Erzeugung landwirtschaftlicher Werte, vom waldbaulichen Standpunkte weiterhin auf Förderung der Holzkultur durch Bodenbearbeitung und auf Erhöhung der Waldrente gerichteten Betriebe haben ilıre Bedeutung verloren. Von Ausnahmen abgesehen kommt hierbei höchstens der Forstwirt, nicht aber der Landwirt auf seine Rechnung. Der Waldboden ist zumeist kein Feldboden oder erfordert, um ihn zu solchem umzugestalten, so große Aufwendungen für Bodenbearbeitung, daß seine

1) V'gl. Bericht über" die XV: Versammlung deutseher Forslmänner zu Darmsladt 1886, S. 81-145; S p e i d e l, Der Waldfeldbau im württemb. Ohersehwaben, Allg. F.- u. J.-Z. 1888, S. 276; it öhle $\mathrm{r}$, Ueber den Waldfeldbau in Oberschwaben, das. 1898, \$. 117, sprieht sich gegen denselben aus. 
nur liurzfristige Benutzung zur Anzurht von Feldgewächsen sich nicht lohnt. Auch vou forstlichen Standpunkte crscheint der landwirtschaftliche Vor-oder Zwischenbau nicht immer einwandsfrei, weil er, meist ohne Düngung verlaufend, zur Verarmung des Bodens führt, wenn er eine Rejhe Jahre hintereinander auf ciner Fläche betrieben wird.

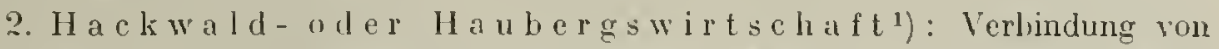
Niederwald init landwirtschaftlichem Fruchithau. Nach dem stockschlag werden die sclwwicheren Reisigteile und der Bodenüberzug verbrannt, teils durch ein über den Schlag hinweglaufendes Feuer, durch ,Ueberlandbrennen" oder ,Sengen“, teils nach Zusammenbringen des Reisigs und des abgeschälten Bodenüberzuges in Haufen, durch sog. „Schmoren". Nach dem Brennen („Hainen") und folgender Bearbcitung des Bodens wird zwischen den Ausschlagstöclien 1-2 Jahre Getreide angebaut. Der seit Jahrluunderten in llessen und Baden (Odenwald, Schwarzwald, Siegen) mit dem Eichenschälwald verbundene Betrieb hat für die in Frage kommenden Gegenden mit einer nur kleinen und noch dazu ziemlich unfruchtbaren Feldfläche und mit intensiven Lebensmittelbedarf eine ziemlich hohe volkswirtschaftliche Bedeutung. Der Lintrieb ist 16-20 jährig. Kü̈rzere Untriebe gefährden infolge der öfteren Wiederkehr des Getreidelaues die Bodenkraft.

Dritter liapitel.

Betriebsumwandlungen.

\section{A I $1 \mathrm{~g}$ e me ines.}

\$ 30. Veranlassung zur Betricbsunwandlung, d. h. zu dem planmäßigen Uebergang von einer Betriebsart zur anderen, ist nicht selten gegeben. Die Gründe hierzu können sehr verschiedene sein. Sie liegen zum Teil in veränderten Interessen des Waldbesitzers (Anlage eines Wildparlis usw.) oder in der L'eberzeugung von der höheren Leistungsfähiglieit einer Betriebsart gegenüber der bisher eingeführten in bezug auf Bodenpflege, Massen- und Wertserzeugung usf., vielfach auch in veränderten Marktverhältnissen, d. h. in der durch einen Unschwung auf dem Gebiete der Holzverwertung herbeigefülırten veränderten relativen Wertschätzung der verschiedenen Forstprodukte. Hin und wieder zwingt auch die Unmöglichkeit, den zeitherigen Betricb infolge Rücligangs der Bodenkraft oder infolge Auftretens schädlicher Einflüsse (Rauch) ferner beizubehalten, zur Betriebsumwandlung. Mitlin sind es teils persönliche, teils sachliche Gründe, welche entscheidend werden. Letzlere haben oft nur örtliche, manchmal aber melır allgeneine Bedeutung, wie beispiclsweise der Einfluß geringerer Absatzfähiglieit des Brennholzes, ebenso der Lohıinde infolge auswärtiger Konkurrenz usf. lhren Zielpunkt finden fast alle bezüglichen Maßregeln in Herbeifülırung einer höheren Rentabilität der Wirtschaft. Es ist aber, wie schon oben S. 43 hervorgehoben wurde, durchaus falsch, wenn man ledighich die ökonomischen Vorteile bei der Entscheidung der Frage, ob eine Betriebsumwandlung zweckinäBig oder notwendig ist, sprechen läßt. Die Umwandlung einer weniger jentablen Betriebsart in eine ökonomisch wertvollere ist immer nur dann gerechtfertigt, wenn die Ertragssteigerung nachlaltig ist, also nicht auf Kosten der Bodenliraft geschieht.

Am einschneidendsten wirken diejenigen Umwandlungen, bei denen eine Aenderung der Holzart und der Betriebsart zugleich in Frage lommen, während sich

1) Vgl. Ber n h a d t, Die Haubergswirtschaft in Kireise Siegen 1867. S t ro he $\mathrm{cker}$, Die Hackwaldwirtschaft. 2. Aufl. 1867. Yogel $1 \mathrm{~m}$ a $\mathrm{n}$, Die Reutherge des Schwarzwaldes. 2. Aufl. 1871. 
jene Vorgänge verhältnismäßig einfacher abspielen, die entweder nur einen Holzartenwechsel oder nur eine Betriebsänderung darstellen. Je beträchtlicher zwei ineinander überzufülırende Betriebsarten in ihrem Gesamtcharakter von einander abweichen, um so schärfer treten die den Uebergang vermittelnden Operationen zu Tage. In vielen Fällen kann nur ein allmähliches Aufgeben des bestehenden Betriebes Platz greifen. Wenigstens wird immer dann, wenn g r ö $B$ e r e Wirtschaftsobjekte in Betracht kommen, jedes durch starke Sprünge sich äußernde Vorgehen ausgeschlossen werden müssen. Die Gründe hierfür liegen in den Rücksichten auf den Holzmarlit, auf das verfügbare Kulturmaterial, die erforderlichen Arbeitskräfte, auf nachhaltige Gestaltung der Holzabnutzung usw. Besonders dann, wenn die neu einzuführende und die bisherige Betriebsart in der Höhe der Umtriebszeit wesentlich von einander abweichen und mithin die vom Nachhaltsbetrieb geforderten normalen Holzvorräte ebenso große Unterschiede aufweisen, kann der Uebergang meist nur langsam und unter sorgsamster Abwägung aller begleitenden Umstände bewerkstelligt werden. Derartige Umwandlungen können nur unter Zugrundelegung eines die Entwickelung der Waldverhältnisse voraussehenden, langfristigen Umwandlungs- oder Betriebsplanes vorgenommen werden. Ohne Entwerfung eines solchen Planes lassen sich Umwandlungen in größeren Waldungen nicht mit der wïnschenswerten Klarheit und Sicherheit durchführen. Waldbau und Forsteinrichtung haben hier gemeinsam zu operieren. Bei einzelnen Beständen, kleinen Parzellen unterliegt jedoch selbst ein plötzlicher Uebergang oft nicht dem mindesten Bedenken.

II. Umw a n d ungen innerhalb des $\mathrm{Hochwaldbetriebes.}$

\$31. A. Der Kiahlschlagbetrieb soll verlassen werden:

1. Uebergang vom Ki a h lsch lagzum Schirm s chlagbetrieb.

Dieser Uebergang läßt sich, wenn die Holzart beizubehalten ist, in meist sehr einfacher Weise bewerkstelligen, indem man im haubaren oder nahe haubaren Bestand die natürliche Verjüngung (je nach Bedarf unter entsprechender künstlicher Beihilfe) mit ihren verschiedenen Hiebsführungen an Stelle des Kahlhiebs treten läßt. Im einzelnen können sich freilich mannigfaltige Modifikationen des Schemas ergeben. Zusammenfassen mehrerer Jahresschläge zum Periodenschlag wird erforderlich. Aenderungen der Umtriebszeit und im Gefolge davon des Normalvorrats bringt diese Ueberführung nicht grundsätzlich mit sich. Soll die Holzart wechseln, so muß künstliche IKultur (bisweilen durch Unterbau, z. B. Tanne unter Kiefer) eintreten.

2. Vom Kahlschlag zum Femelschlagbetrieb, femelartigen Betrieb und Femelbetrieb.

Die Umwandlung vollzieht sich im allgemeinen ähnlich wie die vorbesprochene. An Stelle gleichmäßiger Behandlung des ganzen Bestandes tritt der Horst oder die Gruppe, wodurch zunächst der Femelschlagbetrieb erreicht wird. Der Weg von diesem zum femelartigen Betrieb und schließlich zum eigentlichen Fenelbetrieb ist leicht zu finden; doch wird man sich zumeist mit Beibehaltung einer der Uebergangsformen begnügen und nicht gerade dem reinen Femelwald zusteuern.

B. Ueberfülırung des Fernelbetriebes in einen sclılagweisen Betrieb.

Der betreffende Virtscliaftsplan muß zunächst die Bildung der Orts- und Bestandesabteilungen, sowie die Hiebszüge vorsehen, wobei die jeweilige Beschaffenheit der Femelbestände, die verschiedenartige Beteiligung und räumliche Gruppierung der Altersklassen zumal für die Uebergangszeit besonders zu beachten sind, damit der neue Zustand nicht mit zu großen Opfern erreicht wird. Die zuwachsärmsten Teile, sowie solche mit dem höchsten Durchschnittsalter kommen, soweit es die Schlagfolge zuläßt, in erster Linie zur Behandlung. Inzwischen muß der Gang der Durchliebe in 
den übrigen Teilen eine Minderung der Altersunterschiede anstreben. kelirt.

G. Uebergang rom Schirmschlag zum Femelschlag oder Saumschlag und unge-

1. Die Ueberführung des Schirm schlags zum Fem el-oder Saums c h l a g wird erreicht, indem man die Verjüngung nicht gleichmäßig über dic ganze Bestandesfläche hin, sondern horst- und gruppenweise, bezw. streifenweise rom Rande herein cinleitet und durchführt.

2. Vom F c m c ls c h l a g z u $\mathrm{m}$ Sch i r m s c h I a g gelangt man durch allmähliches Verschwindenlassen der durch Altersunterschiede gekennzeichneten Gruppen und Horste.

D. Uebergang zum Kahlschlag.

Die vorhandenen Bestände, gleichgültig welcher Betriebsart sie angehören, werden schlagweise kahl abgetrieben, nachdem die Abgrenzung der Schlagflächen im Sinne der späteren Hiebsfolge geschehen ist.

Es leuchtet ein, daß fast alle diese Umwandlungen sich nicht ohne mancherlei Opfer in der Uebergangszeit vollziehen lassen. Vielfach werden Bäume und Bestände schon vor oder erst nach ihrer Hiebsreife genutzt. Es ist die Aufgabe der die Aufstellung des Umwandlungsplanes besorgenden Forsteinrichtung, durch Schaffung hinreichender Anhiebe und Wahl ciner geeigneten Hiebs- und Verjüngungsfolge solche Verluste auf das geringste $\mathrm{Ma}$ zu beschränken.

III. Der Hochwald betrieb wird a u $\mathrm{g}$ e ge ben.

$\$ 32$. A. Uebergang zum Niederwald:

Bei dieser in der forstlichen Praxis nur selten vorkommenden Umwandlung ist, wenn infolge Mangels ausschlagfähiger Holzarten gleichzeitig cin Wechsel in der Holzart eintreten muß, künstliche Bestandesbegründung nach vorausgegangener Abräumung des vorhandenen Bestandes unvermeidlich. Die Umwandlung erfolgt unter Zugrundelegung einer dem Niederwaldumtrieb entsprechenden Schlageinteilung. Soll insbesondere ein jährlicher Nachhaltbetrieb mit u-jährigem Umtriebe entstehen, so braucht man u Schläge, welche dann nach und nach in u Jahren umgewandelt werden.

Ist die gewünschte Holzart schon vorhanden (Eiche, Erle), so kann unter günstigen Verhältnissen die künstliche KuItur ganz entfallen. Die jüngeren noch gut ausschlagsfähigen Bestände werden auf dem Stock gesetzt. Bei älteren Beständen wird damit nicht Genügendes erreicht; künstliches Einbringen von Kernpflanzen zur Ausfüllung von Fehlstellen wird dann nicht zu umgehen sein ${ }^{1}$ ).

B. Uebergang zum Mittelwald:

Erfolgt, soweit das Unterholz in Betracht kommt, im ganzen nach gleichen Grundsätzen wie bei A. Wie rasch sich die einzelnen Oberholzklassen in der erforderlichen Art (nach Holzart, Menge, Verteilung usw.) Lerstellen lassen, ist von der Holzartenbeteiligung und der Betriebsform (gleichalterig oder ungleichalterig) im Hochwald abhängig. Soweit jüngere, gesunde und entwicklungskräftige Bäume, die zum Oberholz taugen, nicht vorhanden sind, lassen sich die Oberholzklassen erst nach und nach bei den späteren Unterholzabtrieben heranbilden. Nachhilfen durch Einbringen von Kernpflanzen zur Anzucht von Laßrcisern und durch Auspflanzen von Fehlstellen mit Stummelpflanzen zur Anzucht von Unterholz werden meist notwendig sein.

IV. Nieder.wald oder Mittelwald ist in Hochwald über$\mathrm{z} u \mathrm{f}$ ü h r en. wald.

1) Vergl. die in $\$ 68$ zitierten Aufsätze von $\mathrm{O}$ s $\mathrm{t}$ e $\mathrm{r}$ h e l d, aber den Edelkastaniennicder- 
§33. A) $\mathrm{Nied}$ e r wa $\left.l \mathbf{d}^{1}\right)$ :

Die Verschiedenheit der UTutriebszeit bedingt es, daß, wenn der Niederwald in einen Hochwald-Nachhaltbetrieb übergeführt werden soll, bedeutende Holzvorratsmassen angesammelt werden müssen, danit ein der gewählten Untriebszeit entsprechender Vorrat vorhanden ist. Wird die Holzart beibehalten, so genügt das Aufhören mit den Niederwaldhaungen und das Fortwachsenlassen der Stockausschläge, wekche entsprechend zu durchforsten sind. Allerdings ist hiermit eine Verzichtleistung des Waldbesitzers auf Erträge verbunden, die gemildert werden kann, wenn als Uebergangsstadium eine mittelwaldartige Form gewählt wird. Beim Hieb wird dann immer eine größere Anzahl von Laßreiteln übergehalten und so alhmählich der Hochwald-Vollbestand angebahnt.

Soll ein teilweiser oder vollständiger Holzartenwechsel eintreten, so ist künstlicher Anbau erforderlich. Nach dem Abtrieb des Stockausschlages ist die neue Holzart in kräftigen Exemplaren, zweckmäBigerweise in Gruppen und Horsten, einzubringen und dureh geeignete Bestandspflege vor dem Ueberwachsen durch die Stockausschläge zu schützen. Im einzelnen Falle, namentlich dann, wenn heruntergekommene Niederwälder in Nadelholz umgewandelt werden sollen, ist die Rodung der Laubholzstöcke eine zwar kostspielige, aber empfehlenswerte Maßnahme, um dem sonst unvermeidtichen Ausschneiden und liöpfen der sich vordrängenden Stockausschläge zu entgehen. Man kommt dann allerdings zur Kahlflächenkultur und zu reinen Beständen. Ist die Herstellung von Mischungen erwünschter oder die volle Beseitigung der Stöcke aus Gründen des Bodenschutzes (z. B. an Hängen) nicht zu empfehlen, so bleibt es Aufgabe einer sorgsamen Bestandspflege, den besseren Teil der Stockausschläge hoch zu bringen und Verdämmen der eingebrachten Nadelholzpflanzen zu vermeiden. Die Modifikationen der Ueberführung von Niederwald in Hochwald sind überaus zahlreich.

Die geringe Rentabilität des Eichenschälwalcles ist Veranlassung dazu, daß diese Betriebsform neuerdings vielfach in Hochwald und zwar auf allen geringeren Böden in Nadelholzhochwald übergeführt wird ${ }^{2}$ ).

B) $\mathrm{ll}$ it $\mathrm{tel} \mathrm{w}$ a $]\left(\mathrm{d}^{3}\right)$.

Soll ein solcher in einen Hochwald-Schlagbetrieb übergeführt werden, so ist es, je nach der Art und Beschaffenheit des Oberholzes, oft weniger die Menge, als die Verteilung der verfügbaren Holzmasse, welche geändert werden muß. Jede normale Betriebsklasse des schlagweisen Hochwaldbetriebes zeigt weit erheblichere Altersunterschiede ihrer Bestände, als sie im Mittelwald von Schlag zu Schlag vorhanden sind, wo sich alle analogen Glieder (Unterwuchs, einzelne Oberholzklassen) zweier in der Schlagfolge benachbarter Bestände je nur um 1 Jalı im Alter verschieben, so

1) E in m e $1 \mathrm{~h}$ a in $\mathrm{z}$, Umwandlung der nassauischen Niederwaldnngen. Zlselur. f. F.- u. Jw. 1902, 523, ebenda 1903, S. 619. - I r $\mathrm{r}$ h ö f e r, Die Ueberfürung von Niederwald in Hochwald, Silva 1909, S. 681. - P e t i t h, Die Ueberführung bezw. Umwandlung der Eichenschäwaldungen in Hochwald. Allg. F.- I. J.-Z, 1907, S. 272. - v. F is e h b a $\mathrm{ch}$, Ueberfülirung des Eiehenschä]waldes zu rentableren Betrieben, Forstw. Zentralbl. 1898, S. 333.

2) $\mathrm{H}$ e $\mathrm{y}$ e r, , Eichenschälwald-Umwandlungen im Odenwald" (Forstw. Zentralbl. 1902, S. 415).

3) Zu vergl. u. a. $\mathrm{B}$ ö $\mathrm{h} \mathrm{m} \mathrm{e}$, ,Ueberfülrung des Mittelwaldes in Hochwald" (Forstw. Zentralbl. von 1885, s. 332 ff.), wosclbst für verschicdene Mittelwaldkategorien Spezialregeln angegehen werden. - In säehs. Forstverein stand 1882 die Umwandtung lücligängiger Mittelwaldungen in Hochwald zur Debatte, ebenso auf der Deutschen Forstversammlung in Metz 1893, aut der Badischen Forstversammlung 1899, desgleichen auf der Thüringischen Forstversammlung 1909, desgl. aul der Versammlg. d. deutschen Forstvereins 1902 und 1907. - Weilere Literatur: $\mathrm{J}$ ä ger, Yom littelwald zum Hochwald, 1889. - B r a u n s, Leberfülıung des Mittelwaldes in Hochwald in der Oberf. Bischofsrode. Ztschr. f. F.- u. JW. 1903, S. 530. 
daß das Maximum des Unterschieds zweicr Bestände gleich dem Unterholzumtrieh ist. Man wird der normalen Altersstufenordnung des Hocliwaldes nur insoweit allmählich sich nähern, als es bei möglichst vorteilhafter Benutzung der verfügbaren Bestände erlaubt ist, damit die kritische Zeit der Ueberleitung keine Verluste bringt, welche den durch die ganze Manipulation erhofften wirtschaftlichen Gewinn in Frage stellen. Vermehrung des Oberholzes, Zurückdrängen des Ausschlagholzes ist allgemein erforderlich. Un die für den Hochwaldbetrieb erwünschte Altersstufenfolge in die Wege zu leiten, empfichlt es sich, anf den verschiedenen Mittelwaldflächen teils die älteren, teils die mittleren und jüngeren Oberhölzer zu begünstigen. Die Art und Weise und die Henge, in weleher die verschiedenen Oberholzklassen auf dem einzelnen Schlage vertreten sind, werden hierfür den Wegweiser darstellen. Je oberholzreiclıcr ein Mittclwald ist, um so leichter macht sich seine Ueberführung. Da die stärksten Oberholzklassen immer in der Minderzahl vertreten sein werden, wird bei der Ueberführung den jüngeren Oberhölzern die ausschlaggebende Bedeıtung um so mehr zufallen, als ihre Ergänzung durch Ueberhalten zahlreicher Laßreitel möglich ist. Oberholzarme Mittelwaldnngen bedürfen naturgemäß umfassender künstlicher Hilfe und werden am besten durch Ansaat oder richtiger durch Auspflanzen von Löchern und allmähliche Räumung der vereinzelten Oberständer in einen mehr horst- und gruppenweis zusammengesetzten, also plenterwaldartigen Hochwald übergeführt.

Der letztgenannte WVeg liann besonders dann beschritten werden, wenn mit der Unwandlung in Hochwald zugleich ein vollständiger Holzartenwechsel beabsichtigt ist. In vielen Fällen wird dann der Kahlhieb am schnellsten zum Ziele führen, allerdings auch ohne Verzicht auf nachhaltige Erträge nicht ganz auskommen. Unter Umständen läßt sich die neu einzufülırende Holzart - namentlich danı, wenn es sich um ein Schattenholz handelt - auch mittels Unterbau nach vorheriger entsprechender Schlagstellung einbringen.

\section{Dritter A bschnit.}

\section{Die Bestaudesbegrii $u d u n g$.}

Der Abschnilt bespricht die Arl, wie unler den verschiedensten Verhälnissen Bestände begründel werden. Demnächst hat die ,Bestandeserziehung" (vierter Abschnilt) aus den Jungwichsen haubare Bestände heranzubilden ${ }^{1}$ ).

\section{Erstes liapitel.}

Al $1 \mathrm{~g}$ emeine Gesichts pun $\mathrm{kt}$ e.

\section{Arten der Begründung und ihre wirtschaftliche Bedeutung.}

\section{A. Arten.}

\$34. Man unterscheidet natürliche und künstliche Bestandsbegründung. Bei jener ist das Kulturmaterial auf der Fläche bereits vorhanden oder wird von der Natur auf sic gebracht, während bei dieser menschliche Tätigkeit Samen bezw. Pflanzen herbeischafft und die sonst erforderliche Arbeit leistet. Die natürliche Bestandshegründung vollzieht sich entweder durch Samen ${ }^{2}$ ) (durch Abfall desselben von Bäumen,

1) Bezüglich der Grenze zwishen Begründung und Erziehung der Beslünle isL die Vorbemerkung zum vierlen Abschnitt zu vergleichen.

2) Die aus den abgefallemen Samen entslandenen Jungpflanzen scheidel man nicht selten in Aufsehlag und Anflug: Aufschlag sind im allgemeinen die ans schwereren, direkt herunterfallenden, flügellosen Samen gekeimten Pflanzen (Eiche, Buehe etc.), während nan die aus ange- 
die auf oder neben der Fläche stehen) oder durch Ausschlag ${ }^{1}$ ) (Bildung von Wurzel-, Stock-oder Schaftlohden). Die künstliche Begründung erfolgt entweder durch Saat oder durch Pflanzung. Bei der Saat bleibt die aus dem Samen entstehende Pflanze auf ihrer Stelle, während bei der Pflanzkultur anderwärts erzogene Pflanzen Verwendung finden.

\section{B. Wahl der Art der Bestandesbegründung.}

Zunächst ist zu entscheiden, ob natürliche oder künstliche Verjüngung eintreten soll. Danach ist innerhalb dieser beiden Hauptgruppen von Verjüngungsmethoden die Ausivahl im einzelnen zu treffen.

Die Entscheidung ist bedingt durch Standort und Holzart (cfr. erster Abschnitt), dann insbesondere durch den Wirtschaftszweck, durch das Verhä]tnis von Aufwand und Erfolg, für dessen Beurteilung sehr oft in erster Linie die Gewinnung der erforderlichen Arbeitskräfte ins Gewicht fällt, sowie durch den Umstand, ob auf der Fläche scholl Wald vorhanden war oder nieht. In letzterem Falle kann, wenn man von der seltenen Möglichkeit einer Randbesamung (von seitlich stehenden Bäumen her) absieht, nur künstliche Bestandesgründung in Betracht kommen. Das gleiche gilt, wenn die Fläche zwar bereits mit Wald bestockt war, aber ein Holzartenwechsel beabsichtigt wird. So oft jedoch die nämliche Holzart auf einer Fläche nachgezogen werden soll, treten allgemein die natürliche und künstliche Bestandesbegründung in Konkurrenz. Beide werden unter Umständen vereint angewendet, indem dureh künstliches Einbringen von Samen oder Pf]anzen die auf natürlichem Wege bereits entstandenen oder noch zu erwartenden Jungwüchse vervollständigt werden.

Natürliclıe od r r künstliche Bestandesbegründung?

$\S 35$. Wenn nicht bestimmte Ursachen die künstliche Begründung des neuen Bestandes fordern, kann und soll man die natürliche Verjüngung wählen. So lange man auf dem Wege, welchen die frei wirkende Natur einschlägt, das durch die Wirtschaft gesteckte Ziel genügend rasch und sicher erreichen kann, ist zunächst nicht abzusehen, weshalb man jenen Weg verlassen soll. Vor allem ist die Verscliedenartigkeit der Standortsverhältnisse bei der Wahl des Verjüngungsverfahrens sorgfältig zu beachten. Aber selbst wenn man erwägt, daß man, wie von vielen Seiten scharf betont wird, bei der natürlichen Verjüngung im allgemeinen am leichtesten für ununterbrochene rationelle Bodenpflege sorgen kann, da $ß$ sie auclı die Begründung gesunder gemischter Bestände erleichtere, sowie die Starkholzzucht olıne Erhöhung der Untriebszeit crmögliche, crgibt sich doch in vielen Fällen eine Entscheidung zugunsten der künstlichen Bestandesbegründung und zwar lıauptsächlich nach Maßgabe folgender Erwägungen: a) die natürliche Verjüngung durch Ausschlag ist ausgeschlossen bei den Nadelhölzern. - b) Soll die natürliche Verjüngung bei irgend welcher Holzart durch Samen erfolgen, so muß eine je nach den Unständen größcre oder geringere, jedenfalls genügende Anzahl von tauglichen Samenbäumen zu Gebote stehen, welche den Samen liefern. Man ist also an das Vorhandensein und das Samentragen dieser (der Mutterbäume) gebunden, und es leuchtet ein, daß durch Ausbleiben oder Fehlschlagen einer Mast Störungen in Verjüngungsbetrieb und Verzögerungen in der Schaffung junger Bestände veranlaßt werden können, welche unter Umständen den Gang der ganzen Wirtschaft beeinflussen, inden Abweichungen von der normalen Umtrieb. zeit, Ersatz eines an Haubarkeitsnutzungen zu liefernden Hiebsquantums durch Vorgriffe, stärkere Durchforstungen usw. notwendig werden. Sind auch solche Störungen im einzelnen meist nicht von Belang, so können sie sich doch

flogenen (leichten, gef]ügelten) Samen crwachsenden als Anflug bezeiclınet. Die Trennung ist keine scharfe. Der Name ,Anflug" wird vor allem für Nadelhölzer oft gebraucht.

1) Die Bestandesbegrüdung durch Ausschlag kann nicht wie die Bestandesbegründung durch Samen als, ,Begründung" im vollen Sinne angesehen werden. Es handelt sich bei ihr nur um Wiederverjüngung. Daß sie hier mit zur natürlichen Begründung gerechnet wird, entspricht nur dem allgemeinen Brauch. 
in unangenehmer Weise häufen (mehrmaliges Vernichten der Blüte durch Frühjahrsfröste etc.), so daß die künstliche Verjüngung, in diesem Falle ein Kind der Not, einspringen muß. Kúunstverjüngung kanı auch als Folge von Kalamitäten wie Insektenfraß, Schneebruch, Sturm etc. notwendig werden, wenn solche den betreffenden Waldort in einem Stadium der Entwickelung treffen, in welchem er noch nicht verjüngungsfähig ist. Auch daun, wenn die erforderliche Zahl geeigneter Samenbäume infolge einer lialamität verloren ging oder wenn bedeutende Einschlagmassen den normalen Fällungsgang stören und die zur Benutzung eines eintretenden Samenjahres notwendigen Maßnahmen unmöglich machen, kann die künstliche Bestandsgründung zweckmäßig oder notwendig werden. - c) Stehen, wie in der Regel, die Mutterbäume auf der Kulturfläche selbst, so beschatten bezw. übersehirmen sie, nach Art, Zahl, Verteilung in verschiedenem Maße, die jungen Keimpflanzen. WVenn auch letzteren dadurch wälırend ihrer ersten Jugendentwickelung meist ein nur wohltätiger, ja für manche Holzarten und in bestimmten Oertlichkeiten geradezu notwendiger Schutz gewährt wird, so können doch andere Holzarten (Lichthölzer) allgemein, andere in gewissen Lagen diese Beschirmung nicht oder nur liurze Zeit hindurch vertragen. Hieraus kann sich (ür eine Anzah] von Fällen ${ }^{1}$ ) die künstliche Verjüngung als Erfordernis ergeben.

Die Ansielıten darüber, wie mit Rücksieht auf die Erfordernisse der einzelnen Holzarten die Grenzlinie zwischen natürlieher und künstlicher Verjüngung zu ziehen seí, gehen auseinan$\operatorname{der}^{2}$ ). Daß Sehaltenhözer allgemein durch Samenabfall, also nalürìch verjüngt werden können, sleht, enlsprechende Beslandesbesehaffenheit, d. h. hinreiehendes Alter, genügende Zahl und richtige Verteilung der Sanenbäume, sowie gute Bodenbeschaffenheil vorausgeselzl, außer Zweifel; ebenso, daß diejenigen unler ihnen, welche in der Jugend gegen Frosl und Hitze empfindlich sind und deshałb in der Pegel eines Sehutzbeslandes bedürfen, meisi mit dem größeren Vorteil auch wirktieh nalürlich verjüngt werden. Die künstliche Verjüngung dieser schutzbedürftigen Holzarten, z. B. der Buche oder Tanne, auf der Kahlfläche, event. auch unter Zuhilfenahme eines durch eine andere Holzart erst beschafften Sehutzbeslandes isl Ausnahme. Andererseits sind unbedingte Liehthölzer, wie Lãrehe, Kiefer, Eiche, von der natürlichen Vicrjüngung zwar keineswegs ausgesehlossen, verlangen aber auf allen nicht sehr frischen und kräftigen Böden eine so rasehe Räumung der Mutterbäume, daß man mil ihnen bei künstlicher Verjüngung meist schneller und bequemer zum Zicle homml. Eine Anzahl von Holzarten (Fichle, Esche, Erle, Ahorn) halten die Milte und lassen sich je nach Lage der ktimalischen und Bodenverhälınisse bald natürlich bald künstlich mil größtrem Erfolg verjüngen. Je besser der Boden, um so cher ist im allgencinen dic natürliche Verjüngung durch Samen möglich, weil das geringe Schattenerträgnis der Lichlhölzer in besseren Lagen durch dic sonst guten Waehstumsbedingungen leilweise paralysiert wird (z. B. reichlicher Eschen- und Eiehenanflug auf frischen, kräfligen Böden unter oft noch sehr dichtem Schirmdach der Multerbäume). Aehnlich erhŏl größere Lufteuchtigkeit (in der Nähe des Meeres oder sonstiger großer Wasserflächen, im Gebirge elc.) die Möglichkeit natürlicher Verjüngung. - Rauhe Lagen, steile Hänge, steinige Partien, Böden, welche bei Freistellung starken Unkrautwuehs erwarten lassen, fordern oft natürliche, nasse Orte meisı künslliche Bestandesbegründung. Näheres bei Behandlung der cinzelnen Holzarten, siehe 4. liap. dieses Abschniltes.

d) Wie schon im 2. Abschnitt näher ausgeführt ist, wird die Art und Weise der Verjüngung meist schon von der gewählten Betriebsart vorgeschrieben. Der Kíahlschlagbetrieb bedingt, abgesehen vom Falle der Randbesamung, die künstliche Verjüngung. Und da der Kahlschlagbetrieb ein Günsthing der Forsteinrichtung ist, so unterliegt es keinem Zweifel, daß das Uebergewicht, das die liunstverjüngung vielerorts über die Naturverjüngung aufweist, in vielen Fällen nicht auf waldbauliche Erwägungen, sondern auf das der Forsteinrichtung zugrunde liegende Prinzip zurïckzuführen ist. Schirmsehlag- und Femelschlagbetrieb und noch mehr Femelbetrieb,

1) Die Präzisierung derselben folgl aus dem 4. Fiapitel dieses Absehnittes ,Betriebsarten und Beslandesbegrundung bei den einzelnen Holzarten".

2) Zu vergt. u. a. die Verhandlungen der Versammlung deutseher Forstmänner zu Frankfurt a. ll. 1884 uber das Thema: ,A uf welchem Standpunkl befindet sich augenblicklich die Frage der natürlichen Verjüngung?:- Versammlungsbericht bei Sauerländer, Frankfurt a. 11.1885 
Niederwald und Mittelwald operieren meist mit Beschaffung ihrer Jungwüchse auf natürlichem Wege. - e) Als Vorzug der künstlichen Bestandesbegründung wird auch (insbesondere bei der Pflanzung) eine gleichmäßigere Verteilung der jungen Individuen auf der Fläche geltend gemacht, wоraus sich dann auch eine gleichmäßigere und bei lichterem Stande raschere Entwickelung der Einzelstämme von Jugend auf ergibt. Bei vler Naturverjüngung liann eine reiche Mlast unter günstigen Verhältnissen zu dicht stehende Jungbestände schaffen, die, wenn sie nicht in ihrer Entwickelung sitzen bleiben sollen, schon frühzeitig kostspielige Maßnahmen der Bestandspflege, Verdünnungen durch Ausschneiden und Läuterungen notwendig machen. - f) Wer auf regelmäßige औlschungen Gewicht legt, wird auf dem Wege der kïnstlichen Verjüngungen solche weit elier herzustellen imstande sein als durch Naturverjüngung. - g) In hohem MaRe entscheidet auch der Bodenzustand eines Bestandes über die Anwendbarkeit dieser oder jener Verjüngungsmethode. Die natürliche Verjüngung setzt einen solchen Zustand des Bodens voraus, daß das Ankeimen der Samen und das Weiterwachsen der Liemlinge möglich ist. Man bezeichnet diesen Bodenzustand als Bodengare und ist überall dort. wo diese Bodengare infolge starker Verunkrautung oder infolge von Anlı̈ufung von Trockentorfmassen fehlt, nicht berechtigt, eine erfolgreiche Naturverjüngung ohne Maßnahmen der Bodenvorbereitung zu erwarten. Die Kunstverjüngung führt in solchen Fällen, trotzdem sie auch eine melı oder weniger umfängliche Bodenbearbeitung nicht umgehen darf, oft schneller und sicherer zum Ziele als die Naturverjüngung. - 1 ) Auch der Kostenaufwand ist in manchen Fällen (Waldfeldbaı, arme Böden, seltene und nicht ergiebige Samenjahre, umfangreiche Nachbesserungen in Falle natülicher Verjüngung etc.) bei künstlicher Kultur geringer, obwohl eingeräumt werden muß, daß in allgemeinen gerade im Sinne der liostenersprarnis die natürliche Bestandesbegründung den Vorzıng verdient. Jede Kulturausgabe belastet den Bestand, mit Zins und Zinseszins bis zum Abtrieb anwachsend, derart, daß möglichste Ersparnis geboten ist. Erstmaliger Aufwand und Liosten etwaiger Nachbesserungen sind stets zu kombinieren. Entscheidend ist der vollkommene, nicht nur der erstmalige, oft nur vorübergehende liulturerfolg.

Die Frage, ob kiünstliche oder natürliche Verjüngung, bedarf, wie aus vorstehenden Andeutungen hervorgeht, recht häufig der besonderen örtlichen Untersuchung, da uns die Zweifelsfälle, in welchen beide Aiten möglich sind, in großer Zahıl und vielseitiger Gestalt entgegentreten. Ausschlaggebend ist der nach jenen allgemeinen Gesichtspunkten unter gleichmäßiger Berücksichtigung a $1 \mathrm{l}$ e r konkurrierenden $110-$ mente zu bemessende wirtschaftliche Gesamteffekt. Oertliche Erfahrung ist fïr die Beurteilung höchst wertvoll, jedoch stehen unverkennbar Gewohnheit und durch sie bestärkte Vorurteile nicht selten sachgemäßen Aenderungen hindernd in Wege.

In bezug auf die allgenseinen Gesichtspunkte sei nur wiederholt daran erinnert, daß allein in der Durchführbarkeit einer natürlichen Verjüngung deren vollgültige llotivierung noch nicht liegen kann. Die natürliche Verjüngung darf vielmehr, um gerechtfertigt zu crscheinen, keinenfalls weniger leisten als die künstliche Bestandesbegründung, und als Maßstab dient die Gesamtwertserzeugung auf gegebener Fläche unter voller Berücksichtigung des Faktors "Zeil", bezw. Umtriebszeit. Dies sei hauptsächlich deshalb nochmals betont, weil neuerdings mehrfach für lïngeres Warten auf natürliche Besamung (bes. im İ̈iefernschirmschlag) plaidiert wird, inden für zeitweiliges Fuhlschlagen der Verjüngung auf den Lichtungszuwachs am Oberstand als einen genügenden Ersatz hingewiesen wird. Ist dieses bewußte, lange Zuwarten gleichbedeutend mit Verlängerung der Untriebszeit über die normale Dauer hinaus - ob die Umtriebszeit an sich hoch oder niedrig bemessen ist, kommt dabei nicht in Betracht_, so ist es allgemein zu verwerfen; denu ebensowenig, wie der Wald der Untriebszeit wegenda ist, dürfen Ondung, Uebersichtlichkeit und höchste Rentabilität, welch letztere mehr oder weniger immer nur bei einer bestimmten Höhe der [Tmtriebszeil erreicht wird, der natürlichen Verjüngung zuliebe geopfert werden. Wo diese gar nur zweifelhaften Erfolg verspricht, darf nich bloß die künstliche Verjüngung untel Schirmstand, sondern auch der Kahlschlag in vielen Fällen die lionkurrenz ganz 
beruhigt aufnchmen. Die Losung: "Fort mit jedem Kahlschlag!" ist jedenfalls als eine einseitige Auffassung waldbaulieher und gesamtwirtschaftheher Verhältnisse anzusehen und beruht auf weitgehender Nichtbeachtung unfangreicher wirtsehaflicher Erfolge, wie sie tatsächlich mit dem Kalılschlage erzielt worden sind und noch erziclt werden!

\section{Historisches.}

\$ 36. Im Hochwaldbetriebe hat die natürliche Verjüngung vielfach der künstlichen Bestandesbegründung, sowohl der Saat als der Pflanzung, weichen müssen und zwar auch in Fällen, in welchen natürliche Verjüngung recht wohl möglich ist. Der Grund liegt hauptsächlich in der relativ hohen Sicherheit vieler Methoden der künstlichen Verjüngung, sowie in dem Umstande, daß man bei der Kunstverjüngung den Vorgang der Bestandesbegründung unabhängig von dem mehr oder minder zufälligen Eintreffen gewisser Vorbedingungen (wie der Mast für natürliche Besamung, Vorhandensein eines wenigstens annähernd normalen Altholzbestandes usw.) in jedem beliebigen Zeitpunkte einleiten und durchführen kann. Dadurch wird bis zu einem gewissen Grade größere Regelmäßigkeit und Uebersichtlichkeit in dem ganzen Verjüngungsbetriebe gewährleistet und auch den Interessen der Forsteinrichtung am besten entsprochen. Insbesondere hat die Pflanzung bedeutend an Ausdelmung gewonnen.

Selbstredend ist die natürliche V'erjüngung die älteste Methode der Bestandesbegründung. Bis in die zweite Hälfte des achtzehnten Jahrhunderts findet man außer in den Fällen absoluter Notwendigkeit (Blösenanbau etc.) künstlichen Holzanbau nur wenig, hatte auch nach Lage der Umstände (Bedeutung der Jagd, niedrige Holzpreise usw.) keinen Anlaß, für Kulturen besondere Aufwendungen zu machen. Mit dem Vordringen des schlagweisen, zunächst des Femelsehlag- und Schirmschlag-Betriebes an Stelle des reinen Femelwaldes kam die künstliche Kultur, wenn auch vorerst nur als Unterstützung der natürlichen Verjüngung, mehr und mehr" in Aufnahme und erlangte endlich in Kahlschlagbetrieb die Herrschaft. Hierbei war es namentlich die schon angedeutete taxatorische Rücksicht, d. h. die Sehnsucht nach größerer Uebersicht und Ordnung in der ganzen Wirtschaft, die mehr als die rein waldbaulichen Erwägungen der Ausbreitung des Kahlschlagbetriebes und damit dem Vordringen der künstlichen Bestandsbegründung Vorschub leistete. Ueberhaupt hat die Forsteinrichtung nicht selten mehr, als ihr zukam, die Führung im Wirtschaftsbetriebe übernommen. Hier und da ist man in der Wertschätzung der künsthichen Bestandesbegründung ganz zweifellos zu weit gegangen. Man ließ sich vielenorts mehr und mehr zur bedingungslosen Verfolgung dieser einseitigen Richtung verleiten, so daß mancherlei wirtschaftliche Mißstände nicht ausbleiben konnten, und es ist wohl begreiflich, wenn man in den letzten Jahrzehnten vielfach um so entschiedener zur natürlichen Verjüngung zurückgekehrt ist. Daß wir uns in der Gegenwart einer der letzteren günstigen Strömung gegenüber befinden, erhellt schon aus der neueren Waldbauliteratur, aus den durch manche waldbauliche Werke (insbes. G a y e r s Waldbau, B orggre ve s Holzzucht, W a g n e r s räumbche Ordnung u. a.) angeregten Debatten, sovie aus der Behandlung einschlägiger Probleme in einer großen Reihe von Forstversammlungen der letzten Jahrzehnte $\left.{ }^{3}\right)$. Selbstverständlich wird dem aufmerksamen Beobachter der Umschwung der Anschamungen auch im Walde vielenorts sofort erkennbar. Ilan hat sich aber davor zu hüten, da $B$ man nicht aus

1) Vergl. Bericht über die XIII. Versammlung deutscher Forstmänner zu Frankfurt a. M. $188 \pm$ (Verlag von Sauerländer 1885), insbes. S. 48 ff. Referat von L o r e y über das Thema: ,Auf welchem Standpunkt befindet sich augenblicklich die Frage der natürlichen Verjüngung?" Daselbst sind u. a. auch eine Anzahl Aeußerungen aus der neuesten Literatur, sowie aus Versammlungs-Verhandlungen angeführt.

Handb, d. Fostwiss. 3. Auf. II. 
einem Extrem ins andere fällt und soll namentlich auch nicht vergessen, dab die Verschiedenartigkeit der Wald- und Standortsverhältnisse beide Verjüngungsprinzipien nebeneinander zuläßt.

\section{Reihenfolge der Kulturen.}

\$37. Passende Verteilung der einzelnen Kulturarbeiten auf die einzelnen Jahre und die in ihnen verfügbare Zeit ist erforderlich. Die Kürze der liulturzeit, die Beschaffenheit des Kulturmaterials und die Rüchsicht auf die Arbeitskräfte beschränken den Wirtschafter oft in seinen Dispositionen. Bei den Anordnungen über die Fieihenfolge der vorzunehmenden Arbeiten kommt es darauf an, diejenigen zunächst zu bedenken, welche entweder an einen bestiminten Zeitpunkt gebunden sind oder sich als die für den Gesamtwirtschaftsbetrieb wiehtigsten emeisen. Im allgemeinen gilt der Grundsatz, Nachbesserungen sobald als möglich vorzunehmen, da sie später meist nur mit größeren Kosten und oft nur mit geringerer Aussicht auf Erfolg ausgefülırt werden können. Dasselbe gilt von der Einsprengung von Mischhölzern in die Schläge. Im übrigen ist denjenigen Kulturflächen, auf welchen Bodenverschlechterung zu befürchten ist, die nächste Sorge zuzuwenden, während außerdem solche Flächen baldmöglich mit einem vollkräftigen Bestande zu versehen sind, welche den größten Zuwachs versprechen, deren zeitweiliges Liegenlassen also den größten Verlust mit sich bringen würde. Eine den örtlichen Umständen entsprechende Verteilung der Arbeiten auf Herhst und Frühjahr ist besonders wichtig. Man beachte überdies, daß manche Holzarten (Lärche u. a.) verpflanzt sein sollten, hevor sie ihre Knospen öffnen, während mit anderen (Fichte) noeh ohne besonderen Nachteil liultiviert werden kann, nachdem sie schon kleine Triebe gebildet haben ${ }^{1}$ ). Im allgemeinen stellt man in Frühjahr gern die Pflanzungen den Saaten voran.

\section{Zweites Kapitel.}

\section{Natürliehe Bestandesbegrundung.}

Vorbemerkung. Die allgemeinen Gründe für und gegen natürliche Verjüngung sind in ersten liapitel dieses Abschnitts $z$ U I, B, $\$ 35$ angegeben worden. Die Vorfrage lautet immer: ist die Bestandesbegründung auf natürlichem Wege überhaupt möglich? Aus der Bejahung folgt dann aber noch kieineswegs, daß sie auch rātlich ist. Die Naturverjüngung etwa durch überlanges Abwarten erzwingen zu wollen, ist ein ebenso großer Fehler, wie der Verzicht auf sie in Fällen, wo sie uns ohne besondere liosten einen guten Nachwuchs oder gar Bestände liefert, welche den auf andere Weise begründeten überlegen sind.

Ein Haupterfordernis für das Gelingen der natürlichen Verjüngung ist neben dem Vorhandensein von Samenbäumen, Samenjalıren und geeignetem Bodenzustand die Einleitung der Verjüngung zur rie h tigen $\mathrm{Z}$ e it. Eine zu frühe Verjüngung ist unzweckmäßig, weil die Nutterbäume, solange sie noch nicht im Vollbesitz der Nannbarkeit sich befinden, schwach und unregelmäßig fruktifizieren. Wird die Verjüngung erst im überlaubaren Alter eingeleitet, so bietet teils die dann im Verein mit räumlicherer Stellung der Mutterbäume meist eingetretene Bodenverwilderung ein mechanisches Hindernis für normale Verjüngung, teils erzeugen die llutterbäume nicht mehr den vollwertigen Samen, den sie im Optimum ihrer Nannbarkeit - bei Eiche und Buche in Alter von $80-120$ Jahren, bei Ficlite und Tiefer zwischen $60-100$ Jahren - erzeugten. Der Samen wird im höheren Alter viehmehr kleiner und leichter. Jedoch ist das Zurüekgelıen der Samengüte in allen klinatisch günstigen Standortsverhältnissen praktisch ziemlich bedeutungslos, da hier auch im höheren Alter

1) Vergl. Dr. Wa 1 th e $\mathrm{r}$, „Wann sollen wir die Nadelhölzer verpflanzen?" Allg. F.- u. J.-Z. 1887 , S. 112 fi. 
noclı durchaus brauchbarer Samen erzengt wird. Viel wichtiger für den Erfolg der Verjüngung ist der Bodenzustand, und dieser verlangt, weil er im höheren Alter durch stärkere Unkrautdecken oder Anhäufung nur langsam sich zerselzender Streumengen schlechter wird, die Einleitung der Verjüngung zur richtigen Zeit d. h. im allg. in früheren, nicht zu hohem Alter des Bestandes.

\section{A. Natürliche Verjüngung durch Samen.}

\section{Kahlschlag mit Randbesamung.}

$\$ 38$. Die Mutterbäumc, in geeigneter Zahıl und Beschaffenheit, insbesondere also im samenfähigen Alter, stehen seitlich an der Verjüngungsfläche. Man emwartet das Ueberflicgen der Samen auf diese, was aber nur für leichte, besonders für beflügelte Samen (Nadelhölzer, Ahorn, Esche, Hainbuche), mit hinreichender Sicherheit zu unterstellen ist. Ujebercties dürfen jedesmal nur schmale, 1-2 Stammlängen breite Absäumungen am Rande des Samenbestandes (in der Windrichtung, damit der Samen vom Winde der Kalılfläche zugetragen wird; am Hang womöglich von oben nach unten) stattfinden. Mcist gelingt die Ansamung nicht vollständig und gleichmäßig; man muß entweder längere Zeit warten oder — und das ist das Richtigere die Fehlstellen mittels künstlicher Kultur nachbessern. Schwierigkciten entstehen durch inzwischen angesiedelte Unkräuter, Stockausschläge ॥sw. Man findet diese Art der Verjüngung hier und da in kleinen Umfange mit Erfolg durchgefülı't, wenn die Erfahrung ihre Zulässigkeit nachgewiesen hat oder wenn die Umstände den Aufwand für künstliche Kultur nicht gestatten, während man doch (etwa aus Rücksichten der Holzbringung) von dem Kahlhieb nicht absehen möcbte. Größere Bedeutung lommt dieser Art der Verjüngung nicht zu.

Als ein Spezialfall der Randbesamung sind die sog. Ii u lis se $n$ h i e b c zu betracliten, bei welchen zum Zweck der Verjüngung streifenweise abwechselnd $10-30 \mathrm{~m}$ breite liahihiebe gefüht und Bestandesteile von gleicher oder doppelter Breite dazwischen stehen gelassen werden. Von letzteren ausgehend soll die Besamung der Kahlstreifen stattfinden. Daß dies, wenn Samenjahre und günstige Wittcrung zu rechter Zcit eintreten, sowie Unkrautwuchs, Bodenverödung etc. nicht hinderlich wird, mit Erfolg geschehen kann, wird durch die Erfahrung bestätigt. Ebenso sicher ist aber auch, daß die geschlossen bleibenden Bestandcspartien, welche mit Rūcksicht auf die Bewegung des Samens meist mit der Breitseite dem Winde entgegenstehen, oft der Sturmgefahr preisgegeben und überdies in sich zunächst nicht mit den Bedingungen einer guten Naturbesamung ausgestattet sind. Selbst wenn man, un gleichzeitig mit der von ihnen ausgehenden Randbesamung für sic selbst zu sorgen, einen normalen Samenschlag auf ihnen stellt, ist das Resultat ungewiß. Erfahrungsgemäß verhagert und verunkrautet der Boden unter dem Einfluß von Wind und Sonne an den Rändern der bestandenen Streifen. Kommt nun hinzu, daß tatsāchlich die Küturerfolge mittelst der liulissenhicbe auch bezüglich der Jahlstreifen vielfach nicht befricdigen (Mlangellaftigheit insbes. an den Rãndern, Holzabfuhr, Insekten usw.), so bleibt ein Grund so zu velfahren, kaum übrig; man geht vielmehr besser entweder vollstăndig zur Freikultur oder zur Samenschlagstellung für die ganze Flāche über.

Ilit anderen hat namentlich B org g r e ve-Holzzucht, 2. Aufl. S. 186 ff. - auf Grund der Beobachtung, daß eine Zeit lang in den norddeutschen lijeferebenen dem liulissenhieb in der Praxis der lïiefernverjüngung mehrfach in größerem Umfang Raum gewăhrt wurde, sehr energisch gegen ihn Front gemacht. - Zu vergleichen übrigens Danckehnanns Bemerkungen hierzu, Zeitschr. f. F.- u. Jagdwesen, S. 66 ff. von 1887. -

Der liampl gegen dic Kulissenschlăge wird nicht sowohl in erster Linie gegen die vorstehend geschilderten Hicbsführungen unternommen, bei welchen ausschließlich oder doch ganz vorwiegend durch Randbesamung die Wiederbestockung erwartet wird, sondern allgemein gegen das Prinzip derartiger Wechselstellung von liahlfläche und Bestandesstreifen, also insbes. auch dann, wenn, wie in der Mehrzahl der Fälle, künstliche liultur, z. B. Pflanzung nit ljāhrigen Kiefern auf vielen preußisehen kulissenschlägen (Regierungsbezirk Bromberg), alsbald erfolgt. Von anderer Scite werden dic kulissenschläge in Schutz genommen, wenigstens für bestimmte Verhältnisse (cfr. H o 11 w e g in der Zeitschrift für Forst-und Jagdwesen 1901, S. $323 \mathrm{ff.}$. Wenn nun auch die liulissenverjüngung durch künstliche Fultur eigentlich an anderer Stelle besprochen werden sollte, so möge doch die ganze liulissenfrage hicr ihre Er- 
ledigung finden. Es handelt sich zumeist um Kulissen im Kiefernwald der norddeutsehen Ebene, auf ärmeren Sandbōden, oft bei sehr geringen atmosphärischen Niedersehlägen, bei großer Ausdehnung der zu verjüngenden Flächen, woselbst mit großen, weithin sich erstreckenden liahlschlāgen oft schlechte Erfolge erzielt worden sind Hier hat man (zumal in 1883 bis 1897 ) vielfach, nach sorgfältig erwogenem Plane, $40-70 \mathrm{~m}$ breite kulissenhiebe geführt und die Flächen bepflanzt, da auf durchgehends natürliche Verjüngung der Schlāge nicht zurückgegriffen werden sollte. Einige Wuchsbehinderung durch Beschattung und Rūckstrahlung an den Pẳndern sei zwar erfolgt; Randlichtung mindert diese Schådigung. Schütte, Inselitenschäden, Windwurf seien nicht gesteigert, auch Fällungsschwicrigkeiten ergeben sich nicht; vielfach seien einwandfreie Jungwüchse entstanden.

Aus diesen Andentungen ergeben sich ganz klar die einzelnen Einwendungen, welche (zum Teil auch oben schon) gegen die Kulissenhiebe erhoben werden. Als allgemein anzuwendende Form der Verjüngung kann man sie um so weniger empfehlen, da man mit Schmalschlāgen, über welche später (unter der Rubrik „Kahlschlagbetrieb") zu sprechen ist, in v"ollkommen wirkamer Meise den Nachteilen großer Kahlhiebe rorbeugen kann.

II. Die Mutterbäume stehen auf der Verjüngungsfläche.

\$39. J. A 11 g e m e in e s. Die Mlutterbäume dienen nicht nur der Begründung des neuen Bestandes durch ihren Samenabfall, sondern beschirmen auch den Jungwuchs. Wesentlich von dem Einfluß dieser Ueberschirmung hängt es ab, ob man die Eigenschaft der Altholzstämme, Samen auszustreuen, mit mehr oder weniger Erfolg bei der Begründung des neuen Bestandes benutzen kann. Der Einfluß der Ueberschirmung ${ }^{1}$ ) macht sich teils im und am Boden, an dessen Feuchtigkeitsund Wärmeverhältnissen und an dessen äußerem Zustand bemerkbar, teils trifft er die den Boden bekleidenden Pflanzen, in Sonderheit also auch die Holzpflanzen, deren Nachzucht wir beabsichtigen. Ueberdies wird auch das Tierleben auf der Kulturfläche durch das Vorhandensein eines Kronenschirms von Nutterbäumen berührt.

1. Der Boden. Im großen und ganzen ist der Einfluß der Ueberschirmung günstig, es sei denn in sehr nassen Lagen, deren Wasserüberschuß beseitigt werden muß. In Betracht kommen hauptsächlich die Wirkungen der Sonne, der atmosphärischen Niederschläge, der Winde, und zwar sämtlich in bezug auf Bodenwärme und Bodenfeuchtigkeit und damit im Zusammenhang auf Humuszersetzung usw. Der Kronenschirm der Mutterbäume hält die Sonnenstrahlen vom Boden ab und schützt ilın vor intensiver Erwärmung und Austrocknung. Weiterhin wird durch die Baumkronen ein Teil der atmosphärischen Niederschläge vom Boden ferngehalten. Der Zutritt des Windes zum Boden wird gehemnt, sodaß diesem die Feuchtigkeit besser bewahrt bleibt.

2. Die jungen Holzpflanzen. Zu Sonne, Niederschlag und Vind gesellen sich als wirkende Faktoren die Wärmeausstrahlung gegen den Luftraum, der Anspruch des Obcrstandes an das Nährstoffkapitel des Standorts, die Unkräuter und die Tiere. a) Die S on ne wirkt durch $\mathrm{Li}$ cht und Wärme. Wie sich diese beiden in die Gesamtleistung teilen, ist noch nicht genügend aufgeklärt. Jedcnfalls kommt aber in physiologischer Beziehung dem Licht ein ganz hervorragender Anteil an der Sonnenarbeit zu. Im Licht, wenn auch nicht im direkten Sonnenlichte, sondern vielmehr im zerstreuten (diffusen) Lichte, wachsen unsere Holzpflanzen sämtlich hesser als im Schatten oder Halbschatten, vorausgesetzt, daß alles zu ihrer freudigen Entwickelung Nötige vorhanden ist. Namentlich muß der Boden hinreichend frisch sein, damit den im höheren Licht- und Wärmegenuß stärker verdunstenden Holzpflanzen die nötige Feuchtigkeit nicht fehlt, um die austrocknende Wirkung

1) Zu vergl. B o r g g $\mathrm{r}$ e v e, „Holzzucht", 2. Aufl. S. $118 \mathrm{ff}$. Daselbst findet sich eine sehr vollståndige Andeutung der Einzelmomente, welche zur "Gesamtwirkung der Beschirmung" zusammentreten. Der V'ielgestaltigkeit der Kombinationen gegenüber ist eine allseits erschöpfende Behandlung kaum denkbar. Immerhin lassen sich gewisse, stets wiederkehrende und allgemein festzuhaltende Gesichtspunkte unschwer gewinnen. 
der Sonnenwärme auszugleicheı. Je lichthedürftiger eine Holzart ist, um so weniger lange verträgt sie, wie schon in allgg. Teil S. 17 näher ausgefülnt ist, Ueberschirmung. b) Wenn die atmosphärischen $\mathrm{N}$ i ederschläg e den Holzpflanzen durch den lironenselirm zum Teil entzogen werden, so ist diese Wirliung nicht unter allen Umständen eine nachteilige, sie kann vielmelır in längeren Regenzeiten oder auf kalten, undurclılassenden Tonböden als eine günstige angesehen werden. Immerhin aber muß in sehr vielcn Fällen, in welchen die Fätlichkeit einer natürlichen Verjüngung bezweifell wird, wie z. B. für die Kiefer auf Sandbaden, die Zurücklaltung der atmosphärisehen Niederschläge durch die Baumkronen zu den bedenhliehen Umständen der Ueberschirmung gerechnet werden. Entscheidend ist der Wasserbedarf der nachzuziehenden Holzart und hier wieder die Frage. ol in den kritischen Zeiten längerer Trockenheit ü b e r h a u p $\mathrm{t} n \mathrm{u}$ r durch einen Schirmstand oder in welchem Maße etwa durch einen solchen b e s s e $\mathrm{r}$ für die Erhaltung der nötigen Feuchtigkeit gesorgt wird. Daß im allgemeinen unter einem noch nicht sehr stark gelichtelen Kíronenschirm der Hutterbäume melır Feuchtigkeit verfügbar und damit die Gefahr durch Trockenheit geringer ist, darf als erfahrungsmäßig feststehend betrachtet werden. c) Der W ind wirkt austrocknend auf den Boden und wird, wie schon oben erwähnt, durch eine teilweise Ueberschirmung am Geltendmachen dieser unerwünschten Wirkung gehindert. Ebenso sehützt Ueberschirmung auch vor dem namentlich im Laubholz bemerkbar werdenden Verwehen des Laubes. d) Die IV ä r m ea u s s t r a h l u n g kommt einmal in Betracht wegen der Spätfröste (klarer Himmel, ruhige Luft), sodann wegen der Taubildung. Die Wirkung des Kronenschirms ist ersteren gegenüber unzweifelhaft günstig, wogegen die Becinträchtigung der Taubildung nachteilig ist. Für viele Fälle bedeutet die Verminderung der Wärmeausstrahlung durch den Schirm der Mutterbäume und die damit zusammenhängende Zurückhaltung von Spätfrostschäden ein außerordentlich wiclitiges Homent. Eine der übelsten Jugendkrankheiten der Kahlschlagkulturen, die den Wirtschafter hin und wieder, bein Anbau der sog. Frostlöcher, zur Verzweiflung bringen liann, wird durch die Verjüngung unter Schirm gemindert, wenn nicht ganz aufgehoben. e) Die Beteiligung der Hutterbäume und andererseits der Forstunkiäuter am N ä h r s t of fka p ita I d es B odens (Wurzelkonkurrenz) muß, sobald eine gewisse Grenze überschritten wird, den jungen Holzpflanzen nachteilig werden. Geht man davon aus, daf der nocl geschlossene Altbestand alles, was an Nährstoffen verfügbar ist, für sich ausnutzt, so geslattet erst eine Durchlichtung desselben die Entwickelung eines Jungwuchses. Für dessen Entstehung und Emälrung genügt zunäclıst eine sehr mäßige Sclılußunterbrechung. Unterbleibt dann abel eine weitere Auflockerung des Schirmbestandes, so geht der Jungwuchs wieder ein, er vermag sich im Existenzkampf mit den Wurzeln der Schirmbäume um so weniger zu behaupten, als letztere auch durch Kronenverdichtung und Kronenausbreitung dem Jungwuchs den notwendigen Lichtgenuß verkürzen. Neben der Wurzelkonkurrenz der Ilutterbäume kommt für den Jungwuchs weiterhin die Konkurrenz der Forstunkräuter in Betracht, die bei jeder stärkeren Lichtung, auf gutem wie auf schlechtem Boden, leicht bedenklich werden liönnen. Dureh Beschirmung lassen sich viele von ihnen, in erster Linie alle lichtbedürftigeren, bekümpfen. Die schädigende Wirkung der Unkräuter beruht außer auf Inanspruchnahme der Nälırstoffe und insbesondere der Feuchtigkeit des Bodens, auch auf Beschattung (Verdämmung) der Holzpflanzen. In welchem Maße das eine oder das andere der Fall ist, läßt sich überhaupt nicht und am wenigsten allgemein angeben. Je nach der Art und Henge kann das Unliraut auch nützlich wirken, insofern es die Holzpflanzen vor Frost, Austrocknung etc. 
schützt. f) Bezüglich schädlicher Tiere ist an die durch Ueberschirmung geminderte (event. verhütete) Gefahr durch Mäuse, Engerling, Rüsselkäfer zu erinnern. Bodenfrische unter dem Schirm von Mutterbäumen förclert, wenn die nötige Wärme nicht fehlt, die regelmäßige Streuzersetzung, die höchst wirksame Arbeit der Regenwürmer usw.

Aus den vorstehenden Andeutungen geht hervor, daß der Fironenschirm der Mutterbäume im großen und ganzen bezw. in den weitaus meisten Fällen der Entwickelung des Jungwuchses förderlich ist. Leitet man hieraus ab, daß dic natürliche Verjüngung die Regel zu bilden habe, so ist das waldbaulich richtig, schließt aber nicht aus, daß in zahlreichen Fällen die Verjüngung unter Schirm nicht so viel leistet wie die Verjüngung auf freier Fläche, wo vermehrte Niederschläge, Taubildung, Licht und Wärme im speziellen Falle günstig wirken. Nan hat also zu erwägen, welche Momente jeweils in dem allein entscheidenden Gesamteffekt der Beschirmung, in dem die vielgestaltigsten Einzelwirkungen vereinigt sind, nach Lage der Umstände voraussichtlich die wichtigsten sein und cinen vorwiegenden Einfluß äußern werden.

Die ganze Frage ist, wie S. 63 schon angedeutet wurde, überhaupt nur hinsichtlich eines Teils unserer Holzarten eine kritische, sofern bei Tanne und Buche kaum jemand olıne Not von der natürliclıen Verjüngung Abstand nehmen wird, wälrend man manclıe andere Holzarten, zumal so entschieden lichtbedürftige wie die Lärche, nieist durch Pflanzung an die Orte bringen wird, wo man ihrer bedarf. Auch die Eichen, Esche, Ahorne sind keine für die allgemeine Entscheidung - pro oder contra natürliche Verjüngung - maßgebenden Holzarten, schon wegen des im ganzen nicht großen Gebietes, in welchem sie wirklich in der WVirtschaft führende Holzarten sind. Dagegen ist bei der Fichte dic Frage zweifelhaft. Bei dieser Holzart hat man vielfach die Möglichkicit der natürlichen Verjüngung, und, wo man von ihr abgeht, könnte die Angabe der Gründe dafür gefordert werden. Die weitaus erheblichsten Bedenken aber gegenüber der auf natürliche Verjüngung gerichteten Forderung treten uns bei der Kiiefer entgegen, deren Jungwüchse im allgemeinen lieines besonderen Schutzes gegen Frost und Hitze bedürfen und sich im vollen LichtgenuB unzweifelhaft freudiger entwickeln als unter einem nur einigermaßen dichten Kironenschirm. - Alles Nähere über die einzelnen Holzarten im 4. IKapitel dieses Abschnittes.

Die natürliche Verjüngung durch einen auf der Fläche stehenden Mutterbestand scheidet sich in die vier charakteristischen Formen des Schirmschlagbetriebes Femelschlaghetriebes, Saumschlagbetriebes und Fenelbetriebes.

Die Charakteristik dieser vier Betriebsarten findet sich im II. Abschnitte. Es sei hier nochmals liurz hervorgehober, daß der S c h ir m s c lı l a g b e t r i e b die Verjüngung auf größerer Fläche gleichzeitig und gleichmäßig in Angriff nimmt und womöglich (grundsätzlich wenigstens) mit Hilfe einer einzigen Mast durchfülırt, so daß ein gleichalter und gleichartiger Jungbestand ersteht. Der F e ni e l s c h l a gbetri e b schafft zunächst über die zu verjüngende Fläche hin zerstreute Verjüngungszentren, verjüngt diese durch noch nicht angegriffene Teile des Altbestandes getrennten Partien zuerst und schreitet von ihnen aus allmählich unter Benutzung einer Reihe aufeinanderfolgender Samenjalure vor, indem er die Verjüngungszentren ringsum erweitert, stets neue Angriffspunkte einschaltet und so nach und nach den ganzen Bestand aufrollt. Der Benutzung verschiedener Masten entsprechend ist der Jungbestand aus ungleichaltrigen Gruppen und Horsten zusammengesetzt, die, dem Verjüngungsgange gemäß, nicht mit steilen Rändem aneinanderstoßen, sondern gewissermaßen ineinander überfließen sollen. Der $\mathrm{S}$ a u $\mathrm{m} \mathrm{s} \mathrm{ch} \mathrm{l}$ a g b e t r i e b stellt

1) Femelschlagbetrieb $\mathrm{H}$ e y e r $s ; c f r, s . t 1$. 
einen streifenweise vom Rande aus nach dem Bestandsinnern vorrückenden Schimuschlag- bezw. Plenterschlagbetrieb dar. In F e m el w a l d e endlich stehen alle Altersklassen auf der Flächeneinheit untereinander, die Verjüngung knüpft sich jeweils an den Aushieb einzelner Stämne bezw. Gruppen von solchen. Bis alle Teile des Bestandes durch neue ersetzt sind, vergeht die ganze Umtriebszeit. Alle Samenjalıre wälurend derselben tragen durch Lieferung von Jungwüchsen zur Bildung des neuen Bestandes bei; dieser enthält somit wiederum alle Altersklasscn.

$\$ 40$. 2. Die Verjüngung im Schirmschlagbetrieb. Bei schulgerechter Ausführung des Schirmschlagbetriebes unterscheidet man das V o r-

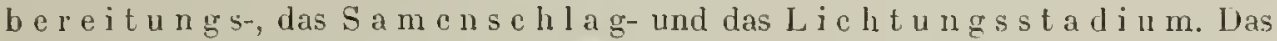
Vorbereitungsstadium beginnt in dem Moment, wo in dem bis dahin mehr oder weniger regelmäßig durchforsteten Vollbestande zum Zwecke der Herstellung günstiger V'erjüngungsverhältnisse eine stärkiere Krronendurchlichtung crfolgt. Die hierzu notwendigen Eingriffe in den Bestand heißen Vorbereitungsschläge, Vorbereitungshiebe, Vorhiebe oder Vorlichtungen; sie liönnen in der Ein- oder Mehrzahl erfolgen. AIs Samen- oder Besamungsschlag bezeichnet man den unmittelbar zum Zwecke der Besamung im Samenjahre stattfindenden Eingriff in die Bestandsmasse. Das Lichtungsstadium endlich umfaßt die nach eingetretener Besamung auf schnellere oder langsamere Entfernung der Nutterbäume gerichteten Licht-, Auslichtungs- oder Nachlichtungshiebe, deren letzter, der Räumungsschlag, die letzten Mutterbäume entnimmt und den verjüngten Bestand allein zurückläßt. Bei der Schirmschlagverjüngung geht man von cinem bestinmten Jahre aus, in welchem man die Verjüngung wünscht ${ }^{1}$ ). Die zum Zweck der Verjüngung auszuführenden Maßnahmen umfassen eine Reilıe von vor und nach diesem Zeitpunkt liegenden Jahren, welche man in ihrer Gesamtheit den ,V e r jü n g u n g s z e i t r a u m" nennt. Der erste Eingriff in den Bestand, wclcher unmittclbar dazu bestimmt ist, die Verjüngung einzuleiten, bezeichnet den Anfangs-, der Hieb des letzten Mutterbaumes den Endpunkt jenes Zeitraums. Die Fällungen während desselben erstrecken sich auf haubares Holz. Der Verjüngungszeitraum ist je nach den örtlichen Bedingungen bald länger bald kürzer. Seine Dauer wird teils durch die Häufigkeit der Mastjahre (Fruchtbarkeitszeitraum), namentlich aber durch die Länge der Zeit, während welcher der Jungwuchs des Schutzes der Mutterbäume bedarf, bestimmt; er kann sich so lang erstrecken, als der Nachwuchs die Ueberschirmung durch die Mutterbäume, ohne Not zu leiden, noch verträgt. Eine Ausdehnung des Ueberhaltens von Mutterbäumen über das den besten Verlauf des Verjüngungsprozesses garantierende Maß hinaus findet ihre Begründung, wo sie beliebt wird, außerhalb des Gebietes des Waldbaues (z. B. längerer Bezug eines Lichtungszuwachses an den Mutterbäumen, Verteilung der Fällungen, Ausstattung der Perioden etc.). Diejenige Holzart, bei welcher sich der scharf ausgeprägte Schimschlagbetrieb - in Bayern neuerdings vielfach ,.Dunkelschlagbetrieb“ genannt — am häufigsten findet, ist die Rotbuche.

a) Vorbereitungs t a d u m. Der Uebergang aus den Durchforstungen in den Vorbereitungshieb, bezw. in die Vorbereitungshiebe - denn sehr oft, ja meist werden die bezüglichen Fällungen nicht auf einmal vorgenommen - kann ein all-

1) Daß diese tatsächlich nicht inmer gerade in diesem einen Jahre, sondern bald etwas früher, bald etwas später erfolgt, und daß man nicht auf das Einzeljahr, sondern auf einen durch ōrlliche Erfahrung bekannten, bald lãngeren bald kürzeren Zeitraum, innerhalb dessen man durchschnittlich eine genügende Mast erwarten darf, alle auf die Terjüngung abzielenden Operationen einrichtet, bedarf kaum der Erwähnung. Für die Darstellung des nornalen V'erlaufs darf man aber anstandslos alles auf das normale Besamungsjahr bezieher. 
mählicher sein. Manchmal wird er durch stärkere Durchforstungen bezw. Lichtungshiebe so vermittelt, daß eine Grenze zwischen den Maßnałmen der Bestandspflege und den auf Verjüngung abzielenden Eingriffen gar niclıt zu finden ist. Wo man bei der Bestandspflege die in der Gegenwart mehr und mehr vertretenen Grundsätze der schärferen Durchforstung beobachtet, entfällt die Notwendigkeit besonderer Vorbereitungshicbe. Die Besamung vollzieht sich in solchen Beständen, wie man zu sagen pflegt, ,aus vollem Ortc". Ueberhaupt ist die Vorbereitung keineswegs immer notwendig. Holzarten, die sich im späteren Alter sowie so licht stellen, machen Vorbereitungshiebe meist enthehrlich. Der Zweck des Vorbereitungshiebs ist, die für die Besamung besten Bedingungen herzustellen und zwar sowohl auf dem Boden wie im Bestand. Der letztere soll so beschaffen sein, daß er im Nloment der Besamung nicht nur das erforderliche Naterial an Nutterbäumen, sondern auch eine solche Anzahl von Stammindividuen enthält, wie sie für den dem Boden und demnächst dem jungen Aufschlag zu gewährenden Schutz nötig ist. Die auf Herbeiführung dieses Bestandeszustandes gerichteten Fällungen abzuschließen, ist später die Aufgabe des Besamungsschlages. Die Vorhiebe bereiten dort, wo die vorhergehenden Bestandspflegemaßregeln nicht linreichend genug waren, den $\mathrm{Be}-$ samungsschlag vor, indem sie durch allmähliche Durchlichtung des Kronenschlusses teils eine stärkere Kronenentwickelung, teils erhöhten Zuwachs, reichliches Fruchttragen, sowic größere Standfäligkeit der stehenbleibenden Stämme zu bewirken suchen. Hierbei ergreift der Hieb, ohne größere Löcher zu schaffen, zuerst solche Holzarten, welche zur Besamung nichts beitragen sollen, z. B. Hainbuchen in Mischbeständen mit der Rotbuclıe, wenn man demnäclıst keine oder nur wenige Hainbuchen im Jungwuchse wünscht. Außerdem werden schon beim Vorbereitungshieb fehlerhafte Stämme, wie tief gegabelte, drehwüchsige, ferner, soweit tunlich, ïberalte, schwere Stämme entfernt, welche für eine gleichnnäBige Schlagstellung stets hinderlich sind und überdies, wenn ilı Aushieb erst stattfindet, nachdem die Besamung bereits erfolgt ist, durch ihren Fall, durch das Aufarbeiten und Anrücken oft schwere Beschädigungen der Jungwüchse herbeiführen. Die Besamung hat in der Hauptsache von den Stämmen der kraftvollen, normalen, mittleren Klassen auszugehen. Schwaches, besonders unter- und zwischenständiges Material ist, soweit es niclıt etwa durch zu dichten Stand die Besamung beeinträchtigt, zu erhalten, weil es meist zur Schaffung eines Schirmdaches trefflich geeignet ist und auch später noch, ohne besondere Gefährdung des Aufschlags durch die Fällung, leiclıt ausgezogen werden kann. Auch im Sinne gleiclımäßiger Verteilung der Fällungen, der Etatserfüllung, wenn die Mast fehlschlägt usw., sind die Vorbereitungshiebe äußerst schätzenswert, jndem sie dann vielleicht weiter ausgedehnt werden können und durch ilıren Holzanfall zur Ertragsausgleichung dicnen. Sie sichern in solchen Fällen eine gewisse Beweglichkeit der Wirtschaft.

Gleichzeitig soll durch die Vorhiebe, wie oben schon angcdeutet wurde, eine Wirkung auf den Boden ausgeübt werden, da sich eine Unterbrechung des líronenschlusses stets durch Veränderungen im Zustand der Bodenoberfläche (raschere Zersetzung der Streuschicht, Begrünung) kennzeichnet. Hierin liegt sogar der Hauptzweck der Torbereitung. Der Boden soll für die Ansamung empfänglich gemacht, d. h. in eine solche Beschaffenheit verselzt werden, daß die Samen kcimen und die Keimlinge anwachsen können. Eine genügende Bodengare, d. h. eine entsprechend weit vorgeschrittene Zersetzung der Streudecke, die Bescitigung etwa vorhandener Rohhumusmassen ist erforderlich, wenn die Mast gut anschlagen soll. Wieweit die Íronenschlußunterbrechung speziell zur Herbeiführung jenes Bodenzustands gehen 
muß, ist nach Lage des Falles ( $\Lambda$ t der Streudeclic, Bodenschicht, Feuchtigkcit etc.) verschieden. Im ganzen sind langsame Yorbereitungshiebe zum Zweck der Bodenvorbereitung plötzlichen, stärlieren Eingriffen vorzuziehen. Auf sog. tätigen Böden, auf denen infolge eines hinreichenden Kalligelialtes und infolge Vorhandenseins der sonstigen Zersetzungsfaktoren die Anhäufung unzersetzter Streumassen überhaupt nicht vorkommt, entfällt dic Notwendigkeit der Bodenvorbereitung sehr oft. IVohl aber ist eine solche Vorbereitung dort notwendig, wo sich infolge Trägheit des Bodens, d. h. infolge von Kalliamut, oder kühler Lage (Nordlage), dichten Schlusses, zu großen Wasserreichtums, kurz, infolge Fehlens der die Streuzersetzung fördernden Bedingungen Trockentorf angesammelt liat. Hier muß durch eine entsprechende Schlußunterbrechung, sei es auf dem Wege der Durchforstung oder auf dem der Vorbereitungshiebe, für das Auftreten einer schwachen Bodenflora gesorgt werden, damit unter deren und der Atmosphärilien Einfluß die der Ansamung und dem Gedeilien des Jungwuchses äußerst hinderlichen unzersetzten Strcumengen in Humus überführt werden. Wo der Vorhicb hicrzu nicht zureicht, muß einc mechanische Bodenbearbeitung zu Hilfe liommen. In der Regel soll durch geeignete Bestandspflege und Hiebsführung eine besondere Bodenbearbeitung unnötig gemacht werden. Sie ist jedoch nicht immer ganz zu umgehen, zumal auf geringeren Standorten, und besteht dann namentlich im Entfernen von Moospolstern (Polytrichum commune), welche die Samen, bezw: die aus ihnen sich entwickelnden Würzelchen nicht zum mineralischen Grund gelangen lassen, im Grobschollighacken (Iíurzhacken) u. dergl. ${ }^{\mathbf{}}$ ). Oft genügt es, diese Maßregeln nur streifen- oder platzweise durchzuführen. Auch Schweineeintrieb kann sich unter Umständen sehr empfehlen. Da und dort findet auch auf besten Böden grundsätzlich immer eine Bodenbearbeitung statt, damit in jeder denkbaren Weise eine gute Besamung und die rasche Entwickelung der Kieimpflanzen befördert wird (Buchenverjüngung in Dänemark als Beispiel ${ }^{2}$ ).

In großen Durchschnitt wird das Richtige getroffen sein, wenn der Vorbereitungshieb $10-20 \%$ des bis dahin liräftig durchforsteten Bestandes an Masse entnimmt. Er erstreckt sich auf die demnäclıst in Samenschlag zu stellende Fläche. An den Schlagrändern ist der Bestand (gegen Sonne und Wind) dunkler zu halten. Vorsichtige Fällung ist ebenso selbstverständlich, wie etwa die Verschonung der der Verjüngung entgegenzuführenden Bestände mit Streunutzung u. dgl.

$\mathrm{Ob}$ und inwieweit etwa von früheren Masten her bereits vorhandener Aufschlag oder Anflug bei der allgemeinen Bestandesverjüngung mitbenutzt werden kann und soll, bleibt späterer Erörterung vorbehalten.

b) S a me n s c h l a g: Wenn die Vorbereitungshiebe im Bestand noch nicht denjenigen Grad der Durchlichtung herbeigefühırt haben, welcher für die eigentliche Besamung und für die Beschirmung des Aufschlags während der ersten Zeit nach der lieimung erwünscht erscheint, wird durch einen besonderen Hieb, den sog. Besamungsschlag, nachgeholfen. Mlan könnte ihn grundsätzlich vielleicht den Vorbcreitungshieben noch zuzählen und aus diesen unmittelbar zı den nach erfolgter Besamung nötig werdenden Naclılichtungen übergehen. Dadurch jedoch, daß der Besamungsschlag an ein bestimmtes Jalır, dasjenige des Masteintritts, gelnüpft ist, während die Vorbereitungshiebc olıne Rücksicht auf das Samenjalır den Bestand nur ganz allgernein für die Ausnutzung einer erhofften Jast tauglich machen wollen, unter-

1) So finden sich z. B. im geschlossenen Buchenort auch nicht selten Laubschichten von solcher Mächtigkeit, daß in ihnen zunächst zur rascheren Reduzierung eine etwas lebhaftere Zersetzungstātigheit wachgerufen werden muß. Eventuell muß die Laubschichte teilweise entfernt werden. Hier und da teilweises Unterpflūgen derselben - (Vogelsberg).

2) Darauf wird bei spezieller Besprechung der Rotbuche zurückgekommen werden. 
scheidet er sich von den Torhieben. Diese sind, weil man nicht sicher voraus weiB, wann sich die Mast einstellen wird, bisweilen noclı nicht bis zu dem für die Besamung geeignetsten Maß der Durchlichtung vorgeschritten. Kommt nun ein Samenjahr, so besorgt alsbald der Besamungsschlag das noch Fehlende. Auch hierbei ist Gleichmäßigkeit der Stellung und in allgemeinen eine dunkle Haltung des Schlages anzustreben. Der Eingriff in den Bestand soll nicht stärker sein, als daß die Keimung sicher von statten geht, und sich der Aufschlag bis zur nächsten Nachlichtung, welche in der Regel nicht vor dem zweiten, vielleicht erst im dritten auf die Besanuung folgenden Jahre vorgenominen wird, normal entwickelt. Den Keimpflanzen ist durch ein relativ dichtes Schirmdach zunächst die nötige Bodenfeuchtigkeit zu garantieren und jeder energische Kampf mit vordringlichen Unkräutern möglichst zu ersparen. Ein allgemein gültiges $\mathrm{Ma} B$ läßt sich für die Schlagstellung nicht geben, weil sie je nach Holzart, Bestands- und Standortsbeschaffenheit eine verschiedene sein muß. Insbesondere kommt es darauf an, wie weit man mit den Vorbereitungshieben schon gegangen war. Im großen Durchschnitt wird man eine brauchbare Stellung gefunden haben, wenn uninittelbar nach der Besamung noch etwa $0,7-0,6$ des normalen Vollbestandes vorhanden sind. Modifikationen im einzelnen sind vorbehalten. Hochangesetzte Kronen z. B., welche mehr Seitenlicht zulassen, erfordern weniger starkes Eingreifen als kurzschaftiges Holz; letzteres aber stoclit meist auf geringerem Boden, weshalb man auch hier vorsichtiger sein muB. Lichthölzer fordern, sofern man es mit der natürlichen Verjüngung bei ihnen versuchen will, inmerhin eine etwas liräftigere Kronendurchbrechung als ausgesprochene Schattenhölzer, wie z. B. die Tanne. Gegen starken Unkrautwuchs hält man den Bestand dunkler. Dichterer Schłuß kann endlich auch auf trockenen und mageren Böden, an steilen Hängen zur Erhaltung der Feuchtiglieit, wie unter Umständen gegen Ueberhandnehmen nasser Stellen (Carex brizoides in Buchenbeständen!) angezeigt sein.

Wie schon erwähnt wurde, ist der Samenschlag erst zu stellen, wenn auf das Eintreten der Mlast mit Sicherheit gezählt werden darf. Seine Größe ist zumeist von dem häufigeren oder selteneren Vorkommen guter Mastjahre, d. h. von dem Fruchtbarkeitszeitraum, dem durchschnittlichen Intervall zwischen zwei Mastjahren, abhängig und jeweils so zu bemessen, daß im jährlichen Nachhaltbetrieb innerhalb der Untriebszeit der gesamte Wald verjüngt wird. Von dem Fruchtbarkeitszeitraum unterseheidet sich der durch die Dauer der Ueberschirmungsbedürftigkeit des Jungwuchses bedingte Verjüngungszeitraum (siehe oben). Decken sich beide, so staltet sich der Vorgang der Verjüngung am übersichtlichsten. Kehren die Mastjahre, wie dies meist der Fall ist, in Zwischenräunen wieder, die kürzer sind als der Verjüngungszeitraum, so liann nicht jede Mast ausgenutzt werden. Jährliches Samentragen würde die Bildung von Jahresschlägen gestatten; anderenfalls wird eine entsprechende Anzalıl von Jahresschlägen in einen Periodenschlag zusammengefaßt.

Die Bodenvorbereitung, von welcher schon gelegentlich der Besprechung des Vorbereitungshiebes die Rede war, wird mit Vorteil erst unmittelbar vor dem Samenabfall vorgenommen. Die Holzhauerei im Samensehlag muß vor der lieimung beendet sein. Zweckmäßigerweise nimmt man sie im Herbst vor oder nach den Abfall des Samens vor, um durch die Arbeiten der Holzernte in ersten Falle der Bodenverwundung, im anderen Falle dem Unterbringen des abgefallenen Samens zu dienen.

c) A us lichtungsstadium. In den nach der Besamung zu führenden Hieben liegt im allgemeinen die Hauptschwierigkeit bei der Leitung des Verjüngungsprozesses, weil man in jedem einzelnen Falle die Grenze zu bemessen hat, von der ab die wolıltätigen Wirkungen der Beschirmung dureh den Nachteil überboten wer- 
den, der durch längeres Zurïcklıalten der Entwickelung des Nachwuchses ersteht. Der Gefährdung durch Frost, Dürre, Unkraut usw. steht das in verstärktem Lichtgenuß (bei genügender Bodenfcuchtigkeit) unzweifelhaft freudigere Heraufwachsen des Aufschlags gegenüber. So sehr sich einerseits Vorsicht in der Richtung empfehlen kann, daß man der sicheren Behütung vor jenen Gefahren den höheren WVert beimißt, so kann doch dureh eine zu weitgehende Aengstlichlieit, welche den Jungwuchs zu lange unter dem Schirmdaclı der Mutterbäume kümmern läßt, cbenso vicl gccschadet werden. Sobald die Verjüngung planmälig eingeleitet ist, wird deren bestmöglicher rascher Vollzug in erster Linie maßgebend. Das Gedeihen des n e u e n Bestandes, nicht die tunliclıst potenzierte Wertsteigerung im a I t e n, ist von da ab für dic IVirtschaftsführung bestimmend, wenn auch einc möglichst günstige Kónbination beider Rücksichten stets anzustreben ist. Allmühliche Gewöhnung des Jungwuchses an freiere Stellung durch langsames Nachhauen im Hutterbestande wird sich vielenorts empfehlen, während in anderen Fällen ein beschleunigtes Tempo der Abräumungen erwünseht, ja notwendig sein liann (z. B. frostfreie Lagen im Gegensatz zu Frostlokalitäten, lichtbedürftige Holzarten gegenüber Schattenhölzern usw.). In bezug auf den zeitlichen und räumlichen Gang der Lichtungshiebe sind Boden und Bodenfrische, Entwicklungsenergie des Jungwuchses, Sturmgefahr der Hutterbäume zu berücksichtigen. Auch ist die Holzart entscheidend, sofern ganz allgemein der Aufschlag und Anflug von Lichthölzern zu seinem Gedeihen rascherer und energischerer Freistellung bedarf als solcher von Schattenhölzern. Es kann als Regel gelten, daß die Lichtung im Oberstand nicht früher ais im zweiten Winter nach der Besamung beginnt („Kräftigungshieb" Grebes), nachdem die jungen Pflanzen wenigstens einigermaßen erstarkt sind. Es ist selbstverständlich, daß bei den Nachhieben die ursprüngliche Gleichmäßigkeit der Schlagstellung nicht gewahrt werden kann, sondern ganz von selbst verloren geht. Einzelne Stellen werden vielleicht schon früher oder doch schon vollständiger besant sein als andere, auf einzelnen wird sich infolge zufällig stärkeren Lichteinfalls etc. der Aufschlag kräftiger, unter Umständen zu förmlichen Vorwuchshorsten entwickelt haben. Daß man solchen Partien Luft macht, um sie noch mehr zu fördern, daß durch allmähliche Erweiterung der im Altbestande hierdurch entstehenden Lücken nach und nach die zwischenhinein noch vorhandenen Oberstandspartien zusammenschrumpfen, bis die vollständige Schlagräumung, der Räumungsschlag, eintritt, leuchtet ein. Von diesen mehr zufällig entstelıenden Ungleichartigkeiten im Jungbestande, welche übrigens kaum je so bedeutend sind, daß sie nicht $d € m$ Auge bald wieder versclıwänden, unterscheiden sich wesentlich diejenigen, welche als Ergebnis der Verjüngung im Femelschlagbetriebe erscheinen.

$\S 41$. 3. Der Femels c h l a g b etri e b. Wie schon mehrfach kurz angefühıt worden ist, will der Femelschlagbetrieb grundsätzlich keine gleichmäßig über die ganze Fläche sich erstreckende Verjüngung herbeiführen und demgemäß auch keinen gleichaltrigen Jungbestand schaffen, sondern erhält, indem er die einzehen Bestandespartien nacheinander behufs ilı'er Verjüngung in Angriff nimmt, in dem erwachsenden neuen Bestand Altersunterschiede, welche der Länge des Verjüngungszeitraumes und der Zahl und Aufeinanderfolge der während desselben benutzten einzelnen Hasten entsprechen. Der Verjüngungszeitraum ist - da die Bewältigung der Aufgabe, zumal bei vorsichtiger, feinster Virtschaftsführung, mehr Zeit erfordert als eine Verjüngung, bei welcher durch wenige, über die ganze Fläche sich erstreckende Hiebe alles Erforderliche erledigt wird - demgemäß ein meist läıgerer, kaum je unter 30 Jahre heruntergehend. 
Der Vorgang ist im allgemeinen folgender:

Van macht planmäßig da und dort stärkere Eingriffe, während die zwischenliegenden Partien noeh intakt bleiben. Diese als Angriffs- oder Vorbereitungs-, in Bayern auch als Gruppenhiebe bezeichneten Eingriffe sollen die wertvolleren BestanJesglieder kräftigen, sie zur Fruktifikation anregen und sollen den Boden empfänglich machen, verfolgen mithin dieselben Zwecke wie die Vorhiebe des Schirmschlagbetriebes. Die Einzelstellen, von welchen die Verjüngung ausgeht, sind entweder nur größere oder kleinere Löcher, absichtlich gelıauen, vielleicht auch melır zufällig entstanden (Tannenwirtschaft: durch Sturm, Aushieb von Kirebsbäumen etc.), oft ohne jeglichen Oberstand, Partien, welche nicht selten bereits besamt sind, anderenfalls von den Randbäumen her sich leicht besamen, - oder es sind Flächenteile, manehmal gleich anfangs von etwas größerer Ausdelınung, auf welehen zunächst (wie beim Vorbereitungshieb des Schirmschlags) geeignete Viutterbäume stehen bleiben, his die Besamung erfolgt ist, und der junge Wuchs des Schutzes nieht mehr bedarf. Die Schutzwirkung der Mutterbäume tritt dabei insofern zurück, als der rings um den Junghorst noch geschlossene Bestandesrand entsprechenden Seitensehutz gewährt, so daß die Räumung der Schirmbäume meist bald erfolgen kann. Regelmäßige Figuren sind natürlich ebenso wenig Bedingung wie gleichmäßiger Abstand der einzelnen Verjüngungszentren voneinander, wenn auch deren annähernd gleiche Verteilung über die Gesamtfläche, sowie tunlichst die Kreisform erwünseht ist. Es muß sich eben bei der Durchführung von Fall zu Fall alles nach den örtlichen Umständen richten; eine scharf ausgeprägte Schablone ist ausgeschlossen. Je nach der Entwickelung der Jungwüchse und dem Eintritt neuer Samenjahre wird dann am Rande in schmäleren oder breiteren Ringen weiter gelichtet, es werden „Umrandungs"- oder „Umrändelungshiebe“ gefülırt. Neue Jungwüchse erstehen in Angliederung an die im Inneren der Verjüngungsplätze heraufwachsenden Partien, neue Angriffspunkte werden zwisehen den alten eingesehoben, und es ist klar, wie durch solches Verfahren nach und nach der ganze Altbestand durch junge Gruppen und Horste ersetzt wird. Größere unbesamte Lücken entstehen dabei also nirgends, sondern nur kleine Löcher und schmale Absäumungen, deren Besamung sich vom Rande oder von Schirmbäumen aus leicht vollzieht. Als Vorzug einer solchen Ungleichförmiglieit im Verjüngungsgange wird größerer Zuwachs, besonders infolge bedeutenderer Boden- und Luftfrisehe, vollkommenste Bewahrung der Bodenkraft, auch wohl örtlich verminderter Schneesehaden und Windwurf bezeichnet. Zweifellos sind dureh die allmählich vorschreitende Femelschlag-Verjüngung örtlich schon sehr gute Erfolge zu verzeichnen, indem man tadellose Jungbestände in großer Ausdehnung erzielt hat. Namentlich wird in Bayern, wo auf G a y e r s energische Anregurg hin die Methode ins feinste ausgebildet worden ist, seit mehreren Jahrzehnten nach ihr erfolgreich gearbeitet. Man braueht aus den dortigen befriedigenden Erfolgen jedoch noch nieht auf eine unbedingte Rätlichkeit dieser Wirtschaft, die vorzugsweise für Tanne, Fichte und Buehe, ganz besonders aber für Mischbestände diesel Holzarten in Betracht kommt, zu schließen, sondern kann die Frage aufwerfen, ob nieht in den reinen und nur wenig gemischten Beständen in vielen Fällen eine durch den ganzen Bestand hindurch annähernd gleichmäßige und gleichzeitige Durehführung der Terjüngung — stets die erforderliche Durchliehtung im Kronenschim vorausgesetzt - die nämliche Wertsproduktion an den gleichmäßig verteilten, sämtlich mit gehörigem Lichtungszuwachs arbeitenden Mutterbäumen erzielen würde und ob dabei nicht unter voller Schonung der Bodenkraft ein allen An- 
forderungen entsprechender Nachwuchs erzogen werden könnte ${ }^{\mathbf{1}}$ ). Unbestrittenen Wert aber hat die horst- und gruppenweise Verjüngung überall dort, wo die Wirtschaft auf Erhaltung der vorhandenen Mischung gerichtet ist. Die von ihr gehotene Beweglichkeit bei der Anbahnung, Pflege und Erweiterung von Verjüngungspunkten gewährleistet mehr als jede andere Betriehsart die Möglichkeit, dem verschiedenen Lichtbedürfnis und dem ungleichen Entwicklungsgang der in Frage kommenden Mischholzarten so Rechnung zu tragen, daß horstweis gemischte Bestande wiecher entstehen. Andererseits ist nicht zu verkennen, daß bei der Gruppenverjüngung durch die Verteilung mehr oder minder geschlossener kleiner Beständehen über die ganze Fläche hin viclfach bedenlliche Unstände (Frostgefahr, Gefährdung durch Stürme, Entzug der Niederschläge etc.) herbeigeführt werden. Die unbedingten Anhänger des Femelschlagbetriebes stehen zwar auf dem Standpunkte, daß gerade diese Gefahren im Femelschlagverfahren weniger bedenklich werden, und weisen zur Erhärtung ihrer Ansicht auf eine Reihe von Beispiclen hin, in welchen Schädigungen wie die angedeuleten ausgeblieben sind.

Für Schirmschlagbetrieb und Femelschlagbetrieb ist noch zu erwähnen, daß bei der Nachlichtung solehen Particn, welche zunächst unbesamt geblieben sind, durch eine Unterbrechung im Kronendach oft am leichtesten geholfen werden kann, daß also solche Stellen im Bestande keineswegs immer besonders dunkel zu halten sind. Vorsichtiger Fällungsbetrieb, mit Rücksicht auf den Unterwuchs, ist geboten. Nachbesserung durch Saat oder Pflanzung, Einbringen von Mischhölzern, soweit es nicht mittels Vorverjüngung (z. B. Eiche im Buchengrundbestand) schon erfolgt ist, hat zugłeich mit den Auslichtungen, spätestens bald nach ihnen stattzufinden. Stocklöcher, im Falle der Rodung, bieten besonders gecignete Stellen zur Einpflanzung. Der Femelschlagbetrieb kann sich, falls nur mit ganz kleinen Löchern operiert wird, offenbar dem reinen Femelbetrieb nähern. Er kann andererseits, wenn die Verjüngungszentren größere Flächen einnehmen, und die Erweiterungsringe breit sind, mehr und mehr einer Auflösung des Ganzen in einzelne im Schirmschlagverfahren behandelte Teile gleichkommen.

$\S 42$. 4. Der Saums chlagbetrie b. Wie ebenfalls schon oben (S. 41) ausgeführt wurde, ist der Saumschlagbetrieb nichts anderes als eine Anwendung der Verjüngungsgrundsätze des Schirmschlag- bezw. des Plenterschlagbetriebes auf schmalen, vom Rande herein allmählich nach dem Bestandsinnern vorrückenden Verjüngungsstreifen. C. IV a g $\mathbf{n}$ e $\mathrm{r}$ - Tübingen, der den Saumschlagbetrieb in der von ihm empfohlenen als Blendersaumschlag bezeichneten Form zu neuem Leben erweckt hat, legt den Schwerpunkt des Saumschlagbetriebes auf die Hiebsrichtung, weil von dieser die mehr oder weniger austrocknende Einwirkung der Sonne und damit der Erfolg der Saumverjüngung in erster Linie beeinflußt wird. Als normale Hiebsrichtungen kommen nach Wagner ${ }^{2}$ ) nur in Betracht: Nordwest-Südost für Laubhölzer und besonders geschützte Lagen, Nord-Süd für Nadellı̈lzer und die weniger festen Laubhölzer in besonders gefährdeter Lage. Der vom nördlichen oder nordwestlichen Bestandsrande aus beginnende und sich langsam nach Süden bezw. Südosten vorwärts bewegende Hieb besteht zunächst in einem ungleichförmigen Auflockern eines Saumes des bisher geschlossenen Bestandsrandes. Durch die Entnahme unerwünschter und zu stark vertretener Holzarten und zwar inmer zuerst

1) Vergl. hierzu die schon oben (S. 46) angeführte Literatur, sowie S c h u b e r g, Schlaglichter zur Streitfrage, ,sehlagweiser Hochwald- oder Femelbetrieb" in forstw. Zentralbl. Von 1886 , S. 129 ff. und S. 193 ff. Diese Abhandlung von Seh., welehe sich auf umfängliche exakte Untersuchungen stüzt, ist, weil bestimmte Zahlen gegeben werden, sehr interessant.

2) Grundlagen d. räuml. Ordnung i. Walde. 1907, S. $135 \mathrm{fl}$. 
der dichtbekrontesten Exemplare werden Löcher und Kileinflächen für die erste Ansamung geschaffen. Diese erfolgt im noch dunklen schirm und in Seitenschutz des geschlossenen Bestandes. Der Dunlielstand befähigt bej V'erjüngung von Mischbeständen zunächst nur die Schattenhölzer Tanne und Buche zur Bildung von Anfluggruppen, die sich beim langsamen Fortgang des Hiebes und beim Lichterstellen allmählich erweitern. Fortgesetzte Entnahme der noch stehenden Nutterbäume vom Schlagrande herein bereitet den erstarkenden Anflug auf den Freistand mehr und melir vor. Nit dem zunehmenden Lichtgenuß finden auch die lichtbedürftigeren Holzarten, zunächst Fichte, Ahorn, Esche, später Kiiefer und Lärche günstige Lebensbedingungen auf dem nach außen gelegenen Teile des Verjüngungsstreifens und vermögen sich hier anzusiedeln. - Den jeweilig in Verjüngung befindlichen Streifen kann man sich gewissermaßen aus 3 in verschiedenen Stadien der Terjüngung befindlichen Säumen zusammengesetzt denken. Der den geschlossenen Bestand nächste Saum befindet sich in Samenschlagstellung, die beiden anderen nach dem Schlagrande zu gelegenen Säume im mehr oder weniger vorgeschrittenen Auslichtungsstadium. In dem Maße der Verjüngungsstreifen rom Schlagrande herein gelichtet und durch Räumung der Mutterbäume abgebaut wird, schiebt sich sein dunkelster Teil, der Samenschlagsaum, gegen den geschlossenen Bestand vorwärts. Die Geschwindigkeit, mit der dieses Vorrücken geschieht, hängt, abgesehen von wirtschaftlichen Momenten, vom Gelingen der Ansamung und von den Bedürfnissen des Anfluges ab. Selbstverständlich nimmt auch die größere oder geringere Häufigkeit der Samenjahre sowolıl auf das Tempo des Hiebsfortschrittes wie namentlich auch auf dip Breite des ersten Ansamungssaumes und damit auf die Breite des Verjüngungsstreifens überhaupt EinfluB. Je seltener die Samenjahre sind, um so melır muB das einzelne ausgenützt, um so breiter mithin der Dunkelsaum angelegt werden. Die Breite des Verjüngungsstreifens aber richtet sich auch nach der Holzart. Den breitesten, vom Dunkel des geschlossenen Bestandes bis zum stark gelockerten Lichtstand abgestuften Verjüngungsstreifen verlangen die Schattenhölzer; auch die Fichte verträgt ihn, obwohl für sic schon ein ziemlich schmaler Streifen genügt. Lichthölzer verjüngen sich am besten auf einen schmalen und lichten Verjüngungsstreifen. Wie bei jeder anderen Naturverjüngung ist auch hier schließlich der Boden in zeitlicher und räumlicher Hlinsicht maßgebend für den Gang der Verjüngung. Je geringer seine Besamungsfähigkeit infolge von Neigung zur Verunkrautung, fehlender Bodenfrische oder infolge anderer Ursachen ist, um so mehr ist Vorsicht bei der Lichtstellung und in bezug auf die Schnelligheit des Verjüngungsganges geboten. Schwierige Böden lassen, um die Sicherheit der Verjüngung zu erlıöhen, meist Maßregeln der Bearbeitung angezeigt erscheinen. Ueber die Vor- und Nachiteile des von Wagner als bestes Verjüngungsverfahren angesehenen Saumsehlagverfahrens vgl. das oben im 2. Abschnitt (S. 47) hierüber Gesagte.

$\$ 43$. 5. Die Terjü $\mathrm{ngung}$ im Femelbetrieb: Ein im eigentlichen Femelbetrieb bewirtschafteter Wald unterscheidet sich seinem Wesen nach von dem mit langer Verjüngungsdauer femelschlagartig, d. h. nicht gleichmäßig durch die ganze Fläche hin, sondern gruppen- oder lorstweise behandelten Walde dadurch, daß in ihm alle Altersstufen - die Abstufungen im einzclnen in kleineren Zwischenräumen - vertreten sind, während, wie wir gesehın haben, im Femelschlaghetrieb der zwischen den ältesten und jüngsten Hölzern bestehende Altersunterschied im Höchstfalle nur gleich der Verjüngungsdauer ist. Hieraus ergibt sich bezüglich der Verjüngung im reinen Femelwald als charakteristisches Merkmal, daß der ganze W'ald gleichzeitig in wirtschaftlicher Behandlung steht. Es trifft der Hieb zwar keines- 
weğs in jedem einzelnen . Iahre die ganze Fläche, wohl aher kehrt er in meist liürzeren Zeitzwischenräumen auf die Einzelfläche wieder. Bald mit mehr, bald mit weniger Regelmäßigkeit wechseln im Plenterwalde kleinere und glößere. ältere und jüngere Partien miteinander ab, indem da und dort die ältesten Stämme genulzt werden und an ilıe Stelle Jungwüchse treten, um welche sich, nach vorgängiger Absäumung im Altholz neue Jungwüchse anlegen, so daß auf diese Weise allmählich die Verjüngung des ganzen Waldes erfolgt. Beim Femelsclılagbetrieb konzentricrt sich der Verjüngungsprozeß in der einzelnen Waldabteilung auf die Zeit der Verjüngungsdauer, so daß sich im Gesamtwalde die einzclnen Periodenflächen deutlich voneinander abheben. Im reinen Feinelwalde hingegen vollzieht sich die Verjüngung fortgesetzt in jedem Limlauf der Hauungen. Einzelne Teile der verschiedenen Periodenflächen des Femelschlagbetriebes, bald kleinere Gruppen, bald größere Horste, sind im Femelwalde gewissermaßen untereinander geworfen, so daß, wenn auch keineswegs in jedem kleinsten Bestandteile, so doch innerhalb der einzelnen Abteilung, alle Altersklassen vertreten sind, selbstverständlich nicht durchweg in Abstufungen von Jahr zu Jahr, sondern je nach der Häufigkeit des Eintritts von Samenjahren in mehr oder minder ungleichen, meist melrere Jahre umfassenden Abstufungen.

\section{B. Natürliche Verjlingung durch Ausschlag.}

Vorbemerkung: Sie ist nur möglich bei Holzarten mit entsprechender Reproduktionskraft, schließt also die Nadelhölzer ans. Die genutzten Bestandesteile werden durch Ausschlag aus den auf der Fläche verbliebenen Baumteilen ersetzt, und hierdurch wird der neue Bestand erzeugt. Man unterscheidet Niederwald, Kopfholzbetrieb und Schneitclholzbetricb. Beim Ni e d e r w a l d wird der gesamte oberirdische Baumteil genutzt; die Begründung des neuen Bestandes vollzieht sich durch Stockausschläge (event. in Verbindung mit Wurzelausschlägen) aus den im Boden verbliebenen Stöcken mit ihren Wurzeln. Der Kopfholzbetrieb nimmt dem einzelnen Kernwuchs einen Teil seines Schaftes. An der Abhiebsstelle brechen Zweige hervor, welche dic nächste Nutzung, die Nutzung des .,nächsten Umtriebs", und somit gewissermaßen den neuen Bestand darstellen. Infolge wiederholter Nutzung dieser Aeste entsteht am Schaftende ein Wulst oder Kiopf. Beim $\mathrm{S}$ c li n e i t e l b e t r i e b werden dem einzelnen Stamme nur seine Zweige und Aeste genommen, während der Schaft ihm in ganzer (oder annähemd ganzer) Länge belassen wird. Die Regeneration erfolgt durch Ausschläge an den einzelnen Aststummeln bezw. Schaftwunden.

\section{Verjüngung im Niederwald.}

$\$$ 44. I. I olzarten und A usseh lagsvermoogen: Außer den baumartig erwachsenden Laubhölzern werden auch viele strauchartige, als Iileinnutzhölzer, Faschinenhölzer u. dgl. verwendbare Holzarten im Niederwald angezogen. Zu ersteren gehören vor allen die Eichen, dann Eılen, Kastanie, Akazie, Weiden, auch Esche, Ulme, Ilainbuche u. a., zu letzteren z. B. Hasel, Schneeball, Hartriegel, Heckenkirsche, Schwarz- und Weißdorn usw. Die mcisten dieser Holzarten treiben nur Stockloden, wie Rotbuche, Hainbuche, Eiche, Kastanie, Esche, Ahorn, Birke $u_{\text {. a.; }}$ bei einigen brechen außer solchen auch Wurzelloden hervor, wie bei Weißerle, Rüster, Feldahorn, Akazie, Pappel, Kirschen usw. Die Reprodultionskraft der verschiedenen Laublıölzer ist nicht gleich groß und von ungleicher Dauer und wird von den äußeren Verhältnissen, namentlich von der Bodengüte und dem Lichtgenuß 々eeinflußt. Am längsten hält die Ausschlagsfähigkcit bei Eiche, Horn- 
baum, Erle und Linde aus, während Buche, Birke, Ahorn und Esche schneller nachlassen. Je älter der Stock ist, um so schwächer ist sein Ausschlagsvermögen und um so mehr bleiben die Ausschläge im Höhenwuchs zurück. Flachgründige, arme Böden erzeugen ebenso keine hoch werdenden Ausschläge, wenn sie auch - namentlich in warmen Lagen - die Reichlichkeit des Ausschlags nicht beeinflussen. 2. D i e V e r jü $\mathrm{n} g$ u $\mathrm{n} g$ : Sie erfordert keine besonderen waldbaulichen Maßregeln, da ihr Gelingen, d. h. die Entstehung eines normalen Jungbestandes, wenn anders sich die passende Holzart auf geeignetem Standort in einem guten Bestand vorfindet, und keine besonderen Störungen, wie Spätfröste, Hagelschläge u. dgl. eintreten, in der Hauptsache nur von einem rationellen Nutzungsbetrieb abhängig ist. Im allgemeinen führt man die Stockschläge im zeitigen Frühjałr (März) aus. Nan umgeht dann die beim Ilerbsthieb bestehende Gefahr, daß die Stöcke bei strenger Kälte zugrunde gehen und hat auch die in Herbstschlägen infolge zeitigen Austreibens der Stöcke leicht vorkommenden Spätfrostschäden nicht zu fürchten. Ausuahmen vom Frühjahrs = (Saft-)Hieb machen sich nur dort nötig, wo die nur bei Frost mögliche Zugänglichkeit des Geländes die Winterfällung bedingt (Erlenniedenwälder), oder wo, wie in den Eichenschälwaldungen, die Gewinnung der Rinde Hauptzweck der Verjüngung ist. Hier findet die Nutzung erst nach dem Laubausbruche im Mai bis Juni statt, weil vorher die Rinde nicht in gewünschter WVeise sich loslöst. Stockschläge zum Zwecke der Futterlaubgewinnung werden im Sommer (Juni-August) geführt. - Bei der Hiebsführung in Stockschlägen empfichlt es sich, da Windgefalir nicht in Betracht kommt, in umgekehrter Riclıtung wie beim Hochwaldbetrieb, von Westen oder Süden, zu hauen, um Wärme und Liclıt in die Schläge zu bringen. Bei der Nutzung der Ausschläge, die bei schwächerem Material mit Heppen, bei stärkerem mit Axt oder Säge geschieht, ist auf möglichst tiefen Abschnitt und glatte, am besten etwas geneigte Schnittflächen zu achten. Einkerbungen der Abliebsflächen, wie sie entstehen, wenn die Beilschläge von zwei Seiten aus und von oben geführt werden, sind zu vermeiden, weil sonst das in dem Einschnitt stehen bleibende Regenwasser zur Fäulnis der Schnittfläclıe beiträgt. Die Nachbesserungsarbeiten in Niederwäldern, zum Ersatz eingegangener bezw. zu alter Stöcke, werden am besten durclı Pflanzung, ev. mit Verwendung von Stummelpflanzen, besorgt.

3. Die pralitisch wichtigen Stockschlag-Betriebe.

a) E i c lı en n i e d e r w a ld. Hauptsächlich zum Zwecke der Rindengewinnung betrieben, hat der Eichenniederwald nach der Reichsstatistik von 1900 noch 446500 ha $=3,2 \%$ der Gesamtwaldfläche Deutschlands als E i c lı e n s c h ä I w a I d eingenommen. Wenn auch der seit 1890 eingetretene beträchtliche Rückgang des

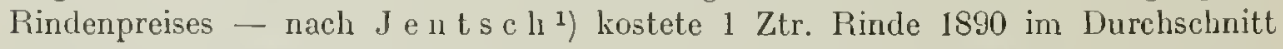
6,01, 1905: 3,19 M. - hier und da zur Verminderung der Schälwaldfläche geführt hat und vielleicht noch führen wird, stellt der Eichenschälwaldbetrieb doch noch immer einen namentlich in Süd- und Westdeutschland sehr beachtenswerten und unter den Ausschlagbetrieben den wirtschaftlich wichtigsten Betrieb dar. Verwendet werden Stiel- und Traubeneiche, letztere ihrer etwas besseren und anhaltenderen Ausschlagsfähigkeit wegen im allgemeinen lieber. Die ihr gleichfalls hin und wieder

1) J entsch, Untersuchungen über die Verhältnisse des deutschen Eichenschälwaldbetriebes. Berlin 1906; Derselbe, Der deutsche Eichenschälwald und seine Zukunft. Berlin 1899; D e r e 1 b e, Der Eichenschälwald in den Niederlanden. Mündener forstl. Hefte, 16. Hft. 1900, S. 89 . - S c h e n c k, Die Rentabilität des deutschen Eichenschälwaldes. Darmstadt 1896. - Bericht ub. d. XXY'. Vers. deutscher Forstmănner 1898: Gegenwärtige Verhältnisse und Zukunft des Eichenschälwaldes. - W a $\mathrm{c} \mathrm{h} \mathrm{s}$. Der augenblickliche Stand der Eichensclıälwaldfrage. Silva $1908, \mathrm{Nr} .20$ und 21. 
nachgerühmte bessere Rindenqualität wird von anderer Seite bestrilten und eher der Stieleiche zugesprochen. Unterschiede in dieser Hinsicht sind auscheinend Folge des Standortes, nicht der Eichenart. Umtrieb, rd. 15jährig, schwanlit zwischen 12 und 20 .Jahren; in neu angelegten Schälwäldern erstmalig etwas länger, da Kernwüchse bis zur gewünschten Erstarkung längere Zeit brauchen als Stochausschläge. Die Neubegründung von Eichenschälwäldern geschieht durch Saat oder Pflanzung und setzt, wenn sie rentabel sein soll, kräftige, wenn auch nicht tiefgründige Böden in warmen Lagen (Weinlagen) voraus. Saat, meist in Riefen, 6-10 hl für I ha; Pflanzung, meist mit 3jährigen Stummelpflanzen in Peihenverband $2: 1 \mathrm{~m}$ oder Quadratverband $1,3-1,5 \mathrm{~m}$. Mischungen sind zu vermeiden. Wo sie früher als richtig angesehen wurden, auf ärmeren Böden, auf denen die eingemischte Holzart (Kiefer, Weymouthskiefer, Lärche, Akazie) den Boden bessern und den Ertrag erhöhen sollte, gehört der Schähald heut nicht mehr hin. Die sich von selbst einstellenden Mischhölzer (Aspe, Sahłweide, Hasel, Hornbaum), die sog. Raumlı̈lzer oder Unhölzer, sind zcitig und nach Bedarf wiederholt so gründlich wie möglich auszujäten. Durchforstungen, die neben der Entfernung der Raumhölzer die unterdrückten Eichenausschläge fassen und mit Aufastungen der besseren Schälstangen verbunden werden können, sind im Interesse der Erhöhung des Rindenertrages emp-

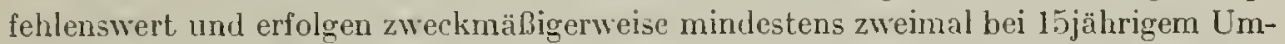
triebe. Abtrieb im llai oder Juni (vgl. hierzu Handbuch, unter IX. Forstbenutzung B.). Normale Schälwalderträge auf gutem Standorte beim Abtrieb jro ha zwischen 80 und $150 \mathrm{Ztr}$. Pinde schwankend. Hierzu kommen 20-30 fm Schälholz und (meist. als Zwischennutzung) 6-15 fm Raumholz. In Hessen ist für Schälwaldungen mit weniger als $80 \mathrm{Ztr}$. Rindenertrag generell Umwandlung in Hochwald angeordnet worden.

b) Kastanien niederwald $\mathbf{1}$ ). In Weinbaugegenden, in Deutschland namentlich im Elsaß, zur Erzielıung von Relpfählen geeignet. Erfordernisse: tiefgründiger, kräftiger Boden, mildes Klima, freie, sonnige Lage. Im Elsaß weisen die östlichen und südöstlichen Hänge der Vorberge bessere Kastanienniederwälder auf als die meist trockeneren und flachgrünligen Süd- und Westhänge. Umtrieb I5-20jährig. Mischung ist auf den besseren Böden zu vermeiden, auf steinigen und sandigen Standorten mit Robinie vorteilhaft. Wo letztere die liastanienstockausschläge bedrängt, muß sie bei der im 7-10jährigen Alter des Stockschlages notwendig werdenden Durchforstung entfernl werden. Gleichzeitig werden die besseren Ausschläge von Zwieseln und stärkeren Scitenästen befreit. Zuwachs auf gutem Boden beträchtlich (14-16 fm für ha und Jahr). Hieb im März und April, in der Pfalz und im Elsaß vielfach aber auch im Herbst. Dem Erfrieren der Stöcke beugt man dann durch Erd- oder Laubbedeckung vor.

c) R obiniennjede $r w a l d^{2}$ ). Weniger für Deutschland, als für Ungarn bedeutungsvoll; dort sind jetzt nahezu 70000 ha mit Robinie bestockt. Lockerer, frischer Sandboden verlangt; auf sterilem, nälırstoffarmem Boden versagt die Robinie trotz ihrer zweifellos vorhandenen Genügsamkeit. Immerhin hat sie sich in

1) K a y ing, Anbau. Bewirtschaftung und Ertrag des Kastanienniederwaldes. Bericht ub. d. XII. Vers. deulscher Forstmănner 1883, S. $118-$ I Is e, Uel. Edelkastanienzucht in OberelsaB. Allg. F.- u. J.-Z. 1898, S. 225. - O s t e r h el d, D. Kastanie an pfälzischen Vorgebirge. Allo. F.- u. J -7.. 1895, S. 22. - H a 11 b a u e r, Edelkastanie und Akazie als Waldbâume in Oberelsaß. Allg. F.- U. J.-Z. 1896, S. 249.

2) Eberts, D. Ikazien-Niederwald. Nllg. F.- u. J.-Z. 1899, S. 168, 290; 1900, S. 74. B und, D. Zucht der Aliazie. Ztsehr. f. F.- u. Jw. 1899, S. 199. - E. V a d a s, D. Bedeutung der Robinie f. d. Forstwirtsehaft Ungarns. Selmecbanya 1910. - F e k e $t$ e, Erdeszeti Kiserletek 1909 , Hft. 3 und 4 .

Haudb. d. Forstwiss. 3. Aut. 11 . 
Ungarn bei der Flugsandbindung gut bewährt. Für den Niederwald ist sie hervorragend geeignet, weil sie durch zähe Ausschlagsfähigkeit (Stock-und Wurzelausschlag) und schnelles Wachstum ausgezeichnel ist. Nach der Pflanzung werden die Pflanzen auf den Stoek gesetzt, am besten im Vorfrühling (März). UmLrieb nach Maßgahe des gewünschten Sortimentes 10-30 jährig: bei Erzeugung von Rebpfählen 7-10jährig; wenn auf Bremnholz und Werkholzsortimente gearbeitet wird, 1520jälıig; wenn stärkeres Nutzholz verlangt wirl, 30 jährig. Höhere Umtriebszeiten empifehlen sich nicht infolge sehr raschen Zuwachsabfalles vom 30 jährigen Alter an. Fekete gibt für Lngam die Waldrente des 30jälıigen Robinienniederwaldes mit 35, $5 \mathrm{kr}$, die Bodenrente mit 11,16 kr an und weist larauf hin, daß der Robinienniederwald damit alle anderen Holz- und Betriebsarten weit hinter sich läßt. Aus Deutschland sind bei $15-20$ jälnigen I'ntriebe Reinerträge von 90 und mehr Mark pro Jah und laa bekannt.

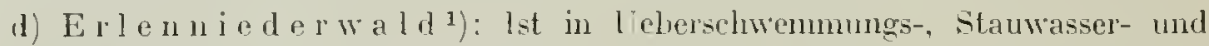
Nieder'ungsmoorgebieten hin und wieder die einzige Betriebsar't, 1 m dem Boden einen Ertrag abzugewinnen. Beiden Erlen ist ein energisches und lang anhaltendes Ausschlagsvermögen eigentümlich, das sich bei der Weiberle in Bildung zalılreicher Wurzelausschläge, bei der Schwarzerte in Bildung von Stockloden bemerkbar macht. Bei Tiefabschnitt oder Anläufehn bewurzeln sich die Stockloden oft von selbst. Bei der Anlage und Ausbessernng von Erlennierlerwäldern ist Pflanzung unumgänglich, da des verdämmenden Gras- und Unkrautwolses wegen auf natürliche Besamung nicht zu rechnen ist. Die zur V'erwendung kommenden f'flanzen müssen so hoch sein, daß sie der Verdämmungsgefalu durch das Gras entwachsen sind. Dreijährige, eimmal verschulte und gut bewurzelte l'flanzen sind zu enplehlen. Die oft sich nötig machende Hügel- oder Rabattenpflanzung krankt, abgesehen ron ilner liostspieligkeit, an dem Nachteil, daß sich bei Hochwasser die Mäuse in die Aufhöhungen flüchten und durch Fraf. bedeutenden Srlıaden anrichten. Umtricb mit Rüclisicht. auf den Wertzuwachs stäkerer Sortinente meist lüher als in den Stockschlägen anderer Holzarten, 30-, 40- auch 50 jährig. Die Abtriebszeit muß in den Brïchern vielfach in den Winter verlegt werden, weil zu anderer Zeit das Gelände nicht zugänglich ist. Baldige Abfuhr der Emte ist dann selbstverständlich.

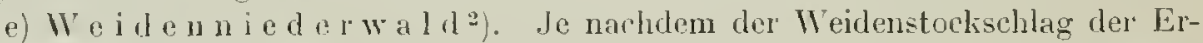
zeugung von Flechtruten oder von sog. Bandstöcken, d. i. stürkerer zu Faßreilen benutzter Ausschläge dient, wird er in 1-oder ?jährigem, im anderen Falle 3- bis 5. jährigem Lmtrieb bewirtschaltet. Zur Anlage einer Weidenkultur eignet sich jeder einigernaßen nălırstoffreiche Boden, sobald er die nötige Frische besitzt. Humusreicher, milder I ehmboden mit nicht zu hochstehendem Grundwasser ist am besten; reiner Sand, Torfhorlen und vollständig trockener Boden eignen sich nicht. l'eberschwemmungsgelände ist un so hrauchbarer, je weniger infolge der periodisch wiederkelnenden Leberstaungen Ersaiz für die durch die Nutzung der Ruten ausgeführten Nährstoffe notwendig ist. Slagnierende Nässe wird von den Weiden nur dann vertragen, wenn Dammkultur angewendel wird. Die Neuanlage einer Weiden-

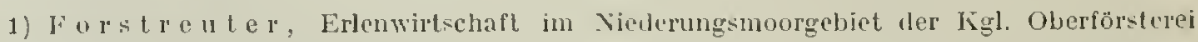
Memonien. 1903.

2) K $\mathrm{l}$ a lı e, Die Korloweidenkultur. 5. Aufl. Aachen 1897. - K e $\mathrm{r}$, Achtzehnjăhige naktischn Erlahrumgen im rationellen liorbweidenbau und Bandstockbetriebe. Dresden 1904. -

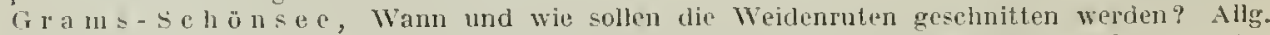
f:- Il J.-Z. 1903, S. 100.- De r S., Die Bandslockgewinnung, das. 1904, S. 380. - D e r S., Arbejlen in der Weidenkultur vom Frühjahr bis zum Herbst, das. 1905, S. 257. - D e rs., Die Ausbesserung der narh einigen Jalnen schwächer werdenten Weidenliulturen, das. 1908, S. 70 
diultur gesehieht in Fröhjahr (Vitle Uärz bis Enıle $\Lambda$ pril) mit $30 \mathrm{~cm}$ langen Stecklingen, die in gut rigolten Boden senkrecht und vollständig im Reilienverband 50 : 10 cm, bei Bandstoclierzichung 50:30 cm eingresteclit werden. Weitere Verbände führen zur Verëstelung der Riuten und zur leichteren Verunkrautung des Bodens. Die zahlreichen Weidenarten und lireuzungen werden nach der Länge und Stärke ilırer Ruten, sowie nach der Ausschlagsfähigkeit der Stöclie und deren Dauer beurteilt. Als Flechtweide empfiehlt sich in erster Linie die Hanfweide (Salix viminalis), weil sie vorzügliche schlanke Ruten ergibt und jälırlichen Schuitt der Ruten, also 1 jälırigen Untrieb, gut aushält. Die ebenfalls empfohlene Mandelweirle (S. amygdalina) verästelt z.u stark. Kreuzungssorten sind in Masse im Handel, taugen aber meist nicht viel. Für Bandstockbetrieb hält Hauptmann $K$ e r $n$, eine Autorität auf dem Gebiete rler Weidenzuchı, S. dasyclados $>$ purpurea ilırer Srhnchwïchsigkeit wegen für besonders geeignet. Ein guter Weidenstockschlag macht dauerude Pflege, Bodenbearheitung, Düngung (bei schlechteren Boden), vor allem aher Bekämpfung des Unkraules notwendig. Verunkrautele Kulturen gehen zu Grunde. Bei rationeller Pflege und Lnterbringen der humosen, die Unkrautsamen beherbergenden oberen Borlenschicht gelegentlich der erstmaligen Anlage genügt einmaliges Behacken und Jäten im Frühjalı (Mai, Juni), un das Lnliraut so lange zurückzulalten, bis es durch den dichten Schluß der Riuten selbst unterdrücht wird. Wie lange ein Stock ausschlagfälng bleibt. hängt sowoh! von ter Weidenart und den Standortsverhältnissen, wie auch von der Intensität ter Nutzung und der Untriebszeit ab. Viele Weidenarten vertragen den 1 jährigen Untrieb nicht. Schwächer werdende Leistungen bei jährlichem Schnitt können dadurch wieder gehoben werden, daß man die Ruten hin und wieder 2 jährig werden läßt. Bei Neuanlagen erfolgt der erste Schnitt zweckmäßigerweise in ersten Wintex. Die jedesmalige Nutzung der Ausschläge erfolgt in der Zeit der vollkommenen Saftruhe (ab Dezenber). Je glatter an Stock die Puten mit Hilfe eines scharfen Messers geschnitten werden, um so gesunder bleibt der Strok; Stummel müssen mögliehst vermieden werden. Bei guter Belıandlung der Stöcke geht die Ausschlagsfähigkeit nur langsam zurück. Rodung und Neukultur aber empfichlt sich dann, wenn die Erträge nicht melır befriedigen. Je besser der Boden an sich ist oder je mehr durch energische Düngung für Erhaltung del. Produlitionsliraft des Borlens gesorgt wird, um so länger läßt sich der Termin der unter Umständen 500 bis 1000 M. für 1 lá erforlemden Neulegründung hinausschieben. In rationellen Flechtweidenbetrieben sind Feinerträge von 300 bis $500 \mathrm{M}$. für 1 ha und Jahr keme Seltenlıeit.

\section{Kopflolzbetrieb.}

$\$$ 4.). Der Betrieb ist gerichtel auf periodische Nutzung der an geliöpften Laubhölzern und zwar an Baumweiden, Pappeln, Hornbaum, Robinie und Platane entstehenden Ausschläge. Eine weitergehende forstliche Bedeutung kommt dem Betrieb nicht zu, da meisi nu. Flußufer, Niederungsgebiete mit Ueberschwemmungsgefahr und Viehweiden als greeignet zur Besetzung mit lioplbäumen angesehen werden. Hin und wieder is die Ueberpflanzung rïrkgängiger Weidenlıeger mit Kopfbäumen von Weide und Jappel erfolgreich gewesen. Bei der Anlage von hopfbaunıkulturen empfiehlt sich die Verwendung bewurzelter Stämmchen aus Baumschulen mehr als die Verwenlung der 2,5 bis 5 m langen, im Ankommen nicht ganz sicheren unbewurzelten Setzstangen. Del Untrieb wird je nach W'uclsenergie und Verwendungszweck ter Ausschläge bemessen und schwanlit zwischen 3 Jahren (bei Weiden) und 6-S Jahren bei Robinie, Platane usw. Die geernteten Ausschläge finden je 
nach der Holzart als Flecht- und Faschinenmaterial, Bindweiden und vielfach als Futterlaub Verwendung. Bei der Nutzung werden die Ausschläge entweder dicht am Kopf oder unter Belassung längerer Stummel. sog. Hörner, weggenommen.

\section{Schneit elholzbetrieb.}

$\S 46$. Der hauptsächlich der Futterlaubgewinnung dienende Betriels erstreckt siclı auf die zeitweilige Wegnahme von Schaftreisem und Ausschlägen von Laubholzbäunen, deren Schaft unverkürzt geblieben oder erst in größerer Höle geköpft worden ist. Die stärkeren Seitenäste werden gestummelt und die an den verbliebenen $30 \mathrm{~cm}$ langen Aststummeln sich bildenden Ausschläge periodisch genützt. Wicderkehr der Nutzung wie beim liopflolzbetrieb.

\section{brittes liapitel.}

Künstliche Bestandesbegründung.

Vorbemerkungen. Arten der Begründung und Wahl zwischen $\mathrm{Sa}$ a $\mathrm{t}$ nd Pflanzung.

Unter dem Einfluß des Unstandes, daß die oben (S. 49) genannten Vorteile der Kahlschlagwirtschaft augenfälliger und deshalb wirksamer hervortreten als ihre meist erst in der Folgezeit und langsamer bemerkbar werdenden Nachteile, sind Kahlschlagbetrieb und mit ilım künstliche Bestandesbegründung mehr und mehr in den Vordergmind getreten. Der modernen Forstwirtschaft mit ihrem Streben nach sicheren und raschen Erfolgen ist die Naturverjüngung leider nicht mehr zuverlässig und nicht mehr schnell genug. Bei der Kunstverjüngung hat der von der Mannbarkeit der zu verjüngenden Bes‘ände und vom Eintritt der Samenjahre unabhängige Wirtschafter den Erfolg seiner Begründungsmaßnahmen relativ sicher in der Hand. Er kostet zwar Gield, dieser Erfolg, und zwar geneinhin um so mehr, je sicherer er sein soll, aber er ist unter sonst nomalen Verhältnissen auch da, schnell und leicht, und diese Vorzüge schlagen die Bedenken in die Flucht, die im Hinblick auf die Unsicherheit der Samenherkunft und auf die Fordermgen der Bodempflege in mehr oder minder erheblichen Maße entstehen müssen.

Die Kunstverjüngung erfolgt als $\mathrm{S}$ a a $\mathrm{t}$ durch $\mathrm{S}$ a $\mathrm{n}$ e $\mathrm{n}$ orler als $\mathrm{P}$ f l a $\mathrm{n} \mathrm{z}$ u $\mathrm{n} \mathrm{g}$ durch Auspflanzen $g$ a n z e r P f 1 a n z e n (Kernpflanzen) oder von P f l a n z e nte il en (Stecklinge, Absenker, Stummelpflanzen usf.).

\section{Wahl zwischen Saat und Pflanzung.}

$\$ 47$. Entscheidend ist, wie oben bei der Wahl zwischen natürhicher und künstlicher Bestandesbegründung, der Erfolg und sein Verhältnis zum liostenaufwand. Dasjenige Verjingungsverfahren ist das richtige, das unter den jeweilig vorliegenden waldbaulichen und wirtschaftlichen Verhältnissen den schnellsten und sichersten Erfolg mit den geringsten liosten verspricht. lı einzelnen sind bei der Walıl zwischen Saat und Pflanzung folgende Punkte zu beachten:

a) die Sicherlueit des Erfolges. Die Qualität des liultumateriales (Samen bei der Saat. Pflänzlinge bei der Pflanzung) kann lier nicht als Grund pro und contra verwertet werden, da die Verwendung nur guten Materiales als selbstverständlich vorausgesetzt werden muß. Immerhin bietet auch in dieser Hinsicht wie in vielen anderen Punkten die Pflanzung eine größere Garantie, denn sie gestattet bei hinreichendem

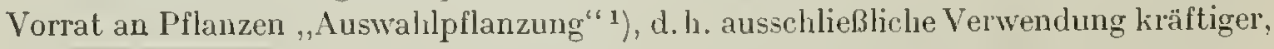

1) Der von M a y. (Waldbau auf nalurgesetzl. Crundlage, S. $\$ 10,426$ ) stammende Ausdruck ist hier nicht im sinne Nayrs gebraucht. M. Versleht unter ,.. Auswahlpflanzung" ein Verfahren, hei welchem die besten und kräliglen Pilanzin in einem V'erbande von $4-5$ in ausqe- 
geradschaftiger guter Pflanzen, deren zufriedenstellendes fugendwaclistum eine ebensolche Weiterentwicklung erwarten läßst. Die Saat gestattet eine derartige künstliche Zuchtwahl nicht, sondern bringt auch bei Verwendung hesten Saatgutes eine Menge minderwertiger Pflanzen auf die Fläche. Dieser Nachteil wird allerdings dadurch wieder ausgeglichen, daB unter der weit größeren Anzahl von Pflanzenindividuen, die bei der Saat auf die Fläche kommeu, auch schnellwüclsige und gutveraulagte Pflanzen in melı oder minder großer Menge vorlanden sind. Unter den Faktoren, welche den Kulturerfolg beeinflussen, ist zunächst die Witterung der erslen, auf die Ausführung der Kultur folgenden Wochen oder Honate, eventuell der ıächsten Jahre zu nennen. Schädlich wirken vor allem Witterungsextreme, wie andauernde Trockenheit, Hitze, zu große Kälte, Fröste usw. Weder Saaten, noch Pflanzkulturen sind vor Schädigungen durch die je nach der Bodenbeschaffenhejt und nach der Lage melır oder weniger gefährlichen Witterungsextreme sicher; sie leiden aber unter sonst gleichen Verhältnissen in versehiedenem Maße. Trockenheit z. B., ebenso wie Hitze, werden, obwohl alles auf die Zeit ihres Eintritts ankommt, Pflänzlingen mit tiefer gehenden Wurzeln oft weniger gefährlich als Kieimlingen. Gleiches gilt von Frösten, soweit es sich um das Ansfrieren handelt. Platzregen bringen an Hängen durch Abschwemmen einer Saat häufiger Schaden als einer Pflanzung. Starker Schneefall, längrres Ljegenbleiben des Schnees kann einer jungen Saat, die vollständig überdeckt wird, durcl Druck und Lichtentzug eher nachteilig werden als einer Pflanzung. Andererseits vermag eine dicliere Schneedecke aber den Frostschaden zu vermindern. Die total von Schmee umlagerten kleineren Sämlinge leiden meist wenjger als die über den Schnee mit ihren Gipfeltrieben herausragenden hölıeren Pflänzlinge, die namentlich in Spätwinter, wenn die Sonne schon wieder höher steigt und unter Tags stärkere Enwärmung er"zengt, leicht Spätfrostschaden aufweisen. Unter Schneeschaden und zwar Schneedruchschaden haben die aus Saaten hervorgegangenen Jungbestände auch dann meist mehr zu leiden als die Pflanzbestände, wenn sie sehr dicht gesclılossen aufwachsen, so daß die einzelne Pflanze nicht gehörig zu erstarken vermag. Wenn auch die meteorischen Einwirkungen sowohl nach Art wie nach dem Grade ihrer Schädlichkeit nicht anders als im Sinne eines auf örtlicher Erfahrung beruhenden Walırscheinlichkeitsschlusses in Rechnung gezogen werden könmen, so sind doch Saaten durch sie mehr gefälırdet als Pflanzungen. Gleiches gilt weiter bezüglich des Unkrautwuchıes. Es ist deshalb festzuhalten, daß auf nassen, trockenen, mageren Böden, auf allen zur V'erunkrautung neigenden Standorten, in Frost- und Schneelagen und anderen irgend einer Gefalnr ausgesetzten Oertlichlieiten die Pflanzung am Platze ist. Wo, wie auf sehr steinigen Orten, die Herstellıng der Pflanzlöcher Schwierigkeiten verursacht, ist die Saat vorzuzielıen. Letztere bewälırt sich der größeren Pflanzenzalıl wegen auch dort vielfach besser als die Pflanzung, wo tierische Schädlinge, namentlich Wild, Engerlinge und Pïisselkäfer als Kulturfeinde zu fürchiten sind. Es stelıt in solchen Fällen zu holfen, daß eine zur Bestandsbildung genügende Anzahl unbeschädigter Pflanzen auch dann übrig bleibt, wenn dem Tierfral3 nicht oder nicht geniigend entgegengetreten werden kann.

b) Jugendentwickil ng der e inzelne $\mathbf{n}$ Pflanze. IIolzarten, die sich in den ersten .Jugendjalıren langsam entwickeln oder wälırend dieser Zeit einer aufmerksameren Pflege bedürlen (Tanne, Sitkalichte, Douglasie, Esche, Ahorn, Ulme usw.) werden am besten gepflanzt, nachdem sie in Forstgärten bis zu der gewünschten Stärke herangrezogen worden sind. Die saat empfielılt sich hingegen für jene Holz- 
arten, deren Sämlinge starke Pfahlwurzeln entwickeln und deslıalb nur seliwer versetzt werden können (WalnuB, Iliekory, liastanie).

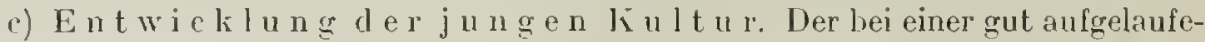
nen Saat von vornherein meist verhältnismäßig dichte Stand der Pflanzen bewirkt, wenn nicht Unkräuterwuchs, Tierbeschädigung (durch Wild, Mäuse etc.), Frost unrl dergl. dies verlundert, einen dichteren, meist aber erst später eintretenden Schluß der Kultur. Sehr dichter Stand hemmt die Entwicklung der Einzelpflanze und ist, sofern nicht durch Verdünnung rler Saat, durch Ausheben oder Ausschneiden für V'ereinzelung der Pflanzen gesorgt wird, ein erhebliches Hindernis für die Entwicklung der ganzen Kultur. Dichte Saaten stocken sehr bald im Wuchs, sie ,verbutten". wenn ihnen nicht rechtzeitig zu Hilfe gekommen wird, und diese Hilfe ist oft recht kostspielig. Anders die Pflanzung. Wurch die gleichmäßige Verteilung der Pflanzen und rlen ihnen zur Verfügung gestellten größeren Wachsraum wird den einzelnen Individuen eine weit raschere und normalere Entwieklung ermöglicht. Außerlem hat die Pflanzung je nach dem Alter der verwenteten Pflanzen einen größeren oder geringeren Altersvorsprung. Infolgedessen tritt der Schluß in den Pflanzbeständen meist weit früher ein als in den gleich alten Saaten mit gleichem Abstand der Saatreihen orler Saatplätze. In den Pflanzungen kommt als verzögerndes 1 loment jedoch die mit der líulturausführung verbundene Störung des nomalen Entwicklungsganges der Einzelpflanze zum Ausrlruek. Selbst bei sorgfältigster líulturausfühıung bedentet das Umsetzen einen gewaltsamen Eingriff in den Lebensprozeß der Pflanze. Die Notwendigkeit, anzuwachsen und neue WVurzeln an Stelle der beim Umsetren beschädigten und verlagerten zu bilden, versetzt die Pflanze oft in einen Zustand des Kämmerns, der um so anhaltender und intensiver ist, je schlechter die hulturausführung war und je älter die Pflanze zur Verwendung kam. Je jünger die in den Pflanzliulturen verwendeten Pflanzen sind, um so leichter wachsen sie an. Weuı sonst andere Gründe nicht die Verwendung ätterer und stärkerer Pflanzen fordern, sind Pflanzungen mit jüngeren [Pflanzen nicht nur billiger, sondern auch sicherer.

1) Wir ls e hafts z we k. In Gegenden, wo starke Nachfrage naclı seliwachen, hei den ersten Durchforstungen ausfallenden Sortimenten (Bohnen- und Zaunstängelchen, Baumpfälılen, Hopfenstangen u. dergl.) vorhanden ist, kann die Saat mehr am Jlatze sein als die Pflanzung. Die aus Saaten hervorgegangenen dicht geschlossenen .lungorte geben weit melw schwaches lurchforstungsmaterial her als die Pflanzbestände. Doch läBt sich auch in solchen durch Wahl eines engeren Verbandes elwaigen Bedürfnissen des Marlites nach Reisstangen u. dergl. gerecht werden. Meist liegt der Fall aluer so, daß für die in großer Menge ausfallenden und gewöhnlich nur mit größeren Unkosten zu gewinnenden schwachen Sortimente jede oder wenigstens jede nennenswerte Absatzmöglichlieit fehlt. Wer Wirtsehafter hat dann, z. B. in allen verkelursarmen Gegenden, weit mehr tnteresse daran, Saaten zu vermeiden, weil sie ihm nur unnölige Arbeit unr Kosten verursaclıen, ohne wesentliche Gegenleistungen zu bieten.

e) Lioste n a $\mathrm{f}$ wa $\mathrm{n}$ d. Beselıffung res hulturmateriales und liosten der Kulturausführung wirken zusammen. sowohl bei der ersten Anlage wie bei etwaigen Nachbesserungen. Es fragt sich zunärhıst, ol z.ır Saat guter Samen billig zu haben ist oder nicht, und analog für die Pflanzung, mit welchem Aufwand die erforderliche Zahl taughicher Pflanzen beschafft werden liann. Begreiflich liegen die Unstände von Fall zu Fall sehr verschieden. Gute Samenjahre hegünstigen die Saat, während hoher Samenpreis, sowie nicht genügende Samenvorräte zur Pflanzung drängen. Hat man in natürlichen Verjüngungen oder auf Saatflichen brauchbares Pflanzenmaterial 
lostenlos zur Verfügung, sn wirl man dieses benutzen. Müsson die nolwendigen Pflanzen aber erst besonders angezogen werlen, so sind die Art und Weise, wie es geschieht (Anzuclıt in Sclutzbeständen, in Forstgärten ouler Waulerkäimpen usf.), sowie die Entfernung der Erziehungsstätte von der Küturfläche zwei den Kostenfreis der Pflanzen wesentlich beeinflussende Faktoren. Der Kulturaufwand hängt weiterhin von der Schwierigkeit und Güte der liulturausführung ab. Es ist zu erwägen, ob und welche Bolenvorbereitungen nötig sind. Lurch sulrhe können insbesondere Saaten leicht nicht unbeträchtlich verteuert werden. Ehenso gibt es gewisse Pflanzverfahren, z. B. die Hügelpflanzung, die infolge umfänglirher Vorarbeiten kostspielig werden. Bei der Saat geht das Aussäen des Samens, besonders danu, wenn geeignete Maschinen Verwendung finden können, meist rasch und olne große Kusten von statten. Eine Kultur nit älteren und stärkeren Pflanzen pflegt sowolıl hinsichtlich der Beschaffung des Kulturmateriales als auch bezüglich der Kulturausfülırung in allgemeinen teurer zu sein als die Saat. Läßt sich hingegen junges, schwaches Pflanzenmaterial und ein einfaches, förderndes liulturverfahren anwenden, so kimn sehr wohl die Pflanzung die billigere Kulturmethode darstellen und ihrer meist hohen Erfolgssicherheit wegen ratsam sein. Oertliche Erfahrung gibt über den für Nachbesserungen, Kulturpllege (Bekämpfung des Unkrautes, Abhaltung schärllicher Tiere usf.) in Aussicht zu nehmenden Kostenaufwand Aufschluls. Schließlich ist bei Beurteilung der statischen Seite von Saat und Pflanzung der bereits oben erwälınte Altersrorsprung der Pflanzung mit in Rechnung zu stellen.

f) Z e it a u f w a n d. Da die für die Kulturausfülırung verfügbare Zeit hin und wieler, z. B. im Gebirge bein raschen Uebergang vom Winter in den Sommer, hnapp bemessen ist, so kann die Schnelligkeit des Kulturvollzuges für die Wahl des Verfahrens bedingend werden, zumal wenn Arbeitskräfte nur in heschränkter Zahl zu haben sind und große Flächen zur Kultivierung vorliegen. Etwaige Bodenvorbereitung kann in solchem Falle oft schon in Herbst vor der liulturzeit vorgenomnen werden, so daß dann in Frïlıjahr das liultu'geschäft sich weit rascher erledigen läßt. Die Saat ist in Hinblick auf den Zeitanfwand in allgemeinen die vorteilluaftere, d. h. schmeller arbeitende liulturmethode.

g) Die MaBregeln der Bestancleserzielung, insbesondere die Durchforstung, werden durch rlie Methode der Bestandeshegründung, wenn bei dieser nicht extreme Verhältuisse, z. B. sehr weiter V'erband orler sehr dichte Sat, vorliegen, meist nur in .Jugendalter der Bestände in beachtenswerten Maße beeinflußt. Die Unterschiede in der Bestandespflege von Saat- und Pflanzbeständen, die sich in öfterer Wiederkehr der Lurchıforstungen in den Saatbeständen und öfter's in Schwierigkeiten bei der Herstellung einer gleichmäBigen Bestandestichte in diesen bisweilen bis ins Stangenholzalter hinein bemerkbar nachen, verschwinden späterlin, vorausgesetzt, daß in den Saatbeständen rechtzeitig die notwendigen Eingriffe geschelıen sind.

11) Rü clisiclıt a uf gewisse Neben $\mathrm{n} u \mathrm{tz}$ u g e n. Grasnutzung, ev. auch Viehweide, ist in den Pflanzkulturen im allgemeinen leichter ausfülırbar als in den Saaten, namentlich in unregelmäßig bestandenen Saaten. Es bieten aher auch die Zwischenstreifen bei Reihensaaten eine ebenso gute Gelegenheit zur Entnahme des Grases, wemn man nur wartet, his die Sämlinge einigermaßen heraus sind. Auch in dicht stehenden Nadelholzvollsaaten läßt sich der Auftrieb von Schafen unter Umständen olıne besondere Schädigung der Kultur bewirken.

i) In gewissen beson de ren $\mathrm{F}$ ä 11 en des liulturbetriehes, z. B. bei Anlage von Alleen, Hecken, Uferbefestigungen, Weidenlıegern, kommt stets die Pflanzung als Kulturmethode zur Anwendung. 
Im Durchschnilt sämtlicher zu beachtender Faktoren ergibt sich beim Vergleich von Saat und Pflanzung ein unbedingtes Plus zugunsten der letzteren. Namentlich sind es die den Pflanzungen eigentümliche rasehere Jugendentwicklung und Erstarkung, der damit zusammenhängende schnellere Schluß der Kulturen und die sehr beachtliche größere Widerstandsfähiglieit der Pflanzungen gegen meteorische Gefahren, die der Pflanzung ein nicht wegzuleugnendes Uebergewieht über die Saat verschaffen. Es ist aber gewiß nicht richtig, die Saat deshalb prinzipiell zu verwerfen, wie es hin und wieder geschieht. Das vollständige Verdrängen der Saat durch die Pflanzung ist nur in den höheren Gebirgslagen, nicht aber in der Ebene berechtigt.

\section{Erster Teil.}

\section{Herstellung eines kulturfăhigen Waldbodens. Urbarmachung.}

Die natürliche Bestandesbegründung selzl in allen anderen Fällen, als denjenigen der Randbesanung, voraus, daß bereits WVald auf der Fläche vorlianden ist. Bei ihr kommt also die Frage, wie manche Bōden in einen kulturfähigen Zustand gebracht werden können, kaum in Belracht. Hier sollen jelzl cinige Fälle kurz berührt werden, in welehen vor den Holzanbau gewisse Ilindernisse einer erfolgreichen Fultur beseitigt werden müssell. Es handelt sich um die Aufforstung von Flächen, welche ohne spezielle Vorbereitung einen brauchbaren Waldbestand zu tragen unlähig sind. In Gegensatz lierzu mögen diejenigen Operationen der Bodenbearbeitung, welche den Waldboden nieht gleichsam erst schaffen, sondern auf die Steigerung eines bereits vorhandenen Bodenproduktionsvermôgens, bezw. auf besseres Anselulagen einer Masl, sicheres Gelingen ciner Kultur, kräftigere Entwiekelung der Besläna gerichtet sind, als unmittelbare Maßnahmen der Beslandesbegründung und -erziehung betrachlet und an der betreffenden Steell (als Vorarbeilen ete.) besprochen werden. Die hier in Betracht kommenden Fälle (,,Oedland" im weilesten Sinue) sind vornehmlich: Sümpfe, FJugsand, Raseneisenstein und Ortstein, Heide, Torfmoore. Grundlegende Erörterungen in bezug auf die in den Paragraphen 48 bis einschl. 53 besprochenen Arbeilen finden sich unter III. "Forstlichen StandurtsJehre" (Jandbuch, 1. Bd.), auf welche hier verwiesen werden muß ${ }^{1}$ ).

$\$$ 48. I. B e h a $u d I u n g$ von S ü $\left.m p f e n^{2}\right)$ : Die Frage bildet auch einen Gegenstand der Besprechung für den Forstschutz (vgl. Handbuch 2. Bd. VII.), weshalb lier nur emige Bemerliungen mehr allgeneiner Natur eine Stelle finden sollen. Jeder Ueberschuß an Wasser (für verschiedene Holzarten verschieden bemessen) ist im allgemeinen dem Holzwuchs nachteilig, ja macht diesen, wenn eine gewisse Grenze übersehritten ist, meist unmöglich. Sollen Orte mit WasserüberschuB kultiviert werden, so ist das Wasser vorher zu entfernen. Solche Orte finden sich in der Niederung, sowie in den ebenen Lagen und Becken der Gebirge. Im allgemeinen erleichtert das Höhenland den Abzug der atmosphärischen Niedersehläge durch seine vielfach geneigte Lage (Einfluß der Sclichtung, Wasseradern etc.). Alle Entwässerungsarbeiten sind nur auf Grund sorgfältigster Begutachtung aller ihrer Vor- und Nachteile einzuleiten. Erstere bestehen - abgesehen von dem indirekten Gewinn, weleher einer Gegend aus der Vermehrung ihres Waldbestandes erwachsen kann - in der Hauptsache in der Ernöglichung oder wenigstens steigerung der Holzproduktion, letztere in den aufgewendeten Kosten, sowie in der dureh Wasserentzug etwa herbeigeführten Schädigung umliegenden Geländes. Nicht dringend genug kann gelordert werden, die gegenseitige Ałwägung nieht auf das in Frage stehende Grundstück allein

1) Zu vergl. $\mathrm{R}$ a r a a $\mathrm{n}$. Forstliche Bodenkunde und Standortslehre. Berlin, 1893; dass. 3. Aufl. unter den Titel Bodenkunde. 1911.

2) Vgl. Í a is er , ,Beiträge zur Pflege der Bodenwirtsehaft mit besonderer Rücksicht auf die Wasserstandsfrage". Berlin, hei Springer, 1883. Insbes. S. 46 if - $\mathrm{B} \mathrm{u} \mathrm{l}^{\circ} \mathrm{ck}$ ll a $\mathrm{r} \mathrm{t}$,

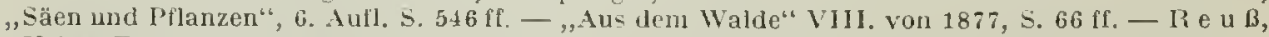
,Ueber Entwässerung von Gebirgswaldungen" Prag 1874. - I r a f t , "Zur Entwåsserungs-

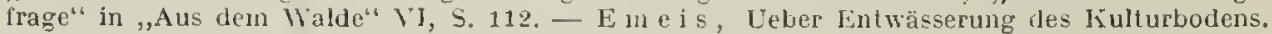
Allg. F.- U J.-Z. 1901, S. 46. 
zu beziehen, sondern den Einfluß der geplanten Wasserstandsverïnderung auf die L'ngebung mit zu berüclisichtigen ${ }^{1}$ ). Die Zuwachsverluste, welche hier eintreten können, ergeben in Verbindung mit dem durelı die Entwässerung geforderten Baraufwand sowie den Kosten der nachfolgenden liultur oft eine Aufwandssumme, welche geeignet ist, jeden noch so holen auf der Fläehe selbst zu erzielenden Holzwert zu paralysieren, bezw. geradezu in einen finanzwirtschaftlichen Verlust unzukeluren. Insbesondere lat eine solche weitere Unschau hinsichtlich der Sumpfstellen der Gehirge einzutrelen. Jedenfalls sollte, wenn irgend möglich, das an einer Stelle freigegebene Wasser dem Walde nicht gänzliclı entzogen werden und damit für den Holzwuchs verloren gehen, sondern zur Bewässerung trockener Partien verwendet werden, indem man es narh solchen hinleitet, in Löchern, GräLen, kleinen Sammelweilıern etc. slaut uud damit seitliches Einsickern in den Boden, sowie reichlichere V'erdunstung, also vermelırte Feuchtiglieit und hierdurch besseren l'flanzenwuchıs herbeifülıt. In manchen Fälleı ist man offenbar nit der Entwïsserung zu weit gegangen. Da und dort haben sich deren Nachteile so bald gezeigt, daß man die bezüglichen Arbeiten unterhrochen, Gräben wieder beseitigt hat usw. Die "Wald- und Wasserfrage" — von einer solchen wird mit Recht geradezu gesprochen - bildete namentlich in der neueren Zeit, wo auch die Anlage von Wasserleitungen für Gemeinwesen vielfach zur brennenden Tagesfrage geworden ist, häufig den Gegenstand eingehender Erörterungen bei Versammlungen und in der Literatur. In Hinsicht auf Entwässerungen wurde hierbei stets zu äußerster Vorsicht gemahnt und der Grundsatz vertreten, da $B$ das im IValde vorhandene Wasser dem Walde tunlichst erhalten bleiben solle, demgemäß das irgendwo in Uebermaß auftretende Wasser entsprechend zu verteilen, nicht aber zu entführen sei.

Erweist sich die Entfernung des Wassers auf Freiflächen, Kulturen usw. als rätlich, so sind zunächst die Ursachen des Wasserüberscliusses festzustellen. Stets rührt dieser von übermäßiger, die Verdunstung und den Abfluß übersteigender IVasserzufuhr her. Diese ist für die Folge hintanzuhalten: Dämme gegen Ueberschwemmung seitens fließender Gewässer; oberhalb der zu schützenden Fläche anzulegende Sammelgräben zun Auffangen und demnächstiger Ableitung von Wassernengen, die an Hängen zumal auf undurchlassender Schicht herabliommen. Oder es ist der AbfluB, bezw. die Verdunstung zu beschleunigen, damit das gewünschte Verhältnis hergestellt werde. Bilden undurchlassende, nicht zu mächtige Schichten (in ebener Lage oder in Einsenkungen) das Hindernis des Wasserabzugs, so kann sich unter Umständen schon das stellenweise Durchstoßen derselben als Ablilfe empfehlen. Anderenfalls müssen etwa vorhandene $W^{\prime}$ asserrinnen (Gräben, Bäche etc.) vermehrtes Gefäll erhalten, oder es sind Grabensysteme neu anzulegen. Hierbei finden offene Gräben im Walde mehr Anwendung als bedeckte (Drains liauptsächlich nur zur Entwässerung kleinerer Stellen in Forstgärten usw.). Ein genaues Nivellement ist oft erforderlich, bei größeren Objekten (Entwässerung ausgedehnterer Flächen) meist unentbehrlich. Sauggräben zum unmittelbaren Herausziehen des Wassers aus dem Boden, Verbindungsgräben, Abzugsgräben werden bei der Durchührung in geeigneter Weise zu einem Grabensystem verbunden.

In allen Fällen ist zu erwägen, ob vollständige Wegführung des Wassers (oft infolge dessen zu weit gesteigerte Trockenheit im Sommer!) an der betr. Oertlichkeit angezeigt ist, oder ob nicht vielmehr schon die Senkung des Wasserspiegels um einen gewissen Betrag die gewünschte Kútur ermöglicht. In letzterem Falle wird auf die

1) Vergl. Rettsta d t, „Ueber den Einfluß der Senkung von Seespiegreln auf benachbarte Forsten", in ,A As dem Walde" VII. von 1876, S. 219 ff. 
Verbindung der Gräben mit den natürlichen Wasserabzugsrinnen (Bäche, Flüsse) verzichtet; entsprechend tief eingesehnittene Stückgräben, Löcher usw. können genïgen, der Wasserstand in ihnen gestattet die Beurteilung des Erfolges.

\$ 49. II. F I u g s a n d 1): Der als Flugsand bezeichnete feinkörnige, bindemittelarme und deshalb vom Winde leicht fortbewegte Sand findet sich am Meere als Dünensand und in Binnenland als Binnensand. Seine Entstehung ist an lleere auf die fortgesetzte Zuführung neuer Sandınassen, im Binnenlande meist auf fehlerlafte wirtschaltliche Behandlung leichter Sandböden, Walılverwïstung, intensive Streu- und Weidenutzung und Liegenlassen der entwaldeteu und abgebrannten Flächen zurïckzufülıren. Man bezeichnet die zum Oedland gehörenden bimenländischen Sandgehiete vielfach als Sandschollen oder Sandschellen und erkennt in ihrer Ueberfülırung in Kulturborlen gleiehwie in der Bindung und Aufforstung des Dünensandes eine der wichtigsten Aufgaben der modernen Kulturtechnik. Toraussetzung für die forstliche Kultur des Flugsandes ist seine $\mathrm{B}$ in $\mathrm{d} u \| \mathrm{g}$, , l. l. seine Beruhigung mit Hilfe der sog. Deckwerke.

1. Bindung und Kultur von Binnensan ( $^{2}$ ). Als Vorarbeit empfiehlt sich neben Fernhaltung aller bodenlockernden llaßnahmen (Vicheintrieb, Befahren mit Fulurwerken) reine mechanische Einebnung der gröbsten Unebenheiten, bestehend in sanfter, glatter Abschrägung schroffer Ränder der ausgewehten Sandkehlen, Abtragung der Firste und Köpfe der Dünen, Abböschung steiler, zerklüfteter Seiten. In den Sandkehlen wirkt Aufstellen von Fangzïunen und Einfüllıng sperrigen Reisigs und Strauchwerks planierend. Die dann folgende D e ek un g, d. I. die Beschwerung des Landes mit Reisig, beasteten Kiefernstangen, Hackreisig (Häcksel), Heidekraut, Schilf, Besenpfrieme, Rohr, Binsen oder anderen sich örtlich darbietenden Unkiäutern, besser noch mit sehachbrettförmig, streifenweise oder quartierweise ausgelegten Plaggen von Rasen, Heide oder Beerkräutern beginnt auf der WVindseite und sorgt für Beruligung der dem Winde am meisten exponierten Rücken und Seiten der Sandhügel. Es ist selbstverständlich, daß von der Art und Dichte der Deckung der Erfolg wesentlich beeinflubt wird. Je leichter das Deckmaterial, um so notwendiger ist es, durch verankerte Querstangen, Bewerfen mit Sand usf. für Festliegen zu sorgen. Plaggen, die mit der Wurzelschicht nach unten gelegt, anzuwachsen vermögen, sind am sichersten, aber an teuersten. Die V'emvendung von aufrecht gestellten Flechtzäunen (Koupierzäunen), die netzförmig die zu bindende Fläehe durchziehen und zum Brechen des Windes und Aufhalten des bewegten Sandes dienen, is beim Dünenbau häufiger. Sie haben sich aber auch bei der Bindung von Binnensanden und zwar um so besser bewährt, je enger sie gestellt und je kleiner damn die von ihnen gebildeten Quartiere wurlen. Die A f forstung der Fhugsandbörten erfolgt gleichzeitig mit ilurer Festlegung oder bald hinterher und geschieht durch Pflanzung von Kieter, Berghiefer, Bankskiefer, Pechliefer. Hin und wieder sind auch Laubhölzer, namentlich Weiden und Pappeln, in Ungarn in großem Naßstabe und mit Erfolg die Robinie, verwendet worden. Die früher öfters angewendete Saat (Zapfensaat) hat sich beim Kiefernanbau weniger bewährt als die Pflanzung mit Ballenpflanzen oder kräftigen ?jährigen verschulten ballenlosen Pflanzen. Kann Düngung mit der Pflanzung rerbunden werden, so ist das im Interesse der Er-

1) Vergl. Wes s e ly, ,Der Europäische Flugsand und seine Kullur", 1873.

2) li e r n er, Die Aufforstung des Flugsandes im ungarischen Tiefland. Oesterr. Moniatsschrift f. Forstwesen 1865 , S. 3. - B u $\mathrm{r} \mathrm{ek} \mathrm{h}$ a $\mathbf{r}$ d i., Zur hitulur des Flugsandes. A. d. Walde, 8. Iff. 1877, S. 167. - If es c h w i t $z$, Die Flugsandbindung und der lliederanbau auf eines Nilitärpachtfläche des Dresdener Forsireviers. Thar. Jhrb. 1882, S. 138. 
lıöhung des meist mur selu geringen Nïlustoffgehaltes des Flugsandes nur erwïnscht. Besonders wertwoll ist die Zufühung von Stickstoff durch Lupinenanban oder durch Beigahe von Moorerde und anderen Humusstofen hei I Terstellung der I'flanzlörher.

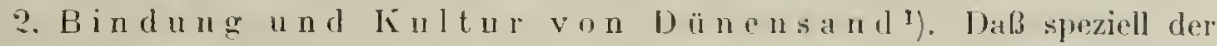
Bindung und event. Bewaldung der Dïne längs der Neeresküste im allgeneinen lïulturinteresse eine hervorragende Bedeutmog zulionmt, liegt auf rer Hand. Unfängliche Arbeiten haben in rlieser Richtung z, B. in Sürwestfrankreich, aber aurlt in den deutschen liüstengebieten (z. B. OstjreuBen: liurische Nelurung usw.) stattgefunden und werden mit großer Energie fortgesetzt. llie wirltigste vorbereitende Mrbeit bei der Aufforstung des Dünengeländes ist die $S$ c $h_{\text {a } ~} f$ f u n g e i n e r. Vord ü ne, die den Zweck lat, den von der See kommenden Sand auch längs der See festzulatten und die unausgesetzte Sandzufulu nach rem Festlande zu verhindern. Die Vordüne wird dadurch künstlich angelegt, daß man entlang der Kï̈ste nnd in entsprechender Entfernung rom Wasserspiegel ( $10-.5 \mathrm{~m}$ an der Ostsee, $7.5-100 \mathrm{~m}$ an der Nordsee) in rler Richtung der geplanten Düne zwei $0,6-0,7 \mathrm{~m}$ holıe lockre Strauchzäune in $2 \mathrm{~m}$. Thstand voneinander im Frühjahr fertigt. Sobald sie versandet sind, was innerhalb rler folgenden Wochen gesclieht, werden 2 neue Zäune auf der krone des entstandenen Sanddammes errichtet, die bis zum Herbst ebenfalls versanden. Der so gebildete $1,5 \mathrm{~m}$ hohe Sandwall wird in Herbst mit Sandgras (Amophila arenaria oder Elymus arenarius) bepflanzt und zwar auf der Seeseite netzweise, auf der Binnenseite nur in parallelen, 2 m voneinander entfernten seukrecht an der Dünenböschung herablaufenten Reilıen. Bei der Graspflanzung werden die auf der seeseitigen Böschung angewendeten 4 (pm großen Netze auch in Innern mit Grasbïscheln besetzt, sie werden ,ausgebüschelt" und zwar unı so dichter, je höher an der Dammlirone sie liegen. Da das Gras den vom Strande antreibenden Sand festhält, verbreitert und erhöht sich die Vordüne nach und nach. Je breiter ilne Basis im Verglcich zur Höhe wird und je flacher ihre Außenböschung ist, um so größer ist ilue Widerstandsfähigkeit. Die fertige, an der Ostsee $6 \mathrm{~m}$, an der Nordsee $8-10 \mathrm{~m}$ hohe Vordüne berlarf einer ständigen und sorgfältigen Unterlialtung. Pflege und Beaufsichtigung, danit den durch Wasser und Wind herbeigeführten Schäden sofort mit Graspflanzungen und Errichtung von Strauchzäunen entgegengetreten werden kann. Sobald die Vordüne den von rler See ausgeworfenen Sand vollständig zurückhält, kann mit der Festlegung und Aufforstung der landeinwärts gelegenen Dünenrïcken, der Binnendünen, begonnen werden. IIan folgt hierbei der Windrichtung, beginnt also hinter der Vordüne und rückt landeinwärts vor. Von dem früher geühten Verfahren, die Festlegung der Lünen durch Sandgraspflanzung zu besorgen und erst naclı 5 bis 6 .Jahren die Aufforstung folgen zu lassen. ist man jetzt abgekommen, weil die $\Lambda$ fuforstung in rliesem Falle in dem mittlerweile fest gewordenen Boden tiefgelıncle und kostspielige Lockerung notwendig maclıt. Die Festlegung der I ünen geschieht jetzt meist durch Bestrauchung, d. h. durrh netzförmiges Bestecken mit Nadelholzreisig oder abgestorbenem Rohr. Man wählt hichei jo narh der Gefährlichlieit dor festzulegenden Stellen eine engere oder größere llaschenweite und steckt an hesonders gefährdeten Oertlichkeiten noch die Diagonalen der viereckigen Felder aus. Das Besteck wird $50 \mathrm{~cm}$ lang genommen und inittels Siatens so in den Boden geklemmt, daß $3 / 5$ heransstehen. Im unmittelbaren Anschlub an rle im Herbst vorgenommene Bestrauchung werden in den Ma-

1) Gerhardt, Handbuch des deutschen Dünenbauts. Berlin 1900. - J e $\mathrm{n} \mathrm{t} \mathrm{s} \mathrm{c} \mathrm{d}$, Dünenbefestigung und Aufforstung im sůdwestlichen Frankreiclı. Forstw. Zentralbl. 1907, S. 10,77 . - Q u ér i te t, Boisement de rlunes et de bruyères en Danemark. Bull. de la Soc. centrale forestière de Bclgiqque $1909, \mathrm{~S} .157 .-\mathrm{B}$ o $\mathrm{k}$, Der bünenhau. Bericht ïb. d. Vers. des deutschen Forstvereins zu Danzig 1906, $S .70$. 
schen je nach ihrer Gröle mehr oder weniger Pflanzplätze für die im zeitigen Frühjahr folgende Bepflanzung fertig gemacht. Die Vorbereitung dieser Plätze geschieht am besten durch Mischung des Sandes mit Humus, humosen Lehm ocler Moorerde, also durch Düngung. Die Beigabe von Kainit und Superphosphaten seheint nach den vorliegenden Erfahrungen ebenfalls günstig zu wirken. Die Pflanzplätze dürfen, um den notwendigen schnellen Schlul der Kultur zu erreichen, nicht über $1 \mathrm{~m}$ von einander entfernt sein und werden so zeitig wie möglich im Frühjahr mit je 4-8 Pflanzen bester Beschaffenheit bejflanzt, damit hleine Horste entstehen. Als llolzart kommen hauptsächlich Kiefer und Bergkiefer, in beschränktem Maße Fichte und Weißfichte, in den feuchten und nassen Einsenkungen Schwarzerle und Birke in Betracht. AuBer diesen sind stellenweise Schwarzkiefer, Pech- und Bankskiefer, auch Rüster, Pappeln, Weiden und Weißerle angebaut worden. Am besten hat sich nach den in Dänemark und Ostpreußen gesammelten Erfahrungen die Bergkiefer und zwar P. montana var. uncinata bewälırt. Sie hält sich dicht geschlossen, schützt dementsprechend den Boden vor den schädigenden Einflüssen von Wind und Sonne gut und ihre dichten, derben Nadeln sind gegen die vom Winde angetriebenen Sandkörner und Eiskrystalle ebenso unempfindlich wie es die ganze Pflanze gegen Winterfrost, plötzliche Temperaturschwankungen und Sturm ist. Die gemeine Fỉefer ist den Einflüssen der See und Seewinde weniger gewachsen und stellt sich auf trockenem, armen Dünenboden leicht licht. Eine wesentliche Bodenbesserung ist von ihr hier nicht zu erwarten. Auf frischeren Stellen und in geschützteren Lagen aber ist sie brauchbar. Man pflanzt sie meist Ijährig, die Bergkiefer 2jährig. Fichte ist weder wind-noch seefest und paßt nirht für die Seenähe. Viel geeigneter scheint infolge größerer Widerstandsfähigkeit die Sitkafichte zu sein. Die amerikanische WeiBfichte (Picea alba), die man mehrfach zur Bildung von Windmänteln benutzte, ist ebenso empfindlich wie excelsa, macht aber geringere Ansprüche an die Bodengüte und Bodenfrische. Die Schwarzerle endlich hat sich, hinreichende Feuchtigkeit vorausgesetzt, ganz befriedigend selbst auf ziemlich ausgewaschenem Seesand entwickelt und ist gegen Wind und Sand ähnlich unempfindlich wie die Hakenkiefer. Die Kosten der Aufforstung einschl. Bestrauchung sind natürlich hoch und stellen sich für 1 ha auf $1000-1200$.llk. Bei Verwendung guter Pflanzen sind größere Naclibesserungen aber nicht nötig. Sie müssen aber, auch wenn es sich um kieine Fehlstellen handelt, so schnell wie möglich und sorgfältig ausgefülnt werden, danit der Boden bald gedeckt wird.

$\$ 50$. 1II. R a seneisenstein un d Ortstein $\left.{ }^{1}\right)$ : Die durch anorganische oder organische Absätze gebildeten Schichten beeinträchtigen den Pflanzenwuchs, indem sie das Eindringen der. Wurzeln sowie des Wassers in die Tiefe (Tersumpfung) und das Aufsteigen des Grundwassers aus der Tiefe hindern. Mangethafte Bodendurchlüftung wirkt ebenfalls schädlich. Bei der häufigsten hierher gehörigen Erscheinung, der Ortsteinbildung, komnt hinzu, daf die zum Entstehen des Ortsteins führende Anhäufung von Trockentorf eine totale Auslaugung und Verdichtung der oberen Bodenschicht zur Folge hat. Diese Verarmung und Verödung der Ortstein-

1) Ueber Wiesen und Entstehung von Ortstein, Vgl. Handbuch Bd. I, III. Standortslchre. - Vgl. überdies A l b e r t, Beilrag zur lienntnis der Ortsteinbildung. Zeitschr. f. F.- u. Jw. 1910, S. 327 . - A. M a y e $\mathrm{T}$, Ueber die Ursaclıen der Bildung von Oristein. Fühlings Landw. Zlg. 1910 , S. 315. - E m c js, Naldbauliche Forseliungen und Betrachtungen. Berlin 18i6. D ers. : Die Ursachen der Ortsteinbildung und ihr Einfluß auf dic Landeskullur in SchleswigHolstein. Allg. F.- U. J.-Z. 1908, S. 1. - O 11 o, Erfahrungen übel die Oedlandaufforstungen im Heidegebjet Nordwestdeulselılands. Bericht üb. d. 4. Vers. d. deutsch. Forstver. 1903, S. 83 ff. $\mathrm{Sch}$ i m m elp fen $\mathrm{ig}$, „Der Dampfpflug in Diensle der Forstwirtschaft" in der Zeitschr. für Forst- U. Jagdwesen V. Band (1873) S. 161 fif. - M ü I l e r, Die natürliehen Humusformen, 1887. - R a m a n n, Bildung und Kultur des Ortsteins. Keitschr. f. Forsl- u. J. 1886, S. 14. 
böden ist in gleichem Maße mitwirkend bej deren Minderwertigkeit wie ihre dureh dic Ortsteinbildung bedingte Flachgründigkeit. Sowohl Raseneisenstein wie Ortstein bilden sich, wo die Bedingungen dafür gegeben sind. fortwährend. Vittels strechenweisen Durchbrechens jener Schichten wird die Verbindung zwischen Obcrboden und Untergrund hergestellt. Beim Raseneisenstein erfolgt das Herausbrechen zumcist unter Anwendung von Spitzhaue und Rodliacke. Da Sh mächtige geschlossene Raseneisensteinbänke meist in feucliten Gebieten finden, wo eine Scnkung des Wasserspiegels der Kultur voraufgehen muß, und die Bearbeitung des Raseneisensteins teurer, die erzogenen Bestände aber oft minderwertig sind, bietet die walclbauliche Bchandlung solcher Flächen häufig lieinen grcifbaren Vorteil.

Auch beim Ortste in muB, wenn er nicht zu tief und mächtig liegt und wenn Abfülırung eines etwa vorhandenen Wasserüberschusses nicht notwendig ist, eine gründliche Zerstörung der verhärteten Schicht eintreten. Das kann nur durch Tiefumbruch geschehen. Welcher Werkzeuge man sich hierbei bedient, hängt von der Größe und Ebenheit der Fläche ab. Die früher vielfach angewendete Methode, mit Hilfe des Spatens den Ortstein zu durchbrechen und durch Umkehren der Schichtlage herauszuheben, ist für den Großbetrieb zu teuer, denn der ha liostet selbst bei nur streifenweisem Rigrolen $200-300$ N. Im Großbetriebe kommt nur die Pflugkultur in Betracht; sie gestattet, dic Ortsteinsclucht. so lange sich diese in erreichbarer Tiefe befinclet, zu durchbrechen und nach oben zu bringen. Eine Methode, die den Ortstein nicht an die Oberfläche bringt. hat keinen Wert. weil sich Ortstein nur bei vollem Luftzutritt zersetzt. Bei der Pflugkultur wendet man teils Gespann-, teils Dampfpflüge an. Letztere arbeiten olne wesentliche Erhöhung der Kosten besser. da sie einen bis $80 \mathrm{~cm}$ tiefen Umbruch fertig bringen, wälirend der von Pferden gezogene Pflug nicht tiefer als $50 \mathrm{~cm}$ arbeitet. Gewölanlich werden beim Pflügen mit Pferden 2 Pflüge verwendet. Die von einem Torpfluge oder Schälpfluge geöffnete Furche wird won dem nachfolgenden Untergrundpfluge tiefer durchgearbeitet und umgebrochen. Ob voller oder nur teilweiser Umbuch der Fläche angezeigt ist, hängt von den Verhältnissen ab. Der geringere liostenaufwand der streifenweisen Bearbeitung spricht scheinbar für allgemeinere Anwendung dieser Methode. Im großen ganzen aber ist der Kostenunterschied kein selı erheblicher, so daß namentliclı beim Dampfpflügen Vollumbruch der Fläche ratsam ist. Bei streifenweisem Pflügen müssen die gepflügten Streifen mindestens 2 bis $3 \mathrm{~m}$ breit genommen werden. Schmale Streifen haben den Nachteil, daß der Boden hier in verstärktem Iaße ausgelangt wird, weil sich die Sickervässer nach den durchbrochenen Stellen hinziehen. Aus demselben Grunde ist auch das löcherweise Durchbrechen der Ortsteinschicht nicht empfehlenswert. Löcherweise Bodenbearbeitung läßt sich aher gewöhnlich auf unebnen, hügeligen Ortsteinböden nicht umgehen, weil hier mit dem Pfluge nichts zu machen ist. In solchem Falle ist es emünscht, die Löcher wenigstens möglichst groß zu machen, da sie sonst, ebenso wie schmale Streifen, Gefalır laufen, bei dem verhältnismäßig raschen Nachwachsen des Ortsteins sich schneller wieder zu schließer, ehe die Pflanze mit ihren Wurzeln in den Untergrund gelangt ist. Die liosten des Pflügens stellen sich bei Verwendung von Gespannpflügen bei gleicher Leistung höher als bei Verwendung des Dampfpfluges, sind aber im ersteren Falle meist etwas geringer, weil weniger tief gepflügt wird. Sie schwanken bei Gespannpflügen und streifenweiser Bodenbearbeitung zwischen 60 und $110 \mathrm{Mk}$. und stellen sich bei Dampfpflugarbeit und Vollumbruch selbst unter schwierigen Verhältnissen im allgemeinen nicht höher als 100 bis 110 IIk. für 1 ha. Je größer die Flächen sind, die nut dem Dampfpfluge gepflügt werden, um so billiger wirrl die Albeit. Stark verheidete Ortsteinböden werden vor dem Dampfpflügen zweckmäßigerweise abgebrannt, 
$111 \mathrm{~m}$ die Arheit zu erleichtem und das Unterbringen der schwer zersetzbaren Heidepolster zu verhindern.

Liegt die Ortsteinschicht sehr tief oder unter einer Noorschicht, liandelt es sich in Bodeneinsenkungen um Abführung überschüssigen Wassers nnd um Beseitigung stauender Xässe. so läßt sich die notwemdige Entwässerung zwar hin und wieder mit der Pflugkultur verbinden, indem offen liegen bleibende Furchen so weit vertieft werden, daß sie als Abzugsgräben wirken, im allgemeinen aber wirl in den angefülırten Fällen R a b a t t je 1 u $\mathrm{g}$ notwendig werden, un den Boden in kulturfähigen Zustand zu bringen. Nan hebt gleichlaufende. hinreichend tiefe $(1-1.2 \mathrm{~m})$ und die Ortsteinschicht durchbrechende Gräben aus und hringt den Ortstein und die unter diesem liegende unverdorbene Bodenschicht auf die Beete oder Bänke, die, wenn die Rabattierung wirksam sein soll, möglichst nicht über 4 m breit genacht werden dürfen. Jebreiter siewerden, un so billiger stellt sich zwar die an und für sich sehr kostspielige Kulturmaßregel, um so melı läßt aber anch die Wirksankeit der Rabattierung nach. Bei richtiger Auslührung hat sich die Rabattenkultur meist als ein sehr vorteillaftes Verfalıren gezeigt, das sowoli in bezug auf Boderverbesserung durch Trockenlegung und hessere Durchlüftung, wie auch in bezug auf das Wachstum der auf den Beeten geschaffenen Kulturen voll befriedigte. Leider ist es, sobahd die Gräben in der wünschenswerten nahen Entfernung voneinander gezogen werden, so teuer, daß seine Anwendung im Großbetrieb nicht rentabel ist. Die Kosten der Rahattierung betragen für 1 ha $250-350 \mathrm{llk}$.

Ob sich überhaujt sowohl bei diesem Verfalıen wie bei der billigeren Pflugkultur der Aufwand für die Bodenmelioration in Holzertrage bezahlt macht, ist von Fall zu Fall Gegenstand besonderer Rechnung. Vielenorts scheint der Holzwuchs die Ausgabe zu lohnen I).

In engstem Zusammenhange mit der Urbamachung der Ortsteinböden steht die der.

\$ 51. IV. He i l e bö (l e $n^{2}{ }^{2}$. In vielen Fällen, aber keineswegs immer, sind die vorgenannten Ortsteinböden mit Heideböden identisch. Die Ortsteinbildung ist, wie grobe ansgedelunte, völlig ortsteinfreie Heideflärıen heweisen, lieine Vorbedingung der Verheidung, wohl aber finden sich Ortsteinbildung und Verheidung oft zusammen und sind auf die schon oben genannten Ursachen (Waldverwüstung, rücksichtslose Streunutzung, Trockentorfhildhng und damit zusammenhängend Auslaugung, Austrockiung und Verdichtung der oberen Bodenschicht, Vermoorung, Senkung des Grundwasserspiegels) zurüclizufülıren. In Deutschland finden sich große durch Zurücktreten des Baumwrelıses und durch mehr oder weniger üppiges Auftreten der Heidepflanzen, namentlich von Calluna vulgaris und Erica tetralix, ausgezeiclnete Heidegebiete in Nordwesten (Lïnelırger Heide, Ostfriesland, Schleswig-Hlolstein, Westfalen, Mecklenburg), an der Ostserküste (Mecklenburg, Pommern, Westpreu-

1) Kr a f t, Ueber Ortsleinkulturen, Zeitsehr. f. Forst- u. J. 1891, 709. - Oristeinautforstung mit kiefer in ller preuB. Olıerförslyrei Nienburg (V'ers. des Vereins deutscher furstl. Versuchsanstalten, 1894, cfr. Allg. Forst- u. J.- \%. 1895, 26).

2) Gra : b n e r, Die Heide Norddeutschlants und die sich anschliebenden Formationen in biologiseher Betrachlung, 1901. 2. Aufl. w. d. Tit.: Hanlbuch der Heidekultur, 1904. -- E r d$\mathrm{m}$ a $\mathrm{n}$. Die Heideaufforstung und die weitere Behandlung der aus ihr hervorkegangen stänte. Berlin 1904. - Ders., Die nordwestdeut-che Heide in forstlicher Beziehung. Berlin 1907. - Em e is, Waldbauliche Forschungen, Berlin 1876. - B o rggrere, Heidr und Wald. Berlin 1875. - Eericht üh. d. 11. Vers. des deutschen Jorstvereins zul kiel 1903, $5.83 \mathrm{ff}$.

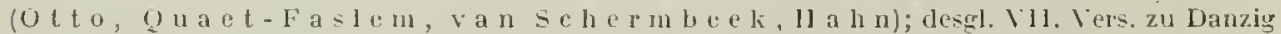
1906 ( 1.5 y d u w: Forstliche Behandlung der Gedländerein in Westpreußen, s. 49). - ll e tz-

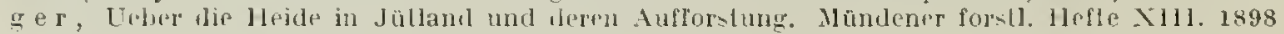
und selor zalileciche andere Arlikel ter formll. Zeilschriflin. 
Ben), in Brandenburg (Prignitz) und in der Lancitz. An das nordwestentsche Heilegebiet schließen die jütländischen und niederläıdischen Heiden an.

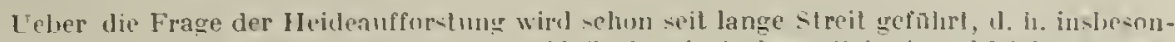
dere auch darnber, ob un-cre aumedehnten lleideflachen in früherer \%eil winmi wald getuagen

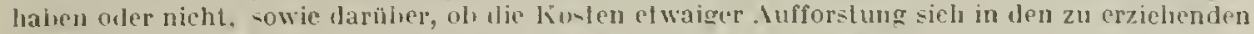

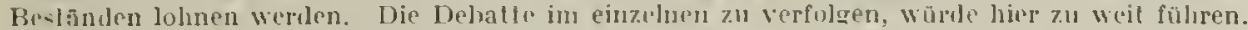

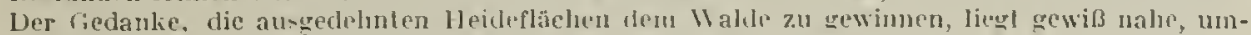
somehr, als es siclı zum großen Trile min ein Wielergewinnen landelt.

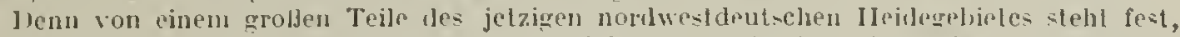
cla $B$ sich früler, und zwar vor nicht lanter Zeit, Wald dort vorfand, wo jotzl die Ileide herrseht.

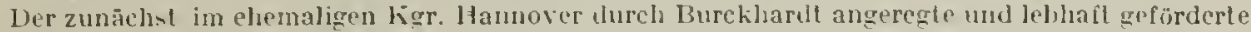
Aufforstungsgedanke hegegnete auf vielen Seiten Belenken linsichllich der Rentalilitil. Man wies von gegnerischer seite darauf hin, daß die Heideflichen auch olne Wald keineswegs ganz. "rtraglos seien, sondern durch Schafwrisl", Plaggenhiel, uncl Streunutzung Ertrigge brèchten, und daß der finanzielle Effekt der Infforsung mindestens zweifelhaft sei. Erfreulicherweise halen sich staatliche und kommunale liörperschaflen dadurch nicht ablialten lassen, sich der Aufforstung von Heidebōen mit aller Encrgie zuzuwenden. Es sind schon sehr bedeutende Siltel für Aufforstungszwecke veraurgabt Worden. In schleswig, Hannover und Däncmark bildeten sich besondere Heidekulturvereine und nahmen sich der Aufforstungsfrage auf das Tatliäftigste an. In Hannover liaben sich neben Forstdireklor B u r k li a rd t namentlich der Leiter der Provinzialforstverwaltune, Landesforstrat Q u a $t-F$ as l e in, in Schleswig der Vorstand des Heidekulturvereins, Forstlirehtor En e is, große Verilien-te un die IIeideauffor-lung erworben. In Hannower sind bis 1903 unter Quaet-Faslems. Nitwirkung 20000 lı, in Schleswig-Holstein spit 1876 bis 1903 17000 ha Heideödland aufgeforstel worden. Die 1867 gegrūndele dänische Heidegesellschaft hat bis 190555000 lı, ,Plantagen ${ }^{*}$, d. H. Aufforstungswälder angelegt.

Die Aufforstungstechnik auf Heideböden lıat ihre Maßnahmen so zu treffen. daß die den Heideböden anhaftenden waldbaulichen Jlängel nöglichst verschwinden. Worin diese waldbaukichen Mängel bestehen, darüber herrscht keine volle Ueborinstimmung. Wälurend $\mathrm{Gr}$ a e bner den Gund für dje kümmerliche Entwicklung der $\mathrm{IV}$ aldvegetation in der Hauptsache in einer weitgehenden Nährstoffarmut erbliclit und dementsprechend Düngung für umumgänglich ansieht, steht E I d $m$ a n $\mathrm{n}$ auf dem Standpunkt, daß die wirtschaftliche Hilfe ihr Hauptaugenmerk auf die Besserung der physilialischen Eigenschaften richten muB. Die Wierlergesunrlung der erkrankten und zum Teil hochgradig erkrankten Heideböden hat nach Erdm a n n zur Voraussetzung, daß dem Boden durch geeignete Vorbereitung und durch Auswahl der richtigen Holzarten und der richtigen Bestandszusammensetzung die ihm fehlende Duchlüftbarkeit wiedergegeben und erhalten wird. Alle Heideböden neigen ihrer Kalkarmut wegen zur Rohhumusbildung und steigern diese Neigung mit zunelmender Luftfeuchtigkeit und Niederschlagsmenge. Jie auf eine dauernde Velioration gerichteten forstwirtschaftichen Vaßnalumen haben deshalb ihre Aufgahe nicht nur in der Beseitigung und Zerstörung der zur Zeit der Auffortung vorlıandenen Rohhumusschichten zu erblicken, sondern wesentich auch in der Beschaffung einer Waldbestockung, die del" ferneren Rohhumusbildung nicht Vorschub leistet.

Nach der wechehnden Beschaffenheit der Heideböden bedingt ihre L'rbarmachung trils eine bloße Bodenvorbereitung, teils eine neben dieser notwendig werdende, nehr uder weniger weitgehende Melioration. Vom den bereits unter III. betrachteten Ortsteinböden abgeschen, bei denen 'Tiefumbruch. Entwässerung vder Rabattierung Vorbedingungen einer erfolgreichen Kultur sind, verlangen die Heideböden Zerstölung der Bodendecke. Bodenluckerung und in nicht seltenen Fällen künst-

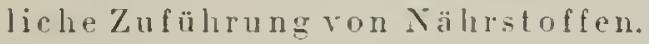

Bei der Z e r s tö ung de r Bod e u d e c k e handelt es sich eisunal um Vernichtung des lebenden Heidekrautes lurch Absicheln nder Abbrenuen - Linterpflïgen empfiehlt sich nicht - soflann um Beseitigung der den Boden abschließenden und das Gedeilien der jungen Holzpflanzen schwer beeinträrhtigenden Heidelımus- 
schicht. Das hierbei empfehlenswerteste Verfahren, den Heidehumus durch Mischung mit dem Mineralboden nicht nur unschädlich, sondern durch Ausnutzung seiner Nähıstoffe noch dienstbar zu machen, hat nur bei schwachen Humusdecken praktische Bedeutung. Das Unterbringen und Vermischen stärkerer Heidehumusmassen mit Spaten oder Pflug aber führt infolge der außerordentlich langsamen Zersetzung dieser Massen zu weitgehenden Schädigungen des älter werdenden Bestandes. Eher empfiehlt sich, jedoch wiederum zunächst nur bei schwachen Heidehumusdecken, dic Zerreißung der Schichten und ihre Vermengung mit dem Boden mit Hilfe des Waldgrubbers, der dänischen Rollegge oder eines anderen der neuzeitlichen Wühlwerkzeuge. 'Stärkere Schichten bedürfen, wenn sie auf diesem Wege zermürbt werden sollen, einer innerhalb mehrerer aufeinander folgender Jahre mehrfach wiederholten Durcharbeitung. Diese wirkt um so besser, wenn gleichzeitig durch Kalkzufuhr für Entsäuerung und raschere Zersetzung des Rohhumus gesorgt wird. Wo man beim Vorliegen mächtiger Heidehumusschichten keine Zeit hat, die letztgenannte gute, aber zeitraubende und teure Methode zur Anwendung zu bringen, tut man gut, auf mechanisclıe Beseitigung der Heidehumusschicht zuzukommen.

Die $\mathrm{B}$ ode $\mathrm{nlockerung}$ ist in allgemeinen in ihrer Wirkung un so nachhaltiger und besser, je gründlicher, $d$. h. je tiefer sie hesorgt wird und je mehr eine Umlagerung und Nengung der oberen und tiefer gelegenen Bodenschichten mit ihr verbunden ist. Löcher- oder platzweise Bodenbearbeitung mit Spaten oder IVühlspaten ist nur auf ortfreien Boden und dort angebracht, wo kein Pflug lin kann. Wo Pflugarbeit möglich ist, ist die dadurch bewirkte Lockerung, und zwar die Tieflockerung, die beste Kulturvorbereitung für Heideböden. Nur auf den feinkörnigen Böden verpuft ihre Wirkung sehr rasch, weil sich diese Böden bereits nach kurzer Zeit wieder vollkommen verdichten. Wit welcher Art von Pflügen die Ticflockerung vorgenommen wird, ob mit Wald-, Schwing- oder Dampfpflug, ist Sache örtlicher Gewohnheit und Gegenstand finanzieller Erwägungen. Der Billigkeit wegen wird man dort, wo verhärtete Schichten nicht zu durchbrechen sind, von der Vollbearbeitung der Fläche meist absehen und auf streifenweise Bearbeitung zukommen.

Die künstliche Zuführung von Nährstoffendurch Dü $\mathrm{ngung}$ mit Mineraldüngern, Kalk oder durch Gründüngung würde, wenn sie nicht Geld kostete, unter allen Umständen zu empfehlen sein. Der mit ihr verbundene Aufwand aber macht eine Beschränkung auf die wirklich nährstoffarmen Heidesande notwendig. Die vorliegenden Erfahrungen sind, von Kalkdüngung abgesehen, noch zu spärlich, als daB über Form, Menge und Art der Dünger brauchbare Fingerzeige bereits vorhanden wären. Sicher aber ist die sowoht in chemischer, wie namentlich auch in physikalischer und physiologischer Hinsicht wirksame lialkzufulır angesichts der notorischen Kalkarmut der Heideböden und angesichts des Vorhandenseins starker Rohhumusschichten auf vielen derselben durchaus vorteilhaft. Auch der Vor- bezw. Zwischenbau der Lupine scheint nach den bisher gesammelten Erfahrungen eine erfolgreiche Kulturvorbereitung zu sein, erfordert aber, da der Boden entweder einen höheren Nährstoffvorrat besitzen oder durch Zufühıung von Mineraldünger erhalten muß, in der Regel einen nicht unbeträchtlichen Kostenaufwand.

Die $\mathrm{Holza}$ a ten frage ist bei der Aufforstung der Heideböden meist in der Weise gelöst worden, daß Fichte oder K̈iefer oder beide in Mischung angebaut wurden, während andere IIolzarten, WVeißfichte, Bergkiefer mehr nur zur Bildung von Wind- und Schutzmänteln Verwendung fanrlen. Inwieweit von den beiden Hauptholzarten die eine oder die andere den Vorzug verdient, darüber entscheiden diє klimatischen Verhältnisse des in Frage kommenden Heidegebietes. Während in Sec- 
klima Schleswig-Holsteins die lïefer im Alter von 20 bis 30 Jahren abstirbt, ist sic auf den Aufforstungsflächen Hannovers die führende IIolzart. Die Meinumgen darüber, ob Reinanbau von Fichte und Kicfer bessere Erfolge erziclt als die in dem eben genannten Heidegebiete lange Zeit bevorzugte reihen- oder streifenweise Mischung beider Holzarten, sind getcilte. Der Umstand, daf recine Fichtenbestänrle auf zweifelhaften Böden zur Rohhumusbildung ncigen und die in reinen Kiefernbeständen später eintretende Verheidung Heidelımus zur Folge lıt, spricht jedenfalls zugunsten der Mischung, solange nicht dem von E rdma n n u. a. in den Vordergrund gestellten Verlangen nach Beimischung von Laublıölzern in das Nadelholz nachgegangen werden kann. Zweifellos verdient der Hinweis auf den Wert der Beimischung von Eiche, Buche, Birke oder Erle um so melır Beachtung, als nur Mischbestände die Gewähr dafür bieten, daß die angestrebte danemde Melioration der kranken Heideböden durch die Bestockung selbst besorgt wird. Für die Verhältnisse SchleswigHolsteins spricht O t o (Bericht der deutsch. Forstver. I903, S. I03) den Laubhölzern bei der Aufforstung der Heidcböden zwar jede Bedeutung ab, doch dürften auch hier, wic das Vorkommen von Eichenstockausschlägen und die günstige Entwicklung der Fichte in deren Nähe beweisen, der Heranbildung des naturgemäBeren Mischwaldes im derzeitigen Bodenzustand nur vorübergehende, nicht dauernde Ilindernisse entgegenstehen. Inwieweit für die Aufforstung der Heideböden neben den genannten noch andere Holzarten, namentlich in Nordwestdeutschland Roljinie, Tanne, Lärche, Weymouthskiefer, vielleicht auch Banks- und Pechkiefer in Betracht kommen, bedarf noch näherer Untersuchung. Jedenfalls ist an die günstigen Erfahrungen zu erinnern, die Dänemark bei der Aufforstung von Heideböden mit der Mischung von Fichte und Bergkicfer ${ }^{1}$ ), Belgien mit der Mischung von Kiefer und Pechkiefer ${ }^{2}$ ) gemacht hat.

\$52. V. Unf ruchtbarer $\mathrm{H} u \mathrm{mus}$. Außer den vorstehend unter IV. näher erwälınten, aus Rückständen des Heidekrautes bestehenden Heidehumus bilden sich, wie schon oben (S. 16) ausgeführt wurde, auch aus anderen nicht genügend zersetzten bezw. zersetzbaren Pflanzenresten mehr oder minder mächtige Humusschichten, die, rasch austrocknend und die Feuchtigkeit schlecht annehmend, den Boden verschließen und der Entwicklung der Holzpflanzen hinderlich sind. Hierher gehören die namentlich auf trocknen Böden aus Rückständen von Flechten, namentlich der Renntierflechte (Cenomyce rangiferina) entstehende $\mathrm{S} t$ a $\mathbf{u}$ b e r d e, der wie der Heidehmmus durch hohen Wachs- und Gerbsäuregehalt gekennzeichnete H e i d e lb e e r h u m us und der aus Blättern. Nadeln und Zweigen unserer Holzgewächse gebildete, aus zusammenhängenrlen, meist dicht gelagerten und schneidbaren humosen Massen bestehende Trock e n $\mathrm{t}_{\text {o }} \mathrm{r}^{\mathrm{3}}{ }^{3}$ ). Seine Bedeutung für Boden und Bestand wurde bereits oben gewürdigt (vgl. auch die Ausführungen im Abschn. ,Forstl. Standortslelıre" Bd. I des Handbuches). Bei der Frage der Beseitigung der

1) Vgl. P. E. M a 11 e r, Ueb. d. Verhältnis der Bergkiefer zur Fichte in den jülländischen Heidekulturen. Naturw. Ztschr. f. L.- u. Forstwirtsch. 1903, S. 289, 378.

2) A. S c h w a p a c h, Ztschr. f. Forst- u. Jw. 1901, S. 223, 1907, 148.

3) Va ter, Auf dem Trocknen gebildeter Rohhumus und seine Bekämpfung. Bericht d. sächs. Forstver. 1903, S, 138. - II a $t$ the s und $V$ a $t$ er, Welche neueren Forschungen und Beobachtungen liegen üb. d. Bedeutung des Humus f. d. Wald vor? Bericht üb. d. 5. Vers. d. deutsch. Forstver. 1904, S. 33. - v. Oerizen, Humus und Kulturen auf Humus. Ztschr. f. F.- U. Jw. 1904, S. 32. - Mö $11 \mathrm{er}$, Die Nutzbarmachung des Rohliumus (Trockentorf) bei Kiefernkulturen, ebendas. 1908 , s. 273. - D e rs., Ueb. d. Ergebnisse der von dem IIerrn IIinister angeordneten praktischen Versuche zur Nutzbarmachung des Rohhumus bei Kiefernkulturen. Bericht d. Märkischen Forstver. Wintervers. 1908. - Q u a e t-F a $\mathrm{I}$ e m und $\checkmark$. B en the im, Die Rohhumusbildung und deren Bekämpfung. Bericht üb. d. 19. Vers. d. Nordmestd. Forstvereins.

Ilundb. d. Forstwiss. 3. Aufl. II. 
schädlichen Wirkungen des Trockentorfes ist vielfach der mechanischen Entfernung und Abgabe stärkerer Schichten das Wort geredet worden. Je gründlicher dicse Entfernung vorgenommen wird, um so mehr geht den Pflanzen die erforderliche Stickstoffzufuhr verloren. An der Hand der günstigen Erfahrungen der dänischen Rohhumusbekämpfung und zahlreicher Versuche hat sich deshalb die Ansicht Bahn gebrochen, daß es nur bei starken Trockentorfschichten angezeigt ist, einen Teil durch direkte Entfernung zu beseitigen, daß es im übrigen aber richtiger ist, auf die teilweis hervorragende Düngerwirkung des Trockentorfes nicht zu verzichten. $\mathrm{Zu}$ diesen Zwecke empfiehlt sich Mischung nit dem Mineralhorlen. Nittels Spatens, Haclie, Spitzenbergs Wülıpaten, Waldgrubber usw. ist ler Trockentorf seiner chemischen und physikalischen Einwirkung wegen unterzubringen. Namentlich ist seine Nutzbamarhung auf ren ärmeren Börten ratsam. Nach den Erfahrungen v. $\mathrm{O}$ e $\mathbf{r}$ t z e n s und Y ö llers lat sich auch das Ueberdecken des nach dem Abschälen der Bodendecke zutage liegenrłen Troelientorfes mit einer einige $\mathrm{em}$ hohen Sandschicht als ein empfehlenswertes Vittel zur Ausnützung seiner Düngerwirkung gezeigt. Weiterhin jst, wie beim Heirlehumus, die Zufulır lïnstlicher Dünger, namentlich von lialk und Thomasmeh], eine die ['mwandlung der schädlichen Humusmassen rasch und in günstigster Weise fördemrle Naßnahme.

\$5. VI. Mo $0 \mathrm{re}^{\mathrm{I}}$ ): Erstes Erfordernis ist eine genaue Bodenuntersuchung (cfr. Forstl. Standortshehre, 1. Bd.), einschließlich der chemischen Untersuchung der Noorsubstanz. Grünlandsnoole kommen für die Walrlkultur wenig in Betracht, wenigstens nicht, soweit sie bei geeigneter Belıandlung gute WViesen ergeben. Da und dort kann sirlı auf ilınen, nach der Entwässerung und Bedeckung mit sand, Bepflanzung mit Erle empfehlen. Viel ungünstiger gestalten sich die Verhältnisse auf Hochmouren. Diese haben im allgemeinen keine Neigung, sich zu bewalden, ein L'mstand, der uns mahnt, daselbst mit forstlichen Unternehmungen vorsichtig zu sein. Befriedigende Fientabilität des Holzanbaues wird sich meist nicht rrgeben, es sei denn, daß die Mächtigkeit des Torflagers keine zu bedeutende ist, sorlaß man hald zu dem mineralischen Grunde gelangen kann. In diesem Falle läBt sich durch Rabattierung der für den Holzanbau erforlerliche Kulturboden schaffen, iudem man Gräben his zum mineralischen Boden aushebt und letzteren auf rlie zwischenliegenden Beete bringt. Entwässerung (bezw. Senken des Wassers), am besten dureh offene Gräben (diese mit steilen Wänden), ist unter allen Lmständen erforderlich (langsames, allmähliches Vertiefen der Gräben). Das Moor setzt sich unter Umständen bis zı $2_{3}$ seiner früheren Mächtigkeit nierler. Bildung einer Grasnarhe rleutet auf genügenlen Rückgang des Wassers. - L'rbamachung event. durch Termittelung des $\mathrm{B}$ r a $\mathrm{n}$ il $\mathrm{fr}$ uch $\mathrm{h}$ b a $u$ es.

Nach der Schilderung von B r ü $\mathrm{n}$ ing ist die Sache in großen Augustendorfer Moor folgendermaßin villaufen: Vermessung des Moores, Enlwässerung dureh Gräben als Vorbercilung. Das Feur' soll demnächst durch Zerstören des festen Fasercewebes cine zerbröekelte, erdartige llasse und damit pin erstes Keimbett bilden und durch die Hlize die Sāuren neutralisieren. Bildung von Acche ist nicht die Jauplsache. Han brennt auf flem lloore (nicht nach

1) Burckhardt, .,säen und Pflanzen", 6. Aufl. S. 55 ff. - De r s., ,Wald, Moor

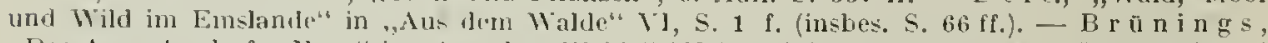
,Das Auguslendorfer Hoor" in ,Aus dem Walde" IX (1879) 5.106 . - D e $r$ s., ,Der forstl. und der landwirtsch. Anbau der Hoclunoore nittelst Brandfuchtbanes". Berlin bej "Springer 1881. - Zu leachten inslies, auch die verschiedenen Rezensionen der letztgenamiten Schrift, z. B. forsll. Blätter von 1882, S. 51. - Nordwestdeutseluer Forstverein 1891, efr. Zeitselır. l', liorst- 11. J. 1891, S. 631. - Honre des Erzgehirgs (Forstass. Dr. Mänuel in Forsll. nat. Zeit-chr. 1896, 325, 373). Moorkulturen in Dänemark (z. B. Oenterr. Forstzeilung 1893, Nr. 17). - Verhandlungen des sehles. Forstwereins 1894. - 13 a u un a $n$, Die Moore und Hoorkuluren in Bayern (Forsll. nat, Zeitschr. 1894, S. 89, 293). 
dessen vorherigen Limbrucli), indem nur die seine Oberflache bilatende Menge lileiner Ilügol (,Bülten"b) ungerissen, nebst dem Grabenauswurf ausgebreitel und angeznndel werden, wolled das Feuer nur oberflelilicl angreift. Dann folgt Ausiaat von Bucliweizen. In nåchsten Jalire wiederholtes Brennen, desgl. im dritten und vierten Jahre, slets in Verbindung mil Fruchtbau. Die Büten sind nun verzehrl und erst in fünften und seehsten Jahre kratzl man behufs erneuten Brennens Teile des eigentlichen Bodens flach auf. Wurzelgefaser, Heidelumus ele. sind nach den sechs Jahren verschwunden. Durch die sechsjälnige Vegetation ist neues Leben in den taten Boden gedrungen. Gebrant wird stet $\mathrm{m}$ i $\mathrm{l}$ dem Winde, sonst greift das lieuer zu tief; an feuergefährichen stellen erfolgt gegen ten Wind ein Vorbrand. In 7 . Jahr erfolgt der forslliche Anbau mit Eiche, Fichle, liefer, event. Lärche und Weymouthakiefer. Gesamtkusten jro ha (Brenuzeit 6 Jahre, Tagelohm 2 Mark) = 360 .Mark; Ertrag (5 Jahre Buehweizen, 1 Jahr Roggen) pro ha $=900$.llark. Die Anfforstung kostel pro ha 65 - 0 . Mark.

viele Moorkulturen, die in der angedenteten Weise ausgeführt worden sind und anfänglich, oft durch 10-15 Jahre, gutes Wachstum zeigten, haben aber nur große Hoffnungen erweckt und haben in ihrer Entwickelung bald nachgelassen, so daß der Erfolg nur ein scheinbarer war und ein Ersatz der aufgewendeten Kiosten nicht entfernt slattfand. Von irgend umfangreichen Mooraufforstungen wird deslalb abzuselien sein, es sei denn, daß es sich un bereits abgetorfle Hochmoore handelt, wie solche 2. B. in Nordwesldeutschland nil Holz angebaut worlen sind und gute Bestände von Eichen, Fichten, Kiefern und Birken tragen. - Nach Prof. Dr. Tacke, Vorsteher der Moor-Versuchsstation in Bremen (Zeitschr. f. Forst- und Jagdw. 1900 , S. 38) kommt, zumal in Niederungsmooren, auch für forstliehe Zwecke unter Unstānden die Rimpau'sche Sanddeckkultur nach vorheriger Enlwàsserung in Frage. Im allgemeinen aber ist auch auf den im Walde belegenen Mooren, wenn sie überhaupt benulzt werden sollen, landwirtschaftliche Benutzung vorzuzichen.

„Flä chlige Moorflächen (Mullwelıen) ${ }^{1}$ ) sind Moorflăchen, dic durch eine überlriebene Benutzung oder fehlerhafle Behandlung ihre nalürliche vegelabilische Bodendecke verloren haben, so daß der rohe Moolboden zutage trilt, der dann bei trockener Witterung staubig und flüchtig, bei nawer Willerung sclulamnig und treibend wird". Unterschied von sandwehen darin, daß sie auch hei feuchtem wetter beweglich sind. Enlstehung besonders durch zu ausgedehntes Heide- und Plaggenhauen oder zu langes Brennen, beides in Verhindung mit läglichem Auftrieb von schafen in geschlossener Herde und demnächst Auffrieren des Bodens. Gefahr für ungebendes Gelände durch Leberwehen mit Mull. - Vorbedingung der Dânfung isl das Aufhōren jeder Renutzung des Boclens. Enlwāsserung. Aufforsten der Mullwehen mil wenig mächtiger (bis $1 \mathrm{~m}$ ) Moorunterlagre und zwar zunächst meist durch . Inpflanzung mit Birke hinter senkrecht zur lierschenden Windrichtung verlaufenden Wällen, zu welchen das llaterial durch Aulhub von Gräben beschafft wird. Mullwelıen auf măchtigem Moorlager sind nach der Entwässerungr zunächst mit líräutern (Rumex), Honiggras (Holcus) etc. anzubauen (am sichersten unter Fruchtbau von Buchweizen miltels Brennens).

An dieser Stelle möge auch der $\mathrm{O}$ ed l a n $\mathrm{d}$ s a u f f o r s $\mathrm{tung}$ in weitestem Simme gedacht werden $\left.{ }^{2}\right)$. Die Sorge für tunlichste Aufforstung des in Europa allein etwa 2: 000 Quadratmeilen eimnchmenden Oedlandes regt sich in allen zivilisierten Ländern. Die Aufforstungsarbeiten im Karstgebiete, in West- und Ostpreußen (Kassubei), sowie sonst in Deutschland, ferner in Voralberg, in der Schweiz (z. B. schweiz. Zeitschr. 1893,6), zunal in schutzwaldgebiete, in Italien, den Pyrenäen seien als Beispiele angefülrt. Auch die Bejflanzung von Alluvionen (Hochgebirge und Ebene: Ueberschwemmungsgebiet (ler Flüsse), je nach ılen Verhältnissen mit Erle, Pappel, Akazie. Birke, auch woht ('lme, Esche. Eiche, sei hier enwähnt ${ }^{3}$ ).

1) Gerdes, "Die flüchtigen Moorflächen in Hannover und Oldenburg" in ,Aus dem Walde" IX, (1879) S. $159 \mathrm{ff}$. - D. in .llündener forstl. Hefte 1, 1892, S. 130.

2) Unter Oedland versteht man in allgeneinen diejenigen Areale, welche zwar hulturfāhig sind, aber z. Z. nicht oder nur okkupatorisch benülzt werden. Event. werden anch landwirtschafllich benūtzte Flächen dem Oedland zugerechnet, welche einen āußerst geringen IBeinerlrag $(0-1,20$ M.) abwerfen. Letztere einbezogen batte Deutschland 1893 rund 3,7 Mill. Ia Oedland, woran ca. 700000 ha aufzuforslen wären. cfr. Gr i e W, Das europăische Oedland, seine Bedeutung und kultur, 1898, bei Sauerlānder. - I a l the's, Vortrag bei der 28. Vers. des 'Thürr. Forstver. 1901, zu Coburg: lereinshelt $\$ .29-46$. - l'reußen hatle allein in Besilz der staathforstverwaltung am 1. X. 1900 noch 34073 ha Oedland, seil 1883 sind 70856 ha crworben worden; 61620 ha waren hievon bis 1900 aufgeforstet. Beteiligt sind in erster Linie die nordö-tl. Provinzen. tales.

3) J. H a In m (Forswix. Zentralbl. 1888, 601): Aus den Waldungen des badichen Rhein- 


\section{Zweiter Teil.}

Sa at.

Zum Gelingen der Saatkultur gehört, von WVitterungseinflüssen abgesehen, vor allem gutes Saatmaterial, ein geeignetes Kieimbett und sachgemäße Ausfülıung.

\section{Allgemeines.}

\$54. A. Verschiedene Arten der Sa t: Je nachdem die Saat aus der Hand oder unter Anwendung einer Maschine ausgeführt wird, nennt man sie Handsaat oder Maschinensaat. - Außerdem werden unterselieden: 1. V olls a a t, wobei die ganze Fläche möglichst gleiclınäßig mit Samen bestreut wird, und 2. stelle nwe ise $\mathrm{S}$ a a $\mathrm{t}$, bei welcher der Samen nur auf bestimmte Stellen der Saatfläche kommt. Hierher gehören: a) die Streif ens a a t, auch Rinnen-, Rillen-, Riefen-, Furchensaat genannt: der Sanen wird auf Streifen gesäet,während die zwischen ihnen liegenden Teile samenfrei bleiben ${ }^{1}$ ). b) die Pl a $t \mathrm{t}$ en s a a $t$, auch P I ät z e s a t: eine Anzahl Samenkörner kommt auf einzelne, über die liulturfläche verteilte Plätze. Werden die Platten mangelnder Feuchtigkeit wegen vertieft, so spricht man von ,Löchersaat". c) Die P unkts a a t, bei welcher man mit Einzelsanıen (Eichel, Kastanie usw.) operiert, die in möglichst gleichnnäBiger Verteilung auf der Fläche untergebracht, ,eingestuft" werden, kann füglich als ein Spezialfall der Vollsaat gelten.

B. Wirtschaftliche Bedeutung der Sa tarten. Wenn Mas c h in en saat angewendet wird, tut man es, teils un die Gleichnäßigkeit der Samenverteilung zu fördern, teils um Zeit, Arbeitsaufwand und Geld zu sparen. Konnpliziertere unr dengemäß teure Maschinen kommen meist nur für große líulturflächen und für regelmäBig wiederkehrende umfängliche Saaten in Betracht. H a n d$\mathrm{s}$ a a $\mathrm{t}$ ist die weit häufigere Methode. Maschinen, namentlich solche, deren Bewegung Spannvieh erfordert, sind überdies meist an bestimmte Eigenschaften der Íulturfläche (nicht zu geneigte Lage, Fehlen von größeren, rasch wechselnden Unebenheiten, von Stöcken, Steinen usw.) gebunden. In größerem Naßstabe finden Säemaschinen, und zwar kleinere IJandapparate, bein Pflanzgartenhetriebe Anwendung. - Volls a t (breitwürfige Saat) gibt, gute Ausführung vorausgesetzt, eine gleichmäBige Samenverteilung, bedingt mithin für die einzelnen Keinpflanzen von vornherein annähernd nach allen Seiten gleichen Standraum, wodurch deren normale Entwirkelung, sowje in der Folge gleichmäßiger Schluß des Jungbestandes und damit auch gleichmäßige Deckung des Bodens angebahnt ist. Sie arbeitet rasch, verlangt aber das größte Samenquantum und erfordert, sobald der Boden eine intensivere Vorbereitung bedarf, gemein lin selı beträchtliche Lockerungskosten. Auch erschwert sie die Reinigung von Lnkraut, die etwaige Jugendpflege der Pflanzen durch Belıacken, sowie das Aushringen der ersten Durchforstıngshölzer. Die Vorzüge und Nachteile der s te II e n w e is e $\mathrm{n}$ Sat folgen aus dem Vorstehenden. Sie bedarf z. B. weniger Saatgut, wenn auch nicht im Verluältnis des wirklich hesäeten zum samenfrei bleilsenden Teil der Fläche, weil nan naturgemäß auf den Einzelstellen dichter säet, hat jeiloch vielfach einen zu dichten Stand der Pflanzen und

1) In bezug auf liese. Art der Saat werden wohl feinere Unlerschoidungen gemacht, indem man von Sireifensaat spricht, wenn die besäeten J3̈nder cine gewisse Breite haben, von Riefensaat oder Rillensaat usw., wenn der Same nur in schmale Linien zu liegen liommi. Sind die Streifen verlieft, so spricht man von Furchen-oder aucl Muldensaat. 
einc ctwas unglcichuäßige, von vornhcrein unsymmetrische Entwickelung der Jungpflanzen zur Folqe, weil sich dic in den Streifen stehenden Pflanzen, ebenso wie dic Randpflanzen auf den Platten nach der freien Seite naturgemäß scitlich mehr ausbreiten als in der Streifenrichtung bezw. nach dem Innern der Platte zu. S tre i f e n s a t cignet sich oft für Anwendung von Maschinen, erleichtert am meisten die Kúturreinignng und dic ersten Durchforstungen, läßt abcr the Zwischenstreifen je nach deren Breite kürzere oder längere Zeit unbedeckt. Auf den Pl a t te n wird das gedrängte Aufwachsen der Pflanzen oft besonders hinderlich; rasche Deckung der zwischen der Platten liegenden Bodenpartien kann nur durch entsprechend nahes Aneinanderlegen der Platten bewirkt werden. Löchersa t kommt namentich für trockene, der Sonne und dem Wind ausgesetzte Orte in Frage. Die Pu n k t s a t kamn (sichc oben) als Vollsaat mit größerem Abstand der cinzelnen Samen voneinander betrachtet werden.

\section{Das Saatmaterial.}

\$55. A. Besclua f f $\mathrm{ng}$ des $\mathrm{S}$ a mens. Je mehr die Forstwirtschaft die künstliche Verjüngung an die Stclle der Naturverjüngung treten läßt, um so wichtiger wird die Frage nach der Beschaffung des notwendigen Saatmateriales. Dic neuzeitliche Entwicklung des Samenhandels weist mit unzweideutiger Sicherheit darauf hin, daß unter den verschiedenen Beschaffungsmöglichlieiten die bequemste, der $K$ a u $f$, im allgemeinen vorgezogen wird. Der fortgesetzt steigende Bedarf, das Fehlen öfterer oder hinreichender Samenjahre und dic mit dem Ausklengen der meist benötigten Nadelholzsamen verbundenen Umständlichkeiten erklären die sehr zu bedauemde Erscheinung, daß der richtigste Weg der Gewinnung, der der Selbstgew in $\mathrm{n}$ u in g, mehr um mehr verlassen wurde. Der in den letzten Jahrzehnten lel haft debattierten Frage nach der wirtschaftichen Bedeutung der Samenherkunft (= Plovenicnz des Samens) war und ist es vorbehalten, den notwendigen Unschwung in diesen Verhältnissen einzuleiten und, wemn nicht die vollkommene Rückkchr zur Selbstgewinnung, so doch die Abstellung der nnit dem Kauf des Saatgutes bisher verbundenen Uebelstände zu bewirken.

Der wichtigstc dieser Uebelstände ist die Unsicherheit hinsichtlich der Herkunft des Samens.

In den Maße, wie die moderne Forstwirtsclıaft dem Aushau des rationellen Wirtscliaftswaldes zustrebt und an der Verbesserung und vollen Ausnutzung ilırer Produktionsnittel arbeitet, muß sie die physiologischen, d. h. die Wuchseigenschaften der Waldbäume in den Bereich ihrer auf Nachzucht bester Rassen gerichteten Maßnalımen ziehen und muß damach trachten, Keime fernzuhalten, an denen auch nur der Verdacht minderwertiger Leistungen lraftet. Nach den bis jetzt vorliegenden Beobachtungen darf angenommen werden, daß sich eine Holzart ihren typischen physiologischen und morphologischen Charakter unter dem Einfluß verschiedener klimatischer Verlıältnisse urn so weniger zu crhalten imstande ist, je größer die Kxlimaunterschiede sind. In Verbreitungsgebict einer Holzart bilden sich vielmehr beim Vorhandensein von Klimadifferenzen Anpassungsformen: Standorts-, physiologische oder klimatische Varietäten =klimatische Formen aıs, von denen - zunächst nach AnalogieschluB, danı aber auch nach manchen Ergelnnissen ad hoc eingeleiteter Versuche ${ }^{1}$ ) - wiederum angenommen werden muß, daß sie ihre Eigentümlich-

1) Vergl. hierzu die Arbeiten von d $v$ Vilmorin, Exposé historique el descriptif de l'école forestière des Barres. Mémoires d'Agriculture 1862, S. 332. - I i e n i tz, Leb. Formen 
keiten auf ihre Nachlommen vererben. Diese Ansicht wird unter Bezugnahme auf

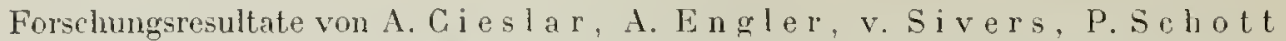
u. a. vertreten, währem H. M a y $\mathrm{r}$ in seinen Lehrbüchern und zahlreichen Spezialartikeln an der Ueberzeugung festhält, daß weder Boden noch Klima imstande sind, den Pflanzen erbliche Eigenschaften aufzudrücken, und daß die Provenienz des Saatgutes keine Bedeutung besitzt, solange es sich lediglich um Standortsformen (Klimarassen) der Holzarten handelt. Die forstliche offentliche Meinung hat sich dieser Ansicht Mayrs nicht angeschlossen. Sie leitete vielmehr aus den allerdings erst kurzfristigen Versuchen, die mit Kiefer, Fichte, Lärche, Schwarzkiefer, Bergahorn, Esche seitens der oben genannten Forscher angestellt worden sind, den durch Erfahrungen der forstlichen Praxis unterstützten Satz ab, daß für einen gegebenen Standort dasjenige Saatgut das geeignetste und beste ist, das von der örtlich angestammten Rasse oder von solchen Standorten gewonnen ist, die gleiche bezw. sehr ähnliche klimatische Verhältnisse aufweisen. Diese zuletzt genannten Standorte kommen beim Samenbezug aber erst dam in Frage, wenn die heimatliche Rasse nichts taugt oder heimischer Samen fehlt.

Die Kunstverjüngung mit wahllos gekanftem Samen hat zur Folge gehabt, daß auf großen Flächon Samen ausgesäet wurde, der infolge seiner Herkunft aus kimatisch anders gearteten Gebieten minderwertig ist, weil er von Bäumen stammt, deren Lebensökonomie sich den anders gearteten Verhältnissen angepaßt hat. Die aus solchem Samen hervorgehende junge Generation wird unter äußere Lebensbedingungen gebracht, die für sie ałsolut nicht passen, und die Folge sind Bestände mit liümmerlichem Wachstum und Bäume mit unerwünschten Wuchseigenschaften.

Die Frage der Samenherkunft ist besonders wichtig für len Nadelholzzüchter. Die Nachfrage nach Kiefern- und Fichtensamen ist in Laufe der Zeit so gestiegen, daß die privaten Klengbetriebe bei weitem nieht melı das notwendige Zapfenmaterial im Inlande beschaffen konnten, wenn sie den vom Käufer verlangten niedrigen Preis des Samens beibehalten wollten. Sie erschlossen sich deshalb ausländische und zwar meist klimatisch wärmer gelegene Bezugsquellen; sie fanden besonders in Frankreich, Belgien und Ungarn Länder, die, soweit namentlich likefer in Betracht kommt, auch in sog. schlechten Zapfenjahren einen großen Berlarf an Zapfen zu befriedigen imstande sind und, was sehr wesentlich ist, billiger liefern als das Inland.

Die Erfolge, die der ausländische lỉefẽrnsamen bei uns gezeitigt hat, waren bei einer Reihe von Samen ausländischer Merkunft durchaus zufriedenstellenu, so bei den Samen aus Belgien, Polen und den Ostseeprovinzen; bei anderen, und zwar bei den Santen aus Sürlfrankreich, Ungarn aber lerart ungünstig, daß man hier und da von einer Verseuchung des deutschen Waldes spricht. Auch der Samen der baltischen Kiefer, dessen Einführung nach Deutschlanı von r. Si vers empfohlen wurde, eignet sich für das deutsche Wuchsgebiet nicht, ebenso wenig wie der Samen, der ron M a y r als besondere Art (P. lapponica) lezeichneten nordischen Kiefer. Der an sich selır schätzenswerten Geradschaftigkeit und Geringästigkeit dieser

und Abarten heimischer Waldbäume. Berdin 1879. - Ci esla r, Zenlralbl. f. d. ges. Forstw. 1887, S. $149 ; 1895$, S. $7 ; 1899$, S. $49 ; 1907$, S. 1, 49. _ - S ivers, llitteilgn. d. deutsch. dendr. Gesellsch. 1895, S. 49. - De r.s., Forstwis. Zentralh. 1898, S. 537. - S c ho t t, Rassen Jer gen. Kiefer. Forstw. Zentrallı. 1907, S. 199, 262. - Le r s., Pinus silvestris, d. gen. Kiefer, ebend. 1904, S. 123, 307, 436, 515, 587. - Eng l e r, Einfluß der Provenienz des Samens usw. Mlittgn. d. schweiz. Zentralanstalt li. d. forstl. Versuchsw. 1905, VIII, S.81. - D e r s., Tatsachen, Hypothesen und lrrtüner anf d. Gebiete d. Samenprovenienzfrage. Forstw. Zentrab). 1908, S. 295 . - I a y r, Die Variationen der Holzgewächse, ihre Entstehung und Bedeutung für die P'raxis, ebenda 1908, S. 1. - Berieln bh. den 8, internationalen landw. Kongreß in Wien 1907. Sekt. V1II. 
Kiefern steht Langsamwüchsigkeit ${ }^{1}$ ) gegenüber, cin Unstaml, der diese Provenienzen für Deutschland ebenso ausschließt, wie der kurzschäftige, krumme und sperrige Wuchs der südfranzösischen und ungarischen Kiefern nicht dazn angetan ist, unsere deutschen lieferngebiete zu veredeln.

Der durch den Handel bezogene Fichtensamen hat so hervorstechende Rassenunterschiede wie bei der liiefer hisher nicht gezeitigt. Es ist verständlich, daß die Herkunft des Samens um so mehr Beachtung verdient, je größer das Verbreitungsgebiet der betreffenden Holzart ist. Mit der Ausdehnung des V'rbreitungsgebietes steigert sich die Möglichkeit größerer Klimaunterschicde, also auch die Möghichkeit der Ausbildung von Rassen mit abweichenden biologischen Eigenschaften. Die Fichtc ist ein Baum der mittleren Gebirgslagen. Hier wirl der meiste Fichtensamen geerntet, um wierler in der Hauptsache in mittleren Gebirgslagen zur Aussaat zu gelangen. Die klimatischen Verhältnisse der Mutterbäune und der jungen Generation sinrl somit in vielen Fällen wenigstens annähernd dic gleichen. Für dic Fichtenzüchter scheint deshalb die Samenherkunftsfrage nicht die Bedeutung zu haben wic für den Kiefernwahl. Immerhin gilt für die Fichte dasselbe wie für die Kiefer, und gerade bei ihr ist von C $\mathrm{i}$ es $\mathrm{l}$ a $\mathrm{r}$ und $\mathrm{E} \mathrm{n} g \mathrm{l}$ er an der Hand exakter Versuche mit Hoch- und 'Tieflagensamen die Vererbung des Zuwachsvermögens und einer Reihe biologischer, morphologischer und anatomischer Eigentünlichkeiten — zunächst wenigstens für dic Jugendjahre - nachgewiesen worden. Wie lange die vererbten Standortseigenschaften sich erhalten, bedarf noch näherer Feststellung durch weitere Beobachtung. Jedenfalls geht aus den bisherigen Erfahrungen aber hervor, daß es sich auch bei der Fichte empfiehlt, das aus Hoch-und Tieflagen, nördlichen und südlichen Wuchsgebieten stammende Saatgut auseinander zu halten und möglichst nur auf Standorten zu verwenden, rlie dem jeweiligen Herkunftsort klimatisch entsprechen.

Eine andere, zur Zeit noch umstrittene, für die Befürwortung der Selbstgewinnung aber gleich wichtige Vererbungsfrage ist die Frage nach der Vererbung von Individualitätscharakteren. Es hanılelt sich hier $u$ die Feststellung, inwieweit Eigenschaften und Eigentümlichkeiten der Nutterbäume, die für die Massen- und Wertsleistungen unserer Bestände von Belang sind: Schnell- und Langwüchsigkeit, Gerach- und Krrummschaftigkeit, Aestigkeit, Zwiesclwuchs, Drehwuchs, Grobfaserigkeit, Gleichmäßigkeit des Jahresringbaues usf. vererbt werden. Dic sog. forstliche Zuchtwahl geht von der Ansicht aus, daß diese physiologischen und habituellen Eigenschaften nicht immer, wie B org g reve (Erblichkeit unıl Zuchtwahl bei Waldbäumen. Forstl. Blätter 1889 , S. 33) und nach ihm 11 a y r vertreten, Folge äuBerer Umstände und Wirkungen des Bodens, lilimas, der Erziehungsform und äußerer Störungen sind. Sie schließt viehmehr aus den Erfahrungen der landwirtschaftlichen und gärtnerischen Praxis heraus, daß die genannten Eigenschaften zum Teil auf Teranlagung beruhen und vererbt werlen. Folgerichtig steht sie auf dem Standpunkt, daß es möglich ist. durch lireuzung die brauchbaren Eigenschaften zu steigern und die Rasse zu veredeln. Sie fordert dementsprechend bei der Samenernte Beschränkung auf jene Bamindividuen, die unseren wirtschaftlichen Zwecken am meisten genügen. Zweifellos hietet die Befolgung dieser Vorschrift, selbst unter der Annahme, daß die unbekannte Vaterpflanze mit unerwünschten Eigenschaften behaftet war, und bei voller Anerkennung des gewiß nicht wegzuleugnenden

1) De n g I e r, D. Wachstum von licfern aus einheimischem und nordischem Saatgut in d. Oberf. Eberswalde. Zeitschr. f. Forst- u. Jw. 1908, S. 137. 
Einflusses von Boden und Ḱlima die beste Gewähr dafür, daß zum mindesten eine Verschlechterung der Rasse vermieden wird.

Ob auch die Widerstandsfähigkeit einer Holzart gegen bestimmte Gefahren, z. B. gegen Frost-, namentlich Spätfrostschaden, Pilzangriffe, Lichtentzug usw. durch züchterische Maßnahmen des Wirtschafters gefördert werden kann, mag angesichts der noch sehr unsicheren Unterlagen hierfür dahingestellt sein. Sicher sind auch ohne dieses die mit der Herdiunft des Samens zusammenhängenden Ervägungen von solcher Tragweite, da 3 bei der Beschaffung des Saatgutes der Selbstgewinnung unbedingt das Wort geredet werden nuß. Sie ermöglicht am besten die Auswahl der geeigneten Samenbëume, gewährleistet die Nachzucht der heimischen Rasse und sichert die Beachtung aller jener Vaßregeln, die leim Sammeln und bei der Behandlung und Aufbewahrung des Samens berücksichtigt werden müssen, wenn qualitativ hochwertiges Saatgut gewomnen werden soll.

In gröBeren Forsthaushalten, namentlich in Staatsbetrieben, ist die Einführung bezw. Wiedereinführung der Regiebeschaffung des Samens um so wichtiger, je mehr die herrschende Wirtschaftsholzart einer Versehlechterung der Rasse durch Einführung ungeeigneten fremden Saatgutes zugänglich erscheint.

Vor allem liegt es im Interesse der Kieferngebiete, Samen einheimischer Provenienz an Stelle des bisher in großem Umfang ${ }^{1}$ ) eingeführten französischen Samens zu verwenden. Es ist mit Freude zu begrüßen, daß auch der deutsche Samenhandel die Hand geboten hat, die bei der Deekung des deutschen Bedarfes an Fiefernsamen bisher bestehenden Mißstände zu beseitigen ${ }^{2}$ ). Dadurch, daß sich eine Reihe von Großfirmen zur Lieferung von nur deutschen Kiefernsamen freiwillig verpflichtet haben, wird namentlich den zahlreichen kleineren Forstbetrieben die gewünschte Garantie für Versorgung mit geeignetem Saatgut gegeben. Der Großbetrieb kann sich diese Garantie durch Selbstgewinnung des Samens selbst verschaffen.

Der Selbstbeschaffung des Samens steht die Gewinnung auf dem Wege der $\mathrm{N}$ a $\mathrm{tur}$ a l a b g a b e annähernd gleich. Es handelt sich hier um Verpachtung der Samenernte, wobei der Unternelnner u. a. vernflichtet ist, als Vergütung für die ihm überlassene Nutzung ein bestimmtes Quantum des gesammelten Saatgutes an den Waldhesitzer abzuliefern. Lieses Verfahren enthebt den Waldbesitzer von der besonderen Sorge für die Ernte und sichert ihm, sofern der Pächter die geeigneten Samenbestände zugewiesen bekommt und bei Ausübung der Nutzung linnreichend überwacht wird, den Bezug frischen, vollwertigen Saatgutes.

Die Gewinnung des Samens in Eigenregie und im Wege der Naturalabgabe krankt naturgemäß an dem Uelelstand, daß in Samenjahren nicht nur der Bedarf eines Jahres, sondern um so mehr Samen gesammelt werden muß, je weiter die Samenjahre auseinander liegen. Sie setzt außerdem voraus, daß Aulbewahrungsmethoden bekannt sind und angewendet werden, mit deren Hilfe es möglich ist, die lieimkraft des Samens melirere Jahre auf einer befriedigenden Höhe zu erhalten. Bei Fichtenund Kiefernsamen stellt das neuere Verfahren, die Samen durch Aufbewahrung unter Luftabschluß und kühler Temperatur Jahre hindurch lieinkräftig zu erbalten, die Möghichkeit einer annähernden Unabhängigkeit vom Markte in Aussicht, wäh-

1) Nach Revue des Eaus et Forêts, 1909, April-1Heft S. 247 gehen jāhrlich 130 Waggon Kiefernzapfen und $30000 \mathrm{~kg}$ geklengter Kiefernsamen von Frankeich naeh Deutschland.

2) Der Anregung des Deutsehen Forstwirtschaftsrates zufolge hat sich eine Kontrollvereinigung der Besilzer von Samenklenganstalten und Forstbaunsehulen gebildet, die sich unter Geslallung der Buehkontrolle dureh eine Kommission des Deutselien Forstwirtschaftsrates verpflichtet, naeh den Vorschriften des Deutschen Forstwirtschaftsrates Kiefernsamen und liiefernpflanzen nur deutseher Herkunft zu liefern. 
rend hei Bedarf an Samen mit schnell zurückgehender Keimkraft die Beschaffung durch Kauf anch für den Großbetrieh nicht immer zı umgelıen sein wird. Gerade bei solehen Simmen, die baldige Aussaat erfordern oder sich nur unter erheblicher Einbuße ihrer Keinfähigkeit his zur Dauer emes Jalures aufbewahren lassen, wie Eiche, Buche, Tanue, Birke, Erle, Ulme, Weide, Pappel, empfiehlt sich aber Sellsstsammeln in erster Linie. Die nicht zu umgehende Abhängigkeit voun Eintreten der Samenjalıre hierbei ist immer noch das kleinere Uebel.

Beim liauf wendel man sich im allgemeinen besser an bewährle große limen als an kleine Händler, weil die großen Anstalten an vollständigsten über die Mlitlel zur Lieferung eines tadellosen Produktes verlügen und, wic die oben crwähnte liontrollvercinigung zeigt, auch gern bercil sind, berechtigten Wünschen der Konsumenten zn entsprechen. Es ist üblich, den Samen unter Zusicherung von Reinheit, guter Beschaffenheit und eines bestimmten lieimungsprozentes zu kaufen. Bei größeren Lieferungen cmpfiehlt es sich, Einhaltung des Lieferungstermines, event. Stellung einer liaution liur rechtzcitige Lieferung zu verlangen ${ }^{1}$ ). Die Samenpreise schwanken je nach dem Auslall der Erute bedeutend, nameutlich bei denjenigen Holzarten, dic, wie z. B. dic Kiefer, manchmal in längeren Zeiträumen nur schwache Ernten geben und bei denen der Bedarl an Saatgut cin großer ist. Es ist selbstverständlich, daß der Samenpreis mit den Anforderungen, die an den Samen selbst gestellt werden, steigen nußB. Es ist tolal verkehrt, sich beim Ankaul von Samen nicht durch die Garantie guter Herkunlt und hoher lieimkralt, sondern durch die Billigkeit bestimmen zu Iassen. Wenn die Samenhandlungen einen nach Keimkraft und Herkunfl einwandsfreien Samen liefern sollen, müssen sie den Preis erhöhen, weil die Beschaffung des Samen aul kleinerem Gebiete und die sorgfältigere Behandlung beim Kỉlengen, Entflügeln, Aurbewahren usw. hỏhere Unkosten verursacht. Ler Preis für Fichtensamen lial $1880-95$ zwisehen $1,05-3,40 \mathrm{Mlk}$. pro kg reschwankt und stell sich jetzt auf $2,50 . \mathrm{Kk}$; Kiefer : $1880-953,05-8,10 \mathrm{Mlk}$; garantiert norddeutscher Kiefernsame ist schon mit $11,00 \mathrm{Ml}$. pro $\mathrm{kg}$ notiert worden und stellt sich jelzt anf 6,50 bis $8 \mathrm{Mk}$. Tanne: $1880-950,38-1,6 ; \mathrm{Mk}$, im Durchschn. $0,75 \mathrm{Mk}$., jetzl 0,80 Mk. pro kg, Lärche $1880-95$ 1,18-6,37, im Durclischn. 2,43 Mk., jelzl 4,50 Mlk. pro kg. Eiche: pro hl (= $80 \mathrm{~kg})$ $15,50$ Stieleiche, $22 \mathrm{Mk}$. Traubeneiche; Buche: pro hl (= $45 \mathrm{~kg}) 21,00 \mathrm{Mk}$, jelzt $36-40 \mathrm{Mk}$. Roterle: pro lig 0,70-1,00 Mlk., Weißerle 2,50 Mk.; Birke 0,60-0,80 Mlk; Ulme 0,40-0,60 Mark; Esche 1,00 Mk.; Bergahorn 1,00 Mk.; Spitzahorn 0,80 Mk.; Hornbaum 0,80-1,00 Mk.

B. Ernte und Aufbewahrung des Samens s. die betreffenden Teile im Abschnitt Forstbenutzung.

C. P r ü f ung d e r. S a m e $\mathrm{n}$ gü $\mathrm{t}$ e. Neben Feststellung der Eehtheit des Samens hat sich die Prüfung zu erstrecken auf Reinheit, Größe und Beschaffenheit, lieimzahl und Keimungsenergie. Nach dem Befund ergibt sich ein größerer oder geringerer Gebrauchswert.

I. Echtheit. Am häufigsten sind Verwechslungen zwischen Sticl- und Traubeneiche, gem. und Berghiefer, Sclwwarz- und Weißerle, Berg- und Spilzalım. (Ueber die bezïgl. Unterscheidungsmerkmale vergl. Abschn. Forstbotanik des Handbuches.) - 2. R e in he it. Das Saatgut soll möglichst rein, frei von Verunreinigungen (Zapfenschuppen, Teilen von Fruchthüllen, Samenflügeln, Harz, Steinchen u. dergl.) sein. Je kleiner die Sämereien sind, um so stärker pflegen sie verunreinigt zu sein. Besonders häıfig sind Beimengungen hei Lärche, Birke, Weide, Pappel, Erle. Die Reinheit wird durch das Reinheitsprozent, d. i. durch den prozentischen Anteil von wirklichen Sanenkörneru an 100 abgezählten Einheiten der Samenheferung angegeben. Das Reinheitsprozent schwankt nach den Angaben der Züricher Samenkontrollstation zwischen $28 \%$ (Birlie) und $99 \%$ (Buche). - 3. G r ö $\mathrm{B}$ e u u d $\mathrm{B}$ es c lı a f e n h e it. Größe und damit Gewicht des Sarnens sind insofern von Belang, als das größere Samenkorn im allgemeinen die kräftigere Pflanze ergibt ${ }^{2}$ ).

1) Unter den grỏßeren leistungsłähigen Klenganstallen, bezw. Samenhandlungen sind nicht wenige von bedeutendem Rule (cfr. Abschnilt Forstbenutzung). Eine Zentrale des (man darl wohl sagen europäischen) Samenhandels ist Darmstadt.

2) Vergl. B a r, Forstwiss. Centralblatt von 1880 , S. 605 f . - Wenn aueh der Unterschied, welchen Pflanzen aus verschicden großen Samen (z. B. großen, mittleren und kleineren Eicheln) anfänglich zeigen, später (nach $3-6$ Jahren) mehr ond mehr verselıwindet, so sind 
Nach den Beobachtungen von F r i e d y i c ll waren Fichtenpflanzen aus schwererem Samen im Alter von 3 Jahren nach Höhe und Volumen noch besser als gleich alte Pflanzen aus leichten Samen. Abgesehen von fler jeweiligen Jahreswitterung uncl der Bodengüte luängt die Größe des Samens vom Alter des llutterbaumes und rom Iilima (Höhenlage) seines Standortes ab. S e ho $t^{t^{1}}$ ) fand, raß im grleichen Revier $150 j a ̈ h r i g e ~ K ̈ i e f e r n$ auffallend kleine Zapfen mit kleinen, leichten Samen, 80jälırige hingegen größere Zapfen mit größeren liörnern erzeugten. Die gleiche Erscheinung, daß der schwerere Zapfen den schwereren Samen liefert, bestätigt F r i e d r i c I von Firhte. - Einen Anhalt für flüchtige Beurteilung des WVertes des Samens bietet seine äuBere und innere Beschaffenheit. Farbe der Samenschale und des Kerns ${ }^{2}$ ), Wasserbezw. Oelgehalt des Kerns, Geruch und Geschmack, ganz besonders aber die Art und Weise, wie der Kern die Schale ausfüllt, orientieren über Frische und damit über das zu erwartende Keimungsprozent. Lange Zeit aufbewahrte oder zu stark ausgetrocknete und dadurch minlerwertig gewordene Samen verlieren ilıre normale Farbe außen wie innen, werlen leichter un!l klappern beim Schütteln. Die größeren Sämereien (Eiche, Kastanie, Buche) lassen sich auch nach ılem Gewicht beurteilen. Taube Samen sind leicht und schwimmen im Wasser, während gute Samen untersinken. Die Prüfung von Eicheln usw, auf diese Weise, die sog. Wasserprobe, gibt zwar nach den Feststellungen G run d n e rs ${ }^{3}$ ) keine durchaus zuverlässigen, aber doch vollkommen zufriedenstellende Resultate. - 4. K e i m z a h l u n d Ke i m ung ge n e r$\left.\mathrm{g}^{\mathrm{i}} \mathrm{e}^{4}\right)$. Das sicherste Mittel, die Brauchbarkeit eines Saatgutes festzustellen, ist die Kieimprobe. Je höher das Kiemprozent, d. h. die Zahl der lieimenden Iíöruer unter je 100 untersuchten und je größer die Kieimenergie ist, d. h. je schneller die Samen unter den ihnen bei der Kimprobe gebotenen günstigen Bedingungen keimen, um so besser ist ıler Samen. Er ist am besten, seine lieimkraft also am größten kurz nach seiner Reife. Je älter er wird, um so melır nimmt die Keinkraft atch bei sorgfältigster Belıandlung ab. Unter sonst gleichen Verhältnissen längt die Schnelligkeit, mit der die Keimkraft zurückgeht, von der Holzart ab. Sehr rasch, oft schon nach wenigen Tagen, verlieren die Keimkraft Ulne, Erle, Birke, Weide, Pappel. Bei Eiche, Buche, Kastanie, Tanue hält sie, sachgemäße Behandlung des Samens voransgesetzt, bis zum nächsten Frülujahr aus. Länger und zwar jalırelang lassen sich Esche, Hornbaum, Linde, und am besten die Narlellıozsamen keinfälig erhalten. Fichte und Kiefer bleiben bei guter Aufbewahrung 3 bis 4 Jahre kieinfähig. Die

doch oft die ersten Jahre (energischer Höhentrieb in Kampfe mit Unliräulern etc.) äußerst wichlig. - B a do $u x$ stellt den Einfluß der Forngröße in bezug auf die lieinkraft dahin fesl, daß groß und nitfelgroß keinen erheblichen Unlerichied zeigen, kleine lïnner aber meist weniger leisten als große und mittelgroße. - F riedrich, Ueber den Einfluß des Gewichlis der Fichtenzajfen und des Fichtensamens auf das Volumen der Pflanzen. Ztschr. f. d. ges. Forslw. 1903, S. 233. - C i esla r, lich. d. Erblichkeit des Zuwachsvermögens, ebendas. 1895, S. 7. - Engle r, Jitllgn. a. d. schweiz. Zenlralanslalt f. d. forstl. Versuchsw. 1111, 1905 , S. 182.

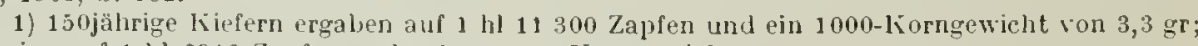

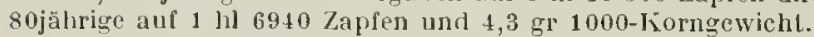

2) Der Kem frischer Samen ixt meist weißlich oder gelblich, bei der Esche bläulich, bein Ahorn ein grünes Pflĩnzchen.

3) G I u n a ner, ,Die Ausscheidung keimfähiger Eicheln mil. Hilfe des Wassers". Allg. F.- U. J.-Z. Mai 1887 .

4) In gewohnlichen Sprachgebrauch pflegt man von der , lieimkraft" eines Samens zu spreclien und brauchl dicsen das lieimprozent und die lieimenergie umfassenden Ausdruck meist (fälschlicherweise) nur für die Keimzahl. Die seither von den Samenhandungen im besten Falle garantierten Keimprozenle schwanken bei Fichte zwischen $70-80 \%$, Kiefer $70-i 5 \%$, Lärche $30-40 \%$, Tanne $40-50 \%$, Eiche, Buche $55-75 \%$, Erle $30-40 \%$, Birke $20-30 \%$, Weide, Pappel $5-10 \%$. 
große praktische Bedeutung möglichst hochkeimenden Sanens ist zwar lüugst alleu Forstwirten bekannt, ist aber erst neuerdings wieder durch die ausüulichen Untersuchungen $\mathrm{H}$ a a $\mathrm{cks}{ }^{1}$ ) an Kiefernsamen in sehr dankenswerter Weise unterstrichen worden und wird, wie Vorgänge ans neuester Zeit ${ }^{2}$ ) beweisen, in Zukunft die verdiente Beachtung wohl mehr finden, als es bisher in allgemeinen geschehen ist. Bei der Aussaat in Freien ist das liemprozent wegen rer weit ungünstigeren Bedingungen, unter welchen der Samen auf der Saatfläche keint, stets geringer als bei der lieimprobe im Zimmer. Nicht einmal im Forstgarten, geschweige denn auf den großen Kulturflächen erhält man auch nur entfernt so viel Pfłänzlinge, als ren Kiemprozent und der angewendeten Samenmenge entsprechen. Das ,Pflanzenprozent", d. h. die Zahl del aus 100 Samenkörnem hervorgehencten Pflanzen steht vielmehr sehr erheblich hinter dem kieimprozent zurück. Von großer Wichtigkeit ist nun, wie die Untersuchungen $H$ a a $c k$ s fïr Kiefer zeigen, daß Keimprozent und Pflanzenprozent nicht parallel gehen, sondern daß rlas letztere bei höherem líeimprozent in schmellerem Tempo ansteigt, mit abnetmender Keimkraft aber auch viel schneller sinkt als das keimprozent ${ }^{3}$. Wie die unten angeführten Zahlen erkennen lassen, liefert rer bei vorsichtigen Klengbetrieh herstellbare 95\%ige Kiefernsamen doppelt so viele Pflanzen als der im derzeitigen samenhandel als gut angesehene Samen mit 75\% Keimkraft. Von Bedeutung ist ferner auch die Keimenergie. Aus schnell keimenten Samen gehen im allgemeinen kräftigere und besser bewurzelte Keimlinge hervor. Für Kiefer fant $\mathrm{H}$ a a $\mathrm{c} \mathrm{k}$, daß bei gleichem Keimprozent und verschieden hoher Kieimenergie der energischer keimende Samen $10 \%$ Pflanzen mehr gibt als rer langsamer keimenrle. Da beide, Keimprozent und Keimenergie, aber vom Alter des Samens und rler Art seiner Behandlung abhängen. wivl der in bezug auf Kieimzahl hochprozentigere Samen im allgemeinen auch der keinenergischere sein. Der Praxis muß also an der Beschaffung möglichst hochprozentiger Samen liegen. Die Sorge hierfür ist un so mehr angezeigt, je ungünstiger die Verhälnisse der Saatfläche sind. Das mit dem lieinprozent in verstärktem Maße anwachsende Pflanzenprozent erleichtert auch die Aufwendung höherer Preise für ein mit größeren Unkosten hergestelltes keimkräftigeres Saatgut, weil ja entsprechend seiner Güte an der Menge des Samens gespart werlen kann.

Die oben genannte K e i m p r b e beruht darauf, daß man eine bestimmte Anzahl (50, 100, 200 Jiörner) durch andauernd gleichmäßige Potenzierung der die Kieimung bedingenden Faktoren Feuchtigkeit und Wärme, bei genügendem Luftund Lichtzutritt zu rascherer Entwicklung veranlaßt. Diese Beschleunigung ist erforderlich, damit man in kürzester Zeit (vor Eintritt rer Kulturzeit) den gewünschten Aufschluß erluält. GleichmäBige Temperatur ${ }^{4}$ ) ist bei ren Kieimproben erwiunscht; namentlich sollten sie nicht in Räumen vorgenommen werden. welche nachts (infolge Unterbrechung der Heizung) erheblich kälter sind als an Tage. Die zu benutzenden Apparate sind vor ılem Gebrauch grünllich zı reinigen, damit Pilzbildungen (Schimmel) möglichst hintangehalten werden: Tonplatten ete. werden zu dem Ende vorher ausgeglüht. Der Beginn der Kejmung, sowie die Zahl der täglich

1) $\mathrm{H}$ a a ek, Leł. d. Keinung und Bewertung des Kiefernsamens nach Keimproben. Ztschr. f. F.- u. Jw. 1906, S. 441. - D e r-., Die Beschaffung des Kiefernamens einst, jetzt und künftig. Mittlgn. 1. deutieh. Forstver. 1909, S. 137.

2) Vach einem Ministerialerlaß vom 29. 1. 1910 soll das Ziel des Darrbetrjebes in ien preuB. Kieferndarren die Gewinnung eine, Saatyutes von mindestens $85 \%$ Keinkraft -ein.

3) Kieferusamen von $50,55,60,65,70,75,80,85,90,95 \%$; Leimkraft ergal, $5,7,11,14,18,22,26,31,37,44$ Pflanzen.

4) Für die heimung der Weymouthskiefersamen ist Temperaturweehsel sehr förderlieh. 
keimenden Körner ist zu notieren. Einzelne späte Naehkömmlinge dürfen bei der Beurteilung der Samengüte unberüeksichtigt bleiben, weil solche, in Freien erst gegen den Sommer hin erscheinende und nicht mehr zu normaler Entwickelung gelangende Pflanzen für das Gedeihen der Kultur meist wertlos sind. Daß man sich, um sicher zu gehen, nieht mit einer einzelnen Probe begnügt, sondern gleichzeitig Parallelproben vornimmt, ist selbstverständlich. Ilan pflegt die Keimprobe nach 4 , bei Kiefer nach 6 Wochen abzuschließen ${ }^{1}$ ). Bei Fichten- und Kiefernproben kommt man aber schon zu einem hinreichenden Urteil, wenn der Kieimversuch naeh 14 Tagen abgebroehen wird und die bis zu diesem Zeitpunkt noch nicht gelieimten, beim Durchschneiden aber als frisch befundenen Körner den gekeimten zugezählt werden. (H i l tn e r und $\mathrm{K}$ i n ze l, Keimungshemmungen. Naturw. Ztsehr. f. L.- u. Fw. 1906, S. 36.)

Die oben angedeuteten Mittel zur Beschleunigung des Tieimprozesses sind u. a. Aussaat in Scherben, deren Erde man ständig feuelıt erhält und die man in einen mäßig warmen Raum stellt (Seherbenprobe); Einlegen des Samens in dauernd feuchte Flanellappen (Lappenprobe) oder Filtrierpapier; Anwendung besonderer K e i ma p p a r a $\mathrm{t} e$, wie z. B. der Hannemann'schen Keimplatte ${ }^{2}$ ) (poröse Tonplatte mit Vertiefungen zum Einlegen der Samen, steht in $\mathbf{W}$ asser bis zur Hölıe des Bodens dieser Vertiefungen), des Nobbe'schen Keimapparates ${ }^{3}$ ) (von einer Wasserrinne umgebener, muldenförmiger Tonbehälter zum Einlegen der Samen, von einem nit Luftöfnung versehenen Tondeckel ïberdeckt), der Apparate von Stainer und Grünwald ${ }^{4}$ ) (poröse mit Vertiefungen versehene Tonplatten, in Wasser liegend, mit einer Glas- oder Porzellangloclie bedeclit), des Apparates von Coldewe und Schönjahn ${ }^{5}$ ) (Auslegen des Samens auf feuchtem Sand, Bedecken mit einer Filzplatte und mit Glasdeckel), Magerstein ${ }^{6}$ ), Keimkasten von Dr. Cieslar ${ }^{7}$ ), Pfizenmayers Keimkasten ${ }^{8}$ ) (ein kleiner, blechheschlagener, mit matter Glasplatte bedeekter Holzkasten, in welchem auf nassem Torfmull der entsprechend kleinere, aus Zinkbleel gefertigte, sandgefüllte, am Boden siebartig durchlöcherte Keimliasten stelıt. Der Apparat wird auf den warmen (nieht überhitzten) Ofen oder Herd gestellt; er arbeitet rasch und genügend sicher: für schnell vorzunehmende Proben zu empfehlen), lieimapparat von Entel ${ }^{9}$ ) (Verliefungen eines in Wasser eingesetzten Gipsbloekes nelımen die Samenkörner auf) usw.

Die Untersuchung einer Samenlieferung auf ihren Gebrauchswert wird am zweckmäßigsten an einer zwischen Käufer und Verkäufer zu vereinbarenden Samenkontrollanstalt vorgenommen. Diese gut eingerichteten Anstalten verfügen über alle erforderlichen Hilfsmitlel, so daß die Prüfung naturgemäß exakter durehgefülırt wird als durch den einzelnen Samenkäufer, dem in den meisten Fällen nur ein mangelhafter Apparat zu Gebote steht. Namentlich dann, wenn es sich um größere, hohe Verte repräsentierende Lieferungen landelt, ist die staatliche Samenprüfungsanstalt der gegebene Ort für die Prüfung. Zur Orientierung in cinzelnen Fällen, bei kleineren Quantitäten ist die Prüfung durch den Empfänger deshalb nicht ausgesehlossen.

1) Vgl. Sehwa paeh, Bestimmungen f. d. Waldsamenprüfungsanstalt bei der Hauptstation des forstl. Versuchswenens zu Eberswalde. Allg. F.- U. J.-Ztg. 1901, S. 33.

2) Allg. Forst- 1. Jagd-Zeitung von 1870 , S. 153.

3) No b b e, ,llandbuch der Samenkunde" 1876, S. 507 .

4) Vgl. Allg. Forst-u. Jagd-Zeitung von $188+$ S. 371. Beide Apparate funktionieren gut.

5) Vergl. Zeitschrift für Forst- und Jagdwesen, Sept. 1886, S. $481 \mathrm{ff}$.

6) Zentralbl. 1. d ges. Forstwesen 1886 , S. 348.

7) Zentralbl. f. d. ges. Forstwesen 1890 , S. 251.

8) Allg. Forst- u. Jagd-Zeitung 1893, S. 17.

9) Forstw. Zentralb]. 1897, S. 535. 
Vom Staat eingerichtete Kontrollanstalten, welche in amtlicher Eigenschaft die Prüfung nach bestimmten Formen vornehmen, bestehen jetzt an vielen Orten; so z. B. in Hohenheim (Württemberg), Züıich (Schweiz), Eberswalde, Dresden, Mariabrunu (Oesterreich), Barres-Vilmorin (Frankreich) ${ }^{1}$ ).

\section{Das Keimbett.}

$\$ 56$. Vorbemerkungen: Da bei der Fieimnng Feuchtigkeit, Wärme und Sauerstoff der Luft zusammenwirken, so muß der Samen bei der Aussaat in Verhältnisse gebracht werden, welche ihm die möglichst ungestörte Einwirkung dieser Fakitoren darbieten. LichtabschJuß wirkt hemmend. Anlaltende Trockenheit, sowie Frost sind hesonders dann schädlich, wem sie im Zeitpunkte der beginnenden Keimung eintreten. Gegen alle schädigenden Einflüsse kann, soweit sie sich in mäßigen Grenzen halten, also z. B. die Trockenheit nicht zu lange andauert oder der Frost nicht zu heftig auftritt, das Umgeben des Samenkornes mit lockerer Erde Schutz gewälnen. Ueberdies ist für das sofortige Anwachsen des zuerst aus der Hülle hervorbrechenden Würzelchens erforderlich, daß dieses baldigst mineralischen Grund erreicht.

Herstellung eines guten Keimbettes: Alle hierauf gerichteten Haßregeln haben ihren Grund in den vorstehend angedeuteten Bedingungen einer raschen, sicheren Keimung. Der Kulturkostenaufwand wird durch derartige Vorarbeiten stets mehr oder weniger bedeutend erhöht, weshalb sorgfältigst zu erwägen ist, ob sie nötig sind, bezw. ob sie die gedeilliche Entwickelung der jungen Saat so fördern, daß sich die Ausgabe lohnt. Die billigsten Mittel, welche uns den Zweck erreichen lassen, sind zu wählen. Dabei ist aber wohl zu beachten, daB - so selır auch rie Kulturkosten das Konto des zu erziehenden Bestandes belasten - dach nicht am unrechten Orte gespart werden darf. Küturen, bei deren Ausführung man an Aufwand für Bodenvorbereitung gespart hat, werden oft durch die erforderliclien Nachbesserungen zu teueren, oder die zweifelhafte Entwickelung des geschaffenen Bestandes bedeutet einen Verlust, der den Kulturkosten zugeschlagen werden muB. Statische Erwägung ist hier besonder's angebracht. Die zur Herstellung eines guten Keimbettes notwendigen Operationen bestehen je nach den Umständen in der Entfernung eines den mineralischen Boden nach außen abschließenden oder die Keimpflanzen demnächst benachteiligenden Bodenüberzugs, in der Auflackerung des Bodens da, wo dieser zu fest gelagert ist, und ausnahmsweise auch wohl in Herbeischaffung des für die lieimung geeigneten Bodens an Stellen, wo solcher fehlt.

A. Entfernung eines hinderlichen Boderüberzugs: Eine lichte Grasnarbe oder diinne Decke aus Lauh, Moos, Kräutern (auch Heide, Beerkraut), unter welchen der Boden, genügend locker, sich einigermaßen frisch erhält, ist im allgemeinen der Saatkultur nicht hinderlich. Fehlt dieser Ueberzug (als Beweis eines lebendigen tätigen Bodens), wie nicht selten auf trockenen, steilen oder sandigen Orten, so liat man öfter mit Erfolg versucht, ihn erst zu gewinnen, indem man die Fläche einige Zeit hinılurch vollständig sich selbst überläßt. Als allgemeine Iaßregel ist dies jedoch wegen der Gefahr weitergehender Aushagerung des Bodens und Zerstörung seiner Krimelstruktur nicht anzuraten. Unbedingt hinderlich dagegen wirkt jede stärkere Bodendeclie, also jede zusammenhängende dichte. hohe

1) Nachrichten über diese Anstalten bezw. deren Unterstützungsergebnisse finden sich u. a. Schweiz. Ztschr. f. Forstw. 1892, 112. Zentralbl. f. d. ges. Forstw. 1899, 339; Tharand. Jalurb. 1890, 103; Allg. F.- U. J.-Ztg. 1901, 33. 
Lauh-oder Nadelschicht, zumal wemn sie sich infolge ungenügender Streuzersetzung als Trockentorf charaliterisiert. Schädlich sind ferner festgeschlossene Polster von Moos und Gräsem oder massige Ueberzüge von Farnliräutern, Heide, Heidelbeere, Himbeere, Brombeere, Ejilobium, Senecio, Digitalis usw. Die Entfernung eines derartigen Ueberzugs geschielıt meist nur teilweise. Man wendet unter solchen Verhältnissen, wenn man überhaupt säet, stellenweise Saat an, weil die Bodenvorbereitung für Tollsaat zu teuer würde. Die Bearbeitung erfolgt 1 . bei L a u b un d M o o s mittels des Rechens (event. besondere kräftig gebaute Waldrechen), oder durch Uebereggen mit Feld- ader Kietteneggen, bei besonders mächtigen Laubschichten auch wohl nnittels Pflügens (Vogelsberg). Weiterhin kommt Unterhacken der oberen Schicht mindadurch Mengung mit dem Mineralboden in Frage. Dem letztgenannten Zwerke dienen auch die dänische Rollegge und die ihr naclıgebildeten Grubber, deren vorzügliche Leistungen schon oben S. 96 ervähnt wurden; 2. bei G r a s, H e i d e, sonstigen Forstunkräutern durch Abschneiden mittels Sichel, Sense, Heppe, Beil, Schere etc. $\left.{ }^{1}\right)$ oder eines Riefenabschneiders ${ }^{2}$ ); 3 . bei Str ä u ch er $\mathrm{n}$ durch Abhauen mit dem Beil oder Abschneiden mit der Durchforstungsschere, oder durch Ausstocken (Schwarzdorn), wenn man vollständige Entfernung wünscht. Auch A b bren n e n liamn unter Umständen angewendet werden und fördert rasch. Bedingungen hierfür sind: mäBig trockenes Wetter, Trockenheit des Bodenüberzugs (Heide, Gras ete. in Frühjahr, stehend; Kräuter nach vorherigem Abmähen und Abwelken). Es ist selbstverständlich, daß alle möglichen Vorsichtsmaßregeln zur Verlütung des Leberlaufens des Feuers ergriffen und beobachtet werden müssen. Dazu gehören Aufgebot der nötigen Mannschaft, streifenförmige Bodenverwundung um die Brandfläclıe, Vermeiden von Tagen mit stärlierem Winde usf.

B. Bod enlockerung: Je besser die Bodentockerung, um so besser der Kulturerfolg. Immerhin wird man des neist erheblichen Kiostenpunktes wegen im allgemeinen sich begnügen, den Borden nur so weit zu bearbeiten, daß eine für den Kulturerfolg genügende Anzah] von Samenkörnem mit dem mineralischen Boren in hinreichend innige Berülırung kommt, um sich zunächst zu guten lieimpflanzen zu entwickeln, und dafo letzteren dann in dem gelockerten Boden vor allem die Bildung eines normalen Wurzelsystems emöglicht ist. Webrigens kann durch Bodenlockerung hin und wieder die Gefahr des Auffrierens in unewwünschter Weise erhöht werden. Die Mittel der Lockerung sind für Vollsaat und stellenweise Saat verschierten.

1. Volls a a t: a) Früher hat man sich zum Lmbrechen des Bodens bisweilen mit Vorteil der $\mathrm{S}$ c h we in e berlient, die, in mäBigem Tempo über die Fläche getrieben, cine unter L'mständen hineichende oberflächliche Bolenverwundung fertig brachten und gleichzeitig durch Vertilgen von Borlentieren aller Art nützlich wurden. Die lıeutige Zeit, die dem Mastschwein die nötige Fertiglieit in Umbrechen des Bodens nicht mehr zutraut, muß zu anderen Mitteh greifen und besorgt die Bodenlockerung durch Kurzhafken, Eggen, Gruhbern mo Pf $\mathrm{k}$ ü gren des Bodens. Die Verwendung ron Spaten, die an und für sich rlie heste Bodentockerung verbürurt, kommt der hohen Kosten wegen nur hei der Bearbeitung kleiner Flächen (Saitkïmpe) orler hei stellenweiser, namentlich Plattensaat in Betracht.

$\mathrm{H}$ a $\mathrm{ck}$ e $\mathrm{n}$ sind Universalin-lrumente für jede Art von Bodenbearbeilung und sind na-

1) Zum Teil eigens für diesen Zweck konstruierte Instrumente; vergl. B e il, ,Forstw. liulturwerkzeuge und Geräte", sowie die bezüglichen liapitel der größeren Waldbauschriften, z. B. He yer s Waldbau, 5. Aufl. S. $115 \mathrm{ff}$.

2) "Der Riefenabsehneider" von ke hrejn. A. F.- u. J.-Z. von 1878, S. 37. 
mentlich dort unumganglich, wo die neist dureh spannkraft fortbewegten grōßeren und bei

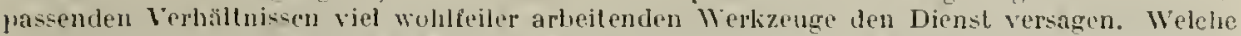

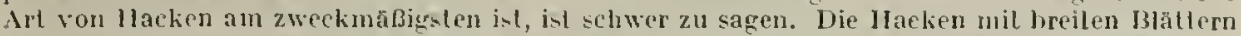
arbeilen gut, wenn es sich nur um Abchälen eines nicht zu dicken Leberzugs handelt. Zur Bodentockerung und zum Beseiligen flick"r, verfilzter Botendecken sind llacken mit sehmïJeren Blälern aber mehr geeignet. Sleinige und verwurzelle Böden verlangen sogar die Anwendung von Spilz- mal Rodehacken. - E g g e n. Außer der gewöhnichen Faldeguge kommen in Tătigkeit: die sog, Slraucherge, bei weleher die Enden ringelegler Reisigbundel die Bodenverwundung hesorgen, fur nicht zu dicht benarblen Sandboden, auf welchem Kiefernsaat ausgeführt werden soll, oft vollkommen genügend; die tlreieckige Egge, rlie liellenegge (aus ciner Anzahl einzelner mit Zinken versehener und durch liurze liellenstucke verbundener kleiner Plallen bestehend - beweglich), wie z. B. die Waldegge ron Laake (Oeslerr. Forsizeitung 1839,8 ), eine Jieltenegge mit auswechselbaren Zahnen; neuestens die Federegge ${ }^{1}$ ) (nit beweglichen Zähnen). Eine gut arbeitende Egge (nach Oberforstmeister Ilahn, Zeitschr. f. Forstu. J. 1892,457$)$ mil Jüeksclılagenden Loffelzinken ist die Ingermann'sche Waldegge. Stöcke, steine, Wurzeln elc. bieten der Arbeit del gewöhnlichen Feldegge IIndernisse; gegen solche sucht die liellenegge und die Federegge anzukämpfen. - G r u b b e r. In neverer Zeil werden nach dinischem Vortilde die auf Zerreißung der oberen Bodendecke und auf Mischung der organichen Sloffe mit dem Mineralboden gerichtelen Wülapparate empfohlen. Der Typus dieser schweren, durch Pferde fortbewegten Werkzeuge ist die danische Rollegge. Nachbildungen derselten von teilweis erhōhter Leislungsfähigkieit sind die Waldgrubber: Webers Waldgrubber. Auf bereils vorbereiteten Böden, in Saatiampen, auf Pflugfurchen usw. treten die lifeineren Handapparate (Spilzenbergs Wührechen, Wühlrad, Wühlspalen) an ihre Stelle. - W a ld p f l a g e sind in mannigfacher Geslalt konslruiert worden. Es sind leils Karrenoder Räderpflüge, teils Stelz-, leils Sehwingpflüge im Gebrauch. Teben gewöhnlichen Pflügen kommen auch Untergrundpflige (tiefere Lockerung) zur Benutzung. Beispiele: Der Waldpflug, sowie der Unlergrundpf]ug von Alemann ${ }^{2}$ ), der Waldpflug von Eckert ${ }^{3}$ ), derjenige von Erdmann ${ }^{4}$ ), von Osterheld (zur furehenweisen Bodenbearbeitung behufs Anfnahme der Buchelmas ${ }^{5}$ ), von Bölzel ${ }^{6}$ ), von Tbaler (A. F.- 1. J.-Z. 1906, 145), von Sehenk $r$. Selimiltburg (ebendas. 1907, 339; 1911, 58), fermerhin die dänisehen Pflüge (vgl. Mełzger, Dänisehe Geräte z. Bodenbearbeilung).

Als ein besonderer Fall der Anwendung des Pfluges möge hier der Jiefernanbau auf Pflugwällen (preuß. Oberförsterei Dohrilugk) erwähnt werden ${ }^{7}$ ). Durch das Ausheben verliefter Pflugfurchen werden wallartige Erhebungen gebildet; auf letzleren wird kultiviert. Allgemein sind auf undurchlassendem Boden die Pflugfurchen nicht selten zu naß.

Die volle Bodenbearbeitung ist (rom Schweineeintrieb und allenfalls von der aberflächlichen Verwundung eines ebenen, mit liurzem Gras überkleideten Bodens durch die Egge abgesehen) meist zu teuer, als daß sie ohne übemäßige Belastung der Wirtschaft ausgeführt werden dürfte. Eventuell ist, wenn nan sich nicht mit stellenweiser Saat begnügen will, von der Saat überhaupt Abstand zu nelımen und zur Pflanzung überzugehen.

2. S t e l l e $n$ w e is e $\mathrm{S}$ a a t. Für sie tritt vorgängige Bodenbearbeitung (wenigstens für Riefen- und Plattensaat) fast immer ein. Die liultur muß, da sie auf einzelne Teile der Fläche beschränkt ist, auf diesen in ihrem Erfolg durch besondere Sorgfalt möglichst gesichert sein. Der Aufwand für rlie Bodenbearbeitung ist hier entsprechend geringer, als wenn die betreffenden Arbeiten auf der ganzen Fläche durchgeführt werden.

a) Streifen: Die Ric h $\mathbf{t} u n g$ ist in der Ehene meist nur bedingt durch die Wege, auf welche die Streifen zur Erleichterung der Holzausbringung bei den Reinigungen und ersten Durchforstungen unter einem annäbernd rechten Winkel

1) Vergl. über diese und einige andere Waldeggen von 11 t e n's Aufsatz in Danckelmanns Zeitschrift für Forsl- und Jagdwesen 1886, S. $375 \mathrm{ff}$ - - vergl. auch Allg. F.- u. J.-Z. von 1879, S. 262 .

2) A l e $\mathrm{m}$ a $\mathrm{n} \mathrm{n}$, Ueber Forstkulturwesen, 3. Autl. S. $25 \mathrm{ff}$

3) Allg. Forst- und Jagdzeitung von 1869, S. 481.

4) Dasell.st 1866, \$. 327 .

5) Forstwiss. Zentralbl. 1900, 131.

6) Holz-Verliaufsanzeiger, 1893, 12.

¡) Zeilschir. f. Forst- u. J. 1888, 513. 
aufstoßen sollen, sowie allenfalls durch die Windrichtung. Es wird als zweckmäßig angesehen, daß der Wind tunlichst senkrecht auf die Saatstreifen trifft, sie aber nicht in ihrer Längserstreckung bestreicht. An Hängen würde die Rücksicht auf die Holzausbringung zur Anlegung der Streifen oft geradezu in der Richtung des gröBten Gefälles (Einmündung in die Tal- und Hangwege) führen. Mit Rüchsicht auf die radurch gesteigerte Gefahr des Abschwemmens von Bodenkrume, Samen und Pflanzen läßt sich diese Richtung der Streifen meist nicht cinhalten. Vielmehr empfiehlt sich hier horizontale Lage der Streifen mit Anhäufung des Abraums am unteren Streifenrande. Eine geeignete Vermittelung wird nicht selten durch eine die Richtung des größten Gefälles in schiefem Winkel durchschneidende Erstreckung der Streifen gefunden. Den rom Wasser (Platzrcgen, Schneeabgang etc.) drohenden Gefährdungen kamm einigemaßen auch rurch Unterbrcchung der Streifen (sog. Stückrimmen) begegnet werden. - B r e i t e der Strcifen: hauptsächlich abhängig vom Unkrautwuchs auf den zwischenliegenden Streifen. Die jungen Pflanzen dürfen von der Seite her nicht überlagert und unterdrückt werden; durchschnittliche Breite $25-50 \mathrm{~cm}$. - A b s t a n d d e r Stre if e $\mathrm{ll}$ : von Rand zu Rand meist $3 / 4-1$ 1 1/2 m, bei langsamwüchsigen Holzarten und zur Erziehung eines raschen Bestandesschlusses am geringsten. - H e r s t e 1$]$ u $\mathrm{ng} d \mathrm{e} \mathrm{r}$ S t r e if e $\mathbf{n}$ : oft, zumal in sehr unebenem Terrain, nach dem Augenmaß; sonst Abstecken unter Anwendung von Pflanzschnur etc., Entfernung des Bodenüberzuges, Lockerı des minerahischen Grundes (mit Hacke oder Pflug), event. Bildung eines erhöhten Aufwurfs (und demnächstige Saat auf dic erhöhten Streifen, damit die jungen Pflanzen nicht von Laub etc. überdeckt werden (sog. Dammkulturen). Die Kosten betragen bei Anfertigung mit der Hacke pro ha (bei $0,3 \mathrm{~m}$ Breite und $1^{1 / 4} \mathrm{~m}$ Abstand der Streifen) im ganzen $30-10$ Taglöhne.

b) Platten: I hre GröBe un E E t fernung (von Mitte zu Mitte) ist abhängig ron der Entwicklung der Keimpflanzen, Art des Unkrautwuchses, vom Eintritt des Bestandesschlusses; mittlere Größe 0,25 DMeter und mittlere Enfernung 1-1 1/2 Meter. Die Platten crhaiten meist eine quadratische Gestalt, werden auch wohl kreisförmig oder als der Quadratform sich annälıernde Rechtecke angelegt. - A n f e r $\mathrm{t}$ i g u $\mathrm{n} g$ : Abräunen res Bodenüberzugs, Lockern des mineralischen Grundes (nit Hacke, lireisrechen ${ }^{1}$ ), Spitzenbergs Wühlspaten).

C. Herbeischaffen ron $\mathrm{K} u l \mathrm{t} u \mathrm{rerde}$. Für den Zweck ener Saatkultur (z. B. zwischen die Steine in Stemräuhen etc.): gute Walderde, liompost, Rasenasche. Die Maßregel ist, weil teuer. möglichst zu vermeiden; nur ausnahmsweise und für kleine Flächen kommt sic in Betracht.

lie zeitliche A us ührung der Bodenbcarbeitung richtet sich teils nach den vorhandenen Arbeitsliräften, teils nach den Bedürfnissen des Bodens. Zumeist gcht sie der Saat unmittelhar voran. Es kann sich aber namentlich auf bindigen Böılen schr empfehlen, die im Frühjahr zu besäenden Stellen bercits in Herbst zuvor zu lockern, teils um dic Arbcit in Frühjahr zu verkürzen, hauptsächlich aber, um den Boden phỵsikalisch zu bessern.

\section{V. Die Aussaat.}

$\$ 57$. A. S a a tze it. Eine allgemeine Vorschrift in bezug auf die Saatzeit läßt sich nicht gehen. Abgesehen von denjenigen Holzarten, deren Samen baldigst in den Boden gebracht werden müssen, weil sie ihre Kímlinaft nach der Reife rasch

1) Vergl. B e i I, "ISulturwerkzeuge" Fig. 90-96. 
verlieren, wie Ulme, Birke, die deshalh im Juni bezw. Juli-August ausgesået werden, säet man entweder im Herbst oder in Frühjahr. Die Frühjalırssaat bildet im allgemeinen die Regel ${ }^{1}$ ). Bei der Herbstsaat hat man zunächst den Vorteil, daß man den Samen nicht aufbewahren muß, sondern in Vollbesitz der Kieimkraft aussäet. Weiter pflegen die Herbstsaten zeitiger aufzulaufen als die Frühjahrssaaten, sie entwiclieln sich dementsprechend, sofern Fröste nicht stören, schon im ersten Sommer kräftiger und nützen namentlich auf trockenen Böden die Frühjahrsfeuchtigkeit besser aus als die erst später ausgeführten Frühjahrssaaten. Sie sinu aber Gefahren aller Art mehr ausgesetzt als jene, leiden unter Tierfraß (Tögel, Mäuse, Wild. Eichhörnchen), Abschwemmen bei der Schnceschmelze, Spätfrost infolge frühen Auflaufens und stehen deshalb in Erfolg sehr oft den Frühjahrssaaten nach. Rücksicht auf Arbeitskräfte, İürze der verfügbaren liulturzeit im Frühjahr, namentlich in höheren Lagen, wo der Boden lange mit Schnee bedeckt ist, ferner Unmöglichkeit der Aufbewahrung des Samens durch den Winter können gleichwohl zur Herbstsaat veranlassen. Bei der Entscheidung ist nicht außer acht zu lassen, daß bei weit hinausgezögerten Frülijahrssaaten die Keimlinge nicht selten, bevor sie einigermaßen erstarkt sind, durch Trockenheit und hohe Temperaturen zu leiden haben. Verspätete Saaten sind auch den Frühfrösten gegenüber oft nicht widerstandsfähig genug. Samen von Holzarten, die infolge eines lieimverzuges zu überliegen pflegen, d. h. nicht sofort nach der Aussaat im Frühjahr keimen, sonrlem meist erst nach ljährigem Lageın im Keimbett auflaufen, säet man zuweilen schon im Herbst, weil dann ein Teil der Körner bereits in nächsten Frühjahr keimt. Inmerhin sind derartige Saaten meist selır unvollkommen. Der Gleichmäßigkeit der Saat wegen empfiehlt es sich mehí, Samen überliegender Holzarten (Esche, Hornbaum, Ahorn, Linde) ein Jahr vor der Aussaat in frischen Boden einzuschlagen und dann im Frühjahr auszusäen.

B. Erforderliehe S a m e n m e $\mathrm{n}$ e. Sie ist abhängig von der Qualität des Samens, dem Saatverfahren, der Holzart, dem Stanłort, dem gewünschten $\mathrm{Maß}$ der Bestandesdichte, der Bodenvorbereitung und dem Wirtsehaftszweck.

1. $Q$ u a $l$ i t ä $t$ des $\mathrm{S}$ a m e n s. Je keinkräftiger der zur Aussaat gelangende Samen ist, um so weniger braucht man, um unter gegebenen Verhältnissen und bei normalem Verlauf der Witterung die Flächeneinheit mit dem nötigen Pflanzenmaterial zu versehen. Wie das oben S. 107 von der lïefer angegebene Beispiel zeigt, kann die Samenmenge stark eingeschränkt werken, wemn hochkeimender, friseher Samen zur Verwendung kcmmt. Samen, der bereits länger aufbewahrt wurde, oder Samen von Holzarten, deren Keimungsprozent selbst bei frischem Samen niedrig ist, müssen entsprechend stärker gesäet werden. Einen ungefähren Anhalt fiir die jeweils zweckmäßige Samenmenge bietet die Feststellung des Pflanzenprozentes bei den verschiedenen lieimprozenten, wie es durch $\mathrm{H}$ a a $\mathrm{k}$ für lïiefer geschehen

1) Speziell findet sich meist die Vorschrift, man solle recht frülı säen, um von der Winterfeuchtigkeit möglichst $z u$ profilieren. Zu beachten ist aber, daß für die Entwickelung der Samen auch eine gewisse Wärmemenge Bedingung ist, und daß eintretende liällerückschläge die lieimung sehr ungūnstig beeinflussen kōnnen. In allgeneinen hat es keinen Wert, vor April zu säcu: vergl. auch $v$. A 1 i e n, "Wie wirkt die Saatzeit. . ?" in Zeitschr. f. Forst- und Jagdwesen 1887, S. $10 \mathrm{ff}$. Dieser hatte - Revier Kupferhütte, Reg.-Bez. Hildeshein - nit Forche die besten Erfolge bei der Aussaat Mitte April. Die Fragr nuß örllich, dureh mehrere Jahre hindureh und in Ausdelnung des Tersuchs auf verschiedene Holzarten untersucht werden. Insbesondere darf daran erinnert werden, daß sich für Gebirgslagen als beste saalzeit nicht selten erst IIai oder Juni ergehen; in eigentlichen Hochlagen ist frülere Aussaat oft gar nicht möglich. Uebrigens wird für trockene steile Hänge, zumal fürs Gehirge. auch Selineesaat (Ausstreuen des Samens auf die Schneedecke) empfohlen: cfr. G. Paßl in Oestelr. Forstz. 1888, 282.

Handb. d. Forstwiss. 3. Anf. 11. 
ist. Die preußische Ministerialverordnung vom 29. I. 1910 schreibt unter Beachtung dieser Feststellungen für Ǩiefer vor, daß bei $85 \%$ igem Samen auf 1 ha in Höchstfalle $3 \mathrm{~kg}$ auszusäen sind und daß einem $\mathrm{kg}$ solchen Samens $1,7 \mathrm{~kg} 70 \%$ iger, $1,4 \mathrm{~kg}$ $75 \%$ iger, $1,2 \mathrm{~kg} 80 \%$ iger, $0,8 \mathrm{~kg} 90 \%$ iger und $0,7 \mathrm{~kg} 95 \%$ iger entsprechen. $\mathrm{S}$ a a t verfah re $\mathrm{n}$ : man rechnet für Streifensaat $2 / 3$ bis $3 / 4$, bei Plattensaat $1 / 2$ der Vollsaatsamenmenge. - Hol z a r t: bei langsamwüchigen, empfindlichen, zärtlichen Holzarten und solchen mit schlechten Ausformungsvermögen säet man dichter als bei Holzarten mit entgegengesetzten Eigenschaften. - S t a n d o r t: je schlechter der Boden, je mehr Gefahren der Standort aufweist (Unkiautwuchs, Frost, Dürre, Insekten etc.), um so mehr Samen. - Bestandesdichte: alle Extreme sind falsch; sehr oft wird zu dicht gesäet. Dichte Saaten imponieren aber nur in der Jugend. Später verursachen sie, wenn sie nicht verbutten sollen, lrostspielige Verdïnnungsmaßregeln. Ausbesserungen zu dünner Saaten sind aber auch nichts Angenelumes. Die richtige Dichte ist nicht leicht zu treffen, ist zum Teil Glïckssache. Mit 10 Jahren soll möglichst auch beim Schattenholz der Schluß eingetreten sein. Dichtere Saaten könmen wirtschaftlich dort gerechtfertigt sein, wo der Markt für die schwächsten Durchforstungs- und Reinigungssortimente empfänglich ist oder wo Anzucht von Pflanzenmaterial (Schlagpflanzen) beabsichtigt ist. - B o d e n v o r b e re i t u $\mathrm{ng}$ : je sorgfältiger diese ist, um so günstiger die Bedingungen des Keimens, um so mehr kamn also an Saatgut gespart werden. - W i r t s c h a f $\mathrm{s} \mathrm{z}$ w e c k: siehe Bestandesdichte.

Durchschnittliche Zahlenangaben ${ }^{1}$ ):

a) Anzahl der Samen pro $M$ a B-, bezw. Gewich $\left\{\right.$ seinhei $t^{2}$ ):

Eiche pro hl $(=70-100 \mathrm{~kg}) 18000-25000$ Stück. - Buche pro hl $(=50 \mathrm{~kg}) 150000$ bis 200000 Stück. - Gem. Kỉefer (ungeflügell) pro lig 150000 Kiōrner. - Fichte pro kg 150000 liörner. - Tanne pro kg 20000 kiörner. - Lărche pro kg 160000 liörner.

b) Samenmenge pro $1 \mathrm{ha}$ bei Vollsaat:

Eiche 7-15 hl. - Buche 3-6 hl. - Genl. Jiefer (ohne Flügel) 6-8 kg. - Fichte 8 bis $12 \mathrm{~kg}$. - Tanne $60-80 \mathrm{~kg}$.

C. B eförderung der Keimung: Nehrfach ist die Frage erwogen worden, ob man nicht durch besondere Behandlung der Samen vor der Aussaat die Keimung beschleunigen und dadurch vielleicht über gewisse Mißlichlieiten (schlechtes, umregelmäßiges oder verzögertes lieimen infolge langen Liegens im Boden etc.) hinauskommen könne. Als einfachstes Mittel erscheint das Anquellen des Samens in Wasser einige Tage vor der Aussaat. Für den liulturbetrieb im großen ist im allgemeinen das Anquellen nicht anzuraten, weil - abgesehen von der Umständlichkeit des Verfahrens und der Erschwerung der Aussaat - der aufgelaufene Sanen, wemn naclı der Saat eine Periode der Trockenleit oder Kälte folgt, zu leicht (meist weit mehr als nicht gequollener) notleidet. Empfehlenswert ist das Anquellen bei dem schlecht lieimenden Lärchensamen und auch bei Bucheckern, wenn diese im Winterlager stark ausgetrocknet sind. Mau mischt sie damn entweder nit feuchtem Sand oder feuchtet sie im geschlossenen Raum durclı Ueberbrausen an und säet sie aus, wenn die Kieime sich zeigen.

1) Zu vergleichen hier und in betreff des gesamlen julturbetriebes bei Zahlenangaben in

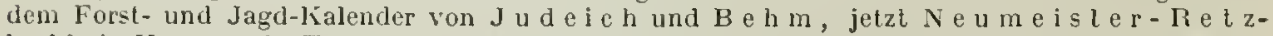
$\mathrm{l}$ a $\mathrm{f} f$, in $\mathrm{He} \mathrm{mpe}$ ls Taschenkalender für den österr. Forstwirt und in den verschiedenen Waldbauschriflen. - Alle angegebenen Zahlen können nur einen ganz ungefähren Anhalt liefern und sind für den konlireten Fall event. zu modifizieren.

2) Vergl. B a u r im forstwiss. Zentralblatl von 1880, S. 341. - H e B, Encylilopädie und Methodologie $1888,11,1$ (S. 61). - H e y e r, Waldbau, 5. Aufl., 1. Bd., 1906, S. 177. - Handtuch, J], Forstbenuzung. 
Fur den Forslgarten, wo man auf kJeinem Raum die Aussaat konzenlriert und, wenn nölig, jederzeit heispringen kann (Bedecken der Beele, Begießen ele.), mag gher einmal vom Anquellen Gebrauch gemacht werden (z. B. bei Verwendung älteren Samens, bei verzögerter Aussaal usw.). Dureh Anwendung chemischer Agentien (Chlorwasser, Kalkwasser, verdünnte Säuren etc.) hat man überdies versuchl, die Samenlülle zu lockern und dadurch die Keinung zu befördern; sicherstehende Resultale sind nicht zu verzeichnen. Denn wenn z. B. aueh Vo nh a u s e n (Allg. F.- u. Jagd-Zcilung von 1858, S. 461 und 1860 , S. 8), sowie He B (Zentralblatt für d. ges. Forstwesen 1875, S. 463) fur Nadelholzsamen gule Erfolge hatten, so hatien andererseits gelegentlich angestellte Proben der wüttemberg. Versuchsstation zu greifbaren Ergebnissen nicht geführt. Neuerdings haben H il t n er und li i n z e l (Naturw. Ztsclur. f. L.11. Forstw. 1906, S. 36, Samen von Pinus silvestris, Strobus, Cembra und Peuce mit konzentrierlor Schwefelsäure benetzl, dann ausgewaschen und die Schwefelsäure mit lialknilch neutralisiert. Die durch die Schwefelsäure bewirkte Abbeizung der Samenschale führte zu einer Erhöhung der lieinungsgeschwindigkeit. Luft und Wasser vermögen durch die dünner gewordene Schale leichter in das Sameninnere einzudringen. - Ulmensamen wird bei der Aussaat zweckmäßig mit feuchtem Sand vermischt. - Für die Nüsse von Pinus Cembra wird Vorkeimen in Gruben empfohlen (Hallbauer in Allg. Forst- u. J.-Z. 1891, 139). Die Nüsse werden im Herbst in eine mit Stroh belegte, mit einem den Luftzug verniltelnden Quandel versehene Grube, mit Sägespänen vermischt, eingebellel; im Mai haben sie ihre kleinen Jieine ausgelrieben und kommen ins Saalbeet, wo die lieimpllanzen nach 14 Tagen aufgehen. - Vorkeimell der Juglans- und Carya-Nüsse in Gruben oder in Haufen über der Erde unter Behandlung mil Sand, Mist, Jauche ${ }^{1}$ ).

D. Die einzelnen Sa atmethoden. I. Vollsa at: Sie erfolgt meist aus der Hand. Größere kompliziertere Säemaschinen kommen für Vollsaaten beim Forstkulturbetriel) wenig in Anwendung, denn sie sind nur auf ebenem Boden ohne Hindernisse, wie Steine, Stöcke etc. zu gebrauchen. Ihre Anschaffung könnte nur etwa für ausgedehnte Nadel-IValdungen (Kiefer) der Ebene in Frage kommen. Doch ist bisweilen auch hier das jährlich zu bewältigende Objeht und danit die bei der Arbeit zu erzielende Ersparnis zu gering im Vergleich zu den Anschaffungskosten. Dort aber, wo die Arbeitskräfte teuer oder unzureichend sind, hat man allen Grund, sich von der Menschenhand zu emanzipieren und zu schneller und demzufolge billiger arbeitenden Säemaschinen überzugehen. Beim Gebrauch einer gutfunktionierenden Maschine ist die Ersparnis an Zeit, Arbeit und oft auch Samen dann so bedeutend, daß die Maschine bald amortisiert ist. Zumeist wird es sich aber um Maschinen zur Streifensaat handeln, da Vollsaat aus dem oben (S. 100) genamnten Grund so wie so nur äußerst selten zur Anwendung kommt. Bei der Handsaat sind geübte Arbeiter zu verwenden (die Zahl derselben in maximo bestimmt durch die Forderung ständiger Kontrolle seitens des Schutzbeamten). Abstecken der Saatgänge, an Berghängen horizontal, Vorrücken von oben nach unten; in der Ehene oft Teilung des Samenquantums und Besäen der Flächen in zwei Richtungen (in die Länge und in die Quere). Unterlassen der Saat bei starkem Wind. Bei Mischsaaten (z. B. Kiefer und Fichte) Ausstreuen der verschiedenen Samenarten nicht in Untermengung, sondern nacheinander zur Erzielung einer gleichförmigen Mischung. - 2. Stellen we is e S a t: Gleichmäßige Verteilung des Samens auf den Streifen und Plätzen ist zu erstreben. Nicht immer werden bei Streifensaaten die Streifen breit besäet, sondern ab und zu werden auf ihnen erst nocl besondere Furchen (Rillen, Riefen, Rinnen) zur Aufnahme des Samens gefertigt. Im Falle diese Rillen nicht in der Längsrichtung der Streifen, sondern,quer wie die Sprossen einer Leiter gezogen werden, spricht man von Leitersaaten. Werden die Streifen alle 2-3 m unterbrochen und die Teilstücke in dieser oder jener Form liesäet, so nennt man eine solche Saat Stückriefensaat. Gleichviel, welche Jethode man anwendet, für alle gilt: Nicht zu dicht säen! Aussaat aus der Hand, oder, auf günstigen

1) Allg. Forst- und J.-Z. 1887, 362. - S e h w a p pa e h, (Zeitsehr. f. F. und J. 1888, 14 und 509). 
Terrain, unter Benutzung von Säeapparaten bezw. -Maschinen zur Erhölung der Gleichförmigkeit rles Ausstreuens und Förderung der Arbeit. $\mathrm{Zu}$ den einfachen Apparaten, welche von Arbeitern getragen werden, gehören z. B. das Säehorn, die Saatflinte ${ }^{1}$ ) und der Harzer Saattrichter. Neben ihnen gibt es eine große Reihe von Maschinen, die teils von Arbeitern geschoben oder gezogen, teils unter Zuhilfenahme von Spannkraft forthewegt werden. Sie bestehen in der Hauptsache aus einem auf einem fahrbaren Karrengestell montierten Samenbehälter, aus dem der Samen so herausfließt, wie es die im oder am Samenkasten befindliche verstellbare Verteilungsvorrichtung oder Ausflußöffnung zuläßt. Zu nennen sind die älteren Maschinen von Runde, Roch, Gölıen, ferner die Sacksche Säemaschine, eine zweiarmige Handdrilhmaschine ${ }^{2}$ ), die Waldsäemaschine von Pollack (Oesterr. Forstzt פ. 1895, S. 61), bei welcher das rotierende Rarl eine Schültelrorrichtung in Bewegung setzt, u. a., sowie die kompliziertere und teuere (Preis $140 \mathrm{Mlk}$.), aber zur Bewältigung großer Flächen in der Ebene sehr leistungsfähige gute Maschine von Drewitz $\left.{ }^{3}\right)$. Für Saat in Pflugfurchen empfiehlt Schenk v. Schmittburg seine von ihm konstruierte Düngerstreu- und Waldsamensäemaschine (Allg. Forst- und J.-Ztg. 191 I, 58). Für ebene und gut vorbereitete Börden, namentlich Satbeete. eignen sich weiterhin die Hackersche und die nach ihrem Prinzip gebauten anderen kleineren Maschinen. Als Jlaschine für Plattensaat ist der, ,Plattensäer" von Zituy ${ }^{4}$ ) empfohlen.

E. Unterbringen und Bedecken les Samens: Die Bedeckung init Errle (zum Schutz gegen Frost, Austrocknen, Tierfraß etc.) soll für größere Samen im allgemeinen stärker sein als für kleine, desgl. darf sie stärker sein für solche, welche beim lieimen die Kotyledonen unter der Erie lassen. Das Maximum soll aber selbst bei Eichehn, Juglans- und Carya-Nüssen, Lastanien $10 \mathrm{~cm}$ nicht überschreiten. Berleckung bei Narlellölzern, wie Kiefer, Fichte etc. nur etwa 5-10 Millimeter, bei Birke, Aspe, Weide mu ganz leichtes Vermengen mit der Bodenkrume oder Andrücken an den Boden. In bezug auf die zweckmäBigste Bedeckungshöhe sind melrfach exakte Versuche angestellt worden, wie z. B. von einer Reihe forstlicher Versuchsanstalten (Württemberg, Sclnweiz etc.). Die Ergebnisse können nur einen allgemeinen Anhalt bei Bemessung rler Berleckungshöhe bieten, weil in einzelnen Falle eine ganze Reihe von Faktoren mitwirkt, wie Bodenart und Bodenzustand, Bedecliungsmaterial (Komposterde, Erde mit Sägespänen oder Torfmull gemischt, Rasenasche, gewöhnliche Erde) und vor allem die Witterung. Auf einigermaßen bindigen Börlen kann ein starker Regen ein Versclılänmen, eine Verkrustung der Oberfläche bewirken, derart, daß selbst eine ganz mäßige Berleckung das Herrorbrechen der Keimlinge aus kleinen Samen lindert, wälırend olme solche Schädigung eine etwas stärkere Bedeckung weniger gescliarlet haben würle. Ilerbstsaaten pflegt man im allgemeinen etwas stärker zu decken als Frülijahrssaaten. 1. Tolls a t: Anwendung der Egge, event. anch Ilandarbeit (Rechen), Ueher-

1) $\mathrm{B}$ a n d o, "Saatflinte und Säthorn" in \%eitschr. Jür Forst- und Jagdwesen von I Hanckelmann 1869, S. 449 .

2) Vo ig 1, Zeitcehr.f. Forst-und Jagdwesen 1888. \$. 703.

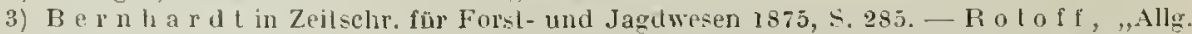
Forst- und Jagd-\%eitung" $1876, \mathrm{~S} .48$. An letztgenannter Stelle wirl berichtet, da $B$ die Maschine auch auf geneigtrm Terrain verwendbar ist. 2 Arbeiter ziehen, 1 Irbeiter führt dieselbe. Am besten auf mittelbindigen Bolen, nicht gut anf festem oder ganz lockerem unt nicht gut bei einem an die Welkzeuge sich festhängenden Boden. Abhängigkeit anch von Welter (Regen bei Jockerem Sandboden oft güntig, nachteilig bei vielen Vertiefungen. wie Stocklöcher usw.). Ersparnis an Samen, nicht an Albeil. liosten der Aussat (reiner Arbeilsaufwand) pro ha $2-3$ Mark. Sorgfaltige Bodenbearbeitung ist erforderlich.

4) cfr. Z i t $n \mathrm{y}$, ,Zentrablatt fül das ges. Forstwesen" von 1882, S. $61 \mathrm{ff}$. 
erden, Auftricb von Vichherden. - 2. Stellenweise sa a t, und zwar bei Streifen: Pflug (Eichelsat), ferner besondere Maschinenteile (Rechen) an den Säiemaschinen, Handarbeit (Hacke, Rechen); bei Plätzesaat event. Anwendung des Lireisrechens.

F. Pf I ege der Sa a tkulturen: Es handelt sich um den Schutz der Samen und demnächst denjenigen del lieimpflanzen, sowie un die erforderliclien Nachbesserungen. I. S $\mathrm{c}$ h u $\mathrm{tz}$ d e r $\mathrm{S}$ a $n \mathrm{en}$ ist vor allem zu gewähren gegen Tiere (siehe Forstschutz); gegen Hitze und Frost schützt das Bedecken. II. Die K c imp f l a n z e n sind zu belüten vor Linkrantwuchs, Wild und Weidevieh, Hitze und Frost. I. Gegen U n k r a u t: Vollsaaten werden unter Lmständen durcli Schafauftrieb gesichert, wobei daron ausgegangen wird, daß die Schafe die Holzplanzen (bes. Fichte und lïefer) verschonen. In Streifen- und Plätzesaaten wird zu starker Unkrautwuchs durch mechanisclie Eingriffe: Abschneiden, Umpflügen usw. unschädlich gemacht. Welche Werlizeuge dazu benützt werden, ist Sache der lokalen Gewohnheit; hin und wieder finden Jätepflüge (Roth-Gerhardsche Jätepflug, Allg. Forst- und J.-Ztg., 1911 S.58) erfolgreicl Verwendung. Unter Umständen genügt Niedertreten des Unkirautes ${ }^{1}$ ), auch woh! (in den ersten Jahren, bei langsam wachseuden Holzarten) vorsichtiges Abmähen über die Köpfe der Holzpflanzen hinweg. Eine Sicherung gegen das Unkraut kann auch dadurch gewonnen werden, daß man die zwischen den Saatstreifen und Saatplätzen liegenden Bodenteile künstlich mit einer unschädlichen oder gar nützlichen Pflanze bestoclit, welche ihrerseits das schädliche Unkiaut, zumal Gräser, zurückhält. Zu diesen Zwecke mag Lupinus perennis empfohlen sein, die durch die Jahr um Jahr wiederkommende Blattfülle in jenem Sinne günstig wirkt und überdies als Papilionacee eine Bereicherung des Bodens an Stickstoff herbeifülırt ${ }^{2}$ ). Auch die Beisaat von Waldkorn (JohannisStaudenkorn) hat sich auf unkrautwüchsigen Böden bewährt (Tharand. Jhrb. 1905, 30I). Der dichte Blattfilz dieses Kiornes läßt Lnkraut nicht aufkommen, und auch nach Aberntung des Kornes hindern die steliengebliebenen Stoppeln den Wuchs des Unkrautes noch ganz erheblich. - 2. Wild und W e i d e vie h: Umfriedigung der Saatfläche (Drahtzäune neuestens vielfach üblich; ein Geflecht aus verhältnismäßig schwachem Draht, auf ein Stangengitter aufgespannt, gegen das Durchlíriechen des Wildes. genügt; Kosten der Zäune - gegen Rot- und Rehwild - pro lauf. Meter ca. 1 Mark. inkl. Holzmaterial). - 3. H it z e u n d F r o s t: Fruchtbeisaat. Ansaat unter Schutzbeständen (Voranbau frost- und hitzebeständiger, raschwüchsiger, lichtkroniger Holzarten: Birke, Kiefer etc.), event. Zwischensaat oder -pflanzung einer Schutzlıolzart. Durch diese Maßregeln wird natürlich zugleich das Unliraut bekämpft. Die sehr beträchtlichen Kosten derartiger Maßnahmen weisen aber darauf hin, daf es viel richtiger ist, in Frost- und Dürrelagen von der Saat überhaupt, namentlich aber von der Saat empfindliclier Holzarten abzusehen und licber zu pflanzen. Auch Bodenlockerung kann in manchen Fällen gegen Austrocknung in Frage kommen. - III. V e r d ü n n u n g e n u n d V e rdichtungen ( $\mathrm{Nachbesserungen).} \mathrm{Zu} \mathrm{dicht} \mathrm{aufgelaufene} \mathrm{Saaten} \mathrm{ma-}$ chen baldige Verdünnung notwendig, wenn sie, zumal auf ärmeren Böden, später nicht sitzen bleiben sollen. Die Verdünnung geschieht durch Ausheben von Büscheln, Ausrupfen oder Ausschneiden. Wenn möglich, suclıt man das überschüssige Pflanzenmaterial weiter zu verwenden. Lückige Saaten und Felılstellen bedürfen der

I) Brombeere schlägt nach dem Abschneiden schr kräftig wieder aus. - Abschlagen von Farnkrautwedeln mit Stōcken.

2) I o c h, Allg. Forst- und J.-Z. 1902., S. 11. 
Verdichtung durch Nachbesserung. Nachsaat ist in solchen Fällen nur dann praktisch, wenn die ganze Fläche oder doch größere Teile mißlungen sind. Fichtig ist Nachbesserung mittels Pflanzung. Sie hat nicht elıer zu geschehen, als das Nachbesserungsbedürfnis klar vor Augen liegt, im allgemeinen niclıt vor dem dritten Jahre. In Saaten sind Fehlstellen oft nicht gleich jm ersten oder zweiten Jahre mit Sicherheit zu erkenmen. Bezüglich der Nachbesserungen, sei es in Saat-oder Pflanzkulturen oder in natürlichen Verjüngungen, möge vor zu kleinlichen, ängstlichem Vorgehen gewarnt werden. Es ist eine unangebrachte Pedanterje, jede lileinste Lücke, die beim Heranwachsen des Bestandes von selbst bald verschwindet, nachzubessern. Andererseits jst es oft falsch, den sog. ,Zuziehen " der Fehlstellen zu viel Gewicht beizulegen. Namentlich erfordern Holzarten, die zu Sperrwüchsigkeit neigen, enge Erziehung in der Jugend, also Nachbesserung im Interesse der Formausbildung. - Ueber D ü $\mathrm{g}$ ung zurückbleibender Saten s. unter Pflanzung. $\mathrm{V}$. $\$ 67$.

\section{Dritter Teil.}

\section{P f I a nzung.}

\section{i. Allgemeines.}

§58. A. A rten d e r P f l a n z u ng. Unterschieden werden: 1. Pflanzung mit bewurzelten und mit unbewurzelten Pflänzlingen, erstere entweder natürlich bewurzelt (Kernpflanzen aus Samen oder Wurzelloden) oder künstlich bewurzelt (Ableger), letztere Steckreiser oder Setzstangen. - Ballenjflanzen (die Wurzeln sind von einem Erdballen umgeben) und ballenlose Pflanzen. - Stummelpflanzen (der Schaft wird über dem Wurzelknoten abgeworfen) und ungestummelte Pflanzen. Sclılagpflanzen = Willlinge (Pflanzen aus Saaten oder natürlichen Verjüngungen), Kamppflanzen, entweder Saat- oder Schulpflanzen (aus Saat- bezw. Schulbeeten der Pflanzenerziehungsstätten). - - 2. Einzelpflanzung oder Büschelpflanzung, je nachdem ein oder mehrere Pflänzlinge in das Pflanzloch kommen. - 3. Ungeregelte oder geregelte Pflanzung. Bei letzterer werden die Pflanzen in bestimmter gleichförmiger Weise räumliclı verteilt. Diese räumliclıe Ordnung nennt man "Verband". Als solche geregelte Verbände unterscheidet man: Quadrat-, Rechtecks- oder Rieihen-, Fïnf- und Drei- oder Dreiecks-Verband. Beim Quadratverband stehen die Pflanzen in den Ecken eines Quadrates, beim Rechtecks- oder Reihenverband in den Ecken eines Rechteckes, dessen längere Seite den Reihen-, dessen kürzere Seite den Pflanzenabstand innerhalb der Reihe angibt. Der Fünfverband ist ein Quadratverband mit Auspflanzung des Diagonalenschnittpunktes, der Drei- oder Dreiecksverband ein Verband, bei dem die Eckpunkte gleichseitiger Dreiecke bepflanzt werden.

B. Wirtschaftiche Bedeutung. 1. Pflanzung mit bewurzelten Pflänzlingen bildet die Regel (Setzreiser oder Setzstangen nur bei Pappel und Weide). Iŕünstlich bewurzelte Pflanzen (Absenlier, Ableger) finden ebenfalls nur ausnahmsweise Verwendung. - B a lle n p f l a n z ung: beste Pflanzmethode, weil bei ilır die W Wurzeln njclıt entblößt werden. Sie ist jedoch teuer bei älteren Pflanzen mit großen Ballen, deren Aushebung entsprechend umständlich und zeitraubend ist. Bedingung ist ein den Ballen haltender (nicht lockerer) Boden. Für kleine Pflanzen ist dieser Bedingung viel leichter genügt, als für große, so daß die Anwendung der Ballenpflanzung sich schon aus diesem Grunde in ziemlich engen Grenzen bewegt. S L u m m e l p f l a $\mathrm{n} z$ e $\mathrm{n}$ sind nur bei ausschlagsfähigen Holzarten (Laubhölzerm), zunächst bei Eiche, Erle, Birke, Robinje, Kastanie, Esche, Ahorn möglich und finden besonders bei der Ergänzung von Nieder- und Mittelwaldungen Verwendung. Der 
Schaft wird mehr oder weniger knapp über den Wurzeln schräg und glatt abgeschnitten; es wird also nur die Wurzel verpflanzt. Am Schaftstummel entstehen Ausschläge, die bis auf einen (den besten und kläftigsten) entfernt werden. Stummeln empfiehlt sich beim Auspflanzen von Laublı̈lzern, dic an den Wurzeln stark beschädigt sind, z. B. beim Bezug der Pflanzen von auswärts, wenn durch Fehler in der Verpackung, bein Transport usw. ein Teil der feineren Wurzeln vertrocknet ist. Die Ausschläge der Stummel sind nach Erfahrungen der Praxis meist aber kräftiger, wenn die Pflanzen erst nach dem Anwachsen, nicht vor dem Einsetzen gestummelt werden. Dann aber kanı man naturgemäß nicht mehr von Stummelpflaızen sprechen. - Im großen und ganzen findet Pflanzung mit bewurzelten, ballenlosen, in ihrem oberirdischen Teile unverkürzten Pflänzlingen Anwendung. - 2. B üs c h el p fla nzung ist, besser war bei einzelnen Holzarten (Fichte) in manchen Gegenden (Harz) verbreitet. Als Vorzüge werden angegeben besseres Gelingen der Kultur, rascher Bestandesschluß, Sicherheit gegen Gefahren (Wildverbiß, Schutz vor Schälschaden, geringerer Schneeschaden usw.). Die Büschelpflanzung ist im allgemeinen zu verwerfen. Sie führt zu Verwachsungen, macht zeitige Reinigungsmaßregeln notwendig, wenn die Pflanzen im Büschel sich nicht drängen und in ter Entwicklung hindern sollen, zielıt wohl auch Rotfäule für die bleibende Pflanze nach sich und zeitigt das ist dic Hauptsache - wenn sie nicht rechtzeitig durchschnitten wird, geringere Wuchsleistungen als die Einzelpflanzung. Die behauptete größere Widerstandsfähigkeit gegen Schneeschaden trifft nur in jüngeren Kulturen in schneereichen Gegenden, nicht aber für die späteren Altersstufen zu. In jüngeren Kulturen schützt das Büschel die inneren Pflanzen gegen Auswuchtin der Seitenäste durch den Schnee. Die Büschelpflanzung findet noch in Dänemark bei der Auspflanzung lückiger Buchenverjüngungen, bei Unterbau mit Buche als sog. Blockpflanzung, d. i. Pflanzung größerer Erdballen, die aus dichten Buchenverjüngungen oder aus Buchensaatbeeten ausgehoben worden sind, Anwendung. Sonst ist man allgemein und mit Recht zur Einzelpflanzung übergegangen. - 3. Annähernd gleichmäßige Verteilung der Pflanzen ist in den weitaus meisten Fällen anzustreben. Sie läßt sich (durch geübte Arbeiter) oft auch ohne genau abgesteckten Verband in genügender Weise erreichen. Ausnahmsweise, wie z. B. unter Umständen beim Unterbau, wird mehr gruppenweise Anordnung der Pflanzen bevorzugt. - G e r e g e l t e V e r b ä $\mathrm{n}$ d e, bei welcher jeder Pflanze ihre bestimmte Stelle angewiesen ist, erfordern die besondere Arbeit des Aussteckens der Pflanzplätze, fördern aber die Ausführung der Pflanzung, sichern der einzelnen Pflanze den gleichen Wachsraum, gestatten genaue Berechnung der Pflanzenzahl, leichte Nachbesserung (sofortiges Auffinden der Fehlstellen), Grasnutzung zwischen den Pflanzreihen, Herstellung regelmäßiger Mischungen ${ }^{1)}$ und gewähren Erleichterung beim Holzausbringen, bei manchen Maßregeln des Forstschutzes usw. - Terrainunebenheiten, Steine, Stöcke, Vorwüchse etc. sind oft Hindernisse ihrer Durchführung.

\section{I. Das Pflanzmaterial $\left.{ }^{2}\right)$.}

\$59. A. Erforderliche Eigenschaften: Normale Entwichelung des Pflänzlings, insbes. gute Wurzelausbildung, stufiger, liräftiger Schaft, genügende

1) Geeignete Bestandesmischungen sind übrigens oft viel mehr voll der speziellen Bodenbeschaffenheit an der einzelnen Stelle, als von der RegelmäBigkeit des Verbandes abhängig.

2) Vergl. u. a. F ür st, ,Die Pflanzenzucht im Walde" 4 . Aufl. 1907, woselbst alle Einzelheiten der Pflanzenerziehung in erschopfender Weise abgehandelt sind. Zahlreiche Literaturnachweise und Erlahrungszahlen etc. daselbst. 
Blatt- bezw. Nadelmenge (nicht zu geil oder in gedrängtem Stande spindelig erwachsen!). - Die für eine liultur zu wählende Stärke bezw. Höhe ${ }^{1}$ ) und damit im Zusammenhang das A l t e r d e r P f l ä n z l i n g e sind abhängiğ von dem speziellen Zweck der Kultur, von den Verhältnissen, in welche die Pflanzen dabei gebracht werden und dem dadurch bedingten Pflanzverfahren. Im allgemeinen verdient, wo immer angängig, die V'erwendung junger, d. h. kleiner Pflänzlinge (gutes Anwachsen, Billigkeit des Verfahrens in Absicht auf Pflanzenbeschaffung, Ausheben, Transport, Einsetzen) den Vorzug. 2-4jälırige Pflanzen, von der diesem Alter unter mittleren Verhältnissen entsprechenden Höhe werden am häufigsten benutzt. In besonderen Fällen kommen auch ljährige (Kiefer), sowie andererseits ältere resp. stärkere und höhere Pflänzlinge (Loden, Halbheister, Heister) in Anwendung: z. B. Tanne (langsame Jugendentwickclung) überłaupt meist 5-6jährig. Stärkere Pflanzen aller Holzarten werden im allgemeinen bei Nachbesserungen, Randpflanzungen, liultur von Vielıweiden, bei bedeutendem Unkrautwuchs, in Frost- und Hochlagen usw. verwendet.

$\$ 60$. B. Arten der Pflanzenbeschaffung. Es kommen in Betracht: liauf, Entnahme aus Schlägen, besondere Anzucht und zwar entweder in Freilagen, unter Sehutzlueständen oder in Forstgärten. 1. Ii a u f: nur ausnahmsweise zulässig; im allgemeinen sollte jedes Revier (mindestens jeder Forst) seinen Bedarf selbst decken. So lautete bis vor wenigen Jahren die allgemeine Regel, und an derselben sollte auelı heute noeh tunliehst festgelıalten werden, schon des großen Interesses wegen, das jeder Forstwirt gerade an der Anzucht seines Pflanzenmaterials nelmen muß. Die hierbei gebotene Gelegenheit zu Beobaehtungen und Versuchen aller Art sollte nicht fortfallen; unnützes, lileinliches Experimentieren lat natürlich zu unterbleiben. In neuerer Zeit haben es jedoch viele, insbesondere große Pflanzenzüchtereien (z. B. Heins-Halstenbek in Holstein) durel weitestgehende Vervollkommnung ihrer Einrichtungen dahin gebracht, daß sie tadellose Pflänzlinge in jeder beliebigen Nenge zu Preisen anbieten können, welche hinter den fíosten, mit welchen die Pflanzen in Forstgarten des einzelnen Wirtschaftsganzen meist nur elzogen werden können, erheblich zurückbleiben. So ist es nicht zu verwundern, daß von der so gegebenen Möglichkeit der Bedarfsbefriedigung durch Ankauf mehr und mehr Gebrauch gemaelıt wird. Immerhin sollte das finanzielle Moment nielit allzusehr betont werden. Auch für das Sehutzpersonal bietet die Pflanzenzucht erweislich sehr oft besonderen Reiz und nicht zu unterschätzende Anregung. Gegen den Kauf der Pflanzen in den großen Pflanzenzuehtbetrieben sprieht auch der Umstand, daß die Pflanzen auf dem mehr oder weniger langen Transportwege jedenfalls nicht besser werden, in vielen Făllen aber leiden, und daß sie ferner vielfach in Lagen erzogen werden, die den klimatischen Verlıältnissen des späteren Standortes gar nieht entspreclıen. Der wünschenswerten Erfüllung der oben (S. 102) erwähnten Provenienzforderungen wird dureh Anliauf der Pflanzen aus einer weit entfernten Pflanzenzuchtanstalt fernerhin auch nicht Vorschub geleistet. Außerdem begibt sich der Waldbesitzer, der den Iiauf der Pflanzen der Selbstzucht vorzieht, in ein gewisses Abhängigkeitsverhältnis zu ler pflanzenliefernden Stelle, das unter Umständen, bei Elementarschäden, Pilzepidemien usw., die den Pflanzenzuchtbetrieb treffen, recht

1) Mit Recht wird mehrfach (z. B. Flury, Mltlgn. d. Schw. Zentralanslalt IV, S. 189) betont, daß die Höle der Planzen in erster Linie anzugeben sei, nicht deren Alter, weil die namliche Höhe auch bei der gleichen Holzart unter verschiedenen Entwicklungsbedingungen bei verschiedenem Aller crreicht werdc, und doch eine bestimmte Höhe des Gipfels über dem Boden in vielen Fällen der enlscheidende Faktor sei, wie z. B. beim liampf mit Unkraut, in Frostlagen, gegen Wildverbiß usw. 
störend werden liann $)$, - 2. E n $($ ı a lı m e a u s S e lı l ä ge n, natürlichen Verjüngungen und Saaten, teils zum Zweck unmittelbarer Verwendung für die liultur, teils zu vorgängiger Verschulung in Pflanzbeete. Gewinuung eines billigen, oft (auf geeignetem Boden, bei nicht zu dichtem Stand) trefflichen Materials (mit oder ohne Ballen, je nach Umständen). Sorgfältiges Ausheben (nicht Ausreißen und Abbrechen der Wurzelenden) ist Bedingung. - 3. B e s o n d e re $A n z u c h t$ : a) in F re il a gen, durch Saat, namentlich ab und zu behufs Anzucht von Balleupflanzen, auf nuäßig bindigem Boden mit leichter Grasnarbe. Nit Vorteil werden auch rie wieder eingeebneten Stocklöcher starlier Stämme zur Pflanzenzucht mit benulzt; infolge der grünllichen Bodenlockerung sind die Ergebnisse hier oft besonders gute. - b) unter lichtselıimigen Schutzbeständen, z. B. Buche (für Zwecke des Unterbaues, Main-Rheinebene) durch Saat in lijefernbeständen, am besten in stark durchforsteten Stangenorten oder angehenden Baumhölzern, nach oherflächlicher Zubereitung des Keimbeetes (Entfernung des Noospolsters, leichtes Durchhacken des Bodens, event. Umgatterung gegen Wild). Das Verfahren liefert oft massenhaftes Material olıne große Kíosten, eignet sich aber nur für Erziehung von Schattenhölzern. - Hier und da Anzuclıt von Pflänzlingen auf Waldfeldern unter dem Schutz von Getreide (z. B. Haferschutz-Saaten zum Ausheben der Pflänzlinge im 3. Jalıre). - c) in F o r s gä r t e n oder Kämpen für Pflänzlinge, welche besonderer Sorgfalt bedürfen, insbesondere, wem Verschulen nötig ist. Wo die Gelegenheiten des Pflanzenbezugs ad 1,2,3 fehlen oder nicht benutzt werden sollen, ergibt sich die Anzucht im Forstgarten von selbst. Sie ist tauglich für alle Holzarten, aber meist relativ teuer. Für viele Arten der Pflanzkultur ist sie unentbehrlich, im ganzen aber doch auf das notwendige Maß zu beschränken.

C. Forstgartenbetrieb ins besond e re ${ }^{2}$ ).

$\S 61$. 1. Arten. Die Forstgärten sind entweder nur Sa tschulen (Saatkämpe) zur Erziehung von Pflanzen, welche ummiltelbar von der Stelle, wo sie gekeint sind, zur Kultur verwendet werden, oder P f I a n z s c h u l e n (Pflanzkämpe), in welchen die Keimpflanzen erst noch versetzt (verschult, verstopft, ungelegt) werden, bevor sie auf die Kulturfläche kommen. Meist sind Saat- und Pflanzbeete in einem Forstgarten vereinigt, doch kommen auch größere liampanlagen vor, in welchen sich nur Verschulpflanzen finden (z. B. Tannensämlinge aus Bestandessaaten, Buchen aus natürlichen Verjüngungen). - Man unterscheidet außerdem s $t$ ä $\mathrm{n}$ d $\mathrm{i}$ g e und u n s $\mathrm{t}$ ä $\mathrm{n} d \mathrm{i}$ g e (sog. Wander-)Forstgärten. Erstere werden durch längere Zeit andauernd benutzt, letztere nur kürzere Zeit, nur die Pflanzen für bestimmte Kulturen liefernd. Die unständigen Forstgärten verden natürlich möglichst unmittelbar bei oder" auf rler líulturfläche angelegt, deren Pflanzenbedarf sie demnächst decken sollen. 1st die betr. Kultur erledigt, so werden sie wieder aufgegeben, bezw. hilden dann mit einem Rest ihrer Pflanzen Teile der Kultur. Ständige Gärten sind teurer in der ersten Anlage (sorgfältigere Bearbeitung etc.), erfordern bej beginnender Erschöpfung künstliche Düngung und liegen oft weiter von der Kulturstelle entfernt, verursachen demzufolge oft größere Transportkosten. Gewölnnlich leiden sie auch durch Verunkrautung mehr als die unständigen Kämpe. Sie sparen dagegen auch wieder an erstmaligem Aufwand (Bodenvorbereitung, Umfriedigung etc.), insofern

1) Vergl. Sch wa r z, Der Waldpflanzenzuchtbctrieb in und um Halstenbeck. Forstw. Zbl. 1903, 472; - d e r s., In Sachen des Waldpflanzenzuchtbetriehes, das. 1904, 629;- H ü r$\mathrm{m}$ a $\mathrm{n} \mathrm{n}$, Der Waldpflanzenzuchtbetrieb in und um Halstenbeck, das. 1904, 141 .

2) Vergl. hicrzu die umfassenden Angaben in Fursts ,Pflanzenzuclıt" (cfr. Anm. 2, S. 119), sowie zahlreiche Artikel der verschiedenen forstlichen Zeilschriften. 
sich dieser auf eine längere Benutzungsperiode verteilt, sind leichter zu beaufsichtigen, gestatten wegen der großen Pflanzenmenge, die in ihnen im Laufe der Jahre erzogen werden soll, die ausgiebigere Beschaffung von Apparaten, Schutzvorrichtungen, unter Umständen die Anlage von Bewässerungsvorrichtungen usw., im ganzen also einen feineren, intensiveren Betrieb. Beide Arten sind, je nach Umständen, in Uebung. Das entscheidende Moment ist vielfach, zunzal wenn Ballenpflanzen bei der Kultur in Anwendung kommen sollen, der Pflanzentransport. Bietet sich günstige Gelegenheit, nah bei einer demnächst zu kultivierenden Fläche W'andersaat-und -pflanzbeete anzulegen, so wird sie benutzt, im großen und ganzen jedoch sind wohl die ständigen Forstgärten mehr beliebt, obwohl finanzielle Erwägungen oft für Wanderkämpe sprechen. Für die Erziehung der einer sorgfältigeren Pflege bedürfenden und oft länger im Forstgarten stehenden Laubhölzer eignet sich der günstiger gelegene und dauernd überwachte ständige Forstgarten im allgeneinen melır als der kleinere unständige Garten. Diesem kommt aber für die Erziehung der weniger Pflege bedürftigen, in großer Menge gebrauchten Nadelhölzer eine überlegene Bedeutung zu.

2. W a lı l d e s P la t z e s. a) L a g e: Außer möglichster Nähe bei den Küulturflächen sowie bequemer Erreichbarkeit und Beaufsichtigung komnt die Umgebung, Abdachung, Exposition in Betracht. Steilere Hänge sind im allgemeinen ausgeschlossen, etwas geneigte Lagen dann erwünscht, wenn ausnahmsweise die Wahl eines etwa zu feuchten oder eines zu trockenen Ortes nicht umgangen werden kann, und im ersteren Falle für Wasserabzug gesorgt werden muß, im letzteren die Möglichkeit einer Bewässerung ins Auge gefaßt wird. Süd- und Südwestseiten sind im Hügelland und Mittelgebirge wegen Hitze und Trockenheit ebenso zu vermeiden, wie ungeschützte Ostseiten (Frostgefahr). Für die Anzucht von Holzarten, die kühle Temperatur sowie gröBere Luftfeuchtigkeit und Bodenfrische lieben, eignen sich, von den höheren Gebirgslagen abgesehen, am besten sanft geneigte nörlliche, nordwestliche und nordöstliche Abdachungen. In den höheren Lagen sind die Südhänge besser, die überall zu bevorzugen sind, wenn Wärme beanspruchende Holzarten erzogen werden sollen. Schutz durch umliegende Bestände kann sehr erwünscht sein; unter Umständen wirken solche aber auch nachteilig (event. Verdämmen durch dieselben, Reflex der Sonnenstrahlen am Trauf). Frostgefahr in tiefen Talsohlen. Nähe von Wasser erwünscht, soweit Wasserlieferung in trockenen Perioden in Frage kommt. Plätze im Inneren des Waldes verdienen den Vorzug vor solchen am Rande, weil letztere vom Felde her von den Mäusen schärfer bedroht werden, die sich im Herbst in den Wald ziehen. Schneebruch- und Windbruchlöcher nicht selten verwendbar, sofern sie noch nicht stark verunkrautet sind. Ueberhaupt ist der liampf mit dem Unkraut sehr zu beachten; man legt deshalb Forstgärten nicht gern auf größere Kulturflächeı. b) $\mathrm{B}$ o d e $\mathrm{n}$ : Zu fordern ist genügende mineralische Kraft in Verbindung mit den nötigen physikalischen Eigenschaften. Insbesondere soll der Boden nicht zu zäh und fest (kalter Tonboden) seiı. Böden mittlerer Beschaffenheit (sandiger Lehmboden) sind vorzuziehen ${ }^{1}$ ). Im Zweifelsfalle wähle man lieber einen etwas zu lockeren als einen zu festen Boden. Beachtung des Untergrunds, hauptsächlich in betreff des Wasserabzugs muß dringend empfohlen werden. Zu feuchter oder undurchlässiger Boden eignet sich der Gefahr des Auffrierens wegen niclıt. - c) G r ö B e: Da nur

1) Die Meinung, als ob Pllänzlinge för magere Kulturstellen auch in Forstgărten mit geringen Bōden erzogen werden müßten, ist irrig. Eher schon sind Pflanzen für rauhe Lagen vor VerzärteJung im Forstgarten zu bewahren. Die Forderung, die Vegetation solle allgemein im Forstgarten sich nicht früher entwickeln, als auf den liulturstellen, ist zu weitgehend, stimmt nieht fürs Hoehgebirge. Für lelzteres ist zu beachlen, daß Südseiten, falls der Boden genügend frisch ist, um so mehr den Vorzug verdienen, je höher die Lage ist. 
die Pflanzenzucht für den eigenen Bedarf hier in Betracht kommt, so ist die Flächengröße entsprechend der Zahl der jährlich erforterlichen Pflänzlinge, dem Alter und der Behandlung derselben (Daner ihres Verbleibens in dem Forstgarten, verschult oder unverschult, Verschulungsverband usw.) zu bemessen 1). Um in der Lage zu sein, nur tatsächlich gutes Pflanzenmaterial zum Auspflanzen zu bringen, empfiehlt es sich, mehr Pflanzen zu erziehen, als man braucht. Das zahlreiche mindervertige Material kann dann auf den Komposthaufen wandern. - d) G e s t a I t: Möglichst regelmäßig in Rücksicht auf Umfriedigung (Quadratform!) und Einteilung. Wo Seitenschutz von Wichtigkeit ist, kann ein langgestrecktes Rechteck den Vorzug verdienen; ebenso in geneigten Lagen (die größere Seite horizontal).

3. Bodenbearbeitung und Verbesserung. a) Nach grünllicher Rodung der Stöcke und Entfernung möglichst auch der schwächeren Wurzeln des Vorbestandes empfiehlt sich im allgemeinen voller Umbruch des Bodens mit Pflug, Spaten oder Hacke. Hand in Hand damit Entfernung von Steinen. Die verhältnismäßige Leichtigkeit der Bodenbearbeitung bei früherem Ackerland darf nicht für die Wahl des Platzes maßgebend sein. Ackerland kann wohl ausnahmsweise in Betracht kommen, ist jedoch meist ausgebaut und neigt zur Verunkrautung. Auch die melrjährige Ueberlassung des ausgewählten Platzes an die Landwirtschaft zum Anbau von Hackfrüchten, wodurch allerdings gute Bodenbearbeitung gewährleistet wird, ist wegen des damit verbundenen Entzugs von $M$ i n e r a l s t of $\mathrm{f}$ e $\mathrm{n}$ n $\mathrm{i}$ e $\mathrm{h} t$ r a t s a m. Vornahme der ersten tiefen Bodenbearbeitung in Herbst empfichlt sich, damit der Boden im Winter von Frost zermürbt wird. Ist der gewällte Ort stark verunkrautet, so bricht man ilan schon im Vorsommer um, damit das Unkraut verwest. Durchschnittliche Tiefe der Bodenbearbeitung $30-40 \mathrm{~cm}$. Das Belassen einzelner Bäume in der Forstgartenfläche ist aus Gründen der Beschattung, Abhaltung von Niederschlägen und Wurzellionkurrenz zu vermeiden. - b) P l a n i e r u n g , soweit nötig, insbes. Einebnen der Stocklöcher, wird mit dem Umbruch unmittelbar verbunden, event. Terassierung an Hängen, falls man zur Wahl eines stärker geneigten Platzes gezwungen ist: die einzelnen Beete sollen horizontal liegen. Unbearbeitete Streifen zwischen ilınen kömnen die Beetpfade ersetzen, dienen als Lagerstellen für Steine, Unkraut usw. Die darauf abgelagerten Naterialien liönnen gegen Abflutung Sicherung bieten. - c) Besserung der p h y ik a lis chen und c he mi$\mathrm{s} e \mathrm{~h}$ e $\mathrm{n} \quad \mathrm{B}$ od e n e igen se ha f t e n sollte von vornherein möglichst nicht erforderlich sein. In erster Linie sind Flächen bei der Wahl als Pflanzenerziehungsstätte unberücksichtigt zu lassen, die in physikalischer Hinsicht einer Melioration bedürfen. Mangelnder Nährkraft läßt sich viel leichter abhelfen. In schlimmsten Falle, wenn sich im ganzen Revier kein geeigneter Platz finden läßt, muß auch auf Besserung mangelhafter physilialischer Bodeneigenschaften zugekommen werden. Entweder ist dam mangelnder Bodennächtigkeit durch Rabattenbildung oder Zufülıung guter Erde abzuhelfen, oder durch Entwässerung, event. Drainierung für Trockenlegung nasser Stellen zu sorgen, oder der Bindigkeitsgrad des Bodens belarf einer Kórrektur. Das letztere ist das häufigste. Zu bindige Böden sind dann durch wiederholte Lockerung und Beimengung von lockernden Substanzen (Sand, Sägespänen, Torf, Humus, Komposterde, Rasenasche, Gerberlohe, Mergel, Stalldünger, Gründüngung), zu lockere durch die gleichen Beimengungen in günstigeren Zustand überzuführen.

1) Etwa $4-5^{\circ}$; der jährlichen Fulturfläche dürfte z. B. für den Fall einer lỉchtenwirlschaft bei Verwendung durchweg 4jähriger Pflanzen nach 2jähriger Verschulung genügen. Bei Verwendung 2jähriger Saatpflanzen stellt sich in der Fichtenwirtschaft der Bedarf an Saalkampfläche auf $1-1,5 \%$ der Kiulturfläclıs. 
Mit der steigenden Bedeutung der Pflanzkultur und dem damit zusammenhängenden Streben nach größter Leistungsfähigkeit und Verbilligung der Pflanzenerziehung hat die Erhöhung ungenügender Nälırkraft des Bodens durch Düngung mehr und mehr Anliłang gefunden. Für Wanderliämpe, deren Benutzung nur durch wenige Jahre währen soll, ist, falls nicht besonders ungünstige Verhältnisse vorliegen, die Düngung entbehrlich. Sie findet aber auch hier schon vielfach Anwendung. Ständige Forstgärten können ohne Düngung nicht auskornmen. Wenn sie auch nicht vom ersten Anfang ihrer Benutzung an die Düngung erforderlich maclien, so bedingt doch die stärkere Inanspruchnahme des Nährstoffkapitales durch die Pflanzenerziehung bald genug kräftige Nachhilfe durch Düngerzufuhr und man tut gut, nicht erst dann zu beginnen, wenn schon eine merliliche Erschöpfung eingetreten ist.

Die wichtigsten Stoffe, welche dem Boden durch die Düngung wieder zugeführt werden müssen, sind Stickstoff, Phosphorsäure und Kali, event, auch Kalk, der, abgesehen von seiner direkt nährenden Wirkung, auch noch eine Reihe günstiger chemischer und physilialischer Wirkungen auf den Boden ausübt. Wo es sich lediglich um Erhöhung des Nährstoffliapitales des Bodens handelt, werden tierische, pflanzliche, Mineral- oder sog. Hengedünger zugeführt. Als tierische Dünger kommen in Anwendung: Stalmist (am besten Rindviehdünger, weniger gut, weil zu hitzig, Roßoder Schafdünger), Poudrette, Jauche, Knochenmehl, Guano, künstlicher Guano (wie Fischmehl, Blutmehl etc.); als Pflanzendünger: Rasenasche, Holzasche, Torfasche, Humus (Dammerde), Gerbertohe, Gründüngung ${ }^{1}$ ); Nineraldïnger (natürliche und künstliche) sind u. a.: Mergel, Aetzkalk, Gips, Staßfurter Abraumsaize, bes. Kainit, Chilisalpeter, Thomasmehl, Superphosphat, Doppelsuperphosphate, schwefelsaures Ammoniak; als Hengedünger liommt zunächst Kompost verschiedenster Art. (unter Beigabe von Aetzkalk, Sägespänen, Torfmull, kräftiger Düngemittel, namentlich aus der Reihe der tierischen und mineralischen Stoffe) in V'erwendung ${ }^{2}$ ). Tierische, pflanzliche und Nengedünger, event. nur aus tierischen und mineralischen Einzeldüngemittehn zusammengesetzt, empfehlen sich, da sie den Boden an a 11 e n für die Pflanze wichtigen Nährstoffen bereichern, namentlich dann am meisten und allgemein, wenn über die Art der Bodenerschöpfung Zweifel bestehen. Die pflanzlichen Dungstoffe, in erster Linie Humus und Gründüngung, verbessern außerdem den physikalischen Zustand des Bodens in vorteilhaftester Weise und unterstützen die Wirkung der konzentrierten Handelsdünger. Gründüngung erfolgt am zweckmäßigsten durch Anbau von Leguminosen auf der später zur Pflanzenzucht zu verwendenden Fläche oder auf brachliegenden Teilen von Forstgärten. Für lialkame, sandige Böden eignet sich nach den Untersuchungen von E $n \mathrm{~g}$ l e r. und G l u t z (Mittlgn. d. schweiz. Zentralanst. f. d. forstl. Versuchw. VII Bd. S. 319) die gelbe Lupine, für Lelım- und Tonböden Futterwicke, für liallireiche Böden Ackererbse und Saubohne. Einsaat im Mai und zwar entweder breitwürfig (pro Ar $2-3 \mathrm{~kg}$ Lupinensamen) oder in Reihen mit ungefähı $25 \mathrm{em}$ Reihenabstand $(1,5-2 \mathrm{~kg}$ pro Ar). Während der Blüte (August, September) werden die Pflanzen angewalzt und grün untergehackt. Gegenüber der Gründüngung mit Gräsern und Unkräutern gewährt die Gründüngung mit Legumi-

1) Vergl. "Lupinenbau in Forsten" in "Aus dem Walde" VIII, S. 160.

2) Liter. Angaben siehe in Fürst, Pflanzenzucht, 4. Aufl. S. $36 \mathrm{ff}$. Mlan vergl. außerdem I Grundner, „Die Düngung im Forstbetriebe, insbes. in Forstgärten" (Harzer Forstverein 1897); R a m nı ,Rationelle Düngung der Forstgärten", in Bericht über die 17. Vers. des würtı. Forstvereins zu Calw, 1900; fermer il a t the s, Ueber kinstliche Düngung in forstl. Belriebe“" (Vers. Thüringer Forstwirle zu Eisenach, 1900). Zahlreiche Mitteilungen über Einzelversuche finden sich in den versch. forsll. Zeitschriften. - H e 1 b ig, Ueber Dünung in forstl. Betriebe. Neudamm 1906; - V a te $r$, Düngungsversuche in Saalkämpen auf Sandsteinbŏden usw. Tharand. Jhrb. 1905, S. 116 , - 
nosen infolge der Fähigkeit dieser Pflanzen, den Stiekstoff der Luft zu assimilieren, den wichtigen Vorteil der Stickstoffanreicherung im Boden, eine Wirkung, die namentlich damn in Erscheinung tritt, wenn vor der Einsaat der Leguminosen eine kräftige Mineraldüngung mit Plıosphorsäure, Kali und Kalk stattfand ${ }^{2}$ ).

In neuerer Zeit finden im Forstgartenbetrieb die oben genanuten künstlichen Mineraldünger (= lonzentrierte, relative oder Hilfsdünger) melır und mehr Verwendung, weil sich nit ilınen dem Boden die notwendigsten Pflanzennälırstoffe in beliebiger Menge auf leichte W'eise zuführen lassen.

Als Spezialdünger für $P$ hos $p$ horsä u re d üng u n g verwendet man hauptsächlich Superphosphat, Doppelsuperphospliat und Thomasmehl. Letzteres empfielılt sich für Sandund saure Böden und wirl, da es für rasehe Düngungen ungeeignet ist, in der Regel im Herbst gegeben und untergearbeitet. Die sehneller wirkenden Superphosphate kommen für seluwere Böden in kalter Lage in Betracht und eignen sich mehr zur Obenaufdüngung im Frülijahr.

Hauptdüngemitlel für K a I i d ü $\mathrm{n}$ g u $\mathrm{g}$ ist Kainit mit nngefähr $12,4 \%$ Kaligehalt. Da das in ihm enthallene Chlor, frisch an die Pflanzenwurzeln gebracht, ätzend wirlit, wird liainit entweder in Fráhjahr nehrere Wochen vor Beginn der Vegetation oder besser noch sehon im Herbst oder Winter in den Boden eingejuracht. Seiner ätzenden Wirkung wegen erietzl man den Jiainit namentlich auf schweren Böten neuerdings mit Vorteil durch den natron- und chlorärmeren ,toprozentigen kialilünger".

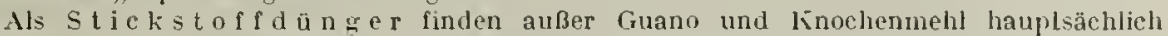
Chilisalpeter und sehwelelsaures Ammoniali Verwendung. Bei Chilisalpeter tritt die Wirkung sofort ein, häll aber nicht lange an. Man benützt ihn deshalb zur Obenaufdüngung kurz vor oder während der legelation und gibt ihn nur in kleineren Mengen (auf 1 qm 20 Gr.). Schwefelsaures Ammoniak muß sich, um wirksan zu werden, im Boden zunächst in ein salpetersaures Salz umwandeln, fordert lierzu einen gewissen lialkgehalt des Bodens und kann entsprechend seiner langsamen Löslichkeit in Herbsl eingebracht werlen.

Außer den genannten künstlichen Düngemilleln sind noch einige andere neuerdings in den Handel gebrachte konzentrierte Dünger, z. B. Kalisuperphosphat, Ammoniaksuperphosphat für verwendung im Forstgartenbetriebe beachtenswert.

Besondere Bedeutung kommt fermer der $\mathrm{k}$ a $\mathrm{l} k \mathrm{k}$ ü $\mathrm{n} \mathrm{g} \mathrm{n} \mathrm{n} \mathrm{g}$ zu und zwar weniger der Zuführung eines direkten Nälırstoffes wegen, sondern namentlich deshalb, weil durch den Kalk der plysikalische Zustand des Bodens gebessert, schwerer Boden z. B. gelockert und erwärmt wird, und weil außerden die in Boden in einer für die Pflanzen nicht aufnelumbaren Form vorhandenen Nährstoffe in assinulierbare Verbindungen übergeführt werien. Die Zuführung

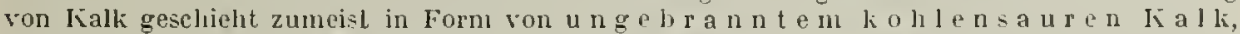
gebran t em oder A etzk a k, fips oder Mergel. Außerdem ist lialk cin Nebenbestandteil cinzelner oben genannter Mineraldünger, z. B. des Superphosphates und des Thomasmehles. Für nasse, kalte und schwere Böden eignel sich unter den lialkiungern am besten der in physikalischer llinsicht am energischsten wirkende $A$ e $\mathrm{z} k \mathrm{k} / \mathrm{k}$. Bei Zufulhung von Aetzkalk ist gleichzeitige Düngung mit schwefelsaurem Anmoniak zu vermeiden. da sich sonst freies, den Pflanzenwurzeln sclıälliches Ammoniak bildet. Aetzlialk wird pulrüörmig ausgestreul und sofort untergehackt. Anf trockenen leichten Böden, wo es sich mehr um eine nachhallige Dünung handelt, wird am besten zermahlener, $\mathrm{u}$ g e b r a n $\mathrm{t}$ er $\mathrm{k}$ o hle $\mathrm{n}$ s a u r $\mathrm{r}$ Kalk verwendel. Der Iangsan wirkende Me rgel, cin Gemenge von kohlensaurem Kalk nit Ton oder Lelnm und Sand, eignet sich der letzteren Bestandteile wegen benonders für sandige Böden, ist aber, um wirksam zı werden, in grōßeren Quantitäten zuzuführen und wird durch die Transporthosten leicht zu teuer. Gipslungung ist in physikaliseluer Hinsicht wenig wertvoll, verdient aber auf trägen, an sich nicht nåhrstoffarmen Böden als indirekte Düngung zur Aufschließung der Nährstofe Beachtung.

A usfü lı rung der D ï $n g$ u $n$ g. Von großem Einfluß auf den Erfolg der Düngung ist der Zeitpunkt der Ausfühong. Man spricht von vorausgehender Düngung, wenn vor der Aussat bezw. vor der Bepflanzung gediungt wird, und bezeichnet die Zuführung von Düngung auf mit Pflanzen bestockte Beete als Zwisehenoder Kopfdüngung. Inwieweit die eine oder die andere Art zweckmäßig ist, clarüber entscheiden Bodenuntersuchung und das im Ausselien und in der Entwickelung der

1) Vergl. hierzu: K o e h, Düngung dureh lebende l'apilionaceen. Allg. Forst- u. J.-Zlg. 1902, 11. - H of $\mathrm{n}$ ä $n \mathrm{n}$ e r, Düngung der Pflanzıåren. D. prakl. Forstwirt f. 1. Schweiz 1900 , S. 6. - G a r e is, Aus den Pflanzgartenbetrieb in k. layr. Forslant Anzing. Funstw. Zbl. $1903,233$. 
Pflanzen zum Ausdruck kommende Düngerbedürfnis. Jeder wiederholten Benutzung eines Saat- ader Pflanzenbeetes hat grundsätzlich eine Düngung voranzugehen. Die Düngungen erfolgen meist gelegentlich der zweiten Bodenbearbeitung im Frühjahr. Gründüngungen, überlıaupt Tiefdüngungen, desgleichen Düngungen mit Kainit und Thomasmeh] werden besser im Herlsst vorgenommen. Holzart und Zuchtziel bestimmen die $\mathrm{T}$ i e f e der Düngung. Tiefwurzelnde Holzarten (Eiche, Kïefer) und Verschulungsbeete erfordern ticferes Einbringen des Düngers als Saatbeete und als Holzarten mit zunächst weniger tiefgehenden Wurzeln. Je tiefer aber die Düngung untergebracht wird, umsomehr wird die Pflanze zur Ausbildung eines ausgebreiteten, das Pflanzgeschäft erschwerenden Wurzelsystems angeregt. Es ist deshalb im allgemeinen zweckmäßiger, nur die obcren Bodenschichten durch Düngerzufulır nährstoffreicher zu machon, um so die Bildung eines konzentrierteren Wurzelbaues zu veranlassen. Ueber die N e n ge des bei der einmaligen Düngung zur Verwendung kommenden Düngers lassen sich nur ungefähre Anhaltszahlen geben. Infolge der großen Beweglichkeit und Veränderlichkeit des Düngemwertes im Boden sind schwächere, öfter wiederholte Düngungen vorteilhafter als einmalige stärkere sog. Vorratsdüngungen. Bei einzelnen Düngerarten, z. B. bei Chilisalpeter und liainit wirken stärkere Düngungen sogar leicht direkt schädlich und sind schon aus diesem Grunde zu vermeiden. Zulässig und gebräuchlich sind Vorratsdüngungen nur bei Kalki und Thomasmehl. Je nach den Bodenverhältnissen werden bei der einzelnen Düngung auf 1 Ar verwendet: Chilisalpeter, schwefelsaures Anmoniak $2-1 \mathrm{~kg}$, Ammoniak-Superphosphat $2-3 \mathrm{~kg}$, liainit $2-6 \mathrm{~kg}$, lialk $30-40 \mathrm{~kg}$, Guano $6 \mathrm{~kg}$, Stalldünger $2-4 \mathrm{Ztr}$, liompost, Dammerde $3-4 \mathrm{cbm}$, Mergel $1,5 \mathrm{cbm}$.

d) Eine wi c d e r ho Ite Boden bea rbeitung mit Hacke und Rechen oder anderen Bodenbearbeitungswerkzeugen (Spitzenbergsche liulturgeräte) findet in Verbindung mit der gartenmäBigen Zurichtung der Beete und dem Ausheben der Fußpfade im Frülijahr vor der Bestellung des Forstgartens statt. Auf selır lockerem Boden ist der Herbstumbruch unter Umständen entbelulich, zumeist aber auch hier rätlich. Wie schon vorstehend erwähnt, wird mit der Frühjahrsbearbeitung vielfach Düngung verbunden. Die Bearbeitung geschieht zwecknäßigerweise einige Zeit vor der Ansaat der Beete, damit sich der gelockerte Boden wieder setzt.

4. Einteilung, in $\mathrm{nere}$ Einrichtung: Beete von angemessener Breite (bis zur Mitte bei clen Arbeiten leicht zu erreichen) und Beetpfade wechseln niteinander ab. Dazu kommen einzelne breitere Wege für Karren etc. Durchschnittliche Beetbreite 1-1,2 Meter, Pfadbreite 0,3 Meter. Da durch die Beetpfade der eigentlichen Pflanzenzucht immerhin viel Areal entzogen wird $(1 / 4-1 / 3$ der ganzen Flächc), so empfiehlt sich bei einheitlichem Betrieb, d. h. bei der Anzucht großer Mengen gleiclıartiger Pflänzlinge das Zusammenschließen von Beeten (ohne zwischenbelegene Pfade) zu größeren Quartieren, welche dann allerdings bei den jeweiligen Arbeiten (Verschulen, Jäten etc.) betreten werden müssen. Es ist deshalb zweckmäßig, sie niclıt mit Saat-, sondern besser mit weiter von einander abstchenden Schulpflanzen zu bestellen.

5. Die Aussa a t in Forstgarten. a) Arten der A ussa t: Vollsaat oder Rillensaat. Bei ersterer crhält man mehr Pflanzen als bei der Rillensaat; auch steht den Pflanzen cin gleichmäßigerer Entwiclilungsraum für Wurzel und Kronc zur Verfügung, cin Vorzug, der namentlich clann zum Ausdruck konımt, wenn nicht verschult verden soll. Dagegen sind dic voll besäeten Beete mühsaner zu reinigen, das Ausfrieren ist bedenklicher, weil sich Deckmittel schlechter anwenden lassen als bei der Rillensaat, die einzeln lieimenden Pflänzlinge (Nadelhölzer) drüclien 
durch eine etwas verkrustete Oberfläche schwerer durch. Rillensaat bildet dic Regel. b) S a n e n m e $\mathrm{g}$ e: Im allgeneinen gelten hier dieselben Erwägungen wie für die Dichte der Saat überhaupt. Nicht zu dicht säen! Weniger dicht, wenn gar nicht oder erst nach 2-3 Jahren verschult wird. Bedingend ist iiberdies die Entwickelung der einzelnen Holzart in der ersten Jugend. Anfangs langsamwüchsige Holzarten liönnen dichter stehen oder länger im Saatbeet verbleiben (Gegensätze z.B. Tanıe und Schwarzkiefer, Buche und Akazie). liein großer Untersehied zwischen Voll- und Rillensaat bezüglich der Samenmenge (z. B. bei Kiefer pro 1 Ar 0,5-1,0 kg) $\left.{ }^{1}\right)$. - c) Z e it d e r A us a a t: Auch hier gelten die allgemeinen Bestimmungsgründe. Nöglichkeit ins einzelne gehender Pflege in Forstgarten kann modifizierend wirken. Meist Frühjahrssaat. - d) Voll z u g: Volls a t stets aus der Hand, nach vorgängiger gehöriger Herrichtung der Beete. - Rill e n a a t: Richtung der Riefen bald quer über die Beete (bequemer für gleichmäßige Aussaat, Bedeckung, Reinigung), bald in deren Längsrichtung. Sclmnale Rillen (womöglich nur1, höchstens 2 etwas voneinander entfernte Samenreihen - Doppelrillen). Entfernung derselben so gering, daß die Pflanzen zu seitlicher Entwickelung gerade genügend Paum liaben. Herstellung entweder mit der Hacke oder einem Rillenzieher (Spitzenberg), oder mit Hilfe von Saatlatten, Saatbrettern, Walzen mit entsprechenden Erhöhungen, wie z. B. der regulierbaren Saatrillenwalze von Holl (Oe. Forstz. 1898, 193), der Saatrillenwalze von Zinger (Allg. Folst- น. J.-Z. 1890, 41:) usw. Aussaat aus der Hand oder unter Benutzung von Apparaten, wie z. B. Sächorn, Saatrinne, Saatbrett ete. Als besonders brauchbar hat sich die Eßlingersclie Säelatte mit zugehörigem Samenkasten (Forstw. Zentralbl. 1890, S. 535) bewährt; sie arbeitet rasch und gibt gleichmäßige Verteilung des Samens. Empfohlen wird auch die Rillensäemaschine von Fekate (Oesterr. Forstzeitung), ferner Hacker's Gartensaatmaschine(Oesterr. Forst-u. J.-Z. 1890, S. 299, Forstw. Zentralbl. 1902, 327), Hörmanns Säeapparat (Forstw. Zbl. 1903, 622; 1904, 122, 452, 639), Schneiders, Spitzenbergs Säemaschine u. a. Bedeckung des Samens in erforderlicher Höhe mittels Rechens, Ueberwerfens oder Uebersiebens mit feiner Erde, Rasenasche etc. Die Höhe der Bedeckung ist je nach der Art des Samens und des Deckmaterials verschieden. Je lockerer das letztere ist, um so stärker kann im allgemeinen der Samen eingedeckt sein. Maßgebend im einzelnen sind die Bemerkungen zu $\$ 57$, E. S. 116.

6. Pflanzbecte in Forstgarten. Verschulen. Das Versclıulen hat den Zweck, den jungen Pflänzlingen vor der Benutzung zur liultur durch Gewährung freieren Standraumes in gut hergerichteten Pflanzbeete zu kräftiger Entwickelung zu verhelfen. Man will dadurch kräftige, gut bewurzelte, stufig und gleichmäßig beastete Pflanzen erziehen, die sich auf allen, irgend einer Gefahr ausgesetzten Standorten brsser bewähren als Saatpflanzen. Im einzelnen Falle dient die Verschulung der Erziehung von Ballenpflanzen. Die mit dem Verschulen verbundenen höheren liosten łassen eine Besclıränkung in der Verwendung verschulter Pflanzen auf solche Standorte erwünscht erscheinen, wo die Saatpflanze in ihren Leistungen zurücksteht. Man lat stellenweise fast rergessen, daß sich durch dünne Saaten Pflanzen erziehen lassen, die den verschulten Pflanzen qualitativ kaum nachstehen und für viele Verhältnisse vollauf genügen, wo man olıne verschulte Pflanzen nicht auszukommen glaubt. a) A I t e r d e r P f länzling e: bei möglichst frühem Verschulen (1—2jälrige Pfłanzen) hat man leichtere (billigere) Arbeit und größeren Erfolg, sofern die

1) Die schweiz. Versuchsanstalt hat bei Fichte und liefer von $10 \mathrm{gr}$ Samen pro laufenden Meter das Maximun an brauchbaren Pflanzen erhalten. cfr. Mitteilungen der schweiz. Zentralanstalt für d. forstl. Versuchsw. I, 1. 
Pflanzen besser anwachsen und länger im Verschulbeete bleiben können. Sogar ganz junge Keimlinge (aus natürlichem Anflug) werden unter Umständen verschult. Werden sie einem etwas bindigen Boden entnommen, so kann der kleinste Heyersche Hohlbohrer mit Vorteil verwendet werden. - b) Z e it d e r Vor n a h m c: Herbst und Frühjahr. Die Erfahrungen im Tübinger Versuchsgarten lassen die Herbst- und die Frühjahrsverschulung als ziemlich gleichwertig erscheinen. Natürlich ist eine Hlerbstpflanzung mit der Pflanzung im nachfolgenden (nicht im voraufgegangenen) Frühjahr zu vergleichen. Dr. Cieslar ${ }^{1}$ ) hat sich gegen die Herbstpflanzung ausgesprochen, und Bühler (1895) hält nach seinen Versuchen das Wachstum nach Herbstpflanzung bei allen Holzarten für geringer als dasjenige nach Frühjahrspflanzung. Geeignete Arbeitsverteilung spricht wesentlich bei der Wahl der Pflanzzeit nit. Wenn bei einer Herbstverschulung kleine Sämlinge verwendet würden, ist die Gefahr des Ausfrierens besonders zu beachten. Durch Leberschirmen, Bodenbedeckung usw. wird ibr vorgebeugt; durch Frost gehobene Pflanzen sind rechtzeitig wieder anzudrücken. c) Da uer des Verbleibs im Pfla 11 zbe t: meist 2-3 Jahre (1 Jahr ist zu wenig, der Vorteil bei so kurzer Zeit zu gering). - d) Sorgfältige B o d e n z uric htung geht voraus. - e) A ush eben, B eschneiden, A n s c hl 1 ä m$\mathrm{m}$ e $\mathrm{n}$ d e r P f l ä n z ling e: Da ein Transport zum Zweck des Verschulens sehr häufig nicht in Frage steht, so werden die Pflänzlinge am besten unmittelbar aus dem Saatbeet ins Pflanzbeet gebracht. Einstutzen von Schaft und Wurzel unterbleibt (abgesehen von zu langen Wurzeln und beschädigten Organen). Desgleichen das Anschlämmen. Erfordert die Platzfrage (Beeträumung etc.) früheres Ausheben, oder kommen Pflänzlinge von auswärts (z. B. Schlagpflanzen oder durch Ankauf erworbene Saatpflanzen), so ist sorgfältiges Einschlagen an feuchtem, schattigem Ort nötig. Sortiercn der schwachen von den stärkeren Pflänzlingen je für besondere Beete ist zur Erzielung der GleichmäBigkeit wünschenswert; andernfalls werden (zumal bei Laubhölzern wie Ahorn und Esche) die schwächeren Pflanzen von den vorauseilenden stärkeren in ibrer Entwickelung beeinträchtigt. Wenn möglich sind nur gesunde, kräftige Pflanzen zu verschulen; alle Schwächlinge sind vorher auszumustern. Hinderwertige Saatpflanzen auf besonderen Pflanzbeeten zu verschulen, um aus ihmen noch brauchbares Material zu erziehen, ist nicht ratsam. Sie haben meist nicht nur stärkeren Abgang, sondern verlangen auch eine sorgfältige, um Jahre verlängerte Pflege im Sclulbeet, ohne dadurch zu besonders kräftigen Pflanzen zu werken. - f) P f l a n z e n e n tf e r n u n g, V e r b a $n d$ : Allseits genügenrler Raum für die Zeit, welche die Pflanze im Verschulbeet verbringen soll, ist Bedingung. Da diese Zeit nach Entwickelung der einzelnen Holzarten verschieden ist, so kann kein einheitliches Maß angegeben wcrden. Um auf gegebener Fläche eine möglichst große Pflanzenzahl zu erzielen, wird man immerhin nicht weitständiger verschulen, als notwendig ist; in kcinem Falle sollten sich die verschulten Pflanzen bald wieder gegenseitig bedrängen. Meist Reihenverband (z. B. für ljülırige Fichten 10:5-7 cm, 2 Jahre in Pflanzbeet) im Interesse der Beetpflege. Sonst ist Quarlratrerband, wegen der gleichmäßigen Verbreiterung nach allen Sciten hin, hesser. - g) A u s f ü h r u g , H il f sm it t e I: Pflanzung im Taglohn oder Akkord. Dabej ist scharfe Kontrolle sehr angezeigt, danit nur tadelloses Material verwendet wird. $\mathrm{Zu}$ beachten ist ferner insbesondere, daß die Pflanzen nicht tiefer eingesetzt werden, als sie im Saatbeet gestanden haben, und daß Verkrümmungen und Unstülpungen der Wurzelenrlen vermieden werden. Die Verschulung kleinerer Saatpflanzen erfolgt gewölunlich unter Zuhilfenahme einfacher

1) Mitteilungen aus dem forstl. Versuchswesen Oesterreichs, Ileft Xil, 1892: ,Die Pflanzzeit in ihrem Einfluß auf die Entwicklung der Ficlite und Kiefer". 
oder komplizierterer Verschulungsapparate (Setzholz, Zapferbretter, Verschulungsgestell von Ecli ${ }^{1}$ ), Verschulungslatten ${ }^{2}$ ), Rillenpflug ${ }^{3}$ ), Verschulungsapparat bezw: -maschine von Itacker ${ }^{4}$ ), Thygesonsche Pflanzharke ${ }^{5}$ ) u. a.) teils in Löcher, teils in Gräben. Der Gefahr von Wurzelverkrümmungen wegen sind in allgeneinen alle Verschulungsmethoden zu verwerfen, die, wie die Handverschulung mit dem Setzliolz oder dem Zapfenbrette, auf Einsetzen der Pflänzchen in kegelförmig in den Boden eingedrückte Löcher hinauslaufen. Einwandfrei erscheint in dieser Beziehung nur die Verschulung in genügend tief hergestellte Gräben, an deren eine senkrecht abgestochene Wand die Pflänzchen mittels Einhängclatten usw. dcrart in bestimnten Abständen verteilt werden, daß ihr fächerförmig ausgebreitetes Wirzelsystem auf der Grabensohle nicht oder eben nur aufstöBt. Durch Wiedereinfüllen und Andrücken des Grabenaushubes werden die Wurzeln der verschulten Pflanzen eingebettet. Die durch die Verschulung angestrcbte Verdichtung des Wurzelsystems sucht man nicht olne Erfolg auch dadurch zu erreichen, daß man die seitlich ausstreichenden Wurzeln der in der Saatrille stehenden Pflanzen mit einem schneidenden Instrument (Hirschänger, Säbel, Muthsche Wurzelschnittmaschine ${ }^{6}$ ), Kaisersches Wurzelschneidemesser ${ }^{i}$ ) durchschneidet. Im Verschulungsbeet angewendet, unterstützt dieses Verfahren die Bildung von Ballen durch Wurzelverfilzung. - h) WV i e d e rl o l u $\mathrm{g}$ : Zur Erziehung besonders starker Pflanzen (Tannen für Kahlschläge, Laubholzheister etc.) manchmal zweimaliges Verschulen (meist nach 2-3 Jahren wiederholt).

7. Scliutz und Pflege der Sa at-und Pflanzbeete. In Revieren mit $\mathrm{W}$ j $I \mathrm{~d}$ s $\mathrm{t}$ a $\mathrm{n} \mathrm{d}$, auch gegen Weidetiere, müssen die Pflanzenerziehungsstätten durch Einfriedigungen geschützt werden. Die Art der Umfriedigung ist insbes. durch die abzuhaltenden Tiergattungen bedingt (feste Zäunc gegen Sauen, entsprechende Höhe gegen Ueberfallen von Rotwild, dicht am Boden gegen Hasen und Kaninchen usw.). Unter Umständen transportable Hürden. a) T o t e U n z ä u n u nge n: Rollsteine (gegen Weidvieh), Mauern (zu teuer); Planken-, Pfosten-, Latten-, Stangen-, Spriegelzäune (in verschiedenster Modifikation); Drahtzäune (starke Horizontaldrähte, event. an stehende Bäume befestigt; zwischengeflochtene dünne Vertikaldrähte). Gilt es, Sauen abzuhalten, so leisten Spriegelzäune (Querstangen mit zwischengeflochtenem starkem Reisig) wegen ilırer Elastizität gute Dienste; sie sind, zumal wenn erste Durchreiserungen oder Durchforstungen in der Nähe das Material ergeben, auch nicht liostspielig. Im übrigen dürften sich transportable, etwa 3-4 Meter lange, $1 \div$ Meter hohe Gatter aus Fichtengestänge mit aufgespanntem Geflecht aus verzinktem Draht besonders empfehlen. Der Draht kann, da das entsprechend hergestellte Stangengatter den erforderlichen Halt verleilht, dünn sein. Das Geflecht braucht, wenn im Winter hohe Schneelagen fchlen, rom Boden an nicht über $1 \mathrm{~m}$ hoch zu sein, um gegen Hasen und Rehe zu schützen. Solches Drahtgeflecht wird

1) Allg. F.- U. J.-Z. 1885, S. 197.

2) Das. 1884, S. 7 .

3) z. B. S c h m it t, ,Anlage und Pflege der Fichtenpflanzschulen" 1875 , sowie F is c lib a $\mathrm{c} \mathrm{h}$ in Allg. F.- u. J.-Z. 1867, S. 85 .

4) Zentralbl. f. d. ges. Forstw. 1886 , S. $230 ; 1891$, S. 373 . Der Hackersche Verschulungsapparat (cfr. Oester. F.-Z. 1891, S. 207) arbeitet gut und ist, teurere Masehinen ersetzend, bcsonders warm zu empfehlen, wenn große Pflanzenmengen zu bewältigen sind, vgl. Forstw. Zbl. 1903,$233 ; 1904,463$.

5) Zeitschr. f. Forst- u. Jagdwesen von D a n cke $1 \mathrm{~m}$ a n n 1885 , S. 25.

6) Bernstein, Das Nuthsche Pflanzenzucht- und Kulturverfahren. Forstw. Zbl. 1906,$18 ;$ F o r s t, Der Muthsehe Wurzelverschnitt, ebend. 1899, 227. -

7) Sinz, das Kaisersche Wurzelsehneidemesser. Allg. F-. U. J.-Z. 1906, 356. 
zu 16-20 Pfg. pro laufd. Meter bezogen. Zur gleichzeitigen Sicherung gegen Kaninchen muß das Geflecht höher sein, da etwa $20 \mathrm{~cm}$ in den Boden eingelassen werden müssen. Sorgfältiges Aufstellen der Gatter auf den Boden und scharfes Aneinanderschließen ist Bedingung. - b) L e be n d e H e c k e $\mathbf{n}$ : Weißdorn, Fichte, Tanne, Eibe, Hombaum. Da die Anlage und Unterhaltung (Besehneiden etc.) viel Mühe und Sorgfalt erfordert und ein liasendichter Abschluß des Gartens durch eine Hecke nicht erreicht wird, wendet man besser eine tote Umfriedigung an. c) $\mathrm{G} r$ ä b e $\mathrm{n}$ in Verbindung mit den Schutzmitteln unter a und $\mathrm{b}$ bewirken eine noch weitergehende Sicherung, bes. gegen das Ueberfallen von Wild. - d) Ii o s t e n nach Material, Arbeitsaufwand sehr verschieden in Hinsicht auf erste Anlage und Unterhaltung ${ }^{1}$ ). - Weitere Gefahren drohen Samen und Pflanzen durch Trocknis, Frost, Regengüsse, Lnkrautwuchs, pflanzliche und tierische Parasiten, Mäuse und Vögel. Gegen Hitze und Frost sowohl als gegen Platzregen sichert Bedecken der Beete mit Laub, Moos, Sägemehl, Torfmull, Brettchen, gespaltenen Stangen, Stroh (rechtzeitige Entfernung der Bedeckung beim Kieimen), Besteeken mit Zweigen (abfallende Nadeln manchmal störend), Leberdecken mit Schattengittern verschiedener Art. Gegen Trockenheit, wenn nötig, Begießen (öftere Wiederholung). Auch oberflächliche Bodenlockerung ist ein Mittel gegen das Austrocknen, demn obwohl die schwache, dabei losgelöste Oberschichte stark trocken wird, schützt sie doch die unterliegende Bodenschicht, welche feucht bleibt. Lebrigens darf solches Belıäckeln nur nach einem durehdringenden Regen gesehehen. Anwendung von senkrecht stehenden Schutzschirnen gegen Wind und Sonne. Gegen Vögel dienen die Schutzgitter (zugleich Schattengitter), gegen Mäuse das Vergiften etc. Behandlung des Samens vor der Aussaat mit Bleimennige in der Art, daß der angefeuchtete Samen mit trockenem Mennigepulver überstreut und dadurch mit einer Mennigehülle ungeben wird, bietet weitgehende Sicherung gegen Vogel- und Mäusefraß. Häher, Tauben, Eichhörnchen sind abzuschießen. Aushängen ron Nistkästen zugunsten inselitenfressender Vögel. Fangen der Maulwurfsgrillen (cfr. lierüber Forstschutz, 2. Bd., VII. des Handbuchs). Ausjäten des Unkrautes, je nach Bedarf mehmals jährlich. Pflege der Pflanzen durch Andrücken vom Frost gehobener Pflänzlinge, durch Bodenlockerung, Anhäufeln der Erde nach den Riefen zu. In ganz hervorragender Weise bewälut sich nach Gi es l a r (Zbl. f. d. ges. Forstw. 1S93, 24) Hoosdechung. Sie erscheint als Universalmittel gegen Austrocknung, Unkrautwuchs, Bodenverdichtung und Auffrieren. Durchrupfen oder Durchschneiden zu dichter Saaten, Zwischendüngung. Pflege einzelner Pflanzen, namentlich bei der Laubholzerziehung durch Besclmeiden (Entfernung von Doppelgipfeln, Zweigen, Ausbrechen von Tinosjen etc.).

S. K o st e $\left.n^{2}\right)$. Alle Forstgärten stellen durch Anlage und Unterhaltung eine mehr oder minder starke Belastung des Küturfonds dar. Die Ausgaben sind auf das notwendige Maß zu heschränken, jede Spielerei ist zu vermeiden. Auf zweckmäßiges Ineinandergreifen der Einzelarbeiten ist namentlich Wert zu legen. Teuer ist insbes.

1) Drahtzăune, inkl. Pfostenmaterial etc., zun Schutz gegen Hasen und Rehwild kaum unter 0,80-1,00 . . k . pro lfd. Meter; thei Befestigung an lebende Bäume ca. 0,50 Mli. Verbindung der Pfosten oben und unten durch je eine Stange gibt ein besonders festes Gefüge beim Durchfleclten dünner Vertiliadrähte. - Bei Inwendung der oben erwähnten Stangengatter mit aufgespanntem Drahtgeflecht liumnt es bezüglich der Kosten hauplsächlich darauf an, ob der Wald das stangenmalerial (aus Fichtendurchforstungen) in genügender Menge und in der Nāhe des Gartens liefert. efr. Mitteilungen der Würtl. Versuehsstation, Allg. F.- und J.-Z. 1897, S. 10t; ferner: Dr. Grieb daselbst S. 74 (enth. Zusammenstellung der kosten versehiedener Unfriedigungen). - Se hu h $\mathrm{m}$ a $\mathrm{e}$ h e r, Wildgatter 2. Aufl. 1898.

2) Vergl. Thar. Jhrb. 1893, 110. - Forstw. Zul. 1894, 140. - 
das Verschulen (Zeit- und Raumerfordernis!). Unter Umständen Versehulen von Schlagpflanzen auf kleinen Stellen in oder bei den Schlägen selbst. Allgemein gültige liostensätze sind nicht zu gewinnen; Ablängiglieit derselben insbes. von den ortsüblichen Tagelölmen. Angaben z. B. in F ü rs ts Pflanzenzuclıt, im Forst- und Jagdkalender usw.

In vorsteliender Schilderung des Pflanzgartenbetriebs ist nur das Notwendigste entlialten und auch das großenteils nur in Andcutungen. Gerade auf dem Gebiete der Pflanzenzucht im Forstgarten hat sich eine große Vielgestaltiglieit entwickelt mit. zahlreicher Modifikation der Durchfülıung aller einzelnen Arbeiten, je nach Oertliclkeit, Holzart, Umfang der Anlage usw. Eigenc Erfahrung und Bcobachtung, zumal der exalite vergleichende Versuch führt fortwährend zu größerer Sicherheit, zu Verbesserungen, Kostenersparnis, also allgemein zu gesteigertem Erfolg, namentlich auch in Punkte der Rentabilität. Dabei sollten aber die Erfahrungen, die anderwärts gemacht sind, sorgfältig beachtet und in ausgiebigster IT eise benutzt werden, damit nicht Regeln, die sich unter bestimmten Verluältnissen bewälırt haben, erst wieder von Neuem und vielleicht erst nach mancherlei Mißerfolgen gefunden werden müssen. Auf das mehrfach erwähnte Werk von F ürst (Die Pflanzenzucht in Walde) als auf einen guten Führer, dann auf die Resultate des Forstgartenbetriebs der schweizerisclien Versuchsanstalt (Mittcilungen der schweiz. Zentralanstalt I, 1, 2, 3, sowie II, I u. 2), ferner auf die Mitteilungen $W$ e ise s ,Erfahrungen und Beobachtungen aus dem Forstgartenbetrieb" (zu Karlsruhe) in Mündener Forstliche Hefte II, S. I, sowie auf die Mitteilungen der württembg. Versuchsstation (Allg. Forst- u. J.-Z. 1897, S. I04, woselbst auf die früheren Mitt. hingewiesen ist) sei u. a. noclımals besonders aufmerksam gemacht. Sehr wertvoll ist auch die Abhandlung von $G$ a $r$ is , Aus dem Pflanzgartenbetrieb im ligl. bayr. Forstamt Anzing. Forstw. Z1)l. 1903, S. 233.

Auch soll an dieser Stelle der Spitzenbergschen Kulturgeräte gedacht werden, von welchen sich nicht wenige gerade beim Forstgartenbetrieb mit Vorteil verwenden lassen $\left.{ }^{1}\right)$. Sie dienen, wie z. B. der Wühlspaten und der Wühlrechen, zur Bodenlockerung, andere (Gitterwalze und Saatbedecker) in großer Zalıl den Saatgeschäft (zur Anfertigung aller Arten von Rillen, zum Decken des Samens usw.), wieder andere sind als Pflanz-Geräte konstruiert, wie z. B. die Pflanzsjaltschneider, Pflanzholz mit und ohne Wühlspitze, Pflanzenlade.

D. Pflanzenbeschaffung beiden einzelnen Holzarten.

$\$ 6$. Die bezüglich der Pflanzenbeschaffung hier folgenden Angaben deuten, ohne entfernt erschöpfend sein zu wollen, nur einige der Fälle an, welche in der Praxis häufig vorkommen. 1. L a u b h öl z e r. a) B u c h e: Erziehung in Saatbeet selten, meist Verwendung von Sclılagpflanzen aus natürlichen Verjüngungen. Empfehlenswert Ansaat unter Iijefernschutzbestand; ?--3jährig unverschult zur Iiultur, bes. zum Unterhau. - b) E i e lı e: Aussaat im Saatliamp, 1-2jälırig verschult, 3-4jälrig zur liultur. Zur Heistererzielıung nochmals verschult und ca. 6jährig verwendet. - c) Ed el ka s t a n i e, J ugla n s-Arte n: Aussaat im Saatkamp, zur liultur als I-2jährige Loden. - d) Esche, A h o $\mathrm{l}^{\circ} \mathrm{n}$, E r l e ${ }^{2}$ ): Aussaat im Saatliamp,

1) Spitzenberg, Die Spilzenbergschen Kulturgeräle, deren Wesen, Zweck u. wirlschaftliche Bedeulung usw. 2. Aufl. Berlin 1898. - S c h w a p a c h, Die Spitzenbergschen Kulturgeräte für den Forstgartenbetricb. Ztschr. f. Forsl- u. Jaggdw. 1902, 176. Man vergl. auch, ,Aus dem Walde" 1897, S. 345, sowie $M 0 / 1 \mathrm{e}$, Ztschr. f. Forst- u. Jagdw. 1900, S. 443.

2) Erlenaussaat noch im Herbst hat sich oft bewährl: Festschlagen des Bodens, frühzeiliges Bedecken mit Reisig in Frülijahr. Erlensaatbeete sind bei Frühjahrssaal feucht zu hallen, z. B. durch Auflegen vou Moos, Begießen usw. Der Erlensamen wirl an besten breitwürfig ausgestreul, nur leicht mit Erde gemischt (nicht bedecht). - Bei Esche unt Ahorn ist wegen der 
1-2jährig verschult, 3-4jährig zur liultur (Erle, Ahorn event. als Sturnmelpflanzen). - U I m e: Dichte Saat im Sommer auf frischen, etwas angewalzten Beeten, schwache Erdbedeckung, dann nochmals etwas anwalzen; einmalige Verschulung im Frühjahr, Auspflanzen der 3jähr. Pflanzen. - c) A k a z i e: Aussaat im Saatbeet (weit säen), zur hultur als 1-oder 2jälrige Lode. - 2. N a d e $\mathrm{l} h$ ö l z e r: a) T a nn c: Schlagpflanzen, neuerdings auch vielfach Ansaat im Saatbeet, in der Regel 2-3jährig verschult, 5jälırig zur Kultur. - b) F i c h t e: Ansaat im Saatbeet, von hier 2-3jähr. ausgepflanzt oder 1-2jährig verschult, dann 3-4jährig, in den höheren Lagen auch 5-6jährig zur Iíultur. Hin und wieder auch llaterial aus Saaten und natürlichen Verjüngungen, dann oft mit Ballen versetzt. - c) I i e f e r: Aussaat im Saatbeet, 1-, 2-, 3jährig zur Iỉultur (im letzteren Falle nach vorheriger Verschulung). Schlagpflanzen nur ausnahnsweise. - d) Schwarzkiefer, We ymouthskie$\mathrm{f}$ e r, L ä r c h e: Aussaat im Saatbect, 1-2jährig verschult, 3-4jährig zur Kultur. - e) Z i r b e l ki i f e r: Keimung in besonderen Kästen zum Schutz gegen Tierfraß, dann Verschulen (cfr. Förster: Zentralbl. f. d. gesamte Forstwesen 18s8, 65).

E. A usheben, Beschneiden, Transport, A u f e wahren der Pflanzen.

$\S 63$. Was im Forstgarten gilt, ist für den großen Kulturbetrieb zu beachten. 1. A us he be n: Die Wurzehn sollen so wenig wie möglich verletzt werden, deshalb Umstechen in derjenigen Entfernung vom Wurzelstock, welche der Entwickelung der Pflanze entspricht. a) B a 11 e $n \mathrm{p} \mathrm{fl}$ a $n$ z e $n$ : Bewalırung des Ballens in gewünschter Form und Größe. Instrumente zum Ausheben von Ballenpflanzen sind außer dem gewöhnlichen Spaten verschiedene Hohlspaten, der Hohlbohrer von Karl Heyer ${ }^{1}$, Kegelbohrer von Eduard Heyer ${ }^{2}$ ), Scherenbohrer von Mühlmann, Barths Pflanzschnabel ${ }^{3}$ ), Jansas $\left.{ }^{4}\right)$ Patent-Hohlbohrer u. a. m. Bei zu steinigem oder zu lockerem Boden lassen sich haltbare Ballen nicht stechen. In solchenn Falle kömıen für besonders schwierige Kulturverhältnisse, für welche bestes Pflanzenınaterial erwünscht ist, durch Verschulen 1jähriger Saatpflanzen in Ton- oder (nach Forstmeister Reuter) asphaltierte Papiertöpfe künstliche Ballenpflanzen erzogen werden. - b) B a 11 e nlos e P f l a n zen: Auszichen (Ausrupfen) ist durchaus zu verwerfen, da selbst auf lockeren Böden Wurzelzerreißungen hierbei unvermeidlich sind. Das Ausheben hat mit der Hacke (auf steinigen Böden), am besten mit dem Spaten zu geschehen. Kleinere, im Saatbeet in Rillen stehende Pflanzen werden in der Weise ausgehoben, daß sie durch Einsterhen des Spatens auf einer Seite der Rille in einen vorher auf der anderen Jillenseite gezogenen Graben ungelegt werden. Die an den Wurzeln anhaftende Erde ist vorsichtig durch Schütteln, behutsames Auflklopfen des Erdballens oder mit der Hand, eventuell auch durch Abspülen im Wasser zu entfernen. 2. Beschneiden. a) des Wurzelteils: beschränkt sich auf glattes Wegnehmen (mit Messer, Schere, Beil) leschärdigter Teile der Seitenwurzeln und Pfahlwurzel; letztere ist zwar oft (z. B. bei Juglans-Arten!) ein Hindernis für die Pflanzung, es ist aber fraghich, ob ihre Verkürzung in allen bezüglichen Fällen

gegenstăndigen linospen darauf zu achten, daß bei der hāufig vorkommenden Beschädigung der Mittelknospe od. des Gipfeltriebes durch Spälfrost od. andere Lrsachen keine Doppelgipfel entslehen: event. rechlzeitiges Entfernen des schwächeren Triebes.

1) $r$. W e d ekin d, ,Neue Jahrbücher der Forstkunde", Heft 1.

2) Tharander Jahrbuch von 1873, 23. Bd., S. 61 ff. und Allg. F.- U. J.-Z. von 1878, S. 39, sowie Heß: A. F.- u. J.-Z. 1898,179 ; T i e m a n n: A. F.- u. J.-Z. 1900, 144.

3) Vergl. Cies] ar: Zeitschr. f. d. ges. Forstw. 1891, 48.

4) Prakt. Neuheiten f. d. forsll. Kulturbetrieb. VerhdIgn. d. Forstw. von Mähren u. Schlesien 1908. S. 43. 
angeraten werden darf ${ }^{1}$ ). - b) des Kr onenteils: Bei stärkeren Wurzelverlust ist (nur bei Laubhölzern und Lärche) entsprechendes Einstutzen der Krone zweckmäBig; letzteres auch zur Erzielung guter Kronenform ${ }^{2}$ ) (Hochstämme). Abwerfen des ganzen Schaftes, Stummelpflanzen, z. B. bei der Eiche, Erle usw. (meist am besten hart üher dem IVurzelknoten). V'gl. das oben S. 119 hierüber Gesagte. 3. Tr a n s port: In liörben, in der Spitzenbergschen oder in der Bromberger (Hollwegschen) Pflanzenlade oder auf Karren und Wagen, je naclı Entfernmg und Pflanzenmenge. Ballenpflanzen werden am besten auf Tragbahren oder in Körben getragen, weil bei Wagentransport die Ballen infolge der Erschütterung leiden. Die Pflanzen sind daleei sorgfältigst vol Austrocknung zu behüten: Schlämmen der Wurzelı, Einschlagen in feuchtes Moos, Bedecken mit einem Tuch etc. - 4. A ufb e w a h r e $\mathrm{n}$ : Kann das Einpflanzen nicht alsbald erfolgen, so ist wiederum sorgsamste Bewahrung der Saugwurzeln, sowic Vermeidung starker Verdunstung nötig. Zu dem Ende Einschlagen der Pflanzen an feuchtem, schattigem Ort in lockere Erde ${ }^{3}$ ).

\section{1t. Herrichtung der Kulturfläche.}

\$ 64. Eine eigentliche Bearbeitung des Bodens für den unmittelbaren Kulturzweck, wie nicht selten vor einer Saat, findet im allgemeinen nicht statt, es sei denn, daß eine der in 3. Kapitel, erster Teil geschilderten Urbarmaclungsarbeiten ausgeführt werden muB. Etwaige Bodenbehandlung des Waldfeldbaubetriebs kommt an dieser Stelle nicht in Betracht. Die Pflanzlöcher werden in der Fegel liurz vor dem Einsetzen der Pflanzen angefertigt. Nur ausnahmsweise, auf schweren bindigen, nassen Böden (Tonborlen) oder vor dem Einsetzen älterer, wertvoller Heister kann es zweckmäßig sein, dic Pflanzlöcher schon im Herbst anzufertigen, um den Winterfrost auf die gelockerte Erde einvirken zu lassen. Die zum Anschütten von Hügeln bei Obenaufpflanzungen oder zur Ausfüllung der mit Pflanzeisen, Hohlspaten usw. hergestellten Pflanzlöcher benötigte Iíulturerde (Füllerde) wird meist schon im Herbst vor der Kultur auf der zu liultivierenden Flächen durch Zusammenharken der oberen

1) Ga y er (Waldbau 4. Aufl. S. 365) spricht sich für mögliclıste Besehränkung des Beschneidens aus. Hauptsächlich bei stärkeren Pflanzen ist Wurzelversehnitl of nōtig, bei schwäeheren zu vermeiden. Manche (z. B. S e h ü $\mathrm{t} z$ ) wollen eine lange Pfahlwurzel lieber zu einem Iinoten schürzen. Nach den von B o g g $\mathrm{r}$ eve (forstl. Blälter 1878, S. 306) u. H e B (Forstw. Zbl. 1882, S. 385) hierüber angestellten Versuchen haben Eichen mil geknoteten Pflahlwurzeln keine wesentlichen Störungen in Wachstum gegenuber Eichen rait eingestutzten Wvureln gezeigt. Erwähnung verdienen hier auch die von $L$ a u r o p u. a. durchgeführten Versuche, das Versetzen von Pfahiwurzelholzarten dadureh zu er]eichtern, daß die Pfahlwurzeln in Saatbeet bei den noch jungen Pflanzen durch Einstechen mit scharfen Spaten von der Seite her abgestoßen werden. Denselben Gedanken, nur aui die Seitenwurzeln übertragen, veriolgen die oben (\$. 129) genannten Verfahen ron M u th I. Ka iser.

2) Vergl. Güyer, Erzielung der Eiche zum Hochstamm, 1870.

3) Das Ausheben und Einschlagen in dünne Sehichten empfiehlt sichı nach $\mathrm{B}$ ü h 1 e r (Prakt. Forstwirt für die Schweiz, 1885, Sept.-Okt.) auclı zum Zurückhalten der Vegetation in Frühjalır, gegenüber von kulturverzogerungen (durch die Witterung, Verwendung von Pflanzen aus der Ebene ins Gebirg usw.). Bedecken der Beete mit Reisig erwies sich nicht als zweckentsprechend. Ferner: Bühler (Schwz. Zeitsehr. 1893, 123): Nadelhölzer haben mehr Abgang als Laubhōlzer, 3- und mehrjährige \adelhōlzer sind weniger empfindlich als 1- und 2jährige; bei niedriger Frühjahrslemperatur hann das Einschlagen bis zu 2 Monaten ausgedehnt werden. - Ausheben im Herbst und Einschlagen uber Winter ist bei sorgfältiger Belandlung ohme Bedenken (efr. Tübinger Versuchsgarten). Das Einsehlagen der Pflanzen in Büseheln ist zu vermeiden, vielmehr reihenweise Anordnung derselben. - Event. Zurückhalten der Vegetation bei den für die Frühjahrskultur vorgesehenen Pflanzen dureh Lagerung (nach den Ausheben) auf Sehnee in sog. Schneegruben, das sind mit festgestanpltem Schnee ausgefüllle 1,5 $\mathrm{m}$ tiefe Löcher, in welche die Pflanzen abwechselnd mit. Reisigschichten eingelegt werden. Die Wurzeln werden einige em hoch mit frischer Erde eingebetlet und das Ganze durch ein verstellbares sehräges Fieisigdach aberdeckt. (cfr. u. a. Kožeśnik, Zeitschr. f. d. ges. Forstw. 189.1, 59.) 
fruchtbaren Bodenschicht gewonnen und in entsprechender Verteilung auf der Kulturfläclie in Haufen oder Hügeln zusammengesetzt. Mit diesen Arbeiten kann im Herbst pine Düngung mit langsam wirkenden Mineraldüngern (Thomasmehl, Kiainit, kohlensaurer Kalk, Mergel) verbunden werden. Vergl. hierzu 4. Abschnitt unter ,Bodenpflege". Unebenheiten, Steine, Felsen, Stöcke usw. beeinträchtigen zwar vielfach einen regelmäßigen Verband, sind aber kein Hindernis der Pflanzkultur an sich und verbleiben zumeist an ihrer Stelle, sofern nicht auf die Nutzbarmachung des Stocliholzes Wert gelegt wird. Zu uppiges Unkraut, unbrauchbare V'orwüchse, nicht gewünschte Oberständer sind zu entfernen. Beim Uebergang von Mittelwald zum Hochwald oder allgemein bei Holzartenwechsel, zumal beim Uebergang von Laubholz zum Nadelholz, können die oft massenhaft erscheinenden Stock- und Wurzelloden für die junge Kultur sehr lästig werden und einen mehrjährigen harten Kampf bedingen. Vorheriges Entfernen der Stöcke und Wurzeln kann sich deshalb empfehlen. Uebrigens ist nicht zu übersehen, daB jene Ausschläge unter Umständen als Schutzund Treibholz von Wert sein liönnen.

\section{Vollzug der Pflanzung.}

\$65. A. P f l a n z z e i t: Man unterscheidet Frühjahrs- und Herbstpflanzung. Bedingend für die ITahl der einen oder anderen Pflanzzeit ist die Sicherheit des Erfolges und diese hängt von Standort. Holzart, Beschaffenheit der Pflanzen, Witterungsverhältnissen usw. ab. Hier und da sprechen auch die Arbeiterverhältnisse und sonstige äußere, den Kostenpunkt beeinflussende Momente mit. Nach der aus Erfahrung hervorgegangenen Gepflogenheit des praktischen Waldbaues fälit die Hauptpflanzzeit in das Frühjahr und endet hier mit dem Austreiben der Knospen. Ausnutzung der Winterfeuchtigkeit, Vermeidung von Pflanzenverlusten durch Ausfrieren und Erfrieren oder Undrücken durch Schnee, namentlich aber Ausnutzung des im Frühsommer besonders lebhaften Wurzelwachstums rechtfertigen die Bevorzugung der Frühjahrspflanzung gegenüber der Ilerbstpflanzung, namentlich insoweit Nadelholzkiulturen in Frage lommen. Höhenlage der Kulturfläche, Jahreswitterung und Kultumethode sind bei der engeren Umgrenzung der Pflanzzeit auf frühere oder spätere Zeitperioden im Frühjahr maßgebend. Kann die Kulturarbeit infolge zu großen Umfanges im Frühjahr nicht bewältigt werden, ist die Kulturfläche im Frühjalır zu feucht, die Witterung zu trocken oder die Vegetation zu rasch vorgeschritten, so nimmt man den Herbst zu Hilfe, am besten die Zeit von Mitte September bis Ende Olitober. Laubhölzer eignen sich zur Herbstpflanzung besser als Nadelhölzer, weil ihre Wurzeln im Herbst kräftiger und nachhaltiger wachsen als die der Nadelhölzer $\left.{ }^{1}\right)$. Laubhölzer sind namentlich dann von der Frühjahrspflanzung auszuschließen, wenn sie bereits angetrieben haben. Ebenso ist Lärclie gegen Verpflanzung im angetriebenen Zustande selır empfindlich. Die übrigen Nadelhölzer, insbes. Fichte und Schwarzliefer, lassen sich mit mehr Erfolg im Frühjahır nach Beginn der Vegetation verpflanzen. Es empfielılt sich aher auch bei ihnen, bei späterer Kulturzeit die Entwiclielung der Tinospen durch Ausheben der Pflanzen und Einschlagen an schattigem, kühlen Orte zurüclizuhalten. Ballenpflanzung gestattet Außerachtlassung des Yegetationszustandes umsomehr, je líleiner die Pflanzen und je größer der Ballen ist.

B. Ilerstellung geregelter Pflanz verbände.

Die Ilerstellung geregelter Verbände erfolgt mit Hilfe der aus starkem Hanf gefertigten oder aus schwächeren Drähten zusammengerlehten Pflanz- und Picht-

1) VergI. EngIer, Untersuchungen üb. d. Wurzelwachstum der Holzarten. Mttlgn. d. Schweiz. Zentralanstalt f. d. forstl. Versuchsw. VII. 1903, S. 247. 
schmuren oder auch mit Hilfe von Pflanzketten. Dem gewählten Pflanzen- bezw. Reilhenabstand entsprechend werden die Schnuren und Kietten mit Zeichen oder Marken verschen (Bärsche Pflanzliette mit verstellbaren Markierungen, Forstw. Zbl. 1997, S. 651). Nacl diesen Zeichen werden an den straff ausgespannten, mit Endpflöcken in den Boden befestigten Schnuren oder lietten die Pflanzstellen auf der Kulturfläche durch Einhiebe mit der Hacke oder durch Einstecken von Holzstäbchen vorgezeichnet. Bei größeren Kulturflächen kann die Zuhilfenalıme einfacher Instrumente zum Abstecken rechter Winkel (Winkelspiegel, Kreuzscheibe, Winkelprisma) angezeigt sein, um regelmäßige liulturen fertig zu bringen. Peinliche Genauigkit ist aber auch hier Spielerei und liein Haupterfordernis guter Liulturen.

C. P f l anzenmenge und P f l anzweit e.

Die zur Bepflanzung einer Fläche notwendige Pflanzenmenge hängt von der Größe der Kulturfläche, von der Verbandsart. sowie von der Pflanzweite ab und ist gleich dem Quotienten Fläche: Standraum der Einzelpflanze. Bei gegebener Kulturfläche F stellt sich die Pflanzenzahl Z bei Reihenpflanzung (Abstand der Reihen = a, Pflanzenabstand in den Peihen $=b$ ) auf $Z=\frac{F}{a b}$; bei Quadratpflanzung (Pflanzenabstand $=$ a) auf $\mathrm{Z}=\frac{\mathrm{F}}{\mathrm{a}^{2}}$ : bei Dreiechspflanzung (Pflanzenabstand $=$ a) auf $\mathrm{Z}=$ $\frac{F}{0.866 \cdot a^{2}}=\frac{F}{a^{2}} \cdot I, 155$ und beim Fünfrerband (Pflanzabstand $\left.=a\right)$, der nichts anderes darstellt als einen auf der Kulturfläche zweinal durchgeführten Quadratverband, $\mathrm{Z}=2 \frac{\mathrm{F}}{\mathrm{a}^{2}}$. Bei gleicher Fläche und gleichem Verband bestimnt somit dic Pflanzweite, d. L. der Pflanzen- bezw. Reilhenabstand die Pflanzenzahl und damit die Bestandsdichte. Ueber die zwechmäBigste Pflanzenweite hat von jelıer ein lebhafter Meinungsaustausch stattgefunden und noch heut ereifern sich die Gemüter, wenn die „Terbandsweite" auf der Tagesordnung von Forstvereinsverhandlungen steht. Schon daraus, daß endlose Zeitscliriften- und Vereinsdebatten über die beste Pflanzweite nicht ins Reine kommen konnten, geht mit Sicherheit hervor, daß es für die Pflanzweite keine allgemeine Regel gibt. Holzart, Alter und Stärke der Pflanzen, Standort, Schutzbedürfnis des Bodens und schließlich auch der von den ölionomisehen Verhältnissen einer Gegend odel eines Landes wesentlich abhängige wirtschaftliche Zweck der zu begründenden Bestände bedingen lier engere und lassen dort weitere Pflanzung zu. Auf guten und besten Böden wird in neuerer Zeit die weitständige Pflanzung ihrer größeren Zuwachsleistungen halber mehr empfohlen als die engere. Letztere ist aber auf armen, trockenen oder unkrautwüchsigen, kurz auf Böden, die eine schnellere Deckung brauchen, in heißen, steileren Lagen, bei langsam wachsenden, kleinen Pflanzen und ganz besonders bei solchen Holzarten durchaus richtig, dic auf cinen größeren Standraum mit Sperrwüchsigkeit und Aestigkeit quittieren. Je cnergischcr eine Holzart in die Aeste geht, sobald sie Ram hat, um so enger muß sie gepflanzt werden, sofern Nutzholzerzichung der Zweck der Wirtschaft ist. Wächst die Holzart auch im Freistande geradschaftig, so steht ilurer Auspflanzung in weiteren Verbande nichts entgegen, wenn auf einen schnelleren Schluß der Kultur verzichtet und cine ctwas gesteigerte Aestigkeit mit in Kauf genommen wird. Fichte, Tanne und Lärche gestatten weiteren Verband und zeigen dann nach den Erfahrungen der zahlreichen Liulturversuchsflächen $\left.{ }^{1}\right)$ gegenübcr den engen Verbänden wesentliche Melırleistungen in

1) Vergl. K u n z e, Ueb. d. Einfluß der Anbaumethode auf d. Ertrag der Fichte. Th. Jhrb. Bd. $39,45,52,5 \div$. D e $r$ s. Ueb. d. Einfluß der Anbaumethode auf den Ertrag der gemeinen kiefer. 
Höhen- und Massenzuwachs und naturgemäß auch erheblich geringere Ixulturkosten. Iỉefer hingegen und die Laubhölzer, unter letzteren namentlich Buche und Eiche, erfordern engen Verband, wenn sonst sie zu tauglichen Schäften heranwachsen sollen. Der engere Verband hat weiterhin den für a lle Holzarten geltenden Vorzug, daB die Mehrheit der auf der Fläche stehenden Pflanzen dem Wirtschafter bei der späteren Bestandspflege zwar größere Arbeit macht, ihn aber auch mehr in den Stand setzt, nur hoffnungs- und zukunftsreiches Material zu pflegen. Auch der Holzmarkt spricht bei der Frage der engen oder weiten Verbände mit, insofern die von inclustriereichen Gegenden geforderte Erziehung schwacher Sortimente auf engere Pflanzung hinweist, während unter Voraussetzung günstiger Standortsverlaältnisse die weitständige Pflanzung dort am Platze ist, wo die Rentabilität der Wirtschaft nur durch Angebot starker Hölzer gehoben werden kann. Die durchschnittlich vorteillaften Pflanzweiten liegen zwischen 1 bis $1,5 \mathrm{~m}$. Man liann sie mittlere Verbände nennen, wenn man die Pflanzweiten unter $1 \mathrm{~m}$ als eng, die über 1,5 als weit bezeichnet.

§66. D. P f I a n z verfa h ren. Man unterscheidet $\mathrm{L}$ o c h - und O b e na $u f p f l a n z u n g e n$. Bei ersteren werden die Pflanzen in auf irgend eine Weise angefertigte Löcher in den Boden, bei letzteren so in angeschüttete Erdhügel, umgestülpte Rasenplaggen usw. eingesetzt, daß sie mit ihren Wurzeln über dem gewachsenen Boden stehen. Zur Verwendung kommen Ballen- oder ballenlose Pflanzen. 1. Pflanzung $\mathrm{mit} B$ a ll en p l a $\mathrm{nz}$ en: Dieselben Instrumente, die zum Ausheben der Pflanzen benutzt werden (cfr. II, E dieses Teiles, $\S 63$ ) dienen in der Regel auch zum Anfertigen der Pflanzlöcher, welche in allen Fällen einen der Gestalt und Größe des Wurzelballens möglichst entsprechenden Raum darstellen sollen, so daB der Ballen, nach leichtem Druck mit der Hand, rings an der Lochwandung fest anschließt. Die Ballen werden mindestens bis zu ihrer oberen Grenzfläche in den Boden eingesenkt.

2. Pflanzung mit ballenlosen Pflanzen. a) Loch pf I anz u n gr e $\mathrm{n}$ : Nach der Art und Weise, wie die Pflanzlöcher hergestellt werden, unterscheidet man $\mathrm{Hack}$ - und $\mathrm{Spalt-oder} \mathrm{Klemmpflanzungen.}$

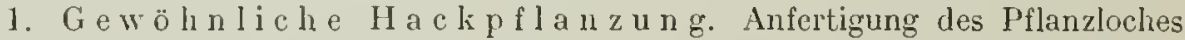
mit Spaten oder Hacke nach Entfernung des Bodenüberzuges. Bindige und unkrautwüchsige Böden, sowie ältere Pflanzen erfordern größere Pflanzlöcher. Die gelockerte Erde wird entweder in Pflanzloch gelassen oder ganz oder teilweise herausgenommen. Im letzteren Falle wird sie oftmals nach ihrer höheren oder tieferen Lage im gewachsenen Boden als gut oder weniger gut sortiert. Bei trockenem Wetter ist Ausheben des Bodens nur dann zulässig, wenn sofort nach Anfertigen des Pflanzloches gepflanzt wird. Die Pflanzen sollen in der Regel nach dem Einsetzen so tief im Boden stehen, wie vor den Ausheben ${ }^{1}$ ), also normal etwa bis zur Grenze von Wurzel und Schaftteil. Sehr häufig findet man bei den Kúturarbeitern die Neigung, die Pflanzen zu tief in den Boden zu setzen. Alle Wurzeln sind möglichst in ihre natürliche Lage zu bringen und mit fiuchtbarer Erde dicht zu umgeben. Ebenso sind Stauchung und Aufwärtsbiegung der Wurzeln - sehr oft die Folge zu kleiner oder schlecht gelockerter Löcher - möglichst zu vermeiden. Zur Erziclung natürlicher Wurzellagerung ist die Pflanze in die Nitte, nicht an eine Seite des Pflanzloches zu setzen. Empfehlenswert ist das vielfach geübte, durch v. U i b l a g g e r (Forstwiss. Zbl. 1904, S. 463 ff.)

Th. Jhrb. IV. Suppl.-Bd., ferner Bd. 43,48,54,59. — S i e f e r t u. B u r g e r, Die IKulturversuche auf d. Köcherhof im Forstbezirli Ettenheim, Karlsruhe 1905.

1) Ausnahme z. B. hier und da die Kiefer im Sand, welche daselbst zunächst etwas tiefer eingesenkt wird, weil sich der lose Sand doch noch merklich setzt. 
beschriebene Verfahren, in dem 40-60 $\mathrm{cm}$ im Quadrat großen Pflanzloch eineu Teil des gelockerten Erdreiches zu cinem Hügel zu formen, die Pflanze hierauf zu stellen, ilıre Wurzeln nach allen Seiten entlang der Hügelwand auszustreichen und durch Hereinzieheı der zunächst aus dem Loch herausgenommenen Erde die Pflanze fest und so tief anzuhäufeln, wie sie an ihrem bisherigen Standorte stand. In erster Linie eignet sich dieses Verfahren für Holzarten mit flachstreichenden Wurzeln (Fichte); Holzarten mit Pfahlwurzel bedürfen eher einer Vertiefung des Loches zur Aufnahme der Pfahlwurzel. Auf sorgfältigsten Vollzug der Pflanzung, möglichst unter Verwendung von Pfänzlingen mit unverstümmelten Wurzeln, ist streng zu lıalten; scharfe Kontrolle ist erforderlich ${ }^{1}$ ). Bei der Pflanzung stärierer Exemplare (Halblıeister, Heister) sind zwei Arbeiter notwendig, von denen der eine das Senkrechthalten der Pflanze, der andere das Einfüllen der Erde besorgt, oder es empfiehlt sich hierbei, sofern ein Arbeiter das Pflanzgeschäft besorgt, die Benutzung des $\mathrm{R}$ e b m a n nschen Pflanzenhalters, weleher die Pflanze an der gewünsehten Stelle und in erforderlicher Höhe festhält, so daß der Arbeiter beide Hände zum Umfüttern der Wurzeln mit Erde frei hat.

$\mathrm{Zu}$ den Haclipflanzungen sind auch jene Pflanzmethoden zu rechnen, bei denen die Herstellung des Pflanzloches durch ein-oder mehrmaliges Einstoßen, Drehen und Wuchten eines die Lockerung und Mischung des Bodens besorgenden Verkzeuges geschieht. Hierher gehört die Pflanzung nach Bi e r m a $\mathrm{s}$ : Fertigen des Pflanzloches mit dem Spiralbohrer. Einsetzen besonders (unter Anwendung von Rasenasche) hierfür erzogener Pflänzlinge ( 2 bis 3jahrig), ebenfalls unter lerwendung von Rasenasche oder guter Iiulturerde. Gut im Erfolg auf mittelbindigem, nicht verwurzeltem und nicht steinigem Boden, aber nicht sehr rasch arbeitend. Besondere Arbeiter, welche die Löcher fertigen, gehen hier, wie auch neist bei der gewöhnlichen Pflanzung, mit dem Bohrer den Pflanzern voraus. Ferner gehört hierher dic Pflanzung mit Hilfe des $\mathrm{Sp}$ itzen berg schen Wühlspatens. Lockerer, steinfreier und nicht verwurzelter Boden vorausgesetzt, gewälrleistet der Wülspaten bei der vom Erfinder vorgeschriebenen Handhabung eine ganz vorzügliche Zerkrümelung und Mischung des Erdreiches.

Als lierher gehōrig mögen von den zahlreichen Lochpflanzungsverfahren noch genannt sein die Kulturmethode des Forstmeisters $\mathrm{K} 0 \mathrm{z}$ e $: \mathrm{n} \mathrm{i} \mathrm{k}^{2}$ ), die den beiden Haupterfordernissen einer guten liulturausführung, guter Bodenlockerung und normaler Wurzellagerung, gebührend Reclinung trägt; ferner das Kiefernkulturverfalıen des Forstmeisters $\mathrm{S} p \mathrm{l}$ e $\mathrm{t} \mathrm{s} \mathrm{t} \delta \mathrm{B}$ e $\mathrm{r}^{3}$ ), wobei das Pflanzloch durch Einstoßen, mehrfaches Umdrehen und Herausheben eines aulklappbaren Zangenbohrers beliebig tief hergestellt wird, und die sog. Ueberwurfkultur von Forstmeister $G \mathrm{r}$ o $\mathrm{h}$ a $n \mathrm{n}^{4}$ ), bei welcher die aus einem Pflanzloch mit dem Spaten ausgehobene Erde in das leere bereits vorher angefertigte Loch geworfen wird. Der bessere Boden kommt auf diese Weise nach unten, der Rohboden nach oben. Wenn diese Umlagerung auch nicht immer zweckmäßig sein wild, so bürgt das Verfahren doch auf alle Fälle für eine dem An. wachsen der Pflanzen günstige gute Bodenlockerung.

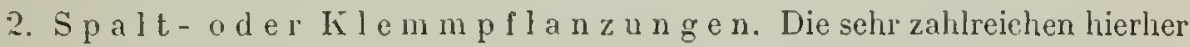
gehörigen Pflanzverfahren haben das Gemeinsame an sich, daß sie dureh Verringerung der Bodenbearbeitung eine Beschleunigung des Kulturgeschäftes anstreben. Sie übertreffen demzufolge die Hackpflanzungen in der Wohlfeilheit mehr oder weniger, stehen ihr aber an Güte und Wert zum Teil bedeutend nach und liranken weiterhin an dem Uebelstand, daß sie fast durchgängig auf lockere, steinfreic und wenig verunkrautete Böden und auf Verwendung kleinerer Pflanzen angewiesen sind. In dem Maße sie diese Beschränkungen außer acht lassen, sinkt ihre Berechtigung. Mit keiloder spatenförmigen, aus Holz, Eisen oder beiden Materialien hergestellten kurz-

1) Vergl. u. a. R e $B$ (Wiener Kiongreß 1890: Ueber die nachteiligen Einflüsse naturwidriger Pflanzenmethoden etc., Allg. F.- U. J.-Z. 1891, 1), sowie K o ž e $\mathrm{n} i \mathrm{k}$ : Zeitschr. f. d. ges. Forstw. 1889, 477 und 1892, 105. - S p i tze n b e rg, Ueber Mißgestattungen des Wvurzelsystems der Kiefer und uber Kulturmethoden. Deutsche Forst-Ztg. 1908, 494, 515 ff.

2) Kožeśn ik, Die neue Pflanzmethode in Walde. 3. Aufl. Wien 1908.

3) Splettstó $B$ er, Einfluß unserer Kulturmethoden auf d. Absterben der Jiefer. Ztschr. f. Forst- u. Jw. 1908, 689.

4) Grohm an n, Ueberwnrkultur im Vierverband. Bericht d. Säclss. Forstvereins $189 \overline{7}, 150$. 
oder langgestielten Werkzeugen werden in den durch Hacken, Rigolen oder Pflügen platz- bezw. streifenweise mehr oder weniger gelockerten, bisweilen auch in den ungelockerten Boden lieil- oder spaltförmige Löcher gestoßen und durclı Hin- und Herrütteln des Instrumentes erweitert. Hierein wird die cinzusetzende Pflanze gehalten. Während des Einhaltens wird das Loch durch einmaliges oder wiederholtes seitliches Einstechen des Lochstoßers und durch Andrücken der Erde gegen das Pflanzloch geschlossen. Alle auf diesem Prinzip beruhenden Pflanzverfalıren haben den auf bindigem Boden in verstärktem Maße hervortretenden Nachteil an sich, daß die Wurzeln der Pflanzen in unnatülicher. Weise zusammengepreßt und gequetscht werden, ein Uebelstand, der namentlich bei mangelhafter Ausfülırung des Pflanzgeschäftes allerhand Wurzelmißbildungen und damit zusammenhängend späteres Kümmern und Lückigwerden der Ḱulturen zur Folge haben liann. Lockere Böden und Verwendung 1- oder 2jähriger Pflanzen lassen diese Nachteile weniger hervortreten und sind deshalb, wie schon hervorgehoben, Bedingung für die Zulässigkeit der Kilemm- und Spaltpflanzungen.

Die Praxis hat eine große Reihe von Lochstoßern erfunden, ron denen genannt seien: Setz- oder Pflanzholz, Pflanzdolch, Spilzenbergs Pflanzholz nit Wühlspitze, Buttlar-Eisen, Wartenhergs Stieleisen, Grünewalds Pflanzenstielsel, v. Alemanns Pflanzspaten, Pflanzbeil, Pflanzlanze, Keilspaten, Spitzenbergs Spaltsehneider. Verrendung haben diese Instrumente hauptsächlich beim Auspflanzen von kiefernjährlingen gefunden, denen oft, um sie besser in das teifweis enge Pflanzloch hineinzulsingen, die Wurzeln eingesehămmt wurden. Diese im Eintauchen der Wurzeln in Lehmbrülıe bestehende Maßnahne enpfiehIt sich nieht, da die Möglichkeit zu Wurzelmißbildungen hierdureh nur noeh gesteigert wird. Viel gebraueht wurden bei der Kiefernjährlingspflanzung das Wartenbergsche Eisen, ein großes Stoßeisen nit Stiel und Krücke, und das Butllar-Eisen. Letzteres, ein spitzer Eisenkeil mit gebogenem Handgriff, wird geworfen, so daß es bis zum Griff senkrecht im Boden steekt. In das durch das Herausziehen gebildete Loch kommt ein eigens erzogener Pflänzling (lange Wurzelstrānge); dureh Beisleehen mit dem Eisen wird die Erde an die Wurzeln gedrückt. Das Verfahren fördert sehr; der nämliehe Arbeiter macht das Loeh und setzt die Pflanze (Führung des Eisens mit der rechten, der Pflanze mit der linken Hand).

Die Zahl der zu den Lochpflanzungen aller Art erfundenen Kulturinstrumente ist Legion, teils sind es neue Erfindungen, teils nur Hodifikationen bekannter älterer Werkzeuge. Uebung ist Hauptsache, gute und zugleich rasche (billige) Arbeit Erfordernis. Unter Unständen weitgehende Arbeitsteilung nach den Einzelmanipulalionen, wie Anfertigen der Pflanzlöeher, Einlegen der Pflanzen, Andrücken derselben usw. Rasches Ineinandergreifen der einzelnen Arbeilen ist zu bewirken. Verwendung von Frauen beim Pflanzen gestattet wohlfeilere und vielfach auch sorgfältigere Arbeit. Zahl der insgesamt zu verwendenden Arbeilshrãfte nieht grõßer, als daß dieselben noch gut überwacht werden kōnnen. Tagelohn- und Akiordarueiten in Uebung; lełztere zulässig, wenn für Verfehlungen hohe Strafen angesetzt sind. Besonders ist darauf zu achten, daß die Pflänzlinge nicht vor dem Einsetzen mit freiliegenden Wurzeln der Sonne und dem Wind ausgesetzt sind.

b) Obena uf p l a n z nge n. Die Pflanzen werden hierbei nicht in Pflanzlöcher, sondern auf dem Boden gepflanzt und zwar zumeist in angeschüttete Erdhügel ( $\mathrm{H}$ ï $\mathrm{g} \mathrm{cl} \mathrm{p} \mathrm{fl}$ a $\mathrm{n} \mathrm{z} \mathrm{u} \mathrm{n} \mathrm{g)} \mathrm{oder} \mathrm{in} \mathrm{umgeklappte} \mathrm{Rasenplaggen} \mathrm{(} \mathrm{Pl}$ a g g e $\mathrm{n}$ oder R a s e $n$ lı üg e l p f l a n z u n g), in einzelnen Fällen - auf besonders nassen, nicht zu entwässernden Böden - auch auf erhöhte Erddämme, die durch Ausheben zusammenhängender oder unterbrochener Gräben hergestellt worden sind ( $\mathrm{R}$ a b a $\mathrm{t}$ te 1 p $f \mathrm{l}$ a n $\mathrm{z} u \mathrm{n} \mathrm{g})$.

Am gebräuchlichsten ist die Hügelpflanzung. Der Hügel wird entweder aus der auf der Pflanzstelle gewonnenen Erde geformt (g e w ö h n li c h e H ü g e l$\mathrm{p}$ f $\mathrm{l}$ a $\mathrm{n} \mathrm{z}$ u $\mathrm{ng}$ ) ader wird - bisweilen schon im Herbst - mit guter, auf der Kulturfläche oder in deren Nähe gesammelter Kultur- (oder liompost-) erde angeschüttet und nach der Bepflanzung mit zwei halbmondförmigen, umgekehrten Rasenplaggen

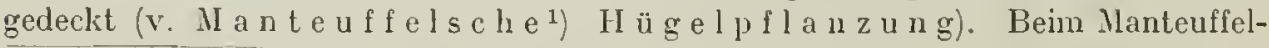

1) v. M a nteuffel, Die Hügelpflanzung der Laub- und Nadelhölzer. t. Aufl. Leipzig 187 . 
schen Verfahren (,,Manteuffelei") wird die Pflanze, nachdem der Hügel bis auf den gewachsenen Bocken auseinandergezogen worden ist, mit ausgebreiteten Wurzeln direkt auf die Bodendecke aufgesetzt. Nach sorgfältiger Einbettung der Wurzeln wird der Hügel wieder herangezogen, leiclit angedrückt und gedeckt.

Zweek der Hügelpflanzıng ist sicherung des liulturerfolges namentlich auf feuchteı und nassen Böden. Durch das Hochsetzen kommen die Pflanzen in solchen Lagen aus dem meist vorhandenen Graswehs und danit aus der Frostzone heraus; außerdem kommen ihnen die in der Hügelerde bezw. in den rerwesenden Rasenplaggen enthaltenen Nährstoffe zugute. Aus letzterem Grunde wendet man Hügel auch auf trockenen, aber armen Kiesböden, in abgebauten Brüchen, beim Zupflanzen von Wegen usw. an. Meist hört in den letzteren Fällen aber das Wachstum del zunächst gut gedeihenden Pflanzungen auf, sobald die Nährstoffe des Hügels aufgebraucht sind. Da die Hügehpflanzung nicht billig ist, bleilst sie im allgemeinen auf kleine Flächen beschıänkt.

In besonderen Fällen wird die Pflanzung nicht mit bewurzelten, sondern unbewurzelten Pflanzen- bezw. Pflanzenteilen, mit S te ckling en, Setzs t a ngen und $A b l e g e r n$ vorgenommen. Mit $S t e c k l i n g e n$ ( $S$ et $z$ reiser $n$ ) bezeichnet man $20-10 \mathrm{~cm}$ lange, beiderseits glatt abgesclinittene Teile ein- oder 2jähriger Weidenruten. Bei der Anlage von Weidenhegern, wo sie fast ausschließlich Verwendung finden, werden sie in gelockerten Boden in Löcher eingebracht, die meist mit dem Setzholz oder einem ähnlichen Instrument senkrecht vorgestoclıen werden, und sind zur selbständigen Bewurzelung befähigt, sofern der Boden die nötige Frische besitzt. (Vergl. Weidenniederwald, S. 82). - Auf der Fähigkeit selbständiger Wurzelbildung beruht auch die beim Koptholzbetriebe bei Pappel und Bammeiden gebräuchliche Verwendung von S e tzstan g en. Man versteht darunter $2-3 \mathrm{~m}$ lange bis $5 \mathrm{~cm}$ starke, aus kräftigen Stockausschägen lıerausgeschnittene schaftteile, die in rorgestochene, $30-50 \mathrm{~cm}$ tiefe Löcher senkrecht cingepflanzt werden. Des unvermeidlichen Einfaulens des Stockes wegen empfiehlt sich jedoch die Verwendung bewurzelter Stämmchen aus Baumschulen mehr als die Verwendung von Setzstangen.

Lückige Nieder- und Mittehwälder lassen sich gegebenen Falles dureh Benutzung von $A$ b l e ge r n oder A b s n k e r $n$ verdichten. Zu diesem Zwecke werden tiefsitzende Aeste herabgezogen oder Stockloden ungelegt, nach Entfernmng hinderlicher Seitenäste den Boden glatt angedrückt und $10-20 \mathrm{~cm}$ hoch mit Erde bedeckt und vom llutterstocke getrennt, sobald sie sich bewurzelt haben.

\section{Schutz und Pflege der Pflanzkulturen.}

$\$ 67$. Bescluränkt sich im allgemeinen auf die bei der Pflege der Saatkulturen (vgl. S. I17) genannten Maßnahmen, d. h. auf die Bekämpfung des Unkrautes, auf das Offenhalten etwa vorhandener Entwässerungsgräben, Anlüufeln der Erde um stärkere Heister, Sicherung der Pflanzen gegen Wildverl,iß, gegen Mäuse und Insekten (Engerling, Rüsselkäfer usw.), worüber Näheres in Forstschutz. Ueber Düngung zurückbleibender Pflanzungen s. unter ..Bodenpflege", Abschn. IV: 


\section{Viertes Kapitel.}

\section{Betrjebsarten und Bestandesbegrüdung bei den einzelnen Holzarten.}

Vor bemerk ung. Nur in kurzen Andeutungen sollen hier die Betriebsarten und die in enger Verbindung damit stehenden wesentlichsten Verjüngungs- und Bestandsbegrundungsarten zusammengestellt werden, welehe man in der forstlichen Praxis bei den einzelnen Holzarten antrifft. Besondere standörìtiche und wirtschaftliche Verhältnisse stellen jeweils spezielle Aufgaben. Das Studium der nachgewiesenen Literatur in Verbindung mit der Beobachtung im Walde inuß die lienntnis der Details vermitteln. Insbesondere ist von den eingangs aufgeführien Werken hier auf Burekhardts Säen und Pftanzen, sowit auf die über die einzelnen Holzarten vorhandene monographisehe Literatur wiederholt hinzuweisen.

\section{Laubhölzer.}

\$68. 1. Buch $\left.\mathrm{e}^{\mathrm{l}}\right)$.

A. B e trie b s r t. Die Buche ist ausgesprochene Hochwald-Holzart. Erscheint sie auch häufig im Mittelwald, sowie da und dort im Niederwald, so kann doch wegen ihrer verhältnismäBig geringen Reproduktionskraft keiner dieser beiden letztgenannten Betriebe auf sie als Hauptholzart gegründet sein. Als Oberholzbaum im Mittelwald ist die Buche überdies zu dichtkronig.

Im Hochwald findet sich die Buche (Umtricbszeit gewölmlich 100-120 Jahre, Haubarkeitsdurchschnittszuwachs auf mittlerem Standort $4-6$ Fm. pro ha) meist im Schimschlag-, auch wohl im Femelschlagbetrieb, in reinen Bestand sowohl, als in Mischbeständen. Reine oder annähernd reine Bestände, welche bis zu dem durch die Konkurrenz der Steinkohle herbeigefülırten Rückgang in der Wertschätzung des Brenuholzes vielfach Wirtschaftsziel waren, können dies heute nicht mehr sein, da, selbst wenn sich für Buchennutzholz noch neue, umfängliche Verwendungsarten finden oder bereits bekannte sich als ausdehnungsfähig erweisen sollten, doch tatsächlich kaum ein besonders hohes Nutzholzprozent bei der Verwertung reiner Buchenbestände von größerer Ausdehnung sich ergeben wird, weil eben jene Verwendungsarten (Eisenbahnschwellen, gebogene Möbel, Holzpflaster usw.) doch nur einen im Vergleich zur Gesamtmassenerzeugung in Buchenwalde nicht sehr erheblichen Bedarf bedingen. In Gegenden, welche von den großen Kohlenlagern weiter entfernt sind, hat Buchenbrennholz nocl einen besseren Absatz. Jedenfalls bleibt der Buche unbestritten der Vorzug eines trefflichen Einflusses auf den Boden, so daß einer irgend einseitigen Verdrängung derselben entschieden widerraten werden muß ${ }^{2}$ ), wenn auch gegen eine wohl erwogene örtliche Einschränliung ihıres Gebietes niclıts eingewendet werden kann. Sie bleibt Hauptholzart im gemischten Bestande, sei es als bestandesbildender Teil,

1) Vergl. Grebe, Der Buchenhochwald 1856. - In n r r, Studien über die Buchenwirtschaft 1863. - F r ö m b l i n g, Der Buchenhochwaldbelrieb 1908. - D e r s., Anleitung zur naturrl. Verjüngung des Buchenhochwaldes. Mündener f. Hefte. Hit. I, 153; II, 24; III. 1892/93. $v$. B e $\mathrm{th}$ e im, Wie sind reine Buchenhochwaldungen zu bewirtschaften? 1890. - I $\mathrm{r}$ a $\mathrm{f}$, Zur natürlichen Verjüngung der Buche. Ztschr. f. Forst- u. JW. 1892, 628. - M a r ti n, Folgerungen der Bodenreinertragstheorie. Bd. 1. 1894. Die Buche. - I u f n a g l, Die Buchenfrage in der österr. Forstwirtschaft. 1900 . - I $u \mathrm{t} \mathrm{s} \mathrm{h}$, Die Stellung des Buchenwaldes im deutschen Nationalvermögen 1898. — Bericht. über die 25. Vers, deutseher Forstmänner 1897, 38; desgl. 1. Vers. d. dentsehen Forstvereins 1900, 135. - H e e k, Allg. Forst- u. J.-Ztg. 1897, 406; L or e y, das. 1897, 391; End res das. 1898, 91. - S e I l h e i m, Zur Buehenfrage. Mündener f. Hefte 13. 1898, 8. - T r e b e l j a h r, das. 14. Hft. 1898, 73. - S c h u b e r g, Aus deutschen Forsten, II. Die Rotbuche 1894. - W i m m e a u e r, Ertragstafeln f. d. Buchenhochwald in Oberhessen. Allg. Forst- u. J.-Ztg. 1893, S. 300. - S c h w a p p a e h, Die Rotbuche 1911. -

2) Namentlich sollte bei Umwandiung in Nadelholz, bes. Fichte, eine gewisse Vorsicht walten, vergl. S. 34 . 
sei es als liöchst schätzbares Unterholz im Unterbau- und Lichtungsbetrieb. Zum Ueberhaltbetrieb ist die Buche wenig geeignet (breite Krone, stark beschattend, Rindenbrand etc.). Besondere Starkhölzer können, von höheren Umtrieben abgesehen, im zweihiebigen Hochwald oder im v. Seebachschen Betrieb erzogen werden.

B. V e r j ü n g u $\mathrm{n}$. Sie erfolgt angesichts des Schutzbedürfnisses der jungen Buche gegen Frost, Hitze und Unkraut vornehmlich auf natürlichem Wege, selten durch Ausschlag bezw. Absenker, ausnahmsweise (und dann meist unter Schirm) durch Saat oder Pflanzung.

1. Natürliche Verjüngung:

a) Durch Samen: Hauptsächlich im Schirmschlagbetrieb. Die in $\S 40$ geschilderten Hiebsführungen (Vorbereitungshieb, Samenschlag, Nachlichtungen) haben insbesondere bei der Potbuche Platz zu greifen, und zwar kommen sie je nach Umständen mit allen daselbst angedeuteten Nodifikationen bezüglich des Tempos, in welchem vorgegangen wird, sowie des Grades der einzelnen Eingriffe in den Iutterbestand vor. Wird die Verjüngung olne länger andauel'nde allmähliche Vorbereitungshiebe im wesentlichen durch eine entsprechend stärkere Durchlichtung zwecks unmittelbarer Schlagbesamung eingeleitet, so spricht man von der ,Verjüngung aus vollem Ort". Eventuell Bodenverwundung bei Eintritt eines Mastjahres (Kurzhacken, Rechen, Schweineeintrieb, Pflug, Egge, dänische Rollegge, Webers Waldgrubber), namentlich auf schlechteren und von stärkeren Trockentorfschichten überlagerten Partien. Wo der Erfolg zweifelhaft, wird am besten nicht lange zugewartet, sondern zur Anpflanzung mit Nadelholz (Fichte, Douglasie, Lärche, Weynouthskiefer, Forche) geschritten. Gefahr durch Frost und Hitze, sowie durch Forstunkräuter ist in erster Linie für die Art der Nachlichtung entscheidend; langsameres Vorgehen bietet hiergegen im allg. mehr Schutz als rasches Nachhauen. Die Gewinnung eines Lichtungszuwachses an den Nutterbäumen kommt bei der Buche zwar meist weniger als Wirtschaftsziel in Betracht, ist aber gerade bei dieser Holzart mehr als bei jeder anderen leicht und beachtenswert. Die Buche reagiert, wie die Lichtmessungen Ci e s l a rs (Rolle des Lichtes im Walde 1904, S. 27, 103) und die Ertragsuntersuchungen S c h w a p p a c h s (d. Rotbuche 1911) zeigen, auf Lichtstellung durch überraschende Ausbreitung und Verdichtung der Krone und ganz erheblichen Massenzuwachs. Genügend reichliche und regelmäßige Mlasten je nach dem Standort rom 70. bis 100 . Jalure ab (oft noch frülıer).

Galt noch in ersten Drittel des 19. Jahrlunderts die gelungene Durchfürung der natürlichen Samenverjünung eines rcinen Rotbuchenbestandes (nach den G. Ludw. Hartigschen Generalregeln: Vorbereitungsschlag, Samenschlag = Dunkelschlag, Auslichtungsschlag) als vornehmste Aufgabe forstlicher Kunst, so ist die Wertschätzung solcher Lcistung heute begrcifIicherweise (cfr. $\$ 15$, S. 33) nicht mehr die gleich hohe. Trotzdem spielt die natürliche Buchenverjüngung in der waldbaulichen Tätigkeit noch eine Hauptrolle, namentlich in allen Fällen, in welchen die Buche als Mischholzal't den Crundbestand zu bilden hat. Daß ubrigens auch der reine Buchenbestand örtlich noch sehr gewürdigt wird, beweisen die Erörterungen, welche die dän is ch e Buchenwirtschaft in den letzten Jahren erfahren hat, im Anschluß an die Schilderung derselben durch Dr. Metzger (,D a n ische $\mathbf{R}$ e is e bilder", Mündencr forstl. Hefte, 1896, IX. und X. Heft). Daraufhin, sowie nach den Verhandlungen versehiedener Forstversammlungen (z. B. Stuttgart, 1897, cfr. S. 38 - Pommerseher Forstverein, 1900Wiesbadener Versammlung, 1900) ist auch die Verjüngung der Buche lebhafi besprochen ${ }^{3}$ ) und namentlich auch in der Richtung diskutiert worden, ob die im dänischen Buchenwalde angeordneten MaBregeln auf Deutschland zu übertragen sein möchten. Auch die reiche Voll-

1) Vergl, u. a. Urich, Dănische und deutsche Buchenhochwaldwirtschaft 1897. - F ü rs $t$, Forstwiss. Zbl. 1897, 241. - r. F i s $c$ h b a $\mathrm{c} \mathrm{h,} \mathrm{Mundener} \mathrm{forstl.} \mathrm{Hefte} \mathrm{12.} \mathrm{Hft.,} \mathrm{42.} \mathrm{-} \mathrm{T} \mathrm{h} \mathrm{a} \mathrm{l} \mathrm{e} \mathrm{r",}$ Allg. l..- u. J.-Z. 1898, 113. - M e tzg ? r, A. F.- u. J.-Z. 1898, 346. - E u lef c I d, Aus dem Walde 1898, 4, sowie Forstw. Zentralbl 1898, 131 und A. F.- U. J.-Z. 1898, 188. - Ml e tzge r, Vortrag f.d. Versammlung zu Schwerin 1899. - S p e i d c I, A. F.- U. J.-Z. 1899, 261. - G r a se r, Forstw. Zentralblatt 1899,121 . - H a u c h, A. F.- U. J.-Z. 1900, 225. 
mast des Jahres 1888 hatte bereits zu vielfachen Aeußerungen über deren zwechmäßigste Ausnutzung Anlaß gegeben.

Die dänische Wirtschaft bedient sich grundsätzlich einer intensiven Bodenbearbeitung (event. Anwendung der Rollegge - cfr. H e tzg e r, Allg. F.- u. J.-Z. 1900, 279), sodann vielfach der Blockpflanzung unter schwachem Schirmstand, d. h. der Pflanzung von 1jähr. Buchen in Reihen und zwar durch Einsetzen von Ballen bezw. Plaggen, mit je mehreren Pflänzlingeı aus engem Stand im Saatbeet entnommen. Besonders charakteristisch ist dann eine intensive Bestandspflege, welche - unter Erhaltung des Zwischen- und Unterstandes so lange, bis die schaftreinigung besorgt ist - schon frühzeitig auf besonders gute Entwickelung einer beschränkten Zahl späterer Haubarkeitsstānme abzielt (darüber später unter, ,Bestandeserziehung."5). Rasche schlagrāumung.

In der Regel kann man eine natürliche Buchenverjüngung in 20 Jahren-gut durchführen. Günstige Verhähtnisse gestatten die volle Schlagräumung schon nach 12-15 Jahren; Ausdehnung des Verjüngungszeitraumes auf mehr als 20 Jahre nur in Ausnahmefällen erforderlich.

Auch im Buchen-Verjüngungsschlage findet sich, wenı auch nicht so regemäBig wie bei der Tanne, so doch nicht selten von früheren (als dem planmäßig zu benützenden) Mastjahren her Aufschlag auf der ganzen Fläche oder als Vorwuchsgruppen und -Horste vor, welehe jedoch im Schiruschlagbetrieb im allgemeinen nicht besonders gepflegt werden. Dies sehlie $B \mathrm{t}$ jedoch nicht aus, daß man ihn, soweit entwickelungsfähig, bei der Verjüngung mitbenutzt. Sperrwüchse sind nicht zu dulden. Das radikalc Vorgehen der dänischen Verjüngungsmethode, die selbst einen recht guten Aufschlag entfernt, um eine durchaus gleichnäßige Verjüngung möglichst mit einer Mast zustande zu bringen, erscheint nicht mit Unrecht manchem deutschen Buchenzüchter als zu weitgehend.

b) Lurch A usschlag: In Nittelwald, soweit die Buche in Unterholz vertreten sein soll; bekanntlich gibt sie nicht andauernd reichliche Ausschläge, so daß sie sich hier wenig eignet.

c) Durch A b s e $\mathrm{k}_{\mathrm{e}} \mathrm{r}^{\mathbf{l}}$ ): Ausnahmsweise in besonders kritischen Lagen (steile, sonnige Einhänge).

2. Küinstlicher Anbaul :

Kommt zur Verjüngung bereits vorhandener Buchenbestände ausnalımsweise dann in Frage, wenn man aus irgend welclıen Gründen das Eintreten einer Mast überhaupt nicht abwarten oder es nicht auf den Erfolg einer nächsten Mast ankonmen lassen will, nachdem bereits eine oder melıere Besamungen fehlgeschlagen sind. Außerdern bei Bestandesumwandlungen, sowie in Gestalt des L'nterbares.

a) S a a t: kommt als Vollsaat, Riefensaat und Plätzesaat vor (letztere beiden häufiger). Voraufgehende Bodenverwuudung ist auch bei der Vollsaat meist wünschenswert. Auf liahıflächın inöglichıst zu vermeiden, da der Erfolg infolge der Frostempfindlichkeit der jungen Buche hier meist sehr unsicher. Eher ist der Anbau von Buchen durch Saat hei Zuhilfenalıme von Getreidebeisaat oder - noch besser, aber nicht rentabel - nach Schaffung eines Schutzlestandes von Kiefer oder Lärche nöghich. Des späteren Auflaufens wegen ist Frühjahrssaat auf freier Fläche der Herbstsaat vorzuziehen, ledingt allerdings gute Leberwinterung der Bucheln.

b) P f l a n z un g: meist :- 3jährige Pflanzen (manchmal auch Jährlinge), welche (besonders :jährige) zweckmäßig mit dem Beil oder der Hackie gepflanzt werden; auch wohl geringe Ballenpflanzen mit dem Hohlbohrer oder Plaggenpflanzung, wie in Jänemark (cfr. oben). lieimlingspoflanzung ist in Elsaß in gröBerem Unfange ausgeführt worden (Vers, zu Schirmeck 1890). Anwendung stärkerer Pflanzen (l,is Halbleister) für Nachbesserung, hier und da auch beim Lntertiau ganzer Schläge, doch stets teuer und weniger sicher, freilich an manchen Orten (Heidelheerüberzug etc.) nicht zu vermeiden. Einzelpflanzung ist Regel; auf trockenem, flachem und steinigem Boden hier und da Büschel. Nach der Vollmast des Jahres 1888 luat man da und dort Ballenpflanzung (nit je etwa 20 Kieimpflanzen in 1 Ballen, zumal zur Nachbesserung ungenügend besamter Steil-

1) Vergl. u. a. v. F is $\mathrm{ch}$ b a $\mathrm{ch}$ in Forstw. Zentrallutt von 1887, S. 137 ff. 
hänge angewendet) '). Pflanzmaterial vielfach aus Schlägen, oft Anzuclıt auf besonderen Beeten unter Nadellolzschutzbestand, sowie in Forstgarten. Beim Anbau ron Kahlflächen ist Pflanzung in allgemeinen erfolgreicher als Saat, besonders dann, wenn durch Beimischung einer raschwïchsigen Schutzholzart für Schutz gegen atmosphärische Einflüsse gesorgt wird. Dringend notwendig aber ist enger Verband, da sich die Buche sonst sperrwüchsig entwickelt.

2. E i $\left(\mathrm{h} \mathrm{e}^{2}\right)$ :

Je mchr allgemein die Ueberzeugung platzgreift, daß umfangliche Nachzucht der Eiche - jedoch nur auf wirklich guten Eichenboden, denen es, in Verein mit den erforderlichen kilimatischen Bedingungen, nicht an mineralischer Tiraft, entsprechender Gründigkeit und Frische mangelt - auch in Hinblick auf Rentabilitāt angezeigt ist, un so lebhafter wird die zweckmảBigste Arl ihres Anbaues, bezw. ihrer Wiederverjüngung besprochen, auf Versamnlungen sowohl, wie in der Literatur. Die Unterscheidung von Stiel- und Traubeneiche wird dabei nıt Reeht von vielen Seilen gefordert. Nach $\mathrm{Ney}$, ,Die Ausnützung der diesjährigen Eichelund Buchelmast" soll auf ständig mindeslens feuchten Orten die Stieleiche, auf frischen Boden der I. und II. Bonität die Stiel- und Traubeneiche, auf alten übrigen Eichenstandorlen nur die Traubeneiche Verwendung finden (Aus d. Walde, 1900, 25). Der Anbau in reinen und in genisehteı Beslande, namentlich die Mlischung der Eiche mit der Buche, werden oft gleichzeilig erörlert. und können auch kaum ganz scharf getrennt gehalten werden, da die Grenze zwisehen dem reinen und gemischlen Bestande (cfr. $\$ 11$, e) nicht unzweideulig gegeben ist, und namenllich beim Anbau der Eiche deren Einbringung in den Buchengrundliestand entsprechend der jeweiligen Bodenbeschaffenheit oft (Spessart, Pfalz) in derart großen Horsten erfolgt, daß nieht mehr ein gemischter Besland, sondern eine Auflosung des Bestandes auf der Abteilungsläche in eine Melirzahl einzeher reiner Beslände vorliegl.

A. B e tri e b s a t. Die Eiche ist die einzige Holzart, die alle möglichen Betriebsarten nicht nur zuläßt, sondern auch in allen mit Erfolg und in wirtschaftlich beachtenswertem Umfange behandelt wird; sie ist Holzart des Hoch-, Mittel- und Niederwaldbetriebes.

a) In $\mathrm{H}$ o c li w a l d e tritt sie sowohl rein wie in Mischung auf. Reine Bestände sind nur auf den allerbesten Böden angezeigt. Auf der großen Menge der mittleren Böden ist die Erziehung der Eiche in Ilischung mit bodenschützenden Holzarten, am besten mit Buche, die einzig richtige Erziehungsform, und allen schlechten Böden soll man mit der Eiche überhaupt fern bleiben. Die Ausnützung des anhaltenden Wertzuwachses bedingt möglichste Steigerung der Stärkezunahme durch hinreichende Umlichtung, mithin Lichtungsbetrieb mit Lnterbau, und holı Limtriebe (140 bis 160 Jahre). Auch Ueberhalt in einen folgenden Untrieb wird zur Elzielung besonders starker Stämme gewählt; doch ist dabei mit Vorsicht zu verfahren, damit nicht plötzliche Freistellung einen Rückgang des Wachstums bei den Oberständern (Wasserreiser, Zopftrocknis, zu starke Ironenausbreitung etc.) bewirkt. Gruppenweiser Leberhalt mit Bodenschutzholz in der Gruppe verdient Beachtung.

b) II ittelwa Id: Die Mittelwaldeiche (Stieleiche) liefert auf kräftigem frischem Boden (besonders in ren Auwaldungen der FluBniederungen) oft hervorragend wertrolle Sortimente, weshalb die Bestandespflege auch hier der Eiche besondere Sorgfalt zuwenden sollte. Die Rentabilität eines Mittelwaldes ist meist ganz wesentlich durch die Zahl der vorhandenen Eichenoberständer bedingt.

1) M o o s m a yer, tus den Walde $1891,8$.

2) Vergl. vo n II a $\mathrm{n}$ e u f e l, Die Eiche, deren Anzucht, Pfjege und Abnutzung, 2. Aufl. 1874. - II a I t i n, Folgerungen der Bodenreinertragstheorie, 4. Bd. 1898, Die Eiche im Hochwaldbetriebe. - C a r l, Eichenstarkholzzucht im Hochwaldbetriebe. Allg. F.- u. J.-Z. 1895, S. 1 ff. - Schot t le, Ueber die Rentabililat der Eichenslarkholzzueht, das. 1898, 253. - S t a u b es a n d, das. 1899,$41 ; 1901,230 ;$ Zlsehr. f. Forsl- L. Jw. 1907, 567. - A r n d t, Aus der Praxis der Eichenverjūngung. Ztschr. f. Forst- 1 . $J \mathbf{~}$. 1899, 641. - W i m m e n a u e r, Ertragsuntersuchungen im Eichenhoehwald. Nllg. F.- u. J.-Z. 1900, 2. - D e r s., Erfahrungen im Lichtwuchsbetriebzun Zwecke der Stalkholzzucht. Silva $1911, \mathrm{Nr}$. 24... S c h w a p p a h, Untersuchungen ūber die Zuwachsleistungın son Eichenhachwalılıesländen in Preußen. Neudamm 1905. 
c) Niederwald, insbesondere Eiche n s c häl 1 a l d, vgl. das oben (S. SO) hierüber Gesagte.

B. Verjü $\mathrm{ng} \mathrm{u} \mathrm{n}$.

1. Natürliche Verjüngung

a) Durch S a m e n: Im Hochwald durch Benutzung des unter einzelnen Altstämmen oder in Gruppen und Horsten von solchen sich ansiedelnden Nachwuclises, sowie durch planmäBige Herbeiführung einer Naturbesamung. Diese geschieht am besten nach den Regeln des Plenterschlagbetriebes, besonders dann, wenn es sich um Verjüngung von Mischbeständen handelt. Die horstweise Verjüngung gestattet am ehesten, der Eiche den ihr meist notwendigen Altersworsprung vor der mitwachsenden Schattenholzart zu geben. Die von selbst sich einstellende Auslichtung der mannbaren Eichenbestände macht eine auf den Bestand sich erstreckende Torbereitung im allgemeinen nicht nötig, wohl aber hann Vorbereitung des Bodens durch Bearbeitung angezeigt sein. Eine lichte Lnkrautdecke des Bodens ist der Ansamung nicht hinderlich, eher förderlicl. Schwache Ilasten und zu lockerer Stand der Mutterbäume bedingen Nachsaat aus der Hand. Bei dichterer Samenschlagstellung baldige Lichtschläge nach erfolgter Ansamung.

b) Durch A ussch lag: Im Niederwald und llittelwald durch Stockloden; lerner auch woh! durch Schaftloden an Schneitelbäumen.

2. Künstliche Bestandesgründung.

Sie bildet in Hochwald immerhin die Regel, weil selbst da, wo in einem zu verjüngenden Altbestande Eichen in der gewünschten Menge und Verteilung bereits vorhanden sind, die Nachzucht ausschließlich durch Samenabfall oft nicht genügend sicher erscheint (Lichtbedürfnis der jungen Pflanzen, obwohl vielfach überschätzt ${ }^{1}$ ), Abgang durch Iäuse, Yögel, Wild etc.). Die Saat wird an manchen Orten schon seit längerer Zeit, neuerdings allgemeiner, vor der Pflanzung bevorzugt. I' wenn nur das Verzehren der Eicheln durch Tiere oder etwa Verstocken derselben im Boden und dennächst Schädigung der Pflanzen durch Unkraut hintangehalten werden hönnen, die junge Pflanze nicht an dem Orte keimen, an welchem sie im Bestand stehen soll? Man spart die Pflanzliosten, außer den Iíosten der Pflanzenerziehung, und vermeidet die immerhin mißliche Behandlung der in der Jugend schon liräftig entwickelten Pfahlwurzel.

a) S a a t: als Vollsaat (Punktsaat unter Anwendung verschiedener Eichelstecker, des Eichelhammers, der Hacke, der Pookschen Doppelhacke etc.), sowie als Riefen- und Plätzesaat. Dichten Saaten wird im allgemeinen der Vorzug gegeben, damit der Neigung der Eiche, zumal der Stieleiche, sich frühzeitig breit in die Aeste auszulegen, durch engen Stand der Pflanzen, sodann auch dem Unliraut entgegengearbeitet wird. Die Saat erfolgt keineswegs immer auf der Freifläche, vielnehr wird

1) Vergl. Geppert, Erfahrungen über die Verjüngung der Eichenbesłände (Zeilschrift für Forsl-und Jagdwesen v. 1887 S. $153 \mathrm{ff}$.). Daselbst wird vom oslpreuß. Revier Flatow berichtel, daß künstliche Bestandesgründung nach liahlhieb nicht gelinge, während sich die Eiche unter dichtem Birkenvorwuchs in erfreulicher Nenge natürlich ansame und lange wuchskräftig erhalte, wie dies ebenso in Kiefernstangenorten in solchem Umfange der Fall sei, daß deren Umwandlung in Eichenstände dadurch möglich werde. - Einschleppen von Eicheln in Nadellolzbestände durch Nußhāher: die daraus entslehenden jungen Eichen sind oft überaus zăhlebig, bilden meist zunāchst ein kräftiges Wurzelsysten aus und sind infolgedessen nach der Freislellung nicht selten vollkommen entwickelungsfähig. Vergl. auch Dr. Ed. H e y e r, Beiłrag zun reinen und gemischten Eichenniederwald und -Hochwald ete. (Allg. F.- U. J.-Z, צ. 18S4, S. 207 u. 229). — Vielfach sehr gute nat. Verj. durch Samen auf Schieferböden der Rhein- und Moselgegend. - Gelegenllich der Versammlung deutscher Forstmänner zu Würzburg (1895) hat sich $F$ ü $\mathrm{r} \mathrm{t}$ mehr gegen, Ki i en it z mehr für die nalürl. Verjüngung der Eiche ausgesprochen. Die für lelzlere erforderliche Bodengare sollle allmăhlich herbeigeführl werden. 
da und dort (cfr. z. B. Kraft, A. F.- u. J.-Z. 1891, 361.-Hauch, A. F.- u. J.-Z. 1900, 225. - Hils-Sollingverein 1900) der Ansaat unter lichtem Schutzbestande, zumal in Hinblick auf Frost und Unkräuter, der Vorzug gegeben. Als Spezialfall der Rillensaat kann die z. B. in Spessart manchmal (Rohrbrunn) angewendete Leitersaat gelten, bei welcher auf $40 \mathrm{~cm}$ breiten Streifen dic Eicheln (7-8 Hektol. pro ha) in Querrillen eingelegt werden.

b) P f I a 1 z u n g: meist mit Forstgartenpflanzen und zwar sowohl mit 2jährigen Saatbeetpflanzen als auch (in der Regel) 3- bis mehrjährigen verschulten Pflänzlingen (bis zum Starkheister zur Nachbesserung in Mittelwaldungen, Auspflanzung im Wildpark etc.); event. Verschulung der I-2jährigen Pflanzen. Ileist Pflanzung mit ballenlosen Pflänzlingen. Pfahlwurzel bei der Kultur oft hinderlich, dann event. Einstutzen derselben (siehe \$63). Anwendung von Stummelpflanzen (abwerfen nahe über dem Wurzelknoten) kann sich bei der Eiclıe unter Umständen enıfehlen : sicheres Anschlagen, kräftige Triebe (doch nicht selten anfänglich melırere gleichwertig). Anzucht guter Heister, nicht selten durch mehrfaches Verschulen, Beschneiden etc. I). Heisterpflanzung ist im Erfolg oft recht zweifclhaft und hat stets nur als Ausnahme zu gelten, auch wegen der großen Kosten der Pflanzenerziehung und des Pflanzgeschäftes, wobei namentlich das Anfertigen entsprechend großer Pflanzlöcher, event. Formieren von Hügeln (auf feuchtem Boden) sehr ins Gewicht fällt.

Pflanzung ron 2jāhr. Pflänzlingen in gut gelockerte Riefen fördert rasch und ist demgemäß billig, auch genügend sicher, wird aber (siehe oben) durch Saat vielfach ersetzl. Enpfohlen wird jene Pflanzung z. B. von 11 o r tz f eld (Zeitschr. f. F. u. J. 1896, 2) auf seinen țleinen (ca. $10 \mathrm{Ar}$ großen) Löchern im Buchengrundbestand. Das von manchen Wirtschaftern (cfr. z. B. R e i B, A. F.- u. J.-Z. 1896, 309) unternommene Einbringen der Eiche auf kahl gehauene Fulissen ist meist zugunsten des horstweisen Anbaues oder der Einzelmischung wieder aufgegeben worden. Verwilderung der Eichen an den Kulissenrändern, sowie örtlich massenhaftes Auftreten der Mlaikäfer wurden dabei besonders beklagt. Je nach Umstånden streifenweises Einbringen der Eichen auf Pflugfurchen.

c) Spezialfall des $\mathrm{W}$ a l d f eld b a es, wobei die Eiche (mittelst Saat oder Pflanzung) auf gerodetem Lande nach Kahlabtrieb nachgezogen wird.

In Frostlagen bedarf die Eiche vielfach des Schutzes (mindestens seitlich) durch eine frostharte Holzart (Kïefer, Birke, etc.), welcher durch lichten Vorbau oder Zwischenbau zu gewähren ist. - Wiederholt sei betont, daß nur frische, kräftige Böden dauernd der Eichenzucht gewidmet werden sollten. Man darf die Eiche, so schätzbar sie als Nutzholzart ist, doch einem zu geringen Standort nicht aufzwingen wollen; sonst sind wirtschaftliche Verluste unvermeidlich!

3. H o r $\mathrm{n}$ b a u $\mathrm{m}$ (Hainbuche).

A. B e trie bs a r t: Zumeist Holzart des Hoch- und Mlittelwaldes, weiterhin Bestandteil des Nieder(Busch-)waldes. Im Hochwald meist nicht rein, sondern llischholz in Laubholz-, weniger in Nadelholzorten. Im Nittelwald brauchbares, gut ausschlagfähiges Unterholz; auch in Oberstand (jedoch nicht zu reichlich) zuzulassen. Gelegentlich auch Kopflolzbaum auf Viehweiden.

B. Verjüngung. Y Y t ürliche Verjüngung infolge von frühzeitigem, öfterem und reichlichem Samentragen ohne Schwierigkeit, ebenso Verjüngung durch Stockausschlag infolge großer Ausschlagfäligkeit leicht. Ki ï n t li c h e r A n b a u nur in besolıderen Fällen, namentlich dann. wenn es sich um Sclıaffung von

1) Vergl. Schwappach, Zur Frage der Erziehung von Eichenhcisteru (Zeitschr. f. Forst-u. Jw. 1887, S. 2 fP.). Nach den daselbst mitgeteilten Versuchen der Hauptstation fúr Versuchswesen in Preußen hat 2 malige Verschulung (zwischen dem ersten und zweiten L'msetzen nur 2 Jahre) mit möglichst wenig Eingriffen in den natürlichen En(wichelungsgang die besten Ergebnisse geliefert, sowohl in Absichl auf das Pflanzeninaterial als auf die Koslen.

Haudb. d. Forstwiss. 3. Aufl. II. 
Unterlıolz, z. B. in Eichen- oder Kiefernbeständen handelt. Schattenerträgnis und Frosthärte machen den Horubaum insbesondere für Unterbauzwecke in feuchteren, kälteren Lagen, wo die Buche gefährdet ist, geeignet. Dann entweder Saat oder besser Pflanzung mit 2-3jähr. Schlag- oder Saatschulpflanzen. Bei Erziehung von solchen im Saatbeet ist Ueberliegen des Samens zu beachten. Um gleichmäßiges Auflaufen der saat herbeizuführen, ist der Samen erst nach Ijährigem Einschlagen in flachen Gräben auszusäen.

4. Es c he.

A. B e tri e b s a t. In Hochwald und als Oberholz im Nittelwald, in beiden Fällen sehr geschätzt als Nutzholz; auch wohl Schneitelbaum zur Futterlaubgewinnumg (Alpen). Im Hochwald meist nicht oder nur auf lileinen Flächen in reinen Beständen; gewöhntich einzeln oder gruppen- und truppweise eingemischt in Laubholz(Buclıen-, Erlen-) Bestäude.

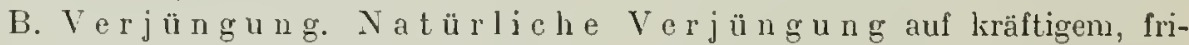
schem Boden unschwer. Eschenanflug stellt sich hier auch unter dichtem Iŕronendach nicht selten äußerst reichlich ein, muß aber infolge wachsenden Lichtbedürfnisses vom 10.-20. Jahre an licht gestellt werden. Vorwiegend $k$ ü $n$ s $t$ l i c h e r A n b a u, ausnahmsweise durch Saat, gewöhnlich durch die infolge reichlicher Bewurzelung sehr sichere Pflanzung, zu welcher ballenlose, vorzugsweise verschulte Pflänzlinge ( I -3jälırig verschult, meist 2jähriges Belassen in Pflanzheet), seltener Schlagpflanzen benutzt werden. Zur Ergänzung des Oberholzes in Mittelwald, soweit daselbst nicht Stockausschläge benutzt werden, ferner zum Einsprengen in bereits lserangewachsene Buchenhegen oder auf sehr unkrautreiche Orte oft stärkere Pflanzen (event. nochmals verschulte Heister). In Saatkamp Behandlung des Eschensamens infolge Ueherhiegens wie bei Hornbaum. Zeitige Aussaat des eingeschlagenen Samens im Frühjahr nötig, weil er zeitig keimt. Schutz der aufgelaufenen Saat gegen Frost sehr notwendig. Verschulung bisweilen schon mit lieimlingen (Krautpflanzen) nach Erscheinen des ersten Blattpaares mit Erfolg vorgenommen. Im Heisterbeete Zwieselbildungen durch Entfernung des schwächeren Triebes korrigieren bezw. durch Ausbrechen einer Seitenknospe bei beschädigter (erfrorener) Gipfellinospe vorbeugen.

5. A horn.

A. B e trie h s a r t: Spitz- und Bergahorn sind Holzarten des Hoch- und Nittelwaldes, Feldahorn hauptsächlich Holzart des Auen-Niederwaldes. Die ersteren in Hochwald selten rein, meist Mischlı̈lzer in Laubholz-, namentlich Buchenbestänılen.

B. Verjüngung. Im allgemeinen wie bei Esche. Na tü $\mathrm{r}^{\mathrm{l}} \mathrm{i}$ c h e Verjüngung ohne Schwierigkeit, da Samenjahre oft und reichlich. Auf minder frischerm und ärmerem Boden haldige Nachlichtungen vom Jungwuchs gefordert. I ü n s tI $\mathrm{i}$ c h e Verjüngung durch Saat, häufiger durch Pflanzung mit 2jährigen und älteren Loden oder Heistern Regel. Platz- und streifenweise Saat hin und wieder in Buchenschlägen zur Zeit der Samenschlagstellung oder schon cinige Zeit vorher im Starlium des Vorbereitungshiehes. In Auslichtungsstadium der Buchenverjüngungen Ausfüllung von Lücken durch Loden- oder lleisterpflanzung, ebenso Pflanzung im Mittelwald.

6. $\mathrm{U} 1 \mathrm{nie}$.

A. Betriebsart: wie bei Ahorn; Mischholz in Buchenbeständen (Berguhme), Oberholz im .littelwald (Felduhme). Hier und im Niederwald auch kräftiges Ausschlagholz.

B. Ver jü ng ung. Na t ü r l i c h e Verjüngung infolge Empfindlichlieit des 
Keimlings gegen Graswuchs selten, meist $\mathrm{k}$ ï $\mathrm{n}$ s $\mathrm{t}$ l i c h durch Pflanzung mit verschicden starken Forstgarteupflauzen (je nach den Umständen von der 1 jährigen Lode bis zum Starkheister). Aussaat des Samens im Saatbect im Sommer. Samen verträgt nur ganz scliwache Deckung durch Uebersieben oder Vermengen mit oberster Erdschicht.

7. Erle.

A. B e trie b s r t: in Hocluwald auf nassen Böden, dann oft rein, sonst Mischholz mit Esche, Ulme, Pappelarten; ferner im Niederwald (Erlen-Brücher in Niederungen, hier meist Schwarzerle in 30-40jähr. Untrieb; im Gebirge zur Aufforstung hängiger Partien, in Thüringen zur Aufforstung verödeter Muschelkalkhänge Weißerle); vereinzclt im Nittelwald.

B. Ve r jü $\mathrm{n} g \mathrm{u} \mathrm{n}$ g. Im Hochwald $\mathrm{n}$ a $\mathrm{t}$ ï $\mathrm{r}$ l i c h e Verjüngung durch Samen wegen Gras- und Unkrautwuchs des Standortes neist ausgeschlossen, hier vorwiegend I u n s t verjüngung durch Pflanzung mit 3-jjährigen verschulten Pflanzen. Auch bei Anlage von Ausschlagwaldungen ist Pflanzung in vielen Fällen nicht zu umgehen (vgl. S. 82), event. Verwendung von Stummelpflanzen. Auch bei der Aufforstung vou Wildbachgebieten mit der bodenhessernden und -bindenden Weißerle ist Pflanzung mit 2- und 3jähr. Pflanzen, hin und wieder auch unter erfolgreicher Verwendung von gestummelten Pflanzen Regel. Weißerle hat sich als Vorbauholzart bei der Aufforstung verödeter Böden, auch als Unterbauholzart in verlichteten, verhagerten Beständen als sehr brauchbar erwiesen.

8. L in d e: Hoch- und Mittehwald. Im dentschen Walde, obwohl wegen ihrer Nutzholzqualität für manche technische Zwecke sehr beachtenswert, doch nicht häufig Gegenstand ausgedehnteren Anbaues, dann fast durchgängig Pflanzung, obwohl Naturverjüngung durch Samen infolge beträchtlichen Schadenerträgnisses erfolgreich. Brauchbares Ausschlagholz im Nittel- und Niederwald.

9. Birlie.

A. Betriebsart: Hochwald- und Mittelwaldholzart, auch in Ausschlagwalde. Reine Bestände im Hochwalcle waldbaulich unzulässig, da schnelle Bodenvermagerung eintritt. In den nördlichen Ländern, wo reine Bestände häufiger vorkommen, ist Rückgang der Bodenkraft weniger auffällig als bei uns. Im heimischen Waldgebiet ist Birke nur als Mischholzart und dann noch mit Vorsicht zu verwenden. Gruppenweises Vorkommen führt leicht zu frühzeitiger Bestandesdurchlichtung, deshalb ist Beschränliung auf Einzelmischung angezeigt. In Nadelholzbeständen macht sich Birlie vielfach durch Peitschen und Bereiben der Nadelholztriebe unangenehn bemcrkbar und führt infolgc frühzeitiger Hiebsreife zu störender Lückenbildung. Die Birke ist in den meisten Waldgebieten Deutschlands nicht eigentlich mitbestimmend für den Betrieb, sondern nur von sekundärer Bedeutung. Besondere Bedeutung hat sie auf ärmerem Sandboden, wo sie namentlich zur Einfassung der Wege und Schneisen, sowie zur Bildung von Fcuermänteln an Platze ist.

B. Verjüngung. Neist reichlicher Anflug, sobald nur einige Samenbäume vorhanden; auch Stockausschläge. Künstlieher Anbau durch Saat (z. B. Vollsaat zur Erziehung eines Schutzbestandes; Behandlung des Bodens nach der Saat mit der Strauchegge) oder durch Pflanzung (meist Schlagpflanzen) am besten zeitig in Frühjahr.

Hier mag besonders darauf hingewiesen werden, daß die beiden Birkenarten, Betula verrucosa und B. pubescens, in ihren waldbaulichen V'erhalten sehr verschieden sind. B. pubescens ist dichter in der Krone, viel mehr eine Holzart feuchter Böden, findet sich z. B. in reinen Beständen auf der Grenze der Brücher (Versuchsflächen in Ostpreußen), mit Erträgen bis zu $300 \mathrm{Fm}$. in 70 . Jahre. 
10. R o b in i e. Waldbauljch meist nur als Ausschlagholz von Belang, an Böschungen zur Befestigung, doch auch auf herabgehommenen Böden als eigentlicher Bestand, z. B. in Mischung (horstweise) mit der Edelkastanie ${ }^{1}$ ) usw. (rgl. S. 81). Das Holz wird als Grubenholz verwandt. Auch als Stickstoffsammler ist die Robinie zu empfehlen, daher für Zwischenbau zur Bodenverbesserung vorzüglich geeignet. Die Hassen- und Gelderträge des Robinienniederwaldes sind selı hoch (bis 12 Fm. für 1 Jahr und Hektar und Preise bis 25, selbst 30 Mark für 1 Fm. Nutzholz).

11. Edelkastanie ${ }^{2}$ ). In Deutschland wegen der klimatischen Bedingungen, welche sie für ihr Gedeihen fordert, zumal wegen ihres Wärmebedürfnisses, nur in beschränktem Umfange (Pfalz, Elsaß etc.) als Waldbaum verbreitet. Besonders geschätzt als Holzart des Niederwalds (Gewinnung von Rebpfählen): Stocliausschläge reichlich und kräftig (vgl. S. 81). Begründung neuer Bestånde meist durch Pflanzung mit 1 -3jährigen (in del Mehrzahl der Fälle 2jährigen) Loden, Anzucht der nötigen Pflanzen (pro ha 6000-8000 Stück erforderlich) in rigolten Saatbeeten (Spitze der Frucht beim Einlegen nach unten!). Kíosten der Erziehung pro 1000 2jähriger Pflanzen ca. 12 Nark. Pflanzung in Frühjahr mit der Hacke oder einem Klemmeisen (spatenartig abgeändertes Buttlar'sches Eisen); Pflanzen teils unbeschnitten. teils (besser) nach Einstutzen der Seitenäste oder als Stummelpflanzen. Jährliches Reinigen und Behacken der Iin]tur. Bodenpflege durch Grabenzichen (.Belebungsgräben"). - Saat hier und da als Vollsaat (bezw. Punktsaat, wie bei der Eiche) mit 3 Helitoliter Liastanien pro ha (30000 Stück) odel Rillen- oder Plätzesaat. Gefahr durch Wildschweine.

12. P a p p e l. Meist im Hochwald, doch für clie Betriebsart nicht entscheidend. Aspe ist infolge ihrer Verwendung zur Fabrikation der schwedisehen Streichhölzer sehr gesucht und an manchen Orten gut bezahlt, so daß ihr Anbau vielfach angezeigt erscheint.

Für den Anbau kommen weiterhin besonders Schwarzpappel und kanadische Pappel in Betracht. Letztere ist wertroller. Die Pflanzung elfolgt vielfach durch Setzstangen, welche aus Stockausschlägen zu gewinnen, wohl auch in der Pflanzschule zu verschulen sind. Bei der Aspe verpflanzt man meist Wrurzelbrut. Doch wird auch künstl. Samenverjüngung empfohlen (Paul in Deutsche Forst-Zeitg. 1899. S. 195). desgleichen Erziehung von verschulten Aspenpflänzlingen (Forstrat Hofmann in Forstw. Zbl. 1902 , S. 360).

13. IT e i d e $\mathrm{n}^{3}$ ). $\ln$ Kopfholzbetrieb (Flußniederungen), sowie im Niederwald (Weidenheger), oft mit nur ljährigem Untrieb (feinste Flechtruten). Sorgfältige Bodenpflege, Sicherung gegen Unkraut. Wenn nach ca. 15-18 Jahren eine Anlage im Ertrag zurückgeht, so liegt dies weniger an Bodenerschöpfung, als an der in jeder Nutzung zu erblickenden andauernden Mlihandlung (trotz rationellsten Schnittes) der Stöcke. Sehr hohe Reinerträge. Frische Böden durchschnittlich am besten.

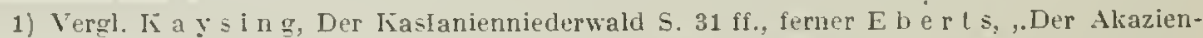
niederwald" (Allg. F.- u. J.-Z. 1900, S. 75), M. s. auch Verhandungen der 23. Versammlung des Elsaß-Lothringisehen Forstvereins.

2) Vergl. K a y s in g, Der Kastanienniederwald, 1884, - Aufsätze in der .Ilg. F.- u, J.-Z. 1879, S. 206;1883, S. 37 (Osterheld - Pfalz); 1883, S. 211 (Rebmann - Elsaß). — E ngl e r, ,Die Edelkastanie in der Zentralschweiz". - M erz, schweiz. Forstver. 1895 und $r$. S e u $t$ le $r$, schweiz. Zeitschr. 1895, 201. - Os t e r h eld. A. F.- H. J.-Z. 1893, 22,..Edelliastanie an pfailzischen Vorgebirge".

3) Verol. S c hulze. Die Iultur der liorbweide, 1874. - S c h m i d. Die Inpflanzung und Fintur der liorb- und Bandweiden, 1883. - Ii $\mathrm{r}$ a h e, Lehrbuch der rationellen korbweidenkultur, 5. Aufi. 1897 . - Z se h i m m e r, Anbau der liorbweide. Thar. Jabrb. 1888, S. 23. - $\mathrm{A}$ u $\mathrm{m}$ a $\mathrm{n}$, Weidenhegerbetrieb in Flußniederungen. Zeitschr. f. F. 11. J. 1894, 712. - liorbweidenkultur lïngs dep öterr. Eisenbahnen. Oeslerr. Forst- u. J.-Zlg. 1894, 66. - P i c c i o l i, La coltura dei salici, 1896. - D e ke r l, Lebel Weidenzuch1. Yünd. Forsll. Hefte 9. (1896). S. 15. - D a n $\mathrm{ckeln}$ a $\mathrm{n} \mathrm{n,} \mathrm{Zeilschr.} \mathrm{f.} \mathrm{F.} \mathrm{U.} \mathrm{J.} \mathrm{1898,} \mathrm{S.} 652$. 
keineswegs nasse. Einzelne Weiden (z. B. Salix caspica) auch selir gut auf trockenerem, wemn nur einigermaßen mineralisch liäftigem Sand. Vgl. das oben (S. 82) über Weidenuiederwälder Gesagte.

Die als ein Iauptteil des sog. Weichholzes in den Schlägen auftretenden Weiden, bes. S. caprea, cinerea, aurita erscheinen meist als Ausschläge und durch Samenanflug.

14. Prunus-, P irus-, Sorbus-Arten. Eingesprengt im Hochwaldbestand, an W' Mittehald. Großenteils als gute Nutzhölzer zu begünstigen, besonders bei den Durchforstungen zu berücksichtigen; doch waldbaulich olıne große Bedeutung, weil die Nachfrage immerhin eine bescluänkte ist; besonders begehrt ist die Elsbeere ( $\mathrm{S}$. torminalis).

15. Unterhölzer in ll ittelwald. Als solche mögen insbesondere für viele Auewaldungen Viburnum, Lonicera, Cornus, Prunus, Crataegus u. a. m. neben den bereits aufgeführten Nittelholzarten lier erwälnnt sein, weil sie oft selır gut verwerthare Kleimnutzhölzer liefern. Abtrieb derselben oft alle $\overline{5}-S$ Jahre. Besondere Pflege findet meist nicht statt.

\section{Nadelhölzer.}

\section{69. 1. T a n n $\mathrm{e}^{3}$ ).}

A. Betrie bs a r t. Dic Tanne ist, wie alle Nadelhölzer, ein Baum des Hochwaldes. Höchstens im llittehwald findet sie sich hier und da in ganz beschränktem Maße durclı Pflanzıng einzeln oder in Gruppen dem Oberholze beigesellt. Im Hochwald wird sie im Femelbetrieb, Femelschlag- und Schirmschlagbetrieb und den Zwischenformen dieser Betriebe behandelt, während sie den Kahlschlag als Betriebsform wegen ihres Schattenbedürfnisses in der Jugend allgemein nicht zuläBt. Wo Tannenkahlschläge gleichwohl geführt werden, sind sie Notbehelfe infolge von Betriebsstörungen, vorübergehende Vaßregeln, nicht aber Wirtschaftsprinzip. Wie schon früher hervorgehoben wurde (z. B. \$27), führen gewisse Eigentünlichkeiten der Tannenwirtschaft (reichliche Ansanung unter noch geschlossenem Kronendach, Zälılebiglieit, Bildıng von Vorwïchsen, Aushieb von Krebstannen etc.) naturgenäß zu ungleiclıartigen, melır femelartigen Beständen im Gegensatz zum durchweg gleichmäBig geste]lten Schirmschlag. Die L'mtricbszeit ist meist auf 100-1?0 Jahre festgesetzt. Haubarkeits-Durchschnittszuwaclıs auf mittlerem Standort $7-9$ Festmeter; die durchschnittliche Höhe solcher Bestände beträgt in jenem Alter 25-30 Neter. Die Durchmesser sind, je nach der Art der Wirtschaftsführung, überaus wechselnd. Besondere Starkhölzer, Stänme von 00 und mehr cm Mittenstärke, werden auch da, wo frülnzeitig Lichtungszuwaclıs angestrebt wird, meist erst in längerer Zeit (mit 140-160 Jahren) produziert. Die femelartigen Betriebsformen bieten aber die beste Gelegenheit, Stämme zu diesem Zweck länger im Bestande zu belassen; im regelmäßigen Schirmschlag müßte man die Untricbszeit ent:precliend erhöhen oder zu

1) Vergl. u. a. G e r wi g, Die Weißtanne im Schwarzwalde, 1868; Referate und Debatten bei der deutschen Forstversammlung zu Wildbad 1880 (Die Referate finden sich in der Allg. F.- U. J.-Z. von 1880: Sc h u berg S. 304, P r o b s t S.311), ferner Verhandlungen des badischen Forstvereins $2 \mathrm{u}$ Wolfach 1584 . - M a $\mathrm{g}$ e $\mathrm{n}$ a $\mathrm{u}$, , Tannenverjüngung auf dem Jura". Allg. F.- u. J.-Z. v. 1887, S. 312 ff. - II a r in, Folgerungen..., 2. Bd. 1895, Die W"eißtanne. - Wirtschaftsegeln für Elsaß-Lothringen, 1892. - C a l l, Allg. F.- U. J.-Z. 1893, 163, 204. - Ilencke, Allg. F.- u. J.-Z. 1897, 287. - B a u dis c h, Zbl. f. d. ges. Forstw. 1897, 101. — iv e in $k$ a $u f$, Die Tanne auf d. Buntsandstein des Pfälzer Waldes. Allg. F.- U. J.-Z. 1897, 321, 345. — S c h a a l, Die Weißtanne in Sachsen. Allg. F.- U. J.-Z. 1898, 200. - K a u $t$ z s c ll, Allg. F.- u. J.-Z. 1892, 145, 2:9; 1893, 350; 1898, 220. - Ders., Beitrāge zur Frage der Weibtannenwirtschaft 1895. - Gretsch, Forstw. Zentralbl. 1898, 455. - 
einer ausgesprochenen Ueberhaltform übergehen. In welchem Ümfange die Anzucht solcher besonders starken Hölzer rätlich erscheint, ist Sache lokaler Erwägung, unter dem Gesichtspunkt der Rentabilität, deren Bemessung sich auf den Holzmarkt, bezw. die Holzpreise stützt.

Die Tanne kommt in ausgedehnten reinen Beständen, sowie in verschiedenen, zum Teil hervorragend wertvollen Mischungen vor, worüber im 1. Absehn. S. 12 das Nötige bemerkt ist.

B. V e r j ü n g u n g. Wenn irgend eine Holzart, so ist die Tanne vermöge ihrer Eigenschaften zur natürlichen Verjüngung durch Samenabfall bestimmt. Künstliche Bestandesbegründung ist - abgesehen von den (neuerdings zahlreicher auftretenden) Fällen, in welchen die Neuanlage von Tammenbeständen erfolgen soll - Ausnahme und findet meist nur da statt, wo wirtschaftliche Mlistände (Ueberaltlı̈̈lzer, Sturmlücken etc.) eine natürliche Verjüngung überhaupt nicht mehr oder nicht mit dev nötigen Sicherheit erhoffen lassen.

1. Natürliche Verjüngung:

Namentlich in den letzten 20 Jahren ist die Naturverjüngung der Tanne Gegenstand eingehender Erörterung gewesen. Sie erfolgt in Femelbetrieb, Schirmschlagbetrieb, Saumschlagbetrieb und im Femelschlagbetrieb. In allen diesen Fällen liommt die Zählebigkeit der Tanne, sowie ihre langsame Jugendentwicklung in Betracht. Eine Folge ilures großen Schattenerträgnisses ist, daß sich Besamung meist ohne besonderen Vorbereitungshieb und Samenschlag oft schon im 70-80jährigen Bestandesalter reichlich einstellt, mindestens auf denjenigen Stellen und in deren Umgebung, welche durch Auszug von Krebstannen, eingesprengten Mischhölzern usw. etwas (wenn auch nur mäBig) geliehtet sind. Werden solche Aushiebe schadhafter oder sonst unerwünschter Bäume in gesteigertem Maße nötig, tritt vielleicht Windwurf hinzu, so entstehen Löcher im Bestande, auf welchen der Jungwuchs bald in die Höhe geht; deren allnälliche Erweiterung führt nach und nach zur Verjüngung des ganzen Bestandes.

Wo sich dieser die Piegel bildende Torgang nicht (gewissermaßen ganz von selbst) abspielt, hat man es in der Hand, die Verjüngung in längerem oder liürzerem Zeitraum mittelst gleichfömiger Schlagstellung durch den ganzen Bestand hin (regelmäßige Vorbereitungshiebe mit gleichmäßiger', allmählicher Durchlichtung ete. Sehirmschlag Gayers) oder derart durchzuführen, daß man die einzelnen Bestandespartien naeheinander verjüngt, bezw. sich jene Löcher durch gruppen- und horstweise Eingriffe künstlich sehafft (horst- und gruppenweise Verjüngung Gayers - vergl. aueh: dritter Alschnitt, $\S 40-13)$. Gleichmäßige Schimschlagstellung auf schmalen Streifen verbürgt den Erfolg event. ebenso sicher wie Löcherhiebe und verdient unter Umständen wegen größerer Uebersichtlichlieit im Fortgange der Verjüngung den Vorzug.

Hinsichtlich des Verjüngungszeitraumes wird die Erwägung maßgebend, ob man im konkreten Falle auf raschere Erstarkung des Jungwuchses oder auf längeres Andauern des Lichtungszuwachses an den Mutterbäumen den größeren Wert legt. Ueber die etwaige Benutzung des Vorwuchses siehe $\$ 73$. Erstreelit sich die vollständige Verjüngung eines Bestandes, d. lı. die Ersetzung sämthicher heute im Bestande vorhandener Individuen dureh neue, auf die ganze Umtriebszeit, so kommt man zum eigentlichen Femelbetrieb.

In wesentlichen ist es für die Art der nat. Tannenverjüngung zunächst entscheidend, ob man grundsätzlieh möglichst e i ln Mastjahr zur Erzielung des Jungbestandes benutzen will (Schirmschlag) und demgemäß mit gleichmäßiger Schirmstellung üher die ganze Fläche hin volgeht, oder ob del allmählichen, partienweisen Verjüngung (Femelschlagbetrieb, Gruppen- 
und Horstwirlschaft, Benulzung mehrerer samenjahre) der Vorzug gegehen werden soll. Martin stell beide Methoden an Wert gleich. Genügende Samenjahre hat man fast überall in 3- bis 5jahrigen Zwischenräumen. Beides läßt sich machen; aber tatsächlich kommt man ganz von selbst bei der Tanne fast immer zu einer mehr oder ininder scharf ausgepräglen Gruppenwirtschaft, weil sicl, wie oben angefūhrt wude, Anflug in d’r. Regel schon in Beständen einstellt, welche noch nicht planmäig zur Verjungung stehen, und dieser Anflug sich wenigstens Leilweise bis zur Zeil der plannäBigen Verjüngung wuchskräflig erhält, bezw, schon zu gut entwickelten Vorwüchsen ausbildet. Vach den allerdings nur auf das .l] urglal sich erstreckenden

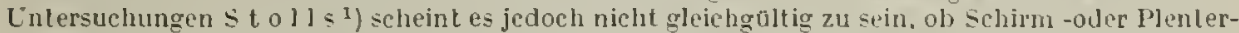
schlagverjüngung gewählt wird, zum mindesten scheint die Höhenlage des jeweiligen Verjüngungsbestandes für den Erfolg der cinen oder der anderen Betriebsform mil tntscheidend zu sein. Ini nōrdlichen schwarzwald ist nach Stol] Schirmschlagverjungung nur lis 400 m Veereshōlıe, im südlichen Schwarzwalde bis $500 \mathrm{~m}$ angezeigl. Die höheren Lagen erfordern, wenn sonst die lieimbettverbîltnisse nicht derartig ungüntig werden sol]en, daß die Verjüngung versagt. l'lenterschlagverjūngung. Der mit der Schirmschlagverjüngung zusammenhăngende dichtere Bestandsschluß verhindert in den höheren Lagen eine himeichende Erwālmung des Bodens, was Trockentorfbildung und damil Versauerung und Verdichtung des lieimbeltes zur Folge hat. In diesen Lagen velnag nur starke SelduBunterbrechung und slaffelung les Beslandes, d. h. Anwendung des Femelschlag-oder des Femelbetriebes die zur normalen Streuzersetzung notwendige Wärmesumme dem Boden zuzuführen. Für die hōheren Lagen des Schwarzwaldes wird von Stol] dalıer die Femelsclalagform nil langer V'ejüngungsdauer und Uebergängen zun Feınelwalde empfohlen. Ilit der Entscheidung für Schirmschlag- oder für Femelselılag. betrieb entsclieidet sich in der Hauplsache auch die wichlige Frage, ob man die Verjüngung in ganzen rascher oder langsamer durchführen und demgemäß nur lileinere oder größere Altersunterschiede im Jungbestande haben will. Da die Bedingungen, unter denen die Tannenwirtschaft geführt wird, örtlich keineswegs die gleichen sind (z. B. in Baden auf der Westseite, in Württemberg auf der Ostseile, d. h. im Regenscliatten des Selıwarzwaldes, - Seenähe in Oldenburg), so erklären sich die twilweis weit auseinander gehenden Forderungen, die in bezug auf die Länge des Verjüngungszeitrames erhoben werden. Die schirmschlagartige Verjüngung führt zu einer verhältnismä Big raschenV erjüngung in 20 - bis 30 jähr. Zeiträumen, während

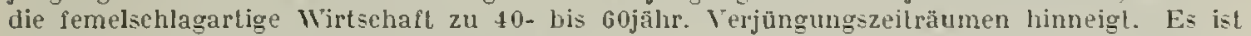
selbstversländlich, daß die Verjüngungszeiträume um so länger werden, je mehr die Femel=chlagform zum reinen Femelbetrieb ubergeht.

\section{Künstlicher Anbau:}

Am besten unter Schutzbestand wegen der Empfindlichkeit der Tanne gegen Frost, Hitze und Unkraut. Doch in Notfällen auch im Freien, dann alıer fast ausschließlich mittelst Pflanzung; genügender Erfolg lauptsächlich bei großer Luftfeuchtigkeit.

a) S a a $t$ :

Sie kommt gelegentlich (Elsaß-Lothringen) in abständigen Orten unter dem Schirm des gelichteten Altbestands, dann aber hauptsächlich bei Lmwandlung anderer Holzarten in Tanne und beim Unterbau in Anwendung, in Ausnützung guter Samenjahre. Ileist als Piefen- oder Plätzesaat; Aussaat am besten noch im Herbst. Dabei erfolgt allgemein, ganz besonders aber bei Anlegung horizontaler Riefen an Hängen, mit Vorteil die Aussaat des Samens auf deu am Riefenrande angehäuften Aufwurf, damit die lieimpflanzen nicht, wenn in der vertieften Riefensohle stehend, von Wasser zugeflößt und von Laub etc. überlagert werden; überdies besonders hräftige Wurzelbildung auf dem Riefenrande. Der Aufwurf befindet sich am Hange am unteren Riefenrande.

b) P f l a n z u g:

Beim Unterbau meist 4-6jährige, einmal verschulte Pflanzen. Material für die Verschulung liefern die Riefen- und Plätzesaaten, sowie die natürlichen Besamungen; andernfalls Anlegung besonderer Saatbeete. Wird in kontinuierlichem Zuge die Umwandlung auf größeren Flächen durchgeführt, so findet man vielfach Saat und Pflanzung (je nach dem Ausfall der Samenernte, der verfügbaren Pflanzenmenge etc.) in verschiedentlich variierter Kombination. Dabei verdient der Altersvorsprung der

1) Sto 11, Das Versagen der Weißtannenverjüngung im nittleren Jurglale. Nalurwiss. Zlschr. f. Land- und Forelwirtschafl 1909, S. 279, 297, 345. 
Pflanzung Beachtung. Verwendung meist ballenloser Pflänzlinge unter Benutzung der Hacke. - Zur Pflanzung auf Iialılflächen werden (besonders wegen Unkiäuterwuchs manchmal stärkere, zweimal verschulte Pflanzen verwendet (teuer!).

Gefährdung der Tannenkulturen durch Wildverbiß.

2. Fic h t e.

A. B e tri e b s a t. Ebenfalls zunächst Hochwald-Holzart, jedoch im Oberholz des Mittelwaldes nicht ausgeschlossen. Von der Tanne hinsichtlich der für die Walıl der Betriebsart hauptsächlich in Frage lommenden Nomente besonders durch das abweichende Verhalten in der Jugend unterschieden: raschere Entwickelung in den ersten Jahren, dabei größeres Lichtbedürfnis und dementsprechend geringere Ausdauer im Schirmdruck, wesentlich geringere Gefährdung durch Frost und Hitze, wodurch die Möglichkeit des Anbaues auf der Kahlfläche bedingt ist. Dazu hommt andererseits größere Gefährdung durch Sturm und durch Schneebruch. Man findet die Fichte in allen Hochwaldbetriebsformen, von der extremen Kahlschlagwirtschaft bis zum eigentlichen Femclwald. Für den in frülıeren Abschnitten mehrfach berülurten Kampf pro und contra Kahlschlag, bezw. Femelbetrieb, Femelschlag, Schirmschlag oder Saumschlag bildet die Fichte das hauptsächlichste Objelst. Man muß einräumen, daß der Kahlschlagbetrieb an vielen Orten und in weitestem Umfange sehr gute Erfolge aufzuweisen hat, so daß man ihm gegenüber kaum belıaupten kann, nit natürlicher Verjüngung würde man unter den gegebenen Verhältnissen noch weiter gekommen sein. Andererseits wärc es eine Uebertreibung, wollte nan im Kahlschlag ınit nachfolgender künstlicher Bestandesbegründung allgemein und ohne Einschränkung die beste Fichtenwirtschaft erblicken. Die Sicherung gegen Stürme läßt sich zwar durch eine sorgsame Hiebsführung im Kahlschlagbetrieb vielleicht am vollständigsten erreichen, aber die Belastung der Bestände durch den Iíulturaufwand, welchen der Kahlschlag erfordert, ist, in Verbindung mit dem oft befürchteten nachteiligen Einfluß der Bodenentblößung, genügende Veranlassung, der natürlichen Verjüngung der Fichtenbestände für die geeigneten Verhältnisse ihr Recht zu wahren. Will man sic anwenden, so sind Femelschlagbetrieb sowie Saumschlagverjüngungen in erster Linie zu wählen, soweit es sich überhaupt noch um einen Wirtschaftswald handelt. Die eigentliche Femelform paßt für die Fichte weit weniger als für die Tanne. Gegen den Schirmschlagbetrieb spricht die Gefahr des Windbruchs, die natürlich auch bei der horstweisen Verjüngung ebensowenig ausgeschlossen ist wie beim Saumschlagbetrieb. Schon oben (S. 48) wurde darauf hingewiesen, daß die von W'agner auch für die Fichte warın empfohlene Saumschlagverjüngung von Norden herein gerade in der Sturmgefährdung eine ihrer schwachen Seiten hat. In schutzbedürftigen Hochlagen ist der Kiahlschlag oft ganz ausgeschlossen. Ueberhaupt hängt die Entscheichung zwischen den im allgemeinen möglichen Betriebsformen ganz wesentlich von der Oertlichlieit ab. Frische Böden sind meist der natürlichen Besamung günstig. Hinreichende Auslichtung der Bestände vorausgesetzt, stellt sich Besamung auf solchen Böden leicht ein und hält sich bei wenig künstlicher Nachhilfe so gut, daß die natürliche Verjüngung ohne besondere Besamungsschläge gelingt. Die Nachteile, welche dem Kahlschlagbetrieb anhaften liönnen, werden durch sofortigen Anbau mittelst Pflanzung unter Anwendung besten Pflanzmaterials auf ein Minimum reduziert. Untriebszeit 80-120 Jahre, Ertragsverlältnisse ähnlich wie bci der Tanne; doch sind schwächere Sortimente der Fichte weit besser verwertbar (Hopfenstangen, Papierholz, geringe Baustämme), weshalb auch niedrigere Umtriebszeiten örtlich noch sehr wohl zulässig sein können. Ueberdies beeinflußt dieser Umstand nicht selten den Durchforstungsbetrieh. Die Bedeutung der Fichte als Mischholzart ist früher erörtert. 


\section{B. Ve r jü $n g \mathrm{~g} n \mathrm{~g}$.}

Wie schon aus den forstehenten hervorgeht, treten bei der Fichte alle für ein Nadelholz überhaupt in Frage liommenden Verjüngungsmöglichlieiten in lebhafte konkurrenz, haupt. sächlich deshalb, weil hier die Freilandskultur in den meisten Fällen ebenso mogglich ist, wie die Verjünırung unter einen Oberstand. Es handelt sich vielfaeh nur um, gut" und, besser". Neben gewissen allgemeinen Grundsătzen sind vorzugsweise hei der Fichte örtliehe Erwägungen von Fall zu Fall entscheidend, und es ist begreiflich, daß gerade uber ihren Anbau von jeher lebhaftester Mleinungsaustauseh stattgefunden hat.

\section{Natü rlich e Verjü $\mathrm{n} g \mathrm{~g} \mathbf{n}$ g.}

Die neuerdings wieder melı als seither geltend gemachten Gründe zu gunsten der natürlichen Verjüngung sind in der Hauptsache die allgèmein gegen den Iiahlhieb sprechenden und betreffen vornehmlich den Bodenzustand ${ }^{1}$ ). Eigentlicher Femelbetrieb, abgesehen von höheren Gebirgslagen, selten; Schirmschlagbetrieb oder Femelschlagbetrieb ist Regel, letzterer, wenn die ausgesprochene Absicht vorliegt, einen ungleichförmigen Bestand nachzuziehen. In ganzen muß die Verjüngung in rascherem Tempo geführt werden wie bei der Tanne. Der junge Aufwuchs der Fichte verlangt haldigst einen bedeutenderen Lichtgenuß (Modifikationen je nach Oertlichkeit), mithin meist stärkere Eingriffe schon in Gestalt von Vorbereitungshieben und demnächst auch rascheres Nachhauen. - Verjüngung durch Randbesamung, wenn je, so am ersten bei der Fichte noch zulässig (siehe $\$ 38$ ).

So sehr von vielen Seiten die natürliche Verjüngung empfollen wird, so entschieden darf man sich andererseits darauf berufen, daß durch künstliehen Anbau in großer Ausdehnung tadellose Bestände erzielt worden sind. Zumal dort, wo in Gegensatz zu großen zusammenhāngenden Kahlhieben, mit Schmalschlägen operiert wird, die nieht alljährlich, sondern erst naeh mehrjährigen Zwischenräumen aneinandergereiht werden, bedarf es der natürlichen Verjungung nicht. Ob letzlere in allen Fällen das Ziel billiger (event. kostenlos) crreichen Jäßt, ist im Hinblick auf das oft überrasehend gute Wachstum künstlicher liulturen mindestens fraglich. Ueberdies wird der Besamung von nicht wenigen Wirtschaftern die wünschenswerte Sieherheit abgesprochen: die Fichte sei launisch in bezug auf die Besanung. - Ungleiehaltrige Bestände, wie sie der Femelschlagbetrieb liefert, werden auch bei der Fiehle von manehen hevorzugt; sie sollen (efr. z. B. Engler) die Vorteile von gemischten Beständen ersetzen.

2. Ii ü $\mathrm{nst} \mathrm{lich}$ e Bestand esgr ün d ung.

Die Frage, ob Saat oder Pflanzung vorzuziehen ist, wird verschieden beantwortet. Saat soll mehr Schutz gewähren gegen Rüsselkäfer und auch gegen Wild; auch für Loshiebe (Schnalstreifen) sei oft Saat besser, wogegen auf großen Kahlschlägen die Pflanzung, event. mit schmalen Saatstreifen längs des Altbestandes, vorzuziehen sei ${ }^{2}$ ). Im großen ganzen ist die Saat von der Pflanzung aber verdrängt worden: es gibt Fichtengebiete, wo man die Saat kaum mehr kennt. (Vgl. die Abwägung der Vorzüge und Nachteile zwischen Saat und Pflanzung S. 84) ${ }^{3}$ ).

a) S a a t: Als Vollsaat, Riefen- und Plätzesaat, erstere im ganzen seltener. Spezialfall der Vollsaat z. B. im früheren wïrttembergischen Waldfeldbau, Forst

1) D i m itz, Wie erhãlt sich die Fiehte in Gebirgsforsten der nördliehen Kalkalpen zum Femelschtag- und Lichtungshetriebe? Zhl. . d. ges. Forstw. 1901, 511. — En g l e r, Verjüngung der Rottannenbestände. Schweiz. Ztschr. f. Forstw. 1899, 1. - M a r t i n, Folgerungen usw. 5. Bd. 1899, die Fiehte. - B r o ill a r d, Revue des eaux et forêts 1897. - B e r n f us, Die Saumsehlagwirtsehaft im Fichtenhoehwalde. Oesterr. V'ierteljahressehr. 1905, 13. - IV a $\mathrm{g}$ n e r, Rảumliche Ordnung, 2. Aufl. 1911.

2) Vergl. N e u m e is $\mathrm{t}$ er, Thar. Jahrb. 1889, 105.

3) Neuestens ist namentlich den Fichtenpflanzungen, gegenūber der natürl. Verjüngung, die BiJdung zahJreicher Doppelgipfel, die ungünstigere Beastung, stärkere Rotfäule ete. vorgeworfen worden. - Vergl. G ra sma $\mathrm{n}$, Beobaehtung in Fichtenpflanzheständen (Forstw. Zentralblatt von 1886, S. $560 \mathrm{ff}$. ), G $\mathrm{r}$ a s m a $\mathrm{n}$, Entgegnung an Rommel (AJlg. F.- u. J.-Z. v. 1887, S. 130), dagegen fũr die Pflanzung Dr. S t o e 1 z e r, ,Zur Frage der Rälliehkeit des Fichtenanhaues durch Pflanzung" (Forstw. Zentralblattv. 1887, S.404) - M a $\mathrm{I}$ t i n, Folgerungen ..., 5. Bd. 1899, Die Fichte. - En g l e $r$, ,Verjüngung der Rottannenbestände, Schweiz. Zeitsehr. $1899,1$. - B r o i J a r d, Rerue des eaux et forêl $\varsigma, 1897$. 
Ochsenhausen 1). - Gelegentlich auch Fichten-Dammsaat $\left.{ }^{2}\right)$ : Aussaat auf erhöhte Saatstellen (analog der Hügelung beim Pflanzen) bei undurchlassendem, tonigem Untergrund und starlier Grasnarbe. Dämme 1/2 $\mathrm{m}$ breit, $10-15 \mathrm{~cm}$ hoch, $1.5 \mathrm{~m} \mathrm{Ab-}$ stand von Mitte zu Mitte.

b) Pf l a n zung: Als Einzel- und als Büschelpflanzung; als Loch- und als Hügelpflanzung, event. auf Rabatten; mit 2-6jährigen Pflänzlingen (mit oder olme Ballen), hier und da mit nocl stärkerem Material (bei Naclibesserungen); unter Anwendung der verschicdensten Instrumente (Buttlars Eisen. Spiralbohrer, Hacke, Stoßspaten etc.).

Pflanzenmaterial liefern Schläge, bezw. Saatstellen (z. B. massenlıft die Waldfelder) und die Pflanzenerziehungsstätten. In letzteren Erzieluung von Saat- und Schupflanzen. Jetzt vielfach Verschulen (1- und 2jährige Pflanzen) und danach 2jähriges Belassen im Pflanzbeet. In windigen Freilagen, wie u. a. auf Hochflächen des Gebirgs, keine zu starken Pflanzen (Losriitteln durch den Luftzug vor dem festen Anwurzeln), event. Pflanzung in Löcher oder hinter kleine Schutzdämme. - Verbandweite ${ }^{3}$ ) je nach dem Wirtschaftszweck (z. B. Einfluß des Hopfenstangenhandels) sehr verschieden; Reihenverband findet sich z. B. von 0.5 bis 1,75 oder melır zu 1 Meter, Quadratverband von 0,75 bis 2,0 und mehr Meter (derart weite Verbände natürlich nur ausnahnsweise).

Die Frage, ob Einzelpflanzung oder Büschelpflanzung (cfr. auch oben S. II9), schien ziemlich allseitig zu gunsten der Einzelpflanzung erledigt, als sie bei Gelegenheit der Versammlung deutscher Forstmänner zu Braunschweig 1896, den meisten Anwesenden unvermutet, wieder aufgeworfen, und dabei von manchen Seiten die Büschelpflanzung befürwortet wurde. Als Regel liann die letztere jedenfalls nicht gelten $\left.{ }^{*}\right)$. Mindestens ist dabei der Fehler, dab zu viele Pflanzen in 1 Büschel vereinigt werden, zu vermeiden. - Wie bei jeder Pflanzung, so ist bei der Fichte ganz besonders vor zu tiefern Einsetzen des Pflänzlings in den Boden zu warnen. - Für Moor- und Torfböden wird Ballenpflanzung auf Rabatten bes. empfohlen ${ }^{5}$ ).

3. Li i e f er.

A. B e tri c bs a r t. Auch bei dieser Holzart ist die Wahl der Betriebsart ziemlich gleichbedeutend mit der Art der Verjüngung. In der Kionkurrenz zwischen Naturund Kunstverjüngung lat im allgemeinen der Kahlschlagbetrieb gesiegt und ist in der zweiten Hälfte des 19. Iahrhunderts zur herrschenden Verjüngungsmethode geworden. Erst in neuerer Zeit ${ }^{6}$ ) haben sicl unter der Wirliung von mancherlei Mißerfolgen, die sich bei der İunstverjüngung auf Iiahlflächen herausstellten und die

1) Verght. Allg. F.- u. J.-Z. von 1884, S. $3 \pm 1$.

2) Vergl. Schulze, Fichtendammsat. Tlarander Jahrbuch $1587, S, 92 \mathrm{ff}$.

3) Vergl. Ma r tin, Die Regelung des Wachsraumes bei der Begründung und Durchforstung von Fichtenbeständen. Ztsehr. f. Forst- und Jagdw. 1905, 419.

4) Vergl. I u n $z$ e, Ueber den Einfluß der Anbaumelhode auf den Erlrag der Fichte. Thar. Jahrb. 1895,$45 ; 1902,1 ; 1907,1$.

5) $\mathrm{Ot} t \mathrm{o}$, Deutsche Forst-Zeitung 1899, 230.

6) Vergl. B org g r e ve, Holzzucht S. $196 \mathrm{ff}$. Daselbst ॠirl die Rüclikehr zur natürl. Verj. gefordert und zwar mit einer verhällnismäBig dunklen Schlagslellung; Gesamtverjüngungszeit 10-20 Jahre. Bei entsprecbend langen Zuwarten soll man genügenden Anflug erhallen. - Vergl. auch D a n c k e $1 \mathrm{~m}$ a n n, Zeitschr. f. F. U. J. 1887 S. 64 ff., sowie P f e i l, Die deulsche Holzzucht. - We i s e, Münd. Forsll. Hefte $1^{\circ}$, Is94, 1. - Slettiner Versanmlung deutscher Forstmänner 189. - Preuß. Forstverein, 1589. - H of f m a n n, Forstl. Blätler 1889, 161. Zeitschr. f. F.- u. Jw. 1896, 112, 378. - ll a y r, ,Sludien im nordwesll. Rußland ${ }^{6}$, A. F.- U. J.-Z. 1900. - R e i B, ,Naturverjüngung der Kiefer", Forstw. Zentralbl. 1898, 5. - Il a $\mathrm{r}$ in, Folgerungen..., 3. Bd. 1896, Die Kiefer. - ki a u $\mathrm{tz} s \mathrm{c} \mathrm{l}$, Zur Frage der Begriundung von liefernbeständen. Forstw. Zbl. 1893, 653. - K i e n i t z, Ueber die Verjüngung der Kiefer im Besanungsschlage usw. Alg. F.- U. J.-Z. 1878, 41. - D ï e s b e r g, Der Wahd als Erzieher 1910. 
hauptsächlich anf Rechnung von Engerling, Schütte und Dürre zu stellen sind, wiederum Stimmen zu gunsten der natürlichen Verjüngung durch Schirmschlag-ader Femelbetricb crhoben. In jüngster Zeit lat D ä es ber gr in seinem Buche ,Der Wald als Erzieher" als erstrebenswertes Ziel für den Kiefernwald ılas Bilr eines planvoll zusammengesetzten, nach der Sechseckschablone aufgebauten Plenterwaldes entworfen. Der Verwirklichung dieses Idealwaldes stehen aber nicht zu behebende Schwicrigliciten entgegen. Der Kiefernzüchter wird es immer mit dem mehr gleichaltrigen Hochwald zu tun haben, gleichviel, ob dieser aus Natur-oder liunstverjüngung hervorgegangen ist. Untriebszeit selur wechselnd, von 50 und 60 bis zu 100 und 120 Jahren, vom Standort weniger beeinfluBt, als vom Wirtschaftszweck, der Absatzgelegenheit usw: Höhere Umtriebe sind auf geringen Börlen wegen der frühzeitigen natürlichen Auslichtung nicht am Platze. Auf besseren Böden kann Ueberhalthetrieb zur Erzeugung von Starkhölzern mit und ohne Unterbau in Betracht kommen. Doch ist die Gefahr des Windbruchs hierbei zu beachten. Mittlere Leistung des geschlossenen Hochwaldes $4-5$ fm Durchschnittszuwachs im 80-bis 100jährigen Umtrieb; mittlere Höhe ca. $20-25$ Meter.

B. Ver j ̈̈ ng u ng.

1. Na tür li c he Ver jüng ung. Die meist schlagweise, hier und da auch wohl melır horst- und gruppenweise durchgcführte natürliche Verjüngung der Kiefer ist auf besseren Standorten zulässig und vollzieht sich un so leichter, je luftfeuchter das Klima ist (Ostpreußen, russ. Ostseeprovinzen, Schweden). Vorbereitungshiebe sind infolge der von selbst eintretenden Auslichtung der älteren lïiefernbestände meist nicht nötig. Eher empfiehlt sich bis zur Samenschlagstellung möglichstes Dunkelhalten des Bodens, weil stärkerer Unkrautwuchs der Verjüngung höchst nachteilig ist. Wenn sich Jungwuchs eingestellt hat, ist verhältnismäßig rasche Nachlichtung mit Rüclisicht auf das Lichtbedürfnis der Kiefer notwendig. Langes Belassen der Samenbäume zum Zwecke der Ausnutzung von Lichtungszuwachs lohnt sich nicht, sondern führt zu ungleicher Entwickelung der Verjüngung und damit zur Sperwuchsbildung. Beihilfe durch Saat oder Pflanzung auf Fehlstellen ist dem langen Wrarten auf vollständigen Anflug vorzuziehen.

Der Kampf um die natürliche Verjūngung der Kiefer war bisweilen ein recht heftiger; in der letzten Zeit ist dieser Frage gegenüber wieder melır Ruhe eingetrelen. Man wird die natürl. Verjüngung unter für sie günstigen Verhältnissen nicht ausschließen, sondern sie als unler Umständen williommene Zugabe zur künsllichen Beslandesbegründung belrachten. Das von manchen Seiten empfohlene geduldige, lange Zuwarten - (oft reichen 20-25 Jahre noch nicht zur vollständigen Besamung einer Abteilungsfläche hin!) - lann gegenüber der Raschheil und Sicherheil, mit der in vielen Fällen die künslliche Beslandesbegründung erfolgt, nicht gutgeheißen werden. Hochanslehender Grundwasserspiegel, Bodenverwundung durch Waldweide, Streunulzung begünsligen die nalürl. Besamung. Auch wird der angeflogenen jungen Kiefer große Enlwicklungs- und Widerstandsähigkeit nachgerühml. Oerilich, zumal bei hoher Lufteuchtiglieit, crlrägt sie selbst Schimuduck. Auf kleinen Löchern fliegt lïiefer besonders leichl an, auf Lücken in Slangenhölzern und angehenden Baumorten. Immerhin liefert sie gerade dann stels horslförmig differenzierte Bestände, dic sich bei der lriefer wohl am wenigsten empfehlen.

2. líunstlicher Anbau.

Sowohl die Saat wie die Pflanzung hat ilıre Vertreter. Viele sind der Meinung, daß der Saat vor der Pflanzung der Vorzug zu geben ist, wenn die Verhältnissc die Saat gestatten.

a) S a a t: Meist unter Verwendung entflügelten Samens, hin und wieder auch Zapfensaat. In beiden Fïllen liamn Vollsaat wie stellenweise Saat zur Anwendung kommen. Vollsaat bedingt einen nur schwach benarbten Boden, der keiner oder nur geringer Bearbeitung (mit der Egge) bedarf. Verheidete oder verunkrautete Böden 
erfordern Bodenbearbeitung und werden zweckmäBigerweise durch Streifensaat in Kultur gebracht. In diesem Falle ist Verwendung des Pfluges (Eckert'scher Waldpflug) zur Entfernung des Bodenüherzuges und zur Bodenlockerung meist billiger als Hacken der Saatstreifen. Unter Umständen Verwendung des Weber'schen Waldgrubbers. Plätzesaat (Anwendung von Hacke, Kreisrechen) meist ebenso selten wie Vollsaat, im allgemeinen auf ungünstige Bodenverhältnisse beschränlit. Zapfensaat ${ }^{1}$ ) ist zwar insofern vorteilhaft, daß der Samen nicht geklengt werden muß und deshalb in seiner Güte weniger leidet, ist aber infolge großen Zapfenbedarfes zu teuer, setzt trockene, warme Witterung voraus und führt leicht zu ungleichmäßiger Saat. Geklengter Samen ist möghichst zeitig in Frühjalır auszusäen; bei größeren ebenen Flächen empfiehit sich Verwendung von Säemaschinen (Drewitz).

b) P f l a n z $\left.u \mathrm{ng}^{2}\right)$. Erfolgt mit ballenlosen Pflänzlingen und mit Ballenpflanzen. Zumeist unverschulte einjährige Pflanzen, ab und $\mathrm{zu}$ auch verschulte 2oder 3jährige. Verwendung stärkerer Pflanzen bei Nachbesserungen bezw. sehr graswüchsigen Kulturen angezeigt; hier auch die früher in großem Umfange angewendeten, im Erfolg vorzüglichen, aber teuren Ballenpflanzen richtig. Zur Pflanzung nit schwächeren ballenlosen Pflanzen Anwendung verschiedener Instrumente: Pflanzdolch, Keilspaten, Setzholz, Spitzenbergs Pflanzholz, Buttlar-Eisen, Wartenbergs Stieleisen, Pflanzspaten, hauptsächlich also von Werkzeugen zu Klemm- und Spaltpflanzungen. Die mit diesen Pflanzmethoden leicht verbundenen Beschädigungen und Quetschungen der Wurzeln haben die Spaltpflanzungen etwas in Nißkredit ${ }^{3}$ ) gebracht und haben zul Bevorzugung der Handspaltpflanzung geführt. Wo Klemmpflanzung infolge Fehlens lockeren Bodens nicht am Platze, hat sich neuerdings Pflanzung mit dem Splettstößer'schen Zangenbohrer als billige und jeder Kilemmpflanzung überlegene Pflanzmethode gezeigt. Meist Reihenpflanzung in Grabe-, Hack-, Untergrundpflug- oder Grubberstreifen, auf graswüclısigen Böden Pflanzung auf Pflugwällen beliebt und erfolgreich ${ }^{4}$ ). Streifenbreite $30 \mathrm{his} 40 \mathrm{~cm}$, Abstand der Streifen von Mitte zu Mitte $1 \mathrm{~m}$ bis $1,5 \mathrm{~m}$, Pflanzenabstand in den Streifen $30-50 \mathrm{~cm}$. Enger Verband notwendig, weil sonst Sperrwüchse.

4. S c hw a $\mathrm{z} \mathrm{k}$ i e f e r. Bei uns nicht, wie in Niederösterreich, rein, soudern nur in Mischung und damn neist nur als Vorbauholzart auf verödeten Fallihängen; Pflanzung 2-3jähriger Pflanzen.

5. W e y m o u th s ki ef e $\left.\mathrm{r}^{5}\right)$. Geeignet für Rein- und llischanbau, letzterer meist bevorzugt. Natürliche Verjüngung infolge öfterer Samenjalıre und beträchtlichen Schattenerträgnisses leicht möglich; in der Regel aber künstlicher Anbau durch Pflanzung mit 2-3jähr. verschulten oder auch Ijälır. unverschulten Pflanzen.

6. B erg-, P e e h- und B a nkski e f e r. Vor- und Zwischenbauliolzarten oder rein bei Oedlandsaufforstungen, Dünenbefestigungen usw. Pflanzung Regel.

1) V. A I e m a n n, Ueber Forstkulturwesen, 3. Aufl. 1884 S. 65 ff, - D i t t m e r, Kiefernzapfensaat. Ztschr. f. F.- U. Jw. 1897, 263.

2) Splettstößer, Einfluß unserer Kiulturmethoden auf das Absterben der Kiefer. Ztsehr. f. F.- u. Jw. 1908. 689. - K r a n o l d, Die Kiefern-Zangenhohrer-Pflanzung, das. 1911, S. 358. - M ö 1 l e r, Versuch zur Bewertung von Kiefernpflanzmethoden, das, 1910. S. 629.

3) Vergl. M u h l, Zur Ehrenrettung des Kiefern-Jährlings. Allg. F.- u. J.-Z. von 1886 S. $221 \mathrm{ff}$., woselbst die neuere Literatur ñher die Frage nachgewiesen ist. - D a $\mathrm{n}$ c k e $1 \mathrm{~m}$ a $\mathrm{n} \mathbf{n}$, Handspaltpflanzung von Kiefern-Jährlingen, Zeitschr. f. F, u. J. 1889, S. 35 .

4) S cott-Preston, Zeitschr. f. F. u. J. 1888, 512.

5) Wa p pes, Zur Kenntnis und Würdigung der Weymouthskiefer. Allg. F.- u. J.-Z. 1897. 8, 51, 365. D e rs., Forstl. naturw. Ztsehr. 1896, 205: Natürl. Verjüngung der W-kiefer in Pfälzer Wald in $410 \mathrm{~m}$ Meereshöhe. - Gru $\mathrm{n}$ d $\mathrm{n}$ e r, Vergleichende Untersuehungen uber die Bestandesentwicklung bei der gemeinen Kiefer und der Weymouthskiefer. Thar. Jlırb. 1901, 114. - Bericht 12. Vers. deutseher Forstmänner 1883, 86. 
7. L ä r c h e. Am besten vorwüchsiges Mischholz im Hochwald oder Oberholz im Vittelwald. Reine Bestände wegen geringer Bodenpflege ungeeignet; wenn sie rorkommen, ist frühzeitiger Unterbau nötig.

Unter gegebenen Bedingungen, z. B. in frischen, sonnigen Gebirgslagen, stellt sich Anflug ein, so daß sich die natürliche Verjüngung leicht vollzieht. Doch meist kïnstliclıer Anbau und zwar

a) S a a t: behufs Einsprengung der Lärche in andere Holzarten, entweder breitwürfig oder als Plätzesaat (z. B. $2 \mathrm{~kg}$ Lärchen- und $5 \mathrm{~kg}$ Kiefernsamen zur Erzielung einer Wischung der Kiefer mit der Lärche im Verhältnis von etwa 5 : 1, da Lärchensamen meist wesentlich geringere Kieimfäligheit hat als die kiefer);

b) P f l a n z u n g: meist verschultes Material (3—-jährig, seltener als stärkerer Heister und dann zweckmäßig unter Einstutzen der unteren Zweige; es kommt darauf an, daß die Lärche ihrer Ungebung voraneilt). Anwendung der Hacke. Gewöhnlich eingesprengt in andere Holzarten (Laubholz- wie Nadelholzbestände, Mittelwald), einzeln oder horstweise oder in Reihen, an Wegrändern usw.

\section{Gemischte Bestände.}

$\S 70$. Angaben über die leitenden Gesichtspunkte finden sich bereits im ersten Absclinitt, III, $\$ 10$ flgde. Ueber die Ausführung der Kulturen ist besonders zu bemerken, daß den langsam wüchsigen Holzarten der erforderliche Vorsprung vor ihrer Uimgebung zu gewälren ist. Dazu dient ganz besonders der Voreinbau auf Löchern und Blößen; namentlich die E i c h e pflegt man auf diese Weise mittelst Saat oder Pflanzung in die $\mathrm{B} u \mathrm{c}$ h e $\mathrm{n}$ b e s $\mathrm{t}$ ä $\mathrm{n}$ d e einzumischen. In derartige Löcher hönnen auch Ahorn und Eschen im ersten Stadium der Buchenverjüngung in die Buchenbestände eingebracht werden. Ebenso ist bei der Absicht einer Einmischung der IV e i Btanne und B u che in die Fichtenbestände zu verfahren $\left.{ }^{1}\right)$. Der Femelschlagbetrieb bietet hierzu die beste Gelegenheit.

Die Anwendung der Pflanzung stärkerer Exemplare findet ilıre Stelle, wenn in den Buchenverjüngungen die edlen Holzarten erst nach erfolgter Ansamung der Buche eingebracht werden. In diesem Falle kann ihnen der emwünschte Vorsprung nur durch Einpflanzung gut verschulter liäftiger Heister gewährt werden. Ebenso pflanzt man Kiefern und Lärchen systematisch in die Buchenverjüngungen ein. Wählt man hierbei liräftige Pflanzen, so arbeiten sich diese durch den Buchenwuchs hindurch, erlangen Schaftreinheit und geben hochwertige Nutzhölzer. Fichten pflanzt man wegen der größeren Schwierigkeit ihrer Schaftreinigung besser in Gruppen auf größeren Fehlstellen nach erfolgter Räumung, insbesondere auf Stellen mit verwi]dertem Boden.

Die Herstellung der Mischung von $\mathrm{K}$ i e f e r und F i c h t e erfolgt auf Kah]schlägen durch gleichzeitigen Anl,au beider Holzarten, entweder getrennt nach den Unterschieden des Standorts. oder in gleichmäßiger Vischung, besonders durch Saat.

1) Vergl. Ga y er, Der gemischte Wald 1886. Darin sind auch hinsichtlich der Kultur eine Menge ảußerst schätzbarer Erörterungen niedergelegt. Als wesentlichstes Mittel der Erhaltung wertvoller Bestandesmischungen betrachtet Gayer den Vo r b a u, bei welchem die Misehholzart vo r Abernlung des jetzl vorhandenen Beslandes eingebracht wird. Der eingesprengten Holzarl wird dadurch (neben horstweiser Isolierung, für welche bekanntlich $G$. in allgemeinen eintritl) ein Altersvorsprung gegeben, hinreichend, un ihre Erhallung wenigslens bis zur ersten Durchforstung zu sichern. Von da ab kann die Bestandespflege einselzen. Warum dabei auch der küslliche Voranbau der einzelnen Horste innerhalb e in e r Abteilung grundsätzlich nach und nach erfolgen soll, isı nicht recht ersichllich. Die Ungleichförmiğkeiı inn einzelnen Bestande sollte nicht weiter gehen, als erforderlich ist, un die vollkräflige Entwicklung des Mischwuchses zu gewährleislen. 
Doch ist zu beachten, daß die Kijefer hierbei leicht vorwüchsig und sperrig wird, wenn sie nicht in dichter Stellung erwächst, so daß sie in Schluß konmt. Ein Uebermaß der Beimischung von Fichten ist hier von Uebel.

In allen Mischungen ist eine sorgfältige Bestandespflege von größter Wichtigkeit.

Durch Vorkultur eines Schutzholzes, insbesondere der Birke, hat man unter n a ch t rägli c hem Anbau des Nadelholzes ebenfalls gemischte Bestände erzogen, so z. B. in Bayern auf den ausgedehnten durch Nonnenfraß entstandenen Kahlschlägen. Del ,Vorwald" gewährt den später emportreibenden Hauptholzarten Schutz gegen Frost, Hitze etc.

Die Ergänzung des Oberholzes im Nittelwald, meist durch Pflanzung von Heistern (Esche, Ahorn, Eiche), sowie von Nadelhölzern, besonders Lärchen, kann auch als eine Begründung gemischter Bestäncle angesehen werden.

\section{Vierter Abschnitt.}

\section{Die Bestandeserzjehung.}

$$
\text { Vorbemerkungen. }
$$

\$71. Alle waldbaulichen Maßnahmen, welche von der Bestandesbegründung an bis zum Zeitpunkt der Hiebsreife oder allgemeiner bis zu den direkt auf Begründung eines Neubestandes abzielenden Wirtschaftsojerationen vorgenommen werden, gehören in das Gebiet der Bestandeserziehung. Die Bestandesbegründung ist beendet, sobald der Boden mit derjenigen Menge entwickelungsfähiger junger Individuen bedeckt ist, welche für das Heranwachsen eines den Wirtschaftszwecken entsprechenden neuen Bestandes erforderlich ist. AuBer der ersten Bestandesanlage gehören also zur Bestandesbegründung auch alle Nachbesserungen, sowie die allmähliche Entnahme des bei der natürlichen Verjüngung zunächst verbliebenen Oberstandes. Hingegen sind alle diejenigen Eingriffe, welche planmäßig in die Substanz des neu erwachsenden Bestandes erfolgen, als Maßnalmmen der Bestandeserziehung aufzufassen. Beim Femelbetrieb läßt sich eine scharfe Scheidung beider Kategorien von Wirtschaftsoperationen nicht leicht durchführen.

Aufgabe aller Bestandeserzichung oder Bestandespflege ist es, die Entwickelung der Bestände so zu leiten, daß sie dem Wintschaftszweck möglichst vollkommen entsprechen. Damit dies Ziel erreicht werde, müssen nicht nur alle Gefahren fern gehalten und die nachtejligen Wirkungen etwa eingetretener Beschädigungen auf ein möglichst geringes $\mathrm{Ma}$ reduziert werden, sondern es muß auch der in ungefährdetem Wachstum stehende gresunde Bestand innerhalb des durch den Wirtschaftszwech gegebenen Pahmens der höchstmöglichen Leistung zugeführt werden.

Durch the Betonung des Wirtschaftszweckes ist, weil dieser wechseln kann, die starre Schulregel vermieden. Der Wirtschaft wird eine gewisse Beweglichkeit gewahrt und dem Willen des Waldbesitzers, dessen Interessen an verschiedenen Orten und unter verschiedenen Umständen sehr von einander abweichende sein hönnen, wird der nötige Spielraum gesichert. Es kommt also vor allem darauf an, die virtschaftlichen Ziele, welche zu verfolgen sind, kłar zu stellen. In allgemeinen hat man das Ziel der Wirtschaft in del höchsten Fientabilität des Betriebes zu erblicken. Da in den meisten Fällen dem Nutzholz der höhere Wert zukomnt, und unter dieser Gesamtrubrik wiederum die stärkeren Stangen und das Stammholz in guter marktfähiger IV are (bestimmte Länge und Stärke, Geradschaftigkeit und Astreinheit) gewöhnlich den Ausschlag geben, so kann man, wenigstens für die meisten Hoclwaldungen, un- 
bedenklich die Anzueht möglichst vielen und guten Langnutzholzes als Wirtschaftszweek hinstellen, zumal in neuerer Zeit die immer weitergehende Vemendung von Surrogaten den Brennholzmarkt fast überall wesentlich eingeschrinkt hat. Selbstredend sind in jedem einzelnen Falle die Absatzverhältnisse aufs sorgfältigste zu beachten. Die gewerblichen Verhältnisse bringen es nicht selten mit sich, daß einzelne Sortimente örtlich eine erlölite Bedeutung crlangen, infolge deren ihrer Anzucht, sofern sie sich nicht schon bein gewöhnlichen Betrieb in genügender Menge nebenbei ergeben, besondere Sorge gewidmet sein muß. Daß bei aller Bestandeserziehung im Interesse des lıeranwachsenden Bestandes, sowie insbesondere mit Rücksicht auf die Nachlaltiglieit der Wirtschaft die Bodenpflege eine hervor'agende Rolle zu spielen hat, ist selbstverständlich, und ist auch in den bisherigen Erörterungen schon mehrfach betont worden.

Einen Uebergang zwischen Bestandesbegründung und -erziehung bilden diejenigen Maßregeln, welche, unmittelbar an die Vornahme der Kultur anschließend, die allererste Entwickelung der jungen Pflanzen fördern bezw. schützen sollen, z. B. Aussteclien von Pflanzen in (absichtlich oder unabsichtlich) zu dichten Saaten ${ }^{1}$ ), Auftreiben von Schafherden gegen Stochausschläge und gegen Unkraut, Ausschneiden des Grases zwischen den Saat- und Pflanzreilıen, Entfernen der Unliräuter usw. Alle diese IIaßnahmen dienen zwar unzweifelhaft schon der Bestandeserziehung, können aber auch noch als zur Ausführung der Kultur selbst gehörig oder als direkte .Iaßregeln des Forstschutzes betrachtet werden. Man bezeichnet sie gewöhnlich als Maßregeln der Lulturpflege. Sie sollen, da sie teils bereits oben (s. S. 117 und 139) erwähnt wurden, teils im Forstschutz (Gefährdungen durch Gewächse) näher gewürdigt werden und da die eigentliche Bestandeserziehung doch in und mit dem auf der Fläche erwachsenden Material an $\mathrm{H} \mathrm{ol}$ z pflanzen arbeitet, an dieser Stelle nicht weiter besprochen werden.

Die Bestandeserziehung umfaßt nach dieser Abgrenzung die $A \mathrm{usz} u \mathrm{~g}$ s h a $\mathrm{u}-$ ungen, die sog. Reinigungshiebe oder A usläuterungen, die Durchforstungen, den Lichtungs- und Unterbaubetrieb, die Aufästungen und die II Bregeln der Bodenpflege.

\section{Erstes Kapilel.}

\section{A uszugshau $u$ ge $n=R$ ä $\mathrm{m} u n g$ von U e berhältern.}

$\$ 72$. Die Auszugshaumgen entfernen solehe vom vorigen Umtrieb überkommene Ueberhaltstämme, welche nicht geeignet sind, bis zur Hiebsreife des jetzigen Bestandes auszuhalten. Die Teranlassung liegt zumeist in den betreffenden Stämmen selbst, indem sie vorzeitig schadhaft werden und im Zuwachs nachlassen; zum Teil aber fordert auch die Pflege des umgebenden Bestandes, welcher durch die oft breitkronigen Altholzstämme in seiner Entwickelung gehemmt wird, deren Aushieb. Es ist zu erwägen, ob im Falle des Stehenlassens die Wertsmehrung des Ueberhälters für den Zuwachsausfall am neuen Bestande ein Aequivalent bietet. (Vgl. die Ausführungen auf Seite 54.) Die Fällung hat mit der nötigen Vorsicht (vorheriges Entasten etc.) zu erfolgen, damit der Jungbestand möglichst wenig leidet.

1) Auf den Waldfeldbauflächen des Würllembergischen Forsts Ochsenhausen wird zur Fichlen-Einsaat ein so bedeulendes Samenquanlum, bis 25, ja $40 \mathrm{~kg}$ pro lia verwendel, daß die auf dem schon vorher durch landwirtschaftliche Benutzung gelockerten Boden meist trefflich keimenden Pflanzen nicht alle Platz linden, sondern zum großen Teil für anderweite Iíulturen abgegeben werden. cfr. Der Waldfeldbaubetricl, im For nchsenhauaen. Allg. F,- u. J.-Z.v. 1884 S. $3+1$. 


\section{Zweites Kapitel.}

\section{Die Reinỉgungshiebe. (A usläuterungen.)}

$\S 73$. Als Reinigungshiebe bezeichnet man die Entnahme solcher Holzgewächse, welchen bei der Bestandesbildung die Nitwirkung versagt sein soll. Es sind dies einmal die Individuen solcher Holzarten, deren Anzucht überhaupt nicht beabsichtigt ist, sodann von den das Objekt der waldbaulichen Tätigkeit bildenden Holzarten diejenigen Exemplare, welchen schon bei oder bald nach der Bestandesbegründung die Fähigkeit abgesprochen werden muß, tüchtige Bestandesglieder zu werden. Hierher gehört:

1. Der A ushieb von V orw ü h se ${ }^{2}$ ) (Wölfe). Vorwüchse sind Individuen der den Bestand bildenden Holzart, die sich schon, bevor die Fläche in Kultur gebracht wurde, auf ihr eingefunden latten oder die, wenn gleichzeitig mit den umgebenden Individuen entstanden, aus irgend einem Grunde eine die Nachbarn schädigende besonders rasche Entwickelung zeigen. Das ist z. B. nicht selten der Fall bei Stockausschlägen, die sich oft ungebührlich vordrängen. Es kann dann die Frage entstehen, ob man sie sämtlich entfernen oder sie in beschränlitem Umfang durch Belassen einzelner Loden zur Bestandesbildung beiziehen soll. Frühzeitig vorgenommener Abhieb von Stockloden lat bei den meisten Holzarten, wie Eiche, Ahorn usw. die Neubildung von solchen und danit oft neues Bedrängen der umstehenden Pflanzen zur Folge. Es ist, falls gänzliches Entfernen beabsichtigt wird, oft zweckmäßig, wenn man, gewissermaßen un die Stöcke lahm zu legen, zunächst auf jedem Stock eine oder wenige Loden stelıen läßt, die in der nächsten Zeit so sehr alle líraft für sich in Anspruch nehmen, daß die ringsum neu entstehenden Ausschläge verkümmern. Dann werden die stehengelassencn Einzelloden, die inzwischen in ihrer isolierten Stellung nicht gescharlet, sondem im Gegenteil häufig vielleicht noch einen ganz wolnltätigen Sclıutzbestand gebildet hatten, nachträglich weggenommen. Inzwischen sind die umgebenden Holzpflanzen so weit herangewachsen, daß ilınen neu erscheinende Stockausschläge nicht melır bedenklich werclen.

In den meisten Fällen aber handelt es sich um solche Vorwüchse, die sich v or der Vomahme der eigentlichen Verjüngung eingestellt haben. Sie liommen namentlich in den natürlichen Verjüngungen vor und rühren hiel von Mastjalıren her, deren Ergebnis mit Rücksicht auf die Beschaffenheit des Altholzes, auf Hiebsfolge, Etatserfüllung usw., also in der Hauptsache aus Gründen der Forsteinrichtung, zur vollständigen Bestamlesverjüngung noch nicht verwendet werden komnte. Derartige Vorwüchse bediurfen je nach ilırer Beschaffenheit einer verschiedenen Behandlung. Eine nonnale Entwickelung zeigen sie meist nur auf lichteren Stellen des Bestandes und auch da nur, wenn sie in Gruppen oder Horsten auftreten. Einzeln vorkommende Exemplare dehnen sich meist in Aesten und Wurzehn zu sehr seitlich aus, werden buschartig und sind nicht hefähigt, sich zu guten Nutzstämmen zu entwickeln. Der unter dem Schatten eines noch dichten lironenschimes in Mastjahren entstehende Vorwuchs vergeht, insbesondere bei Buche und Fichte, oft nach einigen Jahren wieder vollständig. Anders bei der Tanne, deren Jungwüchse so zäh sind, daß sie sich,

1) Zu vergleichen: T $\mathrm{r}$ ü b s w e $\mathrm{t}$ e r, ,Bedeutung des Vorwuchses für die Begründung und Formbildung reiner und gemischter Bestände" ; Tharandter Jahrbuch 35 . Bd, S. 131 ff. (1885), - II a r twig, ,Wirtschaftliche Bedeutung des sog. Vorwuchses bei Begründung und Formbildung reiner und gemischter Waldbeständets; Forstw. Zentralbl., 1882, S. 1. - K r a $\mathrm{ft}$, Zur Sperrwuchsfrage, Ztschr, f. Forst- u. Jagdw. 1891, 327. - P a h I, Die wirtschafliche Bedentung und Beliandlung des Vormichses. Allg. F.- U. J.-Z. 1887. 37. 
wenn auch kümmerlich und ohne irgend welchen nennenswerten Zuwachs, doch lebend erhalten und sich dann, wenn durch Vorbercitungshiebe usw. die normale Verjüngung des Bestandes eingeleitet wird, da und dort, je nach dem verschiedenen Maße der Lichtzufuhr und der ihnen innewohnenden Kraf, einzeln oder in Gruppen und Horsten vordrängen.

Die Entscheidung darüber, ob solche Vorwitichse zu erhalten sind oder nicht, ist unter zwei Gesichtspunkten zu treffen. Zunächst nämlich und vor allem ist der Vorwuchs selbst auf seine Entwickelungsfähigkeit zu begutachten, sodann aber ist die Frage zu erwägen, was mit den zwischen den Vorwüchsen vorhandenen Lückicn geschehen soll, ob sich die auf ihnen (durch Samenabfall auf natürlichem Wege oder durch liünstliche Kultur) entstehcnden Jungwïchse zwischen den Vorwïchsen freurlig hinaufzuarbeiten vermögen werden oder nicht. Die sich im Walde darbietenden Fälle sind äußerst mannigfaltig. Bald ist ein größerer, bald ein kleinerer Teil cler Fläche mit Vorwuchs überdeckt; bald hat letzterer einen bedentenden, bald nur einen geringen Vorsprung; bald sollen die Lücken mit der gleichen, bald mit einer (vielleicht rascher wïchsigen) Mischholzart ausgefüllt werden. Kranker, vollständig verbutteter Vorwuchs ist, einzeln oder in Horsten, jedenfalls zu entfernen. Ebenso wird man einzehe vorwïchsige Exemplare, auch wenn sie an sich gut sind, häufig wegnehmen, sofern jhre fortdauernde Pflege (durch Aufastung etc.) ausgeschlossen erscheint und deshalb Bedrängung der Nachbarpflanzen zu emrarten steht. Im übrigen aber soll man kcineswegs radikal gegen jeden Vorwuchs vorgehen und soll nicht der Vorliebe für gleichförnige, gleichalterige Bestände zu weitgehende Opfer bringen. Die Weißtanmenwirtschaft benutzt die Vorwüclse fast überall schon lange. Dabei ist zu unterscheiden dasjenige Vorgehen, bei dem man den Vorwuchs, wie im Femclbctricb, als den eigentlichen Träger der Verjüngung betrachtet (so daß die Bezeichnung ., Torwuchs" dann nicht mehr paßt) und wo dann von vornherein eine systematische Pflege dieser jungen Anwüchse stattfindet, von derjenigen Wirtschaft (Schimschlagbetrieb), bei der sich der Anflug bezw. Aufschlag als eigentlicher Vorwuchs charakterisiert und nur einen akzessorischen Bestandteil bildet. Hier kann man den lebensliräftigen Vorwuchs zicmlich allgemein benutzen, wenn er nicht über manneshoch ist, weil rann die Hoffnung besteht, daß die auf den freien Plätzen dazwischen sich ansiedclnden Pflanzen in genügender Weise nachwaclsen werden. Höhere Partien liönnen dann stehen bleiben, wenn sie als größere Horste crscheinen, die in sich geschlossene Beständchen darstellen und als solche im Vergleich zu ihrer Fläche nicht zu viel Pandlinie haben. Bei unregelmäBigen Figuren der Vorwuchshorste kann Abrundung zweckmäBig sein. Leberhaupt erfordert der Schutz des zwischen hinein entstehenden Jungwuchses gegen Berlrängung durch die Vorwüchse andauernd sorgsame Beachtung. Soll kein reiner Tannenbestand, sonlern etwa ein . Vischwuchs aus Tanne und Fichte ${ }^{1}$ ) nachgezogen werden, sn hat man beste Gelegenheit, zwischen den Tannenvorwüchsen die Fichte zur Pflanzung cinzubringen.

Besondere Vorsicht erfordert das Aushauen der Vorwïchse rlann, wenn es nicht in frühester Jugrend, sondern bei schon etwas vorgeschrittener Entwickelung des Bestandes (Gertenholzalter) erfolgen muB. Dann hat man einerseits zu sorgen, daß durch den Aushieb keine Lücken entstehen, andererseits dafür, daß nicht in der Folge die ringsum emachsenen schlanken Stämmchen, ihrer Stütze beraubt, sich umlegen. Ist dies, wie insbesondere in Laubholzliegen nicht selten, zu befürchten, so muß

1) Wie z. B. vielfach im würtlemb. Schwarzwalde; cfr. u. a. auch Pahl, , Wirtschaftliche Bedeutung und Behandlung des Vorwuchses". Allg. F.- U. J.-Z. \. 1887, S. 37 und S. 236.

Haudb. d. Forstwiss. 3. Auf, II. 
man sich zunächst auf bloßes Köpfen der Vorwüchse in entsprechender Höhe beschränken.

Oberster Grundsatz bleibt inmer, daß die Vorwüchse nur insoweit beizubehalten sind, als sie einen wirklich brauchbaren, allen Anforderungen bezüglich normaler Entwickelung genügenden Bestandesteil zu lieferı versprechen und nicht durch später nötig werdende erweiterte Bestandespflege (Randverdämmung), sowie event. durch Vermehrung der Frostgefahr (geringerer Luftzug) die Vorteile paralysieren, welche sie durch höheres Alter, durch ihren Zuwachs, sowie durch die Ersparung an Kulturkosten gewähren können. Sorgfältige Erwägung des einzelnen Falles ist geboten.

Die Entfernung der Vorwüchse kann je nach Umständen mittelst der Säge, der Axt und des Beils, der Heppe, des amerikanischen Buschmessers oder der Durchforstungsschere vorgenommen werden. In Jetzterem Falle ist nur eine solche mit konvexer Sclineide vollkommen leistungsfähig.

§ 74. II. A usjätungen (Ausläuterungen), d. i. die Entnahmevon Exenplaren anderer als der das Wirtschaftsobjekt bildenden Holzarten, sowie auch von Exemplaren der letzteren bei übcrmäßig dichtem Stand im jugendlichen Alter ${ }^{1}$ ).

Im ersteren Falle hat man es meist mit spontanem Auftreten zu tun, und zwar sind es gewölnnlich raschwüchsige Laubhölzer (Baum- und Straucharten), die sich in dic jungen Hegen eindrängen und durch Verdämmen der Hauptholzarten nachteilig werden, indem sie vermöge ihrer oft ungemein kräftigen Entwicklung den Boden und den oberirdischen Wachsraum ungebührlich in Anspruch nelımen. Von Nadelhölzern tritt fast nur die gemeine Kiefer ab und zu in der angedeuteten Weise auf: Anflug von Mutterbäumen, der dann gelegentlich durch einen sperrigen Wuchs unbequem wird. Weil ihm die Reproduktionskraft fehlt, läßt er sich durch Aushieb aber leicht meistern. Auch Laubsträucher, wie Lonicera, Prunus spinosa, Crataegus, Rhamnus, Cornus, Viburnum u. a. m., sind nicht für längere Dauer bedenlilich. Sie können zwar einer jungen Kultur, wenn sie nicht rechtzeitig herausgehauen werden, bei reichlichem Torkommen übel mitspiclen, werden aber gewöhnlich in einigen Jahren von dem jungen Holzbestande so vollständig überwachsen, daß ihre Stockausschläge sich nicht mehr hindurchzuarbeiten vermögen. Ton da ab spielen sie, sofern sie sich überhaupt noch lebend erhalten können, die Rolle eines unschädlichen Bodenholzes.

Von diesen Strauchhölzern sind die sog. weichen Laubhölzer zu unterscheiden, die sich baumartig entwickeln, wie Salweide, Birlie $\left.{ }^{2}\right)$ und Aspe. Sie finden sich durch Samenanflug oder als Stockausschlag leicht cin und zcichnen sich, da sie meist geringe Bodenansprüche machen, zumal auch auf schlechteren Standorten, durch Raschwüchsigkeit und relativ bedeutendes Höhenwachstum aus. Man hat es in der Hand, auch diese Holzarten durch energischen Aushieb zurückzudrängen. Oft muß man in liurzer Zeit die Maßregel mehrmals wiederholen, un ihrer Herr zu werden. Aber auch hier ist radikales Torgehen lieineswegs immer als Regel zu empfelılen. Es ist vielmehr zunächst ein wesentlicher Lnterschied, ob sie sich in Laubholz- oder in Nadelholzhegen finden; nur in Jetzteren sind sie im allgemeinen bedenkliche Gäste. Besonders reichlich stellen sie sich begreiflich in Nadelholzkulturen dann ein, wenn diese auf ehemaligen Laubholz-, namentlich Mittelwaldböden angelegt wurden. Wird Stockrodung in solchen Fälen unterlassen oder nur unvollständig durchgeführt, so ist naturgemäB

1) cfr. u. a. Pi ebm a n $n$, ,Bedeutung und Ausführung der Reinigungshiebe". Allg. F.u. J.-Z. von 1881 S. $401 \mathrm{fî}$.

2) Die Birke pflegt, obwohl nicht Weichholz, ihres in diesem Punkte gleichartigen waldbauIichen Verhaltens regen einbezogen zu werden. 
Material für Lieferung von Stock- und Wurzelausschlägen im Boden in Menge vorhanden. Unter diesen Umständen konkurrieren danu mit den oben genannten Holzarten auch Ausschläge von Eichen, Ahorn usw. Sobald die Kultur zum Schluß gekommen ist, darf die Gefahr meist als beseitigt angeschen werden. Laubhölzer, die mit dem Nadelholz gleichzeitig in die Höhe geheı, schaden dem letzteren, abgesehen davon, daß sie ihm den Platz versperren, lin und wieder auch durch Abpeitschen der Knospen an den Trieben. Vorwachsende Laubhölzer, wie es die vor dem ersten, bezw. zwischen diesem und dem zweiten Reinigungshieb entstandenen Stockausschläge und Kernwüchse meistens sind, schaden, sobald sie dem Nadelholz zu reichlich beigesellt sind, möglicherweise auch durch Beschattung. Oft aber gewähren sie andererseits einen sehr wolıltätigen Schutz gegen Frost. In solchen Fällen ist das sonst meist gebotene frühzeitige und radikale Vorgehen gegen die eingesprengten Laubhölzer durchaus nicht inmer am Platze. Ist z. B. die Birke so weit vorwüchsig oder wird regelmäßig so weit ausgeastet, daß sic die Nadelholzgipfeltriebe mit ilıren Zweigen nicht mehr befegen liann, so gewährt gerade sie einerseits dem Nadelholz einen in vielen Lagen überaus dankenswerten Schutz gegen Frost und liefert anderseits eine unter Umständen nicht unbeträchtliche Vornutzung in Gestalt von Besenreisig ${ }^{1}$ ). Von der Entwickelung des Nadelholzes hängt es ab, in welchem Zeitpunkte man später die Birke herauszuhauen hat; sie ergibt dann gute Wagnerlı̈lzer. Einzelne Exemplare läßt man wohl auch einwachsen, damit sie nach dem Abtrieb die Fläche mit dem für die Neukultur als Schutzbestanrl meist erwünschten Anflug versorgen.

In Laubholzverjüngungen ist die Beurteilung der ohne Zutun und oft gegen den Willen des Wirtschafters auftretenden Weichhölzer nicht so generell gegeben. Hauptsächlich sind die Verjüngungen der Rotbuche von Weichlolz und Hornbaum meist mehr oder weniger reichlich durchsetzt. Wenn der Hornbaun dureh massenlıates Auftreten seiner vordringlichen Jungwüchse die empfindlichere Rotbuche sclıädigt, liegt meist ein Verschulden der Wirtschaft vor, indem man nicht rechtzeitig im Vorbereitungsschlag oder schon vorher bei den letzten Durchforstungen für Auslieb der überzähligen Hornbäume gesorgt hat. Einige belassene Exemplare genügen, um die immerhin erwünschte mäßige Beimischung dieser Holzart zu sichern. Die Weichlölzer fliegen, sofern nicht ungerodete Stöcke und WTurzeln für Stockausschläge bezw. Wurzelbrut sorgen, meist von weit her in den Hegen an. Da sie lichitkronige Hölzer sind, ist ihre beschattende Wirkung meist nicht selır von Belang. Da sie weiterhin zum Teil sehr gut nutzbare Holzarten sind, so soll man ihnen, vorausgesetzt, daß sie nur mehr vereinzelt, nicht aber in größeren Gruppen und Horsten auftreten, einen bescheidenen Platz wohl göınen, so lange und in solchem Lmfange, als sie auf dem Holzmarkte durch ihren Preis die ihnen gewährte Nachsicht lohnen. Auch können sie wohl einige Bedeutung als Wildfutter haben. Schlimmsten Falles kann man ja bei Gelegenheit der Durchforstungen noch einschreiten.

Zu den Reinigungshieben gehört schließlich auch die Entnalıme von Holzarten, die der Wirtschafter mit der bewußten Absicht vorübergehender Benutzung bei der Bestandesbegründung als Schutz- und Treibholz für die Wirtschaftsholzart cingebracht

1) X e u me is ter, Wichtigkeil des Birkenanflugs. Thar. Jhrb. 1885, 225. S c li i e r, Ueber die finanzielle Bedeutung der Birke als vorübergehendes $M$ ischholz in Fichtenheständen. Forstwiss. Zbl. 1892, 604. - Nach Mitteilungen des Iigl. Württembg. Revieramts Bebenhausen sind in den staatswaldungen desselben auf einer Gesamtfläche der 1-40jährigen Nadelholzorte von etwa 450 ha (bei sehr ungleichmäBiger Verteilung der eingesprenglen Birken) in den Jahren 1881- $1885 \mathrm{im}$ ganzen an Birkenreisig geerntel worden: a) Besenreisig 3874 Wellen = $77,5 \mathrm{fm}$, Erlös $=1596,33 \mathrm{Mk}$., milhin für $1 \mathrm{fm}=20,6 \mathrm{Mk}$; b) Brennholz-Wellen (die dickeren, zu Besen nicht tauglichen Reiser) 5045 Stück $=100,9 \mathrm{fn}=790.11 \mathrm{k}$; zusammen also durchschnillich jährlicher Erlrag $=477.11 \mathrm{k}$. 
hat. Einer der häufigsten dieser Fälle ist die Entnahme der Kiefer aus Fichtenbeständen, die durch die Kiefernbeimischung über Frosteinwirkungen in der Jugendperiode hinweggebracht werden sollten und num, nachrlen dieser Zweck erreicht ist, vom Druck der vorwüchsigen und sperrig sich entwickelnden liiefern befreit werden. Auf allen weniger liräftigen und trockeneren Böden ist bei der Läuterung der Kiefer zugunsten der Fichte mit großer Vorsicht zu verfahren. Schmeidelung, liöpfen, Einknicken der Kiefer kann unter Umständen vorteilhafter sein als radikales Heraushacken. Die Läuterungshiebe bedürfen in solclıen Orten gesclickter Fülurung, öfterer Wiederholung und sind solange fortzusetzen, bis sie mit den Durchforstungen verschmelzen ${ }^{\mathbf{1}}$ ).

Die ebenfalls zu den Ausläuterungen gehörende Verdünnung zu richter Jungwüchse, sowohl im Nadelholz, als auch im Laubholz, erfolgt durch Ausschneiden der Einzelindividnen ader durelı gassenarige Durchhiehe, letzteres besonders in dichten Nadelholzsaaten nach r. Holleben in Rudolstadt. In ren Rändern dieser Gassen entwickehn sich einzehe stärkere stänmchen kräftig und übernelımen die Führung. Von den Durchforstungen unterscheiden sich cliese Aushiebe ihem Wesen nach dadurch, daß sie ein geringwertiges Material und daher meistens keinen Reinertrag liefern, vielmehr Zuschüsse erfordern.

Drittes liapitel.

\section{Die Durehforstungen ${ }^{2}$.}

\$75. I. B e griff: Han versteht unter Durchforstungen die zum Zwecke der Erziehung und Tutzung stattfindenden planmäßigen Hauungen in dem aus dem laufenden Umtrieb stammenden Vlaterial ${ }^{3}$ ) eines Bestandes. Sie folgen den Läuterungen, wiederloten sich bis zur Hiebsreife und stellen keine bis zum fömnlichen Lichtungshieb gesteigerten Eingriffe in rlie Bestandesmasse dar.

Die Durehforstungen erstrecken sich hesonders auf das zurückhleibende, sowie das für die vorteilhafte Entwicklung des Bestandes ungeeignete Material, um auf die-e Weise durch die freiere Stellung der verbleibenden stämme leren Masien- mul Wertsproduktion zu fördern und durch den Erlös aus dem anfallenden Material Erlräge zu gewälıren. Bei ihrer Ausführung

1) Vgl. $\because$. F a l c ke $n=t$ e in, Ueber planmäBige Durchläulerıngen unserer Jungbestände. Allg. F.- U. J.-Z. 1899. 225. - P a usc, Lăuterungshiebc in Mischbesländen von Fichte und liverer. Thar. Jahrb. 1904. 132.

2) Man verwleiche außer den in Eingang unter Literalur genanten Waldbauschiften u. a.: B a $n$ r, Ur. Franz ron: .Zur Geschichle der Durchforstungen". Forstw. Zenlralblatt von 1882,

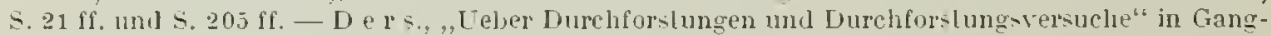
hofers .Versuchswesen" II. Bd. \$. $209 \mathrm{ff}$ - - v. Fis c h l, a c h, ,Zur Weiterenlwicklung der Lehre vou den Durchforstungen". Forstw. Zenlvalblatl r. $1884 \$$. 426 ff., v. 1885 S. 466 u. S. 553. - L er $8 . .$. Die wirtschaftl. Leistungen des Toll- und Ablriplimeslandes, sowie der verschiedenen Stammklasen". Zentralbl. f. d. ges. Forstwesen, 1885, 293. - B o r g g r e r e, ,Zur Plänter-

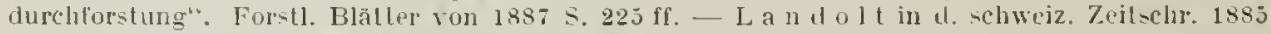

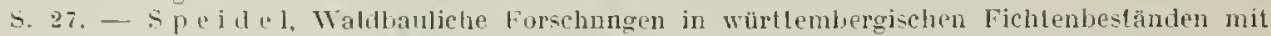
Beilrägen zur Mirtschaftsgenchichte, Zuwach- und Durchforstungshehe 1889. - L a s c hk e,

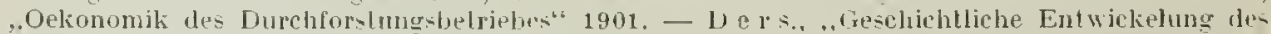

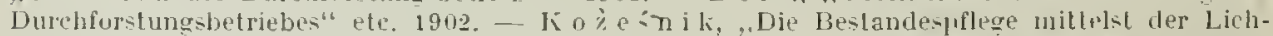

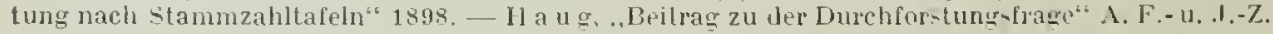
189t-1897 (rersch. Abhanllungen). - D p ss, , Die stammzahlfrage und ihre Bedentung für die Bestandmpflege" A. F.- u. J.-Z. 1899, S.8. - H a u r a 1 h ,Zur Geschichte der Durch-

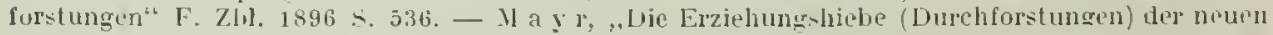

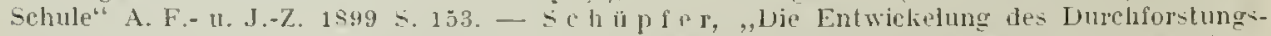
betrebes in Theorie und Praxis seit der ‥ Häfte des 18. Jahrumderts largentellt unter tesonderer

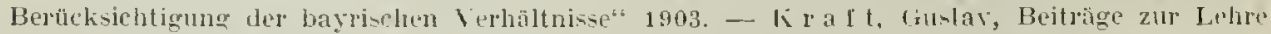
ion den Durchlor-tungen, schlagstellumgen und Lichlungshieben. Hamover 1sst. - D e rs, Beiträge zur Durchforslung- und Lichtungsfrage. Hannover 1889.

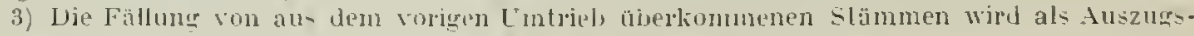

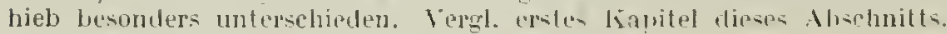


setzt nan immer den Wielereintritt des Schluses bis zur Wielertholung voraus, was bei den Lichtungshieben, di* cine daurnth Schlußunterbrechung im ciefolge haben, nicht eler Fall ist. In Sinne der Forsteinrichtung hört, wo die Einleilung in 20jăhrige Perioden vorliegt, das Gelifet der Durchforstungen im allgemeinen bei den Waletorten ter eriten, die altesten Bestände umfa-renden F'eriode auf. ln Forstbetricben mit nur lojälırigen Wirtsclaftszeitranum finclet diese Bestimmung sinngemäße Anwentung auf die in den laufenden Wirtschaftsplan zum liahlhieb oder zur natürlichen Verjüngung eingestelten Bestände uder Bestandsteile. Eingriffe in die Bestande der altestrn Klassen, sowejt sle nicht sehon starke, mit der Verjüngung in Ver-

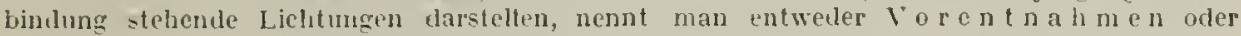
burcin hebe und rechnet ituren Frtrag nicht mehr zur Zwischen-, sondern vielnehr zur Hauptnutzung. L'berdies sollen nach den meisten bezüglielıen Instrulionen auch solehe Eingrife in das Bestandsmaterial jungerer Orte zur Hauptnutzung gerechuet werlen, welche eine fühlbart schntälerung des Haubarkeitsertrages nach sich ziehen, oder die so bedeutend sint, laß dir nurnale Weiterentwiekelung des betreftenden Bealantes obne Füllungr der entsandenen Lücken durch Anbau erwartet werden kann. Die 01 a $n$ m ä $B$ i g e n Hiebe der letztbezeichneten Art sollen als, ,Lichtunghliebe" besonders betrachtet werdern ${ }^{1}$ ).

§ 76. II. Z we ck: Die Durchforstungen ergeben sich als wirtschaftliche Maß3regel aus der Beobachtung der Bestandesentwickelung. Letztere ist chreh die einfache Tatsache geliennzeichnet, daß im llaubarkeitsalter nur noch ein verhältnismäßig kleiner Teil derjenigen Individuen vorhanden ist, welche ursprünglich den Jungbestand bildeten. Die einzelnen Bäume haben in Verlauf ihr er Entwickelung eine solche Ausbildung erlangt, daß auf gegebener Fläche nicht mehr als eine gewisse Anzahl Platz findet, während sich die nummehrigen Altholzstämme in den früheren Lebensperioden in der Gesellschaft einer mit zunehmendem Alter des Bestandes naturgemäß stets kleiner werdenden Menge von Genossen befanden, die von vornherein von der Natur oder dem Wirtschafter meist als gleichberechtigt nebeneinandergestellt worden waren ${ }^{2}$ ). (Das gilt keineswegs nur ron der Saat ocler Pflanzung, sonflern auch von der natürlichen Verjüngung, durch welche ein Vorzug einzelnen Individuen a priori allgemein nicht eingeräunt worden ist.) Irie Zahl der Individuen war bei der Bestandesbegründung im allgemeinen so bemessen worlen, daß früher oder später Bestandes-

1) cir. L o re y, ,Durchforstung oder Liehtungshieb"? Allg. F.- tı. J.-Z. von 1881, S. 406 ff.

2) Dieser Auffassung entspricht es freilich nicht mehr, wenn Oherforstrat Dr. ron $F$ is $\mathrm{c}$ hb a c h (Zentralblatt f. d. ges. Forstwesen, Juli 1885) empfiehlt, schon im Junguestande, wonı̄glich schon bei Vornalme der killur, diejenigen Indisiduen zu bezeichnen, welche spater den Haubarkeitabestand zu bilden haben, und diesen dann, damit sie ihr Ziel erreichen, eine besonders sorgfältige Pflege angedeihen zu lassen, alte übrigun Pflanzen aber, welche zur Deckung des Bodens etc. ron Anfang an notwendig sind, nur als Füllıolz zu behandeln. Leitend ist bei diesem Vorclulag die Tatsache, daß in geschlossenen Bestand die stärkite Stammklasse antauernd (wie insbes. aueh Wagener s. Z. nachgewiesen hat) weitaus am meisten produziert, daß man ferner an liutturkosten sparen müsse und nicht minder an Zeit, indem man jene fur das Abtriebsalter puädeslinierten lndividuen in all $>$ it s unbehinderter Entwickelung möglichst rasch einer den $A n$ forderungen des Varktes entsprechenden Stärke und Höhe zuführt. Was starke Durchforstungen, Freihauungen, Lichlungshiebe etc. -omst erst von rinem späleren stadium der Bestandesentwickelung an erstreben, soll hier sclion von der ersten Jugend an durchgeführt werden. - Den gleichen Gedanken verfolgt neuerdings . 11 a y $\mathrm{r}$ (Waldbau, S. 426) in der von ihm empfohlenen

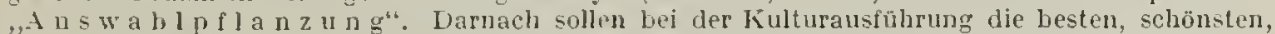
geradschaftigsten und krätigsten Pflanzen in einem Verband von $4-5 \mathrm{~m}$ ausgepflanzt werden. In die Zwischenräume zwischen je 2 dieser Qualitätspflanzen sollen 2 mindergute derselben Holzart zu stehen kommen. Es sei lann anzunehmen, daß die bestgeformten und schnellwüchsigsten Individuen die Föhung in Bestande hilehatten und nach Lnterdrückung des Zwisehenbestandes den Hauptbestand bilden werelen. Der späleren Bestandserziehung würde dadurch ihre Aufgabe wesentlich erlejchtert. - Der Jurchfühung dieses Gedankens stehen erhebliche Bedenken entgegen. Jedenfalls müßte angesichts der vielen Fälıriehkeiten, mit denen der einzetne Baun zu kämpfen hal, von vodnhtrein eine die Zahl der slämme des Attholzes beträchtlich übersteigende Jlenge solcher Plleglinge vorgesehen werden. Weiterhin liegt die sehr beachtliche Gefahr vor, daß sich die schnellwächsigeren Pflanzen unter Ausnutzung des von ihren Nachlarn nicht hinreicheni umstritlenen Vachsraums zwar in sinne der steigerung des Massenertrages, aber durchaus nichl in sinne ter Erböhung der Nutzholzgüte entwickeln. - Bei unseren Irulturen mit Exolen verfahren wir seit Jalren viclfach in dieser Weise, un an den leuren l'flanzmaterial zu sparen. - Vergl. ubrigens die gegenteilige Ansicht von F r e y im forstw. Zentralbl. Fon 1586, S. $242 \mathrm{ff}$. 
schluß eintrat. Hindestens von dem Augenblicke an, wo die einzelnen Individuen bei ihrer Ausdehnung sich berühren, muß nun ein Irampf un die Herrschaft beginnen, der, je nach Holzart, Bodenbeschaffenheit usw. mit verschiedener Heftigkeit geführt wird und die bald mehr bald weniger deutlich zutage tretende Trennung in einen dominierenden und einen unterdrückten Bestandesteil zur Folge hat. Meist sehr bald werden bei diesem Prozeß der natürlichen Ausscheidung zunächst einzelne Individuen entschieden vorwüchsig, ebenso wie andererseits auch selır bald eine Minderzahl unzweifelhaft derart zurückbleibt, daß an ihr normales Emporwachsen olne das Eintreten besonders begünstigender Umstände nicht mehr zu denken ist. Aber auch bei der vorerst sich noch zwischen diesen Extremen haltenden Hauptmasse zeigt sich doch sehr bald die Scheidung in mehrere Kilassen, denen demnächst im Bestandesleben eine sehr verschiedene Rolle zufällt.

Die Aussclıeidung vollzieht sieh im allgemeinen früher, energischer und mit schärfer markierten Unterschieden auf gulen Standorten. Das gleiche gilt von Lichthölzern gegenüber schattenertragenden, bei welchen wenigstens die zurückbleibenden Slammklassen sieh meist weniger deutlieh in absolut leistungsunfähige umsetzen. Daß die von vornherein gewählte Bestandesdichte hierbei von Einfluß ist, leuchtet ein.

Den schon ganz im Anfang alle Nachbarn überragenden Individuen gesellen sich aus der Zahı der übrigen so viele bei, als neben ihnen genügenden Entwickelungsiaum finden. Aber sie erringen sich ihren Platz stets nur durch Kampf nit den Stämmen ihrer Umgebung, die zunächst das gleiche Recht beanspruchen.

Welche Bäume vorwüchsig werden, läßt sich sehwer vorausbestimmen. Es gibt in jeder liultur slets einzetne Exemplare, die sieh von vornherein dureh besonders kräfligen Habitus auszeichnen, und die Annahme liegt nahe, daß sich diese unter sonst gleichen Umständen dauernd zu Führern in Bestand aufschwingen werden. Solche Individuen sind entweder von Haus aus besser veranlagt ${ }^{1}$ ), oder sie kommen - und dieses Nonent ist jedenfalls das weitaus wichtigere - unter günstigeren äußeren Unständen wie die übrigen zur Entwickelung. Aendern sieh die Bedingungen ihres Daseins zu ihren Ungunslen, so kann ein Umsetzen stattfinden, d. h. sie können in die Ǩlasse der zurückbleibenden Stämme versehoben werden, wälırend umgekehrt andere voranstreben. Doch wird dies Ueberholtwerden seltener bei den sehon in der ersten Jugend entschieden vorwachsenden als bei Exemplaren der denıăchst naehsehiebenden großen Masse anfänglich noch mitherrsehender Stänmehen eintreten. Auch lăßt das Umsetzen schon gegen das Stangenholzalter hin, wenn es nicht durch die Wirlschaftsführung (Aushieb dominierender Exemplare usw.) beeinflußt wird, bedeutend nach und findet, nachdem sich einnal ein kräftiger herrschender Besland ausgeschieden hat bezw. dureh Hilfe der Axt zum Ausscheiden gebrachl worden ist, überhaupt nur noch ganz ausnahmsweise statt ${ }^{2}$. Jedenfalls ist der Ausscheidungsprozeß, so lange der Bestand in ungestörter Entwickelung sich selbst üLerlassen bleibt, ein ohne Sprünge sletig fortdauernder, bis schließlich in höheren (das wirtschaftlich zulässige Maß meist übersehreitenden) Aller nur noch so viele Stämme übrig sind, als, ohne sich wechselweise zu beeinhächtigen, auf der Fläelıe Raum haben.

1) Es ist trolz der gegenteiligen Ausführungen $B$ or.g g r'e ve's - efr. u. a. dessen Holzzucht 2. Aufl. S. 293 flgde. - zunäehst an der Ansicht festzuhalten, daß doeh eine den Existenzkampf der Individuen untereinander beeinflussende versehiedene Veranlagung angenommen und daß die latsäehlich verschiedene Entwijklung der einzelnen Pflanzen nieht nur auf Rechnung der in versehiedenslem llaße günstigen oder ungünstigen ảußeren Unstände (Feuchtigkeil, Loekerheit des Bodens, Beschädigungen mannigfachster Art ete.), unter denen die Pftanzen wachsen, gesetzt werden darf. Selbst die allersorgfältigst, durchweg gleichmäßig (z. B. mit Hilfe ron Rasenasche 11 . derul.) zubereiteten Saatbeete lassen alsbald an den erwachsenen Pflänzlingen oft recht nerkliche Lntersehiede hervortreten; warum sollten diese nicht wenigstens zun Teil auf das Samenkorn, hezw. die den Individuun in vershiedenem Maße innewohnende liraft zurückgefüht werden dürfen? Die Analogie im Tierreich liegt doeh zu nahe. Daß dieser Grund nieht der wiehtigste ist, daß er nicht bis ins höhere Alter fortwirkt, sofern jene Schwächlinge von Haus aus die zuerst unterliegenden sind, da $\beta$ vielnehr, soluald der Bestandesschluß erfolgt ist und die ersten Ausscheidungen sich vollzogen haben, in der Hauptsache äßßere Umstände die Versehiedenheit in der Entwickelung der Individuen hedingen, ist einleuchtend, wird auch laum anders angesehen.

2) Wichtig für das Prinzip der Weiserverfahren bei Aufstellung ron Erlragstafełn: es genügl vollständig, wenu etwa vom mittleren Beslandesalter an die höchsten und stäristen stänmie auch die vorwachsenden bleiben. Zu vergl. $\mathrm{B}$ ü hl $\mathrm{e} r$, Dr., Untersuchungen in einem Fichtenbestande etc. Allg. F.- U. J.-Z. 1886 S. 1 ff. 
Der Vorgang ist ein durchaus naturgemäßer, der sich in jedem Bestande, von dem die wirtschaftende Iland des Menschen fern bleibt, zwar in vielfach modifizierter Weise, im ganzen aber doch unter den gleichen charakteristischen Erscheinungen abspielt. Hinter den zur Herrschaft gelangenden Stämmen bleiben die anderen mehr und mehr zurück, bis sic als völlig unterdrückte nur noch kümmerlich ihr Dasein fristen, un endlich ganz abzusterben. Inzwischen ist unter den herrschenden Individuen der Kampf fortgesetzt worden. Das Zurückdrängen bislang dominierender Stämme in die geringeren Stammklassen erreicht innerhalb der allgemein üblichen Untriebszeiten ein Ende ohne Zutun der Wirtschaft überhaupt nicht. Die jeweils dominicrenden bezw. am Lïronenschluß noch teilnclunenden Stämme bilden den $\mathrm{H}$ a u p t b e s t a $\mathrm{n}$, die übrigen den $\mathrm{N}$ e b e $\mathrm{n}$ b e s $\mathrm{t}$ a $\mathrm{n} \mathrm{d}$. Daß trotz dieses andauernden Kampfes massenreiche, hochwertige Bestände emwachsen, ist zweifellos. Ebenso unzweifelhaft ist es aber, daB — wie die Wirtschaft überhaupt sich nit der Leistung der Natur nicht begnïgen kann, sondern sich deren Wirlien dienstbar machen muß, indem sie die Produktionsliraft, soweit tunlich, in bestimmte Bahnen leitet - gerade jener liampf um die Herrschaft im Leben des Bestandes für zielbewußtes Eingreifen des Wirtschafters eine der am meisten Erfolg versprechenden Gelegenheiten darbietet. Es gilt, dadurch, daß man den Streit der Stämme abkürzt, ihm womöglich vorbeugt, einen nutzlosen Kräfteverbrauch hintanzuhalten und eine bestimmte Qualität des Bestandes möglichst rasch zu erreichen. Dazu dicnen vornehmlich die Durchforstungen, deren Zweck es also sein muB, fortgesetzt in angemessenen Zwischenräumen dem Bestand so viel Stämme zu entnehmen, daß den übrigen dadurch in möglichst kurzer Frist eine normale Ausbildung ermöglicht wirl.

Die Wirtschaft hat diejenigen slämme zu bestimmen, welche weiter wachsen sollen. Unter welchen Umstānden lelzleres geschehen soll, ob die gegenseilige Spannung zwischen den Nachbarstämmen zeilweise oder dauernd ganz aufgehoben oder nur verringert werden soll, bezüglieh bis zu welchem Grade, welche Slanmklassen dem Aushieb rorzugsweise zum Opfer fallen sollen, welche Modifikationen je nach den besonderen Umständen des einzelnen Falles angebracht erscheinen, alles dies sind Spezialfragen der Ausiührung. Jedenfalls ist eine Durchforstung, welche sich - wie früher vielfach und hier und da auch jetzt noch - nur auf die Entfernung abgestorbenen oder völlig unterdrückten Holzes erstreckt, als eine die Entwickelung des Bestandes fördernde Maßregel nicht anzusehen. Solches Material, das von den Nachbarn bereits vollständig überwachsen ist, liann diesen nicht mehr wesentlich schaden, wenn auch ab und zu ein solcher Slamm mit seiner Beastung noch die seilliche Ausbreilung eines nebenstehenden hindert. Hiernach sollte die nur auf völig unterdrückles $\mathrm{Holz}$ gerichtele Durehforstung mindestens dann, wenn einem stärkeren Eingriff keine Bedenken bezüglich der Bodenpflege oder der Ausbildung der Stänme in stehenbleibenden Bestandesteil im Wege stehen, ein überwundener Slandpunkt sein. Ein zu starker Aushieb kann unzweifelhafl die fernere Entwickelung des Bestandes schädigen; aber ein Gewinn für den Bestand kann dureh die Durehforstung doch nur dann erziell werden, wenn sic als vorbeugende Iaßregel erscheinl oder mindestens den zum Forlwachsen bestimmlen stämmen wä lı $\mathrm{r}$ e $\mathrm{n}$ d ihres Ringens mil den Nachbarn tälige Hilfe bringt, nicht aber dann, wenn sie stets nachlinkl, indem sie nur die bereits Unterlegenen beseiligt ${ }^{1}$ ).

Ist aber auch die Durchforstung in erster Linie als eine der Bestandeserzielıung, der Massen- und Wertssteigerung dienende Wirtschaftsoperation zu betrachten, so ist sic doch zugleich auch zu anderen Zwecken bestimmt, indem sie

a) eine oft sehr bedeutende Holznutzung gewährt,

b) die Bestände gegen eine Reihe von Gefahren sicher zu stellen sucht und

c) die Bodentätigkeit in günstigster Weise beeinflußt.

Zu a) Die Ergebnisse der Durchforstungen stellen Vor $(=$ Zwischen $)$ nutzungen

1) Von dieser Auffassung ausgehend konnte man bei den vom Verein deutscher forstlicher Versuchsanstalten eingeleiteten Durchforstungs-Versuchen die schwächste (A-)Durchforstung des Arbeilsplanes (Beseitigung nur der absterbenden und abgeslorbenen Ståmme) füglieh ganz beiseite lassen, wie dies z. B. seitens der Würtembergischen Versuchsslation tatsáehlich fast überall gesehehen ist. 
dar, deren reehnerische Behandlung (Bedleutung für die Rentabilität des Betriebs) in der $\mathrm{W}^{\gamma}$ aldwertrechnung nachzuweisen ist. An dieser Stelle sei nur ganz im allgemeinen darauf lingedeutet, daß sie in ihren Nachwerten die Erträge steigern und den Produktionsfonds entlasten, und daß in diesem Einfluß jedenfalls unter Umständen ein vollwertiges Motiv zugunsten stärkerer Vomalıme der Durchforstungen erblickt werden muß. Wie groß, absolut genommen, die bei den Uurchforstungen eingehenden Wertesind, läßt sich, ganz abgesehen von dem nach Standort, Holzart usw. abweichenden Verhalten der Bestände, angesichts der bei ihrer wirtsehaftlichen Behandlung herrschenden Tersehiedenheit, sowie der mendlieh wechselnden Absatzgelegenheiten auch nieht in Gestalt von durehschnittlichen Beträgen mit annähernder Sicherheit angeben. In einzelnen finden sich zahlreiche Mitteilungen in unserer forstliehen Literatur ${ }^{1}$ ), welehe aber aus den angedeuteten Gründen nur mit Vorsicht von einem Fall auf einen anderen übertragen werden dürfen. Nicht einmal hinsichtlich der anfallenden Massen lassen sich allgemein brauchbare Angaben machen. Je nach Gütegrad des Bestandes und Standortes und Durehforstungsstärke sehwanken die Vorerträge zwischen 25 and $50 \%$ des Gesamtertrages. Das neuere, auf stärkere Eingriffe während der zweiten Untriebshälfte zukommende Durchforstungsverfahren ergibt in allgemeinen zwischen 35 bis $50 \%$ des Gesamtertrages liegende Vorerträge und steigert diese in einzelnen Fällen bis 60\% der Gesamtmasse.

Lm die Verschiedenlieil im Werte des Durchforstungsmaterials an einzelnen Beispielen zu zeigen, brauchl man nur an die auch für die geringsten Sortimente in großen Stãdten gebotene Verkaufsgelegenheil gegenüLer der oft absoluten Unverwendbarkeil derselben im Inneren großer, wenig aufgeschlossener Waldumgen oder an die Bedeutung des Handels mil Hopfenstangen in hopfenbautreibenden Gegenden zu erinnern in Gegensatze zu solehen Gebieten, denen diese Absatzquelle felilt usw.

Zu b) Zu den Gefahren, gegen welche die Durehforstungen einen Sehutz gewähren bezw. gewälıren können, gehören u. a. Feuer, Insektenbeschädigungen, Wind, Schnee. Wie hoch in einzelnen dieser Vorteil anzuschlagen ist, bleibt der Beurteilung des ,Forstsehutzes" ̈̈berlassen. Daß aber überhaupt durch Entfernung abgestorbenen und unterdrückten Holzes die Feuersgefahr verringert, sowie manehen Inselitenbesehädigungen vorgebeugt wird, liegt auf der Hand; nicht minder, daß durch fleißigen Aushieb der mit fruktifizierenden Hexenbesen behafteten Bäume in Tannenbeständen der Verbreitung der hrebsbildung entgegengewirkt wird. Von allgemeinerer und größerer Bedeutung ist, daß durch zweekentsprechende reehtzeitige und öfter wiederkehrende Durchforstungen die Widerstandsfähigkeit der Bestände gegen Sturm und Sehneesehaden²) gefördert wird.

1) Siehe z. B. Vorerlragstafeln von $\mathrm{D}$ a $\mathrm{n} \mathrm{e} \mathrm{k} \mathrm{e} \mathrm{m}$ a n $\mathrm{n}$ für liefern-, Fichten- und Rotbuchen-Hochwald (Zeitschrift für Forst- U. Jagdwesen 1887 S. $73 \mathrm{ff.}$ ). Daselbst sind angegeben als Durchschnitts-.Nlassenertrag der sämtlichen Vornutzungen in Prozenten des Haubarkeitsertrags für li i e fer und Fichte ca. 40 mil goringer Schwankung in den verschiedenen Güteklassen, für Buclie ca. 35. - Vergl. ferner $k$ u n z e, ,Ueber den Einfluß verschiedener Durchforstungsgrade auf den Wachstumsgang der Rotbuche" (Tharandter Jahrbuch 1884 S. 37 ff.). Daselbst werden die Ergebnisse eines 21 Jahre lang fortgesetzlen V'ersuchs mitgeteill. - Ferner: Die neueren und neuesten Erlragstafeln für Ficlıte (Baur 1877, Kunze 1877, Schwappach 1890 und 1902, Schiffel 1904, Flury 1907), Kiefer (Weise 1880, Kunze 1884, Schwappach 1889 und 1908 , Torkampff-Laue 1904, Wimmenautr 1908), Buche (Baur 1881, Schuberg 1894, Schwappach 1893 und 1911, Winmenater 1893 und 1911, Grundner 1904, Flury 1907).

2) Bedeutende Sclneebrüche des Winters $1885 / 86$ und noch weit umfassendere des Win. ters $1886 / 87$ (z. B. in den Waldungen - bes. ca. 25jährigen Nadelholzhegen - des Schönbuchs nördliclı von Tabingen, worüler A.F.- u. J.-Z. 1887 S. 286 zu vergleichen) konnten freilich an der günstigen Wirkung der Durchforstungen in dieser Richtung Zweifel aufkommen lassen, da durehforstele und nieht durchforstete Orte in gleicher Weise verwüstel worden sind. Aber es waren meist kurz vorher durchhauene Bestände, welche neben den unberührten gelitten haben; wahrscheinlich, daß sich, wenn allgemein schon in früherem Alter in Absicht auf die Schneegefahr eine durchgreifende Reinigung vorgenommen worden wäre, die Besclıädigungen weniger intensiv 
Zu c) Von nicht zu unterschätzender Wichtigkeit ist der schon S. 16 erwälınte Einfluß, den der mit der Durchforstung verbundene vermehrte Wärme- und Luftzutritt zum Boden auf die Zersetzung der Streu ausübt. Je mehr Standort, Holzart und Bestandesverfassung die Ansammlung von Trockentorfmassen wahrscheintich machen, un so mehr muß durch rechtzeitige und genügende Schlußunterbrechung den atmospluärischen Verwesungsfaktoren Zutritt zum Boden versclafft werden. Die mit der normalen Streuzersetzung verbundene Folılensäurebildung dient der Erschließung der Bodennälurstoffe in gleichem Maße wie die durch Verwesung der Wurzeln herbeigeführte Borlenlockerung und Bodendurehlüftung.

S 77. II. Grundsätze bei der dusführung a er Durchfors t u u ge n: Für den Durchforstungsbetrieb sind drei Fragen zu beantworten, nämlich: 1. wann soll man mit den betreffenden Aushieben heginnen? 2. wie stark soll man sie greifen? und 3 . wie oft soll man sie wiederholen? Lie von $\mathrm{K}$ a r l $\mathrm{H}$ e y e r in dieser Hinsicht gegebene Regel lautet: f r ü h, mä Big und o f t ! Georg Ludwig H a r t ig war für stete Erhaltung des Schlusses, Co t t a lingegen im Interesse der Zuwachsförderung für eine Unterbrechung desselben.

A. Beginnder Dure h forstungen: Bei der Entscheidung über den richtigen Zeitpunkt des Durchfor'stungsbeginns muB man, da die Jurchforstungen in erster Linie wegen ilırer günstigen Einwirkung auf die Entwickelung des Hauptbestandes vorzunelmen sind, zunächst immer die für letzteren zu erwartenden Vorteile ins Auge fassen und clarf nötigenfalls selbst eine Zubuße an Arbeitsaufwand nicht scheuen, wenn sich der Ausfall durch raschere Erstarkung des verbleibenclen Bestandteiles bezahlt macht. Ueberhaupt darf man die Bilanz nicht jedesmal fül die einzelnen Durchforstungen ziehen, sondern muß deren Erträge und Kosten für die ganze Lebensdauer des Bestandes zusammenrechnen und erst die Summen vergleichen ${ }^{1}$ ). Hierbei hat eine Vernachwertung der Erträge mit Zinseszinsen stattzufinden und zu dieser Summe ist der Abtriebsertrag zu addieren. Unter sonst gleichen Unständen ist derjenige Durchforstungsbetrieb der beste, welcher zu einem Maximum der Gesantleistung führt.

Es ist allerdings angenehm, wenn sieh solche Wirtsehaftsoperationen wie die Durehforstungen gewissermaßen aus sieh selbst heraus bezahlt machen, aber ein Hindernis für frühzeiligen Beginn darf im liostenpunlit nur in besehränlitem Maße gefunden werden. Andererseils liann sehr wohl der gänzliche Mangel an Absatz für das zu gewinnende schwaehe Jaterial, somie das Fehlen der nōtigen Arbeitsliäfte da und dort der Vornahme einer Durchforstung erheblich im Wiege stehen.

Berüchsichtigt man die Gefahren, welchen gerade die dichtgeschlossenen Jungwüchse ganz besonders ausgesetzt sind (Feuer, Schneedrucki), so muß man im allgemeinen einem möglichst frühzeitigen Anfang des Durehforstungsbetriebs das Wort reden. Einen absolut geeignetsten Zeitpunkt kann man aber dafür weder ganz allgemein angeben, noch auch nur für einzelne Holzarten oder Standortskategorien bestimmt bezeichnen. Das entscheidende Wort hat das Aussehen des einzelnen Be-

gezeiğ hätten. Hinsichtlich der Sehneebruchgefahr in ihren Beziehungen zur Durehforstung ist eine sehr beachtenswerte Studie von Professor Dr. B a ll l e r erschienen (Forstwiss. Zentralblatt, Sept.-Oktbr. von 1886 S. 485 ff.), morin aus mechanisehen Gründen hauptsächlich die Gefährlichheit unsymmetrisch entwickelter Kronen (einseitige Belastung dureh selnee) Letont wird. Eine dem Sehneehruch entgegenwirkende Durchforstung hat vorzugsweise die Sehaffung gleichnäßig ausgebildeter Kronen ins tuge zu fassen. B $0 \mathrm{hl}$ e $\mathrm{r}$ sieht in der Durchforstung entsehieden ein Mittel gegen Schntehruehsehäden, eine Ansichi, lie durch die Erfalırungen der Praxis als richtig sich erwiesen hal und nur dann widerlegl erseheint, wenn plötzlich und sprungweis stark durehforslet wird und die so behandellen Bestände bald nach Ausführung der Lurchforstung von größerem Schneefall belroffen werden.

2) Man vergleiche $\mathrm{F}$ is $\mathrm{c}$ li b a $\mathrm{ch}$ im forstw. Zentralbl. von $1885 \mathrm{~S} .553$. 
standes zu sprechen. Modifiziert wird aber das in ilım liegende Gebot jederzeit durch die Möglichkeit der Ausführung, für welche die oben angedeuteten Gesichtspunkte (Arbeitskräfte, Absatz etc.) maßgebend werden.

Tatsâchlich wird, nach Beendigung der Reinigungshiebe, im großen Betrieb mit den Durchforstungen auch bei Lichtholzarten kaum vor dem 15.-20. Lebensjahre begonnen, während bei Schattenhôlzern, Buche, Fichte und insbesondere Tanne, oft bis ins 25., 30. Lebensjahr, ja noch långer zugewartet wird, obwohl es keinem $Z$ weifel unterliegt, da $B$ auch (und vielleich $\mathrm{t}$ in hervorragendem Maße) diese Holzarten für recht frühzeitiges Eingreifen sehr dankbar sind.

$\S 78$. B. Stär ke des Eingriffs und Wie derholung: Die Antworten auf die beiden bezüglichen Fragen sind insofern von einander abhängig, als es die häufigere Wiederkehr in den nämlichen Bestand gestattet, mit dem einzelnen Hieb weniger kräftig vorzugehen, ohne daß der mehrfach betonte Hauptzweck der Durchforstungen, die Vermeidung zu gedrängten Schlusses, vereitelt wird. Ja, wenn man erwägt, daß zur normalen Ausbildung des Einzelbaumes immer nur ein gewisses Maß an Standraum erforderlieh ist, wälıend eine weitergehende Unterbrechung des Kronenschlusses je nach Umständen für den Boden bedenkliche Folgen haben kann, so muß man einräunen, daß es am rationellsten ist, die Durchforstungen zwar recht oft, aber jedesmal nur in solehem Unfange vorzunehmen, wie es die vollkräftige Entwickelung des Hauptbestandes gerade erheischt. Jedesmal, wann wieder Iíronenspannung eintritt, sollte von neuem eingegriffen werden.

Meist gestaltet sich die Praxis des Durchforstungsbetriebes so, da B man in Zwischenräumen von 5-10 Jahren, manchmal noch seltener in die Bestände wiederkehrt. Zeit- und Arbeitsaufwand, Uebersichtlichkeit der Wirtschaft, zeitweise Ruhe in den Beständen usw. sind die Gründe gegen kürzere Perioden. Es ist naheliegend, daß nan den Unzuträgtichkeiten, die mit zeitlich weiter auseinander liegenden Durchforstungen in Hinblick auf den Erziehungszweck verbunden sind, zu begegnen sucht, indem man im einzelnen Falle stärker durchforstet.

Vit jener Regel bezüglich der Wiederholung und den sie begründenden Enwägungen ist aber keineswegs auch sclıon die Frage nach der zweckmäßigsten Stärke des einzelnen Aushiebs beantwortet. Die Aufgabe der Durchforstung ist eine zweifache: einerseits ist der jetzt envachsende Bestand zur höchstmögliehen Volliommenheit herauszuarbeiten und zweitens ist die Bodenkraft ungeschmälert, tunlichst sogar noch erhöht an die nachfolgende Umtriebszeit zu überliefern. Beide Aufgaben stehen sich in ihren Zielpunkten keineswegs gegenüber, sondern gehen hierin Hand in Hand, denn eine sorgsame Schonung des Bodens lkommt auch dem jetzt lebenden Bestande zu gute. Wohl aber sind die Mittel, mit denen hinsichtlich der beiden Zweclie gearbeitet wird, verschieden. Der Bodenschutz verlangt im allgemeinen (d. h. von den Fällen zu großer Nässe und zu mächtiger Trockentorfanhäufung abgesehen) dichteren Bestandesschluß, während sich die mögliclıst rasche Erstarkung der Bäume nur bei Gewährung entsprechenden Wachsraumes, also nach Aufhebung stärkerer Kronenspannung vollzielıen kann. Fraglich ist, inwieweit auf gegebener Fläche die quantiund qualitative Zuwachsleistung einer geringeren Anzahl mehr räunlich stehender Bäume, deren jeder dann mit vermehrter Energie arbeitet, durch die Massen- und Wertsmehrung ') einer größeren Anzahl gedrängter stehender, im einzelnen geringerer Stämme aufgewogen werden kann. Alle theoretische Erörterung kann sich nur um diese Frage drehen, da man sieh für dasjenige Verfahren zır entscheiden hat, welches unter voller Berücksiehtigung des Gesamtaufwandes - Bodenkraft, Arbeit, Zeit, Holzvorratskapital - die höchsten Werte erwirtsehaftet. Hienach also ist die Stärke des jeweiligen Eingriffes zu benıessen.

1) Es wird unterstellt, daß der beim Verkauf erzietle Preis der äußere Ausdruck für Wert und Gebrauchsfähigkeit der erzeugten Ware ist; wenigstens hat die Wirtschaft für die Beurteilung ihrer Maßnahmen zunảchst keinen anderen trauchbaren Mlaßstab als den im Erlös beim Produktenverkauf erreichten tatsächlichen Geldertrag. 
Der Wirtschaft im Walde ist mit diesen allgemeinen Erwägungen jedoch nicht gedient; sie fordert greifbare Anhaltspunkte.

Um solche zu gewinnen, hat man mehrfach relsucht, die rersehiedenen in einem Bestande vorkommenden Stammklassen genau zu definieren. Derarlige halassifizierungen sind sehon frühzeilig unternommen worden. So oft man für die Durchforstungen gewisse Regeln begründen wollte, nußle man von einer bezüglichen Unterscheidung ausgehen. So spricht $z$. B. C o t $t$ a (Waldbau, 9. Aufl. S.91) von abgestorbenen, absterbenden, unterdrückten, beherrschten und herrschenden Stămmen. - Dic zur kilärung aller einsehlagenden Verhältnisse von dem Verein deutscher forstlicher Versuchsanstalten beabichtiglen Durchforstungsversuche beruhen anf einem Arbeitsplane, welcher 1902 beschlossen wurde und in der Zeitsclir. f. F.- M. J.-Mesen 1902, S. 668 abgedruckt ist. Er führt folgende Klassen auf:

I. H e r s c h e n d e Stitmme, welche an dem oberen Fronenschirm teilnehnen und zwar 1. Stănme mil normaler lỉronenentwickelung und guter Stammform, 2. Stămne init abnormer Kronenentwickelung oder schlechter Stannform, a) eingekJemmle Stämme (kl), b) schlechlgeformte Vorwüchse (vo), c) sonstige Stämme mit fehlerhafler stammausformung, insbesondere Zwiesel (zw), d) sogenannte Peilscher (pt), e) Jranke Stämme (kr).

II. $\mathrm{B}$ e h e r s c h t e Stämme 3. zurückbleibende, 4. unterdrückte, 5. absterbende und abgestorbene.

Die Durchforstungen entfernen die Stammklassen 5-2 zum Teil oder ganz, Stämme der Kil. 1 nur ausnahmsweise, soweit dies zur Auflösung von Gruppen nolwendig erseheint.

Nach Art und Grad der Durchforstungen werden unterschieden:

I. Nied erdureh fors L ung. 1. Sc h w a c he Durchforstung (A-Grad): entfernt nur die abgestorbenen und abslerbenden Stämme, sowie die niedergebogenen Stangen. 2. M a $\beta$ ig e Durchforstung (B-Grad): entfernt die Klassen 5, 4 und einen Teil von 2. 3. St a r ke Durchforstung (C-Grad): entfernt alle Stämme nit Ausnahme der kilasse 1.

I1. Hoehdurehforstu $\mathrm{g} g$. 1. Sehwach (D-Grad): heschränkt sieh auf den Aushieb der abgestorbenen und absterbenden, niedergebogenen, ferner der schlechtgeformlen und liranken Stänme, der Zwiesel, Sperrwüchse, Peitselıer, sowie derjenigen Slänme, die zur Auflōsung von Gruppen gleichwertiger Stämme entfernt werden müssen (Ki. う́, ein großer Teil von Kl. 2 und einzelne stămne von Iil. 1). 2. St a r k (E-Grad): erstrebt unmittelbar die Pflege einer verschieden bemessenen Anzahl von Zukunitsstämmen und entfernt neben der Klasse 5 und den kranken Stämmen alles, was die gute Fironenentwickelung der Zukumftsstämme behindert (Kil. 5 und Stämme der Kil. 1 und 2).

Eine andere Ausseheidung vollzog $\mathrm{K} r$ a $\mathrm{ft}$ in seinen oben angefühten, Beilrägen zur Lehre von den Durchforstungen", indenı er nicht die Verschiedenheit des Höhenwuchses, sondern die Qualilāt der Krone als das durehschlagende Kriterium ansah. Hiernach ergeben sich folgende Kategorien: 1. vorherrschende Stänme (mit ausnahmsweise liräftig entwickellen Kronen); 2. herrschende (in der Regel den Hauptbestand bildende St. mit verhältnismäßig gut entwickelten Kronen); 3. gering mitherrschende St. (Kirone zwar noch ziemlich normal geformt, aber verhältnismäßig sehwaeh entwiekelt und eingeengl, oft mit schon beginnender Degeneration - untere Grenze des herrschenden Bestandes); 4. beherrschte Stämme (Krone mehr oder weniger verkümmert, entweder von allen Seiten oder nur von zwei Seilen zusammengedrückt oder einseitig entwichelt), hierunter a) zwischenstândige, b) teilweise unterständige Fronen; 5. ganz unterständige Stämme, a) mit lebensfähigen fironen, b) mil absterbenden und abgestorbenen Fronen. - Hienach kann beslinmt angegeben werden, welche der angefüluten Flassen bei der Durchforstung der Nutzung anheinfallen sollen.

Nach allen bisherigen Auseinandersetzungen können nur in bezug auf diejenigen Stämme Zweifel bestehen, welche sich am Kronenschhß im Bestande noch alitiv beteiligen, indem sie über sich noch einen melı oder minder großen freien Luftraum haben oder sich wenigstens mit ihren Aesten noch in die oberen Partien der Nachbarlironen eindrängen, so daß letztere dadurch in ihrer seitlichen Ausbildung behindert sind. Was an Bäumen bereits vollständig unterdrückt ist, darf - unter Nichtbeachtung des geringen Nälırstoffverbrauchs, welcher für den unbedeutenden Zuwachs erforderlich ist - als für die Bestandeserziehung gleichgültig betraehtet werden. Die Zuwachsleistung der mehr oder weniger unterständigen Stämme ist eine äuBerst geringfügige; $80-90$ Prozent der Gesamtzuwachsleistung entfallen auf den Hauptbestand.

Die Ansichten darüber, wie weit man den Kronenschirm lockern soll, gehen sehr auseinander. Wer für Unterlassen jeder Durchforstung oder für nur ganz schwaches Eingreifen eintritt und damit sich weigert, den Kronensehluß überhaupt irgendwie 
zu unterbrechen, kamn sich nur auf möglichst weitgelıende Sorge für den Bodenschutz, sowie für Ausbildung glattschaftiger, astreiner, schlanker Nutzholzstämme berufen. Bei räumlicherer Stellung produzieren die einzelnen Stämme in den heranwachsenden Bestänten, ausweislich aller neweren Untersuchungen, mehr Masse als in den nicht oder nur ganz schwach durchforsteten Beständen. Andererseits beruht aber der IV'ert stärkerer Durchforstungen, wie die Ergebnisse aller V'ersuchsflächen bestätigen, nicht in einer Steigerung der Cesantmassenproduktion, sondern lediglicl in einer Wertsmehrung. Ilie Gesamtmassenleistung der Bestände bleibt dieselbe, gleichviel ob melı oder weniger stark durchforstet bezw. gelichtet wird. Wir erzeugen nicht mehr Mlasse ${ }^{1}$ ), wenn wir die besten Stämme frỉhzeitig und nachlıaltig umlichten, der Gesamtzuwachs wird aber auch nicht kleiner, solange bei der Lichtung nicht unter die zulässige Grenze der Stammzahl herabgegangen worden ist. Der Wert stärlierer Durchforstungen beruht in der Konzentrierung des Zuwachses auf eine geringere Stammzahı. Das ist gleichbedeutend mit rascherer Stärlien- und Wertszunahme dieser Stämme und umschließt Erhı̈hung der Rentabilität, wenn sonst die technische Perwendbarkeit des in der größeren Freistellung erwachsenen Holzes nicht gelitten liat. Die Zukunft des Waldes aber liegt, wie Heck (Freie Durchforstung I901, s. 63) sagt, nicht in der Massen-, sondern in der Wertwirtsehaft. Dieses auch im Worte ,Nutzholzerziehung" ausgedrüclite Leitmotiv des neuzeitlichen Wirtschaftswaldes führte die Durchforstungstechnik von selbst auf die schwerwiegenden Unterschiede, die in der Behandlung der verschiedenen Holzarten infolge ihrer auseinander gehenden physiologisehen und hiologischen Eigenschaften zu beachten sind. Unter Berücksichtigung dieser Verschiedenheiten wurden vielfach für die verschiedenen Altersstufen des Bestandes verschiedene Durchforstungsnormen aufgestellt. In allgemeinen gilt jetzt der Grundsatz, den Bestand bis zur Tollendung seines Hauptlängenwachstums ${ }^{2}$ ) in Schlul3 zu lalten und erst späterlin mit stärkeren Eingriffen zu beginnen. Der Bestand soll dadurch veranlaßt werden, in der ersten Periode seines Lebens Stämme auszubilden, die bis zu einer gewissen Hölı über dem Boden astrein ${ }^{3}$ ) sind. Der vorangehenden Pflege der Schaftform, d. h. der Ausbildung von Astreinheit, Geradsehäftigkeit und Vollholzigkeit, folgt dann die Pflege der Stärkenzunahme durch Vergrößerung des Wachs- und Kronenraumes. Unleugbar hat dieses Verfahren vollste Berechtigung bei allen jenen Holzarten, die nicht, wie Lärche, Fichte und Tanne, über ein bis in holı Alter anhaltendes Schaftlängenwachstum verfügen, sondern, wie unsere wirtschaftlich beachtenswertesten Laubhölzer und Kiefer, zur Verästelung des Schaftes, Kronenaushreitung und Kurzschaftigkeit hinneigen, sobald sie von. Jugend auf freien Wachsraum haben. Hier lewirlit die Erzielıung im Schluß bis zur Vollenrlung rles Hauptlängenwachstums ein Hinausschieben der Irrone, ein

1) Nur bei der Rothuche fand $\mathrm{Se} \mathrm{l}$ w a p l) a $\mathrm{e} \mathrm{h}$ (d. Rotbuche 1911, S. 171) auf den naeh den Grundsätzen der schwachen Hochlurehforstung behandelten Flăchen der 3 ersten Standortsklassen gegenüber den im gewöhnlichen Schluß gehaltenen Flächen eine absolute Mehrproduktion an Derbliolz bei 100 jähr. Untriebe von durehsehnitlich $15 \%$, bei 120 jähr. Untriele sogar von $19 \%$.

2) Der laufend jährliehe Höhenzuwachs kuminiert nach den neueren Ertragstafeln für die Fichte durchselnittlich mit 40-50, die Bnehe nit 30-35, Kiefer 15-20, Tanne 50-70 Jahren, der durchschnittliche Höhenzuwachs bezüglich im Alter von $60-80,40-50,30$ und $70-100$ Jaliren.

3) Die einzelnen Holzarten verhalten sich in dieser Hinsicht sebr verschieden. Die unteren Zweige sollen absterben, bevor sie zu stark geworden sind, um dennächst noch abgestoBen zu werden; sie sollen keine Ilornäste im Holz zurücklassen. Bei Lichthölzern erfolgt das Absterben naturgemäß raseber; Laubbölzer stoßen die starken Jeste meist leichter und vollständiger ab als Nadelhölzer, unter welehen namentlich die Fichte sich nur bei dichtem Selnluß entsprechend schnell und vollständig reinigt. 
Strecken des ganzen Bammes und ist das einzige Mittel, um das Laubholz und rlie Kiefer zur Ausbilchng nutzholztüchtiger Schaftformen zu zwingen.

Anders liegen die Verhältnisse bei Lärche, Fichte und Tanne. Bei ihnen wirlst eine größere Lichtstellung in der Jugend nicht verzögernd, sondern anregend und fördernd auf den Hölenwuchs ein. Hierzu gesellt sich eine Förderung des Stäıknzuwachses, weil mit dem größeren Wachsraum die Ausbildung einer größeren lirone in Verbindung steht. Ungekelurt werden die genannten Narlelhölzer bei Schlußerzieluung an der Ausbildung und Erhaltung einer für ihre spätere Erstarkung notwendigen lirone gehindert. Da den Nadelhölzern größere Nengen entwickelungsfähiger Adventivlinospen nicht zur Verfügung stehen, ist es ihnen nicht möglich, eine infolge dichten. Jugendschlusses verloren gegangene Kirone im späteren freieren stande so zu ersetzen, daß der für eine nennenswerte Stärlienzunahme notwendige Assimilationsapparat vorhanden ist. Es ist daher verständlich, wenn $\mathrm{S} c \mathrm{~h}$ i f f e l' ${ }^{1}$ ) in Anlehnung an die rom Forstmeister $\mathrm{B}$ o h $\mathrm{d}$ a n e ck $\mathrm{y}$ auf der Herrschaft Worlik in Bölunen schon länger geübte Praxis für die Erziehung von Fichte, Tanne und Lärche gerade die entgegengesetzten Regeln aufstellt wie für die Erziehung der Laubhölzer und der Iijefer. Die letzteren sind dicht in der Jugend, licht im Alter, Fichte, Tamme und Lärche aber licht in der Jugend und dichter im Alter zu erziehen. Neben sehr weitständiger Bestandesbegründung verlangen $\mathrm{S}$ clı iffel für Fichte und $M$ e r 2 ) für Tanne starke Schlußunterbrechungen in der Jugend. Der Bestandesschluß und damit der Beginn der Reinigung soll bei der Fichte bei 5 m, auf den besseren Standorten erst bei $8 \mathrm{~m}$ Mittelhöhe eintreten. Die mit dem Schließen der Küultur infolge der Reinigung einsetzende Kronenverkürzung soll dann durch rechtzeitig eingelegte und oftere Durchforstungen so verzögert werden, daß die Stämme des Hauptbestandes in Haubarkeitsalter noch zuwachskräftige, 3 bis 4 Zehntel der Schaftlänge einnehmende Kronen aufweisen. Die von Schiffel empfohlene freiwïchsige Jugenderziehung ist natürlich nur dann zulässig, wenn Gefährdung der Bodenkraft ebenso wie Grobästigkeit, Weitringigkeit und Schwammigkeit, also allgemein gesagt, Qualitätsminderung des Holzes nicht zur Gefoløschaft der genannten Erzielungsmethole gehören. Sie ist weiter an die Voraussetzung gebunden, daß die gesteigerte Massenleistung, das entsprechend nierlige Abtriebsalter und der höhere Prozentsatz Starliholz der freiwüchsig erzogenen Bestände tatsächlich den Mchraufwand an Arbeit und Geld ersetzen, der durch die frühzeitigen und öfter wiederholten, doch nur geringwertiges Ilaterial abwerfenden Durchreiserungen und Durchschneidumgen und durch Verringerung der besser absetzbaren Durchforstungswerte verursacht wird. Eine so intensive Bestandspflege, wie zur Erreichung der Vorteile der freiwüchsigen .Jugenderziehung nötig ist, ist an günstige Arbeiter- und Absatzverhälnisse gebunden. Außerlem kommt hinzu, daß die Vornutzungen bei der Schiffel'schen Methode nach llasse und Wert fühlbar sinken. Wie weit sich speziell dieses lloment in der hentabilität bemerkbar macht, darüber entscheiden die jeweils vorliegenden volkswirtschaftlichen Verhältnisse. Es ist sicher, daß die hervorgehobenen Toraussetzungen für erfolgreiche Anwendung der frewïchsigen Jugenderzichung keineswegs überall rorhanden sind, und es ist zu erwarten, daß rlie forstliche Praxis im großen und ganzen

1) A. Schiffel, Wuchsgestze normalel. Fichtenbestände. Heft 29 der ,.Mitteilungen a. d. forstl. Versuchswesen Oesteireichs". - D e r. s. uber Bestandserziehung, Zbl. f. dl. ges. Forstwesen 1906, 333, 405. - Sc h w a p p c h, Wie sind junge Fichtenlestânde zu durchforsten, 7.lschr. f. Fort- u. Jagdw. 1905, S. 11. - Re b e l, Die Worliker Bestandserziehung, Forstwisn. Zbl. $1905,239$.

2) Il er, Moyens d'accroitre la production de bois d'oeurre. Rerue des eaux et forèts $1905,513$. 
auch bei der Pflege der Fichten-, Tannen- und Lärchenbestände an dem Grundsatz festhalten wird, dem Durchforstungsbetriebe nicht vor, sondern erst nach der Periode des Hauptlängenwachstums größere Freiheit zu gewähren. Damit soll der absoluten Schonung des Hauptbestandes während der Jugendperiode des Bestandes aber keineswegs das Wort geredet sein. Das bei der Bestandeserziehung mehr und mehr in den Vordergrund tretende Prinzip der Sehaftpflege verlangt vielmehr eine möglichst frühzeitige Beseitigung aller jener Glieder des Hauptbestandes, die mit irgend einer unerwünschten Eigenschaft behaftet sind. Zu diesen gehören nicht nur die kranken und schlechtformigen Stämme, sondern unter Umständen auch ein Teil der vorwüchsigsten und danit meist auch stärksten Stämme. Der Tatsache, daß solche Vorwüchse sehr oft nicht über die besten Schaftformen verfügen, namentlich nicht bei Buche und Kiefer, tritt noch der weitere Nachteil zur Seite, daß durch sie oft eine mehr oder minder große Anzahl von entwicklungsfähigen, zuwachstüchtigen Nachbarn zurückgehalten wird. Die rechtzeitige Entfernung dieser Vorwüchse (,Protzen“ im Sinne Borggreves) bedeutet für den Bestand trotz der Entnahme eines Teiles der zuwachskräftigsten Individuen keine Einbuße, sondern Gewinn an Zuwachs, einen Gewinn, der sowohl in der Massenleistung wie auch in der Nutzholz-, also Wertsmehrung zum Ausdruck kommt, wenn, wie wohl selbstverständlich, in erster Linie den schlechtformigen Vorwüchsen zu Leibe gegangen wird. Der Wert dieses von Borggreve in semel Plenterdurchforstung (s. dort) vertretenen Gedankens der Entnahme vorwüchsiger Stämme zu gunsten besserer, entwickelungsfähiger Nachbarn tritt umsomehr helvor, je jünger die Bestände sind, in denen er bei der Bestandspflege zur Richtschnur genommen wird. Er findet neuerdings Beachtung in der Hochdurchforstung und hat sich nach Ausweis der jüngeren Ertragstafeln von Schwappach (s. Fußnote 1 S. 168) nameutlich bei der Erziehung jener Holzarten bewährt, bei denen Sperrwüchse und schlechte Stammformen häufiger sind, d. s. Buche, Eiche und Kiefer.

Wägt man die auBerordentlich zahlreichen Erfahrungen, die mit den verschiedenen Graden der Durchforstung gemacht worden sind und die ein reiches Für und Wider umsehließen, sorgfältig ab, so kommt man zu dem Schluß, daß in allgemeinen ein kiäftiges Eingreifen in Form der starken Niederdurchforstung, vielfach besser noch in Form der schwachen Hochdurchforstung, also ein Eingreifen, das eine zeitweise Unterbrechung des Kronenschlusses nicht scheut, die R e gel z u bil d en h a t, wenn für die Pflege des Abtriebsbestandes und dessen Entwickelung wirklich etwas geleistet werden soll, während die auf die unterdrückten Stämme sich beschränkendemäßigeoder gar die schwache, nur die abgestorbenen und absterbenden begreifende Durchforstung als Ausnahmen zu betrachten sind, für deren Berechtigung im einzelnen Falle bestimmter Nachweis verlangt werden nuß. Dies gilt, wenn nicht schon für die allerersten Durchforstungen, so mindestens vom angehenden Stangenholzalter ab. Abweichungen bleiben vorbehalten, und es wird niemand darüber zweifelhaft sein, daß solche gerade in jüngeren Beständen häufig geboten sind. Wie weit übrigens die einzelne Durchforstung mit der Lockerung im lironendach gehen soll, ist, wie sehon oben angedeutet wurde, wesentlich von der Häufigkeit der Wiederholung abhängig. Die Durchforstumg soll nicht den Charakter eines Lichtungshiebes annehmen; aber es ist zu beachten, daß ein solcher noch lange nicht vorliegt, wenn vorübergehend die Sonne da und dort im Bestande zum Boden dringen kamn, während nach wenigen Jahren schon wieder volle Iironenspannung zu erwarten steht. Mehr als zwei Zehntel der Bestandesmasse wird man, Kronenschluß olıne Ueberfüllung, d. h. ohne merkliche gegenseitige Beengung, vorausgesetzt, auch bei starken Eingriffen liaum auf einmal entfernen, hiermit aber auch meist schon einen Zustand erzielen, bei dem sich der 
bleibende Bestandesteil einer normalen Entwickelung erfreut. Das richtige Maß würde erreicht sein, wenn bis zur nächsten Durchforstung jene mäßige Spannung, bei welcher die Bäume mit möghichst allseits gut gebildeten Kronen sich berühren oder doch höclıstens mit den Astspitzen ineinandergreifen, wieder hergestellt wäre. Jedem weitergehenclen gegenseitigen Beengen sollte sofort durch eine neue Durchforstung abgeholfen werden.

Anstatt den Aushieb nach $\mathrm{Sta} m \mathrm{mk}$ a s s e $\mathrm{n}$ zu regeln, ist mehrfach vorgeschlagen worden, eine Festsetzung der zu beseitigenden Individuen nach der St a mmzahl für I ha, unter Berücksichtigung der Brusthölı endurch$\mathrm{m}$ e s s e r vorzunehmen, so von $\mathrm{H}$ a u g und $\mathrm{K}$ o z e ś n i k (Literatur in Amm. $2 \mathrm{~S}$. 164). Hiermit in Einklang steht der schon vor langer Zeit von Oberforstrat Kö n ig in seiner Forstmathematik gemachte Vorsclılag einer Regelung des Aushiebs nach der Abstandszahl $\left(a=\frac{s}{d}\right)$ d. h. dem Verhältnis der Standraumseite zum Durchmesser. If a rtin ${ }^{3}$ wünscht, daß die Kreisflä chensumme $[=$ Stammgrund$\mathrm{f} l$ ä ch e $(\mathrm{g})]$ in der Durchforstungs- und Lichtungspraxis als Nlaßstab Anwendung finde. Kilein begimend und bis zum mittleren Stangenholzalter stark zunehmend, soll sie, sobald gute Schaftform der Stämme hergestellt ist, eine bestimmte, nach Standortsgüte und Holzart verschieclene Höhe nicht mehr überschreiten, sondern gleich bleiben wie der relative Wachsraum, d. h. wie das Verhältnis der Krone zur Stammgrundfläche in Brusthöhe. Aller Zuwachs, welcher der Kireisfläche dann zugeführt wird, muß periodisch im Wege der Durchforstung entfernt werden.

Welche Stammzahl oder welche Stammgrundfläche den größten Zuwachs sichern, darüber fehlen noch positive Zahlen. Nur für die Buche hat Sc lıw a p p a lh $\left.{ }^{2}\right\rangle$ neuerdings die besten Leistungen bei einer vom 60. Jahre aufwärts zwischen 20 und 25 Quadratmeter schwankenden Stamngrundfläche ermittelt. Die Abhängigkeit solcher Zahlen von Holzart, Bonität, Alter, Wirtschaftsziel usf. läßt aber vermuten, daß das subjektive Erınessen und der fachımännische Blick des Wirtschafters beim praktischen Durchforstungsbetriebe durch solche nur mit Zeitaufwand zu benutzende Zahlenwerte nicht verdrängt weerden. Schon Köönig sprach es aus, daß man über dem Durchforsten sclbst am besten heurteilen kömne, was abkömmlich sei. Einen besser und leichter anwendbaren Naßstab zur Bemessung der richtigen Bestandesdichte bildet die Höhe des Kronenansatzes an den herrschenden Stämmen. tuf Grund eingehender Untersuchungen ist die Forderung einer 30 bis $40 \%$ der Totalhöhe einnelımenden grünen tätigen Krone vom mittleren Lebensalter des Bestandes bis zur Hiebsreife von verschiedenen Seiten (Martin, Schwappach, Schiffel) aufgestellt worden.

Verschiedenheiten der Ausführung ergeben sich im einzelnen in Menge. Namentlich ist für die erste Durchforstung im Jungbestande die Art der Bestandesbegründung bezw, die ursprüngliche Bestandesdichte maßgebend und zwar nicht nur direkt wegen des dadurch bedingten stårkeren oder minder starken Drängens und Ringens der einzelnen Stãmmeheu nebeneinander, sondern hauptsāchlich mittelbar wegen ihrer Beschaffenheit. Man muß nicht selten eine erste Durchforstung schwächer führen, weil die einzelnen Stämmchen so schlanh erwachsen sind, daß jeder plötzliche stärkere Eingriff ein Umtegen derselben zur Folge haben würde. Eluenso ist, wenn nicht freierer Stand von der ersten Jugrend an widerstandsfăhigere Bestānde

1) II a $\mathrm{r}$ I i n, Kritische Vergleichung der wichtigsten forsttechnischen und forstpolitischen Iaßnahmen deutscher und außerdeutscher Forstverwaltungen. Ztschr. f. Forst- u. Jagdw. 1902, 635. - D e r s., Die forstliche Statik, 2. Bd. 124. - D e r s., Rückblicke a. d. V'erhandign. d. 8. internat. landw. liongreß in Wien. Tharandt. Jhrb. 1909, 133.

2) Die Rotbuche. 1911 . 
erzeugt hat, die Schneedruckgefahr in dem kritischen Gertenholzalter sehr zu beachten. Es ist ein Unterschied, ob man an steilen südlichen Hängen oder auf mäßig geneigten, frischen Nordhängen operiert. In allgemeinen wird man in schlechleren Lagren vorsichtiger zu Werk gehen müssen, hauptsächlich un die Bodenkraft zu bewahren. Nan darf aber dabei auclı nicht überselien, daß gerade schlechtere Bestände auf Standorten mit geringer Bodentätigkeit oft für die ilmen durch wirtschaftlichen Eingriff gewährte Beibilfe besonder dankbar sind. Ebenso wird man zum Schutz gegen das Eintreten des Windes in die Bestände (Windmäntel!) die Bestandesränder oft weniger stark angreifen, als das Beslandesinnere ${ }^{1}$ ). Sulbst unterdrückte stämme sind dann zu schonen, wenn ihr Aushieb Lücken im Bestande verursachen würde. welche als Wintlänge oder durch Bodenausliagerung bedenklich verden könnten. Alles in allem braucht man in vorgeschrittenerem Bestandesalter weniger ängstlich zu sein. Dadurch, daß eine zu schwache Durchforstung die Entwickelung des Haupthestandes ungebührlich zurückhäll, wird meist riel größerer Schaden angerichtet, als durch diw wenigen Fälle, in welchen vielleicht dureh einen $2 u$ starken Eingriff in irgend welcher Pichtung einnal ein Vachteil erfolgt.

Einen besonders starken Frad der Durchforstung roheischen we i $B$ L a n n e $n$ b e-

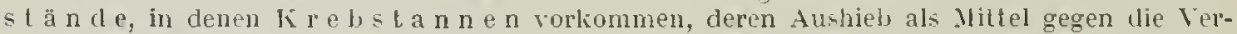
breitung der lirebsirankheit anzusehen ist ${ }^{2}$ ). Hier sind schon von jugendlichen Alter ab die mit krebs behafleten stămme aufzusuchen und zu entfernen. Ein solches Vorgehen bietet zu keinen Bedenken Anlals. Im Jungbestand, in welehem der liampf gegen das Uebel zu beginnen hat, sind die entstehenden Lïcken an sieh nielnt bedeutend und werden dureh einwachsende Indiviluen bald ausgefüllt. In älteren Beständen wird durch den Aushieb der lirebstannen, wenn dadurch Lücken entstehen, die Verjüngung eingeleitet, bezm. da. wo man eine femelschlagarige Bewirtschaftung der Weißtanne erstrebl, diese in der einfachsten Weise begonnen.

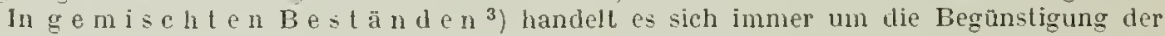
wertvollen Holzart vor der ninder wertsollen, durch Gewäh einer freien, die EnLwickelung begünstigenden stellung belufs Steigerung des Zuwachses und der Nintzlolzausfornung. So z. B. is den Freihieb der $\mathrm{E}$ i $\mathrm{c}$ h e in Buchenbestande besondere Aufmerksamkeit zu schenken, ebenso demjenigen von Esche, Ulue, Alorn, Linde, Tanne, Lärche, sofern sie Anwartschaft auf Erlangung von Niuzholzqualität haben.

In jüngeren Wüchsen ist ofters, wenn schlank aufgeschossene Exemplare zu schützen sind, die sich noch nicht zu tragen verügen, kein rollständiges Aushauen, sondern nur das Einstutzen (kïpfen) der bedrängenden stämme angezeigl. Für höhere Stangen, die nicht geköpft werden können, deren Beseiligung durch Herauslacken aber auch nicht erwünseht ist,

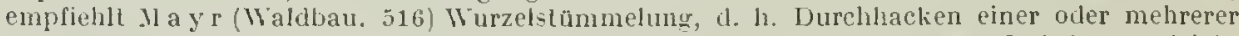
kraftiger Seitenwurzeln. Die dadurch herbeigeführte Verlangsamung les Wachstums erleichtert es dem wertrolleren Nachbarn, den notwendigen Vorsprung in Hölienwuchs zu erreichen.

5 79. C. Besondere Arten der Durchforstung: Der Durchforstungsbetrieb steht in engem Zusammenhang mit der Art des Wirtschaftsbetriehs überhaupt. Ein allen Rücksichten in einzehen gerecht werdender intensiver Durchforstungsbetrieb ist am leichtesten möglich in nicht zu ausgerlehnten lievieren, deren Verwalter die Befolgung ihrer Intentionen überall umi jederzeit gehörig überwachen können, in rlenen es auch weder an Dbsatz noch an Arbeitskräften fehlt. Die ökonomischen Verhältnisse eines Gebietes sind meist bestimmend für die Technik des Durchforstungsbetriebes. Wieses Moment hetont $\mathrm{L}$ a $\mathrm{s} e \mathrm{~h} \mathrm{k}$ e in seiner Schrift ,Oekonomik des Durchforstungsbetriebes" 1901. Die verschiedenen Durchfor'stungen sind, je nach den wirtschaftlichen Zuständen der in Betracht kommenden Gegenden, berechtigt. Je weniger der llarkit schwache Sortimente verlangt. sondern auf stalkes Schnittholz gerichtot ist, um so st ärkere Eingriffe sinch nach der Jugendperiode angezeigt, während andererseits guter Schleifholz- und Gruhenholzabsatz die Berorzugung schwächerer Durchiforstungen nahelegt.

Die großen Verschiedenheiten, die allein bierdurch, weiterhin durch den Wechsel der Holzarten und Standortsverhältnisse in die Durchforstungspraxis hin-

1) Andererseits liann stärkere Durchlauung des Bestandesrandes Lei solchen Bestanden. welche für Anwendung bines Loshiebes gegen Wintwurf schon zul alt mind, geratlezu angezeigt sein, un die Randstänme rascher erstarken und durch Kronen- und Vurzelausbreitung widerstandsfähiger zu machen.

2) Vergl. u. a. die Verhandlungen des badischen Forstrereins zu Wolfach von 1884.

3) ctr. 2. B. Ga y" er, ,Waldbal" 4. Auft. S. 594 lf.; Ney, ,Waldbau" s. $29 j$. 
eingetragen werden, machen die teilweis sehr auseinander gehenden Durchforstungsansichten und die zahlreichen Reformidern verständlich, die in Laufo der Zeit geäußert worden sind. Einige der markantesten Reformvorschläge seien nachstehend hervorgehoben:

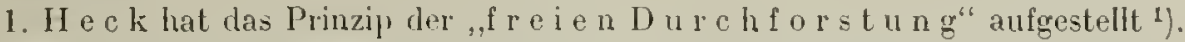
Die Burchforstung soll eine von alten starren Regeh unabhängige, freie sein. Ein teilweises Eingreifen in den IIauptbestand unter Schonung des Nebenbestandes ist nötig, besonders ist die Herausbildıng, Begünstigung und Pflege des voraussichtlichen Haubarlieitsbestandes in möglichst vielen und tunlichst hochwertigen Nutzholzstämmen zu erstreben. Dieser Durchforstungsmethode entspricht ohne Zweifel der E-Grad des neuesten Arheitsplanes der forsthehen Versuchsanstalten. Offeubar gehührt $H$ e c li die Priorität.

2. Die dänische Durch forstung in Buchen. Auf diese hat in Deutschland 11 e $\mathrm{tz}$ g e l aufmerkam gemacht 2 ). Er bemerkt, daß der Unterschied zwischen den deutschen und den dänischen Durchforstungen hauptsächlich darin bestehe, daß erstere $\mathrm{N}$ u t z un g s-, letztere E r z i e h ung s - Durchforstungen seien. In Dänemark unterscheide man die Stammklassen folgendermaßen:

a) $\mathrm{H}$ a u p t s $\mathrm{t}$ a m m e, welche wegen ihrer Geradschaftigkeit und gleichmäßigen Irrone zu begünstigen sind und dereinst den Abtriebsbestand zu bilden haben.

b) S c häd $\mathrm{lich}$ e $\mathrm{N}$ e be $\mathrm{nst}$ ä $\mathrm{mme}$, welche die zu erhaltenden und fortzubildenden Teile der Kironen der Hauptstämme schädigen und deshalb zu entfernen sind.

c) Nützliche $N$ ebenstämme, welche die Astreinheit der Hauptstämme fördern und deshalb zu erhalten sind.

d) I $\mathrm{nd}$ ifferen $\mathrm{t}$ e $\mathrm{S} \mathrm{t}$ ä $\mathrm{mm} \mathrm{e}$, welche weder schaden noch nützen.

Hiemach sind die Kilassen a und e zu schonen, die Kilasse b ist zu beseitigen Klasse $d$ ist zu nutzen, soweit Absatz vorhanden ist.

Die Durchforstungen beginnen frühzeitig und mäßig; sie sollen sich in so viel Jahren wiederholen, als das Bestandesalter Dezennien zähit. Zwisehen dem 60. und 70. Lebensjahr wird alle 6 Jahre, rom 100. bis 110 . Lebensjahr alle I0 Jahre durchforstet. Die späteren, nach Erreichung astfreier Schaftstücken von $15 \mathrm{~m}$ Länge stattfindenden Durchforstungen stellen die $\$ / 10$ der Schaftlänge einnehmenden Fironen der Hauptstämme zum Zwecke der Herbeifülırung eines beträchtlichen Lichtungszuwachses frei und nähern sich den Durchlichtungen. - Ein so intensiver Betricb wie der dänische Buchendurchforstungs- und Verjüngungsbetrieb ist in einem waldarmen Lande wie Dänenark möglich ınd zweckmäßig, anderwärts steht mangelnde Rentabilität seiner Durchführung entgegen.

3. Die Hochdurehforstung (éclaircie par le hant) wurde in Frankreich nach llaßgabe der dortigen Verhältnisse, insbesondere unter dem Vorherschen der Eiche und der Nittelwaldbestände ausgebilitet ${ }^{3}$ ). Ihr Wesen besteht in dem Eingriff in den herrschenden Bestand unter Schonung der heherrschten Stänme. Den Gegensatz dazu bildet die Entfernung der unterdrückten Stämme, welche éclaircie

1) H e ck, „Freie Durchforstung“. Mündentr forstl. Hefte XiII, S. 18. - D e r s., ,Zur freien Durchforstung" (A. F.- u. J.-Z. 1902, S. 298). - D e r s., Die freie Durchforstung 1904.

2) II e l z ger, „Dảnische Reisebilder". Münd. forstl. H. II, S. 81. - D e r s e l b e, „,Zur Beurteilung der dãnischen Forstwirtschaft". A. F.- u. J.-Z. 1898, S. 346. - D e r s e l b e, Referat auf der deutschen Forstversammlung in Schwerin 1899, ,Ist die in Dänemark gebräuchliche Art der Buchenbestandespflege bisher in Deutschland schon zur Anwendung grelangt und unter welchen Umstānden etwa wïrde sich ihre Einfuhrung in deutschen Waldungen bewähren?" (s. Versanmlungsbericht).

3) Empfohten in B o p p e, ,Traité de sylviculture". 
par le bas genannt wird. Aehnlich der éclaircie par le haut ist die P o s t e l e r Durchforstung, durch v. Salisch auf Postel in Schlesien gehandhabt, welche den Kronen der herrschenden Stämme frühzeitig durch Aushieb der zurüclibleibenden und mitherrschenden Stämme Luft schaffen will. Die unterdrückten Stämme bleiben stehen. Das Ziel ist die Heranbildung eines hochwertigen Haubarkeitsbestandes unter Gewinnung tunlichst hoher Vorerträge .bei vollständiger Erhaltung der Bodenkraft 1).

Auch die ästhetische Wirkung dieser Durchforstungsart wird betont, indem die Bestände nicht so leicht „durchsichtig" werden (v. S a lis c h, „Forstästhetik", 3. Aufl. S. 273). Ebenso hat sie Bedeutung zur Gewinnung von Schutz für das IVi]d.

4. Die Kulissendurchforstung empfahl Urieh ${ }^{2}$ ) für Buche als Lichtwuehskulissenhetrieb, d. h. kräftige Lichtungen vom 30 . Jahre ab auf $15-20 \mathrm{~m}$ breiten Kulissen zwischen dunkel belassenen 40-60 m breiten Streifen. Letztere sollen den Boden gegen Aushagerung, Laubverwehung und Vergrasung sicherstellen. Die Lichtwuchskulissen verlaufen senkrecht zur herrschenden Windrichtung. Vom 70. Jahr an sollen die dunklen Zwischenstreifen ebenfalls stark angegriffen werden, so daß mit 90 Jahren der Bestand ziemlich gleichmäßig gestellt ist und zur Verjüngung

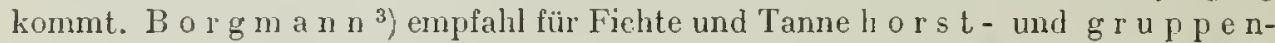
we ise Lichtwuchsd ureh forstung, ebenfalls zur Mehrung von Masse und Wert. Er will die Lichtungshiche seiner etwa 10 a großen Lichtungshorste allmählich ringförmig vorschreiten und an Intensität der Kíronenfreihiebe abuehmen lassen. Seine Lichtungen sollen erst mit 50 Jahren beginnen.

$\mathrm{Reu} \mathrm{B}^{4}$ ) enprahl Kulissendurchforstung, inden in streifenweisem Wechsel starke, mäßige und schwache Durchforstungen ausgeführt werden sollen, um diejenigen Gefahren starker Durchforstungen zu vermeiden, welche zu erwarten sind, wenn der ganze Bestand stark durchforstet wird.

5. Borggreve's Plenterdurchforstung ${ }^{5}$ ). Durch diese wird der früher als Ausnahme betrachtete Aushieb herrschender Stämme vom reiferen Stangenalter, spätestens vom ersten Beginn der Mannbarkeit ab, geradezu als das normale Vorgehen gefordert. Prinzip dabei ist, daß durch den Aushieb dominierender Stämme regelmäßig einer größeren oder geringeren Anzahl beherrschter (immerhin noch entwickelungsfähiger) Stämme Luft gemacht wird, sodaß sie sich clemnächst zu brauchbaren Nutzstämmen herausarbeiten, wälırend sie sonst, d. h. unter dauernder Bedrückung seitens der bisher dominierenden Exemplare lediglich die Rolle des Füllholzes weiter gesfielt und früher oder später ganz abständig geworden wären. Allmählieh wird auf diese Weise eine möglichst große Anzahl der im Bestande überhaupt vorhandenen Stämme einer vollgültigen Entwickelung entgegengeführt, bis bei genügend langer Untriehszeit (140-160 Jahre) und fortdauernder Wiederholung (alle 10 Jahre Aushieb von $0,1 \rightarrow 0,2$ der Bestandesmasse, welche sich durch Zuwachssteigerung entsprechend wieder ergänzt) das brauchbare Material aufgezehrt ist. Inzwischen hat der Bestand das denkbar mögliehe Maximum an guten Nutzholzstämmen geliefert. Die jeweils ausgeforsteten dominierenden Stämme ergehen relativ frühzeitig bedeutende Gelderträge; mithin ist diese Art der Wirtschaft eine in hohem Grade rentable. Bedingung für die Durchführbarkeit ist die Entwickelungsfähigkeit der dureh die Durehforstung freigestellten, bisher Jeherrschten Stämme. Ist diese gesichert, so läbt sich jin übrigen das Verfahren zweifelsohne clurchführen; es fragt sich

1) A. F.- U. J.-Z. 1892, S. 226.

2) Forstwiss. Zbl. 1888, 16; Ztschr. f. F.- u. J.-W. 1894, S. 591.

3) Das. 1893,$689 ; 1895$, S. 630. - W. Borgmann, A. F.- u. J.-Z. 1897, S. $225,273$.

4) Oe. F.Ztg. 1896, S. 73.

5) B org g r ve, "Holzzucht". 2. Aufl. S. 302 ff., sowie Forstl. Blätter von 1887, S. 225 ff. 
dann nur, ob es auch genügend gut bezw. besser rentiert, als jede andere Art der Durchforstung.

Die Möglichkeit der noch leidlich guten Entwickehung eincr Mehrzahl jener Individuen ist zuzugeben, falls die Bedrückung seither keine zu weitgehende war und ihnen entsprechend rechtzeitig beigesprungen wird. Immerhin darf man Bedenken tragen, die Erholungsfähigkeit so weit und so allgemein vorauszusetzen, als Borggreve ${ }^{1}$ ). Aber hicrvon abgesehen darf dic höhere Rentabilität der Plenterdurchforstung bezweifelt werden. Von den herrschenden Stämmen, falls sie allseits genügenden Wachsraum erhalten, ist eine Zuwachsleistung zu emvarten, welche sie befähigt, in k ürzester Zeit den Jarkt mit den geforderten Sortimenten zu befriedigen. Der im 60. Jahre als prädominierend ausgehauene Stamm kann in dieser Hinsicht doch nicht gleiches leisten wie der nämliche Stamm, falls er noch 20 oder 40 Jahre zugewachsen wäre. Der höhere Umtrieb liefert bei der Plenterdurchforstung, da eine Mehrheit stärkster Stämme jeweils herausgehauen wird, doch immer wieder nur Stämme $\mathrm{m}$ it t le rer Dimensionen. Wenn aber solche für die Befriedigung des Marktes genügen, so ist gar nicht abzusehen, weshalb man diese Stämne nicht auf größeren Einzelflächen mit niedrigerem Umtrieb erziehen soll, wobei auch noch alle geringeren Sortimente, die doch cbenfalls gute marktfähige WVare darstellen, in genügender llenge anfallen. Die Plenterdurchforstung verzichtet eigentlich grundsätzlich auf die Nutzung der geringeren Stammklassen, da sie deren lndividuen möglichst. alle noch in höhere Klassen aufrücken lassen will. Wäre dies ohne beträchtlichen Zeitaufwand möglich, so könnte nichts dagegen eingewendet werden. Daß die stets dominierend gewesenen Stämme meist ungünstigere Stammformen haben, ist an sich wolıl richtig, wird aber durch die stärkeren Dimensionen vielfach reichlich aufgewogen (entscheidend ist die Zopfstärke bei bestimmter Länge). Ebenso ist der ungünstige Einfluß der Fruktifikation nicht in dem Naße zu fürchten, wie es Borggreve tut. Borggreve hat vorzugsweise schlecht oder gar nicht gepflegte Bestände im Auge, in welchen eine verhältnismäßig kleine Anzahl von Jugend auf entschieden vorwüchsiger Individuen Luft- und Bodenraum im Bestande in übermäBiger Weise in Anspruch genommen hat, so daß unter und neben ihnen keine auch nur annähernd gleichwertige Stämme vorhanden sind. Solche Bestände bilden freilich nie das Ideal der Wirtschaft. In normal bestockten und ebenso durchforsteten Beständen findet sich eine so weit gehende Abformigkeit der herrschenden Stämme, wie die Plenterdurchforstung annimmt, nicht. Weiterhin darf an der Plenterdurchforstung die Möglichkeit der Nachhaltigkeit ebenso stark bezweifelt, wie der Eintritt von Bodenverhagerung und Verunkrautung, von Sturnschaden (bei flachwurzelnden Holzarten) und ron Wasserreiserbildung (bei Eiche) als sicher angenommen werden.

Was die ,Plenterdurchforstung" Neues darstellt, ist - dies muB scharf betont werden - nur der als $R$ eg el hingestellte Grundsatz, auch gesunde, normal gebildete, vollkommen nutzholztaugliche do $\mathrm{m}$ in i e r en d e Stämme vor der Hiebsreife des Gesamtbestandes, also gelegentlich der Zwischennutzungen lediglich deshalb herauszuhauen, weil dadurch einigen bisher unterdrūchten Individuen die 110 ghtichkeit gewăhrt wird, auch noch wenigstens Mittelware zu merden, während sic soust als nur gering zuwachsende Stämme einem einzelnen, allerdings besonders hochwertigen Stamme zugesellt blieben, bis sie bei einer Durchforstung als minderwertiges Material gehauen werden. Die ganze Frage ist cinfach eine solche der statischen Rechnung. Und gerade die hỏhere Rentabilität der Plenterdurchforstung ist, ohne die

1) Es ist hier natürlich nicht der Ort, ins einzelne auf eine Diskussion der hochinteressanten Frage einzugehen. Nur die Notiz sei angefugt, daß auch die Wirtschaft bei der Weißtanne im Schwarzwald und in den Vogesen, also bei der wohl unzweifelhaft zählebigsten Schattenholzart, zwischen den noch entwicklungsfäligen unterdrückten Tannen und denen, von welchen wegen zu starker und zu lang andauernder seitheriger Bedrăngung eine Erholung und Erstarkung nicht mehr zu hoffen ist, sorgfāltigst unterscheidet. 
Anwendbarkeit der letzleren in einzelnen Fällen zu bestreiten, allgemein zunäclıst nicht zuzugeben. Insoweit die Plenterdurchforstung solche dominjerende Stäme nutzt, welche aus irgend einem Grunde (Holzart, Stammform, Fronenentwickelung usw.) nicht Träger der Nutzholzerzeugung im Bestande sind, fordert sie nichts anderes, als das, was hei jeder richtigen Durchforstung schon längst Regel war.

Die Plenterdurchforstung ist in größerem Haßstab in dem hessischen Hinterland des Reg.-Bez. Wiesbarlen eingeführt. Eine bei Gelegenheit der Tagung des Deutschen Forstvereins in Wiesbaden 1900 unter Leitung Borggreves dahin unternommene Exkursion lat eine Erörterung in der Literatur liervorgerufen, deren Ergebnis nicht als durchgehende Anerkennung der Richtigkeit des Prinzips anzusehen ist (Bericht über die 1. Hauptversammlung des Deutschen Forstvereins S. 200 ff., ferner Fw. Zbl. 1900, S. 589 F ü r t, „Eine Exkursion ins Gebiet der Plenterdurchforstung": I90I, S. 118, Berichtigung von B orggreve und Entgegnung von Fürst, ferner B o r g g r e ve in Ztschr. f. F.- u. J.-IV. 190I, S. 385). Es ist abschließend zu bemerken, daß die Borggrevesche Plenterdurchforstung keine Z w is c h e n lutzung, sondern H a u p t nutzung darstellt. Sie hat in ungleichwüclısigen Beständen, z. B. in Buchenbeständen, die aus fortgewachsenem Nittelwald oder Femehwald hervorgegangen sind, ebenso in ungleichalterigen Weißtamenbeständen, ohne Zweifel ilıre volle Berechtigung, und es ist ein Verdienst Borggreves, auf die Notwendiglieit bezw. Zweckmäßigkeit einer Beseitigung der sog. „Protzen“" aufmerksam gemacht zu lıaben. Eine Verallgemeinerung des Prinzips und die Anwendung desselben aul gleichmäBig erwachsene Bestände ist $\mathrm{zu}$ beanstanden.

\$ 80. IV. Durch führung im Wa l de.

a) $\mathrm{V}$ e r a n s c lı l a g u n g. Für die planmäßige Durchfülırung eines systematischen Durchforstungsletriebes ist die Veranschlagung nach der F lä c h e ein wichtiges Erfordernis, derart, daß der Wirtschafter gebunden ist, jälırlich eiue gewisse Fläche gründlich vorzunehmen, so daß die Wiederkelur in einer, im voraus zu bestimmenden angemessenen Umlaufszeit gesichert ist. Dazu hat die Forsteinrichtung die nötigen Bestimmungen zu treffen.

b) $\mathrm{Hol}$ z a u s z e i c h n u $\mathrm{ng}$. Sorgfältige Leitung des Durclıforstungsbetriebs ist eine der wichtigsten Obliegenheiten des Wirtschaftsbeamter. Ist letzterer auch in einem größeren Reviere nicht imstande, jedes einzelne auszuforstende Exemplar in Jungwüchsen selbst zu bezeichnen. so muß er sich doch durch entsprechend unfängliche Probeauszeichnung überzeugt haben, daß seine Absichten von dem untergebenen Personal nach allen Seiten hin vollständig verstanden sind. Auch lıat er sich durch häufig wiederholten Besuch der Durchforstungen von dem sachgenı̈lien Vollzug seiner Anordnungen zu überzeugen. Zweifelsfälle sind seiner Entscheiduug vorzubehalten. Daß sich die Ausführung in Brennholzbeständen meist sehr viel einfacher gestaltet, als in einer Nutzholzwirtschaft, im reinen Bestande einfacher als in gemischten, liegt aul der Hand. Im frühesten Alter des Bestandes genügt auch eine Probedurchforstung unter den Augen des Virtschafters. Bei geringeren Stangen erfolgt Auszeichnung mit dem Risser, bei stärkeren und bei Stämmen mit dem WValdhammer. Die sprezielle Auszeichnumg der späteren Durchforstungen darf, wenn diese wirklich alles Wünschenswerte leisten sollen, dem Wirtschaftsührer nicht erspart blesben. Die richtige Schlagstellung ist sofort, d. h. rurch eimmalige Auszeichnung anzustreben. Laubholz ist womöglich r o r Laubabfall auszuzeichnen ${ }^{\mathrm{I}}$ ).

1) Die Regel, den Hieb erst schwach zu greifen, und dann eine Naehauszeichnung vorzunehmen, führt koineswegs immer zu dem gewüschten Ziel einer gleichmäßigen Durchlichtung des Beslandes. Ist eine solche bei dem ersten Auslieb erreicht, so werden durch die Nachfällung vielfach Ungleichförnigkeiten entstehen, zumal man mit dem Nachhieh in der Regel in starkere Stanmklassen komml. - In noch belaubten Bestande bietet dichter lironensehluß manchmal 
c) H i e h s fü hr u 1 g: In jüngeren Beständen kommen als Werkzeuge event. besondere Durchforstungsmesser, ferner die Durchforstungsschere und die Heppe in Betracht: demnächst haben Axt und Säge einzutreten. Durchforstungen in Jungwïchsen, wo nicht jedes Exemplar besonders ausgezeiclnet ist, werden meist besser im Tagelohn ausgeführt. Wie Zeit der Vornalıne ist in der Regel von der Ausführung der Hauptfällungen ahhängig, inlem die Durchforstungen mit diesen in passender Weise kombiniert werden müssen. Meistens führt man die Durchforstungen nach Beendigung der Haupthamungen aus. Sie geben öfters neben den Alisläuterungen eine prassende Sonmerarbeit für stïndige Holzhauer.

\section{Viertes liapitel.}

\section{Unterbau und Lichtungsbetrieb.}

$\S 81$. Vorbem erkungen: Unter Unterbau verstelit man das Einbringen eines Unterholzes in einen vorhandenen Bestand, unter Lichtungshetricb einen so liäftigen Eingriff in einen Bestand, daß die einzelnen Bäume in eine räumigere Stellung gelangen, als sie durch den natürlichen Auslichtungsprozeß und die regelnäßigen Durehforstungen kommen würden. Beide, Unterbau und Lielitungsbetrieb, bezwecken eine Steigerung des Zuwachses, der erstere hauptsächlich durch Erhaltung bezw. Verbesserung der Bodenliraft, der letztere durch Gewährung eines vergrößerten Wachsraumes für Wurzeln und lírone. In Vergleich zum nicht unterbauten geschlossenen Hochwaldbestande, welcher in bestimmter Zeit Stämme von gewissen mittleren Dimensionen erzeugt, soll durch die Lichtung entweder in der gleichen Zeit stärkeres und damit wertvolleres Holz oder es soll gleich starkes (gleichwertiges) Holz in kürzerer Zeit erzielt werden. In beiden Fällen hat man einen wirtschaftlichen Gewinn, so lange nicht die Zuwachsmehrung mit einem zu hohem liostenaufwand verbunden ist. Unterbau und Lichtungsbetricb sind an sich verschiedene Maßregeln, gehen aber insofern Hand in Hand, als eine gewisse Bestandeslichtung Bedingung für gedeihlichen Unterbau ist und umgekelırt ein über das Naß einer kiäftigen Durchforstung hinausgehender stärkerer Aushieb in Bestande öfters den Unterbau als Ergänzung fordert, wenn nicht eine Bodenverschlechterung eintreten soll.

I. Un terbau insbesondere ${ }^{1}$ ).

A. Allgeneine Gesichtspunkte.

\$ S2. Der Lnterbau ist in erster Linie eine Maßregel der Bodenpflege. Man unterseheidet den zu unterbauenden Bestand und die einzubringende Holzart. Es ist Tatsache, daß sich in allen anfänglich geschlossenen Beständen frülıer (bei Lichthölzern) oder später (bei Schattenhölzern) von selbst eine Auslichtung vollzieht, indem allıälılich eine immer größere Anzahl von Stämmen infolge der Bedrängung durch

Schwierigkeiten bei der Beurteilung des Werts einzelner Stämme. Immerhin aber dürfen diese we. niger hoch veranschlagt werden, als die nach Laubabfall häufig eintretenden Zweifel bezüglich der relativen Bedeutung von Nachbarslämmen. Es liommt hinzu, daß der Nachsommer meist die ,arbeits fre $\mathrm{i}$ " Zeil des Revierverwalters ist, so daß er dann das Geschält des Auszeichnens olne Kollision mit andern Arbeiten vornehmen kann.

1) $\mathrm{Zu}$ vergleichen $u$. a.: Arbeitsplan betr. Versuche über Lnterbau- und Lichlungsbetrieb in Hochwald, aufgestellt von den Verein deutscher forstlicher Versuchsanstalten (siehe Jahrbuch der preuß. Forst- u. Jagdgesetzgelung und Verwaltung Xil. Bd., 1. Heft, S. 12). - U r i $\mathrm{C}$, "Unterbau von Lichtholzarten" (Forstw. Zentralbl. 1884, S. 472). - B orggreve, ,Lich-

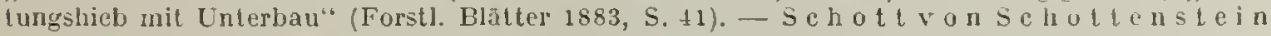
in d. Forsll. Blältern Mai 1883, S. $145 \mathrm{ff}$. : eine Enlgegnung auf den vorzitierten Artikel B o r ggreves. - L a n o $1 \mathrm{t}$, schweiz. Zeitschrift 1883, S. 172. - I a st, Der Unlerbau und seine wirtschaftliche Bedeutung (Z. f. d. g. F. 1889, S. 51. 102. 150). - B i e h ] e r, Finfluf dec [nterbaues auf das Wachstum der Bäunie. 1903. 
die Nachbarn oder aus anderen Gründen abständig wird. Die liermit gegebene Unterbrechung des Kironenschlusses gewährt der Sonne und dem Wind Zutritt zum Boden, welchem dadurch seine Feuchtigkeit entzogen, dann aber auch durch beschleunigte Zersetzung der Streudecke geschadet wird. Die Humusbildung erfolgt nicht mehr im bisherigen Verlauf. Die Ueberkleidung des Bodens mit spontan auftretenden Standortsgewächsen bietet meist kein genügendes Gegenmittel, sondern beschleunigt oft die Aushagerung des Bodens, weil viele jener Gewächse (meist Lichtpflanzen) dem Boden Wasser entziehen, ohne durch intensive Beschirmung und ausgiebigen Laubabfall, also durch Vermittelung reichlicher Humusbildung für Erhaltung, bezw. Vermehrung der Bodentätigkeit zu sorgen.

Die Fälle, in welchen sich blattreiche, dichtgeschlossene Forstunkräuter so massenhaft einstellen, daß sie Funklionen des kūnsllich eingebrachtell Unterholzes übernehmen könnten, bilden nicht die Regel, zumal nicht auf mittleren Standorten, für welche der Unterbau sehr håufig in Betrachl kommt. Beste Böden (z. B. Aumaldungen) bedürfen des Unterbaues oft nicht, weil sich Unlerholz hier meist von selbst einslellt.

In ähnlicher Weise, wie durch die natürliche Auslichtung, wird die Unterbrechung des Kilonenschlusses durch Beschädigungen, welche von außen an den Bestand herantreten (Insekten, Sturm, Schnee), sowie durch wirtschaftliche Eingriffe herbeigeführt. Wird nun ein solcher Bestand unterbaut, so will man durch diese Maßregel die Leistungsfähigkeit des Bodens erhalten, wenn möglich sogar steigern oder, wäre sie schon gesunken, den früheren Zustand wieder herstellen, von der Ueberzeugung ausgehend, daß nur eine dauernd vollständige Bedeckung der Bodenoberfläche hierzu geeignet ist.

Ob der erwartete Erfolg wirktich eintritt, muß demnächst die Beschaffenheit des unterbauten Beslandes dartun. Der überzeugende Beweis kann nur durch den komparaliven Versuch erbracht werden, indem man von zwei im übrigen ganz gleichen Beständen (bezw. Bestandes. teilen) den einen unterbaut, den anderen ohne Unterbau weiter behandelt, so daß die Verschiedenheit des schließlichen Holzanfalls als eine Folge des ausgeführten oder unterlassenen Unterbaues angesehen werden hann. Von vielen Seiten werden günstige Erfolge des Unterbaues gemeldet; aber es darf nicht übersehen werden, daB hāufig der zu vergleichende nicht unterbaute Bestand fehlt. Nach den Untersuchungen von $\mathrm{K}$ a $\mathrm{s} t$ ist eine direlite Steigerung des Zuwachses als Folge des Unterbaus nicht nachzuweisen, jedoch eine Mehrung der Sommerholzbildung und eine günstige Wirkung auf den Boden. Auch die von B i e h 1 e r näher untersuehten unterbauten Eichenflichen der hessischen und braunschweigiseben forstlichen Versuchsanstalt zeigten nicht in allen Fällen einen positiven. Einfluß des Unterbaus auf das Wachstum des Oberholzes. Der Buchenunterbau zeigte sich hier namentlich auf den schlechten Böden wertwoll und un so wirksamer für den Obersland, je jünger dieser war. Gruppen-und horstweiser Unterbau ist weniger an Platze als volter. Wenn geltend gemaeht wird ${ }^{\mathbf{1}}$ ), durch den Unterbau schaffe man für den Oberstand eine am Nährstoffkapital des Bodens mitzehrende gefährliche Fionkurrenz, so ist dies nur insoweit zuzugeben, als Teile des Unterwuchses als Treibholz mit in die Höhe gehen und zur Nutzung herangezogen werten. Dies ist aber in erheblicherem Umfang meist nur dann der Fall, wenn der Oberstand bereits so stark durchlichlet ist, daß dureh ihn allein keine vollständige Auswirkung der Bodenkräfte mehr stattfindet. Aber selbst wenn eine etwas gesteigerte Mineralstoffentnahme einlräte, dürfte sie durch den gūnstigen Einfluß des Unterbaues auf die physikalischen Bodeneigenschaften reichlich paralysiert werden. Dagegen kann allerdings der sehr dichte Unterwuchs einen Wasserentzug in Boden herbeiführen, welcher für den Oberbestand nachteilig wird. Eine derartige bodenaustrocknende und dadureh den Zuwachs mindernde Wirkung des Fichtenunterwuchses unter Fiefern ist durch Untersuchungen von Geh. Oberforstrat $\mathrm{Z}$ e $\mathrm{tz} \mathrm{s} \mathrm{ch}$ e in Meiningen nachgewiesen worden ${ }^{2}$ ). $\mathrm{Zu}$ dem gleichen Ergebnis führten die Lntersuchungen $\mathrm{B}$ i e l $1 \mathrm{e} r \mathrm{r}$ (a. a. O.) üter den EinfluB des Fichtenunterbates in liiefer. Bekannt ist die meist ungünstige Einwirkung eines Fichtenunterstandes in Eichenbeständen. Der Meinung, daB die Fiehte der "Wolf" des Laublolzes ist wie Burckhardt sagt, stimmen die Ermitllungen Bieller's, der in den mit Fichte unterbauten und teilweis zopfdürr wejdenden Eichenbeständen ein Sinken des Zuwachses 1 m 3 bis 4 Zehntel beobachlete,

1) B o g g g v e, Holzzucht, 2. Aufl. $347 \mathrm{ftgdr}$.

2) A. F.- U. J.-Z. 1890 S. $269,305.5$ e $11 \mathrm{~m} \mathrm{i} \mathrm{d} \mathrm{t,} \mathrm{Bodenschutzholz} \mathrm{und} \mathrm{Unkrautdecke} \mathrm{in}$ itıren Beziehungen zu Bodenfeuchtigkeit und Bestandeszuwachs. 
ebenso zu wie die Feststethung ir u $\mathrm{n} \mathrm{z} \mathrm{e}{ }^{1}$ ), daB in einem ru. 60 jähr. Eichenbestande dureh Entnahme des Fichtenunterstandes eine auf $0,45 \%$ sich belaufende steigerung des Flächenzuwachsprozentes herieigefürt wurde.

B. B e dingende $\|$ o m e n te.

$\S 83$. Beim Unterbau lommt in Betraclit: die zu unterbauende Holzart, die einzubringende Holzart, die spezielle Aufgahe des Unterwuchses, der Borlen, die Zeit des Unterbaues, die Art der Ausfülırung.

1. Die zu unterbauend e $\mathrm{H}$ ol zart: Im allgemeinen werden uur solche Holzarten unterbaut, welche für sich allein dem Boden nicht dauernd die nötige Beschirmung gewährer, also vorab Lichthölzer. Namentlich ist Unterbau dort unerläßlich, wo man Starkhölzer erziehen will und hierzu Lmtriebszeiten benötigt, die jenseits des Zeitpunktes der beginnenden, energischen, natürlichen Bestandesauslichtung liegen ${ }^{2}$ ). Der Unterbau findet seine Stelle hiernach zumeist in Beständen der Eiche, lǐiefer und Lärche.

2. Die einzubringende $\mathrm{Holzart}$ : Sie muß, der Natur der Sache nach, eine schattenertragende sein, damit sie unter dem Drucke der Oberholzkronen wuchskräftig bleibt, um die erwarteten günstigen Wirkungen auf den Boden zu gewährleisten. Somit kommen zunächst in Betracht Buche, Tanne und IIainbuche, sodann Fichte, Weymouthskiefer, Linde, Weißerle, event. auch (für besonders nasse Böden) Schwarzerle.

Entscheidend für die Wahl der einzubringenden Holzart ist rorab der Standort, daneben aber der Zweck des Unterbaues. Die $\mathrm{B} u \mathrm{ch}$ e ist diejenige Holzart, welehe, sofern der reine Schutzzweck in Betracht komnt, zunächst in Wahl steht, da sie durch ilıren Laubabfall am günstigsten auf den Boden wirkt. Sie taugt aber nicht in kalte, nasse Lagen. Hier wird sie meist sehr zweckmăßig durch die $\mathrm{H}$ a in b u e h e ersetzt. Guten Eifolg verspricht auch die L in d e (selbst auf minderkräftigem Boden), doch wird man sie meist nicht eigens anbauen, wohl aber ihr, wo sie vorhanden ist, den Platz gönnen. R o t e r l e kann nur ausnahmsweise auf nassen Stellen angewendet werden, wogegen $\mathrm{W}$ e i 13 e $\mathrm{r} l$ e auf trockenem Standorte, $z$. B. auf lialkböden in Betracht kommt. Alle diese Laubhölzer liefern, auch bei tichterer Stellung des Oberstandes, vorwiegend nur Brennholz. Sobald von dem Unterstand auch Nutzholzproduktion verlangt wird, muß man zur Tanne oder Fichte greifen. Vornehmlich eignet sich $T$ a n n e. Sie ist nicht nur sehr zählebig unter stärkerem Schirnidruck, sowie demnächst raschwüchsig, sobald sie freigestellt wird, sondern bleiht auch mit ihrer Wurzel nicht in der Bodenoberfläche, diese verfilzend, und versehließt, trotz reichlicher Benadelung, den Boden nicht zu sehr. Bei der $F$ i e h $t$ e liegt inmer die Gefahr eines zu intensiven Abschhsses des Bodens von Luft und Niederschlägen (durch Wurzelgeflecht und Frone) vor. Jedenfalls sollte die Fichte nicht $\mathrm{zu}$ engstāndig eingebracht werden. Ueberdies ist zu beachten, daß Nadelhölzer, wie Tanne und Fichte, in den ersten Jahren nach dem Einbringen dem Boden nichts zurückgeben, da sie ihre Nadeln während einer Reihe von Jahren behalten. Eine unter passenden Verhältnissen sehr brauchbare Unterholzart scheint nach den vorliegenden, alterdings nur spärlichen Erfahrungen ${ }^{3}$ ) die We y mouthskiefer zu sein. Schattenertrãgnis und Anspruchlosiglieit weisen auf V'ermendungsfähigkeit auf den ārmeren Bodenklassen hin, um so mehr ihr Nadelabfall in bezug auf Bodenverbesserung Zufriedenstellendes leistet.

3. Die spezielle A uf gabe des Unterstandes: Der Unterbau soll entweder nur den Boden bedecken (reines Bodenschutzholz) oder soll neben dem Oberstand noch eine mehr oder minder beträchtliche Nutzung ergeben. Sobald der Unterstand mit heranwächst, kommt ihm meist auch für die Formausbildung, namentlich für die Astreinlıeit und Langschäftigkeit des Oberholzes eine mehr oder minder große Bedeutung zu. Handelt es sich lediglich um Bodenschutzholz, so genügt eine

1) K u $\mathrm{nze}$, Leber die Einwirkung eines Fichten-Unterstandes auf einen Eichen-Oberstand. Thar. Jhrb. 1905, 67.

2) Fûr ausnahmsweise, z. B. im kleinen Privatbesitz vorkommende Unmtriebszeiten von 50 bis 60 Jahren, bei welehen nur Brennholz und geringe Nutzhölzer erzeugt werden sollen, kamn der Unterbau wohl meist entbehrt werden.

3) We d ding, Der Unterbau der Eiche mit Weymouthskiefer. Allg. F.- u. J.-Z. 1901, 153. - Biehler a. a. O. 
Unterbrechung des Kronenschlusses im Oberstand so weit, daß die cingebaute Holzart sich gerade lebenskräftig in Schluß erhalten liann, ohne aber zu irgend lebhafterer Entwickelung angercgt zu sein. In zweiten Falle muß man ihr durch weitergehende Eingriffe in den Oberstand lebhafteres Wachstum gestatten. Es ergeben sich dann, je nach den verschieden woitgehenden Ansprürhen, die man an beide Bestandesteile (Oberstand und Unterwuchs) macht, zahlreiche Modifikationen in der Durchfülırung, die sich, wenn auch nicht schon alle als eigentlichc Lichtungsbetriebe, so doch als Lebergänge zu diesem cliarakterisieren lassen.

4. D c r B o d c n, oder allgemeiner der Standort überhaupt, wirkt einmal auf die Beschaffenhcit des zu unterbauenden Bestandes, sodann auf das Gedeihen der Unterbaulılzart. Da siclı auf besseren Standorten die natürliche Ausschcidung am greifbarsten vollzieht, hier auch Verunkrautung, schelle Humusaufzelırung und Rückgang der Bodenkraft am meisten zu fürchten sind und - was die Hauptsache ist — da auf solchen Böden der Unterbau auch wirklich wächst, so kommen solche Orte für den Unterbau zunächst in Betracht. Wie weit man mit Unterbau auch auf geringem Standorte vorgehen soll, läßt sich nicht allgemein angeben, sondcrn nuß erst durch direkten Versuch festgestellt werden. Die Erfahrung lehrt aber, daß der Erfolg der Maßregel auf schlechten Böden fast stets ein zweifelhafter ist. Sicherheit des Gedeihens der eingebrachten Holzarten und damit auch $\mathbf{W}$ ahrscheinlichkeit einer günstigen Einwirkung auf Boden und Oberholzbestand sind lier bei gleichem, ja vielfach bedentendem liostenaufwand sehr gering.

5. Die Z e it des Unterba u s: Nach der Art der für den Unterbau gestellten Aufgaben ist der richtige Zcit\}unkt für seine Vornahme von der Bescliaffenheit des zu unterbauenden Bestandes abhängig. Frülızeitiger Unterbau gewährt dem Boden am meisten Schutz; doch muß die Entwickelung der eingebrachten Holzart durch entsprechende (natürliche oder künstliche) Lockerung des Kronenschlusses in. Oberstand sicher gestcllt scin. Dic Ausbildung guter Stammformen verlangt aber zunäclıst Erhaltung des Vollschlusses. Dabei ist die verschiedene Wirliung cines hölıeren oder tieferen Kroncnansatzes zu beachten. In einem schon etwas älteren, bezw. höheren Bestande kann das Schirmdach in sich ein etwas dichteres sein. Man wird im algemeinen kaum vor dem 30. Jahre unterbauen, andererseits aber meist auch nicht länger als his zun 60. oder 70. Jalıe mit der Einbringung des Unterholzes warten dürfen, wenn nicht inzwischen schon eine nachteilige Veränderung der Bodenbeschaffenlicit hervortreten soll. Nitbestimmend ist natürlich auch das Abtriebsalter des Oberstandes. Der Unterbau kann sich nur dann empfehlen, wenn das Unterholz noch genügend Zeit hat, anf den Boden zu wirlien. Unter dieser Voraussetzung können auch noch ältere ałs 70 jälırigc Bestände oft mit Vorteil unterbaut werden (z. B. 80-

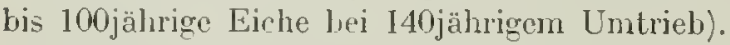

6. A u s f ühru ng: Allgemein, ganz besonders aher da, wo von dem Lnterholz keine Nutzung erwartet wird, ist anf möglichste Reduktion der Kosten des Verfahrens zu achten. Je nachdem das Kulturmateriał verfügbar ist, wählt man Saat oder Pflanzung. Als Saatmethode findet man breitwürfiges Einbringen ebenso wie Riefen- und Plätzesaat in Anwendung. Hastjałure der Buche und Tanne sind möglichst auszunutzen. Wird Pflanzung vorgezogen, so bedient man sich eines cinfachen Verfahrens mit geringen Pflänzlingen (zweijährige Buchen und Hainbuchen, 2-3jährige und äitere Tannen). Die Anzucht del' Pflanzen erfolgt zweckmäßig auf Wandersaatbeeten unter Sclutzbestand ${ }^{1}$ ). Der zu unterhauende Bestand ist vorher, falls die

1) In der Großh. hess. Oberförsterei Viernheim werden z. B. massenhaft Buchenpllanzen in lichten Kiefernbeständen auf oberflächlich vorbereiteten Beeten erzogen. — Der Unterbau 
natürliche Auslichtnng einer Ergänzung bedarf, zu durchforsten, wobei namentlich die zu Nutzholz nicht tauglichen Stämme (Zwieselbildungen, Drelwuchs ete.) herauszumehmen sind. Die Schirmstellung ist in der Regel so zn wählen, daß nicht gleich in den ersten Jalıren nach dem Einbringen des Unterlıolzes eine Nachlichtung nötig wird. Jedenfalls aber ist in allen Fällen mindestens derjenige Grad der Durchlichtung herzustellen, wie er ciner entschieden starken Durchforstung entspricht.

c. Besondere Fälle des Unterbaues.

s4. 1. Unterbau der E i lı e: Als Unterbaulolzart empfiehlt sich zunächst ein Laubholz, in erster Linie die Buche. Namentlich wenn jüngere (40-bis $50 j a ̈ h r i g e) ~ E i c h e n b e s t a ̈ n d e ~ u n t e r b a u t$ werden sollen, ist das Einbringen von Nadelholz - abgesehen von den schon angedeuteten besonderen Bedenken gegen die Fichte - deshalb gefährlich, weil das Nadelholz, sobald es durch weiter vorschreitende Lichtung im Oberstande zu kräftiger Entwickelung angeregt wird, oft zu rasch in die Krone der Eichen nachdrängt und letztere, auch ohne daß vollständiges Ueberwachsen stattfände, durch seitliches Beengen schädigt. Behufs möglichster Vermeidung der Wasserreiserbildung ist beim Unterbau in Eichenbeständen stets vorsichtige, langsan gesteigerte Auslichtung des Oberholzes geboten. Zu dem Ende darf man auch mit dem Aushieb der nutzholzuntaughichen Eichen nicht auf einmal zu radikal vorgehen. 2. Unterbau der $\mathrm{K}$ i efer: Die vorangedeuteten Gründe gegen Fichte und Tanue treten hier zurück. Unterbau mit Buclıe oder Tanne ist besonders empfehlenswert, sofern der Standort kein Hindernis bietet. Die Entwickelung der mit Nadellıolz unterbauten Bestände gestaltet sich oft so, daß man vom waldbaulichen Standpunlite aus bei der weiteren Behandlung sowohl die Kiefer als die Tanne oder Fichte begünstigen und die Entscheidung gänzlich dem lolialen Wertsverhältnis del beteiligten Holzarten überlassen kann. - Vergl. auch Danckelmann , Kiefern-Unterbaubetrieb“ (Zeitschr. f. F.- u. J. 1881, S. 1), desgleichen W e i $\mathrm{k}$ a u f f, Ueber den Unterbau der Iỉefern mit Buchen im Pfälzer Wald (Fw. Zbl. 1896, S. 442). Auch Weymoutlıskiefer kann als Füllholz zur Erziehung von Kiefernstarkholz anf Buntsandstein mit gewählt werden. 3. Un t e r b a u d e r L ä r c h e: Hier kommt zunächst wiederum die Buche als einzubringende Holzart in Frage, doch kann meist ebensogut ein Nadelholz, rorab die Tanne gewählt werden.

11. Lichtungsbetrieb insbesonder e ${ }^{1}$ ).

A. Allgemeine Gesichtspunkte.

$\$$ 85. Die Wirkung des Lichtes ${ }^{2}$ ) ist unter den bei der Entwiclielung der Pflanzen wirksamen Faktoren mit in erster Linie beteiligt. Vermehrter LichtgenuB steigert den Zuwachs, sofern die sonstigen Wachstumsbedingurgen, insbesondere die Feuchtigkeitsverhältnisse und das Nährstoffkapital des Bodens günstig sind. Als direkte Folge des erhöhten Lichteinflusses auf die Baumkrone ist immer ein gesteigerter Zuwachs am einzelnen Baum zu konstatieren, wenn er sich öfters auch nur zunächst im größeren Wachstum der Kírone und der Wurzeln ausdrückt ${ }^{3}$ ). Diese Zuwachsvermehrung mil stārkeren Pflanzen kann nur in sehr verlichtelen Bestānden zur Bewältigung des Unkrauls in Frage kommen, ist aber wegen der hohen liosten hedenklich. - Bereits vorhandene Bodensträucher können je nach ihrer Art (Rhamnus, Viburnum, Lonicera elc.) unter Umstanden belassen bezw. in den Unterbau einbezogen werden (nötigenfalls nach vorherigem Aufdenstoclisetzen), immer jedoch so, daB die einzubringende Schattenholzart nicht notleidel, sondern herrschend wird.

1) Vergl. B u r $\mathrm{ck}$ h a $\mathrm{rd}$, ,Lichtungsbetrieb der Buche und Eiche" in Aus dem Walde VIII, S. $88 \mathrm{ff}$.

2) Vergl. Cicsla r, Einiges über die Rolle des Lichtes im Walde. Mitlgn. a. d. forstl. Versucliswesen Oesterreichs. 30. 11ft. 1904. - W i e s n e r, Der Lichtgenuß der Pflanzen, $190 \%$. - B e ck, Das Licht als Produlitionsfaktor in der Forstwirtschaft. Thar. Jhrb. 1912, S. 4.

3) Gra B ma n n, ,Beitrag zur Lehre vom Lichtungszuwachs etc. “ (A. F.- u.J.-7. 1900, S. 45.) 
findet aber ihre Grenze. Sie geht beim Einzelbaume und entsprechend auch beim Bestande nicht über ein bestimmtes Maß hinaus, weil die überhaupt möghiche Arbeitsleistung des Baumes eine beschränkte ist, bedingt durch die größte Zahl dabei tätiger Organe (Wurzeln, Blätter), die er überhaupt auszubilden vermag, bezw. bis zu einem bestimmten Zeitpunkte ausgebildet hat. Der einzehne Baum kann nicht mehr als einen beschränkten Standraum ausnutzen. Das mögliche Maximum der Leistung des Einzelbaumes ist zu kombinieren mit der auf der Flächeneinheit vorhandenen Anzahl der Individuen. Ueberdies ist die durch Freistellung veränderte Zuwachsverteilung am Baume (veränderte Form, verhältnismäßig starke Verdickung des unteren Schaftteiles), sowie die durch Zuwachssteigerung etwa herbeigeführte Aenderung der technischen Eigenschaften (breite, enge Jahresringe etc.) zu beachten. Diese stärkere Zunahme des unteren Schaftteiles ist nach lletzger ${ }^{1}$ ) bedingt durch das gröBere Andrängen des Windes bei Freistand, das ein Tieferıücken des Schwerpunktes erheischt, wie solches durch Verstärkung des Vickenwachstums im unteren Teile des Schaftes erfolgt. Ausschlaggebend für den Wirtschaftserfolg ist schließlich der Preis der insgesamt auf der Flächeneinheit in gegebener Zeit erzielten Produkte.

Der Lichtungsbetrieb schließt sich unmittelbar an die starke Durchforstung an. Die Grenze zwischen beiclen dürfte, wenn eine durchschnittliche Zahl angegeben werden soll, vielleicht bei einer Entnahme von 0,2 der Masse des normal entwickelten Vollbestandes zu finden sein ${ }^{2}$ ). Ein dieses $\mathbf{~ l a B ~ u ̈ b e r s t e i g e n d e r ~ A u s h i e b ~ u n t e r b r i c h t ~}$ den Kronenschiuß in der Regel schon so weit, daß am stehengebliebenen Bestandestei] ein eigentlicher Lichtungszuwachs zur Auswirkung kommt. Ob aber ein solcher immerhin noch geringer Eingriff genügt, un die höchste Leistung herbeizuführen, ist erst durch zahlreiche komparative Versuche noch weiter zu erforschen ${ }^{3}$ ).

Mit den Namen ,Lichtungsbetrieb" wird nicht gerade eine besondere Grundforn forstlicher Betriebssysteme bezeichnet, sondern man meint damit gewöhnlich nur gewisse Formen des schlagweisen Hochwaldes, welche sich als Jodifikationen des nach der Schablone heraufwaclisenden mehr oder minder gleichalterigen SchluBbestandes charakterisieren. Dagegen ist. der durch neuere Untersuchungen wiederholt nachgewiesene bedeutende Lichtungszuwachs im Plenterwald nicht das Produkt eiues besonderen Lichtungsbetriebs, sondern mit dem normal geleiteten Plenterbetrieb durch dessen grundsätzliche Eigentümlichkeitcn jederzeit verknüpft. Ebenso gehört der Lichtungszuwachs an Ueberhältern für den zweiten Umtrieb nicht unter die Rubrik, ,Lichtungsbetrieb".

B. B edingend e 11 o men te.

$\S 86$. Auch hier kommen, analog wie beim Unterbau, eine Peihe einzelner Umstånde in Betracht, nämlich : der zu lichtende Bestand, der besondere Zweck des Lichtungshiebs, die Zeit des Beginnes, das Maß der Liclıtung, die Art und Häufigkeit wiederholter Lichtungen, der mit der Lichtung etwa verbundene Unterbau.

1. Der B estand: Beim Lichtungshetrieb handelt es sich keineswegs nur um die Erzielung hervorragenden Nutzholzes, sondern um Zuwachssteigerung überhaupt, so daß er auch für Brennholzorte oft mit Vorteil eingefüht werden kann. Nur ist in solchen wegen der verhäItnismäBig geringeren Wertsmehrung der Kostenauf-

1) M e tz g e r, ,Studien über den Aufbau der Bäume und Bestände nach statischen Gesetzen $^{6}$ (Münd, forstl. Hefte $V^{r}$ und $V^{\top} I$ ).

2) cfr. den S. 181, Anm. 1 erwălinten Arbeitsplan der Versuchsanstalten, woselbst der geringste Lichtungsgrad auf Aushieb von $20 \%$ der Holzmasse norniert ist; jede geringere Entnahme würde noch als Durchforstung zu bezeichnen sein.

3) B Orgareve ist der Ansicht, daß eine Verminderung der Masse $\mathbf{m m} 0,2$ als Regel genüge, um volłen Lichtungszuwachs zu gewähren. Bei diesem Eingriff sei ein Unterbau keinenfalls nôtig, weil die Kronenlockerung noch eine sehr mäBige sei. Ueberdies will $B$. hauptsächlich den Lichtungszuwachs der späteren Lebensperioden eines Bestandes nutzbar machen, während andere, wie $z$. B. W' a ge $\mathrm{n}$ e $\mathrm{r}$ davon auschehen, daß der Lichtungszumachs rornehmtich bis zum etwa $80 j a ̈ h r i g e n$ Alter Großes leiste. 
wand für künstliche Einbringung eines Unterstandes vorher noch sorglicher zu erwảgen, als bei dem mit hohem Qualitätszuwachsprozent arbeitenden Nutzholzbestande. Bildet sich dagegen Unterwuchs durch vorzeitige, infolge der Lichtung beschleunigte natürliche Besamung, so daß der Boden gedeckt ist, so kann auch für Brennholzwirtschaften (Buche) die stärkere Durchlichtung infolge der Zuwachssteigerung bei gleichzeitiger Abminderung des Materialvorrates von hoher Bedeutung werden. Inmerhin besteht der Hauptzweck des Lichtungsbetriebes in möglichst kurzfristiger Anzucht hochwertigen Nutzholzes, weshalb nelsen der Eiche namentlich wieder unsere Nadelhölzer: Kiefer, Lärche, Tanne (Fichte) in Betracht konmen. Aber nur Bestände auf besten und besseren Standorten lohnen die auf die Dırchführung des Lichtungsbetriebes verwendete Mühe entsprechend.

2. Der besondere Wirtschaftsz we k: Daß lediglich wuchsfähigen Stämmen in Lichtbestand die gewünschte Zuwachssteigerung zugemutet wird, ist selbstverständlich. Wo Nutzholz crzogen wird, sind im allgemeinen alle Stänme von zweifelhafter Nutzholzqualität in solchem Umfange zu entfernen, daß nicht dadurch eine augenblicklich oder für dic Dauer zu weitgelıende Bestandeslichtung herbeigeführt wird. Man kann in der Folge (durch nu mäßige Lichtung) eine Mehrzahl anuähernd gleichgearteter $m$ it tels a $\mathrm{rker}$ Stämme erziehen oder durch stärkeres Freihauen einzelner Individuen eine kleinere Zahl von Stämmen besonders begünstigen. Außerden ist darüber zu entscheiden, ob man vorzugsweise die Mittelklassen fördern oder die Individuen der stärksten Klasse zur Ausbildung hervorragender Dimensionen bringen möchte; ferner, ob man den Zweck durch gleichmäßige oder mehr gruppenweise Verteilung der zu belassenden Stämme erreichen will.

GleichnāBige Verteilung wird beim eigentlichen Lichtungshetrieb immerhin die Regel bilden. Man muß dabei auf den Einzelstamm eingehen. Möglichst viele, allseilig normal entwickelte Individuen sollen im Bestande vorhanden sein, für deren jeden ein bestimmter Anteil an Boden- und Luftraum verfügbar ist. Die Anordnung in Gruppen ist gleichbedeutend mit dem Uebergang zur Fenelschlagform, welche hier nicht beabsıchtigl wird. Ob mehr die stärksten oder mehr die mittelstarken Stämme bei der Schlagstellung zu berüclisichtigen sind, hăngt zunächst von der Verteilung der Gesantstammzahl auf die einzelnen Durchresserstufen, sowie von der räumlichen Verteilung der einzelnen Stärkeklassen im Bestande ab. Daneben entscheidel das Wertsverhältnis der versehiedenen Sorlimente.

3. B e gi n n: Der Arbeitsplan des Vereins deutscher forstlicher Versuchsanstalten setzt als Zeit für Einleitung von Versuchen über Lichtungsbetrieb das Alter der Bestände von 30-70 Jahren fest. Hiermit ist alles ausgedrückt, was als allgemeine Regel ausgesprochen werden kann. Man will frül beginnen, un den Bestande durch einen möglichst langen Zeitraum seiner Gesamtentwicklung die Vorteile der Lichtung zu sichern, doch aber nicht so früh, daB nicht der Bestand vorher, mehr oder minder geschlossen, eine gehörige Hittelhöhe erreicht und sich dabei von überflüssigen Aesten genügend gereinigt hat. Man will und kann keinen be s t im m t e n $\mathrm{Z}$ e it p u $\mathrm{n} \mathrm{t}$ angeben, in welchen die erste Durchlichtung behufs Herbeiführung des gröBten Erfolgs stattzufinden liat, sondern macht alles von der jeweiligen Beschaffenheit des Bestandes abhängig, der doch mindestens schon als angehendes Stangenholz angesprochen werden soll. Nit jener Umgrenzung soll auch nicht erklärt werden, daß jeder später als im 70. Jahre beginnende Lichtungsbetrich wertlos sei; diese Zahl gilt vielmehr lediglich für die besonderen Zwecke der einzuleitenden Versuche. In vielen Fällen wird auch eine später erfolgende Lichtung noch guten Erfolg haben.

Holzart, Bestandesbegrūndung, bisherige Behandlung, Standorl, auch in beschrānktem Maße die Absalzverháltnisse beeinflussen im konkreten Falle dic Entseheidung in ähnlicher Weise, wie dies in $\$ 83$ bezūglich des Unterbaues angedeutet worden isl. Ueberdies kann ja 
über die cinschlägigen Fragen erst in Zukunft durch komparative Versuche endgültige Aufklärung gewonnen werden. In allgemeinen aber dürfte möglichst frülizeitiger Beginn am erfolgreichsten sein.

4. Da s 11 a $\int$ d e r L i ch t u ng: Ein auch nur in den mejsten Fällen absolut bestes $\lambda$ lla der Lichtung kann nicht angegeben werden. Abgesehen davon, daß auch in dieser Pichtung sichere Anhaltspunkte für jede allgemeinere Beurteilung noch fehlen, erfordern vielmehr die besonderen Umstände des einzelnen Falles je eine besondere Begutachtung. Auf mehr als 50 Prozent des Vollhestandes (bezogen auf die Stammgrundfläche) wird man den Aushieb nur selten ausdehnen, $j$ a in den weitaus meisten Fällen nicht an diese Grenze herangehen, wenigstens sicherlich nicht, wenn nur die Entwickelung rles Oberstandes ins Auge gefaßt wird. Anderenfalls erlalten die Einzelstämme schon einen über das Nlaximum ilurer Ausnutzungsfähigkeit hinausgehenden Standraum. Jedenfalls kann ein $20 \%$ der Mlasse des regchmäßig durchforsteten Tollbestandes übersteigender Eingriff kaum ohne gleichzeitigen Unterbau stattfinden. Wohl aber köunen in Einzelfalle Rücksichten auf die Erzichung eines wertvollen Zwischenbestandes, event. auch Fehlen einer genügenden Anzahl Nutzholz versprechender Oberholzstämme einen weitergehenden Eingriff begründen. Doch steht man dann vor ejner waldbaulichen Aufgabe, chic korrekterweise nicht eigentlich mehr als Erzielung möglichst wertvollen Lichtungszuwachses bezeichnet werden kam. Jedenfalls muß man bei der Herstellung stärkerer Lichtungsgrade, mit Rücksicht auf Schaftlodenbildung (Eiche), Sturmgefalır, Duftbruch usw., vorsichtig sein. Die allmähliche Ueberleitung ${ }^{1}$ ) verdient in solchen Fällen vor plötzlichem L'ebergang den Vorzug.

5. Wiederholte Lic lıt ung: So oft der Charakter des erstmals eingeführten, bezw. dauernd beabsichtigten Lichtstandes durch erfolgte Kronenverbreiterung verloren gegangen ist, muß eine Nachlichtung eintreten. Da eine beschleunigte Neubildung in der lírone des gesunden, wuclskiräftigen Baumes die naturgemäße Folge ller Lichtung ist und dadurch der Bestand seinen Lichtungsgrad alsbald zu verringern beginnt, so kann nur durch andauernden Aushieb von Stämmen, bis zu gewissem Grade auch durch Aufastung, ein hestimmter durchschnittlicher Lichtungsgrad erhalten bleiben. In der Praxis ist dies auf größeren Flächen unausführbar. Vielmehr wirl, von ganz besonderen Ausnahmefällen feinerer Bestandespflege abgesehen, in bestimmten (5-10jährigen) Perioden die Durchlichtung wiederholt, in derselben Weise, wie auch bei den Durchforstungen meist nur periodische Wiederkehr des Hiebs in die einzelnen Waldorte möglich ist. Sorgfältige Begutachtung der einzelnen Stämme bei der Auszeichnung ist hierbei dringend anzuraten.

6. Unter b a 1 : Er bildet beim Lichtungsbetrich immer dann die Regel, wenn sich nicht durch natürliche Besamung (Schattenhölzer wie Buche, Tanme, Fichte) oder durch Stocliausschlag (z. B. von Linde, Buche, Hainbuche, Eiche, selbst von Strauchhölzerı) oder durch Vernittelung von Vögeln ein den Boden schützender Unterwuchs einstellt. Bloßes Ueberkleiden des Bodens mit Forstunkräutern etc. wird aus den in $\$ \$ 2$ angegebenen Gründen nicht für genïgend erachtet. Alle für den Unterbau maßgebenden Gesichtspunkte kommen in Betracht.

C. Spezielle Fälle des Lichtungsbetriebes.

$\$ 87$. Die in $\$ 84$ (lesondere Fälle des Unterbaus) gegebenen Direktiven gelten auch hier, sofern es sich um Lichtung in Eichen-, Kiefern- und Lärchenbeständen handelt. Bei den Schattenhölzern Buche, Tanne und Fichte ist ein Lichtungsbetrieb ziemlich gleichbedeutend mit frïlızeitiger Einleitung des' natürlichen Verjüngung

1) Vergl. die sog. "Vorlichtung" Frafts in Burckhardts ,Aus dern Walde" IX. S. 71. 
und langem Verjüngungszeitraum. Ein künstlicher Unterbau fällt bei diesen Holzarten meist weg, vorausgeselzt, daß man einen stärkeren Eingriff in den Bestand erst im Alter der angehenden Nannharkeit (nach Standort, Bestanrlesbehandlung etc. wechsehnd) romimnt. Bei der weiteren Behandlung ergeben sich zahlreiche Nodifikationen, je nachdem, ol, man die crstmals eingetretene Besamung alshald zur Erzichung eines Jungbestandes benutzt und durch allmählichen Nachhiel dem Aufschlag (durch den ganzen Ort gleichuäßig oder unter besonderer Berücksichtigung von Gruppen und Horsten) den für seine Entwickelung nötigen Raum schafft oder ob man einen sich einstellenden Jungwuchs unter dem Druck eines allmählich wieder mehr oder minder dicht sich schlicBenden lironendaches nicht aus der Rolle eines bloßen Bodenschutzholzes herauskommen, ja demnächst vielleicht wierler ganz verschwinden läßt (Buche und Fichte), um erst einem späteren Vastjah die Begründung eiues neuen Bestandes zu übertragen.

Von den zahlreichen, da und dort herausgebildeten, bezw. in der Literatur für bestimmte Verhältnisse empfohlenm, besonders charakterisierten Formen mögen lier nur folgende hervorgehoben werden:

I. Der zweialterge Hochwald Burckhardts $\left.{ }^{2}\right)$ : Eine gelegentlich für die Buche empfohlene Bestandesform. welche darlurch bezcichnet ist, daß im Moment der Hiebsreife des Oberstandes ein Lnterwuchs vom halben Umtriebsalter vorhanden ist, wobei $u=140-160$ Jahre. Ton Unterwuchs bleiben beim Hieb ca. 50 bis 60 Standbäume pro ha stehen, welche bein nächsten Hieb, also nach $70-80$ Jahren den Oberstand bilden. Verjüngung durch natürliche Besamung, selbst unter Benutzung von Stockausschlag, sowie in Notfällen unter künstlicher Beihilfe. Charakteristisch ist del große Standraum der einzelnen Oberbäume und die dadurch bedingte Entwickehng des Unterwuchses zu einem ertragsreichen Zwischenbestand.

2. Der modifizierte Buchenhochwaldbetrieb von r. Seeb a $\left.\mathrm{c} \mathrm{h}^{2}\right)$. Ein durch die Durchforstung gehörig vorbereiteter $70-80 j a ̈ h r i g e r ~ B u c h e n-$ ort wird unter Benutzung eines Mastjahres rerjüngt. Im Oberstand werden so viele Stämme beibehalten (ca. 300 Stämme = etwa 0.4 der Masse), daß deren lironen nach 30-40 Jahren (also im normalen Umtriebsalter von 100-1:0 Jahren) wierter voll geschlossen sind. Der Unterwuchs wird nur als Bodenschutzholz betrachtet, das mit vorschreitender líronenannäherung des Oberstandes mehr und melı zurückgeht. Im normalen Hiebsalter erfolgt dann eine regelrechte natürliche BuchenhochwaldVerjüngung. Inzwischen sind die Stämme unter rem Einflusse der vor 30-10) Jaluren eingetretenen Lichtung zu besonders starken Hölzern erwachsen.

Angewendet zuerst von Oberforstmeister von Secbach (etwa 1835) im hannöverschen Solling, zunächst als Notbehelf bein Mangel genügender Mengen haubaren Holzes. Inzwisehen mehrfach benutzl (z. B. versuchswise in einigen würtlembergisclen Revieren), um olne Erlıöhung der Limtriebszeit stärkere Buchenhölzer zu erziehen.

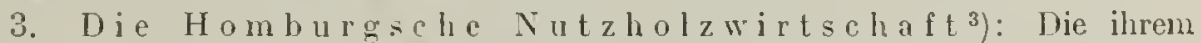
Wesen nach eigentlich als ein l'eberhaltbetrich zu charakterisierende IIrtschaft

1) efr. B u rek ha r d t, ,Säen und Pflanzen", 6. Aufl. S. 139. - B e l in $g$, ,Der Ilangenholzbelrieb" in den Forsll. Blättern von $1874,5.148$.

2) efr. v. Se eb a ch, hirit. Bl. 21. Bd. 1. Heft S. 147 (1845). Kr a f in .,A tus dem Walde" VII, S. 40. B u r c k h r d t, ,. Säen und Pflanzen". 6. Aufl. S. 113.

3) G. Th. H o m b u r g, Die Tulzholzwirtschaft in geregelten Hoehwald-Lelerhaltuetrieb, 18:8, 2. Aufl. 1890. - De rsel b e, ,Ein Beilrag zur Nutzholzwirtschaft im geregellen HochwaldTeberhallsbelrieb" (A. F。- U. J.-Z. Vun 1879, S. 275 ff.). - D e r sel b e, ,Ein weilerer BeiIrag. ." (A. F.- u. J.-Z. 1881, s. 365). - D e rs.., Ein weiterer Beitrag. " (Forstw. Zentralbl. ․ 1891, S. 209$)$. 
darf gleichwohl insofern hier mit aufgeführt werden, als bei ihr durch Freihauen die später den Oberstand bildenden Nutzholzexemplare von Anfang herein auf diese Funktion vorbereitet werden. In der Regel bildet die Buche den Grundbestand. Beigemischt sind ihr, einzeln oder in Horsten, vorzugsweise die Eiche, nach Unständen aber auch Esche, Ulme, Ahorn, sowie Nadelhölzer verschiedenster Art. Durclschnittlich in 70jährigen Alter des Buchengrundbestandes erfolgt dessen natürliche Verjüngung, welche durch $(1 / 5-1 / 4$ des Vollbestandes umfassend) energische, die Plege der demmächstigen Oberständer besonders bcrücksichtigende Vorhiebe bezw. Lichtungshiebe, eingeleitet wird. Gleichzeitig mit rler Verjüngung der Buche werden die übrigen IJolzarten, welche für den nächstfolgenden Umtrieb (neben einer Anzahl von Buchenüberhältern) die Oberbäume werden sollen, durch Saat oder Pflanzung oder durch Vorverjüngung (unter Benutzung der Stocklöcher usw.) und zwar möglichst horstweise eingebracht. Außer der Eiche werden hauptsächlich Tanne, Esche, Ahorn, Uhne, Fichte, Lärche und Weymouthskiefer empfohlen. In welcher Zahl diese vorhanden sein können, hängt, wesentlich auch von den Bedürfnissen des ncu erwachsenden Bestandes ab. Da dieser die Nachhaltigkeit der Wirtschaft vermittelt, darf er selbst in seinen Schattenholzpartien nicht dauernd in starkem Schirmdruck erhalten werden. Die deshalb erforderlichen Nachhiebe bringen zugleich den verbleibenden Oberständern freieren Wachsraum und damit kräftigere Ausbildung.

4. IV a g e n e r's L i chtw uch s b trie b ${ }^{1}$ ): Eigenartig ist der Grad der Lichtstellung und die Zeit des Bcginnes. Wagener geht davon aus, daß eine möglichst frïhzeitige Ausmutzung des Lichtungszuwachses die besten Erfolge zeitigt. Bereits im Alter von 25-10 Jahren werden die künftigen Haubarkeitsstämme ausgesucht und unlichtet.

Der İronenfreihieb wird natürlich nur kräfligen, nutzholztauglichen Stämmen zuerkannt. Unter Vorausselzung der Wiederholung des Freihiebes iı 10 jährigen Perioden würde ein freier Gürtel um die Einzellirone von ca. $60 \mathrm{~cm}$ Breite genügen. Die Erziehung von mindestens $30-35$ $\mathrm{cm}$ in Brusthöhe slarken Stämmen in etwa 80 jährigem Umilieb ist das Ziel der Wirtscluaft - ein Ergebnis, welches bei der gewöhnlichen Erziehung im Schlußbestand nicht innerhalb der üblichen Umiriebszeiten erreicht werden kann. Zeitpunkt für die Vornahme des ersten Fronenfreihicbs ist jenes Sladium der Bestandesentwicklung, wo die Stämme durchsehnitllich bis auf eine Höle von 10-12 Meter vom Boden nur noch düre oder nicht mehr beaehtenswerl fortwachsende Aesle besitzen. Bis dahin (d. h. aul Mlittelboden etwa bis zum $30-40$ jährigen Alter) ist dichler Kronenschluß zu erhallen. Von troekenen, flachgründigen, heidewüclisigen Böden soll der Betrieb fern bleiben. Etwa 500 Stämme pro Helitar bilden schließlielı den normalen Bestand. Vom ersten Kronenfrejhieb werden deshalb mindestens Stäme in je $4-5$ Neter Abstand (auf ca. 20 Quadratmeter Fläche cin Slamm) belroffen, natürlieh ohne daß eine regelmäßige stellung Bedingung ist; man ist bıi der Auszeichnung von der zufälligen Gruppierung der stärksten Stämme abhängig. Im Zwischenstand bleibt der Kronenschluß erhalten. Sind die freigehauenen Stämme Lichthölzer, so ist unter ilnen baldigst ein Unterbau vorzunchmen. Vorsieht bein Kronenfreihieb (Umbiegen in Gertenhölzern etc.) ist geboten. - Auf den Vorteil der raschen Erstarkung wird namentlich auch für Buchenhestände hingewiesen. - Das Hölenwachstum leidet nach W a g e $n$ e $r$ dusclı die frühe Freistellung nicht. Die Abformigkeit des ganzen Schaftes wird durch den stärkeren unteren Schaflteil, suwie durch besseres IIolz ausgeglichen. - Wiederholle Lichtung nach Bedarf (abhängig liauptsächlich von den Absalzverhảlnissen). - Der Licht wuchsbetrieb ist, soweit bekanıt, bis jełzt erst auf kleinen Flächen durclıgeführt. Was er leistel, ist zunäehst noelı durch eine größere Anzahl komparativer Versuche festzustellen. Die Anwendung im großen würde jedrnfalls (bei der Auszeichnung, Hiebsführung etc.) größte Aufmerksamkeil des Ẅirtschafters erfordern.

5. Nayr's Kleinhestandswald mit Erzjehungsverjüng u n g. Un der modernen Forstwirtschaft aus dem Dilemma sich widerstreitender waldbaulicher und ökonomischer Gesichtspunkte und Anfgaben herauszuhelfen,

1) Zu vergleichen: W a g e $\mathrm{n}$ e $\mathrm{r}$, ,Waldbau", insbes. S. $246 \mathrm{ff}$, ferner D a $\mathrm{n} \mathrm{k}$ e $1 \mathrm{~m} \mathrm{a} \mathrm{n}$, „Waldbauliche Theorien und Reform-Bestrebungen von Gustav Wagener" (Zeitsehr. f. For'stu. Jagdwesen 1887, S. 329 ff.); ferner G. W a g e $n$ e r, ,Die Forlbildung des Walduaues", A. F." u. J.-Z. von 1887 S. 7 ff., $145 \mathrm{ff} ., 257 \mathrm{ff}$. 
empfichlt Prof. Mayr in seinem „Waldbau auf naturgesetzlicher Grundlage“, den Wald nur aus kleinen, 0,3 bis 3,0 ha großen reinen Beständen zusammenzusetzen. Diese von der jeweils standortsgemäßen Holzart gebildeten Kleinbestände sollen bis zum 30 . oder 40 . Jahre nur volı den untauglichen Individuen gesäubert, sonst aber zum Zwecke der Reinigung geschlossen gehalten werden. Den vom 30. bezw. 40. Jahre einsetzenden Durchforstungen folgen vom 50. Jahre an Durchlichitungen unter prinzipieller Beseitigung alles Unterdrückten, damit die Kronen der Hauptstämme sich nicht mehr schließen können. Diese Durchlichtungen sind vom 50 . bis 80 . Jahre aller 5, später aller 10 Jahre zu wiederholen. Bei Beginn der Durchlichtungen erfolgt Unterbau nit einer Laubholzschattenart (Buche, Hornbaum, Weißerle), event. unter gleichzeitiger Düngung geringer Böden. Nach Erreichung des Haubarkeitsalters Naturverjüngung unter Schirm mit voller oder teilweiser Beseitigung des Unterbaues im Samenjahr. - Der Mayr'sche Betrieb steht und fällt mit dem Unterbau. Wo dieser nicht gelingt, wie auf vielen mittleren und auf allen geringeren Böden zu erwarten ist, wird der Schlußeffekt der Erziehungsverjüngung, wie bei anderen an falscher Stelle angewendeten Lichtwuchshetrieben, in Laubverwehung, Verunkrautung und Verwilderung des ganzen Bestandes bestehen.

6. Vogl's Lichtwuchsbetrieb $\left.{ }^{1}\right)$ : 50 - 70jährige, vorher in zunehmender Stärke durchforstete Bestände (meist Fichte, Tanne) werden allmählich, zunächst durch Wegnahme der zurückgebliebenen Stämme gelichtet. Die Stammzahl geht bei periodischer Nutzung von 15-20\% der vorhandenen Masse nach und nach von 300 bis $400 \mathrm{im} 60$. bis 70 . Jahre, auf 200 bis $250 \mathrm{im} \mathrm{100.} \mathrm{Jahre} \mathrm{zurück.}$ Unterbau findet nur bei ausbleibender Naturverjüngung statt. Durch die frühzeitig eintretende Verjüngung, wie durch die nus allmählich erfolgende Lichtung soll der Boden vor Verwilderung bewalırt bleiben. Die hiebsreifen Stämme sollen im Durchschnitt $3 \mathrm{fm}$ enthalten, so daß der Endhieb $600-750 \mathrm{fm}$ Masse ergibt.

Großen Wert legt Vogl auf Erhaltung der Vorwüchse und sorgfältige Pflege derselben durch Aufastung. Die frühzeitige natürliche Verjüngung und das Streben, den Jungwuchs zur Bildung des neuen Bestandes zu erhalten und heranzuziehen, lassen sich mit dem Verlangen nach langandauernder Ausnutzung des Lichtungszuwachses der llutterbãume jedoch nicht immer in gewünschter Weise vereinbaren. Die gegensätzlichen Interessen von Jung- und Altbestand müssen vielnehr zu Vernachlässigungen des Jungbestandes und zu weitergehenden Fållungs- und Räumungssehãden führen. Sturm-, Schnee- und Eisschäden sollen in den gelichteten Bestănden wenig oder gar nicht schaden. Ebenso wird von Vogl eine Gefährdung bezw. Verschlechterung der Waldbodenkraft und zwar auch auf den Südsciten in Abrede gestellt. Endres (Bericht d. Deutseh. Forstrereins 1910, S. 88) bezeichnet den Boden im Gegensatz hierzu als, ,zun großen Teil verwildert". Ganz hervorragend aleer sind die von Vogl erzielten Ergebnisse hinsichtlich der Steigerung der Stärken- und Wertszunahme der Lichtwuchsstämme.

D. Würdigung der Lichtungsbetriebe ${ }^{2}$ ).

$\S$ S8. Trotzdem der Gedanke, den zuwachsfördernden Einfluß frülıerer oder späterer Umlichtung ausgesuchten Wertsstämmen zukommen zu lassen, schon alt ist und trotzdem die Lichtungsbetriebe teilweis ganz erstaunliche Beweise für die wertvolle Hilfe des Lichtes bei der Starkholzerziehung beigebracht haben, begegnet die forstliche Praxis der in den Lichtwuchsbetrieben gehandhabten Ausnutzung des Lichtıngszuwachses nur vorsichtig und zurückhaltend. Die Gründe hierfür sind teils bodenpfleglicher Natur, teils darin zu erblicken, daß den zahlenmäßigen Nachweisen für die höhere Rentabilität der Lichtwuchsbetriebe allgemeine Bedeutung nicht bei-

1) Vigl. Vog l, Aus der Praxis 25jāhr. Forstfinanzwirtschaft. Oesterr. Vierteljschr. 1887, 315. - D e r s., Die Forste der Herischaft Kogl, das. 1889, 303. - D e I s., Zum Lichtwuchsbetrieb, A. F.- v. J.-Z. 1902, 270. 309. - M a I t in, Kritische Vergleichung der wichtigsten forsttechn. und forstpolitischen Maßnahmen deutscher und außerdeutscher Forstverwaltungen. Ztsclir. f. Forst- u. Jagd\%. 1901. 511.

2) Vgl. Bericht üb. d. XI. Vers. d. Deutsch. Forstvereins 1910, S. 34. 
gemessen werden darf. Die von Vertretern dieser Betriebe angegebenen Zahlen über Massen- und Wertszuwachs gelichteter Bestände stellen fest, daß der Lichtwuchsbetrieb unter zusagenden Standorts- und Bodenverhältnissen eine sehr beachtenswerte Betriebsform zur Erhöhung der Rentabilität der Wirtschaft ist. Es kann jedoch bei zu weitgehender Lichtstellung der begünstigten Stänme trotz ihrer großen Mlassenleistungen leicht vorkommen, daß das Produktionskapital unzureichend verzinst wird und der Lichtungsbetrieb demnach vom Standpunkt der Rentabilität nicht gerechtfertigt ist.

In seiner reinen Form mit der Tendenz der stammweisen Ausnutzung des Lichtungszuwachses eignet sich der Lichtungsbetrieb zunächst nur für solche Holzarten, deren langanhaltender Lichtungszuwachs einen bedeutenden Wertszuwachs in sich schheBt. Zu diesen Holzarten gehören vor allem die Eiche, nach ihr Kiefer und Lärche.

Voraussetzung für einen anselnhlichen und nachlhaltigen Lichtungszuwachs ist ferner nicht allein ein verstärkter Lichtgenuß, sondern in gleichem Maße das Vorhandensein eines kräftigen, nährstoffreichen und frischen Bodens. Wo dieser fehlt, ist der Lichtungszuwachs zumeist nur eine vorübergehende Erscheinung und der Lichtungsbetriel, un so weniger am Platze, weil auch die conditio sine qua non des Lichtungsbetriebes, der Unterbau, auf solchen Böden versagt. Es ist selbstverständlich, daß die Lichtungsbetriebe umsonehr auf Bodendeckung bedacht sein müssen, je früher und je stärker sie den kironenschluß durchbrechen, je weniger ein bodenschützender Unterstand sich von selbst einstellt und je länger die Untriebszeit bemessen wird. Die in bezug auf Gefährdung der Bodenkraft lant gewordenen Bedenken gegen die Lichtungsbetriebe sind nicht unberechtigt und stehen, wie schon erwähnt, der zweifellos wünschenswerten Verallgemeinerung res Lichtwuchsprinzipes hindernd im Wege. Das ist zu bedauern; denn die Mlehzahl der Lntersuchungen über die Pientabilität der lichtwuchsfreundlichen Bestandeserziehung spricht entschieden zugunsten eines sachgemäß geleiteten Lichtungsbetriebes. ,SachgemäB“ heißt: Beschränkung auf die passenden Standorte und Holzarten und Vermeidung aller Extreme und aller Speliulationsideen. Eine so frülızeitige Freistellung der zu begünstigenden Stämme, wie sie Wagener vorschlägt, ist nichts anderes als der Versuch, mit dem Lichte Spelulationsgeschäfte zu machen. Wir haben bei so frühzeitigen Unlichtungen nicht die Gewißheit, ob der einzelne Baum die Freistellung in gewünschter Weise ausnützen wirl. Weiterhin fehlt uns andererseits die Sicherheit, ob wir bei sehr extremen Lichtstellungen in höheren Alter in den Massen- und Wertsleistungen der wenigen Lichtstänme und in den höheren Vorerträgen einen hinreichenden Ersatz erhalten für den Ausfall an Gesamtleistung der vollbestockten Fläche, für die mit den Unterbau verbundenen Kosten, wie auch für einen möglicherweise in Rechnung zu stellenden Rückgang der Bodenkraft. Alle diese Erwägungen lassen den g e m ä B ig t e n Lichtungsbetrieb richtig erscheinen, d. h. einen Lichtungsbéirieb, der erst nach Abschluß des Hauptlängenwachstums in die Bestände eingreilt und sich dann von zu starken und unvermittelt vorgenommenen Umlichtungen der brauchbar erscheinenden herrschenden Stämme ebenso frei hält, wie von zu weit gehenden Lichtstellungen überhaupt. Diesem aus der allmählich verstärkten Durehforstung ohne scharfen Uebergang herauswachsenden Lichtungsbetrieb ist zum Zwecke der Starkholzerzielıung mehr Beachtung zu wünschen, als er hisher in der großen Praxis gefunden liat. 
Füntes Kapitel.

\section{Die Aufastungen ${ }^{1}$.}

\$ 89. Unter Aufastungen oder Entastungen verstelıt man die Wegnahme von Aesten an stehenden Stämmen. Je nachdem diesc Aeste schon abgestorben oder noch lebend sind, unterscheidet man Trocken- und Grïnastung ${ }^{2}$ ).

I. Z w e k: Die Aufastung kann in dreifacher Beziehung von Berleutung werden, nämlich 1. für die Entwickelung der aufgcastelen Stämme selbst; 2. für die Entwickelung des Unterwuchses; 3. durch die dabei gewonnene Holzmassc. Bald veranlaßt uns dic einc, bald dic andere der genannten Absichten zur Ausführung einer Astung. In den meisten Fällen wird lie Astung aber belufs

a) Erziehung guter $\mathrm{Nutzstämm} \mathrm{e} \mathrm{rorgenommen.} \mathrm{Dabei} \mathrm{konmt}$ in Betracht die ctwaige Wirkung der Aufastung $\alpha$ ) auf die innere Gesundheit des Stanmes, $\beta$ ) auf die inneren Struliturverhältnisse, $\gamma$ ) auf die Wachstumsverhältnisse (Formentwickelung etc.). In jedem Falle steht der Gebrauchswert des Stammos in Frage.

Ob und inwieweit die Aestung günstig wirkt, ist noch nicht endgültig und insbesondere noch nicht durch die erforderliche Reihe exakter komparativer Versuche genügend festgestellt. Je nach den vorliegenden Bedingungen wird der Erfolg ein sehr verschiedener sein. Die angestrebten Vorteile sind: Erzeugung astfreier Holzlagen, verbesserte Schaftform, Anregung des Wachstums überhaupt und insbes. des Höhenwachstums, Erhöhung der Widerstandstähigkeit gegen Stürme und sonstige Witterungsübel. Es fragt sich nur, ob diese Vorteile erreicht werden lönnen, ohne da 3 gleichzeitig Nachteile eintreten, und ob weiterhin der Erfolg derart ist, da $\beta$ sich der durch die Aufastung bedingte Kostenaufwand lohnt.

Solange es sich nur um Entnahme trockener Aeste (event. Aststummel) handelt, wie sie sich namentlich infolge mangelnder Lichtwirhung fast immer mehr oder weniger reichlich vorfinden, kann der Baum, entsprechend vorsichtige Ausführung vorausgesetzt, nur Vorteil von der Astung haben, indem dadurch eine Arbeit vollzogen wird, die er anderenfalls entweder durch allmähliches Abstoßen des toten Organs sclbst vornehmen müßte, odel deren Unterlassung bei del Unmöglichkeit des Abstoßens stärkerer Aeste insofern nachteilig wirkt, als der tote Teil cinwächst, zu Fehlstellen (Hornästen) Anlaß gibt und die Nutzfähigkeit des Stammes vermindert. Erhıbliche Zweifel bestehen aber hinsichtlich der Grünastung: Die Ansichten über ihren Wert gehen sehr auseinander. Im allgemeinen aber steht fest, daß man selbst bei Bäumen von hoher Reproduktionskraft nicht über ein gewisses Maß (Zahl der zu entfernenden Aeste, Größe der Wundfläche) hinausgehen darf, wenn nicht die Nachteile (Hinderung der Organe, mangelhafte Ueberwallung etc.) ïbcrwiegen sollen. Zweck der Grünastung ist meist Steigerung des Nutzwertes des aufgeasteten Stammes. Scluaftreinleit, Vollholzigkeit und Langschaftigkeit sollen durch die Entnahme grüner Aeste ver-

1) $\mathrm{Zu}$ vergleichen: Allgemeiner Arbeitsplan für forstliche Aestungsversuche. Aufgestellt von dem Verein deutscher forstlicher Versuchsanstaiten 1886, abgedruckt im Jahrbuch der preuß. Forst- und Jagdgesetzgebung und Verwaltung, 18. Bd. 4. Heft, S. $26 \pm$ ff. Hier sind sämtliche bei der Aestung irgend in Betracht kommende allgemeine Gesichtspunkte aufs vollständigste zusammengestellt. Zugleich ist daraus zu ersehen, nach welchen Richtungen hin die ganze Frage der Kilärung noch bedarf. - Vergl. auch $\mathrm{k}$ i e $\mathrm{n}$ i $\mathrm{z}$, , Ueber die Aufastung der Waldbäume", Suppl. zur A. F.- u. J.-Z. X. Bd. 2. Heft, 1878. I a y, ,Geschichte der Aufastungstechnik und Iufastungslehre", F. Ztbl. 1889,1890 u. 1891. Ferner, ,Instruktion für Aufastungen" (im Großh. Hessen) F. Ztbl. 1899, S. 317. H e m p e 1, Die Aestung des Laubholzes, insbes. der Eiche. Mitllgn. a. d. Porstl. Versuchsw. Oesterreichs. 18. Hift. 1895. - Z e d e r b a u e r, Untersuchungen über d. Aufästung der WValdbăume. Zbl. f. d. ges. Forstw. 1909, 413.

2) Gelegentlich (z. B. in dem vorgenannten Arbcitsplan) wird auch noch die sog. Welkästung unterschieden, worunter die Wegnatıme natürlich oder künstlich (durch Einstutzen oder Ringelung) gewelkter Aeste verstanden wird.

Handb. d. Forstwiss. 3. Aut. II. 
bessert werden. Daß größere Astreinheit herbeigeführt ist, bedarf lieines Beweises. Auch die Erzichung vollholzigerer Schäfte wird durch das mit der Vegnahme der unteren Aeste verbundene Hinausschieben der Krone unterstützt. Das Verhältnis der Jahresringbreiten im oberen und unteren Schaftteile verändert sich durclı die Aufastung zugunsten der oberen Jahresinge, insofern diese breiter bezw, die unteren sclımäler werden. Der dadurch herbeigeführten Förderung der Walzenform steht. allerdings bei stärkerer Aufastung eine V'erminderung des Gesamtzuwachses gegenüber. Hingegen lassen sich für die Richtigkeit der Annahme, daß durch Aufastung der Höhenwuchs befördert werden könnte, weder aus den vorliegenden Untersuchungen, noch von physiologischen Emwägungen aus einwandfreje Beweise erbringen. Man muB im Gegenteil annehmen, daß die mit jeder stärkeren Astung verbundene Verringerung der Assimilationsfläche einen Rïckgang des Hölıenwuchses zur Folge hat. Die Umstände, welche den Erfolg der Astung beeinflussen, sind nach Art und Umfang noch durch Versuche festzustellen. Im einzelnen sind dabej hinsichtlich der Objelte, an welchen die Astung vollzogen wirl, zu beachten: die Holzart, die Standortsverhältnisse, die Bestandesverhältnisse im ganzen und der aufzuastenden Stämme im besonderen. Naturgenäß stelien hetreffs der $\mathrm{Hol}$ zart für den hier in Rede stelıenden Zwedi nur Nutzholzarten in Frage und zwar dürften in erster Linie die Eiche, sowie unsere Nadellı̈lzer ins Auge zu fassen sein. Jinsichtlich des $\mathrm{S} t$ a $\mathrm{n}$ do $\mathrm{l} \mathrm{t} \mathrm{s}$ kommen alle seine einzelnen Falitoren in Betracht, da sie in ihrer Verschiedenheit unzweifelhaft auch auf den Effekt der Astung modifizierend wirken. Auch das Alter der zu astenden Bäume ist zu beachteı. Einem jungen bis mittelalten vollliräftigen Individum liann man mehr zumuten als einem alten stamme.

b) Förderung des Unterw uchses. Hierbei lommt namentlich der Mittelwalı, sowie del Hochwald mit natürlicher Verjüngung in Betracht. Im Mlttelwald ist die Berłeutung des L'nterholzes bisweilen eine selu erhebliche, weil viele Besitzer, von jeder einseitigen Steigerung der Oberholzproduktion absehend, auf die im Unterholz zu gewinnende Brennholzmenge besonderen Wert legen. Allzu Jeichliche Beschattung seitens der Oberständer behiudert die freudige Entwickelung des Lnterwuchses, so daß durch Entnahme eines Teils der Aeste an jenen, mit möglichster Berüclisichtigung der unter a angedeuteten Gesichtspunlite, nachgeholfen werden muß. Nicht minder können unter Umständen die Jungwüchse des Plenterwaldes und res schlagweisen Hochwaldbetriebes eine Lockerung des Kronenschimes durch Entastung (Wegnalıme der unteren Aeste) forderm. Wadurch wird zugleich das spätere Ausbringen der Mutterbäume mit geringerer Scläıligung des Unterwuchses möglich $\mathbf{1}$ ). Immerhin darf man die nachteilige Wirkung einer nur zeitweise stärkeren Ueberschimnung des. Jungwuchses njcht ïberschätzen, damit nicht für Aufastungen ohne Not zu grofe liosten aufgewendet und nicht Stämme, welche noch längele Zeit stelıen sollen, dırch die Astung zugunsten des Interstandes unverhältnismäßig geschädigt werden.

c) II a te jia la n $\mathrm{f}$ a l]: Die Aufastung liefert nicht nur eine je nach Umständen mehr oder minder schätzbare Holzmasse, sondern wird vielfach auch zur Gewinnung von Streu (Reisstreu ju Gebirg) und Futterlaub (z. B. von Eschen) regelmäßig vorgenommen. Namentlich letztere beide, dem Gebiete des Nebennutzungs-

1) z. B. Aufastungen im Schwarzwald. Die allmälliche Entastung, hauptsächlich zugunsten der Entwickelung des Unterwuchses, ist von der oft vollständigen Enlastung unmiltelbar vor der Fallung, behufs geringerer Beschädirung der Jungwïchse durch den fallenden Stamm, zu unterscheid.u. Von lelzterer ist man vielfach abgelommen, weil infolge des nummehr ganz unvermiltelten Auf'schlagens der stämme auf den Boten (Steinräulıen!) zu vicle, insbes. Tannen-stâmme zerbrechen. 
betriebs zugehörenden Zwecke sind oft Veranlassung einer sonstige Rücksichten vernachlässigenden Ausdelınung der Maßregel (Schneitelbetrieb).

d) In einzelnen Fällen veranlassen noch andere Beweggründe zur Aufastung. Die häufigsten Vorkommnisse dieser Art sind Aufastungen an Wegen belufs Trockenlegung, an Bestandsrändern, um der Sturngefahr vorzubeugen, an Eisenbalınen und Verkehrsstraßen, um feuerfangendes Dürrlolz zu entfernen.

1I. Erfolg der Astung: Außer den unten I a bereits angegebenen bedingenden Nomenten sind von Einfluß die Ausführung der Entastung, die Zeit ihrer Vornahme, ihr Umfang (Anzahl und Stärke der weggenommenen Aeste) und die aufgewendeten Kosten.

A. Art der A us üh rug und zwar

I. Ort der Abtren $\mathrm{r} u \mathrm{ng}$ der A este: Man unterscheidet Astung scharf am Stamme, Astung in geringem Abstande rom Stamme (sog. Stummeln), Einstutzen der Aeste in größerer Entfernung vom Stamme zum Behufe der vorläufigen Verhinderung ihrer Stärkezunahme oder des allmählichen Abwelkens und späteren Nachschneidens am Stamme.

Bein Aesten scharf am Stamm kann der Schnitt parallel zur Baumaehse oder senkrecht zur Islachse geführt werden. In ersteren Falle ist die Wundiläche etwas größer, die Ueberwallung aber geht schneller vor sich, weil die Wundfläehe in gleiche Ebene mit den Leitungsbahnen kommt; der Einfluß der Operation ist ein güntigerer, weil der beim schnitt senlieeht zur A-tachse verbleibende kleine $\Lambda$ stwulst fehlt. - Das Belassen kurzer Stummel ist wegen Verlangsamung des Ueberwallungsprozesses und wegen Einfaulens der Stummel verwerflich, wogegen das Belassen längerer Astreste nit einigen noeh grünen Zweigen sich dann empfehlen kann, nenn man starke Aeste an bald zu fällenden stämmen nicht ganz zu entfernen wagl, inzwikchen jedoch die Besclattung des Unterwuchses vermindern möchte.

2. Instrumente: Ein glatter Schnitt ist bei der Astung zur Erzielung möglichst rascher guter Ueberwallung unbedingt erforderlich; alles Splittern, Einreißen in Holz und Rinde, Loslösen der Rinde vom Holzkörper ist zu vermeiden. Nur für schwache Aeste, welche mit e in e m Hieb rom Stamm getrennt werden können, sind Beil oder Heppe, event. auch ein (ron unten zu führendes) Stoßeisen statthaft. Im übrigen ist die Astung mit der Säge (Hand-oder Stangensäge) vorzunehmen, da es allein mit diesem. Werkzeug möglich ist, glatte Schnitte auszuführen, olne die Rinde aufzureißen. Besondere Aufastungssägen nit kleinen Zähnen und verstellbaren Blättern, wie z. B. diejenigen von Alers ${ }^{1}$ ), Nördlinger ${ }^{2}$ ), sowie Müller-Dörmer ${ }^{3}$ ).

3. A us führung, Bellandlung der Wundfläclı e: Zur Vermeidung des Einreißens in den Stamm ist bei Entnahme aller stärkeren Aeste von unten her zunächst an der Schnittstelle einzukerben; schwere Aeste werden überdies an besten stückweise entfernt. - Iileine Schnittflächen werden bei Nadelhölzern, bei welchen öfters Verschluß dureh Harzaustritt erfolgt, einer besonderen Behandlung nicht unterzogen. Dagegen empfiehlt es sich, - ganz besonders bei der Herhstastung -, alle größeren Wundflächen bei Nadel- und Laubhölzern mit Teer zu überstreichen, un das Eindringen von Pilzkeimen zu verhindern. - O r g a n is a $\mathrm{t}$ i o $\mathrm{n}$ d e r A r b e it: Nur durchaus zuverlässigen, geübten Arbeitern darf die Astung übertragen werden. Bis zu einer gewissen Höhe vom Boden (ca. 6 Meter, ja mit An-

1) Die sog. "Flügelsäge" von For-tmeister Alers in Helmstedt ist besehrieben in Alers "Leber Aufästen der Waldbäume" etc. 2. Aufl. 1874. Leber ihre Leistung zu verchleichen u. a. $H$ e B, ,ilufastung von Eichen" (Zentralbl. 1. d. ges. Forstwesen 1879, S. 353). De rselbe, Allg. F.u. J.-Z. 1874, S. 37 ff, - D e rselb e, ,Astungen in Fichtenstangenholzern" (Zentralbl. f. d. ges. Forstw. 1882, S. 452). - Zum Festhalten schwanker Aeste behufs des Absägens hat Alers eine auf einer Slange befestigle ,Baungabel" konstruiert; cfr. Allg. F.- u. J.-2. V. 1886, S. 395 .

2) cfr. Kritische Blätter, LI. Bd., 1. Heft, S. $220 \mathrm{ff}$.

3) A. F.- u. J.-Z. 1893, S. 200. 
satzgestänge bis zu ca. 10-I2 Meter) kann die Stangensäge angewendet werden; weiter hinauf wird die Astung durch Besteigen der Bäume vorgenommen. Zum Besteigen del Bäume sind besondere Steigapparate erfunden worden, so von $\mathrm{Z}$ e h n p f u n d der sog. Steigrahmen ${ }^{1}$ ). Verbesserungen desselben wurden vorgeschlagen von $\mathrm{Hef} \mathrm{e} \mathrm{l} \mathrm{e}^{2}$ ) und anderen. Die Anwendung der Alers'schen Baumgabel erfordert einen zweiten Arbeiter, der dann auch das Teeren der Wundstellen mit besorgen liann.

B. Z e it der A u f a tun ${ }^{3}$ ): Als geeignetste Zeit der Aufastung wird allgemein die Zeit der Vegetationsruhe (Herbst und Winter) angenommen. Am günstigsten hielt man zeither schon immer den Nachwinter und den ersten Frühling, weil dann durch atmosphärische Einflüsse (Frost, Hitze) lieine ungünstige Einwirkung auf die Wundfläche stattfinden und auch bei der Ausführung rler Astung infolge Festsitzens der Rinde Loslösungen usw. nicht vorkommen liönnten. Die neuerdings veröffentlichten Untersuchungen Zederbauers weisen darauf hin. daß Herbstastung nur bei Anwendung des Teeranstriches zulässig und daß das Frühjahr, März oder April, wegen der sofort eintretenden Ueberwallung die beste Zeit für die Aufastung ist. Bej der Herbstastung entsteht rings um die Wunde Brännung der Pinde und dadurch Vergrößerung der Wunde, ein Vorgang. der nampntlich bei Buclıe und Eiche die Verlegung der Aufastung in das Frühjahr angezeigt erscheinen läßt, während Nadelhölzer (Douglasie und Fichte) ohne große Schädigung auch im Winter oder. Herbst aufgeastet werden können.

C. A usdehnung der Astung: In Frage stelıt die Stärke der zu entnehmenden Aeste, deren Anzahl und Stellung am Stamm, im lionlireten Falle beeinflußt durch Höle des Kronenansatzes, Kronenlänge, Kronendurchmesser, Kronendichte etc. des zu entastenden Stammes.

Welche Größe die einzelne Wundfäche je nach Alter, Slärke und Wüchsigkeit des StamInes ohne Gefalı hahen darf; in welchem Maße durch geringen vertikalen und seillichen Absland mehrerer Wundfäehen voneinander, namentlich bei slärkeren Aeslen der Ueberwallungsjrozeß ersehwerl und die Ciefahr einer von den Wunden ausgehenden Verderbnis erhöh wird; Welche relative Gesamlausdehnung der Wundfächen eines Stammes man nicht ohne Nachteile, auch für die physiologischen Funklionen und die Zuwachsverhältnisse, überschreilen darf, sind Fragen, deren zuverlässige Beantwortung nach dem jetzigen Sland unserer Kenntris noch nichl möglich ist. (Weißtanne und Fichte sollen, nach $\mathrm{D}$ e $\mathrm{n} \mathrm{g}$ e $\mathrm{r}$, his $\mathrm{zu} 0,6-0, \mathrm{\tau}$, Kiefer und Lärche his zu 0,8 der Baumhöhe entastel werden dürten. T l a m $\mathrm{n}$ i $l z$ liält die Entnahme von 20-33․ der grünen lirone für zulässig, fordert alıer lür die Eiche, daß die Wunden [höchstens 4 em Durchmesserl] in $3-1$ Jahren überwallen.) $1 \mathrm{~m}$ allgemeinen ist ror Beseiligung starker Aesle zu warnen, wogegen schwächere teste an schönen stämmen zu beseitigen sind. $\mathrm{Z}$ e $\mathrm{d}$ e $\mathrm{r}$ b a $\mathrm{u}$ e fordert, daß die Cröß der Astwunden je nach Wuehsigkeil des Baumes und der damit zusammenhängenden Schnelligkeit der Ueberwallung nielıt uber 3 bis $6 \mathrm{~cm}$ in Durehmesser belragen soll.

D. Kosten: Die Aufastung ist als eine viel Sorgfalt erfordernde Mlanipulation verlıälnismäßig teuer. Selbst wenn die hinsichtlich des Astungsverfahrens (Instrumente, Arbeitsorganisation etc.) günstigen Bedingungen ausfindig gemacht sind, ist zu erwägen, ob und inwieweit - nach Abzug iles Vertes der anfallenden Astmasse - der Aufwand durch die erwarteten Vorteile gedeckt wird. Für siclteres ziffernäßiges Bemessen fehlen bislang die nötigen Anhaltspunlite.

Angesichts der zahlreichen bedingenden Falitoren ist die Anfastungsfrage eine überaus liomplizierte, zu deren allseitiger Lösung sich Pflanzenphysiologen und Forstleute verbinden müssen. Vorläufig scheint bezüglich del Grünästung große Vorsicht

1) Zul. f. d, ges. Fw, 1892, S. 465 .

2) Fw. Ztbl. 1894, >, 299 ,

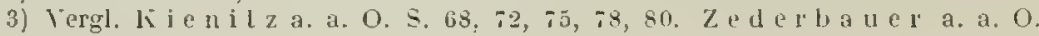


geboten zu scin, mindestens insoweit es sich um Stämme handelt, welche noch längere Zeit wachsen sollen. Jedenfalls wird man gut tun, die Aestung vorerst nur als eine Ausnalımemaßregel zu betrachten.

\section{Sechstes liapitel.}

\section{Die Bodenpflege.}

$\$$ 90. Da die Bewahung der Bodenkraft für die Narhhaltigkeit der forstlichen Erträge von höchster Bedeutung ist, gehört die Bodenpflege als untrennbarer Bcstandteil zur Bestandespflege. Für den Waldboden sind die auf Erhaltung bezw. Besserung der die Bodengüte bedingenden plysilialischen und chemischen Faktoren - namentlich der Bodenfrische und des Nähstoffliapitales - gerichteten Maßnahmen sogar von hesonderer Bedeutung, weil die von der Landwirtschaft zur Hebung erschöpfter Böden lieıutzten Mlittel: Bodenbearbeitung und Düngung in forstlichen Betriebe der Iosten wegen nur in sehr beschränktem Maße zur Anwendung gelangen können. Eine pflegliche Waldwirtschaft muß bemüht sein, zunächst durch waldbauliche Naßnahmen die Notwendigkeit künstlicher Düngung und der S. 88 ff. genannten, bei der Herstellung eines kuIturfähigen Bodeus vielfach unumgänghichen Heliorationsarbeiten vom Waldboden fern zu halten. Hierauf hat sie umsomelu bedacht zu sein, je mehr der Boden von selbst zur Preisgabe seiner Produlitionskraft hinneigt.

Die schon in früheren Abschnitten wiederholt genannten und nach ilırer praktisclıen V'erwirklichung mehr oder weniger erörterten Cresichtspunkte der Bodenpflege im Walde umfassen die Erhaltung des Bodens, seincl Lockerheit und Frische, sowie seines Humusvorrates und Nährstoffgehaltes.

a) Erhaltung des Bodens. Sache des Waldbaues ist es, dureh Wahl geeigneter Holz- und Betrielssarten die Erhaltung ciner daucrnden Bestochung dort zu sichern, wo dic Gefahr der Bodenabschwemmung oder Flıgsandhildung hesteht. Die in solchen Verlältnissen mit Recht auf Schutzwaldbildung gerichteten forstpolitischen IIßnalımen zeichnen auch dem Forstschutz und der Forstbenutzung die Wege vor, die sie im Interesse des gemeinsamen Zieles zu gehen haben (Verbot der Streunutzung, Waldweide, Unterlassung der Stockrodung usf.).

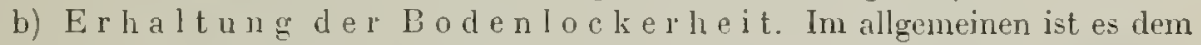
forstlichen Großbetrieb nicht möglich, durch periodische Bearbeitung des Waldbodens mit Hand- oder Zugrverkeugen (Hacken, Grubbern) für einen namentlich auf bindigen Böden wünschenswerten Lockerheitsgrad zu surgen. Auch das in früheren Zeiten in Betracht kommende V'erfahren, durch Schweineeintrieb einen wohltätigen Umbruch der oberen Streu- und Borlenschicht herbeizufülıren, hat heute an Bedeutung verloren. Umsomehr ist den unter d genannten, auf Erhaltung der normalen Streudecke, Streumischung und Streuzersetzung hinauslaufenden liestandespfleglichen Naßnahmen Beachtung zu schenken, damit der Wald selbst die ihm zufallende Aufgabe, den normalen Lorkerungsgrad des Bodeıs zu erhalten, zu lösen imstande ist. Lnter Umstäuden vermag der Wirtschafter durch Düngung mit lockernden bezw. bindenden Materialien, vor allem durch Kalkung (hei Trockentorfbilchung) für eine Besserung der Bodenlockerheit Sorge zu tragen.

c) Erhaltung der Bodenfrische bezw. Herstellung eines normalen Feuclutigkeitszustandes. Da olne Vorhandensein ciner hinreichenden und gleichmäßigen Bodenfrische alle sonstigen Mlaßnalımen der Boden- und Bestandespflege nur wenig nützen, stellt die Regelıng der Wasserfrage eine der wichtigsten Aufgaben der Waldwirtschaft dar. Zumehmende Trocken- 
heit und ständiges Sinken des Grundwasserspiegels bringen es mit sich, daß die Forstwirtschaft an Stelle der eledem auf Verbesserung des Waldzustandes abzielenden Entwässerungen jetzt vielfach auf die gegenteilige Maßnalıne der Wasserzuführung lingewiesen wird.

1. B e wä s s e r u ng. Angesichts der zumeist vorliegenden Unmöglichkeit direkter Wasserzuführung sind an trockienen Partien, soweit es ohne größere IKosten möglich ist, Vorrichtungen zu treffen, die schnelles Abfließen des atmosphärischen Wasser's verhindern, das Wasser aufhalten und langsam versicliern lassen. Als solche Vorrichtungen sind die besonders an trockenen Hängen mit Vorteil anzubringenden Horizontal- oder Sickergräben ${ }^{1}$ ) zu nemen.

Man versteht darunter $20-30 \mathrm{~cm}$ tiefe und ebenso weite, in einem Vertikalabstand von 2 bis $3 \mathrm{~m}$, auf sanft geneiglen Gelände auch bis $5 \mathrm{~m}$ von einander entfernte, nit möglichst senkrechten Wänden ausgehohene, 4 bis $6 \mathrm{~m}$ lange Stüchgräben. Itır Wert beruht darin, daß sie sowohl das oberflächlich abfließentle Wasser, wie auch das abgewehte Laub uni den abgeschwemmten Boden zurückhalten. Sie erleichtern die Wasserverteilung und die anhaltendere Befeuchtnng der unter ihnen liegenden Partien und sinł auf trocknen, steileren Hängen ein vorzügliches Regenerationsmittel für rückgängige Waldungen. Sie bedürfen allerdings, wenn sie nachlualtig wirken sollen, öterer Räumung.

Seitlich der Wegegräloen angelegte quadratische oder rechtwinkliche Löcher (S i c k e rd o hl l $\mathrm{n}$ ), in welche das in den Griben abfließende Masser geleitet wird, Wasserausgüsse, die an trocknen Stellen in die Bestände führen, an bedürtigen Partien zweckmäßig angebrachte Wegedurchlässe mit slauvorrichtungen in den Gräben, un das Wasser zum Abfließen zu bringen, sind anderweitig vielfach ohne erheblichen Kostenaufwand mögliche Maßregeln, welclıe die Wasserentfühung aus dem Walde erschweren und damit der I'roduktionssteigerung des Waldbodens Dienste leisten.

Planmäßige Grabenanlagen zur direkten Bewässerung günstig gelegener bedürftiger Bestände sind infolge zu hoher Kosten meist undurelıführbar. Die in dieser Richtung laut gewordenen Vorsehäge An d e r lin $\mathrm{ds}^{2}$ ) sind utopiseh. Infolgedessen fehlen auch, von kleinen Ausnahmen ${ }^{3}$ ) abgesehen, zahılenmäßige Beweise für den Wert direkter Bewässerung. Hinsichtlich der praktischen Durehführbarkeit der Waldbewässerung trifft $\mathrm{M}$ a \ $\mathrm{r}$ jedenfalls füı die meisten Verhältnisse das Richtige, wenn er (Waldbau S. 523) als beste Bewässerung für bewaldete Gebiete -- die Unterlassung der Entwässerung bezeichnet.

2. En twä s s e r u n g. Die Entwässerung hat sich, wie schon aus den letzten Worten hervorgeht, auf das Notwendigste zu beschränken. Es ist im allgemeinen fehlerhaft, gegen jede im Frühjalu oder auf Blößen sich zeigende nasse Stelle mit Entwässerungsgräben vorzugehen. Der Fehler wird um so größer, wenn das Wasser dem Walde nicht an anderer Stelle wieder zugefülırt werden kann. In vielen Fällen genügt eine zeitweise und nur vorübergehende Entwässerung, um cinen der Bestandesbegründung unzuträglichen Ueberschuß von Wasser zu beseitigen. Der heranwachsende Bestand zehrl den Ueberschuß auf und bedarf der Entwässerungsgräben nicht mehr. Auf nit älterem Holze bestockten Flächen hat die Entwässerung möglichst zu unterbleiben. Sie wird hier leicht zu einem störenden Eingriff in den Wasserhaushalt des Bestandes und zieht möglicherweise Zuwachsrückgang, Zopfdürre und Absterben des Iolzes nach sich. Mit Rüiclisicht auf solche Torliommnisse bedarf auch der Wasserentzug aus dem Walde zugunsten der Wasserversorgung von Gemeinwesen sorgfältiger Prüfung und gegebenen Falles vorsichtiger Einschränkung.

1) H a a g, Ueber horizontate schulz- oder sickergrïben. Forstwiss. Zbl. 1881, 208. M äle r, Horizonlale Schutz-, Siclier- und Regeneralionsträluen, ebend, 1904, 659.

2) A n d e r I i d, Beschreibung der Bewässerung der Valdungen der Ebene miltels Fächer oder Hälter. A. F.- 1. J.-Z. 1903, 447. - D e r s., Streifenbewässerung, das. 1904, 257.

3) B ö h m e r l e und C i e s l a r, Bewāsserungsversuche im Walde. Zbl. f. d. ges. Forstw. 1905,145 น. 195 . 
d) Erlıaltung bezw. Verbesserung des Hum s vor r a tes und des $N$ äh rstof $\mathrm{fgeh}$ a t es. In bezug auf die Humusfrage sind vor allem die der Verhagerung leicht ausgesetzten flachgründigen Böden zweckmäßig zu behandeln. Erhaltung der lebenden und toten Bodendecke und cines mäBigen Bestandesschlusses, Schonung des Lnterwuchses sind hier unbedingte Erfordernisse, während andererseits Lnterlassung gänzlicher Entblößung des Bodens durch Kahllieb und Begünstigung der natülichen Verjüngung als wirksame Vorbeugungsmaßnalimen gegen Bodenverschlechterung und Raubwirtschaft Beachtung verdienen.

Abgesehen von den besonders gefährdeten armen Böden sind Vischung rler Holzarten, namentlich der Licht- und Schattenhölzer, Einbringen der Buche in Nadelholzbestände, Unterbau in natürlich oder künstlich gelichteten Orten, Belassung bezw. Anzucht von Schutz- und Waldmänteln au den Bestandsgrenzen, schnelle Wiecleraufforstung der Kahlschläge und Anwendung geeigneter, baldige Deckung des Bodens herbeiföhrender Fiulturmethoden Wittel, die im Interesse der Erhaltung normaler Humus-. Lockerheits- und Feuchtigkeitsverhältnisse des Bodens überall, hier mehr, dort weniger dringend. Anspruch auf Berücksichtigung erheben.

Waldmäntel empfehlen sich namentlich am Rande exponierter Laubholzbestände, um der hier bei ständiger Windeinwirkung leicht vorkommenden Laubverwehung und Aushagerung der Randpartien vorzubeugen. Der notwendige Schutz kann durch Anlage eines Niederwaldstreifens an der gefährleten Seite, meist besser aber durch Lmsäumung des Laubholzes mit einem Nadelholzbande, oder auch durch Unterbau des Randstreifens mit Tanne oder Fichte hergestellt werden. Auch in Narlelholzbeständen ist ein sorgfältig erzogener Waldmantel ein nicht zu vernachlässigendes Hilfsmittel gegen Sturmschaden und gegen die mit dem Eindringen von Wind und Sonne dem Boden drohenden Gefahren.

Ueber die zweckmäBigste Art und Weise der Erziehung der Waldmäntel gehen die Ansichten aber auseinander. Während die einen den dichtgefügten, aus eng gestellten Bäumen gebildeten und bei den Durchforstungen unberührt gelassenen Wahlmantel für den wirksameren lualten, plaidiert man auf der anderen Seite für den weitständigen, aus frei erzogenen und dementsprechend tiefbeasteten Bäumen zusammengesetzten. Wo neben Bodenschutz auch Stumschutz Aufgabe des Waldmantels ist, dürfte der weitständig erzogene, aus standfesten Bäumen gebildete seinen Zweck besser erfüllen.

Die oben zum Zwecke der Herbeiführung eines günstigen Humuszustandes geforderte Erhaltung des Bestandesschlusses darf, wie schon in früheren Abschnitten mehrfach hervorgehoben wurde, in reinen Fichten-, Buchen- und Tannenbeständen nicht zur Anhäufung von Trockentorfmassen führen. Auf Börlen und in Lagen, wo dieses zu befürchten ist. Lat entsprechende Schlußunterbrechung an Stelle der Schlußerhaltung zu treten, damit durch hinreichende Wärme- und Luftzufülırung die Streuzersetzung gefördert wird.

F o r st d ü ng ung. Die Frage der Oerlandaufforstung, wie der Umstand, daß die Forstwirtschaft auf großen Flächen nur sehr spärliche Erträge infolge Amut des Bodens an Pflanzennälurstoffen zu erzielen imstande ist, haben in neuerer Zeit zu ausgedehnten Versuchen über die Vöglichkeit der Erhöhung des vorhandenen Nährgehaltes des Bodens durch Zuführung natürlicher und künstlicher Düngemittel gefülurt. Jlan nennt die forstliche Freilandrlüngung, um sie von der längst üblichen und erfolgreichen Düngung der Saat- und Pflanzgärten zu unterscheiden, kurz Forstdüngung. 
Neben den ausgedehnten Versuchen, die seit rund 2 Jahrzehnten zuerst in Belgien und Holland $\left.{ }^{1}\right)$ mit künstlicher Düngung hei der Aufforstung von Oedlāndereien durchgeführi worden sind, verdienen die von der laanooverschen Provinzialforstverwaltung, dem Heidekultur-Yerein der Prov. Schleswig-Holstein, dem jütländischen Heidekultur-Verein, ferner die von den deutschen forstlichen Versuchsanstalten ausgefuhrten bezw. in Angriff genommenen Arbeiten Erwälnung. Besondere Anerkennung und Dank gebührt namentlich auch der Deutschen Landwirtschaftsgesellschaft, die durch Schaffung eines Sonderausschusses für Forstdüngungsversuche und durch Bereitstellung reicher $\mathbf{M l i t e l}$ eine wenigstens teilweise Lösung der praktisch wichtigen Forstdüngungsfrage in erreichbare Nähe gerūckt hat.

Aus der großen Zahł der bisherigen erfolgreichen bezw. ergebnislosen Forstdüngungsversuche lassen sich folgende Erfahrungen ableiten: die Forstdüngung hat nur Zweck auf den ärnsten und armen Böden, d. h. hauptsächlich auf unseren sandigen Kiefern- und Fichtenböden. Hier löst die Düngung die Aufgabe, die Bestandesbegründung zı elleichtern und der jungen Kultur über die ersten Jahre hinwegzuhelfen. In mittleren und höheren Alter der Bestände ist die Düngung so gut wie wirkungsłos. Wohl aber kann hier, sofern Trockentorfschichten ${ }^{2}$ ) vorlanden sind, durch Zuführung von Kialk und durch Bodenbearbeitung zur rascheren Zersetzung der Streu und dadurch zur Stickstoffanreicherung des Bodens beigetragen werden.

Auf allen mittleren und besseren Standorten unserer Waldungen ist Düngung nicht nötig. Sichtbare Erfolge zeitigt sie auf solchen Standorten nur dann, wenn der Boden in seinen oberen Teilen durch unzweckmäßige Behandlung gelitten hat.

$\mathrm{Da}$ die geringeren Waldböden nach den vorliegenden Nährstoffmangelversuchen ziemlich überwiegend Mangel an Stickstoff haben, heißt das Problem der Forstdüngung Stickstoffzufuhn. Diese kann mit Hilfe der künstlichen Stickstoffdünger (Salpeter, schwefelsanres Ammoniak) oder durch Auf- bezw. Einbringen vegetabiler Reste (Gründüngung, Waldstreu, Humus, Moorerde, Strolı, Kartoffelkraut) und endich durch Vor- oder Zwischenbau von Leguminosen und Stickstoff bindenden Holzarten, der Polinie und der Weißerle, geschehen.

Die Anwendung der liünstlichen sticlstoffdünger scheitert am Kostenpunkt; ihre Wirkung ist, verglichen mit dem Aufwand, zu liurz und zu gering.

Im forstlichen Betriebe kommen deshall, nur jene Stickstoffruellen in Betracht, die den Stickstoff zwar weniger intensiy wie Kunstdünger, dafür aber nachhaltiger zufülren. Das sind die genannten organischen Dungstoffe und Vor- bezw. Zwischenbau der sog. Stickstoffsammler $\left.{ }^{3}\right)$. Von letzteren leisten die Lupinen vielfach recht gute Dienste. Ihr Anbau setzt jedoch hin und wieder eine vorhergehende Düngung des Bodens mit Thomasmehl und Kainit voraus. Der geringeren Kosten wegen ist.

1) Vgl. I e r s l a l' pen, la culture des lupines el la restauration en Campine du sol épuisé des pinières. 1896. - R a m m, Ueber die Frage der Anwendbarkeit der Düngung im forstlichen Betriebe. 1893. - G i e r s b e rg, I iunstl. Düngung im forstl. Betriebe. 2. Aurl. 1903. - J e n $t \mathrm{se} \mathrm{h,}$ Bestandesdüngungen in den Niederlanden und in Belgien. Forstw. Zbl. 1901, 225. - H e $\mathrm{nz}$ e, Die Entwicklung der Forstdüngungsfrage. Tharandt. Jlrb. 1904, S. 149. - V a t e r, Anleitung zu1 Beschreibung von Versuchen zur Düngung von Freikulturen, das. 1904, 81. - D e r s., Die Tharandter Forstdüngungsversuche, das. 1910, 111. - S c h w a p p a c lı, Versuche über Forstdüngung und Bodenpflege. Zlselır. f. Forst- und Jagdw. 1907, 1+1. — H o r n b e r g e r, Einige Bemerkungen über Düngung in Valde, das. 1908, 230. - Düngungs-Versuche im Walde. Forstwiss. Zul. 1902, 28. - - S c h w a p a c h, Lie Dügung im forsil. Großbetriebe. Deutsche Forst-Ztg. $1910,925$.

2) P. E. If a ll er u. IV e is, Ueber d. Einwirkung des lialkes auf Buchemrohlunus. NaLurw. Ztschr. f. Land- u. Forstw. 1907, 52 flgde. - H e l b i g, Fiallidügung in Buchensamenschlägen, Forstwiss. Zbl. 1902, 120.

3) li $0 \mathrm{ch}$, Düngung durch lebende Pajilionaceen. A. F.- u. J.-Z. 1902, 11. - Eng l e r u, G 1 u t z, Gründüngungsversuehe in Pflanzschulen, Dtittlgn. d. schweiz. Zentralanstalt f. d. forst]. Versuchsw. VII. Bd. 319. - R e u B, Die Besenpfrieme als Amme der Fichte. Weikkirchn. forstl. Blätter, 1903. - M a $t \mathrm{th}$ es, Hittlgn. über Bau und Leben der Fichtenwurzeln und Untersuchung über die Beeinflussung des Wurzelwachstums durch wirtschafliche Einwirkungen. A. F.- u. J.-Z. $1911,1$. 
der Zwischenbau mit blauer Dauerlupine zu empfehlen. Außerdem kommt der Vitund Zwischenbau der stickstoffsammelnden Holzpflanzen, der Robinie auf Sandboden, der Weißerle auf kalkhaltigem Boden, vielfeicht auch der Besenpfrieme in Betracht, um auf geringen Böden die Bestandesbegründung zu erleichtern. Daß auch durch Zwischenbau von andern, durelı reiche Streuprodultion sich auszeichnenden Iolzarten im Pflanzenabfall dem Boden Stoffe zugefülırt werden können, die in plıysikalischer wie chemischer Hinsicht wertvoll sind, ist eine von der forstlichen Praxis längst benutzte Tatsache (Treibholz). Auf Kïicfernböden scheinen sich Berg- und Pechlkicfer in dieser Richtung zu bewähreı. Zweifellos liegen derartige IIilfsmittel zur Besserung des Nährgehaltes des Bodens der Forstwirtschaft auch nahıe, da die düngende Wirkung der Streu durch künstliche Düngung nur sehwer ersetzt werden kann. Geringe Böden, auf denen olıne künstliche Düngung aber nichts wäclıst, machen freilich bei der ersten Inbestaudbringung die Zuhilfenalıme organischer oder Mineral-Dünger erforderlich.

Leider hat sieh bei den Forstdüngungen, namentlich bei denen mit künstlichen Düngemitteln jedoch bis jetzt gezeigt, daß man im allgemeinen keine den Kosten der Düngung nur einigernaßen entsprechende Melıleistung der gedüngten Kulturen und Bestände erzielt. Es wäre aber falselı, nit diesem bisherigen Ergebnis über die Forstdüngungen den Stab brechen zu wollen. Einmal bedarf es, um in der Forstdüngungsfrage zu einem abschließenden Urteil zu gelangen, längerer Erfalırung, als zur Zeit zur Verfügung steht und weiterhin scheint es nicht richtig, die durch die Düngung gebotene Höglichkeit, arme ertragslose Böden einer wenn auch zunächst nur bescheidenen Ertragsfähigkeit zuzuführen. lediglich nach der Rentabilität zu beurteilen. 


\title{
VII. \\ Forsts chutz.
}

Ton

\author{
Hermann Fürst.
}

Mit zwei farbigen Tafeln.

H e B, Der Forstselutz 3. Aufl. 1898. N ö r d ling e r, Lehrbuch des Forslschutzes 1884. Gre be, Waluschutz und Walıpflege 1875 3. Aufl. von Kö $\mathrm{n}$ i g's Waldpflege. F ü s $\mathrm{t}$ (K a usch inger), Lehre vom Waldschulz 7 . Aufl. 1912. G u se, Aus dem Forstsehulz 1876.

\section{Einleitung.}

§ 1. Begriff. Die Lehre vom Forstschu $\mathbf{t} z$ soll uns in den Stand setzen, die mannigfachen Gefahren, welche dem Walde drohen, möglichst erfolg-

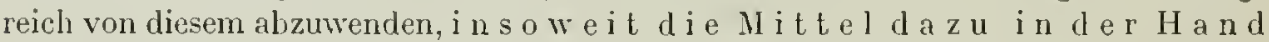
d es Wa Ideigentümers selbst liegen. Nicht selten aber reichen diese Mittel nicht aus, der Staat muß im Interesse der öfentlichen Sicherheit und Wohlfahrt eingreifen und den $W$ aldbesitzer in seinen Bestrebungen unterstützen; die desfallsigen Maßregeln gehören jerloch nicht in das Grebiet des Forstschutzes, sondern in jenes der Forstpolizei und Forstgesetzgebung, und liegen daher außerhalb des Rahmens unserer gegenwärtigen Aufgabe.

Um aber alle Gefalıren von unserem Walde möglichst abzuwenden, müssen wir zunächst diese Gefalıren selbst, die Ursachen ihrer Entstehung, die Art und W'eise ihres Auftretens k e n n e n, wir müssen wissen, ihnen möglichst vo r z u b e u g e $n$, endlich bei trotzdem eingetretenen Beschädigungen verstehen, diese tunlichst $\mathrm{z} u$ beschrän ken und ihre nachteiligen Folgen für den Walı wie für die Kasse des Waldbesitzers nach liräften a b z $u$ m i n d e r $n$.

$\S 2$. B e gr e n z u $\mathrm{n}$ g. Kieine unserer forstlichen Disziplinen ist wohl schwerer zu begrenzen, als die Lehre vom Forstschutz. AuBerordentlich mannigfaltig sind die Grefahren, die dem Walde von Seite der belebten wie der unbelebten Natur drohen; wir bedürfen der gesanten Naturkunde, der Zoologie und Botanik, der Kilimatologie und Bodenkunde, un die nötige Kíenntnis dieser Gefahren und dadurch die Möglichleit der Abwehr zu erlangen. Die Mittel der Abwehr und insbesondere jene der Torbeugung liegen aber auch zum nicht geringen Teil auf dem Gebiete der Lehre vom Waldbau, von der Forstbenutzung und Forsteinrichtung - und dies Verhältnis hat sogar dazu geführt, daß man der Lehre vom Forstschutz das Recht, als eigene Disziplin aufzutreten, bestritt, ihre Lehren teilweise der Forst-Zoologie 
und Botanik, teilweise den oben genannten forstlichen Disziplinen zuweisen wollte. Wir glauben: mit Unrecht, glauben, raB eine vollständige und übersichtliche Zusammenfassung der Lehre rom Forstschut\% unberlingt nötig und deren Unterbringung in den andem forstlichen Fächern in auch nur einigernaBen vollständiger Weise ohne Zwang nicht möglich sei, und möchten daher das Recht les Forstschutzes, als eigene Disziplin aufzutreten, entschieden wahren ${ }^{1}$ ).

Die oben berührte Schwierigkeit der sachgemäßen Begrenzung unserer Disziplin tritt aher auch zu Tage, wenn wir deren Hand- und Lehwbücher vergleichen. In dem einen finden wir der Botanik, im andern der Zoologie eine verhältnismäBig weite Ausdehnung gegehen; die ilteren Werke ziehen das Gebiet der Forstbenutzung Lerein oder lassen insbesondere die scharfe Trennung von Forstschutz und Forstpolizei vermissen. Auch die Frage, in wieweit die Lehre von den Servituten und deren Nachteilen für den Walu in das Gebiet des ersteren gehöre, hat verschiedene Beantwortung gefunden. - Unsere Aufgabe wird hier sein, das Gebiet des For'stschutzes möglichst scharf zu umgrenzen und aus allen den obengenannten Disziplinen nur das unumgänglich Nötige beizuziehen.

$\$ 3$. E i n le itu $\mathrm{ng}$. Die Glierlerung unserer Disziplin erfolgt naturgenäß nach den Ursachen der Gefahren und Beschädigungen, die unsem Waldungen drohen, und es erscheinen als solche Ursachen:

I. II ensehliehe $\mathrm{H}$ a $\mathrm{u}$ ol $\mathrm{u} u \mathrm{~g}$ en, als Eingriffe in das Eigentum des Waldbesitzers, als fahrlässigre oder alısichtliche Beschädigungen des Waldes und seiner Produlite.

I1. Einwirkungen der orga $\mathrm{n}$ i s e h e n $\mathrm{N}$ a $t$ u r, als liemmende, beschädigende oder zerstörende Tätigkeit

1. der Tierwelt,

2. der Pflanzenwelt.

III. Beschädigungen durch Erscheinungen der a n o r g a n is c h en $\mathrm{N}$ a $\mathrm{t} u \mathrm{r}$; solche Erscheinungen sind:

1. Niedere oder hohe Temperatur: Frost und Hitze.

2. Atmosphärische Niederschläge: Regen, Schnee, Duft, Eis, Hagel.

3. Blitzschlag.

4. Heftige Luftströmungen: Winde und Stürme.

5. Ungünstige Bodenbeschaffenheit: Nässe, Flugsand.

IV. Kr a n he it en der Holzgerächse.

\section{Gefïludnugen durch menschliche Handinngen.}

\section{Nähere Bezeichnung.}

$\S 4$. Ein Blick auf die zahhreichen devastierten oder doch in ihrem Ertragsvermögen weit heruntergebrachten. Waldungen in unserem engeren Vaterland wie in noch viel hölıerem Grad in der Melurzahl unserer Nachbarländer sagt uns, daß der Mensch zu den gefährlichsten Feinden des Waldes gehöre. Habgier und Umverstand der Waldbesitzer selbst, Ein- und Cebergriffe der Forstberechtigten sin.l im Verein nit Entwendungen und Beschädigungen seitens fremder Personen vorwiegend die Ursachen jener traurigen Waldzustäncle.

Gegen die nachteiligen Eingriffe des eigenen Besitzers vermag der Forstschutz nicht zu helfen, und nur Belehrung und die almählich steigende Einsicht einerseits, wie eine energisch gehandhabte Forstpolizei anderseits - insoferne dieser

1) Vergl. A. F.- U. J.-Z. 1884. S. 305. 
eine entsprechende Forstgesetzgebung zur Seite steht - vermögen hier einigermaßen Besserung zu schaffen. Nul gegen fre $m$ de Eingriffe lchrt uns der Forstschutz unsere Waldungen schützen, gegen Gefährdungen, die sich entweder auf die eigentliche Substanz des Waldes, dessen Gre n z e n, oder auf dessen verschiedenartige Prod u k t e beziehen. Auch die Gefahr des W a l d b ra n d e s wird wohl zweckmäBiger hier als hei Abschnitt III eingereiht, da es fast stets die fahrlässige oder frevelhafte Hand des Menschen und nur sehr selten die Natur (durch Blitzsehlag) ist, die diese Gefahr hervorruft. - Als eine neue hicrher zu rechnende Schädigung der Waldungen ist seit einigen Jahrzehnten in mit dem Wachstum der Industrie stets steigendem Naße jene durch den industriellen Werken entweichende Gase aufgetreten; man bezeiclinet sie als $\mathrm{R}$ a u $\mathrm{chs} c \mathrm{~h}$ ä d e $\mathrm{n}$.

\section{Sieherung der Waldgrenzen.}

5. Grenzzeichen. Von dem Augenblick an, da Grund und Boden aus dem gemensamen Besitz in Sondereigentum überging, war eine Bezeichnung der Grenzen zur Sicherung des letzteren geboten, und es dienten hiezu in erster Linie die sog. n a tü r l i c he n Grenzzeichen: Wasserläıfe. Bergrücken und Talsohlen, W'ege, Felsen, Bäume; die beiden letztgenannten wurden hierbei meist durch eingehauene Zeichen besonders kenntlich gemacht. Nicht immer aber reichten diese natürlichen Grenzzeichen aus, zumal mit fortschreitender Parzellierung des Grundbesitzes, mit seinem steigenden Wert, der eine genaue und sichere Bezeichnung der Grenzen notwendig machte; man griff daher zu k ün s t li chen Grenzzeichen: Steinhaufen, Hügeln, Winkelgräben, Pfählen und eingesetzten Steinen, bisweilen selbst zur Bezeichnung ganzer Grenzlinien durch Gräben, Hecken, Aufhiebe. Gegenwärtig finden wir etwa mit Ausnahme des Hochgebirges, in welchem die natürlichen Grenzzeichen noch eine Rolle spielen, als Grenzzeichen fast allenthallın die Gr e n zs te in e als dauerhaftestes und sicherstes Material in Anwendung.

Diese Grenzsteine werden bisweilen in rauher, lesser aber in belıuener Gestalt, durch welche jeder Irrtum ausgeschlossen ist, aus möglichst dauerhaftem Material (Basalt, Dolomit, Granit, harte Sandsteine) hergestellt und meist mit bestimmten, den Waldeigentümer kennzeichnenden Buchstaben, sowie um jede Waldparzelle fortlaufenden Nummern bezeichnet - es gilt dies wenigstens für Staats- und Gemeindewaldungen als Regel - nicht selten auch auf dem Kopf mit Visierlinien, welche nach den Nachbarsteinen weisen, versehen.

$\S 6$. Herstellung der. Vermarkung. Unter Vermarkung versteht man die Bezcichnung einer Grenze mit festen Grenzzeichen, und gilt eine solche in allen Iiulturstaaten als Regel. Das bürgerliche Gesetzbuch für das Deutsche Reich bestimmt (\$919) ausdrücklich, daß der Eigentümer eines Grundstückes von dem Angrenzer die Nitwirkung zur Errichtung fester Grenzzcichen in landesgesetzlicher oder ortsüblicher Weise, sowie zur Wiederherstellung schadlaft gewordener Grenzzeichen fordern liann, wobei die Kosten zu gleichen Teilen zu tragen sind. - Der Vermarkung hat stets die Regulierung etwa strittiger Grenzen in gütlichem Einvernehmen oder auf dem Piechtsweg vorauszugehen.

Bei der Vermarliung wird nun in erster Linie jeder Winkelpunlit mit cinem Grenzzeichen bezw. Grenzstein verselıen; ist die Entfernung von cinem Grenzstein zum andern eine sehr große, so werden je nach Bedürfnis ein oder einige Zwischensteine, sog. L a u f e r. auf die Grenzlinie in der Weise gesetzt. daß man stets bequem von einem Grenzstein zum andern sehen kann. - Das Setzen der Grenzsteine erfolgte 
früher in einfacher Weise gemeinsam durch die beiden Angrenzer, pflegt aber seit längerer Zeit gesetzlich allenthalben durch die s. g. Feldgeschworenen oder Siebener stattzufinden, die in jeder Gemeinde aus der Zahl der unbescholtenen Männer (meist in der Siebenzahl) gewählt werden. Dieselben nehmen in Gegenwart der vorgeladenen Angrenzer das Einsetzen der Grenzsleine vor, wobei jedoch kein Zweifel über die Richtigkeit des Grenzpunlites bestehen darf; bestehen solche Zweifel oder lıandelt es sich (bei Grundabtretung, Teilung etc.) um Feststellung neuer Grenzjunlite, so hat stets die Bezeichnung der Grenzpunkte durch den verpflichteten Geometer vorauszugehen. Nur hiedurch ist es auch möglich, eine richtige Landesvermessung aufrecht und die Katasterpläne auf dem Stand der Gegenwart zu erhalten.

Um über den Standort eines irgendwie zu Verhust gehenden Steines möglichst sicheren Anhalt zu geben, legen die Feldgeschworenen vielenorts unter die zu setzenden Steine Unterlagen von unverweslichen Materialien, wie gebrannte Steine oder Zeichen, Porzellan- oder Glasscherben, Kohlenstüclie; diese geben insbesondere auch in jenen Fällen, in welchen zur Vermarkung keine regelmäßig behauenen Steine verwendet werden, darüber AufschluB, ob man es mit einem Grenzstein oder einem beliebigen andern Stein zu tun hat. Diese Zeiclıen werden bisweilen in bestimmter, nur den vereidigten Feldgeschworenen beliannter Weise gelegt und ron diesen als Geheimnis belıandelt.

s 7. Unterhaltung der Vermarkung. Angesichts der Wichtigkeit, welche die genaue und dauemde Feststellung einer Waldgrenze hat, wie der Kosten, welche die Herstellung einer Vermarkung für einen größern Waldkomplex verursacht, ist es Aufgabe der einschlägigen Beamten, fül eine entsprechende I n$\mathrm{s} t \mathrm{a} \mathrm{n}$ d h a $1 \mathrm{t} u \mathrm{n} g$ der Grenzzeichen Sorge zu tragen. Diese letztern sind in mannigfacher Weise bedroht: sie werden an Wegen nicht selten umgefahren und zerbrochen, sind an Gräben, Gehängen, in weichem Boden dem Umsinken oder Abrutschen ausgesetzt, weichere Steine werden durch Verwitterung und Zerfrieren zerstört, und nur eine stete Aufsicht vermag die Grenzen in stets guten Stand zu erhalten.

Eine solche ist daher auch Pflicht der Forstbeamten, und es erscheint deshalb nötig, daß das Forstschutzpersonal alljährlich, der einschlägige Verwaltungsbeamte wenigstens in nicht zu langen Zwischenräumen die Grenze von Stein zu Stein begehe, das Vorhandensein jeden Steines und dessen normalen Zustand konstatiere und allenfallsige Gebrechen notiere; die Hebung letzterer erfolgt sodann auf Anrufen durch die Feldgeschworenen unter Beiziehung der Angrenzer.

Das Geschäft des Grenzbeganges wird erklärlicherweise in hohem Grad erleichtert, allen Irrungen bei Holzfällungen, Streunutzung usw. in sicherster Weise vorgebeugt, wenn die Grenzhinien offen gehalten, von Holzwuchs, Gestrüpp, überlıängenden Aesten stets gereinigt werden; nur hiedurch ist die Möglichkeit, von einem Stein zum andern zu sehen, die Grenze sofort mit Bestimntheit zu erkennen, gegeben, während verwachsene Grenzlinien zu den mannigfachsten frrungen und Streitigkeiten Veranlassung geben können. Man pflegt daher die Grenzlinien im Benehmen mit den Angrenzern auf mäßige Breite, etwa meterbreit, durchzufluchten und diese Grenzlinien stets von allem Holz- und Unkrautwuchs tunlicbst rein zi halten.

Der Gefahr einer Beschädigung sind am meisten jene Grenzsteine ausgesetzt, welche unmittelbar an den häufig längs der Grenzen verlaufenden Weger stehend durch Anfahren mit Fuhwerken bedroht sind. Man sucht diese Steine dadurch zu schützen, daß man sie tief in den Boden setzt oder ihnen durch Abweissteine, eingeschlagene Pfähle u. dgl. den nötigen Sclutz gibt; ist der Weg etwa gemejnsames 
Eigentum der beiden Besitzer, so setzt man die Grenzsteine meist abwecliselnd rechts und links des Weges.

Besondcre Aufmerksamkeit bedarf die Waldgrenze auch dort, wo sie längs des Feldes veläuft, indem hier Uebergriffe durch Ueberackern, Ablagern zusammengelesencr Steine aus den Feldern u. dgl. nicht selten zu sein pflegen. Den sichersten Schutz gewährt in solchen Fällen ein Grenzgraben von cntsprechenden Dimensionen.

Das oben bereits crwälnte, nit dem 1. Januar 1900 in Kraft getretene Bürgerliche Gesetzbuch füı das Deutsche Reich trifft in den $\$ \$ \$ 903$ u. ff, eine Reilıe bezüglich der Grenzen und res s. g. Nachbarrechtes wichtiger Bestimmungen. Es setzt fest, daß das Recht des Grundeigentümers sich auch auf den Raum über und auf den Erdliörper unter der Oberfläche erstrecke; demgemäß hat ersterer das Recht, über die Grenze in sein Grundstück gewachsene Wurzeln abzuschneiden und zu behalten, ebenso herüberhängende Zweige, wenn deren Beseitigung durch den Besitzer des Nachbargrundstückes nicht innerhalb angenessener Frist erfolgt - vorausgesetzt, daß Wurzeln und Zweige die Benutzung des Grundstüclies beeinträchtigen. Auf ein Nachbargrundstück fallende Früchte eines Baumes gclten als Früchte dieses Grundstïclies, ein auf der Grenze stehender Baum gehört den Nachbarn zu gleichen Teilen.

\section{Sehutz der Waldprodukte.}

\$ 8. Forstfrevel durch Entwendung. Fiein Vergehen gegen das Eigentum pflegt bekanntlich häufiger zu sein, als die Entwendung von Forstproduliten, und die Statistik weist in manchen Gegenden hicrüber geradezu elschreckende Zahlen anf. Die Gründe dieser Erscheinung sind mannigfache: sie sind zu suchen zunächst in der verhältnismäßig schwierigen Beschützung der Waldprodukte, insbesondere bei großen Aufsichtsbezirken, parzellierter Lage der Waldungen, dem Vorhandensein bevölkerter oder armer Ortschaften in der Nähc und selbst inmitten der Waldungen. Im Weiteren sind viele Produkte des Waldes dem Menschen teils für sich, teils für seine Haustiere reradezu unentbehrlich: so das Holz zumal im strengen Winter, das Gras und die Streu in Jahren des Futter- nud Strohmangels, - unil werden naclı deun alten Sprüclwort, daß Not kein Gebot kcuse, trotz guter Aufsicht aus dem Walde cntwendet; oder es dienen diese Produlite lndustriezweigen (Anfertigung von Pechen, Besen, liörhen u. dgl. m.), die von der ärmeren Bevölkerung betrichen werden, weich' letztere sich auf möglichst billige Weise, d. h. also in Weg des Diebstahls, in den Besitz des Rohmaterials zu setzen sucht.

Niclıt wenig trägt aber die aus früheren Zeiten stammencle und im Volk noch sehr allgemein verbreitete, durch die Gesetzgebung selbst der ncuesten Zeit unterstützte Anschaumng von der geringen Verwerflichlieit und Strafbarkeit der Entwendung von Forstproduliten zur Vermehrung der Zahl der letztern bei. Schon die an den meisten Orten übliche Bezeichnung ,Forstfrevel" an stelle des korreliteren Wortes ,Forstdiebstahl" ferner die Behandlung dieser Gesctzesverletzung als einer Lebertretung und nicht als eines Vergehens gleich jedem andern Diebstahl, die Bestrafung mit Geld, subsidiär mit Haft an Stelle der schimpflicheren Gefängnisstrafe - alle diese Ilomente zusammen sind sicher mit daran Schuld, wenn wir die Zahl der Forstfrevel vielfach eine so hohe werden sehen. Als deutlichster Beweis dafür, welchen Einfluß dic Art der Bestrafung hicr ausübt, dient die Wahrnelumung, da 3 die als Die bsta $\mathbf{l}$ I bestrafte Entwendung bereits aufgcarbeiteten Holzes verhältnismäßig selten vorzulionmen pllegt! 
Erfreulichemeise zeigt jedoch die Statistik fast aller Länder eine ganz wesentliche Abnalıne der Zahıl der Forstfrevel, dic mit der hesseren Lebenshaltung der ärmeren Volksschichten in engem Zusammenlang steht.

Die Nachteile, welche dem Wald durch Entwendungen zugehen, sind teils geriuger, teils schwererer Art. Ilanche Entwendıngen, wie Lürrholz, Gras voı Ocdungen, Streu aus Gräben und Wegen, schädigen den W a 1 d direlit gar nicht, sondern nur etwa dje Kasse des Waldbesitzers, während durch Grünholzfrevel der Schıßu unterblochen werden kann, Astholzfrevel die Bäume schädigen, Grasfrevel die Kulturen gefährden, wiederholte Streuentwendungen zur Vermagerung des Bodens führen. In der Nähe von Ortschaften werden durch die genannten Frevel bisweilen ganze Bestände geradezu devastiert.

\$ 9. Forstrevel durch Beschä d igu g g. Unverstand und Unvorsichtigkeit, Gewinnsucht, Ilutwillen, Bosheit sind die .Iotive, aus denen Beschädigungen der Waldungen hervorgehen.

Durch Unvorsichtiglieit und Ungeseli cklichkeit ergeben sich insbesondere Beschäcligungen des stehender älteren Holzes und des jungen Nachwuchses in natürlichen Verjüngungen we anstoßenden Beständen bej der Fä]lung, Aufarbeitung und Abfuhr des Holzes, nicht selten also durch unsere eigenen Arbeiter.

Beschädigungen aus $\mathrm{Gew}$ innsuch $\mathrm{t}$ stehen in engem Zusammenhang mit Entwesdungen, wobei nicht selten der Schaden den Wert des entwendeten Objektes überstejgt. Hierher würde beispielsweise zu rechnen sein: das Anreißen von Tadelholzstämmen zum Zweck späterer Harzgewinnung, das Ausscharren alter Harzrisse, das Kienholzhauen, Zapfenbrechen u. s. f. Auch die oft so maBlos und devastierend in Weg des Frevels geübte Waldweide wäre hierher zu zählen, da der von dem Vieh durch Verbeißen der Holzpflanzen verursachte Schaden den Wert des verzeluten Grases weit übersteigt.

Nicht selten sind leider auch jene Beschädigungen, welche aus $\mathrm{M}$ u $t$ w $\mathrm{i}$ I $\mathrm{e}$ I oder $\mathrm{B}$ os heit und $\mathrm{R}$ a c hs u ch $t$ dem Walde zugefügt werden: das Abbrechen oder Entrinden junger Stänme seitens mutwilliger Bursche, die absichtliche Brandstiftung seitens bestrafter Holz- und Wildfrevler mögen hier genannt sein.

$\$ 10$. Verhütung von Forstfreveln. Das Hauptmittel, um Forstfreveln jerler Art vorzubeugen, ist ein energisch gehandlabter Forstschutz, die Aufstellung eines ausreichenden und eifrigen Schutzpersonales, das seitens der Venwaltungs- und Inspektionsbeamten genügend überwacht scin muß. Allerdings muB dessen Tätigkeit auch durch ein hinreichend strenges Forstgesetz unterstützt werden, da zu milde Strafen nicht die nötige abschreckende Wirkung üben; der Erlaß eines solchen liegt jedoch nicht in der Hand der IValdbesitzer und Forstbehörden, sondern in jener der Gesetzgebungsfalitoren eines Landes.

Durch zweckmäßige Dienstesinstrulitionen muß die Tätigkeit des Schutzpersonales geregelt sein, eine gute Holzhauerinstruktion in Verbindung mit entsprechender Leberwachung der Holzhaner wird den oben erwähnten Beschädigungen bei Fällung und Aufarbeitung des Holzes tunlichst vorbeugen. - Aber auch den Freveln durch Entwendung wirl der g r ö B e r e ITaldbesitzer einigerma ßen vorbeugen können : durch Rüclisichtnahne auf die Bedürfnisse der ärmeren Anwohner des Waldes, der kleinen Landwirte und Gewerbetreibenden, und tunlichste Befriedigung dieser Bedürfnisse so durcl Gestattung der Leselolznutzung, Abgabe von Waldgras und Streu in Notjahren, von Strcusurrogaten jeder Art, von Besenreis, Rechenstielen und dergl. um billige Taxe. 


\section{Schutz gegen Waldbrände.}

§ II. Entstehung. In den weitaus meisten Fällen ist es direkt oder indirekt der Mensch, durch welchen Waldbrände entstehen, und hiedurch rechtfertigt sich wohl anch ihre Besprechung in diesem Abschnitt; nur ausnahmsweise ist es der Blitz, der alte trockenfaule Stämme entzündet, die Zah] der Fälle, in welchen dies lonstatiert wurde, ist jedoch eine geringe.

Die überwiegende Mehrzahl von Waldbränden entsteht durch Un v o r s i c ht i g k e i t und F a h r lä s s i g k e i t, nicht selten unserer eigenen Waldabeiter: so durch Anzünden von Feuer an gefährdeten Stellen. Unterlassen entsprechenden Auslöschens beim Verlassen; Mangel an Vorsicht bei dem Brennen von Rasenasche, dem Verbrennen von Rinde und Reisig behufs Vertilgung schädlicher Inseliten, dem Ueberlandbrennen im Hackwald u. dgl. In weiteren entstehen nicht selten Waldbrände durch weggeworfene glimmende Zündhölzchen und Zigarrenstummel, glühende Pfeifenasche 1 . ä., wie dies namentlich das häufigere Vorkommen von Waldbränden in der Nähe größerer Städte, betretener Wege, an Sonn- und Feiertagen beweist.

Als eine nicht seltene Ursache von Waldbränden erscheinen in den von Eisenbahnen durchschnittenen Waldungen, insbesondere den trockenen Kiefernlıeiden, die ausfliegenden $\mathrm{L}$ o k o $\mathrm{m}$ o t i v f u $\mathrm{n}$ k e $\mathrm{n}$ (oder richtiger: ghühende Kohlenstückchen). Endlich aber sind $\mathrm{II}$ u $\mathrm{t}$ w i 11 e n und B o s h e it leider auch in gar manchen Fällen die Entstehungsgründe ${ }^{\mathbf{1}}$ ).

$\$ 12$. A r t des A u tretens. Man unterscheidet nach der Art des Auftretens Boden- oder Lauffeuer, Gipfel- oder Kronenfeuer, Stammfener und Erdfeuer.

An häufigsten tritt das Feuer auf in Gestalt des B o d e n-oder L a u f f e u e r s, entstehend durch die Entzündung des trockenen Bodenüberzuges, namentlich dürren Grases, trockener Heide, weniger des Mooses oder Laubes, welch' letzteres dicht geschichtet liegend nur schwer weiter brennt. Es sind demgemäß vor allem die jungen noch nicht geschlossenen Schläge, in denen das Lauffeuer zu fürchten ist, dann ältere lichter stehende Bestände mit trochenem Bodenüberzug.

Schließen sich an den brennenden Schlag Dickungen namentlich der leicht brenubaren Föhre, so ergreift das fortschreitende Feuer die Aeste und Wipfel zuerst der jüngeren, dann wohl auch der älteren Bestände und aus dem Bodenfeuer wird das verheerende Gipfel-oder lironenfeuer.

$\mathrm{S} t$ a $\mathrm{m}$ m f e e r, die Entzündung eines einzelnen Stammes, kommt nur an alten, schadhaften, trockenfaulen Stämmen vor - als Folge des Blitzschlages, oder verursacht durch Ausräuchern eines Marders oder wilden Bienenstockes, durch mutwilliges Anschüren von Fener im lıhlen Stamm, und tritt natürlich nur selten auf; noch seltener wohl das Erdf euer, die Entzündung torfigen Bodens bei großer Trocknis dureh irgend welche Unvorsichtigkeit ${ }^{2}$ ).

1) Eine Statistik für die bayr. Staalswaldungen für die Jahre $1882-1899$ inkl. Weist 1755 Waldbrände nach, von welchen entslanden sind durch Blitzschlag

, Lokomotivfunken nachweislich mutmaßlich

", Fahrlässigkeit

, Brandstiftung jeder Anhalt fehlend bei 65 Fällen.

2) Die oben erwähnte Statistik für die bayr. Staatswaldungen weist untel 1:55 Fällen nach Bodenfeuer

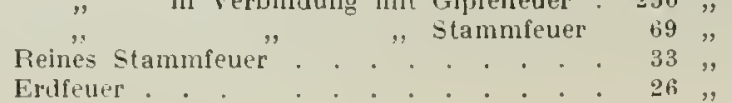


$\$ 13$. Ze it und $\mathrm{O}_{\mathrm{I}^{\circ} \mathrm{t}} \mathrm{des} \mathrm{Auft} \mathrm{retens}$. Die meisten Waldbrände entstehen nicht, wie man wohl anzunehmen geneigt ist, im heißen Sommer, sondern viel häufiger im trockenen Frühjahr in den Nonaten Järz, April, Nai. Die große Zah! der zı jener Zeit in Wald besclıäftigten Venschen - Holzarbeiter, Fuhrleute, Fulturarbeiter -, der vorhandene trockene Bodenüberzug von abgestorbenen Gräsern und Unkräutern, zwischen denen noch die schützende grüne Bodendecke nicht hervorgewachsen ist, erklärt wohl diese Tatsache zur Genüge ${ }^{1}$ ).

Was die Oertlichkeiten betrifft, in denen Waldbrände besonders zu fürchten sind, so sind es vor allem die Schläge mit trockenem Bodenüberzug, in denen das Lauffeuer reichlich Nahung findet, geringe Standorte mit ihrer leichter bremnbaren Bodendecke ven Angergräsern und Heide, ilırer überhaupt in höherem Grad als das Laubholz gefährdeten Nadelholzbestockung. Die Föhrenwaldungen auf armenı Sandboden stehen bezüglich ihrer Gefälırdung obenan und nirgends treten Waldbrände in Deutschland häufiger und in größerer Ausdehnung auf, als in den ausgedehnten Kiefernheiden Norddeutsch!ands.

$\$$ 14. Folgen der $\mathrm{W}$ a l d b r ä n d e. Als unmittelbare Folge eines Waldbrandes erscheint die Zerstörung der betroffenen Bestände. Die Pflanzen, welche in den Schlägen vom Bodenüberzug Limgeben standen, verbrennen entweder direkt (Nadelhölzer) oder sterben infolge der erlittenen Beschädigungen unfelılbar ab; ebenso jene Nadelholzbestände, in welchen ein Gipfelfeuer gewütet hat, das die Benadelung und die sclıwächern Aeste verzehrt, ảie Stämme aber natürlich zurückläßt. - In älteren Beständen dagegen und bei Holzarten mit dickborkiger Rinde (Fölre) bleiben Lauffeuer namentlich bei nur schwächerem Bodenüberzug nicht selten ohne nachteilige Folgen, in andern Fällen dagegen kränkelt der betroffene Bestand und mub zum Hieb gezogen werden.

$\mathrm{Zu}$ dem direkten Verlust gesellen sich insbesondere bei größeren Brandflächen - und solche haben sich in einzelnen Fällen schon über Hunderte von Hektaren erstreckt ? -, deren sofortige Aufforstung nicht bewerkstelligt werden kann, noch eine Reihe anderweiter Nachteile: Verwilderung des Bodens durch in Jenge auftretende Forstunkräuter, Vermagerung des etwa an sich geringen Bodens infolge der Freilegung, Entstehen von Sandschollen auf zum Flüchtigwerden geneigtem Standort. Aurch schädliche Forstinsekten stellen sich ein: Wurzelbrüter in den absterbenden Wurzeln und Stöcken, Borkenkäfer in dem liränkelnclen Stammholz, und bedrohen, sich massenhaft verbreitend, die Nachbarbestände.

$\$ 15$. Vorbeugungs- Ma Brege In. Von ganz besonderer Wichtigkeit sind jene NaBregeln. Welche dem Entstehen von Waldbränden wie deren g r ö B e rer A us d e hnu ng vorbeugen; als solche erscheinen ${ }^{3}$ ):

Beobachtung der nötigen Vorsicht bei Vornalume aller mit den Anzïnden von Feuer imWald verbundenen Arbeiten, wie solche in $\$ 11$ näher bezeichnet wurden; Erlaß strenger Vorschriften ïber das Anzünden von Feuer in Walde überlıapt, wie durch die eigenen Arbeiter; Verbot des Rauchens im Wald zu gefälurlicher Jahreszeit; Entfermen brennbarer Bodenüberzüge in besonders gefälurdeten Oertliclıkeiten, an viel betretenen Wegen, namentlich in der Näle gröBerer Städte. Belassen b r e it e $r$ Schutzstreifen bei großen zusammenhängenden Aufforstungen, insbesondere

1) Von den 1755 Brandfâllen treffen

1156 auf die Monale März, April, Mai

468 " " , Juni, Juli, August

131 " " " " September bis Februar.

2) Vergl. die Waldbrandchronik in $H \in B$, Forslschulz (3. Aufl.) Bd. 2, S. 520 .

3) Vergl. Ki i n i z, Jlaßregeln gegen Waldbrănde, Forsslw. Z.-Bl. 1903, §. 399.

Handb. d. Forstwiss. 3. Auf. II. 
im Heidegebiet; Errichtung von Wachttürmen in großem gefährdetem (Iïefern-) Gebiet, ev. mit Signalvorrichtung (System S e i t z), Deponierung von Löschgeräten in Forsthäusern; erhöhter Schutzdienst zu gefährlicher Zeit, bei großer Trochne, an Sonn- und Feiertagen.

Besondere Vorsichtsmaßregeln sind längrs der $\mathrm{B}$ a h n lin i n namentlich dort nötig, wo sie die trocknen Kiefernwaldungen der Ebene durchschneiden. Eine dauernde Freihaltung der s. g. Bahnlichtungen von Holz ist nach $\mathrm{ki}$ ie $\mathrm{n}$ it z's Beobaehtungen in keiner Weise nötig, denn nie entzünden die glühenden Kiohlenstückchen einen Baum, sondern stets nur den Bodenüberzug. Ton brennbarem Ueberzug sind daher die $12-15 \mathrm{~m}$ breiten Streifen längs der Bahn frei zu halten, durch meterbreite Wundstreifen zu isolieren, die Bestockung auf denselben von den untern Aesten zu befreien; eine Bestockung verlindert den weiteren Flug der Funken, die u $\mathrm{n} s \mathrm{ch}$ äd $\mathrm{lich}$ in den Schutzstreifen niederfallen.

Aufgabe der Forst polizei wird es sein, durch die nötigen gesetzlichen Vorscliriften über das Anmachen von Feuer im Wald überhaupt, den Gebrauch von Fackeln, das Rauchen in Walde, die Reinhaltung von Eisenbahnlichtungen usw. die Bemühungen des Waldbesitzers zu unterstützen.

In jenen Oertlichkeiten, in welchen die Gefahr der Waldbrände eine besonders große ist - also besonders in ausgedehnten Föhrenbeständen mit trocknem Standort - sucht man durch die Anlage von Brandschneißen oder Feuerbahnen, dam von Sicherheitsstreifen oder Feuermänteln wenigstens die Ausdehnung des Feuers zu beschränken, die Bekämpfung zu erleichtern. Durch ein entsprechendes Netz sich rechtwinklig kreuzender Schneißen wird der Wald in mäßig große Abteilungen zerlegt, man gibt diesen zugleich als Thege dienenden Schneißen keine zu geringe Breite und hält sie stets rein von Unkraut; die senkrecht zur herrschenden Windrichtung verlaufenden Schneißen aber werden mit einem 5 - $10 \mathrm{~m}$ breiten Streifen Laubholzes bepflanzt, das als Schutz gegen Boden-wie Gipfelfeuer gute Dienste zu leisten vemnag, und hezeichnet man diese Laubholzstreifen als ,Feuermäntel“.

\$ 16. Löschung von Wa ldbränden. Ein erst im Entstehen begriffener Waldbrand kann oft von einem oder einigen Menschen gelöscht werden, während derselbe, zu gröBerer Ausdehnung gelangt, nicht selten jeder Anstrengung souttet ${ }^{1}$. Rasches und energisches Eingreifen ist deshalb von größter Bedeutung, die Herbeischaffung der nötigen Arbeitskäfte, ilure sachgenäße Verwendung und Leitung die Aufgabe des einsehlägigen Forstpersonales.

Bodenfener wird am zweekmäBigsten lurch A us s c h l a g e n, oder besser gesagt rurch A u s f e g e n oder A u s d r ü ck en mit belaubten Zweigen gedämpft, und in vielen Fällen reicht man damit aus; man rüclit dem Feuer von den Seiten her zu Leihe, la Hitze und Fauch den Angriff von der Stirne oft unmöglich machen, und engt es hiedurch mehr und melır ein his zum völligren Erlöschen. Das Abräumen des Bodenüberzuges ist meist zu zeitrambend, bei schon größerer Ausdehnung des Feuers, stärkerem Luftzng und dadurch erschwertem Löschen aber in der Weise anwendbar, daß man in der Windrichtung in hinreichender Entfernung von der Brandstätte eizen genügend breiten Streifen mögliclıst von allem brennbaren Iaterial reinigt, damit das Feuer hier aus 1 langel an Nahrung erlischt; die Benutzung von Sclineiben und alten Wegen erleichtert diese Arbeit wesentlich, und es erweisen sich auch hier die stets rein gehaltenen Brandschneißen als sehr förderlich.

1) In der bekannten Tuchler Heide brannle in Jahr 1863 binnen 3 Tagen eine Fläche von 1276 ha ab, in der Gegend von Aachen in Jahr 1900 eine solche von 900 ha. Einer der gewaltigslen Waldbrände war wohl jener im Jahre 1905 auf der Herrschaft Primkenau in Preußen, der sich über nahezu 5000 ha erstreckle! 
Schwieriger ist die Belämpfung eines Waldbrandes, wenn aus dem Bodenfeuer bereits Gip felf e u e r geworden, und nicht selten macht dam das entfesselte Element, durch stäkeren Wind unterstützt, jede menschliche Anstrengung vergeblich, erst dann erlöschend, wemn ihm ein breiter Kalılsehlag oder die erreichte Waldgrenze Halt gebieten. Unterhreclung des Schlusses ist hier das einzige Hi]fsmittel; man suclıt diese durch rasches Breiterhauen rorhandener Wege und Schneißen, unter Benutzung etwaiger Brandschneißen und Feuermäntel, zu erreichen und beginnt auch hier, wie bei dem oben erwälnten Reinigen von Bodenstreifen, in genügender Entfernung ron der Brandstelle, um nicht während der Arbeit vom Feuer überrascht zil werden.

Als ein zwar etwas beden]iliches und darum nur bei großer Gefahr anzuwendendes Ulittel, das aber in manchen Fällen gute Dienste geleistet, dient bei Bodenfeuer wie bei Gipfelfeuer das sog. Ge ge n $f$ e u e r: das Anzünden des brennenden Schlages, der hrennenden Dickung an der dem heranzichenden Feuer entgegengesetzten Seite, damit das letztere, einen bereits abgebrannten Streifen vorfindend, hier erlösche. Es erfordert die Anwendung dieses gefährlichen Mittels große Vorsicht, damit nicht im Gegenteil der Brand in die anstoßenden unter Wind liegenden Bestände gretragen werde, und es muß die Linie. Jängs welcler das Gegenfeuer angezündet werden soll, gut nit Arbeitern besetzt sein; der Luftzug, welcher nach einer größeren Brandfläche zu vom allen seiten her zu entstehen pflegt, lat clie günstige Wirliung, daß das Gegenfeuer bei Herannaken des Feuers direkt gegen den herrschenden Wind, also nach der Brandstätte zu brennt.

St a m m f e u e $r$ wird dureh $V$ e rs t op f e n der Oeffmmgen hohler Stämme vor oder nach dem Fällen derselben gelöseht, bei Erdfe u e r n ist die Is o I i er u ng der glimmenrlen Erdschichte durch genügend tiefe Gräben nötig.

Jede Brandstätte ist nach geschehenem Löschen so lange zu bewachen, bis jede Gefahr eines Wiederemachens des Feuers rorüber ist; glimmende Stöcke werden mit Erde überworfen und dadurcl abgelöscht. Tunlichst rasche Wiederaufforstung der rasch rerunkrautenden oder vernugernden Brandflächen ist die weitere Aufgabe des Forstwirtes.

\section{Sehutz gegen Rauehsehäden ${ }^{1}$ ).}

\$ 17. A uftreten und $U \mathrm{l} s \mathrm{a} \mathrm{c}$ he $\mathrm{n}$. Als eine schädigung der Waldungen, die erst in den letzten Jahuzelmten infolge der hochgesteigerten Industrie in größeren llaßstabe aufgetreten ist und stellenveise geradezu zerstörend auf den Wald einwirkt, erscheinen die s. g. Rauchschäden.

Wir selıen in der Nähe industrieller Werke mit starkem Steinkohlenverbrauch, aber auch von Hüttenwerken, Zinkhütten, Sodafabriken und ähnlichen Etablissement: die nalie liegenden Waldungen, inshesondere die in der Richtung des herrschenden Windes gelegenen, in einen kränkelnden Zustand geraten, die Nadeln zuerst rot- oder gelbspitzig werlen und almählich absterben, das Laub in eigentümlicher Weise mißfarbig gerändert, fleckig und vor der Zeit absterbend. Allmählich fangen die lironen der Bäume an, licht zu werden, Gipfel und Aeste werden dürrspitzig und es gehen zuerst einzelne Individuen, zuletzt ganze Bestände ein - es entsteht

J) Literalur: Dr. Schröd e r und Reu B, Die Bescliädigung der Vegetalion durch Rauch 1883. B org greve, Waldschäden in Oberschlesischen Indistriebezirke nach ihrer Entstehung durch Hütlenrauclı etc. 1895. R e u $B$, Rauchbeschädigungen in dem Gräfl. Tiele-

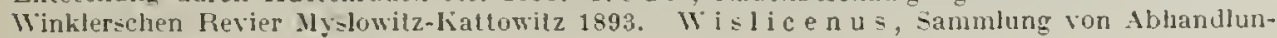
gen ūier Alıgase und Rauchsclıāden 1908 u. ff. 
die Rauchblöße; bei von der Rauchquelle entfernter gelegenen Beständen liommt es nicht so weit, aber sie zeigen in sichtlichem Nachlassen des Zuwachses wie in der mangelhaften und beschädigten Belaubung ebenfalls die Folgen des Rauches.

Als die Ursache dieser Erscheinung ist nach eingehenden Untersuchungen in erster Linie und den weitaus meisten Fällen die schweflige Säure zu betrachten, welche durch Verbrennung des in den Steinkohlen und insbesondere auch in den Braunkohlen enthaltenen Schwefels, dann bei dem s. g. Rösten der Erze in ganz außerordentlichen Mengen in die Luft geht. Seltener sind es andere Gase, wie Chlorgas, Salzsäure, sahpetrige Säure, Zinkdämpfe, welche als Ursache der Beschädigung zu betrachten sind.

§ 18. Größe der Beschädigung. A bwe hr. Die Größe der Beschädigung ist - abgesehen natürlich von der Menge der ausströmenden schädlichen Gase - vor allem abhängig vou der $\mathrm{Hol} \mathrm{z}$ a $\mathrm{rt}$.

Die Nadelhölzer mit ihrer zu mehrjähriger Funktion bestimmten Belaubung sind empfindlicher, als die Laubhölzer, und zwar steht ihre Empfindlichlieit in direlitem Verhältnis nit der Dauer der Nadeln, so daß also die Tanne an empfindlichsten ist, an sie schließt sich sofort die Fichte, dann folgen erst Kiefer und Lärche. - Die Laubhölzer sind dank ihrem alljährlichen Blattwechsel widerstandsfähiger; für sie besteht nach S c hr öd e r etwa folgende Skala von der empfindlichsten zur miderstandsfähigsten Holzart: Bergahorn, Linde, Esche, Buche, Erle, Birke, Eiche, Poteiche, doch spielen bezüglich dieser Reihenfolge auch Standort und Holzalter eine Rolle.

Die Größe und Intensität der Beschädigung ist dann weiter ahhängig von der Nähe der Rauchquelle - je näher, um so größer der Schaden. Doch macht sich letzterer auch noch auf größere Entfernung, bis zu 4 und 5 Kilometer weit, bemerklich und spielt hiebei die Lage der Rauchquelle gegenüber den örtlich herrsehenden Winden eine sehr bedeutende Rolle. Endlich ist auch das örtliche Klima von EinfluB; durch feuchte, nebelreiche Luft und häufige Niederschläge wird der Schaden gesteigert.

Die Bekämpfung des Schadens, der an vielen Orten, so vor allem in dem industriereichen Sachsen, ein sehr bedeutender ist, stößt auf große Schwierigkiten.

Die industriellen Werke, welche für den angerichteten - nach seiner Größe allerdings sehr schwierig zu bemessenden — Schaden haftbar erscheinen, haben sich erklärlicherweise bemüht, ihn tunlichst zu mildern: durch Auffangen der entweichenden schwefligen Säure und deren Ueberfülırung in Schwefelsäure, durch Aufführen hoher Essen, durch welche der Rauch bezw. die entweichenden Gase in höhere Luftschichten geführt werden sollten - beides mit nur geringen Erfolg.

Aufgabe der Forstwirtschaft wird es sein, durch Nachzucht minder enpfindlicher Laubhölzer an Stelle der Nadelhölzer, Erhaltung ron Waldmänteln, plenterweisen Betrieb den Schaden wenigstens zu nundem. Die vollständige Rauchblöße dagegen trotzt allen Kulturversuchen.

\section{Gefihrdungen duch die organische Natur.}

\section{Gefährdung dureh Tiere ${ }^{1}$ ).}

\$19. Bezeichuung der waldsehädlichen Tiere. Die Zahl der Tiere, welche im Wald sich aufhalten, ist eine außerordentlich große, viel größer,

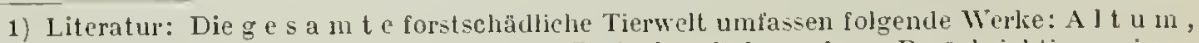
Forstzoologie 1882. D $00 \mathrm{~b} \mathrm{n} \mathrm{e} \mathrm{r}$, Handbuch der Zoologie mit besonderer Berûcksichtigung jener Tiere, welche in bezug auf Forst- und Landwirtschaft wichtig sind, 1862 . $R$ a $t \mathrm{z}$ e h u $\mathrm{rg}$, Lie 
als sie dem flüchtigen Bcobachter wohl erscheinen mag, da deren versteckte, teilweise anch nächlliche Lobenswcise sie vielfach dem Ange entzieht. Ebenso mannigrfaltig ist diese Tienwelt auch nach ihrer Art, von stolzen Hirsch herunter bis zur unscheinbaren Lame im Holz, der Made in Innern der Raupe, und mannigfach sind dementsprechend auch ihı Beziehıngen zum Wald, der ihnen Obdach und Nahrung gibt, letztere entweder direkt durch seine Produlite, oder indirekt durch die von ilum ernährten Tiere.

Ein großer Teil der Tiere des Waldes muß nun infolge sciner Ernährung durch dessen Produkte und bezw. durch Teile der von uns erzogenen und gepflegten Holzgewächse direkt als s $\mathrm{c}$ h ä d l i c l bezeichnet werden; so das eßbare Haanvild, die Iläuse, die eigentlichen Forstinsekten, während andere infolge des Umstandes, daß sie waldschädliche Tiere verzelıren, als $u \mathrm{n}$ be d i n g $\mathrm{t}$ ü $\mathrm{tzl}$ i c h für den Wald bezeichnet werden müssen: so die insektenfressenden Vögel, die Raubinsekten und Iclneumonen. Eine dritte Gruppe wird nur als b e d i n g t $n$ ü $t$ z l i c lı oder s c hä dl i c h erkiärt werden können, so z. B. die Finken, die neben Inseliten auch Holzsamen, die Marder und Wiesel, die neben Mäusen auch nützliche Vögel verzehren. Eine vierteGruppe endlich : mancherlei Insekten, die auf Lnkräutern, von lummosen und faulenden Stoffen leben, wird als in d if f er e $n t$ für den Wald zu bezeichnen sein. Unsere Aufgabe ist num, sowohl die dem Wald nutzlichen und darum in jeder Weise zu begünstigenden, als auch speziell die dort s $\mathrm{ch}$ ä d I i c h e $\mathbf{n}$ Tiere nach ilurer Lebensweise und ilu'em durch letztere bedingten Schaden kennen zu lernen und die Mittel zur tunlichsten Vorbeugung, zur mehr oder minder erfolgreichen Bekämpfung aufzusuchen. Es gehören diese Tiere aber 3 großen Gruppen an: den

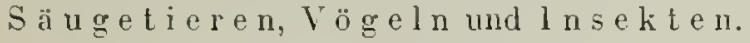

\section{Schädliche Säugetiere.}

$\S 20$. Einteilung. Die dem Wald schädlichın Säugetiere lassen sich in 3.Gruppen lıringen, welche sich insbesondere auch durch den EinfluB, den der Mensch auf die Beschützung des Waldes gegen jede dieser Gruppen zu üben vermag, unterscheiden. Es sind die $\mathrm{H}$ a u stiere: Pferde, Rinder, Ziegen, Schafe, Schweine, welche zum Zweck ihrer Ernähung in den Wald getrieben werden, gegen die der Nensch den letztern vollständig zı schützen imstande ist, insofern die Ueberwachung des Eintriebs oder selbst das gänzliche Fernelıalten in seiner Hand liegt. Es sind die j a g d b a r en Säugetiere - Rot-, Dam-, Reh-, Schwarzwild, Hasen —, die der Mensch bez. ihrer Zahl fast belicbig zu reduzieren, die größeren Arten selbst ganz auszurotten vermag, so daf die Redulition des Schadens ihm anheimgegeben ist; es sind endlich die k le in en $\mathrm{N}$ a g e ti e re des Waldes - Mäuse, Eichhörnchen, Schläfer - , deren Auftreten ein viel wechsehnderes, von äußeren Einflü ßen abhängiges, deren Bekämpfung eine viel schwierigere ist, als jene der vorher genannten Gruppe. Das in manchen Ländern jagdbare, vielenorts selır schädliche $\mathrm{K}$ a $\mathrm{n}$ in $\mathrm{c}$ lı e $\mathrm{n}$ schließt sich mehr dieser letzteren, als der zweiten Gruppe sowohl bezüglich seiner Schädlichıkeit, als seiner schwierigeren Belämpfung an.

\section{A. Die Haustiere.}

§ 21. Beschädigungen durch We i d e tiere. Die Waldweide war früher belianntlich von größerer Bedeutung für die Landwirtschaft und wurde in ausgedehntester Weise ausgeübt, vielfach bis zum direkten Ruin des Waldes — es

Waldverderber und ihre Feinde ( 7 . Aufl. hearbeitet von $\mathrm{J}$ u d e i c h, 1876). R a $\mathrm{tz}$ e b u rg, Die 1 aldverderbnis 1868. A I t u m, Waldbeschädigung durch Tiere 1889. E c ks t e in, Forstliche Zoologie 1897 . 
möge nur an die namentlich durch die Ziegenweide kahl gewordenen Berge Griechenlands, Istriens, Tirols erinnert sein! Sie hat jedoch mit dem Uebergang zu einer rationellen und intensiven Landwirtschaft ihre Bedeutung viclenorts ganz verloren und besitzt eine solche in Deutschland fast nur noch in den Gebirgswaldungen.

Der Schaden durch die Weidetiere - Pferde. Rinder, Ziegen und Schafe hanm nun bestehen in dem Verbeißen und Abä-en der Knospen und jungen Triebe. im Benagen der Rinde, dem Zertreten oder gewaltsamen Linbiegen jüngerer Pflanzen. dem Lostreten der Erde an steileren Gehängen, dem Festtreten schweren und Auflockem leichten, losen Bodens, endlich dem Beschädigen der Entwässerungs- und Hegegräben durch den Tritt.

Es ist dieser Schaden aber zunächst ein sehr verschiedener je nach der eingetriebenen Tiergattung. Während das $\mathrm{R}$ i n $\mathrm{d} \mathrm{v}$ i e $\mathrm{h}$ und die Pferde das Gras den Holzpflanzen vorzichen, die letzteren erst beim Mangel an schon vorhandenem oder oder an noch genießbarem Gras anzugreifen pflegen, sind im Gegenteil die Z i e g e $n$ von Natur mehr auf den Genuß von Laub und Knospen lolziger Gewächse angewiesen, ziehen diese Nahung dem Gras entschieden vor. Die S c h a f e nehmen zwar das Gras gerne an, doch zeigen sie in der Lieblaberei. Holzgewächse zu benagen und zu verbeißen, eine entschiedene Verwandtschaft mit den Ziegen; diese sind als das dem Wald schädlichste Weidetier zu betrachten und von demselben möglichst fern zu halten!

Dagegen ist der Schaden durch den Tritt bei den s c h w e r e n Weidetieren, bei Pferil und Rindvieh, entschieden größer, bei ersterem verstärlst durch den eisenbeschlagenen Huf, durch welchen die Pflanzen empfindlicher beschädigt werden, bei letzterem durch das häufige Ausrutschen an steilerem Gehänge bei feuchtem Wetter, wodurch die Erte und mit dersellen die Pflanzen losgetreten werden. Junge Pferde beschädigen durch Benagen der Rinde, das IVornvieh durch das gern geübte Reiben nicht selten jüngere Stangen oder stärkere Pflanzen (Heister auf Hutängern).

\$22. Bedingungen fü $r$ die Größe des $\mathrm{Sch}$ a dens. Außer durch die Viehgattung ist die Größe des dureh die Waldweide hervorgerufenen Schadens auch durch die Art und Weise, wie der Vieheintrieb nach Z a l. l, Z e it, A ufs i c h t erfolgt, bedingt, nicht minder abel auch durch die $\mathrm{B}$ es c h a f $\mathrm{f}$ nh e it der $\mathrm{B}$ es $\mathrm{t}$ ä $\mathrm{n} d \mathrm{e}$, welche behütet werden. nach Holz- und Betriebsart, nach Alter und Standortsverhältnissen.

Wird das Vieh in $\mathrm{z} u \mathrm{~g} x$ o $\mathrm{B}$ er $\mathrm{Z}$ a $\mathrm{l} 1 \mathrm{in}$ den Wald getrieben. so daß Grasund Krräuterwuchs zu dessen Emährung nicht ausreichen; beginnt der Vieheintrieb im Frühjahr z u b a I d und elıe genügenul Gras gewachsen ist, wie dies namentlich nach futterarmen Jahren gerne geschieht, oder wird el zu lange in den Herbst hinein fortgesetzt, nachdem das Gras schon diurr und ungenießbar geworden; fehlt es endlich an genügender A u f i c ht durch eine der Zahlıl des Viehes entsprechende Anzahl von Hütem, so mub rer Schaden natürlich ein viel größerer sein als im entgegengesetzten Falle.

Was die versehiedenen $\mathrm{H}$ o $\mathrm{l} \mathrm{z}$ a $\mathrm{r}$ t $\mathrm{e}$ n anbelangt. so ist es eine Anzahl ron Laubhölzern, die in erster Linie gerne vom Vieh angenommen verden: Rot- und Weißbuche, Esche, Eiche, Ahom, - während «le Weichhölzer dessen Angriff viel weniger ausgesetzt sind, ja zum Teil (Erle, Birke) uur ausnahmsweise verbissen werden. - Die Nadelhölzer sind im allgemeinen im ninderen $1 l a ß$ dem VerbeiBen durch Teidevieh ausgesetzt, als das Laubholz, dagegen wird ihnen dasselbe bei ihrer geringeren Reproduktionskraft verderblicher. Wo andere Nahrung fehlt, da sehen wir übrigens auch die linospen und jungen Triebe fast sämtlicher Nadelhölzer von dem lung- 
rigen Vieh verl,issen; die cin geringes Ausheilungsvermögen besitzende Föhre wird hiedurch rasch zum Irrüppel, Tame und Fichte dagegen vermögen sich eher wieder zu erholen.

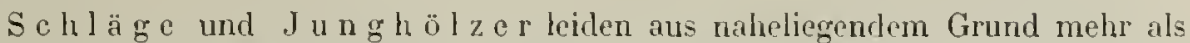
ältere Bestände, in welch' letatern die Weide nahezu unschädlich sein kann. Auf gut e $\mathrm{m}$. f r is c he $\mathrm{n}$ B o d e $\mathrm{n}$ ist dem Vieh reichlichere Borlennahung geboten, der Holzwuchs bleibt infolge dessen mehr verschont, auch vermögen beschädigte Pflanzen sich leichter zu crholen und den crlittenen Verlust zu crsetzen, als auf trocknem, mageren Boden. Endlich wird sich im s c h I a g w e is c bewirtschafteten Hochwald der Schaden durch Tersperren der jungen Bestände auf ein Minimum heschränken lassen, während im P le n t e r w a $1 \mathrm{~d}$ mit scinem bunten Wechsel alten und jungen Holzes ein solcher Schutz des letztern nicht möglich jst, der Schaden sonach ein größerer sein muß. N i e d e r w a I d u n ge n entwachsen durch den raschen Wuchs der Stockausschläge bald dem Maule des Viehes, auch ist der Schaden infolge der bedeutenden Reproduktionsliraft der Ausschäge ein geringerer.

\$23. Schutzma $B$ regeln bei A sübung der Weide. Aus dem im vorigen Abschintt Gesagten ergeben sich der Hauptsache nach die Maßregeln von selbst, durch welche bei Ausübung der Waldweide der Schaden inöglichst vermindert werden kann. Als solche erscheinen:

Zulassung der Weide nur unter A u f s i c $\mathrm{h} t$ verlässiger $\mathrm{H}$ i r t e n, deren Zahl sich nach der Größe der Herde zu richten hat; Verbot der $\mathrm{N}$ a $\mathrm{ch} t \mathrm{~h} u \mathrm{t}$, bei welcher jede Aufsicht unmöglich ist; Behängen des Viehes mit G l o c k c n, um fehlende Stüclie, die sich von der Herde weg in die grasreicheren Schläge geschlichen haben, lejchter zu entdecken.

B e s c lı r ä n k u n g der Weide auf jene Bestände, welche bereits dem Maule des Tiehes entwachsen sind; B e z e i c h $\mathrm{n}$ u $\mathrm{n}$ g der von der Hut ausgeschlossenen Schläge oder in Terjüngung stchenden älteren Bestände durch Warnungszeichen für die Hirten (Strolıwische, Tafeln mit entsprechender Aufschrift). Schutz der Schläge gegen das in angrenzenden Beständen weidende Vieh durch E i n z ä u n u n g oder durch S c ho n u n g g r äb e n. Herstellung genügend breiter T r i f $\mathrm{t}$ w g e zum Durchtrieb des Viehes zwischen den der Hut versperrten Beständen, um das Drängen des Tiehes und dessen seitliches Ausweichen in die Schläge zu verhindern.

Vermeiden cines zu f $\mathrm{r}$ üh e n $\mathrm{B}$ eginns der Waldweide und zu langen F ortsetzens in den Herbst hinein; Einhaltung entsprechenden $W_{\text {e }} \mathrm{h}$ s e ls in den Weideplätzen, damit das Gras wieder genügend nachwachsen liann.

Scliutz der Pflanzheister auf Hutungen durch $U$ m do r n e n oder um die Hcister geschlagene starlic Pfähle zum Schutz gegen Benagen und Rieiben des Viehes. Unterlassen des Vieheintriebes an steilen Gchängen bei f e u c l t e m Wetter, wenn durch das Abrutschen des Viehes das Lostreten des vom Regen durchweichten Bodens zu fürchten ist.

Die Waldweide, früher in ausgedelıntestem Maße und zum schweren Schaden des $\mathrm{Waldes}$ allentlaalben ausgeübt, hat insbesondere in Deutsclıland zur Zeit an Bedentung sehr verloren und ist an vielen Orten nahezu crloschen. Intensiverer Betrieb der Landwirtschaft mit Futterbau und Stallfütterung einerseits, dic derzeitige Forstwirtschaft mit ihrer schlagweisen Verjüngung, ihren gleichaltrigen geschlossenen Beständen anderseits haben ihr den Boden entzogen, und nur die Gebirge pflegen es zu sein, wo sie noch in ausgedehntem Maßstabe stattfindet, aber auch noch berechtigt erscheint. Dort stehen vielfach selbst die Schläge dem Weidevieh offen, ohne bei dem reichen Graswuchs allzusehr durch den Verbiß zu leiden. - Am miBhichsten cr- 
weist sich auch hier die namentlich in südlichen -Gegenden zahlreicher vorkommencle Ziege.

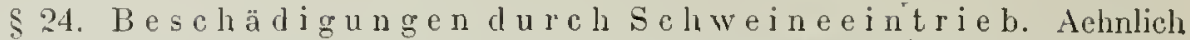
wie die Waldweide hat auch der früher in ausgedehntem Maß ausgeübte Schweineeintrieb in die Waldungen seine Bedeutung verloren: das Verschwinden zalılreicher Eichen- und Buchenwaldungen, der Anlau der als Mlastfutter dienenden, alljährlich geratenden Kartoffel sind wohl als Ursachen lievon zu betrachten, und die Mastnutzung durch Schweineeintrieb findet wenigstens in den deutschen Valdungen nur noch in beschüuktem Nlaße statt.

Die Schweine können nun im Walde schädlich werden direkt durch ilıre $\mathrm{N}$ a lr un g, das Aufzehren von Eicheln und Buclıeln, die sie auch nach erfolgter Kieimung noch gierig anmehmen, indirekt dadurch, dab sie bei dem $W$ ü h 1 e n im Boden nach anderweiter Nahrung, wie Inseliten, Sclıvämmen u. dgl. - der sog. Eıdmast - die Holzpflanzen beschädigen, oft gänzlich herauswühlen, auch die Wurzeln älterer Stämme verletzen. Auf Hutungen werden sie in ähnticher Weise wie das Rindvieh durch das Reiben an Heistern und die damit verbundene Rindenverletzung und Wurzellockerung schädlich.

Man wird dem Schaden vorbeugen, ja ihn unter Umständen sogar in sein Gegenteil verwandeln können, wenn man den Eintrieb nur unter guter Aufsicht gestattet, jüngere Bestände ausselıließt, die durch natürlielıe Besamung zu verjüngenden Bestände in Nastjahren aber entweder nur bis zum Abfall der Mast behütet, oder in reichen Mastjahren die Schweineherdc erst nach vorheriger Sättigung in andern Beständen durch erstere treibt: die Schweine wühlen danu vorzugsweise nach sog. Erdmast, bringen liebei den Samen gut in den Boden, lockern diesen letzteren, und reichliche, kräftige Besamung pflegt zı erfolgen. - Daß der Eintrieb von Schweineherden zur Vertilgung schädlicher im Boden liegender lnseliten - so der Puppen der Fohreneule, des Fohrenspanmers - bisweilen mit gutem Erfolg Anwendung findet, wird später moclı zu emwälnnen sein.

Gegen das Reiben auf Hutungen schützen die im vorjgen $\&$ angegebenen 1 littel.

\section{B. Das jagdbare Wild.}

\$25. Schaden dureh d a s Rotwild. Das Rot-oder Edelwild kann in unsern Waldungen unter Umständen und bei stärherer Anzahl sehr schädlich werden, so daß beispielsweise in reich besetztem Wildpark eine Nachzucht entsprechender Bestände nur bei Anwendung intensiver Schutzmaßregeln möglich ist.

Diese Beschädigungen bestehen zunächst im A b äs en der Ki os p e n und eben entwickelten T r i e b e der meisten Holzarten, so von Laubhölzern insbesondere der Eiche, Buche, Esche, Ahorn, von den Nadellı̈lzern vor allem der Tanne, dann aber auch der Fichte und Föhre; dagegen werden Birken, Erten, WViden fast nie angegangen. Schwächere Pflanzen gehen hiebei selbst ganz zugrunde, stärkere suchen wohl die verlorenen Teile zu ersetzen, verlirüppehn jedoch bei wiederholter Beschädigung niclıt selten vollständig.

Es sind ferner die F r ï c h t e der Eiche, Buche, Edelkastanie, die das IVild begierig aufsucht und nicht nur in den natürlichen Verjüngungen in nachteiliger Menge verzehrt, sondern auch in Saatkulturen mit großer Sicherheit zu finden weiß, Herbstsaaten hiedurch oft vollständig zerstörend; auch die Kotyledonen der Buche sind ihm eine erwünschte Aesung.

Eine der mißlichsten Untugenden des Rotwildes aber ist das sog. S c h ä I e n, 
das Abnagen oder Abreißen der Rinde verschicdener und zwar gerade forstlich wichtiger Holzarten $\left.{ }^{1}\right)$. Dieses Schälen, nach Nördlingers Angabe schon seit Anfang des 18. Jahrunderts in Thüningen zu Hause, hat entschieden an Verbreitung zugenommen, namentlich bei starken Wildständen und knapper Emährung, und wird für viele hoffnungsvolle Fichtenstangenhölzer geradezu zum Ruin. In Wildparks mit ilnen meist übergroßen Wildständen und der dadurch bedingten ausgiebigen Fütterung, bei welcher das trockene Heufutter eine hervorragende Rolle zu spielen pflegt, gehı̈rt das Schälen des Rotwildes zu den ständigen Erscheinungen.

Das Wild benagt nun liebei entweder in Winter die Rinde g l a t t r i n d i g e r jüngerer Pflanzen und Stangen (beginnende Borkebildung setzt demselben sofort ein Ende) zum Zweck seiner Sättigung, die Spuren der Zähne sind bei dieser IV in t e rsc lı äl u n g an den Stangen deutlicl! sichthar; oder es reißt zur Saftzeit ganze Rindenlappen los, oft weit hinauf am Baume schlitzend und durch diese S o m m e rs c häl u n g die Bäume schwer schädigend. Beide Arten des Schälens sind hienach leicht zu unterscheiden.

Als U r s a c h e des Schälens erscheint num einerseits Nahrungsmangel, anderseits aber auch unnatürliclie, den Bedürnissen des Wildes an Wasser und manchen Nälırstoffen niclıt zusagende Ernährung, wie solche insbesondere durch die oben schon emähnte Heufütterung stattfindet. Der Uinstand, daß Rotwild in freier IVildbahn und dort, wo ilım in Schlägen und Feldern eine reichliche und naturgemäße Ernährung geboten ist, nicht oder doch in minderem llaße schält, dürfte für die Richtigkeit dieser Anschauung sprechen. Die Sommerschälung scheint außerdem auch noch auf Naschhaftigkeit, Spielerei, übler Angewöhnung zu beruhen.

Die Holzarten, die namentlich geschält werden, sind Fichte, Buche, Eiche, Esche, Weymouthskiefer, Tanne, in minderem MlaB Fölıre, Läıche; namentlich wird die Föhre durch die zeitig eintretende Borkebildung geschützt, während die glattrindige Buche noch als 60 -70jähriger Stamm geschält wird. Die eigentlichen WVeichhölzer, auch die Birke, bleilen meist ganz verschont.

Als Folgen dieser Beschädigungen aber treten geringer Wuchs der verletzten Stangen, unregelmäßige Stammbildung, Angriffe schädlicher For'stinsekten, Fäulnis der Schälstelle ein; bei Wind- oder Schneebruchbeschädigungen kann man beobachten, daß der Bruch vielfach an der Sclıalstelle erfolgt. Der untere wertvollste Stammteil geschälter Stänme ist zu Nutzholz umbrauchbar.

Endlich wäre noch die Beschädigung stärkerer Pflanzen und schwächerer Stangen durch das F e g e $\mathbf{n}$ der Geweihe und das S $\mathrm{ch}$ l a ge n zur Brunftzeit zu nennen, wodurch die betroffenen Stammindividuen meist zugrunde gehen.

\$ 26. S c hut z mit tel. Einem größern Wildschaden wird zunäclıst v o rg e b e u g werden durch Reduzierung starker Vildstände und durch Sorge für genügende und naturgemäße Emälırung des Wildes durch Fütterung im Winter, Anlage guter Wiesen, Anpflanzung masttragender Bäume (in Wildpark). Bezüglich der Fütterung sei speziell hervorgehoben, daß eine reichliche Beigabe von Eicheln, Kartoffehn, Mlais, Rüben zu dem Heufutter sich als vorteilhaft emveist. Dic Anlage reichlicher Salzlecken soll dem Schälen (wohl der Sommerschälung) einigermaßen vorbeugen, ja in der Beigabe des sog. Holfeldschen Wildfutterpulvers ${ }^{2}$ ) (das namentlich Galläpfel, Eichenrinde, Anis und zweifach basisch phosphorsauren Kalk enthält)

1) Vergl. R e u B, Die Schälbeschädigung durch Hochwild, speziell in Fichtenbeständen 1885. I ä r n e r, Das Schälen des Rotwildes. Thar. Jahrb. 30. S. 39. S e i b t, Das Schälen des Rotwildes 1911.

2) H o l f el d, K., Die Bedcutung des phosphors. Kalkes, des Kiochsalzes und einiger Pflanzenstoffe für Ernährung und Gedeihen des Hoch- und Rehwildes 1893. 
zu den Salzlecken will man ein nahezu vollständiges Schutznittel gegen das lästige Sclıälen gefunden lıaben.

In der Vermeidung der (auch durch andere Feinde gefährdeten) Herbstsaaten von Eicheln und Bucheln, der Anwendung stärkerer Pflanzen, dann der Büschelpflanzung, bei welcher doch eher auf die Verschomung einzelner Pflanzen zu hoffen ist, liegen weitere Vorbeugungsmittel.

Als direktes $S \mathrm{ch}$ h $\mathrm{z} \mathrm{m}$ it $\mathrm{tel}$ aber erscheint das Einfriedigen der Iiulturflächen oder Sclıläge, was bei starkem Wilrstand bezw. in Wildpark kaum zu umgehen ist, und wozu man in neuerer Zeit vielfach Drahtzäune vorwendet hat. In ausgedehntem Maße findet femer das Bestreichen der Gipfeltriebe mit den Wilde widerlichen, den Pflanzen aber unschädlichen Substanzen, das T e e r e n orler L e im e n als Schutz gegen das Verbeißen statt. An Stelle des zuerst verwendeten, für die Knospen aber selıädlichen (ätzend wirkenden) Steinkohlenteers wird vielfach die sog. S e h u b e r t sche Mischung aus $1 / 5$ Teer mit $4 / 3$ Kinhdünger, welche sich als ganz unschädlich elweist, in der Neuzeit aber entsänerter Steinkohlenteer benützt. welch letztere Substanz mit guter Wirkung und vollständiger Unschädlichlieit den Vorzug größerer Appetitlichkeit gegenüber obiger Mischung verbindet. Hỵloservin ron Ermisch, Schwefelcalcium, Pomolin sind weitere Mittel, die auf Grund angestellter Versuche empfohlen werden ${ }^{1}$ ).

Das Bestreichen der Knospen geschieht entweder mit der handschuhbewaffneten Hand, mit einfachen Bürsten und Pinseln oder nit eigens hiezu lionstruierten Bürstenapparaten, so mit der sehr praktischen B ï t t n e r schen Doppelbürste ${ }^{2}$ ). -- Bei zweckmäBiger Ausfïlnung zeigt das Teeren (Leimen) selur bcfriedigenden Erfolg.

Auch das Bespritzen der Gipfel mit Kalk, sowie das ,Verhanfen“, bei welchem auf die Gipfeltriebe eine lileine Partie trockenen Hanfwerges gelegt wird, hat mit Erfolg Anwendung gefunden. - Als neueres Mittel seien die von dem württembergischen Oberförster L a n z erfundenen und empfohlenen B lechliron en genannt, $5 \mathrm{~cm}$ lange und $4 \mathrm{~cm}$ hohe, auf einer Seite $3 \mathrm{~cm}$ tief ausgezaclite Stückchen Weiß- oder Schwarzblech. welche so um die zu schützende Gipfelknospe herumgelegt werden, daß diese Jurch die scharfen Spitzen geschützt ist. Die Befestigung geschieht durch einfaches Andrücken.

Schwieriger als das Verbeißen ist das $\mathrm{S}$ c $\mathrm{h}$ ä $1 \mathrm{e} \mathbf{n}$ zu bekämpfen, das in fast allen Wildparken zu Hause ist, doch auch in freier Jagd vorkomnt und die Waldumgen schwer schädigt. Man schützt jüngere Fichten und Tannen durch Lmbinden des Schaftes mit den noch grünen, hinauf- oder heruntergebogenen Aesten, in Fichtenstangenhölzern die dominierenden Stämme durch Umbinden des Stammes mit dem Astholz der bei der Durchforstung anfallenden Stangen mittelst Draht; Solitärbåume umgibt man mit weitmaschigem Drahtgitter. Uit dem F l a $\mathrm{n}$ m i g e r schen Schutzkratzer ${ }^{3}$ ) verletzt man die Rinde der dominierenden Fichtenstangen leicht und erzeugt dadurch einen sclützenden Harzausfluß, ebenso mit dem 11 ü 1 s $\mathrm{t}$ schen Punktierrad oder dem L a n zschen Harzhobel. Bei Laubhölzern - Buche. Esche. Eiche - erzeugt der L a n z sche Rindenstriegel ${ }^{4}$ ) seichte Kratzwunden auf der glatten Rinde und dadurch die Bildung von Wundkork, der die Rinde l'auh und den Wild minder angenelum macht.

1) VergI. Eekstein in Zeitschr, f. F.- U. J.-IV. 1902, S.540; ferner, Anteeren als Mittel gegen Wildverbiß", Forstw. Z.-BI. 1900, S. 21.

2) Forstw. Z.-B1. 1900 S. 21.

3) Forstw. Z.-BI. 1907 S. 606.

4) Hofjagdinspektor Lanz in "Wild und Hund", 1908. 
\$27. Schad en du reh D a m-und Re hwild. Die Nahrung des D a mwi l d e s gleicht jener des Rotwildes und der Schaden ist daher der Hauptsache nach. der" gleiche; doch schält es nur ausnahnswoise da und dort im stark besetzten Wildpark. so daß wenigrstens diese selur lästige Beachädigung entfällt.

Auch das $R$ ehwild rerbeißt die Knospen und jungen Triebe vieler Holzarten und kann hiedurch bei stärkerem Stand sehr lästig und sclıädlich werlen. verzehrt Eicheln und Bucheh, schält jedoch nie. Der Schaden. den die Rehböcke durch das Fegen ihrer Gehörue aurichten, liann ein fühlbarer dadurch werden. daß dies Fegen mit besonderer Vorliebe an seltener vorkommenden, in die Schläge eingepflanzten Holzarten (Lärchen. Weymouthskiefern, Douglasien) geschieht. Speziell die in unsere $\mathbf{W a l d u n g e n ~ i n ~ d e n ~ l e t z t e n ~ J a h r z e h n t e n ~ n e u ~ e i n g e b r a c h t e n ~ F r e m d h o ̈ l z e r ~}$ haben darunter zu leiden.

Gegen das Verbeißen durcl Dam- und Rehwild bringt man die schon im rorigen $\leqq$ besproclıenen Maßregeln zur Anwendung, gegen das lästige Fegen der Rehböcke schützt man etwa die eingepflanzten Holzarten (wemn deren Zahl lieine zu große) durch sperrige Aeste, welche man neben den hetr. Pflanzen in die Erde stößt oder mit einer Wiede an diese bindet. oder durch angebundene Streifen weißen Papiers als Scheuchen. Auch stärliere, 5-6zackige Lanzsche Kronen (s. $\$ 26$ ) werden zum Schutz um die Stämmchen gelegt und deren Spitzen nach auswärts gebogen.

s 2S. Sch a d e n d u ch Schwarzild. Gleich dem zahmen Schwein geht auch das Wildschwein den Eicheln und Buclseln, sowie den eben aufgekeimten Sämlingen gierig naclı, zerstört dadurch insbesondere Saatkulturen, beschädigt aber auch durch sein Wühlen nach Insekten, Wurzeln und Schwämmen viele Pflanzen in den Schlägen. Im Laubholzwald wird das Schwarzwild viel lästiger als im Narelwald, in welchem es durch Vertilgung zahlreicher schädlicher Insekten nützlich zu werden, dem aufmerksamen Forstmann auch die Anwesenheit solcher Feinde durch sein Wühlen in den befallenen Beständen zu verraten vermag.

Wo Wildschweine in auch nur geringer Zahl vorhanden sind, wird man Saatkulturen mit Eicheln und Bucheln unterlassen und zur Pflanzung greifen müssen. Saatkämpe jeder Art bedürfen stets fester Einfriedigung, da rer lockere Boden die Sauen zum Brechen lockt.

\$29. Schadeudurch Hasen und İan inchen. Der Schaden durch $\mathrm{H}$ a s e $\mathrm{n}$ ist ein mäßiger und nur im strengen Winter, wenn die Saatfelder durch Schneedecke minder zugänglich sind, ein fühlbarer; er besteht im A b ä s e $n$ d e r Ii n o s p en, namentlich der Laubhölzer (Rot- und WeiBbuchen, Ulmen, Ahorne. Eschen), dann im B e n a $g$ e $n$ der $\mathrm{P}$ i n d e, wobei der Hase neben Obstbäumen vor allem die Aliazien, die ilım besonders zusagen, heimsucht. In Forstgärten liann er selır lästig werden und bedürfen solche für Laubhölzer (mit dusnalune etwa der ihm weniger zusagenden Eiche) eine himreichend dichte Einfriedigung; Obstbäume werden dureh Umbinden mit Domen, Stroh, Nadelreisig geschützt.

Yiel lästiger als der Hase wird in Feld und Wald das in manchen Gegenden in großer Zahl vorkommende Ií a n i c he n. Dieses verzehrt die Iínospen nahezu aller Holzarten, verbeißt sellst Föhrenpflanzen vollständig, benagt die Rinde namentlich der Rot- und WeiBbuche, Akazie. Lärche sehr intensiv, und es konzentriert sich der Schaden hiebei durch seinen steten Aufenthalt in größerer Zahl am gleichen Ort - in der Nähe seiner Baue - in viel höherem Grad, als bei dem Hasen. In der Nähe ron Kaninchenbauen ist oft kaun ein Holzwucls aufzubringen und bleiben öfters lästige Lücken in den Kulturen.

Abhilfe ist nur durch tunlichst starken Abschuß (Frettieren), Zerstören der 
Baue, Verwendung starker durch Benagen und Verbeißen minder gefährdeter Pflanzen mögliclı; Saatbeete bedürfen selır diclıter Einfriedigung, ja man hat sich sogar schon genötigt gesehen, ganze Kulturflächen nach vorheriger Säuberung von Kaninchen mit engmaschigem Drahtgeflecht einzufriedigen (so in der Rheinebene). Tielfach ist man geradezu zu einem Vertilgungskrieg gegen die schädlichen Nager genötigt, fängt sie in kleinen vor die Pöhren gelegten Tellereisen oder tötet sie in den Bauen mit Hilfe des giftigen Schrefelkohlenstoff-Gases.

\section{Die kleinen Nagetiere.}

\$ 30. Schaden d u r c h M äus e $\left.{ }^{1}\right)$. Zwei Gattungen von Mäusen halten sich oft als lästige Gäste in mseren Waldungen auf; die Gattung Mus, echte Mlaus, chrch spitzen Kopf, große Ohren und körperlangen Sclwwanz gekennzeichnet, und vorwiegend durch die Wald-oder Springmaus, Mus sylvaticus, vertreten; dann die Gattung Arvicola, Wühlmaus mit dickerem Kopf, kleineren Ohren und kurzem Sclıwanz, durch drei Arten repräsentiert: durch die eigentliche Feldmaus, A. arvalis, die sich namentlich im Herbst vom Feld in den Wald zurückzielht, durch die Rötelmaus, A. glareolus, und durch die Wasserratte oder Mollmaus, A. amphibius.

Der Schaden, der den Waldungen durch die Mänse zugehen kan, ist namentlich in Laubloolzwaldungen ein oft sehr bedeutender: durch das $\mathrm{A} u \mathrm{f} z$ e h r e $\mathrm{n}$ der $S$ äm ereieı, der Eicheln, Bucheln, Kastanien, in Satheeten auch jener von Linden- und Weißbuchen-, in minderem Maß der Nadelholzsämereien; ferner durch das $\mathrm{B}$ e $n$ a g e $n$ der noch zarten Rinde jüngerer Holzplanzen während des Winters, namentlich der Weiß- und Rotbuche, auch Eiche und Esche, im Notfalle aber nahezu sämtlicher Holz- und Straucharten, auch der Nadelhölzer, teils unmittelbar am Boden, teils bis zur Höhe von einigen Metern. wobei ilnen, namentlich der Rötelmaus, die Gewandtheit im Klettern zustatten kommt. Dieses Benagen geht oft bis zum völligen Abschneiden schwächerer Pflanzen, und zarte Nadelholzpflanzen werden unter der die Mäuse schützenden Schneedeclie oft reihenweise abgeschoren. Die Mollinaus nagt unterirdisch selbst starlie Wurzeln vollständig durch.

Jederzeit in geringerer Zahl im Wald rorhanden, vermehren sich die Mäuse unter* dem Einflusse warmer, trockner Frühjahre und Sommel, sowie milder Winter oft außerordentlich, sich dabei im Herbst durch Zuzug vom Felde hel verstäliend. Geschützte Oertlichkeiten, wie starker Grasüberzug des Bodens, Gestrüppe, diclıte natürliche Verjüngungen, starlie Laubdecken zielıen sie einerseits besonders stark an, begünstigen anderseits ihre Vermelnung; dagegen werden sie durch heftige Regengüsse, trockenen Frost olme Schmeedecke, Nässe mit nachfolgendem Frost oft in kürzester Zeit bis auf geringe Fieste verniclstet. Großen Abbruch tun ilnnen die zahlreichen Feinde: alle Raubtiere unseres Waldes vom Fuchs bis zum Wiesel und Igel, die Raubvögel, obenan Eulen und Bussarde, dann Kŕrälıen; auch wilde und zahme Schweine verzelıren die Mäuse begierig, und unter gewölnhlichen Verhältnissen wird ihı' Zahl durch diese Feinde in Zaum gehalten, deren Schonung daher, soferne ilır anderweiter Schaden kein ïberwiegender, als $\mathrm{V}$ or b e u g $\mathrm{ng}$ sm it t e l zu empfehlen sein.

Z e rstörung der Brutstät ten durch Entfernung des Grasfilzes und Gestrüppes aus den gefährdeten Oertlichlieiten; Vermeidung von H e r b s t s a a t e n mit den oben bezeichneten Sämereien in Mäusejahren; Schutz der Saatbeete durch U m f a s s u n g g r äb e $\mathrm{n}$ mit steil abgestochenen Wänden und in der Sohle ein-

1) Vergl. Altu m, Unsere Mäuse etc. 1880. 
gesetzten Töpfen; endlich selbst unschädliche F ü t t e r u n g der Mäuse, inrlem man in den gefähudeten Buchenschlägen Stockausschläge und Weichhölzer fällt und gleich dem Reisig des etwaigen Nachliebsmaterials ïber Winter liegen läßt, damit die Mäuse, sich an den Ǩnospen und Rinden dieser Hölzer sättigend, die Pflanzen verschonen

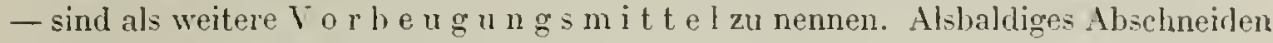
ringsum benagter Laubholzpflanzen im Frülijahr mindert durch den sofort erscheinenden Stockausschlag den Schaden.

Die Vertilg ung der in Ueberzahl vorlıandenen Mäuse wird mit einigem Erfolg nur in Saatbeeten, in denen allerdings schon eine kleinere Zahl lästig werden kann, durch Vergiftung und ausnahmsweise mit Fallen platzgreifen können. Die Vergiftung erfolgt mit Weizenkömern oder aus Mehl gefertigten Pillen, welche mit Phosphor, Arsenik oder Stryclnin vergiftet und entweder direkt mit Hilfe von Blechröhren in die Mauslöcher geworfen oder in Drainröhren von geringem Durchmesser ausgelegt werden; Arsen-IVeizen hat sich nach neueren Versuchen am besten bewälırt. - Der Landwirt macht von dem Mittel der V'ergiftung viel ausgedehnteren Gebrauch als der Forstmann, wenclet bei größerem Mäusefra B auch den Löfflerschen Typhus-Bazillus an, der nach Dr. G e hrh a r d t s Witteilung ${ }^{1}$ ) auch in Wald erfolgreiclie Anwendung fand.

$\$ 31$. Sch a dendurch Ei ch hörnchen und Schläfer. Die Beschädigungen des Waldes durch $\mathrm{E}$ i c h h ö $\mathrm{r} \mathrm{n}$ c h e n können namentlich in Jahren, in welchen ihnen die beliebteste Winternahrung, die Eicheln, Bucheln und Nadelholzsämereien fehlen, oft sehr empfindliche sein.

Sie beißen dann zu ihrer Emährung die Knospen, namentlich auch die kräftigen Terminalknospen der Nadelhölzer ab; minder nachteilig ist das Abheißen der kleinern Seitentriebe der Fichte, deren Blatt- und Blütenknospen damn ausgefressen werden - die abgebissenen etwa fingerlangen Triebe, unriclitig als ,Abspruinge" bezeichnet, liegen oft massenhaft unter den älteren Fichten.

Großen Schaden ${ }^{2}$ ) richten die Eichhörnchen bisweilen im Frühjahr in Nadelholzbeständen durch das bald völlige, bald platzweise oder ringförmige Entrinden der Gipfel an, wobei sie die zarte Rinde verzehren, die Saftschichte ablecken; bisweilen liegt auch die abgeschälte Riude in Fetzen an Boden und rurde sonach nur die Basthaut, das Kambium, verzelırt.

Auch ihre Liebhaberei für die oben genannten Holzsämereien vermag sehr lästig zu werden, namentlich in Saatbeeten; sie holen Eicheln. Bucheln. Edelkastanien aus dem Boden, die Eicheln auch nach schon erfolgter Keimung, verzehren die saftigen Koty̧ledonen der Buclien und können dadurch empfindlich schaden. - Den Nadelholzsamen erlangen die Eichlı̈rnchen durch Entschuppen der halbreifen und reifen Zapfen, und insbesondere unter Fichten liegen die Spindeln und Schuppen der zernagten Zapfen oft in großen Mengen.

Das einzige Gegenmittel gegen den Schaden durch die Eichhörnchen — die auch als Nesträuber durch Vernichten nützlicher Singvögel schaden — ist entsprechende Verringerung durch AbschuB, der ohne große Schwierigheit durch das Schutzpersonal ausgefülnt werden liann.

Die sog. $\mathrm{Sch}$ lä f e r oder $\mathrm{H}$ a s e I m ä u s e (Myoxus) kommen in ganz Deutschland vor, fallen aber als kleine, nächtliche Tiere nicht ins Auge und sind hier wohl

1) A. F. - U. J.-Z. 1911, S. 37.

2) Aus der Schweiz ist ein Fall konstatiert, in welchem ein 13 ha großer $15-40$-jâhriger Bestand von Fichten, Föhren und Lärchen auf solche lleise fast völlig ruiniert wurde. (Schw. Z. 1883, S. 192). 
nirgends so zahlreich, daß der durch sie verursachte Schaden - ringreises Benagen der Pinde. namentlich der Rotbuche, WeiBbuche, sowie auffallenderweise der Erle und Birke, damn Verzehren der Eicheln, Bucheln - ein größerer wäre und zur Abwehr nötigte. In größerer Zahl hommen sie dagegen in Krain, Kärnten, Tirol vor und haben dort durch Entrinden junger Nadelholzstämme schon sehr namhaften Schaden verursacht. Die Bekämpfung ist infolge der nächtlichen Lebensweise dieser Tierchen sehr schwierig und kann nur durch Wegfangen der Haselmäuse in Fallen geschehen ${ }^{1}$ ).

\section{Schädliche Vögel.}

\$32. Die Nachteile, welche durch die V o g e l w e l t unseren Waldungen zugelıen liönnen, sind verhältnismäßig geringe und örtlich legrenzte; ein Teil der hier zu nennenden Vögel macht sich gleichzeitig durch Insektenvertilgung wieder mehr oder weniger nützlich, andere sind jagdlich geschätzte Tierc, und wir werden daher, von Vertilgungsmaßregeh absehend, uns auf Angabe einiger $\mathrm{s}$ c h u t $\mathrm{zm}$ it t e l zu bescluränken laben.

Das Auergeflügel, in Winter vorzugsweise auf die Ernährung durch Holzknosp̣en angewiesen, kann sehr lästig werden, wenn es diese seine Nahrung an den Pflanzen unserer Saatkulturen oder Forstgärten sucht; ein paar Stücke, den einmal angenommenen Aesungsplatz einhaltend, entwipfeln rlann oft Hunderte von Fichten, Föhren und Tannen, zumal bei Schnee jeder herausragenden Pflanze den Gipfel abäsend. - Ueberdecken der Beete mit Schutzgittern, der Beete oder wenigstens Beetwege mit sperrigem Reisig oder Dornen gibt in Saatbeeten den nötigen Schutz; auch Anteeren der Knospen (s. \$26) und Leberspannen der Saatbeete mit Draht hat man mit Erfolg angewendet. Viel geringer ist der schaden durch B ir kw $1 \mathrm{~d}$ und $\mathrm{H}$ a s e $\mathrm{l}$ wil $\mathrm{d}$.

Die $\mathbb{T}$ il d t a u ben verzehren sowohl Bucheln und Eicheln wie Nadelholzsämereien und werden durch letztere Liebhaberei insbesondere auf Freisaaten im Frühjahr biswcilen schädlich, weniger in Saatbeeten, da sie nicht scharren, nur obenauf liegenden Samen verzehren. Durch öfteres Schießen an den bedrohten Plätzen sind sie leicht fern zu halten.

Der $N$ u $\rho$ - oder E i c h e l h ä h e r - nützlich als Inselitenvertilger, schädlich als Nesträuber - kann durch seine Liebhaberei für Eicheln, Bucheln, Edelkastanien und durch die Sicherheit, mit welcher er diese Früchte selbst bei guter Bedeclimng mit Erde zu finden weiß, in Saatiulturen und Saatbeeten oft sehr lästig werden, die Saaten stark dezimieren. Bewachen der Saatplätze, Wegschießen der Häher, Decken der Saatbeete mit Domen, sperrigen Aesten oder Schutzgittem sind die anzuwendenden Schutzmittel.

Die $\mathbf{F}$ in li e $\mathrm{n}$ arten werden in Freisaaten wie saatbeeten durch das Aufzehren der Föhren-, Fichten-, Lärchensamen, das Abbeißen der eben aufgekinten, noch die Samenhülle tragenden Pflänzchen der genamnten Holzarten oft sehr nachteilig. Auch Bucheln und deren Kutyledonen werden von den Bergfinken und Buchfinken verzelırt.

Freisaaten müssen zur Strichzeit gegen die oft starken Flüge der Bergfinken bewacht werken, Saatbeete'schützt man durch die beliannten Saatgitter. Als ein mit gutem Erfolg zum Schutz der Nadellolzsaatbeete angewendetes Mittel ist das Vergiften des Samens mit roter Bleimennige (Bleioxyd) zu nennen. Ein geringes Quan-

1) H e $\beta$ (Forstschutz (Bd. I S. 156 ) teilt mit, da $B$ in Frain in Buchenmastjahren bis 800000 solcher Haselmäuse (Billiche) gefangen, verspeist und deren Felle verkauft werden. 
tum des schr billigen und überall zu habenden Hittels reicht hin, um jedem Korn des etwas angefeuchteten Samens einen leichten Ueberzug jenes Schutzinittels zu geben ${ }^{1}$ ) und sowohl das Konn in ungelieintem Zustand, als den noch die Samenhülle tragenden Keimling zu schützen. Ein Töten der Vögel findet dabei erfreulicherweise nicht statt, docl meiden diese den rergifteten Samen.

\section{Schädliche Insekten ${ }^{2}$ ).}

$\$$ 33. Die Forstinseliten im a $1 \mathrm{lg}$ emeinen. Die gefährlichsten Feinde des Waldes aus ler Tierwelt sind entschieden die Inseliten; ihre rasche Vermehrung und ihr dadurch ermögliehtes Erscheinen in oft kolossaler Zahl, ihre meist greringe Größe und hiedurch bedingte schwierige Bekämpfung und Vertilgung sind es, die sie zu solch gefährlichen Feinden machen.

Nicht jedes Inselit, welches auf unsern Waldbäumen lebend sich von einzelnen Teilen derselben nährt, bezeichnen wir als schäcliches F orstinsekt, sondern belegen mit diesem Namen nur jene, welehe - sei es nun öfter oder seltener - in größerer Anzahl auftretend nicht nur den einzehren Baum, sondern den Bestand oder gar den W'ald melır oder weniger gefährden.

Jederzeit, wenn auch in geringer Zahl im Walde vorhanden, und durch geringe Größe, unscheinbare Färbung und verborgene Lebensweise sich dem Auge leicht entzicliend, vermag sich eine Anzahl jener Inseliten bei ihrer Fortpflanzung gebotenen günstigen Bedingungen außerordentlich rasch zu vermehren. Es läßt sich dabei nicht in Abrede stellen, daß unsere gegenwärtige Wirtschaftsweise mit ihren großen Sclıägen, ihren ausgedehnten gleichalten und gleichartigen Beständen der Vermelurung mancher Inseliten, insbesondere jener aus der Klasse der Kulturverderber, entschieden günstig ist, und daß eine Anzahl früher viel veniger bekannter und gefürchteter Insekten unseren Waldungen in den letzten Jahrzelnten großen Schaden zugefügt hat.

Dieser Schaden tritt nun in sehr verschiedener Weise hervor: In den liulturen werden die Pflanzen durch den Fraß der Insekten im Wuchs gestört, zum Kränkeln und Absterben gebracht, selbst ganze hulturen vernichtet, die dam unter großen Kiosten und mit Zuwachsverlust erneuert werden müssen. Aeltere Bestände werden im Wuchs beeinträchtigt, durch das Abster]̧en befallener Stëmme durchlöchert, ja oft in großer Ausdelunung getötet und müssen vorzeitig abgetrieben werden; infolge der bedeutenden Holzmassen, die zu Markit gebracht werden müssen, sinken die Holzpreise, geringe Sortimente wie Pieisig und Stockholz werden oft geradezu unverwertbar. Die Hiebsordnung, im Laufe oft langer Jalıe mit Opfern hergestellt, wird zerstört, die gesamte Forsteinrichtung durch eine größere Inselitenlialamität über den Haufen geworfen. Die liasse des Waldbesitzers endlich wird durch die anzuwendenden Verhütungs- und Vertilgungsmaßregehn, die Nachbesserung und Emeuerung der Kulturen, die steigenden Arbeitslöhne $u$. ̈̈. oft in sehr harter Weise betroffen.

Angesichts dieser Beschädigungen und der stets drohenden Gefahr ist es Aufgabe jedes Forstmannes, sich mil den wichtigsten Forstinseliten, deren Lebensweise und den auf diese gegrïndeten V'erhütungs- und Vertilgungsmaßregeln bekannt zu

1) Vergl. F î $r$ st, Pflanzenzucht 1 . Aufl. s. 157.

2) Literatur: He $\mathrm{n}$ s $\mathrm{c}$ e 1 , Leitfaden zur Bestimmung der schädlichen Forst- und Obstbauminsekten, 1876. Ra t z e burg, Die Forstinsekten, 3 Teile, 1837-1844. J u d e i c h und Y itzsche, Lehrbuch der mittelewropäishen Forstinsehtenkunde, 1885. T a $\mathrm{c}$ h e $\mathrm{nber} g$, Forstwirtsch. Insektenkunde, 1871. - Dr. F̈ ü B li ll, Leitfaden der Forstinsektenkunde 1905. Vergl. auch die Lit.-Angabe bi \$ 19. 
machen, und es bilden diese letzteren einen wichtigen Teil der Lehre vom Forstschutz.

\$34. Le be n s we is e der Forstins e k t e n. Strenge genommen gehört nur der letzterwähnte Teil der Insektenkunde: die Lebensweise der Forstinsekten, insoferne durch sie die Naßregeln der Verhütung und Vertilgung bedingt sind, in das Gebiet des Forstschutzes, während die Insektenkunde im allgemeinen, die Organographie, Physiologie, Systematik in das Gebiet der Zoologie zu verweisen sind. Zum leichteren Verständnis des Nachfolgenden, wie verschiedener wiederholt gebrauchter technischer Ausdrücke, mögen jedoch gleichwohl einige kurze Erörterungen über die Lebensweise der Insekten im allgemeinen hier folgen.

Die überwiegende Mehrzahl der Insekten durchläuft vier von einander grundverschiedene Entwicklungsstadien und damit eine voll $\mathrm{k}$ o $\mathrm{mm}$ e ne $\mathrm{ll} \mathrm{e} \mathrm{t} \mathrm{a} \mathrm{m}$ o $\mathrm{r}$ p h o s e: Ei, Larve, Puppe und fertiges Insekt (Imago): nur eine kleine Zahl liat eine unvoll kom me ne Ietamorphose, bei welcher sich das Puppenstadium ron jenem des fertigen Insektes nicht oder nur wenig unterseheidet, eine Puppen $\mathrm{r}$ u he nicht besteht.

Von dem Imago werden die E i e r bald einzeln, bald in großer Zahl zusammen abgelegt; je nach der Jalıreszeit, in welcher diese Eiablage erfolgt, schlüpfen aus den Eiern schon nach wenig Wochen oder erst nach vorheriger Ueberwinterung die L a r v e n.

Letztere werden nun $1 /$ a $\mathrm{d}$ e $\mathrm{n}$ genannt, wenn sie wie bei den Fliegen fußlos sind; die L, a r ve n der Käfer zeigen hornigen Kopf und 3 lange Beinpaare (Engerlinge) oder nur Fußstummel, die $\mathrm{R}$ a u p e n der Sclimetterlinge haben 5 oder 8 Beinpaare (erstere geringere Zahl die sog. Spamerraupen), und endlich die sog. A f t e rra upen der Blattwespen besitzen (mit Ausnalume der Gespinst-Blattwespen) 9 -II Beinpaare.

Ist die Larve ausgewachsen, so verpuppt sie sich, und zeigt als $\mathrm{P}$ u p p e entweder schon alle Teile des fertigen Imago, sich von diesem nur durch andere Färbung und ihren Ruhezustand unterscheidend - g e m e i B e l t e P u p p e -, oder sie ist mit einer diese Teile verhüllenden Haut umgeben - mask i r t e Puppe. Diese liegt entweder nackt in der Erde oder, durch einige Gespinstfäden befestigt, in einer Rindenritze, zwischen Nadeln ete., oder sie ist mit einem schützenden dichten Gespinst, dem Ko k on, umgeben. Besteht die die Puppe umgebende Hülle aus der nicht abgestreiften Larvenhaut, so wird sie T o n n e, Tönuchen genannt. Als Beispiele seien für gemeißelte Puppen jene der Kiäfer, für maskierte jene der Schmetterlinge genannt; nackt liegen die Puppen des Föhrenspanners unter dem Hoos, in großen Kokons die Puppen des Kiefernspinners, in Tönnchen jene der Blattwespen.

Der Verpuppung folgt eine bald nur wenige Wochen dauernde, bald aber bei Ueberwinterung im Puppenzustand - über 6-8 Ilonate sich erstreckende Puppenruhe, und dieser die Entwicklung des fertigen Inselits (Jmago), des Jäfers, s'chmetterlings usf.; bei hnsekten mit unvollkommener Entwicklung felilt diese Puppenruhe. Dem Ausschlüpfen des Imago folgt in den meisten Fällen alsbald die Paarzeit, F l u g-oder S c h w ä r m z e i genannt, bei einigen Insekten jedoch auch erst nach vorleriger Ueberwinterung. In den meisten Fällen folgt der Paarzeit zimmlich rasch das Absterben der fast durchaus liurzlebigen Imagines, des Männchens nach der Begattung, des Weibchens nach der Eierablage; doch hat man bei einzelnen Inseliten, namentlich Käfern, auch eine verhältnismäßig lange Lebensdauer beobachtet.

Auf die Größe der Vermelırung ist neben der Zahıl der abgelegten Eier auch die sogr. Ge nerations d a n e ron Einfluß, die Zeit, welche vom Zeitpunkt der 

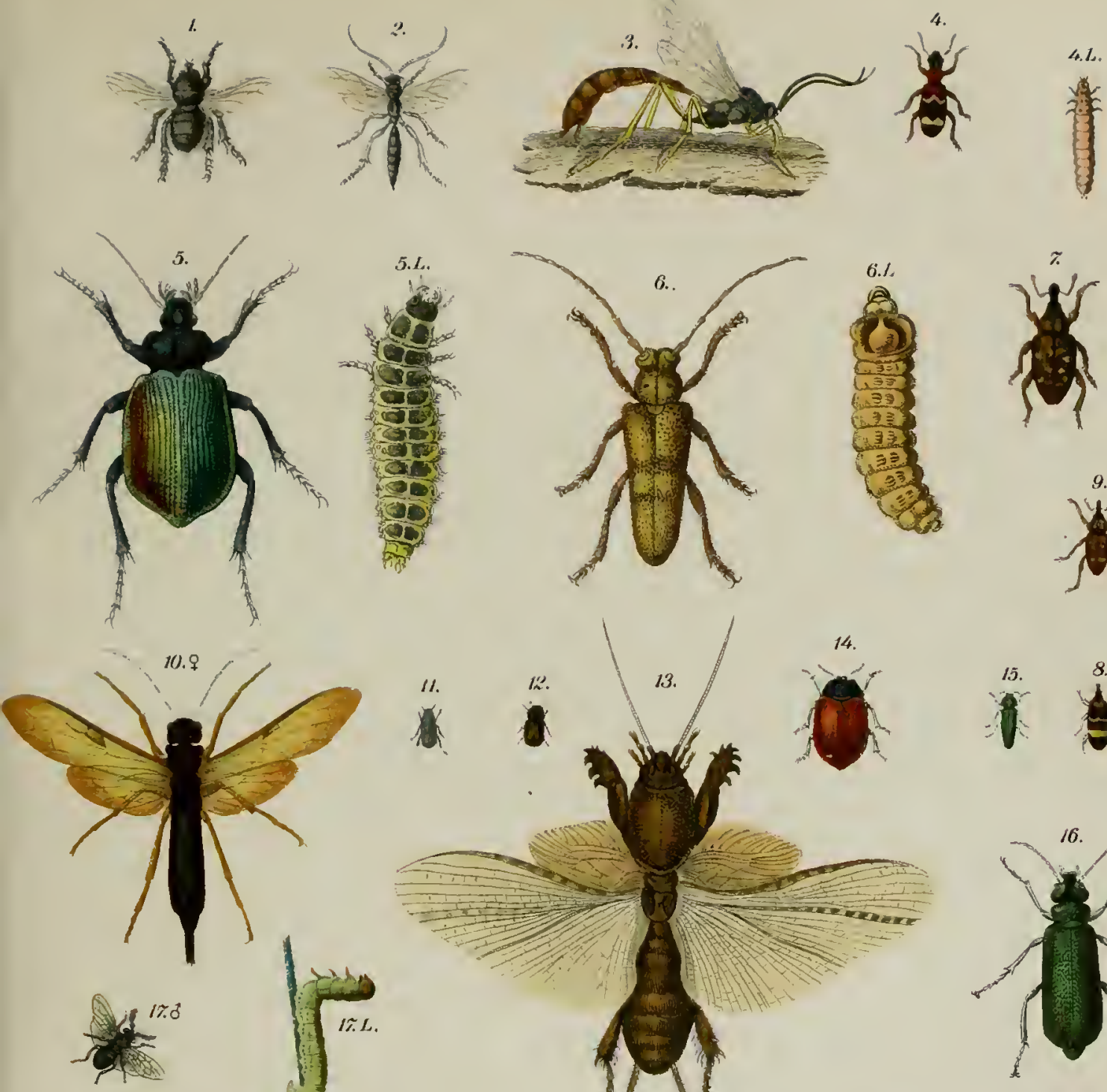

48
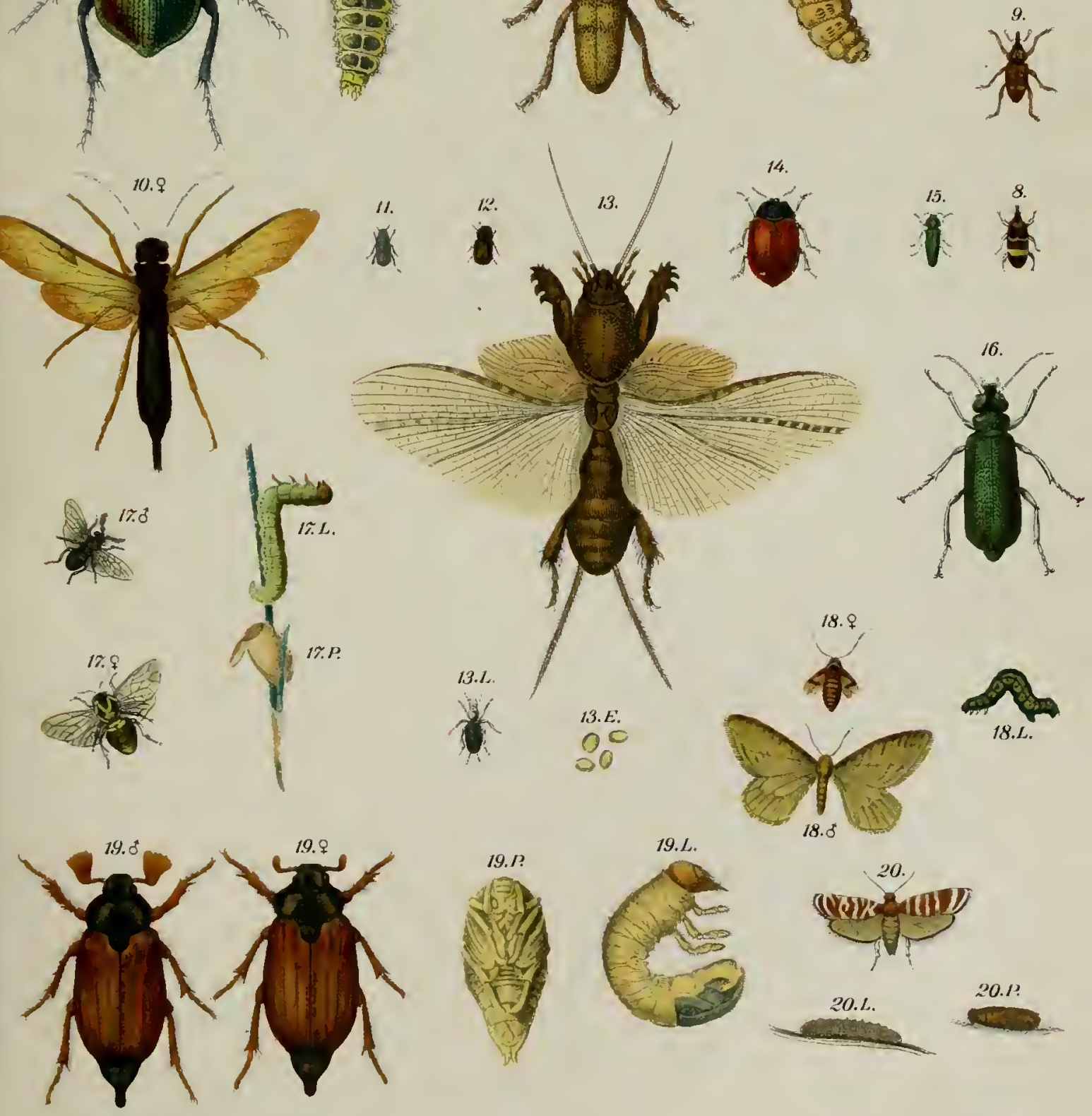

1

in

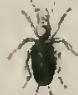

30

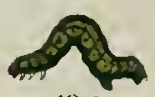

18.L. 

Eierablage bis zur Selwärmzeit der diesen Eiern entsprossenen Inseliten verstreicht; sie ist außerordentlich verschieden, umfaßt bei manchen Arten uur wenige Wochen, bei andern selbst melurere Jahre, und man nenut die Generation

e in f a $\mathrm{ch}$, wenn sich alljährlich e in e Generation entwickelt, wie bei den meisten Selimetterlingen,

d o p pelt, wenn deren zwei in einem Jahre zur Entwiclilung gelangen (Borkenkäfer, Blattwespe),

n e h $\mathrm{r} f$ a $\mathrm{e}$ h, bei sehr kurzer, innerhalb Jahresfrist sich öfter wiederholender Entwicklung (Ichneumonen, Blattläuse),

z we i jä hrig, wenı das Inselit zwei volle Jahıe zu seiner Entwieklung bedarf (Holzwespe, Bockkäfer, Harzgallenwickler), endlich

m e h r jä h r i g, wenn hiezu 3 und selbst 4 Jahre nötig sind (Maikäfer).

Die Insekten werden entweder nur im Larvenzustand schädlich (so die Schmetterlinge), oder als Imagines, vie bei einen Teil der Käfer (ğroßer Rüsselkäfer, spanische Fliege), oder endlich in b e i d e n eben genannten Entwicklungsstadien (so Maikäfer, IV aldgärtner).

$\$ 35$. Verbreitung und Vermel rung. Die Verbreitung der Forstinsekten ist in horizontaler wie vertikaler Richtung eine sehr bedeutende, doclı nimmt aus naheliegenden Gründen zunächst die Zahl der Arten, dann auch jene der Individuen wie gegen Norden, so auch mit der Veereshöhe ab, und im eigentlichen Hochgebirge treten nennenswerte Insektenbeschädigungen nur seltener auf.

Was die gefälırdeten Holzarten betrifft, so lebt zwar auf manchen Laubhölzern, so z. B. der Eiche, eine große Zahl von Insekten, aber nur wenige Laubholzinsekten treten in geradezu bedrohlicher Menge auf, und die den Laubhölzern innewohnende größere Reproduktionskraft vermag die erlittene Beschädigung auch Jeichter wieder auszuheilen. Von den Nadelhölzern belıerbergen Tanne und Lärche nur wenige schädliche Insekten, dagegen sind es zwei unserer verbreitetsten, in reinen Beständen auf ausgedehnten Flächen vorkommende Holzarten: $\mathrm{F}$ i e h t e und $\mathrm{F}$ ö h $\mathrm{r}$ e, welche am häufigsten und schwersten unter Insektenbeschädigungen zu leiden liaben. Auf ihnen findet sich auch eine Anzahl streng monophag lebender Insekten, während eine große Zahl der auf Laubholz vorkommenden polyphag ist, die verseliedensten Holzarten angelit.

Die Vermehrung der schädlichen Forstinsekten ist, wie schon oben erwähnt, einigermaßen bedingt durch die Generationsdauer; im weitern sind es äußere Einflüsse, durch welche die Vernehrung der Insekten begünstigt wird: heiße Sommer, trockene Witterung zur Zeit der Häulung der Larven, des Schwärmens, vor allem aber reichlich dargebotene Brutstätten. Dies letztere gilt insbesondere für eine Reihe von Nadelholzinsekten, die zur Ablage ihrer Brut vor allem Holz mit stockendem oder doch geselıäelıtem Saftluß aufsuchen, erst bei großer Vemehrung auch notgedrungen an gesunde Stänme gehen; ihnen bieten Wind-und Schneebruchmaterial, friseh gefälltes, im Wald liegendes Holz, frische Stöcke, durch vorherigen Raupenfraß kümmernde Stämme und Bestände diese Brutstätten in reichem \aß, und alle Ereignisse, durch welche solche Brutstätten in großer Menge geschaffen werden, fülıren gleichzeitig die Insektengefalır herbei. Oertlichkeiten, von welchen die letztere hienach ausgeht, nennen wir I ns ekten lı e de.

Dagegen treten ungünstige Witterung, lieftige Regengüsse, naßkaltes Wetter der Vermehrung mancher Insekten, so namentlich der nackten Raupen hemmend entgegen; Kranklıeiten, sowie Pilzbildungen, welehe an den Raupen und Puppen in Winterlager sich zeigen, vernichten oft die Mehrzahl in kurzer Zeit; endlich aber ist 
es eine Reilıe von Tieren, welche uns im Kampf gegen die Forstinsekten unterstützen. Als solche erscheinen die insektenfressenden Vögel: Stare, Krähen, Baumläufer, Spechte, Meisen, Drosseln, die meisten der kleinen Singvögel, Kuckuck, Häher, kleinere Raubvögel, Eulen; ferner eine Anzahl Säugetiere: Maulwurf, Spitzmaus, Igel, Eichhom, WViesel, Iltis, Marder, Dachs, Fuelıs, Fledermäuse, zahme und wilde selıweine; endlich

\$36. Dien ützlichen Forstinsekten. Mit diesem Namen bezeichnen wir jene Insekten, welche uns entweder durch Verze h re $n$ der Eier, Larven, Puppen oder Imagines schädlicher Insekten nützlich werden - wir nennen sie R ä ub e r oder Raubinsekten - oder welche ihre Eier in die Larven, seltener Eier oder Puppen, anderer Inseliten absetzen und durch das Schmarotzen ilurer ausschlüpfenden Larven töten - Sell marotzer oder Para site $\mathbf{n}$.

Als die wichtigsten Arten aus beiden Gruppen seien genannt:

1. Als $\mathrm{R}$ ä u be r: Hier steht obenan die an Arten wie Individuen sehr zahlreiche Gruppe der $L$ a u $\mathrm{f}$ ä $f$ er (Carabus), die sowohl als Larven wie als Käfer andere Insekten verzehren. Vou besonderer Bedeutung sind die sog. KJletterlaufkäfer, welche ihrer Nahrung nieht nur am Boden, sondern auch auf den Bäumen nachgehen, in Laubholz der kleinere Calosoma inquisitor, in Nadelholzbeständen der große Calosoma sycophanta (s. Taf. I Fig. 5).

Weiter sind zu nennen die in sandigen Gegenden häufigen und in mehreren Arten auftretenden S a n d ä fer (Cicindela), die Mo de r k ä $\mathrm{fer}$ (Staphylinus), der Bunt-oder Ame isen li äf er (Clerus formiearius) (s. Taf. I Fig. 4), dessen rötliche Larve unter der Rinde den Borkenliäferlarven nachgeht, die S t e e h w e spen (Vespa), Wolfs fliegeu (Asilus), die Sclmetterlinge fangenden L ib e ll e n (Libellula), die allbekannten M a ri e $\mathrm{n} k$ ä $\mathrm{f}$ e r c lı e n (Coccinella) als Vertilger der lästigen Blattläuse, endlich die A m e is e n (Formica).

2. Als Se hmarotzer: Die $R$ a u penfli e ge n (Tachina) und die außerordentlich zahlreiche und mannigfaltige Familie der $\mathrm{S}$ c h l u p f w es p e n (Jchneumon ${ }^{1}$ ). Diese beiden Insektengruppen sind für die V'ertilgung schädlicher Insekten von großer Bedeutung und seien deshalb hier etwas eingehender besprochen.

Die R a u pe $\mathrm{f}$ l i e gen oder Tachinen (s. Taf. I Fig. I), zur Ordnung der Zweiflügler gehörend und Stubenfliegen älnelnd, jedoch an dem stark behaarten Hinterleib leicht kenntlich, kleben ihre Eier äuBerlich an die Raupe und zwar meist wohl nur e in Ei, doch finden sich bei großer Vermehrung der Tachinen deren auch mehrere an einer Raupe. Die ausschlüpfenden Lärvehen bohren sich nun ins Innere der Raupe, von deren Säften lebend; doch gehen die Raupen nicht alsbald zu Grunde, zeigen große Freßlust und gelangen vielfach sogar zur Verpuppung. Die ausgewachsene Tachinenlarve bohrt sich dureh die Haut ihres Wirtes, der Raupe oder Puppe, die nun zu Grunde gehen, heraus, läßt sich zur Erde fallen und verpuppt sich in einem braunen oder sehwarzen, geringelten Tönnchen, aus welehem naelı kurzer Puppenruhe, teilweise auch nach Ueberwinterung die Fliege erscheint. - Im Walde jederzeit vorhanden, vernehren sich rlie Raupenfliegen bei Vorhandensein zahlreicher Raupen und dadurch gebotener reicher Gelegenheit zur Eiablage sehr raseh und leisten bei Bekämpfung, von Raupenkalamitäten - so der Nonne, der Eule - eine selır bedeutende Hilfe.

Bei den zu den Aderfüglern gehörigen $S$ e hl u p f wespe n oder Ichneumonen (s. Taf. I Fig. 2 u. 3) legt das Weibehen je nach (ler sehr weehselnden Größe der

1) Vergl. R a tz e b r g, Die lchneumonen der Forstinsekten, 3 T. 1841-1852. 
betr. Art nur ein oder einige Eier, hei kleineren Arten aber deren oft eine sehr bedeutende Zalıl mit Hilfe eines Legebohrers i 11 die Laren, seltener in die Eier und Puppen. von Schmetterlingen. Käfern und Blattwespen ab. Aehnlich den Tachinen leben die ausschlüpfenden Lärvchen von den Säften des befallenen Tieres (des Wirtes) und boluen sich in der Regel nach vollendetem Wachstum aus dem Ei bezw. der num zugrunde gehenden Larve heraus, um sich in cinem Kokon, der meist auf dem Fraßobjekt kleht, zu verpuppen. Die Raupenkadaver sind oft geradezu unit solchen kleinen Kokons bedeckt - so beispielsweise jene des großen Kiefernspinners mit den zahlreichen weißen Kohons des lileinen Microgaster globatus. Aus den letztern schlüpfen nach kurzer Puppenruhe dielmagines, und da die ganze Entwicklung nur wenige W ochen in Anspruch nimmt - es sei denn, daß sie in den Raupen überwintern -, so ist die Vermehrung bei Vorhandensein reicher Gelegenheit zur Eiablage eine sehr bedeutende.

Ob Raupen angestochen sind, läßt sich bei nackten und hellfarbigen Raupen an den dunkeln Stichflecken erkennen, auBerdem durch Sektion unschwer feststellen. Angestochene Raupen fressen noch mit großer Gier fort, kommen selbst noch zur Verpuppung (bei schwacher und erst spät erfolgter Besetzung), nie aber zur Entwicklung als Imago.

Die Bedeutıng der ichneumonen ist teils überschätzt worden, indem man glaubte, ihnen allein die Bekämpfung eines Raupenfraßes überlassen zu dürfen, teils unterschätzt, indem man darauf hinwies, daß sie in größter Zahl sich erst dann einstellten, wenn jene Tialamität ihrem naturgemäßen Ende nahe sei. Das Richtige dürfte in der Mitte liegen!

Ichneumonen wie Tachinen, jederzcit im Walde vorhanden, werden unter n o rm a l e n Verhältnissen durch ihre Lebensweise der Vermehrung der Raupen hindernd entgegentreten. Treten jedoch Verhältnisse ein, welche diese letztere besonders begüüstigen (s. \$ 35), so werden die genannten Insekten die Vermehrung nicht hindern können, da ihre eigene Vermehrung eben erst durch das Vorhandensein einer größern Zahl von Raupen, die ilınen als Wirte, als Brutstätten dienen, bedingt ist; abel sie werden in solchem Fall dazu beitragen, die Zahl der Raupen rasch zu mindern und hiedurch die Kalamität abzukürzen. -

$\$ 37$. Il ittel d e r A b we hr. Die Mittel zur Abwehr schädlicher Insekten sind zu unterscheiden als llittel der $V^{\circ}$ o b e u $\mathrm{g}$ u $\mathrm{n} g$ und als solche der eigentlichen $\mathrm{V}$ e r t i $\mathrm{lg}$ u $\mathrm{n}$ g. Angesichts des Umstandes, daß die letztere bei bereits vorhandenen großen Insektenniengen schwierig, selbst geradezu unmöglich ist, wird es vor allem Aufgabe des Forstmannes sein, der Vermehrung der im Walde stets vorhandenen schädlichen Insekten nach Kräften vorzub e 1 ge n, nit den Mitteln der V e r i lg u $\mathrm{ng}$ sofort in den ersten Stadien der Vermehrung zu beginnen.

$\mathrm{Zu}$ diesem Zweck ist in erster Linie nötig die rechtzeitige Entdeckung einer drohenden Insektengefahr, wie sie durch aufmerksame und fleißige Revision der Waldungen ermöglicht wird. Kenntnis der in den betreffenden Waldungen vorzugsweise zu fürchtenden Insekten, ihrer Lebensweise, der Oertlichkeiten, wo sie vor allem zu erwarten sind - der Insektenherde - wird hienach selbst dem einfachsten Schutzbediensteten nötig sein. Im Walde liegende Windbrüche, Schläge mit frischen Stöcken, frisch gefälltein Holz (Nadelholz), trockene Sandhügel mit geringen Beständen, liräntielnde Kinturen sind vor allem in Augre zu behalten; Bohrlöcher und Bohrmehl, Raupenkot, abgebissene Nadeln, rasch absterbende Stämme und Pflanzen, dic Tätigkeit insektenfressender Vögel (Kuckucke, Krähen) und anderer Tiere (Wildschweine) verraten dem aufmerksamen Forstmann die sich mehrenden Feinde und lassen ihn zu rascher Abwehr schreiten. 
Wir haben oben gesagt, daß eine Anzahl von Nadelholzinseliten (die Borken-, Bast- und Rüsselkäfer) ihre Brutstätten zunächst in Holz mit stockendem Saftfluß sucht, in frisch gefällten, gebrochenen oder sonst stark beschädigten Stämmen, frisclıen Stöcken u. dgl. Alle Mittel, durch welche wir den Insekten solche Brutstätten entziehen, werden daher als Vorbeugungsmittel zu betrachten sein: Rechtzeitige Aufarbeitung und Abfuhr oder Entrindung des Holzes, Rodung der Stöcke, Verbrennen des etwa wertlosen Astholzes einerseits, aber auch richtige Hiebsführung zur Vermeidung des Windbruches, rechtzeitige Durchforstungen als Mittel gegen Schneeschaden, Unterlassen der Führung großer Kahlschläge und ähnliche Mittel waldbaulicher Art anderseits.

Tritt aber trotz solcher Vorsichtsmaßregeln eine größere Inselitenkalamität ein, wie dies namentlich nach bedeutenderen Beschädigungen des Waldes durch Sturm, Schnee, Brand auch ohne unsere Schuld der Fall sein kann, dann sind die Mittel der Vernichtung in Anwendung zu bringen. Auch sie schließen sich eng an die Lebensweise der einzelnen Insekten an, werden in jenem Stadium der Entwickhung vorzunehmen sein, in welchem eine möglichst massenhafte und vollständige Vertilgung am ersten tunlich; sie sind hienach bei den verschiedenen Insekten natürlich sehr verschieden und werden bej deren Besprechung nälıer bezeichnet werden.

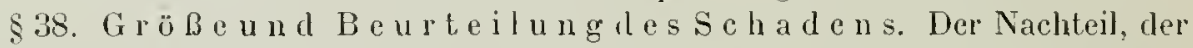
durch die Insekten den Bäumen und Beständen zugeht, ist ein sehr verschiedener, kann sich auf einigen Zuwachsverlust und Störung freudiger und nomaler Entwicklung beschränken, aber auch das Absterben der beschädigten Pflanzen und Stämme nach sich zichen. Bei Laubhözern tritt dies letztere nur selten und dann an Pflanzen oder schwächern Stämmen ein, dagegen sehen wir bei Nadelhölzern die stärksten Stämme und ausgedelnte Bestände in oft kurzer Zeit vernichtet.

Am gefährlichsten erweist sich stets die Zerstörung der $\mathrm{S}$ a $\mathrm{f} \mathrm{th}$ a $\mathrm{u} \mathrm{t}$ oder der W u r z e I n, wälırend eine Zerstörung der Blätter und Nadeln von den reproduktionskräftigen Laublı̈̈lzern überwunden wird, von rlen Nadelhölzerı aber wenigstens dann überwunden werden kann, wenn die linospen für das nächste Frühjahr schon ausgebildet waren; ist dies nicht der Fall, so wird ein Kahlfraß stets das Absterben nach sich ziehen, während die Laubhölzer sich mit Hille der Johannitriebe neu begrünen. - Auf frischem, kräftigem Boden ist die Erholungsfäligkeit beschädigter Kulturen und Bestände stets größer, als auf geringem, trockenem Standort, ebenso in feuchtem, regenreichem Sommer gegenüber anhaltender Trockenheit.

Var die Insektenbeschädigung eine lokal eng begrenzte, so wird man sich. nicht scheuen, stärlier beschädigte Bestände abzutreiben; bei großer Ausdehnung des Fraßes ist es ahel von Wichtigkeit, zu entschejden, welche Bestände $t$ ö $t$ l i c h beschädigt seien, welche dagegen die Joffnung auf Erhaltung und Erholung gehen, damit man den Markt niclıt ınnötig überfülle, aber auch durch verzögerte Aufarbeitung nicht die Qualität des Holzes, die durch Stocken, Blau-Werden etc. rasch eine geringere wird, l,eeinträchtige.

Schlaffe Knospen, bräunliche Flecken auf Bast und Splint, allerlei Insekten unter der Tinde sind schlechte Zeichen, kräftige Knospen, gesunde Safthaut lassen, zumal auf besserem Boden und bei jüngeren Beständen, Erholung loffen; bei letzteren wird man überlaupt mit dem Einschlag länger zögern, als bei einem an sich haubaren Bestand. - Rasche Aufarbeitung des abgestorbenen Holzes, Entrindung, Aufspalten, Aufstapeln auf trockenen luftigen Lagerplätzen beugt der Qualitätsminderung möglichst vor.

\$39. Eiuteilungderschädlichen Forstinseliten. Die Ein- 
teilıng und Gruppierung der schädlichen Forstinsekten kann in mannigfacher Weise erfolgen; man kann sie gruppieren nach ihrer systematisehen Einteilung als Käfer, Sclimetterlinge, Netzflügler usw; nach der beschädigten Holzart als Laubund Nadelholzinseliten, nach dem Alter der gefährdeten Bestände als Bestandsverderber und Kulturverderber, nach den besehädigten Stammteilen als Holzverderber, Blattverderber, Wurzelverderber usw, als teehnisch oder physiologiseh sehädliche lısekten, endlich als selır schädliche, merklich schädliche und wenig schädliche. WVir LaIten es für das zweekmäBigste und ïbersichtlichste, diese Einteilung nach den zwei großen und der Hauptsache nach geseliedenen Gruppen der $\mathrm{N}$ a d el holzund $\mathrm{L}$ a $\mathrm{t}$ b hol z-Inseliten vorzunelımen und innerhalb jeder dieser Gruppen zunächst die Käfer, dann die Schmetterlinge und ansehließend die wenigen den übrigen Insektenklassen angehörigen Insekten zu bespreehen, welche sich als forstschädlich erweisen.

Dem Zweck und begrenzten Unfang vorliegender Ablandlung entsprechend müssen wir uns auf eine kurze Bespreehung der schädlichsten und an häufigsten auftretenden Forstinsekten beschränken, glauben aber doch auch jene anführen zu sollen, welche, wie z. B. Harzgallenwickler und Deformitäten-Erzeuger versehiedener Art, zwar meist keinen wesentlichen Schaden verursachen, jedoch dureh die auffallende Art ihrer Beschädigung die Aufnerksamkeit im Walde auf sich ziehen.

\section{A. Nadelholz-lnsekten.}

\section{Käfer.}

$\$$ 40. Die Borkenkäfer im allgemeine $n^{1}$ ). Die Borkenkäfer (Scolytidae) gehören zu den gefährlichsten Feinden des Nadelholzes, inden sie, in der Regel die Safthaut zerstörend, die stärker befallenen Stämme rasch zum Absterben bringen; auch auf Laubholz kommt eine Anzahl vor (s. $\$ 66$ ), lebt aber vorzugsweise im S p l i n t und gefährdet die Bäume dadurch in minderen Grad. Zur Vermeidung von Wiederholungen erscheint es zwecknäBig, clie Lebensweise der Borkenkäfer und die auf diese gegründeten Verhütungs- und Vertilgungsmaßregeln zuerst im allgemeinen zu besprechen.

Die erstmalige Schwärmzeit der Borkenkäfer ist im Frühjahı, bei einigen Arten schon sehr zeitig, an den ersten warmen und sonnigen Tagen des März (Frïhsschwärmer), bei andern erst im April und selbst Mai (Spätschwärner). Stets erfolgt das Schwärnen nur bei günstiger Witterung, und möglichst rasch bohren sich die líäer meist paarweise in die als Brutstätten ausgewällten Stämme bezw. Pflanzen ein. Als solche Brutstätten suchen sie nun vor allem kränkelndes Material mit etwas stoekendem Saftfuß, und vermeiden bereits zu trocken gewordenes Holz, in welehem die Brut aus Nahrungsmangel zugrunde gehen müBte, ebenso wie gesundle Stämme, in welehen der starke HarzfuB die alten Käfer töten würde. Frisch gefällte Stämme, Windbrüche, durch Schnee und Sturm beschädigte, entwipfelte, gehobene Stämme, frisches Stock- und Reisigholz sind solche ihnen vor allem zusagencie Brutstätlen, die sie durch den Harzgeruch geloekt auf weithin zu finden wissen; felıen ilnnen bei großer Vermehrung solche Brutstätten, so gehen sie notgedrungen an grüne Stämme, in denen allerdings anfänglich eine große Zahl durch den Harzfluß zugrunde gehen mag, bis schließlich der durch Tausende kleiner Wunden verletzte Stamm in kränkelnden Zustand gerät und nun die gewünschte Brutstätte bietet. Hierin, in dem Be-

1) E ic h h of f, Die europäischen Borkenkäfer 1881. B a r bey, Die Bostrichiden von Zentral-Europa 190 . 
fallen gesunden Holzes bei großer Vermehrung, ist dann auch der oft außerordentliche Schaden hegründet, den einzehe Arten anzurichten vermögen.

bie Begattung findet teils vor, teils während des Einbohrens statt, teils erst im Stamm, und in letzteren Fall wird hiezu eine größere Höhlung in die Safthaut zunäehst dem Eingang eingebissen und bei der Paarung als sog. Rammelkammer benützt, von welcher dann der für die Borkenkäfer charakteristische g l e i c li b r e i t e M u t e r ga ng (bisweilen auch deren mehrere) ausgeht, in welchem die Eiablage erfolgt. Die Breite dieser Nuttergänge ist dureh die Größe der alten Käfer bedingt; sie verlaufen teils in und unter der Rinde, zumeist in den kambialen Schichten und den Splint nur berührend ( $\mathrm{R}$ i n d e $\mathrm{n}$ b r ü $\mathrm{t}$ e $\mathrm{r}$ ), teils in dem Holzhörper selbst ( $\mathrm{H}$ ol $\mathrm{z}$ b r ü $\mathrm{ter}$ ), und werden in ersterem Fall als Rindengänge, im zweiten als Holzgänge bezeielınet, und dies sowohl, wie die Art und Weise des Verlaufes ist für die einzelnen Arten versehieden, für ihre Bestimmung von wesentlicher Bedeutung. Man unterseheidet:

L o t g ä n g e oder Längsgänge, in der Längsrichtung des Stammes verlaufend.

IV a g e gä n g e oder Quergänge, in peripherischer Richtung angelegt.

S t e r n g ä n g e, strahlenförmig von der gemeinsamen Rammelkanmer ausgehend.

Die sog. Familien- und Leitergänge (s. unten) sind keine Muttergänge.

In den sehr verschieden langen Muttergängen erfolgt nun die Eiablage, meist einzeln in links und rechts eingebissene likeine Vertiefungen, bisweilen partienweise am Ende eines kurzen Mutterganges; die Zahl der Eier, deren Ablage binnen 3-4 Wochen erfolgt, ist oft eine sehr große, steigt bis auf 100 Stück an. - Aus den Eieru entwickeln sich naeh etwa 14 Tagen die fußlosen, schmutzigweißen Larven mit braunem Kopf und beginnen nun ihren Fraß in rler Safthaut; die anfänglich sehr schmalen, mit dem Wachstun der Larve stets bre i t e r werdende n L a r ve n gä n ge stehen anfänglich ziemlich rechtwinklig zu dem Muttergang, werden beim Breiterwerden stets weiter auseinander gedrängt, da die Larven das Berühren von Nachbargängen sorgfältig vermeiden, und der Verlauf wird hiedurch, wie dureh die Nähe eines andern Mutterganges und daraus hervorgegangener Larvengänge ein oft auBerordentlich unregelmäßiger und damit auch die außerdem meist sehr charakteristische Fraßfigur, welche in Zusammenhalt mit der Größe der Bohrlöeher und der Breite der Muttergänge die Erkennung der Art. welehe den Schaden verübt Lat, ermöglicht, auch wenn der Käfer nicht melı zu finclen ist. Sind die Eier partienweise abgelegt worden und fressen die daraus entstandenen Larven gemeinsam, so entstehen sog. F a $\mathrm{m}$ i l i e $\mathrm{n} g$ ä $\mathrm{n} \mathrm{g}$ e; L e i te r gä $\mathrm{n} g$ e sind kurze, zapfenartig rechtwinklig zum Muttergang stehende und nur zur Verpuppung dienende Larvengänge, und finden sich solche nur bei einer im $\mathrm{Hol}$ z lebenden Art (s. \$ 48).

In der Regel aber erfolgt diese Verpuppung nach 8-10wöchentlicher Dauer, bezüglich deren Länge die Witterung bezw. die Wärme eine große Rolle spielt, von der Eiablage an gerechnet, am Ende der Larvengänge in eingebissenen muldenförnigen Vertiefungen, den W i e g e $n$; die Puppen sind gemeißelt, zeigen alle Teile des fertigen Insekts, sind aber weiß und weich. Almählich dunkler, gelb bis schwarzbraun werdend, entwickeln sie sieh binnen elwa 8 Tagen zum Imago, das bei schleehter Witterung noch einige Tage in der Safthaut frißt, bei wärmerem trockenem Wetter aber sich dureh die Rinde nach außen bolırt, F I u g l ö c h e r hinterlassend, um bei vielen Arten sofort zu sch wä r ne n und eine neue Generation abzusetzen, die in den meisten Fällen noeh im gleichen Jahr zur Entwicklung kommt und unter besonders günstigen Verhältnissen sogar noch schwärut, während in den übrigen Fällen 
die Käfer unter der Rinde, an Stöcken, Wurzeln und sonst geschützten Orten überwinternd erst in folgenden Frühjahr sehwämen. Die Generationsfrage hat in letzten Jahrzehnt zu lebhaften Debatteı' ${ }^{\mathbf{I}}$ geführt; als deren Resultat dürfte festgestellt sein, daß einige Borkenkäferarten infolge raseher Reifung der Geschlechtsorgane nur wenige Tage als Imago in der Puppenwiege verweilen und sofort nach dem Ausfliegen zu einer neuen Brut schreiten - so die Eccoptogaster-(Scolytus-)Arten. Bei einer viel größeren Gruppe ist zu jener Reifung eine längere Zeit nötig, was bei einem Teil - den Hylesinen - zu e i n $f$ a e h e r Generation führt, während bei einem andern, den Tomieus-(Bostrichus-) Arten, diese Zeit der Reifung nicht lange genug ist, un eine dop pelte Generation zu verhindern. Diese doppelte Generation in Verbindung mit der großen Zahl der abgelegten Eier erklärt die große und rasche Vermehung der Borkenkäfer.

Auch die Feststellung, daß die Mutterkäfer längere Lebensdauer besitzen, zu wiederholter Eiablage befähigt sind, verdient Erwähnung.

41. Vorbeugungund Vertilgung. Wie bei allen Insekten, so ist auch bei den Borkenkäfern die Vorbeugung, die Verhütung einer größern Vermehrung der jederzeit in beschränkter Zahl im Wald vorhandenen Individuen von besonderer Wichtigkeit. Als .llittel hiezu dient in erster Linie die möglichste Entziehung der Brutstätten, also reehtzejtige Entfernung (oder Entrindung) des im Walde liegenden Holzes, der Windbrüche, kränkelnder Stämme, frischen Stock- und Reisigholzes; alle Wirtschaftsmaßregeln, durch welche wir schädlichen Naturereignissen, Sturmschäden, Sehnee- und Dufthrüchen u. dgl. vorbeugen, sind zugleich Vorbeugungsmittel gegen die Borkenkäfer, denen durch solche Naturereignisse reichliche Brutstätten geboten werden, und alle größeren durch diese Insekten verursachten Waldbeschädigungen der Neuzeit sind Folgen von Wind- und Schnee-Besehädigungen gewesen.

Das Vorhandensein der Borkenkäfer im Walde aber erkennen wir bei liegenden Stämmen an dem hellen Bohrmehl, welehes die Käfer bei Anfertigung ibrer Muttergänge durch das Eingangsloch sowie durch die im Muttergang in kleinen Abständen angebrachten Luftlöcher herausschaffen und das in kleinern odel größern Häufchen zwischen den Rindenschuppen liegt; am stehenden Stamm finden wir dies Bohrmehl etwa an Spinnweben hängend am untern Teil des Baumes, sehen auch die ausgetretenen weißen Harztıöpfchen. Zahlreiche unregehnäßig beisammen stehende Flughöcher sagen uns, daß die häfer bereits ausgeflogen seien.

Als Mittel, um uns von der Zahl der vorhandenen Individuen zu überzeugen, der stärkern Vermehrung vorzubeugen, und eventuell als Vertilgungsmittel im großen dienen uns nun die $\operatorname{sog}$. F a $\mathrm{n} g$ b ä $\mathrm{u} \mathrm{m} \mathrm{e}^{2}$ ). Man versteht darunter Stämme, welehe man in allen Oertlichkeiten, in denen man die Gegenwart von Käfern vermutet, wirft, um letztere zur Absetzung ihrer Brut in den Stämmen, Stöcken, Aesten zu veranlassen und sich hiedurch einen Anhalt über deren größere oder geringere Zahl und eventuell durch Darbietung weiteren und zahlreicheren derartigen Brutmateriales die Vöglichlieit tunlichster Vertilgung zu verschaffen. Diese Fangbäume müssen zeitig und vor Eintritt der Schwärmzeit gefällt werden; im Frühjahr dient laâufig das noeh allenthalben unabgefahren im Wald befindliche Holz aus der Winterfällıng zu diesen Zweck. Da aber die meisten Borkenkäfer eine doppelte Generation

1) Vergl. Dr. K n o c he in Forstw. Z.-Bl. 1900, 1904, 1908), der insbesondere auf den großen Einfluß der jeweiligen Temperatur auf die Entwicklung der Kăfer und damit auf die einmalige oder doppelte Generation hinweist.

2) Vergl. über Fangbăume die Kontroversen von $\mathrm{E}$ ic $\mathrm{h}$ h of f und $\mathrm{A}$ I t $\mathrm{u} \mathrm{m}$ in $\mathrm{Z}$. $\mathrm{f}$. F. U. J. 1882 und 1883 . 
haben, so ist es nötig, auch im Sommer frische Fangbäume den Käfern zur geeigneten Zeit darzubieten, wobei zu beacliten ist, daß die Käfer entsprechend der wochenlang dauernden Eiablage im Sommer nicht so gleichzeitig schwärmen, wie dies in Frühjahr der Fall zu sein pflegt, und daß zur heißen Zeit die Fangbäume verhältnismäßig rasch austrocknen und nicht mehr angegangen werden. In Nadelholzrevieren, in denen die verschiedensten Borkenkäfer, Früh- und Spätsehwärmer, vorzukommen pflegen, wird man deshalb gut tun, nach Abfuhr des von den Winterfällungen stammenden Holzes wiederholt in kürzeren Intervallen solche Fangbäume zu werfen.

Diese sind nun fleißig zu revidieren, in Falle sie sieh rasch stark besetzt zeigen sollten, zu vermeliren und $r$ e e h $\mathrm{tz}$ e i t i g zu entrinden. Dies Entrinden soll nicht. zu bald gesehehen, damit die darin befindlichen oder noch neu anfliegenden Käfer zur vollständigen Eiablage gelangen; sind die ältesten Larven nahezu ausgewachsen, dann entrindet man und verbrennt die Rinde, welch' letztere Maßregel namentlich dann notwendig wird, wenn größere Mengen soleher Rinden an einem Platz anfallen, die betr. Larven sehon weit in der Entwicklung vorgesehritten sind, vielleicht sehon im Stadium der Verpuppung sich befinden und tiefer in der Rinde liegen. Entgegengesetzten Falles genügt auch das Legen der abgeschälten Rindenstücke in die Sonne, die Safthaut nach oben - in kurzer Zeit sind die noch schwachen Larven abgestorben. Befallenes Reisig wird man verbrennen, Stoekholz verkohlen.

\$ 42. Einteilung der Borkenkäfer. Nan teilt die Borkenkäfer in drei Hauptgruppen:

1. Splin t k ä f r Scolytus (Eccoptogaster), mit schief abgestutztem Hinterleib, nur im Laubholz, und forstlich von geringerer Bedeutung.

2. B a s t k ä f e r, Hylesinus, die Flügeldecken über den Absturz des Hinterleibes lierabgehend, vorwiegend in Nadelhölzern und zwar stets im Bast oder flach in Splint, nie im Holz lebend, vielfael in Wurzeln brütend.

3. Eigentliehe Borkenkäfer, Tomieus (Bostrichus), die Flügeldecken am Absturz oft eingedrückt und gezähnt, der Mehrzahl nach in Nadelholz, in geringerer Zahl im Laubholz lebend, teils unter der Rinde, teils tief in Holz die Brut absetzend, nie aber in den Wurzeln brütend $\left.{ }^{1}\right)$.

Von der großen Menge verschiedener Borkenkïfer, welehe sich in unsern Nadelbolzwaldungen finden, ist es immerhin nur eine kleine Zalıl von eigentliehen Borkenliäfern und Bastkäfern, die zu den in h ö h $\mathrm{e} \mathrm{rem} \mathrm{G} \mathrm{r} \mathrm{a} \mathrm{d} \mathrm{sehällichen} \mathrm{zu} \mathrm{rechnen} \mathrm{ist}$ und nachstehend spezielle Besprechung finden soll.

\$43. DerFichten- o der a chtzähnige Borkenkäfer, Tomicus typographus (s. Taf. I Fig. 12). Dieser Borkenkäfer, einer der gröBten und wohl der verbreitetste und schädlichste, ist 4-6 mm lang, schwarz mit bräunlichgelber Behaarung und mit rötlichgelben Fühlern und Beinen; die Flügeldecken zeigen vertiefte Kerbstreifen und an der schräg abgestutzten Spitze jeclerseits vier gleichweit entfernte Zähne, von denen der dritte der größte ist.

Er ist vorzugsweise im Bergland zu Hause und ist in den Nittelgebirgen unter seine Vermehung begünstigenden Unständen schon wiederholt außerordentlich verderblich aufgetreten, während seine Vermehrung in den eigentliehen Hochlagen eine begrenzte ist. Er gehört zu den Spätschwärmern, je nach der Höhenlage im April bis Ende llai schwärmend, und lebt fast ausschließlich in Fichten, wird nur ausnahmsweise auch in Föhren und Lärehen gefunden; stets befällt er ältere Bestände und auch in diesen wiedel die stärkeren, bereits rauhhorkig gewordenen untern Stammteile,

1) Die einzige Ausnahme bezŭglich des Brütens in Wurzeln dürfte Tomicus autographus sein. S. J u de i c hl und $\mathrm{N}$ it $\mathrm{s}$ che $\mathrm{Bd}$. I S. 454. 
nur im Notfall, bei übermäßiger Vermehrung und mangelndem Brutmaterial auch die oheren, dünnberindeten. Wie alle Borkenkäfer bevorzugt auch er llolz mit stockenden Säften, frisch gefällte, vom Stum geworfene oder geschobene, vom Schnce entwipfelte oder sonst beschädigte Stämme, schon zu trockenes Material chenso meidend wie ganz gesunde Stämne, welch' letztere er erst dann anfällt, wenn das vorhandene kränlielnde Material zum Absatz der Brut nicht ausreicht.

Die Käfer bohren sich zwischen Rindenritzen ein, hiebei gröBere Mengen braunen Bohrmehls auswerfend, fertigen zunächst unter der Rincle die sog. Rammelkammer, in welcher die.Begattung vor sich geht, und nun frißt das Weibehen, von dieser ausgehend, den Mutter- oder Brutgang, einen bis $15 \mathrm{~cm}$ langen nach oben oder unten, auch, wenn 2 Weibchen vorhanden, nach b e i d e n Seiten gehenden Lotgang, der von Zcit zu Zeit ein nach außen gehendes Bohrloch - Luftloch - zeigt. In rechts und links eingebissene kleine Vertiefungen legt nun das Weibchen innerhalb einiger Wochen bis gegen 100 Eier ab, aus denen etwa 14 Tage nach der Ablage die weißen Larven kriechen, die seitwärts geschlängelte, stets breiter werdende, bis $10 \mathrm{~cm}$ lange Gänge in der Safthaut fressen und sich an deren Ende in einer in die Rinde eingenagten Wiege verpuppen. Sind die Stämme stark befallen, verlaufen zahlreiche Miuttergänge nahe beieinander, so geht ein großer Teil der Laren wegen Mangel an Raum für ihre Gänge zugrunde, verkümmert, ebenso vertrocknen sie, wenn die Brut in rasch austrocknendes Material abgesetzt oder letzteres zu raschem Trocknen durch Aufspalten, Lagern in der Sonne gebracht wurde. - Aus der anfänglich weißen gemeißelten Puppe entwickelt sich binnen 8 Tagen der zuerst hellgelbe, allmählich nachdunkelnde Kä fer, der bei ungünstiger Witterung noch einige Tage um die Wiege herum in der Safthaut frißt, bei günstiger sich alsbald durch ein kreisrundes Flugloch herausbohrt; die ganze Entwicklung vom Ei bis zum Imago mag durchschnittlich 8, unter ungünstigen Verhältnissen bis 12 Wochen dauern.

Die erste Generation, je nach Schwärmezeit und Entwicklungsdauer im Juni bis Juli fertig geworden, setzt nun nach einem 14 Tage bis 4 Wochen dauernden Ernährungsfraß der Jungkäfer eine zweite Brut ab, die bis zum Herbst fertig wird und dann in Gestalt unbegatteter Käfer zu überwintern und in nächsten Frühjahr zu schwärmen pflegt; doppelte Generation ist als Regel zu betrachten, Eichhoff behauptete sogar unter günstigen Umständen eine dreifache, während im eigentlichen Hochgebirge die Generation infolge späten Schwärmens und langsamer Entwicklung meist eine einfache bleiben wird.

Die große Zahl der Eier, die doppelte Generation erklären die rasche Vermehrung dieses lnsektes, wenn ihm durch schädliche Naturereignisse - Wind- und Schneebruch - Brutstätten in reicher Menge geboten werden, und der durch diese Ereignisse verursachte Schaden ist nicht selten durch die nachfolgenden lnsektenverlecrungen noch wesentlich gesteigert worden. Alle von dem Käfer nur einigermaßen stärker befallenen Stämme sterben infolge der Zerstörung der Safthaut verlıältnismäßig rasch $a b$, doch findet man die a b g storben e n Stämme stets schon von den Käfern verlassen.

Alle gegen die Borkenkäfer überhaupt anzuwendenden Vorbeugungs- und Vertilgungsmittel, wie sie oben (\$ 41) erwähnt wurden, finden dem Fichtenborkenkäfer gegenüber Anwendung, und ist besonders darauf Bedacht zu nehmen, daß auch die zweite Generation eine genügende Anzahl limreichend frischer Fangbäume vorfindet.

Als eine der großartigsten, vorwiegend durch T. typographus verursachten Käferbeschädigungen ist der Borkenkäferfraß im böhmischen und anstoßenten bayrischen Wald in den Jahren 1871-1875 zu erwähnen, woselbst nach vorher- 
gegangenen sehweren Sturmbeschädigungen noch Millionen von Festmetern vom Käfer getötetes Holz eingeschlagen werden mußten $\left.{ }^{1}\right)$.

$\S$ 44. Der große Kiefernborkenkäfer, Tomicus stenographus (sexdentatus). Der größte bei uns vorkommende $\mathrm{B}$ or k e $\mathrm{n}$ käfer, $6-8 \mathrm{~mm}$ lang, schwarz mit bräunlichgelber Behaarung. nach hinten etwas schmäler werdend, mit tief gekerbten punktierten Flügeldecken, am Absturz tief und scharfrandig eingedrückit und jederscits sechszähnig. Seine Größe schützt ihn vor Verwechslung mit anderen Borkenkäfern.

Er kommt auf den verschiedenen Pinus-Arten vor, ist jedoch viel seltener als B. typographus und fehlt in manchen Föhrengebieten gänzlich. Ein Spätschwärmer, fällt er am liebsten stärkere liegende Föhrenstämme an, bohrt sich jederzeit in den dickborkigen Teil ein und fertigt hier $20-30 \mathrm{~cm}$ lange, verhältnismäBig breite ILuttergänge, wèlche zwar als Lotgänge bezeichnet werden müssen, doch auch seitlich abweichen und sich selbst gabeln. In übrigen gleicht seine Lebensweise jener des Fichtenborkenkäfers, auch bez. der früher mehrfach bezweifelten doppelten Generation.

Da er nur ausnahmsweise stehende Stämme anfällt, so sind besondere Vorbeugungsmaßregeln gegen ihn kaum nötig und genügt das Entrinden der von ihm im Frühjahr befallenen Fangbäume bez. des von den Fällungen her noch im Walde befindlichen Holzes wohl stets, um seine Vermehrung zu hindern.

$\$ 45$. Der sechszähn ige Fi c h te n borken $\mathrm{k} a ̈$ f e r, Tomicus chalcographus. Dieser kleine Borkenkäfer ist nur ca. 2 mm lang, umbehaart, fettglänzend mit dunklem Halsschild und rötlichbraunen fein streifig punktierten, gegen die Spitze zu glatten Flügeldecken, an dem eingedrückten Absturz mit je drei Zähnen beiderseits.

Er gelıört zu den häufig auftretenden Borkenkäfern und kommt nicht selten gleichzeitig mit T. typographus am selben Stamm vor, wobei er dann stets die obern, dünnberindeten Stammteile bewohnt; auch an schwächerem Stangenholz findet er sich häufig. Seine Brutgänge sind sehr charakteristisch, indem sie, der geringen Größe des Käfers entsprechend, als selır schmale Sterngänge in der Basthaut von einer mehr in der äußern Splintschichte liegenden Rammelkammer ausgehend verlaufen. Er schwärmt etwas früher als T. typograplus, hat gleich diesem eine doppelte Generation und befält, wie schon erwälnt, an stärkern Stämmen vorwiegend die obern Stanmnteile, hiedurch wohl häufig die befallenen Individuen in kränkelnden Zustand versetzend und zu geeigneten Objekten für die Angriffe des erstgenannten Käfers machend; der HarzfluB scheint ihm minder gefährlich zu sein, als diesem letztern.

Die Verhütungs- und Vertilgungsmaßregeh sind die schon genannten, doch dürfte zu erstern auch die Entfernung alles unterdrückten, kümmernden Materiales dureh fleißige Durchforstung der Fichtenstangenhölzer zu rechnen sein.

$\S 46$. Ler krummza hnige Ta n nenborkenkäfer, Tomicus curvidens. Der 2,5-3 mm lange käfer ist sehwarz, bräunlichgell, behaart, das Weibchen mit gelbem Haarschopf auf der Stine; die Flügeldecken Laben tiefe Kerbstreifen, sind feinreihig punktiert, die Seitenreihen des steilen Absturzes beim Ilännchen jederseits mit 5-7 Zähnen besetzt, wovon der 1., 2. und 5. hackenförmig gekrüınmt, während das Weibchen auf jeder Seite nur $3-4$ stumpfe Zähne zeigt.

Der liäfer bewohnt fast nur die Tanne, als seltene Ausnahme andere Nadellı̈Izer, befällt in erster Linie cinzeln stehende stärkere Bäume, Randstämme und diese meist zunächst in den obern Stammteilen. Ein Frülıschwärmer, hat er jeden-

1) Vergl. A I t u m, Forstzoologie III. 1. S. 295. (1881). 
falls eine doppelte Generation, die Vuttergänge sind oft sehr ausgeprägte, doppelarmige Wagegänge, weichen aber nieht selten von dieser Gestalt in mannigfachster Weise durch schrägen, geknickten, zackigen Verlauf ab, werden aber nie zu Lotgängen; sowohl die Mutter- wie die Larvengänge greifen etwas in den Splint ein, so daß sowohl dic Bastscite der Rinde, wie die äußere Splintschiclıte die Fraßfigur zeigt; die Puppenwiegen aber liegen zum größ3ern Teil in der Splintschichte.

Bei einigermaßen aufmerksamer Wirtschaft wird man den T. curvidens meist auf das Maß der Unschädlichkeit beschränken können, in manchen Fällen hat er sich in Weißtannenbeständen als ein sehr lästiger Feind erwiesen. Befallene Bäume sind stets reehtzeitig und vor der Verpuppung zu schälen, da, wenn letztere schon eingetreten, ein großer Teil der im Splint liegenden Puppen bei der Entrindung nieht mit vernichtet wird. In einem stets aufmerksamen Auge auf den Wald, in rechtzeitiger Entdeckung und Entfernung der meist vereinzelt befallenen Stämme licgt bei diesem Borkenkäfer der Schwerpunkt der Vorbeugung, da Fangbäume wenig Erfolg haben.

Ein zweiter, in Tannen vorkommender Borkenkäfer ist der selır kleine T. piceae, welcher stellenwcise auch sehon schr lästig geworden ist.

$\$ 47$. Derzweizahnige (zweihakige) Kiefernborkenkäfer, Tomicus bidens (bidentatus). Ein kleincr nur 2-2,3 $\mathrm{mm}$ langer Borkenkäfer, schwarz, glänzend, fein behaart, die Flügeldecken meist pechbraun mit feinen Punktstreifen; das Mänuchen am Flügeldecken-Absturz mit breitem, flachem und glattem Eindruck, der jederseits am obern Rand, e i n e n großen hakenförmig nach unten gekrümnten Zahn trägt.

Der Käfer pflegt sich in allen größeren Kiefernwaldungen zu finden, geht neben der Kiefer auch alle übrigen Pinus-Arten an, und befällt ausnahmsweisc und wohl nur bei Ilangel anderen passenden Brutmateriales auch Fichten. Stets sind es die dünnrindigen Stammteile: die Aeste und Zweige, die oberen glattrindigen Teile der Stämme und Stangen, die er bcfällt, mit besonderer Vorliebe aber geht er an jüngere, bis zu 6 und 10 Jahre alte Kulturen, und hat in solchen sehon sehr bedeutende Verheerungen angerichtet.

Er ist ein Spätschwärmer, und oft verschiebt sich die Schwärmperiode bis in den Juni. Von der meist ziemlich geräunigen Rammelkammer gehen 3-7 ILuttergänge sternförmig aus, durch eine eigentümlieh geschwungene Gestalt und das Bestreben, sic in der Längsrichtung des Stammes anzulegen, charakterisiert. Die geschlängelten Larvengänge greifen etwas, die Wiegen ziemlich stark in den Splint ein. Die Generation ist eine doppelte; Regel ist wohl das Ueberwintern der 2. Generation als fertige Käfer. Reine Wirtsehaft im Walde: Entsprechende Entfernung künmmernder Stangen in Durchforstungsweg, rechtzeitige Abfuhr des Reisigholzes, ist ncben der Darbietung entsprechenden Brutmateriales in Gestalt frischen Reisigs namentlich auch in der Sommer-Schwärmperiode das Nittel der Vorbeugung gegen den oft sehr schädlichen Käfer; das Reisig der für andere Föhtrenborkenkäfer gefällten Fangbäume dient als Brutnaterial für T. bidens und wird, wenn mit Brut besetzt, verbrannt. Nimmt man wahr, daß Iíulturen von ihm befallen sind, so ist das Ausreißen oder Abhauen und Verbrennen der kränkelnden Pflanzen als Vertilgungsmittel anzuwenden.

\$ 48. Der Nutzholz-Borkenkäfer, Nyloterus (Trypodendron) lineatus. Der $2,8-4 \mathrm{~mm}$ lange schwarze Küfer hat trüb gelblichbraune Flügeldecken, ebensolche Fühler und Beine, und auf den Flügeldecken drei dunkle Längsstreifen - Naht, Seitenrand und Mittelstreifen - denen er seinen Namen ,"lineatus" verdankt; die Flügeldecken sind ohne Eindruck, Einkerbung oder Zähne. 
Er kommt nur in Nadelholz, jedoch in allen Arten vor und scheint insbesondere das Holz der Weißtanne zu bevorzugen; er befällt fast nur liegendes, frisch gefälltes Holz und dessen zurückgebliebene Stöcke, selten noch stehendes, wenn auch künmerndes Holz. Im Innern des Holzes seine Brut absetzend, gehört er zu den $\mathrm{t}$ e $\mathrm{c} \mathrm{h} \mathrm{n}$ is $\mathrm{c} h$ schädlichen Insekten und zeigt in seiner Lebensweise sehr wesentliche Abweichungen von jener der übrigen Borkenkäfer.

Sehr frühzeitig, im März oder Anfang April schwärmend, befällt er sofort das zu jener Zeit von den Winterfällungen her wohl allenthalben noch in größerer Menge in W'ald befindliche gefällte Stamm- und Schichtholz, und bohıt das begattete Weibchen sich 4-5 cm tief senkrecht zur Stammachse in das Holz ein, von hier aus seitwärts senkrecht zur Eingangsröhre und meist dem V'erlauf eines Jahresringes folgend einen Mluttergang fressend, in welchem die Eier in kleinen Partien abgelegt werden. Die ausschhüpfenden Larven leben im Muttergang vorwiegend wohl ron den aus den Wänden desselben schwitzenden Säften, fertigen keine Larvengänge; zur Verpuppung reif, fressen sie sich eine kurze, nur 5 mm lange und senkrecht nach oben oder unten zum Muttergang stehende Puppenwiege, und diese Puppenwiegen bilden in Verein mit dem Muttergang den sog. L e it e r g a $\mathrm{n}$. Nach der Entwicklung zum Imago verlassen sie ihren Aufenthaltsort durch den Nuttergang und fressen sich also nicht, wie die übrigen Borkenkäfer, eigene Fluglöcher. - Die Generation ist eine doppelte.

Am Schichtholz unschädlich kann der Nutzholzborkenkäfer am Stamm- und insbesondere an dem Blochholz sehr schädlich werden, indem er, dasselbe durchlöchernd, dessen Nutzholzwert wesentlich herunterdrückt, den Holzhändlern Veranlassung gibt, die Qualität des Holzes und dessen Wert tiefer herabzusetzen, als faktisch der Fall ist; denn da die Gänge nicht tief ins Holz gehen, so sind es nur die äußern, an sich minderwertigen Splintholzschichten, welche beschädigt werden. Immerhin kann der finanzielle Nachteil für den Waldbesitzer ein sehr bedeutender sein.

Als Mittel gegen diese Beschädigungen und gegen die Vermehrung des Käfers erscheinen: rechtzeitige Abfuhr des wertvolleren Nutzholzes vor der ersten Schwärmperiode und bezw. rechtzeitige Fällung und Verwertung; Entrinden des Stammholzes, wenn dessen Abfuhr nicht rechtzeitig erfolgen kann, damit es in den äußern Schichten rasch abtrockne, da es dann vom Küäer minder gern angegangen wird. Befallenes Schichtholz wird zum Zweck des raschen Austrocknens aufgespalten die darin befindliche Brut geht dann zugrunde - oder gleich dem etwa zur zweiten Schwärmperiode geworfenen Brutmaterial, geringwertigem Stammholz, verkohlt.

\$49. Der große Ki efernmarkkäfer, Waldgärtner, Hylurgus (Myelophilus) piniperda (Taf. I, Fig. 11). Der 4-4,5 mın lange Käfer ist länglich, fast walzenförmig, schwarz und glänzend, dünn behaart mit hellbraunen Fühlern und Tarsen; die mit Querrunzeln versehenen Flügeldecken sind mit groben Punktreihen und zwischen diesen mit kurz behaarten Höckerchen versehen; an dem gerundeten, weder eingediückten noch gezälnten Absturz hört die zweite Höckerreihe, von der Naht gerechnet, plötzlich auf, so daß dieser zweite Zwischenstreif hier vertieft erscheint.

Der Markiäfer lebt vorzugsweise auf der Föhre, befällt jedoch auch alle deren Verwandte aus der Gattung Pirus, insbesondere auch die Weymouthskiefer. Er gehört zu den Frühschwärmern, fliegt in den ersten schönen Tagen des März, bisweilen noch frïher, und bohrt sich dann möglichst rasch in die dickborkigen unteren Stammteile des frisch gefällten Holzes, hoher Stöcke, eventuell kränkelnder Stämme ein, hiezu stets Rindenritzen wählend, da ihm dies Einbohren hiedurch erleichtert wird; 
starke Bohrmehlıäufchen zwischen den Rindenschuppen verraten die Anwesenheit des Inselits.

Das Weibchen fertigt mun einen vom Eingangsloch aus mit charakteristisch gebogenem Anfang (Krïcke) verselenen, in der Längsrichtung des Stammes verlaufenden einarmigen Nuttergang (Lotgang) von 8-10 cm Länge und legt, gleichzeitig mit Herstellung dieses Ganges, in links und rechts eingebissene Einkerbungen seine zalılreichen Eier innerhalb 3-4 Wochen ab; man hat deren bis zu humdert in cinem Muttergang gezählt. Das Eingangsloch ist häufig durch einen sehr ins Auge fallenden ,Harztrichter" gekennzeichnet. Der Muttergang führt am stchenden Stamm stets von dem Eingangsloch aufwärts. Die nach etwa 14 Tagen ausschlüpfenden Larven fressen seitwärts geschlängelte, bis $7 \mathrm{~cm}$ lange Gänge in Bast und Rinde, den Splint nur berührend, verpuppen sich an deren Ende in Rindenwiegen und nach etwa 10-12 Wochen vom Beginn des ersten Schwärmens an, also meist im Monat Juni, fliegen die ersten Käfer aus, während die später abgesetzte Brut, sowie jene in rauhen Lagen, in schattig gelagertem Material erst in Juli zur Entwicklung gelangt.

Dic Frage, ob der Markkäfer eine einfache oder doppelte Generation habe, ist durch Dr. Ii no che s Forschungen ${ }^{\mathbf{y}}$ ) wohl dahin entschieden, daß die Generation infolge der langsamen Geschlechtsausreifung der Jungkäfer wenigstens in Deutschland eine überwiegend einfache ist, neuer Befall in Sommer von Altkäfern herrührt, die zum zweiten Mal eine Brut absetzen. Die im Juni und Juli erscheinenden Jungkäfer beginnen eine andere verderbliche Tätigkeit.

Diese besteht nun darin, daß sich die lïäfer in die jüngsten - heurigen und auch vorjährigen - Triebe älterer Föhren einbohren und nun zu ihrer Ernälırung die Markröhre durch einen walzenförmigen Gang ausfressen; das Eingangsloch ist hiebei häufig durch einen wallartigen Harztrichter charakterisiert. Den ausgefressenen Trieb verläßt der Käfer entweder sich rückwärts schiebend durch das Eingangsloch oder clurch eine durchgebissene Oeffnung am Ende der Triebe; letztere sterben ab und bedecken, vom Wind an der Eingangstelle des Käfers abgebrochen, im Herbst oft in großer Zahl den Boden der befallenen Bestände.

Die Käafer, teilweise noch in den vom Wind lieruntergeworfeneu Triebspitzen steckend, überwintern in Rinderitzen, unter lloos und in der dicken Borke der untern Stammteile, in welche sie sich zu ihrem Schutz einbohren.

Der Schaden, den der Markhäfer durch seine Brut verursacht, ist nur ein geringer, da er liezu rorwiegend das gefällte Holz, stärkere Stöcke und kränkelnde Stämme wählt und nur im Notfall an gesunde Stämme geht; dagegen kann der Schaden, den er als Käfer durch das Ausfressen der Triebe verursacht, unter Umständen ein sehr bedeutender sein. Dic Wipfel rler wiederholt befressenen Stangen und Stämme zeigen die merkwürdigsten Formen und Terunstaltungen, sind licht und lückig, selıen aus wie hünstliclı zugeschnitten (Waldgärtner!), der Wuchs der befressenen Stämme wird ein liummerlicher und ganze Bestände - so in der Nähe von Holzlagerplätzen, Sclmeidemühlen etc. - verkrüppeln zuletzt; namentlich sind es dic Randstämme, welche von diesem Inselit heingesucht werden, und für jüngere Bestände muß erklärlicherweise eine derartige fortdauernde Beschädigung besonders einpfindlich sein.

Als Gegenmittel erscheint nun auch hier wieder die schon mehrfach betonte ,reinliche" W"irtschaft, die rechtzeitige Entfermung kränkelnden Holzes, die Abfuhı des gefällten Materiales spätestens bis Mitte Mai, danit die abgesetzte Brut mit aus

1) Vergl. Forstw. Z.-Bl. 1908 S. 201. 
dem Wald komme, andernfalls die rechtzcitige Entrindung und Verbrennung der Pinde, welch letztere Nittel auch dann anzuwenden sind, wenn etwa das Holz in der Nähe des Waldes auf Holzstellplätzen, in Schneidemühlen etc. aufgegantert wird. - Außerdem aber sind reehtzeitig und in entsprechender Anzall geworfene Fangbäume das wichtigste Mittel zur Bekämpfung dieses Feindes, während das ebenfalls schon empfohlene Zusammenkehren und Verbrennen der im Herbst abgefallenen ausgefressenen Zweigspitzen um deswillen nur wenig hilft, weil die Mehrzahl schon vom Käfer verlassen ist.

Als besonderer Feind des Markkäfers wäre der Buntkäfer (Clerus formicarius) zu nennen, dessen gelbrötliche Larve, unter der Rinde der mit Brut besetzten Föhren lebend, die Larven des Markkäfers verzehrt und ganze Bruten vernichtet.

$\$ 50$. Der kleine Ki efernmark käfer, Hylurgus (Myelophilus) minor. Er ist dem großen Nlarkkäfer sehr ähnlich, auch in der Größe nur wenig unterschieden, nach Binzer's Angabe durch den glänzenden Halsschild und mehr bräunliche Färbung charakter'isiert; als sicherstes Kiennzeichen aber ist zu betrachten, daß die bei Hyl. piniperda angegebene Unterbrechung der Höckerpunkte auf den Flügeldecken am Absturz nicht vorhanden ist, diese sich vielmelur auch bei der zweiten Reihe bis zum Spitzenrand fortsetzen.

Wesentlich verschieden ist er dagegen durch seine Lebensweise, indem er vorwiegend, wenn auch nicht ausschließlich, die dünn berindeten Stammteile der Föhre befällt und als Muttergänge zweiarmige W a $g$ gä $\mathbf{n}$ g e anfertigt, so daß eine Verwechslung mit dem großen Markkäfer ausgeschlossen erscheint; seine Larvengänge sehneiden tief in den Splint ein. - Er setzt ferner seine Brut lieber in noch slehendem, wenn auch aus irgend welchen Grunde kränkelndem Material ab, da an gefältem Holz jene dünnherindeten Stanmteile zu rasch austroeknen, wodurel die Brut zugrunde geht, und nicht selten ist er der Vorläufer von Hyl. piniperda, mit dem er sich auch am gleichen Stamme findet, ersterer in den unteren, letzterer in den oberen Stammteilen hausend.

In seiner Lebensweise gleicht er im übrigen scinem Gattungsverwandten und bcschädigt als Käfer Stangen und Stämme in gleicher Weise durch das Ausfressen der Triebspitzen. Dagegen seheint er seltener zu sein und fehlt an manehem Ort, wo der große Markkäfer häufig auftritt, fast gänzlich, während das Ungekehrte nicht leicht der Fall sein wird.

Auch die Mittel der Vorheugung und Vertilgung sind die gleichen, doch wird man als Fangmaterial mehr schwächeres, dünn berindetes Holz fällen und Sorge tragen müssen, daß dasselbe nicht zu rasch austrockne, da es dann vom Käfer nicht mehr angenonimen wird.

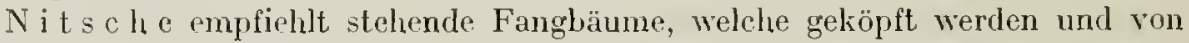
beiden Markkäferarten angenonmen würden. Bei etwas späterer Entrindung der Fangbäume ist zn beachten, daß die Puppen des Hyl. minor im Splint liegen, also durch flaches Entrinden nicht vernichtet werden.

\$5I. Sonstige Bast $\mathrm{k}$ ä fer, Hylesini. Von deren ziemlich großen Zahl mögen noch folgende, welche an manchen Orlen schon größeren Schaden verursacht haben, Erwälnung finden:

Der schwarze li i e f e r n a stkäfer (Hylastcs ater) und der

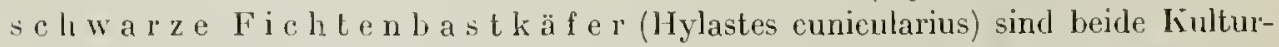
verderber und beide nur als Inäfer schädlich. Sie setzen ihre Brut an die Wurzeln der frischen Nadellolzstöcke auf den Sclılägen in Frühjahı nach der Fällung ab, dic sich dort in unschädlicher Weise unter der Rinde und in den äuBern Holzlagen ent- 
wickelt. Die Muttergänge sind Längsgänge mit seitlichen Eigrühchen und seitlich abgehenden Larvengängen, die aber erklärlicherweise alsbald in die Längsrichtung der W'urzeln übergehen und die gesante Safthaut in braunes W'urmehl verwandeln. Die Iïfer dagegen befallen die jungen Föhren- und bezw. Fichtenschläge, befressen die zarte Rinde und die unter ilır liegende Basthaut, liedurch die Pflanzen zum Kränlielı und vielfach selbst zu raschem Absterben bringend.

Als Vorbeugungsuittel erscheint das möglichst sorgfältige Roden der Stöcke sant den Wurzeln, das Legen von Fangkloben als Brutmaterial, insbesondere auch für die zweite im Sommer schwärmende Generation, das Vermeiden des sofortigen Anbaues der frischen Schlagflächen, da die gesetzten Pflanzen durch die auskomntenden liäfer in holım Grad gefälırdet wären. Als Mittel der Vertilgung ist neben den als solches zı betrachtenden Fangkloben, die nach erfolgtem Absatz der Brut entrindet oder noch besser verbrannt oder verkolnlt werden, das Ausziehen und Verbrennen der kränkelnden mit Käfern besetzten Pflanzen zu betrachten.

Der gro $\mathrm{Be}$ oder $\mathrm{Ri}$ esen-Ficliten b s tiäfer, Dendroctonus micans, ist der größte bei uns vorkonmende Bastkäfer, $8-9 \mathrm{~mm}$ lang, schwarz mit grüngelber Behaarung, und gehört zu den stellenweise sehr schädlich auftretenden Insekten. Der Iäfer, von dem ein eigentliches Schwärmen noch nicht beobachtet wurde, legt seine Eier von Mai bis August ab und bohrt sich das Weibchen meist tief unten am Stamm - bis Meterhöhe - und zwar mit Vorliebe an etwa vorhandenen Wundstellen bis zur Safthaut ein, macht einen kurzen, unregelmäßigen, oft knieförmig gebogenen Nuttergang und legt seine Eier in einem oder melıreren Haufen zu 50 bis 100 Stück daselbst ab. Auch bei diesem Iíf er wurde lange Lebensdauer der Käfer und Eiablage während melırerer Monate (durch Ech s t e in) festgestellt. AlsBrutobjekt dient fast nur die Fichte, in seltenen Fällen die hiefer, und zwar werden mit Vorliebe Stangen von 25-50 Jahren, doch auch stärkere Stämme gewählt und vielfach vollständig gesunde, unbeschädigte Individuen befallen. Die ausschlüpfenden Larven fressen dicht gedrängt neben einander unter der Rinde einen größern Hohlraum, der auch als $\mathrm{F}$ a $\mathrm{m}$ il i e $\mathrm{n} \mathrm{g}$ a $\mathrm{n}$ g bezeichnet wird, und überwintern teilweise als Larven, teilweise nach vorheriger Verpuppung in einzelnen, im Fraßraum liegenden Wiegren als Käfer. - Die Anwesenheit des Käfers in einem Stamne ist an dem reichlich aus dem großen Eingangsloch ausfließenden und zu weißen Klumpen erhärtenden Harz zu erkennen.

Stärker befallene Stangen und Stämme kränkeln und sterben ab, und es werden die Bestände dadurch in bedauerlicher Weise durchlöchert. Als Mittel der Vorbeugung erscheint die tunlichste Vermeidung aller Beschäcligungen der Stämme bei Fällung und Abfuhr, Beseitigung beschädigter, geschälter etc. Stangen; als Nittel der Vertilgung lediglich dic Fällung und Entrindung der befallenen und an dem oben berülırten Harzausfluß kenntliclien Stämme.

Der Schaden, den der Fäfer manclıen Orts (Harz, Thüringen) angerichtet hat, war bisweilen schon ein bedeutender, zumal der Iiäfer vollkommen gesunde Stämne anfällt und durch den starken Harzfluß nicht in seiner Entwicklung gehemmt erscheint.

\$52. Der groBe bra un e R ü ss elkä fer, Hylobius abietis (s. Taf. I Fig. 7). Dieser $8-12 \mathrm{~mm}$ lange und $4-6 \mathrm{~mm}$ breite Käfer mit mäßig langen starkem Rüssel ist dunke]- bis rotbraun, mit gelben Zeichnungen zwischen den Augen, an den Seiten des Halsschildes und Hinterleibes, dann auf den Flügellecken, welche Zeichnungen durch zu Flecken zusammentretende gelbe Haarschüpjchen entstehen, auf den Flügeldecken als Querbinden erscheinen und am frischen Iiäfer lebhaft hervortreten, allmählich aber sich abreiben. 
Ueber die Lebensweise dieses ebenso schädlichen wie zahlreich auftretenden Käfer's - cr wird da und dort nach Millionen gesammelt! - bestand nun merkwürdigerweise lange eine große Unklarheit und bezw. Verschiedenheit der Ansichten unter selbst bewährten Forschern, so zwischen $\mathrm{Al} \mathrm{tum}$ und $\mathrm{E}$ i $\mathrm{ch}$ h of $\mathrm{f}{ }^{\mathrm{I}}$ ), von denen der erstere eine z w e i jä h r i g e Generation auf Grund seiner Beobachtungen beliauptete, während letzterer eine solche entschieden bestritt und selbst eine d o pp el te Generation für wahrscheinlich erklärte. Der Umstaml, daß man zu gleicher Zeit frische und (den abgeriebenen Flügeldecken nach) schon länger lebende Käfer, dann Larven in jedem Stadium der Entwicklung antraf, führte den einen zu dieser. den andern zu jener Erklärung. Eine Reihe von Beobachtungen, die Oberförster v o n $\mathrm{Op} \mathrm{pe}{ }^{2}$ ) in sehr exakter Weise mit möglichst naturgemäß eingezwingerten Käfern angestcllt hat, führte zu höchst interessanten Resultaten und scheint in die Generationsverhältnisse des Rüsselkäfers Licht gebracht zu haben.

Nach v. Oppens Beobachtungen ist die Lebensdauer des Käfers eine sehr lange, bis zu zwei Jahren; die je nach der Oertlichkeit und der Frühjahrstemperatur im April oder Mai aus dem Winterschlaf erwachenden oder auskriechenden Käfer begatten sich alsbald und setzen ihre Brut an den $\mathrm{f} \mathrm{r}$ is $\mathrm{c}$ h e n Stöcken und Wurzeln der in Winter abgetriebenen Nadelholzstämme $\mathbf{a b}$, w i e d e $\mathbf{r}$ h o l e $\mathbf{n}$ aber $\mathbf{B}$ e ga $\mathbf{t}$ t ung und E i a b l age während des ganze $\mathbf{n}$. J h hes, so daß man in den befallenen Stöcken und Wurzehn die gelblichweißen Larven mit großem braunem Kopf, welche zuerst zwischen Holz und Rinde fressen, allmählich aber tief in den Splint eingreifen, im Sommer und Herbst in dem verschiedensten Stadium der Entwicklung finden kann. Die ahwärts gehenden geschlängelten Larvengänge sind mit Wurmmehl gefüllt, unł an deren Ende verpuppen sich die aus den zuerst abgelegten Eiern entstandenen Larven, die eine Größe bis zu $18 \mathrm{~mm}$ erlangen, in einer Wiege, überwintern als Puppen oder Käfer, während die später erschienenen Larven als solche überwintern. In Frühjahr erscheinen nun die jungen und mit ilınen auch ein Teil überwinterter alter Käfer, wälırend des ganzen Sommers fort konmen auch neue Käfer aus der im Vorjahr später - im Juni, Juli, August - abgesetzten Brut zum Vorschein, so daß sich hierhurch jederzeit Käfer des verschiedensten Alters vorfinden.

Als Generations-Dauer haben v. Oppens Versuche, in rauhem Klima angestellt, durchschnittlich 15 Monate ergeben, für eine Anzahl Individuen auch nur 12 Monate. boch schreiten die erst im Spätsommer sich entwickelnden Käfer wohl in diesem Jahre nicht mehr zur Fortpflanzung. - Eine best im $\mathrm{m}$ e Schwärmzeit würde es nach diesen Versuchen gleichfalls nicht geben, Ausschlüpfen und Paarung der Ǩäfer vielmehr während des ganzen Sommers erfolgen; dagegen wird erktärticherweise in Frühjahr und Frühsonmer die Zahl der Käfer eine besonders große sein, da hier die überwinterten alten und die neu ausschlüpfenden jungen Käfer zusammentreffen, und erseheint daher das Frülijahr (Mai, Juni) als rie Zeit des massenhaften Auftretens und größten Schadens.

So unschädlich nun die Brut des Käfers ist, so schädlich wird letzterer selbst durch seinen Fraß an jungen Pflanzen. Er benagt platzweise die zarte Rinde an Stamm und Aesten schwacher Föhren- und Fichtenpflanzen, während er schon härter gewordene Rinde meidet, geht jedoch auch die Pflanzen der übrigen Nadelhölzer, ja in Notfall sellst Laubhölzer an. Die befressenen bezw. benagten Plätze erstrecken sich bei schwachen Pflanzen oft auf den ganzen Umfang des Stämmehens und haben

1) Z. f. F. U. J. 1884. S. 140 und $\mathrm{S}, 173$.

2) Z. f. F. U. J. 1885 . S. 81 und 141 , dann 1887 S. 344 . 


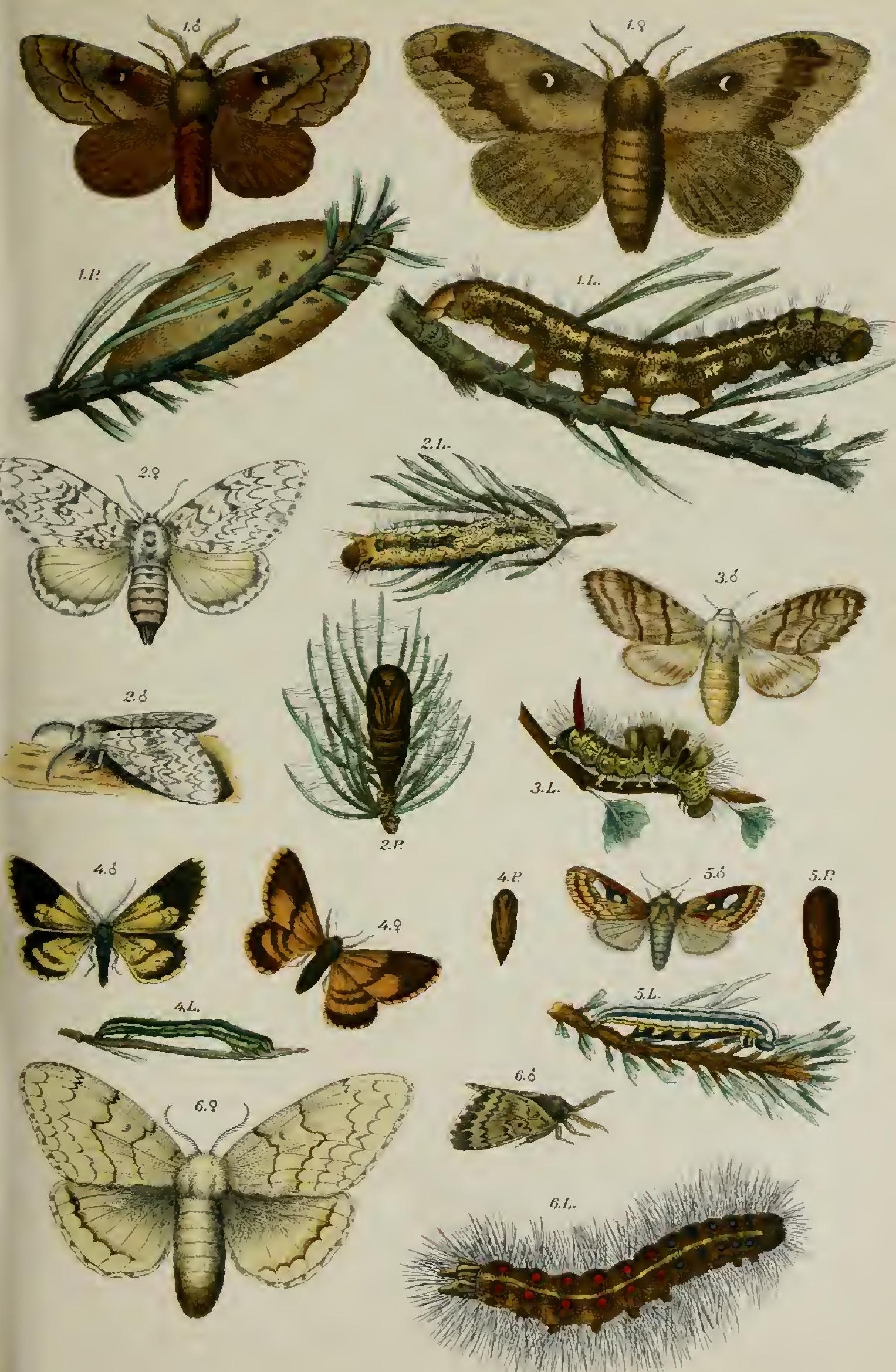



dann, oder wenn sie in größerer Zahl an einer Pflanze vorhanden, ein oft rasclıes Absterben, bei minderer Ausdehnung der Beschädigung ein Kŕänkeln und Küümmern der Pflanzen zur Folge.

Ueber die Lebensweise des Käfers sei noch bemerkt, daß er nach dem Ausschlüpfen und erfolgter Paarung zmm Absetzen seiner Brut den frischen, durch den Harzgeruch ihn von weither anlockenden Schlagflächen zustrebt, meist laufend, doch auch fliegend, dort seine Brut an die zutage tretenden oder flach unter der Erde liegenden Wurzeln absetzt und sich gleichzeitig von der zarten Rinde vorhandenenAnfluges, frischen Reisigs etc. nährt. Besonders günstig wird es für ihn sein, wemn solche frisehe Schlagflächen sofort ausgepflanzt wurden, da ihm dann Brut- und Fraßmaterial zugleich geboten sind. Fehlt ihm letzteres, so begibt er sich laufend nach den anstoßenden liulturen, dort die Pflanzen befressend und in dem vorhandenen Bodenüberzug später sein Winterlager suchend.

In den Nadelholzwaldungen ist er wohl jederzeit in beschränkter Zahl vorhanden, seine Menge kann, wenn ihu durch die Art und Weise der Bewirtschaftung (Kahlhieb ohne Stock- und Wurzelrodung) oder durch Elementarereignisse (Sturm, Schneebruch) Brutstätten in frischen Stöcken und Wurzehn reichlich dargeboten werden, in kurzer Zeit ins ('ngeheure anwachsen ${ }^{\text {I) }}$ und der durch ihn angerichtete Schaden in Kulturen ein sehr bedeutender werden; angesichts dessen ist es nächste Aufgabe des Forstmannes, dieser Vermehrung v o r z u b e $u \mathrm{~g}$ e $\mathrm{n}$.

Das sicherste Vorbeugungsmittel aber ist das vol]s tändige $\mathrm{R}$ od e $\mathrm{n}$ der Fichten- und Föhrenstöcke s a $m$ t W u r z e 1 n, wo immer dies die Standortsund Absatzverhältnisse gestatten, und zwar am zweckmäßigsten im Spätsommer des ersten Jahres, zu welcher Zeit ein großer Teil der Brut abgesetzt ist und mit dem Stockholz aus dem Wald geschafft wird. Die bloße B a u m r od ung, bei weleher eine große Nenge von Wurzeln oberflächlich abgehauen im Boden verbleibt, genügt nicht.

Man wird ferner vermeiden, durch sofortigen Anbau der im Winter gehauenen Kahlschläge - zumal wenn keine gründliche Stock- und Vurzelrodung stattfinden konnte, - dem Käfer Brut- und Fraßnaterial auf derselben Fläche zu bieten, soudern wird die Schläge e in und besser noch zwei Jahre liegen lassen, un die Gefahr der Beschädigung der Pflanzen durch die auf der Kulturfläche aussehlüpfenden Kïäer abzuwenden.

Von ganz besonderer Bedeutung ist ein entsprechender $\mathrm{H}$ i e b s we e h s el in der Weise, daß der Hieb womöglich nur alle $5-6$ Jahre in derselben Abteilung fortgesetzt wird. Wo sich, wie manchen Orts üblich, die Hiebsflächen in Nadelholzbeständen Jahr für Jahr aneinanderreihen, ist dem Käfer Brutstätte und Fraßmaterial stets unmittelbar beisammen geboten. - Die Fäfer aber sucht man teils auf den Stätten ihrer Entstehung, teils auf jenen ihres Fraßes möglichst abzufangen und zu vernichten. Dies geschieht zunächst durch $\mathrm{F}$ a $\mathrm{ng} \mathrm{gr}$ ä be $\mathrm{n}$, etwa $30 \mathrm{~cm}$ breite und ebenso tiefe Gräben mit möglichst glatt und steil abgestochenen Wänden, und umzieht man, wo Boden und Terrain dies gestatten, zunächst die frischen Hiebsflächen mit solchen; auf der Solsle erhalten sie alle $2-3 \mathrm{~m}$ ein tiefes Falloch eingestoßen. In diese Gräben fallen die Käfer, wenn sie, durch den Harzgeruch angeloclit, nach den Jiebsflächen laufen, um dort ihre Brut abzusetzen, und können leiclıt ge-

1) $1 \mathrm{~m}$ sog. Reichswald bei Nürnberg konnte man, dank intensiver Stock- und Wurzelrodung, vor dem Jahr 1868 nur mit Jühe einzelne liäfer finden; nach dem Schneebruch vom Jahr 1868 , dem Sturmsehaden vom Jahr 1870, durch welche jene Rodung unmöglich gemacht wurde, konnten die Rüsselkäfer nach wenig Jahren in Millionen gesammelt werden!

Handb, d. Forstwiss. 3. Auf. II. 
sammelt werden. Da aber ein Teil der Käfer jene Flächen fli e g e n d erreicht, so dienen die Gräben im nächsten Jahr als Mittel zum Fang der nun nach F r a $B$ stätten - Kulturen - wandernden Käfer.

Auf den Hiebsflächen, welche nicht durch Gräben geschützt werden konnten, und in befallenen Kulturen sucht man nun die Käfer zu fangen: dureh $\mathrm{F}$ a $\mathrm{n} \mathrm{g} \mathrm{r}$ i $\mathrm{n}$ d e, frisch geschälte Fichten- und Föhren-Rindenstücke, die man mit der Safthaut nach unten auf den Boden legt, und $\mathrm{F}$ a $\mathrm{ngk} \mathrm{lo}$ be $\mathbf{n}$, meterlange Trumme friseh gefällter Fichten- und Fölırenstangen, an denen man einen etwa 5 cun breiten Rindenstreifen der Länge nach abgeschält liat. Die Käfer werden dureh den Harzgeruch angelockt und sitzen fressend sehr fest an der Safthaut. Auch F a n g b ü s e h e l kleine Bunde frischen Nadelholzreisigs, an dessen Rinde die Käfer ebenfalls fressen, finden als Anlockungsmittel Anwendung. Allmorgentlich während der Hauptflugzeit - Mai und Juni - sammelt man die Käfer von den Fangrinden und -kloben durch Ablesen, von den Fangbüscheln durch Abklopfen auf ein Tuch und tötet die Käfer dureh Ueberbrühen mit koehendem Wasser.

Sehr lıäufig kommt neben dem großen braunen Rüsselkäfer in den Kulturen der gro $B$ e gra u e R üs selkäf e r Cleonus turbatus vor, ein sehöner, weiß und grau gezeichneter Käfer, den aber bisher eine Beschädigung von Külturen nicht nachgewiesen werden konnte.

Bemerkt möge endlich noch sein, daß dureh die Kahlschlagwirtschaft die Vermehrung der Rüsselkäfer entsehieden begünstigt wird, während bei natürlicher Verjüngung, wie sie in Fichtenbeständen und insbesondere in aus Laub- und Nadelholz. gemischten Beständen vielfach stattfindet, der Käfer nur in beschränktem Maße auftritt.

\$53. Derkleine braune Rüsselkäfer, WeiBpunktrüssel$\mathrm{k}$ ä f e r, Pissodes notatus (s. Taf. I Fig. 8). Der Käfer ist 6-8 mm lang, dunkelrotbraun mit hellen Haarschüppchen unregelmäßig bepudert, auf dem Halsschild mit einer Anzahl deutlicher weißer Punkte; auf den Flügeldecken zwei rostfarbene weiß und gelb beschuppte Querbinden, deren vordere an der Naht unterbrochen ist; der Rüssel ist ziemlich lang und fein.

Der Iräfer sehwärmt im Mai, und legt dann das Weibchen seine Eier in kleinen Partien vorzugsweise unter die Quirltriebe junger 5-10jähriger Föhrenpflanzen anch an andere Pinus-Arten, nie aber an Fichten oder Tannen - sowie, wenn auch seltener, an kränkelnde Stangen in feine, mit dem Rüssel eingebohrte Löcher. Wie nach kurzer Zeit ausschlüpfenden Larven, gelbweiß mit braunem Kopf, fressen in der $B$ a s t lı a u $t$ meist abwärts, doch auch aufwärts geschlängelte, allmählich breiter werdende Gänge, an deren Ende sie sich in einer im Holz liegenden, mit Fraßspänen ausgepolsterten und bedeckten Splintwiege in Laufe des llonat Juli verpuppen. Im August verläßt der Käfer durch ein rundes, die Rinde durchbrechendes Flugloch llie Wiege und ülerwintert unter Moos, in Rinderitzen; Eichhoff behauptete eine doppelte Generation auch dieses Käfers, was aber nach unsern eigenen Beobachtungen nicht rer Fall zu sein scheint. Wohl aber haben nenere Untersuchungen ${ }^{1}$ ) auch für diesen Käfer eine längere Lebensdauer, wiederholte Begattung und Eierablage ergeben; auch für die im nächsten $\$$ besprochenen Pissodes-Arten wurulen gleiche Beobachtungen gemacht.

Der fertige Käfer befrißt nicht, wie der große Rüsselhäfer, die Rinde, sondern sticht dieselbe lediglich mit seinem Rüssel zum Zweck des Saftsaugens an und die

1) Eckstein in Z. f. F.- u. J.-IV. 1909 S. 209. 
Pflanzen zeigen oft eine große Zahl solcher fciner, durch cinen Harztropfen kenntlicher Stichpunkte. Viel schädlicher aber werden die L a r ve n, dic durch das Zerstören der Safthaut das Kiränkeln und selır vielfach das Absterben der Pflanzen verursachen, bei zahjeichen Erscheinen die Kulturen stark durchlichten, so daß der allerdings seltener als $\mathrm{Hyl}$. abietis auftretende kleine Rüsselkäfer an vielen Orten zu den sehr schädlichen Kulturverderbern zu zählen ist.

Als sicherstes Gegenmittel ist das Vernichten der Brut durch Ausreißen und Verbrennen der mit Larven hesetzten Pflanzen zu betrachten; letztere sind Ende Juni, Anfang Juli an den welk werdenden und sich senkenden jungen Trieben leicht zu erkennen und werden von den die Kulturen wiederholt furchgehenden Arbeitern ausgcrissen. Bei Anwendung dieses Vittels mehrerc Jahre nach cinander wird es stets gelingen, des Käfers Herr zu werden.

S 54. Sonstige Rü s s elkä f e r. Aus der großen Zahl der Rüsselkäfer wären hier noch folgende, stellenweise oft ziemlich schädliche Nadelholz-Rüssler zu nennen.

Der Ki e fernstange $\mathbf{n}-\mathrm{R}$ ü s s c $\mathrm{k}$ ä $\mathrm{f}$ e $\mathbf{r}$, Pissodes piniphilus. Diescr kleine Käfer, braun mit je einem charakteristischen größern rostgelben Flecken auf den Flïgeln, lebt in den dümurindigen oberen Stammteilen der Föhrenstangen, aber auch der älteren Stämme; dort legt das Wcibchen einzeln in eingebissene Löcher seine Eier ab, und die auskommenden Larven zerfressen in geschlängelten, breiter werdenden Gängen die Safthaut, sich zuletzt im Splinte in kleinen Splintwiegen verpuppend. Die Schwärmzeit ist im Juni, die Generation nach Nitsches Angabe ${ }^{1}$ ) zweijährig, während Dougall auf Grund neuerer Forschungen ${ }^{2}$ ) eine einjälırige Generation mit längerer Lebensdauer und wiederholter Copula feststellen zu können glaubt. Die von dem bisher weniger beachteten, aber doeh verhältnismäßig häufig auftretenden Insekt befallenen Stangen und Stämme fangen bei einigermaßen stärkerer Besetzung an zu kränkeln und gehen schließlich in oft nicht geringer Zahl ein, so daß die Bestände sich lichten und der Schaden ein bedeutender werden kann. Als Gegenmittel wurde ${ }^{3}$ ) nit Erfolg das Fällen der befallenen Stangen und Stämme, kenntlich an den austretenden weißen Harztropfen, die namentlich an sonnigen Tagen gut wahrzunehmen sind, angewendet; ein tiefgreifendes Entrinden ist dann nötig, wenn etwa schon teilweise Verpuppung eingetreten ist.

Der H a r z $\mathrm{r}$ ïs el $\mathrm{k}$ ä f er, Pissodes hareyniae, etwa $6 \mathrm{~mm}$ lang, schmal, fast schwarz mit zwei feinen weißgelben Binden über die Flügeldecken, ist in Harz und Erzgebirg schon sehr schädlich aufgetreten, befällt nur Fichten und zwar vorwiegend in älteren $60-100 \mathrm{j}$. Beständen, wobei das Weibehen nach der Schwärnperiorle im llai und Juni seine Eier unter die Rindenschuppen kränkelnder, aber auch gesunder Stämme ablegt; dic Larve frißt in geschlängeltem Gang in der Safthaut, sich schließlich in einer im Splint liegenden, mit Spänen gepolsterten Wiege verjuppend und zwar nach Altums Angabe erst in Sommer des folgenden Jahres, so daß hienach die Generation als eine zweijährige erscheint. Stärker befallene Stämme kränlieln und sterben schlieblich ab, iri den kränkelnden Stämmen finden jedoch auch andere schädliche Insckten. Borkenkäfer obenan, willkommene Brutstätten. Die austretenden weißen Harztröpfchen verraten dem geübten Auge die befallenen Stämme, unrł wo der Käfer in größcrer Zahl auftritt, läßt man die Bestände von

1) Lehrbuch der mitteleurop. Insektenkunde 1 S. 380.

2) Forstl, naturw. Zeitschr. 1898 \$. 201.

3) Forstw. Z. Bl. 1885 S. 144. 
darauf eingeübten Arbeitern wiederholt durchgehen, die Käferbäume bezeichnen, sowie alsbald fällen und entrinden.

In ähnlicher Weise beschädigt der $\mathrm{T}$ a $n \mathbf{n}$ e $\mathrm{n} \mathrm{r}$ ü s s e l li ä f e r, Pissodes piceae ältere Tannen, der Ki e f e r $\mathbf{n}$ bestands-R üs s e] kä f e r P. pini (s. Taf. I, Fig. 9) ältere Fölıren; beide treten jedoch minder häufig und darum minder schädlich auf.

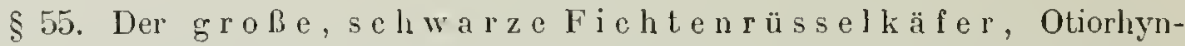
chus ater (niger), ein $8-12$ mm langer, glänzend schwarzer Käfer mit kurzem breiten Rüssel, eiförmigen Körper, stark gewölbten Flügeldecken, aber olıne häutige Flügel, mit roten Beinen und schwarzen Kinien und Füßen, wird als Käfer und Larve insbesondere in Gebirgsgegenden nicht selten schädlich. Der Käfer benagt die zarte Rinde von Fichtenfflanzen, auch deren Knospen, die schmutzig weiße, im Boden liegende Larve deren Wurzeln, stärkere Wurzeln völlig entrindend, schwächere abbeißend und hiedurch die Pflanzen tötend. Die Schwärmzeit ist im Mai, die Eierablage erfolgt in bloBliegendem und lockeren Boden insbesondere in Saatbeeten und Saatliulturen, der Larvenfraß wird im Juni und Juli bemerklich. Ende Juli tritt die Verpuppung ein, Ende August erscheinen die Käfer, die als solche überwintern; die Generation ist demnach eine einjährige; bei größerer Vermelıung treten jedoch mannigfache Versehiebungen im Ersclıeinen der einzelnen Entwicklungsstadien ein.

Ian sucht dem Schaden vorzubeugen durch Ausführung von liulturen unter geringer Bodenverwundung. Vertilgungsmittel gegen Larven sind liaum anwendbar, die Käfer sucht man durch Ablesen von den Pflanzen, Sammeln unter Moosplaggen, welche in die Kulturen und Satbeete gelegt werden, und mit Fanggräben zu vertilgen.

$\S 56$. D e r M a i k ä f e r, Melolontha vulgaris (s. Taf. I Fig. 19). Dieses Insekt beschädigt als Käfer zwar vorwiegend nur Laublı̈lzer, dagegen wird die Larve vor allem den Nadelholzkulturen durch ihre Wurzelzerstörungen lästig, und hiedurch erscheint die Besprechung unter den Nadelholzinseliten gerechtfertigt.

Die Gestalt des Käfers ist eine allbekannte und eine Beschreibung wohl überflüssig; die Gescl!lechter sind an den Fühlern leicht zu unterscheiden, welche beim Männchen schön gekämmt, beim Weibehen fadenfömig sind. Die Larve, Engerling genannt, ist in ausgewachsenem Zustand $4-5 \mathrm{~cm}$ lang, mit dickem gelbbraunen liopf, sechs langen Brustfüßen, der Körper bauchwärts gekrümmt, gelbliclıveiß, mit dickem, infolge des durehschimmernden Íotes bläulich gefärbtem After, die Puppe ist bräunlichgelb mit zweispitzigem After, die Eier sind eiförnig, gelblichweiß und etwa hanfkorngroß.

Was nun die Lebensweise des 1laikäfers betrifft, so schwärmt er je nach klimatisclıen Verhältnissen bald früher, bald später im Honat Mai, in rauhen Lagen selbst bis Anfang Juni. Das Weibehen sucht sich nach der Begattung zur Ablage seiner Eier möglichst freie Flächen mit lockerem, unbewachsenen Boden, der ihm das Eindringen behufs Eierablage erleichtert, wühlt sich in diesen $5-10 \mathrm{~cm}$ tief ein und legt eine Anzahl Eier, bis zu 30 Stück an einer Stelle, ab, wiederholt diese Eierablage melurmals und ist die Zahl der von einem Wéibchen abgelegten Eier eine ziemlich große, bis zu 60 Stück. Bald nach der Begattung und bezw. Eiablage erfolgt das Absterben der Käfer.

Die Larven - Engerlinge - schlüpfen nach etwa 4 Wochen aus den Eiern, entfernen sich im ersten Jahr nicht weit von der Stelle, wo sie auskamen, und verursachen, sich anscheinend nur von im Boden befindlichen Humusteilchen nälırend, noch keinen Schaden. Nit herannahenden Winter wühlen sie sich, um den Frost auszuweichen, tiefer in den Boden, arbeiten sich in Frülnjalır wieder herauf und be- 
ginnen nun ihren allmählich fühllar werdenden Fraß an Pflanzenwurzeln jeder Art, ilın nach nochmaliger Ueberwinterung und almählich zu bedeutender Größe heran-

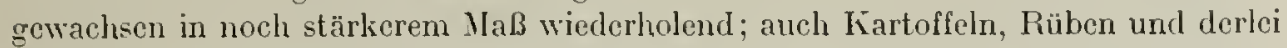
Gewächse werden oft stark beschädigt. Nach abermaliger Ueberwinterung arbeiten sich die tief in den Boden gegangenen Engerlinge nochmals herauf und fressen noch einige Wochen, gehen aber Ende Juni und sonach drei Jahre nach ihrem Aussehlüpfen aus dem Ei zum Zweck der Verpuppung tief in den Boden; letztere erfolgt in einer geglätteten Höble, und nach einigen Monaten, also schon in Spätherbst, entwiclielt sich aus der Puppe der anfänglich weiße, weiche Käfer, der, allmählich crhärtend, im Frühjalır zur oben angegebenen Schwärmzeit die Ercle verläßt, hiebei ein seiner Größe entsprechendes Loch zurüclilassend. - Die ganze Entwicklungsdauer ist sonach eine vierjährige, für das wärmere Süddeutschland aber nur eine dreijälırige, in Nordostdeutschland selbst 5jälırige, und in diesen Intervallen kann man durch besonders zahlreiches Auftreten der Käfer auffallende Flugjahre konstatieren, während sich in den zwischenliegenden Jahren Maikäfor stets nur in begrenzter Zahıl zeigen.

Was nun die Schädlichlieit des Maikäfers anbelangt, so ist sie eine doppelte; er betätigt sie als Engerling und als Imago.

Als Engerling verzehrt cr, vom zweiten Lebensjahr beginnend, die zarten Wurzehn von Gewächsen jeder Art, namentlich die reservestoffreichen Wurzehn von perennierenden Kräutern und Gräsern, so auch die Wurzeln unserer Holzpflanzen; und da auf den Kahlschlägen mit ihrem meist durch Stockrodung wunden Boden vorwiegend Nadelholz und zwar mittelst schwächerer Pflanzen angebaut wird, nebenbei die Nadelholzpflanzen gegen Wurzelbeschärligungen selır empfindlich sind, so sind es die Nadelholzschläge und vor allem die großen Kiefernkahlschläge der Ebene mit ihrem lockern Sandboden, auf welelıen durch die Engerlinge schon großartige Beschädigungen angerichtet wurden, so daß der Maikäfer zu den schädlichsten Kulturverderbern gerechnet werden muß. Auch in Saatbeeten, dic ihm einerseits wunden Boden zur Eierablage und anderseits nur Wurzeln von Holzpflanzen als Nahrung bieten, richten die Engerlinge großen Schaden an - weniger zu fürchten sind sie dagegen in natürlichen Verjüngungen, in Wittcl- und Niederwaldschlägen. In vom Mai-

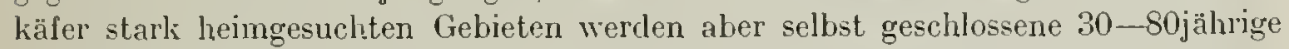
Laubholzbestände durch Engerlinge stark geselädigt, zum Kümmern und selbst Absterben gebracht ${ }^{1}$ ).

Wesentlich geringer ist der Schaden, clen der fertige Käfer verursacht. Dieser frißt das Laub der meisten Laubhölzcr, insbesondere der Eichen, Buchen, Ahorne, auch Roßkastanien, Pappehn, während von den Nadelhölzern nur die weichen Nadeln der Lärche und die Blüten der Föhren angegangen werden. In Flugjahren ist der Fraß oft so bedeutend, daß man ganze Laubholzbestände, insbesonderc auch die Oberholz-Eichen des Mittelwaldes kahlgefressen sehen kann, doch begrünen sie sich mit Hilfe der Johannitriebe wieder, wenn auch nur dünn, und der Schaclen besteht. in einigem Zuwachsserlust ${ }^{2}$ ) und etwa der Zerstörung der Blüten bezw. der Mast.

Die Vorbeugung und Bekämpfung ist nun eine schwierige. Man sucht es zu vermeiden, dem Käfer in F l u g j a l r e n die von ihm bevorzugten größeren Kahlflächen mit wundem Boden darzubieten, vermeidet Bodenverwundungen und Saaten in solchen Jahren, wendet Klemunflanzung an; man hat in den besonders heimgc-

1) Puste r, Ein Jahrzehnt in Kampf nit dem Jlaikäfer. Forstw. Z.-Bl. $1910 \mathrm{~S}, 633$.

2) Nach Xör dlinge rs Angabe (Forstschutz S. 152) lassen sieh in Schwaben die alle drei Jahre eintretenden Flugjahre an den jedesmaligen schmäleren Jahringen von Alteichen nachweisen. 
suchten Waldungen der norddeutschen Sandebene versucht, den üblichen Kahlschlag zu verlassen und zur Verjüngung unter Schirmstand zurückzukelıren - nur mit geringem Erfolg. Bei Anlagen von Saatkämpen vermeidet man tunlichst die Nähe von Eichenstockschlägen, von denen aus der Anflug besonders reich erfolgt, sucht bei dem Umgraben die Engerlinge möglichst zu beseitigen, durch Unfassungsgräben deren seitliches Eindringen zu hindern, durch Deckgitter die Saatbeete gegen die Eiablage zu schützen; selbst Starenkästen, in größerer Zahl um die Saatkämpe angebracht, um dadurch die den Maikäfern sehr stark nachgehenden Stare beizuziehen, laben sich als nützlich erwiesen.

Zahlreiche Feinde unterstützen uns in der Vernichtung der Käfer: die am Bodeı befindlichen werden von Igel, Dachs, Marder, Fuchs, Schwein verzehrt, Fledermäuse, Stare, Jírähen, Dohlen, kleine Raubvögel und andere Yögel vernichten große Mengen. Die im Boden liegenden Engerlinge haben leider wenig Feinde: den Maulwurf, dann die Schweine, denen man allerdings gerade dort, wo sie die meisten Engerlinge finden würden, den Zugang nicht gestatten kann; die beim Pflügen an die Oberfläche gebrachten werden von Krälıen und Staren begierig verzelırt.

Als wichtigstes Mittel der Vertilgung erscheint das S a m m e I n der Käfer Abschütteln von Obstbäumen, Randstämmen, Stockausschlägen in den frühen Morgenstunden, in welchen die Käfer nur lose sitzen, auf untergehaltene Tücher -, doch hat dies Mittel natüılich nur dann Erfolg, wenn es, ev. untel Mitwirkung der ja ebenfalls interessierten Landwirte, in $\mathrm{m} \ddot{\mathrm{g} g} \mathrm{lich} \mathrm{st} \mathrm{er}$ Ausdehnung stattfindet. Die abgeschüttelten Käfer werden in Eimer und aus diesen in Säcke gesammelt, die Säcke schließlich in bereitgehaltene Fässer geleert und die Käfer mittelst Schwefelkohlenstoff rasch getötet. Die Masse kann in Mischung mit Kalk und Torfmulle vorteilhaft zu Kompost verarbeitet werden $\left.{ }^{1}\right)$.

Das Sammeln der Engerlinge, Vertilgen in Saatbeeten mit Benzin oder Schwefelkohlenstoff hat sich nicht von Erfolg gezeigt - am ersten gewährt, wie erwähnt, das Decken der Beete mit Gittern Schutz gegen die Eiablage. Stark gefährdete Saatbeete verlasse man.

Neben dem gemeinen Maikäfer kommt bisweilen in ziemlicher Zahl der etwas kleinere Ro B ka s t a n i e n - Käfer (Mel. hippocastani) sowie, wem auch seltener und nur in sandigen Gegenden, der große $\mathrm{W}$ a $\mathrm{lk} \mathrm{er}$ (Polyphylla fullo) mit schön weib und braun marmorierten Flügeldecken vor, beide in gleicher Weise schadend.

\section{Schmetterlinge.}

\$57. Der Ki efer $n$ s p in ner, Gastropacha pini (s. Taf. II Fig. 1). Der Falter dieses größten unserer forstschädlichen Schuretterlinge hat $6-8 \mathrm{~cm}$ Flügelspannung, und bezeichnet ersteres etwa die normale Größe des Männchens, letzteres jene des Weibchens. Der Leib ist dick, der Kopf kIein und unter dem Halsschild versteckt, die Augen sind groß, die Fühler beim Männchen schön lang doppelt gekämmt, heim Weibchen ganz liurz geliämmt; die Basis der Flügel, die Beine und der Hinterleib sind stark beltaart. Die großen Vorderflügel sind braungrau bis weißgrau, mit einer bein Iännchen grauen, bein Weibchen rotbraunen Querbinde, welche die Flügel in zwei Hälften scheidet; auf der dem Leib zunächst liegenclen Hälfte findet sich ein weißer, halbmondförmiger Fleck auf dunklerem Grund. Hinter-

1) Vergl. die interessante Sehilderung von Pus ter, Forstw. Z.-Bl.1910 S.633 und 1911 S. 511 , der im Jahr 1907 mit einem Aufwand von 16800 Mlk, etwa 15 Mill. Kāfer, im Jahr 1911 rund 22 Mill. vernichtete. 
flügel und Hinterleib braun und graubram, dic Unterseite einfarbig leell graubraun; Farbenvarietäten bald melur ins Braune, bald ins Graue gehend sind sehr luäufig. Befindet sich der Schmetterling in der Ruhe, so liegen die Flügel dachziegelförnnig übereinander.

Die Raupe, ausgewachsen über $7 \mathrm{~cm}$ lang, zeigt in den verschiedenen Stufen der Entwicklung, wie auch in ausgewachsenem Zustand sehr mannigfache Färbungen, aschgraue bis rötlichbraune Grundfarbe mit hellen Längsstreifen an der Oberseite und weißen Flecken an der Seite, dunkeln Flecken und Zeichnungen auf dem Rücken und starker büschılförniger Behaarung. Charakteristisch sind die dunkelblanen Haarbüscltel in den Einschnitten des zwciten und dritten Leibesringes, die sich im Nacken als blaue Querstreifen darstellen, sodann die schwarzblauen Haarbüschelclen zwischen den übrigen Haaren und ein besonders starker solcher Haarbüschel auf dem 11. Leibesring.

Die Puppe, vorn dunkel, hinten heller braun, schwach behaart, liegt in einem großen, clliptischen, schmutzig weiß-grauen Kokon; die Eier etwa halb so groß wie Hanfkömer, rundlich elliptisch und an den Seiten etwas eingedrückt, sind frisch bläulichgrau, später perlgrau.

Die Schwärmzeit des Falters fält etwa Mitte Juli, die Schmetterlinge, unter Tag ruhig an den Bäumen sitzend, fliegen gegen Abend, und die Begattung erfolgt meist tief unten am Stamm, wobei sie mit dem After gegen einander sitzen. Das Weibchen legt sodann seine zahlreichen (bis 200) Eier in Gruppen von 30-50 Stück an die Rinde des Stammes, auch an Aeste und Zwejge ab, und nach etwa 3 Wochen, also beiläufig Mitte August, schlüpfen dic kleinen Räupchen aus, verzehren zunächst die Eihüllen und beginnen sodann die Wanderung in die Krone, dort zuerst die Nadehn nur benagend, später ganz verzehrend. 1 lit cintretendemFrost steigen die noch nicht halbwüchsigen Raupen vom Baum herab, um zusammengerollt unter Hoos und Nadeln meist noch innerhalb der Schirmfläche des bisher bewohnten Baumes zu überwintern. Die beginnende Bodenwärme im Frühjahr (nach Altums Beobachtungen etwa $+5^{0} \mathrm{R}$.) Ende März, Anfang April erweckt sie aus diesem Winterschlaf, sie besteigen sofort die Bäume und setzen ihren Fraß, der nun mit zunehmender Größe der Raupen erst recht ins Auge fällt, bis gegen Ende Juni fort. Die Raupen, deren Nahrungsbedarf ein sehr bedeutender ist, verzehren die ganzen Narleln bis zur Sclseide, bei Kahlfraß selbst Scheide und Knospen, in welchem Fall natürlich der befressene Stamm oder Bestand zugrunde gehen muß, und verpuppen sich dann in einem Kokon, am liebsten in den starken Borkenschuppen des Stammes, doch auch zwischen Nadeln, an den Aesten, um nach dreiwöchentlicher Puppenruhe auszuschlüpfen.

Der Kiefernspinner lebt nur auf Kiefern, und stets sind es in erster Linie die alten Bestände, die er befällt; trockener sandiger Standort der Bestände scheint ihm, weil die Ueberwinterung der Raupen durch trockenes Winterlager begünstigend, besonders zuzusagen. Bei großer Vermelırung aber werden auch die Stangenhölzer, ja zuletzt selbst die Schläge befallen. Der Kiefernspinner gehört zu den scläalichsten Forstinsekten, da er nicht seiten und dann in oft ungeheurer Menge auftritt; er hat in den großen zusammenhängenden K̈iefernwaldungen der norddeutschen Ebene, chenso aber auch in einzelnen Föhrenkomplexen Süddeutschlands schon außerordentliche Verheerungen angerichtet, ausgedehnte Bestände zum Kümmern und Absterben gebracht und fordert daher in den bedrohten Oertlichkeiten die Aufmerksamkeit des Forstmanns in vollem .Haß heraus.

Die Zahl der Feinde, durch welche dic Natur uns in der Vertilgung des so schädlichen Insekts unterstützt, ist infolge der starken Behaarung der Raupe, des Schutzes 
der Puppe durch den Kokon nur eine beschränkte. Die Mleisen vertilgen zah!reiche Eier; der Kúckuck ist einer der wenigen Vögel, welche der Raupe trotz der Behaarung gierig nachgehen. Dagegen verschmähen zahıe und wilde Schweine die im Winterlager befindliche Raupe. Viel mehr Abbruch geschieht dem Spinner jedoch dureh Insekten, insbesondere durch Raupenfliegen und Schlupfwespen, und letztere befallen denselben in jedem Stadium, vom Ei beginnend; auch parasitische Pilze töten oft eine große llenge von Raupen im Winterlager, namentlich in feuchtem, humosen Boden, die gegen Nässe und Kälte minder empfindlich sind.

Eigentliche $\mathrm{V}$ o r b e u g u $\mathrm{ng}$ s mittel stehen nun dem Forstmann nicht zu Gebote - seine Aufgabe ist zunächst, durch fleißige Revision der Waldungen rechtzeitig eine bedenkliche V'ermehrung zu konstatieren, um dann sofort energisehe Vertilgungsmittel in Anwendung bringen zu können. Zur Schwärmzeit sieht man wohıl die sitzenden orler des Abends fliegenden Falter, im Frühjahr baumende Raupen, fallenden Iiot derselben namentlich auf Wegen, in Fahrgeleisen; außerden aber nimmt man in Beständen, in denen man den Spinner vermutet, im Spätherbst, sobald die Raupen ilır Winterlager bezogen haben, Probesuchungen unter der Schirmfläche der Stämme oder streifenweise durch die Bestände vor, indem man vorsichtig das Woos aufheben und nach den Raupen sorgfältig suchen läßt. Findet man deren eine größere Zahl und nnan wird immer nur einen Teil, vielleicht $1 / 3$, der wirlilich vorhandenen entdecken - so hat man ihre Vertilgung ins Auge zu fassen.

Man hat früher vielfach das S a m m eln der Raupen in Winterlager angewendet, allein der Erfolg wird nie ein vollständiger sein, stets ein großer Teil der Raupen unter Moos und Erde zurückbleiben; ebensovenig hat das Sammeln der Eier, Puppen oder der tief an Stamm sitzenden Schmetterlinge wesentlichen Erfolg.

Durchschlagenden Erfolg hat jedoch ein Mittel, das man früher wohl versuchte, aber nicht in Großen anwendbar erachtete: die Anwendung der sog. L e i m r i n g e ; seit es gelungen ist, einen Raupenleim herzustellen, der längere Zeit klebrig, fängisch bleiht, wendet man diese Leimringe in den bedrohten Kiefernforsten in geradezu großartigem Naßstab und nit bestem Erfolg gegen die Kiefernspimner an ${ }^{1}$ ).

Un nämlich den überwinternden Raupen das Besteigen der Bäume unmöglich zu machen, erhält jeder Baum in dem gefährdeten Bestand einen mit dem Irlebestoff leschmierten Ring; dem Anstreichen mit Raupenlein muß das sog. Amröten des Bammes, die Entfermung der r a u h e n $\mathrm{B}$ or k e auf einem $6-8 \mathrm{~cm}$ breiten ling in Brusthöhe mittelst Scl!nitznesser vorausgehen, wodurcl? das Leimen sehr erleichtert und wesentlich an Lein gespart wird. Dieses Anröten erfolgt, wenn man sich von der Notwendigkeit des Leimens überzeugt hat, so zeitig im Frühjahr, daß schon vor Beginn des Raupensteigens mit dem Anstrich begonnen werden kann; der Klebestoff - als solcher dient der Raupenleim von Ermisch, Mützel, Hut, der viele Wochen lang lilebrig bleibt, so daß einmaliger Anstrich für die ganze Periode des Raupensteigens ausrejcht, - wird mit einfachen hölzernen Spateln, die sich besser bewälırt haben, als die mancherlei anderweitigen Leimapparate, in $3-4 \mathrm{~cm}$ breiten und etwa $3 \mathrm{~mm}$ dicken Ringen aufgetragen, und sind liezu 40-70 kg Leim, je nach der Stamnzahl und Stärke der Bestände, nötig. Die aufsteigenden Raupen versuchen entweder das Ueberkriechen des Ringes und bleiben auf diesen hängen, meist aber verhungern sie

1) Man wendete zuerst Steinkolulenteer an, und sprach deshalb von $\mathrm{T}$ e e r ringen, von A $n$ te e r e $n$; die in neuerer Zeit angewendeten İlebemittel, deren Zusammensetzung von den Fabriken als Geheimnis behandelt wird, haben mit Teer nichts zu tun und werden als Raupen. I e i m e bezeichnet. Ueber die Ausfulurung des Leimens s. E ckste i n, Die Technik des Forstschutzes gegen Tiere. 1904. 
unterhalb desselben; einzelne etwa linübergelangende besudeln sich Füße und Freßwerlizeuge derart, daß sie doch eingelien.

Auch $R$ a $u$ pen g $\mathrm{r}$ äb e $\mathrm{n}$ werlen angewendet, wenn starker Fraß und bezw. Kahlfral auf kleinerer, begrenzter Fläche stattfindet; man isoliert den befallenen Waldteil durch scharf abgestochene, etwa 1/2 $\mathrm{m}$ tiefe Gräben (Isolierungsgräben), um die Raupen bei der Wanderung nach den Nachbarbeständen abzufangen, durchschneidet größere Flächen etwa auch noch mit Fanggräben und tötet die Raupen, welche in Fallöcher auf der Sohle der Gräben gestürzt sind, durch Zerquetschen und Uebererden. Man wird solche Gräben namentlich zum Schutz von Ḱulturen, die an kahlgefressene Bestände anstoßen, anwenden.

$\S 58$. D j e Non ne, Liparis (Lymantria) monacha (s. Taf. II Fig. 2). Das Männchen hat 4-5, das Weibchen 5-6 cm Flügelspannung, die Färbung beider ist jedoch eine sehr gleiche: Vorderflügel und Vorderleib sind bei beiden Geschlechtern wei $B$, mit zahlreichen braunschwarzen, tiefgekerbten Zickzackstreifen, die Hinterflügel bräunlichgrau mit helten, schwarz getupften Rändern, der Hinterleib meist schön l'osenrot mit schwarzen Querbinden. Dunkle Varietäten, bei welchen der Hinterleib statt rot schwärzlich gefärbt ist (var. eremita), kommen nicht selten vor.

Die Raupe, ausgewachsen bis $5 \mathrm{~cm}$ lang, ist weißlich, gelblich-oder rötlich-grau, auf der Unterseite schmutzig grün; über den Rücken zieht ein grauer Streifen, der auf dem zweiten Ring mit einem herzförmigen schwarzen Fleck beginnt, sich dann verschmälert und dann wieder zu breitem hellem Sattelfleck verbreitert. Auf dem sonst unbehaarten Körper stehen 6 Längsreilıen von Knopfwarzen mit ziemlich langer blaugrauer Behaarung, von denen die heiden ersten des vordern Ringes stark hervorragen und für die in der Farbe vielfach wechselnde Raupe charakteristisch sind.

Die Puppe, anfangs grünlich, dann braun mit Bronzeschimmer und mit starken, hellen Haaren besetzt, liegt in einem aus einzelnen Fäden bestehenden Gespinst zwischen Rinderitzen am untern rauhrindigern Stammteil oder in den Nadeln der Aeste und des Unterwuchses. Die Eier sind brotförmig, anfänglich rosenrot schimmernd, später bräunlich.

Die Schwärnzeit der Falter beginnt etwa Mitte Juli und danert bis Mitte August; bei Tage, namentlich bei trübem Wetter, sitzen sie meist tief unten an Stamm auf der gegen Regen und Wind geschützten Seite, während heller Sonnenschein die Männchen zu taumelndem Flug reizt. In der Dämmerung aber ist die eigentliche Flugzeit, die Falter laufen am Stamm suchend auf und ab und begatten sich aneinander sitzend. Wenige Tage später legt das Weibchen seine Eier möglichst geschützt in kleinern oder größern Partien zwischen die Schuppen der Rinde, hiezu die älteren Bestände und die stärker berindeten untern Stammteile wählend; bisweilen liegen sämtliche Eier, 200 und mehr, auf einem Häufchen, bisweilen sind es deren nur 20 bis 50 .

Die Eier überwintern als solche - deshalb ihre möglichst geschützte Lage und erst im kommenden Frühjahr im April und selbst erst Anfang Mai schlüpfen die langbehaarten Räupchen aus, bleiben mehrere Tage in einem je nach der Zahl talerbis handtellergroßen, durch die dunkle Farbe der Räupchen schwarz erscheinenden Fleck - dem Spi e g e l - beisammen sitzen und ersteigen dann allmählich den Baum, diesen von unten nach oben befressend. Der Fraß ist ein ganz eigentümlicher: zuerst ein Benagen der Knospen und Nadeln, während später von der stärkeren Raupe die Nadeln der Fichte ganz verzehrt, jene der Föhre in der Mitte durchbissen und nur der Stumpf verspeist, Laubholzblätter zunächst des Blattstieles in der Weise befressen werden, daß die größere Blatthälfte herabfällt, so daß bei einem Fraß der Nonne der 
Borlen sich mit Blatt- und Nadelresten bedeckt zeigt. Bis zur Halbwüchsigkeit spinnen die Raupen, lassen sich bei stärkerem Wind sofort an einem Faden herab und werden dann oft weit verweht oder in Masse an den Boden geworfen, woselbst dann eine nicht geringe Zahl zu grunde geht. Der Fraß dauert bis in die erste Hälfte des Juli, die Raupe sucht sich zur Verpuppung gern einen geschützten Platz zwischen Rindeschuppen, am Unterwuchs, und nach 2 bis 3 Wochen schlüpft der Falter aus.

Die Nonne ist außerordentlich polyphag, denn außer Föhre und Fichte befrißt sie verschiedene Laubhölzer - Eichen, Buchen, Birken, in der Not auch fast alle übrigen Holzarten; die beiden erstgenannten dagegen sind ihre eigentlichen Nälırpflanzen, und sie hat in Fichten- und Fölrenwaldungen schon außerordentliche Verheerungen angerichtet, ausgedehnte Waldflächen zum Absterben gebracht und ist deshalb zu rlen se h r se häd liche n Insekten zu rechnen. Sie gehört zu den B e st a n d s verderbern - stets fällt sie zunächst die älteren Bestände an, und ist die $\mathrm{F}$ i c h t e durch sie in höherem Grade gefährdet, als die Föhre. - Welche Ursachen es sind, welche die oft jahrelang nur in sehr geringer Zahl vorhandene Nonue sich in wenig Jahren zu ungeheuren Massen vermehren läßt, ist noch unerklärt.

Gleich dem Kiefernspinner hat auch die Nonne nur eine beschränkte Zahl von Feinden. Die Eier werden während des Winters allerdings durch Vögel (Meisen) etwas dezimiert, die behaarten Raupen aber von letzteren verschmäht, jedoch von Schmarotzern und insbesondere Tachinen stark befallen; gegen Vitterungseinflüsse sind sie wenig empfindlich. Dagegen ist bei starkem Raupenfraß wiederholt eine merkwürdige Erkrankung der Raupen, das sog. IV i p f e l $\mathrm{n}$ aufgetreten, welche sämtliche Raupen in kürzester Zeit vernichtet und dadurch der Kalanität ein Ende macht; die absterbenden Raupen sammeln sich in großer Zahl in den Astwinkeln und namentlich an den Wipfeln der befallenen Stämme. Man schreibt diese Erkrankung einem Spaltpilz, der sich in den kranken Raupen in großer Zahl findet, zu, hat auch versucht, denselben durch Impfung gesunder Raupen in noch nicht verseuchte Gebiete zu übertragen, doch oline Erfolg ${ }^{1}$ ).

D u r c h s chl a ge nde Mittel der Vorbeugung und Vertilgung stehen dem Forstmann der Nonne gegenüber nicht zu Gebot. Bei aufmerksanem Auge wird derselbe die beginnende Vermehrung der Nonne in seinem Wald dureh die am Boden liegenden Nadel- und Blattreste, die umherfliegenden oder an den Stämmen sitzenden hellgefärbten Schmetterlinge rechtzeitig erkennen und derselben mit allen Mitteln Einhalt tun.

Als solche Mittel wendet man an: das Sammeln und Vernichten der in überwiegender llenge an den untern Stammteilen abgesetzten Eihäufchen, von denen freilich viele den Augen des Sammlers entgehen; ferner das Zerdrücken der in ,Spiegeln" sitzenden frisch ausgeschlüpften Räupchen, bezüglich deren das Gleiche gilt. Durch Zerquetschen der unter tags meist ruhig an den Stänmen sitzenden Schmetterlinge - es sind die fester sitzenden zudem meist Weibchen - können ebenfalls größere Massen vernichtet werden, doch sind die genannten Mittel nur bei erst beginnender Vermehrung anwendbar und von einigem Erfolg.

Bei dem in den Jahren 1889 bis 1892 in Süddeutschland und Oesterreich stattgehabten großen Nonnen[raß hat man in ausgedehntem Maß das (in $\$ 57$ besprochene) $\mathrm{L}$ e i m e n der befallenen Bestände angewendet, gestützt au[ die Wahrnehmung, daß

1) An Losung der Frage nach dem Grunde der oft so rasehen Vermehrung der Nonne, der plötzlichen Erkrankung (Polyederkrankheit), der llöglichkeit, letztere hervorzurufen oder doch zu begünstigen, arbeiten zur Zeit zahlreiche Forscher. Der Raum verbietet, auf diese Verhältnisse hier einzugehen. 
außerordentlich zahlreiche Nonnenräupchen in den ersten Wochen ihres Lebens durch Abspinnen an den Boden kommen; durch Leimringe verlegt man denselben den Rückweg in die Kronen. Es liann dies Leimen nicht den vollen Erfolg haben, wie bei dem Kiefernspinner, da eben nicht a ll e Räupchen an den Boden kommen, unter allen Umständen wird aber eine große Entlastung der befallenen Bäume erzielt und hat sich das Leimen erfolgreich insbesondere in Beständen erwiesen, die noch nicht allzustark befallen waren, sowie zur Herstellung von Isolierstreifen zwischen befallenen und noch raupenfreien Beständen. In Sachsen hat man in den Jahren 1909-1911 das Leimen in ausgedelıntem Maß angewendet und schreibt ihm die erfolgreiche Bckämpfung der Nonne zu; in Preußen hat man sich bei dem zu jener Zeit in Ostpreußen herrschenden Nonnenfraß dem Leimen gegenüber vollständig ablehnend verhalten. - Auch Versuche mit dem Hochleimen hat man gemacht, indem man Leinringe oder geleimte Stricke in größerer Höhe - bis 7 und $8 \mathrm{~m}$ - un die Stämme legte, un hiedurch neben den abspinnenden auch alle unterhalb dieser Ringe ausgeschlüpften Räupchen abzufangen; die Arbeit ist nur zu schwierig und zu teuer! -

Jederzeit ist die Nonnengefahr für Fjehtenwaldungen größer als für Föhrenwaldungen, und wälrend schon mehrfach die Ansicht ausgesprochen wurde, man hönne für letztere die Bekämpfung cines Nonnenfraßes der Natur allein überlassen. wird man in Fichtengebieten doch stets mit allen zu Gebote stehenden Mitteln einem solchen entgegentreten.

§ 59. Di e Föhrene u l e, Trachea (Panolis) piniperda (s. Taf. II Fig. 5). Männchen und Weibchen der Föhreneule sind gleich groß mit etwa $3,2-3,5 \mathrm{~cm}$ Flügelspannung und ziemlich überein gezeichnet, so daß nur die gewimperten Fühler und der schlankere Leib das Vännchen von dem Weibchen, dessen Fühler fadenförnig sind, unterscheiden. Vorderflügel und Vorderleib sind braunrot, weißgelb geflecht und gestrichelt nit je einem größern halbmondförmigen hellen Fleck, Hinterflügel und Hinterlcib braungrau, erstere mit etwas hellerem Saum. Unterseite bläulichrot, auf den Vorderflügeln gegen die Basis schwarzgrau, auf den Hinterflügeln ein schwarzgrauer Punkt; Farbenvarietäten kommen nicht selten vor.

Die ausgewachsene Raupe wird bis zu $4 \mathrm{~cm}$ lang, jst gelbgrün mit weißen Längsstreifen und einem unter den Luftlöchern beiderseits stehenden gelben bis orangefarbigen Streifen, mit dunklen liopf, sehr schwach behaart; die ersten beiden Bauchfußpare sind in den ersten Entwicklungsstadien etwas verkürzt, und die Raupe geht dann spannerartig, spinnt in der Jugend auch Fäden.

Die Puppe, $1.6 \mathrm{~cm}$ lang mit zweidornigem After, ist anfangs mehr grünlich. später dunkelbraun gefärbt.

Der Schınetterling schwärmt sehr frühzeitig, Ende März oder Anfang April; das Weibclıen legt seine Eier reihenweise zu $4-8$ an die Nadeln in den Kronen ab, und die im Nai erscheinenden Räupchen beginnen sofort ihren Fra $\beta$, benagen zuerst die Nadeln, sie später bis zur Scheide verzehrend, und steigen bereits Ende Juli ausgewachsen vom Baum, sich unter der Bodendecke und, wo solche fehlt, in der Erde verpuppend und liegen hiebei auf der ganzen Bestandsfläche zerstreut. Dic Zeit der Puppenruhe ist sonach eine sehr lange, unfaßt 8 .Ionate und darüber.

Die Föhreneule lebt nur auf Fölıren und befällt zunächst Stangenhölzer; bei trockener warmer Witterung wälırend ihrer Raupenzeit vermehrt sie sich bisweilen sehr bedeutend und hat wiederholt ausgedehnte Bestände in dem Maßf beschädigt, daß sic zu den schärllicheren Forstinsekten zu zälllen ist.

Glücklicherweise stehen nancherlei natürliche Henmnnisse der Vermchrung der Föhreneule im Weg; die fast nackte Raupe, die acht Monate lang am Boden liegende 
Puppe haben eine Menge von Feinden jeder Art: Vögel, Raubkäfer, Ichneumonen und Tachinen, dann Sehweine, Igel, Spitzmäuse; die Raupen sind namentlich zur Zeit der Häutung gegen naßkaltes Wetter empfindlich, und nicht selten geht durch solches ein großer Teil der Raupen rasch zugrunde. Insbesondere aber ist es Erkrankung infolge eines Pilzes (Entomophtora aulicae), durch welche wiederholt schon einem größern Fraß der Eule ein plötzliches Ende bereitet wurde - sämtliche Raupen des Fraßgehietes sterben in kürzester Zeit ab.

Es ist diese natürliche Hilfe um so höher anzuschlagen, als man vorbeugende Nittel gar nieht, solclie der Vertilgung nur in beschränktern Maße anwenden kann. Am wirksamsten erweist sich der Eintrieb von Seh we in e herde $\mathbf{n}$ in die befallenen Bestände nach erfolgter Verpuppung, da die Sclwweine den Puppen gierig nachgehen. - Auch das A n p r ä 11 e $\mathrm{n}$ hat man in den Stangenhölzern angewendet, indem ein Arbeiter mit der Axt oder einer hölzernen Keule einige kräftige Sclıläge gegen die Stange - zur Vermeidung von Quetselıwunden auf einen Aststummel führt, wälırend Ǩinder oder Wviber die herabfallenden Raupen von untergelegten Tüehern auflesen. Der Erfolg der immerhin kostspieligen Maßregel ist jedoch nur ein beschränkter. Auch die E n $\mathrm{t} f$ e r n ung d e r S t re u nach stattgehabter Verpuppung erweist sich günstig (s. $\S 60$ ).

$\S 60$. Der Föhrenspanner, Fidonia (Bupalus) piniaria (s. Taf. II Fig. 4). Das Männchen, ebenso groß wie das Weibchen, mit $3,2 \mathrm{~cm}$ Flügelspannung, ist dureh die Färbung deutlich von letzterem unterschieden: gelb, mit breitem dunkelbraunem Rand und Querstreif, die Fransen der Flügel braun und gelb gefleckt; bei dem Weibehen dagegen ist die Grundfarbe der Flügel rotbraun, der Rand und die Querbinden auf den Flügeln ebenfalls dunkelbraun, die Flügelfransen hell und dunkelbraun gefleckt. Die Unterseite dagegen ist bei beiden Geschlechtem gleich, bräunlich mit dunkeln Querlinien, einem breiten, gelbweißen Längsstreif und zahlreichen braunen und weißen Fleckchen.

Die im ausgewachsenen Zustand $3,5 \mathrm{~cm}$ lange Raupe ist gelblichgrün mit weißen Längsstreifen, die sich auch über den liopf fortsetzen; dicht unter den Luftlöchern beiderseits eine gelbe Seitenlinie, aul dem Bauch drei gelbe Längsstreifen.

Die Puppe ist 1,2 cm lang, jener der Eule sehr älmlich, aber etwas kileiner und durch die einfache Hinterleibsspitze leicht zu unterscheiden.

Der Schnetterling schwärmt von Ende Mai bis Ende Juni, und sieht man das Männchen auch am Tag in unıuhigem Fhug am Bestandsrande. Das Weibehen legt nach der Begattung die hellgrünen Eier reihenweise an die Nadeln der Föhre in den Fronen ab, und es erscheinen anfangs Juli die kleinen Räupchen, welche zuerst the Nadeln nur benagen, später sägezähnig befressen, wobei die raseh braun werdende Nittelrippe stehen bleibt; die Baumkronen, in welehen der Fraß stets beginnt und von denen er abwärts rückt, erhalten hiedureh einen braunen nnißfarbigen Ton. Die herangewachsenen Raupen fressen zuletzt auclı die ganzen Nadeln, lassen die Spitzen aber vielfach herablallen. Die Raupen spinnen, lassen sich auch zur Verpuppung nicht selten an einem Faden lierab. Letztere erfolgt im Herbst, September und Oktober, in älullicher Weise wie bei der Eule unter dem Moos, den Narleln oder bei deren Fetzlen flach im Boden, wobei die Puppen gleichfalls zerstreut in ganzen Bestand umherliegen.

Der Spanner lebt nur auf der $\mathrm{F}$ ö h $\mathrm{r}$ e und befällt, auch in dieser Richinng der Eule ähnlich, in erster Linie die Stangenhözer. Er ist stellenweise sehon in sehr großer Masse aufgetreten, so 1893 bis 1895 in Bayern, und hat ausgedehnte Bestände stark durchfressen, selbst kahl gefressen und vemichtet; seine Schädlichlieit wird durch 
seinen späten Fraß vermindert, da dann die Künospen fürs nächste Jahr bereits ausgebildet sind, so daß die Bestände sich wieder zu begrünen vermögen. Folgt aber in solchen sehwach benadelten Beständen nochmals Kahlfraß, so gehen sie wohl stets zugrunde. Als Ilerde, von denen der Fraß ausgeht, erscheinen auch bei ihm namentlich trockene Sandrücken, die offenbar für die Ueberwinter'ung der Puppe die günstigsten Verhältnisse bieten.

Raupe und Puppe des Föhrenspanners haben die gleichen zahhreichen Feinde, wie jene der Eule, die nackten Raupen werden von Sehnarotzern stark heimgesucht, sind gegen Witterungseinflüsse empfindlich und dureh Krankheiten und Sehmarotzerpilze wird die ganze vorhandene Raupen- und Puppenmenge oft rascl getötet.

Als Mittel der Vertilgung ist $\mathrm{S}$ c h w e i n e e in t r i e b zu emplehlen; bez. des auch schon angewendeten Raupensammelns durch Anprällen gilt das bei der Eule Gesagte. Auch En t f e r n en der Stre u im Spätherbst wird empfohlen, und da nach Untersuchungen gelegentlich des letzten großen Spannerfraßes in Bayern $35 \%$ der Puppen in der Moos- und Nadeldecke, 60\% in der Humusschichte und nur $5 \%$ im Mineralboden lagen, so werden mit der Streu einerseits sehr viele Puppen beseitigt, die iibrigen aber bloßgelegt und dadurch ihren mannigfachen Feinden zugänglicher gemacht.

\$61. Der Ki e ferntriebwi e $\mathrm{l}$ le r, Retinia buoliana (s. Taf. I Fig. 20). Bei diesem kleinen, bisweilen jedoch in ziemlicher Zahl auftretenden und dann für Föhrenschläge sehr schädlichen Insekt hat der Falter nur etwa $2 \mathrm{~cm}$ Flügelspannung; die schmalen Vorderflügel und der Vorderleib sind gelbrot mit silberweißen in der Mitte blauschillernden geschlängelten Querbinden und grauweißen Fransen, die Unterseite ist dunkelgrau, seideartig glänzend, an den Vorderrändern gelbrot und weiß gefleckt. Die Raupe ist ausgewachsen $1,4 \mathrm{~cm}$ lang, hellbraun mit kleinem glänzend schwarzem Kopf- und Nackenschild; die Puppe, schmutzig gelbbraun, ist etwa $S \mathrm{~mm}$ lang.

Der Falter sehwärmt Anfang Juli in den Abendstunden, und das Weibehen legt seine Eier einzeln an die Knospen der jungen Triebe und zwar nur jüngerer, 5-12jähriger Kiefern, in welche sich das nach wenig Wochen erscheinende Räupchen einbohrt; doch wird bei der sehr geringen Größe des Räupchens der Fraß im Herbst kaun noch bemerkbar. Die noeh schwach beschädigte Knospe - und zwar ist es in der Regel die am stärksten entwickelte Teminalknospe, welche befallen wird - beginnt in Frühjahı zu schieben, gleichzeitig wird aber der Fraß im Innern des Triebes mit zunehmendem Wachstum des Räupchens intensiver, und meist stirbt der handhoch gewordene Trieb ab, worauf dann der Fraß an den Seitenknospen und bezw. Trieben fortgesetzt wird, bis sich im Juni die Raupe im Innern eines von ihr ausgefressenen Triebes und zwar an dessen Basis verpuppt. Ein etwa unbeschädigt gebliebener Seitentrieb erhebt sich zum Haupttrieb, nicht selten aber senkt sich ein soleher nur mäßig besehädigter Trieh zuerst abwärts, sich dann wieder hebend und die Verwundung verheilend, wobei jedoch die beschädigte Stelle noch in höheren Alter dureh eine eigenartige, oft sehr starke lírümmung erkenntlich ist. - Bisweilen finden sich in Kulturen die Pflanzen in solchem $\mathrm{Naß}$ befallen, daß kaum eine derselben normale Gipfelentwicklung zeigt und bei wiederholter Beschädigung werden die gegen Verletzungen an sich empfindlichen Föhren geradezu krüppelige, strauchartige Büsche.

Hält man in solchem Falle ein Eingreifen für angezeigt, so kann eine Vertilgung bezw. sehr starke Verminderung des Inselits durch Ausbrechen der absterbenden Triebe and Zerdrücken der Raupen und Puppen - Ende Nai und im Juni - erreicht werden. 
In ähnlicher. Weise schädigt der minder häufig auftretende $\mathrm{K}$ i e f e r $\mathrm{n} k \mathrm{n}$ osp en wi ckl er (Retinia turionana), dem Triebwickler auch äußerlich ähnlich und gleich ihm nur jüngere Föhren befallend, die betroffenen Individuen durch Ausfressen der Knospen, die dann meist schon als solehe zugrunde gehen, sich überhaupt nicht mehr entwickeln.

$\$ 62$. Der Harzga 11 e n w i k ler, Retinia resinella. Der Falter dieses Inselites, das wir mehr wegen seines allenthalben, wenn auch in begrenzter Zahl erfolgenden auffallenden Auftretens und seiner eigentümlichen Lebensweise, als um des durch ihn verursachten Schaclens willen auführen, hat nur 1,6 cm Flügelspannung; Jíopf, Rumpf und Vorderflügel sind kupfrig glänzend, bräunlich schwarz, die Flügel mit silbergrauen Querbinden und schwärzlichem Fransensaum, die Hinterflügel dunkelbraungrau mit hellgrauem Fransensaum; Unterseite dunkelbraungrau.

Die Raupe jst etwa $10 \mathrm{~mm}$ lang, gelbbraun, die Puppe $8 \mathrm{~mm}$ lang und dunkel, fast schwärzlich.

Der Falter fliegt in Mai und legt seine Eier einzeln unterhalb der Quirlknospen jüngerer Föhren und zwar vorwiegend der Seitentriebe des laufenden Jahres ab; nach einigen Wochen schlüpft das Räupchen aus und nagt sich durch die Rinde in den jungen Trieb ein, wobei das aus der Wunde fließende Harz eine erbsengroße weiche Galle bildet, in derem Innerem das Räupchen lebt. Im zweiten Jalır vergrößert sich durch Fortsetzung des Fraßes diese Galle etwa bis zur İirsehengröße, jedoch in etwas elliptischer Gestalt, und zeigt in Innern eine deutliche Scheidewand durch die Galle des ersten Jahres; die Wandung der weißen und nun sehr ins Auge fallenden Galle verdickt sich und wird härter, der Trieb selbst aber ist auf einer Seite im Innern der Galle bis aufs Mark befressen und stirbt häufig ab. Erst im April des dritten Jahres verpuppt sich die Raupe innerhalb der Galle, aus der sich die Puppe beim Ausschlüpfen mit dem Vorderteil hervorschiebt; das Insekt bietet also das für Schmetterlinge seltnere Beispiel einer zweijälurigen Generationsdauer.

Der Schaden ist infolge des doch meist beschränkten Auftretens und des Umstandes, daß vorwiegend die Seitentriebe befallen werden, ein geringer und nur stellenweise bei großer Vermehrung fühlbar. Durch einfaches Zerdrücken der großen Gallen in Herbste kann eine Verminderung des Insekts erreicht werden.

\$63. De r Fich te n r in $\mathrm{den}$ w $\mathrm{ckler}$, Grapholitha pactolana. Dieser kleine Wickler mit braunen, glänzend weiß gezeichneten Vorderflügeh und graubraunen Hinterflügeln ist stellenweise schon sehr schädlich aufgetreten. Der Ende Mai, Anfang Juni schwärmende Schmetterling legt seine Eier an die Rinde jüngerer Fichten, insbesondere schwächerer Stangen und zwar an die Quirle ab; die Räupchen bohren sich durch die Rinde ein, fressen in der Safthaut kurze unregelmäßige Gänge, wobei austretentle Harztröpfehen und kleine Kiothäufchen auf der Rinde ihre Anwesenheit verraten, und überwintern als Raupen, un sich Anfang Mai zu verpuppen. Die beschädigten Pflanzen und Stangen kümmern und gehen bei stärkerem Fraß auch ein. Als Gegenmittel empfiehlt sich das rechtzeitige Aushauen und Verbrennen der stärker befallenen Individuen; nach Altum kann bei noch beschränktem Fraß das Bestreichen der befallenen Stellen mit Raupenleim angewendet werden, wodureh die in der Rinde liegende Puppe sich nicht vorschieben, der Schmetterling nicht ausschlüpfen kann. In den mejsten Fällen wird man auf Gegenmittel verzichten müssen.

$\$ 64$. Der Fje htennestwi ckler, Grapholitha tedella. Derselbe gelıört zu den nur mäßig schädlichen, aber bisweilen in größerer Mlenge auftretenden und durch die Art seines Fraßes auffallenden Insekten. Der kleine Schmetterling 
mit gelbbraunen silberweiß durchzogenen Vorderflügeln fliegt in Maj und Juni in der Abenddämmerung, legt seine Eier an die Nadeln der Fichte und zwar vorzugsweise der äußem und untern Zweige sowohl von Pflanzen wie von älteren Stämmen. Die Räupclıen bohren sich in die Nadeln ein, diese ausfressend und verspinnen deren mehrere zu einem kleinen mit liot durchsetzten Nest; die Zweige sind oft dicht mit solehen Nestern bedeckt. Ende Oktober, ja selbst erst im Novernber lassen die Raupen sich spinnend an den Boden herab, überwintern unter dem Bodenüberzug und verpuppen sich erst in Frühjahr. Gegenmittel lassen sich mit Erfolg nicht anwenden.

$\$ 65$. D je L ä r e he $n$ m o t t e , Coleophora laricinella. Der kleine granschwarze Schmetterling schwärmt in Juni und legt seine Eier einzeln an die Nadelı der Lärche; das nach kurzer Zeit aussehlüpfende Räupchen bohrt sich in die Nadel ein, liöhlt diese aus und bedient sieh des leeren Spitzenteils als schützender Umhüllung, in der es an den hinospen und insbesondere den Zweigspitzen angeheftet überwintert und die es auch in Frühjahr, den Fraß an den erscheinenden Nadeln fortsetzend und namentlich deren obere Hälfte äußerlieh befressend, nicht verläßt. In dem Sack verpuppt es sich dann auch Ende Nai, um nach ca. 3 Wochen sich zum Falter zu entwickeln und sofort zu schwärmen.

Die befressenen und ausgehöhlten Nadehn werden gelb und welk und die Beschädigrung ist eine oft so bedeutende, daß die befallenen Stangen und Stämme - an Pflanzen tritt die llotte in viel minderem Maße auf - kaum eine gesunde Nadel mehr zeigen, stalt grün vollständig mißfarbig erscheinen; nicht selten wird diese Beschädigung (in Verbindung mit jener dureh Chermes laricis) von dem Unkundigen oder nicht genauer Lntersuchenden für Folge von Spätfrösten gehalten, von denen aber erfahrungsgemäß die Lärche wenig leidet. Es ist erklärlich, daß die Zerstörung der Nadeln den Baum beeinträchtigen, wiederholte Entnadelung selbst sein Eingehen zur Folge lıaben kann, und Borggreve ${ }^{1}$ ) hält den Fraß der Lärehenmotte für eine Hauptursache der sog. Lärchenkrankheit. Man kann jedoch beobachten, daß die stark befressenen Stämme aus dem Innern der Nadelbüschel frische Nadeln nachtreiben und sich hiedurch, wie dureh die Benadelung der Langtriebe, wieder leidlich begrünen.

Gegenmittel irgend welcher Art sind nicht anwendbar; bisweilen hilft die Natur durch Regenwetter zur Schwärmzeit, wobei viele der kleinen schwachen Falter zugrunde gehen.

\section{Sonstige schädliche Insekten.}

\$66. Die gemeine Ki e f e r $n$ b la t $t$ wespe, Lophyrus pini (s. Taf. I Fig. 17). Das Weibchen hat 1,6-1.8 cm Flügelspannung, kurze scliwach gezähnte Fühler, schwarzen liopf, ist im übrigen blaßgelb mit drei schwarzen Flecken auf dem Rücken und drei schwarzen neben einander liegenden Hinterleibsringeln; das wesentlich kleinere Wännchen mit schön doppelt gekämunten Fühlern ist mehr schwärzlich mit gelblichen Beinen und rötlicher Hinterleibsspitze. - Die Raupen des der Gattung der Aderflügler (Hymenopteren) angehörigen Insekts sind Afterraupen mit ?? Beinen, schnutzig gelbgrün mit braunem Kopf und schwarzer Zeichnung über den Bauchfüßen; bei der Berührung sehnellen sie den Vorderleib in eigentümlieher VVeise zurück. - Die Puppe, welche schon die sämtlichen Teile der Blattwespe zeigt, liegt in einem lederartigen dunkelbraunen Tönnchen, das entweder in rlen Rindenritzen der untern Stamnteile orler am Boden, unter dem Joos sich findet und ron welchem

1) A. F.- แ. J.-Z. 1871 S. 133 . 
die Wespe beim Ausschlüpfen einen kreisrunden Deckel abschneidet. (Nicht selten zeigt das Tönnchen statt dessen ein seitliches kleines Loch - das Flugloch eines Ichneumons.)

Die Generation der Kijiefernblattwespe ist der Regel nach eine doppelte, doch finden von dieser Regel nicht selten Abweichungen statt.

Das erstmalige Schwärmen findet Ende April, Anfang Mai statt, und das Weibchen legt seine Eier, 120 und mehr, partienweise an die Kianten der Nadeln, die es nit seinem sägeförmigen Legebohrer aufschneidet, und verklebt die Einschnitte nach Abłegung der Eier mit etwas schaumigem Schleim. Die nach einigen Wochen erscheinenden Räupclien fressen, so lange sie klein sind, zu zweien an einer Nadel, die Mittełrippe stehen lassend, später aber die ganze Nadel unter Zurücklassung eines Stumpfes und gehen nur im Notfalle an die jungen Triebe. Der partienweisen Eierablage entsprechend hängen sie klumpenweise an den Zweigen und finden sich insbesondere an den Bestandsrändern, schlechtwüchsigen Kieferngestrüpp, bei größerer Vermehrung aber altenthalben mit Verschonung der eigenthichen Schläge, stets nur an der Fö h re.

Etwa Anfang Juli verpuppen sich die Larven, ilıre Tönnchen a $\mathrm{n}$ d i e $\mathrm{R}$ in d e, auch Aeste und Nadeln klebend; die meist nach wenig Wochen ausfliegenden Wespen setzen eine zweite Brut ab, die bis zum Spätherbst fressend sodann am Baum herabkriecht, um sich möglichst geschützt u n te r d e m Moos ihre Tönnchen zu fertigen, in welchen die Larven als solche bis zum Frühijahr liegen, erst dann sich eigentlich verpuppend. Bei starkem Frost liegen die Cocons oft in ganzen Klumpen beisammen. Es finden jednch von der eben geschilderten Entricklung nicht unwesentliche Abweichungen dadurch statt, daß bisweilen ein größerer oder kleinerer Teil der Larven längere Zeit, selbst ein Jahr und darüber, aus unbekannten Gründen ohne sich weiter zu entwickeln in den Tönnchen liegen bleibt.

Die Kïiefernblattwespe, unter günstigen Umständen sich stark vermelırend, hat stellenweise die Föhrenbestände schon stark beschädigt; der Schaden wird dadurch geringer, daß die diesjälurigen Triebe nur ausnahunsweise angegangen werden, hiedurch einerseits also nur selten Kiahlfraß eintritt, anderseits die Möglichkeit der Knospenausbildung fürs nächste Jahr gegeben ist.

Zahlreiche natürliche Feinde der Blattwespe reduzieren glücklicherweise deren Zahl; Wespen wie die nackten Afterraupen werden von insektenfressenden Vögeln verzehrt, die Schweine fressen ebenfalls die zur Verpuppung herabkriechenden Raupen, verschmäten aber thie liokons, aus welı letzteren sich dagegen Eichhörnchen und Spitzmäuse gerne die Larven holen. Die Zahl der letzteren wisd auch noch durch Insekten jeder Art, durch Tachinen und Ichneumonen vermindert, mehr aher unter Unstänclen durch die Witterung, indem bei anhaltend naßkaltem Wetter oft ein großer Teil zugrunde geht.

Es ist dies um so günstiger, als uns wirksame Verhütungs- und Vertiłgungsmittel nur in geringem Maß zur Terfügung stehen; man lıat ihre Zahl durch Sammeln orler durch Zerquetschen der khumpenweise beisammensitzenden Larven an niedern Büschen und Bestandsrändern zu verringern gesucht, Schweine während der kurzen Zeit des Absteigens der Larven von den Bäumen zum Zweck der Verpuppung eingetrieben, zahlreiche mit Raupenleim bestrichene Pfähle zum Fangen der schwärmenden Wespen aufgestellt - doch wird der Erfolg stets nur ein geringer sein und in den meisten Fällen auf solche Hilfsmittel verzichtet werden müssen.

Neben der eben geschilderten fressen noch zahlreiche andere Blattwespen L. Jufus, pallichus, similis - an den Kiefern. - Auch an Fichten und Lärchen 
fressen einige Blattwespenarten (Nematus), ohne jedoch nennenswerten Schaden anzurichten.

\$ 67. Die Gespins $\mathrm{b}$ blattwespen, Lydac. Im allgemeinen wenig schädlich, mögen sie doch um ihı'es auffallenderen Auftretens willen Erwälınung finden. Sie unterscheiden sich von der eben besprochenen Fiefermblattwespe namentlich dadurch, daß die Larven nur drei Paar Brustfüße und ein Paar sog. Nachschicher hahen, während dic Bauchfüße verkümmert sind, und daß sie stets in cinem Gespinst leben, wclches sich dem Zweig entlang zieht und teils durchsichtig ist, meist aber durch Nadelreste und namentlich dureh den Kiot undurchsichtig, zu cinem sog. Kotsack wird. Die Verpuppung erfolgt in der Erde, zu der sie sich meist an einem Faden herablassen, und überwintern die Larven als solche, sich erst im nächsten Jahre verpuppend, lıäıfig aber gleich der Kiefernblattwespe ein volles Jalıs und länger unverpuppt liegend. Als liäufigere Arten seien erwähnt:

Die gelbe $\mathrm{F}$ o $\mathrm{ts}$ a e k b a t $\mathrm{t}$ es p e, Lyda campestris, deren Larve ein-

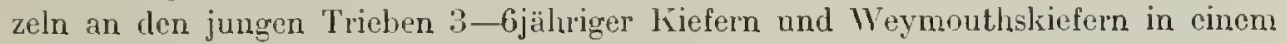
dichten Kotsack lebt. Tritt sie an letzterer Holzart in Forstgärten auf, so wird man sic durch Abstreifen rer Kotsäcke vernichten.

Dic rotköpfige Ki e f e rnblat twespe, Lyda erythrocephala, lebt zu 3 bis 4 Stücken in cinem ebenfalls mit Nadel- und Kotresten etwas verdiehteten Gespinst an jüngeren Föhren und Weymouthsliefern.

Die bunte k o ts a ckblat $\mathrm{tw}$ es pe Lyda pratensis, ist da und dort in ältern Fölırenbeständen in solcher Masse erschienen, daß Abfressen aller ältern $\mathrm{Na}$ deln, sclbst vollständiger Kahlfraß die Folge war.

Die Fich $\mathrm{F}$ engespinstblat $\mathrm{twespe}$, Lyda hypotrophica, ist sehon wiederholt (zuletzt in den Jahren 1893 und 1894) in älteren Ficlitenbeständen in großer Zahl aufgetreten, die Bestände schwer schädigend und selbst zerstörend. Die teils grünen, teils gelben Larven leben in zuletzt bis kindskopfgroßen Gespinsten beisammen, baumen im August und September ab und liegen unverpuppt bis 21,2 Jahre im Boden, sich endlich verpuppend; im Hai schwärmen die IVespen, die sehwerfälligen Weibehen fliegen die Bäume tief unten an, um dann die Baumkrone liriechend zu erreichen und dort ihre Eier an die Nadeln abzulegen. Durch in Brustlıöhe angebrachte Leimringe kann man einen großen Teil derselben abfangen, cloch macht die Natur durch Schmarotzer und Erkrankung der im Boden liegenden Larven der Kalanität zumeist ein melır orter minder rasehes Ende.

§ 68. D i e $\mathrm{ll}$ a u l w u r s grille, Gryllotalpa vulgaris (s. Taf. I Fig. 13). Dieses eigentümlich gestaltete, wohl allbekannte Tier, ausgezeichnet durch ein Paar maulwurfsartige Grabfüßc, denen es auelı scincn Namen verdankt, lebt meist unterirdisch und zwar in überwiegendem Maße von animalischer Nahrung, wird aber durelı Zerstören der Pflanzenwurzeln beim Graben seiner Gänge in Saatbeeten oft sehr lästig. Es gehört zur Kilasse der Geradflügler und hat eine unvollkommene Verwandlung, bei der also ein eigentlicher Puppenzustand felılt.

Die Paarzeit ist im Mai und Juni, und locken sich die Geschlechter in den Ahendstunden durch ein eigentümliches Schrillen. Die Ablage der Eier erfolgt in einer Höhlung in einem bis faustgroßen, durch Schleim zusammengekitteten Ballen etwa 8 bis $10 \mathrm{~cm}$ unter der Erde, und ist die Zahl der Eier oft eine sehr große, bis zu 200 Stück. Die Larven, anfangs weiß, später bräunlich und schon bald dem Imago ähnelnd, zerstreuen sich nach einiger Zeit, Nahrung suchend, im Boden und entwickeln sich, nachdem sie unter der Erde überwintert, bis zur Paarzeit zum fertigen Insckt, das also eine einjährige Generationsdaner hat. 
Zum Suchen ihrer Nahrung wühlt sich nun die Werre mit Hilfe ihrer Grabfüße lange, flach verlaufende Gänge, welche in lockerem Boden durch leichtes Heben der Erde an der Oberfläche sichtbar werden, und zerstört hiebei durch Zerreißen nuit ihren GrabfüBen, wohl auch durch Abbeißen aller ihr im Weg befindlichen Pflanzenwurzeln (nach Nördlingers Angabe frißt sie diese auch) und wird hiedurch wie auf Feldern, so namentlich in den Saatbeeten, insbesondere für unsere schwachen Nadelholzkeinlinge oft lästig und schädlich, so daß man zu ihrer möglichsten Vertilgung genötigt ist.

Diese letztere erfolgt nun nach unsern eigenen Erfahrungen am sichersten in der Weise, daß man dem frisch entdeckten Werrengang mit dem eingeschobenen Finger folgt, bis er sich zur Tiefe senkt; mit einem Reis sucht man dessen weitere Richtung und legt den Gang mit dem Spaten bloß - an dessen Ende, oft schuhtief im Boden, sitzt die Werre.

Man hat weiter das Aufsuchen der Nester, die sieh durch Zusammenlaufen mehrerer Röhren und absterbenden Pflanzenwuchs markicren sollen (aber doch nicht leicht zu finden sind!), das Eingraben von Blumentöpfen oder Blechgefäßen, mit dem obern Rand dem Boden gleich, zum Fang der namentlich zur Paarzeit des Nachts oberirdisch herumlaufenden Werren, endlich auch das Vernichten der zur Paarzeit schrillenden Tiere, indem man sie mit einem Hackensehlag aus dem Boden wirft, empfohlen. Auch das Eingießen eines Kaffeelöffels Oel oder Petroleum in die frischen, nach Regenwetter leicht kenntlichen Gänge, und Nachgießen von Wasser so lange, bis die letztern gefüllt ersclieinen - rlie Werren erscheinen ölglänzend an der Erdoberlächc - soll sich als Vertilgungsmittel bewähren (Ney).

\section{B. La b holz. Insekten.}

\section{Käfer.}

\$69. D i e La u b holzborkenkäf er üb er ha u t. Auch im Lauhholz kommen eine Anzahl Borkenlääfer versehiedener Art vor, jedoch in viel minderer Zahl als in den Nadelhölzem und in viel minderer Schädliehkeit, indem einerseits die an sich reproduktionsfähigeren Laubhölzer erhittene Beschädigungen leichter ausheilen, anderseits eine Anzah! der Laubholzborkenkäfer mehr im Holz als im Bast. lebt, hiedurch technisch, nicht aber physiologisch schädlich wird. Nebenbei selıen wir sie wenigstens teilweise mehr in cinzeln stehenden älteren, oft schon schadhaften Stämmen, in Alleen, Anlagen, als im geschlossenen Wald auftreten; die meisten sind polyphag, finden sich bald an dieser, bald an jener Holzart. Wir beschränlien uns auf Anführung einiger der häufigeren und schädlicheren Arten:

Der bunte Eschenbastliafer. Hylesinus fraxini, und der sehwarze

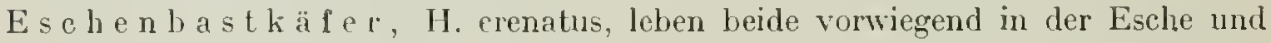
bringen durch den Fraß ihrer Larven in der Basthaut die befallenen Stangen umi Stämme bisweilen zu raschem Absterben; charakteristisch sind die lluttergänge, bei beiden Wagregänge, von ersteren doppelarmig, von letzterem einarmig.

Der ungleiche La ub holzborkenkä $\mathrm{fer}$, Xyleborus dispar, befällt zwar in erster Linie schadhafte ältere Eichen und Buchen, sowie schadhafte Stämme anderer Holzarten, in welchem Falle der durch ihn angeriehtete Schaden kein nennenswerter ist; dagegen hat er sich wiederholt schon sehr schädlich in Eichenheisterpflanzungen gezeigt, indem er die Stämmchen in großer Zahl befält, sich in deren Inneres einbohrt und sie behufs Absatz seiner Brut durchlöchend hiedurch 
zum Tïränkeln und Absterben bringt. Ausreißen und Verbrennen der Heister würde das hier anzuwendende Schutzmittel gegen weiteren Schaden sein.

Vorwiegend in Ulmen und namentlich ältere Alleebäume schädigend treten der groBe und kleine Ulmensplint k ä f r, Scolytus destructor und nultistriatus auf, deren Larven die Basthaut der befallenen Stämme zerstören; beide Muttergänge sind Lotgänge.

$\$ 70$. Die B ockkäfer, Cerambycidac. Die zahlreiche Fanilie der Bockliäfer, wenn auch nur da und dort merlitich schädlich, tritt doch im WValde so häufig auf, ihre Larven und deren Fraß fallen so viclfach ins Auge, daß deren Erwälunung wohl als zwecknäßig erscheint.

Sie gehören zu den technisch schädlichen Insekten. Die Käfer, teilweise durch ansehnliche Größe, lange Beine und oft selır lange Fühler ausgezeichnet, erscheinen in Sommer und legen iftre Eier an oder in die Rinde ab. Die Larven, weiß oder weißgelb, meist beinlos, mit kräftigen lırnigen Oberkiefern, fressen anfänglich nıchr oberflächlich, später tiefer im Holz, die breiten und flacken Gänge sind voll Wurmmelıl; die Verpuppung erfolgt nach zwei und selbst melır Jahren in einer etwas mit Spänen ausgepolsterten Wiege, das Ausflicgen des Käfers dureh ein elliptisches, schief stehendes Flugloch. Die Iiäfer selbst sind vollständig unschädlich.

Vielfach sind es bereits schadhafte Stänme und zwar vorwiegend von Laubhölzern, welche vom Bockkäfer nit seiner Brut besetzt werden, und der Schaden ist dadurch ein geringer, doch finden auch Ausnalmen durch Besetzen gesunder Stämme mit Brut statt. Immerlin werden Maßregeln irgend welcher Art gegen Bockkäfer nicht nötig werden.

Als läufigere und forstlich interessantere Arten seien genamnt: Der g r o B e E i c lı e $\mathrm{n}$ b o e k k ä f e r, Cerambyx (Hammaticherus) heros, dessen kolossale, bis $7 \mathrm{~cm}$ lange, durch starlie Rückenplatten ausgezeichnete Larven in alten Eichen und zwar meist in gesundem Holz leben, das durch die zuletzt fingerdicken Larvengänge natürlich zu jeder bessern Verwendung unbrauchbar wird; der Käfer ist $4-5 \mathrm{~cm}$ lang, selıwarz mit selır langen Fühlern.

An den jüngeren Aspen fallen die linotigen Auftreibungen ins Auge, welchc dureh den Fraß der in ihnen lebenden Larven des $A s p e n b o c k k$ ä fers, Saperda populnea erzeugt werden; in dem Pappelholz leben die Larven des gr o $B$ e n Pap pelbocks, Saperda carcharias (s. Taf. I Fig. 6), eines bis $3 \mathrm{~cm}$ langen gelbbraunen Käfers mit schwarz punktierten Hals und Flügeldecken.

Als eine in Nadelholz lebende schädlichere Art sei hier noch der F i c h t c nb o ckkä fer, Callidium lurirlum, genannt; die Larve frißt zuerst in der Safthaut gesunder ältcrer Fichten, erst später tiefer ins Holz gehend, und bringt durch crstere Art des Fraßes, wenn in größerer Zahl an cinem stamm, diesen rasch zum Iíränkeln und Absterben. Sofortige Fälhung und Entfernung der befallenen Stämme - kenntlich durch Harzausfluß und Welken der Benadelung - ist zu empfehlen.

Als eine ganz unschädliche, abel allenthalben vorkommende Art sei noch der Z a n g e n b o c k, Rhagium indagator, genannt, dessen große, gelbweiße Larven mit breiten, wurmmehlgefüllten Gängen sich überall unter fler Rinde bereits gefällter oder abgestorbener Nadelhölzer, namentlich Föhren, finden.

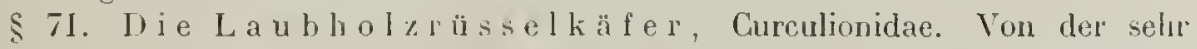
zahlreichın Familie der Rüsselkäfer lebt nur einc lileinere Zahl aụ Nadellı̈̈zern, hier allerdings bisweilen sehr sehädlich werdend (vergh. $\$ 52-55$ ), cine viel größere Zalıl aber auf Blattgewächsen jecler Aıt, so auch auf unsem Laubhölzern. - Charakteristisch ist wenigstens für die Melırzahl der Rüsselkäfer der in einen bald sehr 
langen und feinen, bald in einen kürzern und stumpfen Rüssel ausgezogene liopf des Käfers; letzterer wird durch Befressen von Pflanzenteilen bald mehr, bald weniger schädlich, bei manchen Arten sind es auch die Larven, welche im Innern der Gewächse zerstörend auftreten.

In Pflanzgärten, Kulturen und Schlägen richten eine Anzahl soleher Käfer, nach ihrer Färbung als g $r$ ü $\mathrm{n}$ e oder $\mathrm{gr}$ a u e Rüsselkäfer bezeichnet und zu den Gattungen Phyllobius, Polydrosus, Strophosonus u. a. gehörig, durch Benagen und Zerstören der Kinospen und Befressen der Blätter einen oft nicht unbedeutenden Schaden an, ohne daß jedoch gegen die an sich wenig ins Auge fallenden Käfer, welche sich bei der leisesten Berührung des Gewächses, auf dem sie sitzen, sofort zur Erde fallen lassen, etwa dureh Sammeln viel auszurichten wäre.

Als ein stellenweise in Buchenwaldungen in großer Menge auftretender kleiner Rüsselkäfer sei noeh der winzige $\mathrm{B}$ u e l e e s j r i ll g r üs s e l kä f e r, Orchestes fagi, genannt; die Larve beschädigt durch ganz eigentümliche Miniergänge die Buchenblätter, deren befressenen Teil zum Absterben bringend, so daß die Schläge wie von Frost versengt aussehen; auch ältere Randstämme zeigen sich vielfach besehädigt. Der Kiäfer selbst benagt und durchlöchert die Blätter und Fruchtkapseln.

Zu nennen wäre hier auch noch der E i e he n r üsselkä fer, Balaninus glandium, dessen Larve in den Eieheln und Haselnüssen lebend diese Früchte zerstört.

$\$ 72$. Di e Pra c lı $\mathrm{k}$ ä fer, Buprestidae. Diese bei uns meist nur in kleineren Arten vorkommenden Käfer, welche ilıren Namen von der bei der Mehrzahl schönen metalliseh glänzenden Farbe haben, werden nur durch den Fraß ihrer Larven schädlich. Diese Larven, welche weich, weiß und fußlos den Bockkäferlarven ähneln und sich von diesen dureh den stark verbreiterten ersten Leibesring und meist auch durch zwei nach hinten gerichtete IIornspitzen am After unterscheiden, fressen zwischen Holz und Rinde unregelmäBig geschlängelte, mit Bohrmehl fest ausgestopfte Gänge, an deren Ende sie sich in kleinen Splintwiegen verpuppen. Die Generation der Prachtkäfer ist mindestens 2jährig, vielleicht noch länger; der fertige Käfer fliegt dureh ein seitlich platt gedrücktes Flugloch aus.

Einzelne Arten der zahlreichen Familie sind schon in empfindlicher Weise schädigend aufgetreten:

Der E i c h e n p r a c h $t \mathbf{k}$ ä f e r, Chrysobotris affinis, kujferbraun, I I - I4 mm lang, legt seine Eier vorzugsweise an schwächere Eichen, Stangen und Heister, und hat durch den die Safthaut zerstörenden Fraß seiner Larven in Heisterpflanzungen stellenweise schon erheblichen Schaden angerichtet. Seine Generation scheint mindestens dreijälırig zu sein. - Aehnlich schadet Agrilus tenuis.

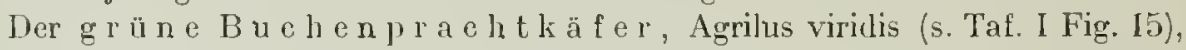
vorwiegend blau oder grün metallisch glänzend, $5-8 \mathrm{~mm}$ lang, beschädigt in gleicher Weise insbesondere Buchenheister, findet sich aber auch an stärkeren Stämmen und anderen Holzarten.

Bei beiden Insekten wird AusreiBen und Verbrennen der kränkelnden Heister wenigstens als Vorbeugungsmittel gegen weitern Schaden zu betrachten sein.

$\S 73$. D i e B l a $\mathrm{t} t \mathrm{k}$ ä f e r, Chrysomelidae. Die Käfer, meist von gedrungenem, stark gewölbtem Körperbau, geringer Größe und bunter, vielfach metallisch glänzender Farbe, kommen in unsern Waldungen auf einer Anzahl Holzgewächse in oft sehr auffälliger WVeise vor und nögen, wenn auch minder schädlich, daher hier kurz erwähnt sein.

Sowohl Larven wie Käfer benagen die Blätter, diese skelettisierend, indem sie Rippen und Aderu stehen lassen und nur das Parenchym dazwischen herausfressen, 
so daß ihr Fraß nicht wohl mit jenem anderer Inseliten verwecliselt werden kann. Ton unsern Holzgewächsen sind es namentlich eine Anzahl minder wichtiger, ja selbst stellenweise lästiger Weielıhölzer, die von Blattliäfern befressen werden, so Aspen, Pappeln, Salweiden, Erlen, so claß der Sehaden nur ein geringer ist; sehädlicher werden einige vorwiegend auf Weiden lebende Arten in den Weidenhegern. Als die häufigst rorkommenden mögen genannt sein:

Der b l a u e Erle n blat t käfer., Agelastica alni, von stahlblauer Farbe, im Mai als Käfer, später als Larve die Erlenblätter benagend; in Erlensaatbeeten kamn er sehr lästig werden und hat, nach Iỉhlfraß älterer Pflanzen die Kíeimlinge befressend, letztere da und dort zum Absterben gebraclıt. Sammeln der Käfer kann in solchem Fall wohl in Anwendung gebracht werden.

Selır in die Augen fallend durch die rote bis braunrote Färbung der Flügeldecken sind der rote Pappelblatthä fer, Lina populi (s. Taf. I Fig. 14), und der Aspenblat käfer, Lina trenulae, auf Aspen und andern Pappelarten, auel Weiden lebend. In den Weidenhegern macht dieser Käfer, und ebenso der gelbbraune $\mathrm{S}$ a $\mathbf{l}$ we $\mathrm{i}$ cl e $\mathrm{n}$ b l a $\mathrm{t} t \mathrm{k}$ ä $\mathrm{f}$ er, Galeruea capreae, dann der kleme erzgrüne W e i d e $n$ b la $\mathrm{t} t \mathrm{k}$ ä $\mathrm{f}$ e l, Chrysomela vitellinae, oft bedeutenden Selıden und sucht man sie hier durch Abstreifen in Körbe oder Karren möglichst zu sammeln und $\mathrm{zu}$ vernichten $\left.{ }^{1}\right)$.

Endlich wäre der in Forstgärten oft sehr lästige E r d flo lh, Haltica erucae, weil ebenfalls hieher gehörig, zu nennen, der durch Zerfressen der liotyledonen aufgehende Saaten zerstören kann und den man durch Bestreuen der Beete mit Asche oder Kialk und durch Begießen derselben mit verdünnter Karbolsäure zu vertreiben sucht.

\$7. Diespanisehe Fli ege, Lytta vesicatoria (s. Taf. I Fig. 16). Ein Inselit, das nur seltener merklich selıädlich auftritt, doch um seiner auffallenderen Erseheinung willen Erwähnung verdienen dürfte. Der $1,2-3 \mathrm{~cm}$ lange Käfer ist schön smaragdgrün mit weichen Flügeldecker, fliegt im Juni und legt seine Eier in die Erde, wo die Larven in den Nestern von Blumenbienen zu lelen seheinen auffallender Weise ist ilure Entwicklung noch nicht genauer erforscht. - Die im Juni oft in noch unerklärter Weise plötzlich in großer Menge erscheinenden, stark riechenden Käfer befallen insbesondere Eschen, sie bei großer Zahl oft völlig kahlfressend und dadureh im Wuchs zurücksetzend; selbst vollständiges Absterben kann die Folge sein. Auch verschiedene Sträucher, wie Liguster, Geisblatt, Spiräen dienen eventuell zur Nalırung.

An Eschenkulturen und in Saatbeeten sucht man durel Abschütteln die Kï̈fer zu sammeln und zu vernichten, was olme große Mülle ausführlar ist; die gesammelten Käfer könmen in Apotheken verkauft werden, woselbst sie infolge eines in ilınen enthaltenen Stoffes (Cantharidin) zu Blasenpflaster verwendet werden.

\section{Schmetterlinge.}

$\S$ 75. Der Buehenspinner oder Rotsehwanz, Orgyia pudibunda (Taf. II Fig. 3). Das Männehen dieses Selımetterlings hat etwa $1, \overline{\text { con, das }}$ Weibehen 5 bis $6 \mathrm{em}$ Flügelspannung; das erstere ist noch insbesondere dureh die gekämmten gelbbraunen Fühler kenntlich, wälırend die Färbung eine nahezu gleiche ist: Vorderflügel rötlichweiß oder grauweiß nit zwei braungrauen schmalen Querlinien,

1) S. Kra he, Lehrbuch der Korbweidenkultur. 
Hinterleib und Hinterlügel etwas heller mit verwaschenem Bindefleck, Unterseite durchaus weiß mit einer die Flügel durehziehenden grauen Querlinie.

Die Raupe wird ausgewachsen etwa $4 \mathrm{~cm}$ lang, mit anfänglich grüngelber, später mehr rötlicher Färbung, 4 starken gelbgrauen Haarbïrsten auf dem 4 ten bis 7ten Leibesring, starken rotbraunem Haarbüschel auf dem vorletzten Ring (daher der Name „Rotsclıwanz"), zwischen den mit Bürsten besetzten Leibesringen samtsehwarzen, bei dem Zusammenrollen der Raupe stark hervortretenden Ligamenten. - Die Puppe, dunkelbraun, mit graugelber Behaarung, liegt in einem mit Haaren durchwebten losen Kiokon.

Die Schwärmzeit ist Ende Mai, Anfang Juni, und legt das Weibchen die anfangs graugrünen, später braungrauen Eier in einer oder mehreren Partien und im ganzen bis zu 300 Stück an die Rinde stärkerer Buchen meist in geringer Höhe über dem Boden ab. Die nach etwa 3 Woelıen erscheinenden behaarten Räupchen verzelıren zunäehst ihre Eihüllen, hiebei ähnlich den Nonnenräupchen einige Tage beisammen sitzend, und besteigen sodann den Bamm, die Blätter zuerst nur benagend, später stärlier befressend und sehließlich meist die stark befressenen Blätter am Stiel abbeißend; sie setzen ihren Fraß etwa bis zum September fort und steigen dann in der Regel vom Baum herab, um sich in einem Kokon in der Laubdecke, am Gestrüpp, seltener an Zweigen zu verpuppen und so zu überwintern.

Der Rotschwanz kommt vor allem auf Buchen und zwar in den älteren Beständen vor, im Notfall jedoch auch andere Laubhölzer befressend. Er tritt in Buehenbeständen bisweilen in solchen Massen auf, daß die Bestände vollständig kahl gefressen werden - der Unstand aber, daß seine Hauptfraßzeit in den Spätsommer und Herbst fällt, in welchem die Knospen fürs kommende Jahr bereits vorgebildet sind, vermindert den Schaden wesentlich, beschränkt ihn auf Zuwachsverlust, ev. auf Beeinträchtigung einer etwa in Aussicht gewesenen Mast. Zudem hat man beobachtet, daß ein Raupenfraß fast stets im zweiten Jalur zu Ende geht und daß insbesondere parasitische Pilze, in den Raujen auftretend, diese in kurzer Zeit fast völlig versehwinden lassen.

An manchen Orten, wo der Rotschwanz wiederholt und in beunruhigender Weise auftrat, hat man das Sammeln der zur Verpuppung herabsteigenden Raupen und der Kolions versucht, jedoeh mit geringem Erfolg; guten Erfolg dagegen hat nach Altums llitteilung der Versueh gehabt, die in geringer Höhe über dem Boden ahgesetzten und auf der glatten Buchenrinde leicht sichtbaren Eihäufchen mittelst eines Pinsels mit Oel zı überstreichen, wodurch sämtliche Eier zugrunde gingen. In der Regel wird man auf Mittel der Abwehr verzichten.

§ 76. Der Prozessionsspinner, Cnethocampa processionea. Größe des Selimetterlings beim Iännchen etwa 3,2 , beim Weibchen bis $4 \mathrm{~cm}$; die Vorderflügel bräunlich-grau nit zwei dunkleren Querbinden, die Hinterflügel gelblich-weiß mit braun-grauer, etwas verwasehener Querlinde, wobei die Färbung des Männchens meist etwas schërfer und lebhafter ist.

Die Raupe wird bis $3,5 \mathrm{~cm}$ lang, ist blaugrau oder rötlich-gran mit großen braunen Samtflecken auf dem Rücken; sie zeigt auf jeden Ringel I0 rötliehe Iínopfwärzchen, die mit langen hellen Haaren besetzt sind. Die rotbraune, stumpf abgerundete Puppe liegt in einem tonnenförmigen Kokon in den gemeinsamen großen Gespinst.

Die Schwärnzeit des Schmetterlings ist im August und fliegt dlerselbe in den späten Abendstunden. Das Weibchen legt nach der Begattung seine sehr zahlreichen Eier, bis zu 200 Stück, meist in e i n e r Partie an die Rinde älterer Eichen ab, sie 
mit etwas Afterwolle überziehend; die Eier überwintern und etwa Anfang Mai sehłüpfen dic Räupehen aus, mun ihren eigentümlichen Fraß beginnend. Stets beisammen bleibend sitzen sie unter Tags dicht gedrängt in cinem gemeinsamen, an gesehützter Stclk, unter einem starken Ast oder sonst am Stanm hängenden, anfänglielı kleinen, allmählich größer werdenden Gespinst, das sie zum Zweek des Fraßes meist gegen Abend verlassen. $\mathrm{Zu}$ diesem Fla $\mathrm{B}$ setzen sie sieh in gesehlossener Ordnung in Bewegung; der Zug pflegt mit e in e r Raupe zu beginnen, nach der Mitte zu breiter zu werden und wieder mit ciner einzelnen Raupe zu enden; die Raupen marschieren in steter Fülhung miteinander, suchen jede Unterbrechung ihres Zuges rasch wieder auszugleichen und bezeichnen ihren Weg dureh einzelne Gespinstfäden. Nach geschehenem Fraß kehren sie wieder in ihr Gespinst zurück, in dem sie sich auch häuten, und durch die zunehmende Größe der Raupen, die in dem Gespinst lıängenden Raupenbälge und Kotreste erreicht letzteres zuletzt selbst Kindskopfgröße; nicht selten vereinigen sich auch mehrerc Fanıilien zu großen Geseltschaften. In Juli findet die Verpuppung in dem Gespinst statt, und nach $2-3$ Wochen fliegt der Sehmetterling aus.

Der Prozessionsspinner tritt in manchen Gegenden, so in Nordwestdeutsehland, ziemlich häufig und in entsehieden waldschädigender Weise auf, letzteres zumal dann, wenn sieh der Fraß rasch wiederholt. Es ist fast nur die Eiche, die von ihm zu leiden hat, und man hat beobachtet, daß es namentlich frei stehende Stämme, Oberholz in Mittelwald, Randbäume sind, die in erster Linie befallen werden. Stärkerer Fraß wird stets Zuwachsverlust zur Folge haben, kann aber im Wiederholungsfall zum Kränkeln und endlichen Absterben führen.

Die Vertilgung des Insekts, die bei großer Vermehrung wohl angezeigt sein kann, wird durch das gesellige Zusammenleben, die in die Augen fallenden großen Gespinste erleichtert und erfolgt durch Zerstörung der letztern, am besten wohl durch Verbrennen mittelst eines an entsprechend langer Stange befestigten Büsehels Werg, der mit Petroleum befeuchtet ist; dic Gespinste liegen in versehicdener Höhe am Baum, viele tief unten, die meisten wohl nicht über $10 \mathrm{~m}$ hoch. Gegen hoch oben befindliche Nester läßt sich (nach Altum) selbst ein Flintensehuß mit wenig Pulver und starker Ladung Vogeldunst anwenden.

Bei der Vertilgung der Raupen, wie bezüglich der befallenen Distrikte überhaupt ist aber besondere Vorsicht geboten: dic Haare (und zwar nach Nitsehes Untersuchungen die mikroskopisch kileinen Härchen auf den Samtflecken des Rückens) rufen auf der Haut entzündliche Erschcinungen hervor, können, in Nase oder IIund von Menschen oder Weidetieren gelangend, sehr unangenehme Folgen haben. Die mit dem Vertilgen betrauten Arbeiter haben sich dementsprechend durch Handschuhe und vor Nlund und Nase gebundenes Tuch zu schützen, auch den Luftzug zu beachten, durch den beim Abnelmen oder Verbrennen der Gespinste die Haarfragmente wegwärts vom Arbeiter getrieben werden sollen. Für Nutzungen jeder Art: Beeren, Gras, Weide - sehlicßt man die betr. Distrikte.

Natürliche Feinde hat die stark behaarte Raupe außer Ichneumonen wenige; während des Winters werden wohl dureh Meisen cine nicht geringe Zahl von Eiern veruichtet.

Erwähnung dürfte noch der im noriöstlichen Deutsehland auftretende Ki i ef ern-Prozessionsspinuer, Cn. pinivora, verdienen.

$\$ 7$. Sonstige Spinner a $\mathrm{f}$ La ublolz. Von Spinnern, welehe außer den eben genannten noch auf Laubholz bisweilen in großen .Hassen und dadurch schädlich auftreten, die Aufmerksamkeit des Forstmannes in Anspruch nehmen, dürften zu nennen sein: 
Der S ch w a m m s p in n e r, Liparis dispar (s. Taf. II Fig. 6), auffallend durch den Größenunterschied der Geschlechter, indem das schmutzig gelb-wciße mit dunklen Zickzackbinden gezeichnete Weibchen bis doppelt so groß ist, als das graubraune, ähnlich gezeichnete Männchen. Ersteres legt zur Schwärmzeit (August, September) seine 3-400 Eier an die Rinde, meist tief am Boden und überzieht sie mit etwas graugelber Afterwolle, so daß das Ganze cinem lileinen Baumschwanm ähnlich sicht. Im Frülıjahır schlüpfen die Räupchen aus und erwachsen zu großen, starbkehaarten Raupen, die auf beiden Seiten einer gelblichen Rückenlinie auf den 5 vordern Leibesringen blaue, auf den 6 folgenden rote, große Kinopfwarzen zeigen und sich im Juli und August in einem leichten Gespinst zwischen Rindenritzen oder Blättern verpuppen. Die Puppe ist tief braun mit heller Behaarung.

Dic auBerordentlicl polyphage Raupe findet sich besonders an Obstl,äumen, aber auch an Waldbäumen und Sträuchern jeder Art, insbesondere an E i c h e n, Buchen, Linden; im Notfall geht sic selbst an Nadelholz. Sie tritt bisweilen überraschend in großer Zahl auf, hat Kahlfraß an Eichenbeständen in großer Ausdehnung verursacht, ausnahmsweise selbst Nadelholzliulturen zerstört; in Nordamerika ist sie geradezu als Landplage aufgetreten.

Als Nittel der Abwehr hat man das Zerstören der leicht sicht- und erreichbaren Eierschwämme durch Abkratzen, Ueberstreiclıen mit Raupenleim und neuerdings durch Tränken mit Petroleun mittelst eines einfachen Apparates ${ }^{1}$ ) angewendet. Zumeist hilft aber auch bei cliesem Insekt die Natur rasch und der Fraß geht ohne weitern Schaden als einigen Zuwachsverlust vorüber.

Ebcnfalls zunächst an Obstbäumen, aber auch an E i c hen, Llmon, Weißbuchen, Pappeln findet sich der Pi in e ls p i in n e r, Gastropacha neustria, der, in Juli schwämmend, seine Eier als ringförmiges Band um dic schwächern Zweige legt. Ihm ähnlich befällt auch der Gold a f $\mathrm{t}$ e r, Porthesia chrysorhoea, vorzugsweise Obstbäume, doch auch Eichen; seine in zusammengespomenen Blättern überwinternden Räupchen bilden die sog. Raupennester, deren Vernichtung an Obstbäumen unschwer durchzuführen ist.

Der B i $\mathbf{r}^{-}$en - N e stspinner, Gastropacha lanestris, befrißt die sonst von Insekten wenig lıcingesuchte Birke (auch Kirschbäıme) und verdankt seinen Namen dem geselligen Zusammenleben der Raupen in gencinsanem Gespinst, welches zuletzt als langer Beutel von den Aesten herahhängt.

Der Forstmann wird nur ausnalımsweise in die Lage liommen, Mittel der Abwelır gegen die drei letztgenannten Insekten anwenden zu müssen.

$\$ 78$. D i c Frostspan ner. Die Frostspanner lıaben ilıen Namen von der späl im Herbst, ja selbst im Winter - bis Dezember - liegenden Flugzeit; als besondere Nerkwürdigkeit ist anzuführen, daß die Flügel der Weibchen stets ver-liümmert sind, so daß diese nur kriechen, nicht fliegen können. Es sind mamentlich 2 Arten, deren Fraß in den Waldungen ein oft sehr in die Augen fallender ist, nämlich:

Der kleine Frostspan ner, Cheimatobia brumata (s. Taf. I Fig. I8); das Nännchen hat etwa $2,6 \mathrm{~cm}$ Flügels]annung, gelblichgraue Vorderflügel mit feinen dunkeln Wellenlinien und hellgraue Ilinterflügel mit undeutlicheren Streifen; das Weibchen ist etwa $0,8 \mathrm{~cm}$ lang mit schwachen Flügelansätzen, der Körper graubraun mit weißen Schüppchen, langen Fülılern und Beinen. Die Raupe, anfänglich grau, nach der ersten Häutung gelbgrün mit lichten Rückenstreif, später grün nit. dunkler Rüchenlinie, ist ausgewaclısen etwa 2,6 cm lang; die Puppe hellbraun.

1) Band I, Heft 2 der Publikationen der biol. Anstalt des Reichsgesundheitsamtes. 
Die Flugzeit ist im November und Dezember; das Weibchen legt, an den Bäuunen hinauflaufend, scine Eicr namentlich an die Kinospen der Obstbäume, dann der Weißbuchen, Eichen, Eschen, Lindeı, und die im Frühjalı ausschlüpfenden Räupchen benagen nun zuerst die Kinospen, dann die sielı entwickelnden Blätter, sie nach allen Seiten durchlöchernd, dabei auch durch Gespinstfäden zusanmenwickelnd. Anfangs Juni etwa lassen sie sich ron den Bäumen spinnend lierab und verpuppen siclı in Boden.

Der Obstbaumzüchter, dem der Frostspanner durch Zerstörung der Blütenlinospen sehr schädlich werden liann, sucht sich durch Teerringe - sog. Raupenleim wird auf steifes Papier gestrichen und dieses zur Sehwärmzeit um den Stanm festgebunden, wodurch die Weibchen am Besteigen der Bäume gehindert werden bezw. sich auf dem bestrichenen Papier fangen - nit Erfolg zu helfen; im Wald wird man auf Anwendung irgend welcher Mittel verzichten müssen.

Die oft sehr bedeutende Zerstörung an Buelenaufschlag wird durch eine dem kleinen Frostspanner nahe verwandte Art Cheimatobia boreata verursacht.

Der g r o $\beta$ e F ros t s p a n n e r, Hibernia defoliaria, - nit etwa $4 \mathrm{~cm}$ Flügelspannung, hellgelblichen Vorderflügeh mit gelbbrauner Zeichnung und dunklen Punkt auf jedem Flügel, den etwas schwächer auch die helleren Hinterflügel aufweisen, das langbeinige Weibchen ganz flügellos; dic Raupe gelb mit breitem, braunrotem Rückenstreif, der mit feiner dunkler Linie beiderseits gesäumt ist -, lebt in ganz ähnlicher Weise, schwärmt etwas früher im Herbst; er ist seltener als der lileine Frostspanner, tritt jedoch bisweilen in sehr großer Zahl auf und befrißt neben Obstbäumen vor allem auch die Eichen $\left.{ }^{1}\right)$. Gegenmittel sind gleichfalls nicht anwendbar.

$\$ 79$. Der E i c lr e n w i c k l e r, Tortrix viridana. Der kileine Falter mit etwa 2,2 cm Flügelspannung hat schön hellgrüne Vorderflügel mit gelbweißem Fransensaum und hellgrauem Hinterflügel mit grauweißem Saum, ein dunkel-gelbgrünes Räupchen mit schwarzem Kopf und selwwarzen Wärzchen, welche feine Haare tragen, fast schwarze Puppe.

Der Schmetterling schwärmt Ende Juni, und das Weibchen legt seine Eier einzeln oder in kleinen Partien an die Knospen in den Kronen älterer E i c h e $\mathrm{n}$; die im Frülıjahr erscheinenden Räupchen befressen zuerst die Knospen, dann Blätter und Blüten, und verpuppen sich Anfang Juni in zusammengerollten Blättern, Rindenritzen u. dergl. Sie treten bisweilen in ungeheurer Menge auf; der Fraß beginnt, entsprechend der Eierablage, in den Kironen und wird bisweilen zu vollständigem Kalıfraß, doch begrünen sich die Bäume nit Hilfe der Johannitriebe wieder, und einiger Zuwachsverlust ist wolll der ganze Schaden.

Gegenmittel sind nicht anwendbar, doch gehen durch Spätfröste, welche das junge Laub zerstören, oft sämtliche Räupchen zugrunde und ebenso vermag naßlialtes Regenwetter der Kalamität nielıt selten ein schnelles Ende zu bereiten.

\section{Die Deformitäten-Erzeuger.}

$\$ 80$. Man versteht hierunter jene Insekten, welche dureh ihren Stich und bezw. Fraß an verschiedenen Teilen unserer Waldbäume eigentümliche Rollungen und Kräuselungen oder oft selı in die Augen fallende Wucherungen (Gallen) hervorrufen; der hiedurch verursachte Schaden ist zwar in den meisten Fällen ein nur geringer, kann aber bisweilen floch ein nennenswerter sein - jedenfalls soll der Forst-

1) Im Jahre 1883 fand in Spessart in Eichenbeständen auf größerer Fläche ein Kahlfraß durel $H$. defoliara statt. Den Puppen gingen die Wildsclweine begierig nach. 
mann die Ursache solcher auffallender Erscheinungen kennen, und wir führen deshalb die häufigsten dieser Deformitäten-Erzeuger kurz an:

1. A u f Nadel holz.

Hier tritt uns durch auffallende Bildungen die Gattung der $\mathrm{R}$ in $\mathrm{d}$ e $\mathrm{n} \mathbf{l}$ ä u s e, Chermes, entgegen, merkwürdig durch ihre teils geschlechtliche, teils ungeschlechtliche Fortpflanzung, ihr Auftreten in geflïgeltem und ungeflügeltem Zustand und ihr. Wandern in den verschiedenen Stadien der Entwicklung von einer Nadelholzart auf die andere unter Erzeugung ganz verschiedener Erscheinungen an den Nadeh. Diese erst in der Neuzeit lilar gestellten Verhältnisse waren Ursache, daß die verschiedenen Entwicklungsstadien als eigene Arten betrachtet wurden. Es seien hier genannt: Die gr ü ne Fi c h te n r ind e n l a us, Chernes viridis Ratz.; sie verursacht die großen, grünen, rotgeränderten, zapfenartigen Gallen an der Basis der Zweige meist jüngerer Fichten, diese halb umfassend und zu eigentümlicher Krümnung veranlassend. Die Zwischenform findet sich auf der Lärche, an den Nadeln saugend, wodurch sie an der Fraßstelle verblassen und sich knieförmig bicgen; weiße Wollausscheidungen lassen das bisher als eigene Art - Chermes laricis - bezeichnete Insekt leicht ins Auge fallen.

Die rote $\mathrm{Fichtenrinden} \mathrm{a} \mathrm{us,} \mathrm{Chermes} \mathrm{strobilobius} \mathrm{Kaltenb.,} \mathrm{er-}$ zeugt ebenso wie eine zweite sehr ähnliche Art Ch. coccineus Ratz. kleine, zuerst gelblichweiße, später braune Gallen an den Triebspitzen der Fichte, diese nicht selten abschließend und die Spitzen zum Absterben bringend; beide finden sich vorwiegend an schon älteren und minder gutwüchsigen Fichten. Die Zwischenform der ersteren Art lebt auf der Weißtanne, der letztern auf der Lärche.

In sehr in die Augen fallender Weise zeigt sich nicht selten die Rinde von Weymouthskiefern und Tannen mit einem weiBen, wachsfleckigen Ueberzug bedeckt, herrührend von Ausscheidungen an der Rinde sangender Chermesarten, deren hier tätige Generation früher ebenfalls als eigene Art (Ch. strobi, piceae) bezeichnet wurde.

2. A u f L. a u b holz.

Die Gallwespen, Cynipidae, erzeugen durch die Ablage ihrer Eier an Blätter, Zweige, Knnospen, Blüten und durch den Reiz, wclchen der Fraß der kieinen Larve verursacht, eigentümliche Wucherungen, Gallen, verschiedenster Art und Größe, die oft sehr ins Auge fallen. Namentlich ist es die Eiche, auf der eine Anzah] solcher Gallwespen lebt: so die E i c he n g a 11 w e s p e, Cynjps quercus folii, die bekannten großen rot und grünen sog. Galläpfel auf der Unterseite der Eichenblätter elzeugend; die Z a p feng a 11 wespe, C. fecundatrix, die Verursacherin der hopfenartigen, anfänglich grünen, dann braunen Zäpfchen an der Spitze der Eichenzweige; die Eichenlosengall wespe, G. terminalis, große, rosenfarbige Schwamngallen an den Zweigspitzen der Eiche hervorrufent. Hierher gehören auch jene im Süden vorkommenden Gallwespen, deren Stich die bekannten, als Gerbemittel Verwendung findenden Knoppern erzeugt.

Die $\mathrm{B}$ u c h e $\mathrm{n} g \mathrm{~g} / \mathrm{l} \mathrm{m}$ ü $\mathrm{c} \mathrm{k} e$, Cecirlomyia fagi, verursacht in ähnlicher WVeise die kegelförmig zugespitzten grün und roten Gallen, welehe sich allenthalben und oft in großer Menge auf den Buchenblättern finden.

In auffallend starker Weise wird die Uhe von einigen Blattlausarten heimgesucht. Die Blätter derselben zeigen sich auf der Oberseite oft ganz überdeckt mit großen, grünen, später mißfarhigen Blasen, von der B l a t t a s c he n- U l m e nb l a t t l a us, Tetraneura nlmi, herrührend; an der Basis der Blätter jüngerer Ulmen finden sich häufig die bis walnußgroßen blasigen Auftreibungen der B e u t e l g a ll e n - U l m e n b l a t t l a 1 s, Schizoneura lanuginosa. 
Dic Rinde alter Buchen findet sich bisweilen dicht bedeckt mit dem weißen Sekret der Bue he nwo 11 a us, Coccus fagi.

\section{Gefährdung durch Gewächse.}

\section{Forstunkräuter.}

\$ 81. Begriff; A u f tre ten. So wenig wir jedes im Wald vorkommende und von Baumteilen sich nährende Insekt sofort als ,Forstinsclit" bezcichnen können, ebensowenig werden wir jede im Wald auftretende Pflanze als ,Forstunkraut" ansprechen. Mit diesem lctztern Namen bezeichnen wir vielmehr nur jene Gewächse, welehe in $\mathrm{g} \mathrm{r}$ ö B e r e r Zahl und ge me in s c h a f t l i e h auftretend unsern waldbaulichen Bestrebungen in irgend welcher Weise lindernd entgegentreten, das Gedeihen unserer Iolzgewächse bceinträchtigen.

Dieses Auftreten von Forstunkräntern und deren Art ist nun durch verschiedene Faktoren bedingt: lureh die mineralische $\mathrm{Zus}$ am mensetzung des Bodens, dessen größern oder geringem Gehalt an $\mathrm{Fe} \mathrm{u}$ e h tig $\mathrm{k}$ e it, vor allem aber auch durch die Einwirkung des L i c h t es. Im dicht geschlossenen alten Buchenbestand sehen wir keinen Grashałn, in der Kieferndickung ist keinc Spur des Heidekrautes mehr vorhanden, das vorher die Schlagfläche dicht überzog, und das alsbald wieder erscheint, wenn der ältere Föhrenbestand sich anfängt zu liehten, ebcriso wie der zum Zweck der Verjüngung gelichtete Buchenbestand alsbald eine leichte Begrünung, die kahle Fläche des abgetriebenen Fichtenbestandes eincn dichten und mannigfaltigen Unkrautüberzug an Stelle der bishcrigen Moosdecke zeigt.

Je frischer und kräftiger der Boden, jo voller die Einwirkung des Lichtes, un so mannigfaltiger und üppiger pftegt dicser Ueberzug zu sein, während auf ärnerem Boden und bei gedämpfter Lichteinwirkung nur wenige Unkräuter - etwa Heide in erstern, Heidelbeere im letztern Fall - oft weithin die Decke des Bodens bilden. Die Ansprüche der verschiedenen L'nkräuter an das Licht, wie an die Eigenschaften des Bodens sind hiebci vielfach so charakteristisch, daß der Forstmam aus deren Auftreten manche wichtige Sehlüsse ziehen kamn: eine l e i ch te B e gr ü n u ng des Buchensamenschlages sagt ihm, daß genügend Licht für den aufkeimenden Nachwuchs vorhanden sei, im Eichenstangenholz gilt sie ilım als ein Zeichen, daß der bodenschützende Unterbau nun bald an Platze ist; wo Heicle wuchert, wird cr auf die Nachzueht anspruchsvoller Holzarten verzichten, während ihm Himbecre und Tollkirsche den Boden als noch frisch und kräftig bezeichnen, Binsen und Simsen auf stagnierende Feuchtigkeit deuten $\left.{ }^{1}\right)$.

$\$$ 82. Zu fürchtende $\mathrm{Nachtcile;} \mathrm{Nutzen}$. Ein mehr oder weniger dichter Ucberzug von Forstunkräutern versehließt den Boden der natürlichen Ansamung, bereitet aber auch der künstlichen Aufforstung, der Bearbeitung des Bodens für die Saat, der Herstcllung der Pflanzlöcher Schwierigkeiten und verursacht hiedurch, wie durch die etwa gebotene Anwendung stärkeren Pflanzenmateriales oft wesentlich höhere Aufforstungskosten. Die Forstunkräuter, meist raschwüchsig, und, wenn auch bei der Kultur entfernt, rasch wieder erscheinend, überwachsen dic ıncist langsamer als die Unkräuter wachsenden Holzpflanzen, entziehen ihnen den Licht- und Taugenuß, nehmen einen großen Teil der im Boden vorhandenen löshiehen Nährstoffe in Anspruch, halten namentlich die nur leichteren Regen ab, in den Boden einzudringen, während sic sclbst durch Verdunstung dem Boden viel Feuchtigkeit

1) Vgl. A. K. C a j a n d e r, Ueber Waldtypen. Forstw. (Blatt 1912 S. 99). 
entziehen; überlagern endlich, im Herbst und Winter absterbend, die Holzpflanzen oft so vollstündig, daß diese zugrunde gehen. Ebenso überwuchern einzelne Schlingund Rankengewächse selbst stärkere Pflanzen rollständig, sie zu Boden drückend.

An den im Grase stehenden Pflanzen beobachten wir im Frülıjalır häufig Frostbeschädigungen als Folge starker Verdunstung, und Mäuse finden williommenen Schutz im dichten Gras- und Unkrautüberzug.

So sind die Forstunkräuter dem Forstmann eine meist unwillkommene Erscheinung, willkommen nur etwa zur Bindung allzu lockern Bodens oder als lichter Schutzbestand in trockenen oder frostigen Lagen in Gestalt von Besenpfriemen und Wachholder. Daß sie zur Fütterung des Viehes - durch Gras- oder Weidenutzung - dann als Streumaterial - Heide, Besenpfriemen, Farnkirant, dürres Gras - oft ausgedehnte Verwendung finden, und ihre mannigfachen Beerenfrüchte - Heidel-, Preißel-, Erd- und Himbeeren -, die teilweise geradezu Handelsartiliel geworden sind, eine allerdings mehr der armen Berölkerung als dem Waldbesitzer zugute kommende wertvolle Nebennutzung bieten, möge zugunsten der Forstunkräuter noch hervorgehoben sein.

\$ 83. Bezeichnung der lı̈ ufigsten Forstunkräuter. Die Forstunkräuter sind bald krautartig und alljährlich absterbend, bald zwei- und mehrjährig, in letztern Falle teils am Boden hinkriechende kleinere Sträucher, wie die Beerkräuter, die Heide, bald aber zu liräftig in die Höhe strebenden eigentlichen Sträuchern sich entwickelnd, wie Schwarz- und Weißdorn, Hollunder u. dgl. Für das Auftreten der einen oder andern Art ist der Standort, insbesondere aber auch der Feuclıtigkeitsgrad des Bodens maßgebend, so daß wir sie nach diesen letztern einigermaßen gruppieren liönnen.

Auf $n$ a ssem und torfige $\mathbf{m}$. Boclen finden wir einige Beerkräuter: die Moosbeere und Rauschbeere, ferner die Sumpfheide, den Sumpfporst, das IVollgras, verschiedene sog. saure Gräser: Riedgras, Binsen und Simsen, damn das Sumpfrnoos, auch das sog. Bürstenmoos.

Manniglaltig ist die Unkräutervegetation auf $\mathrm{g} u \mathrm{t}$ e $\mathrm{m}$, f r i s c h e m Boden: Fingerhut, Tollkirsche, W'eidenrösclıen, Brennessel, Hanfnessel, Himbeeren, Bronbeeren, Farnliräuter und breitblätterige Gräser verschiedenster Art bilden den dichten Bodenüberzug in vollen Licht; in geschlossenen älteren Fichten- und Tannenbestand sind es Moose, meist zur Gattung Hypnum gehörig, die den Boden decken. Auf kalkhaltigem Boden treten insbesondere auch noch Kileearten auf, wic auch sonst die Flora desKallibodens eine besonders reiche und charakteristische zu sein pflegt.

Auf trockenem, sandigem oder durch Freiliegen, Streunutzung etc. heruntergekommenem Boden finden wir Heide, Heidelbeere, Preißelbeere, die Ginsterarten, Besenpfrieme, Habichts- und Kreuzkraut, Wolfsmilch, Hauhechel, Wollblume, dann die trockenen, schmalblätterigen Angergräser.

Die $\mathrm{S}$ t r ä u c lı e r, welche in unseren Waldungen auftreten, namentlich auf gutem, frischem Boden (Auwaldungen) üppig und lästig wuchernd, sind: Schlelıdorn (Schwarzdorn), Weißdorn, Hollunder, Faulbaun, Hartriegel, Beinweide, Spindelbaum, Stechpalme, Geishlatt, auf trockenerem Boden Wachholder, Sanddom.

$\$ 84$. I it tel d e r A b we lı r. Wie bei der schädlichen Tierwelt, so werden wir auch hier dem nassenhafteren Auftreten der Forstunkräuter in erster Linie vo r$\mathrm{z} u$ b e u g e n suchen, inden wir ilnen die Bedingungen freudigen Gedeilıens tunlichst entziehen. Wir suchen den Bestandesschluß zu erhalten, stellen unsere Besamungsschläge dunkel, liauen so langsam nach, als dies die Holzart gestattet; suchicn dort, wo wir zum Kahlhieb genötigt sind, diesem mit der Aufforstung rasch zu folgen, 
wählen die Pflanzung ev. mit stärkeren, verschulten Pflanzen an Stelle der Saat oder kleiner Pflänzlinge, da erstere weniger durch Unkrautwuchs leiden, den Schluß rasch wieder herstellen.

Ist aber der Gras- und Unkrautwuchs auf den von uns zu kultivierenden Flächen schon vorhanden ouler stellt er sich alsbald nach der Kultur in bedrohlicher Entwicklung ein, so gilt es, ihn tunlichst zu z erstören. Starken Graswuchs hält man mit der Sichel durch Abgabe des Grases als Viehfutter nieder, oder läßt in Saaten das Gras durch Rupfen (wozu sich die Futterbedürftigen allerdings viel weniger gern herbeilassen) entfernen; Heide, Besenpfrieme, Farnkrëuter sind in chen meisten Gegenden als Streumaterial absetzbar und werden koztenlos entfernt. IVo aber solche Abgaben lästiger Unliräuter als Futter und Streu nicht möglich, darf man auch Kosten für das Ausschneiden derselben, das Niedertreten von Farn und Brombeeren, das Heraushauen holziger Sträucher nicht scheuen; selbst Eintrieb und resp. Durchtrieb von Schafen und Rindvich durch stark graswüchsige Fichtenkulturen hat man schon mit überwiegendem Vorteil angewendet.

Gegen den Wiederausschlag der Stöcke lästiger Sträucher und Weichhölzer leistet das Uebererden der Stöcke, Zudecken derselben mit nicht zu kleinen Erdhaufen und Plaggen gute Dienste. - Landwirtschaftlicher Zwischenbau, wie er in der Rheinebene teihweise im Gebrauch, zerstört den Unkrautwuchs zwischen den Pflanzenreilien vollkommen.

Sehr lästig kann der Unkrautwuchs in Forstgärten werden. Neben dem Ausjäten als Mittel der Z e r störung wären das Decken der Räume zwischen deı Pflanzenreihen mit Laub und Moos, Vorsicht bei Anvendung des sog. Kiompostdüngers, der viel Unkrautsamen enthalten kann, wie bej Auswahl des Platzes für Saatbeet oder Forstgarten als Mittel der Vor b e u g ung zu nennen.

\section{Schmarotzergewächse.}

§ 85. Als solche erscheinen zunächst zwei Gewächse aus der Familie der II ist e In: die allenthalben verbreitete gewöhnliche Nlistel (Tiscum album) und die Eichenmistel oder Riemenblume (Loranthus europaeus), welche mehr in südlichen Ländern zu Hause ist. Erstere durchsetzt mit ihren Senkwurzeln das Holz insbesondere von Tannen, Föhren, Linden, Schwarzpappeln, Akazien (nie von Eichen, Buchen, Lärchen, höchst selten Fichten) und macht, wenn sie am Stamm auftritt, das Holz zu Nutzholzzwecken unbrauchbar; letztere erzeugt namentlich an Eichen oft kopfgroße Wucherungen, olserhalb deren der Stamm nicht selten abstirbt. Mittel gegen beide Schmarotzer, die im großen anwenubar wären, gibt es nicht.

In weitern sind es Pil z e, welche, in das Innere der Gewächse oder einzelner Teile derselben eindringend, diese mehr oder weniger zerstören, ihr langsameres oder rascheres Absterben bewirken. In engen Zusammenhang mit den Pflanzenkrankheiten stehend und vielfach deren Ursache mögen sie mit jenen Besprechung im IV. Abschinitt finden.

\section{Gefährdungen Jurch die anorganische Natur.}

\section{Gefährdungen dureh njedere oder hohe Temperatur (Frost und Hitze).}

\section{A. Frost.}

$\S$ S6. Je nach der Zeit des Auftretens unterscheiden wir den zur Zeit völliger Vegetationsruhe auftretenden $\mathrm{W}$ in $t$ e $\mathrm{r}$ frost, den spät im Frühjahr nach bereits eingetretenem Erwachen der Vegetation sich einstellenden $\mathrm{F}$ r ü h j a h r s- oder 
$\mathrm{S} p$ ä $\mathrm{t}$ frost, endlich den $\mathrm{H}$ e r b s t- oder F r ü h frost, welcher, zeitig im Herbst eintretend, die noch nicht vollständig abgeschlossene Vegetation beschädigt. Eine besondere Art von Frosterscheinung ist endlich das sog. A u f $\mathrm{r}$ i e re $\mathrm{n}$, der B a rf rost, durch welchen lockerer, wasserhaltiger Boden und mit ilum die in demselben wurzelnden schwächern Pflanzen gehoben werden.

\$ 87. Der WV in terfrost wird unsern Waldbäumen nur dann schädlich, wenn er entweder besonders hohe Grade erreicht oder nur schwach verholzte Pflanzenteile trifft - andernfalls geht er ohne Beschädigung vorüber. Er kann physiologisch schädlich werden, das Pflanzengewebe tötend oder doch schädigend, und mechanisch schädlich, das Gewebe zerreißend, ohne weitere nachteilige Folgen für das Leben des Baumes (Frostrisse).

Durch den Winterfrost leiden namentlich die nicht vollständig verholzten Pflanzenteile, und wir sehen daher einerseits die sog. Johannitriebe häufig erfrieren, dann aber auch die Triebe jener Holzgewächse, welche dank feuchtwarmer Herbstwitterung, reichlicher Lockerung und Düngung des Bodens bis spät in den Herbst hinein fortgewachsen sind; ebenso z. B. auch einjährige, infolge später Saat und trockenen Frühjahrs erst spät, aufgekeimte Eichenpflanzen. Bei hohen Kältegraden, insbesondere wenn mit anhaltender starker Kälte des Nachts sonnige Wintertage mit verhältnismäßig hoher Temperatur weehseln, leirlen aber auch ältere Stämmchen und Pflanzen an Stamm und Wurzeln Not, die Nadeln unserer Fichten und Tannen röten sich; so starben im strengen IVinter 1879/80 zahlreiche Eichenstangen ab, Tannenpflanzen wurden getötet, die Sonnseiten der Narłelholzbestände gerötet. Auch plötzliche Freistellung von Pflanzen, die bisher sehr geschützt standen, läßt bei nur etwas stärherer Kälte Besehädigungen wahrnehmen, und ebenso scheint im Früljahr unmittelbar vor Laubausbruch bei manchen Holzarten - so Fichten und Tannen - gesteigerte Empfindlichkeit gegen Frost zu bestehen. Schneeloser Winter verhält sich ebenfalls ungünstiger, läßt die jüngern Wurzelteile erfieren, während eine Schneedecke guten Schutz gewährt.

Mittel zum Schutz gegen diese Beschädigungen stehen uns, wie leicht einzusehen, nur im geringsten Mla zu Gebote.

Als mechanisch schädliche Folge strengen Winterfrostes erscheinen die sog. Frostrisse oder Eiskl ü fte. Während R. Hartig ${ }^{1}$ ) sie dadureh zu erlilären suchte, daß beim Gefricren das Wasser aus der Holzwandung austrete, wodurch bei stärkerem Frost Schwindrisse entstehen, ist H. Mayr ${ }^{2}$ ) der Ansicht, daB das Aufreißen der Stämme hei sehr niederen Temperaturen Folge der Zusammenziehung durch Abkühlung sei, wobei in den äußern am stärlisten sich abkühlenden Holzschichten flie Zusammenziehung am größten ist und schließlich die Trennung durch einen zur Sehne senkrechten Riß erfolgt. Diese Frostspalten, welche sich beim Auftauen wieder schließen, sucht der Baum durch gesteigerten Zuwachs an den Seiten des Risses (infolge verminderten Rindendruckes) zu ülerwallen; hiedurch entsteht eine anfänglich geringe, bei wiedcrholten Aufreißen und Ueberwallen aber sich steigernde Erhöhung längs des Stammes, welche als Frostle is t e bezeichnet wird. - Der Nachteil durch Frostrisse, welche man insbesondere an Eichen, Edelkastanien, Nußbäunen, auch Eschen und Ulmen - und zwar auf deren Nord- und Ostseiten wahrnimnt, besteht darin, daß solche Stämme zu mancher technischen Verwendung

1) Lehrbuch der Baumkrankheiten. Ausführlieh bespricht die verschiedenen bez. der Entstehung der Forstrisse bestehenden Ansichten Nör d l ing e r (Forstschutz S. 420 ff.).

2) S. Gayers Forstbenutzung, 10. Auft. S. 334. 
unbrauchbar werden; auch beginnt ron den Frostrissen aus nicht selten Fäulnis des Stanmes. - Schutzmittel stehen uns nicht zur V'erfügung.

$\$$ 8S. Viel gefürchteter als der Winterfrost ist der $\mathrm{S} p$ ä t- oder F r ü lı j a lı r sf rost; die durch diesen verursachten Beschädigungen sind um so größer, je später im Früljahr er sich einstellt, je weiter die Vegetation entwickelt ist. Er tötet die zarteı Blätter und frischen Tricbe, die Kicimlinge und die Blüten vieler Holzarten völlig, durch die Vemichtung der letzteren die Aussicht auf ein Samenjahı zerstörend; stärkere Pflanzen werden zwar nielıt getötet, können aber infolge wiederholter Frostbesclıädigung zuletzt vollständig verkrüpleh (so Fichten in sog. Frostlöchern).

Sehr verschieden ist nun das Verhalten der einzelnen $\mathrm{H} \mathrm{ol} \mathrm{z} \mathrm{a} \mathrm{r} \mathrm{t} \mathrm{e} \mathrm{n} \mathrm{dem} \mathrm{Spät-}$ frost gegenüber, und manche ertragen eine Temperatur bis zu -5 , ja -7 Grad, werden daher, da solch' bedeutende Temperaturerniedrigung nach schon erwachter Vegetation fast nie stattfindet, als $\int \mathrm{r}$ os th a $\mathrm{r}$ t bezcichnet, während jene, welche schon bei viel geringeren Frostgraden crfrieren, e m $\mathrm{p}$ in $\mathrm{d} \mathrm{l}$ i c h e Holzarten genannt werden. Zu den ersteren gehören: Hainbuche, Birke, Erle, Ulme, Aspe, Weide, Vogelbeere, danı Fölıre, Schwarz- und Weymouthskiefer, zu den letzteren Esche, Edelkastanie, Eiche, Buche, Akazie, Tanne; in ler Mitte dürften etwa Ahorn, Linde, Fichte und Lärche stehen.

Verschiedene Momente erhöhen die Schädlichlieit des Spätfrostes, die Gefahr durch diesen. Die meisten Waldbäume ertragen einige Grade unter 0 bei trockenem Frost, Reifbildung dagegen und längere Dauer des Frostes erhöht dessen schädliche Wirkung; bewegte Luft wirlst günstig - wir selsen dort, wo der Luftzug fehlt, in den sog. Frostlö chern, die Frostheschädigung fast alljährlich auftreten, ebenso dort, wo durch Wasser- und Wiesenflächen die Verdunstung eine besonders starke ist; Pflanzen inmitten dichten Graswuchses erfrieren leichter als jene auf unbenarbtem Boden. Die Frostbeschädigung macht sich vielfach nur bis zu einer gewissen Höhe, der sog. Frost h ö h e bemerkhar, oberhalb deren die Pflanzen unbesehädigt bleiben; es ist dies dadurch bedingt, daß nach oben die Luft bowegter wird und die kaltén Luftsehichten, weil schwerer, melı nahe dem Boden bleiben. Aus gleichem Grunde sehen wir Frostbeschädigungen in Tälern und Einsenkungen auftreten, während die höheren Lagen unbeschädigt bleiben.

Süd- und Südwestgehänge sind infolge der dort früher erwachenden Vegetation gefälırdeter, als Nordwest- und Nordgehänge; Ostgehänge leiden durch die kalten, frostbringenden Ostwinde, ebenso aber auch dureh die sofortige Erwärmung durelı die Sonne nach einer hellen Frostnacht, da rasches Auftauen der gefrorenen Pflanzenteile stets besonders nachteilig wirkt.

Die empfindliche $\mathrm{E} i \mathrm{c}$ h e und $A \mathrm{k}$ a $\mathrm{z}$ i e entgehen nicht selten durch ihr spätes Ergrünen dem Spätfrost. ebenso der Gipfeltrieb der $\mathrm{T}$ a $\mathrm{n} n \mathrm{c}$, der sich später entwickelt, als die Seitentriebe; die $\mathrm{L}$ ä $\mathbf{r}$ c h e ist am empfindlielısten im Mloment der allerdings sehr früh eintretenden Knospenentfaltung, später weniger. - Dic dureh Spätfröste entlaubten Laubhölzer begrünen sich innerhalb einiger Wochen mit Hilfe von Adventivknospen zwar wicder, jedoch nur spärlich; auch die Lärche treibt wieder nach, dagegen ersetzen dic wintergrünen Nadelhölzer die erfrorenen Triebe im selben Jahr nicht wieder.

$\$ 89$. Die Mittel, durch welche wir im größem Forstbetrieb den Wirkungen des Spätfrostes einigermaßen vor b e u g e n können, liegen vorwiegend auf den Gebiet des Waldbaues. Gestützt auf die Wahmehmung, dal3 unter dem Sehime stärkerer Bäume infolge der gehemmten Wärmeausstrahlung Spätfrosterscheinungen nicht oder doch nur in abgeschwächtem Naße auftreten, erziehen wir unscre empfind- 
licheren Holzarten unter einem M u t ter- oder Schutz-Bestand, halten diesen dunkel, hauen langsam und allmählich nach, jeden plötzlichen Uebergang zur Freistellung tunlichst meidend. - Fehlt ciner aufzuforstenden Fläche der Schutzbestand, so erziehen wir, wenn die Aufforstungen mit gegen Frost empfindlicheren Holzarten zu erfolgen hat, uns nicht selten einen solchen durch vorausgehende Bepflanzung der Fläche mit raschwüchsigen und frostharten Holzarten - Föhre, Erle, Birke - die nach genügender Erstarkung der zwisehen den Pflanzenreihen eingebrachten empfindlicheren Holzart (Fichte) allmählich und vorsichtig wieder entfernt werden. Hochstengliche Forstunkräuter, wie Besenpfriemen, Wachholder, Sträucher verschiedener Art bilden bisweilen einen natürlichen und gut zu benützenden Schutzbestand. - In Ermangelung des letztern wählen wir bei empfindlieheren Holzarten zur Aufforstung stets stärkere Pflanzen, die von Frost nur beschärigt, nicht aber getötet werden, der Gefahr auch rascher entwachsen; Wildlinge, die bisher etwa unter stärkerer Beschattung standen (Buchen, Tannen, Fichten), sind, weil gegen Frost und Hitze gleich empfindlich, zu solchen İulturen ins Freie verwerflich.

Von besonderer Bedeutung ist der Schutz unserer Saatkämpe und For'stgärten, und stehen uns für diese neben den Vorbeugungs- auch direkte Schutzmittel zu Gebot.

Zu ersteren gehört die zweckmäßige Auswahl der Oertlichkeit: das Vermeiden von Frostlagen, das Vorhandensein von Seitenschutz durch umliegende Bestände; ferner die Aussat empfindlicher Holzarten (Eichen, Buchen) im Frühjahr statt im Herbst, da hiedurch die Keimung wesentlich verzögert wird. Als direktes S c h u t z$\mathrm{m}$ it te $\mathrm{l}$ ist das Bestecken der Pflanzenbeete mit Reisig, das Decken mit Schutzgittern zu betrachten, ja man ist da und dort so weit gegangen, dem ganzen Saatbeet cine Hochdeckung zu geben. Das Ueberhalten einer Schutzbestockung auf einer Saatbeetfläche führt so viele Nachteile mit sich, daß es nur ausnahmsweise anwendbar ist.

Hide

$\$ 90$. Vinl weniger Gefahr als die Spätfröste bringen die zeitig im Herbst eintretenden F r ü h- oder H e r bs t f r öst e mit sich; abgesehen davon, daß sie überhaupt seltener eintreten, werden durch sie nur die noch unverholzten Pflanzenteile betroffen, der Schaden ist hiedureh ein geringerer. Später Hicb in Ausschlagwaldungen (Schälwald), warmer und feuchter Herbst, der die Vegetation lange nicht abschließen läßt, steigern die Gefahr; namentlich die Eiche mit ihren sog. Johannitrieben erscheint bedroht.

\$ 91. Eine in Forstgärten und Saatkulturen gefürchtete Erscheinung ist jenc des Auffrierens des Bodens, rles Ausfrierens der Pflanzen: die Erscheinung des sog. B a rf rostes. Der lockere, feuchte, einer festigenden Bodendecke b a r e Boden wird durch rlas Gefrieren des WVassers gehoben, mit ihm die Pflanzen, und bei dem mit eintretendem Auftauen stattfindenden Zurücksinken des Bodens bleiben diese letztern obenauf liegen und gehen dann durch Vertroeknen meist zugrunde. Lockerer, feuchter Boden und wechselndes Frost- und Tawwetter, wie wir solches insbesondere an bellen Tagen im Februar und März wahrnehmen, sind sonach Bedingungen dieser Erscheinung.

Dureh den Barfrost leiden erklärlieherweise vorwiegend flachwurzelnde Holzarten, die $\mathrm{Fichte,} \mathrm{die} \mathrm{Tanne} \mathrm{mit} \mathrm{ihrer} \mathrm{langsamen} \mathrm{Entwieklung,} \mathrm{während} \mathrm{die}$ tiefwurzelnde Eiche, Föhre, Edelkastanie wohl nur ausnahmsweise beschädigt werden.

Wir beugen der Gefahr des Ausfrierens vor durch Entwässerung feuchter Orte, Anwendung der Pflanzung an Stelle der Saat, der Ballenpflanzung an Stelle der Pflanzung mit nacktwurzeligen Pflanzen in gefährdeten Oertlichkeiten. Im Saatbeet unterlassen wir cin Lockern und Ausgrasen der Beete im Herbst, decken die 
Zwischenräume zwisehen den Pflanzen mit Laub oder Moos, häufeln die Pflanzen an; drückicn naclı eingetretener Beschädigung die gehobenen Pflanzen wieder an oder ïbersieben die bloßgelegten Wurzeln mit klarer Erde.

\section{B. Hitze.}

\$ 92. Die $\mathrm{H}$ it z e - hohe, durch die Einwirkung der Some hervorgerufene Wärme - wird direkt nur durch den sog. Rindenbrand, indirekt aber dureh das Austrocknen des Bodens bei gleichzeitig gesteigerter Verdunstung der Blätter nachteilig, so daß die Pflanze ilıren Wasserbedarf aus dem Boden nicht mehr zu decken vermag. Trockene Ostwinde steigern diese nachteilige Wirkung.

Sie macht sich geltend in dem Kümmern und endlichen Absterben von Keimlingen und schwächern, ja selbst stärkern Pflanzen, im Vertrocknen keimender Samen, im Welkwerden von Blättem und Blüten vieler Gewächse, dem Taubwerden und Abfallen bereits angesetzter Früchte. Selbst an älteren Bäumen kamn man ein frühzeitiges Welkwerden und Vergelben der Blätter walırnehmen, und heißen Sonmern pflegt stets ein verhältnismäßig starker Anfall an Dürrholz zu folgen ${ }^{1}$ ).

Begünstigung der Vermehrung schädlicher Insekten, welehen trockenes Wetter stets günstiger als naßjaltes ist und durch die kränkelnden Stämme vermehrte Brutstätten geboten sinł, dann erhöhte Gefahr durch Waldbrände erseheinen als sekundäre Folgen der Trockenlitze.

Die nachteiligen Wirkungen der Hitze und bezw, des durch sie hervorgerufenen Austrocknens des Bodens machen sich nun erklärlicherweise ganz besonders geltend: auf an sich trockenerem oder flachgründigem Boden (Sand, Kalk), an den heißen Süd- und Westgehängen, bei seicht wurzelnden Holzarten ( $\mathrm{F}$ i $<$ h $\mathrm{te}$, Tanne) bei Saatkulturen und jungen Pflanzungen, namentlich bei erst frisch versetzten und noch nicht genügend angewurzelten Pflanzen. Aus letzteren Grund ist auch Trockenhitze und austrocknender Ostwind zur Fulturzeit und unmittelbar nachher besonders verderblich.

Auch die Wirkung des Reflexes macht sich in der Nähe einzeln stehender Bäume oder ganzer Schlagwände oft in unangenehmer Weise geltend; wir sehen dort den Selnee zuerst selmelzen, den Boden früher ergrünen, aber auch im heißen Sommer die Vegetation an ersten kümmern und selbst absterben.

$\S 93$. Wie bei dem Frost, so liegen auch bez. der Hitze die Mittel der V orb e u g u n g auf waldbaulichem Gebiet: Verjüngung unter Nutter- oder Schutzbestand, Erhaltung des Seitenschutzes gegen Süd und West dort, wo man Kahlhiebe fülren muß, und nur geringe Breite dieser Iiahlhiebe; Erhaltung eines Waldmantels zum Sehutz gegen austrocknende Winde und ev. selbst Erziehung eines solehen; richtige Wahl der Holzart, sowie der Pflanzung an Stelle der stets gefährdeteren Saat, Verwendung stärkerer und reichbewurzelter Pflanzen an Stelle schwacher, unvelschulter Pflänzlinge; tiefe BodenJockerung und vertiefte Saatstreifen dann, wenn irgend welche Gründe gleichwohl zur Saat nötigen - das sind etwa die wichtigsten Vorbeugungsmittel in Wald.

Im Forstgarten stehen uns solche Mlittel zu Gebote zunächst wieder in der richtigen Auswahl des Platzes, seitlich gegen Süd und West geschützter Oertlichkeiten; in dem Decken der frisch angesäten Beete mit Reisig, Moos, Sehutzgittern, dem Sehutz der Kieinlinge und schwachen Pflanzen dureh aufgesteckte Aeste und übergelegte

1) Der abnorn heiße und trockene Sommer 1911 hat bekanntlieh ganz außerordentliche Verheerungen in den Waldungen angerichtet; schon gesehlossene Fichten- und Föhrenkulturen, ja selbst die Ränder von Fichtenstangenhölzern, vereinzelt auch ältere Stāmme starben ab. 
Gitter; in dem häufigen Lockern, Ausgrasen, Anhäufeln der Beete und resp. Pflanzen. Auch zur Gieskanme greifen wir wohl im Notfall; wo die Bewässerung der Saatbeete ohne allzugroße liosten möglich ist, wird sic sich stets vorteilhaft erweisen.

\$94. Als eine Folge direkter Einwirkung der Sonne erscheint der sog. R i nd e n brand, bei welchem an den der Sonne in hohen Grade ausgesetzten Südund Südwestseiten der Stämme deren Rinde streifenweise trocken wird, aufreißt und schließlich abfällt; das bloBgelegte Holz stirbt ab und verfällt der sich mehr und mehr ins Stamminnere ziehenden Fäulnis. Es ist diese Erscheinung zu erklären als Folge der außerordentlich hohen Temperatur, welche bei direkter Bestrahlung durch die Sonne im Hochsommer zwischen Holz und Rinde entstehen kann, eine Temperatur, die zur Tötung des Cambiums ausreicht.

Nur unter bestimmten Verhältnissen schen wir diese Erscheinung auftreten bei $\mathrm{glat} \mathrm{t}$ ' in d ige $\mathrm{n}$ Holzarten, obenan der $\mathrm{B} u \mathrm{c}$ h e, dann Hainbuche, Esche, Alorn, auch j ü $\mathrm{n}$ g e r e n Fichten und Eichen, wenn sie, im Schluß bezw. Seitenschutz erwachsen, plötzlich gegen Süd oder Südwest bloßgestellt werden, wie dies etwa bei neven Weg- und Eisenbahnanlagen, durch starke Aufastungen am Feldrand oder durch Abnützung eines gegen die Sonnseite vorliegenden Bestandes der Fall ist. Namentlich zeigen auch übergehaltene Buchen diese Erscheinung, die dann nahe dem Boden zu beginnen pflegt, und fordern in diesem Fall zu rascher Nutzung auf.

Im übrigen sucht man die Veranlassung zum Rindenbrand, die plötzliche und unvermittelte Freistellung von Bestandsrändem, bei empfindlichen Holzarten möglichst zu vermeiden; ist dies nicht möglich und zeigen sich die Randstämne schadhaft, so wird man diese gleichwohl erhalten, um die hinter ihnen stehenden Stämme vor gleicher Beschädigung zu schützen. Selbst die Heister empfindlicher Holzarten, aus der Pflanzschule ins Freie gesetzt, zeigen Spuren des Rindenbrands, und wird die Erhaltung einer rauhen Beastung, wenn diese fehlt das Umwinden mit Reisig, als Schutzınittel zı betrachten sein. Auch bei älteren, plötzlich freigestellten Stärnmen hat man solche schützende Mäntel von Reisig und Moos erfolgreich verwendet.

\section{Gefährdungen durch atmosphärisehe Niederschläge.}

\section{A. Fliebendes und stagnierendes Wasser.}

§ 95. So wohltätig in allgemeinen die Wirkungen des Regens für die Vegetation sind, so unentbehrlich er im heißen Sommer ist, so nachteilig liönnen doch auch heftige Regengüsse und die hiedurch gesteigerten Mengen fli e $B$ enden W a s s e is unsern Waldungen werden.

Durch starken und anbaltenden Regen, Platzregen, Wolkenbrüche wird dic bloßliegende Erdkıume an steilen, abgeholzten Grehängen, in Saatbeeten und auf Kulturflächen mit gelockertem Boden abgreschwemmt und weggefühnt, mit ihr vielfach die Samen und selbst schwächere Pflanzen; Wege, Böschungen, Gräben werden häufig zerrissen und beschädigt. Dieser durch die Gewalt des abfließenden Wasser's verursachte Schaden steigert sich in Gebirg, woselbst infolge der Terraingestaltung

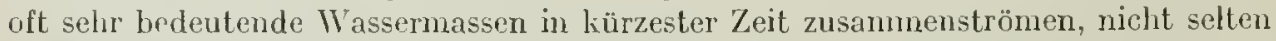
zu großartigen Kalanitäten, zu Uferabbrüchen, Ab- und Ueberschwemmungen und zu Zerstörungen, die weit über den Wald limausreichen ${ }^{\mathbf{1}}$ ).

1) In großartigem Maßstab haben soIche Zerstörungen in Südrankreich im Juragebiet staltgefunden, in gleichem Maßstab aber ist man durtselbst auch mit Mitteln der Abhilfe vorgegangen. Vergl. hierüber das Werk von D e m o n tze y, Studien über die Wiederbewaldung der Gebirge, übersetzt von Seckendorff 1880. 
Sorgfältige Erhaltung des Maldes, seiner schützenden Bestockung und Bodendecke, wo solehe noch vorhanden, ev. Wiederbewaldung der kahten Flächen; Vermeidung jeden größern Kahlhiebes an steilen Gehängen, der Stockrodung und Streunutzung sind hier vorbeugende Mittel, um so wichtiger, je gefährdeter die Oerthichkeit. Im eigentlichen Gebirg, zumal wenn dieses schon durch Entwaldung gehitten, gesellen sich hiezu Schutzbauten versehiedenster Art, Uferlefestigungen, Talsperren von oft so großartiger Konstruktion, daß die Mitwirkung des Bautechnikers geboten erscheint.

An minder steilen und ausgedehnten Geluängen haben neuerdings die sog. H o r iz o n t a l g r äb e n ziemliche Verbreitung gefunden, Stückgräben von etwa $30 \mathrm{~cm}$ Tiefe und 3-5 m Länge, welche in Entfernungen von 5-10 m - je steiler, desto enger - horizontal am Berg hinlaufend in der Weise hergestellt werden, daß immer der Unterbrechung an einer Stelle ein Stückgraben der nächsten Horizontalen entspricht. Sie fangen das Regenwasser auf, geben ihn Zeit, in den Boden einzusinken, brechen bein Ueberfließen dessen Gewalt und erweisen sich hiedurch sehr nützlich. An trockenen Gehängen werden sie aber aus naheliegendem Grunde auch der Bestockung wohltätig, beleben diese und haben deshalb in solchen Oertlichkeiten den Namen „Regenerations-Gräben" erhalten 1).

Saatstreifen an Gehängen legt man stets horizontal; Forstgärten und Saatkämpe, wenn deren Anlage an stärker geneigten Gehängen nicht zu vermeiden ist, terrassiert man zum Schutz gegen das Abschwemmen, und Verschwemmen des Samens angesäter Beete sucht naan durch Deckung mit Reisig oder mit Schutzgittern zu verhindern.

§96. Aber auch stagn i c re nd es W a s s e r kann im Wald sehr lästig und nachteilig werden; wir sehen dort, wo der Boden ein Uebermaß an Wasser enthält, die Pflanzen unserer meisten Holzarten liümmern, ja bei längeren Unterwasserstehen sowohl jüngere Bestände wie selbst ältere Bäume auf ganzen Flächen abständig werden ${ }^{2}$ ). Auf feuchtem Boden tritt an älteren Stämmen (so besonders der Fichte) häufig die Erscheinung der Stock- und Rotfäule auf, ältere Bestände in dem durchweichten Boden werden durch Windwurf heingesucht. Die Frage nach Abhilfe tritt an den Forstwirt heran, und Entfernung rler überschüssigen Feuchtigkeit wird diese Hilfe bieten.

In erster linie werden wir die Ursache jenes Ueberschusses an Feuchtigkeit zu erforschen haben. Undurchlassender Untergrund, eine Lettschichte in geringer Tiefe, Quellen, welche keinen genügenden Ablauf haben, Grundwasser, welches von einer nahe gelegenen Wasserfläche herdrängt, in Verbindung mit reichen atmosphärischen Niederschlägen werden sich als Gründe ergeben; auch Ueberschwemmungen bei mangelndem WViederabfhu können die Teranlassung stagnierender Nässe oder völliger Versumpfung sein.

Q u e l l e n sucht nan zu fassen und das Wasser durch Gräben abzuleiten, und ebenso wird man bei undurchlassendem Un terg rund sich mittelst Entwässerungsgräben zu helfen suchen, wobei allerdings ein entsprechendes Gefüll nach einem natürtichen Wasserlauf oder Wasserbecken hin Bechingung ist. Das Versenken des Wassers, intem nan die unhrehlassende Schichte an der tiefsten Stelle zu durchbrechen sucht und den Schacht mit Steinen - zum Schutz gegen

1) Verul. den Aufsatz von $\mathrm{H}$ a a g, F, Z.-BI. 1881. S, 208

2) Vergl. EB I in gers .lltteilung in Forstw. Z.-Bl. 1911. S. 394, nach weleher infolge der dauernden Leberselıweminung in den Rheinwatdungen der Pfalz 31 ha Laubholz, 17 ha Kiefernkultur und etwa $\$ 0000$ Laubholzheister eingingen. 
rasches Wiederverschlämmen - ausfüllt, wird nur ausnahmsweise Anwendung finden können.

Gegen seitlich durchdrückendes Grundwasser gibt es kein Mittel der Abhilfe, und auch die Vorsorge gegen Uebersehwemmungen geht meist über den Wirkungskreis und die Mittel des Forstmannes hinaus.

Bei der Vornahme einer Entwässerungsarbeit wird nun in erster Linie zu beachten sein, daß nur das $U$ e b e r m a $B$ des Wassers entfernt werden soll, daß jede zu weit getriebene Entwässerung für den Wald und namentlich auch für die Umgebung der entwässerten Oertlichkeiten geradezu nachteilig werden kann. Man hat erkannt, daß es ein Fehler sei, Hochnoore zum Zweck von Kulturen zweifelhaften Wertes zu entwåssern und dadurch dem Wald das im Sommer so wichtige Wasser jener Moore zu entziehen, oder kleinere nasse Stellen im Wald zun Nachteil der ringsum gelegenen Bestände zu entwässern. Ja man ist an manchen Orten dalin gekommen, daß man die in zu großer Zahl angelegten Entwässerungsgräluen wieder zugeworfen hat ${ }^{1}$ ). Das durch Entwässerung einer höher gelegenen Fläche dem Wald entzogene Wasser sucht man wo möglich durch Einleiten und Verteilung in trockene Gehänge dem Wald zu erhalten und nutzbar zu machen ${ }^{2}$ ), ebenso das Wasser der Wegegräben.

Stets soll die Entwässerung einer unbestockten Fläche ilırer Aufforstung einige Zeit vorausgehen, damit der Boden sich genügend setzen kann; eine Entwässerung sehon bestockter Flächen muß mit großer Vorsicht geschehen, wird meist besser unterlassen.

Grö B e re n Entwässerungsarbeiten hat stets ein entsprechendes Nivellement und der Entwurf eines Grabennetzes vorauszugehen, kleinere können vielfach nach dem Augenmaß ausgeführt werden. Die Herstellung der Gräben, welche meist offene, seltener gedeckte (Reiserdrains oder Steindrains) sind, erfolgt zur trockensten Jahreszeit, im Spätsommer oder Herbst, und beginnt an der tiefsten Stelle; die Tiefe und Weite des Hauptgrabens wie der Seiten- und Schlitzgräben richtet sich nach der abzuführenden Wassermasse und den Bodenverhältuissen, durch welch letztere namentlich auch die steilere oder flachere Böschung der Grabenwände bedingt ist. Die ausgehobene Erde läßt man nicht am Grabenrande aufhäufen, sondern wirft sie, um das Zurücksehwemmen in den Graben bei Regen zu verhindern, entsprechend auseinander.

So lange als nötig müssen die Gräben entsprechend unterhalten werden; vielfach läßt sich aber wahrnehmen, daß eine nasse Fläche dann, wenn der auf ihr begründete Bestand in Schluß tritt, durch den starken Wasserverbrauch des letztern an sich trocken wird, und eine femere Erhaltung der Gräben wird dann unnötig, nöglicherweise selbst nachteilig sein.

\section{B. Schnee.}

$\S 97$. Gerne sieht der Forstmann während der Wintermonate eine mäßige Schneedecke im Wald: sie ist ihm ein Schutz für die jungen Pflanzen bei höhern Frostgraden, Jei den Fällungen in Nachhieben, erleichtert die IIolzausbringung und Abfuhr in hohem Grad und speist endlich, langsam schmelzend, den Boden mit Feuchtigkeit für die kommende trockene Jahreszeit.

Fein und trocken fallender Schnee bringt nun den Wald keine Gefahr; anders, wenn er naß und großflockig fallend sich an die Nadeln und Zweige oder, sehr zeitig

1) Vergl. Re u $\beta$, Die Entwässerung der Gebirgsmaldungen 1874.

2) Vergl. Kr a is e r, Beiträge zur Pflege der Bodenwirtschaft 1883. 
im Herbst erscheinend, an die noch an den Laubbäumen befindlichen grünen oder dïrren Blätter is Massen anhängt: Aeste und Gipfel, Stangen und Stämme vermögen der übermäßigen Belastung nicht zu widerstehen und brechen ab - S c h n e eh r u c h -, Junghölzer, Dickungen werden durch diese Belastung zu Boden gedrückt, ohne zu brechen, verlieren jedoch durch längeres Niederliegen rlie Fähigkeit, sich wieder aufzurichten - Seh ne ed $\mathrm{s} u \mathrm{c} k$.

Außerordentlich groß sind die Besehädigungen, die unsem Waldungen in solcher Weise zugehen können und schon zugegangen sind: ältere Bestände werden durch Ast- und Gipfelbruch so durchlöchert, daB deren vorzeitiger Abtrieb erfolgen muB, jüngere Bestände werden auf kleineren oder größeren Flächen durch Bruch und Druck so vollständig zerstört, daß Abräumung und Wiederaufforstung nötig wird. Große Zuwachsverluste, bedeutende liulturkosten, Störungen des Betriebsplanes sind die nächsten Folgen; mit Mühe nur und zu gedrückten Preisen gelingt es, das in großen Massen angefallene und vielfach geringwertige Material, das Ast- und Gipfelholz, das geringe Gestänge zu verwerten, das Stockholz muß ungerodet im Walde verbleiben - und neue Kalamitäten sind die Folge hievon, wie von verzögerter Aufarbeitung und langsamem Absatz: Rüsselkäfer und Wurzelbrüter aller Art erscheinen, die Borkenkäfer mehren sich durch das reichlich dargebotene Brutmaterial, und abermalige Waldbeschädigungen und finanzielle Verluste sind die weitere Folge.

\$98. Nicht überall und namentlich nicht überall im gleichen Maß sehen wir diese Beschädigungen durch Schnee auftreten. Wenn auch k e in e Standörtlichkeit v ö $11 \mathrm{i} g$ verschont bleibt, so sind doch Vorberge und Mittelgebirge die eigentlichen Schneebruchlagen, während die Ebene dusch geringern, das Hochgebirge durch trockeneren Schneefall in minderem Maß leiden.

Was die Holzarten anbelangt. so ist es erklärlich, daß die win $\mathrm{t}$ e r g r ü n e n $\mathrm{N}$ a d e $\mathrm{lh}$ ö lzer in viel höherem Grad zu leiden haben, als die Laubhölzer, und letztere werden durch Schnee nur damn beschädigt, wenn zeitig eintretender Schneefall noch viel dürres Laub als entsprechende Stützfläche an ihnen vorfindet, wie dies insbesondere an Eichen- und Buchengertenhölzern der Fall. Die brüchige F ö hr e hat mehr durch Schneebruch, die zähe F i c h $\mathrm{t} e$ in der Jugend sehr durch Schneedruck zu leiden. Doch werden auch ältere Fichtenbestände durch Absprengen der Gipfel, sowie der Stämme und Stangen häufig schwer heimgesucht, zumal wenn etwa erstere mit Zapfen reich beladen, letztere durch alte Harzlachen oder Schälrisse des Wildes von früheren Zeiten her beschädigt sind. Von den Laubhölzern sehen wir die brüchige Akazi e und Erle bisweilen durch Schneebruch geschädigt, während die frisch übergehaltenen $\mathrm{E}$ i c he $\mathrm{n}$ a $\mathrm{B}$ re is er des llittelwaldes nicht selten durch auflagernden Schnee zur Erde gebeugt und bei längerer Belastung für ihren Zweck untauglich gemacht werden.

Auch die Beschaffenheit der Bestände ist nicht olne Einfluß: aus Laub- und Nadelholz ge mis c h te Bestände leiden in geringerem Maß, als re in e Nadelhölzer, und dicht geschlossene, durch Saat oder natürliche Verjüngung entstandene Fichtenjunghölzer sind dem Schneedruck in viel höherem Grad ausgesetzt, als rechtzeitig durehforstete oder durch weitständigere Pflanzung entstandene derartige Bestände.

\$99. Die Mittel, die dem Forstmann gegenüber den geschilderten Gefährclungen zur Verfügung stehen, sind mehr Mittel der Vor be u g u g als clirekter Abwehr, liegren auf dem Gebiete des Waldbaues und der Bestandspflege und kömnen den Schaden nur mindern, nicht völlig verhindem.

Als solche llittel erscheinen nun die Wahl der richtigen $\mathrm{H}$ ol z a r te $\mathrm{n}$, eine 
zweckentsprechende B est and es b e gr ünd ung und Best and es p f l e ge. Man wird die brüchige Föhre nicht in höheren, durch Schneebruch erfahrungsgemäß heimgesuchten Oertlichkeiten anbauen, wird eine entsprechende Bestandesmischung anstreben, zur Bestandesbegründung an Stelle der Saat oder engeren Pflanzung die Pflanzung mit liräftigen, stufigen Einzelpflanzen in weiterem Verband wählen, wird vor allem mit $\mathrm{Durch}$ orstungen frühzeilig beginnen, sie rechtzeitig wiederholen und hiedurch die Stangen zu stufigerem Wuchs bringen, dem Schnee das Durchfallen erleichtern. Besondere Vorsicht bez. der Durchforstungen ist in jenen Beständen nötig, die lange in sehr dichtem Schluß standen, und dürfen lier die ersten Durchforstungen nur sehr mäßig geführt werden.

Eine direkte A b w e h durch Abschütteln des Schnees ist nur in Parkanlagen, kileinen, besonders wertvollen Junghölzem und etwa bei den niedergebogenen Laßreisern des Mittelwaldes möglich; hier könnte allerdings ein einziger Mann bisweilen Hunderte von Stangen an e in e m Tag retten.

Eine $1 /$ i n d e r u n g des durch Schneedruck angerichteten Schadens in Laubholz-Junghölzern kann in manchen Fällen durch Aufrichten niedergebogener Horste und selbst Aufbinden der dominierenden Stangen mit Hilfe des Nebenbestandes ${ }^{1}$ ) erfolgen; auch Köpfen der niedergebogenen Stangen an der Biegungsstelle in der Absicht, durch an der Abhiebsstelle erseheinende Ausschläge den Schluß herzustellen, hat man in Buchengertenhölzern mit Erfolg angewendet. - Im Nadelholz müssen die niedergedrücliten Partien abgeräumt, die größern Lücken mit schnellwüchsigern Holzarten, die lileinern in Interesse des Bodenschutzes mit Schattenhölzern ausgepflanzt werden: letztere wendet man auch zur Ausfüllung durchbrochener Fölırenstangenhölzer, die erhalten bleiben sollen, an.

Aufgabe des Wirtschafters ist es aber auch, durch möglichst rationelle und rasche Aufarbeitung und Verwertung der Bruchhölzer den finanziellen Schaden möglichst zu verringern, ebenso mit allen ihm zu Gebot stehenden Mitteln der in Nadelholzwaldungen drohenden Insektengefahr entgegenzuarbeiten. Nan wird zunächst den Wald durch Räumung der Wege zugänglich machen, die Junghölzer und Schläge ron auflagemdem Bruchholz befreien, aus dem anfallenden Mlaterial möglichst viel Nutzholz ausscheiden, das Holz an luftige Wege ausrücken, Nadelholz entrinden, Prügelholz aufspalten, Stammholz auf Unterlagen bringen - letzteres alles im Interesse besserer Kionservierung des Holzes. Entrinden des Nadelholzes, Verbrennen des Reisigs, tunlichste Rodung von Stöcken und Wurzeln, Beseitigung kränkelnder Stämme sind die Vorbeugungsmittel gegen das Ueberhandnehmen schädlicher Insekten.

\section{Duft, Eisanhang und Hagel.}

$\$$ I00. Nit dem Ausdruck, $D$ u $\mathrm{ft}, \mathrm{R}$ a u h $\mathrm{r}$ e if, $\mathrm{A} \mathrm{n}$ h a $\mathrm{n} \mathrm{g}^{\text {" }}$ bezeichnen wir bekanntlich jene Erscheinung, bei welcher sich der Wasserdampf cler Luft in Gestalt von Eiskrystallen und langen Eisnadeln an den Zweigen, Nadeln, Blättern in oft sehr bedeutenden Massen ansetzt, diese rlarlurch so belastend, daß sich Wipfel und Aeste beugen und schließlich abbrechen. Unter dieser namentlich in höheren Lagen auftretenden Erscheinung leiden wieder insbesondere die wintergrünen Nadelhölzer, obenan die brüchige F ö h $\mathrm{r}$ e, die Laublı̈lzer aber nur dann, wenn sie noch dürres Laub als Stützpunkt für den Rauhreif in größerer Venge tragen, so namentlich auch die Eichenlaßreiser des Mittehwaldes. Es sind insbesondere Bestandsränder, dann

1) Dies Mittel wurde im Spessart mit Erfolg angewendet; vergl. die Mitteilung von $\mathrm{F} u ̈ \mathrm{r} s \mathrm{t}$ in A. F.- U. J.-Z. 1882. S. 325 . 
Nord- und Ostgehänge, wo dic oft selır schädliche Erscheinung des Duftbruches auftritt.

E i s b il d ung entsteht namentlich, wenn bei strenger Kälte plötzlich Tauwetter und Regen eintritt; die aufschlagenden Tropfen erstarren zu Eis und übcrziehen Stamm und Aeste, Nadeln und dürre Blätter mit einer mehr oder weniger starken Eiskruste. Gesellt sich bei wieder sinkender Temperatur hiczu noch Schmecfall, so wird die Belastung eine so bedeutende, daß Eisbruch in oft großartigem Maßstab eintritt. - Erklärlieherweise sind es auch hier wieder die brüchigen Holzarten: Föhren, Erlen, Akazicn, die zuerst Not leiden, aber auch Fichten- und Buchenbestände wurden schon durch Eisbruch schwer geschädigt.

Durch dic allbekannte, glücklicherweise nicht allzu häufig auftretende Erselıeinung des $\mathrm{H}$ a ge $\mathrm{Is}$ werden auch die Waldungen oft sehr bedeutend beschädigt: Pflanzen in Saatbeeten und Kulturen werden teils ganz vernichtet, teils bis zur Verkrüppelung beschädigt, älteren Bäumen die jungen Schosse, Blüten oder Früchte abgeschlagen; zahlreiche Rindenverletzungen, oft nur langsam ausheilend, sind die weitere Folge, ja diese Verletzungen sind oft so bedeutend, daß ganze Bestände abgetrieben werden müssen. In Weidenhegern sind die Folgen des Hagels besonders verderblich, indem die Schosse beim Verarbeiten an der beschädigten Stelle abbrechen. - Selır empfindlich zeigt sich die Föhre gegen Hagelbeschädigung, wälırend Fichte und Tanne durch ihre dichte Benadelung geschützter sind; auch die Lärche leidet weniger.

Schutzm it tel gegen die 3 eben crwähnten Naturerscheinungen stehen uns nur in sehr besehränktem $\mathrm{Ma}$ zur Verfügung: gegen den Duftbruch etwa das Vermeiden des Anbaues der brüchigen Föhre in der Duftregion, das Erhalten von Waidmänteln an den gefährdeten Nord- und Osträndern; gegen Eisbruch und Hagel aber fehlen selbst solche Mittel. Daß in einer entsprechenden Bewaldung insbesondere der Höhenzüge ein wichtiges Schutzmittel gegen Hagelbildung gesucht wird, möge hier nur nebenbei noch bemerkt sein ${ }^{1}$ ).

\section{Blitzschlag.}

$\S 101$. Der Blitz schlägt bekanntlich verhältnismäBig häufig in Bäume ein, und zwar vorwiegend in solche, welche entweder allein stehen oder ihre Ungebung mehr oder weniger überragen.

Die Folgen dieses Einschlagens sind nun sowohl nach der äußern Erseheinung, wie nach dem Einfluß auf das Leben des Baumes sehr verschieden. In manchen Fällen wird lediglich ein sehmaler Rindenstreifen abgelöst, wir sehen den Baum ohne sichtbare Störung fortwachsen, die entstandene „Blitzrinne" überwallend, so namentlich bei Eichen, die nicht selten die Spuren alter Blitzverletzungen zeigen, während in andern Fälien selbst bei solch geringeren Besehädigungen die betroffenen Bäume mehr oder weniger rasch absterben, so namentlich die Nadelhölzer. Bisweilen kommt breitstreifige, ja gänzliche Entrinchung der getroffenen Stämme vor, und nicht selten werden diese vollständig zerschmettert, gespalten oder in eine Menge weit umher liegendei Splitter aufgelöst. Merkwürdig erscheint ferner das Ueberspringen des Blitzes von cinem Stamm auf einen zweiten und ebenso das allmähliche Ahsterben einer oft größeren Zahl von Stämmen in der Ungebung eines vom Blitz getöteten Stammes, wie solches namentlich in Föhrenwaldungen beobachtct wurde.

Dürre oder im Innern trockenfaule Stämme werden wohl auch church den Blitz

1) Vergl. Rin ik e $r$, Die Hagelschläge im Kanton Argau 1881. 
in Brand gesteckt, und kann sonach der Blitz, wenn auch selten, Ursache eines Waldbrandes werden.

Was endlich die Holzarten anbelangt, die vom Blitzschaden heimgesucht werden, so ist wohl keine gänzlich verschont, doch sehen wir allerdings die einen mehr, die andern weniger betroffen. Am häufigsten wird wohl die Eiche, weil einzeln stehend, oder als Ueberhälter ihre Ungebung weit überragend, vom Blitz getroffen, ebenso die Pyramidenpappel; von den Nadelhöłzern sehen wir Föhre und Fichte häufig greschädigt - dagegen scheint die Rotbuche sehr selten heimgesucht, so daß sie in manchen Gegenden geradezu als blitzsicher gilt. ${ }^{\mathbf{1}}$ )

\section{Gefährdungen dureh Winde und Stürme.}

§ 102. Luftbewegung von mäBiger Stärke und Schnelligkeit nennen wir IV in d; erreicht die Sehnelligkeit 22 Meter in der Sekunde, so bezeichnen wir diese Bewegung der Luft als S t u r m, eine solche von 35 Meter und mehr als $0 \mathrm{rka}$. Nicht nur die beiden letztern, auch der erstere wird unter Umständen den Waldungen nachteilig, doch treten diese Nachteile hier erst nach längerer Einwirkung, bei den Stürmen aber sofort zutage.

Durch die anhaltend oder doch oft aus der gleichen Richtung kommenden W in d e finden wir an WVald- und Bestandsrändern, auf Bergköpfen und freiliegenden Pücken das Laub weggeweht, wodurch also die wohltätige Humushildung verhindert, der Boden bloßgelegt, dem Vermagern und Austrocknen preisgegeben wird. Wir sehen hier jüngere Pflanzen kümmern, ältere Bäume in Wuchs nachlassen, dürrwipfelig werden, sehen den Bestand verlichten, den Boden sich mit Heidelbeerkraut und Heide überziehen. In Eichen- und Buchenbestäuden tritt dies in oft sehr deutlicher Weise zutage, weniger in Nadelholzwaldungen, deren Decke dem Verwehen weniger ausgesetzt ist; doch macht sich auch in ihnen die austrocknende Wirkung des Windes bemerkbar. Letztere zeigt sich besonders deutlich bei den trockenen Ostwinden und wird im Frühjahr, zur Kulturzeit und unmittelbar nach derselben, zur besondem Gefahr für Saaten und Pflanzungen. - In hohen Freilagen, namentlich aber auch in der Nähe des Meeres, macht sich der Einfluß der anhaltend aus einer Richtung wehenden Winde (in Deutsehland der West- und Nordwestwinde) auch d ir e k t auf die Vegetation geltend - in kümmerndem, krüppeligem Wuchs, sehiefer Stellung, einseitiger Beastung der Stämme, zerrissenen, unregelmäßigen Kronen.

Gegen diese letzteren Wirkungen steht uns nur das Schutzmittel einer sorgfältigen Erhaltung und möglichst plenterweise Behandlung des Bectandsrandes an der Windseite, der damı wenigstens die dahinter liegenden Bestände schützt, zu Gebot. Das Verwehen des Laubes suchen wir dureh Bestandsmäntel (Waldmäntel), am besten aus einigen Reihen dichtbenadelter Fichten, besser noch aus dichten Laubholzhecken und Stockausschlägen bestehend, zu schützen, unterpflanzen den gauzen Saum mit Schattenhölzern, soweit dies die Bodenverhältnisse gestatten; auch grobscholliges Umhacken des verhärteten Bodens hat nan angewendet, um das Laub in den Vertiefungen festzuhalten, dem Regenwasser das Eindringen in den Boden zu ermöglichen.

1) Vergl. die Mitteilungen von F e y e, Z. f. F. U. J. 1886. S.287, sowie die Mitt. voln R.H a r t ig in s. ,Pflanzenkrankheiten" (3. Aufl.) 1900. lerner v. T u b e u f , "Gipfeldüre der Fichte" in der Nalurw. Zeitsehr. fül Forst- und Landwirlschaft 1903, 1904, wonach das von ihn beobachtele Abstcrben zahlreieher Fichtenwipfel auf der bayr. Hoeliebene dem Blitz zugesehrieben wird. 
Lultiviert man während trockener Ostwinde, so ist auf das Feuchthalten der Pflanzenwurzeln beim Ausheben, Transport und Einsetzen der Planzen jedmögliche Sorgfalt zu verwenden und hat das Einpflanzen der Anfertigung der Pflanzlöcher möglichst rasch zu folgen, damit die letztern und die Pflanzerde nicht zu stark austrocknen.

$\$ 103$. Größer und mehr ins Auge fallend sind jene Beschädigungen, wclche durch S t ü r m e und Orka n e den Waldungen zugehen. Einzelne Bäume, ja ganze Bcstände werden entweder mit den Wurzeln aus dem Boden gehoben und niedergeworfen - IV in d w ü $\mathrm{r} f \mathrm{e}$ oder $\mathrm{W}$ in d $\mathrm{f}$ ä $\mathrm{l} \mathrm{l}$ e -, oder sie werden in größerer oder geringerer Höhe über dem Boden abgebrochen - W in d b r ü $\mathrm{ch} e$; bald reißt hiebei der Wind nur einzelne Stänme nieder, bald bricht er, meist bei einem starken Stamm beginnend, Gassen und Streifen durch den Bestand, bald nur einzelne Löcher, und heftige Orkane brechen und werfen ganze Bestände und Bergwände ausnahmslos nieder $\left.{ }^{1}\right)$.

Eine lange Reihe von Nachteilen ist es, die dem Wald und dem Waldbesitzer durch gröBere Sturmbeschädigungen zugehen: durch das $\mathrm{Z}$ e r b e ch en und Z e r s p l it t e r n der Stämme geht eine Menge Nutzholz verloren, die massenhaften Splitter und Brüche sind selbst als Brennholz nicht verwertbar; die A r be it sI öl ne steigen, die $\mathrm{Holzpreise} \mathrm{sinken,} \mathrm{geringe} \mathrm{Sortimente,} \mathrm{wie} \mathrm{Reisig-} \mathrm{und}$ Stockholz, werden bisweilen ganzunverwertbar. Die im Stadiun des Besamungs- und Nachhiebes stelıenden Schläge werden durch die geworfenen Mutterbäume, die Junghölzer durch die dies Schicksal teilenden Ueberhälter beschädigt; Bestände, die noch im besten Zuwachs standen, müssen wegen Durchlöcherung abgetrieben werden, andere, die erhalten bleiben, zeigen geringern $\mathrm{Zuw}$ a $\mathrm{chs}$, V V r wilderung des Bod ens, seinerzeit geringere Abtriebserträge und erschwerte natürliche Verjüngung. Endlich folgen den Sturmschäclen, wie beim Schneebruch, nicht selten schädliche $\mathrm{F}$ orstinsekten, denen in dem liegenden und hängenden kränkelnden Holz, den zahllosen Stöcken reiche Brutstätten geboten sind.

\$ 104. Mancherlei Umstände und Einflüsse bedingen die Größe der Sturmgefahr und Sturmbeschädigungen.

Stürme treten vorzugsweise im Spätherbst und Frühjahr ein (Aequinolitialstürme); dengemä $B$ sind es erklärlicherweise die auch zu dieser Zeit belaubten w i nt e rgrü $\mathrm{n}$ en $\mathrm{N}$ a d elhöl zer, die, dem Wind eine größere Angriffsfläche bietend, vor allem gefährdet sind. Ohenan steht hier die F i c h t e mit ihrer dichten Benadelung, ihrem langen Schaft und ihrer flachen Bewurzelung, durch letztere namentlich dem Windwurf ausgesetzt; etwas sturmfester ist bereits die tiefer wurzelnde $\mathrm{T}$ a $\mathrm{n} \mathrm{ne}$, dann die lichtkronige und ebenfalls liefwurzelnde $\mathrm{F}$ ö h re, die allerdings in dem leichten Sandboden, ihrem Haujtstandort, nur geringeren Halt findet, auf flachgründigeren solchem Boden sogar sehr gefährdet ist. Die Lärche und die Laubhölzer leiden nur wenig, von letzteren infolge ihrer flachem Bewurzelung etwa Aspe, Birke, Hainbuche, die Rotbuche dagegen nur bei heftigen Stürnen und in exponierten Lagen; am sturnfestesten erscheint die Eiche. Die selteneren Sommerstürme, Zyklone, gefährden natürlich die Laubhölzer in gteichem Maße.

Mit dem A l ter der Bestände und sonach auch mit rer U m trie bs z e it steigt die Sturmgefahr, die der Niederwald gar nicht, der Mittelwald nur in geringem Ilaß kennt; der Plenterwald mit in freieren Stand erwachsenen Stämmen erweist sich sturnfester als der gleichalterige Hochwald. Zum Zweck der natürlichen Ver-

I) Vergl. "Forstliche Stumbeobachtungen im Nittelgebirg" von Oberförster Eifer t, A. F.- U. J.-Z. 1903 und $B$ a $r$ g m a $n$ n, das. 1904 . 
jüngung g e lichte te Bestände sind stets gefährdeter, als noch geschlossene ein Grund für viele, von der natürlichen Verjüngung der Ficlite abzusehen.

Auch der $\mathrm{S} t$ a n d o r t spielt eine nicht geringe Rolle bei der Gefahr durch Stürme: Südwest-, West- und Nordwestgehänge, Bergköpfe und Rücken sind in höherem Grade exponiert, als mehr oder weniger gegen Nord und Ost geneigte Oertlichkeiten; vorliegende Berge schwächen die Gefahr ab; guter Boden mit sehr langschaftigem Holzwuchs, dann flachgründiger, lockerer, mooriger und feuchter Boden erhöht die Sturngefahr, tiefgründiger, steiniger, bindender Boden verringert diese, und.zwar gilt dies vor allem bez. der Wind w ü $\mathrm{r} f \mathrm{e}$, die unter den ersteren Verhältnissen häufiger eintreten, während in letzterem Falle der Wind b r u c h zu fürchten ist. Sinı, wie häufig, die Westwinde von Regen begleitet, so erlı̈ht das Durchweichen des Bodens gleichfalls die Gefahr des Windwurfes; lei stark gefrorenem Boden werden wir den Bruch der Stämme überwiegen selıen, ebenso bei kernfaulen Stämmen, bei Stämmen mit schadhaften Stellen infolge früherer Verletzungen durch Harzgewinnung oder Schälen des Vildes.

$\S 105$. Auf Grund der Beobachtungen über das Verlalten der einzelnen Holzarten und Standörtlichkeiten gegenüber den Stürmen, wie der allgemeinen und lokalen Erfahrungen über die herrschende Windrichtung suchen wir nun den Beschädigungen durch Stürme möglichst vorzubeugen - gegen lı e f i ge Stürme oder gar O $\mathrm{r}$ a $n$ e versagen allerdings diese Vorbeugungs-Maßregeln!

Von ganz hervorragender Bedeutung unter diesen letzteren ist insbesondere für Nadelholzwaldungen die $\mathrm{Hi}$ e bs fü $\mathrm{h} \mathrm{r} u \mathrm{ng}$, die richtige Aneinanderreihung der Schläge. Gestuitzt auf die Wahmelımung, daß plötzliche Freistellung bisher geschützt gestandener Stämme besonders gefährlich ist, daß in stetem Kampf mit dem Wind aufgewachsene Stämme und Bestandsränder besonders widerstandsfälig sind, greifen wir die Bestände tunlichst auf der den herrschenden Stürmen entgegengesetzten Seite an - sonach in Deutschland, woselbst die heftigsten Stürme aus West, Süd- und Nordwest zu kommen pflegen, an der Ost-, Nord-, Nordost- oder der Südostseite, unbeschadet natürlich lokaler Abweichungen von der herrschenden Sturmrichtung, - und führen die Hiebe den Stürmen so entgegen, daß stets der geschlossene Bestand nach der Sturmseite vorliegt, dessen sturmfester IVestrand bis zuletzt erhalten bleibt. Die Erhaltung eines solchen sturmfesten, stark bewurzelten und tief herab beasteten $\mathrm{W}$ a I $\mathrm{dm}$ a $\mathrm{ntels}$ ist von großer Bedeutung.

Ebenso ist die plötzliche Freiste llung jüngerer, aber doch schon sturmgefährdeter Bestände durelı Abnutzung älterer, auf der Sturmseite vorliegender Bestände zu vermeiden, und es müssen einer zweckmäBigen Hiebsführung durch den spätern Abtrieb älterer und die frühere Nutzung jüngerer Bestände nicht selten wesentliche Opfer an Zuwachs und Nutzwert gebracht werden. Dureh sog. L os h i e b e, d. h. durch frühzeitigen Abtrieb eines $10-15 \mathrm{~m}$ breiten, alsbald wieder anzupflanzenden Streifens des älteren Bestandes auf der Grenze der beiden Bestände, tunlichst rechtwinklig zur Sturmrichtung, sucht man dem jungen Bestand die Höglichkeit selbständiger Bemantelung durch entsprechende seitliche Wurzelbildung und Beastung zu geben und hiedurch dic seinerzeitige Wegnahme des alten Bestandes ohne Gefälırdung des jüngeren zu ermöglichen ').

Den Hicben zum Zweck der natürlichen Verjüngung in Fichten- und Tamnenbeständen wird man lieine zu große Ausdehnung geben, da nit solcher die Sturm-

1) Ueber die im Prinzip richtigen, gleichwohl außerhalb Thüringen und Sachsen minder verbreiteten Loshiebe hat $\mathrm{H}$ e $\beta$ in der allg. Forst- und Jagdzeitung 1862. S. 369 eingehend beriehtet. 
gefahr wächst, sondern wird diese Hiebe in schmalen Streifen der Sturmrichtung entgegen führen; dagegen wird man in gefährdeten Lagen auf die natüıliche Verjüngung der Fichte, ebenso auf das Ueberhalten von Föhren in den zweiten Umbrieb verzichten, wird den gefährdeten Holzarten sturmfestere beizumischen suchen so den Nadellö̈zeru in passenden Oertlichkeiten die Buche, der Fichte die Tanne und Föhre; wird schon bei der Aufforstung holzleerer Flächen auf Anzucht eines Waldmantels von sturmfesteren Holzarten Bedacht nehmen.

Es ist in erster Linie Aufgabe einer guten Forste in rich t ung, den Sturmgefährdungen durch eine zweckmäBige Reihenfolge in der Abnutzung der Bestände, durch Bildung richtiger $\mathrm{H}$ i e b s z ü g e, rechtzeitige Einlegung von $\mathrm{L}$ o sh i e be n Rechnung zu tragen; für reine Fichtenwaldungen ist dies von größter Bedeutung.

Ist aber eine größere Windbruchkalamität über einen WValdkomplex hereingebrochen, dann gelten bez. der $\mathrm{A} u \mathrm{f}$ a $\mathrm{rbejtung}$ und Konservierung des Holzes, der Vorsichtsmaßregeh gegen $\mathrm{s}$ c hä $\mathrm{d}$ l i c he I n s e li te n die gleicheı Grundsätze, wie sie oben bez. des Sehneebruchholzes (s. § 99) angegeben wurden. Der Unstand, daß man es vorwiegend mit stärkerem Holz zu tun hat, erleichtert Aufarbeitung und Verwertung.

\section{Kranklıeiten der Holzgewäehse.}

Literatur: R. H a r t ig, Lehrbuch der Pflanzenkrankheilen, 3. Aufl, 1900. - D e r s e 1 b e , Die Zerselzungserscheinungen des Holzes der Nadelholzbäume und der Eiche. 1878. - D e rs cl be, Untersuchungen aus dem forstbotanisclien Institut in Munchen 1880.

$\S$ 106. Ueber liein Gebiet unserer Disziplin war man wohl länger im Unkilaren, als über jenes der sog. Pflanzenkrankheiten, über deren Ursachen und Folgen, und in nicht wenig Fällen - so bei den Pilzen - hielt man das für die Folge, was eigentlich die Ursache war. Kiein Gebiet bot aber wohl auch der Forschung gröBere Schwierigkeiten, und insbesondere war dasselbe für den eigentlichen Forstmann schwer zu betreten und mit Erfolg zu bebauen: der Botaniker, der mit allen Hilfsmitteln der Wissenschaft ausgerïstete Forscher, muBte ihm zu Hilfe kommen, sollte ein entsprechendes Resultat erzielt werden.

Neben andern Forschern war es vor allem $\mathrm{R}$ o be r t $\mathrm{H}$ a $\mathrm{r}^{\prime} \mathrm{t} \mathrm{i}$, der sich dem Studium der Pflanzenkrankheiten mit großen Erfolg gewidmet, der Licht in dies bisher dunkle Gebiet gebracht und zahlreiche Rätsel gelöst hat, dabei auch gleichzeitig Fingerzeige gebend, wie so mancher unsern Holzgewächsen drohenden Gefahr vorzubeugen sei. Diesem verdienten Forscher folgen wir denn auch in der nachstehenden kurzen Skizze über die Pflanzenkrankheiten vorzugsweise und verweisen im übrigen auf dessen oben angegebene IVerke behufs näherer Belehrung ${ }^{1}$ ).

Pflanzenkrankheiten nennt man jene Störungen im Organismus, durch welche die ganze Pflanze oder doch ein Teil derselben zu vorzeitigem Absterben veranlaßt wird. Dic Ursachen dieserStörungen aber können verschiedene sein, nämlich:

1. Aeußere Verwundungen und Verletzungen,

2. Ungünstige Einflüsse des Bodens,

3. Ungünstige atmosphärische Einflüsse, und

4. Phanerogame oder kryptogame Pflanzen.

1) Es mōge jedoch hier nicht unerwähnt bleiben, daß einzelne Stimmen manchen der Hartigschen Forsehungen geringere Bedeutung beimessen, - vergl. N ö r d li n g c r, Forstsehutz. (Einleitung) und B orggreve in F.-Bl. 1886. S. 121 und 1887. S. 18, dann M o $1 \mathrm{l}$ e $\mathrm{r}$ in F.-Bl. 1889. S. 134. 
Nicht jederzeit aber sind die Pflanzen gegen diese äußern Einflüsse gleich empfänglich, sondern gewisse Zeiten und Verhältnisse, vorübergehende, im übrigen ganz normale Zustände lassen sic gegenüber solchen Einflüssen besonders empfindlich erscheinen, präd is po n i ere $\mathbf{n}$ sie zu Erkrankungen. So sehen wir manche Gewächse nur im jugendlichen Alter für gewisse Krankheiten besonders empfänglich, für andere dagegen erst in höłeren Alter, sehın im Schutz und Schatten erwachsene Pflanzen gegen die Einwirkung von Frost und Hitze empfindlicher als solche, die in Freien erwuchsen, sehen in Glattrindigkeit und plötzlicher Freistellung eine Veranlassung zur Erscheinung des Rindenbrandes, beobachten, daB Pilzkranklieiten bei feuchtem Wetter in höherem Grad üherłandnehmen u. dgl. mehr. Das Zusammentreffen besonderer Empfänglichkeit, begünstigender Umstände mit Kŕrankheitsursachen wird die Erkrankung dann häufiger und intensiver auftreten, entgegengesetzten Falles vielleicht spurlos vorübergehen lassen.

\section{Krankheiten infolge von Verwundungen.}

$\S 107$. Auf die mannigfachste Weise gehen den Pflanzen und Bäumen während ihrer oft so langen Lebensdauer geringere oder größere Verletzungen zu: bei dem Fällen und Ausbringen des Holzes erleiden Stämme und Wurzeln Quetschungen und Rindeabschürfungen, Aeste werden abgerissen, brechen dürr werdend ab oder werden durch Aufastung mittelst Axt und Säge entfernt; durch Harznutzung, Schälen oder Fegen des Wildes, Benagen der Rinde durch Kaninchen, Mläuse, Eichhörnehen, endlich durch Insekten verschiedenel Art werden ebenfalls nicht wenige Verletzungen verursacht, die teils V'cranlassung zur Infektion dureh parasitäre Pilze und dadurch bedingter Zersetzung des Holzes, teils zur Zersetzung des Holzes durch saprophytisehe Pilze unter Mitwirkung der Atmosphärilien geben - Hartig bezeichnet diese Form der Zersetzung als WV u n d f äule.

Auf nanchellei Weise schützt sich der Stamm gegen die äußern Einflüsse bei solchen Verletzungen: bei den Nadelhölzern insbesondere durch alsbaldigen Harzaustritt und Ueberziehen der Wunde mit Harz, bei Laubhölzern durch Entstehung sog. Schutzholzes, dann aber bei Laub- und Nadelholz durch die bekannte Erscheinung der Leherwałlung, die aber bei größeren Wundflächen nicht rasch genug eintritt, um das Entstehen der W u n d f ä u ] e zu hindem. Unter Zutritt von Regenwasser beginnen sich die bloßgelegten und abgestorbenen Zellen zu bräunen und zu zersetzen; das Holz färbt sich durch die dunkle IJumuslösung schwarzbraun und erst in höheren Zersetzungsstadien wieder heller. Schließt sich die Wunde durch Ueberwallung, den weitern Zutritt des Regenwassers lemmend, so wird das Weiterdringen der Fäulnis sehr verlangsamt oder hört selbst ganz auf.

Un der Wundfäule, dic das Holz zu technischer Verwendung unbrauchbar macht, vorzubeugen, wird man Verletzungen der Stämme möglichst zu verhindern suchen: durch Vorsicht beim Fällen und Rücken des Holzes, bei Ausastungen, die immer möglichst nahe am Stanm, ohne weitere Rindenverletzungen, bei Laublı̈lzern außer der Saftzeit gesehchen und bez. starker Aeste tunlichst unterlassen werden sollten. Man wird fermer die Wunden der Laubhölzer nach den Entasten durch Bestreichen nit Teer gegen die Feuchtigkeit zu schïtzen suchen, bei einzehnen wertvolleren Stämmen (in Park) die Ueberwallung durch Entfernung toter und gequetschter Rindenteile befördern, eventuelł durch Unwicklung des Stanmes nnit feuchter Leinwand oder Wachstuch das Vertrocknen des Cambiums verhindern. 
2. Erkrankungen durch Einflüsse des Bodens.

$\S$ 108. Die $\mathrm{e}$ h e $\mathrm{m}$ i s $\mathrm{e}$ h e Konstitution des Bodens ist für Erkrankungen der Bäume und Bestände ohne Bedeutung, dagegen können ungünstige physikalische Eigenschaften desselben, namentlich Mangel oder UeberfluB an Feuchtigkeit, fehlender Luftwechsel in Boden, solche hervorrufen. Als solche Erkrankungen erscheinen nun:

Gi p f e l d ü r r e oder $\mathrm{Z}$ opftroc $\mathrm{k} n$ is: in höherem Alter der Bäume als Beginn des Absterbens auftretend, sehen wir sie auch in jüngern, noch zuwachsfähigen Beständen als Folge von mangelnder Feuchtigkeit und damit zusammenhängend von Nahrungsmangel; so werden Erlenbestände infolge von Entwässcrung, Tiefcrlegung eines nahen Wasserspiegels wipfeldürr, ebenso Buchenbestände durch wiederholte Streunutzung insbesondere auf an sich trocknerem und ärmerem Boden, an Süd- und Westgehängen, Eichen bei Lichtstellung der Bestände und Vermagerung des Bodens, bei plötzlicher Freistellung und dadurch hervorgerufener WVasserreisBildung.

Dic Gegenmittel, auf dem Gebiet des Waldbaues liegend, ergeben sich aus den Ursachen von selbst: Vorsicht bei jeglicher und Vermeidung zu starker Entwässerung, möglichste Beschränkung der Streunutzung zumal bei empfindlichen Holzarten und Oertlichkeiten, Deckung des Bodens in Eichenbeständen durch Unterbau, Unterlassen des Einzelüberhaltes.

Wic aber hier vielfach der Wassermangel, so ist auch ungekehrt ein UeberschuB an Feuchtigkeit - wie schon früher hervorgehoben - der Vegetation nachteilig, und wir sehen, wohl als Folge des durch Feuchtigkeit in Verbindung init an sich schwerem, dichten Boden gehemmten Luftwechsels im Boden nicht selten in jüngern $20-30 \mathrm{j}$. Föhrenbeständen die W u r z e I f ä u l e auftreten und derselben zahlreiche Stämme erhiegen. Infolge des mangelnden Sauerstoffzutritts fault die Pfahlwurzel, die zwar in den bindenden Boden eindringen konnte, welcher aber bei eintretendem Schluß und dichter Humusdecke der nötige Luftwechsel entzogen wurde, während die flach laufenden Seitenwurzeln gesund bleiben, und nach kurzem Kümmern bricht der Stamm bei irgend welchem äußern Anlaß — Wind, Schnecbelastung am Boden um ${ }^{\mathbf{1}}$.

Man wird dem Uebel, durch welches die Bestände in bedenklichem Grad verlichten können, etwa dadurch vorzubeugen trachten, daß man rlurch baldige Durchforstung, Entfernung der luftabschließenden Humusdecke die Bodendurehlüftung fördert, wird eventuell bei der Wiederaufforstung zu andern, durch die Wurzelfäule minder gefährdeten Holzarten - Fichte, Laubhölzer - greifen oder sie wenigstens beimischen.

Aehnliche Verhältnisse crgeben sich bisweilen, wenn ältere Bäume infolge von Erdarbeiten in der Nähe tief übererdet werden und führen zu deren Absterben.

\section{Erkrankungen durch atmosphärische Einflïsse.}

\$ 109. Beschädigungen durch Frost und Hitze, insofern hichurch Pflanzen oder Pflanzenteile direkt getötet werden, können nicht wohl als Pflanzen k r a n khe it e $n$ betrachtet werden, wurien deshalb auch in speziellen Abschnitten behandelt. Wohl aber kömnte man hierher jene church die eben genannten atmosphärischen Einflüsse hervorgerufenen Beschädigungen rechnen, welche wir als F r o s t r is se

1) Nach God bersen (Die kiefer) tritt diese krankheit insbes. auf bisherigem Feldboden ein und steht in Verbindung mit dem Kiefernwurzelpilz Polyporus annosus. 
und Rin den b r a n d bereits ( $\$ 87$ und 94) kennen gelemt und um des bessern Zusammenhanges willen in jenen Abschnitten mit besprochen haben, da durch beide für rlie betroffenen Bäume der Grund zur Fäulnis gelegt wird (Rindenbrand) oder doch gelegt werden kann (Frostriß). Auch krebsartige Krankheiten können Izach Hartig durch Frost hervorgerufen werden und würden als F r o st k r e b s hier zu erwähnen sein.

Die in der Neuzeit so häufigen Waldbeschädigungen durch $\mathrm{S} t$ e in $\mathrm{k}$ o h $\mathrm{l}$ e noder $\mathrm{H}$ ü t t e n r a u $\mathrm{c}$ h wurden, weil Folgen menschlicher Tätigkeit, in Absclinitt I $\$ 17$ und 18 besprochen.

\$ 110. Eine weitere Krankheitserseheinung möge h i e r besprochen sein und den Uebergang zu den durch Pilze erregten Schäden bilden: es ist dies die unter dem Namen der $\mathrm{S}$ e h ü $\mathrm{t}$ te allbekannte Kinderkrankheit der Föhre, die von den einen der Wirkung von Früh frösten, von andem einem Vertroeknungsproze $B$ und endlich von dritten $P$ il z e n zugeschrieben wurde, nach den neuerdings geltend gewordenen Anschauungen aber wohl allgemein auf eine Pilzerlirankung zurückgeführt wird.

Während Professor Eber m a e $r$ den Grund in einer Vertrocknung der Nadeln suchte, welche in zeitigen Frühjahr bei Sonnenschein das durch Verdunstung verlorene Wasser aus dem noch gefrorenen Boden nicht ersetzen lionnten, hatten schon vor 30 Jahren P r a $\mathrm{t} l$ und $\mathrm{T}$ u r s k festgestellt, daß die Sehütte durch einen Pilz, den Ki e f e r n r itzens chort, Lophodermium (früher Hysterium) pinastri, veranlaßt werde. Professor Dr. vo n T u be u f kommt durch von ihm ausgeführte Infektionsversuche zu dem Satz: „Daß der Schüttepilz an den Nadeln junger Pflanzen parasitär auftritt, erseheint zweifellos $\left.{ }^{1}\right)^{6}$, und Professor Dr. II. II a y r, der solche Versuche ebenfalls angestellt hat, spricht auf Grund derselben die Ueberzeugung aus $\left.{ }^{2}\right)$, daß es weder eine Frost- noch Ueberverdunstungssehütte gebe, sondern nur eine P i l z s c h ï $t \mathrm{t} e$, veranlaßt durch eine Infektion mit Sporen des oben genannten Pilzes.

Diese Infektion erfolgt an einjährigen, wie älteren Pflanzen nur zur Zeit des Wachstums der Nadeln, von Mai bis Juli; die Zunahme der Mißfarbigkeit und enrlliche Rötung der Nadehn in Herbst und Winter ist keine Ausbreitung der Krankheit auf gesunde Gebiete, sondern nur fortschreitende Entwickelung des Schüttepilzes. Die infizierencten Sporen haben nur geringe Flugfähigkeit, verbreiten sich aber ausfallend durch Wind auf ihre nächste Umgebung.

Stets sind es nur schwächere I-5jährige Pflanzen, welche vollstän dig von der Sehütte befallen werden, während an älteren Pflanzen nur die untern Aeste die Erkrankung zeigen. Schwächere Pflanzen, so namentlich jene in diehten Saatkulturen und Saatbeeten, sterben ab, kräftigere erholen sich wohl wieder, doeh werden die Saatbeetpflanzen wohl stets als verloren bezw. unbrauchbar zu letrachten sein; zweijährige Föhren im $\mathrm{S}$ a a $\mathrm{tb}$ e e $\mathrm{t}$ schütten fast mausbleiblich. Für den Wirtsehafter aber entstehen dureh die bisweilen innerhalb weniger Tage siehtbar werdende Erkrankung seiner Föhrensaatbeete oft große Verlegenheiten.

Als Mittel der V o r be u g u $\mathrm{n}$ in Saatkämpen empfichlt M a y r die Ansaat vieler kleiner Kämpe oder die Trennung der Saatbeete in größern Kamp durch isolierende Itecken von Fichten, Thujen u. dgl., das Untergraben der getöteten oder

1) „Studien über die Schüttekrankheit" 1901 in Arbeiten aus der biologischen Abteilung für Land- und Forstwirtschaft am Kaiserl. Gesundheitsante.

2) „1st der Schüttepilz ein Parasit?" Forstw, Z.-BI. 1902 S. 473 und 1903 S. 547. 
stark erkiankten Pflanzen und Benutzung der Saatbeete zur Nachzucht anderer Holzarten.

Zur B e k äm p f $u$ Ing der Sehütte in Saatkulturen hat die Neuzeit ein Mittel durch Bespritzung mit Kupfersalzen gebracht ${ }^{1}$ ). Zur Verwendung kommt insbesondere die sog. Bordelaiser Brühe, lıergestellt dureh Lösung von $2 \mathrm{~kg}$ Kupfervitriol in $100 \mathrm{l}$ Wasser unter Zusatz von $1 \mathrm{~kg}$ friseh gebranntem Kalk, dann eine liupfersoda-Brühe - $1 \mathrm{~kg}$ Kupfersoda in $100 \mathrm{l}$ Wasser -, endlich auch Lösungen von Kupferzuckerkalk und Kupferklebekalk. Mit diesen Brühen werden die im 2. Lebensjalır stehenden Kiefernstreifensaaten in Sommer (Juni bis September) teils ein-, teils mehrmals mit Hilfe einer Rebenspritze bespritzt und hiedureh in vielen - nieht allen - Fällen gute Erfolge erzielt; in den Satbeeten dagegen an den im ersten Lebensjahr stehenden Pflanzen erweist sich das Bespritzen als erfolglos. - Eine Wiederholung des Bespritzens der Kulturen im 3. und 4. Lebensjahr ist bisweilen nötig. Die nieht geringen Kosten stehen der ausgedehnten Anwendung etwas im Weg.

\section{Erkrankungen durch Pilze ${ }^{2}$ ).}

$\$ 111$. Wie insbesondere durch Robert $\mathrm{H}$ a r t ig nachgewiesen wurde, werden eine nicht geringe Anzahl von Mißbildungen und Erkrankungen unserer Waldbäume durch auf und in ihnen wuchernde parasitisehe Pilze hervorgerufen. Teils auf dem Weg direkter Ansteckung, indem das sog. Hycelium des Pilzes unterirdiseh (weil es oberirdiseh dem rasehen V'ertrocknen ausgesetzt sein würde), von der Wurzel einer erkrankten Pflanze ausgehend, in jene der Naelıbarpflanze eindringt, teils dureh die Sporen, die in großer Masse erzeugten, sehr kleinen und daher durch Wind, dureh Tiere und Menschen leicht zu verschleppenden Fortpflanzungsorgane, gelangen die Pilze auf und in die Gewächse, wobei ihnen nicht selten Verwundungen irgend weleher Art den Zugang öfnen. In versehiedenster Weise beeinträchtigen sie dann die Wirtspflanze, bald nur unwesentliche Mißbildungen hervorrufend, bald das Holz zersetzend, bald den Baum, die Pflanze mehr oder weniger rasch tötend.

Es ist jedenfalls Aufgabe des Forstmannes, sich auch mit diesen Feinden des Waldes bekannt zu machen, umsomehr, als gar manchen dureh vorbeugende Maßregeln entgegengearbeitet, die weitere Verbreitung oder Wiederholung des Sehadens vermieden werden kann. Als solehe Maßregeln im allgemeinen bezeichnet Hartig die Erziehung genischter Bestände, wodurch jeder Baum gleiehsam dureh Nachbarbäume anderer Art isoliert, gegen direkte Ansteckung gesehützt werde; Wechsel der Holzarten auf Böden, die dureh Wurzelparasiten infiziert sind; Ausreißen erkrankter Pflanzen tunlichst mit den Wurzeln, Entfernung pilzkranker Stämme (Sehwammbäume ete.); lsolierung erkrankter Bestandspartien (bei Wurzelparasiten) durch Stichgräben.

Dem knappen uns hier gestatteten Raum entsprechend führen wir nur jene dureh Pilze hervorgerufene Kranklieiten an, welehe einerseits dureh häufiges Auftreten ins Auge fallen oder bez. deren uns llaßregeln des Sehutzes zur Seite stehen. Systematik und Lebensweise der Pilze gehören in das Gebiet der Forstbotanik.

$$
\text { a. Pilze auf Blätternund Nadeln. }
$$

$\$$ 112. Der Buehenkeim lingspilz, Phytoplstora omnivora (fribler fagi, weil zuerst an der Buche beobachtet), tritt vorwiegend auf den lieimpflanzen

1) Osterheld, Friedrielı, Die erfolgreiche Bekämpfung der Kiefernschütte. Forstw. Z.-BI. 1898 S. 399 .

2) Bezüglich der Besprechung der Pilze an dieser Stelle, statt bei dem Schaden durch Pflanzen, sei auf das in $\$ 85$ Gesagte verwiesen. 
der Rotbuche auf, ebenso aber auch auf jenen des Ahorns und sämtlieher Nadelhölzer, und äußert sich dureh Sehwarz- oder Schwarzfleckigwerden der Stengel, Samenlappen und ersten Blätter. Die befallenen Pflanzen gehen rasch zugrunde, die jungen Nadelholzkeimlinge sterben oft in großer Menge während des Aufgehens oder unmittelbar nach demselben ab. Feuchtwarmes Wetter befördert die Verbreitung sehr; die sieh raseh entwickelnden Schwärmsporen gelangen teils direkt, teils dureh Versehleppung (im Pelz der Mäuse, Kleidern der Mensehen) auf die Nachbarn wie auf entferntere Pflanzen, auch diese infizierend und tötend.

Vorsichtiges Ausziehen erkrankter Pflanzen im Saatbeet oder Uebererden beim Zusammenstehen vieler; Vermeiden der Wiederbenutzung eines infizierten Saatkampes z u r S a a t, da die Sporen mehrere Jahre keimfähig bleiben, werden als Sehutz- und Vorbeugungsmittel zu betraehten sein.

Als eine vorher wenig beobachtete Erseheinung ist in den Jahren 1908-19II der E i e h e n m e h $1 \mathrm{t}$ a $\mathrm{u}$ in ganz Deutschland wie den Nachbarländern epidemiseh aufgetreten, die Blätter und Triebe insbesondere von Eichen-Stockaussehlägen und jüngeren Pflanzen mit weißem Myeel überziehend. Blätter und Triebspitzen bräunen sich vielfach und werłen trocken, insbesondere die Johannitriebe. Die Zugehörigkeit des Pizes (ob Microsphära quereina oder Erysiphe Quereus) konnte, da bisher nur Konidien gefunden wurden, noeh nicht festgestellt werden. Gegenmittel sind nicht anwendbar ${ }^{1}$ ).

Häufig treten auf den Nadehn unserer Narkelhölzer, wie auf ren Blättem von Laubhölzern Erscheinungen auf, die man nach ihrer Färbung als R o s t erscheinungen bezeichnet hat. Als einer der verbreitetsten sei hier der Fi c h t en n a d el rost (Chrysomyxa abietis) genannt, der auf den jungen Nadeh der Fichte, insbesondere in Dickungen und Stangenhölzern, auftretend diese im infizierten Teil gelb färbt und zum Vertrocknen und Abfallen bringt. Die Erscheinung tritt in manchen Jahren in sehr bedeutendem Grad auf, in anderen nur sehr sehwaeh - die Witterungsverhältnisse zur Zeit des Ausfallens der Sporidien spielen hiebei offenbar eine sehr wesentliche Rolle; eine Gefahr, die zu Gegenmitteln aufforderte, bringt sie jedoeh nieht mit sich. Aehnliche Erscheinungen treten auf den Nadeln der Tanne und Lärehe auf.

Auch der lí i e f e r n it z e n s h or f (Lophodemium Pinastri) gehört hierher; auf den natürlich absterbenden Kiefermadeln allenthalben als Saprophyt auftretend, finden wir ihn auch parasitisch auf den grünen Nadeln junger Pflanzen, die bekannte und schon oben besproehene Krankheit der S c h ü t te erzeugend. (Vergl. $\$ 110$.

\section{b. Pilze an den Wurzeln.}

\$ 113. Der Honigpilzoder Ha llim ase h (Agarieus melleus) ist ein sehr verbreiteter Pilz, der teils saprophytisch an den abgestorbenen Stöcken und Stämmen von Laub- und Nadelholz lebt, teils als echter Parasit insbesondere jüngere Nadelholzpflanzen befällt und tötet, und als liulturverderber schon sehr schädlich aufgetreten ist. Die unterirdisch fortwachsenden schwarzen Mjycelstränge des Pilzes bohren sich in die Rinrle der Wurzeh ein, auf die sie stoßen, und verbreiten sich dann unter der Rinde emporwachsend als ein weißes hautartiges Gewebe, das Rindengewebe tötend. In Herbst entwickehn sich sowohl an infizierten Pflanzen und Stämmen, wie an im Boden wachsenden Mycelsträngen (Rhizomorphen) vielfach die großen

1) Bericlit der biol. Anslalt für Land- und Forslwirtschaft 1908. Forstl. naturw. Zeitschrift 1909. 1910 . 
hraungelben Schwämme, die Fruehttrüger, deren Sporen dureh lind und Tiere weiter verbreitet werden. Clarakteristiseh ist der starke HarzfuB, den die befallenen Pflanzen unmittelbar an und über der Erile zeigen. - Auch ältere Stämnı fallen diesem Pilz zum Opfer.

In Nadelholzkulturen nacht sich der Pilz durch das platzweise Erkranken und Absterben von Pflanzen oft selı lästig und veranlaßt wiederholte Naehbesserungen. Man wird die erkrankten Partien zur Vermeilung weiterer unterirdischer Ansteckung dureh Stieligräben isolieren, die liranken Pflanzen ausreißen und verbrennen, die Lücken wo m ö gli $\mathrm{e}$ h mit Laubholz statt mit aufs neue bedrohten Nadelıolzpflanzen ausfüllen.

Der Wurzelsell w m in (Trametes radieiperda oder Polyporus annosus) lebt ebenfalls saprophytisch wie als Parasit und ist als soleher ein gefährlieher Feind der Fichten- und Föhrenbestände, in welchen er als Ursache der Rotfäule uml des Absterbens zahlreieher Individuen auftritt, die Bestände licht und lückig machend. Die Ansteckung erfolgt in doppelter Weise, durch Sporen wie durch den liontakt der Wurzeln eines erkrankten mit jenen eines gesunden Stammes, wohei damn von der infizierten Wurzel aus die Fäulnis bei der Fjehte oft rasch im Stamm aufwärts dringt, während bei der Föhre dureh den starken Harzgehalt und das Ergießen des Harzes aus den zersetzten in die unzersetzten Schichten der Wurzelstoek verkient, worlurch dem Aufsteigen der Fäulnis im Baum ein Hindernis entgegengesetzt wird, der Stamm aber raseh abstirbt. - Das Mycel des Pilzes dringt teils ins Holz, dieses zersetzend, teils ins Bastgewebe, dasselbe tötend; die Fruchtträger des Pilzes elscheinen an Wurzelstock und den Seitenwurzeln, weiß, auf der sterilen Seite braun, aueh ringförmig in mannigfacher Weise gelärbt und von verschiedener Gestalt, und vegetieren $4-5$, Jahre fort.

Nittel gegen diesen Pilz stehen uns nicht zur Verfügung; vor den von H a r t ig empfohlenen isolierenden Stichgräben wird von anderer Seite (Kienitz, Möller) geradezu gewarnt, da sieh in ihnen aus allen etwa durchstochenen erkrankten Wurzeln üppige Fruchtkörper entwiekeln, die der Verbreitung des Pilzes durch Sporen Vorscliub leisten.

In Eichensaatbeeten wurde der E i c h e n w u r z e l t ö t e r (Rosellinia quercina) vielfaeh beobachtet, ein Pilz, der mit seinen Strängen die Wırzeln 1-3jälıriger Eichen umspinnt und, in die jüngsten Wurzelteile eindringend, diese in kurzer Frist tötet. Die Pflanzen verbleichen und vertrocknen, und insbesondere in feuchten Sommern nimmt die hrankheit oft größere Himensionen an. - Auch hier werden, da die Ansteckung nur unterirdisch durch Kontakt erfolgt, isolierende Stichgräben um befallene Pflanzengruppen sowie Ausgraben und Verbremen erkirankter Prlanzen als Gegenmittel empfohlen.

\section{e. Pilze a $\mathrm{m}$ Sta $\mathrm{mm}$.}

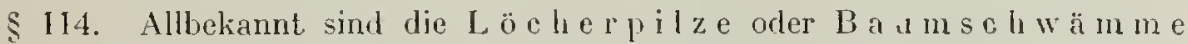
der Gattung Polyporus, die früher allgemein als ein Beweis für die Erkinankung eines Baumes und für auf und in dem abgestorbenen Holz lebende Saprophyten gehalten wurden, die aber zum Teil auch eehte Parasiten sind, deren Nyeel in Innem des Stammes wuchert, das Holz zersetzend, wälırend die verschieden gestalteten, häufig konsolenförmigen Fruchtträger außen am Stamm sitzen. - Da die Ansteckung dureh die in großer Zahl erzeugten Sporen erfolgt, wenn diese eine passende lieinstätte in Astwunden, Selıälıissen U. dgl. finden, so erscheint baldmäglichste Ent- 
fermung der Schwammbäume unsomehr geboten, als der ZersetzungsprozeB in deren Innerem rasehen Fortgang zu nehmen pflegt. Es sind Laub- wie Nadelhölzer, welche diese Erkrankung zeigen, und konmen einzelne Polyporus-Arten nur auf einer Holzart, andere an den versehiedensten Laub- und Nadehö̈zern vor.

Der L ärchenkrebspilz (Peziza Willkommii) erscheint als eine sehr häufige Krankheit der $\mathrm{j}$ ü n g e r n Lärchen, rliese verunstaltend, zum Kümmern und selbst Absterben bringend. Dringen die Sporen an irgend einer Wundstelle des Stammes ein, so entwickelt sich das llycel des Pilzes, wuchert unter der Rinde, deren Gewebe tötend und selbst ins Holz eindringend; infolge der Bildung von Korksehichten wird die Rinde ausgedehnt, platzt auf und es entsteht eine sog. Krebsstelle, auf der sich auch der Ausfluß von Terpentin zeigt und die sich alljährlich vergrößert, zuletzt bisweilen den Stamm umfassend und ihn dann tötend. Auf der krebsstelle nimmt man die Fruchtträger des Pilzes, rote Schüsselfrüchte, wahr, aus kleiner gelbweißen Pusteln sich entwickelnd, die bei Trocknis und Luftzug sehr leicht vertrocknen und absterben. Hartig glaubt in diesen leichten Vertrocknen den Grund zu finden, weshalb die Lärchen in den lichten Beständen und luftigen Hochlagen der Alpen von dem Pilz wenig zu leiden haben, während die Krankleit in allen feuchteren und dumpfigeren Lagen und in geschlossenen Beständen nicht selten in solcher Ausclehmung auftritt, daß hiedureh die Erhaltung der Lärche direht gefährdet erscheint. Vermeidung der eben bezeichneten Lagen und mögliehst vorwüchsiger Anbau der Lärehe im gemischten Bestand würden als Vorbeugungsmittel zu bezeichnen sein ${ }^{1}$ ).

Der 'T a n n e n p i l z (Aceidium elatinum) erzeugt zunächst, wenn seine Sporen in eine Wundstelle eines Tannenastes eindringen, durch sein Myeel die bekannte eigentünliche Erscheinung der sog. Hexenhesen, deren oft auf einer Pflanze, einem Stämmehen eine größere Anzahl erseheint, beulenartige Auftreibung und Wucherung an der befallenen Stelle hervorrufend und von dieser Stelle aus, vielleicht auch durch direkte Infektion von Wundstellen an den Stamm gelangent. Hier erscheinen dam die gleichen, den ganzen Stamm umfassenden Anschwellungen, die später aufplatzend die sog. Krebsheulen erzeugen; der Stanm wird an der betr. Stelle schadhaft, das Ilolz, durch Wundfäule oder eindringende andere Parasiten weiter zersetzt, zu Nutzholz untauglich, und bei Sturm oder bei Schneebelastung sehen wir die Stämme nicht selten an der befallenen Stelle abbrechen. Bei dem häufigen Auftreten des Iírebses in Weißtannenbeständen (Schwarzwald) kann der Schaden ein sehr bedeutender werden; man sucht ihn dureh sofortige Entfernung jeder krebskranken Tanne, insbesondere bei Durehforstungen, sowie durels tunliehste Beseitigung der Hexenbesen in Walde zu mindern.

Der lí efernbaumsehwamm (Trametes pini), vorzugsweise in den ältern Kiefernbeständen Norddeutsehlands auftretend, selten in Süddeutschland, inı ührigen auch an Fiehten, Lärehen und Tannen beobachtet, erscheint als Ursache der sog. Ring- oder Kernschäle, die fast immer von den Aesten, also der lírone der Stämme, ansgeht. Seine Sporen, auf frische, durch Harzüberzug nicht geschützte Astwunchen gelangend, lassen den Kieimsehlauch ins Innere des Stammes eindringen, und da sich das Mycel mit größerer Geschwindigkeit innerhalb des Jabresringes als seitlich verbreitet und das $\mathrm{Holz}$ zersetzt, so entsteht hiedurch die Ringsehäle. Die nach reicher Wucherung des llycels im Inmern an jenen Stellen, wo tote Ast-

1) B o r g g eve trilt dieser Ansicht entgegen, hält vor allem die Lärchenmotte (s. § 60 ) für die Ursache des schlechlen Gedeihens so vieler Lärehen. Vergl. A. F.- u. J.-Z. 1871. S. 133 und F.-Bl. 1875. S. 195. Naeh C i e s l a $\mathrm{r}$ s Angabe erseheint der Pilz in den Alpen an den Lärchen sehr häufig als unschädlieher Astkrebs an alsterbenden Aesten. 
-tummel die Splintsehicht durehsetzen, erscheinenden konsolenförmigen Fruehtträger fordem zu rascher Entfermug der infizierten Stämme auf. Iter Scharlen ist bei der großen Verbreitumg des Bammschwammes ein anßerordentlich großer, da die lefallenen Stämme ganz orler grolienteils zu Nutzholz unbrauchbar sind; gibt doch If ö $1 \mathrm{l}$ e r den Anfall an Sehwammholz in den preuBisehen Staatsforsten 1905-1908 auf rund 4 Millionen Festmeter an! Angesichts dessen hat die preuß. Regierung, eine intensive Bekänpfung dureh Aushicb ter hefallenen Stämne mud, wo dies nicht tunlich, Bescitigung der Pilzkonsolen unter Bestreichung der Anheftungsstetlen mit Faupenleim angeordnet ${ }^{1}$ ). Jie abgestoßenen fonsolen sind zu verbrennen.

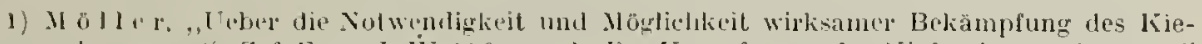

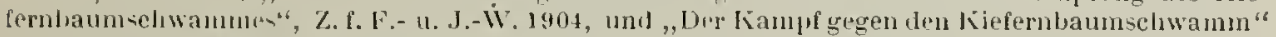
Z. f. F.- II. J.-II, 1910, S. 130. 


\title{
VIII.
}

\section{Die Wildbach- und Lawinenverbaum g.}

Von

\author{
Ferdinand Wang.
}

$\S 1$. E in le it u n g. Die außerordentlichen Hochwasserverhecrungen, welche namentlieb in den letzten Dezennien des verflossenen Jahrhunderts in rascher Folge das europäische Festland heimgesucht haben, lenkten die Aufmerksamkeit auf cine früher wenig geübte kulturelle Tätigkeit, auf die Verbauung der Wildbäche.

Seither vollzog sich auf dem in Rerle stchenden Gebiete ein außerordentlicher Umschwung, es entwiekelten sich Theorie und Technik rler Verbaung, und die gemachten reiehen Erfahrungen erwiesen die Zweekmäßigkeit und Notwendiglicit rationeller Verbauungsmaßnahmen.

Die zunchmenden Lawinenschäden erfordern ein energisehes Vorgehen aueh auf diesem Gebiete, welches sich gleichfalls einer steten technisehen Entwicklung erfreut.

IVenn Natur und Technili dieser beiden kulturellen Maßnabmen in dem vorliegenden Handlueh in kürze erörtert werden sollen, so gesehieht dies aus dem Grunde. weil mit der burchführung derselben in einzelnen Staten, so insbesondere in Oesterreich und Frankreich, teilweise auch in der Schweiz, del Forstmann betraut ist, rer ïbrigens auch allenthaben in die Lage versetzt werden kann, wenigstens kleine Lebel rasch, biltig und wirksam zu heilen und hiemit großen Kiatastrophen in manehmal ganz unberechenbar günstiger Weise vorzubeugen.

Er soll deshalb zum mindesten im a $1 \mathrm{lg}$ em e i n e $\mathrm{n}$ üher dic einschlägigen Verhältnisse unterrichtet sein, und hiezu sollen ihm die folgenden, dureh ten vorgeschriebenen Raum in enge Grenzen gezogenen Ausführungen dienen.

Dieselben bilden einen dureh dic Erfahrungen der letzten Jahre bereieherten Jurzen Auszug des bei S. Hirzel in Leipzig in den Jahren 1902 und 1903 ersehienenen Werkes des Verfassers: „Gr un d ri $B$ d e r W il d b a c h ver b a u u ng " I. und 11. Teil.

\section{A. Die Wildbaelıverbaunng.}

\$2. Die Gharakteristik und Einteilung der Wildbäche. Aus naheliegenden Gründen ist es nieht leieht möglich, mit kurzen Worten eine allge- 
mein geltende, sich allen Verhältnissen anschmiegende und erschöpfende Charakteristik Jer Wildbäche aufzustellen. Zeigen schon die Bäche der Alpen je nach den geognostischen, oro- mol hydrographischen Verhältnissen oft wesentlich von cinander verschiedene Eigenschaften, so muß selbstverständlich auch der Bach des Nittelgehirges, der Bach der Niederung, wenn zum Wildbach geworden, ganz hesondere, unterscheidende Merkmale an sich tragen.

Immerhin drückt die Bezeichnung , $W$ il d b a c h" allen jenen Gewässcrn, welche man mit Recht in diese Kategorie einreiht, einen gewissen Stempel auf, der sie vielleicht allgemein am besten, wenn auch nicht erschöpfend charakterisiert.

Ohne die speziellen Verhältnisse näher zu kennen, wird man unter der Bezeichnung , W il d b a $c h "$ ein Gewässer vermuten, das nicht ununterbrochen, sondern nur bei gewissen Anlässen verhältnisunäig rasch und mit ganz außerordentlicher Liraftentwickelung dic Wässer talabwärts führt und sich eben dadurch seiner Ungebung gefahrbringend zeigen muB. Dieses plötzliche oder doch sehr rasche Entfesseln ist es, das so eigentlich fem Bache den Charaliter des Wildbaches gibt und dem auch die meisten und größten Verhcer:ingen zngeschrieben werden müssen.

Bringt allein schon die plötzliche oder doch sehr rasche Zufuhr von großen Wassermassen Unzuliommlichlieiten aller Art mit sich, wje furchtbar müssen diese letzteren erst werden, wem dem entfesselten Elemente noch Schotter, Schutt, Gerölle usw, wie dies in der Regel der Fall ist, beigemengt sind! Abgesehen von vielen schädlichen Folgen, als Verklausungen, zahlreichen Ufereinbrüchen usw., die eine solche Beimengung haben kann, muß auch die Ablagerung dieser letzteren besonders gefahrbringend sein.

Einer jeden, wenn man so sagen darf, krankhaften, raschen Entfesselung des Wildbaches muß auch verhältnismäBig rasch wieder ein - zumeist sehr teuer crkaufter - Zustand der Ruhe folgen. Aus verschiedenen Grïnden bricht sich oft schon während des Verlaufes der Katastrophe die Kraft der Wässer des Wildbaches, und gleichsam erschlaffend läßt letzterer die nitgeführte Last, unbelümmert um die Oertlichkeit, sinken, ohne imstande zu scin, sie schadlos an andere Wässer abzugeben. Diese Ablagerung, Alluvion, macht nun aber die Wildbäche besonders beachtenswert unl sie gehört zu den gefährlichsten Folgeerscheinungen ihrer Tätiglicit. Aus dem Vorstehenden kann der Schluß gezogen werden, daß einerseits rasche Entfesselung und Zufuhr von großen Wasser- und Geschiebemassen oder von beiden zugleich, dann andererseits in der Regel gefahrvolle Ablagerung der letzteren als die wesentlichsten Eigenschaften der Wildbäche anzusehen sind.

Diese sind wolıl auch in größerem oder geringeren Maße den Flüssen eigen ${ }^{\mathbf{1}}$ ). Es darf aber nicht außer acht gelassen werden, daß diese wildbachartigen Flüsse ihren Charakter zumeist dem Charakter jener Wildbäche verdanken, aus welchen -ie sich zusammensetzen, und man muß sie umsomehr aus der Reihe der ejgentlichen Wildbäche ausscheiden, als sie sich von den letzteren in einer Richtung ganz wesentlich unterscheiden. Während die eigentlichen Wildbäche mit verhältnismäßig kurzem Laufe und steilem Gefälle vorherrschend das Bestreben zeigen, ihre Sohle zu vertiefen, sich also kolkend verhalten, zeigen die wildbachartigen Flüsse mit verhältnismäßig längerem Laufe und geringerem Gefälle den Charakter des Flusses, d. h. sie erhöhen vorherschend ihr Bett und verhalten sich entweder gar nicht oder doch nur in geringem Haße auf kiuzen Strecken kolkend.

1) Prof. Dr. Breitenlohner, "Wie Murbrüche entstehen", W'ien 1883. 
Diese wildbachartigen Flüsse haben sehon Fabre ${ }^{1}$ ) und Surell ${ }^{2}$ ) von den eigentlichen Wildbächen geschieden. Ersterer nenut sie zum Untersehiede von torrents. torrents-rivières, letzterer rivières torrentielles.

Die vorstehende allgemeine Charalsteristik der Wildbäche erfährt eine wesentliche Ergänzung, wenn die von einigen Autoren getroffene Einteilung berücksichtigt wird.

Josef Duile ${ }^{3}$, der nur die Verlıältnisse Tirols vor Augen hat, teilt die Wildbäche wie folgt ein:

1. In solehe, welehe ununterbroehen das ganze Jahr hindurch flieBen; sie werden entweder von immerwährend tätigen Quellen oder von Seen und Gletschern gespeist;

2. In solche, welche erst bein Eintreten der wärmeren Witterung auftreten und mit der kälteren Witterung zu versiegen beginnen; ihnen gibt die Wärme, welche den auf den Gebirgen angehäuften und teilweise in Eis übergegangenen Schnee auflöst, ilır Entstehen; ilıre Wassermasse steht daher immer in Verlıätnisse zu dem Wärmegrade in den Sommermonaten und der den Winter hindurch gefallenen Vasse des Schnees auf den Gebirgen;

3. in solche, die erst bei länger andauemdem, warmen Winde, außerordentlich warmen Regen, bei Hagel oder Wolkenbrüehen entstehen.

So sehr nützlich nach Anschauung Duile's die Wildbäehe der beiden ersten Arten unter gewöhnlichen Verlältnissen dem Menschen durch fruchtbare Bewässerung der Fluren usw, werden können, so schädlieh müssen sie, in tosende Wildbäche ungewandelt, sich erweisen. Da die Ursachen des Entstehens der Wildbäche der dritten Art zumeist nur in einzelnen Gegenden vorliegen, so sind die Verheerungen auch in den meisten Fällen nur partiell. Selbstverständlich werden aber durch diese Ursachen auch die Bïche der beiden ersten Arten in verheerende Wildwässer verwandelt.

Von einem ganz anderen Gesichtspunkte geht Surell ${ }^{2}$ ) bei der Kilassifikation aus.

Je nach der Lage des Aufnahmsbeckens unterscheidet er:

I. Wildbäehe, die von einem Sattel ausgehen und in ein eigentliches Tal fließen;

2. solehe, die von einem Gebirgskann ausgehen und in der Linie des stärksten Gefälles herabstürzen und

3. solehe, deren Ursprung unterhalb des Gebirgskammes und auf den Abhängen selbst gelegen ist.

Demontzey ${ }^{4}$ ), der einstige Leiter des Verbauungswesens in Frankreieh, teilt die Wildbäche in zwei große Kategorien ein.

Die erste umfaßt alle jene Wildhäche, deren Sehuttmassen lediglieh von der Unterwühlung der Gel,irgshänge herrülıren. Er nennt sie die unterwühlenden Wildbäche, ,torrents à affouillements". Zur zweiten Kiategorie zählt Demontzey jene Wildhäehe, die vorwiegend Verwitterungsprodukte führen, oder die von Gletsehern gespeist werden. Die ersteren nennt er ,,torrents à easse", die Wildbäche der Schutthalden; rie letzteren ,turrents glaciaires“, die Gletseherbäehe.

Eine weitere Einteilung ist diejenige von Gosta de Bastelica ${ }^{5}$ ) in einfache Wildbäche, ,torrents simples“, mit nur emer Schlucht, und in zusammengesetzte Wild-

1) Fabre, ,Essai sur la théorie des lorrents et de rivières". Paris 1797.

2) Alexandre Surell, ,Etude sur les torrents des Hautes-Alpes". Paris $18+2$.

3) Josef Duile, ,Ueber Verbaung der Wildbäche in Gebirgständern". Innsbruck 1826.

4) P. Demontzey, "Traité ıratique du reboisement et du gazonnenril des montagnes".

t'aris 1878. In deutscher Uutbersetzung ron Dr. A. Freiher'n von Seckenrlorff. Wien 1880.

5) Costa de Bastelica, ,Les torrents, leurs lois et leurs effets". Paris 1874. 
Jäche, "torrents composés", mit zwei oder nehreren Schluchten. Demontzey fügt diesen beiden Arten noch eine dritte, den sogenamnten muschelförmigen Ausriß, „la combe", bei.

Gestützt auf die Verhältnisse der österreichischen Monarchie hat Ministerialrat Johann Salzer ${ }^{1}$ ) die Wildbäche in zwei große Gruppen, und zwar in die Wildbäche des Hochgebirges und in jene der Berg- und Hügelländer - Böhmen, Mälıren, Schlesien. Galizien, Bukowina - eingeteilt. Die Wildbäche der ersten Gruppe werden von ihın in vorwiegend unterwühlende und in vorwiegend Verwitterungsłrodukte führende geschierlen. Zu den letzteren werden ausschließlich die Wildbäche der Kalkalpen gerechnet.

Die Wildhäche des Berg- und Hügellandes mit vorwiegend mäßigem Gefälle haben brüchige Stellen zumeist mur in den höheren Lagen, weisen im Unterlaufe vorherrschend Ufereinbrüche im Diluvium auf und zeichnen sich besonders durch Zufuhr von großen Wassermassen aus. Von den Wildbächen des Hochgebirges sind sic zudem noch in der Regel dadurch unterschieden, daß bei ihnen die Gebiete der Erosion und Alluvion nicht so scharf getremnt sind wie bei diesen.

Noch sei hemerkt, daß Professor A. Freiherr von Seckendorff ${ }^{2}$ ) die sogenannten Gießt,äche von den Wildbächen trennt. Es sind dies seiner Ansicht nach Bäche, die meist über festes Gestein herabstürzen, häufig Wasserfälle bilden und selten außer Wasser- noch Erd- und Schuttmassen mit sich führen. Nach Seckendorff kann ein Gießbach niemals zum Wildbache werten. Die Gießbäche sind übrigens nichts anderes als die sogenannten „ruisseaux "Surell's, der die Gewässer außer in die bereits namliaft gemachten .,rivières torrentielles" unıl ,torrents" noch in , ,rivières", das sind Flüsse und in ,ruisseaux", das sind Bäche, unterteilt. Demontzey fügt allen diesen noch die Runse, den Wasserriß, ,ravin" hinzu.

Die vorstehend namhaft gemachte, allerdings nicht erschöpfende Einteilung der Wildbäche hat mehr oder minder ihre Berechtigung. Die Einteilungen nach Surell, Bastelica und selbst nach Duile sind ron melı untergeordneter Bedeutung, weil sie den Charakter des Baches nicht genug klarstellen, wenigstens nicht so klarstellen, daß nach ihm auf die allenfalls nötigen orler ratsamen Gegenmaßregeln geschlossen werden könnte.

Es bilden diese Einteilungen überdies nichts Feststehendes und es kann ihre Anwendung häufig auf Schwierigkeiten stoßen.

Einen wesentlich höheren Wert dagegen haben die Unterteilungen nach Demontzey und nach Salzer. Sie geben wenigstens in großen Zügen den Bachcharakter an und lassen auf die entsprechenden Gegenmaßregehn schließen.

Offenbar gebülırt Demontzey das Verlienst, daß er der erste war, welcher die eigentliche Tätigkeit des Wildbaches als für die Einteilung maßgebend erachtete. Daß er die sogenannten Gletscherbäche zu den vorwiegend Verwitterungsprodukte führenden Wildbächen zälılt, ist nicht ganz gerechtfertigt, da Gletscherbäche sich auch vorwiegend durch Unterwühlung auszeichnen können und daher bei ilmen im allgemeinen das anzuwendende System der Verbaung zweifelhaft erscheint.

Einen großen Vorzug hat rlie Einteilung nach Salzer, weil sie auch rlie Wildbäche der Berg- und Hügelländer ins Auge faßt, was um so gerechtfertigter ist, als bei diesen in der Regel das System der Verbauung mehr oder weniger abweichend ist von

1) Johann Salzer, ,Leber den Stand der Wildbaehverbauungen in Oesterreich". Vortrag. gehalten im österreichischen Forstkongresse. Wien 1886.

2) A. Freikerr von Seckendorf, ,Verbaung der Wildbäche, Aufforstung und Berasung der Gebirgsgründe". Wien 1884. 
jenen Systemen, die bei der Verbauung der Wildbäche des Hochgebirges in Anwendung zu konmen haben.

Wenn an dieser letzteren Einteilung festgehalten wird, so sollen doch bej den Wildbächen des Hochgebirges die geognostischen Verhältnisse deshalb außer Betracht bleiben, weil sich nicht allein die Wildbäche des Kalk-, sondern auch jene des kiristallinischen oder des Schiefergebirges vorwiegend durch Führung von V'erwitterungsproduliten auszeichnen können.

Die von Surell und Seckendorff getroffene Einteilung in Gießbäche und IVildbäche, ,ruisseaux " und ,torrents", hat nur insoferne Berechtigung, als die ersteren aus gewissen Gründen zeitweise den Charakter der letzteren tatsächlich nicht besitzen. Die allgemeine Behauptung aber, daß Gießbäche njemals den Charakter der IVildbäche annehmen können, erscheint zum mindesten sehr gewagt, denn so mancher der heute wütenden Wildbäche war vielleicht vor nicht geraumer Zeit zu den Gießbächen zu zählen.

\$. 3. Die Einteilung des B a chverla uf es. Duilo (vergl. Anm. 3, S. 294) unterschcidet innerhalb des Niederschlagsgebietes drei Sondergebiete, welche von ihm in weiteren Verlaufe seiner interessanten Schrift als ,,Sammelbecken“, weiters als ,"Tobel" oder ,Klamm" und sehließlich als "Ablagerungsgebiet" oder ,Ausgußbetl" bezeichnet werden. Die Beschreibung lautet: ,Man denke sich nur enge, auch bis 12 Stunden lange Täler, eingeschłossen von Höhen, steilen Gebirgen, deren Gipfel vielfältig mit ewigem Eis bedeckt sind, und welche da, wo sich das Tal schlieBt, das ist in Hintergrunde, öfters $\mathrm{T} \mathrm{r}$ c h $\mathrm{te} \mathrm{r}$ von ungeheurer Ansdehmung bilden und nicht selten an Ferner grenzen; man denke sich weiters diese Gebirge vielfältig velwittert, die Felsmassen, aus denen sie bestehen, noch locker, unzusammenhängend, ihre jäh sich gegen das Tal abdachenclen Flächen der sie schützenden Decke vielfältig beraubt, das Gefälle des Tales selbst bis zur Ausnündung äußerst groß: welche Verwüstungen müssen dann woh! in solchen Tälern erfolgen, wem Schnee und Eis, in den Schluchten jalırelang verborgen liegend, auf einmal schmelzen; wenn bei andauerndem, warmem Regen die große Wassermasse in die schon damit gesättigten steilen Flächen nicht mehr eindringen kamm, sondern mit Gewalt sich über dieselben und über Felsen herabstürzt, Schotter, lockere Erde, entwurzelte Bäume, Felsstücke und Steine in das tiefe Tal fortreißt; wenn hier dam das sich sammehnde Wasser - durch des Tales Fallen an Geschwindigkeit immer zunehmend - diese schrecklichen Massen unter fürchterlichem Getöse mit sich fortwälzt, bis es dieselben da, wo das Gefälle sich mindert, d a s T a 1 e r w e i t e r t, daher das Wasser an liraft abnimmt, liegen läßt."

Vollkommen übereinstimmend mit der Anschauung Duiles ist jene Surells (vergl. Anm. 2, S, 294). Er unterscheidet das Aufnahmsbecken, ,bassin der réception", den Abflußkanal, ,canal d'écoulement", und das Ablagerungsgebiet, ,lit de déjection". Während in Aufnahmsbecken die Wässer vorwiegend unterwühlen, im Ablagerungsgebiete, wie der Name sagt, vorwiegend ablagern, ist nach Surell im mittleren Gebiete, im Abflußkanale, eine wesentliche Tätigkeit der Wildwässer nicht zu konstatieren, das Gebiet also in gewissem Sinne neutral zu nennen. Dieser AbfluBkanal wircl von Costa rle Bastelica (vergl. Anm. 5, S. 294) als ,Schlueht", , ,gorge", von Cuhnann ${ }^{1}$ ) als Sanmelkanal bezeichnet.

Demontzey (vergl. Anm. 4. S. 294), der für das Ablagerungsgebiet den Ausdruck „ê̂ne de déjection", Sehuttkegel, gebraucht, akzeptiert die Bezeichnung ,gorge",

1) Culmann, „Bericht an den schweizerischen Bundesrat über die Untersuchung der sehweizerischen Wildbäche, vorgenommen in den Jahren $1858,1859,1860$ und 1863". Zürich 1864. 
Schlucht, nach Bastelica, welch letztere seiner Ansicht nach wenigstens rudimentär hei jedem Wildbach vorkommt. Dagegen ist er mit der Surcllschen Charakterisierung des Abflußkanales insoferne nicht einverstanden, als sich seiner Erfahrung nach, die man übrigens nicht selten selbst machen kann, die Ablagerung durch cinen Teil orler selbst durch die ganze Schlucht hindurch vollziehen kaun.

Dr. Paul Lehmann ${ }^{1}$ ), der die Bezcichnungen ,.Schuttkegel", ,.Sanunelgebict"“ und .,Sammelkanal" gebraucht, scheint innerhalb der beiden letzteren Gebiete die Neigung des Wassers zur Sohlenverticfung, Kolkung, zu erkennen; die diesbezügliche Stelle lautet:

"Noch mannigfacher als bei den Schuttkegehn sind die Erscheinungen im Sammelgebicte und im Sammelkanale der Wildbäche; doch treten uns überall, am Gletscherbache, wie an der öden Rüfe, die nur bei Regenwetter ,.geht", ein starkes Gefälle, steile L'fer und infolgedessen die Neigung des Wassers zur Sohlenvertiefung, Iiolkung, als bezeichnende Ierkmale cutgegen".

Edmund Graf ${ }^{2}$ ) akzeptiert die Duilesche Einteilung, während Martin Kowatsch ${ }^{3}$ ) den Wildbach in drei Zonen scheidet und zwar:

1. Zone des absoluten Abtrages, den obersten Teil des Wildhaches umfassend.

2. Zone des absoluten Auftrages im untersten und

3. Zone der Nullarbeit im mittleren Laufe des Wildbaches.

Offenbar ist diese Einteilung in Lebereinstimmung mit jener von Surcll.

Kowatsch bemerkt überdies, daß die 3 . Zone, also jene der Nullarbeit, dann als die für die Verbauung tauglichste angesehesı werden müsse, wenn das Lobel nicht am Lrsprung behoben werden kann.

Während G. R. Förster ${ }^{4}$ ) mul oberflächlich rom Schuttkegel, Sammel- oder Einzugs- und rom Durchflußgebiete spricht, äußert sich Elias Landolt ${ }^{5}$ ) in eingehender Weise hinsichtlich des Bachverlaufes und unterscheidet an den größeren Bächen des Hochgebirges in der Regel vier wesentlich von einander abweichende Tejle, und zwar:

I. Das Sanmel- oder Einzugsgebiet, gewöhnlich von einer großen Zahl von Zweigen des Hauptbaches durchschnitten. Es fällt im Hochgebirge auf die als Weide benutzte obere Terrasse, beziehungsweise in die unwirtlichen Gegenden (Felspartien, Gletscher und Schneefelder), in den Vorbergen in die obere Waldregion. Die einzelnen Zweige der Bäche sind. wenn nicht von Quellen, Gletschem, Schneefeidern gespeist, in der Regel wasserarm, oft sogar trocken, füllen sich aber bei Schneeschmelze, Gewittern usw. rasch und führen dann den Runsen und Schluchten jn Erosionsgebiete große Wassermassen und Geschiebemengen zu. In der Regel liegen dic sich oben oder in der Schlucht zu ejnem Bach vereinigenden Gräben in einer weiten Mulde.

2. Das Erosions- oder Auswaschungsgebiet, in den der Hauptbach nicht selten auch noch Seitenbäche aufnimmt. Es befinclet sich zum größten Teile in der Waldregion, weil die steilsten Partien der Hänge dieser angehören. Hier fließt das Wasser durch enge, tief eingeschnittene Runsen, deren Einhänge häufig "v`rrutscht" und unproduktiv sind, und nimmt den größten Teil des Materiales auf, wclches bis ins Tal befördert wird und dort den scluuttkegel bildet.

1) Dr. Paul Lehmann, „Dje Ẅildbăche der Apen“". Brèlau 1879.

2) Edmund Graf, , Waldverwōstung und Ilurbrüche“. Wien 3879.

3) Martin Kowatseh, ,Das obere Fellagebiel im Kanaltale in Kärnten und die dorligen Wascerbaulen".

4) G. R. Fōrster, ,Das forslliche Transportwesen". Wien 1885.

5) Elias Landolı, „, Die Băclıe, Schneelawinen und Sleinschläge und die Mlillel zur lerminderung der Schädigung durch dieselben". Zürich $188 \%$. 
3. Den Schuttkegel, das Gebiet der Ablagerung, in dem das Bachbett häufig böher liegt als tlas ancrenzende Kulturland.

4. Die Bachstrerke im Tale, die je nach den Gefällsverlıältnissen sehı verschieden gestaltet ist, oft auch ganz fehlt und nicht selten zur Versumpfung Veranlassung geben kamn.

Eine ähnliche Einteilung in 4 Teile trifft auch Thiéry ${ }^{1}$ ), doch scheidet er das eigentliche Aufnahnsgebiet, ähnlich wie dies Scipion Gras ${ }^{2}$ ) tat, nach vier charakteristischen Typen. Der ersten Type gehören jene Gebiete an, die von steilen, vielfach durchfurchten, oft viele hundert Meter hohen Felsen umrahmt sind. Die Möglichkeit des raschen Sammelns der Gewässer, wie nicht minder der sich stetig fortsetzende, den Tälern Material in großen Mengen liefernde Verwitterungsprozeß, lassen derartige Wildbäche gefälırlich erseheinen.

Die Aufnahmsgebiete der zweiten Type liegen in leicht verwitterbarem Boden, zeigen immer die Form eines durch einen Hals geschlossenen Triehters und haben, wenn kahl, stets das Bestreben, sich durch Einsturz der Wandungen zu vergrößem. Die Aufnahmsgebiete der dritten Type vereinigen die Charaktere der beiden vorhergehenden. Sie bestehen aus nackten Felsen, an deren Fuß die Wässer in leicht verwitterharem Gesteine eine Vertiefung, ähnlich dem Trichter der vorhergehenden Type, ausgehöhlt haben. Auch Wildbäche dieser Type werden als sehr gefährlich bezeichnet. Die Wildbäche der vierten Type zeigen ein hochgelegenes, im allgemeinen von einem Gebirgspaß ausgehendes Tal, in welches sekundäre Wildwässer münden.

Jedes der letzteren hat ein verschiedenes, einer der vorhergehenden Typen angehöriges Aufnalimsgebiet; alle sind untereinander durch einen gemeinsamen Schlauch verbunden.

Wie zu entnehmen, ist die Frage der Einteilung res Wildbachverlaufes zwar schon vielfach erörtert worden - des Raumes wegen muß manch andere Einteilung übergangen werden — doch bieten alle diese Einteilungen nichts Feststehendes, da die obwaltenden Verhältnisse nicht nur teilweise, sondern auch gänzlich abändernd zu wirken imstande sind. Im allgemeinen kann behauptet werden, daß die Verhältnisse der Talbildung in der Kalkalpenwelt wesentlich verworrener sind, als jene in der Urgebirgswelt, so z. B. innerhalb der Kette der Zentralalpen. Diese Verworrenheit der Talbildung, welche in den höheren Gegenden in völlige Unbestinntheit ausartet, ist für sich ein charakteristischer Zug der Kalkalpenwelt.

Nichtsdestoweniger lassen sich unter allen Umständen, wenigstens bei den Wildbächen des Hochgebirges, zwei scharf getrennte Gebiete unterseheiden und zwar:

1. Das Gebiet der Materialbeschaffung. "Denurlation", zumeist das ganze Niederschlagsgebiet unfassend, und

2. das Gebiet rer Materialablagerung, ,Akkumulation“, der Scluttkegel.

Bei den Bächen des Mittelgebirges sind beirle Gebiete nicht so scharf getrennt und bei jenen rer Niederung vielleicht gar nicht zu unterscheirlen.

Eine ähnliche Einteilung hat auch Schindler ${ }^{3}$ ) getroffen, der das erstere Gebiet als jenes der" „Erosion" bezeichnet, was jedoch nicht immer zutreffend ist, da sich dort mitunter auch andere Prozesse materialschaffend erweisen können.

1) E. Thiéry, ,Restauration des nontagnes, correction des torrents, reboisenuent". Paris 1891.

2) Seipion Gras, "Etudes sur les torrents des Hautes-Mlpes". Annales des ponts et chaussées. Paris 1857.

3) A. Schindler, ,Die Wildbach- und Ftubverhaung nach den Gesetzen der Natur". Zürich 1889. 
\$4. Das Herliommen des Gesehiebes. Von ganz hesonderer Bedeutung erscheint die den Wildbächen zukommende Eigenschaft der starken und unregelmäBigen Geschicbeführung, bei deren Beurteilung das Augenmerk in erster Linie dom Herkommon der Geschiebemassen zugewendet werden muß.

lm großen und ganzen ist das in den Kinmsalen der Wildbäche angehäufte und von diesen geführte Geschiebe als das Resultat, sei es der V e rwit t e r ung, sei es der E r o sio noder auch der U n t e r w ï h I u ng, bezichungsweise. Durchfeuchtung lockerer, hangender Schichten anzusehen.

Die Verwitterung liefert den Wildbächen bedeutende Geröllmassen. Hır Fortschritt hängt nicht allein von der geognostischen Beschaffenheit des Grundgesteines, sondern auch von dem Kilina, der Hölıenlage, der Exposition und insbesondere von der Beschaffenheit der Bodendecke ab.

Was die geognostische Beschaffenheit des Grundgesteines anbelangt, so leisten die kristallinischen Massengesteine, insbesondere der Granit, dem Verwitterungsprozesse im allgemeinen großen Widerstand. Jhen zunächst die kristallinisehen Schiefer und unter diesen namentlich der Gneis. Verhältnismäßig geringen Widerstand setzen der Verwitterung die Sedimente, so der Tonschiefer und die sandsteinartigen Gesteine, in den einer Vegetationsdecke entbehrenden Hochlagen auch die Kalke entgegen.

Die allgemeinen klimatischen V'erhältnisse könmen selbstverständlich nicht olme Einfluß auf das Fortschreiten des Verwitterungsprozesses bleiben. Oertlichkeiten mit häufigen und reichlichen Niederschlägen, Winden, Gewittern, Hagel unı insbesondere mit raschem Temperaturwechsel über und unter dem Eispunkte und daher sehr vermehrter Wirkung des in die Gestemsritzen dringenden und dort frierenden Wassers, müssen als dem Fortschritte des Verwitterungsprozesses günstig bezeichnet werden.

Zum großen Teile hängt jedoch die Einwirkung der klimatischen Verhältnisse von der Höhenlage und der Exposition ab.

Hinsichtlich der Höhenlage erscheint erwiesen, daS die Region unmittelbar unter der Schneegrenze die größte Zertrümmerung erleidet. Hier mangelt es zumeist an der schützenden Bekleidung des Bodens mit Vegetation oder mit Schnee und hier ist der häufigste Wechsel der Temperatur ober und unter dem Nullpunkte zu konstatieren. Das ist aber auch jene Region, in welcher in der Regel das eigentliche Sammelgebiet der Wildbäche gelegen ist.

Was die Exposition ambelangt, so sind Südabhänge der Verwitterung mehr ausgesetzt als die nördlichen. Der Grund liefür ist namentlich darin zu suchen, daß die Schneedecke schon im zeitlichen Frühjahre durch die mehr senkrecht auffallenden Sonnenstrablen und den direkten Anprall des Südwindes entfernt und die Einwirkung der schädlichen Nachtfröste begünstigt wird. Auch ist zu berücksichtigen, daß die südlichen Hänge in der Regel in größerer Ausdehnung und oft bis in die höchsten Lagen der Agrikultur gewidmet sind, was bei allzu intensiver Ausnützung des Bodens häufig eine Verschlechterung der Standorte und cin Herabdrücken der Vegetationsgrenze mit sich bringt.

Einen wesentlichen Einfluß auf die Art, den Grad und Fortschritt der Verwitterung übt die Beschaffenheit der Bodenoberfläche aus. Der natürlichen Kileidung beraubt, ist der Boden in erhöhten Maße und schutzlos der zerstörenden Einwirkung der Atmosphärilien, der Einwirkung der' Somenstrablen preisgegeben, der 'Temperaturwechsel wird fühlbarer und der Frost vermag die Verwitterung wesentlich zu fördern. 
Hieraus geht hervor, welch hochwichtige Aufgabe der V'egetationsdecke im Wildbachgebiete linsichtlich der Hintanhaltung der Geschiebebildung und hinsichtlich der Regelung der Geschiebeabfulır zufällt, und wie sehr es nötig ist, die Besscrung der kulturellen Verhältnisse im Niederschlagsgebiete ins Auge zu fassen.

Es würde zu weit führen, wollte man an dieser Stelle die hydrologische Bedeutung der Pflanzendecke und insbesondere jene des Waldes zu erörterm versuchen. Es muß genügen, diesbezüglich auf das eingangs bezogene Werk des Verfassers ,, Grundriß der Wildbachverbaumg" zu verweisen. In ganz ausgezeichneter und sehr wissenschaftlich gehaltener Art hat diesen Gegenstand jüngst Ney ${ }^{1}$ ) behandelt. In beiden bezogenen Arbeiten sind vielfach gleiche Anschauungen vertreten.

Die Verwitterungsprodukte können auf verschiedene Weise in die Rinnsale der Bäche gelangen. Einerseits werden sie durch das von den Hängen herabfließende und den Rinnsalen zueilende Wasser, sowic auch durch Lawinen und Gletscher tahärts befördert, andererseits gelangen sie durch Steinschlag oder auch durch Bergstürze in den eigentlichen Bereich des Wildwassers.

Ganz wesentlichen Anteil an der Beförderung der Verwitterungsprodukte bis zu jenem Orte, wo dieselben der transportierenden Tätigkeit des Wassers unterworfen sind, haben wohl die Gletscher und die Bergstürze. Leider sind es gerade sie, mit denen im Naturhaushalte gerechnet werden muB, ohne ihrer Tätigkeit sehr wirksam entgegentreten zu kömnen.

Auf die Tätigkeit der Gletscher ist das reiche Vorkommen des Glacialschuttes in den Alpen zurückzuführen, eines Gebildes, welches ein außerordentlich günstiges Feld für die erodierende Tätigkieit des Wassers bildet und auf dessen Bindung nicht genug geachtet werden liann. Die Bergstürze schaffen außerordentlich große Materialmassen in die Schluchten und Täler und hegründen hiemit auch eine wesentliche Gefahr für das Unterland. Der Einfluß der Lawinenstürze und der Steinschläge auf die Geschiebeführung ist in der Regel von geringerer Bedeutung, denn die Masse des auf solche Weise in das Rinnsal gelangten Nateriales ist in der Regel in Verhältnisse zur tatsächlichen Geschiebeführung des Wildbaches doeh nur eine relativ geringe.

Ueherraschender in iluen Wirkungen gegenüber der Verwitterung ist dic Erosion. Sie äubert sich in den Wildbächen nicht allein in der Vertiefung der Rinnsale und den hiemit häufig verbundenen Lehnenfußunterwaschungen und ihren Folgen, sonderm nicht selten auch in der Zerwühlung der Hänge, in der. Schaffung von Runsen und neuen, wenn so gesagt werden kann, zur Existenz nicht berechtigten Rinnsalen. Naturgenäß wird die Erosion untes sonst gleichen Verhältnissen, also unter gleichen geognostischen, gleichen Gefälls- und Verwitterungsverlıältnissen umsomehr zur Geltung kommen müssen, je rascher der Wasserabfluß ist, und es wird deshalb und weil die Tegetationslecke der erodierenden Kraft des Wassers mechanischen Widerstand entgegensetzt, die Erosion in einem kahlen Sammelgebiete mehr zur Geltung liommen, als in einem mit V'egetation hinreichend bedecliten und geschützten Gebiete. Daraus erhellt wieder deutlich die Aufgabe der Kultur in Niederschlagsgebiete, gleichzeitig aber auch die Notwendigkeit der Durchführung solcher Maßnalımen, die geeignet sind, dem schon entstandenen Lebel Einhalt zu tun und dic vorhandenen Wunden zur Heihung zu bringen.

In ilırer Wirkung gleichfalls außcrordentlich unregelmäßig und zumeist schadenbringend ist die Tnterwühlung hangender Bodenschichten. Diesc Erseheinung, die

1) liarl Eduard Ney, ,Die Gesetze der Wasserbewegung im Gebirge". Neudamm 1911. 
bekanntlich auf die Tätigkeit rer Sicker- und Quellwässer zurückgeführt werden muß, tritt unter sonst gleichen Verhältnissen in der liegel um so raseher und in um so größerem Umfange cin, je zusammenhangloser, je nackter und verwitterter der Boden ist. Ganz gewaltig sind oft die Materialmassen, die auf solche Weise in die Rimsale gelangen, und von großer Wichtigkeit ist es deshalb, diese Erscheinung in den Wildbächen genanestens zu beobachten.

5. Die Ursachen der Wildbaehverheerungen: Als Ursaclien der Wildbachverheerungen sind anzusehen:

I. Außerordentliche meteorische Niederschläge, wie sie periodisch wiederkehren. Im Falle reichlicher fester Niederschläge in Winter oder m zeitigen Frühjahre ist es die rasehe Schneeschmelze, welehe die Führung großer" Wassermassen nit sich bringt. In Wildbächen sind es besonders die wolkenbruchartigen Regengüsse, namentliclı aber unter gewissen geotelitonischen Verhältnissen, bei Vorhandensein nackter, aus Schutt und leicht erodierbaren Gesteinsmassen zusammengesetzter Gehänge die Hagelwetter, welche zur Entfesselung der Gewässer beitragen.

2. Die mangelhafte Wasserpolizei und im Zusammenhange damit der trostlose, vernachlässigte Zustand der Gerinne. Hier ist zu erwähnen: das Vorhandensein nicht widerstandsfähiger neuer, an und für sich nicht entsprechender Einbauten, insbesondere Wehren, die oft ungenügenden Profile, die nicht hochwasserfreien Brücken, die Ablagerung von Holz und dergl. in den Inundationsgebieten, die Belassung von hochstämmigem Holze innerhalb derselben und besonders an den Ufern der Gewässer sowie an den Rändern der Bruchflächen, die Benützung der Rinnsale als Wege, die Unterlassung der Reinigung der Gerinne von Wildholz, die oft irrationelle Ausübung der Trift und Flößerei. damn im Falle der Auflassung des Holztransportes zu Wasser die nicht genügende Instandhaltung von Klausen, Rechen und Uferschutzbauten, welche früher dem Transporte dienten, u. a. m.

3. Vielfach fehlende orler unzureichende Flußregulierungen, insbesondere aber Wildbachverbauungen, und alle jene Lmstände legislativer, finanzieller, administrativer und wohl auch mitunter partikularistischer Natur, welche der energischen und ausreichenden Durchführung dieser im höchsten Interesse der Landeskultur gelegenen Jaßnahmen in Wege stehen.

4. Die gewiß auch noch unzureichende Forstgesetzgebung unrl ungenügende staatliche Forstaufsicht. Trotz des unverkennbaren Fortschrittes bleibt in dieser Richtung noch vieles zu tun. Die Güterschlächterei und das vielfach offenbar nur auf schrankenlose Ausbeutung des Waldes gerichtete Bestreben nach Errichtung von holzverzehrenden Betriebsstätten, sind als weitere Ursachen zu nennen; die die ordnungsmäßige Wirtschaft hehindernde Streu- und Weideservituten, die nicht selten prakitizierten Waldteilungen im Gebirge können nicht unerwähnt bleiben.

5. Die zumeist mangelhafte Bewirtschaftung rler Alpen und Gebirgsweideflächen. Die Folge dieser mangelhaften Bewirtschaftung ist zunächst das Bedürfnis nach Ausdehnung des Weideterrains, und diesem Bedürfnisse ist es wieder zuzusehreiben, daß so manche, vermöge ihrer konkreten Bodenbeschaffenheit dem WaIdlande angehörige unr als solche im Hinblick auf möglichste Retention zu erhaltende Fläche der Waldiultur entzogen, selbst aber nach und nach infolge der mangelhaften landwirtschaftlichen Benützung der Verödung zugeführt wird.

Dieser mangelhaften, füı das Regime der Wildwässer sehr berleutungsvollen Bewirtschaftung liegt wierler vielfach der 1 angel an Alpenbewirtschaftungsgesetzen, an nicht genügender Würdigung der Hebung des Futterbanes auf den Alpen zugrunde. 
6. Ist der Entwässerung des Waldlandes und der Gebirgsmoore und Filze zu gerlenken.

\$6. Di e Systeme der Wildba o hverba u u ng. Den Wildbächen des Hochgebirges ist im Gegensatze zu jenen der Berg- und Hügelländer, und an dieser Einteilung soll bei den folgenden Ausführungen festgelıalten werden, zumeist eine ganz besondere, häufig mit den Wassermassen in gar keinem Verhältnisse stehende Materialführung eigen. Man begegnet hier einer Erseheinung, dem Murgange, die als eine Eigenheit des Hochgebirgswildbaches angesehen werden kann und die bei den Bächen des Berg- und Hügellandes wenigstens nicht in so bestimmter Weise zum Ausdrucke kommt.

Je nach dem Herkommen der Geschiebemassen hat man in IIochgebirge Wildbäche zu unterseheiden, welehe vorherrschend Verwitterungsprodukte führen und solche, welche das Geschiebe vorwiegend durch ihre erodierende oder unterwïhlende Tätiglieit in Bewegung setzen.

Wenn, wie hervorgehoben, bei derlei Bächen die Geschiebeführung vorherrseht, so ist in der Regel bei den Wildbächen der Berg- und I Uügelländer die WVasserführung überwiegend; doch kann auch hier die Materialführung als Folge von Uferbrüchen und wegen des beständigen, unregelmäBigen Wühlens in alten Schotterdeponien, mitunter eine ganz bedeutende, sowie in Anbetracht des sich meist auf wertvolle Kulturgründe ausdehnenden Inundationsgebietes, auch eine sehr sehädliche werden.

Die vorwiegend Verwitterungsprodukte führenden Wildbäche des Hochgebirges, zu welchen in erster Linie die des Kalkgebirgès zu zählen sind, bieten der Verbauung in allgemeinen keine günstigen Operationsgebiete. Wie aus dem Vorhergehenden erhellt, inuß es sich naturgemäß in solehen Fällen um die tunlichste Bekämpfung der Verwitterungserscheinung durch Selaffung womöglich besserer kultureller Verhältnisse im Niederschlagsgebiete handeln. Wenn schon die Durchführung der diesfalls nötigen Maßnahmen innerhalb des Vegetationsbereiches oft, und zwar deshalb mit großen Schwierigkeiten verbunden ist, weil man nur allzuhäufig dem Widerstande seitens der Bevölkerung begegnet, so ist leider mit der Vegetationsgrenze der diesfälligen Tätigheit überhaupt eine Schranke gesetzt.

Unter allen Umständen ist in solehen Fällen das Hauptaugenmerk auf die Erhaltung oder Schaffung eines Waldgürtels an der Waldvegetationsgrenze zu legen, weil nur auf diese Weise eine größcre Gewähr für dic Zurückhaltung des Geschicbes über diese Grenze nach aufwärts geboten erscheint. Selbstverständlich ist auch der Bewirtsehaftung der ober der Waldgrenze gelegenen Alpsgründe besondere Sorgfalt zuzuwenden und überhaupt zu trachten, der Vegetation soweit als möglich in den höchsten Lagen Eingang zu verschaffen.

Die Besserung der Alpenwirtschaft ist eine auch wasserwirtschaftlich außerordentlich wiehtige Maßnalıme, denn sie zielt in erster Linie auf die Verhinderung der Bodendeteriorierung hin, die aueh dem Regime der Hochwässer zugute kommt.

Andere und namentlich bauliche, in solchen Wildbächen auszuführende Arbeiten können in der Regel nur als Palliativmittel angcsehen werden. Sic sind wohl geeignet, die Gefahr momentan oder für längere Zeit zu bannen, nicht aber auch, sie vollkommen zu belıeben. Zu diesen Vaßnahmen gehört die Herstellung g r ö $\beta$ e re r T a lsper ren als Materialstawwerke, welche den Zweek haben, die Geschicbeführung durch eine gewisse Zeit hindureh auf ein vielleicht unsehädliches Maß einzusehränken. Unter Umständen kann so Zeit gewomen werden, die wirtschaltlichen Verhältnisse in Niederschlagsgebiete in zufriedenstellender Weise zu bessern. Weiters sind als inı Innem solcher Gewässer eventuell noch durehzuführende Maßnahmen 
die Vorkelumgen gegen den Steinschlag und gegen den Aligang von Lawinen erwähnenswert.

Der leidigen Tatsache, daß derartige Wildbäche der Verhaunng kein besonders günstiges Operationsgebiet liefem, kam immerhin der Lnstaml entgegengehalten werden, dals sie, weil in ilırer Tätigkeit und schädlichen Wirkung eine gewisse Regelmäßigkeit zeigend, auch nicht zu den besonders gefürchteten Wildwässem gezählt werden liönnen. In den meisten Fäller nehmen die von ihnen herabgeführten Verwitterungsprodukte an Talausgang für sich ein gewisses Gebiet in Anspruch, welches die Bewohner der Ungebung im Hinblick auf die vorhandene, nahezu unabweisliche Gefahr in der Regel auch nicht nutzbar zu machen bestrebt sinr. In nicht seltenen Fällen wird es deshalb bei solehen Bächen auch angezeigt sein, auf Ien Schuttfelderı förnłliche Materialablagerungsplätze zum sicheren Schutze des unliegenden Küulturlandes zu schaffen, oder die Bildung solcher Materialdeponien auch schon im Talinnern an geeigneten Stellen durch entsprechende Vorkehrungen zu begiunstigen.

Selbstverständlich schließt es das bisher gesehilderte Verfalıren nicht aus, daß die in solehen Wildbächen in größerem oder geringerem Iaße dureh andere Erscheinungen, z. B. durch Erosion und Unterwühlung verursachte Geschiebeführung auch auf andere, diesen Erscheinumgen entgegenwirkende, entspreehende Weise bekämpft werden muß.

Ein bei weitem reichhaltigeres und danlibareres Feld für die V'crbaunngstätigkeit liefern die vorherrschend erodierenden und unterwühlenden Vildbäche. Hier bieten sich dem Fachmanne die mannigfachsten Aufgaben dar, deren richtige Lösung nur an der Hand reichlicher pralitischer Erfahrung gelingen kann. Als die hauptsächlichsten Aufgaben sind die Verhinderung der we it eren sohlenerosion, danu häufig im Zusammenhanghiemit die sicherung der anbrüchigen Lehnenf ü $B$ e, die unsehädliche $A$ bleitung der Quell- und Sielierwässer, die eventuelle Zur ücklıaltung der bereits angehäuften Erosions-, Unterwühlungs-oderteilweise auch Verwitterungsprodukte, die honsolidierung der der Erosion und der Unterwühlung unterworfenen Hänge der Niederschlagsgebiete und endich die Besserung der kulturellen und wirtschaftichen Verhältnisse innerhalb der letzteren an z u s e lie $\mathrm{n}$.

Die Solılenerosion ist das Resultat zweier, sich nicht im richtigen Verhältnisse gegenüberstehender Faktoren, das ist der Gewalt des abfließenden Wassers einerseits und der Widerstandskraft der Bachsohle andererseits. Die Mittel, die beiden genannten Falitoren in das richtige Gleichgewicht zu setzen. müßten also in der Veruinderung der Wasserkraft, beziehungsweise in der Festigung der Bachsohle bestehen.

In ersterer Hinsicht kommen mehrere Iomente in Betracht. Die Kraft des abfließenden Wassers ist in einem gegebenen Querprofile bei gleicher Wassermenge, bei gleichem Grade der Sättigung mit Geschiebe, von der Neigung des Wasserspiegels beziehungsweise von der Sohlenneigung abhängig. Einer gewissen Wassermenge und Geschiebeart, einem gewissen Sättigungsgrade und einem gewissen Querprofile entspricht bei gegebener Sohlenbeschaffenheit ein Sohtengefälle, welehes mit der Wasserkraft im Gleichgewicht stehend, den Bestand der Sohle sichert. Es muB deshalb zunächst Sache der Verbaumg sein, in einer der Erosion unterworfenen Baclısohle dieses, den konkreten Verhältnissen entsprechende, sogrenamnte ,Ausgleichsgefälle" durch Einbau von Duerwerken, Talsperren oder Grundsehwellen zu schaffen, 
oder, wenn dies nicht tunlich wäre, in anderer Weise auf die Erhöhung des Sohlenwiderstandes hinzuwirken. (Abb. 1.)

Es darf aber hiebei nicht außeracht gelassen werden, daß mit der fortschreitenrlen Verbaumg im Talinnern die auf Bildung des Ausgleichsgefälles Einfluß nelmenden Faktoren andere werden können. Inshesondere wird durch die Verminderung

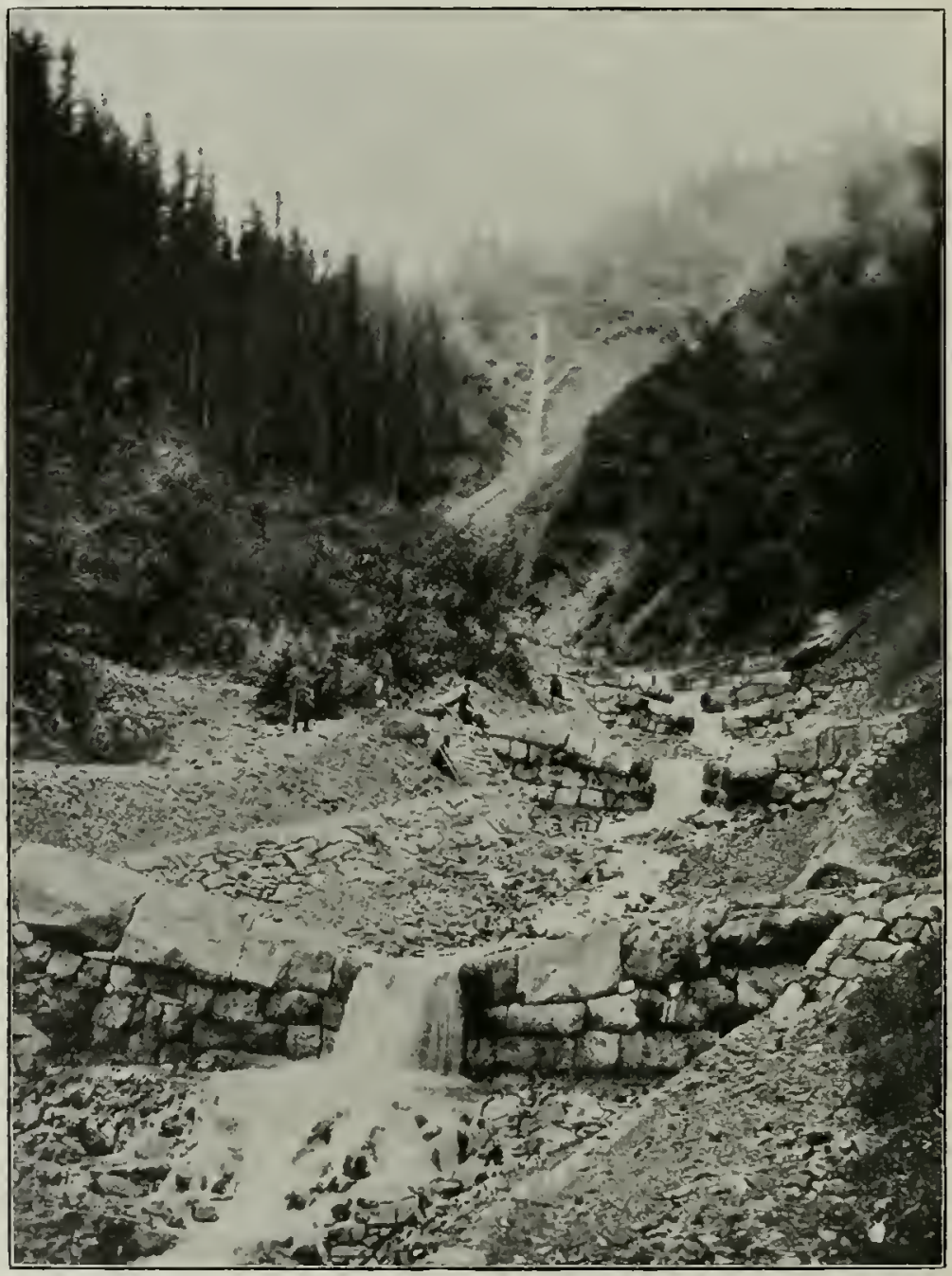

Solılenstaffelung mittelst Querwerken. Im Hintergrunde Sieherung einer Bruchflāche.

der Geschiebeführung bei sonst gleichbleibenden Verhältnissen die Gesehwindigkeit des abfließenden Wassers eine heträchtlichere und das Ausgleichsgefälle deshalb ein geringeres, denn das seiner Größe und Beschaffenheit nach als gleichbleihend angenommene Gesehiehe vermag sich bei dieser erhöhten Gesehwindigkeit auf einer gleich steil geneigten Sohle nicht mehr zu halten. Die so mit der fortschreitenden 
Verbauung verbundene stete Abnahme des Ausgleichsgefälles läßt es behufs Verhinderung der Gefährdung schon bestehender Objekte nötig erscheinen, dureh Einschaltung weiterer, sogenannter sekundärer Werke ein der jeweiligen Wassertätigkeit entsprechendes, geringeres Gefälle zu sehaffen. So kann endlich ein den konkreten Verhältnissen entsprechender und ein gewisses Gleichgewicht gewährleistender Zustand

\section{Abbildung 2 .}

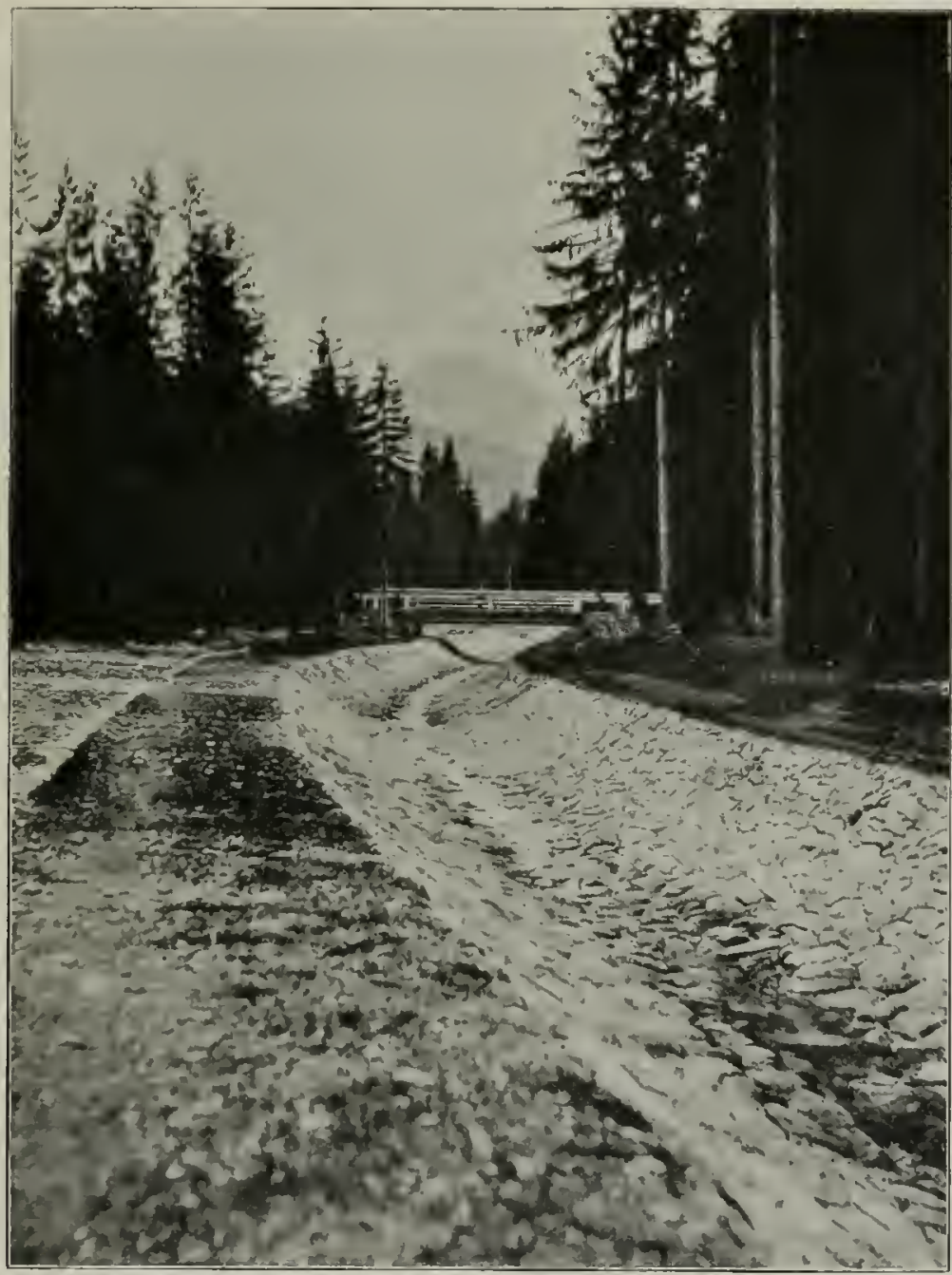

Ausschalung eines Bachgerinnes.

geschaffen werden, bei dessen Eintritt das Ausgleichsgefälle die möglichst unterste Grenze erreicht und sich zum sogenannten .Gleichgewichtsgefälle" entwickelt hat.

Aus dieser wohl nur ganz allgemein gehaltenen Auseinandersetzung, auf deren theoretische Begründung hier nicht eingegangen werden kann, ist doeh zu entriehnen, daß einer derartigen Verbaung nicht nur eine ausgedehnte Beohachtung der Bach- 
verhältnisse vorausgehen muB, sondern daß auch nach Vollzug derselben ihre stete Ergänzung nötig wird. Die diesbezügliche theoretische Begründung findet sich in den in den Anmerkungen I, S. 298 und 1) dieser Seite angeführten Abhandhungen ${ }^{1}$ ).

Die Geschwindigkeit des Wassers kann auch durch Verbreiterung der Querprofite oder durch Schaffung längerer und somit auch weniger steil geneigter Bachläufe, durch Erhöhung der Rauhigkeiten vermindert werden. Es soll sonach Grundsatz rationeller Verbauung sein, womöglich jede Konzentration der Wässer, jedwede glatte Ausgestaltung der Gerinne zu vermeiden.

Ander's ist es, wenn die Sohlenerosion durch direkte Hebung der Sohlenwiderstandskraft bekämpft werden soll. In solchen Fällen handelt es sich um die teilweise oder vollkommene Sohlenfixierung dureh Pflasterung oder auf ähnliche Weise. Diese Verbauungsart, die in ihrer vollkommensten Ausfülırung zur Herstellung der Steinschalen oder Steinkunetten führt (Abb. 2) und zu der Sohlenstaffelung mittels Querwerken in einem gewissen Gegensatze steht, kann sich insbesondere dort empfehlen, wo infolge des bestehenden größeren Gefälles die Entwickelung des wünschenswerten Ausgleichs- bezichungsweise Gleichgewichtsgefälles nur durch Einbau einer unverhältnisnäßig großen Zahl von Querwerken möglich wäre. Das ist namentlich in den engen und sehr steil verlaufenden Runsen, Wasserrissen, der oberen Einzugsgebiete der Wildbäche der Fall. Obwohl diese Methode den offenbaren Vorteil für sich hat, daß dem Wasser keine Gelegenheit zum „Kolken" geboten wird, soll sie doch unter allen Umständen nur clort zur Anwendung kommen, wo die mit ihr verhundene rasche Wasserabfuhr und Begünstigung des Materialtransportes den Effekt der ganzen Verbauung nicht nachteilig beeinflussen oder einzelnen Verbauungspartien zum Schaden gereichen könnte und wo durch Steinschlag oder Terrainbewegung oder auch auf andere Weise der Bestand des Objektes, der Schale, nicht zu sehr in Frage gestellt wäre.

Die seitliche Erosion, die Unterwaschung der Lehnenfüße, als Folge von Verwerfungen, oder als Folge des Wasseranpralles an stark konkav gekrümmte Ufer kann durch Uferversicherungen entsprechend behoben und für die Zukunft durch Schaffung möglichst geregelter Abfhßverhältnisse verhindert werden.

Ein besonderer Anteil an sler Naterialbeschaffung in den Wildbächen ist der unterwühtenden Wasserwirkung zuzuschreiben.

In allgeneinen hat man es mit zwei Bordenschichten, mit einer oberflächlich lagernden, mehr oder minder wasserdurchlässigen, der sogenannten ,hangenden", und einer darunter befindlichen, mehr oder minder wasserundurchlässigen, der sogenannten , liegenden“ Schichte zu tun. Letztere kanı aus einem festen Grundgestein, beispielsweise Schiefer, oder auch aus einem mehr weichen, tonigen Gebilde bestehen. Es ist klar, daß bei geneigtem Terrain der Zusammenhalt der hangenden und liegenden Bodenschichten von gewissen Berlingungen abhängig ist.

Das Lostrennen der oberen Schichten von der unteren ist selbstverständlich schon bei einem gewissen Schichten-Neigungswinkel und unter einem bestiumten Kiohäsionsverhältnisse möglich, auch kann clurch die Wirkung der oberflächlich alfließenden Veteorwässer, also infolge von Erosion, oder selbst durch Hagel eine Bodenabschwemmung verursacht oder gefördert werden. In ganz besonderem Maße ist aber in den meisten Fällen das oherflächlich einsickernde Wasser bei Entstehung von Terrainabsitzungen tätig. Es durchtränkt nicht nur die obere Bodenschichte, vermindert zumeist die Kohäsion, vermehrt ihr Volumen und ihr Gewicht, sondern

1) Ferdinand Wang, ,Die Gesetze der Bewegung des Wassers und des Geschiebes, die Berechnung de' Wasserabfhßmengen und der DurchfluBprofile". Wien 189!. 
es beseitigt auch, auf der Trennungsfläche abwärts gleitend, gänzlich odler doeh zum Teile die Reibungswiderstănde und führt sehließlich zur Absitzung der durehtränkten und unterwïhten hangenden Bodenschichte. Bei weicheren liegenden Schichten kann das eindringende Wasser selbst bei sehr geringem Selnichten-Neigungswinkel schon dann Absitzungen veranlassen, wem es entweder, durch ein llindernis gehemmt, auf der Trennungsfläche zu stagnieren und die liegende Schichte selbst zu durchweichen beginnt, oder aber wenn es durch Kisse in dieselben einzudringen und so von innen aus ihre Durchfeuehtung zu vollführen vermag. Unter allen Unständen ist es nötig, solch schädliehe, bereits eingesiekerte Wässer abzuleiten und auch, wo tunlich, in Hinkunft ihr Eindringen möglichst zu verhindern. In ersterer Richtung wird man durch ausreielıende Entwässerungsanlagen, in letzterer Richtung dureh tunlichste Ermöglichung und Erleichterung des oberirdischen, schadlosen Abflusses der Meteorwässer das angestrebte Ziel erreichen.

Es nöge noeh bemerkt werden, daß bej schon unterwasehenen und mit Holz bestockten Böden die Bewegungstendenz durch die Schwere der oberirdisehen, allenfalls auch noelı flach bewurzelten Holzmasse, insbesondere im Vereine mit starken Luftströmungen gefördert werden kann. Das ist aber keineswegs ein Argument für eine ungünstige Wirkung der Bewalıłung; in einem solehen Falle handelt es sieh lediglich um die richtige Wahl der Bestanclesform, also um die Anzucht bodenbindender, im Niederwalde zu bewirtsehaftender Holzarten.

Bei Verbauung der in Rede stehenden Art der Wildbäehe ist es selbstverständlich nieht ausgesehlossen, daß es außerordentlieh erwünscht oder notwendig sein kann, das bereits in den Rinnsalen des Niedersehlagsgebietes angehäufte Erosions- oder Unterwühlungs-, eventuell auch teilweise Verwitterungsprodukt im Innern des Wildbaehgebietes festzuhalten. Nan lıat dann in der Regel, ähnlich wie bei den vorwiegend Verwitterungsprodukte führenden Wildbäehen, durch die Herstellung von Talsperren an geeigneten Stellen Materialdeponien zu schaffen, dabei aber insbesondere im Auge zu behalten, daß es an gewissen Oertlichkeiten möglich sein kann, einer 'lalspcrre gleiehzeitig die Wirkung eines Material-Stau- und eines Konsolidierungswerkes zu geben.

Weitere wiehtige Aufgaben bej Verbauung erodierender oder unterwühlender Wildbäche sind die endgültige lionsolictierung der anbrüchigen Hänge dureh Schaffung der Vegetationsdecke auf denselben, sowie die Besserung der kulturellen und der wirtschaftlichen Verhältnisse in Niederschlagsgebiete. Diese Aufgaben dürfen nicht aus dem Auge gelassen werden, denn von ihrer zielbewußten und gelungenen Ausführung hängt vielfach der volle Effekt der Verbaung des Wildbaches ab.

Die Wildbäche der Berg- und IIügelländer, in ihrem Charakter von jenen der Alpen versehieten, erfordern auch im allgemeinen die Anwendung eines anderen Verbauungssystemes. Bei vorherrschend geringem Gefälle in den tieferen Partien und in der Regel einem bloß auf die höelısten Lagen beschränkten starken Gefälle, fülıren diese Bäche größere Wassermassen und das aus dem Niederschlagsgebiete lierabkommende Material den Talflüssen zu. Brüchige Stellen, „Lehnenbrüche“, finden sich zumeist nur in den oberen Teilen der Niederschlagsgebiete; in den tieferen Lagen, in welchen der Bach häufig sehon beiderseits von älteren oder jüngeren Anschwemmungen eingerahmt jst, sind es die stetigen Uferbrüche, welehe die Materialbewegung verursaehen. Das Augenmerls Jei Verbauung soleher Bäche ist, was den Oberlauf anbelangt, meist der lionsolidierung vorkommender Brüche, der Zurückhaltung des im Bachbette schon vorhandenen Geschiebes und der möghiehsten Hintanhaltung des raschen Abflusses der Niedersehlagswässer zuzuwenden. In den tieferen Lagen 
finden sich in den verhältnismäBig breiten Bachbetten nit flachen Ufern, bei höchst unregelmäßig ım IVasserabflusse große Schotterdeponien vor, und es erwächst hieraus die Notwendigkeit, der Wandelbarkeit dieser Schottermassen durch entsprechende Regulierungsarbeiten ein Ziel zı setzen. Die Hauptfrage ist und bleibt aber die tunlichste Verminderung des raschen Wasserabflusses im Niederschlagsgebiete, und diese Aufgabe ist, da ausgiebige IVasserbehälter, Reservoirs, oft nicht oder nur in beschränkter Zahl oder Dimensionierung ausführbar sind, meist nur auf liulturellem IVege $\mathrm{zu}$ erreichen.

Nit der Durehführung der vorbeschriebenen Vaßnahmen zur Beruhigung der Wildbäche, sei es nun jener in Hochgebirge oder jener im Berg- und Hügellande, nuß nötigenfalls die Herstellung von Schutzvorrichtungen am Schuttkegel Hand in Hand gehen, wobei auf den richtigen Zusammenhang der Arbeiten im Innern der Wildbäche und in Tallaufe großes Gewicht gelegt werden muB. Naturgemäß erfordert die Verbaung der Wildbäche im Talinnem einen relativ größeren Zeitaufwand als jene am Schuttkegel, so daß es in vielen Fällen nicht zulässig wäre, den Effekt der Verbauung im Talinnem abzuwarten und dic Durchführung von nöligen Schutzvorrichtungen am Schuttkegel oder im Tallanfe des Wildbaches außer acht zu lassen. Doch muß darauf verwiesen werden, daß es mitunter ratsam ist, diese letzteren, wenn tunlich, vorerst nur in einfacher Bauweise, also mehr provisorisch herzustellen. Ein liostspieliges Definitivum wäre einerseits während der Verbauungsperiode zu stark exponiert und liönnte andererseits möglieherweise den nach der Verbauung eintretenden Abfhßverhältnissen nicht mehr entsprechen, denn die Wirlungen eines verbauten Wildbaches sind naturgemäl ganz andere als die eines unverbauten. - In manchen Fällen wird nach vollzogener Verbaumg von der Herstellung eines Definitivums vielleicht überhaupt ganz abgesehen werden können, jedenfalls ist aber anzunehmen, daß sich die Notwendigkeit der Durchfühung besonderer Vorkchrungen gegen Versehotterung im Tallauf mit dem Fortschritte der Verbaunng im Talinnern vermindert.

Als integrierender Teil eines jeden Verbauungssystems ist auch die Reinhaltung der Bäche von Wildholz und die sorgfältige Beobachtung der Rimnsale, cventuell das langsame und zweekmäBige Aussteinen derselben anzuseben. Dringend geboten ist es selbstverständlich, daß das Gehänge der Wildbäche in keincr Weise, weder durch irrationelle forst- noch landwirtsehaftliche Maßregel, zu welch letzteren insbesondere und unter gewissen Verhältnissen Bewässerungen und Wasserleitungen gezählt werden müssen, beunruhigt werde.

Ton ganz besonderer Wichtigkeit ist die Handhabung, strenger Wasserpolizei, die sich auf entsprechende wasserrechtliche Bestimmungen zu stützen hat. Wemn man sich bei Novellierung der Wasserrechtsgesetzgebung melr mit der Nutzung als mit der Abwehr der Gewässer besehäftigt, so ist das bedauerlich, denn die erstere ist wesentlich von der letzteren abhängig.

§ 7. Die allgemeinen Regeln für den Bau und die Er-

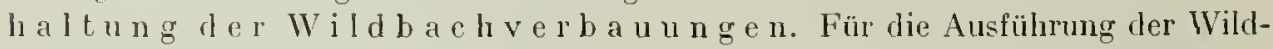
bachverbaumgen muß als Grundsatz nicht nur das rechtzeitige, sondern auch das ausrcichende Eingreifen bezeiclnet werden. Jedes Säumen ist von oft umberechenbarem Scharlen begleitet und jede Lücke im Verbauungswerke wird leicht zu dessen Achillesferse. Auch ein allzu rasches, überstürztes Vorgehen empfiehlt sich nicht und kann der Sache nur allzuleicht sehädlich werden.

Einen maBgebenden Faktor der Ausführung bilden die Liosten, von deren Hölı nicht selten die Durchführbarkeit einer bestinmten Verlaunng abhängt. 
Insoferne die Solidität der Ausführung hiedurch nicht in Frage gestellt erscheint, wird demnach vor allem zu erwägen sein, auf welche möglichst einfache Weise und mit welchen möglichst geringen liosten die Verbauung durchgeführt werden könnte. Dic Kiosten der Bauausführung sind in allgeneinen zunächst abhängig von der Wahl und Beschaffung der Baumaterialien, von der Art und Weise der Konstruktion der einzelnen Werke und von den lokalen Arbeitsverlaältnissen. Bei den in den Wildbächen vorherrschend schwierigen Transportverhältnissen wird man sich sell,stverständlich, wenn dic Ausführung überhaupt eine Wahl zuläßt, jenes Nateriales bedienen müssen, welches ohne zu erhebliche Kosten zur Baustelle geschafft werden kann. Wenn auch Steinbauten unter sonst gleichen Verhältnissen in der Regel teurer als Holzbauten zu stehen kommen, so verdienen die ersteren in Anbetracht ilurer Solidität und Dauerhaftigkeit im allgemeinen doch den Vorzug.

Unter der Voraussetzung, daß gutes Bauholz an Ort und Stelle oder in der Nähe zur Verfügung steht, kam sich dasselbe allerdings mitunter für eine billigere Bauweise insbesondere deshalb empfehlen, weil die heimische Bevölkerung in der Regel mit der Holzarbeit mehr vertraut ist und deshalb auch fremde, zumeist kostspieligere Arbeitskräfte nicht herangezogen werden müssen. Der Bestand der lıölzernen Werke ist übrigens namentlich dort, wo dieselben beständig unter W' asser stehen, oder vom Materiale verdecht sind, oder wo mit Rüchsicht auf die Bodenverhältnisse cine baldige Begrünung des verbauten Baches zu erwarten steht, ein zumeist hinreichend dauerhafter. Ein wesentlicher Vorteil der Holzbauten ist darin zu suchen, daß eingetretene lokale Beschädigungen in der Regel nicht so rasch zur Zerstörung des ganzen Baues führen und daher öfter 'rechtzeitig wieder gut gemacht werden können. Es wäre deshalb gewiß einseitig, wollte man unter allen Umständen dem Holzbaue aus dem Wege gehen, es ist vielmehr Sache des Projektanten, je nach den örtlichen Verhältnissen die richtige Wahl und das richtige Maß in der Verwendung ron Stein und Holz zu treffen. Unter allen Umständen sind zu den Steinbauten nur gute und dauerhafte Steine von möglichst großen Dimensionen zu verwenden. Steine, die in einem feuchten Grunde der Verwitterung stark unterliegen, wie z. B. alle Schieferarten, Sandsteine usw., sind für Bauten im Wildbachgebiete nicht gut verwendbar. Der Betonbau konnte sich bisher im Wildbachverbauungsdienste nicht recht einbürgern. Die Ursache ist die gröBere Gefährdung der oberirdischen Bauteile durch Abschleifen und durch Frost. Für Fundierungen eignet sich Beton selbstverständlich vorzüglich.

Zu den Holzbauten ist gesundes Lärchen-, Fiefern-, Tannen- und ausnahmsweise auch Fichtenholz in genügender Stärke zu verwenden. Die Hölzer sind rund zu belassen, zu entrinden und nach Erfordernis untereinander am besten mit Holznägeln zu festigen. Zu den Faschinenbauten ist, wo immer möghich, aussehlagfähiges Material zu verwenden, während sich dicht und stark beastete Tannen für Packwerke an zweckmäßigsten erweisen. Der Kostenpunkt der Ausführung hängt auch von den lokalen Arbeitsverhältnissen ab. Es soll als Grundsatz gelten, sich, wenn halbwegs tunlich, eine ständige Arbeiterschaft zu bilden und nicht durch Zugeständnisse einzelner hoher Löhne diese letzteren nach und nach auf eine den Verhältnissen nicht entsprechende Höhe zu bringen. In dieser Hinsicht hat sich die Verwendung von Sträflingen und Zwänglingen bestens bewährt.

Zur Sicherung einer entsprechenden Solidität des Verbauungswerkes, sowie auch zur Erzielung einer möglichst billigen Ausführung, ist die stete Aufsicht durch tüchtige, fachmännisch gebildete Organe erforderlich, welche vorgefundene llängel olme Rücksicht sogleich abzustellen und die nötigen Weisungen an Ort und Stelle 
zu erteilen haben. Nicht nur die Kosten der Ausführung, sondern auch die kiosten der ferneren Erhaltung sollen einen hervorragenden Faktor bei Projektierung von Verbauungen bilden. Die Erhaltung der Bauten ist von den vemendeten Materialien und Arbeitskräften, von der Art del Ausführung, sowie selbstverständlich von der Art und Weise der Durehführung der Erhaltung selbst abhängig. Wie bereits an frülıeren Stellen hervorgehoben, stellt sich die Erhaltung der Steinbauten, weil diese im allgemeinen dauerhafter sind, unter sonst gleichen Verhältnissen billiger als jene der Holzbauten. Kileinere Objekte, die überdies in allgemeinen leiehter lıerzustellen sind, erfordem weniger intensive Erhaltung als große, an deren Bestand sich auch gleichzeitig und naturgemäß ein böheres Interesse knüpft. Die Kosten der Erhaltung können übrigess durch intensive Beaufsichtigung wesentlich verringert werden. Es erseheint deshalb unbedingt nötig, daß gleich nach Verlauf eines Elementarfalles die Bauten einer eingehenden Untersuchung unterzogen und vorgefundene, noeh so geringfügige Mängel ohne Verzug behoben werden. An Bauten, bei welehen die heimische Bevölkerung werktätig beteiligt war, werden derartige Schäden leichter behoben werden können, weil in einem solehen Falle das Verständnis und das Interesse in weit höherem Grade vorhanden sind, als umgekehrt. Sehäden, welche nicht mit Elenıentarfällen zusanmenhängen, sondern dem natürlichen Zersetzungsprozesse zugeschrieben werden müssen, sind gleichfalls tunlichst raseh zu beheben, und wird diesbezüglich die Veranlassung periodiseher Baehbegehungen von großem Vorteile sein. Da die intensive und verständige Erhaltung der Bauten insbesondere in den ersten Jahren von großer Bedeutung ist und mangelhafte Objekte den Talgrunde nur unberechenbaren Schaden bringen können, so soll und muß auf die Bildung eines Erhaltungsfonds und insbesondere auch auf die Möglichkeit sorgfältiger Ueberwachung der Instandhaltung Bedacht genommen werden. Die Aufstellung von Instandhaltungskatastern ist empfehlenswert.

Wenn es sich um die systematische Verbauung eines Wildbaches handelt, so muß vorerst eine gründliche Durehforsehung des Gebietes in geologiseher und geognostischer Beziehung vorgenonmen werden, der sich aueh noch die Ermittehing jener Grundursachen anzuseliließen hat, welche aussehließlich oder doch vorwiegend zur Entstehung des nunmehr zu verbauenden Wildbaches die Veranlassung gegeben haben. Erst auf Grundlage dieses möglichst sorgfältig erhobenen Materiales kann an die Abfassung des eigentliehen Verbauungsprojektes geschritten werden. Dasselbe hat im allgemeinen aus der Situation des Niederschlagsgebietes, den Längenprofilen der zu verbauenden Baelıstreeke, den nötigen Querprofilen und denı Kostenvoranschlage zu bestehen. In der Situation sind die vorhandenen Terrainbrüehe und alle sonstigen, für die Verbauung wichtigen materialschaffenden Oertlichkeiten kenntlieh zu machen.

Der Motivenbericht enthält die Begründung der Verbauung und die der zeichnerisehen Darstellung nicht zu entnehmenden, jedoeh zu berüchsiehtigenden Verhältnisse.

In einigen Staaten sind für die finanzielle Sicherstellung und für die Durchführung der Wildbaehverbauungen eigene Gesetze gesehaffen worden und es dient dann das technisehe Elaborat als Grundlage für die im Sinne dieser Gesetze durehzuführenden Verhandlungen und für die technische Ausführung selbst.

\$ 8. Die teehnisehen llittel der Wildbaehverbau ung. Die Mittel, un einen Wildbach zu beruhigen und ihn in normale Verhältnisse zurüekzuführen, sind zweifacher Art. In erster Linie sind zu ihnen die technisehen Arbeiten, d. I. die untersehiedlichen Sehutz- und Festigungsbauten, und in zweiter 
Linie die eigentlichen forstlichen Arbeiten, d. h. Bindung und Festignug der Terrainbrüche und des entwaldeten Sammelgebietes dureh Berasung und Bewaldung, damm sonstige kulturelle wirtschaftliche Maßnahmen zu zählen. Die letzteren Vorkehrungen unterstützon nicht mur wesentlich die ersteren, es ist vielmehr in vielen Fällen eine gelungene Wiederbewaldung fü» den Gesanterfolg der Verbauung ausschlaggebejıd.

Zu den technischen Nitteln der Verbauung sind zu zählen:

1. Die $Q u$ e $\mathrm{r}^{\mathrm{b}}$ a $\mathrm{t}$ en.

2. Die Parallelbauten.

3. Die $S$ chalenbauten.

4. Die Entwässerungsanlagen.

5. Die Lehnenbjindungen.

6. Die Schut thegelversicherungen.

I. D j e $Q$ u e r b a u $\mathrm{t} n$. Es sind das Werke, Welche ähnlich wie ein Wehr von einem Ufer zum anderen reichen, und zumeist senkrecht auf den Stromstrich zu stehen kommen. Nit Hilfe solcher Bauten wird die Bachsohle entweder in ihrem konkreten Zustande erhalten oder aber gehoben, immer aber vor der weiteren Sohlencrosion geschützt. Bei Hebung der Bachsohle tritt in der Regel gleichzeitig eine Profilerweiterung ein und angebrochene Füße der seitlichen Hänge erhalten eine Stütze. Ueberdies wird das wirksame Bachgefälle und hiemit die Schleppkraft des Wassers vermindert.

Je nach der Höhe über der Bachsohle trennt man die Querwerlie in $\mathrm{T}$ a lsperren und in Grundsehwe 11 en.

a) $\mathrm{D}$ je $\mathrm{T}$ a ls per e n. Uan bezeichnet gemeiniglich solche Querbauten als Talsperren, welche mindestens eine Höhe von 2-3 Heter über der Bachsohle haben. Je nach der ihnen zufallenden Aufgabe werden $\mathrm{Sta}$ u we k e und Konsolid i e r ung g w e k unterschieden. Im ersteren Falle hat das Objekt die einzige oder doch vornehmliche Aufgabe, Material zurückzuhalten, im zweiten Falle aber die Bachsohle vor Erosion zu schützen oder anbrüchige Lelınenfüße durch die Verlandung zu decken. Nicht selten kann das Objekt durch günstige Wahl der Baustelle beiden Aufgaben zugleich gerecht werden. Stauwerke finden insbesondere bei Verbauung der Wildbäche, Welche vorwiegend Verwitterungsprodukte fülıren, Anwendung. Als Grundsatz fül die Wahl der Baustelle solcher Objekte gilt die Ausnützung felsiger Stcllen innerhalb des Bachgerinnes, und dies in engen Querprofilen, oberhalb welchen sich das Tal bei vorherrschend geringem Gefälle zu cinem Becken erweitert.

Die Wahl der Baustelle für Konsolidierungszwecke soll zwar von älnhlichen Grundsätzen geleitet sein, docl laängt sie zumeist von der Beschaffenheit der zu versichernden Bachstrecke ab. Immer sollen Konsolidierungswerke auf einer der Erosion unterworfenen Bachstrecke derart systematisch im Zusammenhange stehen, daß die unter dem A u sgle i chsgef älle geneigten Linien ihrer Verlandung ron der Krone des einen Objclites bis zum Fuße des nächst höheren reichen. Auclı soll es Grundsatz sein, wenn tunlich, an Stelle eines höheren Objektes mehrere niedrige zu crrichten, weil hiemit der Gefahr der Auskolkung des Sperrfußes, welche den Bestand des Objektes am meisten gefährdet, wirksamer vorgebeugt wird.

Die Talsperre besteht aus dem Sperrkörper samt seinem Fundamente und der seitlichen Einbindung, dann aus der Vorfeldversichcrung, dem Fall- oder Sturzbett, dessen Aufgabe es ist, den Sperfuß zu sichern, d. h. ihn vor liolkungen und Unterspülungen durch das herabfallende Geschiebe und abfließende Wasser zu bewahren.

Nachdem Talsperren in der Regel größere und bedeutungsvollere Objekte sind, 
so werden sie zumeist in Stein, oder, wenn sehon aus Holz, so doeh nur mit Zuhilfenahme von Stammholz errielitet.

Talsperren aus Fasehinen oder aus Paekwerk gelangen selten zur Herstellung.

Der Körper einer S t e in s p e r r e wird zumeist in Form eines liegenden Gewölbes mit dem Scheitel stromaufwärts erbaut. Der Vorteil der Bogenform, deren Pfeilhöhe beiläufig den Zehntel der Sehne, diese letztere also annähernd dem Bogenradius entsprechen soll, liegt in der größeren Widerstandsfähigkeit gegen den Stoß und Druck der sich ansammelnden Wasser- und Geschiebemassen.

Bei geringer Spannweite und dort, wo starker Seitendruek zu erwarten ist, werden die Talsperren gerne in Art freistehender Mauern geradlinig errichtet. Die talwärts gekelırte oder talseitige Stirnwand einer Sperre ist vorteilhaft mit einem Anzug von 20-25\% der Höhe, in seltenen Fällen vertikal herzustellen. Allerdings wird mit der vertikalen Stellung die kolkende Einwirkung der überstürzenden Wassermassen auf den unmittelbaren FuB der Sperre vermieden, auch wird die Abnützung der talseitigen Stirnfläche auf die oberste Lage beschränkt. Dagegen ist die Standfestigkeit einer an der Talseite gebösehten Sperre größer und die Inanspruehnahme des Sturzbettes im allgemeinen geringer. Die bergwärts gekehrte sog. bergseitige Stirnwand wird in der Regel vertikal gehalten.

llit Rücksicht auf die Ausführung kann der Körper einer Steinsperre entweder aus einer in hydraulischen 1 Jörtel gelegten Bruehsteinnauer oder aus einem gemischten Mauerwerk, d. h. teilweise in Mörtel, teilweise trocken gemauert, oder endlich aus einem reinen Trockenmauerwerk mit melı oder minder gut behauenen Steinen bestehen. In neuerer Zeit werden auch Talsperren in Beton ausgeführt, wobei es sich enpfiehlt, die Krone mit gutem Stein in hydraulisehem Zement abzudecken.

Bei den Wildbachverbauungen in Oesterreich und in der Schweiz werden die Talsperren vielfach als Trockenmauem mit lagerhaft zugehauenen Steinen erbaut, während in Frankreich zumeist Mörtehmauerungen oder gemischte Mauerungen Anwendung finden. Wo großer, schöner Stein vorlıanden, liann die Trockenmauerung in Art der Zyklopenmauerung immerhin Anwendung finden, es wäre denn, daß es sich um die Herstellung selır hoher und wichtiger Objekte handelt, in welchem Falle unbedingt der Zementmauerung der Vorzug einzuräumen ist,

Wird der Körper einer Talsperre in hydraulischen Mörtel gelegt, so muß eine größere Abflußöfnung, eine sog. Dohle oder mehrere kleine Mlauerschlitze für den Abfluß des Sickerwassers, letztere in ausieichender Anzahl und Verteilung, hergestellt werden. Bei den Aufbaue der Sperre sind für die Herstellung der talseitigen Stirnwand möglichst große und gute Steine bei entsprechender Ausarbeitung der Stoßund Lagerfugen zu benützen.

Die einzelnen Steine sollen mit ilsrer längsten Dinension nach der Tiefe der Mauer grelegt werden; die Höhe der einzelnen Steinlagen entspricht der zweitgrößten Dimension der verwendeten Steine.

In jeder Steinlage (Gewölbering) sind womöglich gleich hohe Steine zu verwenden. Das selbständige, gewölbartige und tunlichst rasehe Abschließen einer jeden einzelnen Steinlage ist mit Hinblick auf die Möglichkeit großer Besehädigung im Falle eines Hochwassers oder llurganges geboten. Höhe und Mauerstärke werden mit Rücksicht auf die örtliehe Beschaffenheit fallweise zu bestinmen sein.

Die Krone der Steinsperre wird mit hesonders großen Steinen abgedeckt, und erhält vielfach ein schalenförmiges Profil, d. h. es wird der IVasserüberfall gegen die Mitte der Krone in eine sogenannte AbfluBseltion verlegt. Ist die eine Böschung felsig, die andere locker, so wird der AbfluB gegen die erstere gerichtet. 
Die horizontale Krone ist dort zulässig, wo die Seitenhänge beiderseits aus festem, felsigen Materiale zusammengesetzt sind. Es ist ihr im übrigen der Vorteil der Vermeidung der Kionzentration der Wässer zuzusprechen, welcher Vorteil auch teilweise durch die Wahl eines trapezförmigen Profiles der Abflußsektion, an Stelle des schalenförmigen, zu erreichen ist. Diese letztere wird nicht selten der erhöhten Sicherleit wegen abgedielt, wobei die Bedielung als Sehußtenne über die talseitige Stimwand hervorragt.

Die Widerlager einer Sperre werden durch das möglichst tiefe Einbauen des Sperrkörpers in die Seitenhänge des Wildbaches ersetzt und in den wenigsten Fällen durch künstliche Anlagen geschaffen.

Ist das Gehänge locker, so erscheint es vorteilhaft, Böschungsversicherungen, anlehnend an das Ufergelände, von den Sperrflügeln aus nach auf-besonders aber nach abwärts möglichst weit zu führen und an den Enden in das natürliche Terrain einzubinden.

Das Fundament einer Steinsperre ist um so sorgfältiger herzustellen, je höher und massiver der Bau errichtet werden soll. Ist in der Bachbettsolsle, und zwar in mäBiger Tiefe fester, gewachsener Boden anzutreffen, so ist der Sperriörper bis auf den Felsen hinabzuführen; es muß also dieser bloßgelegt und die Fundamentmaner unmittelbar darauf bezw. in den Fels entsprechend vertieft gesetzt werden. Dabei ist die Oberfläche des Felsens vorerst, sei es stromaufwärts etwas geneigt, sei es in Staffelform herzurichten. Ist ein felsiger Untergrund nicht vorhanden oder doch erst in bedeutender Tiefe anzutreffen, damı sollen nur Objekte von mäßiger Höhe erbaut werden oder es müssen selbe auf eine solide Rostanlage gestellt werden.

Sind die beiderseitigen Ansehlußlehnen felsig, die Sohle dagegen aus losem Schotter zusammengesetzt, so kann es sich behufs Verhinderung der gefalırvollen Auskolkung empfehlen, das Fundament des Objektes gewölbartig, mit dem Scheitel nach aufwärts, auszubauen, wobei die beiderseitigen festen Anschlußlehnen dem Fundamentgewölbe als WViderlager zu dienen haben.

Das Vorfeld der Talsperre ist jener Teil der Bachbettsohle, welcher unmittelbar von den über die Sperre abstürzenden Wasser- oder Geschiebemassen getroffen wird. Derselbe wird selbstredend, soll nicht eine Auskolkung und Unterspülung der Sperre eintreten, deren Folgewirkung der Einsturz der gesamten Anlage wäre, dieser erhöhten Kraftäußerung Widerstand leisten müssen. Eine feste und dauerhafte Versicherung dieser Stelle ist somit die wichtigste Aufgabe des Gesamtbaues und kann nur dann entfallen, wenn die besagte Stelle felsiger Beschaffenheit sein sollte.

Bei Steinsperren hommt zumeist die solide Abpflasterung des Vorfeldes als Vorfeldversicherung in Anwendung. Hiebei ist darauf zu sehen, daß die Steine, die vorteilhaft in Zement zu legen sind, auf die ,hohe Kante" gesetzt werden und daß die Vorfeldversicherung genügend weit nach abwärts reiche. Die doppelte Fallhöhe des Objektes als Länge der Vorfeldversicherung wird unter allen Umständen genügen. Vorteilhaft hat sich die Abdielung der Pflasterung nit Holz erwiesen. Je weiter die Pflasterung gegen die Krone heraufgezogen wird, desto mehr wird die Fallhöhe verringert und desto melır wird der Besehädigung des Vorfeldes vorgebeugt.

Das Vorfeld kann auch durch die Herstellung eines sekundären Vorbaues, einer sog. Vorsperre oder Gegentalsperre geschützt werden, welchem Baue dann der Charakter einer Grundschwelle zukommt. Ihre Verlandung hat bis zum Fuße des Hauptobjektes zu reichen. Oft wird zur erhöhten Sicherung das talseitige Ende der Vorfeldversicherung durch eine Grundschwelle, eine Gegensperre, abgeschlossen, Abb. 5. 
Für die Ausführung gilt rler allgemeine Grundsatz, vorerst jene Oljjekte zu bauen, welche den anderen zum Schutze zu dienen haben. Es wird deshalb zunächst

Abbildung 3 .

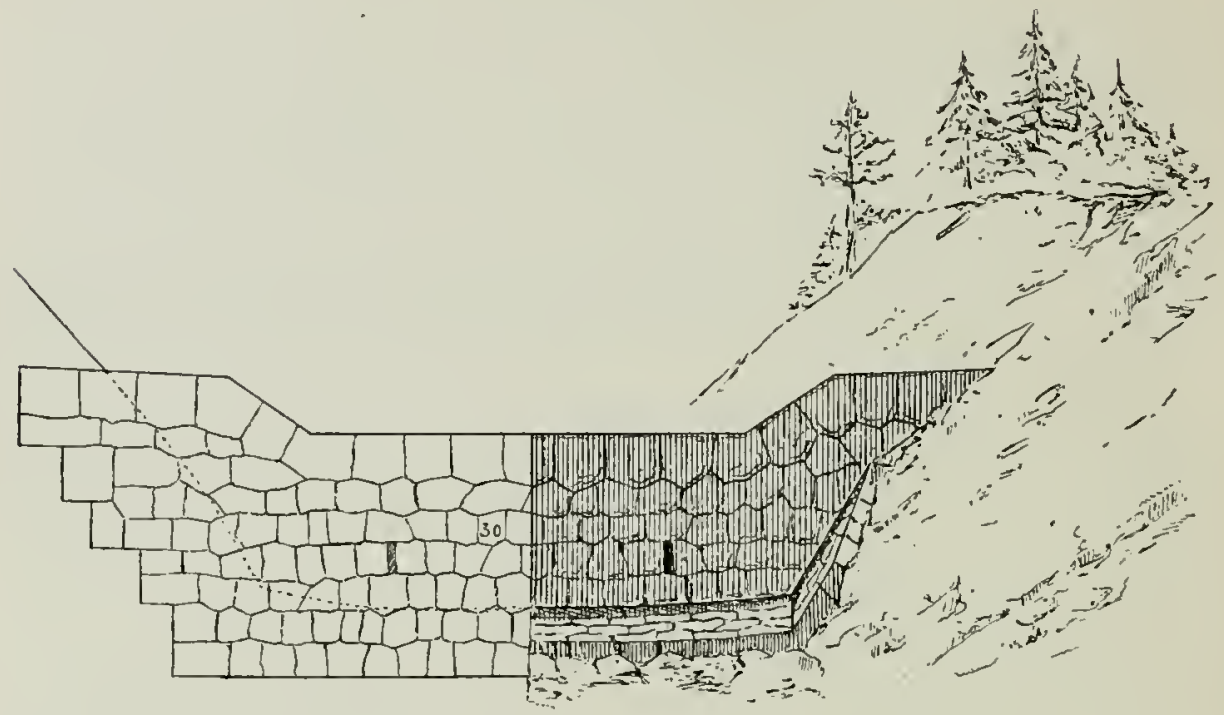

Abbildung 4.

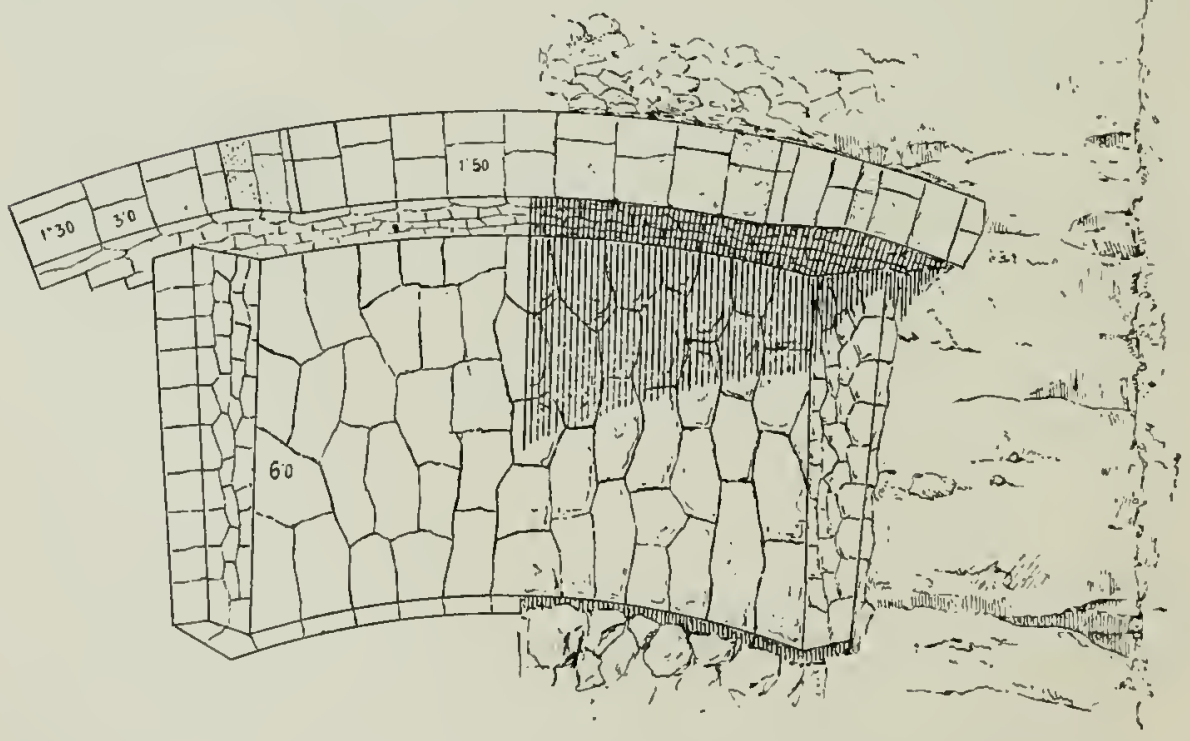

die Vorsperre, daran anschließend eventuell die Pflasterung des Vorfeldes und danı erst die eigentliche Sperre zu errichten sein.

Es kann nicht unbemerkt bleiben, daß oft die stärksten Vorfeldversicherungen der Kraft des abstürzenden Wassers nicht Widerstand zu leisten vernögen. Es hat 
sich daher als vorteilhaft erwiesen, bei genügender Tiefe des Fundanentes der Sperre, oder bei gewölbartigem Aushaue derselben, den sich vor den Objekte stets bildenden Kolk selbst künstlich herzustellen und iln mit großen Steinen auszufüllen unl immer wieder nachzufüllen, das gänzliche Abschwemmen dieses Steinvorgr'undes aber durch Herstellung einer Pilotenwand zu verhindern.

In den Abb. 3, 4 und 5 ist die Type einer Steinsperre in Trockenmauerung ersichtlich gemacht. Die Krone ist tripezfömig ausgestaltet, die Vorfeldversicherming am talseitigen Ende verstärkt, d. h, in Art einer Grundschwelle hergestellt. In Falle der Verwendung von Mörtel würde sich die Form des Objektes nicht ändern, nur müßte für die Freilassung einer Dohle oder von Sickerschlitzen Sorge getragen werden.

Ta ls per ren a us $\mathrm{Holz}$ können ein- oder zweiwandig sein. Die ersteren bezeichnet man als Blockw and-oder B a lkensperren, die letzteren als

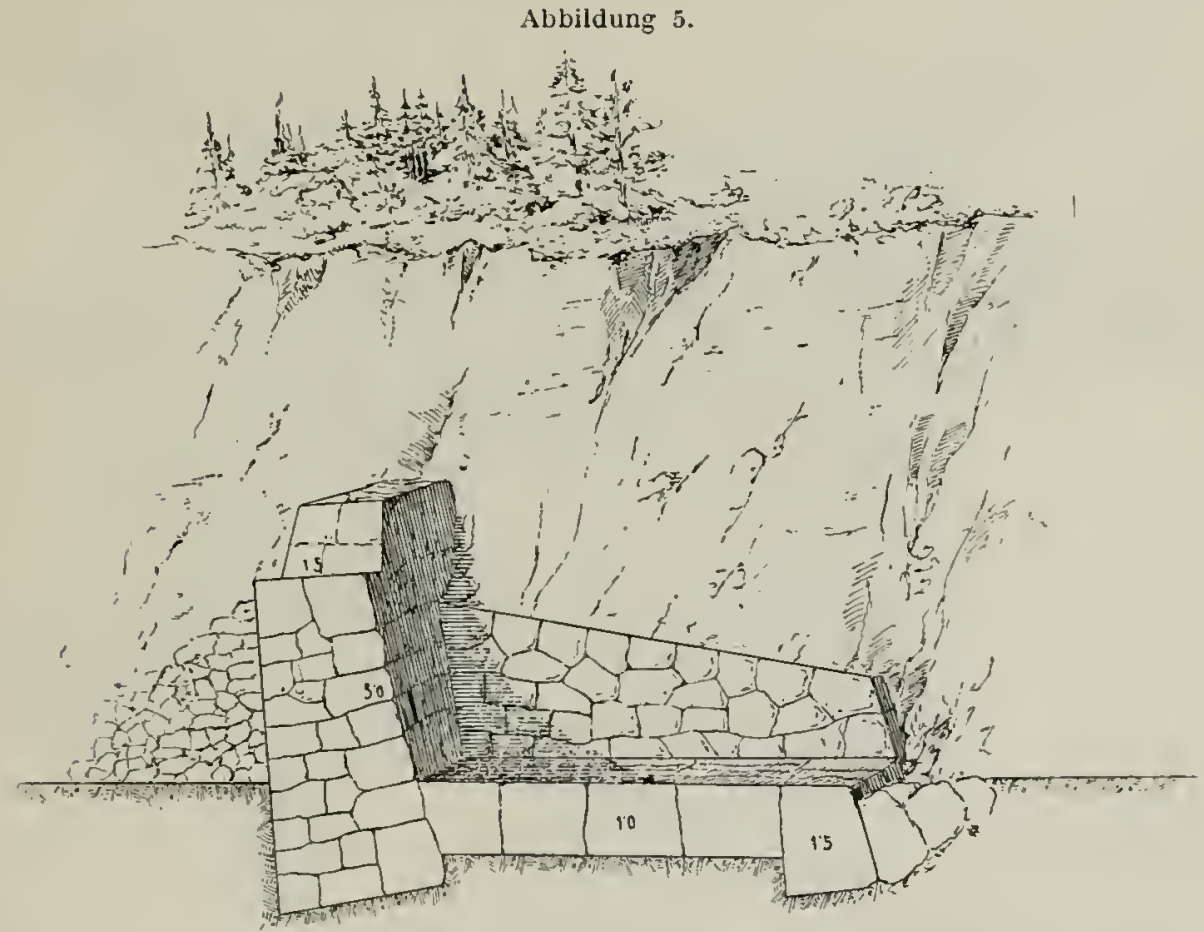

Steinkastensperren. Der liörper der Balkensperren besteht aus einer Anzahl von übereinandergelegten, runden Stammstücken von gehöriger Länge und Stärke, die entweder unmittelbar aufeinanderliegen oder untereinander Zwischenräume von $15-20 \mathrm{~cm}$ Weite bilden. Im ersteren Falle wird die Sperrwand in der Regel durch vorne eingerammte Piloten gehalten. Im zweiten Falle dienen zur Festigung dieser Wand Zangenhölzer, welche in dic Hinterfüllung möglichst weit hineingreifen. Nicht ohne Vorteil ist die Verwendung von ganzen Stämmen mit voller Beastung als Zangenhölzer, in welchem Falle dje in der Hinterfüllung fest eingesehlossene lírone einen weit höheren Festigkeitsgrad gewährt. Es entsteht dann die im Gebirge häufig angewendete $\mathrm{R}$ a u h b a u m s p e r re, Abb.6, 7 und 8. Die Steinkastensperre, Abb.9, I0 und 11, besteht aus zwei Balkenwänden, die untereinander mittels Querhölzern verbunden sind, während der Zwischenraum mit Geschiebe aus- 
Abbildung 6 .

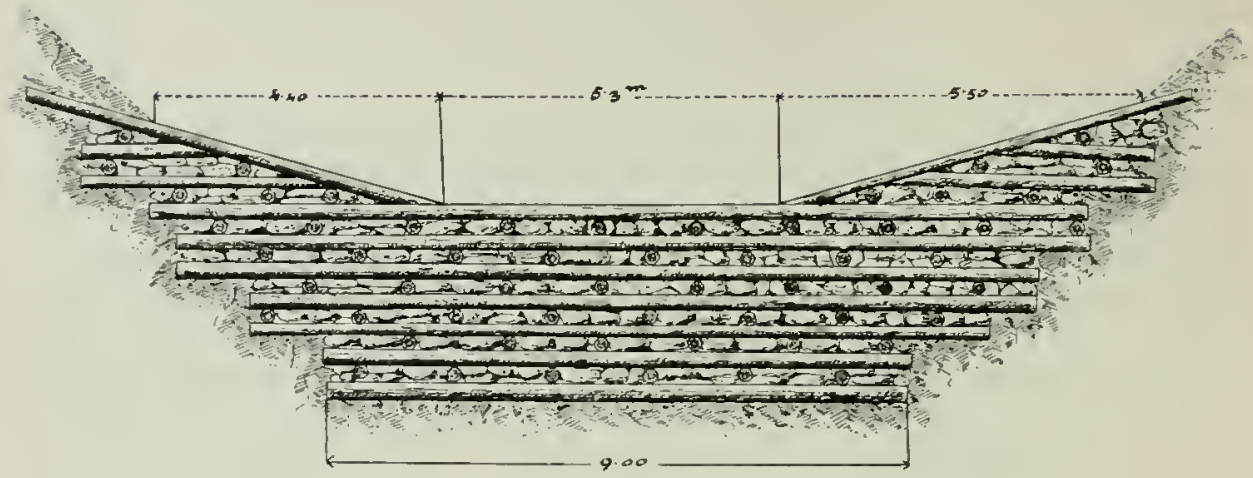

Abbildung 7 .

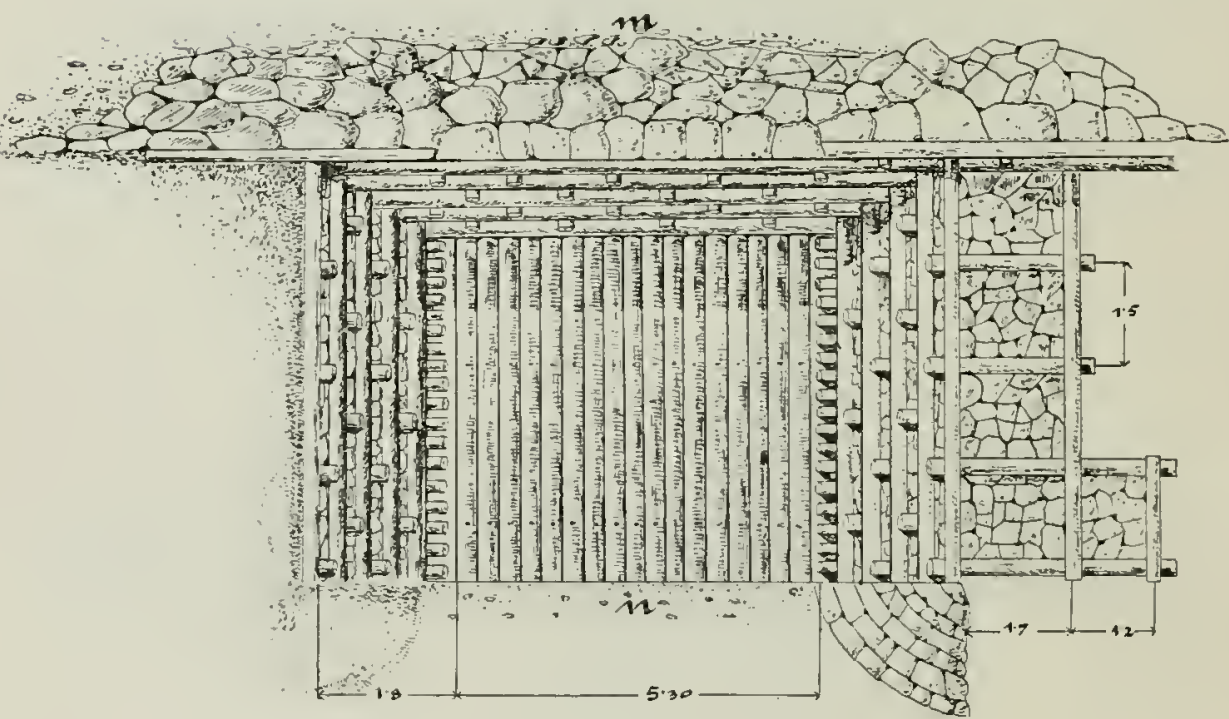

Abbildung 8 .

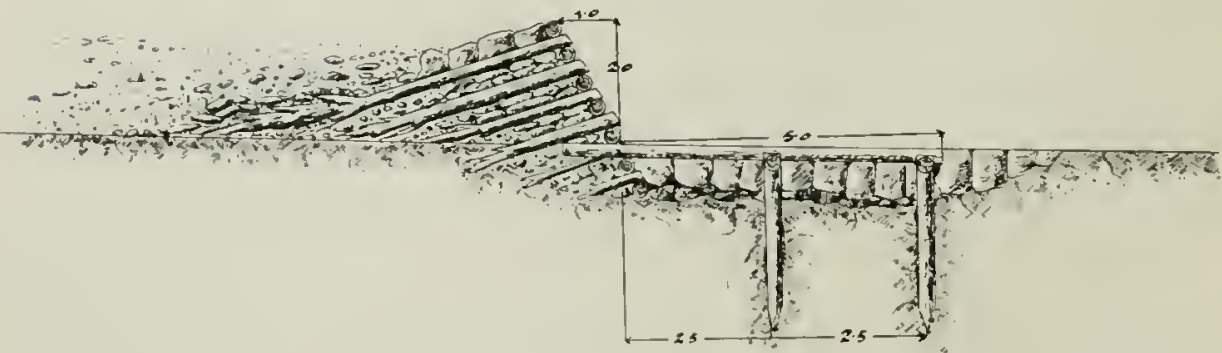


gefüllt und an der Oberfläche überdielt oder abgepflastert wird. Ist die Profilweite sehr beträchtlich, so wird der Holzbau aus zwei oder drei Teilen derart zusammengesetzt, daß zwei Teile bergwärts einen stumpfen Winkel bilden oder daß bei drei Teilen der mittlere Teil senkrecht auf den Stromstrich und die Seitenteile schief und talwärts gefülrt werden, so daß die Form einen mit dem Scheitel bergwärts liegenden Gewölbe älınlich wird. In der obersten Balkenlage wird durch Einschnitte und durch

Abbildung 9 .

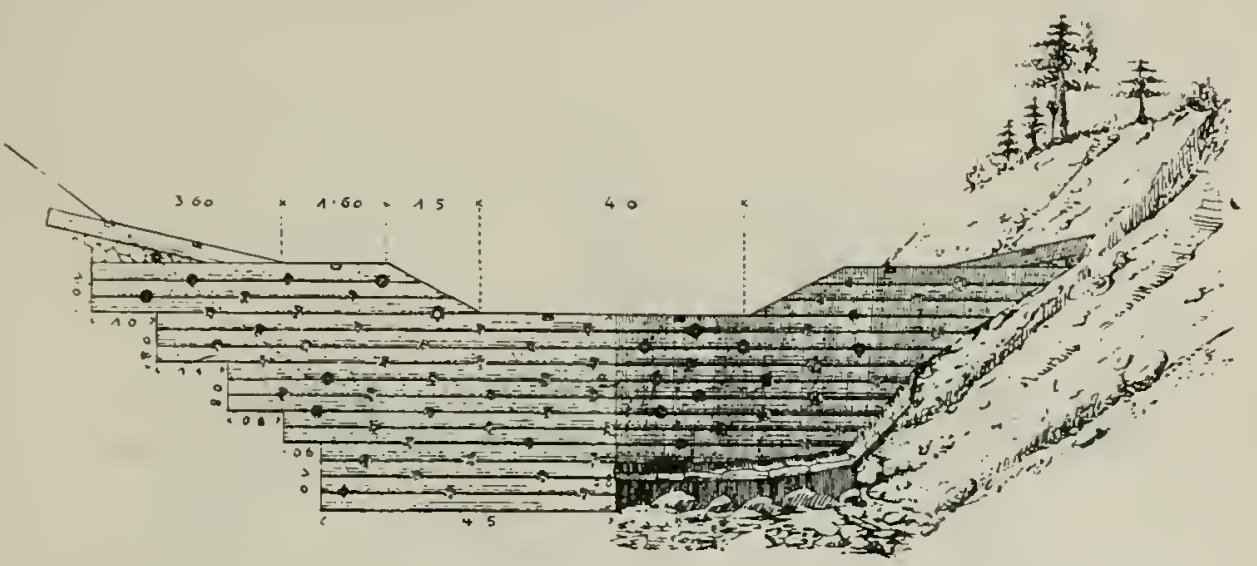

Abbildung 10 .

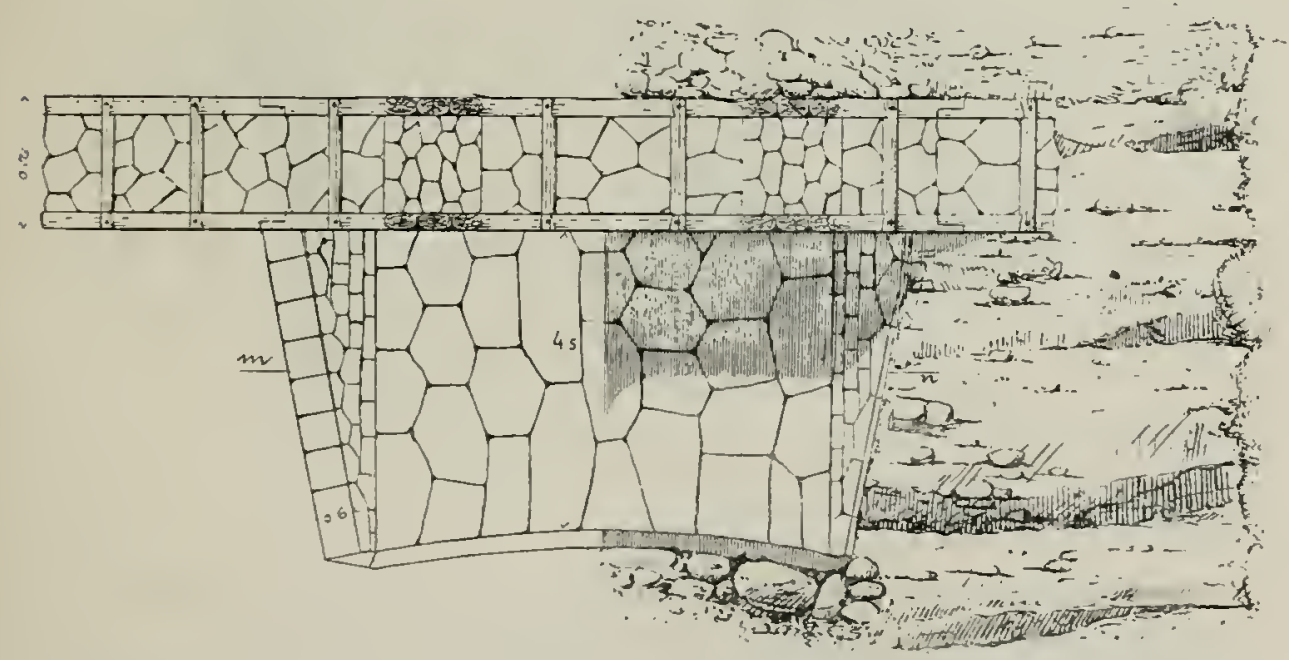

Befestigung von kürzeren Seitenstïcken eine AbfluBrinne für die Wässer geschaffen und damit auch der Stromstrich von den gefälırleten Uferpartien abgelenkt. Die Versicherung des Vorfeldes bei hölzernen Talsperren erfolgt in ähnlicher Weise wie bei den Steinsperren unl ist den Abb. T-1I zu entnehmen. Zu beachten ist, daß Holzsperren im untersten Teile einen Holzbolen, den sog. Schwerboden zu dem Zwecke erhalten sollen, danit im Falle der Auskolkung die Füllung, wo eine solche vorlianden, nicht nachsinken kaun. 
b) Die Grundsehwellen sind nierrige Querwerke, welehe im allgemeinen die Aufgabe haben, entweder, ähnlich wie die Talsperren, in systematischen Zusammenhange die Erosion zu verhindem, oder aber anderen Objekten, Parallelwerken, Schalenbauten, auch den Talsperren als Vorsperren zur Stütze zu dienen.

Die Wahl der Baustelle hängt von der Aufgabe ab, welehe das Objekt oder eine ganze Reihe solcher Objekte zu erfüllen hat. Im allgemeinen gelten für die Wahl der Baustelle die bei den Talsperren zu berücksichtigenden Grundsätze.

Grundschwellen kömnen, ähnlich wie die Talsperren, in Stein und Holz bei entsprechend geringerer Dimensionielung ausgeführt werden.

Abbildung 11.

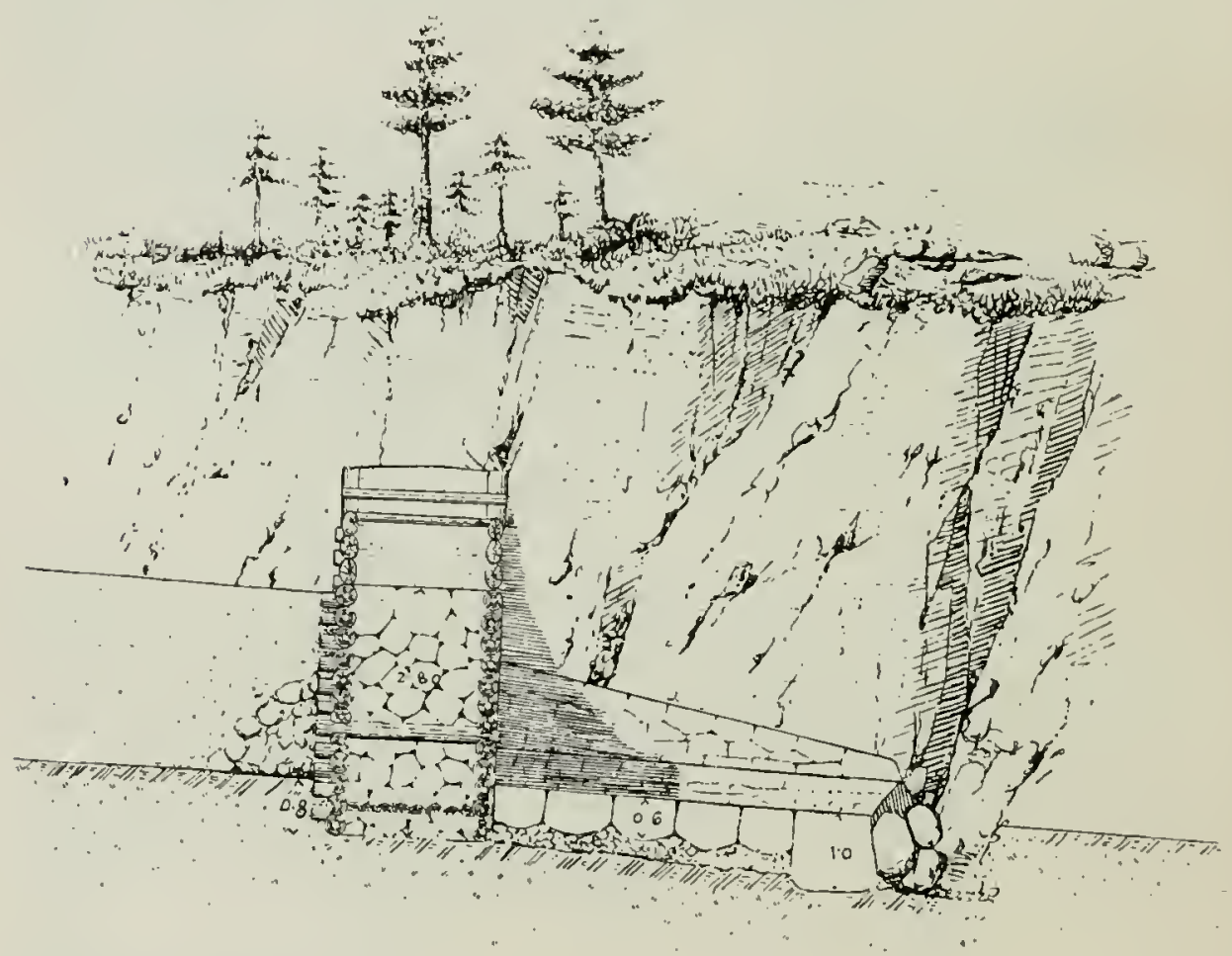

Eine Steingrundschwelle, welche einer sich anschließenden Sohtenpflasterung zur Stütze dient, ist in den Abb. 12, 13 und 14 ersichtljeh gemacht.

Hölzerne Grundschwellen bestehen aus einem, aus zwei oder mehreren Balken, die senkrecht auf den Stromstrich in die Bachsohle eingelassen und beiderseits mit den Hängen entspreehend verhunden werden.

Die geringere Dimensionierung der Grundschwellen und ihre Anwendung in den kleinen Wasserinnen, welche sich raseh begrünen sollen, lassen es oft wïnsehenswert erscheinen, ausschlagfähiges Material zu ihrer Herstellung als sog. I e b e n d e Werke zu verwenden. Derartige Objekte sind dann als Querflechtwerke, Abb. 15, 16 und 17, orler als Faschinenquerwerke, Abb. 18, 19 und 20 bekamnt. 
Abbildung 12.

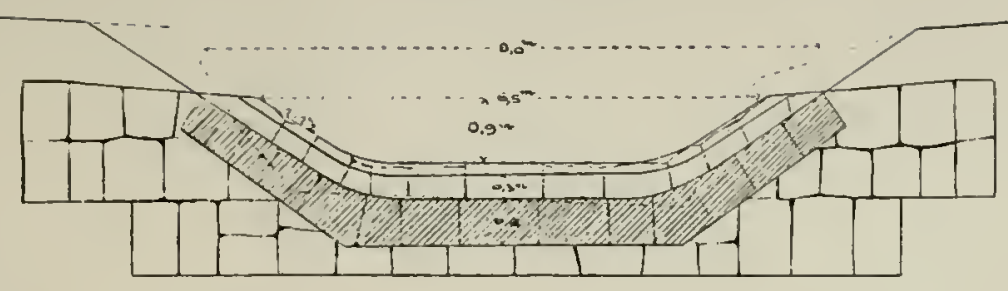

Abbildung 13 .

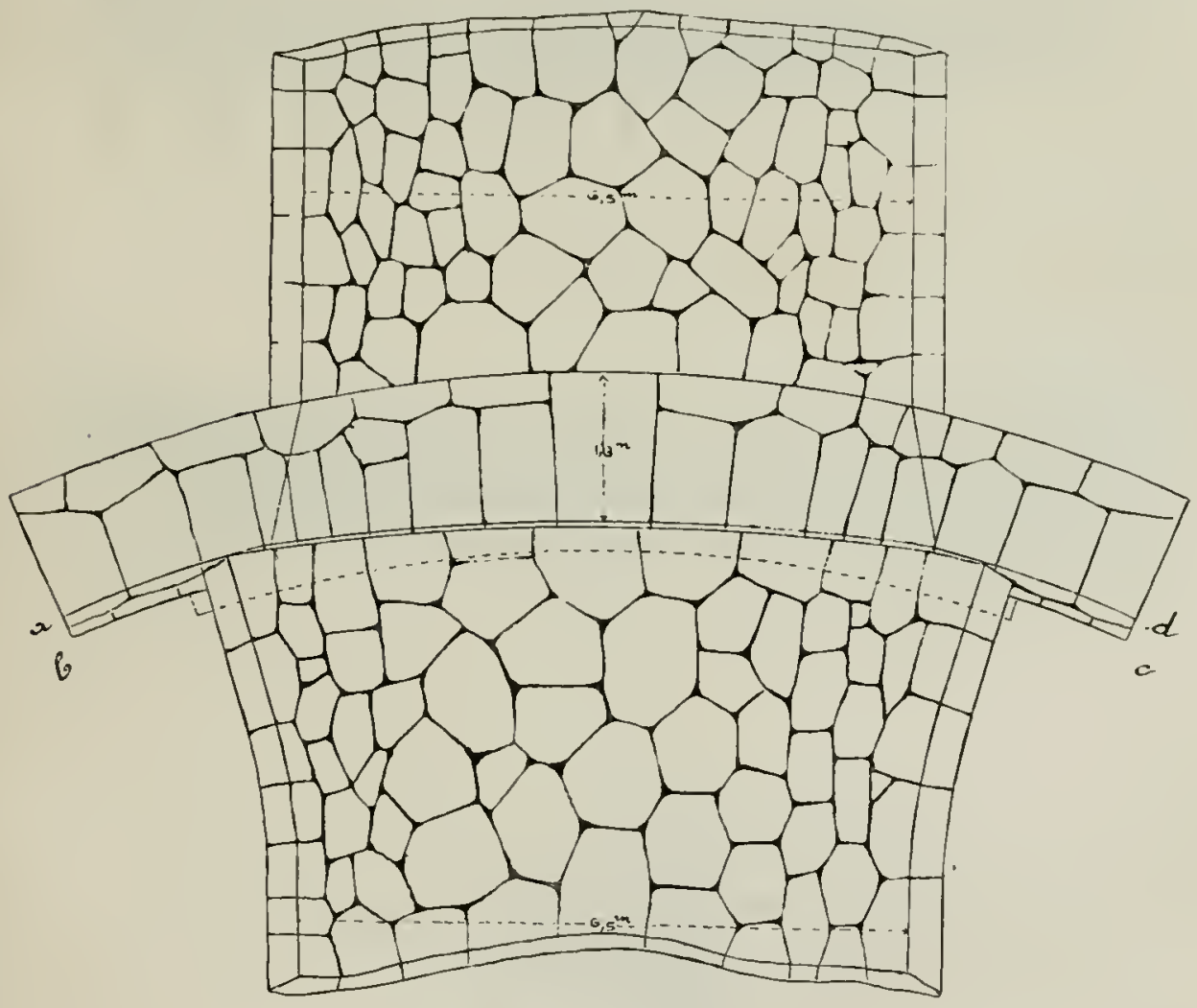

Abbildung 14.

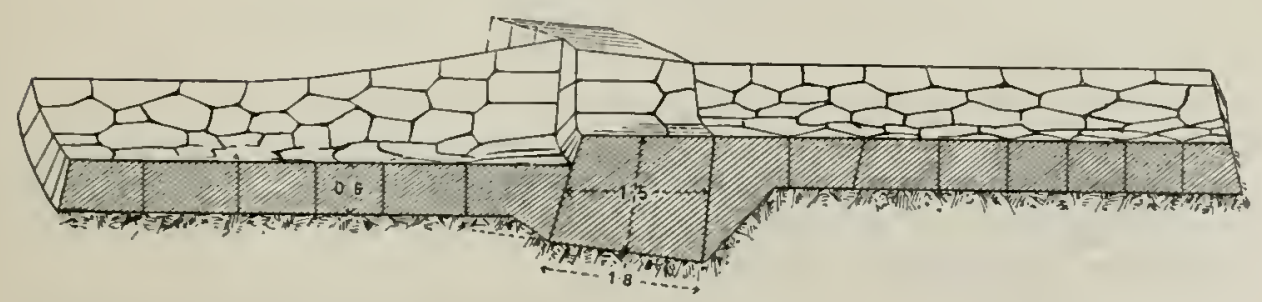


Die Art der einfach gehaltenen Vorfeldversicherung ist den bezogenen Abbildungen zu entnehmen. Im Bedarfsfalle können die Konstruktionelı entsprechend verstärkt werden.

Steht ausschlagfähiges Material nicht zur Verfügung, so müssen derartige Objekte aus sonstigem Astwerk, als sog. to t e Werke errichtet werden.

Abbildung 15 .

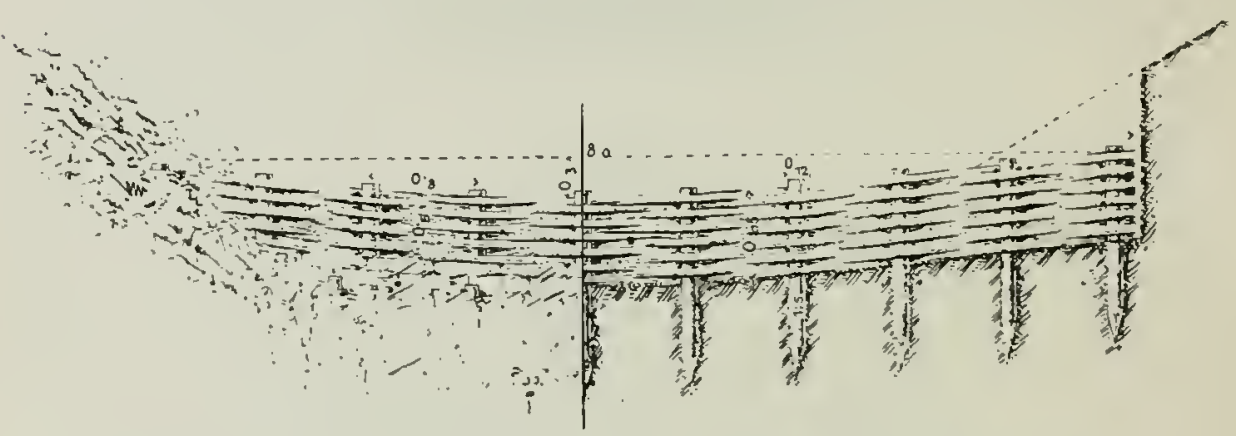

Abbildung 16 .

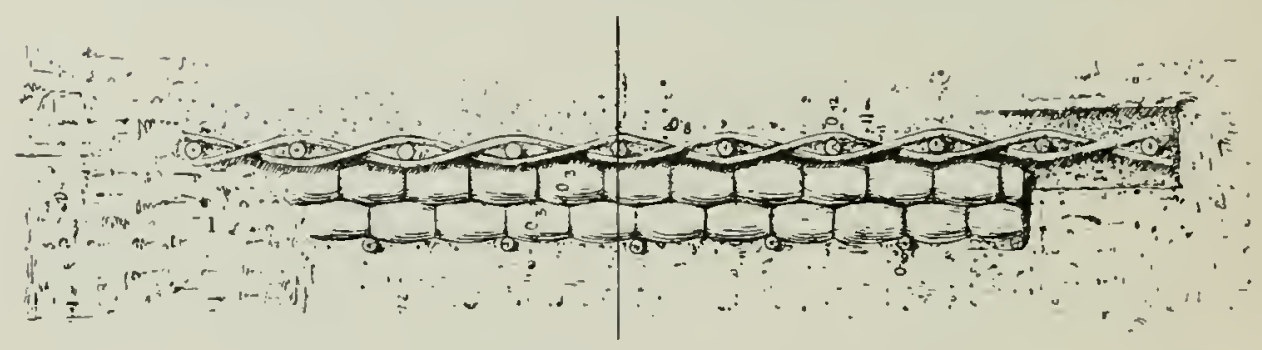

Abbildung 17.

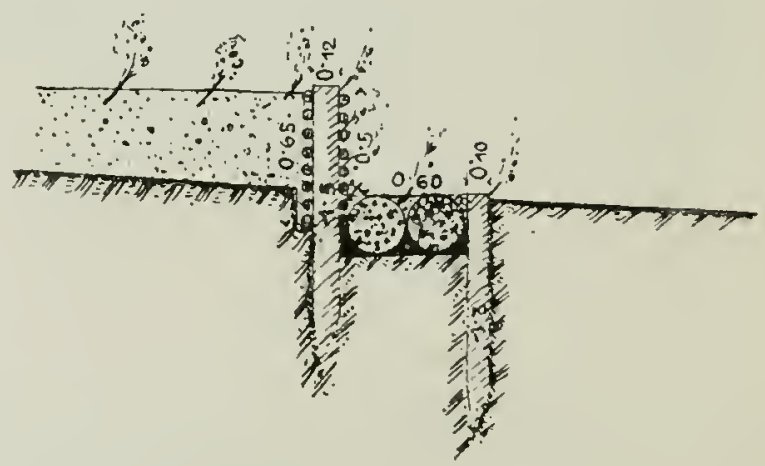

Die lebenden Werke finden übrigens auch dort Anwendung, wo es sich darum handelt, auf die Verlandung der Querwerke erster oder zweiter Ordnung sehwächere Objekte höherer Ordnung zum Schutze dieser Verlandung und zur Ermöglichung ihrer raschen Begrünung aufzusetzen.

Die lebenden Werke, die mit Rücksicht auf ihre Widerstandskraft und längere Dauer den toten Werken vorzuziehen sind und zu deren Ausführung ausschlagfähiges 
Material verwendet wird, sollen zu einer Zeit hergestellt werden, zu welcher aul das Austreiben mit Bestimmtheit gerechet werden kann. Das Mlaterial soll daher frisch gewonnen werden und speziell zur Ilerstellung von Faschinen aus möglichst langen und nicht zu starken Weidenruten bestehen.

Abbildung 18.

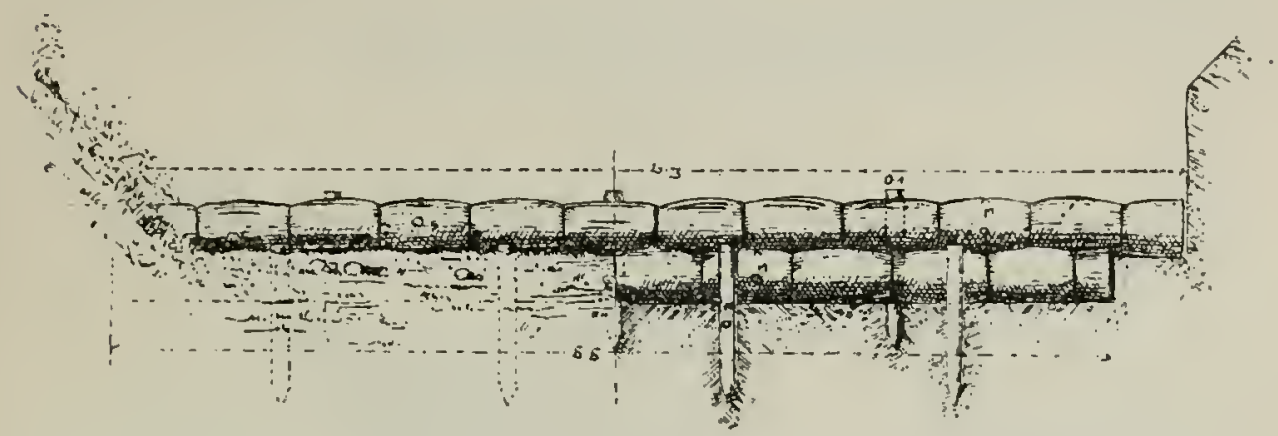

Abbildung 19 .

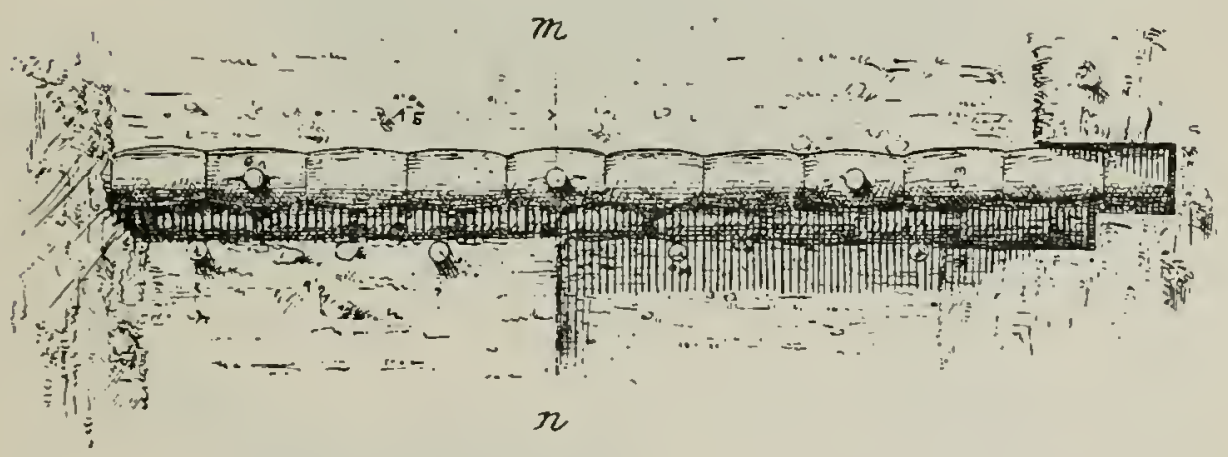

Abbildung 20.

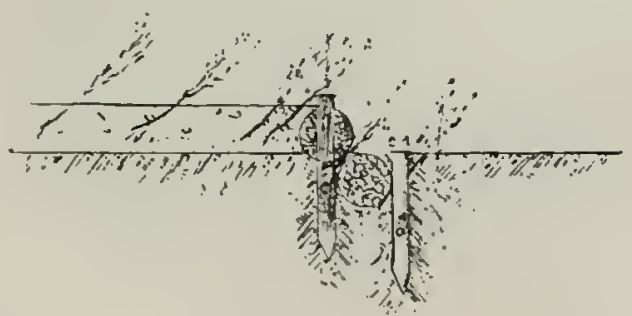

Im Falle der Errichtung von Flechtwerken werden senkrecht auf den Stromstrich Pfähle aus womöglich gleichfalls ausschlagfähigem Materiale in einer oder in zwei Reihen geschlagen und mit ausschlagfähigen Weidenruten, deren unteres Ende genügend tief in den Boden zu versenken ist, verflochten.

Die Faschinen werden durch Binden des Materiales mittelst Draht oder Wieden ergänzt und sollen länger sein, als die Breite des damit zu verbauenden Rinnsales. Wird die Faschine init einem Schotterkem versehen, so entsteht die Senkfaschine, 
in größerer Dimensionierung auch Sinkwalze genannt, welche den Vorteil einer gewissen Beweglichkeit insoferne Lesitzt, als sie im Falle der Ausliolliung durch ihre Schwere nachzusinken und den Kolk wenigstens teilweise auszufüllen vermag.

2. Die Parallelbauten. Es sind dies Objekte, welche nach der Längsrichtung des Baches in der Regel zum Schutze von anbrüchigen Lehnen oder Ufem, oder auch zur Schaffung geregelter Gerinne errichtet werden. Zu derlei Bauten gehören zunächst die verschiedenen Arten des $\backslash$ ferschutzbaues, auf deren nähere Beschreibung wegen Raummangel hier nicht eingegangen werden kann.

\section{Abbildung 21.}

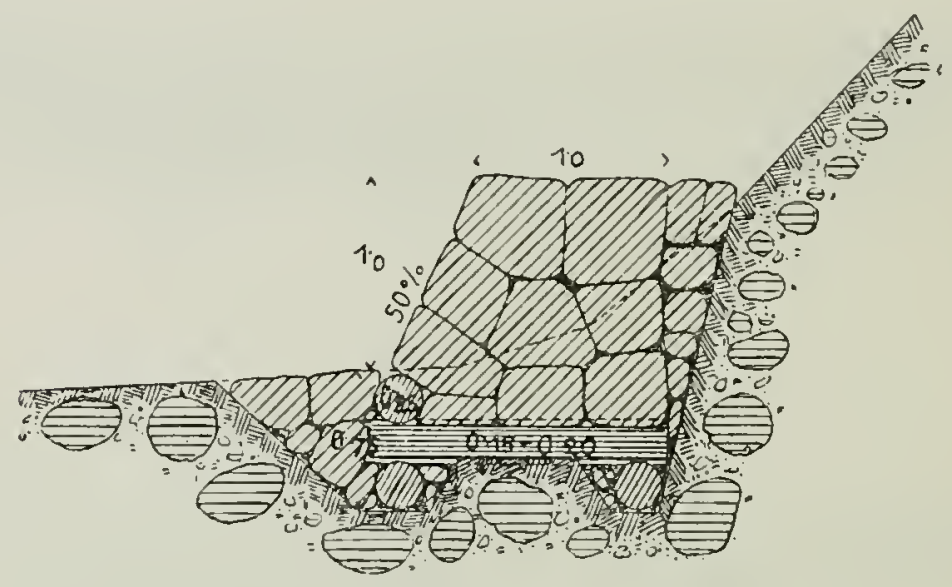

Abbildung 22.

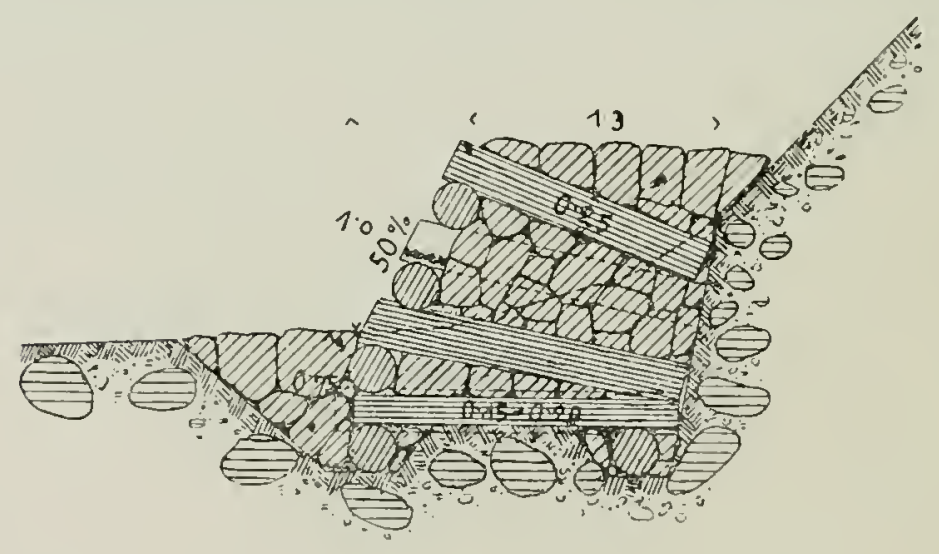

Die Wahl der Baustelle isl durch die örtlichen Verhältnisse gegeben; für die Wahl des Baumateriales gelten die allgemeinen Grundsätze. Ufersehutzbauten werden in den Wildbächen nicht selten als Flechtwerke oder in Form von Streichwänden, dann in Form einfacher oder doppelter Stemkästen, rohen oder geschlichteten Steinwürfen u. dergl. m. errichtet. Flache Böschungen sind den steilen vorzuziehen. Gegen die Gefabr der Auskolkung sowohl, als auch rer der Ueberflutung mu 3 entsprechend vorgesorgt sein. 
Abbildung 23.

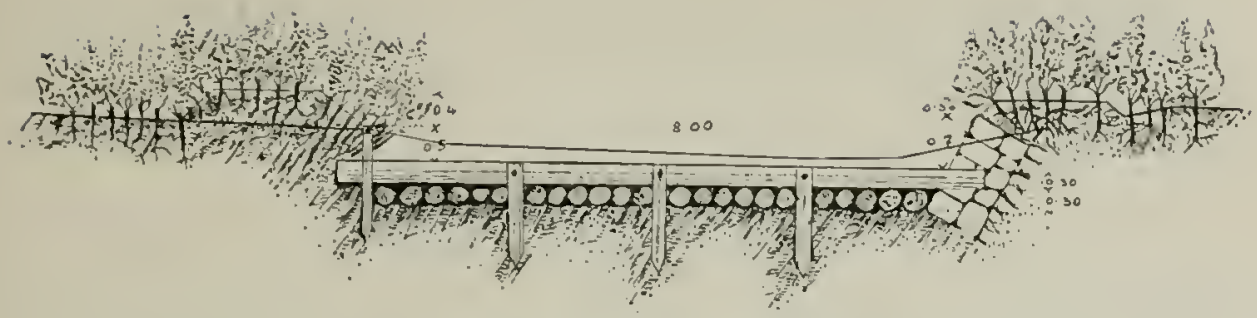

Abbildung 24 .

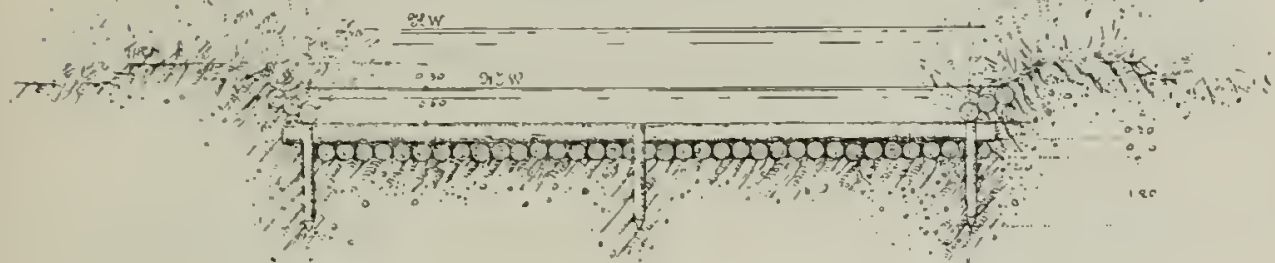

Abbildung 25 .

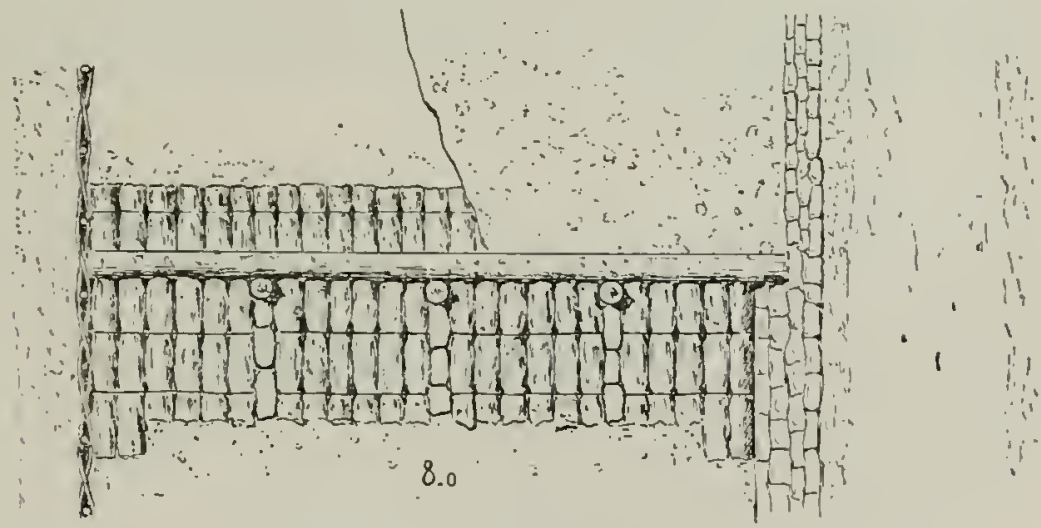

Abbildung 26.

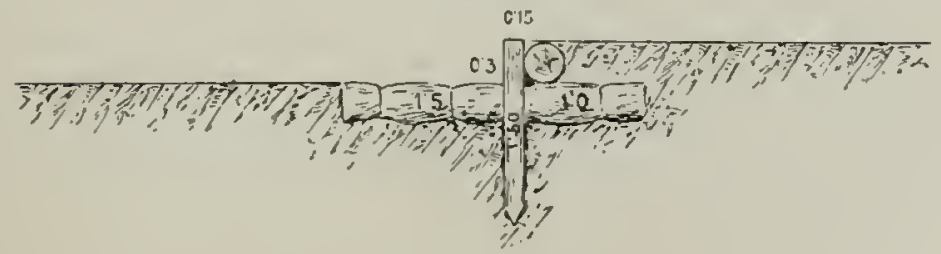


Die Abb. 21 und 22 zeigen solche nicht selten in Anwendung kommende Uferschutzbauten.

Wenn es sich um die Herstellung geschlossener Gerinne handelt, was insbesondere in den ausgedehnten Talläufen der Wildbäche der Berg- und Hügelländer nötig fällt, so kommen oft Flechtwerke, Faschinenwerke, Spreitlagen oder auch Sinkwalzen in Anwendung. Wo Steine vorhanden, werden gemauerte Leitwerke oder Böschungspflasterungen, Taludierungen, ausgeführt.

Zur Verhinderung der Unterwaschung sind nach Bedarf Grundschwellen einzubauen. Die Abb. 23-26 zeigen derartige Bachlaufkorrektionen, Abb. 27 überdies den Sinkwalzenbau.

Die sehr veränderlichen Wasserstände der Wildbäche der Berg- und Hügelländer schließen die Wahl des einfachen, alle Wasserstände konsumierenden Querprofiles aus, weshalb zumindest den extremen Hochwässern die Ueberflutung nicht verwehrt wird. Aus diesem Grunde erseheint es aber umso mehr geboten, das Vorland durch Einziehen von Traversen aus Flechtwerk, oder in Art von Steinwürfen auf Faschinenbettung, u. dergl. m. zu festigen.

In seltenen Fällen wird das Doppelprofil gewählt.

Abbildung 27.

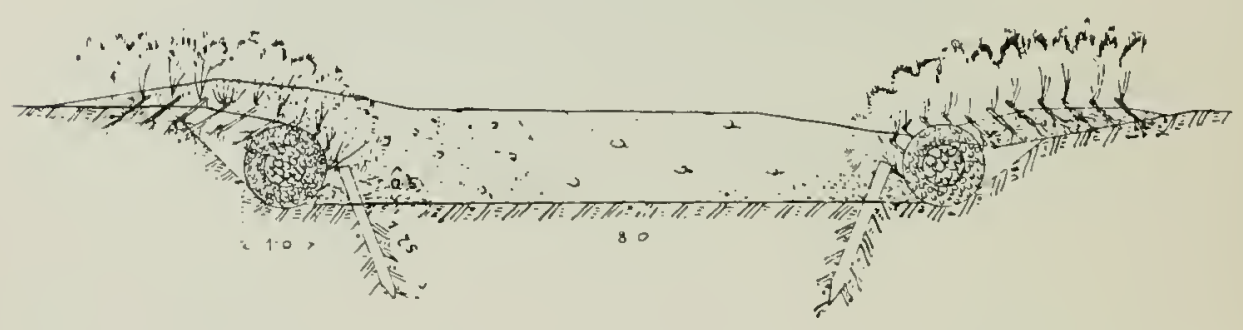

Strenge genommen zu den Parallelwerlien nicht zu zählen sind die Buhnen, welche, mehr oder weniger weit und verschieden gestellt, in das Bachbett ragen. Sie werden als Schutz-, Treib- und Verlandungsbulnen errichtet, bilden aber in den Wildbächen stärkeren Gefälles ein zweischneidiges Schwert in der Hand des Projektanten, denn je offensiver ihr Charaliter, desto größer wird die Gefahr von Bachverwerfungen. In den Vildbächen der Berg- und Hügelländer können sie bei den dort vielfach herrsclıenden geringeren Gefällswerten dazu benützt werden, um durch langsames Vorschieben, bei gleichzeitiger Kúltivierung des Vorlandes, die Entwickelung des Normalprofiles zu fördern und dessen nachträgliche Stabilisierung zu erleichtern.

Ihre Herstellung erfolgt in Art des Uferschutzbaues. Besonderes Gewicht ist auf die ausreichendste Versicherung des Buhnenkopfes zu legen.

3. D i e $\mathrm{Sel}$ a 1 e $\mathrm{n}$ b a u te $\mathrm{n}$. Schalen oder Kunetten sind künstlich Ihergestellte Abflußkanäle mit am vorteilhaftesten segment- oder halbkreisförmigem Profile.

In der Regel kommt der Schalenbau zur Verhinderung der Sohlenerosion in den obersten Runsen des Niederschlagsgebietes eines Wildbaches zur Anwendung, doch setzt das voraus, daß die beiderseitigen Gelıänge schon so weit abgebösclıt sind, daßß durch ihren Einsturz oder selbst durch Heral,fallen größerer Steine die Schale, die in der Regel gepflastert ist, nicht Schaden leide. In größerer Form können Schalen auch behufs Ableitung des Baches, sei es im Talinnern, sei es am Schuttkegel errichtet werden. Unter gewissen Verhältnissen liamn es genügen, an Stelle von Steinschalen 
hölzeme, schalenfömige Gerinne oder selbst solche aus Rasen (Rasenkunetten) zu ähnlichen Zwecken herzustellen. Vorteilhaft sind gepflasterte Schalen in Verbindung mit Verpfählungen, die sog. Pfahlkunetten. Die Dimensionierung hängt in allen Fällen von den zu crwartenden Abflußmengen ab. In steilem Gefälle wird die Unterstützung durch Grundschwellen nottum. Die Abb. 28-31 zeigen eine durch Grundschwellen

Ablildung 28 .

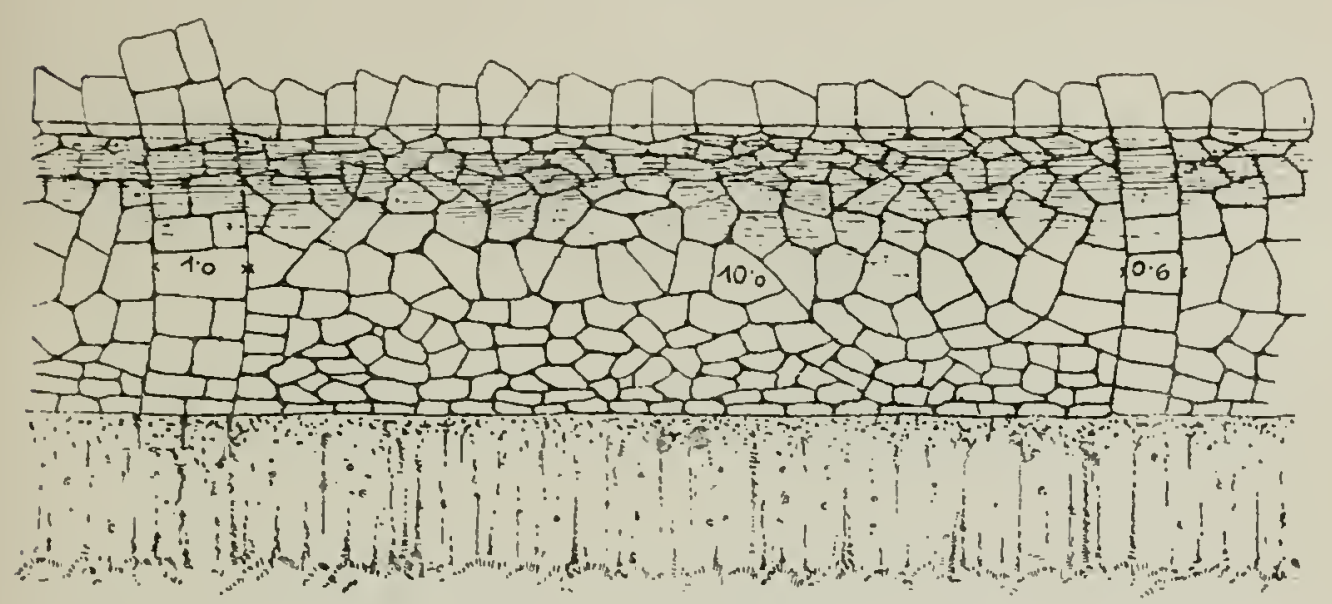

Abbildung 29.

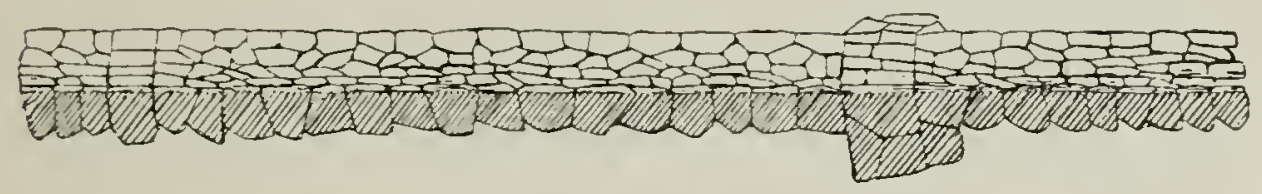

Abbilung 30 .
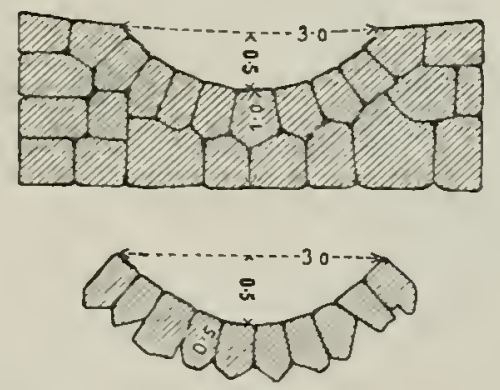

Abbildung 31 .

gestützte Steinschale. Hervorzuheben ist, daß derartige Objekte, wenn es besondere Verhältnisse nicht anders erheischen sollten, von unten hinauf zu bauen sind, weil so im Falle des Eintrittes eines Hochwassers während der Arbeit größeren Beschädigungen besser vorgebeugt erscheint.

4. Die En twässerungsan lagen. Dieselben bestehen in der Errichtung von Entwässerungsgräben zum Zwecke der Ableitung ded Quell- und Sickerwässer, welche 
vornehmlich durch Unterwülnlung schädlich wirken. Für die Anlage sind die lokalen, oft sehr verschiedenen Verhältnisse derart maßgebend, daß sich in gedrängter Kï̈rze allgemeine Grundsätze für die technische Durchfülırung nicht aufstellen lassen. In den Vildbächen ist es unbedingt notwendig, die auf die Unterwühlung der Gehänge zurückzuführenden Terrainbrüche sorgfältig zu beobachten und eventuell vorerst provisorisch zu entwässern, bevor zur Anlage definitiver derartiger, zumeist kostspieliger Anlagen geschritten wird.

Abbildung 32 .

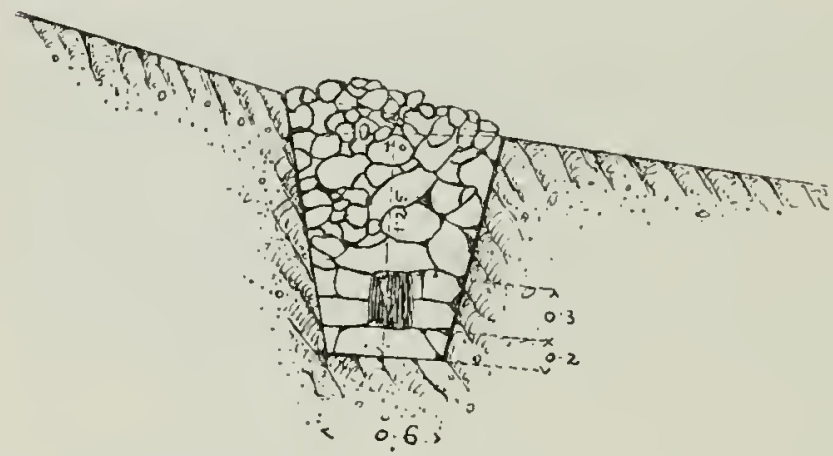

Die Abb. 32 und 33 zeigen Querschnittevon Entwässerungsgräben, wie solche zumeist zur Herstellung gelangen. In Abb. 33 ist der Graben durch eine Schale gedeckt, welche den Zweck hat, das oberflächlich abfließende Meteorwasser unschädlich über den lockeren, unterwühlten Hang abzuleiten.

Die Anlage, die wenn nötig, in anderen voranzugehenden baulichen Maßnahmen, als Fußversicherungen, Solnlensicherungen u. dgl. m. ilıre Stütze finden muß, soll unsomehr die Eigenschaft der tunlichsten Bauölionomie aufweisen, als ihre Zweckmäßigkeit oft von vorneherein nicht hinreichend beurteilt werden kann. Zur Füllung

Abbildung 33.

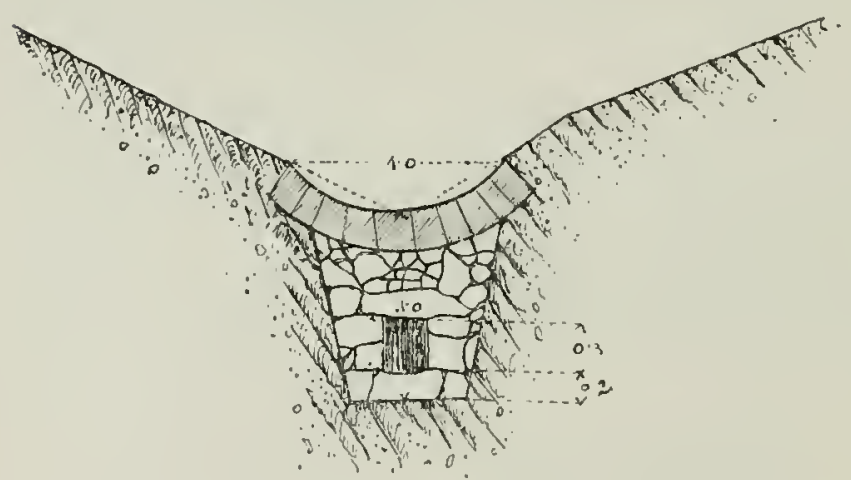
der Gräben ist deshalb das in der Regel nicht weit von der Baustelle zu gewinnende Stein-, Holz- oder auch $\mathrm{Fa}$ schinenmaterial zu verwenden. Drainröhren und ähnliche Leitungen sind der Kostspieligkeit und der in der Regel hohen Transportkosten halber selten, und wohl nur an zugänglicheren Orten im Gebrauch.

Der zu verwendende

Stein ist von der anhaftenden Ercle zu befreien und mit der breiten Fläche nach abwärts zu legren. Die größten Steine liommen zu nnterst zu liegen. Un das Verschlämmen zu verhindern, ist eine Einlage von lloos oder Fichtennadeln vorteilhaft. Bruchstein in loser Schichtung ist, weil dem Wasser mehr Zwischenraum zum Abflusse geboten wird, verwendbarer als Findlinge. Bei größerem Gefälle ist die Sohle des Entwässerungsgrabens durch Pflasterung oder sonstwie zu versichern. Die Anlage ist an geeigneten Stellen, so insbesondere am unteren Ende durch Grundschwellen zu stützen; auch stützt sich nicht selten der Entwässerungsgraben (Hauptgraben) in seinem untersten Teile an ein Parallelwerk, 
welches der zu entwässernden Lelne als Fußversicherung dient, wobei naturgemäß für den ungehinderten Abfuß der abgeleiteten Wässer Sorge getragen werden muß. Offene Gräben kommen im Hinhlick auf die Gefahr der Verschüttung oder Beschädigung seltener in Anwendung.

Eine besondere Art der Entwässerung kömnen Horizontalgräben bilden, deren Anlage oft empfolılen wird. Sie durchziehen die Lehne horizontal, ununterbroehen zumeist, und sollen das Meteorwasser im Abflusse übel die Lehne aufhalten. Ihre allgemeine Anwendung kann jedoch im Hinblick auf den liostenpunkt und auf den Unstand, daß das Wasser zum Stagnieren veranlaßt wird und so in etwa vorhandenen lockeren Boden einzudringen und damn vielleicht zu unterwühlen vermag, nicht empfolılen werden.

Entwässerungen werden auch dann mitunter erforderlich, wenn es sich um die Verneidung der Gefahr von Bergstürzen oder größeren Steinschlägen handelt, falls diese auf die Frostwirkung oder Unterwühlung des in das Gestein eindringenden Wassers zurückzuführen sind. Mit ihnen Hand in lland gehen dann nicht selten Untermauerungen des zum Sturze bereit liegenden Gesteines.

5. Die $L$ e h n e n b in d u $\mathrm{n}$ g e $\mathrm{n}$. Sind dieGrundursachen, welche die Terrainbewegung hervorufen, als Erosion, Korrosion, Unterwühtung, durch die vorangeführten baulichen Ilaßnahmen behoben, so kamn, wemn dies noch nötig fallen sollte, zur oberflächlichen Bindung des Terrains geschritten werden. Es erfolgt dies durch Verflechtung, Plaggadierung, in seltenen Fällen durch Abplasterung, durch Herstellung von sog. Berauhwehren und auf mancherlei andere Weise.

Die Verflechtung ausgedehnter Flächen ist eine in der Regel ziemlich kostspielige Maßnahme und soll, wenn nicht unbedingt nötig, vernieden werden. Ihr, sowie andern Bodenbindungsarten geht gewöhmlich das Planieren (Sliarpieren) des Bruchterrains voraus. In vielen Fällen wird man sich mit der Entfernung der größern Steine aus der Bruchfläche, deren Wasserrisse auf tunlichst primitive Weise gegen weitere Erosion versichert werden, begnügen können. Nach Herstellung möglichst einfacher Terrassen wird das am vorteilhaftesten aus ausschlagfähigen Pflöcken und Flechtmateriale zusammenzustellende einfache Flechtwerk in am besten horizontal verlaufenden Reihen errichtet, wobei die Arbeit grundsätzlich von unten nach oben hin fortzusehreiten hat. Der Zaun soll behufs Verhinderung seiner Beschädigung durch herabrollende Steine möglichst wenig aus dem Boden hervorragen, oder doch an der Bergseite durch angelegtes Erdreich gedeckt werden.

Bei Anweurlung von Rasenplaggen wird die Lehne entweder vollkommen mit diesem Materiale bedeckt, oder es ist dasselbe schachbrettförmig angeordnet; die so freibleibenden stellen werden beplanzt. Die Anwendharkeit dieser Mlhode ist eine beschränkte. Ebenso eignet sich volle Abpflasterung nur für kileine Flächen von besonderer Wichtigkeit. Berauhwehren bestehen in dem Aushub von horizontal verlaufenden kleinen Gräben, in welche ausschlagfähiges Vaterial gesteckt und an der Lehne befestigt wird.

Nach einem von Müller $\left.{ }^{1}\right)$ empfohlenen System werden Rasenplaggen vereinzelt auf der Lehne mit je einem Pflocke befestigt; die Zwischenräume sind zu bepflanzen. Auch die den Firmamente zugekehrte, gewöhnlich noch beraste Seite der oft überhängenden Bruchwände wird nach Nüller durch vereinzelt aufgelegte, mit Pflöcken befestigte Plaggen versielert, verschlagen.

Die weitern Lehnenbindungsarbeiten, als Berasung und Aufforstung, zählen zu den forestalen IaBnahmen, auf die an anderer Stelle zurückgekommen wird. Hervor-

1) F. Müller, "Die Gebirgsbäche und ihre Verheerungen". Landshut 1857. 
gehoben sei, daß es stets geboten erscheint, das allenfalls innerhalb der Bruchfläche und an deren Rändern stockende schwere Holz zu entfernen.

Wenn auch nicht als Lehnenbindung, so doch als ein Mittel, welches vor allenfalls abgehenden Steinen, vor Steinschlag zu schützen hat, sind innerhalb der Lehne zu errichtende höhere Flecht- oder auch Schwartling-Zäune anzusehen.

6. Die Schut kegelsicherungen. Die diesbezüglichen Arbeiten kommen vorwiegend bei den Wildbächen des Hochgebirges, woselbst die Schuttkegelbildung in der Regel eine ausgesprochene ist, in Anwendung. Im allgemeinen kann die Versicherung des Schuttkegels auf zweifache Weise erfolgen, und zwar durch Herstellung eines mehr oder minder festen, stabilen Gerinnes, oder aber durch Schaffung eines Ablagerungsplatzes, in welch letzterem Falle strenge genommen weniger der eigentliche Schuttkegel gesichert, als vielmehr das angrenzende Gelände vor der Schuttkegelvergrößerung bewahrt wird.

Bei Schaffung eines Gerinnes am Schuttkegel sollen die folgenden wichtigsten Gesichtspunkte nicht außer acht gelassen werden.

Das Gerinne soll ein Querprofil erhalten, welches genügend groß ist, um die Wässer des höchsten Standes samt Gesehiebe abzuführen. In den Hochgebirgsbächen wird das einfache schalen- oder das trapezförmige Profil gewählt, weil die in der Regel größern Gefällswerte die Abfuhr des Hochwassers sowohl als auch des Niederwassers in einem solchen Profile gestatten. Das Längenprofil des Gerinnes muß ein Gefälle aufweisen, einerseits groß genug, eine ungehinderte Materialabfuhr zu gewährleisten, anderseits nicht zu groB, um der Gefahr der Beschädigung des Baues, namentlich der Sohle desselben, zu begegnen. Die lokalen Verhältnisse lassen bezüglich der WVahI des Längenprofiles in der Regel nicht viel Spielraum. Längenprofil und benetzte Querprofilfläche bedingen die AbfluBgeschwindigkeit und die Masse des ungehindert abzufließenden Wassers. Geschwindigkeitswerte von über $4 \mathrm{~m}$ pro Sekunde gehören schon zu den bedeutenderen im Hinblick auf die Gefahr der Erosion und Verletzung der Gerinnsohle bei größerer Geschiebeführung.

Die Mündung des Gerinnes in den Rezipienten soll die ungehinderte Abfuhr des IVassers und des Geschiebes gestatten.

Die in der Regel durch ein festes Querwerk gestützte Einmündung soll deshalb tunlichst spitzwinkelig erfolgen. Behufs Vermeidung jedes Rückstaues bezw. Schaffung der nötigen Vorflut soll, was allerdings nicht immer tunlich ist, die Sohle des Gerimes höher liegen als der Hochwasserspiegel des Rezipienten.

Der Beginn des Gerinnes, dessen Trasse naturgemäß mit Rücksicht auf $\mathrm{Ab}$ wendung der Gefahr für Ortschaften, liommunikationen gewählt sein soll, muß gegen die Gefahr der Beschädigung, insbesondere Hinterspülung geschützt sein.

Endlich muß die ganze Anlage allen sonstigen technischen Anforderungen entsprechen. Bei vorherrschenden größern Gefällswerten ist unter allen Umständen die Pflasterung der Sohte in Zement, vielfach aber auch die Unterstützung des Sohlenplasters durch Grundschwellen bei allenfalls staffelförmiger Ausgestaltung des Längenprofiles der Gerinnsohle geboten. Die beiderseitigen Böschungen sind der größern Stabilität halber tunlichst flach zu halten. Die Ausführung erfolgt nach Art des Schalenbaues und wie dort, von unten nach oben, nach vorhergegangener genauer Trassierung und Profiliemung.

Was die Schaffung von Ablagerungsplätzen auf Schuttliegehn anbelangt, so bestehen dieselben aus der Errichtung von entsprechend hohen Fassungsmauem, welche, von der Spitze des Schuttkegels ausgehend, sich an einer entsprechenden Stelle an seinem unteren Ende wieder vereinigen. Diese Vereinigungsstelle ist zu- 
meist durch ein Querwerk, eine Talsperre oder Grundschwelle gestïtzt und von da ab wird der vom Gesclicbe entlastete Bach in einem in der Regel auf kurzer Strecke talab gesicherten Gerinne geleitet. Ablagerungsplätze kommen im Hinblick auf ihren denn doch nur problematischen Wert und die Kosten ihrer Ausführung selten zur Ilerstellung.

\$ 9. Die B erasung und A ufforstung. Die erstere soll den Boden oberflächlich hinden und gegebenenfalls zur Aufforstung gecigneter machen.

Zur Berasung von Gebirgshöden eignet sich die Esparsette (Hedysarum onobrychis), welche vorteilhaft im Herbste mit Ueberfüichten gesät wird. Weiters sind zu nemnen je nach Lage und Beschaffenheit der Oertlichlieit: die Luzerne, Medicago sativa und media, die Carex-, Poa- und Luzulaarten, das riedgrasartige Rauhgras, Lasiagrostis calamagrostis $\mathrm{u}$. dgl. m. In neuerer Zeit werden wegen ihrer Pfahlwurzelbildung, bezw. besonderel Widerstandskraft gegen Temperaturwechsel gerülmnt: die veredelte Platterbse, Lathyrus silvestris und das Flohkraut der Insel Sachalin, Polygonum sachalinense.

Speziell im Gebirge soll die Rutschfläche nur mit einer Handhaue stellenweise aufgelockert werden, und es sind eventuell rorhandene einzelne Grasbüsche, besonders von Alpenrispengras, stehen zu lassen. Vor allem ist es ratsam, den als erste Besiedlungspflanze auf Rutschflächen charakteristischen Huflattich (Tussilago farfara), in höhern Lagen den Alpenlatticlı (Adenostyles albifrons) wegen der bodenbefestigenden unterirdischen Kriechtriebe möglichst zu schonen.

$\mathrm{W}^{\text {}}$ as die Aufforstung anbelangt, so kann von diesbezüglichen Erläuterungen hier wohl abgesehen werden, zumal ja jeder Forstmann mit den einschlägigen Arbeiten betraut sein muB. Es wäre hervorzuheben, daß, insoweit es sich um Aufforstung von entblößten und zur Rutschung geneigten Böden handelt, die Erziehung von Niederwaldheständen ins Auge zu fassen ist, damit einerseits die Aufforstung rascher vollzogen werden könne und damit nicht späterhin durch die Schwere der oberirdischen Hochwaldmasse die Bewegungstendenz des Bodens gefördert werde.

Bei Ergänzung der Aufforstung innerhalb des Niederschlagsgebietes des Wildbaches ist insbesondere darauf zu achten, daß die geeigneten Oertlichkeiten, d. h. die mehr oder minder steilen Einhänge, der Waldkultur zugeführt werden.

Es handelt sich im Wildbachgebiete mehr um die Oertlichkeit des Waldbestandes und um seine Beschaffenheit, denn um die Ausdehnung desselben.

S 10. Die besonderen Verbauungsysteme. Als besondere Verbauungssysteme, die hier des knappen Raumes wegen nur in Kürze lerührt werden können, sind zu nennen:

1. Das System nach Jenny. Dieses besteht in der schalenförmigen Auspflasterung der Bachbettsohle. Vorerst wird jedoch die letztere, die melir oder minder tief eingeschnitten ist, entsprechend gehoben und erst dann gegen neuerliche Unterwühlung durch die Ausführung der Schale gefestigt. Das Profil der letzteren richtet sich ausschließlich nach den zu erwartenden Hochwasser-Abflußmengen. Das Heben der Bach- oder Runsensohle - zumeist kommt dieses System bei Verbauung von Runsen in Anwendung - wird in einfacher Weise durch gewöhnliche Flechtzäune derart erziclt, daß diese, von unten nach aufwärts fortschreitend, in passenden Abständen in einer von der Tiefe des Gerinnes und der Höhe der einzelnen Objekte abhängigen Anzahl von Etagen errichtet werden. (Siehe des Verfassers ,Grundriß der Wildbachverbauung", 1I. Teil, pag. 110.)

2. Das System nach Schindler ${ }^{1}$ ). Das sogenannte natürliche Ver-

I) A. Schindler, „Dic Wildbach- u. Flußverbauung nach den Gesetzen der Natur". Zürich 1889. 
b a u u ngs y s t e m nach Schindler jst für sich etwas originelles und berulıt in der Schaffung nach oben konvexer Gerinnsohlen, sowie in der fast ausschließlichen Anwendung des gewöhnlichen Holzpfahles als Baumittel. Die Anwendung dieses Systems, sellst in einfachster und auch etwas modifizierter Form, ist bisher eine sehr beschränkte geblieben. (Siehe des Verfassers „Grundriß der Wildbachverbauunc", Jl. Teil, pag. 124).

3. Das Regulierungssystem nach Wolf $\left.{ }^{1}\right)$. Es besteht in der Anwendung der sog. schwimmenden Gehänge, hat sich jedoch in den Wildbächen, der dort vorherrschenden größeren Gefällswerte und besonderen Geschieheführung haber, nicht bewälırt.

4. Das System nach Seeling. Dasselbe ist häufiger und vorteilhafter anzuwenden. Es besteht in rer Verwendung von losem, nur mittelst Pflöchen und Draht oder Wieden an den Ufern befestigten Faschinenmateriale. (Siehe des Verfassers „Grunclriß der Wildbachverbauung“, II. Teil, pag. 364.)

5. Das System nach Serrazanetti ${ }^{2}$ ). Es besteht in der Anwendung von Drahtgeflecht, zumeist zum I'ferschutzbau (Drahtgefleclıtsäcke, sogen. Tuben, mit Schotter gefüllt). Genügende Erfahrungen konnten bisher in Oesterreich und soviel bekannt. auch in Deutschland, mit diesem Systeme noch nicht gemacht werden. Der liostenpunkt fält jedenfalls sehr in die Wagschale. In Italien ist die Anwendung häıfiger.

SII. Die wirtsehaftlichen $\mathrm{ll}$ a $B$ n a h m en. Von der Berasung und Aufforstung abgesehen, sind in Interesse der Regelung des Regimes der Wildbäche noch manch' andere wirtsehaftliche Maßnalımen zu beachten.

Unter Hinweis auf die diesbezüglichen Auseinandersetzungen in des Verfassers "Grunrlriß fler Wildbachverbaung", II. Teil, pag. 253-29I, sollen hier nur hervorgehoben sein: die entsprechende Bewirtschaftung der Waldungen; die gefahrlose Bringung und Lagerung der Forstprodukte; die stete Reinhaltung und Räumung der Gerinne, sowie die rationelle Bewirtsehaftung der Alpen und Weiden. In letzterer Richtung möchte insbesondere angeraten sein: die Entwässerung nasser Böden; die Kultivierung öden Terrains; die Vermeidung des Einsickerns des Wassers in zur Absitzung geneigten Böden aus Brunnen, Zisternen, Bewässerungs- und Entwässerungsanlagen, aus Nutzwasserleitungen u. døl. m.

Als von ganz besonderer Wichtigkeit sind auch die ordnungsgemäße Instandhaltung bestehender Wasserbauten, namentlich Wehren; die Vermeidung der Profilsverengungen durch Einbauten jeder Art; die Einführung und Handhabung eines organisierten Flußaufsichts- und Hochwassermelderienstes; die Ausgestaltung des hyrlrographischen Dienstes überhaupt u. dgl. m. anzusehen.

In jüngster Zeit ist speziell bezüglich der wasserwirtschaftlichen Nutzung des Waldes manch wertvoller Ratschlag erteilt worlen. Im algemeinen wird vom wassemirtschaftichen Standpunkt der Plenter- oder der Femelschlagbetrieb an Stelle des Kahlschlagbetriebes empfohlen. Ton besonderer Bedeutung sind der ratiınelle Nebennutzungsbetrieb, der Holztransport, die Entwässerung des Waldlandes und der Gelirgsmoore, sowie manches andere mehr. Es ist in allgemeinen nicht so sehr der Wald als solcher, sondern die in demselben vorhandene Bodendecke, welche als das beste Mittel der Wasserregulierung in Walde, namentlieh im Gebirgs-

1) ".litteilungen über das Wesen und die Erfolge der vom Kgl. Bayrischen Bauamtmann A. Wolf erfundenen FluBregulierungsmethode", von R. Iszkowski. Wochenschrift des österr. Ingenieur- und Architeliten-Vereines. Nr. 8 u. 9. 1888.

2) "Cemni Monografici sulla difesa dei funni, torrenti, canali, secondo il sistema e coi nuovi apparecchi ideati", von Giulio Serrazanetti. Bologna 1899. 
walde anzusehen ist. Auf den Schutz der Bodendecke soll die Wirtschaft in erster Linie hinzielen.

Der Wirtschaft in Wohlfahrtswalde sind im Hinblick auf ressen wasserwirtschaftliche Bedeutung gewisse Grenzen gezogen.

Sie einzuhalten, gehört uicht zı den letzten Aufgahen des Hochwasserschutzes.

\section{B. Die Lawinenverbaunng.}

\$12. Die Ursachen und die Einteilung der Law inen. Verschiedene Einflüsse sind es, die den auf den Gehängen angehäuften Schnce in Bewegung setzen und so das Entstehen der Lawinen verursachen. Auf schiefen Flächeu findet mitunter schon bei geringem Gefälle, den Gesetzen der Schwere folgend, eine Bewegung des Schnees statt. Dieselbe hängt von der Neigung des Hanges, von der Beschaffenheit und Masse des gefallenen Schnees, von den Witterungsverhältnissen, so namentlich Windströmungen, dann von der Konfiquration, Beschaffenheit der Bodendecke und mitunter auch von Zufällighieiten ab.

Die Grundursache des Entstehens gibt den Lawinen in der Regel auch ilıren Charaliter. So werden die Lawinen nach Coaz ${ }^{3}$ ) in Staub-, Grund- und Oberlawinen geteilt, zu welchen noch die Gletscherlawinen gezählt werden können. Staublawinen entstehen, wenn es bei kalter Witterung stark schneit. Die große Ilasse des leichtflügigen Schnees gerät dann auf steilen waldlosen Hängen wie eine Schichte Sand in Bewegung und reißt die übrige Schneemasse mit sich fort. Der feine Schnee wird vom Winde getragen, der schwerere bewegt sich am Boden. Die Luft wird liomprimiert und strönt als Orkan, dessen Wirkung zumeist eine größere ist als jene der Lawine selbst, dieser voraus zu Tale. Solche Lawinen brechen gewöhnlich schon während des Schneefalles ab, oder sie werden nachträglich durch Windströmungen veranlaßt.

Der bei mäßiger Kälte gefallene Sclmee ist naß, massig, schwer und liängt an dem Boden ziemlich fest an. Größere Massen solch frisch gefallenen Schnees rutschen viel eher ab oder sind bej mäßig warmer Temperatur noch zu locker, um nicht von selbst in Bewegung zu geraten. Dieser Schnee bleibt aber mehr massig beisanmen, zerstiebt nicht. übt daher auch keinen so großeı Druck auf die Luft aus wie derjenige der Staublawine. Die Schnelligkeit der letzteren ist vermöge der Reibung, vermöge der Hindernisse an der Gleitfläche, eine verhältnismäßig geringe, ilıre Wirkung eine räumlich beschränkte. Solche Lawinen heißen Grundlawinen, Schlag-, Schlaßoder Schlessemlawinen.

Wenn auf die Fimkruste des gefrorenen alten Schnees frischer Sclinee fällt, und dieser dann auf der glatten Gleitfläche in Bewegung gerät, so wird von Oberlawinen gesprochen.

Gletscherlawinen dagegen entstehen, wie schon der Name sagt, wenn sich an Ende eines Gletschers bedeutende Eismassen loslösen, über steile Hänge stürzen, dabei in kleine Eisteilchen zerstieben und in Form einer Staublawine ins'Tal stürzen. Abrutschende Schneemassen endlich oder Lawinen von kleinem Linfange werden als Schneerutschen bezeichnet.

Un die Ursachen der Lawinenbjldung kurz zu berïluen, ist zunächst hervorzuheben, daß die Nejgung des Hanges, wenn auch nicht immer als aussclilaggebend, so doch als maßgebend angesehen werden muß.

Unregelnı̈̈ßiges Gefälle ist der Lawinenbildung weniger günstig, als regehmäßiges.

1) S. Coaz, „Die Lawinen der Schweizer Alpen". Bern 1888. 
Ein terrassierter Hang kann das Entstehen von größern Grundlawinen verhindern. Das gleiche gilt von sanft verlaufenden Mulden, in welehen sieh größere Schneemassen anzusammeln vermögen. Mluldenförmiges, absehüssiges Terrain dagegen ist der Lawinenbildung förderlich, weil durch das sich am Muldengrunde ansammelnde Schmelzwasser der Schnee leicht in Bewegung gerät.

Eine hervorragende Rolle spielen die Masse des gefallenen Schnees und die herrschenden Witterungsverhältnisse. Während die Staublawinen zu Beginn und während des Winters an häufigsten zu beobachten sind, gehen die Grundlawinen zumeist zu Endle des Winters oder zu Beginn des Frühjahrs, zur Zeit der Sehneeschmelze, und zwar gewöhnlich innerhalb eines Zeitraumes von 14 Tagen ab. Ein zur Zeit der Schneeschmelze eintretender Regen befördert den Abgang von Grundlawinen ganz besonders. Oberlawinen bilden sich zumeist während der Nonate Dezember, Januar und Februar. Bei ruhigem Wetter hält sich der Schnee bis zu einer bedeutenden Sehichte am Hange; bei stürmiseher Witterung rutseht er sehon bei geringer Schichtenhöhe. Je bewegter die Luft, desto leichter entwickeln sieh daher die Lawinen, insbesondere die Staublawinen. Das Ueberspringen des Windes von einer in eine andere Richtung soll das Anbrechen von Lawinen ganz besonders begünstigen.

Der Grad der Sonnenwärme zur Zeit der Sehmeeschmelze ist von hervorragendem Einfluß auf den Abgang von Lawinen. Die Südabhänge mit direkt einfallenden Sonnenstrahlen sind daher der Lawinenbildung günstiger als die Nordabhänge. Wegen der sich auf der Sonnenseite des. Gebirges leichter bildenden Firnkruste treten dort Oberlawinen häufiger als auf der Schattenseite auf. Bei windstillem Wetter und kräftigem Sonnensehein fält die Zeit des Lawinensturzes nach Coaz auf die ersten Nachmittagsstunden, je nachden der Hang etwas früher oder später von den Sonnenstrahlen getroffen wird. Bei Südwind, Sciroceo, halten sich die Lawinen an keine Zeit mehr. In Hochgebirge fallen übrigens Lawinen nicht selten bei jedem neuen Schnecfall, selbst nitten im Sommer. Es wird aueh beobachtet, daß Lawinen zumeist bei heiterer Witterung, seltener bei bewölktem Himmel abgelsen, weil bei heiterer Witterung, namentlich morgens, Kälte eintritt, der Schnee, d. h. die Eisfäden, welche ihn an die Bergseite festhalten, sich zusammenziehen, brechen und die Bewegung der Massen herbeiführen. Quell- und Sickerwässer, dann die Schmelzwässer durehfeuchten die untere Bodenschichte bis zur Sättigung und vermindern im Abwärtsgleiten auf der Trennungsfläche die Reibungswiderstände dortselbst. Sie sind sonach der Bildung von Grundlawinen förderlich.

Die geologischen Verhältnisse des Grundgesteines sind weiter sehr einflußnehmend. Die kristallinisehen Massengesteine sind bei gleicher Steilheit des Hanges der Lawinenbildung weniger günstig als die kristallinischen Schiefergesteine, z. B. Glimmersehiefer, Flyseh usw. Stark in Verwitterung begriffenes Gestein ist der Bildung von Grundlawinen förderliclıer als festes, obzwar große Steine und Felsblöeke mitunter gute Hindernisse dem Lawinenabgang bieten. Gefährlielı, und zwar im Hinblick auf das Abgelıen von Grundlawinen, sind steile, mit Quell- und Sickerwässern durchtränkte Schichtenseiten, auf welchen die Bodensehichte stets feucht und in gefrorenen Zustand auch schlüpfrig bleibt. Die Seite der Schichtenköpfe mit rauher Oberfläche ist der Lawinenbildung, wenn nieht besonders starkes Gefälle vorhanden, weniger günstig.

Von Einfluß auf die Lawinenbildung ist die Besehaffenheit der Vegetationsdecke. Geradstämmiger, dichter, nicht zu alter Wald bietet die meisten Hindernisse. Weiden-, Iirummlıolz, Erlen-, Jungbuchen- und Junglärehenbestände liönnen infolge 
ihrer Elastizität die Bildung ron Lawinen nicht immer und nicht überall virhindern. Rasen ist dem Abgleiten des Sehnees günstig. In den über der Waldvegetation gelegenen sogenannten „Bergmähdern" 11 it oft 40-50 Grad Neigung sind Lawinen an meisten zu beobachten. Insbesondere treten dieselben gerne im zweiten Winter dort ein, wo die Ernte nur jedes zweite Jahr erfolgt. Im ersten Winter nach der Heuemte geben näılieh die steifen Grasstoppeln noch einigen und zwar mehr Halt, als das lange und sehlüpfrige Gras des zweiten Jahres.

Unter den Zufälligkeiten, welehe die Lawinenbildung begünstigen können, ist das Abfallen von Eiszapfen, Steinen, Aesten und namentlich von Sehneesehildern und Schneewächten, wie solehe sich nicht selten an seharfen Gebirgsrücken, vorstehenden Felspartien ete. bilden, zu nennen. WVird der Fuß einer Sehneewand vou einem Bache unterwaschen, oder unterbricht eine Quelle oder sonst ein Umstand den Zusammenhang der Sehneemassen, so wird das Entstehen der Lawinen begünstigt. Hinsichtlich zufälliger Ersehütterung wird auch darauf verwiesen, daß die Landbevölkerung nicht selten sogar das Glockengeläute als Lawinen-Erreger fürchtet.

$\$$ 13. Die $\mathrm{L}$ a wine $\mathrm{n}$ v e $\mathrm{rb}$ a u u g. Im Anbruchgebiete einer Lawine ist die Gewalt der in Bewegung geratenen Sehneemassen zumeist eine noch so geringe, daß man gewöhnlieh mit unbeträehtlichen Jitteln helfend eingreifen und die $\mathrm{Cr}$ sachen der Bildung, insbesondere von Grundlawinen, nicht selten dureh zweckentsprechende MaBnahmen beheben kann.

Sehwieriger ist es, Staublawinen und wohl auch Oberlawinen in ihrem Entstehen und ilıren Wirkungen zu bekämpfen. Im allgemeinen kann man $B$ a u t e $\mathbf{n}$ zur Festigungund Bindung der Lawinen in deren unmittelbarem Anbruehgebiete, dann Baten, die eine Ableitung der Lawinen bezweeken, und solehe, die a us ehlieblieh zum Sehutze einzelner objekteerriehtet werden, unterscheiden. Nach Maßgabe des verfügbaren Materiales können die einzehnen Werke ausschließlich aus $\mathrm{Holz}$, aus $\mathrm{Holz}$ und $\mathrm{E}$ isen oder aus $\mathrm{Stein}$ hergestellt werden. Endlich können die Verbauungsanlagen noeh in dauernde und in vorübergehende unterteilt werden. Die ersteren, für welehe der Steinbau zunäehst zu berücksichtigen kommt, sind in jenem Anbruchgebiete auszuführen, wo die Bodenverhältnisse oder die Höhenlage eine Bewaldung aussehließen, während dort, wo eine Aufforstung noeh möglieh ist und gleichzeitig aueh veranlaßt wird, den Bauten der Charakter provisorischer Anlagen zufällt, die nach einer bestimmten Zeit dureh den heranwachsenden widerstandsfähigen Holzbestand ersetzt werden sollen.

\$14. Iittel zum Abbaue der Lawinen in Anbruehgeb i e t e ${ }^{1}$ ). 1. Allgemeines. Als Maßnahmen zum Abbaue der Lawinen im Anbruchgebiete sind alle jene anzusehen, welche die Peibung zwisehen Schnee und Unterlage vergrößern, sowie ein Abtrennen orler Abrollen losen Sehnees verhindern.

Als ein Lawinenbildung hinderndes Mittel gilt dichter, geradstämmiger, nicht zu alter Wald, während, wie bereits an anderer Stelle hervorgehoben, steile Weidefläehen, Wiesen, Felshänge, Mulden, Runsen und Tobel, sowie auch Krrummlıolz-, Ellen-, Jungbuchen- und Junglärehenbestände $u$. dgl. infolge ihrer Elastizität die Bildung von Lawinen nicht immer und überall verhindern können.

Es ist ein naheliegendes Mittel, dureh Aufforstung der Anbruchgebiete die Bildung von Lawinen zu verhindern. Damit jedoel an solchen Stellen das Fort-

1) ,Ueber die Lawinen Oesterreichs und der Schweiz und deren Verbaungen“; dann „Ueber den Schnee im Gebirge": Von Vinzenz Pollak. Zeitschrift des osterr. Ingenieur- und Architcktenvereins. Wien 1891. 
kommen von Kulturen üherhaupt ermöglicht wird, sind bis zur Kräftigung derselben weitere Nittel in Anwendung zu bringen. Sie dienen dazu, die Bewegung des Sehnees zu verhindern, welche einerseits den Anlaß zur Lawinenbildung gibt, andererseits die zarten Pflanzen leicht entwurzelt. Diese littel sind: Verpfähl u $\mathrm{ngen}$, Sehneebrü cken und Schneefänge.

2. Die $V^{\top}$ e r p f ä h 1 u n g e n. Die Verpfählung glatter Flächen besteht darin, daß Rund- und Spaltholzpliöcke in einer Länge von 1,6 - 2,0 n nach entsprechenden Vorbohren etwa zur Hälfte in den Boden getrieben werden. Die Pfähle stehen meist reihenartig mit einer Pfahldistanz von 0,6 m und einer Reihendistanz von einem oder auch nehreren Metern. Diese Anlagen erfüllen den bescheidenen Zweck dem sie dienen, bei nicht zu bedeutenden Schncehöhen und nicht zu trockenem körnigen Schnee gut, doeh ist das Ausrutschen von Sehnee aus den Lücken oder oberlalb der obersten Pfähle beobachtet worden.

Abbildung 34 .

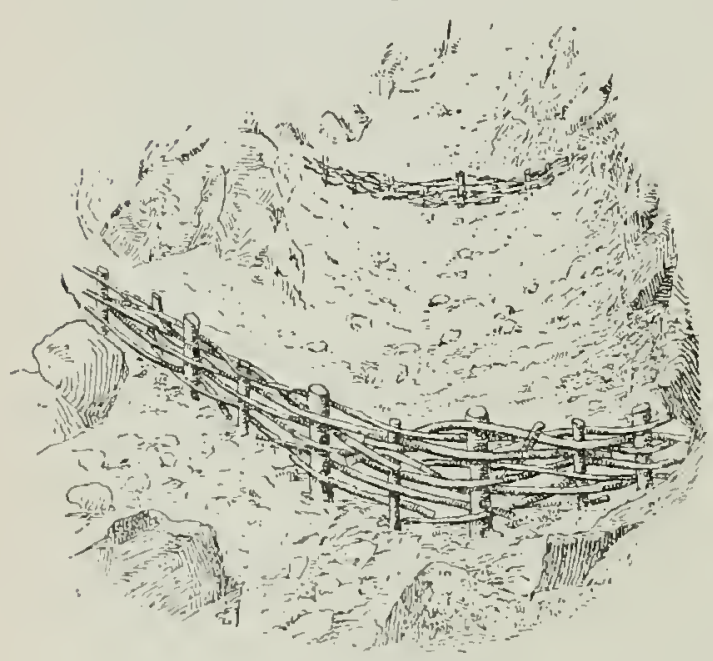

Abbildung 35 .

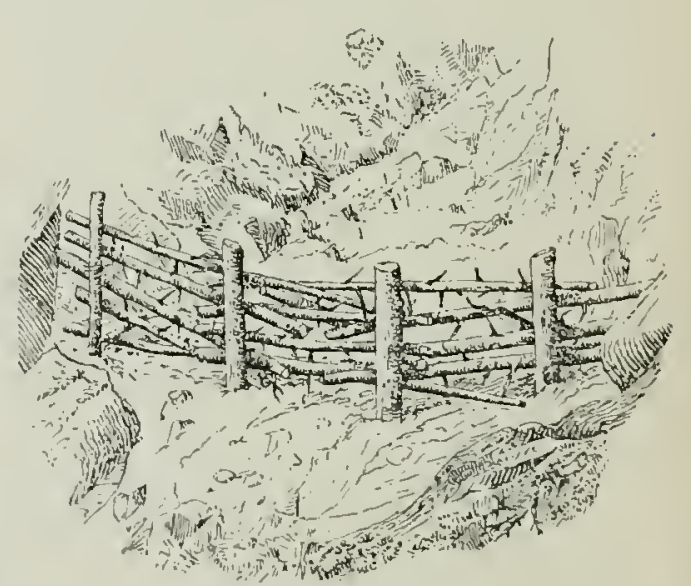

Nicht zu hoch oberhalb der Pfähle abreißende Schneemassen gehen entweder zerteilt zwisehen deu Pfählen dureh oder rutsehen, wenn die Pfähle im Schnee steeken, darïber hinweg, dabei wohl auch Schärlen verursachend.

Pfähle bis zu $0.3 \mathrm{~m}$ Entfemung geschlagen, kommen als gesehlos c ne Pf a hl l e i he $n$ oder auch P f a h $1 \mathrm{w}$ ä $\mathrm{d}$ e hie und da zur Anwendung.

Bald naeh dem ersten größeren Schneefall zeigen sich jene Stellen, wo die Pfähle zu wenig Boden fassen konnten, indem sie durch den Selmeedruek aus ihren Lagen gebracht werden.

Im allgemeinen soll man solche Verpfählungen, sowie Holzwerke überhaupt, über der Waklgrenze nur anwenden, wenn eine Aufforstung möglich ist und die ersteren daher nach genügender Erstarkung letzterer nieht mehr erneuert zu werden brauchen, was je naeh Höhe und Lage 15-25 Jahre dauern kann. Während dieser Zeit sind die Pfähle je nach Stärke und Güte $1-3$ mal zu ernenern.

In minder steilen Lagen und bei geringer Bodentiefe lassen sich mit Vorteil 3seitige Pyramiden, welche aus Pfählen hergestellt sind, wobei die Pfähle am Kopfe durelı einen hölzernen oder eisernen Bolzen und Eisenring zusammengehalten werden, 
verwenlen. Die Bockfüße können noch überdies mitlelst Querbänlern unterenıander verbunden und versteift werden. Alle einzuschlagenden Pfähle sind zuzuspitzen marl anzukohlen.

Eine zweite Art der Verbaung bestelıt darin, daß man dic Pfalle in unterschiedlich langen Reihen aufstellt, beziehungsweise $30-60 \mathrm{~cm}$ tief in den Boden einschlägt und dann mit alten Stangen, Ast- und Abraumholz verflicht, Abb. 34 und 35. Es genügt, wemn diese 4-10 Im langen Pfahlreihen in Abständen von 6-15 m in Lorizontalen Linien ober- und unterhalb der Anbruchstelle derart errichtet werden, daß stets über einen Zwischenraum der untem Reihe ein Flechtwerk in der obem Reihe zu stehen liommt.

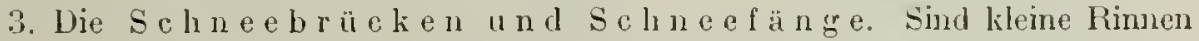
oder Gräben zu verbauen, dann werden sog. Schneeloücken, Abb.36, angebracht.

Abbildung 36 .

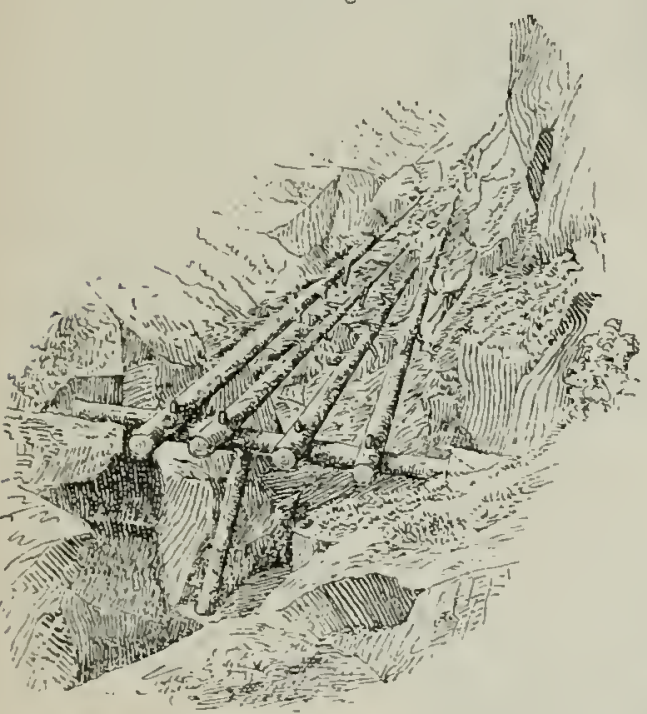

Abbildung $3 \%$.

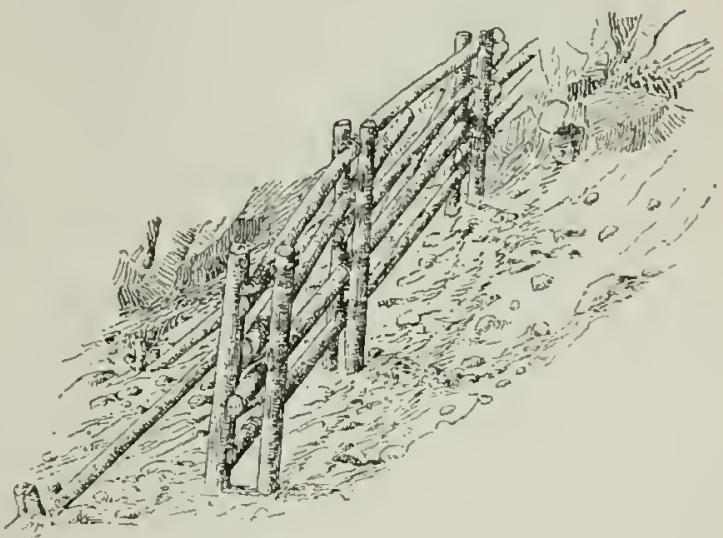

Eine Schnecbrüclic besteht aus einem über den Graben gelegten Stammstück, ähnlich dem Tragholz einer Brücke, welches an den beiden Auflagern durcli vorgeschlagene Pfähle befestigt wird. In Abständen von $20-30 \mathrm{~cm}$ werden an dieses Stammstück gegen den Hang gestellte Stangen befestigt. Bei großer Spanmeite wird dasselle auch noch durch unterstellte Joche versteift.

Die Form eines einfachen Schneefanges ist in Abb. 37 dargestellt. Fin solcher besteht aus Säulen und Querhölzem, die im Anbruchgehiet zur Aufstellung liommen. Stärkere Sclıneefänge sind entweder aus Altschienenstänrlern mit Altsclıwellen orler Holzriegeln, dann in fester Holzkonstruktion oder aus Trockennauerung hergestellt.

Diesfällige Anlagen sind in den Abb. 38-41 ersichtlich. Die in den Abb. 38-40 dargestellten sollen mit Rücksicht auf ihre in der Regel beträchtlichen 1 Terstellungs- sowie Kosten der alljährlichen Erhaltung und Nachbefestigung nur dort Anwendung finden, wo andere llittel nicht in Betracht kommen kömen. Selneofänge in Trockenmauerung, bei geringer Stärke $0,6-1 \mathrm{~m}$ und Höhe von $1-2 \mathrm{~m}$, Abb. 41, sinul mit Erfolg zur Ausführung gebracht worlen, olne daß durch Schneedruck oder Lawinen nemmenswerte Schäden an ilmen verursacht worden wären. 
Dort, wo man auch Oberlawinen tunlichst vermeiden will, muß als nötige Maßnahme die entsprechend vermehrte Höhe der Mauern und sonstigen Schneefangvorrichtungen

Abbildung 38 .

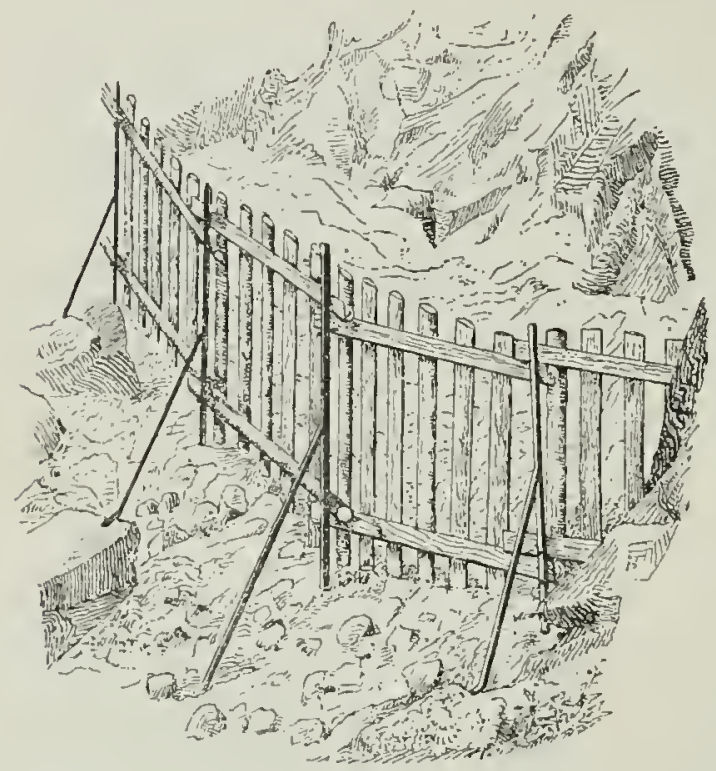

keitsgrad, die Höhenlage, die Exposition, ins Auge gefaßt werden. Man hat denn auch in neuester Zeit die Nauern bis zu $2 \mathrm{~m}$ hoch angelegt.

Die Mauer- und Schneefanghöhe und der Höhenabstand der Werke muB eine schädliche, also rasche Bewegung der gefallenen oder zusammengewehten Sclıneemassen unmöglich machen. Der Abstand, welchen unan den zu erstellenden Objekten zu geben hat, bildet sonach einen der wichtigsten Faktoren bei Verbau des Anbruchgebietes einer Lawine. Eine theoretische Untersuchung des Gegenstandes ist mit Rüeksicht auf die vielfachen, unwägbaren Einflüsse nicht möglich. $\mathrm{Zu}$ diesen letzteren sind die $\mathrm{Be}-$ schafienheit der Bodenoberfläche, ihre Form und geologische Zusammensetzung, dann der FeuchtigBeschaffenheit des Schnees usw. zu zählen.

Die Erfabrung gibt jedoch manchen Fingerzeig.

Abbildung 39.

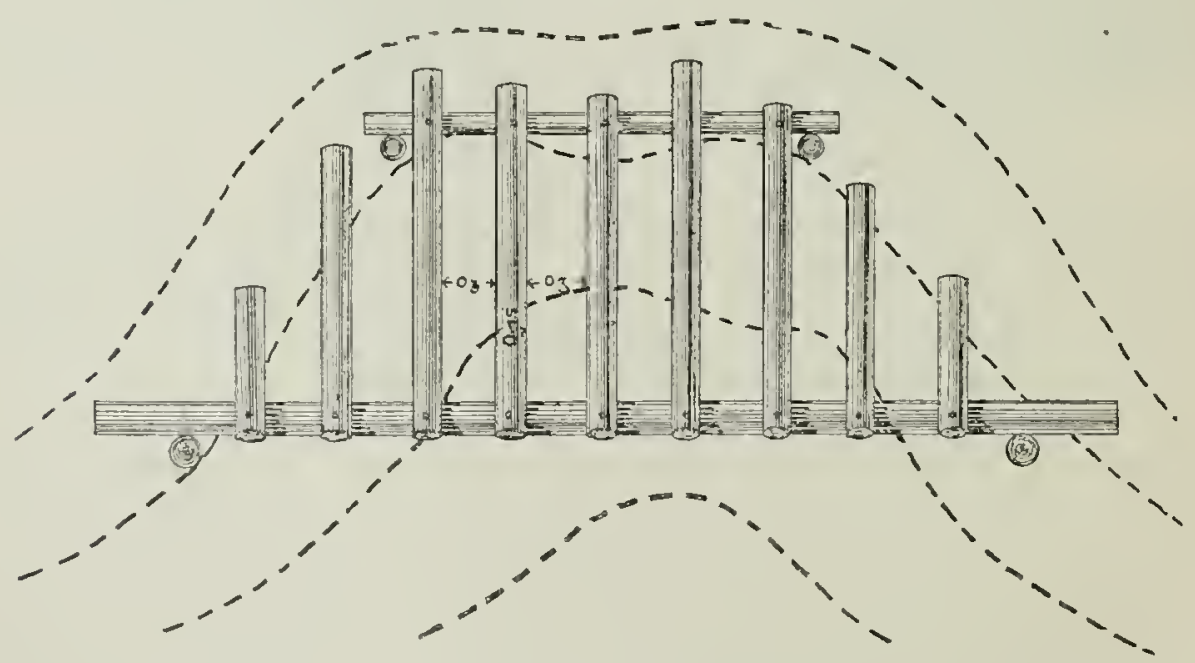

Ein bekannter Fachmann, der eidgen. Forstinspektor Dr. F. Frankhauser ${ }^{1}$ ), meint,- es lasse sich die zurückhaltende Wirkung eines Einbaues durch dessen in

1) ",Zur Bestimmung des Abstandes von Einbauten beim Lawinenverbau", von Dr. F. Frankhauser. Schweizerische Zeitschift für Forstwesen, Nr. 1, 1912. 
vorhinein zu bestimmende, sogenannte nützlielıc Breite, a-c Abb.41, ansdrüicken, d. i. die Länge der Horizontalen ron ter vorderen Oberkante bis zur Lehne genessen. Die durch diese Linie gelegte Horizontalehene kann wenigstens ammähemd als Basis des vom Einbau gestützten Schmeefeldes betraehtet werden.

Sie wächst einerseits nit der Höhe les Bauwerkes, andererseits mit der Breite der Terrasse, welche hinter jenem ausgehoben wird.

Abbildung 10 .

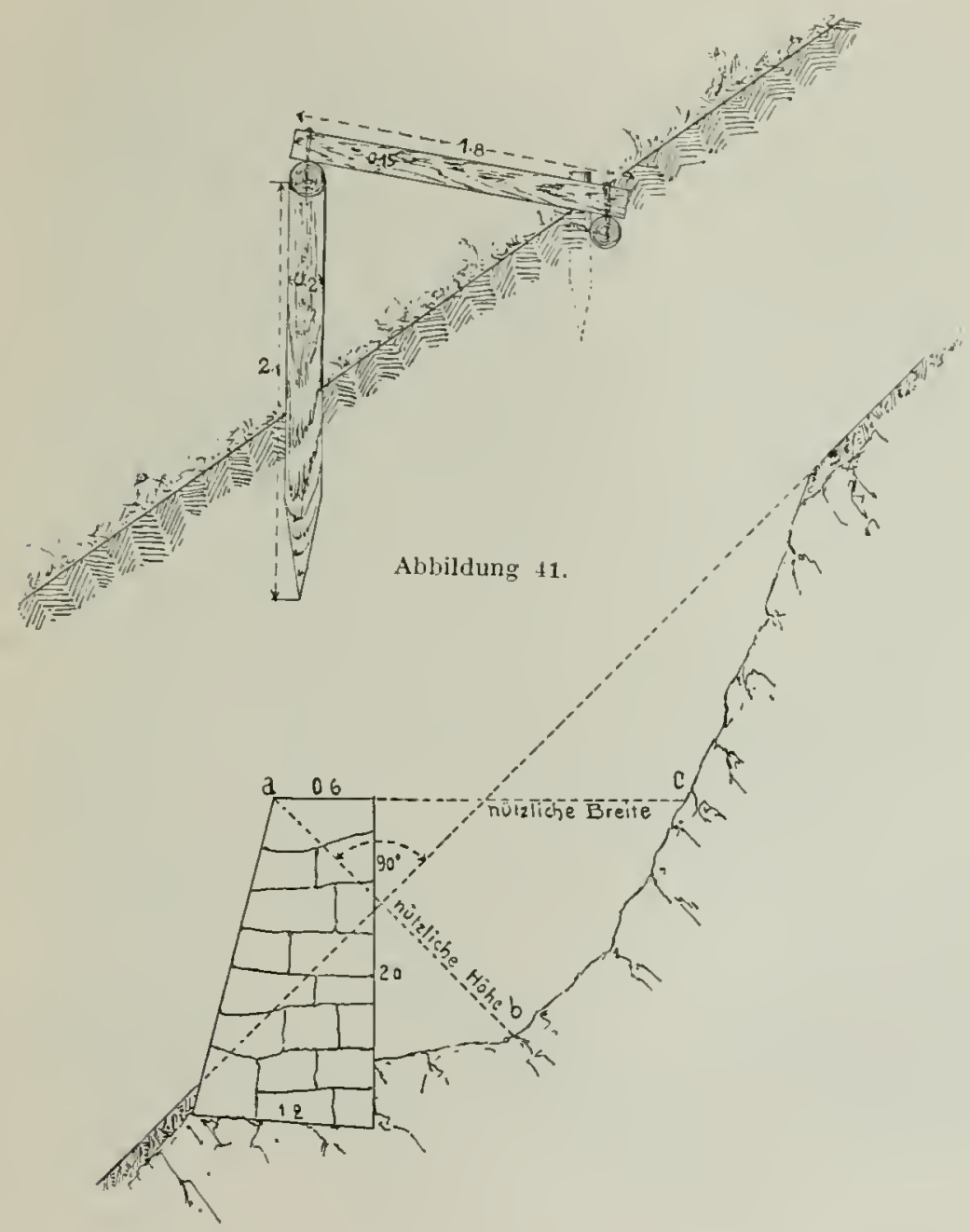

Die zurückhaltende Wirkung eines Bauwerkes von gegebener nützlicher Breite, so meint Frankhauser weiter, wird sich an Hange verschieden hoch hinauf erstrecken, je nachdem er mit stärkerem oder schwieherem Gefälle ansteigt. Ije durchsehnittliche Terrainneigung, bei welcher Grundlawinen abgehen, schwanlit zwischen 80 bis 130\%. Nach Professor Engler ${ }^{1}$ ) kanı innerbalb dieser Gefällswerte ein Bauwerk die Last der Schneedecke aufwärts amnähernd bis zur nämlichen vertikaten Höhe

1) Leber Verbau und Aufforstung von Lawinenzügen. Fon Arnold Engler, J'rofessor am udigen. Polytechnikum in Zürich. Zentralblatt für das gesaute Forstwesen. 1907. 
tragen. Zur Bestimnung des zulässigen größten Abstandes zweier Bauten hätte man somit deren Niveaudifferenz zur nützlichen Breite in Beziehung zu bringen unter gleichzeitiger Berücksichtigung der maximalen Schncehöhe und eines die Reibung der Schneeschicht an der Bodenoberfläche zum Ausdrucke bringenden Koeffizienten. Dieser letztere schwankt jedoch innerhalb so weiter Grenzen, daß es ausgeschlosien erscheint, ihn zahlenmäßig zu fixieren. Auf tiesen Unstand weist auch Coaz ${ }^{1}$ ) hin. Frankhauser giht üher das Verhältnis zwischen der Niveaudifferenz h und der nützlichen Breite b, Ahb. 40, welches Verhältnis $\frac{\mathrm{h}}{\mathrm{b}}$ er als den Vertikalabstandsfaktor oder kurzweg Ahstandsfaktor bezeichnet, Erfahrungszahlen arı, die je nach Dimensionierung der Anlagen, Neigung des Hanges usw. bei Trockenmauern zwischen 2,0-5,1, bei Bermen mit Pfahlreihen zwischen 3,3-3.6, bei Erdterrassen zwischen 2,7-7,1 schwanken.

Wie Frankhauser richtig bemerkt, lassen sich aus diesen Zahlen noch lieinerlei Schlüsse ziehen; immerhin wäre dies bei einer großen Zahlenreihe möglich, weshalb einschlägige Erfahrungen zur Veröffentlichung gelangen sollten.

Die Frage, ob Mauern und ähnliche Objekte, die in der Regel in der Schichtenlinie, also, wenn in längerem Zusannmenhange errichtet, wurmförmig verlaufen, freistehend oder im hinterfülten Zustande bessere Dienste leisten, ist dort, wo keine größern Steinschläge drohen - in welch letzterenı Falle Hinterfüllungen vorzuziehen sein dürften, da sie die Mlauer besser vor Deformationen schützen -, nach dem dermaligen Stande dahin zu beantworten, daß die nicht hinterfüllten Mauern den Schnee besser zurückhalten dürften. Die volliommene Lösung inuß von weitern Erfahrungen abhängig gemacht werden. Wenn es sich darum handelt, das Entstehen von Schneeschildern, Schneewächten, zu verhindern, - durch deren Abbruch wird nicht selten das Abgehen von Lawinen veranlaßt - so kommen auf scharfen Rücken oder an sonst geeigneten Stellen Schneefänge mit Vorteil in Anwendung.

4. Die A ufforstungen. Bei Lawinenverbaunngen, bei welchen es sich um die lnstandhaltung umfangreicher Ausfülırungen handelt, sollen durch Aufforstung mit einer dicht gesetzten, äuBerst stämmigen, liräftigen, demSchneedrucke widerstehenden Pflanzenart nicht nur die Erhaltungskosten wesentlich verringert, sondern es soll außerdem noch eine erhöhte Sicherung erreicht werden, indem der zweckentsprechend dichte Wald das beste Mittel zur Verhinderung der Entstehung von Lawinen ist.

Soll del Wald diesen seinen Zweck erfülleı, so muß er gewisse Eigenschaften besitzen, und zwar: Er darf nicht von offenen Streifen, Wiesen, Bächen, Runsen, Erdriesen u. dgl. naclı der Linie des größten Gefälles durchzogen werden, oder größere Lücken aufweisen, auch sollen die einzehen Stämme in ziemlich dichtem Schlusse stehen. Der Wald darf nicht zu alt werden, indem dam einerseits clie Stämme zu weit von einander zu stehen kommen und ras Abgehen von Schnee zwischen denselben ernöglicht wird, und andererseits die einzehen Stammindividuen durch Ueberstäncligkeit und losen Stand leicht zu Fall kommen können.

Ueberständige, wurzelumsichere Stämme sollten überall entfernt und die entstehenden Lücken nachgeforstet werdex. Doch ist es nicht zu verwundern, wenn dort, wo alte Wälder als Schutz gegen fallende Lawinen dienen, die Bedrohten einem massenhaften Entfernen der alten großen Bäume zum Zweck der Neuauforstung deshalb Widerstand entgegenstellen, weil sie dadurch auf längere Zeit ihres Sehutzes

1) "Statistik und Verbau der Lawinen in den Schweizeralpen". In Aufrage des eidgen. Departements des innern hearbeitet und veröffentlicht von Dr. J. Coaz, eidgen. Oberforstinspektor, Bern 1910. 
beraubt werden. Hier kam wohl nur eine allmähliche, pattienweise, wem auch schwierige Verjüngung zam Ziele führen.

Wenn man unter natürlicher. Waldgrenze jene lïchsten Lagen iu Gebirge versteht, bis zu welcher Höhe unsere derzeitigen Wälder vordringen, so wirt in der

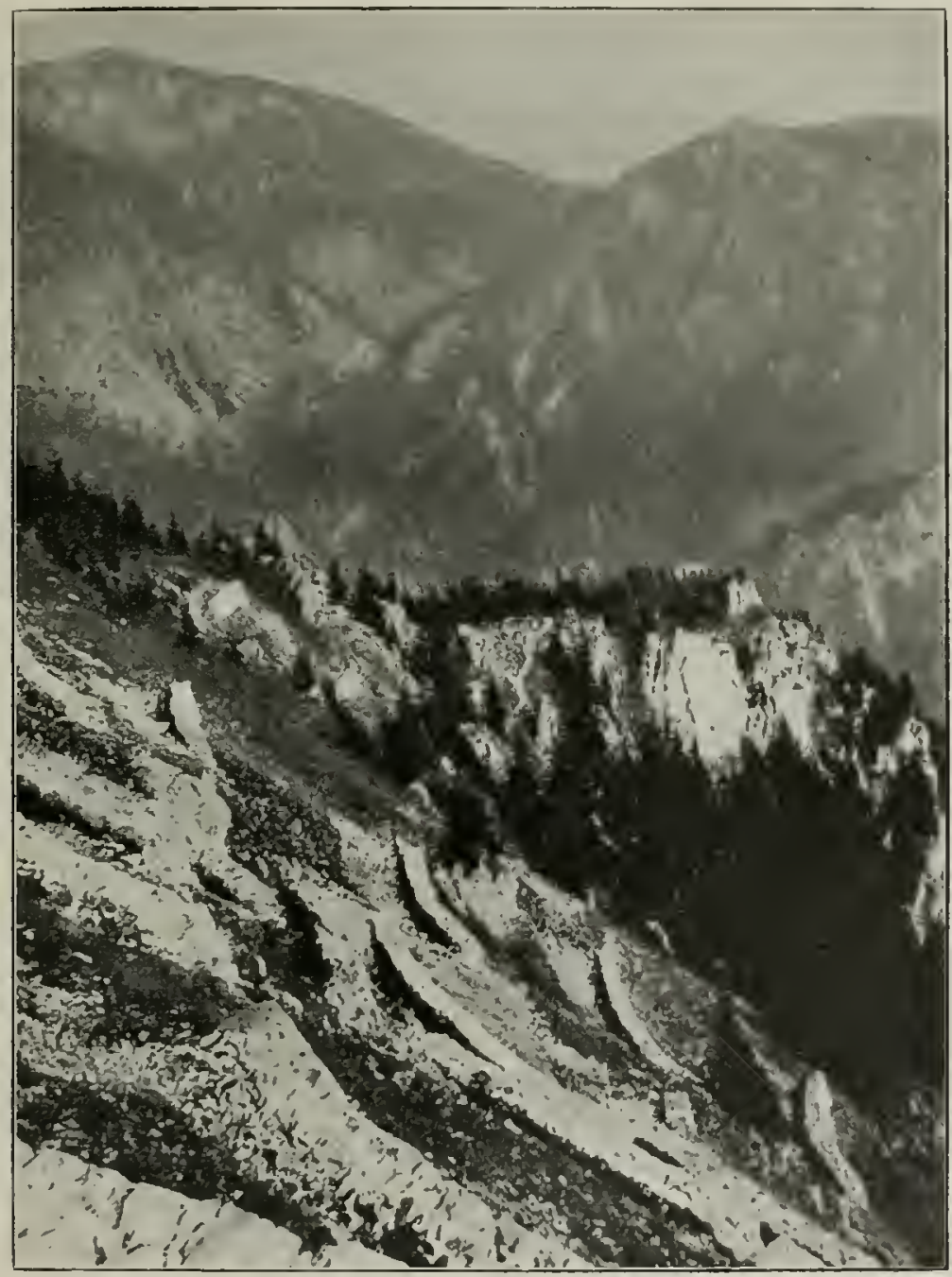

Lawinenverbauung mit Trockenmauern.

Mehrzahl der Fälle die Meereshöhe ron 1800 m gewöhnlich wenig üherschritleı. Daß in vielen Gegenden des Hochgebirges, wo früher Wälder bestanden haben, jetzt dieselben verschwunden sind oder deren obere Grenze herabgedrückt erscheint und hauptsächlich den Weideflächen Jehufs Vergrößerung der Alpenwirtschaft Platz machen mußten, ist bekannt. Die Möglichkeit der Wiederhebung der herahged rückten Waldgrenze unter Anwendung der richtigen Maßregeh muß jedoch zugegeben werden. Wenn in dieser Richtung nur selten Versuche gemacht werden, so liegt nicht nur 
passiver und aktiver Widerstand der um dic Schmälerung der Weidegründe besorgten Besitzer vor, es befassen sich auch Forstleute nur mngeme mit einer so schwierigen Arbeit in schneereichen und lawinengefährdeten Lagen, wo von cinem Erträgnisse keine Rede sein kam.

Bezüglich der zu Lawinenverbaungen geeigneten Holzarten möchte folgendes erwälnnt sein: Reine Lärchenbestände sind für Schneezurückhaltung trotz des rasehen Wachstumes gegenüber anderen Nadelhölzem viel zu nachgiebig und elastisch. Selbst schon größere, melırere Jahre altc Stämme leisten wenig Widerstand und biegen sich unter einen dichten, reichlichen Schneefall oder dem langsam wirkenden Drucke der anwachsenden Schnecmassen. Ïiefern leiden von Schnecbruch viel, stellen sich auch licht, und die Buchern bekommen an Lehnen den behannten Säbelwuchs, der auf wenig Widerstand in ihrer Jugendperiode hinweist. Deshalb sind die genannten Baumarten allein für die Aufforstung in den Lawinenverbauungen njcht z11 empfehlen, ja selbst nicht für Bepflanzung von Bahnböschungen, wo Schnee zurückgehalten werden soll. Die Zirbe ist besonders für Hochlagen eine außerordentlich genügsame, liräftige Pflanze, die sehr leicht Wurzel faßt. Sie ist es insbesondere, die zum Abbaue von Lawinen in den höchsten Lagen empfohlen werden kann. Ihr zunächst reiht sich die geradstämmige Varietät dcr Legföhre, die Bergfölıre.

Nach abwärts zu wäre diesen Holzarten Lärche und noch ticfer Fichte beizumischen.

$\$$ 15. Die Lawinenbaten, die eine Ableitung der Lawinen bezwecken, oder a usschließlich zum Schutze einzelner Objekte errichtet werden. Zu derlei Maßnahmen, welche nur als Palliativmittel anzuselsen sind und weniger in das Gebiet der Forstteclinik fallen, sind die Leitwerlic, Schutzdämme, Schutzmauern und Ablenkungswerke zu zählen. Un durch derlei Torkehrungen einen größeren Sclneestrom zurücklialten zu könmen, müssen gewöhnlich bedeutende Mauer- oder Dammhöhen zur Anwendung gelangen, wobei außerdem der zur Ablagerung nötige Raum oberhalb und längs des Baues vorhanden sein muB.

Leitwerke haben gewöhmlich den Zweck, die abgleitenden Schneenassen in eine zweite Gleitrinne abzuleiten, wo sie allenfalls unschädlich nach der Tiefe stürzen. Die Lcitwerke liönnen gleichfalls aus Holz oder Stein bestehen und beliommen die Form einer schiefen Block- oder Balkenwand; mitunter werden sie auch aus einer hinreichend holen Trockenmauer hergestellt, die sich in einer sanften Liurve längs des Hanges bis zu jener Stelle hinzielıt, wo die Einleitung der abstürzenten Sehneemassen erfolgen soll. Das Leitwerk bildet mit dern aufwärts ansteigenden Terrain die neue Gleitrinne, deshalb muB das Profil derselben dem Unfange der voraussichtlich zum Absturze grelangenden Schneemassen entsprechen, aber auch den genügenden Festigkeitigrad besitzen, um dem Scitendruck rler gleitenden Schneemassen widerstehen zu können. Die Leitwerke können suwohl innerhalb als auch am oberen oder unteren Ende des Lawinenzuges erbaut werden.

Zum Schutzc einzelner Objekte, z. B. Apenhütten, Wohnhäusern usw., haben sich auch entsprechend dimensimierte Steinpyramiden bewährt, deren eine scharfe Kante gegen den Lawinenzug gerichtet ist. Nur dürfen die abstürzenden Schneemassen nicht übermäßig große sein. Dagegen haben sich Grähen oder Terrassen im Anbruclisgebiete als erfolglos gezeigt. Im übrigen enthalten die in der Fußnote 1, Seite 333 zitierten Alhandlungen Pollaks genauen Aufschluß über ausgeführte derartige Bauten und die hiebei zu befolgenden Regeln.

In erster Linie sind die beschriebenen Verbaungen wohl nur als Schutz gegen 
den Absturz von Grundlawinen anzusehen; innerhin seheint es als würde dic dureh die Werke erzielte wellenförmige Oberfliehe der Schneemassen auch das Algleiten der Oberlawinen verhinlem. wenigstens sind erfahungsgenäß in einem verbauten Lawinenzuge noch keine Oherlawinen abgegangen.

\$ 16. Die L a w in e n s t a t istik. Das zielbewußte Forgehen auf dem Gebiete des Lawinenbanes, wie es sich in manchen Staaten hereits als nötig erweist, erfordert dic Schaffung einer sich auf gewisse Grumdsätze anfhanenton Lawinenstatistik. Die Schweiz besitzt schon seit langer Zeit eine derartige Statistik, unrl nummelır ist man auch daran, für sie in Oestrreich die Grunclage zu schaffen. Die rou den in Betracht liommenden Behörden zu sammelnden Daten sollen sich bezieher auf:

Gebiet (Land, Flußgebiet, polit. Bezirk),

Art der Lawine (Grund-, Staub-, Gletscherlawine),

Periodizität des Lawinensturzes (jährlich einmal, zweimal, mehrmal),

Zeitraum des Lawinenalgganges (Herbst. Winter, Frühjahr),

Ursprung der Lawine (innerhalb oder oberhalb der Maldgrenze),

Höhe des Lrsprunges über dem Meere (unter $1500 \mathrm{~m}$, ̈̈ber $3000 \mathrm{~m}$ ),

Geologisehe Beschaffenheit des Ursprungsgebietes.

Ausdehnung der Lawine,

Höhe und Beschaffenheit tes Schnees,

Angerichteter Schaden,

Gefahrenbereich der Lawine,

Ausgeführte V'erbauungen,

Aufforstungen und deren Effekt, sowie manches andere mehr.

Diese Statistik wird sicherlich auch imstande sein, die bis heute gesammelten Erfahrungen über die Bewegung des Sehnees, über die Wirkung der Verbauungen zu ergänzen und wird so vielleicht auch der Entwickelung der Theoric des Lawinenverbaues zugute kommen. 


\title{
IX \\ Die Forstbenutzung.
}

\section{A. Die technischen Eigenschaften der Hölzer.}

\author{
ron
}

\section{Wilhelm Franz Exner.}

Für die 3. Auflage bearbeitet von G a b r i e l J a n k a.

E in l e it ung. Allgemeine Gesichtspunkte. - Geschichte der einschlägigen Forschung und Lileratur. - Eintrilung des Stoffes.

$\$$ 1. Die Fachleute stimmen nicht darin überem, welche Eigentümlichkeiten, welche Erscheinumgen, welche Verhältnisse im Holzkörper als ,.E i g e n s c h a f $t$ e n“ aufzufassen und unter diesem Schlagwort abzuhandeln seien. Mancher Autor erörtert als ,Eigenschaft des Ilolzes" dessen ,,imneren Bau", ,Gefüge“, "Gewebe“, „Struktur", ,Textur", wälırend derselbe die ,,chemische Zusammensetzung" kemer näheren Untersuchung wert hält, ein anderer Fachmann beschränkt sich auf ,Elastizität und Festigkeit", auf ,Wichtigkeit und Fcuchtigkeits- otler Wassergehalt" und läßt dic Spaltbarkeit, die Farbe, den Glanz, den Geruch ganz außer Betracht. Die Grenzen des Stoffes, welehen man unter olsigem Titel belıandeln soll, sind aber auch in der Tat sehr diskuticrbar.

Wir sind der Ansicht, laß sich jene in Recht befinden, welche den „Bau des Holzes" und die "Chemie des Holzes" als das ummittelbare Ergebnis des Lebensprozesses im Baume dem Pflanzen-Anatomen und -Physiologen zur Erforschung und Erörterung überlassen, hingegen die Eigenselıaften als auf d e r Z u s a m m e nse tzung dos Holzkör pers, nittelbar auf den Lebensumständen des Baumes, b e r u h e w d e Verhältnisse an und für sich ins Auge fassen.

Dic Eigenschaften verhalten sich zur Konstrulition des Iolzkörpers elwa wic die Wirkung zur Ursache, wie die Folge zur Voraussetzung.

Die Beziehungen, welche zwischen den Graden der Eigenschaften einerseits und den Modifikationen im räumlichen und stofllichen Aufbau des Holzes existieren, haben sich aber lisher gar sehr unserer Erkenntnis entzogen, und nur äußerst wenig ist in dieser Beziehnug wissenschaftlich sichergestellt.

Auch über dic Beziehungen der Eigenschaften des Holzes untercinander ist 
noch wenig bekannt; Vernutungen, mehr oder minder plausible Anmahnen überwiegen die positive, aus Tatsachen oder Versuchsergehnissen hergeleitete Erkenntnis.

Noch dürtiger ist mser Wissen hinsichtlich der Bezichungen zwischen den Eigenschaften und des Methoden der Ungestaltung, Unformung, Bearbeitung des Holzes, sowie der hiezu benützten Hilfsmittel. Sind die Lebenslıedingrungen für ein Holzgewächs erfüllt, so entsteht die Pflanze und mit ihr der Holzkörper; dieser hat bestimmte Eigentünlichkeiten (Merknale seiner Gatung) und lestimmbare Eigenschaften (Eigenschaftsgrade). Auf diesen basiert die Verwendungsart und das Verfahren zur Herstellung des Gebrauchsohjelites. Welch interessinte Kette von Verhältnissen und Beziehungen, die mit der ehenischen Zusammensetzung des Bodens, der Luft und des Samens, Wärme- und Lichtzufuhr jetzt erst beginut und mit dem fertigen Dachstuhl, der Brücke, dem slöbel oder der Heiligenfigur endet! In dieser Fiette sind uns die einzelnen Glieder meistens genau genug bekannt, nur das ist uns ein bisher unerschlossenes Rätsel geblieben, wie sich die Ringe ineinander gelegt und geschlossen haben.

Vorläufig arbeiten jene Wissenschaften ziemlich unabhängig voneinander, die zur Erkenntnis von Tatsachen an einem bestimmten Punkte der Reihe fülren.

Pflanzen-Physiologie, Biologie, Anatomie, mit ihren empirischen Schwestem Agrikulturchemie, Standortslehre, Pflanzen- oder IValdbau stehen der $\mathrm{Hol}$ z l) r od uktion zur Seite und gelangen auf analytischem oder inchlitivem VVege zu Gesetzen, auf synthetischem oder snekulativen Wege zu Regeln für lie Praxis.

Nun kommt die spezielle Nylotomie und lehrt uns die Kennzeichen der Holzarten, indem sie dieselben im Wege des Vergleiches der Prudukte ermittelt.

Hierauf folgt die Erforschung der sogenannten ,technischen", d. i. der für die Verwendung des Holzes zur Befriedigung von Lebensbedürfnissen belangreiclien Eigenschaften. Diese wissenschaftliche Aufgabe hat keinen speziellen Namen, sie ist nahe verwandt init der Xylotomie und ergänzt sie.

Mit dieser wissenschaftlichen Aufgabe, welche $\mathrm{N}$ ö r d l ing e r zur Disziplin entwickelt hat, beschäftigten und beschäftigen sich Botaniker, Physiker, Mechaniker, Forstleute und Vertreter der sog. Warenkunde, endlich Technologen, alle von ihrem Standpunkte aus, mit dem ihnen zu Gebote stehenden wissensehaftlichen Apparate und in Verfolgung ihrer spezifischen Zwecke und Aufgaben. Dabei wurde aber nur ausnahmsweise mit Erfolg nach einer $\mathrm{B}$ e zi e h ung $\mathrm{zw}$ is chen de $\mathrm{r}$ E ig ensehaft und den Bedingungender Entstehung des Holzes gefragt, der naturgesetzliche Zusammenhang der Eigenschaften untereinander, der Eigenschaften mit der Anatomie und Chemie des Holzes aufgedeckt. Der Forstmann sowie der Physiker, der Technologe sowie der Ingenieur gehen jeder ihren eigenen Weg, isoliert, und nur ihr Zie] vor Augen habend. Hier könnte nur durch die Vereinigung von Fachleuten Ersprießliches geleistet werchen!

\$ 2. Eine kurze Uebersicht der wichtigeren Arbeiten auf unserem Gebicte wird das eben Gresagte bestätigen und die weiteren Darstellungen einleiten.

$P$ a re $n$ t veröffentliclrte in den Mémoires de l'Académie des Sciences in den Jahren 1707 und 1708 Untersuchungen über die Festigkeit der Hölzer ler Eiche und Tanie.

Welehen Grad von Genauigkeit man zu jener Zeit für ausreichend hielt, zeigt das Resumé der Arbeit: daß die nittlere Festigkeit der Tanne sich zu jener der Eiche verhält wie 358 zu 300 oder 119 zu 100. Von dem für die technische Verwendung der Pohstoffe im Bawesen viel wichtigeren Begriffe der Elastizität ist noch nicht die Rede, wurde doch erst durch Young und Tredgold der Begriff des Elastizitätslioeffizienten in die Wissenschaft eingeführt. 
Eine bemerkenswerte Arbeit rülırt von Il u s s c he n b r o e c k her (Introductio ad philosophiam naturalem, Lugrluni Batavorum 1762, I. Band S. 409). Dieser Gelehrte glaubte behaupten zu dürfen:

„Der Teil der Bäume, welcher gegen Norden gekehrt ist, wird in der Mehrzahl der Fällc von schmäleren Jahrringen gebildet; die Kälte des Nordens hindert nänlich die Zunahme und die Entwickelung der Vegetation; die dem Süden zugewendete Seite setzt sich dagegen aus breiteren Jahrringen zusammen, - freilich findet zuweilen auch das entgegengesetzte sta11. . . ."

"Bei all' meinen Versuchen habe ich die folgeuden Resultate gefunden: Die Festigkeit des liernes des Bammes ist die geringste. . . Vom lierne ausgehend ist die Festiglieit im ganzen gegen Norden zu gelegenen Teile geringtr, als in dem gegen Süden exponierten; die Festigkeit in dem westlichen Teile hat einen Mitelwert zwischen den beiden vorangeführten, die größte Festigkeit findet sich aber in dem gegen Osten gelegenen Teile. Wenn man weiters das Holz von der Axe bis zur Peripherie verfolgt in der Richtung der viel Weltgegenden, so findet man das festeste $\mathrm{Holz}$ an einer mitheren Stelle, die zwischen Rinde und Mark liegt, und die den Splint zunächst gelegene Partie des Holzes ubertrift jenes bedeutend an Festigkeit, welches dem jerm zumeist genähert ist".

„Wie Festigheit der höheren Teile des Stammes, wo sich die Aeste abzweigen, differiert von jener der dem Boden lienachbarten fast niclıt, auch giht es lieine derartigen Lnterschiede zwischen den Stamn und den Aesten. Ich weiß, daß mehrere Plivsiker entgegengesetzter Ansicht sind; sie behaupteu, der Kern des Holzes enthalte das härteste und festeste Holz und auf gleiche Entfernung vom Kern und um denselben sei es von gleicher aber schwächerer liohäsion, der Splint endlich sei die sehwächste Partie; ich aber führe ejnfach das an, was inich die lersuche mit unseren Băumen gelelırt lıben."

„Es gibt einen von der Natur des Bodens bedingten Unterschied. Die Bäume, welehe auf einem sandigen Boden erwachsen, sind gebrechlicher, während die auf einem thonigen Grunde stehen, zäher sind. Das grüne, frisch getällte ist fester als das gleiche Holz im getrockneten Zustande"

Die Arbeit Musschenbroecks basiert, obwohl sie, besonders was die Verschiedenheiten der Festigkeit in einem und demselben Baume betrifft, eine der vollständigsten in der ersten Periode ler wissenschaftlichen Bestrebungen auf diesem Gebiete darstellt, auf einer nicht so großen Zalıl genïgend ïberzeugender V'ersuclıe, um die oben angeführten Folgerungen sicher zu stellen. Ilies scheint der Autor auch gefühlt zu haben, demn er sagt selbst in seinem Buche: "Tielleicht habe ich nicht alle Umstände beachtet, welche auf die Festigkeit rer Hölzer Einfluß nelınen."

Der berühmte Naturforscher B u f f o n lat sich ebenfalls mit den mechanischen Eigenschaften des Holzes beschäftigt, doch ist wohl zu beachten, daß sich die Arbeit Buffons, obwolıl sie nach einem selır großen llaßstabe durchgeführt wurde, nur auf E i chen holz bezieht. was also ausschliebt, die von Buffon gezogenen Schlüsse, selbst wenn sie vollständig erwiesen wären, auf audere Holzarten anzuwenden.

In den Oeuvres de Buffon, toue I, finden sich folgenrle Belıuptungen, die hier ihren Platz finden sollen.

S. 10. „Das junge Holz ist weniger fest, als das ällere; ein dem Fuße des Baumes ent. nommener Barren widersteht mehr als ein dem Gipfel desselben Baumes entnommener; ein an den Umfang dee Baumes nahe den splint gewonnener Barren ist wenjuer fest, als ein gleiches aus dem Mittelpunlite des Bames herrührendes Stüch. Ueberdies modifiziert der Grad der Austrocknung sehr dessen Widerstandsfähigkeit; das grüne Holz bricht viel sehwerer, als ein trockienes."

S. 18. "Das Holz, welches auf einm gewissen Boden am schnellsten erwächst, ist das festeste; jenes, welches langsam erwachsen ist und hei dem die Jahringe sehr schmal sind, ist scliwäclıel als das erstere."

"lelı liabe gefunden, daß die Festigkeit des Holzes seinem Gewicht proportional ist, folglich laß ein Stücli, welches gleiche Abmessungen wie ein anderes hat, aber schwerer ist, auch bejlïufig in demselben Verhälnisse fester sein wird."

S. 27. , Wie Dichte des Holzes nimmt vom Zentrun gewen den Hißßersten Unfang des Splintes hin nach einer arithmetisclicn Progression ab.....

„Das 11 olz vom linße des Baunes wiegl nehr als jenes rom Stamm aus der Milte seiner Höle, und dieses wieder wiegt meht als jenes vom Gipfel, min zwar nalrezu nach einer arithmetischen l'rogression, welehe von Trachstum des Bambes abhängt. Es gibt eine Zeit, zu welcher das Holz in der Jitte und an Unfange des liernes nahezu gleiches Gewicht haben, und das ist 
jene Zeit, in welcher das $1 \mathrm{folz}$ in seiner Vollendung (Roife) ist (dime brobachtungen wurden an

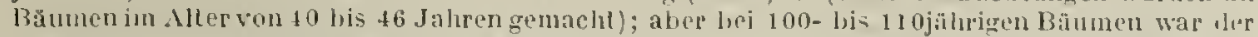
liern nicht melur der solideste Teil des Banmes; ter Splint ist schwerer und lester in den alien als in den jungen Bilumen."

Im Jahre 1870 ersehien das oft zitierte Werk: Traiti de la eonservation et de

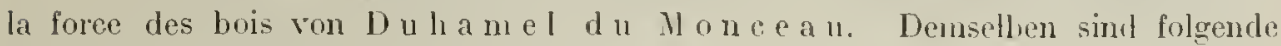
Thesen zu entnehmen:

S. 50. „, Man soll trockene Hölzer anw'nuten. . . "

S. 56. „Das llolz bedarf jedoch einer kleinen Menge Feuchtigkrit, damit es liart sei, woraus ich schlioße, daß zu trockene IJ̈ber nicht zute Dienste zu leistur vermögen." Gipfel."

S. 65. ,Das $1101 z$, das man dem Fuße des Banmes entnimmt, ist scluwerer als jenes rom

\$.71. .,Das grune 11012 muß ein Drilteil seines Totalgewichtes verlieren, um für so trocken zu gelten, daß es sich so verhalte, wie ein llygronteter."

S. 264. „Es scheint, daß die Extraktion les Saftos die Festigkeit des Holzes nieht rermindert, nachden der Saft die Festigkeit, welehe von der. Juzah] und Slirke der Fasern abhängt, auch nicht zu steigern verme. Der Saft macht die Holzfaser geschmodiger und geneigtrer, zu lirechen."

S. 378. ,Es ist ferner cine erwiesene Tatsache, daß die Jahringe von Mastbäumen ausgezeichneter Beschaffenheit, welche in einem sehr kalten Lande erwachsen sind. schmãler und daher näber aneinander gerückt sind."

S. 411. ,So lange die Bäume liräftig und in lebhaftem Wachstum begriffen sind, ist das Kernholz das dichleste, und in den dicken Bälumen, wetehe anfangen in die Räekbildung cinzutreten, ist das kiernholz oft Jeichter als das Reifholz (la couronne, qui est entre le coeur et la circonférence); folglich gewinnt das Holz nach und nach seine Dichte und verliert an derselben, nachdem es das llaximum derselben erreicht hat."

S. 438. , Dic Bodenarten, welche diı geeignetsten sind zur Bildung sehöner Bäume, sind nicht jene, welche das Holz be-ter Qualität hervorbingen."

S. 458. , In diesen starken Fichten (Pins du Nord von heiläufig 260 Jahren) ist das festeste Holz jenes, Welches sich in der fünften ringförmigen Zone befindet, vorausgesetzt, daß man die Querschnittsfläche einschließlich Splint in sechs glrich breite Ringe teilt; aber man begreift, daß dies zufolge von Umständen Aenderungen unterliegt."

Die drei Autoren, welche wir nun zitiert haben, sind fast die einzigen, welche sich mit den in ein und demselben Baume auftretenden Unterschieden von D i e h t e und F e s t ig k e it und mit dem Einflusse der Bodenbeschaffenheit auf diese Eigenschaften befaßt haben. Die Widersprüche in itren Ansichten ließen diese großen Fragen als mentsehieden bestehen. Die Divergenz der Auffassungen ist vielleieht der geringen Gleichförmigkeit und Genauigkeit zuzuschreiben, weleher die Bruchversuche unterworfen waren.

Die Untersuchungen, welehe Duhamel über den Einfluß der Spaltbarkeit und des Verhältnisses zwischen der Zusammendräekung und Ausdehnug der Fasern auf den Totalwiderstand von der Biegung unterworfenen liörpern angestell hat, kömnen hier übergangen werden.

Erst die Autoren späterer Perioden haben sich dem Studium der E l a s t i z i$\mathrm{t}$ ä $\mathrm{t}$ gewirlmet.

G i r a r d (Traité de la résistance des solides 1798, p. 183) schließt aus dem Gange seiner Versuche, und zwar in Uebereinstinmmg bezüglich dieses Punktes mit Perron e t (Oeuvies de Perronet, 1782, Tome I, Memoire sur les pieux et pilotis, page 93), daßs sich die Elastizität der Eiche verlıalt zu jener der Tame wie $63: 47$. und er sagt weiters (p. 159), daß die kontinnierliche gleiche Belastung die Pfeilhöhe der Durchbiegungskurve vergrößere, was, nach seiner Ansicht, nicht der Fall sein könnte, ohne daß lie Elastizität sich ändern und in jedem Augenblick einen gewissen Teil ihrer Energie eimbüßen würde.

Schon im Jahre 1782 und am Beginne des vorigen Jahrhunderts hahen einige anerkannte Männer der Wissenschaft auf experimentellem Wege fül cine große Zahl ron Holz - A r t e n und - V o r k o m m e n die Dichte, die Festigkeit und den Elasti- 
zitäts-Koeffizienten bestinmt. Es sind zu nennen: Bélidor (Arehitecture hydraulique 178\%), Rond e let (Art de hâtir), B a r low (Essay on the strength of timber 1817), E b b e ls u. Tredgold in verschiedenen Werken.

Cha $\mathrm{r}$ les $\mathrm{D}$ u p in hat in Joumal de l'Ecole pulytechnique, tome $\mathrm{X}, \mathrm{I}$ I5 eine große Arbeit über die mechanischen Eigenschaften des Holzes veröfentlicht (Expérienees sur la llexibilité. la foree et l'élasticité des bois). Dupin untersuchte die Natur der elastischen Kurve, die Lage der nentralen Sohichte (fibre invariable), er berichtigte die Formeln, welche die Beziehmngen rler Abriessungen der Stïclie und der angewandten Belastungen zu den erzeugten Durchbiegungen ausdrücken.

Er bewies S. 142, daß, die Durchbiegungen der Hölz’r, welche durch sehr kleine Gewiehte hervorgebracht. werden, diesen Belastungen proportional sind", und S. 150 folgert er aus einem die Versuehe mit Eichen-, Zypressen-, Buchen- und Tannenholze enthaltenden Tableau, daß ,die spezifischen Gewichte gleichzeitig, aber in viel geringerem Grade mit dem Widerstande gegen Durchbiegung zunehmen."

S. 194 bemerkt Dupin, daß ,die kräfte, die man anwenden muß, un die Hölzer dem Bruche zuzuführen, in keiner notwondigen Relation zu den liräften stehen, welche die Durchbiegung der Jiölzer hervorrufen."

„, So setzten einige Holzarten der Biegung einen sehr geringen, dem Bruche einen großen Wijlersland entgegen; solche sind die Rotbuche, der Nußbaum, die Ulme, die Tanne ete. Einige Arten widerstwen im Gegenteile sehr stark der Biegung nnd vicl weniger dem Bruche, z. B. die Zypresse, das Wahagoni ete. Andere endlich bieten gleichzeilig großen Widerstand dem Bruche und der Biegung dar, hieher gehören die korsische Föhre und die Eiche."

Diese Klassifikation führt Dupin clazu, die beste Anwendung dieser verschiedenen Holzarten in der Praxis anzugeben.

$\mathrm{B}$ e v a n befaßte sich romehmlich mit der Bestimmung des Elastizitäts-Moduls in Wege der 'Torsion (Philosophical transaetions, 18\%9).

$\mathrm{S}$ a $\mathrm{r}$ a $r^{\mathrm{t}} \mathrm{b}$ bediente sich der durch Tonschwingungen auf Holzplatten hervorgerufenen Kinotenlinien, um die Untersehiede der Elastizität und die Lage ilırer Aelisen zu ermitteln. Diese Platten waren aus einem Stücke Rotbuchenholz nach ver schielenen Fichtungen herausgesehnitten worden.

Er bemerlit S. 104 seiner in den Mémoires de l'Académie des Seiences 1830 publizierten Arbeit, daf, ,die Hölzer, bei denen die Jahrringe nahezu zylindriseh und konzentrisch sind. eine nach allen Radien in jedem zur Axe senkrechten Schnitt auffallend gleiche Elastizilät besitzen".

S. 417. ., Jeder Stab kann bei derselben Art der Einteilune, je nachden die Schwingungen nach der Breite oder Dicke erfolgen, zwei Töne zum Vorschein bringen, aber man kann den Lntersehied zwischen diesen Tönen, als selır geringfügig, vernachlässigen, wenn jene Abmessungen sehr klein sind."

Savart nimmt drei Achsen an: Die erste, parallel zu den Fasern, clie zweite im Sinne des Radius und die dritte tangential zu den Jahrringen. Er fand dureh Versuche, die er mit kleinen im Sinne dieser drei Achsen dem Stamme entnommenen Barren angestellt hat, daß, wenn man den Widerstand gegen Biegung im Sime der Tangente als Einheit annimmt, jener im Sinne des Radins 2,25, jener im Sinne der Faserrichtung 16 betrïigt.

Dieselbe Frage verfolgte $\mathbb{I}^{\top}$ he atstone, der siel hierüber in den Philosophical transactions, 1833 , S. 608 fulgendermaßen äußert:

„Wenn man eine Platte so ausfornt, daß die Fasern zu einer der Seitenlanten parallel laufen, so sinł die Axen der grōBten und lileinsten Elastizität rechtwinklig zu einander und parallel geatellt zu den anliegenden Seiten"... .

.. Wenn di: Platte die Form eines Rechteckes hat, dessen Seitenkanten sich ungekehrt wie die Guadrate ihrer Widerstande gegen Biegungen verhalten, so werden die beiden Arten der Schwingungen parallel zu den Seilen, wiewohl diese verschieden lang sind, isochronisch sein, und ihre lioëxistenz wird eine resultierende Figur liefern, deren Linien parallel zur Diagonale verlaufen."

Man könnte demnach, indem man die diesen Seiten zu gebende relative Länge 
durch Versuche ermittelt, das Verhältuis der Elastizitäts-Lioeffizienten in zwei auf cinander senkrechten Richtungen finden.

Pon c e l e t geht in seinen Werke Mécanique industrielle, 1839, S. $316 \mathrm{in} \mathrm{sehr}$ genaue Details über die Elastizität der Hölzer und besonders über Lelnungsversuche mit denselben ein. Er leitet aus den Versuchen von Minard und Désorme und jenen von Ardant ab, daß für die ersten Belastungen die Verlängerungen den spannenden Kräften ausgesprochen proportional sind und rechnet aus diesen Verlängerungen die Elastizitäts-Koeffizienten. Die Elastizitätsgrenze für die Eiche entspricht naclı d’u Versuchen von Minard und Désorme einer Belastung von 2,13 Kilogrammen pre Quadratnillimeter und einer Verlängerung von 0,0016 der ursprünglichen Läinge. Die analogen Zahten sind nach Ardant für die Vogesen-Tanne 1,85 Kilogramm und 0,00117. Diese verschiedenen Daten verstehen sich für die Elastizität in Sinne des Fasernlaufes. Poncelet urgiert weitere Versuche über die Elastizilät in Sime der Tangente und der Normale zu den Jahrringen.

Nach E a t o n Hodgkins o n (Combes, Exploitation des mines, I. Band, S. 550) alteriert eine Verkürzung um 0,0027 der ursprünglichen Länge eines nicht gebogenen Prismas die Elastizitat um ein Erhebliches.

H a g e n hat die Elastizität mehrerer Holzarten durch Bicgung von Stäben, die in Sinne der Fasern und senkuecht auf dieselben genommen worden waren, untersucht und hat keine große Differenz zwischen Kieln- und Splintholz gefunden; er hat indessen erkamnt, daß der Elastizitäts-Koeffizient bedeutend abnimml, wenn das Holz sehr stark durchnäBt ist. (Poggendorff's Amnalen, LVIII. Band, S. 125.)

In Jahre 1845 debutierten zwei italienische Physiker, und zwar P a c c i n o t t i und Peri (Il Cimento, III. Jahrgang) mit einer äußers屯 prëzisen und detaillicrten Untersuchung über die Elastizität der Hölzer, in welcher sie die verschiedenen Methoden zur Bestimmung des Elastizitäts-Koeffizienten untereinander verglichen und auf ihren Wert prüten. Sie operierten nach den drei Nethoden auf Zug, Biegung und Torsion mit qquadratisehen Stäben von 27-36 Millimeter Querschnitt-Seite. Bei den Biegungsversuchen wendeten sie fünf verschiedene Arten der Befestigung beziehungsweise Unterstützung der Stäbe an. Diese Experinentatoren haben sowohl die elastischen als auch die permanenten Verlängerungen, Torsionswinkel, und die verschiedenen Punkten des Stabes entsprechenden Ordinaten des Stabes während dessen Durchbiegung bei wachsender Belastung desselben gemessen. Im zweiten Teile ilırer Arbeit vergleichen Paccinotti und Peri dic ziffermäßigen Ergebnisse ilıer Versuthe mit jenen Ziffern, die sich unter Anwendung der bekannten Formeln berechnen ließen, und suchen für die von ihnen untersuchten Hölzer eine Relation zwischen der Dichte und dem Elastizitäts-lioeffizienten aufzustellen.

Sie gelangten endlich zu folgenden Konklusionen:

1) „Die Elastizität ermögticht in den verschiedenen Teilen des Holzes Veränderungen der Dimensionen, w. lche nicht bloß den ersten Belastungen, sondern auch jenen, die der Bruchbelastung nahe liegen, proportional sind, vorausgesetzt, daß man dafür Sorge trägt, von den elastischen Veränderungen jene permanenten auszuscheiden, die entweder der Weichheil dis Materials oder der fiontinuitat der Betastung zuzuschreiben sind".

2) ,Die Durchbiegungskurven, welehe die an einem Ende fest eingelassenen (eingreklammerten) Hölzer annehnen, weichen unler sonst gleiehen Umsländen von jenen ab, welche die gleichen Hölzer bilden, wenn sie an beiden Enden unterstützt sint, was man der Reaktion der Fasern in den beiden entgegengesetzten desten zuschreiben muß. Indesseu kann dieselbe Theorie dazu dienen, un die beiden Arten von liurven abzuleiten, vorausgesetzl, daß bei der Integration der betreffenden Differentialgleichung auf die gehörige Bestimmung der Lionstanten Bedacht genommen werde (deren Größe von dem Grade der Unveränderlichkeil der Einfügung, Einklemmung des Endes des Versuchsstückes abhängig ist)."

3) ,Die Unterschiede, die sich bei der Bestimmung des Elastizitäts-lioeffizient'n bei demselben zeigen, verschwinden fast rollständig. wenn man nil diesen Ausdrucke den (Yuotien- 
ten $E^{\prime}=\frac{E}{G}$ bezeichnet, wobei $E$ den gewöhnlichen Begriff des Elastizitäls-Koeffizienten und C das spezifische Gewicht bedented."

4) ,Der Elaslizitäts-lioeffizient $\mathrm{E}^{\prime}$ ist, wiewohl es einige Unterschiede bei den diversen Holzarten gibt, im allgemeinen = 2000 für den Quadratmillimeler Querschnitt."

5. ,Man kann den Elastizitäts-lioeffizienten nicht nur durch Zug, sondern auch durch Birgung und Drehung ermitteln, aher man erhält mit diesen verschiedenen Methoden auch verschiedene Werte und, um sie auf eine gleiche Ziffer zurückzufühen, wird man in jedem Falle rinen von der Art der Operation ablängigen konstanten Koeffizienten zu bestimnen haben."

6. ,Die leichteste Vethode zur Bestinmung des Elastizitäts-Koeffizienten besteht darin, den liörper an beiden Enden zu unterstützen und in der llitte des Abstandes der stützpunkte zu belasten."

Die Beobachtungen Paccinottis und Peris sind so exakt, als sie es o h n e A $11-$ we $\mathrm{nd}$ u $\mathrm{ngdes} \mathrm{K}$ a th e t o me ters scin komiten. Auch das Gesetz, das unter 1 ausgesprochen ist, stimmt mit jenem überein, das man als für die Mctalle gültig hinstellte. Aber es blieb einige Lnsicherheit bezüglich der aus den Versuchen abgeleiteten Ioeffizienten und des Vergleiches der Methoden untereinander, denn diese Autoren haben es vernachlässigt, den Teil des Bammes, dem die Versuchsstïcke entnommen sind, sowie den Feuchtigkeitsgrad der Versuchsstücke zur Zeit der Erprobung in Rechnung zu ziehen. Bekanntlich ist aber die Elastizität nicht in allen Teilen des Baumes dieselbe und sie verändert sich bemerkenswert mit den Feuchtigkeitsgehalte. und dieser ist in so kleinen Stähen, wie sie die Autoren benützt haben, besonders variabel. Demnach sind die Ergehnisse der Beobachtumgen Paccinottis und Peris, welche unter verschiedenartigen Umständen an dem nänlichen Holze, und jene, welche bei diversen Holzarten gewonnen wurden, denn doch nicht ganz vergleichbar untereinander. Es ist ferner zu bemerken, daß nach den bekannten Formeln, welche die Beziehung zwischen dem Elastizitäts-Koeffizienten und der Schallgeschwindigkeit ausdrücken, der von Paccinotti und Peri eingefülırte Begriff E' dem Quadrate der Schallgeschwindiglieit proportional sein müßte, woraus folgt, daß, wenn $\mathbf{E}$ eine unveränderliche Größe darstellen wärde, auch dic Schallgeschwindigkeit für alle Arten von Itülzern die gleiche zu sein hätte, was bekanntlich nicht der Fall ist, rlenn sie schwankt nicht nur mit der Holzart, sondern auch in demselben Baume in den verschiedenen Partien desselben, ja in demselben Versuchsstab mit den Grarle der Trockenheit desselben. Nachdem E im allgemeinen mit rlem Grade der Trockenheit wëchst, und $G$ bei Feuchtigkeitsabnahme sich verringert, so muß in um so stärkerem Maße E' bei steigender Trockenheit zunehmen.

\$3. Teberblickt man die auf unserem Arbeitsfelde bis gegen das Ende der elsten Hälfte des vorigen Jahrhunderts gewonnenen Forschungsergebnisse, so findet man, daß rlie Methode und die Schärfe des Raisonnements zwar große Fortschritte machte, - der wichtigste war jedenfalls die Aufnahme der Untersuchungen über die Elastizität -, aber die R e s u I t a $\mathrm{t}$ c der Untersuchungen widersprachen sich häufig untereinander, die Fragestellung der Autoren ist häufig unsystematisch und ließ empfindliche Lücken, die Einseitigkeit der Autoren ist vorherrschend. In voller Erkenntuis dieser Verdältnisse unternahmen zwei französische Fachleute, ein Forstmann und ein Techniker, Ch e r a n d i e r und W e r the in, eine epochemachende Arbeit. Tlie Versuchshölzer wurden einem Forstgebiete der westlichen Vogesen entnommen, dessen lokale Verhältnisse den Forschern genau bekannt waren. In den 4000 Hektar messenden Komplexe fanden sich genügend viele Varianten von Wachstumsbedingungen und Holzarten. Der Auswahl, Beschreibung und Torbereitung der Versuchsstücke wurde die gleielıe weitgehende Sorgfalt zugewendet, wie den Versuchen selbst, für welche alle nötigen Hilfsmittel in befriedigender Qualität zur Verfügung standen. Chevandier und Wertheim publizierten ihre Arbeit, die Frucht 
mehrjähriger Anstrengung, welehe in einem bis dahin nicht erreichtru Gracte von Vollkommenheit durehgefïhrt worde, im dahre 1818 als Monographio: Menoire sur les proprictés méeaniques du Bois, nachdem die Ergehnisse schon an 5. Olitolier 1846 der Akademie der Wissenschaften in Paris vorgelegt worden waren. I he beilen Autoren hewiesen zunäehst in ersten, den historischen Teile ihres Memoire, dom wir hiej' bisher gefolgt waren, die Unentbehrlichkeit einel neuen Untersuchung, welche sich mit der Feststellung der allgemeinen Gesetze, mit der Bewegung der mechanischen Eigenschaften in den Individuen und mit jenen Abveichungen derselben, welehe der Verschiedenheit der Art, des Alters, der Exposition und der l'rovenienz zuzuschreiben sind, zu befassen lätle, wobei die theoretischen Untersuchungen unter Iiöksichtnahme auf die in der praktischen Verwendung des Holzes auftretenden Veruältnisse komplettiert werden sollten.

Chevandier und Wertheim legten sich folgende Fragen ror:

1. Welche Wirkung übt eine allmählich wachsende Belastung auf die IIölzel aus, nach welchen Gesetzen vollziehen sich die dahei entstehenden Formveränderungen und welche Hethoden sind zur Bestimmung der mechanischen Eigenschaften der Hölzer verwendbar?

2. Varijeren die mechanischen Eigenschaften des Holzes

a) mit der Orientierung, d. h. nach der Lage in Bame in Beziehung auf die II eltgegend;

b) mit dem Feuchtiglieitsgehalte;

c) mit der Lage im Baume, bei gleicher I löhe über dem Erdboden, in Beziehung auf die Entfermung vom Mittelpunkte gegen den Umfang hin;

d) mit der Lage im Baune nach der Höłe über den Boden?

3. In welchem Verhältnis stehen die mechanischen Eigenschaften des Holzes in Sinne der Fasernlänge und der auf dieser senkrechten Richtungen in Stamme je nach der verschiedenen Höhe über dem Boden?

4. Welchen Einfluß übt das Alter der Bäume aus?

5. Welchen Einfluß zeigen die Jahrringbreite, die Exposition und die Budenbeschaffenheit?

6. Welche Beziehungen bestehen zwischen den mechanischen Eigenschaften ler Hölzer untereinander?

7. Welche Mittelzahlen kann man für die mechanischen Eigenschaften der Hölzer als richtig annehmen und welehe Folgerungen ergeben sich daraus für die Praxis?

Mit Beziehung auf diese Fragen stellten Chevandier und Werthein die Ergebnisse der Arbeiten aller weiter oben zitierten Autoren zusammen und zeigten auf diese Art die bestehenden Widersprüche, endlich stellten dieselben in einer Tabelle die von den beachtenswerten Experimentatoren gefundenen Ziffern einander gegenüber und fanden hierbei, daß die Resultate innerhalb sehr weit auseinander liegender Grenzen selwwankten.

Beispielsweise fand man für

Diclite

Eiche

Rotbuche

Tanne

Fichte
0,616 bis 0,993

$0,600, \quad 0,811$

$0,443,, \quad 0,703$

$0,396, \quad 0,793$
Elastizitäts-lioeffizient Festigkeit

500 bis $1600 \quad$ jo bis 12

$950,1483 \quad 8,12$

$611,1615 \quad \overline{3}, 49$

$433,1776 \quad 1,8$

Was immer die Ursache so großer Abweichungen sein mochte, die Tatsache stand fest, daß von diesen Ziffern ein sicherer Gebrauch nicht gemacht werden konnte, und 
die Erneuerung der Anstrengungen seitens der fachmännischen Kreise, zu deren hervorragendsten Zierden Chevandier und Wertheim zählten, erscheint als volliommen gerechtfertigt.

Die Resultate, welche aus den Forschungen der letztgenannten Gelehrten abzuleiten waren, gehören schon in jene Gruppe von Daten, mit denen wir heute noch zu rechnen haben, und die sicher teilweise schon in die Darstellung des gegenwärtigen Zustandes unserer Erkenntnis über den in Rede stehenden Stoff fallen, weshalb sie an dieser Stelle nicht weiter erörtert werden.

§ 4. Außer den mechanischen und physikalischen Eigenschaften - Elastizität und Festigkeit, Dichte und Volumsveränderlichkeit - fanden manche andere Eigenschaften vorühergehend in der Fachliteratur, namentlich der Forstleute, Beachtung. Auch hierin gab ja D u h a mel d u Mo n c e a u ein leider nur zu wenig nachgeahmtes rühmliches Beispiel. Alles zusammengenommen, was, abgesehen von dem bereits hier Erwähnten in der Entwickehng unseres speziellen Stoffes, vor dem Jahre 1850 erreicht wurde, verschwindet im Vergleiche zu der Bedeutung der Nördlingerschen Leistung, weshalb wir gleich ohne weiteren Aufenthalt zu dieser übergelien.

Dr. H. N öl d l ing e r, Professor der Forstwissenschaft und Oberförster zu Hohenheim, der Sohn eines hochgebildeten Forstmannes (Julius Nördlinger), hatte eine umfassende natumissenschaftliche Grundlage für seinen Beruf erhalten und in dieser selbst schon Bedeutendes geleistet, als er erkannte, welche enorme Wichtigkeit eine genaue Kenntnis der Hölzer für den Forstmann und den holzverbrauchenden Techniker habe und beklagte, daß ,Forstleute selten erfahren, welche Eigenschaften das von ilmen gelieferte Holz gezeigt habe, während Bauleute, Handwerker und Fabrikanten andrerseits an Hölzern Erfahrungen sammehn, zu deren Begründung ihnen der verbintende Faden, nämlich die lienntnis der Herkunft der Bäume, abgehe. Jeder verfolge seinen WVeg ohne den anderen." Im Jahre 1847 bewilligten dem Professor Nördlinger die Direktion der Hohenheimer Akademie und das Finanzministerium die Nittel zur Anstellung von Versuchen, welchen er sich mit bewunderungswürdigem Fleiße hingab. Prof. Dr. R e u s ch und der Assistent $\mathrm{H}$ ä b e r le am polytechnischen Institute zu Stuttgart sowie eine große Zahl seiner Schüler unterstützten den begeisterten Forscher. Als Frucht seiner Studien erschien im Jahre 1860 das tonangebend gewordene Werk: ,D ie te c hn is e he $\mathrm{n} \mathrm{Eigens} \mathrm{chaf-}$ ten der Hölzer für Forst- und Baubeamte, Technologen und Gewerbetreibende".

In Bezichung auf die mechanischen Eigenschaften stützte sich Nördlinger auf die für sein Unternehmen rechtzeitig erschienene Monographie von $\mathrm{G}$ h e v a n d i e r und $\mathrm{W}$ e $\mathrm{r}$ t h e i $\mathrm{m}$. Für alles andere war die gesante Literatur weniger maßgebend, und er selbst füllte mit wahrem Bienenfleiß die Lücken aus, die sich bei einer universellen Behandlung des Stoffes darboten.

Nördlinger bezog in sein Werk auch die Schilderung des ,i n $n$ e r e $\mathrm{n}$ B a u e s" der Hölzel ein, da er hoffte, aus demselben manche Eigenschaft und ihre Schwankungen ableiten oder erkłären zu können. Außerdem behandelt Nördlinger Feinheit, Farbe, Glanz und Durchscheinen, Geruch, Wärmeleitungsfähigkeit, Fähigkeit des Holzes, zu dunsten und WVasser oder Dunst einzusaugen, spezifisches Gewicht, Härte, Spaltbarkeit, Schwinden, Quellen, Sichwerfen, Federkraft, Biegsamkeit und Zähigkeit, Festigkeit, chemische Zusammensetzung, Brennkraft, natürliche Dauer und Fehler des Holzes. Diese Inhaltsangabe, ein reiches Durcheinander, zeigt, daß Nördlinger den Stoff weiter umfing ats irgend einer seiner Vorfahren. Die Bearbeitung 
manchen Abschnittes ward durchaus originell ohne irgend eine Vorarheil anderer

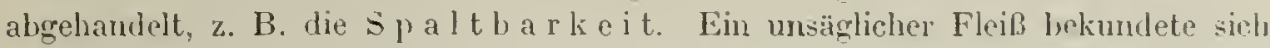
in der Revision der von anderen Fachleuten gewonnenen Daten und in der Unreehnung auf ein einheitliches Vaß und Gewicht. Das Nördlingersehe Buch muß heute noch, nach melır als einem lablben bahrhundert, von jedem zu Ratr gezogen werden, der gewohnt ist, an der Quelle zu schöpfen. Von den seither erschienenen, mitunter schr hübsch angeordneten kompilatorischen Abhandlungen ïber die technischen Eigenschaften der Hölze fult jeile his zu einem gewissen Grade auf Nördlinger, keine brachte quantitativ mehr an ,neuem Material".

Nördlinger hat auf dem Gebicte der Erforschung der techmischen Eigenschalten auch später noch weitere Studien gemacht, und besonderes Augenmerk den mechanischen Eigenschaften der Hölzer zugewendet. Seine diesbezüglichen Resultate publizierte er 1890 unter dem Titel ,Die gewerblichen Eigensehaften der Hölzer". Dieses Schriftchen enthält die Ergebnisse seiner Forschungen in gedrängter Kürze, während die Versuchsresultate in den Jahrgängen 1888 und 1889 des ,österr. Zentralblattes für das gesamte Forstwesen" enthalten sind.

$\$ 5$. Ton den Publikationen des letzten halben Jahrhunderts ist folgende kurzgefaßte Uebersicht zu geben.

Die Errichtung von mechanisch-technischen Laboratorien an technischen LehrInstituten bot Gelegenheit zu neuen Studien über die mechanischen Eigensehaften der Hölzer. Die Resultate werden bej der später zu liefernden Darstellung der heutigen Auffassung des Gegenstandes zu verwerten sein. An dieser Stelle sei nur erwähnt, wo und wie diese Arbeiten entstanden sind. Zuerst einige Worte von einem Vorläufer.

Das Science and Art Departement of the Committee of Council on Education in London lieB in Jahre 1867 ,Tables of the results of a series of experiments on the strength of british colonial and other woods" drucken, deren Autor und Veranlasser der Königliche Ingenieur-liapitän F r a $\mathrm{c}$ is $\mathrm{Fow}$ e war. Dieser hatte schon während der Pariser internationalen Ausstellung vom Jahre 1855 Versuche mit Hölzern von den englischen Kiolonialbesitzungen und anderer Provenienz durchgeführt, um deren Ejgenschaften zu demonstrieren. Nach der internationalen Ausstellung zu London 1862 wurden die Versuche mit dem reichlich der Universal-Exposition zugeströmten Materiale und in vergröBertem Naßstabe sowie mit vermehrter Sorgfalt vorgenommen. Die von Hayward Tyler u. Co. zur Verfügung gestellte hydraulische Presse war indessen nach unseren heutigen Vorstellungen ein selır primitiver, in Beziehung auf die Bedürfnisse der Beobachtung unzureichender Ayparat. In Intervallen von 1120 Pfund oder einer halben Tonne wurden die Formveränderungen an den Versuchshölzern in Tausendstel-Zollen gemessen. Diese Versuchshölzer waren 16 Zoll lang und maßen 2 Zoll engl. an der quadratisehen Querschnittseite, oder bildeten Würfel von 1 Zoll Seite. Untersucht wurde an beilïufig 3000 Versuchsstücken die relative und die rückwirkende Festigkeit, letztere im Sinne der Faser oder senkrecht zu derselben, ermittelt die Einwirkung der Belastungent auf die Form. Aus den Ergebnissen vergleichbarer Versuche wurden Nittelwerte gereclinet. Von den Hölzern waren meist nur der Vulgär- oder Lokalnane, nur ausnahmsweise der botanische Name und die Provenienz behannt. Folgerungen über den gesetzmäßigen Zusammenhang von Eigenschaften zog der Autor nicht. Dic* Riesenarbeit hat der W"issenschaft geringe Dienste geleistet.

Eine ähnliche Veranlassung wie die Fowkesche Arbeit hatte die Arbeit des Professors an der k. $k$. technischen Hochschule in Wien, Bergrat $K$ a $r \mid r$, e $1 \mathrm{n} y$, 
welcher über Antrag des hönigl. Ungarischen Jommissärs für die forstliche Abteilung auf der Wiener Weltausstellung, $\boldsymbol{J}$ os e f W e s s e l y , dem beliannten Forstschriftsteller, von der ungarischen Regierung für Untersuchungen von Hölzern aus den Ländern der ungarischen Lirone gewonnen worden war. Diese Untersuchungen wurden nach einem weitausblickenden Programme begonnen, und ein Teil der Resultate gelangte als selbständige Publikation (Lntersuchungen über die Festigkeit der Ilölzer aus den Ländem der ungarischen lirone, verfügt vom Kïnigl. Ungarischen Finanzministerium, Budapest 1873, I. H e f t) in die Oeffentlichkeit. Jenny untersuchte die lluck-Elastizität und-Festigkeit, die Scherfestigkeit parallel zur Faser und die Zug-Elastizität und -Festigkeit von Hölzem, bei denen bekannt war: Provenienz, Bodenleschaffenheit, Jolzart und Jahrringbreite. Der lliteilung der Resultate ist eine theoretische Betrachtung vorangestellt.

Infolge einer Anregung von seiten der k. k. forstlichen Versuchsleitung (Regierungsrat Prof. Dr. A r thur Frh. v. Seckendorf in Wien veranstaltete der vormalige Assistent an deutschen Prager Polytechnilium Ka $\mathrm{rl}$. I k o l a s che k eine ansehnliche Reihe von Versuchen über die mechanische Beschaffenheit von in Böhmen erwachsenen Hölzem mit Hilfe der Gollnerschen Probiermaschine bei der Lelırkanzel für Maschinenbau an der k. k. deutschen technischen Hochschule in Prag. Mikolascheli untersuchte vierzig Jolzausschnitte, von denen meist 3 demselben Baume, unmittelbar über dem Stocke, eine gemessene Höhe über dem Storke aus dem Stamme und einem Aste entnommen waren. AuBer der Holzart, dem Alter und dem Ihurchmesser des Baunteiles war die Lage und Beschaffenheit des Standortes bekannt; ermittelt wurde die Elastizität und Festigkeit auf Zug und Druck in sinne der Faserrichtung, Elastizität und Festigkeit bei Biegung und Torsion, endlich dic Abscherfestigkeit sowohl in der zur Faser parallelen als in einer darauf senlirechten Richtung. Gesetzmäßige Folgerungen wurden aus den Versuchsergebnissen nicht gezogen, die Resultate verdienen als zuverlässige Daten Beachtung. Die Arbeit ist im Heft I Band II der, ,Witteilungen aus dem forstlichen V'ersuchswesen Oesterreichs" und als Scparatabdruck veröffentlicht im Jalıre IS79.

Die Zahl der auf die mechanischen Eigenschaften der Hölzer Bezug habenden Untersuchungen und Abhandlungen vermehrte sich nun in der periodischen Fachliteratur von Tag zu Tag; es muß hier vorläufig darauf verzichtet werden, eine Uebersicht zu geben, da es sich doch jetzt zunächst nur um die Feststellung jener Nomente handelt, welche für die Entwickelung des ganzen Faches eine weittragende Bedeutung haben. Flazu gehören aber zunächst zwei größere Studien, welche beide in das Jahr Is8:3 fallen.

I. Methoden und Resultate der Prüfung der schwe i z. B a u höl z e r, bearbeitet von L. T e tm a jer, Ingenieur, Professor am schweiz. Polytechnikum, Zürich.

2. Untersuchungen über die Elastizität und Festigkeit von Fichten- und KỉefernBauhölzern (Mlitteilungen aus den meclıanisch-technischen Laboratorium der Königl. Technischen IJochschule in Iünchen, IX. Heft) von J. B a uschinger, ord. Professor der technischen Mechanik und graphischen Statik, München.

ad I. Las eidgenössische Festigkeits-Institut hat für die Gruppe der „Baumaterialien" auf der schweiz. Landesausstellung eine sehr umfangreiche Untersuchung nach einem Programme durchgeführt, welches ein Kiompromiß zwischen den bautechnischen und forstwirtschaftlichen Interessen darstellt und die Prof. T e $t m$ a je r und L a $\mathrm{nd} \mathrm{ol}$ t zu Verfassern hat. Im ganzen waren $3 \mathrm{I}$ Bauholzstänme zur Erwobung gelangt und zwar in der Weise, daß von jedem 22 Versuchsstücke vorgerichtet 
wurden. Diese dienten zur Ermittlung der Diehte und des Feuchtigkeitsgehaltes, dann der Elastizitäts- und Festigkeits-Verhältnisse bei Zug, Druck, Knickung, Abseherung und Biegung. Die Holzarten Tanne, Fichte, Fölıre, Lärche, Eiche und Buche wareı aus verschiedenen Höhenlagen repräsentiert und für jedes Individuum war mit Sorgfalt festgestellt: Geologie des Standortes, örtliche Lage und H ö h e d e ss e I b e 1 ii b e r dem If e resspiegel, Alter und Beschreibung des Ausseliens des Holzes.

Tetmajer hat eine sehr bemerkenswerte Methode der Qualitütsbestimmung des Holzes in bautechnischer Richtung an der Hand der $\mathrm{Ar}$ be it s k a p a i $\mathrm{t}$ ä $\mathrm{d} \mathrm{e} \mathrm{r}^{\circ}$ Biegungsfestigkeit in Vorsehlag gebracht. Auch in Beziehung auf den Wert der Ziffern, welche die umfangreiche Studie lieferte, nimmt dieselbe einen ersten Rang ein.

ad. 2. Banschinger beasichtigte, Aufschluß über den Einfluß des Standortes und der Fällzeit auf die Elastizität und Festigkeit der wichtigsten Nadelbauliölzer zu gewinnen. Dabei wurde überaus rationell vorgegangen. Ton vier Standorten wurden je vier Iïiefern und Fichten in Alter von 90 bis 100 Jahren, welehe unter ähnlichen Standortsverhältnissen volliommen gesund und fehlerfrei erwachsen waren, ausgewählt und nach der ,Anleitung zur Standorts- und Bestandesbeschreibung beim forstlichen Versuchswesen" (abgedruckt und erläutert in Ganghofers forstlichem Versuchswesen, Band I, Heft 1) gesehildert. Je zwei der Stämme wurden von jedem Standort im Sommer (August 188I) und je zwei in folgenden Winter (Dezember und Januar) gefällt und untel bestimmten Modalitäten ans Münchener Laboratorium gesandt. Bauschinger unterwarf die Ballien, welehe verhältnismäßig g r o B e A b m es s u n g e n hatten, auf der Werderschen Maschine den Versuchen auf Biegung (250 cm Spannweite), Zug, Druck, Abscherung. Außerdem wurde an einem speziell zu diesem Zwecke hergestellten Stammstücke eine Untersuchung über die Beziehung zwischen den mechanischen Eigenschaften (Elastizität und Festigkeit) und den physikalischen (Dichte und Feuchtigkeit) angestellt, um die obigen Versuchsergebnisse untereinander vergleichbar zu machen. Hierauf konnten die nötigen Fiorrektionen und Reduktionen vorgenommen und endlich die Resultate verglichen und bestimmte Folgerungen gezogen werden.

Die neueren Forschungen und Untersuchungsresultate, welche sich durch ihren wissenschaftlichen Wert ganz besonders auszeichnen, sind die Arbeiten von II. R ud e l o f f, Bericht über die im Auftrage des Herm llinisters für Landwirtscliaft, Domänen und Forsten ausgeführten Holzuntersuehungen, Berlin 1889. - Dr. A. $\mathrm{S} c \mathrm{~h}$ w a p a $\mathrm{ch}$, Untersuchungen über Raumgewicht und Druckfestigkeit des Holzes wichtiger Waldbäume. I. Die Kiefer. Berlin I897. - II. Fichte, Weißtanne Weymouthshiefer und Rotbuche. Berlin IS9S. - A n to n $\mathrm{H}$ a d e k und G a b ri e I $\mathrm{J}$ a $\mathrm{n} \mathrm{k}$ a , Untersuchungen über die Elastizität und Festigkeit der österr. Bauhölzer. I. Fichte Südtirols. Wien 1900. - G. J a n k a, Untersuchungen übel die Elastizität und Festigkeit der österr. Bauhölzer. Il. Fichte von Nordtirol, vom Wienerwalde und Erzgebirge. Wien 1904, und III. Fichte aus den liarpathen, aus dem Böhmerwalde, Ternovanerwalde und den Zentralalpen. Technische Qualität des Fichtenholzes im allgemeinen. Wien 1909.

§ 6. In Beziehung auf die $\mathrm{m}$ e $\mathrm{c}$ h a $\mathrm{n}$ is $\mathrm{e}$ h e $\mathrm{n}$ (bei der Anwendung des Holzes im Bau- und Konstruktions-, also allgemein im lngenieur-TVesen ausschlaggebenden) Eigenschaften liegt ein ungemein reiches, aber ebenso vielartiges und erst seit $C h_{\mathrm{e}} \mathrm{e}$ v a n d i e r und W e r the in heute noch berücksichtigungswertes Material an Forschungsergebnissen vor. Hier sind aber trotzdem erst die Wege gefunden und einzelne Beispiele gelungen, ein weites Feld ist der Forschung noch offen, - freilich erfordert 
sie bedeutenden Aufwand an physischen und pekuniären Jíräften und sollte, statt von den zufälligen Veranlassungen abhängig zu sein, durch ernste planmäßige Anordnungen geregelt werden. Die hiehergehörigen neuesten Arbeiten von M. Rudeloff, Dr. Schwappach und A. Hadek und G. Janka haben bereits den gezeichneten Weg cingehaiten, und wäre es nul zu wünschen, daß solche Versuchsreihen auch fernerhin zur Ausführung gelangten. Ist doch unser technisches Versuchswesen heute derart ausgebildet, daß die Lösung dieser wichtigen Aufgaben leicht zu erreichen ist. Die Hilfsmittel hiezu sind allenthalben vorlıanden, die präzisesten Apparate stehen zur Verfügung, ein allgemeiner Arbeitsplan für Holzuntersuchungen ist aufgestellt, - nur die Auftringung derfinanziellen Mlittel zur Durchführung sołcher unfangreicher Arbeiten bereitet uns heute leider oft genug noch die größten Schwierigkeiten.

Die Entwickelung der Erkenntnis von anderen Gruppen von Eigenschaften ist zwar natürlich eine ähnliche, aber das heute Errungene steht in mancher Beziehung von dem wünschenswerten Zicle noch weiter ab.

Schon im Jalıre 1869 hat Wilh. Fr. Exner in seinen Vorträgen über das Holz als Rohstoff für das Kunstgewerbe am österr. Nuseum für Iiunst und Industrie die Untersuchung des Holzes sowohl nach der technisehen als nach der kunstgewerblichen Seite hin verlangt und dadurch tatsächlich die Holzuntersuchungen nach dieser Richtung hin inauguriert.

Der berühmte Technologe $\mathrm{K}$. I a r m a r s $\mathrm{h}$, welcher bekanntlich die ,beschreibende Technologie“ zum Range einer Wissenschaft erhob, legte mit seinem epochemachenden W'erke: "Handbuch der mechanischen Technologie“ die Grundlage für die Erörterung aller technischen Eigenschaften, die zur $\mathrm{V}$ e r a r b e i $\mathbf{t} u \mathrm{ng}$ u n d Verwendung des Holzes in der Industrie in Relation stehen. Dabei treten dic Elastizität und selbst die Festigkeit in den Hintergrund, und Dichte, Härte, Spaltbarkeit, namentlich aber die Volumsveränderlichkeit erhalten für die Gestaltgebung und die Erhaltung des beabsichtigten Gefüges Belang. Karmarsch hat sellust mancherłei Beobachtungen gemacht, sein Ilauptverdienst besteht aber in der zusammenfasserden Darstellung aller zuverlässigen älteren und neueren Daten, welche ja nur für die mechanischen Eigenscliaften von Chevandier und Wertheim gemacht worden war, und in der Einbeziehung jener Erfahrungen, die man bei der mechanischen, physilialischen und chemischen $\mathrm{B}$ eh a $\mathrm{nd} \mathrm{lung} \mathrm{g}$ er $\mathrm{Hölzer}$ auch in bezug auf ihre Eigenschaften gewomen hatte. Seine Nachfolger E. H o y e r (Lehrbuch der vergleichenden mechanischen Technologie, Wiesbaden 1878), F. S t ü b c hr enKi irclıner (Kammarsch-Heerens technisches Wörterbuch, 3. Auflage ergänzt und bearlecitet von F. I i ck und Dr. W. G in t 1, IV. Band, Prag 1S86), endlich Prof. A. L e cl e L u r (Wie Verarbeitung des Holzes auf mechanischem Wege, Braunschweig 1881) und Prof. H. Fischer (Die Bearbeitung der Mctalle, des Hölzer etc., Handbuch der mechan. Technologie 1891) konnten wie Karmarsch in den späteren Auflagen seines Werkes schon die Arbeiten der Forstlcute und Botaniker Nördlinger, Dr. J. Wiesner, Jr. R. II artig, Th. Hartig ete. mit in ihre Darstellung einbeziehen ${ }^{1}$ ). Eine völlig morlerne Auffassung der Rolle, welche dic Eigenschaften in technologiseher Richtung spielen, bekundet aber erst der obengenannte Technologe ( $L$ e d e b u r), indern er zwischen A r beits- und Gew e r b s e i ge n s c h a f t e n unterscheidet.

Nebst den Vertretern der mechanischen Technili, dem Forstmanne Nördlinger und den Technologen ist aber weiters die Gruppe der Botaniker zu besprechen, welche

1) Eine gute kompilatorisehe Arbeit über die Eigensehaften des Holzes, welche in lechnischen Kreisen viel benulzt wird, findel sich bei: $R$ ud olph $G$ o $t$ lg e tre $u$, Physische und chemische Besehaffenheil der Baumaterialien, 3. Auflage, Berlin 1880, I. Band. 
sich speziell auf das Holz, dessen Anatomie, Physiologic, Histologie verlegten und dem Nikroskop zu neuen Erfolgen verhalfen.

Hofrat Prof. Dr. Julius von IV i es n er, welcher früher als Dozent für Warenkunde an der Wiener k. k. technischen Hochschule wirkte, gab diesen Fach ncue Gestalt und newen Inhalt auf naturwissenschaftlicher Grundlage. Seine beiden Hauptwerke auf diesem Gcbicte, „Einleitung in die technische Mikroskopie“, Wien 1867, und „Die Rohstoffe des Pflanzenreichs“, Leipzig (II. Auflage 1900), behandeln das Holz vornelımlich rom Standpunkte der Anatomie aus. In dem letztgenannten Werke werden von Prof. Dr. K. Wi l h e I m-Wien, welchen Wi esner für die II. Auflage die Bearbeitung des Abschnittes über die Hölzer übertragen hat, zum ersten Male in umlassender Weise die Unterscheidungsmerkmale der Holzarten und deren physikalische Eigenschaften sowie die Verwendung der Hölzer festgestellt und manche landläufige Irrtümer aufgedeckt und bleibend beseitigt.

Dr. J. M o e ll e r hatte sich schon durch seine ausgezeichneten „Beiträge zur vergleichenden Anatomie des Holzes" (Denlischiften der math.-naturwissenschaftl. Kilasse der liais. Akademie der Wissenschaften, Band XXXVI) und andere einschlägige Studien eine hervorragende Stellung als Fachmann erworben, bis er endlich die für die Technologie höchst wertvolle Monographie: Die Rohstoffe des Tischler- und Drechsler-Gewerbes, I. Teil, Das Holz, liassel 1883, veröffentlichte, in weleher er auch die dem Botaniker femer liegenden Verhältnisse, insbesondere die technischen Eigenschaften geschickt darstellte.

Es dürfte genügen, hier darauf hinzuweisen, daß Botaniker wie $\mathrm{B}$ ö ln $\mathrm{m}, \mathrm{R}$. und Th. H a r t ig, Höhne l, R e in k e, R o $B m$ a $n n$, Unger, S a n i o, S c h a c ht, IV e i $B$, Willkom m. a. m. manchen Beitrag lieferten. Nördlinger beschenkte die Literatur auch nach dem Erscheinen seines Hauptwerkes mit maneher Spezialstudie (z. B. Der Holzring als Grundlage des Baumkörpers, Stuttgart 1872); R. H a r t i g untersuchte, das spez. Frisch- und Trockengewicht etc., den Wassergehalt und das Schwinden des Kiefernholzes (Berlin 1874) und veröffentlichte 1885 (Berlin) die vortreffliche Monographie: „Das Holz der deutschen Nadelwaldbäune*; seine zahlreiclien, auf die Qualität des Holzes bezugnehmenden Arbeiten hat R. II a r$\mathrm{t}$ i g schließlich zusammengefaßt in seinem Buche: „Holzuntersuchungen. Altes und Neues" 1901. J. S a c h s veröffentlichte eine beachtenswerte Untersuchung über die ,Porosität des Holzes", Würzburg 1877; in den ,Studien über die Qualität rasch erwachsenen Fichtenholzes" (Zentralbl. f. d. g. Forstw. 1902) haben Dr. C i e sI a r und G. J a n k a auf Grund von anatomischen bezw. technologischen Untersuchungen auf die Nachteile einer zu weitständigen Begrünclung und Erziehung von Fichtenbeständen bezüglich der Holzqualität aufmerksam gemacht, usw. usw.

Um einigermaßen vollständig zu sein, muß noch auf jene literarischen Produkte hingewiesen werden, die entweder den B ed ürfnissen der Praxis unmittel b a r entspringend oder der Popularisierung der Wissenschaft dienend, manches wertvolle Datum enthalten. Gerade nur um typische Bcispiele anzuführen, nennen wir folgende Werke und Schriften, chronologiseh geordnet:

Instruction sur les bois de marine et leur application aux constructions navales. Publiée par Ordre de S. Exc. le ministre secrétaire d'état au départencnt de la marine. Paris.

Holzhandel und Holzindustrie der Ostseeländer von Dr. G. M a r e h e t und W. F. Exin e r. Weimar 1885 .

Studien über das Rotbuchenholz von W. F. Ex n e r. Wien 1875.

Les bois indigènes et étrangers, Physiologie - Culture - Production - Qua- 
Jité - Industrie - Commerce. Par Adolphe E. D u pon t et B o u quet de I a Gry e. Paris IS75.

Untersuchungen über den Einfluß ıer Fällungszeit auf die Dauerhaftigkeit des Fich $\mathrm{t}$ en ho l zes, ausgeführt an der Königl. Sächs. forstlichen Versuchsstation zu Tharandt und am Irönigl. Sächs. Polytechnikum zu Dresden, mitgeteilt von Dr. E. H a $r$ t ig in Dresden, 1877.

$\mathrm{B} u \mathrm{r}$ k a $\mathrm{t} \mathrm{s}$ Sammlung der wichtigsten europäischen Nutzhölzer in charakteristischen Schnitten, herausgegeben vom Technologischen Gewerbe-Museum in IVien. Mit einem erläuternden Text. Brünn $\mathbf{I} 880$.

Die Unterscheidungs-Nerkmale der wichtigeren in Deutschland wachsenden IJölzer (Spezielle Xylotomie) von Dr. R. H a r tig. Hünchen 1879.

Experimente über Gewichts- und Volumenemveiterung am Holze der jurassischen Waldbäıme vom grünen Zustande bis zur Verkohlung, ausgeführt 1877, elweitert und ergänzt 1883 zur Beschickung der schweizerischen Landesausstellung von J. A. Frey. Münster im Jura Is83.

Die industrielle Verwertung des Rotbuchenholzes, eine Denkschrift, herausgegeben von einer liommission, welche von dem österr.-ungar. Verein der Holzproduzenten, Holzhändler und Holzindustriellen und dem Technologischen GewerheIIuseum cingesetzt wurde. Wien 1881.

Versuche und Erfahrungen mit Rotbuchen-Nutzholz von P. von A I e n. Berlin 1895.

Die Buchenfrage in der österr. Forstwirtschaft von L e o p o l d l I u f n a g l. Wien 1899.

Ein vorzügliches, populär geschriebenes Büchlein über die technischen Eigenschaften des Holzes ist Sig. G a y e r s ,.Die Holzarten" (Bibliothek der gesamten Technik). In jüngster Zeit ist erschienen: ..Gewerbliche Materialkunde, Die Hölzer, Stuttgart, Verlag Iír a is 1910, das vollständigste Werk, das bisher über diesen Gegenstand veröffentlicht wurde.

$\S 7$. Mit dieser kurzen Uebersicht von Forschungen und Arbeiten, Darstellungen und Anregungen mannigfaltigster Ait und aus den verschiedensten Veranlassungen entsprungen, ist wolll der Nachweis geliefert, daß auf unserem Gebiete inancherlei erreicht, viele Anliüpfungspunkte für weitere Bestrebungen erlangt wurden, daß wir uns aber docl erst am Anfange exakter Forschung befinden und daß namentlich die breite Basis fehlt, welche d i e Großartigkeit des Banes erheischt, die unerläßlich ist, um zur hefriedigenden Höhe der Erkenntnis zu führen. An wenigsten ist noch in technologischer Hinsicht geschehen. Während Ernst Jartig in Dresden gelehrt hat, die Maschinen zur Bearbeitung des Holzes auf ihre Leistung zu erproben, ihren ,Wirkungsgrad" zu ermitteln, lat es noch niemand versucht, die Arbeitseigenschaften des Holzes in solcher W' des Arbeitsaufwandes dienen köınten.

Die vorliegende Abhandlung kann nun nicht den Zweck haben, die wissenschaftliche Bearbeitung des Stoffes selbst direkt zu fördern; es liann nur erwartet werden, daß die bisher gewonmenen Resultate in neuer Form übersichtlich und brauchbar für den Fachmamn zusammengestellt werden. Da eine Zusanmenstellung überhaupt nicht existiert, welche nicht den Stempel der Einseitigkeit an der Stirne tragen würde, so ist die Aufgabe eine wichtige und dankenswerte.

§ 8. In Beziehung auf die Einteilung des Stoffes mögen folgende motivierende Bemerkungen noch hier in der Einleitung ihren Platz finden. 
Dic Erörterung des Baues des Holzkörper's, seiner lionstitution, seines Gefüges, seiner Struktur oder Textur, die chemische Zusammensetzumg und die im Leben der Holzpflanze bedingenden Umstände elc., gelegenen Voraussetzungen obiger Verhältnisse werden in der volliegenden Abhandhung cutfallen, da hiezu andere Fachleute berufen sind.

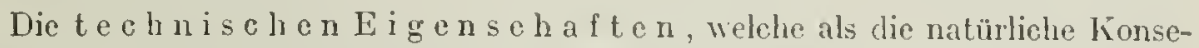
quenz des Baues und der Chemie des Holzes aufgefaßt werden müssen, werden in mechanische und physikalische (Chevandier und Wertheim, Bausehinger u. a.) oder in Arbeits- und Gewerbs-Eigensehaften ( $\mathrm{L}$ e d e b u r u. a. m.) eingeteilt. Die letztere Einteihng hat einen Nachteil für die Behandhung des Stoffes, inden manehe Eigenschaft, wie die Härte, e in m a l als Arbeits-Eigenschaft, d.i. cine auf die Formgebung Einfluß nehmende Beschaffenheit, ein a n d e rm a 1 als Gewerbs-Eigenschaft, d. i. eine die Verwendbarkeit als Gewerbeprodulit bestimmende Beschaffenheit auftritt und daher der Platz dieser Eigenschaft im Systeme nicht ein fixer ist. Es soll daher von einer neuen Einteilung Gebrauch gemacht werden.

Die Eigenschaften zerfallen in drei Gruppen:

1. A e u B ere Erschein ung. Eigenschaften, welehe im unveränderten oder veränderten Bestande durch den Gesichts-, Geruchs- und Tastsinn walırnelimbar sind.

11. II a terielle r Zustand. Dichte, Feuchtigkeitsgelıalt, Veränderlichkeit desselben, Veränderlichkeit des Volumens, Folgen desselben.

III. Verhaltengegen von a $B$ en einwirkende Energien. Gestaltsveränd e r u n g ohne Aufhebung des Zusammenhanges der Substanz. Elastizität, Biegsamkeit, Zähigkeit.

Gest a l t s verän d e r u ng mit Aufhebung des Zusammenhanges. Festigkeit, Spaltbarkeit, Härte.

\section{Aeussere Erscheinnng.}

Eigensehaften, welche im unveränderten oder veränderten Bestande des Holzes durel den Gesiehts-, Geruehs-und Tastsinn wahrnehmbar sind.

s 9. 1. Farbedes $\mathrm{Holzes}$. Wir verstehen unter Farbe des Holzes den Farbton, sow ohl seiner Artals seiner Tiefe n a h, wie sich derselbe dem Auge darstellt, nachdem irgend eine Fläche am Holzkörper erzeugt worden ist. Man hat von dieser jedem Holze zukommenden Eigenschaft wohl zu unterscheiden den Fall, daß ein F a r b s of $\mathrm{f}$ bei besonders reichem Vorkommen im Holze nicht nur demselben eine auffällige Farbe verleiht, sondern auch aus diesem Holz auf verschiedenem Wege gewonnen und zu Zwecken der Färberei benützt werden kann ${ }^{1}$ ).

Die Farbe des Holzes stellt nicht nur eine wichtige G ew e r bs-Eig e ns c h a f $t$ dar, wenn das Holz ohne weitere künstliche Veränderung der Farbe in dem Produlite zum Vorschein kommt, sondem die Farbe hat auch eine allerdings beschränkte symptomatische Bedeutung für die Qualität des Holzes nach bestimmten Richtungen.

1) Solehe an Farbstoffen sehr reiche Hölzer sind beispielsweise: Die Rothölzer (Fernambuk, Sappan, Brasilienholz), welche såmllich von Cäsalpinia-Arten stammen; das Blau- oder Campeche-Holz (Haematoxylon campechianum); das rote Sandel- oder Caliaturholz (Pterocarpus santalinus); der Färbermaulbeerbaum (Maclura aurantiaca); der Perückenhaum (Rhus cotinus); das Wurzelholz des Sauerdorns (Berberis vulgaris) usw. Vergl. Dr. J o s e f ll oc lle r, „Die Rohstoffe des Tischler- und Dreehsler-Gewerbes", I. Teil, Iiassel 1883, und Dr. G us l a v A dolf WV i B, Allgemeine Botanik, I. Band, Wien 1878. 
In ersterer Hinsicht ist etwa folgendes zu bemerken: Das Holz hat sehr häufig durch seine Farbe einen erhöhten Gebrauchswert, namentlich für jene Gewerbe, in welehen nebst der Form des Produktes auch die Farbe der Oberfläche eine Wichtigkeit hat, wie bei allen $\mathrm{K}$ u n s t g e w e r b e n. In der Nöbeltischlerei ist selbstverständlich die beabsichtigte Farbe der Oberfläche mit entscheidend für die Wahl der zu verwendenden Holzart. Das Mahagoniholz, das Ebenholz, das Nußholz, versehiedene Obstbaumhölzer, wie Birne, Kirsche, Apfel, Pflaume usw. spielen in der Möbelerzeugung, abgesehen von anderen Eigenschaften, durch ihre Farbe eine hervorragende Rolle. Von gewissen Artikeh verlangt man, daß sie ein möglichst helles WVeiß zeigen und bei der Verwendung beibehalten. Dies ist ein Grund der Bevorzugung des Ahornholzes bei versehiedenen Gegenständen des Kücheninventars.

Die M os a ik - A r b e i t beruht bei allen Rohstoffen auf der Verschiedenheit der Farbe der einzelnen Bestandteile, welche zu einem polyehromen Bilde zusammengesetzt werden. Die verschiedenfarbigen Hölzer bilden auf diese Art die Grundlage eines speziellen Kunstgewerbes, der sogenannten ,eingelegten Arbeit", der Intarsia. Es ist daher die Farbe des Holzes die Vorbedingung für die kunstindustrielle Verwendung des Holzes in der gedachten Richtung.

Die Zusammensetzung des Holzes mit anderen, durch eine gewisse Farbe oder einen bestimmten Glanz ausgezeichneten Pohstoffen, wie z. B. Perlmutter, Schildkrot, Elfenbein, Zinı und Zink, Messing etc., wie dies in der äußersten Kompliziertheit bei der sogenannten „Boule"-Arbeit vorkommt, setzt für jene Hölzer, welche in diese Verbindung eintreten, wieder bestimmte, namentlich dunkle Farbtöne voraus.

Da die Hölzer nicht immer von Natur aus in den gewünschten Farbtönen erscheinen, so werden häufig technische Verfahrungsweisen zu Hilfe genommen, um die natürliche Farbenwirkung des Holzes zu erhöhen oder vollständig zu verändern, wie dies durch das Beizen, Färben an der Oberfläche, durch Dämıfen und Imprägnieren, durch Räuchern oder durch das neue Verfahren der Bodenverbräunung dureh den ganzen Bestand des Holzstückes hindureh erreicht wird.

In Bezielıung auf die Bedeutung der Farbe als Kennzeichen für die Beschaffenheit des Holzes hat man zu unterscheiden: 1. die Farbe des frisch gefällten Holzes von jener, welche etwas später erscheint, und von jener, welche sich schließlich am vollständig trockenen Iolze zeigt; 2. hat man zu beobachten den Unterschied zwischen der Farbe des Splint- und Kernholzes an sich und in den sub 1 bezeichneten Fällen.

Als Kennzeichen für die Holzart, also zur Entscheidung der Provenienz des Holzes hat die Farbe fast gar keinen Wert; so zeigt das Holz der Koniferen hinsiehtlich der Farbe nur geringe Verschiedenheiten; es ist weiß mit einem sehwachen gelblichen oder rötlichen Schimmer. Das hie und da sich bildende Kernholz ist braun bis rotbraun gefärbt. Gerade bei den nahe verwandten Arten sind die Farben-Nuancen diagnostisch nicht zu verwerten. Sie lassen lıäufig den geübtesten Praktiker im Stiche.

Wenn wir doch eine Uebersicht der verschiedenen Farben der Hölzer im trockenen Zustande hier geben, so will damil keineswegs ein besonders wertvolles Malerial gebolen werden. W e i B: Ahorn, Linde, Roßkastanic, Eschensplint, Weißbuche;

g e lb: Fisettholz, Perückenstrauch, Sauerdorn, Zitronenholz, Satinholz, Buchs;

b r a n: Eiche, NuB, Mandel, Tulpenbaum, Ulme, Vogelbeere;

g r a u b r a u n: Trompetenbaum, Ailanthus, Edelkastanie, Zürgel;

g el b b a un: Maulbeerbaum, Pappel, Hartriegel, Kirsche, Robinia, Olive;

rolb r u n: Eibe, Lärche, Föhre, Pflaume, Hahagoni, Cornelkirsche, Apfel (hell), Elsbeere, lireuzdorn;

sch wa r b r a n: Eisenholz von Casuarina, braunes Ebenholz, Palisander, Teak, Grenadille, Cocoholz;

s c h w a r z: Ebenholz; 
r o t: Virginischer Wachholuer, Padouk, Korallenholz, Rosenholz von I'fysocalymna; g e tb r o t: Fernambul, Gleditschia, Gymnocladus, Getbholz, Goldregen;

ziegelrot: Sappan, Bruyère (hell), Faulbaum:

b l u trot: Sandelholz von Pterocarpus;

rot $v$ i o l e $t \mathrm{t}$ : Campecheholz, Amarantt, Königsholz;

gr ü n: Guajak, grunes Ebenholz, Veilchenholz, Cocus ${ }^{1}$ ).

Von verschiedenen mit der Farbe des Holzes zusammenhängenden Beobachtungen und Ansichten wollen wir hier Notiz nehmen, um die Bedeutung der Farbe als technischer Eigenschaft zu markieren.

No r d I i g g r behauptet beiläufig folgendes: ,Wenn die Witterung nach dem Holz. schlage regnerisch, die Luft sehr feucht ist, wie in milden Wintern oder im Spätherbste, so behāit der Schrot der Bāume die natürtiche Farbe des nassen Holzes oft längere Zeit. Ist dageren die Luft sehr trocken, wie gewöhnlich in Frühling, so nimmt das ge h a u e n e Holz in kurzer Zeit die Trockenfarbe an und zwar Kern- und Reifholz früher als der seine Nässe immer noch aus dem Stamme ziehende Splint. Je heller dieser anfänglich war, um so dunkler kann er in der Folge werden, wenn er ohne oberfăchliche rasche Austrocknung allmählich rielen Saft und damit auch sich umsetzende Farbstofle an die Oherfläche gefülırt tıat.

$\mathrm{G}$ es ā $\mathrm{t}$ e Holzftächen dagegen beliommen wegen ihres faserigen Ueberzuges schnell ein sich nachher längere Zeit gleichbleibendes äußeres Aussehen.

Die eigentümliche Farbe des grünen Holzes bildet sich häufig erst an der Luft aus. So die des Erlentiolzes, das auf dem frischen Schrot nur fleischrot aussieht, nach $1 / 2$ Stunde aber stark getbrot wird, und das jüngere, saftreichere Holz mehr als das ältere. Gefrorene Erlenspachen fangen erst an rot zu werden, wenn sie auftauen und der LuIt zugängtich werden. Eschenholz ninmt auf der Hirnseite eine leicht violette, Zürgelbaum eine graue Fürbung an. Das grünliche Stechpatmenholz dagegen wird schön grünblau.

Ilit dem Austrocknen des Holzes verbleicht häufig wieder ein Teil der Grüntholzfarbe. An einem Würfel aus frischem Erlenholze entfärben sich daher zuerst die lianten, an einem Rundholze zuerst das weichere Frühtingsholz der Jahresringe. An einem dielförmigen Holzstücke, an dessen ener Breitseite die .litte lag, verlor sich die Farbe früher auf der entgegengesetzten Seite.

Auf gutem, geeigneten Boden, in freien Stand kräftig erwachsenes Holz hat grün und trocken frischere, lebhaftere Fārbung, als im Schluß oder auf zu nassem Boden erwachsenes. Die Tischler behaupten, die Färbung sei bei Jíirschbäumen zur Zeit der Blüte an stärksten, was dahin gestellt bleiben inag.

Besonders auch ist bei Eichenholz die Gleichförmigkeit der Farbe ein gutes kennzeiehen. Nicht bloß die ganze Flāche des liernholzes soll dieselbe Färbung haben, sondern auch die einzelnen Jahresringe. Dies ist vorzugsweise der Fall, wenn der Porenring nur aus sparsamen, zerstreuten Poren besteht. Ist er breit- und weit- und vietporig, so pflanzt sich dic Porosität noch über einen Teil des festen Ringes fort, wodurch, zumal infolge der beginnenden Austrocknung, konzentrisch verschiedene Färbung, $R$ i n $g$ s $t r$ e if u $n g$ entsteht: .

Die Farbe hat einen wesentlichen Einfluß auf den Verwendungswert des Eichenholzes für die Mlarine und ist sogar in der offiziellen, von dem Staatssekretär des MIarine-Departements in Frankreich herausgegebenen Verordnung: „Instruction sur les bois de marine et leur application aux constructions navales " (Paris, Arthur Bertrand) zum Ausdrucke gelangt. Man unterscheidet nämlich nach dieser Verordnung jenes Eichenholz, welches auf der frischen Schnittfläche eine s $t$ ro h g e 1 b e Farbe besitzt, das bois maigre, von jenem Eichenholze, dessen Farbe b l a $B$ oder b r a u n bis ro tb r a u n ist und bois gras genannt wird. Yon dem ersteren wird behauptet, daß es erfahrungsgemä $B$ viel mehr unter den atmosphärischen Einflüssen leidet, also in hohem Grade geneigt ist, zu schwinden, zu quellen, sich zu werfen und zu reißen, daß es aber trotzdem das geeignetste Holz für das gesamte Rippenwerk des Schiffes bilde, hingegen zeige das bois gras bei großer Sprödigkeit eine höhere Widerstandsfähigkeit gegen Temperatur- und Feuchtigkeits-Aenderungen und es ist daher dieses Holz für Parkett-, Tischler-Arbeit und für die Schiffsverlieidung besser zu verwenden.

Die Grünholzfarbe des Eichenkemes soll nach den dänisch-preußischen IIarine-

1) Vergl. Dr. J os eph M o I. Teil, Kassel 1883, und Dr. Gus Lav A do If W e i $\beta$ a. a. O., ferner Dr. J. W i es $n$ er, Die Rohstofse des Pflanzenreichs, Leipzig, 11. Auflage 1900. 
satzungen (H ä r i n g, Zusammenstellung der Kíennzeichen 1853) weiBlichgelb, bräunlichgelb, rötlichgelb sein, alle drei häufig mit einem Stich ins Graue. Die weißlichgelbe Farbe werde, sagt man, später mehr und mehr strohfarbig oder sandgrau, die bräunlichgelbe grünbraun, die rötlichgelbe schmutzig- oder staubiggelbbraun. Von entschieden geringerer Qualität seien die Eichen von brauner Grünholz-Farbe, diese teils von der wirklichen Färbung der Holzmasse, teils von den dunkel erscheinenden starken Porenkreisen abzuleiten und verbunden mit sehr engen, porenreichen Jahresringen; als häufigste Farbe die dritte, die schlechteste Beschaffenheit von Eichenholz bezeichnend. Auch eine bläulichrote (Lila-) Farbe kann vorkommen und ist in Verbindung mit sehr breiten Jahresringen ein schlimmes, ,Brauschheit" verratendes Zeichen, wofür allerdings auch der Umstand spricht, daß dieses Holz nach Häring sehr wenig eingewachsene und abgestorbene Aeste zeigt. Bläulichrotes oder rotblaues Eichenholz mit schmalen Jahresringen wäre das schlechteste, brüchigste Eichenholz. Nach demselben würde die Lilafarbe am Längsholz öfters einen mehr bräunlichen, oft auch ganz hellgelben und weißen Ton annehmen.

Man sieht aus diesen sowohl in Frankreich als auch in Deutschland herrschenden Ansichten über die Kionnexität der Farbe mit der wahrschemlichen Qualität des Eichenholzes, welche Wichtigkeit die Farbe für den Ver k a $\mathrm{f}$ s we r t des Holzes besitzt.

Nördinger macht weiters folgende beachtenswerle Bemerkungen:

„Auch die Farbe des Eichenholzes wechselt slark beim Austrocknen. Die ringförmige Streifung Lei Hölzern von ungleichem Bau der Jahreslagen versehwindet. Braunes Eichenholz, vor Regen geschülzt, wird heller und sieht sieh vorteilhafler an, helles, wenn es Wind und Wetter ausgeselzt liegt, dunkler, zumal sehwammiges, sehr poröses; der Splint oft ganz schwarz. Geflößtes wird dunkler und unscheinbarer in der Farbe, 'auch gleichförmiger, und sein Splint ofters braun wie junger Iiern.

Es ist deshalb in bezug auf die Farbe immer von Wert, schon im Schlag oder kurz nachher die Hölzer zu untersuchen. Ist dies nicht möglich, so legt man allerdings noch nach Monaten, zunal bei Stämmen in der Rinde, durch Absägen einer dicken Scheibe die ursprüngliche Farbe wieder einigermaßen bloß. Es gesehieht solehes aber wegen des Holzverlustes nicht immer gern und lrilft bei Hölzern nichts, die schon jahrelang der Witterung ausgesetzt waren .

Aus den hier vorangestellten Nitteilungen erhellt, daß die Praktilier der Farbe des Holzes im grünen und trockenen Zustande einen großen, vielleicht zu großen Wert beilegen. Von technischer Wichtigkeit ist indessen sicherlich der schon früher erwähnte Unterschied in der Farbe von Kern und Splint des Holzes. Bei genauerer Untersuchung findet man nicht selten, daß das zwischen Splint und Kernholz liegende Reifholz nicht erheblich dunkler als der splint, aber fast so trocken als der Kern erscheint. Mitunter verwandelt sich der Splint bloß in Reiflıolz, dieses aber nicht in Kernholz. Da die Ausbildung dieser Schichten bekanntlich lieineswegs zufällig, sondern für die Holzart charaliteristisch ist, so unterscheidet man ja Splintbäume, Reifholzbäume, Kernbäume und Reifholzkembäume. Diese Unterscheidung kann namentlich bei den Kembäumen durch die Iifferenz in der Farbe von Splint und Kern ein wichtiges Hilfsmittel für die Erkennung der Holzart sein und spielt sogar in der Industrie eine Rolle. Eibe, Wachlioler und Zeder, die zu den Kembäuner gehören, einen sehr lichten Splint und einen an denselben ummittelbar angrenzenden, sehön braunrot gefärbten Kern besitzen, gestatten eine derartige Verarbeitung, daß an dem fertigen Objekte hervorragende Partien dem lichten Splint, tiefer gelegene dem dunklen Kern angehören; es ist dies das der Camée zugrunde liegende Priuzip. Ein Erzeugnis dieser Art, welches sehr beliebt ist und vielfach angetroffen wird, bilden Eßbestecke - will sagen Gabel und Löffel - mit reicher ornamentaler Verzierung des Handgriffs, wie solche namentlich im Bemer Oberlande aus Eiben- und Wachholderholz erzeugt werden. Manschetten- und Rucliniöpfe, Eierbecher, Zahnstocher, Serviettenringe und ähnliche 
Gegenstände werden überaus läufig aus den genannten Holzarten unter geschickter Benutzung der Versehiedenfarbigkeit von Splint- und liernholz erzeugt.

Hier muß auch des ganz speziellen und eharaliteristischen Falles gedacht werden, der beim Zirbenholz vorkommt. Die kastanienbraunen, an den Schnittflächen wachsartig erglänzenden Astlinoten, die bei dem Zirbenholze überaus häufig in Innern der Stämme vorkommen, fallen aus den Brettern oder aus sonstigen Objekten nicht heraus, wie dies bei den Hornästen auderer Nadelhölzer der Fall ist. Diese dunkelbramen Fleckien treten häufig recht zahlreich auf, verteilen sich über die Oberfläche der Gegenstände mehr oder minder regelmäßig, verleihen dem Holze einen eigentümtichen Reiz und dadurch auch einen erhöhten Wert.

Bei manehen Hölzern ist der Abstand zwisehen der Farbe des Splint- und jener des Kiernholzes ein sehr großer und gleichzeitig auch die Versehiedenheit anderer Eigensehaften eine sehr bedeutende; so z. B. beim Ebenholz und beim Guajakholz. Bei diesen beiden Hölzern ist der Splint nalıezu weiß, etwa von der Farbe des Elfenbeins, der Kern hingegen bei ersterem schwarz, bei letzteren dunkelgrünlichbraun. Der Splint dieser beiden Bäume hat für die technische Verwendung geringen Wert, wälırend das Kernholz sehr gesehätzt wird. Da außerdem das Splintholz sich von dem Kemholz leicht absplittert, muß bei technischen Verwendungen dieser Hölzer Sorge getragen werden, daß der Splint vollständig beseitigt wird. Hier ist also die Farbe des Holzes ein IVegweiser bei der technischen Verarbeitung desselben. Ein ganz elilatantes Beispiel bietet in dieser Hinsicht die Verwendung des Guajakholzes zu Kiegelkugeln. Das Kernholz ist ungemein hart, widerstandsfähig gegen jede Art von Abnützung, von dichter Struktur und hohem Gewichte. Diese Vorzüge werden zum Teil der im Kernholze enthaltenen, verhältnismäßig großen Menge des sogenannten Guajak-Harzes zugeschrieben. Eine aus diesem Materiale hergestellte Kegelkugel darf keinerlei Splint enthalten. Im entgegengesetzten Falle plattet sich die Splintstelle der Kugel rasch ab, d. h. die Kugel wird unrund und schlieBlich unbrauchbar.

Im allgemeinen ist der Unterschied zwischen der Splint- und Kiemholzfarbe bei den Hölzern, die in heißen Klimaten heimisch sind, hervorstechender als bei den Holzgewächsen der gemäßigten Zone. Das Kernholz der Tropenhölzer zeigt oft eine warme, satte, mitunter tiefdunkle Färbung.

Von der den Hölzern im gesunden Zustande eigentümlichen Farbe sind jene Färbungen zu unterscheiden, welche die Hölzer infolge von $\mathrm{Kr}$ an k h e its e rs c h e i n u n g e n annehmen. So tritt bei manchen Hölzern in der Nähe des Markes in kleinen Flecken, beim Ahornholze Strahlenrissen entlang, bei der Ulme gleichfalls in Strahlenrissen oder an der Peripherie des Kiernholzes, dann beim Pflaumenbaume im Kerne ringförmig eine liupfergrüne, oft sehr dunkle Färbung ein, welche als die Folge eines Zersetzungsprozesses zu betrachten ist. Von Wundstellen sickert mitunter ein dunkel gefärbtes Zersetzingsprodukt an Baumstamme abwärts und erzeugt an den tiefer gelegenen Stellen des Baumes eine dunklere Färbung, die sogenannte ,falsche Kembildung" (Rotbuche). Diese anormalen Färbungen müssen nicht mit einer Verringerung der Qualität des Holzes in sonstiger Beziehung Hand in Hand gehen.

Wir gelangen mit dieser Bemerkung zur Angelegenheit der F a r b e n - V e r ä nd erung. Fast alle Hölzer dunkeln unter dem Einflusse der Atmosphärilien und des Sonnenlichtes nach. Auch nahezu weiße Koniferenhölzer nelmen, dem Lichie ausgesetzt, eine stets satter werdende gelbe Färbung an, eine Erscheinung, welche auch bei dem größere Mengen ,Holzschliff" enthaltenden Papiere auftritt. Das unnittelbar nach der Erzeugung im gebleichten Zustande völlig weiße Papier wird mit der Zeit gelb bis lichtbraun. Aber auch warme Töne, welche das Kermholz ge- 
wisser Bäume zeigt, wie Lärche und Mahagoni, dunkeln bedeutend nach. Nahagoniholz, welches im frischgeschnittenen Zustande warm rot erscheint, wird mit der Zeit kastanicnbraun, nanchmal düster schwarzbraun ${ }^{1}$ ).

Eine besonders auffällige Veränderung der Farbe unter dem Einflusse von Licht und Luft zeigt das Amarantholz, welches an frisch bloßgelegten Stellen graubraun mit einem bläulichen Schimmer erscheint, aber, längere Zeit hindurch in lichten Räumen aufbewahrt, dunkel blauviolett wird. Dieser Eigenschaft verdankt auch das Holz den Namen L u f h o l z.

Diese Erscheinungen der Farbenveränderung sind von den Pflanzen-Physiologen noch nicht aufgeklärt worden; dagegen sind zwei technisch wohl weniger interessante, aber doch sehr auffällige Erscheinungen in der Veränderung der Farbe durch eine Untersuchung IV i es n e rs in hinreichender Weise erörtert worden. Es sind dies: Das Grauwerden der Dachschindeln und das Auftreten einer tief rotbraunen Färbung, ähnlich der gebrannten Siena, bei dem Nadelholze an der Außenseite von Gebäuden in solchen Gegenden, welche reich an Niederschlägen sind, so insbesondere in unseren Alpenländern in der Nähe von Gebirgsseen usw. Dieses Braunwerden der Hölzer gibt den Gebäuden ein überaus malerisches Aussehen, hat aber selbstverständlich keine technische Wichtigkeit. Dagegen sind jene Farbenveränderungen, welche gleichzeitig mit gewissen Krankheitserscheinungen auftreten, von großer Tragweite; so z. B. die Weißfäule und die Rotfäule. Hieher gehört wohl auch die seltener beobachtete sogenannte Grünfäule, eine spangrüne Vermoderung, die bei Birken-, Ahorn-, Buchenund Eichenholz auftritt. Selbstverständlich ist derartig infolge eines Fäulnisprozesses verändertes Holz von jeder technischen Verwendung ausgeschlossen. Solange ein solcher Krankheitsprozeß nur an der Oberfläche des Holzes auftritt, bildet derselbe für die gewerbliche Verwertung wohl kein Hindernis, doch kann er den Vlarktpreis des Holzes stark beeinflussen. Auch das Blauwerden frischen Kiefernsplintholzes, hervorgerufen durch den Blaufäulepilz Ceratostomella, beeinträchtigt noch nicht den technischen Gebrauchswert des Holzes, gilt aber als Schönheitsfehler.

Bis nun haben wir nur von der $\mathbf{n}$ a $\mathrm{t}$ ü $\mathrm{l} \mathrm{l} \mathrm{i} \mathrm{c}$ h e $\mathrm{n} \mathrm{F}$ a $\mathrm{r}$ b e des Holzes gesprochen. Zufällige oder beabsichtigte Veränderungen der Farbe auf künstlichen Wege gehören nicht in den Rahmen dieser Abhandlung; doch sollen ihnen einige Worte gewidmet werden.

Gerbsäurehaltige Hölzer, in grünen Zustande mit Werkzeugen aus Schmiedeeisen oder Stahl bearbeitet, zeigen dunkelbraune bis schwarze Streifen, wie dies z. B. oft an den Schnittflächen der Eichenholz-Sortimente beobachtet wird. Eichenholz, welches sehr lange auf der Sohle von fließenden oder den Grunde stehender Gewässer gelegen ist, nimnt von selbst eine blauschwarze oder grauschwarze Färbung an und bleibt dabei zu technischen Zwecken vorzüglich geeignet. Solches Eichenholz heißt IV a s s e r-E i c h e $\mathrm{n} \mathrm{holz}$ und bildet ein vortreffliches Material für den Möbelbau.

Von besonderer Wiehtigkeit ist die Methode der Behandlung des Rotbuchenholzes nnit gewöhnlichem Dampfe. Das Dämpfen des Rotbuchenholzes bewirkt eine auffallende Verringerung des Grades jener Eigenschaften, die der industriellen Verwertung des Rotbuchenholzes in vielen Fällen hindernd in Wege gestanden. Gleichzeitig erhält aber das Rotbuchenholz durch das Dämpfen eine fleischrote bis rotbraune Farbe, welche auffallend an die Farbe der verschiedenen Arten des Mahagoniholzes erinnert. Diese durch das Dämpfen des Rotbuchenholzes herbeigeführte Farbenveränderung ist die Folge einer Art Humifizierungszersetzung der gegen holse Tempera-

1) D ing le rs Polytechnisclies Journal Band CII, Seite 198 
tur und gegen Alkali und Wasserdampf empfindlichen Ligninbestandteile (Zuckerund Gummiarten, Gerbstoffe etc.) des Holzes.

Zur Erzeugung eines angenehmen Graubraun, das bei antiken Eichenholzgerätern so hoch geschätzt ist, ist bei gerbstoffreichen Hölzern das $\mathrm{R}$ ä $\mathrm{u}$ c h e r $n$ mit A m$\mathrm{m}$ o $\mathrm{n}$ i a $\mathrm{k}$ in Aufnahme gekommen. Es geschieht in der Weise, daß die fertig gearbeiteten Hölzer 1-2 Tage lang in einem luftdieht versehließbaren Raum der Einwirliung von Ammoniakiünsten und Luft ausgesetzt werden. Das Ammoniak erzeugt mit dem Sauerstoff der Luft zusammen mehr oder weniger braune Farbtöne, die un so tiefer ins Holz hinein reichen, je länger dic Dämpfe einwirken.

Auch gerbstofffreie Holzarten können auf diese Weise durch Ammoniak dunkel gefärbt werden, wenn man als Beize eine 5-10\%ige wässerige Lösung der âußerst leicht oxydierbaren Pyrogallussäure in heißem Zustande verwendet, die sich mit Ammoniak und Luftsauerstoff dunkiel färbt. Das von $\mathrm{T}$ h i $\mathrm{m}$ in angegebene $\mathrm{S}$ a $\mathrm{l}$ $\mathrm{mi} \mathrm{i}-\mathrm{R}$ ä $\mathrm{u}$ h e rverf a h ree besteht darin, daß in gerbstofffreic Hölzer Lösungen von solchen Metallsalzen eingebracht werden, welche beim Räuchem mit Ammoniak oder mit Schwefelwasserstoff verschieden gefärbte Metallverbindungen in der Holzschicht bilden. Aber alle diese Räucherfarben dringen nicht tief ins $\mathrm{Holz}$ ein; die Farben sind anch nicht wasserbeständig.

Dagegen entspricht das von Prof. Dr. W is I i c e n u s - Tharandt erfundene Grauholzverfahren vollkommen dem Grundsatze, die natürlichen Verfärbungsvorgänge des Holzes mit möglichst natürlichen Mitteln zu fördern. Es besteht in der Behandlung von Holz mit Bodengasen, wodurch eine Bodenverbräunung (echte Humifizierungsverfärbung) des Holzes lıerbeigeführt wird. Durch dieses patentierte Verfahren, wclches in den Dresdner Werlistätten für Iandwerkskunst geübt wird, ist es gelungen, in einer verhältnismäßig kurzen Zeit matte, braungraue Altersfarbtöne in jeder Holzart durch die ganze Masse selbst starker Hölzer hervorzurufen. Es eigenen sich hiezu besonders Buche, Erle und Birke, dann von den Nadelhölzern am besten die Lärche und die amerikanischen lioniferenhölzer, ja selbst Fichte und Kiefer. Das Verfahren besteht darin, daß das zu Brettern oder Bohlen verschnittene Holz in einen Boden eingebettet wird, der mit einem Ammoniakbildner gemiseht ist. Die Bodengase: Wasserdampf, Luft, Ammoniak und Kiohlensäure, vielleicht auch Wasserstoffsuperoxyd, vollbringen dann die gewünschte, dem Altersgrau ähnliche Bräunung der eingebetteten Hölzer. Die auf diese Art behandelten Hölzer gewinnen aber infolge der Verwesung der leicht zersetzlichen Bestandteile bei der Bodenverbräunung noch weitere wertvolle Eigenschaften, vor allem eine gewisse Altersieife, die man als „Bodengare" bezeichnen könnte ${ }^{1}$ ).

Erzeugnisse aus weißem Holze, welche besonders auffällig aussehen sollen, werden mitunter gebleicht oder mit weißen pulverigen Substanzen (auch Schwefel) geschüttelt, wie z. B. die aus Ahorn- oder Birkenholz hergestellten Schuhstifte. Dabei handelt es sich nur um eine vorübergehende Verstärkung des Effektes der natürlichen Farbe.

Ganz etwas anderes ist das künstliche Färben des Holzes, welches entweder bloß von der Oberfläche her auf eine verhältnismäßig geringe Tiefe eindringend oder die ganze Masse des Holzes durchsetzend bewerkstelligt wird. Ueber das oberflächliche Färben oder Beizen, wozu man häufig die aus anderen Hölzem gewonnenen Farbstoffe verwendet, wollen wir uns hier nicht weiter verbreiten. Es muß jedoch erwähnt werden, daß die anatomische Beschaffenheit und die chemische Zusammensetzung der

1) „Behandlung des Holzes mit Gasen und Dãmpfen". Von Hans Wislicenus. In Krais „Gewerbliche Materialkunde. Die Hölzer". Stuttgart 1910. 
Hölzer die Eignung derselben so sehr beeinflussen wie ihre natürliche, man könnte sagen die Grundfarbe. So ist es kein Zufall, daß sich zum Schwarzbeizen ganz besonders gut das Birnholz eignet, welches sich schwarz gebeizt sowohl massiv als auch insbesondere in der Form von Fournieren zum Ersatze von Ebenholz eignet. Zur Erzielung von matten und zarten Farbtönen durch Beizen qualifizieren sich am besten Ahorn, Erle, Weißbuche und Linde.

Für die Kenntnis der Natur des Holzes in anatomischer und physiologischer Beziehung interessanter sind jene Verfahren, durch welche dem Holze seiner ganzen IIasse nach eine fremde Farbe aufgenötigt wird. Hieher gehören die Verfahren von A ugustin D elmas in Bordeaux ${ }^{1}$ ), das Holzimprägnierungs-Verfahren von J. B. B I y the in Bordeaux und Wien ${ }^{2}$ ), dann das Verfahren von G. A. O n k e n in Hamburg ${ }^{3}$ ), und von $\mathrm{P}$ f is te $\mathrm{r}-\mathrm{B}$ re u n e $\mathrm{r}$ in IVien.

Von besonderem Interesse ist die Arbeit von F r i e d r i c h G o p p e ls r oe de r (Basel I901), ,, die Kapillaranalyse beruhend auf Kapillaritäts- und Absorptionserscheinungen" mit dem Schlußkapitel: Das Emporsteigen der Farbstoffe in den Pflanzen.

Weiter oben wurde erwähnt, daß zur künstlichen Färbung des IIolzes auch die aus den eigentlichen Farbhölzern gewonnenen Farbstoffe benutzt werden. Es sei hier noch die Ergänzung gestattet, daß auch Dekokte oder die beim Dämpfen verschiedener Hölzer sich hildenden Jauchen eine Verwertung zurn Färben des Holzes zulassen. Ein soleher Rüclistand bei der Behandhung der sogenannten Zedernhölzer wird dazu benützt, um ordinäre inländische Weichhölzer, die zum Fassen der Bleistifte dienen, wie z. B. das Erlenholz, der Farbe und dem Geruche nach dem Zedernholze ähnlicher zu machen.

Wir entnelimen dem, ,Zentralblatte für dlas gesamte Forstwesen", VI. Jahrg., 1880 (S. 327), die Notiz, daß man aus dem Pappelholze oder aus dem Stamme der Erica (Besenhaide, Calluna vulgaris) durch Erhitzen mit einer Alaunlösung eine sclıöne, hellgelbe Flüssigkeit erhält, die durch weitere Filtration ete. eine prächtige goldgelbe Färbung annimmt. Die neue Farbe heißt Ericine. Durch Behandeln mit Eichenrinde wird diese Farbe chamois oder nußbraun und soll sich als Holzbeize gut verwenden lassen.

Damit haben wir uns aber schon sehr den Gebiete der Holzfärberei geuähert, welches uns doch hier zu fern abliegt, da es schon der Technologie im engeren Sinne des Wortes angehört.

$\$ 10$. 2. G l a n z des $\mathrm{H}$ olzes. Wie jede mehr oder minder glatte Fläche das auffallende Licht reflektiert und dadurch jene Erscheinung zeigt, welche man gemeinhin den G I a n z oder das S p i e g e In nennt, so erscheint auch bei Hölzern der Glanz oder das Spiegeln, wenn man Flächen, seien sie nun eben oder gekrümmt, durch eine entsprechende Bearbeitung möglichst glättet. Nicht zu verwechseln damit sind jene Erscheinungen, welche man durch das Ueberziehen der Holzfläche mit einer glänzenden, wenn auch noch so dünnen Schicht, z. B. mit Politur, hervorrufen kann. Wenn man aber vom Glanze des Holzes spricht, so meint man damit gewöhnlich nicht jene optische Wirkung, die erst durch eine vorangehende mehr oder minder sorgfältige Bearbeitung erzielt werden kann, sondern man versteht unter dem Glanze oder dem Spiegeln des Holzes gewöhnlich die auf den Spaltflä c h e n, selbst wenn sie durchaus nicht vollkommen eben sind, hervortretendenReflex-Erscheinungen.

1) „Die mechanische Holzbearbeitung, deren Hilfsmittel und Erzeugnisse“, Bericht von W. F. Ex n e r und G. L a u b e e $k$ über die Welt-Ausstellung in Paris 1878; IVien 1879, 2. Heft, S. 57.

2) WV. F. Exner und G. L a u b o e k, Pariser Ausstellungsbericht a. a. O. S. 59.

3) ,Zentralblatt für das gesamte Forstwesen", V. Jahrg. 1879 S. 613. 
Namentlich ist es die radiale Spaltfläclıe, auf woleher die Mlarkstrahlen oder Spicgel ihrer Längenausdehnung nach zum Vorscheine kommen, die bei manchen Holzarten eincn hohen Glanz zeigen; man nennt deshalb diese Fü̈hen auch $\mathrm{S} p$ i e g c lf I äc he n, das nach Spiegelflächen ausgefornte Holz Spaltholz, Spiegelholz. (Die französische Bezeichnung der Markstrahlen, Spiegel : ,miroil" stammt offenbar davon her, daß die vertikale IVandfläche der Markstrahlen eben den Glanz der Holzfläche crhöht. Auch der Ausdruck Mark s tr a h l e n rührt vielleicht nebst der strahlenförnigen Richtung, in der sie vom Miltelpunkte des Stammes aus verlaufen, von dieser Eigentümlichkeit her $\left.{ }^{1}\right)$. - Bekanntlich zoichnen sich die Spaltflächen des Ahornholzes durch lohen Glanz aus; ebenso die Radialschnitte des Holunders, ' der auf der Hirnseite mattbraun erscheint.

Die Markstrahlen machen ihrem Namen wenig Ehre, ja sie verleugnen sogar die Herkunft der Bezeichnung Spiegel in manchen Fällen, indem sic zuweilen den dem Holze an sich zukommenden Glanz vermindern oder ermäßigen, wic bei der Aspe und einigen Pappeln, verschiedenen Pyrus-Arten usw:

Wenn die Markstrahlen als verhältnismäßig große Körper auf der Spaltfläche des Holzes erscheinen, so glänzen sie für sich, und es ist dann nicht die ganze Spaltfläche, welche spiegelartig das Licht reflektiert, es sind vielmehr dem freien Auge sehr auffällig nur die platten Seiten der Markstrahlen, welche spiegeln odeı glänzen. Ein prägnantes Bcispiel hiefür bildet die Rotbuche, auf deren radialen Spaltflächen die Spiegel als braune Streifen erscheinen, die bei unter einern gewissen Winkel einfallendem Lichte hohen Glanz zeigen, eine Erscheinung, welche sogar als ein Kiennzeichen des Rotbuchenholzes aufgefaßt werden kann.

Bei gewissen Hälzern bietet der Glanz der Spiegelfasern ein Moment, welches für die Wertschätzung des Holzes ausschlaggebend ist; so brilliert der Ahornmaser und das sogenannte ungarische Eschenholz an den geebneten Flächen durch den Glanz der zutage tretenden Spiegelfasern in so hohem Maße, wie bei gewissen Scidenstoffen, dem Moirée. Wenn auch die Spiegelfasern in der ganzen Angelegenheit eine entscheidende Rolle spielen, so sind sie es doch nicht allein, welche die Gesamtwirkung herbeiführen, und es ist manchesmal ein kompliziertes Zusammenwirken von Lichtreflex-Erscheinungen, welches gewissen Holzarten ein eigentünliches Gepräge verleiht. So spricht man von einem Silber- oder Metallglanze beim Holze des Götterbaumes, des Ahornbaumes, der Platane, Esche, Robinie usw. Diese Wirkung wird, es kann das nicht überraschen, durch gesteigerte, auf künstlichem Wege erzielte Glättung sehr erhöht. Dies ist z. B. beim Sapeli-Mlahagoni-, Atlasholz usw. zu beobachten.

$\S$ I1. 3. F e in he it. Farbe und Glanz des Holzes gehören zu den Gewerbeeigenscliaften, d. h. sie nehmen keinen unmittelbaren Einfluß auf die Bearbeitungsfähigkeit des Holzes, aber sie wirken mitbostimmend auf die Wahl und auf den IVert desselben für das künftige Produkt. Die Feinheit des Holzes ist hingegen eine Eigenschaft, welche nicht bloß das Aussehen der Oberfläche mitbestimmt, sondern auch die Methoden der Bearbeitung des Holzes ebensosehr wie den künftigen Gebrauchswert des fertigen Produktes bedingt.

Nach dem Sprachgebrauche versteht man unter feinen Hölzem solche, welche mit freiem Auge keinerlei Einzelheiten des Baues oder diese nur höchst unvollkonmen erkennen lassen. Bei diesen Hölzern sind in Querschnitte die Jahrringe und im

1) Ueber die Natur der Markstrahlen vergl. Dr. The od or H a $\mathrm{r}$ ig, Anatomie und Physiologie der Holzpflanzen, Berlin 1878 (S. 168 u. ff.) und Dr. J. R e in ke, Lehrbuch der allgemeinen Botanik mit EinschluB der Pflanzen-Physiologie, Berlin 1880 (S. 268 u. ff.). 
Längsschnitte das Spätholz vom Frühjahrsholze kaum zu unterscheiden. In einem solchen Holze sind die Größenunterschiede sowohl zwischen den verschiedenen Zellenarten sehr gering, als auch zwischen gleichnamigen Zellen an verschiedenen Orten, in verschiedenen Jahrringen, in altem und in jungem Holze. Die absolute Größe der Zellen ist dabei weniger entscheidend. Ein Holz kann großzellig, demnach weich, aber dennoch sehr fein sein (Lindenholz); freilich wird ein äłnlich zusammengesetztes, aber aus kleinen und zarten Elementen aufgebautes Holz in noch höherem Grade als fein angėsprochen (Buchshołz). Je geringer der Unterschied in den Dimensionen der einzelnen Elemente des Holzes, wozu auch die Dicke der Zellwände gehört, ist, desto weniger wird durch eine Häufung gleichartiger Zellen dic Feinheit des Holzes beeinträchtigt und umgekehrt. Von diesem Gesichtspunkte aus ist auch die Ausgeglichenheit der Jahrringe zu betrachten, worauf nicht nur die Organisation der Holzart, sondern auch die klimatischen Verhältnisse Einfluß nehmen, unter denen das Holz erwachsen ist. Endlich sind in feinen Hölzern die Holzstränge einander so stark genähert, daß die Markstrahlen auf dem Querschnitte unkenntlich sind; auch nüssen die Markstrahlenzellen den Dimensionen nach sich den Hołparenchymzellen nähern, die Markstrahlen von geringer Höhe daher mit den Strängen enge verflochten sein. Die Feinheit des Holzes ist im allgemeinen, wie aus dem Gesagten hervorgeht, für eine gegebene Holzart eine gegebene, kann aber bei jeder Holzart durch die Wachstumsrerhäłtnisse in ihrem Grade modifiziert erscheinen. Aus dem Vorangehenden leitet sich von selbst die Vorstellung von dem ,groben" Holze ab, indem dies die eben für das feine Holz angeführten Kennzeichen nicht besitzt, welches also makroskopisch die Gefäßporen zeigt, welches auffäłlig gezeichnet ist durch die gruppenweise Anordnung der Elemente, durch die scharfe Ausprägung und ungleiche Beschaffenheit der Vegetationsperioden, welches endlich auffallend breite oder hohe Markstrahlen besitzt. Typische Beispiele groben Holzes sind Eiche, Zürgelbaum (Celtis), NuB, Ulme usw.

Es wäre ein großer Irrtum, wollte man annehmen, daß die nach der vorangehenden Erklärung als grob anzusprechenden Hölzer für gewerbliche Vollendungsarbeiten wenig gecignet seien. Grobe Hölzer, die sich dem Auge sofort als solehe darstellen und sich auf den Hobel-, Drechsel- oder Fräsflächen rauh anfühlen, lassen sich mitunter sehr gut polieren, indem das Poliermittel auf der Oberfläche des groben Holzes in den Poren in größerer Menge zurückgehalten wird, als dies bei den feinen Hölzern, an denen es reniger haftet, der Fall ist $\mathbf{1}$ ).

\$12. 4. Textur, Z e i c h n ung, F l a d e r, M a s e r. Der Ausdruck T ext $u \mathrm{r}$ des Holzes ist synonym mit $\mathrm{S} t \mathrm{r} u \mathrm{ktur}$ oder bedeutet beiläufig das a $\mathrm{n}$ a $\mathrm{t}$ o$\mathrm{m}$ is che Gef üg e des Holzes. Die Gewerbetreibenden jedoch, welche Holz verarbeiten, gebrauchen den Ausdruck Textur häufig für die aus dem inncren $\mathbf{B}$ a u e des Holzes hervorgehende äußere Erschcinung auf den angearbeiteten Flächen. Man verwechselt also dabei die Ursache mit der Wirkung, indem tatsächlich die Zeichnung auf der Holzfläche das in die Erscheinung tretende Bild des Gefüges des Körpers ist. Je gröber das Holz nach der weiter oben gegebenen Definition, desto deutlicher die Zeichnung oder nach dem Sprachgebrauche die Textur. Der buchstäbliche Sinn des Wortes Textur: Gewebe, also hier Holzgewebe, deckt sich nicht einnal vollständig mit des Ursache der Erscheinung, daß auf den Holzflächen dem unbewaffneten Auge eine Zeichnung erscheint, denn in der Zeichnung drücken sich melır oder minder deutlich die Unterschiede zwischen Herbst- und Frühjahrsschicht in Jahrringe, die

1) Vergl. bei Dr. J o se f $\mathrm{Ml}$ o e $11 \mathrm{e}$ r a. a. O., 1. Teil (S. 74 u. ff.). 
Poren und die Markstralilen je nach den Dimensionen und den Grade der Färbung aus.

Dic Zeichnung des Holzes ist demnach bei regelmäßig emachsenen Bäumen eine andere im Querschnitte, cine andere im radialen Längsschnitte und wiedel cine andere im tangentialen oder Schnen-Längsschnitte. (Es sei hier ein-für allemal bemerkt, daß wir in dicser Abhandlung nur von den dikotyledonen Bäunıen sprechen, da das Holz der $\mathrm{P}$ a $1 \mathrm{~m}$ e $\mathrm{n}$ nur eine sehr untergcordnete, man könnte sagen ausnalımsweise Verwendung in del europäischen Technik findet. . Demnach ist das charakteristische Merkmal der Zeichung des Hirnschnittes der R in g b a u, das der beiden Längsschnitte die p a r l l c l e $\mathrm{Str}$ if u $\mathrm{ng}$, welche beim radialen Längsschnitte vollkommener als beim Sehnen-Längsschnitte auftritt.

Olme uns weiter in die Details zu verlieren, sei hier nur hervorgehoben, dab in der Holzindustrie die Zeichnung des Hirnschnittes verhältnismäBig selten auftritt; wohl konmt der Hirnschnitt des Holzes bei Eckverbindungen zum Vorschcine, auch bei Holzskulpturen und bei den diese vertretenden Holzpressungen, beim Stiftenmosaik, dem Holzstöckelpflaster, dann bei einer in neuester Zeit aufgetauchten Art von Parquetten. In weit überwiegendem Maße jedoch ist es die Zeichnung, welche auf tangentialen oder richtiger Sehnen-Längsschnitt-Flächen des Holzes zum Vorschein liommt, die unser Interesse erregt und verdient. Pfosten oder Dielen, Staffelholz und Bretter, Tavoletti und Fourniere zeigen auf ihren Oberflächen die Zcichunung des Sehnenlängsschnittes der Holzstämme. Bei den foumierten Möbcln wird das ganze blinde Holzgerïste und somit auch bei den Holzverbindungen die hie, und da auftretende Himfläche mit Längsholz bedeckt.

Ist das Holz normal erwachsen oder , schlicht", so heißt die Zeichnung des Holzes, oder soll wenigstens ausnahmslos so genannt werden, der Fla d e r.

An der Gabelung des Baumstammes, d. i. an der Stclle, wo die Iŕronenbildıng beginnt, ferner überall dort, wo ein Ast aus dem Stamme abzweigt, hören die dunkel gefärbten Grenzen der Jahrringe (die Iterbstholzschichten) auf, geradlinig zu verlaufen. Die Zeichnung von aus diesen Teilen des Baumes entnommenen Holzsortimenten wird in gewissen Fällen besonders geschätzt, so z. B. bezahlt man die Fourniere aus dem Gabelungsteile des Mahagonistammes mit bedeutend höheren Preisen als die schlichten, in der Zeichnung reizlosen Stücke aus dem geradwüchsigen Staınme; man nennt diese Art von Mahagoni-Fournieren Blumen- oder Pyramiden-Mahagoni ${ }^{1}$ ).

Bei unregelmäßigem Wachstume, möge es veranlaßt sein durch natürliche Hindernisse, wie Aeste, schlafende Augen, oder durch Verwundungen aller Art, werden die Jahrringe in ihrer Entwicklung in mannigfacher und mitunter in höchst abenteuerlicher Weise verändert. Die durch unregelmäßiges Wachstum entstehenden Holzbildungen nennt man wimmerig oder mas e rig und die durch dasselbe bedingte Zeichnung der Schnittflächen: Ma s e r.

Der wimmerige Wuchs ist strenge genommen ein Fehler des Holzes und gilt auch als solcher bei Bauholz und bei Schnittware. Vielfach, namentlich für Zwecke der Kunsttischlerei und Drechslerei, ist jedoch der Maser ein geschätztes Vorkommen und zwar umsomehr, je stärker ev entwickelt ist ${ }^{2}$ ). Für foumierte Möbel bildet dic abwechselnde Verwendung von schlichten und Naserfournieren, so z. B. die ersteren bei Friesen, die letzteren bei Füllungen, ein oft verwendetes, wirkungsvolles Motiv. Der Wert von Maserfournicren kann durch die phantastische Zeichnung ein sehr

1) Vergl. G. M a r c h et und W. F. Ex n e r, Die Holzindustrie der Ostseeländer. Kapitel Hamburg. Weirnar 1864.

2) Vergl. Nörd ling e r a. a. O. (S. 498 u. ff.). 
hoher werden und namentlich ist es das Emporium der Fournier-Erzeugung, Paris, welches ror noch hurzer Z it mitunter enorme Summen für linorrige Stammausrüchse (loupes) bezahlte. Wäre die Zeitdauer, welche zur Entstelıung von Vaserwüchsen notwendig ist, nicht eine so enorm lange, daß während derselbeı der Gesclimack der Konsunenten öfter wechselt, so würde man wohl die liünstliche, richtiger $\mathrm{a} b \mathrm{~s} \mathrm{ich} \mathrm{t} \mathrm{l} \mathrm{i}$ l, hervorgerufene Bildung von Jaserwüchsen ernstlich ins Auge gefaßt haben.

Ein interessanter Fall des wimmerigen Wuchses, der ein bestimmtes Holzrorkommen betrifft, ist unter der Bezeichnung , ungarisches Eschenholz“ in der Industrie bekannt. Dasselbe wird zu Fournieren für die linnsttischlerei vera!beitet nnd übertrifft an Schönheit der Zeichnung, erhölıt durch prächtigen Seidenglanz regelmäBig verteilter Partien, das Atlasholz (satin wood). Andere besonders schöne llaserbildungen, die in der Technik von West sind, findet man an der Wurzel von Buchs (Tabaksdosen), an Stöcken und dem Wurzelhals von Erlen, an liopfholzstämmen von Ulmen, Erlen (auserlesene Foumiere) etc., am Stamme von Birken (Birlienmaser, Pfeifenköpfe), von Nußbäumen und Ahornen (der hochgeschätzte Vogelaugenmaser ron dem amerilianischen Zuckerahorn), am Stamme mehrerer Pterocarpus-Arten (P. indicus, P. saxatilis u. a.), welche unter dem Namen Amboina-Maser oder Amboëne ans Indien und den ostasiatischen Inseln nach Europa, besonders nach Frankreich eingeführt werden. Der Rohstoff einer bekamnten französischen Spezial-Industrie, welche übrigens auch in Belgien und Wien eine zeitlang blühte, ist das sogenannte Bruyère-Holz. Dieses Holz stammt von der maserwüclısigen WVurzel der Erica arborea (Baumheide). Dieses Wurzelholz von fleisch-oder ziegelroter Farbe, welches aus Spanien, dem südlichen Frankreich und aus Kiorsika in den Handel kommt, bildet ein vorzügliches IIaterial für Pfeifen, indem einerseits der hochgradige. Masemuchs das Springen der Pfeife während der großen Erhitzung verhindert, andererseits der bedeutende Kieselsäuregehalt eine schwere Verbrennbarkeit begründet I).

Winmeriger Wnchs oder Maserwuchs und sonstige phỵsiologisch nicht aufgeklärte Abnornitäten inı Wachstume, in der Verteilung von Farbstoffen, Harzen u. dgl. fülıren zu verschiedenen Erscheinungen in der Zeichnung, welche vorübergehend eine gewisse Bedeutung erlangen, wobei natülich die Ilode ein ausschlaggebendes Moment bildet. Der Wellenförmige Verlauf der Holzringe (auf dem Querschnitte sichtbar) und das dadurch verursachte flammige Aussehen auf den radialen Spaltflächen sucht $\mathrm{N}$ ö r d I $\mathrm{ing}$ e $\mathrm{r}$ in einer Abhandlung über den ,Rindedruck“" im Oktoberlieft ISSO des, ,Zentralblatt f. d. ges. Forstwesen" zu erklären. Später (ISS2) hat $\mathrm{K} \mathrm{r}$ a b b e in der Iiönigl. PreuBischen Akademie der Wissenschaften eine Untersuchung über die Pindenspannung und deren Beziehmngen zur Jahrringhildung veröffentlicht, welche $\mathrm{N}$ ö $\mathrm{rd}$ lin gers Auffassung teilweise in Frage stellt.

Ton dem hochgeschätzten Mahagoni-Holze kommen im Handel, ganz besonders ron Paris aus, IIahagoni-Sorten vor, die ihren Namen nicht von der Provenienz erhielten, wie Iiuba-, Jamaika-, Haiti-, Iucatan-, Tabasco-, Laguna-, St. Domingo-, Porto Plata-, Honduras-Malagoni etc., sondern von ihrer Zeichnung. So z. B.: Acajou moucheté, Acajou ronçeux, A. branché, A. condé. Solche auffällige Zeichnungen verschaffen gewissen Gattungen eine vorübergehend gesteigerte Verwendung, eine Art Blüteperiode. Häufig verschwinden solche Industriehölzer aber wieder so rasch aus dem Verkehre, daß man kaum die Zeit findet, ihre botanische oder geo-

1) Vergl. Dr. J o seph yoe ll e r a. a. O. (S. 164 u. ff.) 
graphische Herkunft zu eruieren. Hölzer dieser Kategorie sind das Ziricota-Holz, das geperlte Holz, das grüne Havanna- oder Haiti-Holz. das Tiger-Holz, das Partridge-Holz usw.

§ 13. 5. Geruch des $\mathrm{Holzcs}$. Im grünen frischen Zustande hat jedes Holz einen eigentümlichen Geruch, der mitunter sehr kräftig und für das Holz charaliteristisch ist. Bei vielen Hölzern verliert sich dieser Geruch mit der Austrocknung derselben und nur wenige unter jenen Hölzern, die auch in trockenen Zustande wohlriechend sind, verdanken dieser Gewerbseigenschaft einen erhöhten technischen Wert.

Die ätherischen Oele, welche die Lrsache des Wohlgeruches einer Reihe von Hölzern bilden, sind nur in einigen wenigen Fällen genau erforscht. IIeistens nur dann, wenn diese ätherischen Oele selbst als Produkt aus den betreffenden Hölzern gewonnen und weiter verwertet werden. Diese Gruppe von Fällen kommt hier aber nicht in Betracht, wir haben nur darauf aufmerksam zu machen, daß der Gehalt an gewissen wohlriechenden Stoffen für bestimmte Hölzer in gewerblicher Beziehung charakteristisch geworden ist.

In erster Linie stehen diesbezüglich die Nadelhölzer. Ihr Gehalt an Terpentinen verleiht ihnen einen auffälligen, mitunter köstlichen Geruch. Bekannte Beispiele bilden die sogenannten Zedernhölzer und das Wachholderholz, besonders vom virginischen Wachholder (Juniperus virginiana. fälschlich Zedernholz genannt), welche Hölzer unter anderem ilıres Geruches wegen für manclie Verwendungen spezifisch geworden sind; so als Bleistiftholz, als Yateriale für die Laden von Schımuckkästen und sonstigen hochfeinen llöbeln, für allerlei Galanteriewaren, für Zigarrenkisten u. dgl. $m$.

Von den in Europa leeimischen Nadelhölzern ist es besonders das Zirbenholz, welches sich durch einen edlen, bestechenden Geruch auszeichnet.

Bei manchen Nadelhölzern kann jedoch der übermäßige Terpentin-Reichtum sogar ein Ausschließungsgrund für technische Verwendungen sein, und es ist dann die Ursache des Wohlgeruches ein Uebelstand, welchen der Geruch selbst wett zu machen nicht hinreicht.

Die wo hlriechenden Hölzer im engeren Sinne des Wortes, das sind solche, welche ihre technische Verwendung vo o a $l \mathrm{l}$ e m ihrem Geruche verdanken, stammen meistens aus anderen Klimaten; hieher gehören das australische Ve il$\mathrm{ch}$ e $\mathrm{nholz}$ und das den Gegenstand wichtiger Iílturen in Oesterreich bildende Weichselrohr.

Das letztere sind die Triebe der Irahaleb-Küirsche (Prunus mahaleb), welche bei dem in Baden bei Wien eingelaltenen Iiulturverfahren im Holze und in der Rinde einen köstlichen Geruch besitzen, der nach der Ansicht II o ell e r s von den Gehalte an Kumarin oder eines diesem ähnlichen ätherischen Oeles herrülırt. Das Weichselrohr, richtiger Nahaleb-Kïirschenlıolz, wird nicht nur zu Pfeifenröhren, sondern auch zu Holzgalanteriewaren aller Art, Spazier- und Sclirmstöcken, Reitgerten, Fächern, Papiermessern etc. verwendet.

In der ostasiatischen Industrie spielt eine Rolle ersten Ranges das wolliriechende gelbe Sandelholz. welches übrigens ein vortreffliches schnitzereiholz ist. Die Vorliebe und damit die eifrige Suche nach wohlriechenden Hölzern und deren Verwendung insbesondere in der Marqueterie-Arbeit hat ziemlich nacligelassen, und die verschiedenen Arten von Veilchenholz, das Moschusholz u. dgl. sind nicht mehr sehr in der Mode.

Es darf hier nicht unerwähnt bleiben, daß der bei Laubhölzern häufig auf- 
tretende Gehalt an Gerbstoff manchen Holzarten einen auffallenden Geruch nach Gerberlohe verleiht. H ä r ing, den wir schon an anderer Stelle zitiert haben, reklamiert diesen Geruch sogar als ein Kiennzeichen der guten Qualität des Eichenholzes. Von unseren einheimischen Holzarten hat das Holz des gemeinen Schneeballs (Tiburnum opulus) einen höchst widerwärtigen Geruch.

Eine auffallende Erscheinung, welche mit dem Geruche der Hölzer zusammenhängt, mag hier noch flüchtige Erwähnung finden. Ein Baum, welcher in Ostasien Bestände von enormer Ausdehnung bildet, ist der $\mathrm{K}$ a m p f e l o r b e r b a u m (Laurus camphora); dieser Baum enthält in allen seinen Teilen, besonders aber auch in seinem Holze ein schon bei gewöhnlicher Temperatur festes ätherisches Oel, das fast wie Alabaster aussieht und bei geringen Quantitäten einen sehr angenehmen Geruch besitzt. Der sogenannte Japan-Kampfer wird aus den Teilen des genannten Baumes durch Destillation gewonnen. Bewahrt man Kampferholz in geschlossenen Gefäßen auf, so überzichen sich die Innenseiten der Wandungen mit Kampferliriställchen, welche durch Sublimation von selbst entstanden sind.

Eine ähnliche Erscheinung zeigt sich am frischen Holze des virginischen Vachholders, welches sich mit einer dünnen Schichte feinster weißer Kíriställchen überzieht.

\section{Materjeller Znstand des Holzes.}

\$ 14. Während in crsten Abschnitte nur die äußere Erscheinung des Holzes behandelt wurde, weiche allerdings in enger Beziehung mit der substanziellen Zusammensetzung steht, soll num die Substanz selbst vom physikalischen Standpunkte aus erörtert werden. Auch hier wollen wir von den anatomischen und physiologischen Verhältnissen des lebenden Baumes möglichst abstrahieren und die Holzsubstanz, so wie sie ist, nach den technisch wichtigen physikalischen Eigenscliaften beschreiben.

Viele physikalische Eigenschaften, wie die Wärmeleitungsfähigkeit 1), haben nur eine sehr untergeordnete technische Bedeutung; dagegen ist es ein bestimmter liomplex von physikalischen Eigenschaften, welcher nicht nur auf die Verwendung des Holzes zu technischen Zwecken und daher auf dessen Auswahl und Wert den bestimmendsten Einfluß ninmt, sondern auch den aus Holz angefertigten Gegenständen eine bestimnte Beschaffenheit verleiht. Das Holz als Rohstoff für die Industrie wird durch die hier in Erörterung zu ziehende Gruppe von physikalischen Eigenschaften so beherrscht, daß der Handwerker, der Industrielle oder der Techniker im weitesten Sinne des Wortes diese Eigenschaftsgruppe mit den aus ihr resultierenden Verhältnissen sich stets gegenwärtig halten muß. Diese Gruppe von Eigenschaften hat das Eigentümliche, daß unter den einzelnen Eigenscluaften ein durch keinerlei Mittel aufzuhebender Zusammenhang besteht, und wem man mit der Be-

1) Vergl. H o c lle r a. a. O. S. 107.

Nach Wi e d e mann's mit großer Sorgfalt ausgeführten Versuchen über W ä r m e*

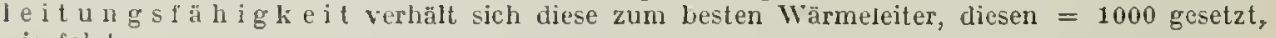
wie folgt:

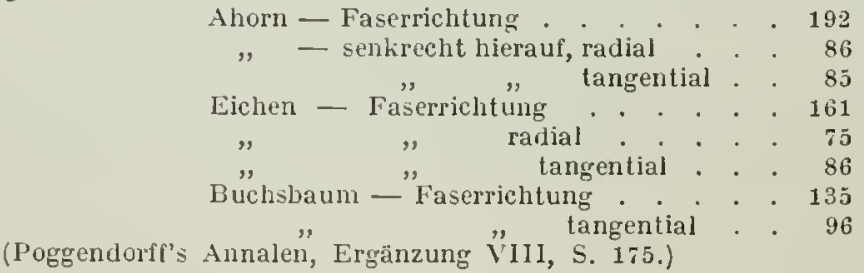


sprechung einer dieser Eigenschaften beginnt, so muf man sogleich auch die mit derselben in Iionnexität stehenden anderen Eigenschaften ins Auge fassen.

Diese Eigenschaften sind: Die Dichte oder das spezifische Gewicht, der Wasseroder Feuchtigheits-Gehalt, die Veränderlichlicit des letzteren, welehe zugleich die Veränderlichlieit der Dichte zur ummittelbaren Folge hat; die Veränderlichkeit des Volumens, welche ebenso wie dic Veränderlichkeit des Gewichtes mit der Veränderung des Feuchtiglicitsgehaltes zusammenhängt.

Die Veränderlichlieit des Tol umens, welche sich als Verkleinerung oder Vergrößerung des Volumens äußern kann, als: Schwindung oder Schrumpfung einerseits und als Quellung andererseits, vollzieht sich nicht in einer nach allen Richtungen hin gleichen Weise, vielmehr ändern sich die Dimensionen sowoh] bei der Schwindung als bei der Quellung in verschiedenem Grade, was eine Veränderlichlieit der Gesta $1 \mathrm{t}$ zur Folge hat. Diese Gestaltsveränderungen, welche die verschiedensten Bezeichnungen fülıren, können auch in letzter Linie die Aufhebung des Zusammenhanges der einzelnen Teile des Holzstückes, also die Ueberwindung der Kiohäsion, herbeiführen.

Es besteht also eine Konnexität zwischen $\mathrm{Dichte}, \mathrm{Fe} \mathrm{u} \mathrm{cht} \mathrm{igke} \mathrm{its-}$ ge halt, Volume $\mathrm{n}$ und Gestalt derart, daß jede Aenderung in der einen Pichtung eine Aenderung in allen anderen als unausbleibliche Fionsequenz nach sich zieht. Die Kionnexität der Eigenschaften in dieser Gruppe physikalischer Verhältnisse erschwert und kompliziert die Erforschung oder auch nur die Ermittlung eines bestimmten Datums bezüglich e i n e r Eigenschaft in außerordentlichem Maße. Der Praktiker sagt, das Holz sei , lebendig“", und er ist damit vollständig im Rechte. Das Holz ist ein organisierter Körper und der Organismus fungiert in gewissem Sinne fort auf lange Dauer. Erst wemn cine Zerstörung des Organismus durch Fäulnis oder Verliohlung eintritt, wird die Kionnexität jener Eigenschaften mehr oder minder aufgehoben.

$\$ 15$. I. D i ch te oder s pezifis ches Gew i ch t (Raumgewicht) de s Hol z es. Das Mischungsverhältnis der das Holz zusammensetzenden ElementarBestandteile ist in verschiedenen Teilen des Holzkörpers ein verschiedenes. Neben der Holzsubstanz kommen viele andere Stoffe im Holze vor und überdies besteht nirgends das Holz aus einer zusammenluängenden, lückenlosen Masse. Es bestehen im Gegenteile viele das Holz durchsetzende, mit Luft odel Wasser gefüllte Hohlräume (Zellen und Gefäße), welche gruppenweise oder auch zerstreut auftreten. Der in Holze überwiegend rorkommende Stoff, oder richtiger der das Holzgerüste bildende Stoff ist die Holzfaser.

Man kann im Wege des Tersuches die Holzfaser ziemlich von den anderen substanziellen Bestandteilen trennen und das spezifische Gewicht der kompakten, ohne Zwischenräume gedachten Holzmasse ermitteln. Dasselbe beträgt nach den übereinstimmenden Untersuchungen von $\mathrm{S}$ a $\mathrm{c} h \mathrm{~s}$ und $\mathrm{R}$. H a r t i g (, Untersuchungen aus dem forstbotanischen Institute zu IIünchen", 2. Heft) für Eiche, Buche, Birke, Fichte und Kiefer gleichförmig 1,כ6. Dabei ist ein Unterschied zwischen Kem- und splintholz desselben Stammes nicht bemerkbal.

Dieses spezifische Gewicht der Holzfaser hat jedoch keinerlei technische Wichtigkeit und ist daher auch nicht als technische Eigenschaft aufzufassen. Man versteht vielmehr unter der Dichte des Holzes wie unter dessen spezifischem Gewichte jene Zahl, welche ausdrücht, wie viel mal größer oder kleiner das absolute Gewicht des Holzes, wie es besteht, ist, als ein gleich großes Volumen chemisch reinen Wassers von der Temperatur von $4^{\circ} \mathrm{C}$. 
Die im Wege des Experimentes gefundene Ziffer gilt nur für das der Ermittlung selbst unterzogene Versuchsstück und nur für den Noment, in welchen das Versuchsergebnis durch rlie Beobachtung zum Vorschein kommt. Richtig ist die erhaltene Ziffer auch nur dann, wenn durch den Versuch selbst der Feuchtiglieitsgehalt nicht geändert wurde. Es ist auch nur unter gewissen Voraussetzungen gestattet, aus dem durch den Versuch ermittelten spezifischen Gewichte eines Probestückes auf die Dichte des größeren Holzkörpers, dem das Probestück entnommen wurde, einen Schluß zu ziehen oder die abgeleitete Ziffer für eine längere Zeitperiode gegenüber dem betreffenden Holzkörper als giltig anzunehmen.

Aus dem Gesagten geht hervor, daß man zwischen der wissenschaftlichen Untersuchung der Dichte des Holzes im Dienste der Forschung und zwischen der Bestimmung des spezifisehen Gewichtes zu irgend welchem praktischen Ziele wohl unterscheiden muß.

Die erstere muß auf alle Umstände Bedacht nehmen und kann ohne Gegenüberhalt der mit der Dichte komnexen physikalischen Eigenschaften gar nicht behandelt werden; die letztere wird sich mit einer mehr oder minder scharfen Methode begnügen, um ein Näherungsresultat zu erlangen, das für den gedachten technischen Zweck genügende Anhaltspunkte bietet.

Wir wollen uns vorerst gerade der zuletzt angefülırten, mehr empirischen Seite der Frage zuwenden.

Es ist einleuchtend und allgemein bekannt, daß das Holz im lebenden Baume oder unmittelbar nach der Fällung, das Holz, im Safte" bedeutend schwerer sein muß als trockenes Holz, da dasselbe teils in den Zellhohlräumen, teils in den Zellwandungen eine verhältnismäßig große Nenge von Wasser enthält. Je länger der Trocknungsprozeß gedauert hat, desto mehr Wasser hat das Holz verloren, desto leichter ist es geworden. Das Holz im lebenden Baume oder unmittelbar nach der Fällung heißt waldgrünes oder gr ü n es Holz, dessen Dichte $\mathrm{Gr}$ ü $\mathrm{n}$ g e w i c h $\mathrm{t}$. Durclı die natürliche Trocknung in Freien entweicht ein großer Teil des in den Zellenräumen enthaltenen Wassers, dieses wird durch Luft ersetzt und nach einer gewissen Zeit tritt ein Zustand relativer Trockenheit ein, in welchem man das Holz I u f ttrock e n nennt, dessen Dichte heißt dann L u f t r o c k e n g e wi c ht. Allein auch die im luftroclienen Holze enthaltene Wassermenge ist noch immer ziemlich beträchtlich. Wenn man daher das spezifische Gewicht möglichst wasserfreien Holzes erfahren will, so muB das Holz durch Zufuhr von Wärme, ,k ü nstli clı" getrocknet werden. Nan geht dabei gewöhnlich nicht höher als auf eine Temperatur von $100^{\circ} \mathrm{C}$. und setzt das Verfalmen so lange fort, bis eine Abnahme des Gewichtes durch Verdunstung des Wassers nicht mehr wabrgenommen wird. Man nennt das so getrocknete Holz: künstlich getrocknetes, gedarrtes oder a bsolut trockenes und die Dichte hönnte kurz mit D a r g e w i cht bezeiclinet werden.

Für den Bedarf der Technik genügt meistens die Angabe des Lufttrockengewichtes. Die Danebenstellung des Grüngewichtes hat schon wenig Wert, des Darrgewichtes bedarf man in der Praxis schon gar nicht. Wohl aber ist das D a r r g ewicht (spezifische Absoluttrockengewicht) für die Zwecke der wissenschaftichenForschungrongröBter IT ichtigkeit und nicht zu umgehen, da es a 11 e i n eine feststehende, von dem Einflusse des variablen Wassergehaites befreite Größe darstellt. Holz, das längere Zeit in trockenen, zeitweilig geheizten Räumen (Zinmem) aufbewahrt wurde, hat einen Feuchtigkeitsgehalt von etwa 10 bis $13 \%$ (es ist zimmertroclien); Holz in geschlossenen Schuppen 
einen solchen von etwa 13 bis $17 \%$ (lufttrocken), Holz in feuchten Räumen, im Freien unter Dach oder in Kellern aufbewahrt, zeigt schlicflich einen Feuchtigkeitsgelialt von etwa 17 bis $22 \%$ (kellerfeucht).

Mit Rücksicht anf die Labilität des lufttrockenen Gewichtes, das sich ja jeden Augenblick mit dem Feuchtigkeitsgehalte der atmosplıärischen Luft ändert, mit Rüclisicht auf den Umstand, daß die spezifischen Gewielıte in grünen und lufttrockenen Zustande innerhalb derselben Holzart nit der Exposition des Baumes, mit der Jahreszeit, mit dem Kỉlina, mit der örtlichen Lage im Baume selbst schwanken, endlich im Hinblicke auf die unvermeidlichen Beobachtungsfehler bei den gewöhnlichen Bestimmungsmethoden ist es zweckmäBig, die Dichten nach Gre n zwe rt e $n$ anzugeben.

Tabelle 1.

Namen der Holzarten

Ahorn (Bergahorn, Acer pseudoplatanus L.) .

" (Feldahorn, Acer campestre L.)

" (Spitzahorn, Acer platanoides L.)

Akazie(Robinia Pseudacacia L.)

Apfelbaum (Pyrus malus L.) .

Aspe (Populus tremula L.) .

Birnbaum (Pyrus communis L.) .

Buche (Rotbuche, Fagus sylvatica L.)

Cypresse (Cupressus fastigiata DC.) .

Edelkastanie (Castanea vesca Gärtn.) .

Eibenbaum (Taxus baccata L.)

Eiche (Stieleiche, Ouercus pedunculata Erh.)

, (Traubeneiche, Quercus sessiliflora Lm.)

Elsbeerbaum (Sorbus torminalis Crantz)

Erle (Schwarzerle, Alnus glutinosa Gärtn.)

Esche (Fraxinus excelsior L.).

Feldrŭster (Ulmus camjiestris L.) .

Fichte (Rottanne, Picea excelsa Lli.)

Föhre (Neißfōhre, gemeine İiefer, Pinus sylvestris L.)

," (Schwarzliefer, Pinus laricio var. austriaca Tratt.)

, (Weymouthskiefer, Pinus Strobus L.)

(Zirbelkiefer, Pinus Cembra L.)

Hopfenbuche (Ostrya vulgaris Willd.)

Kirschbaum (Prunus avium L.)

Lārche (Larix europaea D. C.

Linde, lieinblättrige (Tilia parvifolia Ehrh.)

Naulbeerbaum (Norus nigra L.)

Mehlbeerbaum (Sorbus Aria Crantz)

Oelbaum (Olea europaea L.)

Pappeln (Populus sp.)

Platane (Platanus occidentalis L.) .

Roßkastanie (Aesculus Hippocastanum L.)

Salweide (Salix caprea L.) .

Tanne (Weißtanne, Edeltanne, Abics pectinata DC.) .

Wachholder (Juniperus communis L)

Waltnußbaum (Juglans regia L.) .

Weiden (Salix sp.)

Weißbuche (Carpinus Betuius L.)

Zwetschgenbaum (Pflaumenbaum, Prunus domestica L.)

\begin{tabular}{|c|c|c|c|}
\hline \multicolumn{4}{|c|}{ Spezifisches Gewicht } \\
\hline \multicolumn{2}{|c|}{ Grün } & \multicolumn{2}{|c|}{ Lufttrocken } \\
\hline Grenzen & $\begin{array}{c}\text { Mittel- } \\
\text { zahl }\end{array}$ & Grenzen & $\begin{array}{c}\text { Mittel- } \\
\text { zahl }\end{array}$ \\
\hline $0,83-1,04$ & 0,94 & $0,53-0,79$ & 0,66 \\
\hline $0,87-1,05$ & 0,96 & $0,61-0,7 \pm$ & 0,68 \\
\hline $0,90-1,02$ & 0,96 & $0,56-0,81$ & 0,69 \\
\hline $0,75-1,00$ & 0,88 & $0,58-0,85$ & 0,75 \\
\hline $0,95-1,26$ & 1,11 & $0,66-0,84$ & 0,75 \\
\hline $0,61-0,99$ & 0,80 & $0,43-0,56$ & 0,50 \\
\hline $0,80-1,09$ & 0,95 & $0,51-0,72$ & $0,6 \pm$ \\
\hline $0,96-1,07$ & 1,02 & $0,71-0,73$ & 0,72 \\
\hline $0,90-1,12$ & 1,01 & $0,66-0,83$ & 0,75 \\
\hline 一 & - & - & 0,66 \\
\hline $0,84-1,14$ & 0,99 & $0,60-0,72$ & 0,66 \\
\hline $0,97-1,10$ & $1,0 \pm$ & $0,74-0,94$ & 0,84 \\
\hline $0,93-1,28$ & 1,11 & $0,69-1,03$ & 0,76 \\
\hline $0,87-1,16$ & 1,02 & $0,53-0,96$ & 0,75 \\
\hline $0.87-1,13$ & 1,00 & $0,69-0,89$ & 0,79 \\
\hline $0,63-1,01$ & 0,82 & $0, \pm 2-0,64$ & 0,53 \\
\hline $0,70-1,14$ & 0,92 & $0,57-0,94$ & 076 \\
\hline $0: 3-1,18$ & 0,96 & $0,56-0,82$ & 0,69 \\
\hline $0,40-1,07$ & 0,74 & $0,35-0,60$ & 0,48 \\
\hline $0,38-1,03$ & 0,70 & $0,31-0,71$ & 0,52 \\
\hline $0,90-1,11$ & 1,00 & $0,38-0,76$ & 0,57 \\
\hline $0,45-1,02$ & 0,74 & $0,31-0,56$ & $0, \pm 0$ \\
\hline - & 0,88 & - & $0,4 \pm$ \\
\hline - & 1,05 & 一 & 0,84 \\
\hline $0,65-1,05$ & 0.93 & $0,557-0,79$ & 0.64 \\
\hline $0,52-1.00$ & 0,81 & $0.44-0,80$ & 0.60 \\
\hline $0,61-0,87$ & 0,74 & $0,32-0,59$ & $0, \pm 6$ \\
\hline $0,87-1,18$ & 1,02 & - & 0,82 \\
\hline $1,02-1,21$ & 1,12 & $0,73-1,02$ & 0,88 \\
\hline- & - & $0,84-1,12$ & 0,98 \\
\hline - & 0,75 & - & 0,43 \\
\hline $0,78-0,99$ & 0,89 & $0,61-0,68$ & 0,65 \\
\hline $0,76-1,04$ & 0,90 & $0,52-0,63$ & 0,58 \\
\hline $0,73-0,97$ & $0,8 j$ & $0, \pm 3-0,63$ & 0,53 \\
\hline $0,77-1,23$ & 1,00 & $0,37-0,60$ & 0,45 \\
\hline $102-1,12$ & 1,07 & $0,53-0,70$ & 0,62 \\
\hline $0,91-0,92$ & 0,92 & $0,65-0,71$ & $0,6 \mathrm{~s}$ \\
\hline-1 & 0,78 & - & $0, \pm 6$ \\
\hline $0,92-1,25$ & 1,09 & $0,62-0,82$ & 0,32 \\
\hline $0,57-1,17$ & 1,02 & $0,68-0,90$ & 0,80 \\
\hline
\end{tabular}


Das Grüngewicht der fremdländischen Hölzer ist nur in sehr wenigen vereinzelten Fällen bekannt, und wir müssen uns daher darauf beschränken, die mittlere Dichte im luftrockenen Zustande nach einer Zusammenstellung von 11 o elle r u. a. hier vorzuführen:

Holzart.

Amaranth (Copaifera bracteata)

Bambus (Bambusa) . .

Brasilienholz (Caesalpinia brasiliensis)

Bruyère (Erica arborea) . . . .

Cocoholz (Inga vera)

Ebenholz, schwarzes (Diospyros Ebenum)

Eisenholz (Mesua sp.) . . . . . .

Fernambuk (Caesalpinia echinata)

Grenadille (Brya Ebenus) (Dalbergia)

Grünholz (Nectandra sp.)

Guajak (Guajacum officinale)

Jacaranda (Jacarandra brasiliensis)

Kokus (Lepidostachys Roxburghii)

Mlahagoni (Swietenia Mahagoni) .

Padouk (Pterocarpus indicus)

Rosenholz (Convolvulus scoparius)

Satinlıolz (Ferolia guyanensis)

Teak (Tectona grandis) .

Veilehenholz (Acacia homalophylla)

Zebraholz (Omphalobium Lamberti)
Dichte.

0,9

0,4

1,1

1,0

1,3

1,2

1,1

0.8

$1.1-1.3$

. 1,0

$0.7-1,4$

0,7

- 1,4

$0,6-0,9$

0.7

1.0

1,0

0,8

1,1

1.1

Die hier eingeschalteten Tabellen dürften für die technische Praxis vollständig ausreichen. Die Forstleute und Holzhändler, sowie die Holzindustriellen legen wohl den Daten über spezifisches Gericht eine höhere Bedeutung bei als die Ingenieure, indem dieses direkt auf die Vewendung und die Transportkosten Einfluß ninmt, andererseits als ein W'ertmesser für die Härte, Festigkeit, Dauer, Bremnliraft etc. gilt. Um den Stand der Auffassung, die der gebildete Forstwirt von der Rolle hat, welche die Dichte des Holzes spielt, zu charakterisieren, verweisen wir auf $\mathrm{G}$ a y e r s Forstbenutzung, in welehem Werke ausführlich berichtet wird, von welchen Faktoren die Dichte des Holzes abhängig ist, resp. welche Unstände maßgebenden Einfluß auf das spezifische Gewicht einer Holzart nelınen.

Die Bestimmung des spezifischen Gewichtes zum Behufe der Erlangung von beiläufig richtigen Ziffern mit AusschluB der durch wissenschaftliche Zwecke gegebenen Aufgaben erfolgt nach den allgemein gebräuchlichen Methoden unter der Einhaltung gervisser, durch die Natur des Holzes gegebener Vorschriften ${ }^{1}$ ).

$\$ 16$. 2. D e r W a s s e g e l a lt. Das $g r$ ü $\mathrm{n}$ e oder $\mathrm{f}$ i s c h e Holz enthält beiläufig zur llälfte seines Gewichtes Wasser. So schreibt man den harten Laubhölzem emen Jahresdurchschnitt an perzentualem Wassergehalt von 42 , den weichen Laubhölzem von 52 und den Nadelhölzern von 57 Gewichtsteilen zu. Das Wasser, welches in grünen Holze enthalten ist, füllt die Zellräume zum großen Teile aus und durchdringt die Zelhwände. Nach der Fälhung des Holzes beginnt sofort eine Wasserabgabe an die atmosphärische Luft, welche quantitativ stets abnimmt. Das I $\mathrm{m}$ b i b i t i o n $\mathrm{s}$ - Wasser wird so lange verdunsten, bis ein gewisser Gleichgewichts-

I) Vergl. Nōrdling er a. a. O. (S. 115 u. If.). 
zustand zwischen der Spanmung der atmosphärischen Luft und den Verdunstungsstreben des Wassers im Holze eintritt: Das Holz ist l u f t r o cken geworlen, enthält aber in diesem Zustande, wie oben angegeben wurde, noch immer eine bedeutende Quantität Wasser, deren Größe von del wasserlialtenden Firaft verschiedener Zellmembranen und Inhaltsstoffe abhängt. Dieses im huftrockenen Holze enthaltene Wasser liann man mit Pecht hygrosk op is ch os Wasser nennen, indem sich der Gehalt desselben mit dem Feuchtigkeitszustande der Luft proportional ändert. Die Wasserhaltungskraft des Holzes ist je nach der llolzart verschieden, bei den Nadelhölzern größer als bein Laubholze. Das hygroskopische Wasser kann nur auf dem Wege der $k$ ünst $\mathrm{l}$ ic h en Trockn ung aus dem Holze entfernt werden. Beide Arten von Wasser, dasjenige, welches durch Dunstung von selbst aus dem Holze austritt, und jenes, welches nur durch Wärmezufuhr beseitigt werden kann, d. i. verdampft werden muß, bilden zusammen den $W^{7}$ a s s e g e halt, welcher mit der Holzart, del Jahreszeit, dem Baumteile, dem Standorte etc. wechselt. Das im Holze enthaltene Wasser ist nie chemisch reines Wasser und bekanntlich wechselt die Menge und Art der gelösten Stoffe, S a f $\mathrm{ts} t$ of $\mathrm{f}$ e, bei derselben Holzgattung je nach dem Individuum, der Jahreszeit, dem Kilima etc.

So wie der Gehalt an hygroskopischem Wasser im lufttrockenen Zustande mit der Witterung und mit dem Feuchtigkeitsgehalte der Luft wechselt, ab- und zunimmt, so kann man dem Holze auch den gesamten Wassergehalt, den es beim Uebergange rom grünen in den lufttrockenen Zustand verloren hat, wieder zuführen durch das ,T $\mathrm{r}$ än $\mathrm{k}$ en d e s $\mathrm{Hol} \mathrm{z}_{\mathrm{e} \mathrm{s}}$ ", $\mathrm{d}$. h. durch das Untertauchen des Holzes in Wasser eine entsprechende Zeit hindurch.

Die Hölzer sind fähig, mehr Wasser aufzunehmen, als sie ursprünglich in frisch gefällten Zustande besaßen, besonders dann, wenn beim Tränken durch eine höhere Wassersäule ein besonderer Druck ausgen̈bt wird. Doch steht die Quantität des auf künstlichem Wege den Holze zugeführten und von diesem aufgenommenen Wassers in einem approximativen Verhältnisse zu der bei der Austrocknung verdunsteten Wassermenge.

Das mit Wasser völlig getränkte Holz hat ein höheres Gewicht, als das Grüngewicht betrug. IV e i $\mathrm{B}$ b a $\mathrm{c} h$ beobachtete, daß auch frisch gefälltes Holz durch Tränkung mit Wasser noch eine bedeutende VIenge desselben aufzunehmen imstande ist.

Speziell über das W a s s e r - A u f s a n g un $\mathrm{g} \mathrm{s}$ - V e r m ög e n stellte Foratverwalter L. H a m p e 1 in Gußwerk (Zentralblatt f. l. ges. Forstweser, ISS1) einen Versuch an, der die aufgenommene Wassermenge in Prozenten des Volumens der Versuchsstücke zum Ergebnis hatte. Siehe folgende Tabclle:

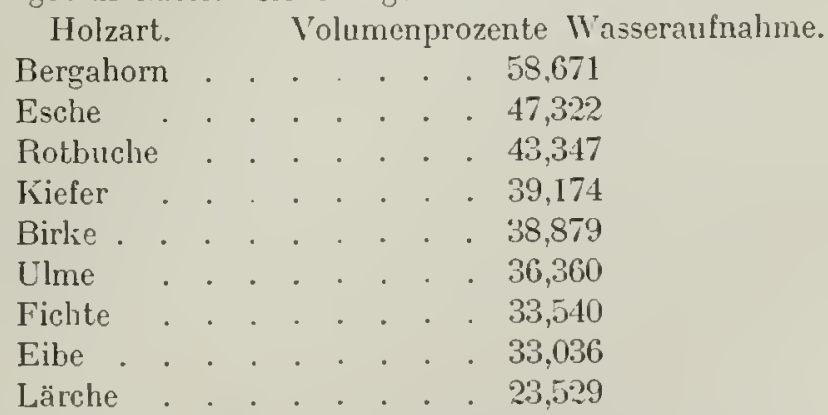

Um im nächsten Kapitel nicht wieder darauf zurücklimmen zu müssen, sei hier erwähnt, daß das Quellen lufttrockenen Holzes und die Wasseraufnahne nicht 
gleichen Sehritt halten. Ersteres ist nach den Beobachtungen Weißbachs binnen 11/2_2 Monaten beendigt, die Gewichtszunahme erfordert aber viele Jahre, um ihr Maximum zu erreichen.

Nach den Beobachtungen $J$ a $n$ li a s betrug das schließliche, nach 10jähriger Lagerung in Wasser lionstatierte spezifische Wassersättigungsgewicht

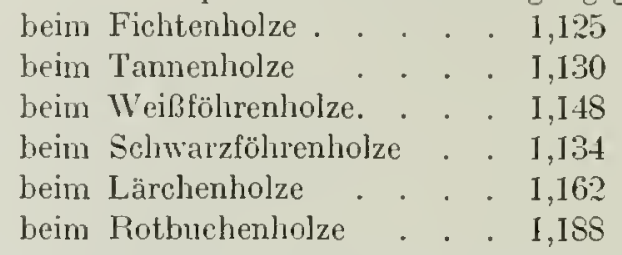

Diese durch Wasseraufnahme hervorgerufene bedeutende Gewichtsvermehrung ist für den Schwemmbetrieb sowie bei der Berechnung des Gewichtes der Holzwände beim Schiffbau und des schließlichen Gewichtes der hölzernen Wasserräder nicht ohne Bedeutung.

Den Gesam $\mathrm{t}-\mathrm{W}$ a ssergehalt nemnt man auch die absolute F e u c h tig li e it des Holzes. Zur Bestimmung derselben sind verschiedene, mehr oder minder präzise IJethoden eingeschlagen worden. In jenen Fällen, wo es sich um die Auffindung eines gesetzmäßigen Zusammenhanges zwischen dem Vassergehalte und anderen physikialischen oder mechanisch-technischen Eigenschaften des Holzes gehandelt hat, wurde natürlich getrachtet, ein möglichst zuverlässiges und genaues Resultat zu erlangen. In dieser Beziehung sind bemerkenswert die Verfalıungsweisen von: $\mathrm{C}$ h e v a n d i e r und W e r t h e i m, B a u s c h in ger (,,Mitteilungeh aus dem mechanisch-techischen Laboratorium der ligl. Technischen Hochschule in Nünchen“, 1883), T e t m a jer (,,Hitteilungen der Anstalt zur Prüfung von Bammaterialien am eidgenössischen Polytechnikum in Zürich",, 2. Heft, 1884), endlich $\mathrm{H}$ erm a $\mathrm{n} \mathrm{n} \mathrm{S}$ ch ild (Nitteilungen aus den Figl. Mech.-Techn. Versuchsanstalten in Berlin“ IV. Jahı'gang, 3. Heft, 1886) ${ }^{\mathbf{1}}$ ).

Die letztangefülırte Untersuchung ist eine erschöpfende Darstellung aller Verhältnisse, welche auf die Richtigkeit des Resultates Einflıß nelımen können. Diese höclıst beachtenswerte Forschung führte eigentlich zu einem negativen Resultate, nämlich zu der Erlienntnis, daß alle bisher gewählten Methoden zur Bestimmung des absoluten $\mathrm{W}$ assergehaltes vollkommen richtige Ergebnisse zu liefern nicht geeignet sind und daß bei Nadelholz zur Erlangung von für die wissenschaftliche Forschung verwertbaren Daten $H$ a r z gehalts-Bestimm ungen unerläßlich sind. Alle bisher zustande gebrachten Versuchsergebnisse über den absoluten Wassergehalt liönnen daher nur als Näherungswerte aufgefaßt werden.

Eine interessante Arbeit: ,Ueber den Einfluß der Feuchtigkeit auf den Längenzustand von Hölzern" a) rührt von P. Hil d e b r a n d her, welche folgende Punkte umfaßt: I. Untersuchungen über die Längenunterschiede von Hölzern in völlig trockenem Zustande und dem Zustande der Fenchtigkeit, der durch gesättigte feuchte Luft eintritt, die entsprechenden Wasserquantitäten und endlich den Einfluß der vollständigen Tränkung der Hölzer mit Wasser; 2. die täglichen Schwanliungen an Gewicht und Länge und 3. inwieweit eine geeignete Behandlung des Holzes, als z. B. Politur, Lacküberzug, Tränkung mit Paraffin usw. die Einflüsse der Feuchtigkeit in bezug auf Länge und Gewicht lintanzuhalten vermag.

1) Siehe auch die Feuchtigheitsbestimmung in den Vorschriften für einheitliche Prüungsverfahren für Holz, Seite 390 diesel Abhandlung.

2) Annalen der Physik und Chemie, Band XXsIV, Heft 2. Leipzig 1888. 
§ 17. 3. Volums rexänderlich ke it. Es wurde schon weiter oben auseinandergesetzt, daß die Abmahme an Wasserchalt beim Holze, ob sic sich nun auf dem Wege der natürlichen Trocknung vollzicht, oder durch künstliche Zufuhr von Wärme beschleunigt wird, eine Verkleincrung des Volumens zur Folge hat. Das Schwinde u, dic Schwindung oder die Schrump fung vollzicht sich jedoch nicht nach allen Richtungen im Holzkörper gleichartig. Das IIolz ist auffallend a $\mathrm{n}$ is o trop.

Jene Größe, welche die Volumsveränderung an einer bestimuteu Dimension des Holzkörpers angibt, die mit einer der Hauptrichtungen im Stamme: Axe, Radius oder Sehne zusanmenfällt, nemt nan $\mathrm{l}$ i n e a res $\mathrm{S}$ e h w in d m a $B$, dasselbe drückt die Schwindung in Prozenten der Längeneinheit aus.

Von dem linearen Schwindmaße ist zu unterscheiden die Flächenschwindung und die Volumsschwindung, das ist die Differenz in der Oberflächenausdehnung oder in dem gesamten Körperinhalte des Holzes, welche sich aus dem Tergleiche bestimnter Teile der Oberfläche oder des ganzen Körperinhaltes in grünen und trockenen Zustande ergibt.

Die Oberflächen-Schwindung wird selten in Betracht gezogen; auch das lineare Schwindmaß nach der Achsenrichtung des Holzes wird häufig seiner Geringfügigkeit wegen unbeachtet gelassen. Dagegen interessiert den Techniker zumeist das lineare Schwindmaß mach der radialen Pichtung und bezüglich der Sehnenrichtung; den Forstmann die gesamte Schwindung des Körperinhaltes, die Volumen-Schwindung.

Nachdem die Schwindurg die Folge der Abgabe von Wasserdünsten des Holzes an die umgebende Luft ist, so richtet sich die Dauer des Schwindungsprozesses in der Hauptsache nach der Dauer des Dünstungsprozesses. Genau genommen wird jedoch im Anfange des Trocknens die Feuchtigkeit aus den offenstehenden Holzporen austreten. Der Austritt dieser zuerst sicl verflüchtigenden Feuchtigheit äußert noch keine merkbare Wirkung auf die Dinensionen des Holzes. Je mehr aber die Holzzellen ilure Feuchtigkeit in weiteren V'erlaufe der Austrocknung abgeben, desto energischer tritt die Schwindung auf. Das Schwinden folgt also im Anfange zögernd, später umnittelbar und mehr proportional der Wasserabgabe.

Aus demselben Grunde ist die Rückwirkung des Feuchtigkeitsgehaltes in der Luft auf das Volumen des Holzes, sei sie eine Abnahme oder eine Zunahme, nicht eine augenblickliche, sondem die Volumsveränderungen folgen alluählich oder, wie Nördlinger sagt, ,in einiger Entfernung" jenen Verändemungen des Feuchtigkeitszustandes im Holze, die es seiner Hygroskopizität verdankt.

Die Dauer des Schwindens ist konform der Dauer des Austrocknens bei den weichen Nadelhölzem eine auffallend geringere, als bei den harten Hölzern. Das langsam trocknende Kernholz schwindet langsamer, als der Splint.

Bei einer und derselben Holzart schwindet das spezifisch schwerere Holz stärker ats das leichtere.

R o b e r t H a r ig hat eine sehr bemerkenswerte Studie über den Einfluß des Holzalters und der Jahrringbreite auf die Vlenge der organischen Substanz, das Trockengewicht und das $\mathrm{Schwindendes} \mathrm{Holzes} \mathrm{angestellt,} \mathrm{welche}$ in mehreren Jahrgängen der ,Untersucli ungen des forstbotani-

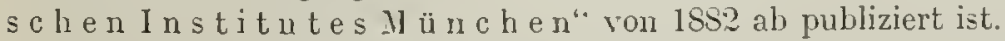

Einen sehr bedeutenden Einfluß auf die Dauer der Schwindung und die Größe derselben übt der Umstand aus, ob das Holz in vollkommen oder nur teilweise berindetem Zustande oder gänzlich entrindet der Austrocknung unterzogen wird. Es ist ferner von Bedeutung, ob das Schwindnaß an aus dem Jlassiv des Holzes heraus- 
gearbeiteten axialen, radialen oder Sehnen-Stäben gemessen wird, oder ob man die Schrumpfung der Radien und Sehnen an kompletten Stammscheiben untersucht. Auch bei diesen stellen sich wesentliche Unterschiede heraus, wenn die Zusammenziehung des Holzes durch einen Radialschnitt erleichtert wird. Nö $\mathrm{r}$ d l in g e r war der erste, welcher eine rationell angelegte Forschung über die bei der Schwindung auftretenden Erscheinungen angestellt hat. Er hat den Einfluß der Rincle auf die Schwindung erwogen, ebenso die Schwindungs-Verhältnisse im Kern- und SplintHalbmesser, an den Kern- und Splint-Sehnen, je naclidem dieselben f r e i gelegt oder im kompakten Holze befindlich waren.

Aus der Verschiedenheit des Kernes und Splintes in Beziehung auf ihr Verlialten beim Schwinden entstehen Erscheinungen, welche, wie das $\mathrm{Kl}$ e m m e n, das ist die Verengerung von Schnittfugen, zuerst von $\mathrm{N}$ ö r $\mathrm{I}$ in $\mathrm{g}$ e r mit großer Klarheit erörtert wurden.

Die Nördlingerschen Untersuchungsmethoden haben in wenigen vereinzelten Fällen noch weitere Ausbildung erfahren ${ }^{1}$ ).

Nördling er ließ sich bei seinen Arbeiten, welche gerade in dem Kapitel „Schwindung" besonders mustergültig sind, hauptsächlich von der Absicht leiten, einerseits den Zusammenhang zwischen den Verschiedenheiten des anatomischen Baues des Holzes, dem Wassergehalt in den einzelnen Teilen des Holzes im Baume usw. und andererseits den Vorgängen bei der Schwindung aufzufinden. Bei diesen Arbeiten steht $\mathrm{NördI}$ inger als Botaniker und Holzanatom im Vordergrund. Doch sind von ihm auch die Konsequenzen der Schwindungsverhältnisse bei verschiedenen Holzsortimenten: Spalthölzern, Pfosten, Brettern usw., in so anschaulicher Weise dargestellt worden, daß sicls eine große Zahl von Autoren auf dem Gebiete der Forstwissenschaft und Technik nicht versagen lionnte, $\mathrm{N}$ ö r d I in g e r abzuschreiben und die erläutemden Figuren zu kopieren. So kommt es, daß man gewissen graphisehen Darstellungen der Form und Abmessungen von verschicdenen Holzsortimenten nach vollzogener Schwindung in einer großen Anzahl von Büchern neuen und neuesten Datums begegnet. Wir können daher füglich darauf verzichten, nochmals eine Wiederholung dieser Darstellung unseren Lesern anzubieten. Der Vollständigkeit halber müssen wir aber hier eine kleine Tabelle über das SchwindmaB der technisch wichtigen Hölzer anfügen.

Schwindung radial tangentia]

$\begin{array}{lll}\text { Ahorn } & 2,56 & 4,90 \\ \text { Birke } & 4,50 & 6,50 \\ \text { Eiche } & 3,08 & 5.52 \\ \text { Erle } & 3.16 & 4.15 \\ \text { Esche } & 4,60 & 7.20 \\ \text { Fichte } & 2,25 & 4,85 \\ \text { Hopfenbuche } & 4.32 & 7,67 \\ \text { Lärche } & 3,04 & 6,06 \\ \text { Linde } & 5,73 & 7,17\end{array}$

Schwindung radial tangential

$\begin{array}{lll}\text { Robinie } & 3,90 & 5,80 \\ \text { Potbuche } & 4,65 & 8,36^{2} \text { ) } \\ \text { Schwarzliefer } & 2,79 & 4,82 \\ \text { Tanne } & 2.01 & 5,32 \\ \text { Ulme } & 3.27 & 5,10 \\ \text { Weißbucle } & 6.09 & 9,00 \\ \text { Weißkiefer } & 2,29 & 4,78^{3} \text { ) } \\ \text { Weide } & 2.85 & 5.55\end{array}$

1) Siche Schwindungs-Versuche in: IV. F. Exn er, Studien über das Rotbuchenholz; Wien $1875\langle$ S. 59 ).

2) Exn e fand durch seine eigenen Untersuchungen bei Rotbuchenholz das Schwindmaß des Radius in der vollen Scheibe mit $4 \%$, das Schwindmaß der Sehnen in der vollen Scheibe aber mit $81 / 5 \%$.

3) VergI. die interessante Monographie: R. H a r t i g, ,Das spezifische Frisch- und Trockengewicht, der Wassergehalt und das Schwinden des Kiefernholzes." Berlin 18: $t$. 
M o e 11 e r beschränkit sich darauf, anzugeben, daß die Nadclhölzer in allgemeinen am wenigsten schwinden unl die gebräuchlichsten Tischlerhölzer nach der Größe des Schwindmaßes in aufsteigender Reilıe geordnet anzuführen wie folgt: Aliorn. Pappel, Eiche, Ulme, Buche, Linde, NuB.

Die Sehwindung in der Faserriehtung beträgt durchschnittlich $0,1 \%$, in der Selnnenrichtung durchschnittlieh $10 \%$ und in der radialen Richtung durchschnittich $5 \%$. Von allen untersuchten Arten ausländischer Hölzer schwindet Mahagoniholz an wenigsten, nämlieh nach der Breite. im Sinne der Spiegel nur 1,09\%, im Sinne der Jahrringe nur $1,69 \%$. -

K a r m a $r$ e h linüpft an die einschłägigen Daten einer sehr vollständigen Tabelle folgende Bemerliungen:

Von dem bedeutenden Unterschiede zwischen der Schwindung des Linngenholzes und jener des Querholzes überzeugt man sich oft an Zeichenbreltern u. dergl., welche mil sogenannten Hirnleisten oder eingeschobenen Gratleisten versehen sind, indem hier nach längerer Zeit, wenn das Brett durch Eintrocknen schmāler geworden ist, die Enden der erwảnten, nicht merklich verkürzten Leisten über den Rand etwas vorspringen. - Hölzerne Gemäßé (zu Kiorn, Mehl etc.) werden hăufig durch Rundbiegen cines - gespaltenen oder geschnitlenen - dünnen Eichenholzbrettes gebildet, wobei die Fasern in der Peripherie herum liegen, die Gemāßwand ihrer Höhe nach aus Querholz besteht; auf solche Weise verferligt, verkleinern sie ihren Fassungsraum durch Auslroclinung, oder vergrößern sie denselben durch Feuchtigkeit bemerkbar mehr, als wenn das Gemäß aus Stäben (Dauben) zusammengesetzt ist; denn im letzteren Falle ist in der Richtung der Wandhöhe Lāngenholz, welches viel weniger schwindet und quillt. Jach genauen Tersuchen vergrōßerten Gemāße von rundgebogenem Eichenholze, bei welchen die Tiefe sehr nahe dem inneren Durchnesser gleich kam, nachdem sie zuerst im warmen Zimner ausgetrocknet waren, durch achttägiges Verweilen in einem feuchten Kieller ihren Inhalt um $1-24 \%$ (durchschnitlich nahe $2 \%$ ); Wogegen die Vergrößerung bei den aus Stảben zusanmengesetzten Gemăßen (halb so tief als weit) nur ${ }^{1}$ an bis $\%$ (im Durchschnit etwa $1 / 3 \%$ ) betrug.

Von Hölzern, welche geringe Unterschiede in den Abmessungen bei dem durch den Feuchtigkeitsgehalt der Luft auftretenden Schwinden und Quellen zeigen, sagt man, daß sie ,gut stehen“. In Gegensatze hiezu bezeichnet der Sprachgebrauch den Umstand, daß das Holz verschiedene Volumina annimmt, mit den Worten , es arbeitet".

Ueber die Zunahme der Abmessungen des Holzes bei neuerlicher Steigerung des Feuchtiglieitsgehaltes nach vorangegangener Austrochnung, die sogenannte Quellung des Holzes, wurde bereits an einer früheren Stelle, soweit es notwendig, gesprochen.

Bisher war nur von den Schwindungs-Erscheinungen die Rede, welche die natürliche Austrocknung begleiten. Es kann nicht überraschen, daß die fortgesetzte Trocknung auf künstlichem Wege auch zu einer Steigerung der Schwindung fülırt, nachdem im Wege der künstlichen Trocknung noch ein Teil des Wassergehaltes aus dem lufttrockenen Holze beseitigt werden kann. Die Schwindung vom nassen zum lufttrockenen Zustande ist größer als diejenige rom lufttrockenen zum absoluttrockenen Zustande.

Eingehende Studien über die H ygrosk o pizität und die damit zusammenhängenden Erscheinungen des Schwindens und $Q$ uellens der Hölzer hat $J$ a $n$ k a unter dem Titel : ,Die Einwirkung von SüB- und Salzwässern auf die gewerblichen Eigenschaften der Hauptholzarten "veröffentlicht 1). Es wurden Rundklötze der Fichte, Tanne, Weißlicefer, Lärche, Rotbuehe, Eiche, Ulme, des Ahorns und Walnußbaumes, teils von der Sommer-, teils von der Winterfällung

1) Mitteilungen aus den forstlichen Versuchswesen Oesterreichs. XXX111. Heft. Die Einwirkung von Süß- und Salzwässern auf die gewerblichen Eigenschaften der Hauptholzarten. I. Teil. Unlersuchungen und Ergebnisse in mechanisch-technischer Hinsicht. Von G. Janka. Il. Teil. Entersuchungen und Ergebnisse in chemischer Hinsicht. Von Dr. X. Lorenz R. v. Liburnau. Wien 190\%. 
herrührend, in stehendes und fließendes Süßwasser, in Salzsolen-IIutterlauge und in Mleerwasser eingebettet, um die Wirkungen zu studieren, welche das Wasser auf die Eigenschaften des Quellens, schwindens und Reißens, dann auch auf die Druckfestigkeit der so behandelten Hölzer ausübt. Selbstverständlich wurden die gleichen Eigenschaften auch an unausgelaugtem Vergleichsholze erhoben. Die Feuchtigkeitsverhältnisse, das Schwinden und Quellen wurden teils an den von Nördlinger empfohlenen Scheibenproben (60grädigen Iíreissektoren), teils an Pfosten und Brettern elinittelt, die aus den Rundhölzern erzeugt worden waren.

Bezüglich der Hygroskopizität, welche sich aus der Zunahme des Feuchtigkeitsprozentsatzes der lufttrockenen Schwindungsscheiben nach 5monatlicher Lagelung in stets feuchter Luft in ziffermäßiger Höhe ergab, wurde konstatiert, daß das Süßwasser-Auslaugholz am wenigsten, das Salzwasser-Auslaugholz am stärksten hygroskopisch war; die Zunahme an hygroskopischer Feuchtigkeit ist aus der nachfolgenden Tabelle II zu ersehen. Korrespondierend mit der Feuchtigkeits-Zu- oder Abnahme tritt natürlich auch die Quellung beziehungsweise Schwindung des Holzes auf, so daß das in Süßwasser geschwemmte Holz weniger quillt und schwindet als das nicht ausgelaugte Holzmaterial, während sich das in Salzwasser präparierte Holz vermöge seiner vermehrten Hygroshopizität verschieden verhält. Die Größe des Schwind- und Quellmaßes ist für die untersuchten Holzarten gleiehfalls aus der Tabelle II zu entrehmen.

Tabelle 1I.

\begin{tabular}{|c|c|c|c|c|c|c|c|c|c|}
\hline \multirow{7}{*}{ Holzart } & \multirow{3}{*}{\multicolumn{3}{|c|}{$\begin{array}{l}\text { Zunahne } \\
\text { an hygroskopischer } \\
\text { Feuchtigkeit beim }\end{array}$}} & \multicolumn{3}{|c|}{ Lineare Schwindung. } & \multicolumn{3}{|c|}{ Lineare Quellung. } \\
\hline & & & & \multicolumn{6}{|c|}{$\begin{array}{l}\text { Mittelwert zwischen Kern- und Splintholz, } \\
\text { zwischen radialer und tangentialer }\end{array}$} \\
\hline & & & & \multicolumn{3}{|c|}{ Schwindung rom } & \multicolumn{3}{|c|}{ Queliung vom } \\
\hline & \multirow{3}{*}{$\begin{array}{c}\text { unaus- } \\
\text { gelaug- } \\
\text { ten } \\
\text { Ver- } \\
\text { gleichs- } \\
\text { holz }\end{array}$} & \multirow{3}{*}{$\begin{array}{c}\text { SüB- } \\
\text { wasser- } \\
\text { Aus- } \\
\text { laug- } \\
\text { holz }\end{array}$} & \multirow{3}{*}{$\begin{array}{c}\text { Salz- } \\
\text { wasser- } \\
\text { Aus- } \\
\text { laug- } \\
\text { holz }\end{array}$} & \multicolumn{3}{|c|}{$\begin{array}{c}\text { nassen zum lufttrockenen } \\
\text { Zustande }\end{array}$} & \multicolumn{3}{|c|}{$\begin{array}{l}\text { Jufttrockenen zum feuchten } \\
\text { Zustande }\end{array}$} \\
\hline & & & & \multicolumn{3}{|c|}{$\begin{array}{l}\text { in Prozent des nassen } \\
\text { Zustandes }\end{array}$} & \multicolumn{3}{|c|}{$\begin{array}{l}\text { in Prozent des luft- } \\
\text { trockenen Zustandes }\end{array}$} \\
\hline & & & & - & In 8 üB- & Saiz- & Un & In $S u ̈ ß-$ & Salz= \\
\hline & \multicolumn{3}{|c|}{ Wassergelualts-Prozente } & $\begin{array}{l}\text { schwemm- } \\
\text { tes Holz }\end{array}$ & $\mid \begin{array}{l}\text { schwemm- } \\
\text { tes Holz }\end{array}$ & $\begin{array}{l}\text { A uslaug- } \\
\text { holz }\end{array}$ & $\begin{array}{l}\text { schwemm- } \\
\text { tes Holz }\end{array}$ & $\begin{array}{l}\text { schwemm- } \\
\text { tes Holz }\end{array}$ & $\begin{array}{l}\text { Auslaug } \\
\text { holz }\end{array}$ \\
\hline Fichte & 11,56 & 9,78 & $1 \pm, \pi 1$ & 3,72 & 3,63 & 2,96 & 2,56 & 2,24 & 2,49 \\
\hline Tanne & 10,06 & 9,13 & 13,89 & 3.03 & 3,01 & 2,35 & 2,13 & 2,00 & 2,02 \\
\hline Weißliefer & 10,20 & 8,52 & 13,06 & 3,61 & 2,66 & 2,53 & 2,26 & 1,56 & 1,88 \\
\hline Lärche & 10,03 & 9,66 & $12,81^{\circ}$ & 4,21 & 3,36 & 3,21 & 2,60 & 2,13 & 2,56 \\
\hline Rotbuche & 11,21 & 9.64 & 15,13 & 5,56 & 5,30 &, \pm 75 & 3,39 & 2,78 & 3,52 \\
\hline Eiche & 8,87 & 8,62 & 9,23 &, \pm 04 & 3,73 & 3,92 & 2,28 & 2,03 & 2,47 \\
\hline Ulme & 10,60 & 8,83 & $15, \pm 0$ & 4,21 & 4,39 & 3,67 & 2,42 & 2,12 & 2,57 \\
\hline Ahorn & 11,07 & 9,88 & 16,32 & 3,37 & 3,54 & 2,90 & 2,39 & 2,18 & 2,24 \\
\hline NuB & 11,10 & 8,00 & 8,75 & 3,55 & 3,56 & 3,48 & 2,22 & 1,73 & 1,80 \\
\hline
\end{tabular}

Aus Tabelle II ergibt sich, daß die lineare Schwindung vom nassen (waldgrünen) zum luftrockenen Zustande bei dem in Salzwasser ausgelaugten Holze am lileinsten, beim ungeschwemmten Vergleichsholze am größten ist, weil das Salzholz infolge der hygroskopischen Wirkung des Salzgehaltes bei der Trocknung zum lufttrockenen Zustande unter sonst ganz gleichen Bedingungen die meiste Feuchtigkeit zurüekhält und daher nicht so schnell austrocknet und schwindet wie das weniger hygroskopische ungeschwemmte und das in Süßwasser ausgelaugte (geflößte) Holz. Dagegen quillt 
das in Süßwasser geschwenmte Holz, wenn es nach der Austrocknung Gelegenheit findet, Wasserdunst aus der umgebenden Luft anzuzichen. am wenigsten, ist also am schwächsten hygroskopisch, während das mausgelaugte Holz dabei die stürksten linearen (und Volums-) Veränderungen crlcidet.

Es ist nicht möglich, an dieser Stelle auf die weileren Ergehnisso dieser unfangreichen Untersuchungen über die Wirkungen der Auslaugung des Holzes durch Süß-oder Salzwasser einzugehen, und es muß in dieser Hinsieht auf die objge Abhandlung verwiesen werden. Die Schlußfolgerungen, welche Janka aus seinen Untersuchungen zieht, seien hier jedoch kurz angeführt; sie lauten: ,, Das Auslaugen des Holzes in Süßwasser, also das Flōßen, Selıwemmen und Triften, vielleieht auch schon das óftere Begjeßen mit Sußwasser, übl auf die gewerblichen und industriellen Eigensehaften desselben einen rorteilhaften Einfluß aus, indem es die Hygroskopizităl und damil sie Sehwindung und Quellung rermindert und aueh die unangenehme Eigenschaft des Reißens etwas einschränkl; auch bezūglich der Dauer dürlte das sūßwasserAuslaugholz dem ungesehwemmten Holze überlegen sein.

Das in Salzwasser prāparierle Holz hat zwar auel eine geringere Schwindung als das unausgelaugte Holzmaterial, aber nur infolge seiner dureh den höheren Salzgehalt bewirklen vermehrlen Hygroskopizität; die Folge davon ist ein slārkeres Quellen und Arbeiten, wenn es weehseInd feuchler Luft ausgeselzt wird; es reißt auch weniger als ungeselwemmtes Holz.

Es ist also für industrielle und gewerbliche Zwecke die Auslaugung des Holzes in Sußwasser nur wārmstens zu empfehlen, zumal auch die Farbe des Auslaugholzes, sofern nieht zu unreines oder sehlammiges Wasser zur Verwendung kommt, nicht leidet, - und es ist von diesem Standpunkte aus eigentlich zu bedauern, daß man in der Forstwirtschaft von der Trift und Flößerei allmāhlich zum Landtransport übergeht.

Die Prāparation des Holzes in Salzwasser dagegen kōnnle, natürlieh nur dorl, wo solehes Wasser unentgeltlich zur Verfügung steht, also bei den Salinen und am Meeresstrande, für solehe Vermendungszweke empfohlen werden, bei welehen die erhöhte Hỵgroskopizilāt und das dadureh bedingte Arbeiten unter dem Einflusse wechelnder Feuchtigkeit der Luft nicht slōrend wirkt, dagegen melır die Dauer des Holzes in Frage liommt, - also zu Bau- und Iionstruktionshölzern im Hoch- und Brūekenbau, im Erd- und Grubenbau, zu Eisenbahnschwellen, Holzstōekelpflaster und dergI. - Lnumgängliche Voraussetzung dabei ist aber, daß das Auslaugbolz vor seiner Verwendung wiederun vollständig lufttrocken geworden. Wohl aber ist stărker salzhaltiges Holz fŭr feinere industrielle Zweeke ausgeschlossen, da das aufgenommene Salz, namentlich bei Berührung mil Eisen und in feuchter Luft, immer wieder ausblülıt und dabei jeden Holzanstrich durehbricht."

Wir können dieses Kapitel nicht schließen, ohne jener bemerkenswerten Arbeit zu gedenken, welche, im Auftrage der Direlition der Domänen und Forste des Kiantons Bern in Jahre 1877 ausgeführt, im Jahre 1893 anläßlich der schweizerischen Landesausstellung revidiert, ergänzt und publiziert wurde. Der Forstinspelitor J. A. F r e y in Münster hat nämlich die Gewjchts- und Volums-Veränderung an einer Reihe jurassischer Waldbäume untersucht, indem aus dem frischen Holze Würfel von $1 \mathrm{dm}$ Seite hergestellt und dann in 4 Stadien der Austrocknung., sommertrocken". .abgetrocknet", ,ausgetrocknet" und ,dürr", endlich im verkohlten Zustande in Beziehung auf spezifisches Gewicht und Tolumen untersucht wurden. Wen man sich auch über die absolute Richtigkeit, respelitive Brauchbarkeit dieser Erhebungen ebensowenig als der Versuchsansteller Illusionen hingeben darf, so dürfte es doch im Hinblick auf die relative Richtigkeit der Versuchsergebnisse begründet sein. hier ein Resümee derselben mitzuteilen.

\section{(Siehe Tabelle I11, Seite 382.)}

s 18. 4. Folgen der Hg̣oskopizitä und Volums rerän de r lichkeit. Nachdem das Schwinden in den den verschiedenen Baumteilen zugehörigen Holzkörpern, wie oben gezeigt wurde, in verschiedenem Maße stattfindet und dabei außerdem wieder in jedem Teile für sich verschieden nach den Hauptabmessungen ist, so ergibt sich ron selbst, daß das Schwinden nicht nur zu einer Volums-Verkleinerung. sondern auch zu einer Gestaltsveränderung führt, welche um so meln die Bezeichnung ..D e fo r m a $t$ i o $n^{6 " v e r d i e n t, ~ a l s ~ d i e ~ d u r c h ~ d a s ~}$ Schwinden hervorgerufene neue Gestalt meistens für die gewerbliche Verwertung, bezw. weitere Verarbeitung des Rohstoffes unbequem ist. 
Tabelle 111.

\begin{tabular}{|c|c|c|c|c|c|c|c|c|c|c|c|}
\hline \multirow{2}{*}{$\begin{array}{l}\text { Name der } \\
\text { Holzarten }\end{array}$} & \multirow{2}{*}{ 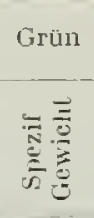 } & \multirow{2}{*}{ 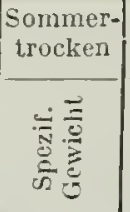 } & \multicolumn{3}{|c|}{ Ausgetrocknet } & \multicolumn{3}{|c|}{ Dürr } & \multicolumn{3}{|c|}{ Verkohlt } \\
\hline & & & 焉 & $\stackrel{\bar{e}}{\stackrel{\bar{E}}{\bar{D}}}$ & 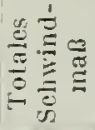 & 这部 & $\stackrel{\bar{\Xi}}{\stackrel{\Xi}{\Xi}}$ & 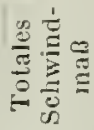 & 这 & $\stackrel{\bar{E}}{\stackrel{\bar{E}}{\bar{\theta}}}$ & 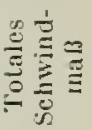 \\
\hline & & & & $\mathrm{cem}$ & $\%$ & & $\operatorname{cem}$ & $\%$ & & $\mathrm{~cm}$ & $\%$ \\
\hline Eicho & $1,07.15$ & 0,9852 & 0,804 & 939 & 6,1 & 0,766 & 867 & 13,1 & 0,387 & 6. & 35,2 \\
\hline Escl & 0,8795 & 0,8304 & 0,771 & 916 & 8,4 & & 835 & 16,5 & 0,371 & 523 & 47,7 \\
\hline Buche & 1,0288 & 0,8160 & $0,7 \pm 7$ & 616 & 8,1 & 0 , & 85 & 14,4 & 0,319 & 569 & $\pm 3,1$ \\
\hline líefer & 0,8734 & 0,7828 & 0,678 & 933 & 6,7 & 0,662 & 865 & 13,5 & 0,351 & \pm 92 & 50,8 \\
\hline Ulme & 0,9166 & 0,7502 & 0,635 & 93 & 7,0 & & 885 & 11,5 & 0,284 & 586 & 41,4 \\
\hline Eibe & 0,9030 & 0,7106 & 0,696 & 979 & 2,1 & 0,642 & 911 & 8,9 & 0,262 & 801 & 19,6 \\
\hline Ahor & 0,9210 & & 0,637 & 966 & 3,4 & 0 , & 911 & 8,9 & 0,247 & 693 & 30,7 \\
\hline Aspt & 0,8809 & 0,6398 & 0,515 & 922 & 7,8 & 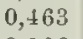 & 879 & 12,1 & 0,179 & 672 & 32,8 \\
\hline Lärc & 0,7633 & 0,6112 & 0,607 & 83 & 6,9 & 0,560 & 895 & 10,5 & 0,238 & 733 & 26,7 \\
\hline Weißtanne & 0,8041 & & 0,527 & 954 & 4,6 & & 886 & 11,4 & 0,214 & 713 & 28,7 \\
\hline Lind & 0,7690 & 0,5810 & 0,505 & 889 & 11,1 & 0,484 & 831 & 16,9 & 0,240 & 511 & 48,9 \\
\hline Rottanne & 0,5266 & 0,4931 & 0,487 & 939 & 6,1 & 0,457 & 887 & 11,3 & 0,193 & 729 & 27,1 \\
\hline
\end{tabular}

Ebenso wird ein im trockenen Zustande zugerichteter oder verarbeiteter Holzkörper dureh die Aufnahme von Feuchtigkeit und das daraus resultierende Anquellen gleichfalls eine neue Gestalt annehmen, und diese Deformation wird lhäufig den bei der Verarbeitung vor Augen gehabten Zweek vereiteln, nieht selten zur Zerstörung oder Verminderung des Wertes oder der Gebrauchsfähigkeit des Objektes beitragen. Dieses Verhältnis, welehes im allgemeinen nit „Werfen des Holzes" bezeichnet wird - das Holz "wirft" oder ,verzieht sieh" - , tritt in um so drastiseherem Naße auf, je größer der Abstand in dem Verhalten der zu einem Holzkörper organisch verbundenen Holzteile ist. Die versehiedenen einzelnen in der Praxis vorkommenden Fälle des Schwindens von Halbholz, Viertelholz, Kantholz, Brettern, Spaltholz usw. sind in der Mehrzahl der Lehrbüeher abgehandelt und zu bekannt, um hier neuerdings erörtert zu werden.

Kann sieh die aus dem Schwinden oder Quellen entspringende Deformation nur dadureh vollziehen, daß an einzelnen Teilen die Kohäsion der Holzsubstanz überwunden wird, so entstehen Spalten, Kílüfte oder Risse, man sagt dann: „das Holz reißt". Neistens sind diese Art von Rissen als aus der Sehwindung entspringende Fehler des Holzes zu erkennen, man nennt sie "Schwindrisse“, „Troekenrisse" und je nach der Lage derselben „Strahlenrisse“, wenn sie von der Peripherie des Holzes ausgehen; "Kemrisse", wenn sie aus der Achse des Baumes entspringen und sieh gegen den Umfang zu verlieren.

Beim Reißen des Holzes können entweder ,weitklaffende Sprünge“ oder viele kleine Rißehen („Luftrisse“) entstehen; das letztere sclädigt den Gebrauchswert natürlich in geringerem $\mathrm{Vaße}$.

Die Behandlung des Holzes vor, während und nach der Fällung, die gänzliche oder teilweise Entrindung, das sukzessive Torgehen bei der Entrindung, versehiedene Naßregeln zur Verlangsamung des Troeknungsprozesses, namentlich an den Hirnflächen, ferner Vorkehrungen mechanischer Art gegen die Deformation: alles das, vereinzelt oder nach Gruppen vereinigt, bildet das Verfahren, welches von dem Praktiker eingeschlagen wird, um das ,Sichwerfen“ und „Reißen" des Holzes zu vermindern oder bis zu einem gewissen Grade unsehädlich zu machen. Dieses Gebiet bildet ein dankbares Feld für das Vorurteil, aber ebensosehr eine Domäne der praktischen Erfahrung. Es liann nieht unsere Sache sein, hier die verschiedenen Rezepte 
beglaubigten oder nieht beglaubigten Lrsprunges für die Behandlung des Holzes anzuführen. Es ist vielmehr Sache der Technologie, den Holzindustriellen zu lehren, wie er mit den Eigentümlielikeiten des Holzes zu reehnen hat, welehe im Gefolge des Schwindens und Quellens des Holzes auftreten.

\section{Mechanisch-technische Eigreuschaften.}

$\$ 19 . .1$. E l a s t i z i tä $t$ u nd F est i g k e i t. Die Kenntnis der Elastizitätsund Festigkeits-Eigenschaften des Holzes, welehe in die Gruppe ,m e c l a n i s e he $\mathrm{E}$ i g e n s e h a f te n" fallen, ist bis in die jüngste Zeit sehr zurückgeblieben.

Bei dem stetigen raschen Fortsehritte, welchen die mechanische Technik überhaupt genommen hat, überrascht es, daß wir gerade auf diesem einen Gebiete - mit Ausnahme der Ergebnisse, welche den verflossenen letzten Dezennien angehören nur wenige positive Daten besitzen.

Die Wiehtigkeit solcher Versuche, welche uns zuverlässige Aufsehlüsse über die „Qualität" der verschiedenen Konstruktionshölzer geben, braueht wohl nicht erst besonders hemorgehoben zu werden, da über die ,Bedeutung des Holzes als Baumaterial" ja kaum ein Zweifel besteht. Nicht nur wissensehaftliehen Spekulationen, sondern auch den praktischen Bedürfnissen sollte die V'ornahme jener Versuche in erster Linie dienen, welehe die Ermittlung obiger Eigensehaften zum Gegenstand hat.

Dem Techniker brauchbare Daten über die Festigkeits-Eigenschaften der Hölzer zu geben, ist zunäehst der leitende Gedanke gewesen, welcher den Versuchs-Anstellern vorsehwebte, und erst im Wege der Diskussion der gewonnenen Resultate ist die Frage reif geworden: ,In welehem Zusammenhang steht der Bau des Holzes mit den mechanisclien Eigensehaften desselben?" Die Lösung dieser Frage erheischt zunächst, eine Relation zu finden zwischen den mechanischen Eigenschaften des Holzes und den physikalisehen, z. B. der Diehtigkeit und dem Feuehtigkeitsgehalt des Holzes. Die Bekanntsehaft mit jenen Beziehungen, welehe zwisehen den mechanisehen und physikalisehen Eigenschaften des Holzes bestehen, ist aber andererseits notwendig, da sonst ein Vergleieh jener gewonnenen Resultate, die unter versehiedenen Verhältnissen, vorzugsweise bei versehiedenen Feuchtigkeitsgraden der Probestüeke, angestellt wurden, unmöglich wäre. Hier stehen wir aber vor einer Aufgabe, welche eine Fülle von in gegenseitigen Abhängigkeits-Verhältnis sich befindlichen Falitoren in sich vereinigt.

Sehon aus der einfachen Aufzählung der wichtigsten Eigensehaften des Holzes, welche hier in Zusammenhang zu bringen sind, läßt sieh auf die Ausdehnung der Versuehe und die Schwierigkeiten schließen, welehe sich dem Forseher entgegenstellen.

Die Hauptfragen sind: Welcher Zusammenhang besteht zwischen der Elastizität und Festigkeit des Holzes und dem spezifischen Gewieht und dem Feuehtigheitsgehalt desselben; wie verhalten sich die ersteren Eigenschaften sowohl in Beziehung auf die Höhenlage der Probestücke im Stamme selbst als auch gegenüber der Lage im Quersehnitt, d. i. in Beziehung auf die Nord-, Süd-, West- und Ostseite; in welehem Abhängigkeits-Verhältnis stehen Viemholz, Reifholz und Jahrringbreite zu den genannten Eigensehaften? Nebst diesen Beziehungen, welehe auf den anatomisehen Bau des Baumes Rücksicht nehmen, besteht aber noeh der Zusammenhang der Festigkeits-Eigenschaften mit der eigentlichen Holzsubstanz, ihrer Qualität und chemischen Zusammensetzung. 
Stellen nun die im T'oranstehenden gegebenen Fragen schon ein überaus großes Arbeitsgebiet für den Forscher dar, so erweitert sich dasselbe noch in beträchtlichem Maße dadurch, daß alle oben angeführten Eigenschaften auch in Beziehung zu bringen sind mit den Fragen nach dem Einfluß des Bodens und der Fällungszeit des Holzes auf dessen mechanische und physikalische Eigenschaften. Berücksichtigt man ferner, da $B$ der Einfluß der Fällungszeit und des Standortes auf die $D$ a $u$ e $r$ h a f t i g k e j t des Holzes zu obigen Fragereihen hinzutritt, wodurch erst die in Rede stehenden Forschungsaufgaben als nahezu erschöpfend aufgezälılt zu betrachten sind, so dürfte die Fülle des sich darbietenden Materiales erliannt werden, welches aber dadurch noch einen geradezu überwä]tigenden Umfang nimmt, wenn man bedenkt, daß die Erforschung obiger Daten sich niclit nur auf e in e $\mathrm{H} \mathrm{ol} \mathrm{z} \mathrm{a} \mathrm{r} \mathrm{t}$ zu bezichen lıat, sondern auf eine nicht unbeträchtliche Zahl von Holzarten auszudehnen ist, da die zur praktischen Verwendung gelangenden europäischen Hölzer allein schon belianntlich eine stattliche Reihe ausmachen.

$\S 20$. Bevor wir auf die gewonnenen Resultate selbst übergehen, wollen wir im Nachstehenden die für das Verständnis dieses Kapitels notwendigen Definitionen und Formeln der Festigkeitslehre wiedergeben und bemerken, daß wir uns in der Bezeichnung der Festigkeitsformeln an jene durch Prof. J. B a u s c hinger gewählte anschließen.

Unter F e s tig k e it verstelit man den Widerstand, welchen ein fester Körper der Trennung seiner Teile entgegenstellt, oder mit andern Worten, jeneliraft, welche zur Aufhebung ihres Zusammenhanges notwendig ist.

E l a s t i z i t ä $t$ ist der Widerstand, den ein fester Förper der vorübergehenden Formänderung entgegensetzt.

Im gewöhnlichen Leben versteht man unter Elastizität jene Eigenschaft, welche ein Körper äußert, wenn derselbe bei einer durch die Einwirkung einer äußeren Kraft erlittenen Veränderung der Lage seiner Teile zueinander bestrebt ist, nach Auflıöıen dieser Iíraftäußerung wieder in seine ursprüngliche Gestalt zurückzukehren.

Ein Körper kehrt entweder vollst ä $\mathrm{n}$ d i g in die frühere Lage seiner Teile zueinander zurück oder nur $t$ e il 1 e is e, und dabei gibt es eine Grenze des Gebietes des ersten Falles der Elastizität, welche man mit dem Ausdrucke E l a s t iz i tä t s gr e n z e bezeichnet; man versteht demnach hierunter den äußersten Grad der Formänderung, bis zu welchem man sicher ist, daß der Körper nach Beseitigung der auf ihn einwirkenden Kraft wieder in seine ursprüngliche Form (Lage seiner Teile) zurückkehrt. Es gibt Körper, die sofort bei der Inanspruchnalıme über die Elastizitätsgrenze hinaus in Stücke zerspringen (spröde Kiörper) und solche, die noch eine weitere Formveränderung zulassen (geschmeidige, zähe Körper).

E la s tiz i tä ts m o d u I (das $M a ß$ der elastischen Nachgiebigkeit eines Materiales) ist die Spamung (Fraft pro Flächeneinheit des Querschnittes), bei welcher ein prismatischer, in seiner Längenrichtung beanspruchter Körper innerlıalb seiner Elastizitätsgrenze um seine ganze Länge ausgedehnt oder zusammengepreßt werden könnte, falls dies die Substanz zulassen würde.

T r a g m o d u l ist die Spannung, welche der Elastizitätsgrenze entspricht.

Der Zug- und Druckfestigkeit entsprechen ein Z u g- und D r u c k - Tragmodul.

$\mathrm{Bruchm}$ o d u 1 hingegen nennt man die Spannung, welche den Bruch des Holzes lierbeiführt.

Alle Moduli drückt man in Kïlogrammen aus und bezieht sie auf einen QuadratZentimeter Querschnitt; sollten jedoch große Iiräfte zur Ueberwindung der mechanischen Eigenschaften (bei Verwendung großer Querschnitte) erforderlich sein, so 
drückt man die Kräfte bequemer in Tonnen à IOng ligr aus und gilit dis Querschnittfläche in Quadrat-Zentimetem an. dußerden kann man die Morkuli in Atmosphären ausdrücken (at, unter Atmosphäre $1 \mathrm{~kg}$ pro ([cm verstandru).

$\$ 21$. Die rersehiedenen Arten ron Festigkeiten, welche wir zu unterscheiden haben, sind folgende:

a) Zugfestiglieit oder absolute Festigkeit. d. i. der Mirlerstand, welchen das Holz der Trennung seiner 'Teile dureh Zerreißen oder Abreißen entgegensetzt, wenn Kräfte in der Richtung der Fasem ${ }^{1}$ ) ziehenil oder spannend wirken:

b) Quer-Zug festigkeit, der Wilerstand, den das Holz gegen das Zerreißen leistet, vorausgesetzt, daß die Richtung des Zuges reehtwinkeliggegen die Lage der Fasern ${ }^{2}$ ) steht.

c) Druckfestigkeit oder rückwirkende Festigkeit. Ist die Kraft gerade entgegengesetzt der Zugfestigkeit, so wird der Körper auf seine Druckfestigkeit beansprucht, rorausgesetzt, daß die Länge des Stabes in Vergleiche zu dessen Querschnitts-Abmessungen nicht zu groß sei. Ist ile Länge des Stabes so viel mal größer als seine Querschnitts-Abmessungen, daß dem Bruche eine Durchbiegung vorangeht, so wird der Stab auf

d) Zerknickung s- oder Säu len-Festigke it beansjirucht, dem hier kommt neben der D r u ck- auch die Biegung - Festigke it gleichzeitig in Betracht.

e) Die Bi e gung $g-F$ estigkeit oder relative Festigrkeit, d. h. der Widerstand gegen das Zerbrechen, wobei das Holz an einem Ende oder an beiden Enden unterstützt (befestigt) ist und eine Kraft rechtwinkelig gegen die Fasem, sowie gegen die Hauptdimension (Länge) des Stückes wirkt.

Die B i e g s m k e it des Holzes läßt sich ausdrücken durch die äußerste Größe der Biegung, welche unter festgesetzten Unständen ein an seinen beiden Enlen unterstützter, in der Nitte seiner Länge belasteter Stab annimmt, bevor er luricht. In diesem Sinne gebraucht man dafür auch der Ausdruck $\mathrm{Z}$ ä h i g ke it. Frisches (grünes), durchnäßtes und gedänpftes Holz ist in viel höherem Grade biegsam oder zäh als trockenes. Sofeme das Holz nach solcher Behandlung die ihm aufgezwungene Form beibehält, spricht man von dessen $F$ orm b a $\mathrm{k}$ e it.

f) Die Dre hung s- oder Torsious-Fest $\mathrm{g} \mathrm{k}$ e i t ist der Miderstand, welchen ein Körper der Verdrehung um seine geometrische Achse entgegensetzt.

g) Die Festigkeit gegen das Verschieben oder Abscherung sF e st igkeit (Schubfestigkeit), welche sich äußert, wenu durch eine in der Richtung der Fasem oder senkrecht zu derselben wirkende Fraft ein Teil der Fasern längs der übrigen Holzmasse fortgeschoben oder fortgezogen und dadurch von derselben abgetrennt oder abgerissen werden soll.

h) Die Spaltungsfestigkeit; d. i. der Widerstand gegen Trennung der Fasern durch einen zwisehen sie eindringenden, keilförmigen Körper. Geht diese Trennung leicht vor sich, so bezeichnet man diese Eigenschaft als $\mathrm{S} p$ a $1 \mathrm{t}$ l, a $\mathrm{r} k \mathrm{e}$ it. Nach den Ebenen der Spiegelfasem ist diese in der Regel größer als nach der Sehne der Jahresringe; gar nicht .spaltbar" sind die llaserhölzer.

i) H är t e ist der Widerstand des Holzes gegen das Eimlringen eines heliebigen

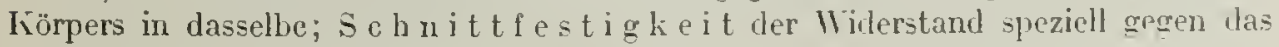
Eindringen eines schneidigen Werkzeuges.

1) Bezeichnet mit // zur Faser.

2) Bezeichnet mit I zur Faser.

Handb. d. Forstwiss, 3. Aut. II. 
\$2.2. Der Lelne ron der Elastizität und Festigkeit der Materialien, die uns Aufschluß über die Widerstände gibt, welche feste löorper den auf sie von außen einwirkenden Kräften entgegenstellen, sind die nachstehenden Formeln entnommen, welche zur Berechmung der durch Versuche gewomenen Daten erforderlich sind.

1. Z u g- und Druckifestigkeit.

Die Belastung P, wełche ein auf Zug- oder Druckfestigkeit in Anspruch genommener Körper zu tragen vermag, ist:

$$
\mathrm{P}=\frac{\dot{L} \mathrm{l}}{\mathrm{l}} \mathrm{F} \cdot \mathrm{\varepsilon},
$$

wobei $\triangle 1$ die Verlängerung bezichungsweise Verkürzung der urspränglichen Länge I des Stabes für die Belastung P, F den Querschnitt des Stabes und $\varepsilon$ den Elastizitätsmodul bezeichnet.

2. Zerlinickíng s- oder Säulen-Festigke it.

Die Bruchbelastung $\mathrm{P}$ eines auf Zerknicken beansprucliten Stabes ist, je nach der Befestigungsweise der Stabenden, wenn:

1. ein Ende fest (eingelilemmt), das andere frei ist,

$$
\mathrm{P}=\frac{\tau^{2}}{4} \frac{\varepsilon \Theta}{\mathrm{l}^{2}}
$$

2. beide Enden frei und in der ursprünglichen Achse geführt,

$$
P=\pi^{2} \frac{\Xi \Theta}{l^{2}}
$$

3. ein Ende fest, das andere frei in der Achse geführt,

$$
P=2 \pi^{2} \frac{\varepsilon \theta}{l^{2}}
$$

4. beide Enden fest und in der ursprünglichen Stabachse gefülırt,

$$
P=4 \pi^{2} \frac{\varepsilon \Theta}{1^{2}},
$$

wobei I die Länge der Säule, $\Theta$ das Träghcitsmoment des Querschnittes in der Mitte des Stabes und $\varepsilon$ den Elastizitätsmodul bezeichnet.

3. Bi egungs estigkeit.

Lie biegende liraft

$$
\mathrm{P}=\frac{2}{3} \frac{\mathrm{bh}^{2} \delta}{\mathrm{l}} \text { oder } \delta={ }_{2}^{3} \mathrm{P} \cdot \mathrm{l} \mathrm{h}^{2},
$$

wohei $\delta$ die Biegungsspannung in den äuBersten Fasem, P clie in cler Mitte konzentrierte Kraft, I die spannweite, b und h des Querschnitts Breite und Höhe bezeichnen.

Bedeutet $₹$ den Elastizitätsmodul, $\rightarrow$ das Trägheitsmoment des Querschnittes und $f$ den Biegungspfeil, so ist

$$
\varepsilon=\frac{1}{1}-\frac{P]^{3}}{f \cdot \theta}=\frac{1}{4} \frac{P l^{3}}{\mathrm{fbl}^{3}} .
$$

4. Torsions-Festigkeit.

Bezeiclunen:

$\tau$ die Naxinalschubspanmung, welche beim kreisfömigen Querschnitt ringsum in der Peripherie, beim quadratischen in den Seitenmitten, beim elliptischen an den Enden der dileinen Habachse und bein rechteckigen Querschnitt in den Mitten der Langseiten stattfindet,

$T$ das Torsionsmoment $=$ der Kraft $\mathrm{P}$ mal dem Hebelarm 1 , an welchem die liraft $P$ wirlit, 
w die durch dasselbe hervorgebrachte Verdrehung zweier Qucrschnitte gegenemander:

r den Radius des Kreises, auf welchem w als Bogen gemessen wird;

e die gregenseitige Entfermung jener beiden Querschnitte;

$F$ den Flächeninlalt und

$\theta \cdot$ das polare Träghcitsmoment eines Onerschnittes, hezogen auf dessen Schwerpunkt;

a, b die große und kleine Halbachse eines elliptischen oder die große und kleine Halbseite eines rechteckigen Querschnitts, spezicll aber

a den Radius eines lireisförmigen oder die Halbseite eines quadratischen Querschnittes,

A) das Trägheitsmoment des Querschnittes in bezug auf eine, durch seinen Schwerpunkt gehende, mit der Achse a zusammenfallende, oder mit der Seite a parallele Momentenaclise und

$\gamma_{1}$ den Schubelastizitätsmodul, so ist

$$
\begin{gathered}
\tau=\mathrm{x}^{\prime} \frac{\mathrm{T}}{\mathrm{\theta} \%} \mathrm{~b} \text { und } \\
\eta=\mathrm{x}_{\mathrm{w}^{\prime} \mathrm{F}^{\prime}} \mathrm{er} .
\end{gathered}
$$

In diesen Formeln bedeuten $\mathrm{x}$ und $\mathrm{x}^{\prime}$ Koeffizienten, welche fül die verschiedenen Querschnittsformen nach $\mathrm{S}$ a in $\mathrm{t}-\mathrm{V}$ e $\mathrm{n}$ a $\mathrm{n} \mathrm{t}$ folgende $\mathrm{IT}$ erte besitzen:

Für den kreisförmigen und elliptischen Querschnitt ist

$$
x=4 \pi^{2}=39,48 \text { und } x^{\prime}=0,5
$$

für den rechteckigen Querschmitt mit dem Seitenverhältnis:

$$
\begin{aligned}
& 1: 1 \text { ist } \mathrm{x}=42,65 \text { und } \mathrm{x}^{\prime}=0,75 \\
& 1: 2 \text { ist } \mathrm{x}=4 \cdot, 00 \text { und } \mathrm{x}^{\prime}=0,75 \\
& 1: 4 \text { ist } \mathrm{x}=40,20 \text { und } \mathrm{x}^{\prime}=0,75
\end{aligned}
$$

5. A b s cherungs - Festiglieit.

Bezejchnet man mit $\mathrm{P}$ die abscherende Kraft in $\mathrm{kg}, \mathrm{F}$ den abgescherten Flächeninhalt in çcm, so hat man als Iaß für die Abscherumgs- ader Scherfestigkeit

$$
\mathrm{S}=\frac{\mathrm{P}}{\mathrm{F}} \text {. }
$$

Es stellt also die Scherfestigkeit die Irraft in liilogrammen vor, welche notwendig ist, um eine Fläche von 1 qृem abzuscheren; $d$. h. ist die abscherende Kraft parallel zur Fichtung der Holzfaser, so ist die Scherfestigkeit jene kraft in Kilogrammen ausgedrückt, welche erforderlich ist, um die Parallelliohäsion von 1 qqem zu überwinden.

ริ 23. Die Beschreibung der bei den Versuchen benützten Maschinen mit in den Rahmen dieser Arbeit aufzunehmen, würde viel zu weit führen, doch halten wir es für angemessen, jene Quellen anzugeben, aus denen die Konstrulition der Versuchsapparate entnommen werden kann. Eine kurz gehaltene Lebersicht der Literatur, welche die Versuchsreihen der verschiedenen Autoren enthält, wurde bereits in der "Einleitung" gegeben. Dic Resultate, welche ältere Autoren gefunden haben, hier zu benutzen, halten wir nicht für angezeigt. Wolıl ist es höchst lehıreich, die Art und Weise der Durchführung auch dieser älteren Versuche zu verfolgen, da sie zeigen, mit welch geringwertigen technischen Hilfsmitteln die Versuche durehgefülnt wurden; die Resultate bewegen sich aber innerhalh so weit voneinander entfernter Grenzen, woran nicht nur die Heterogenität des Versuchsmateriales, sondem viehnelır auch die primitiven Versuchsapparate Schuld tragen, daß dieselben für die pralitisclıe Be- 
nutzung kaum mit Vorteil Anwendung finden können. Wir beschränken uns daher auf die Wiedergabe der Versuchsresultate, welche die neueren Forscher gefunden haben, aus dem Grunde, weil dieselben mit Versuchsstüclien größerer Dimension und mit Versuchsapparaten gearbeitet haben, welche die Ablesung der Beobachtungsresultate entweder gleich genau oder doclı nit nahezu gleicher Präzision zuließen.

$\mathrm{Zu}$ den vollkommensten Festigkeits-Maschinen gehört die Maschine von L u dwig $W^{\top}$ erder", welche ron der Maschinenbau-Aktiengesellschaft "Nürmberg", vormals Ḱlett u. Co. ausgeführt wird. Die zu dieser Maschine gehörigen Instrumente zum Messen der Gestalts-Veränderung der Probekörper, lionstruiert von Prof. J. $\mathrm{B}$ a u s c h ing e r, werden in dem mechan.-technischen Laboratorium der K. Techn. Hochschule in München ausgeführt. Die Beschreibung der Maschine sowolıl als der dazu gehörigen Instrumente ist in der von der genannten Fabrik publizierten Schrift: „Lie Jaschine zum Prüfen der Festigkeit der Materialien, konstruiert von L. IV e rd e r ${ }^{6}$, München 18S?, zu finden.

Hit dieser Haschine sind sowohl die Versuche ron B a u s c h i n g e r durchgeführt worden als auch jene, welche der Vorstand der eidg. Anstalt zur Prüfung von Baumaterialien in Zürich Prof. L. T e t $m$ a je r und der Professor an der k. k. technischen Hochschule in Wien $\mathrm{K}$ a $\mathrm{r}$ I V. J e n n y bezüglich der Festigkeit des Holzes unternommen haben.

Auch die neueren Versuchsreihen, herrihrend von M. $\Gamma$ u d e l of $f$, wurden auf der Werderschen Maschine durchgeführt. Die Untersuchungen über die Druckfestigkeit des Holzes von Dr. A. S c h w a p a c h wurden mit der Festigkeitsprobiermaschine von Pohlmeyer vorgenommen, während bei den größeren Probekörpern die 500 Tonnen-Maschine Bauart Hoppe zur Anwendung gełangte. Beide Naschinen standen dem Versuchsansteller in der Charlottenburger NaterialprüfungsAnstalt zur Verfügung, während A. H a d e $k$ und G. J a n $k$ a eine 130 Tonnen-Presse von der Firma Ansler-Laffon u. Sohn in Schaffhausen benutzten, welche mit einem Spiegel-Apparat Srstem Martens ansgerïstet war. Letzterer dient bekammtlich zur Beolvachtung der äußerst geringen Längenveränderungen, welche das $\mathrm{Holz}$ durch Druck parallel zur Faser innerhalb seiner Elastizitätsgrenze erleidet und deren IIessung zur Berechnung der Druck-Elastizitätskoeffizienten erforderlich ist.

Nebst den Arbeiten der letztgenannten Autoren sind noch zu berücksichtigen:

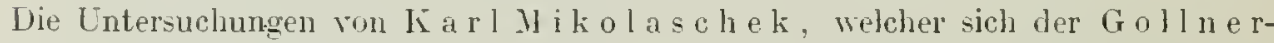
schen Festigkeitsmaschine bediente (siehe "Technische Blätter" Jahrgang 1877 bis 1884) und die Arbeiten ron Prof. Emst H a r tiğ, welcher seme Tersuche mit einen Schlagapparat, ausgeführt in der Sächsischen Maschinenfahrik zu Chemnitz, rorgenommen hatte.

Jene Untersuchungen von II. F. Ex n e r, welche gelegentlich der ..Studien über das Rotbuchenholz, Wien 1875" in Beziehung auf die rückwirliende Festigkeit dieses Holzes angestellt worden sind, wurden mit einer englischen hydraulischen Presse durchgefülnt, welche eine Drucksteigerung bis zu $\mathrm{I} 2000 \mathrm{~kg}$ auf die Preßkolbenfläche von 25,51 Quadrat-Zentimeter zuläft. Wit dem gleichen Apparate sind jene Untersuchungen vorgenommen worden, welche zur Lösung der Frage der technischen Verwendung des Ailanthus-Holzes mit besonderer Berücksichtigung des Wragenbaues (siehe Mitteilungen des Techn. Gewerbe-Huseums $\mathrm{Nr}_{\mathrm{r}}$.62) in Ausfühung gebracht wurden $\mathbf{1}$ ).

1) Eine sehr hübsche, ubbersichtliche Darstellung der Einrichtung und Ausrüstung aller wichtigeren Inechanisch-technischen Laboratorien findet nan in der Monographie: The Use and Equipment of Engineering Laboratories by Alexander Blackie William liemedy, London: Published by the Institution of Civil Engineers, 1887 . 
5 24. Lm die $H$ olzuntersuchungen auf eine einheit liche Grund lage zu stellen med zu erreichen, daf dic von verschiedenen Versuchssteller erhaltenen Ergehnisse untereinander v e r g l e i c h b a r sind, wurle auf dem liongreß des Internationalen Verbandes für clie Materialprüfungen rler Technik zu

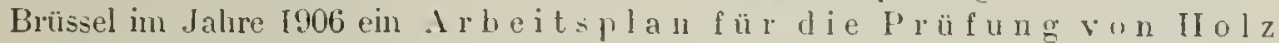
a uf seine teehnischen Eigenselu a t en vereinbart, der unter Nitwirkung von Forstleuten und Technikem unter dem V'orsitze Prof. Ir. Schwappachs nach dem Referate Prof. Rudeloffs ausgearbeitet worden war. Es scheint uns am Platze, chie Grundzüge dieses Arbeitsplanes für die Lntersuchungen des Holzes wenigstens in kurzen Unrissen hier vorzufühnen.

Diese Grundsätze für einheitliche Verfahren zur Prüfung von Holz enthalten:

1. Angaben über den L'sprung des llateriales.

II. A euBere Ii en ze ichen der Eigensehaften.

III. Di e Prüfungsverfahren.

1V. Die Probenentnalıne.

I. Die Angaben über den U rsprung des. Il a teria l s erstrecken sich auf den Standort, die Standortsgüte, die Art des Bestandes und die Wachstumsveruältnisse sowic das Alter der Bäume, die Fällungszeit, die Art der Lagerung und des Trocknens von der Fällung bis zur Prüfung und die Lage des Versuchsstückes in Stamme.

I1. Als ä u Bere Kennzeichender Eigenschaften des Holzes sind anzugeben: Das Aussehen des Längsschnittes oder der Spaltfläche und des Querschnittes, also die Jahrringbildung und Jahrringlagerung, worunter auch die Daten bezüglich des Spätholzprozentes inbegriffen sind.

III. Bei den P r ü f ung v e r f a h ren wird grundsätzlich festgestellt, daß die Proben zunächst an ast- und fehlerfreien Material vorgenommen werden sollen, oder doch wenigstens die Ergebnisse für astfreies und astiges Material auseinanderzuhalten sind.

A. Zur Kemneichnung der Festigkeitseigenschaften eines Bauholzes dient an erster Stelle der Druchversuch, der Biegeversuch und der Scherversuch; Zug- und Spaltrersuche sind nicht obligat, werden aber anempfohlen. Als Belastungrgeschwindigkeit wird die Laststeigerung von $20 \mathrm{~kg}$ auf $1 \mathrm{~cm}^{2}$ in der llinute festgenetzt. Der Feuchtigkeitsgehalt der Probe ist zu ermitteln, die Beobachtungswerte sollen womöglich auf den Feuchtigkeitsgehalt von $15 \%$ (Nomalfeuchtigkeitsgehalt) reduziert werden.

1. Bein Druckversuch ist zu emitteln: Die spannung an der Proportionalitätsgrenze, der Elastizitätsmodu\}, die Bruchspamnung und die Verliürzung mit fortsehreitender Belastung bis zum Bruche, dann der Ouotient $\begin{aligned} & \text { I'ruckifestigkeit } \\ & \text { spezif. Gewicht }\end{aligned}$ beim Normalfeuchtigkeitsgehalt. Als Form des Probckörpers für crewöhnliche Druckversuche gilt der Würfel, für Druckelastizitätsuntersuchungen das Prisna, descen Länge der 3fachen Querschnittskante gleich sein soll. Bei Lutersuchung ganzer Stämme sind die Proben in der Art aus dem Stammquerschnitt zu entnelmen, daß eine Diagonale der quadratischen Druckfläche des Probekürpers einen Halbmesser des Stammquerschnitts billet; hei Sonderuntersuchungen sind Probenentnalimen derart anzuwenden. das inmer 2 Sciten des Probeliörpers möglichst tangential zu den Jalırringen verlaufen.

2. Der B i egevers u ch wird an prismatischen stäben in der. Irt durchgeführt, daß der Stab an heiden Enden unterstützt und in der Nitte durch eine Einzel- 
last auf Biegung beansprucht wird. Der Reiter, d. i. die Zwischenlage zwischen der Angriffsschneide der Maschine und dem Probebalken, hesteht aus hartem Holz und wird in seinen Dimensionen genau vorgeschrieben. Die Entnahme der Biegeproben aus dem Stammquerschnitt erfolgt analog wie bei der Entnahme der Wruckproben. Die Stützweite der Biegebalken soll mindestens gleich der Sfachen Stärlie des Balkens sein; sie wird mit 1,5 nt lestgesetzt. Ermittelt werden beim Biegeversuch: Die Proportionalitätsgrenze, der Elastizitätsmodul, die Bruchspannung, der Verlauf der Durchbiegungen mit fortschreitender Belastung bis zur Bruchlast zur Verzeichnung des Biegungsdiagrammes, die Biegungsarbeit lis zur Proportionalitäts- nurl bis zur Bruchgrenze. Die Biegungsarbeit ist auf einen Normalbiegestab von $10 \times 10 \mathrm{~cm}$ Querschnitt und $1,5 \mathrm{~m}$ Stïtzweite $z$ beziehen, um rie llerte für Stäbe von verschiedenen Abmessungen vergleichbar zu machen.

3. Der S c h e r versu h ist an prismatischen Prolen einsehnittig auszuführen und soll sich auf die Ermittlung der Festigkeit radial und tangential zu den Jahrringen erstrecken. Der Angriff der Belastung clfolgt stets von Hirn aus; die Scherbacken sollen nicht über $10 \mathrm{~cm}$ breit sein, die Breite iler Proben bei Radialschnitt nicht über $50 \mathrm{~mm}$, bei Tangentialschnitt nicht über $30 \mathrm{~mm}$ betragen; die Länge der Proben in der Kraftrichtung soll gleich der 4fachen Breite der Scherbacken sein. Ermittelt wird die Bruchspannung, bezogen auf den vollen Probenquersclnitt.

4. Zur Ermittlung der Z u g f estigkeit in rler Längsichtung der Faser dienen Flachstäbe, die aus Spaltstücken herausgearbeitet werden sollen. Die Dicke der Stäbe beträgt $1 \mathrm{~cm}$, die Breite mindestens : $\mathrm{cm}$, die Versuchslänge $2: 2 \mathrm{~cm}$.

5. Der S p a l t versuc li wird an liluppenförnigen Proben in der von Nördlinger eingeführten Form durchgeführt; die Dimensionen der Spaltfläche sind $2,5 \times 4,0 \mathrm{~cm}$; beobachtet wird die Bruchlast.

B. Der F e u cht ig ke itsge ha l t ist in Prozenten des Absoluttrockengewichtes anzugeben; er ist möglichst ummittelbar an den g a n z e n Festigkeitsproben, andernfalls an Scheiben ron 2 -5 cm Stärke zu ermitteln, welche möglichst nahe der Bruchstelle quer zur Faserrichtung entnommen sind und den ganzen Prolenquerschnitt umfassen. Hie Trocknung der Proben behufs Ermittlung des Feuchtigkeitsgehaltes erfolgt im Trockenkasten bei $95-98^{\circ} \mathrm{C}$. Als Nomalfeuchtigkeitsgehalt, auf welchen Gewrchts- und Festigkeitszalılen zu reduzieren sind, ist derjenige von 15\%: anzunehmen.

C. Das spezifische Gewicht (Raungewicht) wrird entweder stereometrisch aus den Abmessungen sabuer bearbeiteter ribfreier Proben oder mittels Eintauchverfahrens nach der verdrängten Wassermenge emittelt. Wie Zahlenwerte für das spezifische Gewicht sind auf einen einheitlichen Feuchtigkeitsgehalt (15\%) unzurechnen.

D. Die Veränlerung des Rauminhaltes des Holzes durch S c h w in d e $\mathrm{n}$ u n d Qu elle n wird entweder unnittelljar mittels Eintauchverfahrens an Stücken beliehiger Form oder durch Berechnung aus ılen Längenänderungen prismatischer Proben senlirecht und tangential zu den Jahrlingen sowie in del Längsrichtung der Faser ermittelt, wobei gleichzeitig auch die Gewichtsänderungen der Probehölzer anzugeben sind.

E. Bezüglich der D a u e r l es $\mathrm{HI}$ olzes sind bestimmte Vorschläge für eine einheitliche Prüfung noch nicht festgesetzt. Nach den Vorschlägen von Prof. Ur. Tubeuf dürfte sich hiezu am besten die Infizierung der auf Dauer zu untersuchenden Hölzer mit dem lebenden Mycel des Hausschwammes und die Beohachtung der 
Zersetzungserscheinungen, die sich in der Verminterung des spezifisehen Gewiehtes des Holzes äußem, eignen.

IV. Betreffs der En tha hme der. Proben aus ganzen Stämmen wird zur Ermittlung von Durchschnittseigensehaften vorgeschlagen, einen $A$ bschuitt zur Ausformung der Biegeproben zwisehen 7 und 10 in 1 löhe vom Boden aus, die Proben zu den übrigen Versuchen ummittelbar ober- unil unterhalb der Biegeproben zu entnehmen. Zur Erprobung der Stämme auf V'erwendbarkeit zu Tragbalken und Stïtzen von bestinnter Länge soll die Mitte der Biegeproben tunlichst nit der Mitte der Gebrauchsstücke zusammenfallen. Bei Untersuchungen über den Einfluß der Hölıenlage der Probe an Stamm soll der unterste Abschnitt zur Emittlung der Druckfestigkeit und des spezifischen Gewichtes I,3 m über den Boden (Brusthöhe) gelegen sein, die weiteren Abschnitte in je $6 \mathrm{~m}$ Abstand dem Stamme entnonmen werden. Um die durehschnittliche Beschaffenheit des Holzes eines bestimmten Standortes festzustellen, sind mindestens 3 Stämme zur Untersuchung heranzuziehen.

§ 25. Im Nachstehenden geben wir num im A uszugedie Resulta $\mathrm{fe}$ jener Versuchsreihen, welche mit den eben zitierten Masehinen von den folgenden Autoren gewonnen wurden:

K a r l M i k o l a s c he k, Untersuchungen über die Elastizität und Festigkeit der wichtigsten Bau- und Nutzhölzer Böhmens. Mitteilungen aus dem forstlichen Versuchswesen Oesterreichs Band II, Heft I, Wien 1879.

II. J e n n y , Untersuchungen über die Festigkeit der Hölzer aus den Länderu der ungarischen Iírone. Budapest IS73.

Dr. IV. F. Ex n e r, Studien über das Rotbuchenholz. Wien I875.

Georg La uboek, die technische Verwentung des Ailanthus-Holzes mit besonderer Berücksichtigung des Wagenbaues. Mitteilungen des Technologisohen Gewerbe-1luseums Nr.62. I885.

Dr. E. H a r tig, Untersuchungen über den Einfluß der Fällungszeit auf die Dauerhaftigkeit des Fichtenholzes, ausgeführt an der Kigl. Sächs. Forstlichen Versuchsstation zu Tharandt und am Kigl. Sächs. Polytechnikum zu Dresden. I876.

L. T e tm a jer, Methoden und Resultate der Prüfung der schweizerischen Baulı̈łzer. Zürich I883 und Zürich 1896.

J. B a u s c h in ge r, Untersuchungen über die Elastizität und Festigkeit von Fichten- und Kiefern-Bauhölzem; Mitteilungen aus dem mechanisch-technischen Laboratorium der Ii. Technischen Hochschule in Hünchen, IS83 und 1887.

II. R u d e 1 o f f , Bericht über die in Auftrage des Ilerm Ministers für Landwirtschaft, Domänen und Forsten ausgeführten Holzuntersuchungen. Berlin 1889.

Dr. A. S e h w a p p a h, Untersuchungen äber Raungewicht und Uruckfestigkeit des Holzes wichtiger Waldbäume. I. Die lỉefer. Berlin 1897. - II. Fichte Weißtanne, Weymouthskiefer und Rotbuche. Berlin I898.

A. $\mathrm{H}$ a $\mathrm{d}$ e $\mathrm{k}$ und $\mathrm{G}$. J a $\mathrm{n} \mathrm{k}$ a , Untersuchungen über die Elastizität und Festigkeit der österr. Bauhölzer. I. Fichte Südtirols. Wien I900.

G. J a n k a , Untersuchungen über die Elastizität und Festigkeit der österr. Bauhölzer. II. Fichte von Nordtirol, vom Wienerwalde und Erzgebirge. Wien 1904 , und III.Fichte aus den Karpathen, aus dem Böhmerwalde, Ternovanerwalde und den Zentralalpen. Technische Qualität des Fichtenholzes im allgemeinen. Wien I909.

$\$ 26$. Die Versuche von M i k l a sehe k hatten den Zweck, die E I a s L iz it ät und Festigkeit der wichtigsten Bau- und Nulzhölzer Böhmens h i ısichtlich der Lagedes Holzes im Stam me selbst zu emitteln. Die Untersuchungen erstreckten sich auf $I 4$ verschiedene Holzarten. Von diesen 
Hölzern wurde vom untersten Teile sowie von jenem Teile des Stammes, der in einer gewissen Höhe über dem Stocke lag, und endlich rom Astholz je ein meterlanges Stück samt Rinde entnommen und der Untersuchung auf folgende Arten von Festigkeit unterzogen:

1. Zugfestigkeit in der Riclitung der Fasem,

2. Uruclifestigkeit in der Kichtung der Fasern,

3. Biegungsfestigkeit,

4. Torsionsfestigkeit,

5. Abscherungsfestigkeit somohl in der zu den Fasem parallelen als auch in emer darauf senkrechten Richtung.

Bei den ersten vier Festigkeitsarten wurden hestimmt: Die Elastizitätsgrenze sowie die Formveränderungen an derselben, der Elastizitätsmodul innerlralb der Elastizitätsgrenze, die Bruchgrenze und bei den Biegungs- und Torsionsversuchen auch die bleibenden Formveränderungen an derselben. Bei den Abscherversuchen konnte natürlich bloß die Bruchgrenze bestimmt werden.

Zur Erprobung des Holzes auf seine $\mathrm{Z} u \mathrm{~g}$ f estigkejt in der $\mathrm{F}$ a se $\mathrm{r}$ richtung wurden Probestücke ron rechteckigem Querschnitte gewählt. Die Probestücke waren sämtlich aus nahe der Nitte des Querschnittes gelegenen Teilen desselben entnommen. Il $\mathrm{ikol}$ a s $\mathrm{che} \mathrm{k}$ hat bei allen Festigkeitsuntersuchungen jeder einzelnen Holzart folgende Baunteile in Berücksichtigung gezogen: Untertrunm, Witteltrumm und Asthulz. Wir beschränken uns in Nachfolgenden auf die IViedergabe der hauptsächlichsten Versuchsresultate, das sind jener, welche sich auf das M it teltrum in beziehen.

Die Probelänge der T'ersuchsstücke hei den Z u g v e l's u c h e $\mathrm{n}$ betrug 17 Zentimeter. Die bei den W r u ck versuch e n verwendeten Probestïcke waren von prismatischer Form und zwar dem Würfel sehr genähert; die Höhe der Versuchsstücke betrug ca. 6 Zentimeter.

Zur Vornalime der B i g gu ng s versu c h e wurclen Probestüclie von rechteckigem Querschnit grewällt und rlieselben auf die Hochliante gestellt. Die Spannweite betrug 0,5 Meter der frei aufliegenden stäbe.

Die für die Torsions rersu che verwendeten Probestücke hatten einen lireisförmigen Querschnitt und waren mit quadratischen Köpfen versehen, mit welchen sie in die Maschine zentrisch eingepaßt wurden. Dic Länge der Probestüclie betrug 40 Zentimeter. Zur Bestimmung der Verdrehungen murde mur eine Faser beobachtet, was hier, wo die Formveränderungen regelmäBig siıd, ohne Becinträch tignmg der Genauigkeit geschehen konnte. Dem Bruche ging häufig eine bedeutende (bis 160 Grad) Terhehung voraus und trat nit dieser eine starke Verkürzung des stabes auf.

Bei den A l s c h e r ve r s u c he m wuden zylindrische Probestüclie von lireisförmigem guerschnitte verwendet, und zwar war der Durchmesser bei sämtlichen Stücken nahezu gleich (ca. 3,55 Zentimeter). Jelles Prohestück murde auf seine Scherfestigkeit somohl in der Faserrichtung als auch quer gegen dieselbe untersucht. (Siehe Tabelle IV, S. 393).

Aus diesen Tersuchsiesultaten, welche sich auf die Ergebnisse des Mitteltrumms') der einzelnen Holzarten beziehen, und aus jenen, welche $11 \mathrm{j} \mathrm{k}$ o l a s c h e $\mathrm{k}$ für das Lntertrumm und Astliolz gefunden hat, ließen sich folgende schlußresultate zusammenfassen:

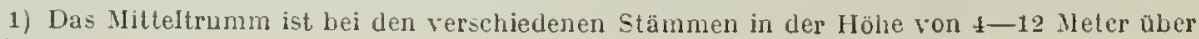
dem Stocke entnommen worden. 


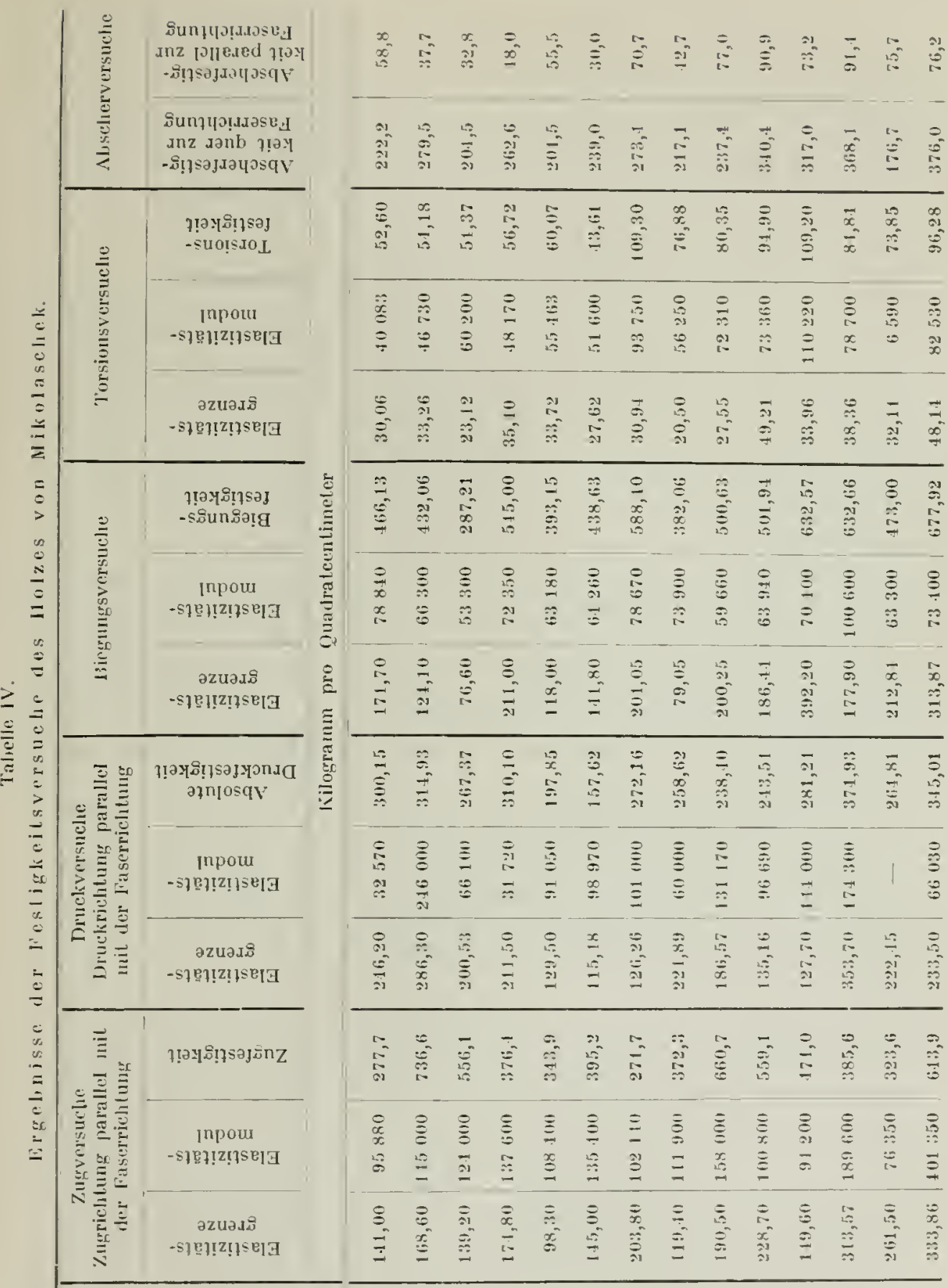<smiles>CCC</smiles>

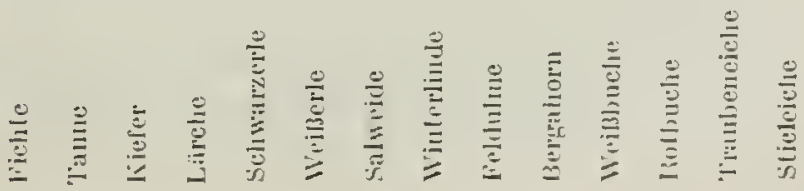


1. A u s d en Zugversuc he n: ,Die Zug-Elastizitätsgrenze zeigt sich im allgemeinen bei dem Untertrummholze höher als beim Nitteltrummholze und diese liegt in manchen Fällen sehr bedeutend höher als jene beim Astholz.

Die Elastizitätsgrenze für Zug liegt zirka zwiselsen 0,2 und 0,5 des Mertes der absoluten Zugfestigkeit (Bruchgrenze). Der Elastizitäts-Nodul zeigt sich bei allen Holzarten beim Nitteltrummholze am größten, beim Untertrummholze kleiner, jedoch in den meisten Fällen hier noch immer gröBer als beim Astholze.

Die absolute Zugfestigkeit (Bruchgrenze) zeigt sich dagegen hauptsächlich beim Unterholze größer als beim Vittełholze und Astholze.

Es stellt sich somit nach den Zugversuchen heraus, daß das Unterholz nicht nur eine größere Elastizität, sondern auch eine größere Festigkeit besitzt als das Mittelholz, welchem eine größere Steifheit zuliommt. In bezug auf die Festiglieit steht das Astholz dem Mittelholze nach, bezüglich der Elastizität dagegen hält es zwischen dem Unter- und Nittelholz die Nitte.

Der Bruch erfolgte bei den meisten Stäben nicht in e in em Quersehnitt, sondern in zwei oder mehreren von einander entfernt liegenden, die durch einen oder mehrere Längsrisse mit einander in Verbindung standen. Manchmal, namentlich bei den Nadelhölzern, war der Bruch sehr splitterig, nur bei wenigen war derselbe stumpr und kurzfaserig."

2. A us d e n D ruckrersuch e 11 :, Die Elastizitätsgrenze für Drucli stellt sich für die Mehrzahl der Hölzer beim Mitteholze höher als bein Lnterlıolze und beim Astholze häufig höher als heim Unter- und Mittelholze.

Die Zusammendrüekungen sind beim Unterholze kleiner als beim Mittelholze unrl diese wieder bei nahezu allen Holzarten kleiner als beim Astholze. Der Elastizitäts-Modul ist beim Unterholze bei rer Mehrzahl der Holzarten größer als beim Nittelholze, beim Astholze ist bezüglich dieses Wertes eine große Verschiedenheit zu konstatieren.

Die absolute Druekfestigkeit ist beim Unterholze nur wenig größer als beim Mittelholze, heim Astholze rlagegen größer als bei beiden ebengenamnten Arten. Es zeigt sich daher, daß die absolute Druckfestigkeit des Unterholzes wenig größer als jerue des Mittelholzes, hingegen jene des Astholzes am größten ist; dagegen ist das Unterholz steifer als das Vittelholz, während das Astholz mancher Sorten steifer, anderer Sorten wieder elastischer ist als das Jittel- und Unterholz derselben Baumgattung."

3. A us den Biegungsversuehen: „Nach denselben stellte sich die Elastizitätsgrenze für Biegung beim Unterholze höher als beim Vittelholze und jene beim Astholze höher als hei den beiden anderen Holzarten heraus. Sie liegt zirka bei 0,25 bis $0,50 \mathrm{der}^{\circ}$ Inanspruchnahme an der Bruchgrenze. Die Einbiegungen an derselben sind beim Unterholze am líleinsten, beim Astholze am größten. Der Elastizitätsmodul ist beim Astholze del meisten Holzarten kleiner als beim Unter- und Mittelholze und der Elastizitätsmodul dieser letzteren ist nahezu der gleiche; weiters ist die Biegungsfestigkeit beim Unterholze am kleinsten, beim Astholze am größten.

In bezug auf diese Festigkeit zeigt sicl dasAstholz am festesten, das Unterholz am wenigsten fest; bezüglich der Elastizität stellt sich gleich falls das Unterholz minder elastisch, also steifer, als das Mittelholz heraus, während das Astholz die größte Elastizität besitzt.“

4. A us d e n T orsions re r suc he n: ,Die Elastizitätsgrenze für Torsion liegt beim Astholze am höehsten, bein Mittelholze am tiefsten und befindet sich zirka bei $1 / 3$ bis $3 / 1$ der Inanspruelmahme des Materials an der Bruchgrenze. Die 
Verdrehungen sind beim Astholze ebenfalls am größten, beim Mittelholze cntweder größer als diese oder nahezu grleich jenen beim Unterholze. Der Elastizitätsmodul ist beim Nittelholze am klcinsten, bein Lnterholze teils größer, teils kleiner als beim Astholze. Die Torsionsfestigkeit ist beim Astholze am größten, heim Nittelholze am kleinsten. Es ist deshalb das Astholz an festesten, rlas Mittelholz am wenigsten fest, während mit Rücksicht auf rie Elastizitätsverhältnisse das Mittelholz am steifsten, Ast- und Unterholz sich aber in dieser Bezichung nahezu gleich verhalten."

5. A us den A bscherrersucben: „Die Festigkeit in der Richtung quer gegen die Fasern ist beim Astholz am kleinsten, beim Unterholz teils größer, teils kleiner als beim Mittelholze; in der Richtung der Fasern ist rke Festigheit bei der Mehrzahl der Holzarten beim Mittelholze größer als beim Ast- und Unterholze, welch letztere sich in dieser Beziehung nahezu gleich stellen."

Aus sämtlichen Versuchen von Mikolaschek läBt sich folgender Schluß ziehen: „Nimmt man speziell auf die Fest i g k it Rücksicht, so ereibt ,, sich nachstehende Reihe, wenn die größte Festigkeit vorangesetzt wird: Astholz, ,Unterholz, Nittelholz. In bezug auf E I a s t i z i tät, wenn die größte Elastizität ,,orausgesetzt wird: Astholz, Unterholz, Mittelholz, woraus das Schlußergebnis re,,sultiert, daß dem Holze von größerer Festigkeit a uch die ,größ ere Elastizität zuko m $\mathrm{m} \mathrm{t}^{\text {"6 }}$.

Endlich zeigt sich, daß wegen der großen Verschiedenheit der Werte der Elastizitäts- und Bluchgrenze, sowie der Mloduli für die verschiedenen Holzarten eine sehr große Zahl von V'ersuchen notwendig wäre, um entsprechende Vittelwerte aufstellen zu können.

$\$ 27$. Die Versuche J e n n y hatten den Zweck, die Elastizitäts- und Festigkeits-Eigenschaften der u $\mathrm{n}$ a $\mathbf{r}$ is c h e n Hölzer kennen zu lernen. Die Versuche erstreckten sich auf die Ermittlung der Zug-, Druck- und Abscherfestigkeit rer Buche, Tanne, Fichte und Lärche.

Eine Diskussion der Versuchsresultate wurde von dem Versuchsansteller unterlassen; von demselben wurden nur die nackten Ergebnisse der Messungen und Bestimmungen der Elastizitäts- und Festigkeitsgrößen angegeben.

Die 3 Holzarten Buche, Tame und Fichte wurden von dem Forstante Fuccine (ITroatien), Lärche und Fichte ron dem Forstamte Hradek (Nordkarpathen) eingesandt. Die erstgenannten Hölzer wurden in Frühjahr; die letztgenannten im Herbste gefällt. Das Alter dieser Hölzer war ziemlich das gleiche (120 .Jahre). Nebst diesen Versuchen hatte $\mathbf{J}$ e $\mathbf{n} \mathbf{n}$ y gleichzeitig noch an zwei Holzarten, nämlich an der Fichte und Tanne, aus Siebenbürgen, der Marmaros und den West- und Ostkarpathen stammend, dic Elastizität und Festigkeit erhoben, und zwar wieder in bezug auf Zug, Druck und Abscherung. Dicse Resultate aller dieser Untcrsuchungen hier in extenso anzuführen, würde zu viel Raum einnehmen, wir verweisen in lieser Beziehung auf die oben zitierte Quelle.

Nachdem wir es hier mit Resultaten zu tun haben, welche unter gleicharligen Verhältnissen und überdies in großer Anzahl von Probestïcken derselben 1Iolzart gewonnen wurden, so ist man berechtigt. Mittelwerte abzuleiten; diese sind in der nachstehenden Tabelle $V^{\top}$ (S. 396) wiedergegeben.

Hieraus gebt hervor, daß die Fichte aus Irroatien hinsichtlich der Zug- und Abscherfestigkeit den anderen ungarischen Fichtenhölzern iberlegen ist; dagegen hat das Siebenbürger Fichtenholz sowohl in bezug auf die Druck-als auch auf rie Abscherfestigkeit gegenüber den anderen Fichtenhölzern den Vorrang.

Das gleiche gilt ron dem kroatischen Tannenholz. Dasselbe ist hinsichtlich 
Tabelle V.

\begin{tabular}{|c|c|c|c|c|c|c|c|c|}
\hline \multicolumn{9}{|c|}{ Mlittelwerte der } \\
\hline \multirow[b]{2}{*}{ Provenienz } & \multirow[b]{2}{*}{ Holzart } & \multicolumn{3}{|c|}{$\begin{array}{l}\text { Zugversuche } \\
\text { // zur Faser }\end{array}$} & \multicolumn{3}{|c|}{$\begin{array}{c}\text { Druckversuche } \\
\text { // zur Faser }\end{array}$} & \multirow{2}{*}{$\begin{array}{l}\text { A b scher- } \\
\text { v e rsucho } \\
\text { // zur Faser } \\
\\
\end{array}$} \\
\hline & & 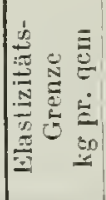 & 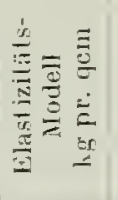 & 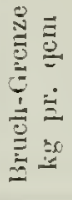 & $\mid \begin{array}{ll}0 \\
0 \\
0\end{array}$ & 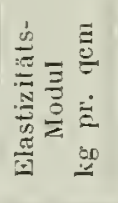 & 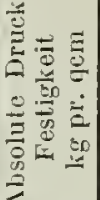 & \\
\hline Kroatien & $\begin{array}{l}\text { Buche } \\
\text { Tanne } \\
\text { Fichte }\end{array}$ & $\begin{array}{l}565 \\
369 \\
372\end{array}$ & $\begin{array}{l}122250 \\
115175 \\
117350\end{array}$ & $\begin{array}{l}813 \\
558 \\
596\end{array}$ & $\begin{array}{r}88 \\
119 \\
114\end{array}$ & $\begin{array}{l}83650 \\
67625 \\
77975\end{array}$ & $\begin{array}{l}391 \\
354 \\
337\end{array}$ & $\begin{array}{l}71,7 \\
39,2 \\
43,2\end{array}$ \\
\hline Nordkarpathen & $\begin{array}{l}\text { Lärche } \\
\text { Fichte }\end{array}$ & $\begin{array}{l}312 \\
288\end{array}$ & $\begin{array}{r}130820 \\
99967\end{array}$ & $\begin{array}{l}551 \\
436\end{array}$ & $\begin{array}{l}114 \\
133\end{array}$ & $\begin{array}{l}88933 \\
78817\end{array}$ & $\begin{array}{l}446 \\
346\end{array}$ & $\begin{array}{l}55,8 \\
34,7\end{array}$ \\
\hline $\begin{array}{l}\text { Siebenbürgen } \\
\text { Marmaros } \\
\text { Ost- und West- } \\
\text { karpathen }\end{array}$ & $\begin{array}{l}\text { Fichte } \\
\text { Tanne }\end{array}$ & $\begin{array}{l}310 \\
336\end{array}$ & $\begin{array}{l}115392 \\
115531\end{array}$ & $\begin{array}{l}494 \\
426\end{array}$ & $\begin{array}{l}220 \\
209\end{array}$ & $\begin{array}{l}127565 \\
104970\end{array}$ & $\begin{array}{l}363 \\
357\end{array}$ & $\begin{array}{l}42,0 \\
40,2\end{array}$ \\
\hline
\end{tabular}

der Zugfestigkeit jenem aus Siebenbürgen vorzuziehen, während letzteres hinsichtlich der Druckfestigkeit dem kroatischen Tannenholze überlegen ist. Die Abscherfestigkeit dieser beiden Tannenhölzer liann nahezu als übereinstimmend angesehen werden.

Lie aus verschiedenen Gegenden Ungams eingesandten Fic h t en höl z e r würden in bezug auf ihre Zugfestigkeit wie folgt beurteilt werden können:

Dic größte Z u g f estigke it kommt dem kroatischen Fichtenbolze zu, in zweiter Linie steht jenes aus Siebenbürgen, während das Fichtenholz aus den Nordkarpathen das mindestwertige ist;

die größte Druckfestigkeit zeigte hingegen das aus Sicbenbürgen stammende Fichtenholz, minderwertig erscleint jenes aus den Nordkarpathen, und in letzter Fieile steht das aus Kroatien stammende Fichtenholz. -

Die A b s c her festigke it des Fichtenholzes aus den Nordkarpathen steht gegenüber den beiden anderen Fichtenhölzern beträchtlich zurück, während diesen Hölzem nahezı die gleiche Abscherfestigkeit zuliommt.

W'ürde man die aus den verschiedenen Gegenden Ungarns eingesandten Fichtenhölzer nut den Tamnenhölzern hinsichtlich ihrer Festigkeit vergleichen, so gelangte manz zu dem Resultate, daß zwischen diesen Holzarten, also zwischen dem ungar. Fichten- und denı ungar. Tamnenholze, nur ein sehr geringer Untersehied besteht. Fichtenholz hat eine etwas größere Zugfestigkeit (ca. 3,5\%o) als das Tannenholz, dieses aber eine größere Druclifestiglieit (ca. 2\%) als das Fichtenholz: hingegen ist die Abscherfestigkeit beider Holzgattungen gleich.

Was das aus den Nordkarpathen stammende L ä r c he n hol z betrifft, so nub hervorgehulen werden, daß dieses hinsichtlich seiner Druck- und Abscherfestigkeit den säntlichen untersuchten Fichten- und Tannenhölzem voransteht; in bezug auf die Zugfestigkeit des Lärchenholzes jedoch geht hervor, daf dieses, wenn auch niclit bedentend, hinter rler Zugfestigkeit des kroatisclien Fichten- und Tannenholzes zurückbleibt. 
Dagegen übertrifft das $\mathrm{B}$ u $\mathrm{e}$ h e $\mathrm{ul}_{\mathrm{h}} \mathrm{ol}$ z hinsichtlich dey Zug- und Abscherfestigkeit alle untersuchten Hölzer, hinsichtich seiner Druckfestigreit wiml ulieses voon dem Lärchenholze überragt.

Ob diese Untersehiede vorzugsweise den verschiedenen Bodenverhältnisspñ zuzuschreiben sind, kann zwar nit Grund vermutet, nicht aher hestimnt behauptet werden, schon deshalb nicht, weil die Fällumgszeit der Hölzer eine versehieden war und der Feuchtiglieitsgehalt der Probestuclie leider g a r u i c h t in Betracht gezogen wurde.

\$98. Ueber die rü ckwirkende Festigkeit des Potbur hronho lzes hat W. F. Exn er in semen "Studien über das Rotbuchenhnlz" weitgehende Versuche angestellt, welche ren Zweck hatten, diese Festigkeit in Berirhung auf den Einfluß der Höhenlage des Holzes in Stanme selbst und ferner jenen Einfhß auf die Festigkeit kennen zu lemen, welehen die nach den 4 Haupt-Weltgegrndeu verschiedenen klimatischen Verhältnisse nehmen. Die Ex n e r sehen Versuche, welche sich u. a. auch auf die Ermitthung des spezifischen Grün- und Trockengewichtes, sowie auf die Schwindung des Rotbuchenholzes erstreckten, wurlen an e in e $r$ in der Nähe von Vorder-Hainbach (Wiener-IVald) gefällten 130jährigen Rotbuehe vorgenommen. Die zur Erprobung bestinmten Zỵlinder hatten rinen Durchmesser von $40 \mathrm{~mm}$ und eine Länge von $80 \mathrm{~mm}$; dieselben wurden gleich altem Holze entnommen, d. h. es gehörte jedem Probezylinder ein bestimmter Jahrring des Holzes an. So wurden unzweifelhaft rlem Splintholze angehörige Probezylinder (mit a bezeichnet) gewonnen, bei denen der gegerl die Außenseite des Baumes gelegene Teil der Probezylinder mit dem im Jahre 1869 entstandenen Ilolze begann, und somit gehörten diese Zylinder gleichalterigem, unter gleichen klimatischen Verlältnissen entstandenem Holze an. Die zweite Serie von Probezylindern (mit b bezeichnet) wurde aus jenem Teile des Stammes entnommen, bei welchen der 42. Jahrring als Anfangspunkt für die Gewinnung der Probezylinder diente, also aus jenem Holze bestand, welches nicht später als 42 Jahre vor der Fällung entstanılen war. Auch diese Zylinder gehörten noch dem Splintholze an. Die dritte Sorte von Probezylindern endlich (nit $\&$ bezeichnet) wurde jenem Teile des Stammquerschnites entnonmen, bei welchem der S0. Jahrring, von der Außenseite des Baumes gezählt, begann. Die Probezylinder e enthielten häufig schon zum Teile dentlich erlienubares Kiernholz.

Der ganze Schaft der Potbuche wurde in Stücke von ? Mletern Länge zerschnitten und so ergaben sich 10 selır regehmäßig zylindrisch gestaltete Abschnitte, welche mit römischen Ziffern bezeichnet wurden. Fon jeder Walze wurde an deren unterem Teile eine Scheibe herausgenommen und zur Anfertigung der Prohezylinder benützt.

Hiezu muß bemerkt werden, daß das mittlere spezifische Gewicht des grünen (frischen) Stammholzes zu 0,945 gefunden wurde, während das mittlere spezifische Troekengewicht des Stammes zu 0,694 angegeben wird.

Die nachstehende Tabelle VI (\$.398) gilut eine Lebersicht der Lrucksestigkeit pro qon jener zur Bestimmmg des Troekengewiehtes verwendeten Probezylinder.

Aus dieser Uebersicht geht hervor, daß die geringsten Druckfestigkeiten die Probezylinder $11^{\circ} \mathrm{Na}$ und $11^{\circ}$ Oa nit 496 hezw. $510 \mathrm{~kg}$. die liöchste der Zylinder II Oa nit 685 Kïlogramm pro y jem zeigten. Eine Relation zwischen der Druckfestigkeit und der Höhe im Baume konnte nicht erkannt werden. Der Vergleich zwischen den a-, b- und c-Ringen der Scheibe ergibt, daß das der Bammachse zunächst liegende 
Tabelle VI.

\begin{tabular}{|c|c|c|c|c|c|c|c|c|c|c|c|c|c|c|c|c|c|}
\hline \multicolumn{2}{|c|}{ Rotbuche } & \multicolumn{12}{|c|}{ Rückwirkende Festigkeit in $\mathrm{kg}$ pr. qcm } & \multicolumn{4}{|c|}{ Mittelwerte } \\
\hline \multirow{2}{*}{ 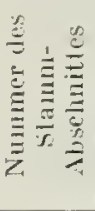 } & \multirow{2}{*}{ 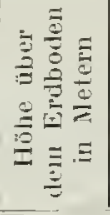 } & \multicolumn{3}{|c|}{ Nord } & \multicolumn{3}{|c|}{ Ost } & \multicolumn{3}{|c|}{ Süd } & \multicolumn{3}{|c|}{ West } & \multirow{2}{*}{ 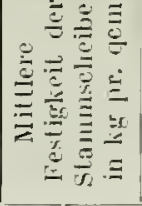 } & \multicolumn{3}{|c|}{$\begin{array}{l}\text { Mitllere Festigkeit } \\
\text { der Probe-Zylinder } \\
\text { in lig pr. qem }\end{array}$} \\
\hline & & a & b & c & a & b & c & a & b & $\mathrm{e}$ & a & b & c & & a & b & c \\
\hline 1 & 0,5 & .547 & 518 & 597 & 601 & 575 & 591 & 613 & 589 & 615 & 627 & 616 & 643 & 594 & 597 & 575 & 612 \\
\hline II & 2,5 & 602 & 571 & 630 & 685 & - & 633 & 582 & 592 & $6 \pm 2$ & 569 & $58 t$ & 583 & 607 & 61 & 583 & 622 \\
\hline III & 4,5 & 643 & 618 & - & - & 605 & -1 & 570 & 608 & 595 & 594 & $5 \pm 8$ & 613 & 599 & 602 & 595 & 604 \\
\hline IV & 6,5 & 496 & - & - & 510 & 525 & 586 & 547 & - & - & 616 & 588 & 607 & 559 & 512 & 557 & 597 \\
\hline I & 8,5 & 604 & 572 & 518 & 593 & 588 & - & 603 & 567 & - & - & 565 & 539 & 572 & 599 & 573 & 529 \\
\hline $\mathrm{VI}$ & 10,5 & 554 & 568 & - & 589 & 580 & -1 & 663 & 533 & - & 564 & 587 & - & 580 & 593 & 567 & - \\
\hline I] & 12,5 & 593 & 589 & - & 592 & - & -1 & 560 & 553 & - & 611 & - & -- & 583 & 589 & 571 & - \\
\hline$V[]]$ & 14,5 & 568 & 571 & - & -1 & 592 & - & - & - & - & 553 & 589 & - & 575 & 561 & 584 & - \\
\hline IX & 16,5 & 560 & - & - & 588 & $5+7$ & - & 525 & - & - & 561 & 518 & - & 550 & 584 & 533 & - \\
\hline $\mathrm{X}$ & 18,5 & 609 & - & - & 615 & - & -1 & 570 & - & - & 611 & - & - & 601 & 601 & - & - \\
\hline $\mathrm{XI}$ & 20,5 & 1556 & - & -1 & 550 & -1 & -1 & $1-1$ & $1-1$ & -1 & 533 & $1-1$ & -1 & 546 & 546 & - & - \\
\hline
\end{tabular}

Holz die höchste rückwirkende Festigkeit zeigte, die geringste zeigte das der Querschnittslage b entnommene Holz, während das äußerste Splintholz hinsichtlich seiner rückwirkenden Festigkeit in der Mitte, richtiger näher dem Werte für das Kernholz liegt. Auffallend ist enrlich, daß die niedrigste rückwirkende Festigkeit bei der höchsten Stelle an den einzelnen Holzringen bemerkt wurde. Da dieses Sinken ganz unvermittelt auftrat und dafür ein plausibler Grund auch nicht gefunden werden kann, im Gegenteil die hier nicht weiter angeführten hohen Ziffern für das Ast- und Wijfelholz der Annahme, daß die Festigkeit mit der Höhe abnimmt, widersprechen, muß wohl diese Erscheinung einen zufälligen Zusammentreffen nicht bekanuter Umstände zugeschrieben werden.

In Beziehung auf die Bewegung der rïckwirkenden Festigkeit hinsichtlich der Lage des Holzes nach den WVeltgegenden wurde gefunden, daß das Vaximum der Festigkeit gegen Osten, eine ihı zunächst stchende gegen Westen und eine minimale gegen Süden lag, doch kann auch dieses Datum nicht Anspruch darauf machen, zu weiteren Schlüssen zu berechtigen.

Wichtiger ist die bei dem Bruche rer einzelnen Zylinder beobachtete Erscheinung, daß diese in der Richtung der llarkstralılen eine bedeutend höhere Festigkeit zeigen, als im Sinne der Jahrringe. Die sämtlichen Probezylinder sind nämlich immer so gebrochen, daß die herausgedrückten Holzteile in kles Richtung der kurzen Achse der Querschnitts-Eilinie, also in der Richtung der Sehne zu den Jahrringen heraustreten.

Bezüglich der $\mathbf{r}$ ü $\mathrm{k}$ w $\mathrm{rkenden} \mathrm{Festigkeit} \mathrm{des} \mathrm{in} \mathrm{nevester} \mathrm{Zeit} \mathrm{vielfach}$ (namentlich im Schiffua) in Anwendung kommenden Te a k h o zes geben wir im nachslehenden die Resultate ${ }^{1}$ ), welche für die Druckfestigkeit in k. k. See-Arsenal zu Pola gewonnen wurden. Zur Untersuchung gelanglen zweierlei Arten des Tealiholzes, näulich solches aus Java und aus Indien (Feslland). Die Probestücke waren würfelfömig bearbeitet, von 25 Millimeter, resp. 100 .lillineter kiantenlänge.

Als Nitlelwerte ergeben sich für die Druckfestigkeiten pr. qen:

F ü r Tealiholz a us Ja $\mathrm{ra}$ :

senkrecht zur Faseo $182 \mathrm{~kg}$, paralle] zur Faser $430 \mathrm{~kg}$ bei Prohestücken von 25 Millineler Iiantenlänge ;

senkrecht zur Faser $133 \mathrm{~kg}$, parallel zur Faser $354 \mathrm{~kg}$ bei Probestücken von 100 Mlilimeter liantenlängre; 1885.

1) Sielse Mitteilungen des Technologischen Gewerbe-Mtuseums in Wien Nr.61. Jahrgang 
fur ind isehes Teaklo tz:

senkrecht zur Fasel $240 \mathrm{~kg}$, parallel zur Faser $196^{\circ} \mathrm{kg}$ bei 25 Millimeter-Probestueken; senkrechl zur faser $151 \mathrm{~kg}$, parallel zur laser $38 ;$ liqf lud 100 .llillmeter-Probestücken.

Hieraus geht hervor, daß das javanische Teakloolz gugen da indisehe in der Druclifestigkeit senkrteht zur Faser un 9-13\%o zurūcksteht. Die Lintersuchungen des spezifischen Crewiclites, des llargehalles und I-chtngehaltes haben folgendes ergeben:

für Tealilolz a us I a va: spezifisches Gewicht 0,6884 . llarzgehalt $\quad 11,25 \% 0$. Aseliengehalt $\quad 1,15$,

far Teaklolz a us Indien: spezilinches Gewielıt Harrerelatt Asehengeliall
0,697

$11,29^{\circ}$. 1,28,

Aus dienen Resultaten ergibt $-i c h$, da $B$ die beiden Holzgattungen in hezug auf spezifisches Gewicht, Harz- und Asehengehall als nalezu gleichwertig zu betrachtes sind.

Hier tarf wohl ateh an jene Mitleilnng erinnert werden, die wir aber mehrere der wiehligsten japan isehe n $110 \mathrm{lza}$ a ten an anderer slelle machten "), in der auch einige Zahlen bezüglich der rückwirkenden Festigkeit enthalten sind.

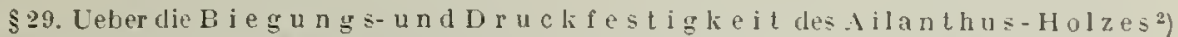
(Götterbaum), untersucht ron Ingenieur G. L a u b o e $\mathrm{k}$, liegen die nachstehenden Daten vor.

Der zur Untersuclung verwendete Stammabsehnilt zejgle ein Alter von 26 Jahren (Provenienz lirain). Das spezifisehe Gewicht des Holzes wulde mit 0,69 erhoben. Zur Ermitlung der Festigkeits-Eigenschaften dienten in ganzen 22 1'robestũcke.

\section{a) Druckifestigliejt.}

Da es interessant ist, die Festigkeit des Holzes sowohl als auch zu den Fasern kennen zu lernen, so wurde bei beiden Festigkits-Arten daraut Rückicht genommen. Ueber die Gewinnung der Versuchsstüelie sel hier folgendes bemerkt:

Dic Zylinder, welehe der Druekprobe // zu den Fasern unlerzogen wurden, wurden derart aus einer entsprechend der Zylinderhōhe dimensionierten Stanmseheibe gewonnen, daß jeder derselben den 15. Jahresring in seiner Mitte enthielt. Der Durehmesser der Zylinder betrug 35 Millimeter.

Sodann wurden aus der nächstfolgenden Stanmseheibe, welehe als Dicke den Durehmesser der Zylinder enthielt, sechs Zylinder gewonnen, welche 1 zu den Jahresringen der Druckprobe unterzogen $\pi u$ ulen. Dieselben wurden-aus der Stammscheibe in der Weise gesehnitten, la $B$ die Aehse des Zylinders als Radius des Baunstammes aufzufassen ist und deslalb kürzer angefertigt werden mußten, da eine Höhe derselben von 100 Millimeter aus dem Grunde anzulāssig war, als die Gruntflāehen der Zylinder sowohl nicht als ,völlig frei vom splint", als andererseits, ,vom liern" hälten bezeichnet werden kōnnen.

Die Querschnittsfläehe in der halben Hōhe des Zylinders enthielt den 15. Jahresring.

Auf liese Weise wurde erreicht, daß die zur Untersuchung gelangten Probestüche möglichst gleichalterigen Holze angehörten, welcher Lmstand gewiß nieht außer acht zu lassen ist, da bekannt ist, daß die Lage des Holzes im Stanme eine V'erschiedenheit der teehnisehen Eigensehaften des Holzes zeigrt.

Die Versuchsstäche wurden einer möglichst genauen Bearbeitung unterzogen und die Versuche ausgedehnt auf die Ermittlung der Druckfestigkeit // und I zur Faser.

Die Art der Zerstorung bestand in einem Ineinanderschieben der Fasern. Es biluet sich ein sogenannter Wulst, dessen Lage abhängig ist ron der inneren Beselaffenlteit des liolzes, und somit von lokalen Verhältnissen beeinflußt wird. Da die Versuchsstücke ein āußerlich vollkommen gleichartig gestaltetes Material, respektive gleiche Strulitur zeigten, also z. B. Aeste oder dergleichen njeht vorhanden waren, so traf die Bruchstelle bui allen Probestueken ziemlieh nahe der Milte der Zylinderlöhe ein.

Bei forlgesetzter Steigerung der Belastung, und zwar hei jenen Versuchsolucken, welche

zu den Fasern der Belastung unterworfen wurlen, zeigt sich nebst der Verschiebung der Jahresringe ein keilförmig gestalteter liörper, weleher an jene Form von deformierten Prüfungsobjekten erinnert, wie solche die küntlichen und natürlichen Bausleire zeigen.

Jene Zylinder, welehe /i zu den Fasern gedrückt wurden, zejgrtur nach der Deformation eine parallele Verschiebung ilurer Endflähen und zufolge desin eine einfach-ouler zuweilen auch doppeltgekrummte Linie ats liontur, welche lort am weitesten ausgebauclit ist, wo die Jahresringe die größte Breite besitzen.

DieBelastungen erfolgen innerhalb bestimmter Grenzen, wobei stet- die jeweilige Zusammendrūckung des Probestuckes gemessen wurde, um dic permanente und tastische Dehmung, respektive konpression (Verkürzung) zu ermitteh. Vach jedesmaliger Belastung erfolgte die Entlastung und wurde die permanente Zusammendrūckung angegeben.

1) Japans Holzinduatrie von Prof. W. F. Ex n er in der ,Oesterreichisehen Monatsschrift für den Orient", 7 . Jahrgang, 1881, Xr. 4. und 5, Beilaren.

2) Siehe Mitteilungen des Technologisehen Gewerbe-Museums in Wien, Or. 62 Jahrgang 1885. 
Die auf den Quadratzentimeter reduzierte Belastung, wei welcher der Bruch eintrat, (Druckfestigkeit) ergab:

1. // zu den Fasern 652 Kilogramm per Quadrat-Zentimeter (im Vittel):

2. I zu den Fasern 316 Kilogramm per Quadrat-Zentimeter (im Mittel), woraus hervorgeht, daß das Holz // zu den Fasern in Anspruch genommen, zirka das doppelte zu tragen vernag, gegenüber dem in darauf senkrechter Richtung beanspruchten Holze.

Es ergab sich der Ëlastizitāts-Modul

$$
\begin{aligned}
& \varepsilon=721,76 / / \text { zur Faser, } \\
& \varepsilon=50,02 \text { I }, ",
\end{aligned}
$$

Die Elastiziläts-Grenze:

E lag bei 538 Kilogranm per Quadrat-Zentimeter // zur Faser,

E " "77

Die bedeutenden Differenzen zwischen der "Beanspruchung" des Holzes in der Richtung der Jahresringe und in jener senkrecht zu diesen dürfen nicht überraschen, um so mehr, ats ja das innere Gefüge der Hölzer darauf hinweist, daß las Hołz ałs ein in der Hauptsache aus Längsfasern zusammengesetzter K̄örper betrachtet werden muß und bekanntermaßen seine größeren Festigkeits-Eigenschaften zeigt in der Beanspruchung durch eine Kraft parallel dieser Richtung.

b) Biegungsfestigkeit.

Zur Ermitlung der Biegungsfestigkeit wurden im ganzen sieben Versuchsstücke verwendet, wetche einen quadratischen Querschnitt von 30 auf 30 llillimeter zeigten, bei einer Stablãnge Von 300 Miltimeter. Die Stützweite der Stăbe betrug 250 Millimeter.

Einzeine Versuche wurden derart ausgefüht, da $\beta$ die Biegung des Stabes //zu den Fasern crfolgte, während bei drei Versuchen die Biegung des Stabes 1 zur Richtung der Fasern vorgenommen wurde.

Betreffs der Gewinnung der Stäbe aus dem Versuchsstamn sei hier mitgeteilt, daß die Mitte derselben gleichfalls wie alle anderen Versuchsstücke den 15. Jahresring enthielten, also aus den gleichalterigen Teilen des Stammes entnommen wurden. Die Zerstörung der Versuchsstücke erfolgte ausnahmslos durch das Reißen der gespannten Fasern. An den Stützpunkten des Stabes und dem Angriffspunkt der liraft waren nur geringe Kompressionen des Hotzes bemerkbar. Unmittelbar vor dem Eintreten des Bruches war ein mehr oder weniger wahrnehmbares Reißen der gespannten Fasern hörbar.

Aus den Versuchs-Ergebnissen folgten nachstehende Mittelwerte:

B eanspruchung//zur F a ser:

Biegungsfestigkeit $\partial_{0}=118+$ Kilogramm per Quadrat-Zentineter; elastische Biegungsspannung $\partial_{e}=973$ Kilogramm per Quadrat-Zentimeter;

Elastizităts-Modul $\Xi=89840$ Kilogramm pel Quadrat-Zentimeter.

Beanspruchung 1 zur Faser:

$$
\begin{array}{rrr}
\delta 0 & =1144 & \text { Kilogramm, } \\
\delta \Xi= & 972 & , " \\
\Xi & =84070 \quad, "
\end{array}
$$

Der Voltstândigkeit halber sei hier bemerkt, daß der Feu c ht i g k e i $\mathrm{t}$ s g r a d der zur Untersuchung gebrachten Probestücke sich mit 10,2\% ergab. Die Ermittlung des Wassergehaltes erfolgte dureh Austrocknung mehrerer Versuchsstücke während so langer Zeit, bis eine Gewichts-Abnahme infolge der Trocknung nicht mehr bemerkbar wurde.

Da es sich bei der Durehführung obiger Versuche darum handełte, ob das Ailantluusholz dem Eschenholz in bezug auf Festigkeit etc. gleichsteht, so soll hier noch folgende kurze Betrachtung ihren Platz finden.

Das Schwind- und Quellmaß der beiden Hölzer ist nahezu ubereinstimmend, weshalb nach dieser Richtung hin die beiden Hölzer als gleichwertig betrachtet werden können.

Die Angaben mehrerer Autoren über die Biegungsfestigkeit des Eschenholzes varieren zwischen 705 und 1025 lilogramm, im Mittel also 865 Kilogramm, während $\mathrm{N}$ ö $\mathrm{r}$ d I i g e r die Biegungsfestigkeit der Esche zu $83+$ Kilogramm angibt. Die gefundene mittlere B i e gungsfestigkeit des Ailanthushotzes ergab sich zu 1164 filogramm per qcm, ist somit um 27,4\% g r ö $B$ e r als jene des Eschenholzes.

Angaben uber die Druckfestigke it les Eschenholzes sind nicht bekannt, aus welchen Grunde ein Vergleich der beiden in Rede stehenden Hölzer nach dieser Richtung nicht geführt werden kann. Immerhin weisen die von uns gefundenen ziemtich großen Werte darauf hin, daß das Ailanthusholz auch in bezug auf Druckfestiglieit kaum gegenüber den Eschenholze zurückstehen dürite.

Aus den gewonnenen Resultaten konnte sohin mit Sicherheit geschlossen werden, daß das Ailanthusholz zufolge seiner technischen Eigenschaften i m a $11 \mathrm{~g}$ e m e in e $\mathrm{n}$ m in $\mathrm{d}$ stens als gleichwertig, in einzelnen Fällen sogar als relativ besser wie Esctien holz bezeichnet werden muß.

$\$ 30$. Ueber den Einflu 13 der Fällungszeit a $\mathrm{f}$ die Da u erhaftigkeit des Fichtenholzes hat Prof. Dr. E. Hartig Unter- 
suchungen durchgeführt, welche zur Bcantwortung der Frage: .. In welchen Betrage vermindert sich die Festigke it der zu verschiedenen Jahreszeiten gefällten Hölzer beim Liegen in freiem Sandboden?.. führten.

Das Versuchsmaterial bildeten zwci Reihen von Stammstücken, deren cine von der im Jahre 1868 erfolgten Fällung an in einen trockenen Sammlungsraum der K. Forstakademic in Tharandt aufbewahrt worden war und deren andere aus Schwellstücken bestand, welche während eines Zeitraumes von 6 Jahren aufrecht stehend und bis zur oberen Fläche eingegraben in freiem Sandboden gesteckt hatten, nach ihrer Aushcbung jedoch auch in lufttrockenen Zustand übergeführt worden waren. Dic Probestüclie der crsten Reilic erhiclten die Bezcichnung "Luftholz", die der zweiten Reihe ,Faulholz“. Für jeden Fällungsmonat standen 4 Probestücke zur Verfügung und außerdem noch einige Stücke zur Vornahme von Torversuchen. Von

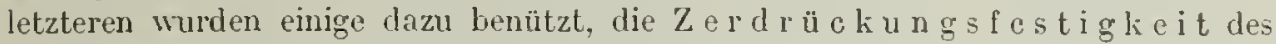
Luftholzes und des Faulholzes in der Richtung des Faserlaufes zu ermitteln. Es crgab sich hiebei die Zerdrückungsfestigkeit des Faulholzes zu $65 \mathrm{~kg}$ pro qcm, des Luftholzes zu $500 \mathrm{~kg}$ pro qcm Querschnitt. Durch sechsjähriges Liegen in freiem Sande hat sich sonach die Zerdrücliungsfestigkeit des Fichtenlıolzes un $87 \%$ des ursprünglichen IFertes vermindert. Das spezifische Gewicht betrug beim Faulholz 0,357, beim Luftholz 0,579, war also beim Faulholz um 37,3\% geringer als bcim Luftholz.

Von der Festigkeitsprüfung der g a n z e n Holzstücke mußte wegen der schon vorgeschrittenen Zerstörung der Faulholzstüclie abgesehen werden; es wurden viclmehr kleinere Probestücke in Zylinderform von $50 \mathrm{~mm}$ Durchmesser und cbcnsogroßer Höhe ausgeformt und diese durch Schlagproben auf ihre Festigkeit untersucht. Der Schlagapparat bestand aus einer gußeisernen Chabotte mit Stahlamboß von zusammen $258,84 \mathrm{~kg}$ und cinem Gestell, in welchem ein gußeisernes Schlaggewicht bequem auf bestinmte Höhe gehoben und plötzlich herabfallen gelassen werden konnte. Als angemessenstes Schlaggewicht für die Versuche ergab sich dasselbe zu $48.81 \mathrm{~kg}$ bei einer Fallhöhe von 0,375 .Ieter. Bei Anwendung desselben führten nänlich 2-15 Schläge beim Faulholz und 10-35 Schläge beim Luftholz zur völligen Zerstörung. Für die Vergleichung der Viderstandsfähigheit von Faulholz und Luftholz wurden die nachfolgenden Momente benützt:

1. die Zahł der Schläge bis zum Eintritt des ersten Langrisses;

2. die Zahl der Schläge bis zur vollen Zerstörung:

3. die mittlere Verkürzung des Probestückes pro Schlag;;

4. der hieraus zu berechnende Widerstand des Materiales gegen bleibende Formänderung, bezogen auf die Flächencinheit und

5. das totale Arbeitsquantum, welches zur gänzlichen Zerstörung erforderlich war.

Nach Beschaffenheit der Beobachtungsreihen erschien cs nicht ratsam, irgend eines dieser Nomente in der Weise zu benützen, daß der Eintritt der Zerstörung als Iŕriterium angesehen würde, denn es war besonders bei dem Luftholz äußerst schwierig anzugeben, nach welchem Schlage die Zerstörung als eingetreten anzuseluen war; dagegen schien der Beginn der Zerstörung an der rascheren Zunahme der Verkürzung des Probestückes ziemlich sicher erkennbar. Deshalb wurde für je zwei zusammengehörige Paare von Probestücken zunächst für das Faulholz aus der Zahl der Schläge und der totalen Verliürzung für den bezeichneten Noment der mittłere Widerstand pro qcm Querschnitt (Stoßfestigkeit $\mathrm{I}_{0}$ ) berechuet, sodann für das Luftholz unter Berücksichtigung der gleichen Zahıl ron Schlägen dieselbe Rechmung durchgefülırt (Stoßfestigheit des Luftholzes $\mathrm{l}_{1}$ j; ferner wurde der Quotient $\frac{\mathrm{h}_{0}}{\mathrm{~L}_{\mathrm{I}}}$ gebildet, der um 
su näher an die Einheit fällt, je widerstandsfähiger das Holz sich beim Liegen im freien Sand erwiesen lat. Säntliclie zur Untersuchung gelangten Zylinder waren srorgfältig genessen und gewrgen worden, in der Absicht, das spezifische Gewicht zu ermitteh; es ergah sich als Durchschnittswert für das Faulholz 0,469, für das Luftholz 0,537. Auch der Wassergehalt der Probestïcke wurde bestimmt, wobei sich als Ilittelwert für das Faulholz $13,1^{\circ}$, für das Luftholz 14,1\% ergab.

In der nachfolgenden Tabelle VH sind die für die einzelnen Fällungsmonate erzielten Durchschittswerte des Wilerstandes (Stoßfestigkeit) in lig pro qcm enthalten.

Tabelle VII.

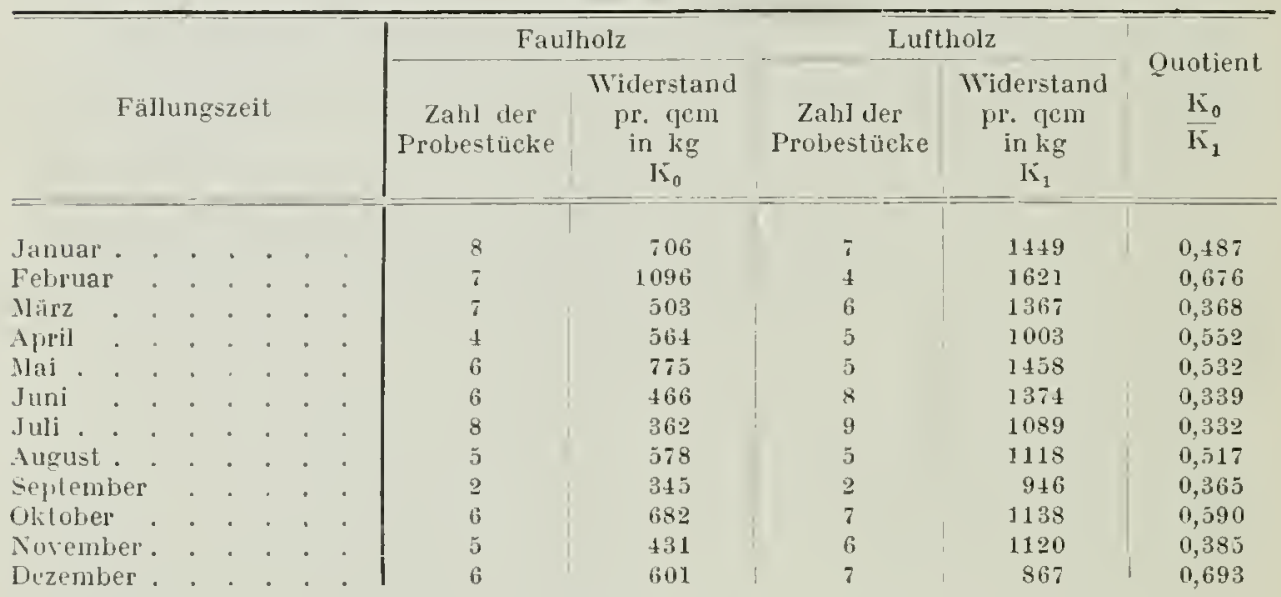

Die in der letzten Iiolumne enthaltenen Zahlen stellen nun leider nicht, wie ler Versuchsansteller nach der aufgewendeten Sorgfalt erwartet hatte, ein lilares Gesetz unzweifelhaft dar; wohl fällt der niedrigste Wert rer verhältnismäBigen Festiglieit $(0,332)$ auf cinen Sommermonat (Juli), der höchste Wert $(0,693)$ anf einen Winternonat (Uezember); auch ist der Durchschnittswert der für die Frühjahrs- und Sommermonate (April bis Septemher) geltenden Zahlen um 17,6 o nierlriger als rlerjenige für die IJerbst- und Wintermonate (Okitober bis März), nämlich 0,439 gegen 0,533; trotzdem kann aher aus diesen V'ersuche nicht mit Bestimmtheit hehauptet werden, daß in bezıg auf die technischen Eigenschaften und die Danerhaftigkeit der Hölzer die Vinterfällung vor der Sommerfällung den Torzug verdient. Bisher sind auch alle in dieser Richtung angestellten Versuche negativ ausgefallen, so daß es den Anschein hat, daß lie Fällungszeit keinen Einflu $B$ a u $f$ die te c lu i seluen E i gen sehaften des Holzes ausïbe, sofern nur das Holz von der Fällung bis zur Vemendung sachgenäß behandelt, vor allem gut getrocknet wurde.

S31. Tetm a je r in Zürich lıat eine Peihe von Untersuchungen der Elastizitäts- un! Festiglieits-T erhältnisse der schweizerischen Bauhölzer durchgefülırt. Für die Aufstellung des Versuchsprogrammes waren folgende Gesichtspunkte maßgebend: Einerseits sollten hiemit jene Festigkeits-Koeffizienten festgestellt werden, welche zur Dinensionierung bei Holzkonstrulitionen erforderlich sind, anderseits abor sollten in möglichst eingehendler und unfassender Weise die Festigkeitsverhältnisse der verschiedenen Teile des Stammes unl soweit als möglich auch ihre Abhängigkeit von lilimatischen und geognostischen V'erhältnissen klargelegt werden.

Zur Emittelung der Fostigkeitsverlıältnisse wurulen Zuğ-, Druck-, Kinickungs-, Scher- und Biege-Prolıen an Fölıre, WeiBtanne, Ruttanne (Fichte), Läıche, Eiche und Buche vorgenommen. 
Zum Behufe der Erforschung des Einflusses klinatiseher und geognostischer Terhälnisse des Standortes wurden die Versuche ausgedehnt auf Nord- und Südhänge, auf IÖ̈henlagen von unter und über 1300.Meter und auf Molasse-, Kalk-, Tonschiefer- und Granit- res]. Gneishöden. Die Fïllungszeit der Versuchshölzer war ver Monat Dezember, das zur Untersuchunge gelangte Holz wurde der Stammmitte, i. h. der halben Höhe his zur lirone gerechnet, entnommen. Nit Ausschluß der Versuchsproben für die Zugfestigkeit gelangten durchweg prisnatische Proben von quadratischem Querschnitt mit $10 \mathrm{~cm}$ Seitenlänge zur Untersuchung.

Zur Ermittelung der Zäligkeitsverhältnisse des Holzes, worïlıer korrekte Ausdrücke noch fast gänzlich fehlten, wälılte $\mathrm{T}$ e $\mathrm{tm}$ a je r die Biegungsarbeit, und zwar deshalb, weil die Widerstandsfähigkeit des Holzes gegen Biegung in den Bauwerken eine besondere Bedeutung annimmt, volzugsweise aher deshalb, weil die Deformation relativ erheblich, die Bestimmung der Elemente des Arbeitsdiagrammes eine sicherere und exaktere $\mathrm{i}=\mathrm{t}$, als dies unterZugrundelegung der Deformationsarbeit irgend einer anderen Festigkeitsart möglich schien. Mit Rücksicht darauf, daß die Qualitätsbestimmung des Holzes von dem jeweiligen Feuchtigkeitsgehalt desselben abhängig ist, wurden parallel den Biegungsproben Versuche zur Feststelhng des Wassergehaltes der der Biegung unterworfenen Versuchsobjekte ausgeführt. Von der Bestimmung des Feuchtigheitsgrades der Versuchsobjekte der Zug-, Druck-, linickungs- und Scherfestigkeit mußte wegen der großen Anzahl von Versuchsstïckel Alstand genommen werden. Im ganzen gelangten 660 Versuche zur Durchführung und zwar fielen:

9 Versuchs-Serien auf die Weißtanne

- 3 Serien von ïher, 6 Serien von unter 1300 m über dem lleeresspiegel erwachsenem Holze;

11 Versuchs-Serien auf die Fottanne

- 5 Serien von über, 6 Serien von untel $1300 \mathrm{~m}$ ï. d. II.;

2 Versuchs-Serien auf die Föhre

-2 Serien von unter $1300 \mathrm{~m}$ ü. d. .I.;

j Versuchs-Serien auf die Lärche

- 3 Serien von über, 2 Serien von unter $1300 m$ ü. d. II.;

?Versuchs-Serien auf die Eiche, gewachsen untel $1300 \mathrm{~m}$ ü. d. It.;

1 Versuchs-Serie auf die Buche, gewachsen unter $1300 \mathrm{~m}$ ü. d. I.

Zur Beurteihung des Einflusses der Höhenlage des Standortes auf die Holzqualität konnte dem vorstelrenden Programme gemäß unter den div. Holzarten mur die Weiß- und Rottanne herangezogen werden, während der Einfluß der geognosticchen Verhältnisse, des Wachstums etc. trotz des namhaften Lmfanges dipser Arbeit mit Sicherheit nicht emittelt werden komnte.

Lebergehend zur Veranstaltung der Versuche ist hervorzuheben, daß die Zugestigkeit der Hölzer an $\mathrm{B}$ a u $\mathrm{s} \mathrm{ch}$ h $\mathrm{n}$ g e rschen Normalstäben gewonnen wurde, welche eine Scluaftdicke von $0,5-0,7 \mathrm{~cm}$ hei einer Breite von $3-1 \mathrm{~cm}$ hatten.

Die Druckfestiglieit in de. Faserrichtung wurde an Würfeln won ca. $10 \mathrm{~cm}$ liantenlänge ermittelt; als Kinickfestigheitsproben rurden $50 \mathrm{~cm}$ lange Prismen von 10 auf 10 cm Stärke verwendet.

Zur Erhebung der scherfestigkeit wurden Platten von 10 auf $10 \mathrm{~cm}$ Querschnitt und $4,5-5,5 \mathrm{~cm}$ Dicke benützt. Wie eine der Scheiben gehörte der Stanm-Ilitte an, wälırend ،lie beiden anderen dem Reifholz entnommen wurden.

$\mathrm{Zu}$ den Biegungsversuchen wurien Balkm ron 10 auf $10 \mathrm{~cm}$ Ouerschnitt und $1,5 \mathrm{~m}$ Stützweite verwenrlet. Die Beanspuchung erfolgte senkrecht zu den Jahrringen. 
Sieht man von der Dauer des Holzes ab, so bleibt als entscheidendes Moment bei der Beurteilung der V'erwendbarkeit einer Holzart für bautechnisehe Zwecke neben der Festigkeit nur noch das Maß der durch ihre $\mathrm{Z}$ ä $\mathrm{h}$ ig $\mathrm{k}$ e i t berlingten Leistungs fähigkeit übrig, welche am besten aus der Arbeitska paz it ät der B i e g u In g f e stig k e i t bestimmt werden kann. Hiebei ist die fragliche Arbeitskapazität durch Ausmaß eines Diagrammes erhältlich, welches aus den bis zum Bruch gesteigerten Belastungen und zugehöıigen Biegungen eines normalen Prüfungsobjektes in der Art gelildet wird, daß man zum jeweiligen Biegungspfeil als Abszisse rechtwinlshig die korrespondierende Belastung als Ordinate aufträgt und die so gefundenen Punkte durch einen Linienzug verbindet. Der Inhalt des so konstruierten Diagrammes stellt den Wert der Biegungsarbeit rlar. Diese Arbeit muß durch Schlag oder allmähliche gesteigerte Belastung verrichtet werden, soll ein Bruch des Balkens erzielt werden.

Bezeichnet man mit $\mathrm{f}_{0}$ den Biegungspfeil des Balkens beim Bruch, mit $\mathrm{B}$ die Bruchkraft desselben, so stellt das Produkt $\mathrm{f}_{0}$. B den Inhalt des dem Biegungsdiagramne umschriebenen Rechteckes dar. Ein Bruchteil dieses Inhalts gibt den Inhalt A der Arbeitsfläche, welche man somit durch

$$
A=r_{1} f_{0} \cdot B
$$

ausdrücken kann, worin $\gamma$ den lioeffizienten der Biegungsarleit bezeichnet. Dieser Fioeffizient ist selbst bei ein und derselben Holzart nicht lionstant. Dersellye ändert sich mit dem Zähigkeitsgrade des Materials, er ist desto kleiner (sinkt his auf 0,5 ), je geringer der Alleitswert, je größer der Grad der Sprödigkeit und Brüchigkeit ist ungekehrt wächst rler alsolute Wert des Koeffizienten mit zunehmender Zähiglieit des Materials und erreicht eine Größe von $0,8-0,8.5$.

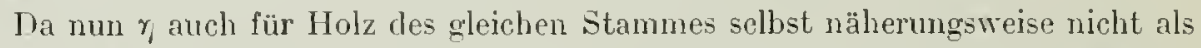
konstant angesehen werden kann, so ist auch weder die absolute Größe des Biegungspfeiles noch das Produkt aus Biegungspfeil und Bruchkraft zur Qualitätsbestimmung maßgebend und bleibt somit nichts anderes übrig, als Fall für Fall den tatsächlichen Wert der Biegungsarbeit. A in t/cm ausgedrïckt der Beurteilung zugrunde zu legen.

Am Schlusse dieser Auseinandersetzung gelangt T e t m a j e r zu folgender Betrachtung: Zur Beurteihng des Wertverhältnisses der Bauhölzer untereinander sowie zur Vergleichung des Holzes aus verschiedenen Teilen des Stammes ist das Maß ler Arbeitskapazität (stets unter Zugrundelegmg einheitlicher Prüfungsobjekte maßgebend; dieselbe stellt eine durch Festigkeit und gleichzeitig Zähigkeit hedingte Zahl dar, die unter sonst gleichen Umständen sich sowohl mit der Zähiglieit als anuler seits mit der Festigkeit ändern kann. Ist das Iolz spröde, brüchig (d. h. clastisch, fest, aber nicht zähe - biegsam), so wird sein Arbeitswert gering ausfallen, ungekehrt kann das Arbeitsvermögen erheblich werden, wenm das Material neben geringer Bruchfestigkeit große Zähigkeit und Biegsankeit hesitzt. Ein Maximum der Biegungsarbeit wird aus der Vereinigung möglichst großer Festigkeit und Zäligheit resultieren; es erscheint dahel die Größe rer Biegungsarbeit ( $A$ ) als wohlherechtigter Qualitätsmesser des Holzes.

Bevor wir die Zusammenstellung der T etmaje r schen Versuchsresultate wiedergeben, wollen wir nicht versäumen, jene Erfahrungen anzuführen, welche der Versuchsansteller gelegentlich der hinichungsfestigkeit gewomen hat und sich auf die Feststellung des Gesetzes Ier Abnahme dor Iruckfestigkeit mit wachsenrler Prismentänge bezogen. Gewöhnlich wird der linickmgskoeffizient is für variable Verhälınisse der Balkenlängen und Querschnittsabmessungen als ki o s t a n t an- 
genommen. T e tm a jer ist gelegentlich des Studiums rlieser Frage zu folgenden Schliüssen gelangt: daß

1. die Druekfestigkeit mit wachsender Lïnge der Balken sich mehr orler weniger sprumgweise ändert;

2. die Knichungsgefahr hei Balkenlängen von fünf- bis zehmfacher, schätzungsweise von achtfacher Querschnitsbreite leginnt;

3. die Annahme der Druckfestigkeit lei Balkenlängen von zehn- bis zwanzigfacher Querschnittsbreite unerheblich, jedoch fast stetig wächst.

In der folgenden Tabelle VIII (s.406) führen wir nur jene Mittelwerte an, welche als Festigkeitskoeffizienten für bautechnische Zwecke Verwendung finden sollen.

Darin bezeichnet:

气 in $t$ pro qem den Elastizitätsmodul;

$\gamma$ in $t$ pro qem den Grenzmodul (speziell Tragkraft an der Elast.-Grenze);

$\tilde{r}$ in $\mathrm{t}$ pro qen den Festigkeitsmodul für Zug, Druck und Biegung; speziell:

$j_{c}$ in $t$ pro qem den Festigkeitsmodul für das Stamnzentrum (Nittelstück);

$j_{s}$ in $\mathrm{t}$ pro qem den Festigkeitsnodul für seitliches Holz (Seitenstück);

$\bar{j}_{m}$ in $t$ pro qem den nittleren Festigkeitsmodul;

o. in $t$ pro qen den Sehemodul für das Stanmzentrum;

$\sigma_{3}$ in $t$ pro qem den Sehermodul für seitliches Holz;

$\sigma_{\mathrm{m}}$ in $\mathrm{t}$ pro qcu den mittleren Schermodul;

$x$ in $t / e n$ die spezifische Arbeit an der Elastizitätsgrenze;

$A$ in $t / e n$ die Deformationsarbeit beim Bruch;

Il in $\%$ den Feuchtigkeitscrad desHolzes.

Was die Festigheitsverhältnisse des Holzes an verschiedenen Stellen des Querschnittes betrifft, so ergibt sich, daß das Holz der Stamm-llitte selbst bei Stämmen im Alter des vorgelegenen Versuchsmaterials ( $80-100$ Jahren) s c h w a c h e r ist als clas Reifholz seitlich der Stamm-Nlitte (gleichviel ob aus Höhen über oder unter $1300 \mathrm{~m}$ ü. d. M.).

Aus einer anderen Tabelle, bezüglich welcher wir der Raumökonomie halber auf die Publikation des Versuehsanstellers verweisen müssen, geht ferner hervor, daß die Nadellölzer in der Stamm-Mlitte sowohl an Festigkeit wie Zähigkeit als wesentlich minderwertig erscheinen; so ist z. B. die Biegungsfestiglieit des seitlichen Holzes der Ioniferen um $16^{\circ} \%$, die Leistungsfähigheit um $39^{\circ}$ o größer als für die Stamm-1litte.

Nach ihren Festigkeitsverlaältnissen rangieren die geprüften Baulölzer in folgender IVeise:

\begin{tabular}{|c|c|c|c|c|}
\hline Nr. & Zugfestigkeit & Druckfestigkeit & Scherfestiglieit & Biegungsfestigkeit \\
\hline I & IVeißtanne & Föhre & Föhre & Föhre \\
\hline 11 & Rottanne & Rottanne & Weißtanne & Rottanue \\
\hline III & Lärclie & Weißtanne & - Fottanne & Weißtame \\
\hline $\mathrm{IV}$ & Föhre & Lärche & Lärche & Lärche \\
\hline $\mathrm{V}$ & Eiche & Buclie & Eiche & Eiche \\
\hline Vl & Buche & Eiche & Buche & Buche. \\
\hline
\end{tabular}

Den kleinsten Arbeitswert zeigte die Fölre. Setzt man denselben $=1$, so $\mathrm{er}$ scheint bei einem Wassergehalt vin $11-20^{\circ}$ (lufttrockenes Holz)

der Arbeitswert der Weißtanne um $19 \%$ größer;

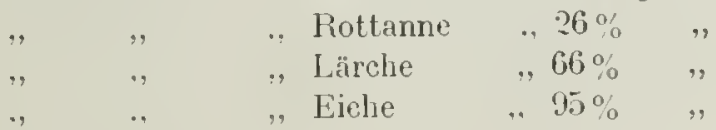

Der Arbeitswert der Buche rürfte neben jenem der Eiche stehen. 


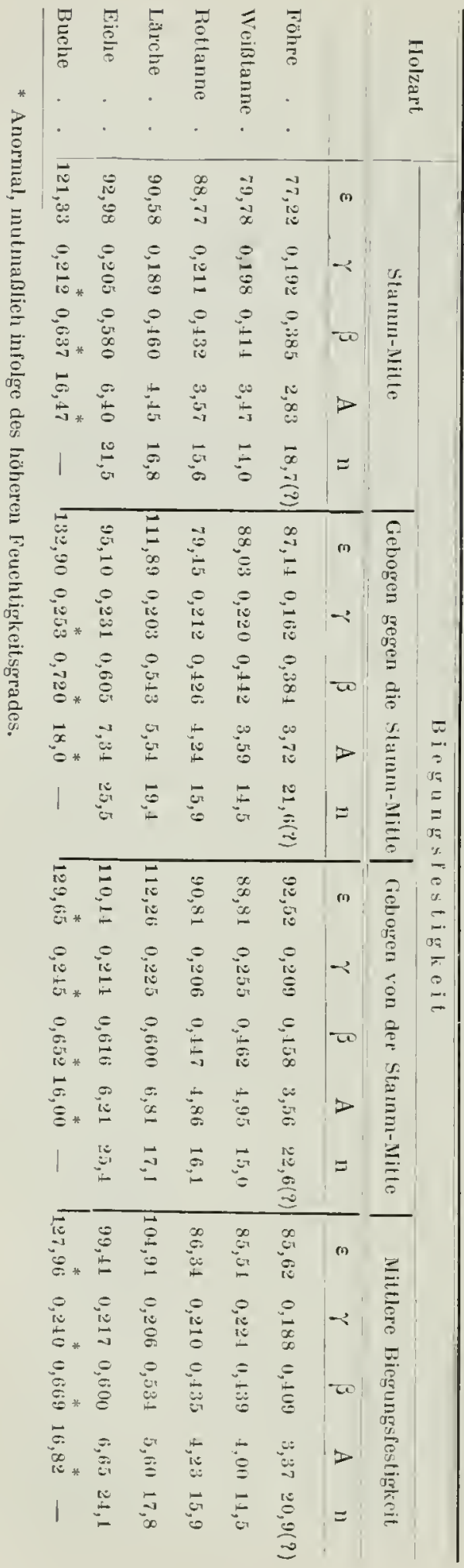

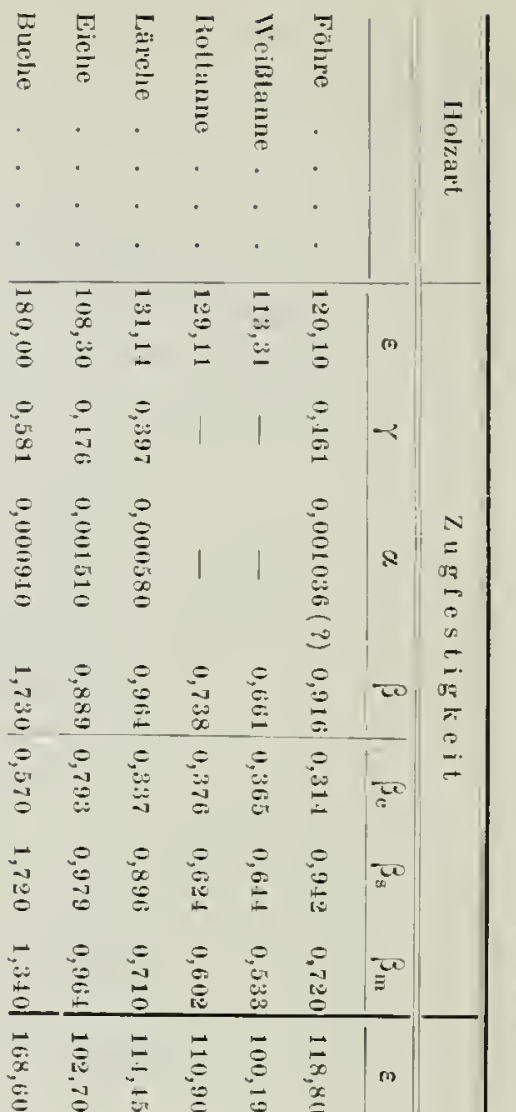

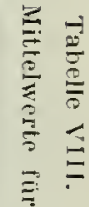

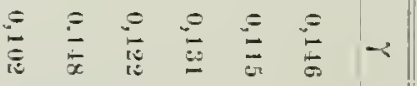

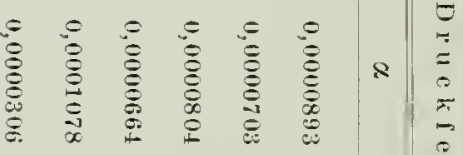

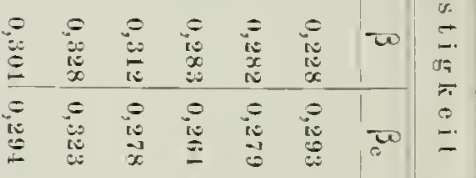

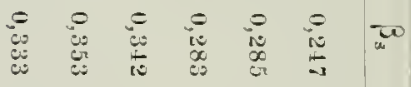

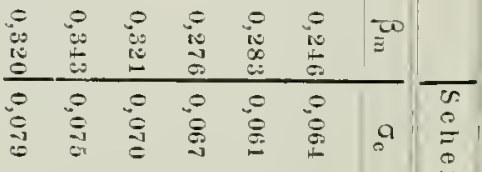

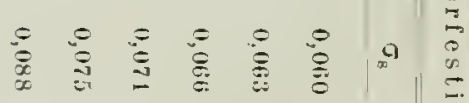

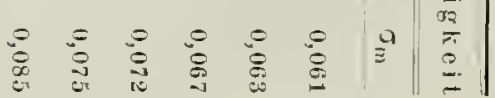


Hinsichtlich der interessanten Folgerungen, welche sich ergehen, ob das llulz unter oder über $1300 \mathrm{~m}$ ï. d. I. erwachson ist, müssen wir aut die höchst heachtriswerte Publikation Tetmajers selbst verweisen.

Hofrat 'T e tm a je r hat spailer gelegentlich der schweizerischen Landesansstellung in Geuf 1896 die voranstehenden Versuche weitor verfolgt numl deren licsultate in dem Werke: Methorlen und Resultate der Prüfung dè schweiz. Bauhölzer. 11. Heft. Zürich 1896 niedergelegt. Dortselbst finden sich nolst den erweiterten Untersuchmingresultaten der Festigkeitseigenschaften der sehweiz. Bauhölzer auch folgenule interessante Kapitel: 1. Resultate rer Lntersuchungen rer Einflüsse les Dïmpfens und Darrens auf die Festigkeitsverhältnisse der Bauhölzer; ?. Resultate der Prüfung der Einftüsse der Inprägnierung der Iölzer auf deren Festigkeitsverhältnisse; 3. Intersuchung des relativen Wertes der Bündener Lärehe und der amerikanischen PitsohPine; 4. Lntersuchung des Einflusses des exzentrischen Wuchses auf the Druckfestiglieit einiger Nadehölzer; 5. Lntersuchung der liompressibilität eichener Bohlen und 6. Untersuchung der Einflüsse der Exzentrizität auf die Druckfestigkeit des Holzes.

$\$$ 32. Die Untersuchungen, welche Prof. B a u s $\mathrm{ch}$ inge $\mathrm{l}$ angestellt lat, behandelten hauptsächlich den Einftuß des Standortes und der Fällzeil auf die Elastizität und Festigkeit des Fichten- und Kiefernholzes. Als Versuchsmaterial dienten je 4 Stämme, welche 4 verschiedenen Standorten (Lichtenhof, Frankenhofen, Regenhütte und Schliersee) entrommen und woron je : Stämme in Sommer, llie beiden anderen im Winter gefält wurden. Von dem Standort Lichtenhof wurde liviefernholz (Föhre), von deq anderen drei Standorten Fichtenholz eingesandt. Die Bäume wurden $1.5 \mathrm{~cm}$ über den Boden abgeschnitten unl aus jerlem del so gewonnenen 32. Abschnitte ein Balken von möglichst großem quadratischem Querschnitt so herausgenommen, daß der Kern ganz oder doch nahezu in dessen Nitte zu liegen kan und die Querschnitsseiten parallel zur Süd-Nord-, bezw. Ost-IVest-Richtung liefen. Diese Probestücke wurden auf Biegung untersucht. Fon den beim Ausschneiden jenel Balken abgefallenen Schwartlingen wurden $50 \mathrm{~cm}$ lange Stücke abgeschnitten und hieraus Lamellen ron $8 \mathrm{~cm}$ Breite und $2 \mathrm{~cm}$ Dirke gewonnen; diese Probestücke, welche dann noch weiter hergerichtet wurden, sind der Zugfestigkeit unterworfen worden. Von den bei den Biegungsversuchen erhaltenen beiden Bruchstüclien wurden jene Probestücke gewonnen, welche man zur I'nter'suchung auf Zug-, Druck- und Abscherungs - F e s tig k e it benötigte.

Die zu den Bieg u n s versu ch e n verwendeten 3 ? Ballien hatten eine Spannweite von $250 \mathrm{~cm}$. Ihr Querschnitt war nöglichs groß und schwankte zwischen $15,2 \mathrm{~cm}$ Breite und $33,49 \mathrm{~cm}$ Höhe.

Gelegentlich der Zusammenstellung der Resultate gibt B a u s c h i n g e r auch die Biegungsarbeit an, welche sowohl als Maßstab fül die Festigkeit als auch zugleich für die Zähigkeit des betreffenden Holzstückes dient.

Bei Ausfuhrung der Versuche über die Zugfestigkeit hat B a us ch in ge r fünf typische Bruchformen unterschieden und folgendemaßen charakterisiert: kurz stumpf; kurz zackigr; blattrig; faserig und langfaserig, und zugleich gefunden, raß in derselben Reihenfolge, in welcher die Bruchformen aufgezählt sind, von der leineren zur größeren aufsteigend, in der Rugel auch die Zugfestigkeiten der Probestücke stehen.

Die Druckversuche wurden an Probestïcken von $9 \times 9$ cm Querschnitt und $15 \mathrm{~cm}$ Länge vorgenommen, während für die Abscherungsversuche Seheiben von $8 \mathrm{~cm}$ Dicke zur Verfügung standen.

Gelegentlich der Vonnahme dieser. Versuche hatte B a u s c h ing e r noch eine 
eigene Versuchsreihe (an Fichtenholz) unternommen zu dem Zwecke, den Beziehungen zwischen den $m e c h$ a nischen un t physikalischen Eigenschafte $\mathrm{n}$ des Holzes auf die Spur zu kommen. Zu diesem Ende wurden die Probestücke auf 1 Trockenstufen, d. h. nach und nach rurch almähliches Austrocknen bis zu jenem Zustand gebracht, wo das Holz an Luft von gleichbleibender Feuchtigkeit nichts mehr abgibt und feuchter oder trockener wird, je nach dem Feuchtigkeitsgehalt der Luft.

Hierauf wurde der Feuchtigkeitsgehalt der einzelnen Probestücke und die Festigkeit derselben ermittelt.

Wir müssen uns darauf beschränken, die Hauptresultate dieser höchst instruktiven Arbeit wiederzugeben, welche sich in Folgendem ausdrücken: „Im großen und ganzen ist bei geringerem Fenchtigkeitsgehalt und größerem spezifischem Trockengewicht ein höherer Elastizitätsmodul und eine größere Festigkeit vorhanden, aber letztere Eigenschaften unterliegen noch anderen Einflüssen, die mindestens ebenso mächtig sind wie die Wirkungen der Feuchtigkeit und des spezifischen Gewichtes und folglich diese ganz oder teilweise verflecken. Diese Einflüsse rühren natürlich von der örtlichen Beschaffenleit der Holzsubstanz in dem betr. Probestück oder an dessen Bruchstelle her, dieses organischen Gebildes von fester Holzmasse (Zellulose, Lignin) mit Hohlräumen verschiedener Art (Poren, Höhlungen der Holzfasern etc.), das sich schon beim näheren Besichtigen eines Querschnittes mit bloßem Auge, noch mehr aber bei der Beobachtung eines Dünnschnittes unter dem Miliroskop von außerordentlich verschiedener Beschaffenheit zeigt, sowohl innerhalb desselben Querschnittes als auch an gleichen Querschnittsorten in verschiedenen Höhenlagen desselben Stammes, wenn diese auch mur verhältnismäBig wenig, um 2-3 Meter, voneinander entfernt sind."

B a u s c h in ge r hat num eine Relation zwischen der. Druclifestigkeit und dem Feuchtiglieitsgehalt aufgestellt und gefunden, daß

$$
\beta 0=\beta\left[1+\lambda\left(\varphi-\varphi_{0}\right)\right]
$$

wobei $\beta$ die Druckfestigkeit beim Feuchtigkeitsgehalt o und $\beta_{0}$ diejenige bei einem niedrigeren Feuchtigkeitsgehalt $\rho_{0}$ bezeichnet, welcher in der Nähe der Lufttrockene liegt. Die Kionstante $\lambda$ wurde im Mittel zu 0,0366 gefunden.

In ähnlicher Weise fand B a u s c h i n g e r den Zusammenhang zwischen der Schubfestigkeit und dem Feuchtiggkeitsgehalt aus der ähnlich gebauten Formel:

$$
r_{0}=r_{i}\left[1+\mu\left(p-\varphi_{0}\right)\right] \text {, }
$$

worin $\gamma$ rlie Schubfestigkeit beim Feuchtigkeitsgehalt tigkeitsgehalt on bezeichnet. Der Loeffizient \& wurde zu 0,0430 ermittelt.

Dieser Wert $\mu$ stimmt so ziemlich mit jenem (i) für dic Druckfestigkeit überein.

In Nachstehendem geben wir die Mittelwerte der Versuchsresultate.

(Siehe Tabelle IX., S. 409.)

Bezüglich der Resultate un d Folgerungen aus denselben müssen wir auf die $\mathrm{B}$ a u s e h i n g e r sche Arbeit selbst verweisen, können aber nicht umhin, wenigstens die wichtigsten derselhen hier anzuführen, da dieselben neue Perspelitiven eröffnen.

Bezüglich der Zugfestigli e it wurde gefunden, ,daß die Zugfestiglieit unabhängig ist von der ganzen Jahrringbreite, und nur bedingt ist von der Beschaffenheit der beiden Zonen und daher bei der fast konstanten Beschaffenheit der Frühjahrszone wesentlich abhängig von der Festigkeit der Spätholz-(Herbst)zone und außerdem von der verhältnismäßigen Breite derselben“".

Es hat sich ferner ergeben, daß, ,eine dichte Herbstzone von großer verhältnis- 
Tabelle IX:

\begin{tabular}{|c|c|c|c|c|c|c|c|c|}
\hline \multirow{3}{*}{$\begin{array}{l}\text { Fällzeit } \\
\text { Holzart } \\
\text { Slandort }\end{array}$} & \multicolumn{4}{|c|}{ Sommer } & \multicolumn{4}{|c|}{ Winter } \\
\hline & \multirow{2}{*}{$\frac{\text { Kijefer }}{\begin{array}{c}\text { Lichten- } \\
\text { hof }\end{array}}$} & \multicolumn{3}{|c|}{ Fichte } & \multirow{2}{*}{$\frac{\text { Jiiefer }}{\substack{\text { Lichten- } \\
\text { hof }}}$} & \multicolumn{3}{|c|}{ Fichte } \\
\hline & & $\begin{array}{l}\text { Franken- } \\
\text { hofen }\end{array}$ & $\begin{array}{l}\text { Regen- } \\
\text { hütte }\end{array}$ & $\begin{array}{l}\text { Sehlier- } \\
\text { see }\end{array}$ & & $\begin{array}{l}\text { Franken- } \\
\text { hofen }\end{array}$ & $\begin{array}{l}\text { Regen- } \\
\text { hütte }\end{array}$ & $\begin{array}{l}\text { Schlier } \\
\text { see }\end{array}$ \\
\hline & \multicolumn{8}{|c|}{ Biegungsversuche. } \\
\hline Elastizitāts-Modul in at & 108000 & 110000 & 115000 & 73000 & 103000 & 116000 & 110000 & 69000 \\
\hline Elastizitäts-Grenze in at & 201 & 228 & 216 & $1 \pm 6$ & 220 & 262 & 227 & 132 \\
\hline $\begin{array}{l}\text { Biegungsfestigkeit at } \\
\text { Spezif. Gew. bei Luft- }\end{array}$ & $4: 2$ & 419 & $\$ 16$ & 295 & 451 & 446 & 446 & 257 \\
\hline $\begin{array}{l}\text { trockene } \\
\text { Feuchtigkeitsgehait in }\end{array}$ & 0,50 & 0,45 & 0,46 & $0,3 \overline{5} 5$ & $0, \overline{5} 5$ & 0,43 & $0, \pm 3$ & 0,375 \\
\hline $0_{0}^{\prime}$ des Holzgerichtes & \multicolumn{7}{|c|}{$\mathrm{Zug}$ uersuche. } & 25 \\
\hline $\begin{array}{l}\text { Mittlere Festigkeit der } \\
\text { Lmfang-Stücke in at } \\
\text { Mittlere Festigkeit der }\end{array}$ & 1050 & 790 & 1030 & 800 & 750 & 1240 & 960 & 580 \\
\hline $\begin{array}{l}\text { Jern-Stücke in at } \\
\text { Mittlere Festigkeil des } \\
\text { ganzen Querschnittes }\end{array}$ & 230 & 310 & 410 & 290 & 290 & 345 & 300 & 255 \\
\hline in at..... & \multicolumn{5}{|c|}{ Druckversuche. } & e. & 740 & \\
\hline $\begin{array}{c}\text { Druckfestigkeit für den } \\
\text { ganzen Querschnitt }\end{array}$ & & & & & & & & \\
\hline $\begin{array}{l}\text { in at } \\
\text { Feuchtigkeitsgehalt } \%\end{array}$ & $\begin{array}{r}281 \\
19\end{array}$ & $\begin{array}{r}246 \\
20\end{array}$ & $\begin{array}{r}234 \\
27\end{array}$ & $\begin{array}{r}162 \\
20\end{array}$ & $\begin{array}{r}319 \\
26\end{array}$ & $\begin{array}{r}313 \\
17\end{array}$ & $\begin{array}{r}281 \\
20\end{array}$ & $\begin{array}{r}225 \\
19\end{array}$ \\
\hline $\begin{array}{c}\text { Druckfestigkeit f. } 10 \% \\
\text { Feuchtigkeit (Luft- } \\
\text { trockene) in at }\end{array}$ & 373 & 335 & 379 & 222 & 504 & 393 & 383 & 298 \\
\hline & \multicolumn{8}{|c|}{ A bscher ungsversuch e//zur Faser. } \\
\hline $\begin{array}{l}\text { Schubfestigleit in } \\
\text { Durchmesser in at . } \\
\text { Schubfestigkeit im }\end{array}$ & 43 & $\$ 1$ & 38 & 32 & 49 & 51 & 49 & 38 \\
\hline $\begin{array}{c}\text { Quadrat in at } \\
\text { Feuchtigkeitsgehait }\end{array}$ & 46 & 41 & 38 & 31 & 51 & 52 & 49 & 38 \\
\hline in des Holzgew. & 25 & 38 & 38 & 28 & - & - & - & - \\
\hline
\end{tabular}

mäßiger Breite stets eine große Zugfestigkeit (und Dichtigkeit), eine locker gewebte und verhältnismäßig dünne Herbstzone aber stets eine geringere Festigheit (und Diehtigkeit) des ganzen Querschnittes zur Folge hat und daß die so bedeutend geringere Festigkeit der Kernstücke nieht sowohl von der großen Breite der Jahrringe, sondern vielmehl von der lockeren Besehaffenheit und verhältnismäßig geringen Breite der Herbstzone herrührt".

„Inmer ist eine höhere Zugfestiglieit von einem faserigen Bruch, eine niedrigere von einem kurzen, stumpfen oder zackigen Bruch begleitet."

Die ungeheure Jannigfaltigkeit, welehe in der Anordnung der Fasem betreffs ihrer Lage neben- und hintereinander möglieh ist, seheint der Hauptgrund der großen Versehiedenheiten zu sein, welche die Zugfestiglieit innerhalb desselben Stammes, ja innerhalb desselben Quersehnittes eines solchen zeigt."

Außer den im anatomisehen Bau des Holzes sich ausspreehenden Verhältnissen hat auch noeh die eigentliehe Holzsubstanz ihrer Qualität, ihrer chemischen Zusam- 
mensetzung nach Einfluß auf rie Festigkeit. Um dieser Frage näher zu konmen, wurden mehrere Probestïcke auf ihren Lignin-Gehalt und Gehalt an Zellulose untersucht und gefunden:

„Die Zugfestigkeit nimmt mit dem Gehalt an Zellulose zu und umgekehrt wird die Zugfestigkeit kleiner, wenn der Lignin-Gehalt wächst."

„Lignin scheint das Holz härter, spröıler, widerstandsfäliger gegen Biegung zu machen, währenıl die Zugfestigkeit durch Ligninbildung verringert wird."

Bezüglich der Fragen nach dem Einfluß des Bodens und der Fällzeit auf die Festigkeit gelangte B a u s h ing e r zu folgenden Resultaten:

1. Die anf den Standorten Frankenhofen und Regenhütte erwachsenen Stämme hahen ungeführ gleiche mittlere Zugfestigkeit, etwas geringer ist diejenige der liefern von Liehtenhof und entschieden die geringste Festigkeit haben die breitringigen Fichtenstänme von Schliersee.

2. Ein EinfluB der Fällzeit ist bei Hölzeru, die kürzere Zeit, etwa einen Monat nach ihrer Fällung geprüft werden, nicht zu erkennen.

Der Elastizitätsmodul für Zug variiert selır berleutend mit der Festigkeit; er nimmt mit der Festigkeit zu und ab, doch in der Regel bei weitem nicht in demselben Verhältnisse wie diese.

Die Elastizitätsgrenze für Zug fällt nahezu mit der Bruchgrenze zusammen.

Aus ten Ergebnissen über die B i e g u n g s f es t i g k e i t folgt, daß die Zahlen für die Biegungsfestigkeit ebenfalls von der zufälligen örtlichen Beschaffenheit des Iolzes, die innerhalb desselben Stammes so sehr verschieden sein kann, beeinflußt werden wie diejenigen für die Zugfestigkeit, wenı auch nicht in so hohem Grade wie diese. Ein Zusammenhang zwischen den mechanischen Eigenschaften und der Wichtigkeit war hiebei nicht festzustellen, wenigstens nicht mit Sicherheit. Aus den Mittelwerten ließen sich folgende Schlüsse ziehen:

1. Die auf den Standorten Frankenhofen und liegenhütte erwachsenen Stämme haben bei fast gleichem spezifischemGewichte ungefähr gleiche Qualität für die Beanspruchung auf Biegung und werden von den in Lichtenhof gewachsenen Stämmen trotz deren beleutend größerem spezifischem Gewichte kaum übertroffen; dagegen stehen jenen die Schlierseer Stämme bedeutend nach, sowohl was die mechanischen Eigenschaften anbelangt, als auch betreffs des spezifischen Gewichtes.

2. Ein Einfhß rer Fällzeit ist auch hier nicht zu konstatieren.

Bei den D r u c k versu c he $n$ ist charaliteristisch, daß lie Ueberschreitung der Festigkeitsgrenze sehr scharf zu beohachten ist, olwohl eine Lösung des Zusammenhanges der Teile nicht stattfindet. Die Elastizitätsgrenze lagegen ist bei Druekversuchen in der Regel sehr verschwommen und rler Elastizitätsmorul wegen der großen Schwierigkeiten einer völlig gleichmäßigen Verteihung des Druckes etwas unsicher. Auch hier zeigte sich wieder, daß die Kernstücke eine geringere Festigkeit haben als die Seitenstücke. Ein EinfluB der Himmelsrichtung ließ sich nicht erkenmen.

Ferner hat sich ergeben:

1. Die auf den Standorten Frankenhofen und Regenhütte erwachsenen Stämme haben bei fast gleichen spezifischen Gewicht ungefähr gleiche mittlere Lruckfestigkeiten und werden von den in Lichtenhof gewachsenen Stämmen trotz deren größerer Dichtigkeit kaum übertroffen, dagegen stehen jenen die Schlierseer Stämme bedeutend nach.

2. Bei allen vier Standorten ist die Festigkeit der im Winter gefälten Stämme größer als die der in Sommer gefällten, un zwar verhalten sich beide Festigkeiten im lufttrockenen Zustand im Mittel wie $1: 1,22$. 
Aus den Resultaten der I b s h e r e e s u che greht hervor, daß die Selubfestigkeit unabhangrg von ter Breite der Jaluringe und daB sie im Fern am kleinsten ist und ron da aus bis zur Peripherie hin wächst. Sehr häufig ist sie aber närhat lesm Splint wieder lileiner ats zwishen them liern und thesem.

Es lionnte weder ein Einfluß aler Himmelsrichtung auf alic Schubfestigkeit norh cin entschiedener Einfluß der Höhenlage in Stanme alogeleitet werden. In ziemlicher Uebereinstimmung mit den bej der Druclifestiglieit gefundenen Sitzen ergab sich auch hicr:

1. Die Schubfestigkejt des Holzes längs der Faser von den ilri Standorten Lichtenhof, Frankenhofen und Regenhüte ist nahezu die gleiche, die des Schliersecr Holzes aber wesentlich geringer.

2. Die Schubfestigkeit des im Winter gefällten Holzes ist größcr als diejenige der Stämme, welche in Sommer geschlagen wurden, und zwar verhalten sich beide Festigkeiten in Mittel wie $1: 1.27$.

In seiner Schlußbemerkung gibt $\mathrm{B}$ a $\mathrm{u} s \mathrm{c}$ h i $\mathrm{ng}$ e $\mathrm{r}$ auf lic lieiden Hauptfragen: Einfluß des Standortes und der Fällzeit auf ılie Elastizitäts- und FestigkeitsEigenschaften des Fiehten- und Kiefernlıolzes, folgende Antwort:

1. Fichten- oder hiefernstämme, welche bei gleichem Alter ungefähr gleichen Durchmesser haben, dic atso ungefähr gleich schnell gewachsen sind, haben, unabhängig rom Standorte, die gleichen mechanischen Eigenschaften bei gleichen Feuchtigkeitsgehalt. Stämme, welche bei gleichem Alter" größBeren Durchnesser, also breitere Jahrringe haben, schneller gewachsen sind, haben eine geringere Festigkeit, als langsamer gewachsene.

2. Fichten- oder Kiefernstämme, welche in Winter gefällt wurlen, haben, zwei bis drei Monate nach ihrer Fällung greprüft, unter sonst gleichen Lmständen einc um ca. $25 \%$ größere Festigkeit als solche, die im Sommer geschlagen-werden.

$\$ 33$. Nebst dieser ausgezeichneten Arbeit, welche B a us c h i n ger im Jahre 1882 zur Durchführung brachte, hat derselbe in dem ..sechzelnnten Heft iler Mitteilungen aus dem mechanisch-technischen Laboratorium der Ki. Technischen Hochschule in Jünchen 1887" als Fortsetzung dieser Studie die Resultate der Untersuchungen über, , l i e V e r änderung der Festiglie it les $\mathrm{N}$ a d e l holzes n a c h d c m Fälle n" publiziert. Diese Arbeit hatte den Zweek, den Einfluß der Fällzeit und des Stanilortes auf die D a u e r des Nadelholzes zu untersuchen. Als Versuchsmaterial wurden aus den zu Gebote stehenden 32 Balkenstücken der oben zitierten IIölzer an möglichst astfreier stelle zwei $15 \mathrm{~cm}$ dickev viereckige Platten unmittelbar nebeneinander herausgeschnitten, und beschränkte sich die Prüfung dieses Versuchsmaterials auf die Ermittlung der Druchfestigkeit und des dalrei vorhandenen Feuchtigkeitsgehaltes der Probestücke. Das Material war 5 bezw. 4 12 Jahre im Freien gelagert und während dieser Zeit den Witterungseinflïssen ausgesetzt. Eine der beiden Platten wurde benützt, um ein quadratiches Prisma mit ca. $10 \mathrm{~cm}$ Querschnittsseite zu gewimnen, welches in seiner Mitte den Kern enthielt; die andere Platte wurde durch zwei aufeinander senkrecht stehende und durch die Mitte des Fernes gehende Schnitte in \& rechtwinkelige Parallelepipede zerlegt, aus welchen Prismen gearbeitet wurden, deren Querschinitt nahezu quadratisclı und deren Längc, parallel der Faser, 1 ’amal so groß als die kleinste Dimensiun war.

Lim die Resultate für das spezifisehe Gewicht und die Druekfestigheit mit jenen Daten für frisch gefälltes Holz vergleichen zu können, mußten alle auf den gleichen Feuchtigkeitsgehalt reduziert werden. B a us c h i n g e l wählte hiezu den Feuchtigkeitsgehalt der Lufttrockene $\varphi_{i}=10 \%$ des Gewichtes des feuchten ader 
$\psi=12 \%$ des Gerichtes des im Trockenofen getrockneten Holzes und benutzte die Formeln :

für die Dichtigkeit und

$$
\delta=\delta_{0}(1+0,006('+-12)
$$

$$
\beta_{0}=\beta\langle 1+0,0366(\varphi-10)
$$

für die Druckfestigkeit.

Aus den so erhaltenen Daten für das spezifische Gewicht und die Druckfestigkeit ergab sich, daß die spezifischen Gewichte teils gleich geblieben, teils ein wenig größer oder ein wenig kleiner geworden sind. Was Wittel aus 64 Zahlen für das spezifische Gewicht des Holzes, 5 Jahre nach der Fällung, war 0.424 , und das spezifische Gewicht des Holzes 3 Monate nach der Fällung betrug 0,43 ; die Dichtigkeit ist also im ganzen fast unverändert geblieben.

Dagegen zeigt die Druckfestigkeit fast durchweg eine und zwar meist sehr erhebliche Z u n a h me: Ausnahmen finten mur da statt, wo schon das äußere Ansehen des Probestückes beträ c h t l i c h e Zeichen von Zerstörung durch Fäulnis zu erkemnen gibt. Das Anfaulen von g e r i n g e r e m Betrag vermag die Erhöhung der Druckfestigkeit nicht aufzuheben, sondern nur zu verringern. Um zu sehen, ob bei der Erhöhmg der Druckfestigkeit durch das Ablagern die im Sommer gefällten Stämme gegenüber den im Winter gefälten einen Lnterschied zeigen, hat B a u s ch ing er für jeden der 4 Standorte die durchschnittliche Druckfestigkeit des ganzen Querschnittes wie folgt ermittelt:

Tabelle X.

\begin{tabular}{|c|c|c|c|c|c|c|c|c|}
\hline \multirow[b]{2}{*}{ Fällzeit } & \multicolumn{2}{|c|}{ Lichtenhof } & \multicolumn{2}{|c|}{ Frankenhofen } & \multicolumn{2}{|c|}{ Regenhūtte } & \multicolumn{2}{|c|}{ Schliersee } \\
\hline & $\begin{array}{c}5 \text { Jalure } \\
\text { n. d. } \\
\text { Fällen } \\
\text { at }\end{array}$ & $\begin{array}{l}3 \text { Monate } \\
\text { n. d. } \\
\text { Fällen } \\
\text { at }\end{array}$ & $\begin{array}{c}5 \text { Jahre } \\
\text { n. d. } \\
\text { Fällen } \\
\text { at }\end{array}$ & $\begin{array}{l}3 \text { Monate } \\
\text { n. d. } \\
\text { Fällen } \\
\text { at }\end{array}$ & $\begin{array}{c}5 \text { Jahre } \\
n \text {. d. } \\
\text { Fällen } \\
\text { at }\end{array}$ & $\begin{array}{l}3 \text { Monate } \\
\text { n. d. } \\
\text { Fällen } \\
\text { at }\end{array}$ & $\begin{array}{c}5 \text { Jahre } \\
\text { n. d. } \\
\text { Fällen } \\
\text { at }\end{array}$ & $\begin{array}{l}3 \text { Monate } \\
\text { n. d. } \\
\text { Fällen } \\
\text { at }\end{array}$ \\
\hline Sommer & 505 & 368 & 451 & 338 & 442 & 374 & 322 & 221 \\
\hline Vinter & 446 & 477 & 465 & 395 & $\$ 16$ & $3 ; 6$ & 336 & 298 \\
\hline
\end{tabular}

Durchschnitlliche D r u c $\mathrm{fes}$ ig k e i des ganzen Querschnitts der Stämme von

Sieht man hierin von den im Winter gefällten stämmen von Lichtenhof ab, deren Stücke sämtlich so beträchtlich angefault waren, daß sie eine Verminderung der Druclifestiglieit ergaben, so folgt hieraus:

„Die Zunahme der Druckfestigkeit ist bei den in Sommer gefälten Stämmen größer als bei den im Winter gefällten, so daß die anfänglich, kurze Zeit nach dem Fällen, geringere Druckfestigkeit der in Sommer gefältten Stämme diejenige der in Winter gefällten wälırend des Ablagerns ganz oder nahezu einholt."

Wie lange die liedurch bewirkte Erhöhung der Druckfestigkeit des Holzes dauert, in welcher Zeit dieselbe ein mzweifelhaft bestehendes Maximum erreicht, konnte durch die vorstehenden Versuche nicht ermittelt werden. Sie zeigten nur die Erhöhung, welche nach 5 Jahren stattfand.

B a u s c h i n g e r kommt am Schhuse seiner Arbeit unter Berücksichtigung der weiter unten angeführten Resultate zu dem Schlusse, ,daß die Erhöhung der Druckfestigkeit durch das Ablagern nicht über 1 Jahr hinaus, vou der Fällzeit an gerechnet, dauere".

\$ 34. AuBer diesen Untersuchungen publizierte B a us ch inger in dem gleichen Hefte der Mitteilungen eine Arbeit, ,ü be r die Elast i z it ät und Festigkejt vel'sehiedener $\mathrm{N}$ a d e lhö l z er", welche als Folgerung den von ihm bereits früher aufgestellten Satz ergiht, daß bei jenen Versuchen, bei denen 
es sich um dic Durchschniltsqualität eines stammes handelt, wie bei den Fragen über den Einfluß des Standortes, der Fällzeit etc., Druchiversuche, angentellt an prismatischen Stücken von ca. $15 \mathrm{~cm}$ Länge und $8-10 \mathrm{~cm}$ Qucrschnittsseite am sichersten zum Ziele führen dürften. Ton dem Gedanken ausgelıend, daß dem Hauptrerwendungszwecke entsprechend die wichtigste Eigenschaft des Holzes die B i e g u n $r \mathrm{~s}$ Elastizität und -Festigkeit sei, war der Giundplan der folgenden Versucle der, daß ein und demselben Baumstamme Probestücke für Bi egungs- und D r u ckversu che entrommen und die Resultate dieser Versuche unter Berücksichtigung des Feuchtigkeitszustandes der Probestïcke untereinander verglichen werden sollten.

Als Versuchsmaterial dienten im ganzen 45 Stämme, welchc 4 verschiedenen bay̧rischen Revieren angehörten. Dieselben wurden 1 Meter über rlem Borlen abgeschnitten und es liamen die 4 lleter langen Trunme zur Verwcndung. Das gewomene Versuchsmaterial diente zur Erhebung der Druchfestigheit, des spez. Gewichtes nud des Feuchtigkeitsgehaltes sowie der Biegungs-Elastizität und -Festigkeit.

Die Druckiversuche wurclen an ganz frischem (nassem) Holze, in getrochnetem Zustande befindlichem Holze und an ganz oder doch nahezu lufttrockencm Holze rorgenommen.

Aus den Versuchsresultaten lassen sich folgende Ergebnisse anführen:

Zunächst folgte wicder die Abhängigkeit der Druckfestigkeit und des spezifischen Gewichtes rom Feuchtigkeitsgehalt, und zwar nimmt die Druckfestigheit bei zunehmendem Feuchtigheitsgehalt anfangs rascher, dann langsamer ab, ebenso das spezifische Gewicht bei abnehmenden Feuchtigkeitsgehalt.

Bezüglich des Zusammenhanges zwischen den Festigkeits-Eigenschaften des Nadelholzes und seinem anatomischen Bau hat B a u s c h i u g e r gelegentlich semer ersten Versuche (siehe Seite 409) den Satz aufgestellt, daß eine dichte SommerholzZone der Jahrringe von verhältnismäßig großer Breite in Vergleich zur Frühjahrszone eine große Zugfestig̣keit, eine locker gewebte und verhältnismäßig dünne (schmale) Sommerzone dagegen stets eine geringere Festigkeit (und Dichtigkeit) des, ganzen Querschnittes zur Folge hat. Ferner hat er gefunden, daß Stämme, welche bei gleichem Alter größeren Durchmesser, also breitere Jahrringe haben, schncller gewachsen sind, eine geringere Festigkeit haben als langsam gewachsene Stämme. Wohl traf diese Annahme bei den damals untersuchten Stämmen zu, doch ist sie im allgeneinen nicht richtig. Aus den in Rede stehenden Versuchen hat sich vielmehr ergeben, daß die verhältnismäßige Breite der Sommer- gegenüber der Frühjahrszone von der g a n z e n Brcite der. Jahrringe unabhängig ist, daß größere verhältnismäßige Breiten der Sommerzone sowohl bei weit- als bei engringigen Stämmen vorliommen und ebenso kleinere verhältnismäßige Breiten. Hieraus folgte der Schluß, ..daß dip Qualität des Holzes, für welche seine Druckfestigkeit maßgebend ist, mit der ganzen Breite der Jahrringe in keinem gesetzmäßigen Zusammenhang stehe". Daß eine rerhältnismäßig größere Breite der dichten sommerzone auch eine größere Dichtigkeit des Holzes zur Folge hat, wurde schon in den frülieren Arbeiten B a us ch in gers hervorgehoben, und daß zwischen rer Druchfestigkeit und dem spezifischen Gewicht bei eincm bestimmten Feuchtigkeitsgehalt ein inniger Zusammenlang bestehe, hewies auch diese neue trbeit. Als annähernder Ausdruck für die Abhängighcit der Druckfestigkeit vom spezifischen Gewicht hei $15{ }^{\circ}$ Feuchtigkeitsgehalt wurde folgende Gleichung gefunden:

$$
\beta=1000 \delta-100 \text {. }
$$

worin $\beta$ die Druckfestigheit, $\delta$ das spezifische Gewicht bei dem Feuchtiglieitsgelialt von $15 \%$ bedeuten. 
Wenn man sich fragt, wonach die "Qualität" des Holzes bezüglich seiner mechanischen Eigenschaftru bei seiner bautechnischen V'erwenctung zu beurteilen sei, so konmt dabei in erster Linie die Biegungsfestigkeit in Betracht, in zweiter die Druckfestigkeit bei der Verwendung zu Säulen, Pfosten etc. Nun ist aber, wie dies wie Versuche bestätigen, die Biegungsfestigkeit und mit ihr auch die Biegungsarbeit, welch erstere ja inmer gerade an einer bestimmten Stelle des Probestückes. im gefährlichen Querschnitt, überwunden wird, in außerordentlichem Grade abhängig von den Einflüssen, welche besonders Aeste an oder in der Nähe jener Stelle ausüben, so daß zwei stämme von in ganzen gleicher Qualität bei dem Versuche sehr verschiedene Biegungsfestigkeit und Biegungsarbeit ergeben können. Eine ähnliche Bewandtnis hat es mit der Elastizitätsgrenze, wozu noch lommt, daß diese immerhin nur zienlich unsicher zu bestimmen ist. Dagegen zeigt las Holz, daß sein Elastizitätsmodul, sowohl jener für Zug als auch der für Druck und Biegung, in hohem Grade mit diesen Festigkeitseigenschaften veränderlich ist, mit ihmen steigt und fällt. Da nun der Elastizitätsmodul von der Qualität des g a n z e n Probestïckes abhängig ist uml innerhalb der Elastizitätsgrenze eruittelt wird, also einer Grenze, innerhalb deren nur das Ilaterial in Wirkilichkeit angestrengt wird, so hält $\mathrm{B}$ a u s c h in $\mathrm{ger}$ diesen um so eher geeignet als llaßstab für die Beurteilung der Qualität, als er durch Biegungsversuche leicht mit genügender Sicherheit bestimmt werden kann.

Un die Richtigkeit dieser Ansicht zu prüfn, hat B a us ching e r seiner Arbeit eine graphische Aufzeichnung der diesbezüglichen Daten beigefügt, welche unverkennbar einen gesetzmäBigen Zusammenhang zwishen dem Elastizitätsmodul einerseits und der Biegungs- oder Inuckfestigkeit andererseits zeigt, und folgert hieran-, daß die bruckfestigkeit ein sichereres Kennzeichen für die hautechniseh wichtige Qualität rles Holzes ist als die Biegungsestigkeit. I'nol da rie Druckfestiglieit bei der zweiten, wichtigen Verwendungsart des Holzes in der Bautechnik, zu Pfosten u. dgh, von direktem EinfuB int, weil ferner die Probestücke für Druckfestigkeit so leicht und ohne beleutende liosten zu beschaffen sind und weil endlich rlieselbe so sicher und genau bestimmt werdon kann, so empfiehlt B a u s c h in $g$ e $\mathrm{r}$ aufs neue dieses Verfahren zur Prüfung des Holzes. Seine Vorschläge sind zum Teil in dem allgemeinen Irbeitsplane für Holzprüfungen, weleher vom Internationalen Verband für die Materialprüfungen der Technik aufgestellt wurde, berïckisichtigt worden.

S35. Iie Arbeiten M. R u d e lo f f s hatten den Zweck, eine umfassende Untersuchung über dhe Abhängigkeit rler Festigkeit ler in Preußen vorkommenden Hauptholzarten von den Standortsverhältnissen durchzufïhren. Der hiefür erforderliche Versuchs-Arbeitsplan wurle von Prof. Jartens ausgearbeitet. Es wurde zunächst die L'ntersuchung von drei Kieferstänmen aus der L'mgegend von Berlin in den Arbeitsplan aufgenommen. Die Versuchsergebnisse lassen sich wie folgt kurz charakterisieren: Bezüghich des Einflusses der Höhenlage im Stamme auf die D r u c kfestigke it ergab sich aus den Mittelwerten für die einzehen Trockenstufen, dafs die Festigkeit im allgemeinen mit zunehmender Höhe im stamme abnimmt. Ferner wurde gefunden, daß die loruckfestigkeit mit rlem spezifischen Gewichte und zwal annähern in dem gleirhen Verhältnisse wie dieses abnimut. $1 \mathrm{~m}$ allgemeinen entsprach der g̣ößcren .lahrringshreite auch die größere Druckfestigkeit. Für diesen auf den ersten Blick scheinbaren Widerspruch ist in der genannten Abhandhung eine Erktärung gegeben, un! ferner gelangten die Versuchsansteller zu dem Schlusse, daß die Druchfestigkeit les Holzes wesentlich von den Widerstande abhängt, welchen die einzelnen aus Herbstholz bestehmon Schichten (Platten) dem Zerknicken entgegensetzen und daß "lie Druckfestigkeit einer "Ton IIim" aus beanspruchten 
Iolzprobe hei sonst gleiehen Verhältnissen um su gröber ist, je geringer der lïrümungsadius der .Iahrringe ist.

Ebenso wie bein luftrockenen llolz zeigt sich much, daß beim grünen Holz die Mruckfestigheit mit dem spezifischen Gewieht, der Jahrringhreite und warhsenter Jöhenlage im Stamme abnimmt. Bezüglich der Lage in Querschnitt und der Ilinmelsuchtung ist ein bestimmter Einfluß auf die Festigheit nicht ersichtlich.

hie seluerversuche dienten zur Ermittung ler Festigkeit des Holzes in der Richtung des Spiegels und in der Richtung tangential zu den . Iahrringen. dus den Ergelunisen läßt sich hinsichtlich des Einfluses der Lage des llolzes in Stanmquerschnitt erkennen, daß rie Scherfestigkeit des dem llark zunäehst gelegenen Kemholzes germger ist als the der übrigen Kemstücke. Ein gesetzmäßiger Zusammenhang zwischen Sehubfestigkeit unı Höhenlage im Stamm dionnte nieht nachgewiesen werden. Die Seherfestigkeit des luftrockenen Splintholzes sowohl im spiegel als auch in der Wölbfläche zeigte sieh un $12-13^{\circ}$.o kleiner als die des hernlolzes. In allgemeinen ergab sieh die schubfestiglieit im Spiegol um etwa $10-15 \%$ größer als in der Wölbfläclıe.

Die Versuche auf B i e $g$ u $\mathrm{n} g$ des Holzes konnten nur an wenigen Probestïcken volgenommen werden. Es ergab sich, daß die Widerstandsfähigkeit des Holzes gegen Jnanspruchnahme auf Biegung mit her Höhenlage im Stamm abnimmt.

Die Resullate über die $\mathrm{Z} u \mathrm{gfest} \mathrm{g}$ ke it sind vielfach dureh Sehwierigkeiten und Lnzulänglichlieiten beeinflußt, welehe sich der Inurchführung diesor Versuche entgegenstellten. Inmerhin konnten aus den Zahlenwerten folgende Sehlüsse gezogen werden: 1. Der Einfluß der IImmelsrichtung tritt nicht scharf zutage, obgleich sowohl in lufttroekenen als aueh im halbtrockenen Zustande das nach Osten gelegene Holz den niedrigsten Elastizitätsmodul zeigt. Zieht man hior die Jahringbreite mit in Betracht, so ergibt sich, daß auch diese ohne gesetzmäBigen Einfluß ist. 2. Der Einfluß der Höhenlage in Stamm äußert sieh in der Weise, daß bei allen drei stämmen das Holz des höher gelegenen Trunms einen wesentlich geringeren Elastizitätsmodul aufweist, als am Stanm-Ende. Der. Untersehied betrug im Mittel für das grüne Holz $18,8 \%$, für das lablbtrokkene $21,20^{\circ}$ und fül tlas lufttrockene $22,8 \%$. 3. Bezüglich des Troekenzustandes ergab sich, daß das Holz mit zunehmenrler Troekenheit an starrheit gewinnt, unıl zwar ist der mittlere Elastizitätsmodul aller Stämme bei dem grünen Holz um 3:,7\%o und bej dem habtrockenen um $7,4^{\circ}$ o kleinel als derjenige des lufttrockenen Holzes.

Bezüglich der Sehwindungs-Terhältnisse sei auf diese aungezeichnete Publikation direkt verwiesen.

Ceberblicken wir die Hauptresultate, so muß zunäehst erkannt werden, daß lel Versuch untemommen wurłe, aus den Ergebnissen allgemeine Schlüsse abzuleiten, deren Richtigkeit teils durch die Versuche von Tetmajer, Bauschinger und Yörıllinger ihre Bestätigung gefunden haben, teils aber dureh weitere Versuche erst noch finden werden.

lmmerhin läBt uns auch diese mühevolle Irbeit die großen schwierigkeiten der Versuchsausführungen bei Hölzern in vollen .laße erkennen unu zu den liesultate gelangen, daß wir hei der Ermittlung der technischen Eigenschaften des Jlolzes nach einem ganz bestinunten unł rorher reiflich zu überlegenden Arbeitsprogranm vorzugehen haben, sollen die Resultate für die Technik brauchhare I aten liefern. Ein derartiger allgemeiner Arbeitsplan für llolzuntersuchungen ist mittlerweile (in Jahre 1906) vom Internationalen Verband für die llaterialprüfungen der Technik (sirlıe Seite 389) aufgestellt worlen. Rurleloff gebührt das Verdienst, die Grundzïge für 
eine Vereinheitlichung der Holzprüfungen zusammengestellt und den Entwurf dieses Arbeitsplanes verfaßt zu haben.

Von demselben Versuchsansteller rührt auch die höchst interessante Arbeit: „Untersuchung über den Einfluß des Blauwerdens auf die Festigkeit von Kiefernholz* her, welche im Heft I der Mitteilungen aus den Kigl. Techn. Versuchsanstalten zu Berlin 1897 erschienen ist und in V. Heft des Jahrganges I899 zum Abschlusse gelangte.

Aus den umfangreichen Untersuchungen über den Einfluß des Blauwerdens und des Lagerns der Stämme in Walde zieht Rudeloff den Schluß, 1. daß die Lnterschiede zwischen dem weißen und blawen Fiefernholz nicht derart seien, daß man in dem Blauwerden eine Schädigung der Festigkeitseigenschaften des Holzes erblicken könne, und 2. daß das Holz durch das Lagern der Stämme in Walde, selbst wemn es keine Veränderung in Aussehen zeige, hinsichtlich seiner Festigkeit minderwertig werde.

\$ 36. Die Untersuchungen von Dr. A. S $\mathrm{e} \mathrm{h} \mathrm{w} \mathrm{a} \mathrm{p} \mathrm{p} \mathrm{a} \mathrm{c} \mathrm{h}$ über Raumgewicht und Druckfestigkeit der Kiefer, Fichte, Weißtanne, Weymouthskiefer und Rotbuche stellen das Resultat einer gemeinsamen Arbeit der preußischen Hauptstation des forstlichen Versuchswesens in Eberswalde mit den Iönigl. Technischen Versuchsanstalten in Berlin-Charlottenburg dar. Die ersteren Versuche erstreckten sich auf 135 Kỉefernstämme, welche verschiedenen Standorten angehörten. Sowohl das spezifische Trockengewicht als auch die Druckfestigkeit wurden an den Probeliörpem erhoben. Ohne auf die wertvollen Einzelergebnisse einzugehen, seien hier die Schlußresultate angeführt, welche diese höchst instruktive Arbeit geliefert hat.

Die wichtigsten Ergebnisse über die Qualität des Kiefernholzes sind folgende:

Als Mlittelwerte ganzer, haubarer Stämme von besseren Standorten liömen angenommen werden: ein spezifisches Trockengewicht von 0.49 und eine Druckfestigkeit von $480 \mathrm{~kg}$ per $\mathrm{ccm}$. Die Güte des Kiefernholzes hängt nach den Untersuchungen über Raumgewicht und Druckfestigkeit gleichmäßig ab von a) Stammteil, b) Alter, c) Prozentsatz des Sommerholzes, d) Wachstumsgebiet und e) Standortsgüte.

ad a) Das Holz aus den untersten Stammteilen ist das schwerste und härteste; beide Eigenschaften nehmen zuerst rasch, dann in den mittleren Baumteilen langsamer ab, das Verhalten der obersten Stammteile ist wechselnd und hauptsächlich durch die Lage der Aeste bedingt.

ad b) Gesundes altes Holz ist besser als junges; Raumgewicht und Druclifestigkeit verhalten sich jedoch in dieser Richtung nicht ganz gleichmäßig. Das laufendjährige Optimum an Gewicht wird etwa im 60 jährigen Alter erreicht, von da ab sinkt das Raumgewicht des erzeugten Holzes zuerst langsam, dann rascher. Das durchschnittliche höchste Raumgewicht tritt etwa im 90-I00jährigen Alter ein.

Eine Ausnahme von diesem Gang machen nur die geringsten Standorte, auf denen das schwerste Holz in frühester Jugend erzeugt wird. Die Drickfestigheit nimmt mit dem Alter innerhalb der Grenzen dieser Untersuchung noch zu.

ad c) Einem geringen Prozentsatz von Sommerholz (30\% und weniger) entspricht stets ein niedriges Raumgewicht unl eine geringe Druckfestigkeit; beide steigen mit einer Zunahme dieses Prozentsatzes rasch an. Alle Verhältnisse und wirtsehaftlichen Maßregeln, welche eine Zunahme des Prozentsatzes vou Sommerholze zur Folge haben, steigern auch die Güte des Holzes.

ad d) Die Qualitäl des lïefernholzes wechselt nach dem Wachstumsgebiet; das Optimum für die Güte des Kïefernholzes imnerhalb des líreises dieser Unter- 
suchung und anscheinend wohl auch wenigstens fü $1^{\circ}$ Deutschland liegt zwischen del* Oder und Weichsel, und zwar zwischen den mittleren und unteren Lauf dieser Ströme. ad e) Kiefernholz von geringeren Standorten des gleichen Wachstunsgebietes ist weniger gut, als solches von besseren Standorten.

Das Verhältnis zwischen Raumgewicht und Druckfestigkeit ändert sich nach Alter, Wachstumsgebiet und Standortsgüte. Jo besser die Qualitït, desto geringer ist unter sonst gleichen Umstünden das Raumgewicht, welches einer bestinmten Druckfestigkeit entspricht.

Da mit zunehmendem Alter Veränderungen im Ǐ̈iefernholz eintreten, welche dessen Qualität wesentlich elhöhen, so sind auf den besseren Standorten Lintriebszeiten von 120-I40 Jahren angezeigt. Die notwendige Toraussetzung hiefür besteht aber darin, daß diese bessere Qualität auch im Preise zum Ausdruck gelangt.

Das Holz der Pinus silvestris besitzt unter günstigen Bedingungen eine Druckfestigkeit, welche jener der als Pitch-pine-Ilolz in Handel vorkommencien Arten durchschnittlich gleichwertig ist, mehrere derselben aber sogar wesentlich übertrifft. Hinsichtlich des Raumgewichtes steht das Holz von Pinus silvestris hinter jenem von P. cubensis und australis zurück, kommt aber jenem von P. taeda und mitis gleich.

Unter dem Einfluß ständiger Windströnungen entsteht ein exzentrischer Wuchs der Kỉefer, bei welchem das härteste $\left.{ }^{1}\right)$ Holz auf der schmalen Seite liegt. Die Ausdrücke ,harte" und ,weiche" Seite der Kiefer entsprechen nicht der Druckfestigkeit.

Diesen lehrreichen Untersuchungsresultaten über das Kiefernholz ließ Dr. $\mathrm{S}$ c h w a p p a c h ein Jahr später die Veröffentlichung über die Ergebnisse der Fichte, Weißtanne, Weymouthskiefer und Rotbuche in einem separaten Bande folgen. Ein Rückblick auf die Ergebnisse dieser höchst beachtenswerten Arbeit führte den Versuchsansteller zu folgenden Schlüssen:

Das Raumgewicht und die Druckfestigkeit hängen ab: von der Holzart, und bei gleicher Holzart: vom Stammteil, Alter, Wachstumsgebiet, Standortsgüte und wenigstens bei der Kiefer auch vom Prozentsatz des Sommerholzes. (Bei den übrigen Holzarten sind Ermittlungen über den Einfluß des Sommerholzes auf Raumgewicht und Druckfestigkeit nicht angestellt worden). Das spezifische Trockengewicht der einzelnen Hölzer wurde in Mittel gefunden für Rotbuche 0,67 , lïiefer 0,49 , Fichte 0,46 , Weißtanne 0,41 und für die Weymouthskiefer 0,37. Die Druckfestigkeit der einzelnen Hölzer in Vittel betrug für die Rotbuche 510, IViefer 480, Fichte 460 , Weymouthskiefer 420 und Weißtanne $400 \mathrm{~kg}$ pro ( $[\mathrm{cm}$.

Hinsichtlich der Beziehungen zwischen dem Vorhalten von Raumgewicht und Druckfestiglieit am Einzelstamm und hinsichtlich des Zusammenhanges zwischen Alter einerseits und Raumgewicht bezw. Druckfestigkeit andererseits sei auf die betr. Arbeit selbst verwiesen.

Nach der Volumenschwindung ordnen sich die Holzarten für 100-120jähriges Alter wie folgt: Buche 15\%, Fichte 13,2\%, Iiefer und Weibtanne 11,8\% und Weymouthskiefer $9,1 \%$; die Rotbuche schwindet also an meisten, während die 1 Weymouthskiefer durch sehr geringe Schwindung ausgezeichnet ist.

An Schlusse seiner Ergebnisse sind die Einflüsse präzisiert, welche die V'achstumsgebiete auf die Güte des Holzes haben.

1) Soll richtiger heißen ,druckfesteste". Sielıe auch die Bemerkungen über die harte und meiche Seite der Nadelhölzer im Kapitel über die Härte des Holzes auf Seite 439.

Handb, d. Forstriss, 3. Auf. II. 
Die Arbeiten Schwappachs haben ncucrdings gezcigt, wic verschieden die Eigenschaften des Holzes der gleichen Art je nach Wachstumsgebiet, Alter, Standort und wirtschaftlicher Behandlungsweise sind. Handelt es sich um die Beantwortung der Frage, ob inmerhalb eines größeren Landes ein Unterschiod in der Qualität des in verschiedenen Gegenden erwachsenden Holzes der gleichen Art besteht, so genügt jedenfalls nelon der Emittlung des Raungewichtes die Untersuchung der Druckfestigkeit. Daß die Untersuchung säntlicher Arten von Festigkeiten zur Erlangung sicherer Werte wünschenswert, ja notwendig ist, wird auch von Schwappach anerkannt.

\$37. Diek.k. österreichisehe forst]iche Versuchsanstalt in $\mathrm{M}$ a ri a br $\mathrm{r}$ n $\mathrm{n}$ hat den Untersuchungen über die technischen Eigenschaften, speziell der Elastizität und Festigkeit der Hölzer stets besondere Beachtung gewidmet; nach einem weitausgreifenden Arbeitsplane sollen die Hauptholzarten Oesterreichs: Fichte, Lärche, Eiche, Buche, Tanne und Kiefer in möglichst vollständiger, alle einzelnen Wuchsgebiete umfassenden Weise in monographischer Bearbeitung nach der angedeuteten Richtung in den Bereich der Untersuchung gezogen werden.

Die hieliei gesteckten Ziele sind cinerseits rein $\mathrm{t}$ e $\mathrm{ch}$ h i s e h e r Natur, indem durch diese Untcrsuchungen die Festigkeitskoeffizienten der Bauhölzer sowie deren Abhängigkeit von den sie beeinflussenden Faktoren festgestellt werden sollen, anderseits forstechnischer $\mathrm{N}$ a tur, da hicdurch die Verbindung hergestellt werden soll zwischen Produzenten und Konsumenten des Holzes, zwischen der Forstwirtsehaft und den Holz verarbeitenden Gewerben und Industrien; spezicll wird den die Forstwirtschaft interessierenden Fragen eine besondere Beachtung gewidmet, wie gutes und sehlechtes Holz schon dem äußeren Aussehen nach unterschieden werden könnc, welche Unstände maßgebend seien für die Erzcugung guten oder schlechten Holzes und welche Maßnahmen der Forstwirtschaft zu Gebote stehen, um ein qualitativ wertvolles Holzmaterial zu erziehen.

Bisher liegt die Bearbeitung des Holzmaterials der Fic h t e in 3 Heften der Witteilungen aus dem forstlichen Versuchswesen Oesterreichs, ,Untersuchungen über die Elastizität und Festigkeit der österreichischen Bauhölzer" vor, und zwar: Heft XXV, Fichte Südtirols, von A. Ha dek und G. J a n ka, I900; Heft XXVIII, Fichte von Nordtirol, von Wienerwalde und Erzgebirge, von G. J a $n \mathrm{k} a, 1904$; und Heft XXXT, Fichte aus den Jarrathen, aus dem Böhmerwalde, Temovanerwalcle und den Zentralalpen. Technische Qualität des Fichtenholzes im allgemeinen, von G. J a n k a, 1909. Das letztgenannte Heft enthält einc Zusammenfassung der Untersuchungscrgebnisse über die technischen Eigenschaften des Fichtenholzes überhaupt, ohne Tremnung des Untersuchungsmaterials nach Wuchsgebieten; die wichtigsten Ergebnisse hieraus seien hier wiedergegeben. Bemerkt wird, daß sich die hierbei in Anwendung gekommenen Prüfungsmethoden mit nur geringen Abweichungen mit den Vorschriften des intemational festgestellten Arbeitsplanes für Holzuntersuchungen docken.

$J$ a $n \mathrm{k}$ a rollt hicbej die ganze Frage über dic $Q$ u a 1 i t ät des 11 ol zes auf. Zunächst ist die Tatsache zu konstaticren, daß in neuerer Zeit die Forderung immer nachdrüeklicher erloben wird, daß dic Forstwirtschaft bei Erziehung der Bestände niclıt nur auf die Quantität, sondern auch auf die Qualität des Holzes Rï̈ksicht nchmen müsse, wie dies auf der Versammlung des Internationalen Verbandes forstlicher Versuchsanstalten in Stuttgart 1906 und bei dem internationalen land- und forstwirtschaftlichen Jiongreß zu Wicn 1907, dam auch in don Aussprüchen von Ci e s l a r- Wien, Schwap pach-Eberswalde, C. W a g n e r-Tübingen und II a r till-Tharandt u. a. zun Ausdrucke kam. 
Da aber die Qualität eines Holzmaterials ein relativer Begriff ist und scitens der verschiedenen holzverarbeitenden Gewerbe eine versehiedenc Auslegung findet, so ist man, wenn man die Qualität cines Holzmatcrials ziffemäßig exalit feststellen will, genötigt, dieselbe im Sinne des das meiste Holz verbrauchenden Gewerbes, d. i. der Bautechnik, zu definieren; und für diesen Vemendungszweck sind eben die Festigheitseigensehaften des Holzes vor allen maßgebend.

Die Untersuchungen $\mathrm{J}$ a $\mathrm{n} \mathrm{k}$ a s ïber die tcehnischen Eigenseliaften des Fichtenliolzes liaben nun crgeben, daf die Festiglieitscigenschaften des Holzes mit dem spezifischen Gewichte. Hand in Hand gehen, in der Art, daß mit steigendem spezifischen Trockengewichte diese Eigenschaften gleichsinnig ansteigen. Anderscits sinkt die Festiglieit bei gleicheı spezifiselıcn Gewichte mit zunelimendem Feuchtigkeitsgehalte des Holzes, so daß dieses Gesetz, welches in aller Schärfe zunächst für das Fichtenholz nachgewiesen wurde, zweifellos aber für alle Holzarten gilt, folgendermaßen formuliert werden liann: D i e F estigkeitseigenschaften des Holzes einer und derselben Holzart steigen beigleielıem Feuchtigkeitsgehalte proportional mit steigenden spezifischen Gewieht und bei gleichem spezifischen Gewicht mit abnehmender Feucht igkeit. Feuchtiglieit, spezifisches Gewicht und Festigkeit stehen also untereinander in innigstem liontalit, so daß eine gemeinscliaftliche Abhandlung derselben notwendig ist.

Daß das spezifische Gewicht des Holzes mit zunehmendem Feuchtigkeitsgehalte ansteigt, ist sellstverständlich; aber dieses Wachsen des spezifischen Gerichtes init dem Wassergehalte erfolgt nur in den unteren und obersten Stufen des Feuchtigkeitsgchaltes proportional; in dem Nomente, in welehem das trockene Holz liquides II asser aufnimnt, ändert sich der bis dahin geradlinige Verlauf der die Beziehungen zwischen spezifischem Gewicht und Feuchtigkeitsgehalt darstellenden Linie; es ist dies bei Feuchtiglieitsprozentsätzen von etwa $25-40 \%$ der Fall. Eine ähnliche, nur noch schärfer ausgeprägte Wendung der Diagrammlinie tritt auch bei der Darstellung der Beziehungen zwischen Feuchtigkeit und Druckfestigkeit ein. Die beigegebene Fig. 1 stellt dieses Gesetz der Abbängigkeit a) des spezifischen Gewichtes, b) der Druclifestigkeit rom Feuchtigkeitsgehalte für die verschiedenen Trockengewichtsstufen des $\mathrm{F}$ i c h $\mathrm{t}$ e $\mathrm{n}$ h o $\mathrm{l} \mathrm{z}$ es dar.

Da es hei der Variabilität sowohl des spezifischen Gewichtes als auch der Druckfestigkeit des Holzes einer bestimmten Holzart wünschenswert ist, diese Zahlenangaben untereinander vergleichbar zu machen, so sind dieselben auf einen e inhejtlichen Feuchtigkeitsprozcntsatzzu reduzieren, und zwar gemäß internationaler Vereinbarung auf den Feuchtigkeitsprozentsatz von $15 \%$, bezogen auf das Gewicht des absoluttrockenen Holzcs.

Dic diescr Pieduktion dienenden Formeln sind für Fichtenholz crmittelt worden und lauten:

Hiebei bedeutet

$$
\begin{aligned}
& \mathrm{s}_{15}=1,02 \mathrm{~s}_{0}+2,2 \text {. . . . . . . . . . . } 1 \text {. } \\
& \mathrm{s}_{15}=\mathrm{s}_{\%}+\left[\left(0,00133 \mathrm{~s}_{0}+0,14 \bar{\gamma}\right)(15-0)\right] \quad . \quad 2 . \\
& \beta_{15}=10,3 \mathrm{~s}_{15}-60 \text {. . . . . . . . } 3 \text {. . } \\
& \beta_{15}=10,5 \mathrm{~s}_{0}-38 . . . . .4 .4 .4 . \\
& \beta_{0}=22.5 \mathrm{~s}_{0}-200 \text {. . . . . . . . 5. }
\end{aligned}
$$

$s_{15}$ das spezifische Gewicht, $\beta_{15}$ die Druckfestiglieit beim Normalfeuclutiglieitsgehalte von $15 \%$, 


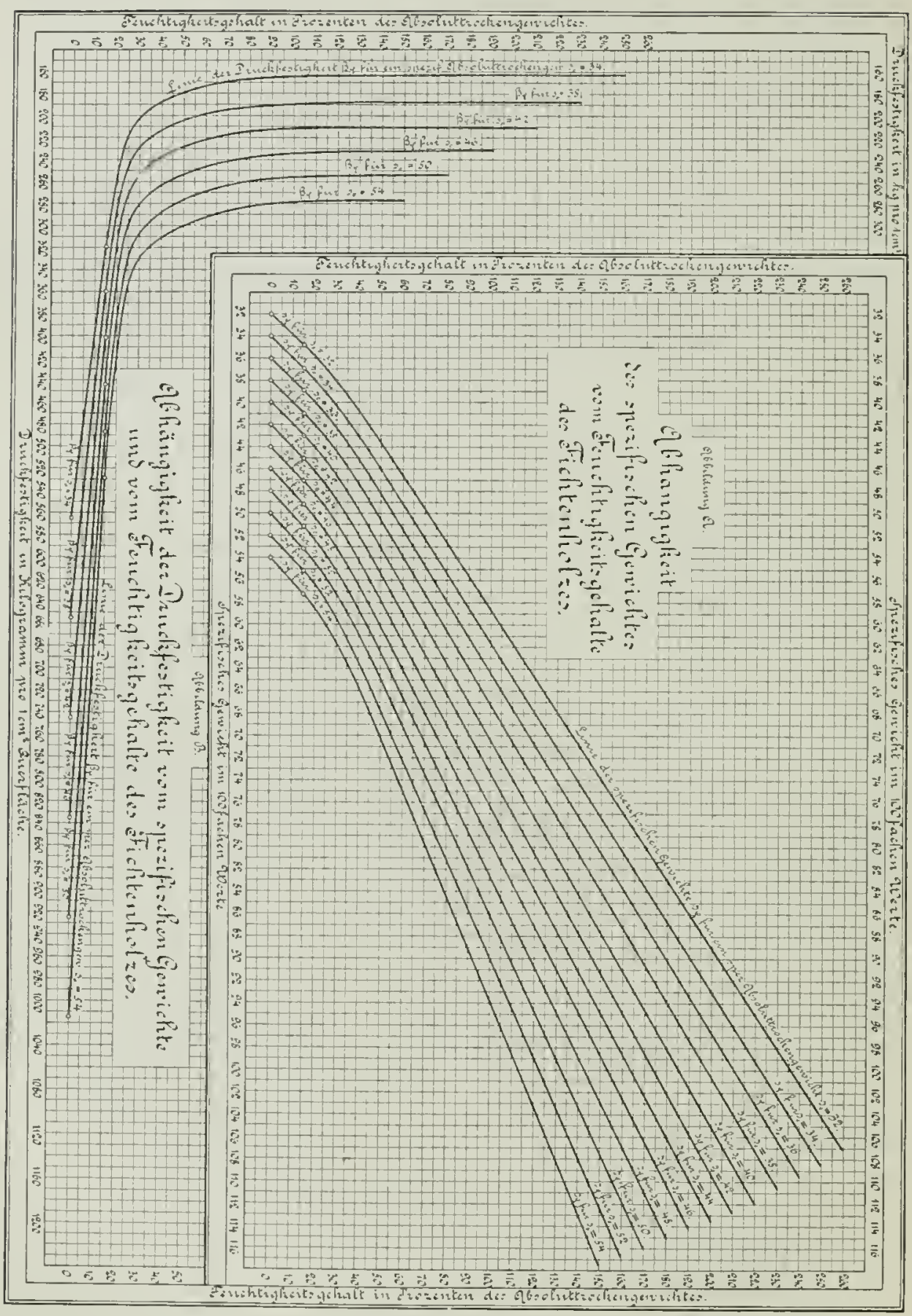




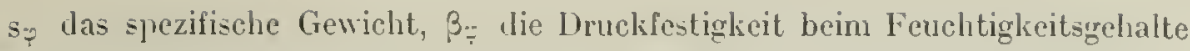
von $\% \%$,

$s_{0}$ das spezifische Absoluttrockengewicht,

$\beta_{0}$ die Druckfestigkeit absoluttrockenen Holzes (also beim Feuchtigkeitsgehalte $0 \%$ ), und zwar ist

$s$ in loofachen Werte,

$\beta$ in $\mathrm{kg} / \mathrm{cm}^{2}$ für astfreie plattenförnige Druckprohen ausgedrückt.

Aus dem Graphilion auf Seite 420 läßt sich noch folgendes erkennen: Je größer das spezifische Trockengewicht eines Holzes, desto weniger Wasser braucht dasselbe zur endgültigen Erreichung des wassersatten Zustandes. Daher sinken, z. B. bei verzögerter Trift, unter sonst gleichen Umständen, d. i. bei gleichem anfänglichen Feuchtigkeitsgehalte, die schwersten, also besten Hölzer zuerst unter.

Die Druckestigkeit ist bei $0 \%$ Feuchtigkeit ein 11 aximum und fällt mit zunelımendem Wassergehalte zunächst rasch, bei höheren Fenchtigkeitsgraden (über 25 bis etwa $40 \%$ ) langsaner, un sodann lis zum Wassersättigungszustande annähernd auf gleicher, sehr geringer Höhe zu verharren.

Je größer das spezifische Trockengewicht cines Holzes, desto größer ist die Zunahme der Druckfestigkeit nicht nur im ahsoluten, sondern auch im relativen

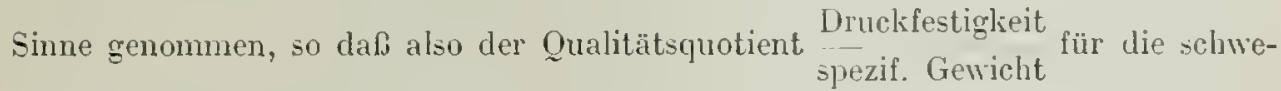
reren, festeren Hölzer ein günstigerer wird als für die leichteren, schlechteren Hölzer der gleichen Holzart.

Aher nicht nur die Druckiestigkeit, sondern auch a l] e ü b rige n E ig e nscluaftender Elastizität und Festigke it werden vonder Fe uchtiglicit und dem spezifis chen G e w c h t e eines Holzes beeinflußt.

Die Abhängigkeit dieser Festiglieitseigenschaften rom Wassergehalte zeigt zunächst die naclistehende Tabelle XI.

Tabelle XI.

Abhängigkeit der Fcstiglieit des Ficllenholzes vom Feuchtiglie itsgelia $1 \mathrm{t}$ e.

\begin{tabular}{|c|c|c|c|c|c|c|c|c|c|c|}
\hline \multirow{3}{*}{$\begin{array}{l}\text { Feuchtig- } \\
\text { lieitszu- } \\
\text { stand der } \\
\text { Proben }\end{array}$} & \multicolumn{5}{|c|}{ Druclielastizität u. -Festigheil } & \multicolumn{5}{|c|}{ Biegungselastizităt u. -Festigkeit } \\
\hline & 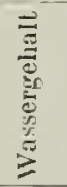 & 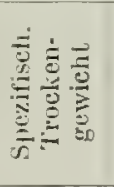 & 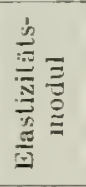 & 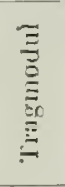 & 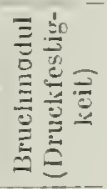 & 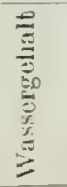 & 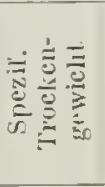 & 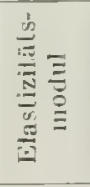 & $\begin{array}{l}\Xi \\
\Xi \\
\Xi \\
\vdots \\
\Xi \\
E \\
E\end{array}$ & 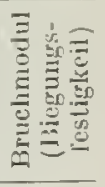 \\
\hline & $\%$ & $100 \mathrm{fach}$ & $\mathrm{t} / \mathrm{cm}^{2}$ & & $\mathrm{~cm}^{2}$ & ${ }^{0}{ }_{0}$ & $100 \mathrm{fach}$ & $\mathrm{t} / \mathrm{cm}^{2}$ & & $\mathrm{~cm}^{2}$ \\
\hline luftrocken & 13.9 & 38.9 & 115.1 & 202 & $34 \%$ & 13.5 & 35.7 & 104.1 & 338 & 584 \\
\hline lufteucht & 17.0 & 36.7 & 99.1 & 200 & 233 & 19.3 & 36.9 & 89.1 & 263 & 496 \\
\hline$n a B$ & 63.1 & 39.6 & 96.8 & 49 & 172 & 57.8 & 38.8 & 84.0 & 153 & 336 \\
\hline
\end{tabular}

Aus dieser Tabelle ist die Abnalıme der Festigkeits- und Elastizitätseigenschaften bei zunehmender Feuchtigheit hlar ersichtlich; das gilt ganz besonders für den Tragnıodul der Druck- und Biegungsfestigkeit, weniger stark werden die Elastizitätsmoduli vom Feuchtigkeitsgehalte beeinflußt.

Scharf ansgeprägt tritt das Ablängigkeitsverhältnis zwischen den E I a s t izitäts-und Festigkeitseigensehafteu und demspezifischen 
Ge wi $\mathrm{eht}$ e des Fichtenholzes unter gleichen Feuchtigkeitsverhältnissen hervor, wie die nachstehende Tabelle XII (S. 423) dies beweist.

Diese Tabelle zeigt, weleh großen Einfluß das spezifiselze Gewicht auf die Festigkeitseigenschaften eines Holzes ausübt; es können in dieser Hinsicht Unterschiede in der Festigkeit zwisehen leiehtem, sehlechtem und schwerem, guten Holze bis zu $100 \%$ konstatiert werden, so daß also ein qualitativ sehr gutes Holz eine fast doppelt so große Festigkeit aufweisen kann als ein schlechtes Holzmatørial derselben Holzart.

Für ein Fiehtenholz mittlerer Qualität von 42.4 spezifischem Lufttrockiengewieht (entsprechend einem Absoluttroekengewieht von 39.0) und von etwa $14.0 \%$ Feuchtigkeitsgehalt ist nach Tabelle XII anzunehmen

ein Druckelastizitätsmodul von . . . . . . . $115 \mathrm{t} / \mathrm{cm}^{2}$ ein Druck-Tragmodul von . . . . . . . . . $200 \mathrm{~kg} / \mathrm{em}^{2}$ eine Druckfestigkeit (50 cm lange Prismen) von . . $347 \mathrm{~kg} / \mathrm{em}^{2}$ ein Biegungselastizitätsmodul von . . . . . . $104 \mathrm{t} / \mathrm{em}^{2}$ ein Biegungs-Tragmodul von . . . . . . . . $338 \mathrm{~kg} / \mathrm{cm}^{2}$ eine Biegungsfestigkeit von . . . . . . . $584 \mathrm{~kg} / \mathrm{em}^{2}$

Bezüglich des Untersehiedes wischen Kern- und Splintholz der F i c h t e haben die Untersuchungen Dr. Jankas ergeben, daß das Splintholz hinsiehtlich der Festigkeit dem Kiernholze nicht nur nicht nachsteht, sondern demselben sogar überlegen ist. Daß das Splintholz allgemein geringer geseliätzt wird als das Kernholz, hat seine Ursache in dem höheren Feuchtigkeitsgehalte desselben, woraus natürlich bei unvollständiger Austrocknung eine geringere Festigkeit desselben gegenüber dem trockeneren Kernholze sich von selbst ergibt; dann aber auch in dem Umstande, daß das Splintholz zahlreiehe Saftbestandteile, Eiweiß, Gummi, Stärke, Zucker etc. aufgespeichert enthält, die einen vorzüglichen Nährboden für holzzerstörende Pilze abgeben, weshalb Splintholz im feuchten Zustande von sehr geringer Dauer ist, im trockenen Zustande aber wieder von Holzbohrkäfern angegangen wird. Kernholz hat dagegen eine geringere Biegungsfestigkeit als Splintholz, es zeigt sich beim Biegeversuch spröcler als letzteres. Diesel Umstand tritt besonders deutlich in der Arbeitskapazität ron solehen Balken hervor, die .,kerndurchschnitten “ in der Art beansprucht werden. daß die Kemfasern in die Zugseite des Balkens fallen. Bei dieser unrichtigen Verlegungsweise der Fichtenbalken zeigt sich eine Verminderung der Biegungsfestigkeit um S\% , der Biegungsarbeit beim Bruche um $40 \%$ gegenüber der richtigen Beanspruchungsweise, bei weleher der Splint in die Zugseite des Balkens fällt.

Was nun die Beziehungen $\mathbf{z}$ ischen. Jahringbreite $11 \mathrm{~d}$ den technisehen Eigenschaften des Fiehtenholzes anbelangt, so läßt sieh der Erfahrungssatz der Pralitilier, daß engringiges Fichtenholz qualitativ besser sei als breitringiges, in dieser allgeneinen Form nicht aufreeht erhalten; es kann in einzelnen Fällen ein reeht breitringiges Holz größere Festigkeit aufweisen als ein sehr selmalringiges - nur darf die Breitringigkeit eine gewisse Maximalgrenze nicht übersehreiten. Maßgebend für die Höhe des spezifischen Gewichtes und damit gleichzeitig auch für die Festigkeit des Fichtenholzes ist lediglich der Umstand, ob das betreffende Holz einen hohen oder niedrigen Prozentsatz an festem, hartem, dicht gebautem und daher schwerem Spätholze aufweist. Die Festigkeit eines Holzes ist in erster Linie von dem Verhältnisse des Spätholzes zum Frühholze abhängig; dieses Verhältnis läßt sich auf der glatt gehobelten Hirıfläche einer Holzprobe schon mit freiem Auge heurteilen. Nichtsdestoweniger aber hat der oben erwähnte Satz 
Versuchsresultate ron Janka. $\$ 37$.

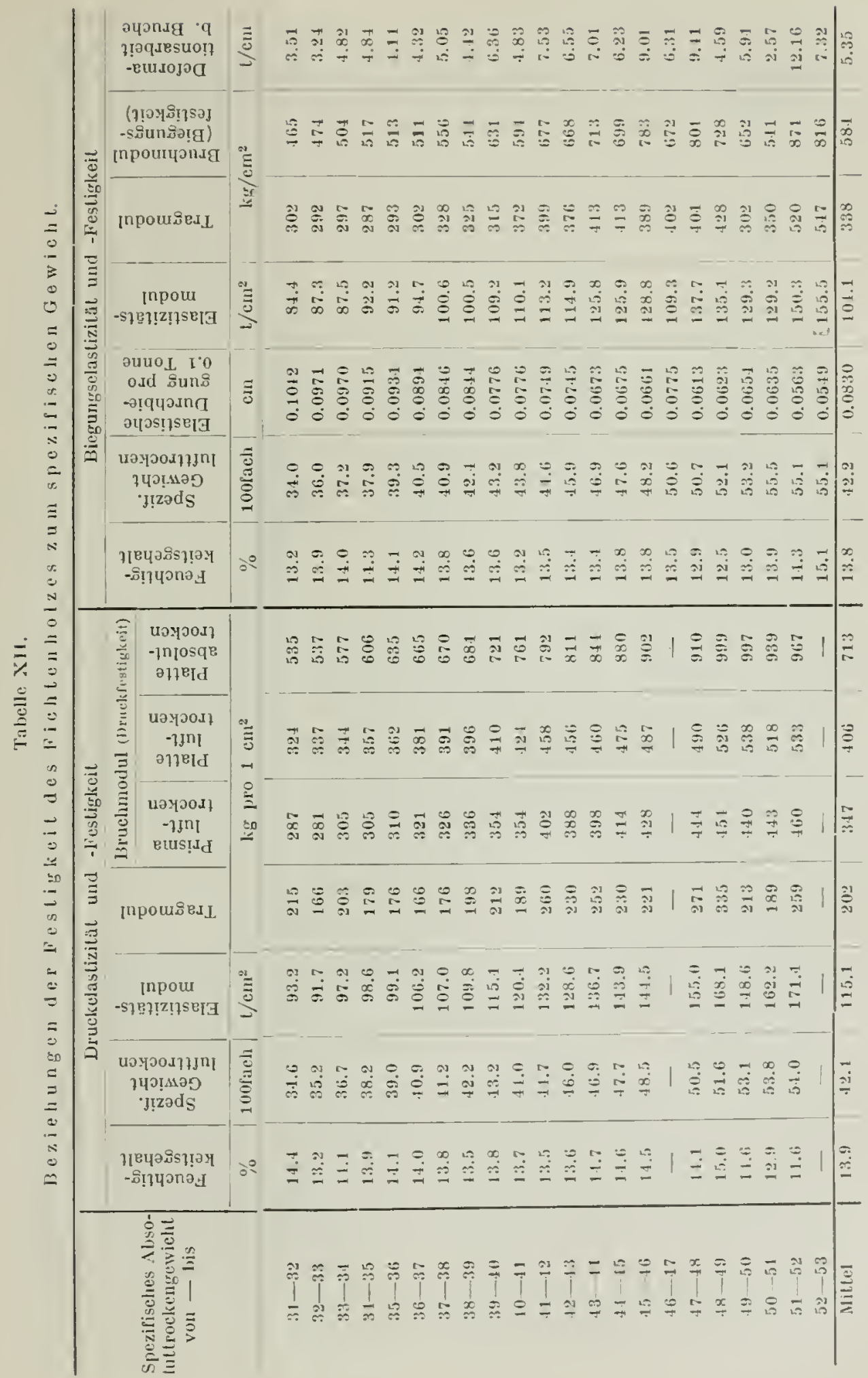


der Forstleute, Holzarbeiter und Holzhändler, weleher die Güte eines Fichtenholzes (überhaupt eines Nadelholzes) nach der bloßen Jahrringbreite beurteilt, im großen Durchschnitte seine Gültigkeit, weil die Breite der Spätholzzonen bein Nadelholz sowohl bei eng- als bei weitringigem Holze im allgemeinen zienlich lionstant bleibt, und nur die Frühholzzonen bei breitringigen Holze in ihrer Breite wachsen.

Aus der großen Zahl von Einzelproben des $\mathrm{F}$ i c h t e $\mathrm{n}$ holzes aus den rerschiedensten Wuchsgebieten Oesterreichs hat Janka folgende Zahlen für Jahrringbreite, spezifisches Gewicht und Druckfestiglieit abgeleitet:

\begin{tabular}{|c|c|c|c|c|c|c|c|}
\hline \multicolumn{2}{|c|}{ Jahrringloreite } & \multicolumn{2}{|c|}{ Spezif. Gewicht (100fach) } & \multicolumn{4}{|c|}{ Druckfestigkeit } \\
\hline & & lufttrocken & absoluttrocken & luft & ocken & absolt & ttrocken \\
\hline $0,5-1,0$ & $m m$ & 44,9 & 41,7 & 397 & $\mathrm{~g} / \mathrm{cm}^{2}$ & 743 & $\mathrm{~kg} / \mathrm{cm}^{2}$ \\
\hline $1,0-1,5$ & , & 44,3 & 41,3 & 395 & " & 729 & , \\
\hline $1,5-2,0$ & $"$ & 43,1 & 40,2 & 386 & $"$ & 708 & , \\
\hline $2,0-2,5$ & , & 41,9 & 38,9 & 364 & , & 666 &, \\
\hline $2,5-3,0$ & , & 41,3 & 38,4 & 3.53 & $"$ & 647 & , \\
\hline $3,0-3,5$ & , & 39,9 & 37,0 & 339 & $"$ & 622 & , \\
\hline $3,5-1,0$ & ," & 40,2 & 37,2 & $34 ?$ & $n$ & $6 I 9$ & $"$ \\
\hline $4,0-1,5$ & , & 39,1 & 36,0 & 314 & , & 581 & , \\
\hline $4,5-5,0$ & , & 40,2 & 36,8 & 308 &, & 54 & , \\
\hline über 5,0 & $"$ & 38,1 & 34,9 & 306 & , & 510 & ", \\
\hline
\end{tabular}

Im Mittel ergab sich für das Fichtenholz Oesterreichs eine Jahrringbreite von $2,2 \mathrm{~mm}$, ein spezifisches Absoluttrockengewicht von 39,6 (entsprechend einem spezifischen Lufttrockengewicht bei $15 \%$ Feuchtigkeit ron $4 \%, 6)$, eine Druckfestigkeit lufttrocken von $348 \mathrm{~kg} / \mathrm{cm}^{2}$, absoluttrocken $657 \mathrm{~kg} / \mathrm{cm}^{2}$.

Neben der Jahrringbreite ist aber auch die Art der Anlagerung der einzelnen

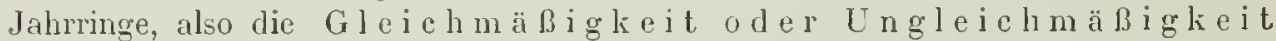
in der Brejte der a ufeinanderfolgenden $J$ ahringe für die Güte eines IJolzmaterials von Bedeutung. Das Ideal, welehes dem Forstwirte bei der Erzielıung sciner Bestände vorschweben muß, ist eine durchaus gleiche Jahrringbreite rom innersten Fiern bis zum äußersten Splint, eine Forderung, welehe Prof. Martin in seinem Gesetz von der Erhaltung gleicher Ringbreiten formuliert hat und zu deren Erreichung er für die Erziehung der Fichte einen dichteren Stand in der Jugend beziehungsweise die natürliche Verjüngung unterm Schimbestand der Mutterbäume, in der Folge allmählich und schwach beginnende und immer stärker werdende Durchforstungen und schließlich im späteren Alter der Bestände ausgiebige Lichtungen vorschlägt.

Eine der wichtigsten Forderungen, die an die Beschaffenheit eines Holzmaterials gestellt werden, ist die A s trein li e it. Astreines Holz wird nun zwar stets ein fronmer Wunsch des Baugewerbes bleiben; aber die Astigkeit auf das möglichst geringe Maß herabzudrücken und den Baumschaft möglichst astfrei zu erziehen, das muß die Forstwirtschaft als Ideal unter allen Umständen anstreben. Das Mittel, möglichst astfreies Holz zu erziehen, beruht in der guten SchluBregelung der Bestände, besonders der Nadelhölzer. Glücklicherweise treffen die Bedingungen, unter welchen ein qualitativ wertvolles, festes Fichtenholz erwächst, mit jenen Bedingungen zusammen, unter welchen ein astreines Holz zu erwachsen pflegt; es ist dies der engere Sclıluß der Nadelholzbestände schon von Jugend an.

Die Qualität des Fichtenholzes ist aber auch rom Alter d e r S t ä m m e abhängig, in der Weise, dab junge Stämme ein geringeres spezifisches Gewicht und 
daher eine geringere Festigkeit des Holzes hesitzen als ältere Stämme. Nach den Untersuchungen Jankas lıatten Fichtenstämme

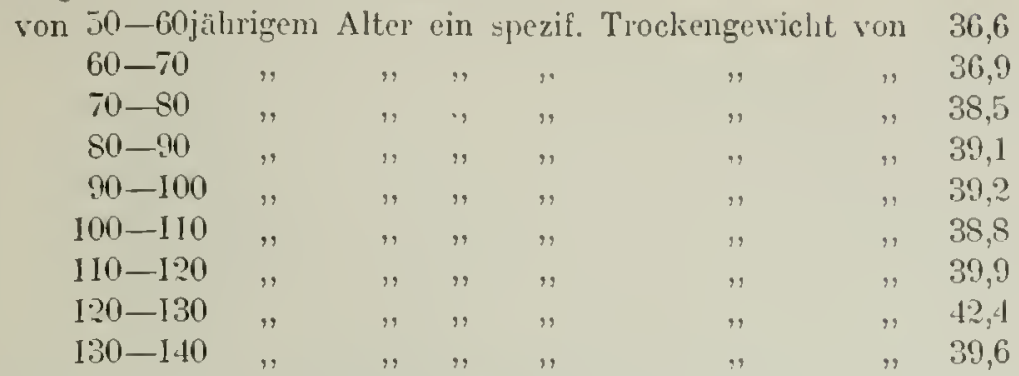

Leberalte Stämme zeigen daher wieder eine Abnahme in der Qualität ihres Holzes, aus dem Grunde, weil diese überständigen Stämme aus den Hochlagen der Alpen stammten, wo die Fichte bei der kurzen Vegetationszeit zwar ein sehr feinringiges, aber ein etwas leichteres, wenig Spätholz uimfassendes Holz bildet.

Wenn man berücksichtigt, wie selı die Festigkeit eines Holmaterials durch den Feuchtigkeitsgehalt und das spezifische Gewicht beeinflußt wird, so erscheint es gerechtfertigt, daß die für Baukonstruktionen bisher in Anwendung stehenden Festigkeitskoffizienten in der Ilinsicht einer Revision unterzogen würden, daß für sebweres und festes Holz einerseits, für leichtes und schlechtes II aterial anderseits, dam auch für die Verwendung von Holz in stets trockenen und in stets feuchten $\mathrm{P}$ ä u m en oder ganz un ter. Wasser verschiedene Festigkeits$\mathrm{k}$ o e f $\mathrm{f}$ i z i e $\mathrm{n} t$ e $\mathrm{n}$ den statischen Bereclnungen von Baukonstruktionen zugrunde gelegt würden. Gutes, schweres, tragfähiges Holz verdient in jeder Beziehung den Torzug vor leichtem, schlechtem, leichthrüchigem Holzmaterial. Diesem Unstande sollten auch die Techniker und die Baugerrerbe Rechnung tragen, inden sie für gutes Holz bessere Preise bewilligen als für schlechtes. Unter dieser Toraussetzung würden sich auch die Forstwirte bei der Begründung und Erziehung ihrer Waldbestände veranlaßt sehen, nicht so sehr auf Massenerzeugung als vielmehr auf die Erziehung qualitativ wertrollen Holzmaterials hinzuwirken.

\$ 38. Ueber die technische Qualität des Eschen hol zes und die Eigenschaften, welche dieses Holzmaterial für die Verwendung bei der Fabrikation von Slis, deu norwegischen Schneeschuhen, anfweisen soll, hat Forstmeister Dr. J a n k a eine Abliandlung im Zentralblatt für das gesamte Forstwesen 1911 publiziert. Auch bei diesem Holzmaterial ergaben sich ähnlich wie beim Fichtenholze große V'erschiedenheiten in der Qualität, so daß die zahlenmäßigen Werte der Elastizitäts- und Festigkeitseigenschaften für schlechtestes und bestes Eschenholz um 100 und mehr Prozent auseinanderliegen. Wie nicht anders zu erwarten, gilt auch für das Eschenholz das gleiche Gesetz der Abhängigkeit der Festigkeit rom Feuchtigkeitsgehalte und dem spezifischen Gewichte wie für Fichtenholz. Wenn sich hie und da in den Tabellen der techuischen Eigenschaften des Eschenholzes Unregehmäßigkeiten im Verlauf dieser Eigenschaften geltend machen, so kam dieser Umstand bei der komplizierten Natur des Holzes und dem organischen Aufbau desselben nicht wundernehmen; auch war das diesen Lntersuchungeı zugrunde liegende llaterial nicht umfangreich geıug, um etwaige Ausnahmen auszugleichen.

Wir geben in der nachstehenden Tabelle XIII die Ergebnisse der Qualitätsuntersuchungen des Eschenholzes auszugsweise wieder. 
Tabelle XIII.

Abhängigleit der Festiglieit des EschenhoIzes rom spezifischen Gewichte und von der Feuchtigkeit.

\begin{tabular}{|c|c|c|c|c|c|c|c|c|c|c|}
\hline \multicolumn{6}{|c|}{ Biegeproben } & \multicolumn{4}{|c|}{ Druckproben (Würiel) } & \multirow{2}{*}{$\begin{array}{l}\text { Härte- } \\
\text { proben }\end{array}$} \\
\hline \multirow[b]{2}{*}{ 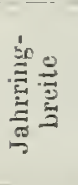 } & \multirow[b]{2}{*}{ 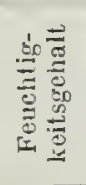 } & \multirow{2}{*}{ 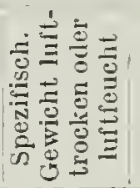 } & \multirow{2}{*}{ 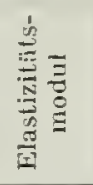 } & \multirow{2}{*}{ 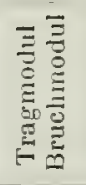 } & \multirow[b]{2}{*}{ 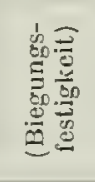 } & \multicolumn{4}{|c|}{ Spezif. Gewicht Druckfestigkeit } & \\
\hline & & & & & & 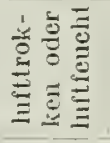 & 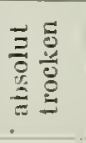 & 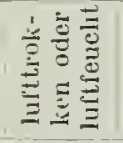 & 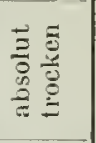 & $\begin{array}{l}\text { Härte luft- } \\
\text { trocken od. } \\
\text { luftfeucht }\end{array}$ \\
\hline $\mathrm{mm}$ & $\%$ & 100 ach & $t / \mathrm{cm}^{2}$ & \multicolumn{2}{|c|}{$\mathrm{kg} \mathrm{cm}^{2}$} & \multicolumn{2}{|c|}{$100 \mathrm{fach}$} & \multicolumn{2}{|c|}{$\mathrm{kg} / \mathrm{cm}^{2}$} & $\mathrm{~kg} / \mathrm{cm}^{2}$ \\
\hline \multicolumn{11}{|c|}{ 1. Lufttrockener Zustand. } \\
\hline 0.6 & 11.5 & 50.3 & 67.0 & 249 & 636 & 51.0 & 47.4 & 394 & 639 & 476 \\
\hline 1.2 & 11.2 & 58.5 & 84.3 & 322 & 846 & 60.0 & 55.8 & 462 & 787 & 574 \\
\hline 2.0 & 11.3 & 63.4 & 106.9 & 385 & 1010 & 64.8 & 60.8 & 454 & 975 & 630 \\
\hline 8.8 & 11.1 & 65.5 & 74.6 & 362 & 945 & 66.8 & 62.5 & 500 & 857 & 716 \\
\hline 1.6 & 11.4 & 68.6 & 117.0 & 460 & 1239 & 69.9 & 65.5 & 588 & 1036 & 612 \\
\hline 1.8 & 11.8 & 70.0 & 148.5 & 588 & 1029 & 72.7 & 68.6 & 649 & 1138 & 628 \\
\hline 2.4 & 11.5 & 71.8 & 139.7 & 571 & 1258 & 74.2 & 70.3 & 609 & 1158 & 714 \\
\hline 1.9 & 12.0 & 77.5 & 160.0 & 579 & 1382 & 79.7 & 75.8 & 634 & 1222 & 828 \\
\hline 1.8 & 11.6 & 84.0 & 167.4 & 750 & 1563 & 86.7 & 8..2 & 759 & 1352 & 1012 \\
\hline 4.0 & 11.8 & 88.7 & 151.8 & 589 & 1500 & 91.0 & 86.1 & $: 70$ & 1312 & 1066 \\
\hline ttel & 11.0 & 70.9 & 110.0 & 465 & 1133 & 72.6 & 68.3 & 566 & 1007 & 716 \\
\hline
\end{tabular}

II. Lufteuchter Zustand.

\begin{tabular}{r|rrr|r|r|r|r|r|r|r}
0.6 & 16.6 & 50.5 & 54.6 & 243 & 571 & 50.8 & 45.9 & 275 & 587 & 340 \\
1.3 & 17.4 & 62.8 & 74.4 & 284 & 698 & 53.4 & 57.0 & 368 & 822 & 502 \\
1.2 & 17.0 & 70.6 & 100.6 & 287 & 764 & 71.9 & 66.3 & 362 & 1000 & 512 \\
2.9 & 18.4 & 77.1 & 99.9 & 532 & 882 & 78.4 & 73.0 & \pm 39 & 1169 & 628 \\
1.9 & 16.5 & 87.0 & 153.1 & 509 & 1250 & 90.1 & 84.7 & 592 & 1485 & 8.2 \\
\hline MitteI & 17.3 & 69.7 & 91.3 & 337 & 837 & 71.2 & 65.6 & 398 & 992 & 573
\end{tabular}

Man ersieht aus dieser Tabelle, daß auch hier die Jahrringbreite für sich allein nicht maßgebend ist für die Qualität des Eschenholzes, da sowohl sehr engringiges als auch übermäßig breitringiges Holz minderwertig ist. Ausschlaggebend ist auch hier wieder das V'erhältnis des Spätholzes zum Frühholze. Je mehr Spätholz die Querschnittsfläche aufweist, und je schmäler die porenreichen Frühholzzonen sind, desto schwerer das Eschenholz, desto besser die technische Qualität desselben. Allerdings darf die Wuchsgeschwindigkeit des Holzes eine gewisse Grenze nicht überschreiten, weil bei sehr breiten Jahrringen ein lockeres, wenig festes Spätholz entsteht.

Nlaßgebend für die Eignung eines Eschenholzes zu Skischienen sind neben der Zähigkeit des Materials noch die Festigkeit gegen Biegebruch, die Steifigkeit, die sich in der Größe des Elastizitäts moduls ausdrückt, und die Hä r t e, die wiederum mit der A b n üt z b a r k it beim Gleiten über den Schnce Hand in Hand geht; alle diese Eigenschaften gehen mit dem spezifischen Gewichte parallel. In diesem Sinne ist also dem schweren, daher harten und festen Eschenholze vor dem leichten der Vorzug einzuräumen. Ein größerer Feuchtigkeitsgehalt vermindert säntliche Festigkeits-Eigenschaften des Holzes, wie Tabelle XIII dartut; nur die Zähigkeit wird durch höheren Wassergehalt des Holzes erhöht.

Die Esche produziert ihr bestes Holz nicht im gedrängten Schlußstand wie die Nadelhölzer, sondern unter nöglichst hohem Lichtgenuß, also in Freistand oder an Bestandesrändern und in lichten Auwaldungen, offenbar weil die Beanspruchung des Baumschaftes durch delı Wind den Baum veranlaßt, ein gegen Biegung und Bruch 
möglichst widerstandsfähiges Holz zu bilden. Junges Eschenholz ist zähel als alles, das braune Kernholz spröder als das weiße Splintholz.

§39. Die Frage, wie sich die Druckfestigkeit vou Hölzern, velche im W a s s e r a s ge I a ug t worden waren, gegenüber der Druckfestigkeit von ungeschwenmnten Hölzerı verhält, hat $J$ a $\mathrm{n} \mathrm{k}$ a zum Gegenstand eingehender Untersuclıungen gemacht ${ }^{\mathrm{I}}$ ) und dabei gefunden, daß die Auslaugung in Süß- und Salzwasser eine Verminderung der Druckfestiglieit des lufttrockenen (nach der Wassertränkung wieder lufttrocken gewordenen) Holzes zur Folge hat, daß also ungeschwemmtes Holz die geschwemmten Hölzer in der Druckfestigkeit des lufttrockenen Zustandes übertrifft, wälurend andererseits die Druckfestigkeit des im absoluttrokkenen Zustande geprüften Iolzes bei dem in Salzwasser ausgelaugten Holzmaterial höber ist als die gleiche Druckfestigkeit der unausgelaugten und der im Süßwasser geschwemmten Hölzer, wie dies die nachstelıende Tabelle IV zeigt.

Tabelle XIV.

Druckfestigkeit geschwemnten und ungesehwemm ten $\mathrm{Holz}$ es.

\begin{tabular}{|c|c|c|c|c|c|c|c|c|c|}
\hline \multirow{4}{*}{ Holzart } & \multicolumn{3}{|c|}{ Ungeschwemmtes $\mathrm{Holz}$} & \multicolumn{3}{|c|}{$\begin{array}{l}\text { In Sußßwasser } \\
\text { geschwemmtes Holz }\end{array}$} & \multicolumn{3}{|c|}{$\begin{array}{c}\text { In Salzwasser } \\
\text { ausgelaugtes Holz }\end{array}$} \\
\hline & \multirow{2}{*}{ 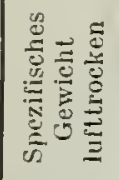 } & \multicolumn{2}{|c|}{ Druckfestigkeit } & \multirow{2}{*}{ 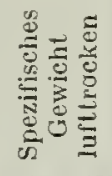 } & \multicolumn{2}{|c|}{ Druckfestigkeit } & \multirow{2}{*}{ 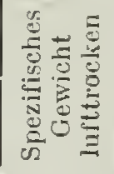 } & \multicolumn{2}{|c|}{ Druckfestigkeit } \\
\hline & & $\begin{array}{l}\vdots \\
\Xi \\
\Xi\end{array}$ & 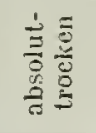 & & $\stackrel{5}{\Xi}$ & 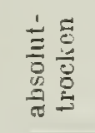 & & 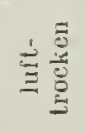 & 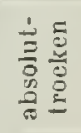 \\
\hline & $100 \mathrm{fach}$ & \multicolumn{2}{|c|}{$\mathrm{kg} / \mathrm{cm}^{2}$} & 100 fach & \multicolumn{2}{|c|}{$\mathrm{kg} / \mathrm{cm}^{2}$} & 100 fach & \multicolumn{2}{|c|}{$\mathrm{kg} / \mathrm{cm}^{2}$} \\
\hline Fichte & 43.2 & 443 & 722 & 43.9 & 435 & 762 & 43.7 & $\$ 12$ & 809 \\
\hline Tanne & 41.9 & 409 & 654 & 43.1 & 417 & 700 & 44.3 & 402 & 789 \\
\hline WeiBkiefer & 50.8 & 477 & 760 & 49.5 & 430 & 704 & 54.2 & \pm 63 & 872 \\
\hline Lärche & 59.4 & 589 & 1035 & 62.3 & 563 & 1032 & 60.5 & 565 & 1175 \\
\hline Rotbuche & 74.6 & 650 & 1144 & 74.2 & 621 & 1118 & 76.1 & 604 & 1260 \\
\hline Eiche & 73.9 & 608 & 986 & 70.6 & 530 & 957 & 75.9 & 571 & 1069 \\
\hline Ulme & 67.2 & 571 & 953 & 66.3 & 501 & 953 & 66.4 & 500 & 1110 \\
\hline Ahorn & 64.6 & 579 & 979 & 65.2 & 541 & 917 & 65.9 & 571 & 1090 \\
\hline NuB & 61.5 & 539 & 938 & 64.9 & 467 & 822 & 61.0 & 480 & 858 \\
\hline
\end{tabular}

$\S 40$. 2. B i e gs a m k e it und Z äh ig k e it. Es wurde sch on weiter oben auseinandergesetzt, daB Biegsamkeit und Zähigkeit, als A r b e i t s e i g e n s c h a ft e $n$ aufgefaßt, jene Beschaffenheit gewisser Hölzer bedeuten, welche eine dauernde Formveränderung ohne Herbeiführung eines Bruches zulassen. Dabei muß die Elastizitätsgrenze überschritten werden, olne daß man sich deshally schon gar zu sehr der Bruchgrenze nähert. Die Voraussetzung für die Anwendung von Biegsamkeit und Zähigkeit ist nämlich die, daß selbst bei beträchtlichen perman enten Ausdehnungen oder Zusammendrücliungen der Substanz eine Ueberwindung der Kohäsion nicht stattfindet. Es muß also der Festigheitsmodul (Bruchmodul) von dem Tragmodul ziemlich entfernt liegen, mit anderen Worten, der Spielraum zwischen Bruchgrenze und Elastizitätsgrenze ein beträchtlicher sein. Der Gegensatz voll b i egsam oder $\mathrm{z}$ ä he ist br ï $\mathrm{e} \mathrm{h} \mathrm{i} g$ oder s prö d e.

Um den Begriff der Biegsankeit im Sinne einer A r b e it se ige n s e h a f t, also der Grundlage für e in e formumstaltende produlitive Tä tig-

1) Mitteilungen aus den forstl. Versuelıswesen Oesterreiclıs. Dic Einwirkung von Suß- und Salzwässern auf die gewerblichen Eigenschaften der Hauptlolzarten. 
keit, von jener Biegsamlieit bezw. Zähigkeit zu unterscheiden, welche jedes Material innerhalb der Elastizitätsgrenze besitzt und als Grundlage der bautechnischen Verwendung S. 404 dieser Abhandlung erörtert wurde, wäre es zweckmäBig, das Wort "Biegsamlieit" im ersteren Sinne durch die Bezeichnung ,Bildsam ke it" zu ersetzen.

Ein e r ll ö h e r Gra d der Biegsamkeit oder, wie wir sie zu bezeichnen vorschlagen, der $\mathrm{B}$ i I d s a m k e it ist die, $\mathrm{Z}$ ä h ig ke it". Man verbindet mit diesem Ausdruclie die Vorstellung, daß ein Holz, welches schon in einzelnen Teilen bis über die Bruchgrenze hinaus in Anspruch genommen wurde, doch noclı ein großes $1 \mathrm{laß}$ von Widerstandsfähigkeit gegen die vollständige Trennung des Körpers in zwei oder mehrere Teile entgegensetzt. Die Bildsamlieit sowohl als die Zähigkeit ist bei den Hölzern in grünen Zustande meist größer als im halb- oder völlig trockenen Zustande. Der im frischen Holze vorhandene größere Vorrat an Wasser steigert die Bildsamkeit und Zähigkeit des IJaterials. Lalıer liommt es auch, daß dic Behaudlung des trockenen Holzes mit Wasser orler Dampf gewöhnlich zu einer Steigerung von Bildsamkeit und Zähigkeit führt. Wird das Holz nit warmem Wasser, wamer Leimlösung oder Dampf behandelt, so wirkt die höhere Temperatur gleichfalls günstig im Sinne einer Steigerung der in Perle stehenden Eigenschaften. Die Bildsamkeit und Zähigkeit werden daher, falls sie die Grundlage einer industriellen Benützung des Holzes darstellen, zumeist durch Anwendung von Feuchtiglieits- und Wärmezufuhr erhöht. Interessant ist die Tatsache, daß, wie W. Fr. Exner nachgeviesen hat, das gedämpfte und dureh den Biegeprozeß gestauchte Rotbuchenholz eine Erhöhung seiner rückwirkenden Festigkeit erfährt.

Las Biegen von stahförmigen Holzkör]ern zum Zwecke, geraden Stäben eine gekrümmte Gestalt, oder geliüummten lïrpern eine gerarlinige Form zu geben, ist ein Verfahren, welches seit langer Zeit bei verschiedenen Gewerben in Uebung steht. Die Zurichtung von Spazier-, Regensehirn-, Sonnensehirm-, Fischangelstöcken usw. usw. wird seit Jahrhunderten praktiziert. Das Biegen ron Radfelgen ist gleichfalls ein altes Verfahren. Schon in .Tahre 1810 wird berichtet, daß in Vorarlberg Radfelgen in e in e $\mathrm{m}$ Stücke aus gebogenem Holze angefertigt wurden. Melchior Fink in Bregenz suchte im Jahre $1820 \mathrm{um}$ ein Privilegium für aus gebogenem Holze angefertigte Radfelgen an. Dem im Privilegiums-Arehive liegenden Gesuche Finlis, das im Jahre 18:1 erledigt wurde, ist das Gutachten der Professoren Arzherger und Prechtl beigeschlossen, welches dahin geht, dal. Finks Produkt, als neu und wichtig, privilegierlar erscheine. Fink verwendete für diese Radfelgen Eschenholz und nach einer beglaubigten llitteilung waren solehe von Fink gefertigte Padfelgen noch in den letzten 1860er Jahren in Vorarlberg im Gebrauch, was auf eine außerordentliche Dauerhaftigkeit dieser Produkte hinweist.

Die Idee, das Holz durch Biegen in zu gewissen Zwecken verwendbare Formen überzuführen, hat den großartigsten Erfolg in einem modernen Zweige der Möbelindustrie errungen. Der Pheinpreuße Nichael Thrnet hat mit bewunderungswürdiger Ausdauer und großem technischen Geschick das Verfahren des Holzbiegens zum Zweclie der Herstellung von Möbeln so weit ausgebildet, daß es heute das Arbeitsprinzip einer großen, weit verzweigten, die Verwertung der Rotbuchenholzbestände nerkbar beeinflussenden Industrie (sog. Bugmöbel- oder Wiener Möbel-Industrie) geworden ist. Jas Thonetsehe Verfahren besteht der Hauptsache nach in der Behandlung des lotbuchenholzes mit Lampf, in dem Biegen des gedämpften Holzes in Formen, endlich in der Sicherung der auf der konvexen Seite der gekrümmten Holzteile liegenden Faserbündel-Gruppen gegen das Abreißen während der Bie- 
gung, sodann in entsprechender Behandlung in Trockenkammern '). Thonet hat auch die Erzeugung ron Radfelgen aus gebogenem Holze wieder anfgenommen, und selbst Räder für Kanonen-Lafetten und sonstige dem Kiringsdienste zugehörige Fuhwerke erhielten Radfelgen aus gebogenem Holze. Bei Luxus-Fuhwerken haben die gebogenen Radfelgen aus Mickory-Hol\% (Carya alba, amerik. Weißnußhaum) eine große Verbreitung erlangt. Das gleiche Verfahren findet heute auch Inwentung bei des Fabrikation von Rorlelschlitten, Kummethölzern, den norwegischen Schneeschuhen (Ski) u. dgl., wobei in erster Linie Eschenholz Verwendung findet.

Holzplatten nach verschicdenen Verfalıren gebogen, so daß sic gewöll,te Flächen darstellen, finden beim Bau von Schiffen, Wagenlasten usw. mannigfaltige Verwendung.

Die Bildsamkeit und Zähigkeit spielen eine ganz besonder's wichtige Rolle auch in dem Falle, daß dünne Stäbe, Späne oder Färlen, aus Holz angefertigt, zu g ef l o c h $\mathrm{t}$ e n e n und g e w e b t e n liörpern vereinigt werlen. Die ganze liorbflechterei und Holzweberei (Sparterie), sowie die Herstellung von Gegenständen aus Holzgeweben haben als Voraussetzung einen hohen Grad von Bildsamkeit und Zähigkeit des Rohstoffes. Die Weidenruten in ganzen oder in der Form des gespaltenen, bezw. gehobelten Spanes, ferner Fichten- und Föhrenwurzeln, ganz oder gespalten, Späne von Fichten-Stanmbolz, Spältlinge von Bambus, das spanische hohr, der Bast von verschicdenen Holzpflanzen und diverse Gräser bilden die Hauptgattungen von $\mathrm{Fle} \mathrm{cht}$ a $\mathrm{te} \mathrm{r}$ a l e, zu denen das Stroh, die Piasava und andere Pflanzenteile in Konkurrenz treten.

Dünne und schmale Späne von Aspenholz bilden den Rohstoff der $\mathrm{Hol}_{\mathrm{z}}$ w e b e re i (Sparterie).

Die V'erwendung des Holzes zu Faßreifen, ferner die sogenannten Bandweiden und endlich die in der Flößerei verwendeten Wieden sind Beispiele für die Anwendung biegsamer und zäher Hölzel.

$\S 41$. Eine wissenschaftliche Bestimmung del Bildsamkeit und der Zähigkeit ist bisher in befriedigender Weise $\mathrm{f} \mathrm{ü} \mathrm{r} d$ a s $\mathrm{Hol}$ z nicht rorgeschlagen worden ${ }^{2}$ ). Die einsch]ägigen Versuche von Karmarsch und Nördlinger befriedigen nicht.

Am ehesten gewährt noch die von Tetmajer in die Vaterialprüfungstechnik

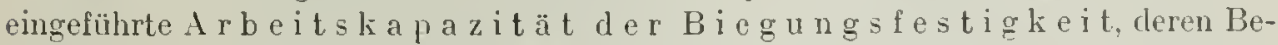
griff und Ermittelung schon Seite 404 auseinandergesetzt wurde, cinen Anhaltspunkt für die $\mathrm{Z}$ ä h i g k e i t oder S p lö d i g k e i t eines Holzmaterials. Je langgestreckter das Biegungsdiagramm ausfällt, je größer also die Durchbiegung nach $L^{\top}$ cberschreitung der Elastizitätsgrenze, desto zäher das Holz. Holzproben, die bei der Biegeprobe bald nach Ueberschreitung der Elastizitätsgrenze brechen, sind als spröde anzusehen. In diesem Sinne zeigt in Fig. ? das Diagramm des Prohestabes 18 a (oben - Stab aus norwegischem Eschenholze) ein äußerst zähes, das Diagramm ì c (links unten - von einer sehr engringigen Esche aus der Bulsowina herrülıend), ein

1) Siehe, ,D a s B i g e $\mathrm{n}$ des $\mathrm{H}$ olz e $\mathrm{s}^{4}$, cin für Möbelfabrikanten, Wagen- und Schiffbauer wichtiges Verfahren. Mit besonderer Rücksichtnalne auf die Thonetsche Industrie ron Prof. Dr. W. F. Ex n e r. Dritte neubearbeitete und erweiterte Auflage von Prof. G e o r g L a ub o e ck, Weimar 1893.

2) Unter den wenigen Arheiten über, ,Bildsamkeit" bei anderen Rohstoffen sind bemerkens. wert jene ron $\mathrm{k}$ i $\mathrm{c}$ k und $\mathrm{H}$ u g o F i s $\mathrm{c}$ h e r. (Kick, Das Gesetz der proportionalen Widerstande. Leipzig 1885; Hugo Fischer, Beitrag zur mechanischen Untersuchung plastischer liŏrper, ,ZivilIngrenieur" XXXI. Band. 7. Heft.) 
selır sprödes Holz an. Natürlich kann man diese Diagramme nur dann untereinander vergleichen und einen Schluß auf die Zähigkeit oder Sprödiglieit des betreffenden Holzmaterials ziehen, wenn sie von Stäben gleicher Länge und gleichen Querschnitts gewonnen wurden; dies ist bei den Diagrammen der Fig. 2 der Fall; die betreffenden Eschenholzstäbe hatten $4 \times 4 \mathrm{~cm}$ Querschnitt und eine freie Auflage bei der Biegeprobe von $58 \mathrm{~cm}$.

Schwieriger gestaltet sich die Sache, wenn man die Eigenschaft der Zähigkeit z i f f e r m ä B i g ausdrücken soll. Hiezu würde sich auf Grundlage der Biegeprobe und immer unter der Voraussetzung gleicls dimensionierter Probekörper der Quotient aus der Durchbiegung und der Belastung in dem zwischen Elastizitäts- und Bruchgrenze gelegenen Teile der Biegungsarbeit eignen, also der Quotient $\frac{\mathrm{D}-\mathrm{d}}{\mathrm{P}-\mathrm{p}}$, wenn

unter d die Durchbiegung|

p die Belastung an der Elastizitätsgrenze,

unter $\mathrm{D}$ die Durchbiegung ! beim Bruche
$\mathrm{P}$ die Belastung

zu verstelien ist.

Figur 2.

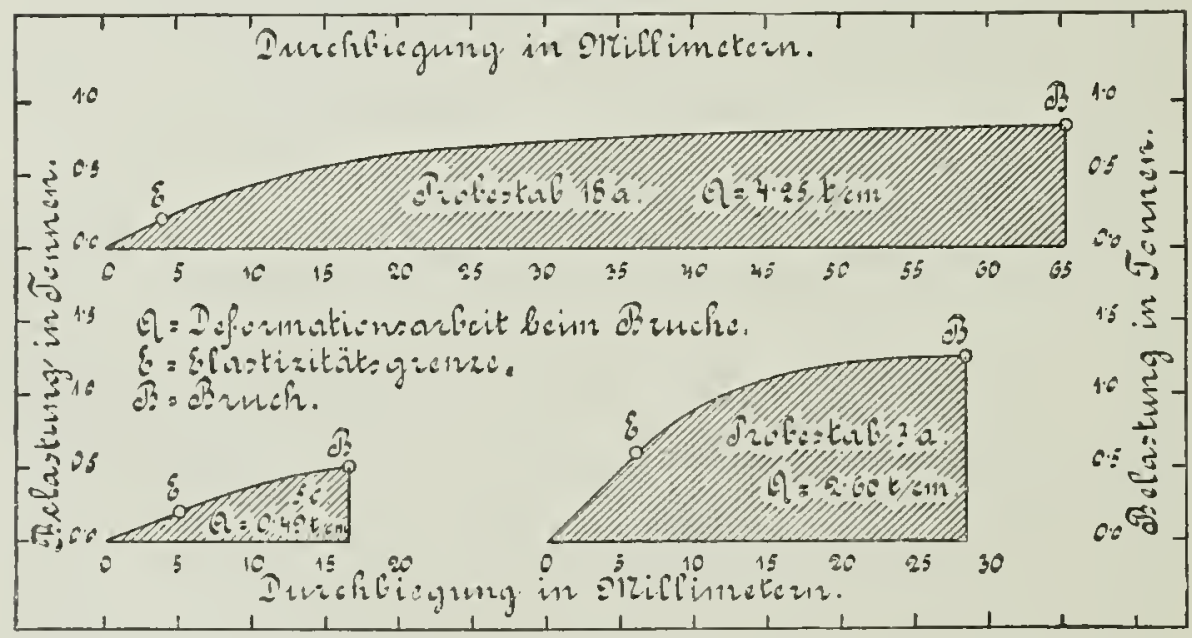

Nachdem die international vereinbarten Vorschriften für die Holzprüfungen ganz bestimmte Dimensionen für die Biegestäbe vorschreiben $(10 \times 10 \mathrm{~cm}$ Querschnitt und $1,5 \mathrm{~m}$ Stützweite), beziehungsweise die Piedulition rer Biegungsarbeit von in Querschnitt anders dimensionierten Biegebalken auf den Normalquerschnitt von $10 \times 10 \mathrm{~cm}$ fordern, so würde die hier vorgeschlagene Ermittlung des ziffermäßigen Ausdruckes der Zähigkeit ohne weiters möglich sein.

Nach den Untersuchungen Jankas ergibt sich dieser Zähigkeitskoeffizient aus einer großen Zahl von Einzelproben

für Fichtenholz lufttrocken . . . zu 1,73

feucht . . . . zu 2,50

naß . . . . zu 3,53

für Lärchenholz lufttrocken _. . zu 1,26

naß . . . zu 2,35 
Diesc Zahlen zeigen zunächst die Erhöhung der Zähigkeit mit den Steigen des Wassergehalts im Holze, dam aber auch die bedeutend größere Zähigkeit des Fichtenlolzes gegenüber rem Lärchenholze.

Mit den nachfolgenden Ausführungen berühren wir bereils das Gebiet jener teehnischen Eigenschaften der Hölzer, welche mit einer Aufhebung des Zusammenhanges der Substanz verbunden sind.

Die größere oder geringere Zähigkeit eines Holzmaterials läßt sieh nach den Brueherseheinungen bei der Biegeprobe beurteilen; je nachdem die gespannten Fasern an der Zugseite des auf Biegung beanspruchten Balkens plötzlich in einer mehr oder weniger geraden, quer zur Faserrichtung gestellten Linic - oder allmählich unter teilweisem Zerreißen einzelner Faserbündel in einzelnen Splittern abreißen, unterscheidet man einen g latten und einen splittrigen Bruch, zwischen welchen Bruchformen noch ein $\mathrm{z}$ a $\mathrm{ck}$ i g e r Bruch unterschieden werden kann. Ein glatter Bruch deutet auf ein sprödes, ein splittriger Bruch auf ein zähes Holz hin. Nlanche Laubhölzer, z. B. nasses Eschenholz, sind bei der Biegeprobe überhaupt nicht zum Bruche zu bringen; hierauf beruht ja, wenigstens zum Teile, die Industrie, Stabhölzer zu Möbelbestandteilen, zu Radfelgen, Schlittenkufen u.dgl. im gedämpften Zustande zu biegen (Thonetsche Bugmöbel).

Es hat sich gezeigt, daß die Biegungseigensehaften beispielsweise beim Fichtenholz tatsächlich mit der Form des Biegebruches in Zusammenhang stehen, und zwar ist einglatter $\mathrm{Brueh}$ mit einem n i edrigen Ela stizit ä ts-, Tragund Bruchmod ul und kleiner Deformations a r be it verbunden, während ein splittriger Brueh mit cinem ll aximum aller dieser E i g e $\mathrm{n} s \mathrm{ch}$ a f t e n einhergeht, wie die nachfolgende Tabelle für Fichtenholz zeigt.

Tabelle $\mathbf{X}$.

\begin{tabular}{|c|c|c|c|c|c|c|}
\hline \multirow{4}{*}{$\begin{array}{c}\text { Fornı des } \\
\text { Biegebruches }\end{array}$} & \multicolumn{6}{|c|}{ Biegungseigenschaften } \\
\hline & $\begin{array}{l}\text { Elastische } \\
\text { Durch- } \\
\text { biegung }\end{array}$ & \multirow[t]{2}{*}{$\begin{array}{l}\text { Elastizi- } \\
\text { tätsmodul }\end{array}$} & \multirow{2}{*}{$\begin{array}{l}\text { Grenz- } \\
\text { (Trag-) } \\
\text { modul }\end{array}$} & \multirow[t]{2}{*}{$\begin{array}{l}\text { Biegungs- } \\
\text { festigkeit }\end{array}$} & \multirow{2}{*}{$\begin{array}{l}\text { Deforma- } \\
\text { tionsarbeit } \\
\text { beim } \\
\text { Bruche }\end{array}$} & \multirow{3}{*}{$\begin{array}{c}\text { Quotient } \\
\text { Deformationsarbeit } \\
\text { Durchliegung } \\
\text { beim Bruche }\end{array}$} \\
\hline & pro $0.1 \mathrm{t}$ & & & & & \\
\hline & $\mathrm{cm}$ & \multicolumn{3}{|c|}{ Tonnen pro $1 \mathrm{~cm}^{2}$} & $\mathrm{t} / \mathrm{cm}$ & \\
\hline glatt & 0.0890 & 98.0 & 0.323 & 0.565 & 4.95 & 1.53 \\
\hline zackig & 0.0843 & 102.2 & 0.339 & 0.593 & 5.45 & 1.64 \\
\hline splittrig & 0.0769 & 111.9 & 0.376 & 0.648 & 6.90 & 1.91 \\
\hline
\end{tabular}

Wenn es sich um die Terwendung eines Holzmaterials zu Bauholz und speziell zu Traghalken handelt, die auf Biegung beansprucht werden, würde also ein Probeholz mit glattem Bruch eine schlechte, cin solches mit splittrigem Bruch eine gute Qualität anzeigen. Hier sei speziell des sog. Rotholzes der Nadelhölzer gedacht, welches an Stämmen (und zwar an der dem Winde abgewandten seite) entsteht, die ständig unter Windanprall zu leiden haben. Solehes Holz zeigt sich sehr spröde, es bricht bei Ueberlastung glatt $a b$; dahingegen zeigt das an solchen freistehenden Stämmen an der $W^{\top}$ in d s e i t e gebildete engringige Holz einen doppelt so grofen Biegungselastizitätsmodul wie das Holz der andem breitringigen Seite.

$\$$ 42. 3. In der Riegel sollen nun zwar Bau-und lionstruktionshölzer höchstens bis zur Elastizitäts-, nicht aber bis zur Bruchgrenze beansprucht werden; solehe Fälle 
der Ueberlastung kommen aber ausnahmsweise doch vor, z. B. bei den Verzimmerungen in Bergbaubetrielsen.

Die Bergbautechniker sprechen in dieser Hinsicht von emer Eigenschaft des Holzes, die mit der Zähigkeit oder Sprödigkeit und der Art des Biegebruches indirekt zusammenhängt; es ist dies die sog. $\mathrm{W}$ a r' $\mathrm{n}$ ä $\mathrm{h} \mathrm{i} g \mathrm{~g}$ e it des Holzes. Unter einem „warnfähigen“ Holz ist jenes Holzmaterial zu verstehen, welches bei eincr etwaigen Ueberlastung vor dem Abbrechen knistert, nur allmählich zum Bruche kommt und daher dic Bergleute "warnt", auf der Hut zu sem, demzufolge derartig überlastete Konstruktionshölzer der Bezimmerung rechtzeitig ausgewechselt werdeı können; dies trifft bei jenem Holzmaterial zu, welches einen splitterigen Bruch zeigt; ein mit plötzlichem, also in der Regel glattem Bruch brechendes Holz kann in dieser Hinsicht durch Gefährdung der in der Grube beschäftigten Arbeiter gefährlich werden.

$\$ 43$. Die Erfahrungen, welche die Holzhauer und die holzverarbeitenden Gewerbe bezüglich der Zähigkeit des Holzes und ihrer Kennzeichen schon seit altersher gemacht haben, hat Nördlinger in folgende Sätze zusammengefaßt:

„Nach einem alten und jedenfalls für Buchen, Eichen und noch andere Holzarten richtigen Salz erzeugt nasser Boden sprōdes Holz, nur trockener oder mäßig feuchter zähes."

,Zähe Hölzer sind in der Regel an der großen Faserigkeit kenntlich, die sie beim Abreißen, und, (wenigstens Weichhölzer), an dem faserigen, wie man sagt wolligen Schnilt, den sie bein Durehsägen zeigen. Erst mit der Verwilterung der Fasern tritl auf solchen Schnitten das eigentliche Gefüge an den Tag."

"Wurzel- und Stockholz sind zäher als Stammholz. Der Stock soll zäher sein, als das Zopfencle. Das A $\mathrm{s} t \mathrm{~h}$ o $\mathrm{l}$ z bei Eichen, Linden, Erlen, kiefern gilt für spröder als das $\mathrm{S} t \mathrm{a} \mathrm{m} \mathrm{m}$ holz. Bei der Birke wird das Ungekehrte angenommen, wie auch bei der Fichte; ob bei letzlerer mit Recht in gleichem Grade, mag dahingeslellt bleiben. Das zäheste Holz liefern die jungen Triebe der Flechtweiden (Salix viminalis, purpurea, caspica, anygdalina etc.), Schlingstrauch, Hasel, Birke, Ulme, Waldrebe, Hainhuche, Maßholder, Eibe. Esche, Aspe." ,Mit dem Alter und Frankheiten verliert das Holz der Stämme seine Zähigkeil mehr und mehr, ja schon an angehend haubaren Stämmen von NuBbaum und Eiche ist der $\mathrm{spl}$ in $t$ zälıer als der İ e rn. Ebenso, und auf der Drehbank wohl fühlbar, bein Perüclienstrauch. Bei der slarken Föhre auf passendem Boden erhöht der große Harzgehalt die Zähigkeit, wie auch schon an einzelnen Jahresring der äußere harzreichere Teil der zähere, beim Abreißen faserige:e ist. Föhren, die auf unpassendem Boden stehend, kein Fernholz bilden, verhalten sich wie Fichlen und Tannen und haben das zähere Holz gegen außen, wo die Jahresringe schmäler und relativ larzreicher sind."

"Das Verhältnis der Zähigkeit von Splint und liern oder Reifholz sieht man hänfig schon sehr deutlich an der verschiedenen Faserigkeit auf Hiebsflächen an Stöcken. Man muB sich aber bei der Beurleilung inmer vergegenwärtigen, daß der Splint saftreicheres und dadurch sclion in grünen Zustande zäheres Holz sein muß."

,Abgewelktes Holz gill als zäher denn saltreiches und trockenes, und das Einweichen in Wasser und Bähen anı Feuer trägt zur Vermehrung der Biegsamkeit und Zähigkeil wesentlich bei."

„Holz, das den Einwirkungen der Wilterung ausgesetzt ist, und selbst im Trockenen verbaules, verliert allmählich an Zähigkeil."

Hervorragend bildsame und zähe Hölzer sind die jungen Stockloden von Weide, Birke, Hainbuche, Aspe, Esche, Eiche und Ulme. Ebenso das Astholz der Birke, der Fichte, dann die jungen ITurzelstränge von Fiefern und Fichten im nahrungsarmen Sandboden. Zu den biegsamen und zähen IIolzarten des Baumstammes rechnet man die Birke, Esche, Weide, Vogelbeere, Hickory-IJolz, die Sorkus-Arten, Pappel und Rotbuche, letzteres jedoch nur im gedämpften Zustande, Weißbuche, Ulme, Aliazie und Zürgelbaum, dann die Gerten und Stangen von Eichen, Hasel, Kornellirsche und unterdrückten Fichten.

\$ 44. 1. S p a l t b a rke i t. Aus der Bauart des Holzes ergibt sich eine für diesen Rohstoff höchst charakteristische Eigenschaft, welche darin bestcht, daß sich dasselbe durch Eintreiben eines Kieiles parallel zum Faserverlaufe leicht in Teile zerIegen läBt. Dabei hat man zwei Hauptspaltrichtungen zu unterscheiden: Die radial 
stehenden Flächen, welehe die Markstrahlen enthalten, und dic darauf senlirecht stehenden Sehnenflächen oder Tangentialflächen. Diese Richtungen schlaigt die Spaltkluft, der Schneide des Spaltkeiles voraneilend, ein. Dis Spalten setzt die Ueberwindung des seitlichen Zusammenhanges der Faserbiundel, bezw. der liohärenz, mit welcher die Markstrahlen an den Holzfasem haften, voraus. Der Wiilerstand gegen das Spalten müßte S p a l t festiglieit genannt werden. Je höher die Spaltfestiglieit, desto niedriger die S p a l t b a r k e i t oder S p a l t i g k e i t. Wenn man von schwerspaltigen oder leichtspaltigen (d. i. spaltbaren) Hölzem spricht, so meint man damit nicht nur, daß das $I I$ a $B$ d e $r$ S p a I t festig k e it eim hohes oder niedriges sei, sondern auch, daß die entstehenden Spaltfä̈chen minder oder mehr glatt und eben ausfallen und mehr oder weniger eine weitere Bearbeitung erheischen.

Die Spaltbarkeit ist eine für die erste Ausformung der Hölzer, also für die Herstellung von Halbfabrikaten, in gewissen Fällen hochwichtige Eigenschaft und verdiente daher, daß sie nicht nur mit Rücksicht auf die sie bedingenden Umstände mehr als bisher beobachtet würde, sondern sie hätte auch Anspruch darauf, ciner exakten experimentellen Untersuchung unterzogen zu werden. Der einzige bemerkenswerte Versuch, die Spaltbarkeit einer experimentellen llessung zu unterwerfen, rührt von Nördlinger her, welcher jedoch den Fehler beging, als Probestück ein ganz willkürlich geformtes, gabel- oder kluppenartiges Holzstück zu wählen $\left.{ }^{1}\right)$. Abgesehen davon, daß die Nördlingerschen Probestücke, die Zweckmäßigkeit der Form zugegeben, in Beziehung auf ihre Abmessungen durch lieinerlei Erwägung begründet werden können, muß auf den entscheidenden Untersehied aufmerksam gemacht werden, welcher zwischen dem Nördlingerschen Experiment und der Praxis besteht. Bei den Nördlingerschen Versuchen wird nämlich die Spaltfestigkeit durch eine allmählich anwachsende Kraft, Belastung durch eine Wagschale, in welche Schrot zufließt, überwunden. In der Praxis der Holzwaren-Gewerbe sind es wohl ausnahmslos Stoß-Homente, die den Kieil in das Holz eintreiben. Der Unterschied zwischen diesen beiden Arten der Leberwindung der Spaltfestiglieit ist aber ein fundamentaler. Immerhin kann man, bevor nicht eine befriedigendere Forschung vorliegt, die von Nördlinger gewommenen Resultate als Anhaltspunkte für den Vergleich der Spaltfestigkeiten verschiedener Hölzer untereinander benützen.

Prof. II. Rudeloff fülırte eine Versuchsreihe ïher die spaltfestiglieit des hiefernholzes durch, wobei den Versuchsstücken die lilammerartige Form (Nördlinger) gegeben wurde. (Siehe Jitteilungen aus den Kigl. Techn. Versuchsanstalten zu Berlin 1899. V. Heft.)

Gelegentlich der Untersuchungen über die Härte des Holzes hat $J$ a n k a einige Studien über den Widerstand angestellt, welchen die Hölzer dem Eindrücken einer A xtschneide von $60 \mathrm{~mm}$ Länge und $28^{\circ}$ Schneidewinkel in die Oberfläche der Holzprobe entgegensetzen $\left.{ }^{2}\right)$. Wenn auch diese Untersuchungen in erster Linie der Prüfung des Holzes auf seine $\mathrm{H}$ ä r te e i g e n s c h a f t dienen sollten und daher eine Spaltwirkung tunlichst ausgesehaltet werden mußte, so war es doch in einzelnen Fällen nicht zu vermeiden, daß die Probehölzer, vor allem Eiche, Buche, Ahorn und NuB, clabei aufspalteten. Diese Prüfung entspricht mun aber, abgesehen davon, daß hier nicht StoBliräfte, sondern ruhig wirkende. von der Materialprüfungsnaschine ausgeübte Druckkräfte in Anwendung kamen, der Erp r o bu ng des H o l zes a u $\mathrm{S}$ Spaltfestigke it viel besser als die Tördlingersche Methode der Er-

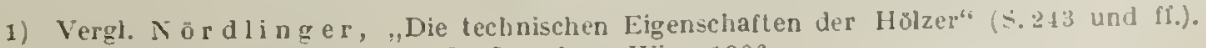

2) Die Härte des Holzes. Von G. J a n ka. Wien 1906. 
probung ter Spaltfestigkeit. Danit ist im Simne der Ausfühungen Ex n e r s der Weg gezeigt, wie ein Verfahren zur Spraltestigkeitsprüfung der Hölzer ausgebildet werden könnte; aus der GröBe der Kraft, welche erforderlich ist, eine Keilschneirle von bestimmter Form bis zum Eintritte der Spaltung ins Holz einzudrücken und aus der Tiefe der Eindringung rlieser Keilschneirle beim Beginne der Spaltung wäre die Spaltfestigkeit zu bestimmen; dabei werden allerdings auch, wie beim Nördlingerschen Versuch, die Dimensionen der Spaltprobe einverständlieh festzusetzen sein.

Bei der Lage der Dinge müssen wir uns hier darauf besehränken, jene E rf a h r u g s sät ze zusammenzufassen, die als ziemlich feststehend betrachtet werden können.

Die Spaltfestigkeit ist bei manchen Hölzem so gering, daß oft unbedeutende, in Stamme selbst auftretende Spannungen o h n e das Hinzutreten einer Kraft von auBen eine S raltung herbeiführen. Wer Weelısel der Temperatur oder das Verdunsten des in grünen Holze enthaltenen Wassers rufen bei der Ungleichartigkeit des Materiales Spanmungen hervor, wełche die Spaltfestigkeit überwinden und die Klüftung des Holzes herbeiführen (Frostrisse, Waldrisse). Liese Erseheinungen stehen mit der Spaltbarkeit im Zusammenhange, doch dürfen sie nicht mit der Spaltbarkeit als technischer Eigenschaft verwechselt werten, welehe so erklärt werden muß, wie sie weiter oben definiert wurde. Diese Eigenschaft setzt nämlich die Anwendung eines keilförmigen Werkzenges voraus, welches, wie erwälnt, meistens dureh Stoß-Alitionen in das Holz eingetrieben wird und zwar entweder von der Himseite aus oder von der Mantelfläche der Holzwalze aus; im ersten Falle entweder in der Richtung des Radius oder einer Sehne, in letzteren Falle immer in der Richtung des Radius.

M o eller sagt ganz richtig (,Die Riohstoffe des Tisehler- und Drechsler-Gewerbes" S. 97): ,Die Arf der Zellen und ihre Verteilung ist ebenfalls für den G $\mathrm{r}$ a d der Spaltbarkeit maßgebend, ajer mehr noch für die $B$ ese h a f e n he it der Spaltfäche. Sind die Faseru kurz, lazı stark inkrıstierl, sogar zu ciner kompliten Masse verschmolzen, so leidet die Spalt. larkeit sehr erheblich, die Spraltfäche wird uneben, höckerig, fast der Bruchfläche eines Mlnerals ähnlich (z. B. Guajali). Jitunler sind die Faserbümtel von den Parenchym- nud GefäBgruppen scharf abgegrenzl, ein Linsland, der die spaltharkeil begünstigt, aber die spaltfäche gerieft erscheinen läßt (z. B. Linde). Ist der Unterechied zwischen Herbst- und Frühlingsholz bedeutend, so spalten sie auch mit ungleicher Leichtigkrit, die Spallfläche ist stufig abgesetzl (z. B. die ringlorigen Laubhölzer, die meisten Nadelhölzer, besonders die harzreichen). Die faserige oder wellige, spiegelglatte oder seidenglänzende, rauhe oder sehuppige Spaltfläche erliärt sich aus der Länge, Innigkeit der Versehmelzung, Art der firümmung nebst anderen Eigentümlichkeitun der Fasern und der Häufigkeit der Unterbrechung durch die in Bau und Ausdehumg ebenfalls verselicdenen Iarkstrahlen."

Meistens ist das Holz in der Richtung ter Selne schwerer spaltig als in der Ebene der Markstrahlen, und deshalb wird die industrielle Verwertung der Spaltbarkeit vorwiegend zur Ausformung von Stücken lenützt, deren Oberfläehe hauptsächlich von Tadialfläehen gebilłet werden soll. Wie äuBeren Stammteile pflegen leichter zu spalten als die inneren, teils deshab, weil die ersten Jahrringe häufiger unregehnäßig rrwachsen, teils deshalb, weil in den äußeren Holzschichten zumeist cine größere sjrannung zwischen ren einzelnen Strahlen herrseht.

Die Weichhölzer gelten als leichter spaltbar, welche Auffassung nieht Anspruch auf algoneine Geltung erheben kann. Lebrigens hängt die Spaltharkeit von verschiedenen anderen Eigenschaften des Holzes und allerlei Unständen ab. So sleht die El a s lizität im engster Zusammenhange mit der Spaltbarkeit. Lie einmal dureh den Kieil geöfnete Filuft erweitert sich un so leiehter, je elastiseher das Holz ist. Alle Umstände, welche die Elastizitä, also das Bestreben, die frühere Lage wieder zu gewinnen, steigern, sind der spaltbarkeit günstig, d. l. steigem rliesellue. Wer Feuehtiglieitsgehalt übt auf die Spaltbarkeit einen schembar 
widerspruclusvollen Einfluß aus. Ta die Feuchligkeit die Elastizitït mindert, sollte sie auch die Spaltbarkeit benachteiligen; in vielen Fïllen wirk sie jerlocl in entgegengesetzten Simne. Wa die Feuchtigkeit das erste Eindringen des lieiles erleichtert und die seitliche Kohärenz der Fasern lı̈ufig abschwäelıt, so kanı der förderude Einfluß der Feuchtigkeit dessen lienuende Tendenz üherwiegen. Dalıer erkïït es sich, daß gewisse Hölzer in frischın Zustande schwerer spaltig sind als in trockenen, wie Aspe, Pappel, Erle, Salweide, andere hingegen in trockeneı Zustande schwerer spalten als grün, wie fast alle Harthölzer.

Der F r o s t vermindert dic Spaltbarkeit, hebt dieselbe wolıl manchmal günzlich auf, indem er die Elastizität erhelılich schwächt. Auch hietet das gefrorene Holz den Nachteil, daß das Spaltwerkzeug wegen zu geringer Reibung an den Spaltflächen in der Spaltliluft nicht liaftet, sondern zurïckspringt.

Hoher $\mathrm{H}$ a r z g e h a $\mathrm{t}$ vermindert die Spaltbarkeit, vielleicht indirekt dureh die Schwächung der Elastizität; so sind die Wurzelstöcke der Föhre, wenn harzreich, schwerspaltig. Gerad- und langfaseriges, astarmes Holz, wie es auf frischen Boden im geschlossenen Stande erwïhst, ist leichtspaltig. Hohen Grad der Spaltbarkeit kamn man bei Stämmen von bedeutender Schaftlänge, gleichförmiger Abnalıne der Stammdiche, feiner Rinclenbildung, geradelinigen Verlauf der Rindenritzen ete. vermuten ${ }^{1}$ ). In Beziehung auf die Spaltbarlicit liann man die Hölzer folgendermaßen klassifizieren:

Le i chtspaltig: Fichte, Tanne, Weymouthskiefer, Kïefer, Lärche, Erle, Linde;

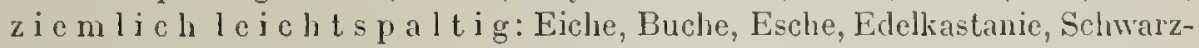
licfer, Zirbelliefer;

se hw Elsbeere, Pappel, Legfölıre.

Alles bisher Gesagte bezielıt sielı auf die Spaltbarkeit, als A r b e i t s e i g e ns ch a f t betrachtet, sie bildet die Vorbedingung für die Erzeugung von ,Spaltwaren" und ,Spaltholz-Sortimenten", wie Faßdauben, Dachschindeln, DranitzenSclrachtelwänden und -Böden, Siebzargen, Weinpfählen, Zamnstöcken, $\mathrm{P}$ e s o n a 11 zHolz- Il u s e In und Resonanz-Hölzern, Liorbflechtspänen, Leuchtspänen usw.

Die Spaltbarkeit begünstigt manche Verfahrungsweisen, die der Form dez Werkzeuges nach als Hobelarbeit aufgefaßt werden, bei denen aber das Hobeleisen nur die Rolle des Spaltkeiles spielt; dies bezieht sich namentlich auf die versehiedenen Arten der Spanerzeugung und der Fabrikation von Zündholzdralıt, Zündhölzern, gemesserten Joumieren, Jalousie-Holzdralıt usw. Auch wird die Spaltarbeit angewendet als Mittel oder Endglied ciner Liette von Arbeitsprozessen, die auf die Erzeugung gewisser Waren abzieleı. Hicr sei erwähnt das Spalten der Schuhstifte aus dünnen Hirnholzscheiben des Ahorns und der Birke, das Spalten jener auf der Urehbank hergestellten Ringe, deren Profil der Form gewisser Tierfiguren (in der Spielwaren-Industrie) entpricht usw.

Als Gewerbs-Eigens chaft tritt die Spaltbarkeit in einem höchst ungünstigen Sinne auf, und die Neigung zum Spalten, also große Leichtspaltigkeit, ist eine für das fertige Produlit aus Holz höchst unwillkonmene Eigenschaft. Der Tischler und Drechsler findet sich lıäufig während der Arbeit, beim fertigen Produkte aber immer mit der Spaltbarkeit selwwer ab. Das Einreißen des Holzes unter dem Hobel, d. h. cine nach der Spaltflächenrichtung eintretende, die beabsichtigte spranform vereitelnde spanbildung ist eine Folge der Spaltbarkeit, die siclı un so ungün-

1) Vergl. G a y ers Forstbenutzung. $\mathbf{X}$. Auflage, lierausgegeben von H. Mayr. 
stiger äußert, je höher ihr Grad ist und je mehr die Richtung der Spaltfläche von der Richtung der Bewegung des Werkzeuges abweicht.

$\S 45$. 4. Härte. Die $\mathrm{H}$ ä $\mathrm{r}$ te des $\mathrm{H}$ o l z es übt nicht nur auf die Gewinnung, sondern auch auf die Bearbeitung und die Verwendbarkeit eines Holzmaterials einen großen Einfluß aus; sie nimmt Einfluß auf den Arbeitseffekt bei der Schlägerung, beim Verschnitt im Sägewerke und bei der Bearbeitung mit Hilfe der verschiedenen holzbearbeitenden Werkzeuge und Maschinen; sie ist maßgebend für die Verwendbarkeit der Hölzer zu bestimmten Verwendungszwecken und für ganze Gewerbebetriebe, z. B. in der Holzdrechslerei, Bildschnitzerei, in der Möbelfabrikation, und bestimmt endlich auch die Brauchbarkeit eines Holzmaterials zu jenen Gebrauchsgegenständen, bei denen es vor allem auf eine große Widerstandsfähigkeit gegen Abnützung ankommt, auf eine Eigenschaft, die mit der Härte in innigstem Zusammenhange steht, beispielsweise bei der Verwendung von Holz zu Straßenpflaster, Kegeln und Kegelkugeln, zu Holzkammräılern u. dgl.

Nach dem Sprachgebrauche verbindet das technische und das Laien-Publikum mit dem Ausdrucke H är te dem Holze gegenüber dieselbe Vorstellung wie bei allen anderen Substanzen. Man versteht unter Härte den Widerstand, den eine Substanz dem Eindringen eines fremden Körpers in dieselbe von außen her entgegensetzt. Diesen fremden Körper denkt man sich dabei zumeist als ein IVerkzeug von einer für das Eindringen in den Rohstoff günstigen Gestalt.

Für die Härte der Hölzer hat der Holzarbeiter schon das richtige Gefühl; er klassifiziert sein Holzmaterial nach dem fühlbaren Widerstande, den dasselbe bei der Bearbeitung durch die verschiedenen Werkzeuge entgegensetzt. Es wirken uun aber die Werkzeuge in ganz verschiedener WVeise auf das Holz; man nüßte also, wenn es gilt, die Härte der Hölzer exakt und nicht nur nach dem Gefühle festzustellen, eine Härte unterscheiden gegen das Eindringen schmeidender Werkzeuge, wie llesser, Stemmeisen, Axt, Beil, Hobel, Bohrer - gegen das Eindringen von die Fasern zerreiBender Geräte und WVerkzeuge: Säge, Raspel, Feile, und gegen das Eindringen spaltender Werkzeuge und Hilfsmittel: Spalteisen, Keil, Nagel, Schraube. Auch ist es nicht gleichgültig, ob das Arbeitswerkzeug unter ruhigem Zug oder Druck oder durch plötzlichen StoB und Schlag wirkt. Das Holz ist ferner kein homogener, sondern ein organischer, äußerst kompliziert zusammengesetzter Körper, dessen Härte sich je nach der Richtung, in welcher das Werkzeug die Fasern angreift, verschieden äußern wird, so daß man von Hirnholzhärte und Längsholzhärte sprechen kann, je nachdem die Angriffsrichtung des Werkzeuges senkrecht oder parallel zur Faserriclitung geht.

Ueberdies setzt sich das Holz aus verschieden harten Gewebselementen zusammen; der Spätholzteil des Jahrringes kann eine Härte besitzen, welche die Härte des Frühholzes um das Vielfache übertrifft; je nach dem Vorviegen des harten und schweren Spätlıolzes gegenüber dem weichen und leichten Frühholze werden auch verschiedene Holzstücke einer und derselben Ilolzart gewisse Abweichungen in bezug auf ihre Härteeigenschaft zeigen müssen. Hiezu kommt schließlich beim Holze noch ein Faktor, der, wie jede Art von Festigkeit, auch die Härte desselben sehr stark beeinflußt; es ist dies der F e u c h $\mathrm{tigkeitsgehalt} \mathrm{des} \mathrm{Holzes.}$

Wie nan sieht, sind die Schwierigkeiten, welehe sich einer exakten, ziffermäßigen Feststellung des Härtegrades eines llolzes entgegenstellen, sehr große; sie wären unüberwindlich, wenı man sich nicht auf ein bestimmtes, zweckentsprechendes Verfahren der Härteprüfung einigen würde, in der Art, wie man sich ja auch bezüglich 
der Vorschuiften für einheitliche Prüfungsverfahren für Holz auf bestimmte Melıoden der Festiglieitsprüfung international geeinigt hat.

Prof. Dr. M. B ü s g e ${ }^{3}$ ) hat eine Reihe von Holzarten in der Weise auf ilıre Härte geprüft, daß er mit Hilfe eines der Bodensonde nachgebildeten Apparates eiıe Stahlnadel mittels allmählich aufgelegter Gewichte 2 mm tief in den Holzkörper eintrieb und die Größe des hiezu notwendigen Gewichtes, in Grammen ausgedrückt, als Härte ansah. Gegen diese Methode läßt sich das Bedenken erheben, daß die Stah]nadel beim Eindringen zwischen die Holzfaserı den harten und festen Spätıolzzonen ausweichen und in der Richtung des geringsten Widerstandes vordringen wird, wodurch eine zu geringe Härte resultieren würde, daß ferner die ins Holz eingedrückte Nadel ebenso wie ein eingeschlagener Nagel in erster Linie spaltend wirlit und von der Elastizität des Holzmaterials beeinflußt wird, und daß man schließlich wegen der Kleinheit des Querschnittes der verwendeten Nadel zu viele Partien einer Holzprobe prüfen müßte, um einen richtigen Durchschnittswert der Holzhärte zu erhaiten.

Dr. J a n k a hat ein Verfahren der Härteprüfung des Holzes ausgebildet, das geeignet erscheint, die Härte des Holzes ziffermäßig exalit zum Ausdrucke zu bringen ${ }^{2}$ ). Dieses Verfahren lehnt sich an das von dem sehwedischen Oberingenieur Brinell 1890 eingeführte Härteprüfungsverfahren an, das bekanntlich darin besteht, daß eine kleine Stalılkugel in die Oberfläche des zu prüfenden Naterials (Metalles) unter ruhigem Druck eingedrückt und aus dem Irugelhalbmesser, dem angewendeten Druck und der Tiefe des erzeugten Eindruckes die Härtezahl des Materials in ziffermäßiger Größe gefunden wird.

$J$ a $\mathrm{n}$ k a verwendet für die Härteprüfungen des Holzes eine aus der ebenen Fläche eines eisernen Druckstückes hervorragende $\mathrm{Halbk}$ a g l v o n $1,00 \mathrm{~cm}^{2}$ g r ö B tem $\mathrm{K} r$ e is e, also von 5,642 $\mathrm{mm}$ Halbnesser, und drüclit diese eiserne Halbkugel zwischen den Preßplatten einer Materialprüfungsmaschine unter stetigem Druck in die geglättete Hirnfläche des zu prüfenden Holzes bis zum größten Kreise der Halbliugel ein. Der W i d e r s t a n d, ausgedrückt in Kilogrammen, den das Holz hiebei in dem Momente leistet, in welchem die Halbkugel bis zu ihrem größten Kreise ins Holz eingedrungen ist, stell t o h n e we i teres d i e Här te des Holzes d a r; da die Größe der Eindrucksfläche im Holze $1,00 \mathrm{~cm}^{2}$ beträgt, so erscheint die IJolzhärte analog wie bei den anderen Festigkeitsangaben auf $1 \mathrm{~cm}^{2}$ bezogen. Um von einer Holzprobe von größeren Dimensionen, die ja auf der Querfläche in den verschiedenen Partien oft verschiedene Härte aufweist, einen verläßlichen Durchschnittswert zu erhalten, ist es natürlich notwendig, nit dieser Härteprüfung melırere Stellen der Hirnholzfläche zu treffen; zweckmäßig wird man diese Einzelprüfungen der Härte in regelmäßiger Anordnung auf die ganze Querfläche verteilen (siehe Fig. 3). Es ist klar, daß diese Härteprüfungsmethode des Holzes zwar der allgemeinen Definition der Härte entspricht, aber mit lieiner Beanspruchungsweise auf Härte durch die verschiedenen schneidenden W'erkzeuge vergleichbar oder älınlich ist; die damit erhaltene Härte stellt also gleichsam eine neutrale Ilärte dar.

Die Härte des Holzes ist abhängig von der Holzart, innerhalb derselben Holzart aber vom Feuclıtigkeitsgehalte und vom spezifischen Gewiehte, in der Art, daß bei gleichem Feuchtigkeitsgehalte das spezifisch schwerere, bei gleichem spezifischen (Trocken-)Gewichte das trockenere Holz die größere Härte besitzt. Während aber die Abnahme der Härte vom lufttrockenen zum wassergetränkten Zustande des Holzes

1) Zur Bestimmung der Holzhărten. Zeitschrift für Forst- und Jagdwesen 1904.

2) "Die Hảrte des Holzes". Zentralblat für das gesante Forstwesen 1906, und "Ueber Holzhărteprūfung" ebendaselbst, 1908. 


\section{容}

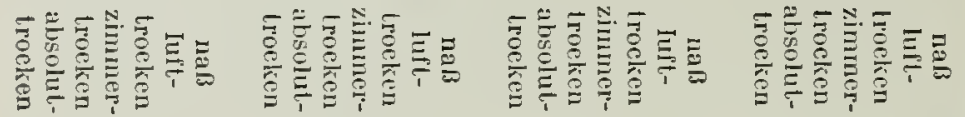

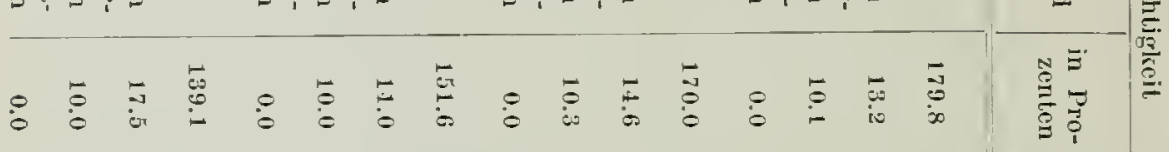

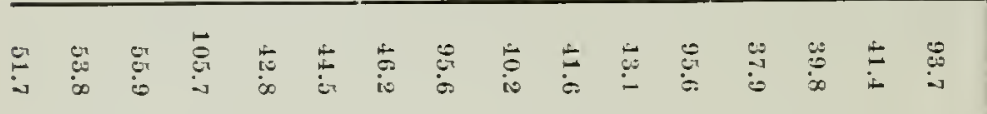

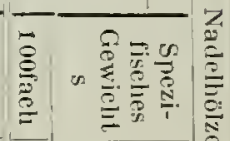

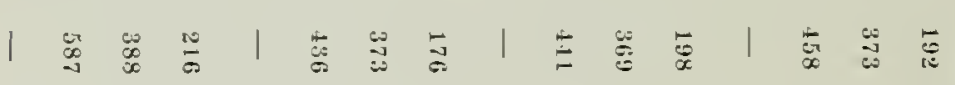

幽

\begin{tabular}{|c|c|c|c|c|c|c|c|c|c|c|c|c|c|c|}
\hline $\overrightarrow{8}$ & $\dot{b}$ & $\ddot{q}$ & 1 & $\begin{array}{l}\infty \\
\stackrel{\infty}{g}\end{array}$ & $\grave{a}_{-\infty}^{\infty}$ & $\stackrel{\infty}{\infty}$ & 1 & 8 & $\begin{array}{l}\infty \\
\vdots \\
\stackrel{0}{\sigma}\end{array}$ & $\begin{array}{l}1 \\
8 \\
8\end{array}$ & 1 & $\bar{\sigma}_{\tilde{E}}$ & $\stackrel{\varphi}{\varrho}$ & $\stackrel{\leftrightarrow}{8}$ \\
\hline$\ddot{\circ}$ & $\begin{array}{l}0 \\
\text { i⿱ }\end{array}$ & $\bar{c}_{0}$ & $i^{\infty}$ & $\begin{array}{l}01 \\
-1\end{array}$ & 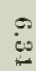 & $ت$ & $i_{i j}$ & $\begin{array}{l}\infty \\
\downarrow\end{array}$ & $\ddot{\infty}$ & $\bar{\sigma}_{\bar{s}}$ & $\ddot{\theta}$ & 0 & $\stackrel{D}{i}$ & $+\infty$ \\
\hline
\end{tabular}

\section{$\stackrel{5}{5}$}

$\frac{2}{\frac{5}{5}}$

率部

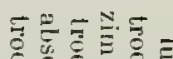

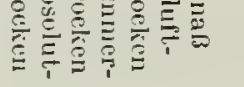

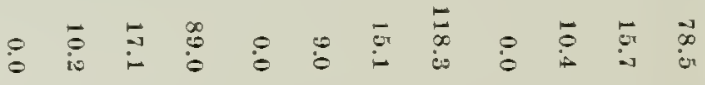

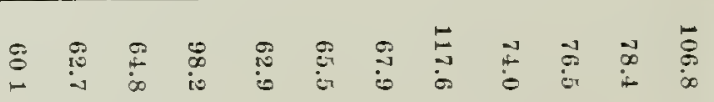

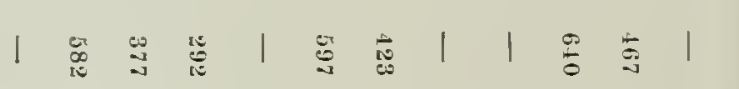

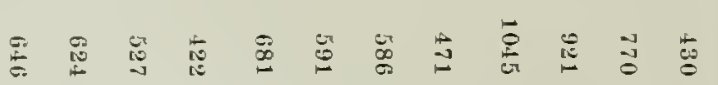

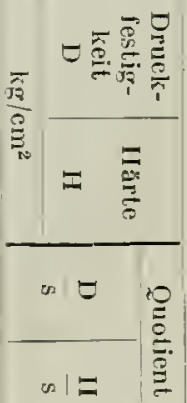

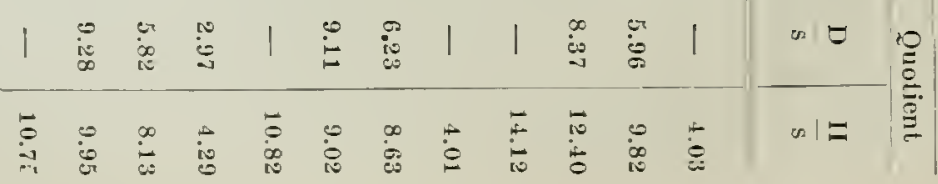


eine bedeutende ist, ist die Zunalme dieser Eigenschaft von lufttrockencn zum absoluttrockenen Zustande nur eine selır geringe. Dieses Gesctz der Mbhingiglieit der Härte rom Feuchtigkeitsgehalte des Holzes ist für einige unserer wichtigsten Holzarten aus der nachstehenden "labelle zu erselıen; die je in 4 verschiedenen Feuchtigkeitsstadien geprüften Hölzer stellen natürlich fül’ jerle einzelne Holzart vollkommen gleiches Holzmaterial dar.

(Siehe Tabelle Seite 43s.)

Der Quotient $\frac{\text { Härte }}{\text { spez.Gewicht }}\left(\frac{H}{s}\right)$ ist bei den Nadelhölzerm likeiner als der Quotient $\frac{\text { Druckfestigkeit }}{\text { spezif. Gewicht }}\left(\frac{D}{\mathrm{~s}}\right)$, während sich diese beiden Quotienten bei den Laubhölzern umgekehrt verhalten, woraus sich die Folgerung ergibt, daß die Nadelhölzer geeigneter sind für Bauzwecke, bei denen es auf größtmögliche Festigkicit bei möglichst geringem spezifischen Gewichte ankommt, während die Laubhölzer wiederum geeigneter sind für die Verwendung als Zeug- und Möbelholz, wozu wegen der geringeren Abnützbarkeit die größere Härte, wenn auch mit löherem spez. Gewichte verbunden, mehr geschätzt wird als die Festigkeit.

Bei Nadelholzbäumen, welche wegen Freistandes einem ständigen Anpralle des Windes ausgesetzt sind, bildet sich an der dem Winde abgewandten Seite des Stammes ein Holz aus, das bei größerer Ringbreite breite Rotholzzonen entwickelt; diese breitringige Seite des Stammes lıcißt bei den Holzarbeitern, ha r $\mathrm{t} \mathrm{e}$ "Seite, die lem I"inde ausgesetzte, schmalringige Seite ,w e i c h e" Seite; es wurde von Janka durch exalite Härteprüfungen nachgewiesen, daß diese Bezeichnmngen der Holzarbeiter tatsächlich vollkommen berechtigt sind, indem die harte Seite wirklich die größere Härte aufweist als die weiche Seite, wenn auch die Druckfestigkeit des Holzes dieser beiden Stammseiten sich umgekehrt verhält, die harte Seite also mit einer geringeren, die weiche Seite nit einer größeren Druclifestiglieit verbunden ist.

Im allgemeinen steigt innerhalb einer und derselben Holzart bei gleichem Feuchtigkeitsgehalt die Härte mit dem Wachsen des spezifischen Gewichtes an; da aber auch die übrigen Festigkeitseigenschaften, der Elastizitäts-, Trag- und Bruchmodul der Druck- und Biegungsfestigkeit mit steigendem spezifischen Gewichte ansteigen, so ist die Härteprobe geeignet, über die technische Qnalität eines Holzmaterials einen ziemlich verläßlichen Aufschluß zu geben, wie dies die nachstehende Tabelle XTII bezüglich der Qualität des Fichtenholzes dartut. Die in dieser Tahelle aufgefülırten Fichtenhölzer verschiedener Qualität sind in Fig. 3 auch bildlich dargestellt.

(Siehe Tabelle Seite 440. )

Was die Beziehungen der Ilärteeigenschaft zum Jahrringbaue des Holzes anbelangt, so gilt diesbezüglich das schon bei der Erörterung der Festigkeitseigenschaften Gesagte: Die Härte ist von der Jahrringbreite direkt nicht abhängig, sie wird vielmehr durch das Verhältnis beeinflußt, in welchem bei einer gegebenen Probe das Spätholz zum Frühholze steht.

Die Härte der Hölzer überhaupt variiert nach den Eroebnissen der Härteprüfungen mittels der Jankaschen Kiugeldruckmethode zwischen 200 (Paulownie) und etwa $2000 \mathrm{~kg} / \mathrm{cm}^{2}$ (Grenaclilholz); unsere härtesten europäischen Holzarten dürften kaum über $1000 \mathrm{~kg} / \mathrm{cm}^{2}$ IIärte haben; höhere Härtegrade weisen viele exotische Holzarten von hohem spezif. Gewichte auf. Wenn num anch die llärteeigenschaft verschiedener Holzarten nicht immer mit dem spezifischen Gewichte derselben in genauem Einklang steht, so läßt sich doch im allgemeinen behaupten, daß ein Holz 
Tabelle IVIl.

Abhängigkeil der Här te des Fichtenholzes vom spezifischen Ge wi cht c.

\begin{tabular}{|c|c|c|c|c|c|c|c|c|c|c|c|c|c|c|c|}
\hline \multirow{4}{*}{ 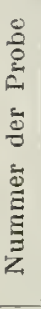 } & \multirow{3}{*}{ 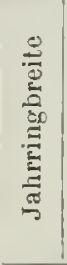 } & \multicolumn{2}{|c|}{$\begin{array}{c}\text { Spezifisches } \\
\text { Gewicht }\end{array}$} & \multicolumn{5}{|c|}{$\begin{array}{c}\text { Biegungs-Elastizität } \\
\text { und -Festigkeit }\end{array}$} & \multicolumn{6}{|c|}{ Druck-Elastizität und -Festigkeit } & \multirow{3}{*}{ 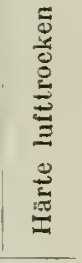 } \\
\hline & & \multirow[b]{2}{*}{ 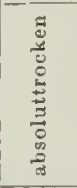 } & \multirow[b]{2}{*}{ 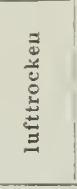 } & \multirow[b]{2}{*}{ 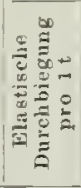 } & \multirow[b]{2}{*}{ 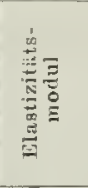 } & \multirow[b]{2}{*}{ 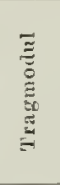 } & \multirow[b]{2}{*}{ 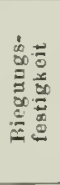 } & \multirow[b]{2}{*}{ 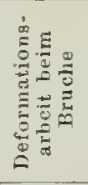 } & \multirow[b]{2}{*}{ 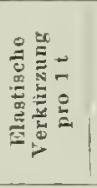 } & \multirow[b]{2}{*}{ 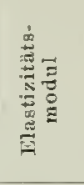 } & \multirow[b]{2}{*}{ 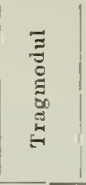 } & \multicolumn{3}{|c|}{ Druckfestigkeit } & \\
\hline & & & & & & & & & & & & 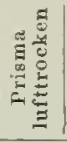 & 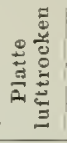 & 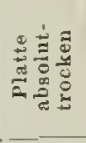 & \\
\hline & $\mathrm{mm}$ & \multicolumn{2}{|c|}{100 fach } & $\mathrm{mm}$ & $\mathrm{t} / \mathrm{cm}^{2}$ & $\mathrm{~kg} /$ & & $\mathrm{t} / \mathrm{cm}$ & $\mathrm{mm}$ & $\mathrm{t} / \mathrm{cm}^{2}$ & $\mathrm{~kg} / \mathrm{cm}^{2}$ & \multicolumn{3}{|c|}{$\mathrm{kg} / \mathrm{cm}^{2}$} & $\mathrm{~kg} / \mathrm{cm}^{2}$ \\
\hline 1 & 3.70 & 31.4 & 34.7 & 9.69 & 87.1 & 331 & 487 & 2.97 & 0.0192 & 94.5 & 217 & 282 & 309 & 523 & 168 \\
\hline 2 & 2.33 & 33.6 & 36.4 & 9.01 & 93.4 & 332 & 543 & 6.03 & 0.0138 & 95.5 & 184 & 317 & 332 & 579 & 197 \\
\hline 3 & 3.17 & 35.6 & 39.4 & 8.27 & 102.2 & 392 & 570 & 4.15 & 0.0176 & 112.2 & 237 & 356 & 336 & 629 & 213 \\
\hline 4 & 1.61 & 37.7 & 40.7 & 6.78 & 124.4 & 423 & 595 & 3.25 & 0.0199 & 120.4 & 228 & 386 & 403 & 709 & 206 \\
\hline 5 & 3.41 & 39.9 & 42.5 & 7.17 & 117.5 & 402 & 664 & 7.51 & 0.0140 & 128.6 & 333 & 374 & 406 & 738 & 237 \\
\hline 6 & 1.54 & 41.1 & 44.2 & 6.94 & 121.9 & 419 & 742 & 9.80 & 0.0161 & 140.8 & 375 & 449 & 418 & 773 & 247 \\
\hline 7 & 2.10 & 44.6 & 47.3 & 6.10 & 138.4 & 477 & 781 & 6.64 & 0.0130 & 148.7 & 252 & 437 & 484 & 861 & 311 \\
\hline 8 & 1.27 & 47.7 & 50.4 & 5.95 & 141.8 & 509 & 835 & 10.71 & 0.0135 & 167.3 & 349 & 481 & 534 & 957 & 324 \\
\hline 9 & 1.01 & 51.2 & 53.5 & 5.63 & 150.3 & 520 & 871 & 12.16 & 0.0168 & 171.4 & 259 & 460 & 573 & 1053 & 341 \\
\hline
\end{tabular}

Fig. 3.

Ansicht der Quelsehnittsflächen von a uf Härtegenrüten Fichten hölzern

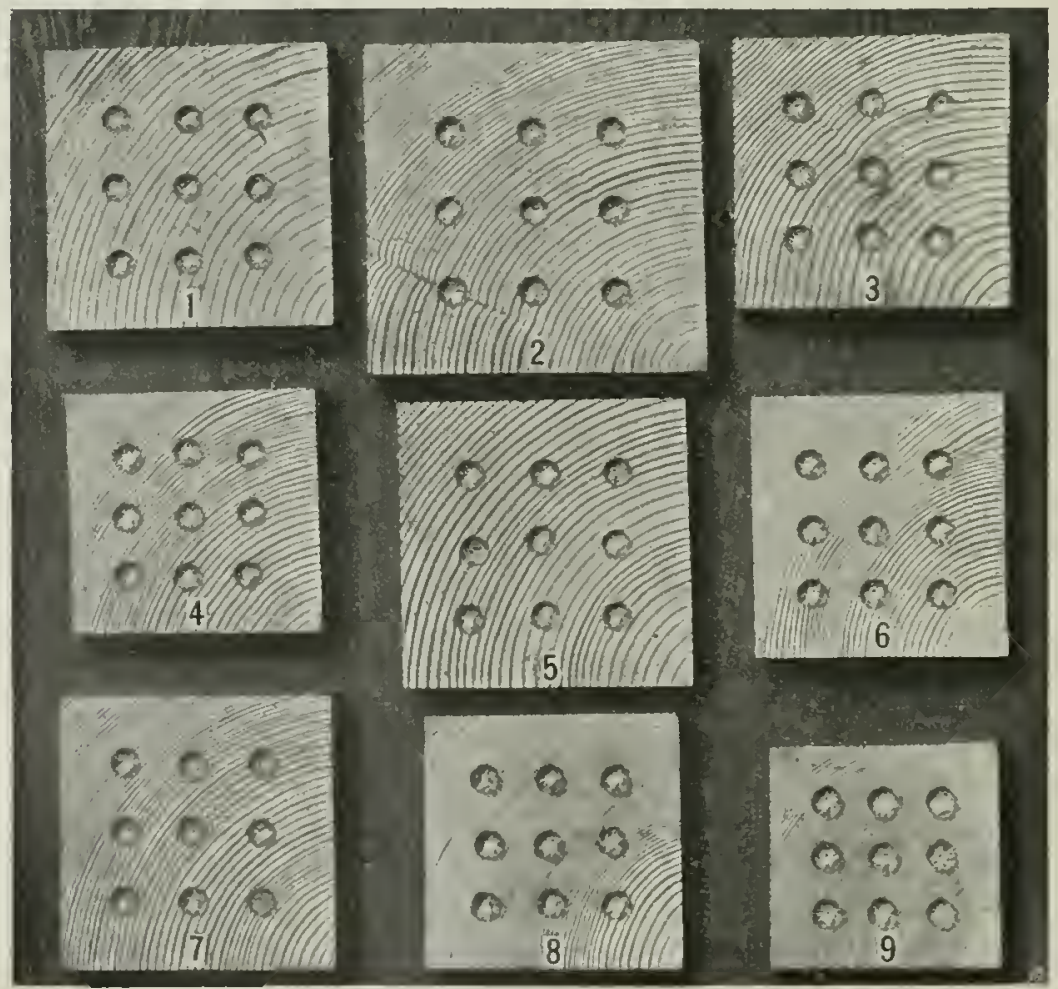


um so lärter ist, je schwerer es ist - immer unter Voraussetzung gleichen Feuchtigkeitsgehaltes.

Mit Hilfe der oben auscinandergesetzten Prüfungsmethode und unter Berücksiclitigung der auf die Härtecigenschaft Einfluß nehmenden pliysikalischen Eigenschaften des Holzes unterliegt die Aufstellung einer Härtesliala, dic nicht auf unzuverlässigen Angaben und dem Gefühle der Holzarbeiter beruht, sondern auf Grund von exakten Härteprüfungen aufgebaut ist, keiner weiteren Schwierigkeit; nur sind diese Untersuchungen an den verschiedenen Holzarten noclı nicht durchgeführt. Solange wir aber eine derartige exakte IIärteskala der Hölzer nicht besitzen, bleibt nichts anderes übrig, als dieselben in der von Nördlinger, Gayer, Nöller u. a. angegebenen Weise bezüglich ihres Härtegrades zu gruppieren, wie dies in der nachfolgenden Reihe geschehen ist ${ }^{1}$ ).

1. S e hr har t: Pockholz, Grenadill, Quebracho, Korallenlıolz, Ebcnholz, Veilchenholz, Buchsbaum, Partridgeholz, Rainweide, Steineiche, (Quercus Ilex), Sauerdorn, Kornelkirsche, Hartriegel, Heckenkirsche, Weißdorn, Schlche, Mandelbaum, Gleditschie, Syringe.

II. H a r t: Hickory, Akazic (Robinic), IVeißbuche, Oelbaum, Palisander, Stechpalme, Maulbeerbaum, Zürgelbaum, Zwetschge, Wildkirsche, Mehlbeerc, Holunder, Rotbuche, Eiche, Zerreiche, Esche, Ahorn, Goldregen, Sperberbaum, Kreuzdorn, Mahagoni, Schwarznuß, WalnuB, Apfelbaum, Birnbaum, Eibe.

II]. M i t t e l h a r t: Teakholz, Elsbecre, Platane, Ulme, Edelkastanie, Götterbaum, Tulpenbaum, Pitchpine, Legföhre, Vogelbeere, Traubenkirsche.

IV. W e i c h: Lärche, Douglastanne, Birke, Erle, Roßhastanie, Hasel, Schwarzföhre, Weißföhre, Fichte, Tanne, Wacholder, Zypresse, Lebensbaum, Faulbecrbaum, Salweide.

V. Se hr we i c h: Aspe. Zirbelkiefer, Weymoutlıskiefer, Weiden, Pappeln, Linde, Paulownie.

$\mathrm{N}$ ö $\mathrm{rd} \mathrm{l}$ ing e $\mathrm{r}$ hat in seinem bekannten Werke eine Reihe von Bcobachtungen über das Verhalten verschiedener Hölzer diversen W'erkzeugen gegenüber veröffentlicht. Dieser Teil der Nördlingerschen Arbeit ist aber bis heute eine fast völlig vereinzelte Anregung geblieben.

Die unter der Fülirung Ern st $\mathrm{H}$ a r t i g s unternommenen Studien über den Kraftverbrauch und die Arbeitsleistung gewisser We r k e u g smas e h in en würden eher noch als die Nördlingerschen Versuche einen sicheren Rückschluß auf die Schnittfestigkeit der Hölzer gestatten. Exner hat eine Reihe von Arbeiten in Verfolgung des von Emst Hartig gezeigten Weges bezüglich der Werkzeugsmaschinen für Holzbearbeitung durchgeführt; er hatte dabei aber weniger dic Arbeitseigenschaft der Schnittfestigkeit als den Wirkungsgrad der Holzbearbeitungsmaschinen und den Zusammenhang derselben mit ihrer Konstruktion im Auge; immerlin waren aber diese experimentellen Forschungen geeignet, die Ueberzeugung zu reifen, daß man nur auf diesem Wege zu einer genaucren Kenntnis der durchschnittlichcı Härte eines bestimmten Bearbeitungsmateriales gelangen könne ${ }^{2 !}$.

Ueberblicken wir den ganzen an dieser Stelle abgehandelten Stoff, so können wir uns dem Gedanken nicht verschließen, daß dem Leser je nach seiner speziellen

1) Hărleskala der Hölzer in den ,Besonderen Bedingungen für den Handel in Holz an der Wiener Bōrse".

2) Werkzeuge und Masehinenzur Holzbearbeitung von W. F. Exn e r. II. Band, Handsägen und Sãgemaschinen, dynamischer Teil 1881. III. Band von C a $\mathbf{I}$ P f a f 1883. Weimar, B. F. Voigt. 
Berufsrichtung unsere Darstellung als melı oder weniger lückenhaft erscheinen mu B. Der eine wird die Erörterung der "Dauerhaftigkeit", der andere die Abhandlung der „Qualität" des Holzes im allgemeinen, ein dritter die Besprechung der „Fehler und Krankheiten" vermissen; dem einen wird zu wenig p o s it i v es M a t e r i a l, dem andern zu wenig $\mathrm{Reflexion}$ oder $\mathrm{K}$ on $\mathrm{klus}$ i on geboten worden sein; wir selbst jedoch betrachten unsere Abhandlung nur als den Versuch einer M a $\mathrm{r}$ i erungderinderforst echnischen, mechanisch-technischen und technologischen Forschungund Literaturbetretenen IV e g e für die Erprobung des Holzes als Grundlage der gewerblichen und industriellen Produktion. 


\title{
IX. \\ Die Forstbenutzung.
}

\author{
B. Die Hauptnu $(z) n g)$.
}

(Ernte, Verwertung und Aufbewahrung ron Holz und Rinde.)

Von

\section{Hermann Stoelzer.}

Für die 3. Auflage bearbeitet ron $\mathrm{Chr}$ is to $\mathrm{ph} \mathrm{IV}^{\mathrm{r}}$ a g $\mathrm{n}$ e r.

L i $t$ e r a $\mathrm{t}$ ur. G a y e r: Die Forstbenutzung. 1. Auflage 1863, 10. Auflage 1909, bearbeitet von .11 a y r. - $\mathrm{K}$ ö $\mathrm{n}$ i g: Die Forstbenntzung. Ein Nachlaß, bearbeitet und herausgegeben von Grebe. 3. Auflage. 1882. (1. Auflage 1851). - I e B: Die Forstbenutzung. Ein Grundriß zu Vorlesungen mit zahlreichen Literaturnachweisen. 2. Auflage. 1901 (1. Auflage 1876). H u f n a g l: Handbuch der kaufmännischen Holzverwertung 1905, 3. Auflage. 1910.

\section{Einleitung.}

Die Nutzung der Erzeugnisse des Waldes stellt ohne Zweifel die früheste Form forstwirtschaftlicher Tätigkeit des Menschen im Walde dar. Lange beror man für einen regelmäßigen Ersatz der dem Walde entnommenen Stoffe durch wallbauliche Maßregeln Sorge zu tragen begann, hatte eine, wenn auch von Hause aus ziemlich planlose Benutzung der Wälder zur Befriedigung der fühlbaren Bedürfnisse der Menschen Platz gegriffen. Dies ging an, so lange die Walderzeugnisse in beliebiger, ;edenfalls aber ausreichender Menge vorhanden und daher mehr oder weniger wertlos waren.

Mit der Verschlechterung des Zustandes der Waldungen, die eine solche ungeordnete Benutzungsweise mit sich brachte, sowie mit der Vermehrung der Ansprüche,

1) $\mathrm{H}$ а $\mathrm{p} \mathrm{p} \mathrm{tn}$ u $\mathrm{z}$ ung, im Gegensatz zur Febenmutzung, (nicht zur Zwischennutzung), deckt sich nicht mit Holznulzung, sondern umfaßt a l] e N u t z u n ge $\mathrm{n}$, d i e d u c h W e g$\mathrm{n}$ a h m e von $\mathrm{B}$ ä $\mathrm{u}$ en e $\mathrm{r}$ h ben werden. Damil fäll neben der Gewinnung des Holzes auch diejenige der $\mathrm{R}$ in $\mathrm{d}$ e unler dic Hauptnutzung. Die Rindennutzung darf nicht, wie meist geschieht, unter die Vebennutzungen gerechnet werden, denn Rinde fällt immer mit an, wo Hauptnutzung erhoben wird, und bildet dabei nicht selten einen wichtigen, ja bein Eichenschảlwald den wichtigsten Nutzungsgegensland. Dazu bleibt sie meist mil dem IIolze vereinigt, wird mil ihm vermessen, gebucht, verwertet und z. T. verbraucht (Brennliolz). 
die an den Wald von seiten der zunelımenden Bevölkerung gestellt wurden, mußte nach und nach ein Unsschwung in der Benutzung eintreten. An Stelle eines Zustands sorgloser Holzverschwendung trat die Furcht vor Holznot. Hieraus, sowie aus dem mehr und mehr in den Vordergrund tretenden Bestreben der Waldbesitzer, ihre Forste zu einer Einnahmequelle von hoher Bedeutung zu machen und die Einkünfte aus denselben zu heben, entsprang die Notwendigkeit, die Benutzung der Waldungeu eigenen Forstverwaltungsorganen zu überweisen, und so bildeten sich nach und nach die Regeln und Grundsätze für Gewinnung und Verwertung der Forstprodukte zu einer eigenen Disziplin, zu der L h re von der Forstbenut$\mathrm{z}$ u $\mathrm{ng}$ aus.

An Stelle der ursprünglich reinen Okkupation von Naturerzeugnissen ohne weitere Waldpflege und Nachhaltiglieit trat schließlich eine geordnete Forstbenutzung mit folgenden Rücksichten und Aufgaben:

1. der Sicherung nachlhaltiger, d. h. gleichmäßig fortdauernder Holzlieferung aus dem Walde - einer wa lderli a l te n d e n, wald p flegliche $\mathbf{n}$, ja waldfördernden Ernte.

2. der Erzielung technisch wertvollster Produkte, daher zweckmäßigster Aufbereitung und Behandlung - eines Zerlegens in transportable Formen und Dimensionen, in Stücke mit möglichst vielseitiger Verwendbarkeit; der Sorge für Erlıaltung bester Qualität,

3. der Erhöhung der WValdrente, daher billigster Ernte und bester Verwertung der Produkte - einer Awwendung waldpfleglichster und dabei billigster Entemethoden und der Sorge dafür, die Erzengnisse denjenigen Verwendungsarten zuzuführen, für die sie sich am meisten eignen und für die sie daher am höchsten geschätzt werden.

Nach der Einteilung des Handbuches der Forstwissenschaft wurden die technischen Eigensehaften der Hölzer in einem besonderen vorhergehenden Abschnitt bereits besprochen; es bleibt uns daher in der Darstellung der Forstbenutzungslehre die Aufgabe, dem Leser die Lehren von der Hauptnutzung und von den Nebennutzungen vorzuführen. Der vorliegende Abschnitt wird sich auf die Darstellung der Hauptnutzung beschränken. Dabei werden wir zunächst eine kurze Uebersicht über die $\mathrm{V}$ e rwe $\mathrm{n}$ d u $\mathrm{n}$ d e r $\mathrm{H}$ öl z e r darzubieten haben, an die wir alsdann die Lehren von der Ernte und von der V e r vertung anschließen werden. Dem Abschnitt über die Hauptnutzung wird ein solcher über die $\mathrm{N}$ e b e n$\mathrm{n} u \mathrm{tz} u \mathrm{n}$ g e $\mathrm{n}$ unmittelbar folgen. Eine gemeinsame Behandlung von Haupt- und Nebennutzungen erschien nicht erforderlich, da ja beide, sobald die Rindennutzung zur Hauptnutzung gezählt wird, in keinem unnittelbaren Zusammenhange zueinander stehen.

Uebrigens ist das V e rhälthis der Ha uptnutzung zu den Neb e n n u t z n ge n im rationellen Forstbetriebe gekennzeichnet durch eine grundsätzliche Unterordnumg der Nebennutzungen unter die Hauptnutzung; d. h. im intensiven Forstbetriebe darf die erstere durch die letzteren nicht beeinträchtigt werden.

\section{Verwendung des IIolzes und der Rinde.}

$\S 1$. A llgemeines. Um mit Erfolg die sorgfältigste Ausnutzung der Forstprodulite anordnen, leiten und überwachen zu können, muß der Forstmann vor allem über die Zwecke, zu denen dieselben in den verseliedenen Gewerben seines Absatzgebietes Verwendung finden, genau unterrichtet sein. Die meiste Rücksicht 
verdient in dieser Hinsicht das Hauptprodukt der Wälder, d a s $\mathrm{H}$ o I z. Die Verwendung desselben ist eine überaus mannigfaltige, es bildet ein für viele Zwecke geradezu unentbehrliches Filfsmaterial und dient zur Befriedigung der ersten und wichtigsten Bedürfnisse der Nenschen. Wir haben dasselbe nicht nur zur Herstellung unserer Wohnungen und zur Heizung und Erwärmung nötig, sondern in noch höherem Umfang zu technischen Zwecken in den verschiedensten Gewerben und Industrien. Je nach diesen Verwendungszwecken unterscheiden wir vor allem zwischen dem Nutzholz und dem Brennholz.

Die höheren Ansprüche, die an Form und innere Eigenschaften des Nutzholzes gestellt werden und die ausgedehntere Verwendbarkeit, die sich aus letzteren ergiht, bedingen in der Regel dem Brennholz gegenüher einen erheblich höheren Preis des Nutzloolzes insofern nicht alles Holz, das noch recht gut zu Brenulıolz tauglich ist, die zu Nutzholz erforderlichen Dimensionen und Eigenschaften besitzt. Um so mehr wird der Forstmann daher die Rente der seiner Leitung anvertrauten Waldungen zu heben imstande sein, je eingehender er sich bemüht, die Schlagergebnisse in möglichst ausgedehnter Weise als Nutzholz aufarbeiten zu lassen und zu verwerten.

In den meisten Fällen wird die Forstverwaltung sich darauf beschränken, das rohe $\mathrm{Holz}$ in den vom Verkehr an meisten begehrten Formen und Sorten den Käufern darzubieten; nur in seltenen Fällen wird derselben die Aufgabe zufallen, eine ins feinere gehende Bearbeitung desselben im Walde selbst vornehmen zu lassen.

Die gewöhnlichsten Verwendungsarten des Nutzhol zes sind: Die Verwendung zum $\mathrm{H}$ o c h b a u (Häușerbau), S c h if $\mathrm{s}$ b a u, B e r g b a u (Grubenholz), Erd-, $\mathrm{Brücken-}$ und Wasserbau, in den Werkstät $\mathrm{W} n$ (Küfer und andere Spaltwarengewerbe, Schreiner, Glaser, Wagner usw.), zum 11 a s c h in e 11 b a $u$ (Werkholz), zur P a p i e r f a b rikation und in der L a n d w i r t s c h a $\mathrm{t}$.

Es ist unmöglich, in unserer gedrängten Darstellung mehr als eine liurze Uebersicht des gewöhnlichen Bedarfs zu geben, zumal örtlich die Anforderungen selır verschieden sind. Es ist deshalb eine wichtige Aufgabe des Forstmanns, die ganz besonders betont werden muß, daß er a 11 e in seinem Bezirk befindlichen Gewerbe und Industrien. die Holz verbrauchen, kennen lernt, allen Nachfragen tunlichst a u den Grund gehtund sich so viel als möglich durcheigene Anschauung und spezjelle Erkundigung unterrichtet; denn seinen Abnehmern gegenüber ist er Kaufmann.

$\S 2$. B a u h o l z. Die zum Bau von Häusern erforderlichen Kionstrulitionshölzer werden je nach dem Unfang der Bauwerke und deren einzelnen Teile in verschiedenen Dimensionen begehrt. Da diese Hölzer nicht in rundem, sondern in beschlagenem Zustande verwendet werden, so ist es von Bedeutung, daß die verwendeten Stämme nicht zu viel Abfall, d. l. keine allzu große Differenz zwischen oberem und unterem Durchmesser aufweisen, vielmehr recht vollholzig sind, weil auf diese Wreise bei gleichem Kubikinhalt des Rundholzes stärkere Balken gewonnen werden können.

Man unterscheidet $\mathrm{s}$ c h a $\mathrm{rf} \mathrm{k}$ a $\mathrm{n} \mathrm{t} \mathrm{i} g \mathrm{es}$ Bauholz, das einen regelmäßigen vierseitigen (quadratischen oder rechteckigen) Querschnitt haben muß, und w a l d-, wa hn-, rund-oder sch a lk a n t iges Bauholz, bei dem statt der scharfen Kanten des vorigen schmale Rundholzbänder als Kreisabschnitte in den Ecken des Querschnittes vorhanden sind. - Die letztere Form gestattet eine weit vorteilhaftere Ausnutzung der Stänme und bedingt einen geringeren Verlust an abfallenden Spänen und Schwarten. Wit noch geringeren Verlust ist das B e r a p p e n der Hölzer 
verbunden; solche berappte Holzstücke sind an vier Seiten leicht behauen, gewöhmlich doppelt so breit als die gebliebene Rindenkante.

Der zweckmäBigste Querschnitt eines wagrecht verlegten, also auf seine $\mathrm{T}$ r a gis a $\mathrm{r} t$ in Ansjruch genommenen Balkens ist nicht der quadratische, sondern der rechteckige, insofern bei $\mathrm{g} l$ e i c l e r Querschnittsfläclıe die Tragkraft des rechteckig geschnittenen Balkens eine erheblich größere ist als die des quadratischen. Die tragkräftigste Rechtechsform in Kreise, oder der stärkste scharfliantige Balken, dessen Breite $=\mathrm{b}$, dessen Höhe $=k_{1}$, wird aus einem Stamme erhalten, wenn die Breite zur Höhe sich verhält wie $1: \bigvee \overline{2}$, annähernd wie $5: 7$, wobei das Produkt b. $h^{2}$ seinen Höchstbetrag erreicht.

Die Bauhölzer erhalten ihre Bearbeitung entweder durch das Beschlagen oder Bezimmen von Hand durch den Zimmermann, wobei der Abfall in die Späne geht, oder durch das Besägen (Besäumen) mit Hilfe von Sägmasehinen auf der Sägmühle.

Die älteste Fonstruktionsfom der Gebäude ist olme Zweifel der B l o clih a u s b a u, bei dem die Wände und Dächer ausschließlich aus Holz hergestellt werden; man findet denselben heute noch in den Alpen, sowie in waldreichen Gegenden des deutschen Ostens in Gebrauch; er ist durch grö $\beta$ ten $\mathrm{Hol}$ z be d a r f gekennzeichnet, denn die $W$ ände sind bei ilm ausschließlich durch Balken gebildet, die aufeinander gelegt und verzapft werden.

Die nächst höhere Stufe ist der F a c h we r k b a u; er bedeutet, was Holzersparnis anlangt, schon einen Fortschritt. Die Wände werden hier durch Holzwerk in Fache eingeteilt, lie mit Bachsteinen oder Bruchsteinen ausgemauert, oder mit Lehm ausgefüllt, wohl auch mit schwächerem Holze ausgesetzt werden.

Mit der zunchmenden Steigerung der Holzpreise ist man vielen Ortes, insbesondere in Städten, zum Ste in- o d e r 11 a s s i v b a u, als der höehsten Stufe des Hochbaus, übergegangen, bei der dieser sich bezüglich der Verwendung von IJolz auf die Konstmition der Decken und les Daches und die innere Ausrüstung der Geläude (Treppen, Täfelungen, Fußböden, Türen, Fenster usw.) beschränkt.

Ilan unterscheidet bei dem zum Hausbau erforderlichen Bauholz folgende Sorten: S c h w e ll e n, die im untersten Stockwerke auf der Grundmauer als Unterlage des Gebäudes (Grundschwellen), im übrigen als Unterlagen der höheren Stockwerke über den Wänden des Gebäudes (Saum- oder Brustschwellen) ihren Platz finden. Grundschwellen werden in Dimensionen von $20-25 \mathrm{~cm}$ Kante verwendet und müssen, da sie, auf Stein liegend, den Einwirliungen der Grundfeuchtigkeit am meisten ausgesetzt sind, aus besonders dauerhaftem Holze, am besten aus E i c h e $\mathbf{n}_{\text {hol }} \mathrm{l}$, hergestellt werden. Saum- oder Brustschwellen nimmt man von $16-20 \mathrm{~cm}$ Beschlagstärke. Säul en kommen zunächst an die vier Ecken eines Gebäudes (Ecksäulen), außerden an alle Thüren, sowie in angemessenen Zwischenräumen (etwa $1^{1 / 4}-1$ 1/2 $\mathrm{m}$ ) imnerhalb der Wände. Sie werden in die Grundschwellen eingezapft. - Auch zu den Ecksäulen verweulet man vielfach Eichenholz.

Auf die Kopfteile der Säulen werden die $R$ a h m e $n$ aufgezapft; man unterscheidet $\mathrm{D}$ a c lı a h $\mathrm{ln}$ e $n$ bein obersten Stockwerli unterhaib des Daches, IV a $\mathrm{n}$ dr a h $\mathrm{m}$ e $\mathrm{n}$ bei den tieferen Stockwerken. Jede Wand erhält einen Rahmen.

Zwischen Säulen von weiter Entfermung, sowie an den Eclien der Gebäucte bringt man Winkelbänder oder Streben an, d. h. Bauhölzer, die in schräger Stellung von der Schwelle bis zum Rahmen reichen.

Außerdem werden, un die zwischen den Säulen und Streben entstehenden Zwischenräune in kleinere Fache zu teilen, die Säuleı unter sich durch wagrecht 
angebrachte Riegellı̈̈zer verhunden. Bei hohen Stockwerken hat man zweimalige Verriegelung.

Zu den Streben und Riegehn genügt schwächeres Holz; man verwendet meist Nadellolz mit einer Beschlagstärke von $10-12 \mathrm{~cm}$.

Die B alli e n werden quer über die senkrechten Wände wagrecht auf die Wandrahmen aufgelegt; ihre Länge entspricht der Tiefe des Gehâdes. Da sic die auf ihnen liegenden Declien zu tragen lıahen, so müssen sie rechteckigen Querschnitt besitzen und ,auf die hohe liante gelegt" werden; auch ist cine ausreichende Stärlie erforderlich (bei langen Balken rechnet man 25/30, bei kürzeren 20/25 Zentimeter Beschlag).

Ueber jede Säule in der Längenwand kommt ein solcher Ballien zu liegen.

Zur Unterstützung der Ballien verwendet man bisweilen noch die $\mathrm{T}$ r ä g e r oder D u I c h z ü g e, die parallel mit der Längsseite des Gebäudes quer unter den Balken aufliegen. Sie werden von ähnlicher Beschaffenheit und von gleichen Dimensionen wie diese genommen.

Die oberste Balkenlage dient nun zum Tragen des D a c hs t u h Is und der S p a r r e n; ersterer wird beim Massivbau auf sog. „Mauerlatten" aufgelegt. "Sirarren" sind die schräg liegenden Hölzer, welche die Fläche des Daches bilden. Bei kileineren Dächem stellt nan die Sparren bloß unten auf die Balken auf und stemmt je zwei sich gegenüberstehende oben aneinander an; bei größeren Dïchern werden die Sparren, damit sie sich nicht biegen, zwei- bis dreinal je nach ihrer Länge auf quer unter denselben, also der Länge des Daches nach liegende Hölzer, die „R a h $m$ e $\mathbf{n}^{\text {“ }}$ oder „D a chruten" gelegt, welch letztere wiederum auf Säulen ruhen. Diese Rahmen und Säulen bilden den $\mathrm{V}$ a $\mathrm{chs} \mathrm{t}$ u h l. Die Säulen und Dachruten werden unter sich noch durch sogenannte Binder verbunden. Je zwei cinander gegenüberstehende Säulen verbindet man dureh "K e hl b a li e $n^{\prime \prime}$, auf welche Wreise der Dacluraum in zwei Stocliwerke zerlegt wird.

Dachsparren erhalten Stärken von $13-17 \mathrm{~cm}$; Dachruten werden etwas stärker genommen, und Dachsäulen erhalten eine Stärke von etwa $20 \mathrm{~cm}$.

Auf künstliche lionstrulitionen, wie sie beim Bau größerer Häuser, insbesondere solcher, welche leträchtliche Säle enthalten, nötig werclen, z. B. Hänge- und Sprengwerke, gehen wir nicht ein, da dieselben ohne Zeichnung nicht gut verdeutlicht werden können.

Beim Massivbau liommt von den vorstehend beschriebenen Sortimenten nur derjenige Teil vor, der zum Dachwerk und zur Herstellung der lnnenwände und Decken erforderlich ist.

Ein gewisser Holzverbrauch beim Häuserbau, besonder's beim Massivbau, findet noch statt durch Anbringung der sog. Baugerüste, die aus den senlirecht gestellten Gerüststämm e n, den wagrecht an diese angebundenen $\mathrm{s} t \mathrm{reck}$ h ö z e r n und den wiederum rechtwinkelig zu diesen wagrecht mit dem Bau sich verbindenden $S$ c h l u $B$ r i e g e l n bestehen. Auf letztere wird ein Bretterbelag aufgebracht, der den Werklenten zum Standort dient. Zu diesen Baugerüsten ver'wendet man da, wo sich das Baugewerbe höher entwickelt lat, nicht melu wie friiher Rundholz, sondern kantig geschnittene Hölzer, die mit Sehrauben untereinancler verbunden werden.

In Zeiten lebhafter Bautätigheit ist der Verbrauch an Bauhölzern ein so lredeutender, daß er einen sehr erheblichen Teil des gesamten Nutzholzanfalls unserer Nadelwälder verschlingt. Die schwächeren Klassen unserer Nadelhol\%-Langhölzer 
verdanken ihre steigende Wertschätzung zum großen Teile dieser Verwendungsart (neben der Papierfabrikation).

Die Holzmenge, die zu einem Hausbau Verwendung findet, wechselt selbstverständlich sehr stark je nach Dimensionen und Bauart. Ein größeres bürgerliches Wohngebäude mit Fachwerkskonstruktion beansprucht immerhin gegen $150 \mathrm{fm}$ Rundholz. Hierbei wird Gewicht darauf gelegt, daß etwa $40 \%$ stärkeres (von ca. $35 \mathrm{~cm}$ Mittendurchmesser), gegen $30 \%$ mittelstarkes (von $30 \mathrm{~cm}$ Durchmesser), $20 \%$ schwaches Holz (von $25 \mathrm{~cm}$ Durchmesser) vorhanden sei, und nur $10 \%$ der schwächsten Sorte (von 18-20 cm Stärke). Der Fachwerkbau ist in der neueren Zeit mehr und mehr durch den Massivbau ersetzt worden und ist eigentlich nur noch auf dem Lande, sowie in kleineren Städten in Anwendung, Der Bedarf an stärkerem Bauholz, das zudcm vielfach durch Eisen (Träger) ersetzt wird, ist infolgedessen gegenüber der Verwendung mittlerer und schwächerer Hölzer geringer geworden.

Man verlangt vom Bauholz vor allem cinen geraden, schlanken, möglichst vollholzigen Wuchs, nicht zu viele Aeste, weil letztere die Tragkraft beeinträchtigen und die Bcarbeitung erschweren. Das Holz muß ferner vollkommen gesund und darf nicht drehwüchsig sein.

Man kann annelimen, daß ausgewachsenes Holz zum Bauen am besten ist, da das junge Holz niemals so fest und daucrhaft sein wird, als dieses; altes, überständiges $\mathrm{Holz}$ besitzt wiederum nicht den erforderlichen Grad von Elastizität.

Holz, das zu Balken bestimmt ist und einen möglichst hohen Grad von Tragfähigkeit haben soll, nimmt man lieber vom Stammende als von Gipfelstücken.

Engringiges, langsam im Schluß erzogenes Nadelholz gibt nach der allgemeinen Annahme ein haltbareres Bauholz als solches. das üppig mit breiten Jahrringen erwachsen ist.

Das Material zu den Bauhölzern liefern vorwiegend die $\mathrm{N}$ a d e lhö l z e r, insbesondere Fichte, Tanne, Kiefer, Lärche. - Zu den Grundschwellen und Ecksäulen, die am meisten dem Eindringen der Feuchtigkeit ausgesetzt sind, verwendet man in der Absicht, größte Festigkeit und Dauer zu erhalten, gerne E i c h e n h o l z, wo solches noch zu mäßigen Preisen zu haben ist. In Nadelholzgegenden jedoch findet meist ausschließlich nur Nadelholz Verwendung.

Unter diesem wird ausgewachsenes kerniges Kiefernholz zu Schwellen und Säulen, ähnlich dem Eichenholz, vor der Fichte den Vorzug verdienen. Zu Schwellen sowie zu allen Verwendungen in dunstigen Räumen wird auch Tannenholz verwendet, da es gegen Feuchtigkeit weniger empfindlich ist. Zu Balkenholz, bei dem es auf einen möglichst hohen Grad von Tragkraft ankommt, wird hingegen die Weißtanne, (wenigstens örtlich, so z. B. in manchen Gegenden Thüringens) zurückgesetzt. Auch nach B a u s hinger (Mitteilungen aus dem mechanisch-technischen Laboratorium der Königl. Technischen Hochschule in München) ist die Tragkraft der Weißtanne geringer als diejenige von Kxiefer und Fichte. Im übrigen wird Kiefernholz in Küieferngegenden gegenüber dem Fichtenholz meist bevorzugt ${ }^{1}$ ). Zugunsten der Fichte macht sich ihr gerader Wuchs (Schnürigkeit), sowie die große Vollholzigkeit der im Bestandesschluß erwachsenen Stänme geltend.

Ein schr dauerhaftes Bauholz ist das $\mathrm{L}$ ä $\mathrm{r}$ c h e $\mathrm{n}$ h o $\mathrm{l} z$; man findet in manchen Gegenden, z. B. in Schlesien, der Schweiz und Tirol, uralte, aus Lärchenholz errichtete Gebäude, die sich ganz vorzüglich gehalten haben. Doch finden sich auch weniger

1) Interessante Untersuchungen über die Wert-, bez. Preisverhältnisse verschiedener Nadelholzer finden sich in dem Referat von $\mathrm{Ne} \mathrm{y}$, ersłattet auf der Xirl. Versammlung deutscher Forstmänner zu Frankfurt a. M. 1384 (cf. Protokoll S. $111 \mathrm{ff}$.). 
günstige Urteile, z. B. Linsichtlich der Neigung des Lärchenholzes, sieh noch längere Zeit nach der Verbaung zu drehen, was wohl bei exzentrischem Wuchse vorkommen kann (Bericht über die 28. Versammlung Thüringer Forstwirte in Coburg 1901). Der W e y m o u th s i e f e macht man den Vorwurf einer gewissen Sprörligkeit und mangelnder Tragkraft; dagegen ist ihre Daucr infolge des Harzgehaltes eine große.

Die Verwendung ausländischer Nadelhölzer, z. B. des sehr dauerhaften Pitchpine-Holzes (von pinus taeda und palustıis aus Süd-Iiarolina herrülrend) heschränkt sich auf die innere Ausrüstung der Gebäude (Fußhödm, Getäfel).

Zu Riegelholz und schwachen Sparren verwendet man whl auch A spenh o I z; die edleren Laubhölzer, Ahorn, Esche, Ulme stehen vermöge ihrer Verwendungsfähigkeit zu vielen anderen Zwecken zu hoch im Preis, als daß sie zu Bauholz gebraucht werden könnten.

Die $\mathrm{Buch}$ e ist anscheinend im eigentlichen Buchengebiet in früheren Zeiten, als es in vielen Gegenden Deutschlands an Nadelholz noch fehlte und die Einführung desselben durch den Mangel an Verkehrsmitteln sehr erschwert war, mehr im Gebrauch gewesen, als dies heute der Fall ist. In alten Gebäuden findet man Buchenholz niclıt selten in einzelnen Stïcken; auch liegen Nachriehten vor, nach denen dasselbe zum Aufbau einer größeren Anzahl von Häusern im Eichsfeld (Provinz Sachsen) verwandt wurde; so ist festgestellt, daß dies im Dorfe Lenterode bei Heiligenstadt nach Beendigung des dreißigjährigen lirieges geschehen ist; das betreffende Holz war beim Laubausbruche gefällt worden und man hatte die Stämme in Laube liegen lassen, bis sie durch die Belaubung ausgetrocknet waren $\left.{ }^{3}\right)$.

Vor einiger Zeit hat man bezüglich des Pfarrhauses zu Lengfeld, ebenfalls im Eichsfeld gelegen, aus dem Jahr 1619 die Erbauung aus Buchenholz, mit Ausschlıß der Schwellen, die aus Eichenholz sind, nachgewiesen und an diese Tatsache mancherlei Wünselıe und Hoffnungen für die Zuliunft der Buche hinsichtlich ihrer Verwendung zu Bauzweken angelinüpft (Zentralblatt der Bawverwaltung für 1886). Der bauliche Zustand dieses Hauses war mit Rüclisicht auf sein hohes Alter ganz ausgezeichnet zu nennen, das Holz hatte insbesondere wenig vom Wurmfraß gelitten. Die Jahreszeit der Fällung des verwendeten Buchenholzes ist nicht angegeben, hingegen finden sich in den Rechnungen Notizen über die Ausgaben für Beschaffung von Salz zur „Beizung" von Brettern, die an einem Tirehturn verwandt wurden; an einer andern Stelle findet sich wieder eine Notiz, nach welcher die Bretter ".gesolten" wurden; es scheint also eine Art von Imprägnierung stattgefunden zu haben ${ }^{2}$ ).

Ausgedehnte Nachweisungen über die Verwendung der Buche zu Bauzwecken in der Gegend des Eichsfeldes hat Oberförster Lauprecht in Iirit. B1. 1865 geliefert. Hier wird die Anwendung besonderer llittel zur Erhöhung der Dauer des Buchenholzes entschieden geleugnet, ebenso die ausgedehntere Anweulung der Sommerfällung in Abrede gestellt. Zur Erhaltung der alten Gebäude hat nach Lauprecht wesentlich beigetragen, daß das Holz nicht wie heute in Schlusse des Hochwaldes, sondern im weiten und lichten Stande des llittel- und Plenterwaldes erzogen war, daß man viel stärkeres Holz verbaute, was einen durchgehenden scharfiantigen Beschlag gestattete, daß man Schornsteine nicht kannte, daß man die Ballien nicht mit Lehm bewarf und so dem durch das Flaus sich verbreitenden Rauche freien Zutritt zum Holze schaffte ${ }^{3}$ ).

1) A. F.- u. J.-Ztg. 1865 , S. 149.

2) Eine Imprāgnierung von Brettern mittelst Einlegen derselben in eine durch Mischuug von Salz und Kalklösung herzustellende Flüssigheit wird noch heute in Frankreich zur kolservierung derselben vorgenommen.

3) Vergl. den Aufsatz von We is e, Oe. F.-Ztg. 1886, Nr. 12.

Haudb. d. Forstwiss, 3. Aufl. II. 
Im Jahr 1864 hat die preuBische Regierung die Anstellung von vergleichenden Versuchen darüber angeordnet, welche Fällungs-Art und -Zeit zur Erhöhung der Dauer und Gebrauchsfähigkeit des Buchenholzes am vorteilhaftesten sei ${ }^{1}$ ).

Aus diesen Untersuchungen, die bis zum Jahr 1876 ausgedehnt worden sind, hat sich ergeben, daß ein erheblicher Unterschied in der Dauer des Winterholzes im Vergleich mit dem Saftholz nicht hervorgetreten ist, daß hingegen trockene Aufbewahrung bei gehörigem Saftumlauf die Bewahrung der Güte des Holzes als Bauund Werkholz zweifellos herbeigeführt hat ${ }^{2}$ ).

Wir bezweifeln, daß die Verwendung des Buchenholzes zu Bauzweeken jemals eine ausgedelnte werden wird; das geringere Gewicht des Nadelholzes, die größere Leichtigkeit seiner Bearbeitung, die Möglichkeit, aus den in weit längeren Stanmstücken zur Verfügung stehenden Nadelhölzern eine viel bessere Auswahl für die einzelnen Bauholzsortimente treffen zu können, weiter die besondere Sorgfalt, die dem Buchenholz bei der Fällung und Aufbewahrung stets zuteil werden muß, wenn es nicht stockig und rissig werden soll, dazu der an den meisten Orten billigere Preis der Nadelhölzer werden diesen immer das Uebergewicht in der Verwendung zu Bauzweckien sichern, wenn auch im eigentlichen Buchengebiet eine untergeordnete Verwendung des Buchenholzes zu gewissen geringeren Sortimenten, z. B. Sparren, Riegeln, Innenwänden immerhin möglich und ratsam sein wird.

\$ 3. S c h if f s b a u l o l z. Der Bau hölzenner Schiffe beschränkt sich in der neucren Zeit mehr und mehr auf die Küstenfahrzeuge und Segelschiffe, die jedoch vielfach durch Dampfschiffe ersetzt werden. Bei diesen, insbesondere den Personendampfern, sowie in der líriegsmarine ist das Holz vollständig durch Eisen- (Stahl-) Konstruktionen verdrängt. Doch werden wohl auch Eisenschiffe, die in die Tropen gehen, außen noch mit $\mathrm{Holz}$ belieidet, da sich dieses leichter von den anhaftenden Seenuschelı etc. reinigen läßt. Auch wird eine Innenbekleidung von Holz wegen Milderung der Temperaturunterschiede für zweckmäBig gehalten.

Hinsichtlich der Benützung deutscher Hölzer zum Bau des Schiffskörpers kann fast nur gutes Eichenholz, weniger Buchenholz, in Betracht kommen, während für Mastholz Nadelhölzer (Kiefer, Fichte und Tanne) Verwendung finden.

In Indien und auf den indischen Inseln wächst das für den Schiffsbau so vorzügliche Teakholz (tectonia grandis); eine weitere Bezugsquelle ausgezeichneten Holzes hat sich seit einiger Zeit in Australien in den daselbst vorkommenden Eucalyptusarten (Blue gum) gefunden.

Die meisten Teile des Schiffsgerippes bestehen aus Hölzeln von verschiedener Krrümmung; falls die natürlichen Holzgrößen zu gewissen Teilen nicht zureichen, müssen dieselben gut und dauerhaft aus verschiedenen Stücken zusammengeschäftet werden. Für die gekrümmten Hölzer verwendet man zwar gerne Stücke, die schon von Natur krumm gewachsen sind, doch lassen sich durch heiße Wasserdämpfe auch Stämne von sehr ansehnlicher Stärke erweichen und durch Maschinen in die gewünschte Kírümmung bringen.

Die Grundlage eines hölzernen Schiffs, gewissermaßen dessen Grundbalken, bildet der li i e l, ein vierkantiger, rechteckiger Balken von bedeutender Stärlze und Länge (der Länge des Schiffs entsprechend), aus bestem Eichenholz oder, da er ganz unter Wasser liegt, auch Buchenholz hergestellt, meist zusammengestückt, da Dimensionen bis zu $2 \mathrm{n}$ Seitenkante bei schweren Schiffen vorkommen. Am Vorder-

1) Die betr. Anleitung findet sich A. F.- u. J.-Ztg. 1865 , S. 150 ff.

2) v. A $1 \mathrm{t}$ e $\mathrm{n}$ : Versuche und Erfahrungen mit Rotbuchen-Nutzholz etc. 1895. (Im Auftrag des Ministers für Landwirtschaft, Domänen und Forste bearbeitet.) 
ende ist als Fortsetzung der Vordersteve n, schräg aufwärts gekrümınt, angefügt, am hinteren Ende melır senkrecht aufsteigend der H in te r s t e v e 1.

Die R i p p en erheben sich vom Kiel bis zur Höhe des Schiffsrandes und sind meist aus drei oder mehr Teilen zusammengesetzt. Zwei gegenüberstehende Ripuen heißen Spanten. Zur Befestigung der Spanten auf dem liel dient das K i e ls c h w e in, ein auf dem Kriel aufliegender Ballien von älnnlichen Ausmaßen, wie der lïiel selbst; zwischen ilın und dem lïielsehwein sind die unteren Enden der Rippen eingezwängt. In das Trielschwein werden zugleich die unteren Enden der Masten eingelassen.

Am vorderen Ende des Schiffes steht sehräg nach außen das Bugsprict; am hintern Ende senkrecht abwärts, in Angeln drehbar, das Stcucruder, ein starker Ballien, an dessen Ende ein breiterer Ansatz ist, der die drückende Wirkung auf das Wasser ausübt. Nancherlei Nebenstücke müssen zur Verbindung eingefügt und eingezapft werden.

Von außen und innen werden die Rippen mit den P I a n k e n benagelt; die innere Wandung derselben dient gleichzeitig als Lager für die querüberlaufenden Balken, die das aus Bohlen bestehende $\mathrm{D}$ e e li zu tragen haben. Die D e e k b a l k e $\mathrm{n}$ wölben sich schwach nach oben, damit das Wasser vom Deck rasch nach den Seiten hin ablaufen hann. Sie werden meist aus Eichenholz hergestellt, doch verwendet man auch Nadelhölzer, z. B. Pitch-pine-Holz. Zur Befestigung der Deckbalken mit den Planken und zur Unterstützung dienen die $\mathrm{I}$ n $\mathrm{i}$ e li öl $\mathrm{z}$ e r, die jedoch vielfach durch Eisenkniee ersetzt werden. Zur Herstellung der D e ck e werden nun noch $\mathrm{D}$ e e k pl a $\mathrm{nken}$, zumeist aus starken Nadelholzbohlen bestehend, aufgenagelt. Den Rand des Schiffes faßt noch eine Holzwand, welehe I $1 / 4-I \frac{3}{4}$ Neter hoch das ganze Sehiff unzielıt, ein. Zu diesem Zwecke sind die Rippen schon entsprechend über das Deck emporgefülırt und bilden feste Pfeiler für die Holzwand, welche $\mathrm{B}$ o r d genannt wird.

Alles über den Schiffskörper sich crhebende und zum Tragen der Takelage dienende Holzwerk heißt $\mathrm{Rundholz}$; dasselbe scheidet sich in M a te $\mathrm{n}$, $\mathrm{Stengen}$ und $\mathrm{R}$ a a e $\mathrm{n}$.

II a $\mathrm{t}$ ist nur der unterste, dickste Teil des Ganzen; die zunehmend schwächer werdenden Aufsätze, welche diesem Teile erst die volle Länge geben, heißen S t e ng e $n ; \mathrm{R}$ a a e $\mathrm{n}$ sind die an die Masten anfgehangenen Querbäume, welche die Segel tragen und ausspannen. Die Jasten, deren die Schiffe je nach ihrer Größe drei, zwei oder nur einen tragen, werden aus den besten Nadelholzstämmen gezimmert, und die größeren müssen immer gestückt werden, da es Nasten von etwa $1 \mathrm{~m}$ Durchmesser bei $40-50 \mathrm{~m}$ Höhe giebt. Je größer daher der Mast, um so mehr besteht er aus künstlich zusammengesetzten Teilen. Der Zusammenhalt wird durch eine entsprechende Anzahl sehr starker, eisemer Ringe vermittelt.

Auch die größten Raaen sind nicht aus einem Stücke hergestellt, sondern ähnlich den Ilasten aus Teilen zusammengesetzt.

Bei den eisernen Schiffen werden auch die Masten, wenigstens in ilıren unteren dicken Partien, aus Eisen konstruiert, indem man dieselben aus Blech röhrenförmig herstellt, wobei dieselben, obgleich leichter als Holzmasten, doch widerstandsliräftiger als diese sind.

Aus der Mannigfaltigkeit der zum Schiffsbau erforderlichen Hölzer folgt, daß der Forstmann unmöglich das zu dieser Verwendung taugliche $\mathrm{Holz}$ in Walde zu passenden Sortimenten ausformen lassen kann. Eine Hauptrücksicht ist die, daß man da, wo überhaupt auf den Absatz von Schiffsbaulıolz zu rechnen ist, dic Stämme in 
ganzen Längen liegen läBt, selbst wenn dieselben Lỉümmen haben; letztere können bisweilen den Wert eines Stückes Holz gerarlezu erhöhen.

Das aus Süddeutschland in großen Nengen nach dem Rhein und ron da nach Holland zu Wasser verschickte sog. Holländer Holz, starke Eichen- und Narlelholzstämme, wird noch vielfach zum Schiffsbau verwendet.

Es wurden früher für diese Hölzer sehr beträchtliche Preise gezahlt, die jetzt zum Teil wesentlich gesunken sind ${ }^{1}$ ).

Für die F l u B f a h $\mathrm{r}^{\circ} \mathrm{z}$ e $\mathrm{g}$ e, die statt des Kieles einen breiten wagrechten Boden haben, an den die von den $\mathrm{K}$ u $\mathrm{i}$ e hö $\mathrm{l}$ z e r n getragenen Schiffsünde im scharfen Winkel angefügt sind, bildet die Ausformung dieser Inniehölzer ein Hauptaugenmerk des Forstmannes. Zul Herstellung derselben wird ein in angemessenem Winkel vom Stamm abzweigender Ast oder am Stammende von Fichten ein wagrecht abziehender Wurzelstrang benutzt.

Während für den Bau des eigentlichen Schiffskörpers neben starkem Buchenholz fast aussehlieBlich Eichenholz in Anwendung kommt, wird zu den Balken und Decken Nadehholz in großen Nengen rerwendet. Zu den Masten und Raaen gebraucht man nur Nadelholz. Hierbei findet feinjähriges, gleichmäßig in Schlıß gewachsenes Kiefernholz die meiste Beachtung. In Mitteldeutschland werden jedoch zu den Masten der Fhufahrzeuge auch Fichten gern genommen. Lärchenholz ist in jerler Beziehung gleichwertig.

\$ 1. Gruben h o l z. Man versteht lierunter alles beim $\mathrm{B}$ e r g b a u rerwendete Holz, welehes zur Auszinmerung der Schächte und Stollen, sowie zur Anlage von Förder- und Pumpwerken gebraucht wird.

Da das zu diesen Zwecken verwendete Holz den Einflüssen einer feuchten, warmen und dumpfen Luft ausgesetzt ist, so müBte man eigentlich besonderes Gewicht darauf legen, nur sehr haltbare Holzarten, insbesondere Eichen, zu benutzen. Allein die große llenge des Bedarfs, sowie der bei manchen bergmämnischen Anlagen nur vorübergehende Gebrauch derselben, so z. B. kurzer Seitenstollen bein liohlenbergbau, die man, nachdem die Kohle ausgebaut ist, wieder verfallen läßt, führen dazı, daß man anch Nadelhölzer in großen Mengen benützt.

Unter riesen steht die $\mathrm{L}$ ä $\mathrm{r} \mathrm{c}$ h e $\mathrm{im}$ besten Ansehen; der Hauptrerbrauch findet aber neben dem Eichenlolz in Ki i f e r 1 statt; da dieses Holz harzreicher ist als Fichtenholz, so widersteht es der Fäulnis mehr als das letztere. Dazu kommt sein meist niedrigerer Preis.

Man sieht meist anf II in t e r fälung.

B u c h e n verstocken leicht und sollen rlen großen Fehler haben, daß sie in gestocktem Zustande nicht. wie andere Hölzer, Warnfähigkeit hesitzen, d. h. den Bruch vorher durch Finistern anzeigen ; in frischer gesunder Bescluaffenheit ist Buchenholz haltbar und wird auch in manchen Kohlengruben, z. B. der Saargegend, in größeren llengen auf Seitenstrecken, die rasch abgebaut werlen, verbraucht.

Im ehemaligen liurhessen soll man beobachtet haben, daß Buchenholz, das im Frühling bis $1 \mathrm{~m}$ Höhe rom Boden im Stelsen geschält und sodann nach dem Abtrocknen im Herbst gefällt wurde, sich sehr gut gehalten hat.

Als sehr bratchbar hat sich insbesondere $\mathrm{A} k$ a $\mathrm{z}$ i e $\mathrm{n} \mathrm{hol} \mathrm{z}$ erwiesen, das an

1) Besonders berühmt waren die Preise für das Holländer Kiefernholz. das im lIauptsmoor bei Bamberg gewonnen wurde. Vergl. A. F.- 11. J.-Ztg. 1851, S. 151, woselbst Ergebniase einer Versteigerung mitgeteilt werden, aus denen sich ein Preis von 116 Mlark für ein Festmeler soleher Kiefern berechnet. Noch 1879 sind Preise von 89 M. pro fm erzielt worden. (Vergl. Z. f. F. U. J. 1884 , S. 267$)$. 
Dauer der Eiche gleichkommt. Sein Anbau wird darum dureh die Grubenverwaltungen empfohlen.

Der Verbrauch des Grubenholzes ist an stäristen in den lin h I e ngruben; von dem Umfange des Bedarfs an Grubenholz kam man sich einen Begriff machen, wenn man aus L o n u e r, Forstliehe Verhältnisse Preußens (3. Aufl. ১. 6.l) erfährt, daß im Oberhergantsbezirk Dortmumd im Jahr 1892 nicht weniger als 1075599 fm Berghauholz (darmter $309633 \mathrm{fm}$ Eichen, $42735 \mathrm{fm}$ Buchen und $723 \mathrm{I} 6 \mathrm{I} \mathrm{fm}$ Nadelholz) gebraucht worken sind. Es fält hierbei ins Gewicht, laß lie meisten IIolzzimmerungen alle 4-6 Jahre, bei Nadelholzverwendung noch ofter, rler Erneuerung bedürfen. Die Haltbarkeit des Holzes wechselt sehr je nach dem Iruck des Gebirges. In Schlesien wurde ermittelt, daß auf eine Förderung von $100 \mathrm{Ztr}$. liohlen 0,1240 cbm Holz unl Schnittmaterial verwandt worden sind. In den liönigl. Steinkohlengruben zu Saarbrücken gebrauchte nan in den 5 Jahren IS78-82 für je 100 Ztr. Kiohlenförderung $0,1325 \mathrm{cbm} \mathrm{Holz}^{1}$ ). Die Förderung von Stein- und Braunliohlen in Deutschen Reich betrug I898 128 Millionen Tonnen à 20 Ztr. Nach obigen Zahlen würden daher für das Jahr 1898 3,3 . Villionen Festmeter Holzverbrauch kommen, bei 3 Festmeter Durchschnittsertrag an Nutzholz pro ha also nachhaltig über eine Million Helitar Wald zur Deckung des deutschen liolnhengrubenholzbedarfs nötig sein.

Die Grubenhölzer werden teils 4seitig, teils nur ?seitig beschlagen, teils auch ganz rund verwendet.

Die gebräuchlichsten Sortimente sind 'T ü l's t ö c k e, $1-3 \mathrm{~m}$ lang, $16-20 \mathrm{~cm}$ stark: sie werden 4seitig beschlagen. Auf ihnen ruhen die liappenhölzer, $11_{z}^{\prime}-3 \mathrm{~m}$ lang, $13-16 \mathrm{~cm}$ stark und zweiseitig beschlagen: ferner verwendet man $\mathrm{St}$ e m$p$ el in den verschiedensten Dimensionen ron $0,6-4$ Meter Länge und $8-25 \mathrm{~cm}$ Durchmesser. AuBerdem werden gebraucht: Schwellen, 2seitig beschlagen, $0,8-1 \mathrm{~m}$ lang, $10-18 \mathrm{~cm}$ stark, endlich $\mathrm{S} p \mathrm{i}$ t z e $\mathrm{n}$ oder $\mathrm{S}$ c heid e $\mathrm{n}, 1-1 \frac{1}{2} \mathrm{~m}$ Länge, 3 bis $10 \mathrm{~cm} \mathrm{~m}$. D.

Zum Auszimmem der. Schächte gebraucht man $S c h$ a $c$ h $t$ h ö $1 \mathrm{z}$ e $r$, die 1,25 bis 5 Meter Länge und einen thantigen Besehlag ron $15-18 \mathrm{~cm}$ haben müssen.

Außerdem hatman F a hrtse he n ke l oderl, ejter bä u me, Sch a c h toder Spurlatten oder Stro B bäume als besondere Arten von Scliachthölzern nötig. wozu stärkere Hölzer von $6 \mathrm{~m}$ ab bei $35-15 \mathrm{em}$ mittlerem Durchmesser verwandt werden. Zwischen den Geleisen der Förderbahnen bedarf man großer Massen von Brettern, Laufdielen oder Bohlen, wozu mit Nutzen Buchenholz verwendet wird, das wenig splittert: Zu Verseluahngen verwendet man Schwarten von Sägewerken in großen Quantitäten.

Die Grubenhölzer gewinnt man teils in Durehforstungen, teils durch Abtrieb ganzer Bestände. Die Forstverwaltung wird sich wohl nur ausnahmsweise darauf einlassen, das Holz in den rom V'erkehr grewünschten Sorten ausformen zu lassen, falls nicht etwa ein Verkauf vor der Fällung abgeschlossen ist. In der Regel wird man die Grubenholzstämme und -stangen in ganzen Längen aushalten und es dem Käufer überlassen, die Ausformung in die seinen Zwecken dienlichen Sortimente selbst zu bewirken.

Alles Grubenholz muß fest und gerade sein', nur die Türkappen liönnen etwas Biegung haben.

Eichenholz verwendet man fast nur norh in den Hauptstrecken; wo besonders lange Haltbarkeit derselben erreicht werden soll, matuert man sie wohl auch aus; statt des Holzes verwendet man auch Eisen.

1) Z. f. F. U. J. 1885 , S. 114 . 
§5. Holzrerbrauch zum Erd-. Brücken- und Wasserb a u. Bei diesen Verwendungsarten wird das Holz in der Erde und im oder am Wasser verwendet.

Es schlagen in dieses Gebiet die $\mathrm{R}$ os t b a $\mathrm{t}$ e $\mathrm{n}$. die W e g e b a u $\mathrm{t}$ e $\mathrm{n}$, der

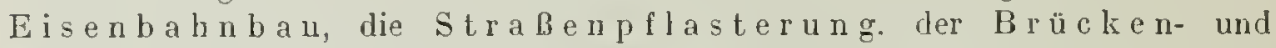
IV a sserbau, die Verwendung als $M$ a sten und Leitungsstangen.

In weichem, feuchtem Baugrund bedarf man der R o s t e zur sicheren Grundlegung der Bauwerke. Dauerhafte Grundł̧ähle aus Eichen-, Kíiefern- oder Lärchen-, sowie bei konstanter Nässe auch aus Erlenholz werden eingerammt und auf ilmen Schwellen eingezapft, die man aus Eichen- oder altem Kiefern-, seltener Weißtannenholz herstellt. Es finden hier Höłzer von $20-30 \mathrm{~cm}$ Stärke als Rostpfähle Verwendung.

Zum IV e g b a u wird Holz neuerdings nur noch in sehr untergeordnetem Umfang, insbesondere zum Belegen feuchter Stellen, in steinarmen Gegenden verwendet: 15 bis 20 7entimeter starke gerade Stangen von Fichten, Tannen, lỉefern oder Erlen werden querüber mit etwas schwächeren, der Breite der Wege entsprechenden Knüppeln (Prügehn) belegt (Inüppel- oder Prügelwege). Auch gebraucht man Stangen zu Wasserableitern und Sickerungen, sowie als Pfähle zur Befestigung von Böschungen und Faschinen in ganz sumpfigen Partien. Alle diese Bauten sind Notbehelfe bei Mangel an Steinen und bei der Absicht billigen Baues.

Beim E i s e $\mathrm{n} \mathrm{b}$ a h $\mathrm{n}$ b a u bedarf man der Schwellenhölzer. Die Lieferung der Eisenbahnschwellen erfordert beträchtliche Nengen von Holz, auch wenn neuerdings eine gewisse Konkurrenz durch die mehr und melir in Aufnahme kommende Verwendung eiserner Bahnschwellen eingetreten ist.

Für das Betriebsjahr 1897/9s wird die Eigentumslänge aller deutschen Eisenbahnen zu $51904 \mathrm{~km}$ angegeben, die Geleiselänge auf $93814 \mathrm{~km}$. Hiervon entfallen auf Vollbalmen $81739 \mathrm{~lm}$, von denen 62004 auf hölzernen, 19293 auf eisernen Schwellen und $443 \mathrm{~km}$ auf Steinwürfeln Hiegen $(72,1$ Millionen Holz-, gegen 2.2, 6 . Willionen Eisenschwellen). Von 72 Mill. Holzschwellen entfallen 41 Mill. auf Nadeholz (56\%), 28 lill. auf Eichen (39\%), 3 Mill. auf Buclien (5\%). $88 \%$ waren imprägniert, $12 \%$ nicht. Die Verwendung von Eichenholz nimnt stetig ab, die ron Buchen- und Nadelholz zu. Im ganzen ist aber die Zunahme der Eisenschwelle größer als die der Holzschwelle. Von 1887 bis 1897 haben die Geleise auf Holzschwellen sich nur um $20 \%$, hingegen diejenigen auf eisernen Schwellen um $129 \%$ vermehrt ${ }^{1}$ ). Nimmt nan die mittlere Dauer einer Schwelle zu 10 - I? Jahren an, so erfordert die Erhaltung des Oberbaues jährlich ca. 5 Millionen Schwellen, wozu, da aus 1 Festmeter Rundholz etwa 6 Schwellen gearbeitet werden können, über 1100000 Festmeter Schwellenholz benötigt werden. Rechnet man einen Durchschnittsertrag von 2 fm Nutzholz je Hektar, so würden nach dieser Annahme 550000 ha Wald zur Lieferung des jälırlichen Bedarts an Schwellen erforderlich sein.

Da die Waldfläclie in Deutschland etwa I4 Millionen Hektar beträgt, so würde die Erzeugung des nötigen Schwellenholzes, wenn dasselbe ausschließlich in Deutschland gewonnen werden sollte, zwar nur $1 / 25$ der gesamten Waldfläche in Anspruch nehmen, allein immerhin ist örtlich die Abgabe von Hölzern zur Schwellenfabrikation, insbesondere im Gebiete des $\mathrm{E}$ ic h e $\mathrm{n}$ w a l d e s, von besonderer Bedeutung.

Man unterscheidet gewöhnliche Bahn- oder Stoßschwellen und sog. Weichenschwellen; die ersteren haben eine Länge von $2.5 \mathrm{~m}$, die letzteren sind länger und werden von verschiedenen Maßen (bis $5 \mathrm{~m}$ ) gebraucht: man rechnet die untere Breite

1) Die deutschen Eisenbahnen im Betriehsjahr 189798 (Mitteilung von Dr.Laspe y r s in Ztschr. f. F.- U. J.-W. 1901, S. 626). 
der Schwelle zu $26 \mathrm{~cm}$ (geringere Kilassen bis zu $24 \mathrm{~cm}$ ), dic Höhe beträgt $16 \mathrm{~cm}$, die untere Fläche, sog. Lagerfläche, muß durchaus vollkantig sem, an der oberen Fläche wird beiderseits $5 \mathrm{~cm}$ Waldkante zugelassen.

Man verlangt kerniges, festes, gesundes Holz, das keine Astlöcher lat. Eine klcinc einseitige lírümmung ist zulässiğ; die Lagel- und die oberen Flächen müssen jedoch eben sein.

Nach einem vom Minister der öfentlichen Arbeiten in Preußen unter dem 6. Juli 1885 erlassenen Reskript wird vorausgesetzt, daß die Fällung des Schwellenholzes innerhalb der Zeit vom 1. November bis 1. Uärz liegt.

Was nun die zu Schwellenholz geeigneten Holzarten anlangt, so kommt in erster Reihe die E i c h e, ferner die $\mathrm{K}$ i e f e r, untergeordnet die B u c h e in Betracht. In Frankreich werdeu auch Schwellen aus Kastanienholz benützt; sehr dauerhafte Schwellen hat man aus Quebrachoholz hergestellt.

Vergleichende Versuche der französischen Ostbahn mit imprägnierten Schwellen verschiedener Holzarten haben folgendes ergeben. Die Haltbarkeit betrug für:

Kiefer 15 Jahre im Hauptgeleise und 5 Jahre im Nebengeleise

Eiche 18 Jahre ,, , 7 Jahre

Buche 20 Jahre , , 10 Jahre

Die Buche hat sich somit bei guter Imprägnierung als haltbarste Holzart erwiesen.

Auf den meisten deutschen Bahnen verwendet man E i c h e n schwellen, auf Nebenbahnen jedoch auch Kïfern, im Lärchengebiet wohl auch Lärchen. Außerdem lhat sich die Buchenschwelle an manchen Orten eingebürgert; mehr als in Deutschland wird dieselbe in Frankreich verwendet ${ }^{1}$ ); auch auf den niederländischen Bahnelı hat man in ausgedehnter Weise Buchenschwellen, die mit Kreosot imprägniert waren, in Verwendung gebracht. Sehr gute Erfahrungen mit Rotbuchenschwellen, die mit karbolsäurehaltigem Teeröl getränlit waren, sind in Elsaß-Lothringen gemacht worden; hier hat sich insbesondere eine längere Haltbarkeit als bei den Eichenschwellen erwiesen (Mitteilungen des Landforstmeisters von B e rg), was darin liegen soll, daß die Buchenschwelle tränkfähiger ist und daher mehr Teeröl aufnimmt, als die Eichenschwelle. Eine Eichenschwelle nimmt $11 \mathrm{~kg}$ Imprägnierungsflüssigkeit (Teeröl) auf, eine Buchenschwelle dagegen $36 \mathrm{~kg}$. Daher hat auch die Imprägnierung sehr verschiedenen EinfluB auf die Kiosten für die Schwelle:

eine Schwelle, bearbeitet, aber roh kostet: Eiche 5,50 MI. Buche 3,30 MJ. INiefer 3,35 M. die Imprägnierung:

Daher die imprägnierte Schwelle: $\frac{1,00 \mathrm{M}}{6,50 \mathrm{M}} \quad \frac{2,10 \mathrm{M}}{5,70 \mathrm{M}} \quad \frac{0,80 \mathrm{M}}{4,15 \mathrm{M}}$

Da die aus Buchenholz gearbeiteten Schwellen zur Erhöhung ihrer Dauer imprägniert werden müssen, so gilt es als ein wesentliches Erfordernis, daf das Rohholz nicht mit dem, in Buchenbeständen nicht selten auftretenden, roten Kern behaftet ist, weil in diesem Fall das Holz sich nur schwer und unvollkommen imprägnieren läßt ${ }^{2}$ ).

Für die größere Rentabilität des deutschen Buchenwaldes ist die gesteigerte Einbürgerung der Buchenhahnschwellen von großer Wichtigkeit. Leider sind nicht allenthalben die Auffassungen der Eisenbahntechniker einer solchen günstig. Insbesondere will man auch Schwellen mit versteckten Fehlern gefunden haben, derart,

1) Vergl. A. F.- u. J.-Z. 1867 , S. 66 ; ferner W e is e: Die Buchennutzholzfrage. Z. f. F. u. J. 1881 , S. 545 , sowie Z. f. F. J. 1881 , S. 196.

2) Vergl. W i l b r a $\mathrm{n}$ d: Nutzholzwirtsehaft in Basaltgebiet des Vogelsberges. A. F.- U. J.-Z. 1885 , S. 147 . 
daß solehe, von außen gesund aussehend, doch brachen und dadurch den Eisenbahnbetrieb gefährdeten.

Was den oben erwähnten roten Iiern anlangt, so beruht derselbe auf einer, von Verletzungen, Astwunden, Wasserlöehern in Zwieseln und Astgabeln ihren Anfang nehmenden Bildung, die von manchen (R. II a r t $\mathrm{ig}$ ) für den Beginn einer Zersetzung, von H e r r m a n $n$ (Zeitsehr. f. F. u. J.-W'esen 1902, S. 596 ff. „Ueber die Kernbildung bei der Rotbuche") für eine durch sog. Wundgummi veranlaßte Schutzbildung gegen das Eindringen holzzerstörender Pilze gehalten wird. Nach H errm a n n (а. a. O. S. 617) sollen auch Stammstücke mit rotem Kern, wenn sie nur astfrei sind, ohne Bedenken zu Eisenbahnsehwellen benutzt werden können, sofern sie ordentlich ausgetroeknet sind und der Splint gehörig mit Teeröl getränkt wird.

Die Bahnsehwellen werden an vorteilhaftesten aus mittelstarkem Holze gefertigt; bei ihm fällt am wenigsten Abfallholz in die Späne. Mlan kann annehmen, daß ein Rundholzstück liefert bei:

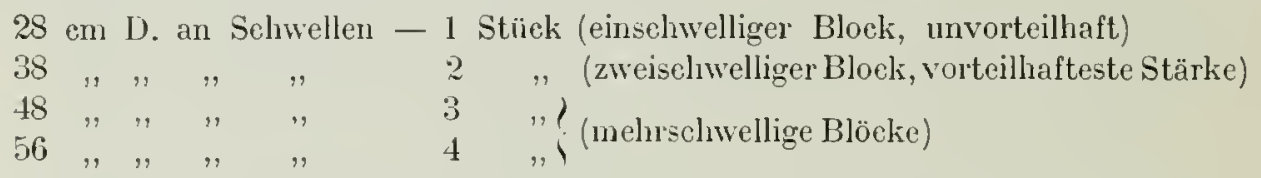

Eine Schwelle lat $0,0+q \mu$; somit finden folgende Ausnutzungsverhältnisse statt: $28 \mathrm{~cm} \mathrm{D.}=0,06 \mathrm{qm}$ enthält $0,04 \mathrm{qm}$ oder $66 \% \frac{2 \%}{3} \%$ nutzbares Holz,

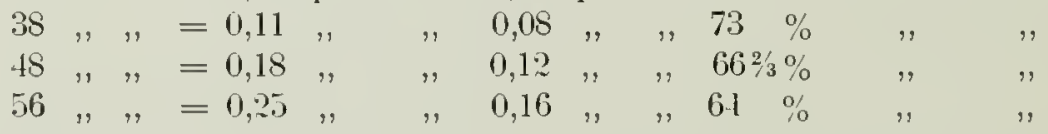

Es fällt hiernach bei der Sehwellenholzbearbeitung $27-36 \%$ des Pundholzes in die Späne und es zeigt sich, daß mittelstarkes Holz (38 $\mathrm{cm} \mathrm{m.} \mathrm{D.)} \mathrm{am} \mathrm{vorteilhaftesten}$ ist, weil es den geringsten Abfall hat (siehe oben).

Ob der mit den loölzernen Schwellen mehr und mehr in Wettbewerb tretende e is e r n e $\mathrm{Ober}$ b a u die Holzschwelle in erheblichem Naße verdrängen wird, bleibt abzuwarten. Tatsache ist, daß mit den Eisensehwellen eine größere Abnutzung des rollenden Eisenbahnmaterials verbunden ist als mit Holzschwellen, da jene weniger Elastizität haben und dem auf sie wirkenden Drucke nicht answeichen. Nach belgischen Erfahrungen, mitgeteilt auf den 1885er intemationalen Eisenbahnkongreß in Blüssel, wird den eisernen Schwellen nicht nur der Vorwurf der geringeren Solidität und Festigkeit gemaeht, sondern auch angegeben, daß sie teurer und schwieriger zu unterhalten seien als Holzschwellen. Insbesondere fällt hier das Zerschlagen des Schotters beim Kŕmpen ins Gewicht, das es notwendig macht, die Strecken von Zeit zu Zeit neu zu beschottern, ein Aufwand, der bei der Holzschwelle wegfällt. Aehnliehe Erfahrungen wie mit den Eisenschwellen hat man mit Steinquadern gemacht.

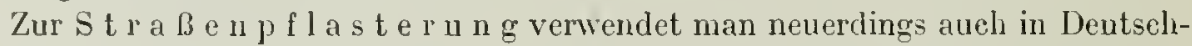
land Holzwürfel, nachdem schon längst in Amerika, Frankreich (Paris) und England in ausgedehntem Maße von diesem Material Gebrauch gemacht worden ist. Besonders sind in Berlin seit 1873 versehiedene Ver'suche gemacht worden. Es wurden anf einer isolierenden Betonschichte von $20 \mathrm{~cm}$ Stärke, welehe die Ebenheit des Pflasters sichern und die verderbliche Wirkung der Feuchtigkeit abschneiden soll, teils Würfel der amerikanischen yellow pine (Pinus Jeffreyi, Jeffreys Kiefer), teils solehe der deutschen Kiefer, 18 en hoch geschnitten, imprägniert mit Teer und Kreosotöl, als H irn h o l z, sodaß dic Längsfasem aufrecht stehen, gelegt, hierauf mit Kies über- 
fahren und gewalzt. 1886 wurde eine l'flasterung mit imprägnierten Buchenholzwürfeh ausgeführt, welelıe aus den Forsten des Fürsten v. Bismarck stammiten.

Auch in Frankfurt a/Al. sind Versuche mit Buchenholzpflaster gemacht worden, die 18 Mark liosten pro qu - gegen 12 Mark Kosten pro qu für Basaltpflaster ergaben (cf. R e i B in A. F.- U. J.-Z. 1887 S. 71).

Das Holzpflaster vermittelt ebenso wie Asphalt einen geräuschlosen Verkehr, gestattet jedoch den Pferden einen sichereren Tritt, indem es das Eingreifen der Hufe erleichtert und so das Stürzen der Pferde verhindert. Seine Einfülırung würde, falls deutsches Buchen- und Kïicfernholz sich bewährte, der besseren Ausnutzung mancher Wälder guten Vorschub leisten. Die Kälte verschiedener Winter in den $1890 \mathrm{cr}$ Jahren lat das Holzpflaster in Berlin und andern Städten schr in Mißkredit gebracht, indem dasselbe vielfach zerrissen und auseinandergetrieben wurde. Buchenpflaster nutzt sich zudem leicht und ungleichmäßig ab und wird bald bolperig. Auch Schmutz und Staub werden in der bald filzig werdenden Oberfläche in besonderen Maße festgehalten, was die Reinigung erschwert. Von ausgedehnter Verwendung des Holzpflasters ist man in Berlin zurückgekommen. In Paris lingegen scheint sich das Holzpflaster, zu dem neben fremdländischen Nadelhölzern namentlich pinus maritima verwendet wird, bewährt zu haben.

Eine besondere Empfehlung des $\mathrm{B}$ u chen holzes zu Straßenpflaster veröffentlichte J a n k a im ,Zentrablatt für das gesamte Forstwesen" 1902 (Oktober- und Novemberheft). Durch gecignete Imprägnierung soll das Schwinden, Quellen und Werfen verhindert und das Reißen desselben beseitigt werden. Die Dauer wird als hoch und die Abnutzung als gering geschildert.

Der WV a s e r b a u bedarf anschnlicher Quantitäten von Holz zur Herstellung von Uferbefestigungen, zu Schleusen und Webrbauten. Viele Uferbefestigungen stellt man durch Steinpackungen her, wobei öfters zunächst ein Holzrost einzurammen ist. Unfängliche Uferbauten von Holz kommen in Holland vor, wo vielfach sumpfiger und mit keinem haltbaren Untergrund versehener Boden vorherrscht. Zu diesem Zwecke gehen aus Mittel- und Süddeutschland viele Eichen- und Nadelhölzer in Form von Pfahlholz und stärkerem Rundholz aul dem Phein dorthin.

Ausgedelnnter Verbrauch von Holz zu Wasserbauten findet ferner in Gebirgsgegenden statt, in denen Holzflößerei betrieben wird. Insbesondere sind es hier die Uferbefestigungen, die namhafte Jengen Holz in Anspruch nehnen; außerdem wird solches zum Bau der Rechen, sowie zu lcichteren Stau- und Schlcusewerken benutzt ${ }^{\mathrm{I}}$.

Zu den bei der Holzflößerei vorkonmenden Bauten verwendet man zumeist Fichten- und Tannenholz und gibt letzterem den Vorzug, da es sich im abwechselnden Zustand der Nässe und Trockenheit besser als ersterés hält.

Bei den anderen Wasser- und Brückenbauten findet Eichen- oder ausgewachsenes harzreiches Kiefernholz Verwendung. Zu Pfeilern u $\mathrm{t}$ e r IV a s s e r (Piloten) eignet sich auch Buchenholz, namentlich wenn es im Saft gefällt und sofort verbaut wird; dasselbe soll steinhart werden. Ebenso ist Erlenholz bei ausschließlicher Verwendung unter Wasser (z. B. für Roste) zu gebrauchen. Der B r ü ck e nb a u erfordert bestes Eichen- und Nadelholz; zum Belag von Brücken werden neuerdings auch Bohlen aus Buchenholz gerühmt. Dic an der Kölner Rheinbrücke gemachten Erfahrungen haben ergeben, daß Buchenbohlen sich zwar abreiben, aber

1) Darstellung der Holzbringungsmittel in den Kigl. Bayerischen Salinenwaldungen, herausgegeben vom bayerischen Ministerialforstburcau 1860 , Teil 11, sowie G a y e s Forstbenutzung, 9. Iufl., S. 261 ff. u. S. $297-335$. 
nicht in dem Mlaß splittern wie Eichenbohlen. Die Dauer der letzteren war 2 1/2jährig. der ersteren 3jährig. Da der Festmeter Buchenbohlen sich auf nur 41 Mark, hingegen der Festmeter Eichenbohten auf 87 Mark stellte, so ergab sich mit Rücksicht auf die längere Dauer der Buchenbohten bei ihrer Anwendung eine Ersparnis von $59 \%$.

In das Gebiet des Wasserbauholzes gehören noch die $\mathrm{F}$ a s c h i n e $\mathbf{n}, \mathbf{d}$. l. drei und mehr Meter lange Reisigbunde, welche aus langen schlanken Ruten ohne Laub, die sich leicht zusammenlegen lassen, zu Wellen gebunden werden. Am gesuchtesten sind Faschinen aus Weiden, die gerade und schlanke Triebe haben. Auch schwache Nadelhölzer, Aeste alter Fichten, sowie Stockausschläge der Rhammusarten, der Erlen und Haseln u. dergl. eignen sich selı gut dazu, am wenigsten hingegen sperrige Astreiser.

Zur Befestigung der Faschinen verwendet man $B$ u h n e $n p f$ ä $h l$ e, I- 2 m lang und 5-8 cm stark, aus Kiefemdurchforstungshölzem, Erlen etc. gefertigt. Dieselben werden durch die Faschinen hindurch in den festen Grund eingeschlagen.

Zunehmende Bedeutung gewinnt die Verwendung des Holzes zu M a s t e n und L e itungs t a ngen für Telegraph, Telephon, elektrische Starkstromleitungen usw. Verwendet werden Nadelholzstangen und -stämme besonders der Fichte und Tanne, bis zu den stäristen Dimensionen. Die in den Boden gelangenden Enden werden imprägniert; neuerdings finden auch in Beton und Eisen konstruierte HaIter Verwendung, in welche die Stangen eingeschraubt werden, ohne den Boden zu berülıren, so daß ein Hauptgrund ihrer Verderbnis, die unmittelbare Berührung mit der feuchten Erde, wegfällt und dadurch die Haltbarkeit bedeutend erhöht wird.

$\S 6$. Spaltholz. Zur Herstellung von Gefäßen für Aufberahrung von Flüssigkeiten (Fässer, Bottiche u. dergl.) verwendet der Böttcher (Küfer, Kübler) vorwiegend spaltiges, möglichst astfreies $\mathrm{E}$ i c b e $\mathrm{n} \mathrm{h}$ o $\mathrm{l} z$ in kürzeren oder längeren Stücken. Das Ausspalten der Faßhölzer, der sog. Dauben, sowie auch der Bodenstücke, erfolgt nach der Richtung der llarlistrahlen, nicht nach der Sehne des Holzes, weil im letzteren Falle die Gefäße durchlässig gegen Flüssigkeit sein würden.

Langsam erwachsenes, ganz feinjähriges Eichenholz ist minder dicht als weitringiges.

Kkleinere Gefäße für den Haushalt (Butten, Kübel, Eimer, Wannen) werden von $\mathrm{N}$ a d e thol z verfertigt, wobei der Fichte der Vorzug gegeben wird.

$\mathrm{B}$ u e h e n h o l z wird ebenfalls zu Böttcherware, insbesondere zur Herstellung von Packfässern verwandt. Der Butterlandel Schleswig-Holsteins und Mecklenburgs bedarf großer Mengen von Buchenfässern. Auch Seefische werden vielfach darin versandt. Allgemein geschätzt vor anderem Holz wird das Buchenholz für Packgefäße zur Aufnahme von Lebensmitteln verschiedener Art wegen semer Geruchlosigkeit.

Außerdem verpackt man in solche: Zement, Seife, Salz, Erze, Eisenwaren und dergl. ${ }^{1}$ ); auch kommt Petroleum vielfach in Buchenfässern zum Versand.

In Ungarn soll Buchenholz zu Faßdauben, selbst zu Bierfässern in ausgedehnter Verwendung stehen; die Faßdauben werden jedoch vor der Bearbeitung mit Wasserdämpien ausgelaugt ${ }^{2}$ ).

Die Dauben zur Anfertigung von Fässem, die zur Aufnahme trockener Gegenstände bestimnt sind, werden nicht gespalten, sondern durch die Kreissäge in den erforderlichen Dimensionen geschnitten, da es hier nichts schadet, wenn der Schnitt

1) W e is e, Buchennutzholzfrage in Z. f. F. U. J. 1881, S. 543.

2) A. F, - U, J.-Z, 1865, S. 463 . 
nicht in radialer Richtung geführt ist; anch hat man zur Herstellung der Faßdaulıen besondere Maschinen.

Bei ungewöhnlich großen Gefäßen, selbst wenn dieselben zu Aufnahme von Flüssigkeiten bestimmt sind, kömnen die einzelnen Bestandteile nicht durch Ausspalten gewonnen werden, sondern man fertigt dieselben aus geschnittenen Bohlen. $k \because \because$ Zum Binden der Böttcherwaren dienen R e i f e; bei größeren und schwereren Fässem und Bottichen verwendet man Eisenreife, außerdem solche von schlanken spaltigen Stockausschlägen der Birken, Haseln, Weiden, wolıl auch Eichen.

Spaltholz wird außer zur Herstellung von Böttcherwaren benulzt zur Fertigung von Siebrändern und Schachteln; hierzu wird meist Fichten- und Tammenloolz verwandt. Mit dem Seltener- und Teurerwerden der schönen astfreien und spaltigen stärkeren Stämme nimmt die Herstellung größerer Schachteln, die besouders wertrolles Holz beansprucht, das im Groben ausgespalten, mit dem Schnitzmesser glatt gearbeitet und alsdann in die den Schachteln eigentümliche runde oder ovale Form gebogen wird, mehr und mehr ab, zunal dieselben durch billigere Kisten oder Pappschachteln vielfach leicht ersetzt werden; kleinere Schachteln, insbesondere Zündholzschachteln, beanspruchen weniger wertvolles Holz. Dieselben werden zwar auch aus glatten Holz hergestellt, allein man gewinnt die Bänder nicht durch Spalten, sondern diese werden durch besondere Hobel in den den Schachteln entsprechenden Größen liergestellt und es ist daher die Spaltbarkeit des Holzes kein unbedingtes Erfordernis mehr. In ähnlicher Weise, nämlich durch Abschälen mit Hilfe von Hobeln werden auch die Späne zu den Schiebkästchen, die zur Aufnahme der schwedischen Zündhölzer dienen, hergestellt. Man verwendet dazu Aspen-, in Deutschland auch Pappel- und Nadelholz, besonders Weymouthskiefer.

Die gleiche Herstellung haben Späne für Etuis, Degenscheiden, Schulisohlen, Spiegelbelege, sowie die für Bierbrauerei und Essigfabrikation wichtiggen Kilärspäne, aus Hasel- oder Buchenlolz, dic an manchen Orten einen beachtenswerten Verbrauch von Buchennutzholz hervorrufen.

In holzreichen Gegenden wird durch die Schind elf a brik ation eine beträchtliche Menge von Spaltholz verarbeitet. Die Schindeln dienen zur Dach- und Wandbeklcidung, inan läßt sic bein Auflegen derart übereinandergreifen, daß die Fugen stets gedeckt sind. Sie werden aus spaltigem, astreinem Fichten- und Tamen-, wohl auch Lärchen-, seltener Buchenholz radial ausgespalten und mit dem Schnitzmesser geglättet. Auch gibt man ilnen durch ein besonderes Schindelmesser auf der einen Seite eine Nut, auf der anderen Seite schneidet man eine scharfe Kante (Feder), so daß gegenseitiges Eingreifen stattfindet. Auf Sägewerken stellt man Schindeln durch Bearbeitung mit der Kreissäge oder besonderen Mlaschinen (Gangloffsche Schindelmaschine) her. Da dieselben jedoch nicht in der Richtung der Radien gearbeitet, sondern öfters schief über die Jahrringe geschnitten sind, so werfen sie sich und reißen leichter, liaben daher nicht den Wert und die Haltbarkeit der Handschindeln. Die Maschinenschindeln werden jedoch als Unterlage für Schieferbedachung begehrt.

Zur Instrumentenfabrikation bedarf man dés $\mathrm{R}$ e s o $\mathrm{n}$ a $\mathrm{n} \mathrm{zhol} \mathrm{z} \mathrm{es,} \mathrm{zu} \mathrm{dem}$ sich gleichmäßig langsam erwachsenes, mit nicht zu breiten Jahrringen versehenes astreines und spaltiges Holz von Fichten oder Tannen besonders eignet. Dasselbe wächst namentlich in höheren Gebirgslagen, so z. B. in Böhmen, ebenso im bayrischen (Vald ${ }^{1}$ ).

1) Im Z. f. d. ges. F. 1884, S. 155 wird auf die $\mathrm{H}$ a s e I f i c h t e, eine Spielart der gewöhnlichen Fichte, aufmerksam gemacht, welche zu Resonanzholz besonders geeignet sei, indem sie die Reinheit des Klanges befördere; dieselbe soll in Kärnten und Bosnien vorkommen und sich äuBerlich durch weißgelbe Früjahrssprossen, oft auch trauerweidenartige Beastung auszeichnen. 
II olz d I a h t nennt man die aus glattem Holz hergestellten feinen Stäbe, die zu Jalousien, Rouleaux, Tischdecken, in liurzem Zustand aber in großen Massen zu Streichhölzerı verwendet werden. Vielfach eignen sich hierzu noch die bei der Resonanzholzfabrikation vorkommenden Abfälle. An anderen Orten wird Aspenholz in großen Mengen benutzt. Die Herstellung erfolgt durch Hobel, die keine glatte Schneide, sondern statt derselben nebeneinander scharfe Rölirchen haben, deren jedes je einen runden Holzdraht von dem Rohholz abstößt. Für die schwedischen Streichhölzer werden auf Drehbänken bandartige Streifen von Rundholz (meist Aspe) dünn abgeschält und alsdann entsprechend zerleinert. Eine Zukunft in der Zündholzfabrikation (für Herstellung schwediseher Zündhölzer) spricht M a y $\mathrm{r}$ der Weymouthskiefer zu, die in Zündlolzfabriken als ,Korkkiefer" Eingang gefunden hat $\left.{ }^{1}\right)$.

Zu den Spaltwaren sind endlich noch die II o l z s t if te zu rechnen, die namentlich für Schuhmacher in großen Massen aus Birlien-, Ahorn- und Hainbuchenholz gewonnen werden.

S 7. Verwendung des Holzes zur schleinerei und den verwandten Betrieben, sowie zum Glaser- und Wagnerge werbe.

Der S c ls re in er liefert vornehmlich Arbeiten zum inneren Ausbau der Häuser, sowie den größten Teil der Hausgeräte und Möbel. Er verarbeitet sog. Schnittwaren, die auf den Sägewerken aus Stammlıolz liergestellt werden. Ueberwiegend ist hierbei der Verbrauch von Nadelholzschnittware, doch werden auch Eichen-, Buchen-, zur Möbelfabrikation außerdem noch Ahorn-, Ulmen-, Lärchen-, Nußbaum-, sowie wertvolle ausländische Hölzer (Mahagoni, Rosenholz etc.) in großer Mlenge verarbeitet.

Getrennt zu behandelı sind B a u- un d $\mathbf{l l o ̈ b e l s c h r e i n e r e i . ~}$

Der B a u s h re in er verwendet zu FuBböden vorwiegend Nadelholz, seltener Eiche und Buche. Fichte und Kiefer haben den Vorzug vor der mehr splitternden und weniger glatten Tanne. Statt der gewöhnlichen Dielen kommen mehr und mehr Parkett- und RiemenfuBböden in Aufnalıme, wozu die Hölzer (Eiche und Buche) in schmalen, kurzen Brettchen (Ricmen) geschnitten werden, die teilweise glatte Seitenwände, teils solche mit Nut und Feder haben.

Die Verwendung der Buche zu Dielungen wird im Gebiete ausgedehnter Buchenhochwaldungen mit Eifer zu fördern gesucht. Ueber die Erfolge wird die Zukunft entscheiden. Es wird gegen sie geltend gemacht, daß infolge der schwierigeren Bearbeitung der Buche, sowie der für wirklich gutes Buchenholz schon jetzt nicht gerade niedrigen Preise, Buchendiehng lieineswegs durch erhebliche Billigkeit sich auszeichnet. Zu Treppenstufen ist die Buche neben der Eiche ohne Zweifel sehr geeignet, nicht minder zu Treppenwangen. Ebenso bewährt sie sich vollkommen zu Parliettfußböden in imprägniertem Zustande. Nur muß die Eigentümlichlieit des Buchenholzes, daß es auch nach guter Austrocknung noch leicht sein Volumen durch Aufnahme von Wasserdampf vergrößert, beachtet werden, indeın längs der Wände ein kleiner Raum frei bleibt, den das sich ausdehuende (arbeitende) Buchenholz einnehmen kann ${ }^{2}$ ).

$\mathrm{Zu}$ Vertäfelungen in modernen vomehmen Häuseı findet Eichenholz, wohl auch Lärche, Arve Verwendung.

Zur II öbelschrein e re i verlangt man an meisten Nadelholz bester

1) Allg. F.- u. J.-Zlg. 1904, S. 351.

2) Ueber Erfahrungen bezüglich der Verwendung von Buchenholz für Dielungen s. v. A 1 t e $n$, Versuche und Erfahrungen mit Rotbuchen-Nutzholz 1895, S. $35 \mathrm{ff}$. 
Qualität, insbesondere zur Herstellung der die Hauntmasse des Verbrauchs bildenden geringeren Wöhel.

Auch die wertrolleren Iöbel werden selten massir aus tenerem Hariholz. (Eichen-, Nußbaum-), sondern aus Blindholz (Nadelhölzer, Pappel) hergestellt, auf welch letzteren die Foumiere wertvoller, zum Teil ausländischer Hölzer aufgeleint werden. Auch hier wie in so viclen Gegenständen der modemen Lebenscinrichtungen ist die Node tonangebend. Während früher Nahagoni, später NuBbaum (namentlich der schön gemusterte amerikanische Nußbaum) eine Hauptrolle spielte, wirl nenerdings Eichenholz zu den in besonderer Gunst stehenden Renaissançemöbeln verwendet.

Einer Erwähnung bedürfen noch die aus ge bogenem $\mathrm{B} u \mathrm{chenholz}$ zuerst durch die österreichische Firna Gebrüder T ho n e thergestellten sog. Wiener Möbel, deren Fabrikation auch in Deutschland (z. B. Sachsen) mit Erfolg versucht worden ist. Die zu diesen 1 löbeln verwendeten Buchenhölzer werden aus glattem, langschäftigen Buchenholz in Form von Latten ausgeschnitten, durch Dampf ausgetrocknet, mit Hilfe von Maschinen rund gehobelt und in erhitztem Zustande gebogen; die Verbindung der einzehen Teile untereinander erfolgt lediglich durch Verzapfung und Verschraubung.

Diese Industrie scheint nur da mit Erfolg einführbar zu sein, wo schönes Buchenholz stärkerer Dimensionen noch billig zu haben ist. Auch die Thonetschen Fabriken beziehen das Nlaterial meist aus dem holzreichen Osten der österreichischen Monarchie.

Bedeutende Vengen von Holz bedarf man zur Herstell $\mathrm{ung}$ von $\mathrm{K}$ i s t e $\mathrm{n}$ und Packfässern. Die Kistenbretter werden insbesondere in großen Jlengen durch die Sägewerke aus ihren Abfällen (Schwarten) hergestellt, doch werden auch ganze Stämme zu Kistenbrettern usw. verarbeitet. Wegen ihrer Leichtigkeit liaben Nadelhölzer, sowie Pappeln und Aspen den Vorzug. Mengen von schwachen Kästenbrettchen werden jedoch auch aus Buchenholz gewonnen, so z. B. für die in sïdlichen Ländern, insbesondere in den Hafenplätzen des mittelländischen Meeres zur Verpackung und zur Ausfuhr von Früchten dienenden Kistchen, die vielfach aus Oesterreich bezogen werden (sog. Tavoletti).

Kistchen von geringen Dimensionen zum Verpacken von Parfüms, Seifen etc. sowie Farbkasten, ferner Schatullen werden im großen in Fabriken verfertigt, und es kommen hierbei neben Nadelhölzern auch Erlen, Ahorn und sonstige bessere Laubholzarten zur V'erwendung. Zu Zigarrenkisten werden vielfach Erlen, für die besseren gewisse Sorten des sog. ..roten Zedernholzes", einer dem Mahagoni verwandteu Laublolzart, verwandt. Zu Jalousiebrettern nimmt man Nadelholz; besonders geeignet ist hier die Weymonthskiefer, denn sie ist leicht und wirft sich nicht.

Der Glaser braucht zu Fensterrahmen ein gleichmäßig emrachsenes, den Einflüssen der Witterung widerstelıeudes, dem Reißen und Werfen nicht ausgesetztes Holz; er bevorzugt Eiche und ganz besonders K̈iefer, auch Lärche ist brauchbar; den Hauptbedarf liefert das engringige, ausgewachsene, kernige Ir̈iefernholz, das auf ärmerem Boden langsam erwachsen ist. (Polnische Kiefer.)

Der II a $\mathrm{g}$ e r verwendet vorwiegend Laubhölzer, unter diesen besonders Esc he und $\mathrm{E}$ i c h e, aber auch Buche, Ulme. Hainbuche und Birke, sowie schwächeres Nadelholz; die Hölzer müssen gesund, fest und zähe sein, damit sie, ohne zu brechen, einer größeren Gewalt widerstehen können.

Von erheblichem L'mfang ist der Bedarf an Wagnerholz gerade nicht; dagegen ist dieses vorwiegend ländliche Gewerbe, das nicht allein Wagen, sondern auch ländliche Geräte aller Art fertigt. für die Forstwirtschaft ein sehr erwünschter, ja wertvoller Abnehmer für schwache Nutzhölzer aller Art: Eichen-, Eschen-, Birken- und 
Nadelholzstangen, schwache Eichenstämme (sog. „Wagnereichen“), Eschen- und Birkenstämme, starke kurze Abschnitte, Spalt- und Tirummhölzer usw. der verschiedensten Holzarten. Nlanches, was früher aus Holz verfertigt wurde, stellt man jetzt aus Eisen her; so z. B. die Aclssen, die gegen hölzerne nicht nur eine weit größere Dauer, sondern, da sie weniger Reibung verursachen, auch einen leichteren Gang gewähren.

Der g e w öh n l c he W a ge n besteht aus den Rädern, dem Gestell, der Langwiede und der Deichsel.

Die Räder haben in der Mitte die Nabe, die aus einem durchbohrten und metallgefütterten Eichen-, Ulmen- oder Eschen-Rundstück besteht; in dieselbe greifen die Speichen ein, die auf der äußeren Seite in dem aus einzelnen Teilen (Felgen) zusammengesetzten hranz befestigt sind.

Die Speichen fertigt man aus zähem ausgespaltenen Jungeichen- oder Eschenholz, bei Luxuswagen aus Hickory (Carya alba), das Leichtigkeit und Festigkeit in sich vereinigt.

Die Felgen werden aus gesunden spaltigen Buchenscheiten im Rohen abgespalten, so daß der Kemm abfällt; die Rindenseite bildet die äußere Krrümme der Felge. Zur Herstellung der nötigen Krümme wird beiderseits entsprechend abgespalten.

Die Herstellung der Felgen erfolgt in ausgedehnten Buchenwaldungen in großen Mengen zum Zwecke des Handels.

Neuerdings liommt es (insbesondere bein Luxuswagenbau) auch vor, daß der Radkranz nicht melır aus Felgen zusammengesetzt, sondern aus e in e m Stück gedämpften und durch starke mechanische Kraft gebogenen Holzes geformt wird ${ }^{\mathbf{1}}$ ).

Ueber den Achsen liegen nun die Vorder- und IIntergestelle der Wagen; dieselben werden durch die Langwiede verbunden. Die Zugvorrichtung besteht aus den Deichselarmen und der Deichsel. Zur Ausrüstung der Last-Wagen gehören endlich noch die Leitern. Zu den Bäumen der Leitem verwendet der Wagner Nadelholzstangen, zu den Langwieden Eichen- oder Eschenstangen, die Deichseln stellt er aus Eichen-, Birken- orler Eschenstangen her. Die sonstigen Erzeugnisse des Wagnerund Stellmachergewerbes, Pflüge, Schlitten, Eggen, Schiebekarren, Leitern, Futterbarren, Futtertröge usw, bedürfen keiner nähereı Beschreibung; Buchen- und Eichenlıölzer, sowie Nadelholzstangen werden auch hierzu besonders verwendet. Gelirümmte, wenn nur gesunde und astlose Stüclie verwendet der Wagner vielfach; ja sie sind sogar in vielen Fällen von besonderem Wert.

Der Bau der L ux u s w a g $n$ hat so viel Mannigfaltigkeiten, daß derselbe hier übergangen verden muß. Zum Oberbau derselben werden auch leichte Hölzer, Linde, Pappel etc. als Füllholz benutzt.

Zu L a f etten wurde früher in ausgedehntem IIaße Ulmenholz verwandt, da es bei besonders hoher Festigkeit und Härte wenig splittert; in neuerer Zeit hat es vollständig dem Eisen weichen müssen.

Zu dem Wagenbau gehört endlich noch die Herstellung der E is e n b a h nwa ge n, welche in ihrem Balkengerippe viel Eichen- und Eschenholz, in ihrer Füllung weiche Hölzer, besonders Kiefern, neuestens auch Fichten und Tannen in großem Umfange beanspruchen. Nach $\mathrm{G}$ a y e $\mathrm{r}$ bedarf man zu einem verschlossenen Eisenbahngüterwagen ca. I cbm Eichenholz; neuerdings wird ferner Kiefernlıolz und jetzt selbst Fichten- und Tannenholz verwendet.

1) Die Herstellung solcher Radkränze beschreibt Forstassessor $\mathrm{S} \mathrm{ch} \mathrm{mid} t$ in $Z$. f. F. u. J. 1886 , S. 194 . 
\$ S. Holzverbrauch in der Schnitzerei und Spielwarenf a bikation. Die eigentliche Kunstschnitzerei verbraucht Linden-, Aspen-, Ahom- und Nußbaumholz; in den Gebirgsiändem der Sehweiz und Tirols bildet auch die Zirbelliefer vielfach den Rohstoff zu den überaus mannigfachen Gegenständen, dic in alle Welt gehen (z. B. Tierfiguren, seschnitzte Rahnnen aller Art, Uhrgestelle, Schmuckbehälter).

Zu groben Schnitzwaren als Mulden, Schüsseln, Tellem, Wurfschaufeln, Kiochlöffeln, Stiefelhölzern, Kummethölzem werden Buchenhölzer verwandt, für feine Schulleisten Hainbuchen, für gewöhnliche Rotbuchen.

$\mathrm{H}$ ol z s c h u h e verfertigt man aus Buchen, Erlen, Birken, auch Pappeln und Weiden. Flintenschäfte werden aus Nußbaum, Ulme, geringere aus Buchenholz hergestellt.

Ki nd erspiel w a re n, z. B. Tiere, Kinderflinten, Holzmusikinstrumente (Flöten, Geigen) werden hauptsächlich aus $\mathrm{Fichtenholz}$ gemacht. Sie sind Gegenstand der Herstellung im Erzgebirge und Thüringerwald; ilıre Produktion verringert sich jedoch melı und mehr wegen des verfeinerten Geschmacks, der bessere Produkte verlangt.

\$9. Sonstiger Holzverbrauch in Gewerben und Fabrike n. Viele Gewerbe werden mit Wasserkraft betrieben und bedürfen der Räder und der dazu gehörigen Wellen; zu letzteren braucht man gerade, gesunde, starke Stämme von Eichen oder Tannen, auch Kiefern. Zu Wasserrädern nimmt man Buclien- und Eichen-, zu den Schaufeln auch Nadelholz, wofern nicht Konstruktionen aus Eisenblech gewählt werden.

$\mathrm{Zu}$ den Oel-, Walk-, Pochmühlen und Hammerwerken bedarf man starker Eichenstanmhölzer, weniger Nadelhölzer. Die Pochstempel sowohl, als auch die Stoßtröge werden nur vom zähesten harten Holz verfertigt. In Hammerwerken bestehen die Hammerwellen und die dazu gehörigen Gerüste aus Eichen, der den Hammer tragende Arm oder Helm aus Buchen, Birlien, Eschenstammenden; der Ambosstock, auf den der Ambos eingelassen ist, wird aus einem I m starken und $2 \mathrm{~m}$ langen Eiclienstock hergestellt, der in Eisen gebunden ist. Die innere Einrichtung der Gewerke, Ilühlen und Fabriken fällt hinsichtlich ihrer Verwendung in das Kapitel vou Hochbau.

\$10. Holzverbrauch zur Papierfabrikation ${ }^{1}$ ). Wenn auch der geringere Papierverbrauch früherer Zeiten durch das gewöhnliche, aus Hadern hergestellte Papier vollständig gedeckt worden ist, so wurde doch schon um die Mitte des vorigen Jahrhunderts versucht, den gesteigerten Verbrauch durch andere Pflanzenstoffe zu decken. Den Fortschritten der modernen Technik und den erweiterten chemischen Kenntnissen gelang es, aus Holz sehr brauchbare Produkte herzustellen, die zu Papier verarbeitet werden. Man unterscheidet zwischen dem lediglich durch $\mathrm{Z}$ ersclıle if e $\mathrm{n}$ auf mechanischem Wege hergestellten $\mathrm{Holz}$ s of $\mathrm{f}$ und dem auf chemischem Weg aus dem Holz gewommenen Zellstoff, der $\mathrm{H}$ o l z z e ll u los e, deren Gewinnung jedoch ebenfalls eine mechanische Zerkleinerung vorausgehen muß.

a) Bei den un e c lı a $\mathrm{n}$ is c he $n$ Z e r s e h le if en des Holzes, das in schwächeren Rundhölzern von $10-20 \mathrm{~cm}$ Durchmesser verwendet wird, findet zunächst Entrindung, Spalten der stärkeren Stücke, Entfernung der Aeste durch Aushauen oder Ausbohren statt; hierauf werden mittelst der Kreissäge Abschnitte von $25-50 \mathrm{~cm}$ hergestellt und diese an rotierende Steine gepreßt, wodurch Holzteilchen abgerissen

1) W e ber, Ueber die Bedeutung einiger Holz verarbeitender ludustriezweige. F. Z.-Bl. $188^{3}$, S. 73 u. 189. 
werden. Stetig zuströmendes Wasser vereinigt sie zu einem dünnen Brei, aus dem die Fasern nach Länge und Dicke sortiert, dann gebleicht, entwässert, und in Formen gepreßt werden.

Derartige Fabriken, meist mit Wasserkraft betrieben und in waldreichen Gebirgsgebieten belegen, waren nach Günther-Staibs Adreßbuch für die PapierIndustrie in Deutschland in Jahr 1899/1900 601 (in Sachsen allein etwa 300) vorhanden und es wird der Jahresbedarf derselben an Schleifholz auf nahe an 1 Mitlion $\mathrm{fm}$ angegeben.

b) Bei der Z e llu J o se f a britia tio n werden die Hölzer durch eine mechanische Hackvorrichtung in flache Späne zerlegt, diese Späne zwischen geriffelten Quetschwalzen weiter zermahlen und demnächst hurch Kochen unter hohem Druck entweder in kaustischer Natronlauge (sog. Natronverfalıren) oder unter Einwirkung von doppeltschwefligsaurem Kalk (Mitscherlichs Sulphit-Verfahren) in ihre einzelnen Zellen aufgelöst.

Die auf diese Weise hergestellte rohe Zelhlose wird gewaschen, mit Chlorkalk gebleicht und schließlich durch Walzen gepreßt und getrocknet.

Nach dem Adreßbuch von Günther-Staib kann man für die in Deutschland zur Zeit bestehenden großkapitalistisch betriebenen 7 I Zellulosefabriken einen Jahres-Holzkonsum von $850000 \mathrm{fm}$ annehmen.

Zur Verwendung in der Papierfabrikation gelangen in erster Linie $\mathrm{F}$ i c h $\mathrm{t}$ e n-, dann auch Tannen- und Küiefernhölzer; Aspen, Pappeln und Linden geben einen ganz besonders weißen, sehr gesuchten Stoff und ihre ausgedehnteste Verwendung wird nur durch ihre Seltenheit und verhältnismäßig hohen Preise verhindert. Große Schwieriglieiten bereitet dagegen das Buchenholz. Für das mechanische Verfahren ist es ganz unbrauchbar, weil es sich vermöge seiner großen Abscherfestigkeit nicht zerfasern läßt; die Fasern zerreiben sich vollständig. Hinderlich ist auch seine Farbe. Da schon ziemlich schwache Prügel und Stangen verwendet werden können, so ergibt sich durch diese Fabrikation ein ausgedehntes Feld für die Zugutemachung von Durchforstungshölzern; freilich spielt die Frage der Transportkosten hierbei eine große Rolle, um so mehr, als durch den hedeutenden Wettbewerb, namentlich auch des Auslandes (Norwegen, Schweden, Oesterreich-Ungarn, Finnland, Kanada, Vereinigte Staaten von Nordamerika) die Preise des Erzengnisses gedrückt sind und den Fabriken hinsichtlich der beim Einkaufe des Holzes anzulegenden Preise gewisse Beschränkungen auferlegen. Die großen Zellulosefabriken beziehen deshalb emen beträchtlichen Teil ihres Holzbedarfs aus dem Ausland (Oesterreich-Ungarn). In Indien wird eine Zellılose aus Bambus hergestellt, die sich durch beträchtliche Zähigkeit, sowie billigen Preis vor der europäischen Holz-Zellulose auszeichnen soll.

Außer zur Papierfabrikation wird die Zellulose roh zur Herstellung von Pappe, sowie von gepreßten Ornamenten für Möbel, zur Imitation von Leder verwendet ${ }^{1}$ ).

$\$ 11$. Darstell ung von $\mathrm{Hol}$ zwo $\mathrm{ll}$ e. Unter Holzwolle versteht man einen Stoff, der durch grobe mechanische Zerfaserung von Hölzern, namentlich Nadelhölzem gewomnen und in großem Maßstab zur Terpackung, sowie als Polstermaterial, ferner als Stren für das Vieh, endlich auch zum Filtrieren von Flüssiglieiten benutzt wird. Die Holzwolle, zuerst in Amerika dargestellt, wird als ein Nebenerzeugnis in größeren Holzwarenfabriken, aber auch in eigenen Werken vorwiegend

1) Zu solchen Ornamenten verwendet eine Thüringer Firma (B. Harras in Böhlen) gemalılene Sāgespāne, die mit einem Ǩlebstoff durehtrânkt sind und auf die eine ganz feine, äußerst biegsam gemachte Holzfournierplatte aufgepreßt wird. Diese verbindet siel dann untrennbar mit der Unterlage und ergibt so ein ganz seliari gepreßtes Holzornament, das mit den Produlten der Holzbildhauerei netteifert. Die Firna nennt ihr Produkt, ,I Lustholz". 
aus Nadelhölzern (jedoch auch Aspen, zu Polsterzwecken auch aus spranischem Rohr) gewonnen. Die Hölzer werden in Stücken von $50 \mathrm{~cm}$ Länge und $15 \mathrm{~cm}$ Breite vorgearbeitet, zwisehen zwei Walzen gespannt und mittelst eines Apparates, der eine Anzahl nebeneinander stehender Messer enthält und durch eine Kurbelstange hin und her bewegt wird, geritzt. Seitwärts von diesem Apparat steht je ein glattes Hobelmesser, das die geritzten Fasern abschneidet, die nun als Holzwolle unter die Masehine fallen. Je nachdem die Ritzmesser enger oder weiter gestellt sind, wird die Holzwolle feiner oder gröber ausfallen.

Auch diese Fabrikation verwendet vorwiegend schwache Hölzer, die in ITege der Durchforstungen zu gewinnen sind, so daß ihre Einbürgerung örtlich eine nicht zu verachtende Hebung des Holzabsatzes bewirkt.

\$12. Holzverbrauch im J a n d w i ts chaftlichen Gewerbe. Der Hauptverbrauch der Landwirtschaft an Nutzhölzern erstreckt sich auf schwächere Stangenholzsortimente, Bohnenstangen, Hopfenstangen, Baumpfähle, Baunstützen, Weinpfähle, sowie Zaunpfähle und Zaungerten, Stangen und Pfähle zu Notschuppen, Feimen ${ }^{1}$ ); außerden kommt mancherlei Reisig zu Erbsenreis, Zäunen, Bindweiden, Besenreisig in Betracht, ferner Geschirrholz zu Deichseh, Leiterbäumen, Heubäumen und sonstiges Material zur Instandhaltung der ländlichen Fulıwerke.

$\mathrm{DaB}$ auch geringeres Reisholz in zerkleinertem (gequetschten) Zustand und mit eineın Gärungsstoff (Sauerteig) versetzt, vorteilhaft zur F ü t t e r u n g von Rindvieh und Pferden verwendet werden kann, wurde durch Versuche festgestellt, welche Gutsbesitzer von J e n a - Cöthen und Prof. Dr. R a m a $n$ n angestellt haben. (Vergl. Dr. R a m a n n und von J e $\mathrm{n}$ a - Göt he $\mathrm{n}$ : Holzfütterung und Reisigfütterung, Berlin 1S94.) Auch hat man aus Sägemehl, Kleie und Roggenmehl Brote liergestellt, die ein brauehbares Pferdefutter darstellen.

Die meiste Beachtung des Forstmannes verdient der Bedarf an $\mathrm{H}$ o p f e lsta $\mathrm{ng}$ en und We in p fähle $\mathrm{n}$, die in großen Nengen begehrt werden und zu Zeiten einen sehr guten Absatz für Durchforstungsergebnisse selbst entlegener Waldungen darbieten.

Die $\mathrm{H}$ op $\mathrm{f}$ e $\mathrm{n} \mathrm{s}$ t a $\mathrm{ng}$ e $\mathbf{n}$, deren Absatz allemal dann besonders ausgedehnt zu sein pflegt, wenn einige gute Hopfenjahre vorausgegangen sind, durch welche der Antrieb zur weiteren Ausdehnung der Hopfenanlagen gegeben wird, sind Gegenstand des Großhandels. Man unterscheidet im Handel verschiedene Preisklassen von Hopfenstangen je nach Stärke und Länge der Stangen, die örtlich verwendeten Längen richten sich nach dem Längenwuchs des Hopfens auf den einzelnen Standorten. Verwendung finden mit Vorliebe Fichtenstangen, seltener Tannen und lïiefern. Zur Förderung des Austrochnens, behufs Ersparnis an Fracht, werden die Stangen entrindet, jedoch nur streifenweise, so daß die Hopfenranken noch Halt finden. Neuerdings werden vielfach Drahtanlagen hergestellt, wohei nicht mehr die schwachen Hopfenstangen, sondern stärliere Stangen, ja selbst schwache Stämme der Nadelhölzer zur Herstellung der Gerüste Verwendung finden.

$W^{\top}$ e in $\mathrm{f}$ äh le gewinnt man aus Eichen, Fichten, Tannen, lijefern, sowie auch Kastanien und Akazien. Man unterscheidet die wertrolleren gespaltenen und die weniger dauerhaften gesägten und runden Weinbergpfähle. Die Kastanienpfähle, die im Elsaß in Vemendung stehen, stellt man durch gespaltene Stockaussehläge der Edelkastanie her, die im Niederwaldbetrieb gewonnen werden.

1) Ein beachtenswerter Absatz von Eichenpfahlhölzem stärkerer Dimensionen findel aus Mittel- und Süddeutsehland auf dem Rhein nach Holtand statt, woselbst zu den Gerüsten der Feimen in Sechsecksform diese Eichenpfähle (Bergruten genannt) tief in die Eıde gerammt werden. Auch Weißtannenhölzer werden zu diesen Zweeken verwendet. 
Ueber die senkrecht eingeschlagenen Weinpfähle werden da, wo man den IVein in die Länge zicht, auch noch Querlatten gespannt.

Die Verwendung der Fichten-, Tannen- und Kiefernweinpfähle bildet in manchen Gegenden einen beachtenswerten Beitrag zur Erhöhung der Nutzholzausbeute $\left.{ }^{1}\right)$.

$\$$ 13. Brennlolz. Je mehr durch Ausdehnung des Eisenbahnnetzes die fossile Iiohle als Feuerungsmaterial für Wohnungen und Fabrikanlagen an Boden gewonnen hat, un so mehr ist der Bedarf an Brennholz zurückgegangen, und es ist in dieser Beziehung in vielen Forsthaushalten ein völliger Umschwung in den Absatzund Verwertungsverhältnissen eingetreten. Dank der ausgedehnten Verwendungsfähigkeit des Holzes als Nutzholz zu den vielen Zweeken, deren hervorragendste wir bereits betrachtet haben, hat sich dieser Unschwung in den meisten Gegenden mit nur vorübergehenden Störmgen vollzogen; dieselbe Eisenbahn, welche die Kohlen ins Land bringt, ermöglicht auch öfters die Ausfuhr von Nutzhölzern in früher nicht gekanntem Umfange und begünstigt die Anlage nutzholzverbrauchender Fabriken. - Immerhin ist die Verwendung des Holzes als Brennholz, wenn man die Masse desselben im prozentischen Verhältnis zum Gesamtholzeinschlage ausdrückt, gegenüber der des Nutzholzes in Deutschland immer noeh überviegend, hauptsächlich im Gebiet der ausgedehnten Laubholz-, namentlich Buchenforste, da sich der Uebergang zur grundsätzlichen Nutzholzwirtschaft nur allmählich vollzieht und noch viel langsamer wirksam werden kann.

Die Verwendung des Holzes zu Feuerungszwecken ist eine verschiedene. Dasselbe dient rorwiegend zur $\mathrm{Hejzung}$ d e r W o h n $\mathrm{r}$ ä u m e, also zur Erzeugung stetiger Wärne, wozu sich die Laubhölzer, insbesondere das Buchenholz, eignen; dann aber als $\mathrm{Anz}$ ünd holz f ür di e Steinkohlenfeuerung, hier ist das Nadelholz vermöge seiner raschen Entzündbarkeit vorzuziehen; und endlich zum Betriel) gewerblieher und industrieller Anlagen.

In geringerem Umfange dient das Brennholz auch der Gewinnung von Holzkohle im Wege unvollkommener Verbrennung, worauf diese dann ihrerseits wieder in mannigfaltiger Weise seitens der Gewerbe Verwendung findet.

Zur Heizung der Wohnräume sowie zum Verbrauch in der Küche sind die liarten Holzarten, und unter diesen die Potbuche, besonders begehrt. Ihr nahestehend ist die Birke sowie das geschälte Jungeichenholz, während Alteiche im Wert bedeutend zurücktritt; altes Eichenholz wird besonders zum Räuchern von Fleiseh- und Wurstwaren geschätzt.

Zur Bäckerei, zum Betrieb maneher gewerblichen Anlagen und Fabriken, z. B. Ziegelbrennereien, Kalköfen, Porzellanfabriken, Glashütten, kurz zu allen Zwecken, bei denen es auf intensive flammende Hitze ankommt, wird dem Nadelholz der Vorzug gegeben.

Die Kohle endlich verwenden zahlreiche Gewerbe, die Metalle verarbeiten, z. B. Schlosser, Schmiede, Goldschniede, sowie, wenn auch nicht mehr im früheren Umfange, clie gesamte Metallindustrie.

Auch gebraucht man Kohle zur P u lverfa brik a t i n, wobei für feineres Pulver die sehwaehen, I $1 / 2-3 \mathrm{~cm}$ starken Ruten des Faulbaumholzes (Rhamnus frangula), für geringere Sorten die Prügelhölzer der Weißerle in großen Mengen Verwendung finden.

In G l a s I ü t $t$ e $n$, in denen eine anhaltende, stark brennende Flamme notwendig ist, findet eine Verbrennung resp. Verkohlung des Holzes statt, vermittelst

1) Sehnittspahn, Anfertigung der Wingertspfähle. F. Z.-Bl. 1883, S. 22. 
deren ein Holzgas gewomnen wird, dessen Flamme die Glasnasse in geschmolzenen, glühendflüssigen Zustand bringt und leichter darin erhält als bei unmittelbarer Anweudung von Holz. Zur Herstellung lilarer Gläser ist B r e n $\mathrm{n}$ h o l z ganz unentbehrlich, da das Glas durch Verwendung von Steinkohlen getrübt wird.

Auch in der P o r z e l l a n $\mathrm{f}$ a li $\mathrm{i} k$ a t i o n liann Holz für Herstellung von Gegenständen, die eine gewisse empfindliche blaue Farbe erhalten, nicht entbelırt werden, da bei Anwendung der Fiohle die sich bildenden Gase dureh ihren Gehalt an schwefliger Säure auf diese Farbe zerstörend einwirken.

Durch $\mathrm{V}^{\top}$ erko h lu g g des Holzes in Retorten werden neben der Kolıle noch gêwisse Nebenprodukte, z. B. Holzessig und $\mathrm{Holzt}$ o er, gewonnen. Diese Stoffe haben durch die Entwickelung der cliemischen Industrie große Bedeutung erlangt, der Holzteer wird überdies in beträchtlichen Mengen zum Anstrich von Schiffen verwendet. Die gewinnbringende Erzeugung clieser Stoffe in Deutschland ist jedoch durch den lebhaften Wettbewerb des billiger elzeugenden Auslands heute noch sehr erschwert. Die Verkohlungsindustrie kann mangels eines wirksamen Zollschutzes nicht in Blüte liommen; ein solcher ist aber wohl, da es sich um die Rohstoffe für blühende Industrien handelt, auch in Zulunft nicht zu erwarten. Holzteer wird in IIassen aus Schweden, Finnland und Rußland eingeführt.

S I4. Holzverwendung nach den verschiedenen Holza reu und Sortimenten. Wir fassen hier das über die Verwendung des Holzes, insbesondere des Nutzholzes, bisher Mitgeteilte zusanmen, und zwar getrennt nach den gebräuchlichsten Holzarten und deren einzelnen Sortimenten:

1. L a $u$ b hölz e r.

Der Eic he n wa ld liefert in sta rke n Stämmen das Material zu Mühlwellen, zu den stärksten Teilen der Poch- und Hammerwerke, zu Schiffsbauholz (Holländer), zu Brücken- und Schleusenbauten, außerdem Schneidehölzer für das Tischler- und Glasergewerbe, zu Bohlen für Brïcken, sowie in den untersten Stammteilen Ambosklötze ${ }^{1}$ ). In großen .lengen werden ferner die wertvollsten Eichenspalthölzer zu Fässern verarbeitet. Das mittelstarke Eichenholz wird ausgenutzt zu gewöhnlichem Bauholz, zu geschnittenen Hölzern für den Grubenbetrieb, in der Hauptsache aber, besonders bei mangelnder Astreinheit, zu Bahnschwellenholz. Auch fallen hier wiederum, sowie in den anbrüchigen Abschnitten der stärksten Klasse zah]reiche Spalthölzer für Böttcher an.

Die geringeren Stämme verwendet man vorzüglich zu Wagnerholz, zu Pfählen für Erd- und Wasserbau, zu Pfosten für Zäune und Unfriedigungen aller Art, ferner zu Grubenholz.

Die Stangenhölzer von $14 \mathrm{~cm}$ abwärts gewähren die Hauptmasse des Grubenholzes, sowie viel Material für Wagner, für Umzäunungen, ebenso Weinbergpfähle. Die Finde jüngerer Hölzer (Stockausschläge) wird als Gerbrinde benützt.

Der $\mathrm{B} u \mathrm{c}$ h e $\mathrm{n}$ a $\mathrm{l} d$, dessen geringe Rentabilität an vielen Orten noch der

1) Ein bedeutendes Absatzgebiet für sũd-und westdeutsches Eichenholz bildet II o 11 a n d: starke Stammenden von 60-100 em Durchmesser, in der Iitte durchschnitten oder durchspalten, um die Güte und Spaltbarkeit beurteilen zu können, nennt man W a g e $\mathrm{n}$ s c h u $B$ (von Wainscot, Wandgetāfel, abgeleitet). Man verlangt zartes, astreines, geradrissiges, feinfaseriges Holz. Dasselbe wird zu feinen Tischlerarbeiten, Vertäfelungen, Fournieren etc. verwandt. Rundkiütze und beschlagene Eichen von stärkeren Dimensionen gehen als sog. Hollă $n \mathrm{~d}$ e $\mathrm{r}$, dipselben können ästig sein, auch schadet eine geeignete lírümmung nichts. Sie finden Verwendung als Kanthölzer und beim Sehiffsbau. B e r g r u ten und $\mathrm{P} f$ a $\mathrm{h} l \mathrm{e}$ sind eine geringere Art der leschlagenen Eichen; erstere werden zu Pfälen fur Frucht- und Heuschober, lelztere zu liammpfăhlen und Bauholz gebraucht. In Betreff der Sortimente des überseeischen Handels aus den Ostseehäfen vergl. G u s e in Z. f. F. U. J. 1887, S. 175. 
Gegenstand steheraler IKlagen ist, bietet nur in beschränktem Maße Material zur Verwendung als Nutzholz. Im Hochbau sind bei genügender Stärke Buchenschnitthölzer zu verwenten zu Treppen, Fußböden, Parketts.

Im Eisenbahnbau wird Buchenholz imprägniert zu Schwellen, für Brücken zu Belagbohlen verwandt; für Straßenpflaster, sowie zur Pflasterung von Pferdeställen wird es ebenfalls imprägniert gebraucht. Für Schiffskiele, sowie zu Wasserbauten, sofern das Holz ganz unter Wasser kommt, ist Buche stets sehr vorteilhaft zu verwenden. Buchenklötze sind zweckmäßige Unterlagen für Maschinenbestandteile, anch liefern sie sog. Werkholz für Maschinen, Handgriffe, Werkzeugstiele usw., und ebenso das Material für Spaltwaren von mancherlei Art (Siebläufe, Faßdauben für Butter- und andere zur Aufbewahrung trockener oder doch nur allenfalls feuchter oder fettiger Gegenstände bestimmte Fässer). Der Wagner gebraucht Buchen in Massen zu Felgen und sonstigen Bestandteilen der Oekonomiewagen, als Schlittenkufen usw,; im Luxuswagenbau wird Buchenschnittware verwandt, ebenso im Pianofortebau; ausgedehnt ist die Verwendung zu Buchenmöbeln. Kisten geringerer Dimensionen, sowie Schatullen, eine Nlenge landwirtschaftlicher Geräte, Bürstenlı̈lzer, Zigarrenwiclielformen. Schuhabsätze, Schuhleisten, Kklärspäne, sowie Haushaltungshölzer der verschiedensten Art verfertigt man ebenfalls aus Buchenholz, geringere Rundhölzer geben Grubenholz. Die unbestreitbar erste Stelle nimmt endlich das Buchenholz als Brennholz und Kohlholz ein. sowohl was die Eignung, als was die tatsächlich verbrauchten Massen betrifft.

H a in b u c h en gebraucht man zu Kämmen für Mühlwerke, zu Maschinenholz (Werkholz), zur Zusammensetzung von Fleischwiegeklötzen, zur Herstellung von Hammerstielen, Dreschflegeln, von besseren Schuhleisten, zu Schuhmacherstiften.

A h o r n verwendet der Tischler zu Möbehn und Fournieren, man fertigt daraus Parketts; in Holzwarenfabriken wird er in ausgedehntem Maße zur Herstellung feiner Kästchen, zu Thernometer- und Barometerbrettchen u. dergl. gesucht; auch der Holzschnitzer und Drechsler verarbeitet dieses Holz.

Eschenholz ist als Wagner- und Schreinerholz (in starken Stücken zur Herstellung von \löbeln), sowie beim Bau von Eisenhahnwagen, ferner zu Werkzeugen, Turngeräten, Lanzenschäften, s̀chneeschuhen überall gut absetzbar.

U l m e n geben Wagnerholz sowie gesuchtes Tischlerholz; zu Hackklötzen verwendet man die Stammenden.

Lindenlolz wird zu feinen Schnitzarbeiten, als Blindloolz zu Fourniermöbeln, außerdem nit Vorliebe in der Etuisfabrikation verwandt.

B i r k e h o l z gibt in genügender Stäke gutes Schnittmaterial für Tischler, außerlem findet es vielfachen Absatz an Wagner; die geringen Stangen geben Reifholz für Böttcher.

R o t-Erlen werden beim Wasserbau gebraucht, vom Schreiner zu Wöbehn, insbesundere Kileinmöbeh verarbeitet, außerdem liefern sie Schnittmaterial zu Zigarrenkisten; schwaches $W^{T}$ e i $B$ - E r l e n h o I z giht Kohle zur Pulverfabrikation.

Pappel- und Aspen h o l z findet Verwendung in der Kistenfabrikation, zu Etuis, zu Blindholz für Möbel. Aspen werden ferner mit Torliebe zur Papierfabrikation, zu Zünthölzern und Zündholzschachteln benutzt. Auch Mulden und viele andere Schnitzlabrikate stellt man aus ihnen her.

E Is b e e re ist eines unserer wertvollsten Nutzhölzer; Drechsler und Tischler benützen dasselbe; besonders gesucht und sehr gut hezahlt wird es zur Verwendung für Thermometer- und Barometerbrettchen. 


\section{Nadelhölzer.}

Die größte Ausbeute an Nutzholz gewähren F i c h $t$ e n und T a n n e n. Sie liefern die große Masse der Hoch-, Wasser- und Brückenbauhölzer, Mastholz beim Schiffsban sowie das Material zu Schnittwaren der verschiedensten Art (Bohlen, Bretter, Latten) zu Bauzwecken und zur Verwendung von Tischlern und Kistemuachern. Spalthölzer gebraucht man zur Schindel- und Schachtelfabrikation und zu Packfässern.

Geringere Stärken verwendet man zu Gerüststangen, Telegraphen- und anderen Leitungsstangen, zu Grubenliolz, zur Herstellung von Holzwolle, und große Massen von schwächerem Rundholz zur Papicrfabrikation.

Schlanke Stangenhölzer liefern Bau-, Hag-, Hopfen- und Bohnenstangen, Baum- und Weinpfähle usw.

Tannenholz ist manchen Ortes weniger gesucht als Fichte, insbesondere weil vielfach alte Tannen des früheren Blenderwalds zur Abnutzung gelangen, die astig und kernschälig sind und deshalb versteckte Fehler haben; auch ist Tannenholz schwerer als Fichtenholz, was höhere Transportiosten nit sich bringt. Zu Fußböden verwirt man Tanne wegen des Splitterns. Der Zimnermann nimmt Tannenholz weniger gem zu Balken, weil seine Tragkraft derjenigen der Fichte nachstehen soll, er verwendet es aber mit Vorliebe zu Schwellen.

Beim Wasserbau hat es den Vorzug vor der Fichte.

I i e f e r n geben in stärkeren Dimensionen und bei genügender Feinjährigkeit ein gesuchtes Qualitätsholz für Glaser, Tischler, sowie Mastholz. Auch findet Kicfernholz viel Verwendung zu Bahnschwellen. Als Bauholz wird es in den eigentlichen Kieferngegenden dem Fichtenholz vorgezogen, findet auch vielfach Verwendung zu Treppen, Zimmerböden, Täfelungen usf. Sehr gesucht ist es zu Grubenholz und wird als solches in ungeheuren Mlassen verbraucht. Ebenso wird es geschätzt zu andern Verwendungsarten unter der Erde (Pfähle zu Rostwerken); auch zu Eisenbahnwagen, Geschützbettungen usw. und hier der Fichte und Tanne vorgezogen.

L är c h e steht zu Bauholz sowie Schreinerholz, ebenso zu Grubenholz im besten Ansehen. Oertlich wird sic gesucht zur Auskleidung der Lohgruben in den Gerbereien, zu Stallböden, Düngerfässcrn usw.

W e ym o u th s k e f er gilt wegen ibrer Stetigkeit (geringen Neigung zum Werfen) als ein gutes Holz für Tischlerzweelie (Blindholz) sowie als llodellholz; als Bauholz ist sie wegen mangelnder Tragfähigkeit für manche Zwecke etwas nit Mißtrauen angesehen; gegen Fäuhnis ist sie entschieden sehr widerstandsfähig; Stangenhölzer sind außerordentlich zähe und haltbar. Das Holz hat eine gute Zukunft in bezug auf Verwendung in der Zündholzfabrikation, zu Kisten, Jalousien, Särgen usw.

$\mathrm{Z}$ ü r b e lk i e f e (Arve) ist cin wertvolles Tischlerholz, das infolge seiner schönen gelbbraunen Farbe namentlich zu Täfelungen gesucht wird. Auch findet es Verwendung zu Schnitzarbeiten.

$\S 15$. Verwe nd ung der Rinden. Die Rinden verschiedener unserer Holzarten, insbesondere der Eiche sowic der Fichte, untergeordnet der Erle und Birkc, finden vermöge ihres Reichtums an Gerbsäure Verwendung beim Gerben des Leders aus tierischen Häuten. Als bestes gerbstofflieferndes Material wird zweifellos die Eichenrinde anerkannt; ihr gegenüber erscheinen die Rinden anderer Hölzer teils als Ergänzungs-, teils als Ersatzmittel ${ }^{1}$ ).

1) Z. P. F. U. J. 1879, S. 1. S $\mathrm{ch}$ ū $\mathrm{tz}$ e, Untersuchungen über den Gerbstoffgeliait der Eichenrinde; das. 1882, S. 103. C o u n e I e r, Untersuchungen über den Gerbstoffgehall der Eichenrinde; das. 1884 , S. 1. D e r s., Gerb-toffgehalt einiger inlāndischer Rinden; das. S. 543. D e rs., Ueber einige inlāndische Gerbmaterialien und deren Gerbstoffgehalt. 
Eine Zeitlang hatte in den I8s0er Jahren eine Bestrebung Platz gegriffen, um die immerhin langwierige, große Kapitalien beanspruchende $\mathrm{L}$ o h gerberei durch das Verfahren der Mletallgerbung mit Eisen (nach $\mathrm{K}$ n a p p) oder Chrom (nach $\mathrm{H}$ e inz e r l i n g) zu ersetzen. - Durchschlagende Erfolge im großen sind damit nicht erzielt worden; die Haltbarkeit und Güte lohgaren Leders, insbesondere des Solnlenleders, scheint eine längere Einwirkung des Gerbstoffes auf die rohen Häute zu bedingen, als dies bei der Metallgerbung vorausgesetzt wird ${ }^{\mathrm{l}}$ ).

Hingegen ist der inländischen Lohrinde ein beträchtliche1. Wettbewerb durch auswärtige Rinden (aus Ungarn, Frankreich), ferner durch die im Verhältnis zum Wert billig zu verfrachtenden Gerbsäureextralite, endlich durch gewisse Ersatzstoffe emwachsen, z. B. die $\mathrm{V}$ a $\mathrm{l}$ o n e a, d. h. den Fruchtbecher der Quereus aegilops und Q. graeca, die K n o p p e r n, d. h. Gallen der Gynips calycis auf den Fruehtbechern der Eichen, bes. in Ungarn, 30-45\% Gerbsäure entlualtend; lazu sind noch in neuerer Zeit gekommen: Dividivi, die Schoten eines Strauches Caesalpina coriaria, M y r o b a I a n en, Früchte von Terminalia Chebula in Ostindien, ferner die Rinde der $\mathrm{M}$ i mos e n u. a. Der bedeutendste Wettbewerb erwächst jedoch der deutschen Eichenrinde in neuerer Zeit durch das Quebrachololz (Schinopsis balance), das aus Argentinien bezogen wird und in geraspeltem Zustand oder auch als Extrakt zur Anwendung gelangt, wodurch - gegenüber dem älteren Verfahren der Gerberei in Lohgruben - eine wesentliche Abkürzung des Gerbungsprozesses herbeigeführt und somit die Lederfabriliation verbilligt wird. Während verschiedene Ersatzstoffe nur zur Ilerstellung leichter Luxusledersorten gebraucht werden. wird mit Hilfe des Quebracho auch Solylenteder gegerbt. Es ist eine Erzeugung minderwertigen Leders mit Anvendung dieses Stoffes an sich nicht verbunden; um insofern soll dessen Güte beeinträchtigt werden, als eine Behandlung der Häute mit angreifenden Säuren behufs leichter Schwellung derselben mit der Terwendung des Quebrachoholzes Hand in Iland zu gehen pflegt.

Bei der großen Entwickelung der deutschen Gerbereibetriebe steht es fest, daß der Bedarf der deutschen Lederfabrikation an Gerbmaterial durch dic inländische Pindenerzeugung bei weitem nicht gedeckt wird, daß also ein Ersatz des Mlangels durch Einfuhr und durch Ersatzstoffe unentbelırheh ist $\left.{ }^{2}\right)$.

Der Gerbstoff findet sich in der Bastschicht der Stämme; die Rinde von üppig erwachsenen jüngeren Eichenstämmen und Stockausschlägen aus den Eichenniederwaldungen (Lohschlägen), die noch eine glatte Borlie hat und deshalb S p i e ge loder G l a n z rin d e genannt wird, ist besonders reich an Gerbsäure und laher am wertvollsten. Die von älteren Eichenstämmen gewonnene Rinde hat einen lıöhereı Prozentsatz von abgestorbener, liarter Borke, die einen für die Gerberei weniger geeigneten Zusatz zu der eigentlichen Lohe darstellt. Daß die jungen Zweige der Eiche, insbesondere der unverholzten Spitzen, einen bedeutenden Gehalt an Gerbstoff besitzen, darauf hat schon Th. H a r t ig in seiner Schrift (Ueber den Gerbstoff der Eiche, 1869) aufmerksam gemacht, neuerdings wird diese Erfahrung praktisch zur Gewinnung von Eichenlohextralit verwertet. Auch aus Eichenastlinüppeln gewinnt man Tannin; diese Fabrikation findet sich u. a. in Slavonien; 1885 wurde berichtet, daß eine einzige dortige Eichenlıolzextralitfabrili jährlich 80000 m Abfallholz verarbeite ${ }^{3}$ ).

1) Z. f. F. u. J. 1883, S. 306. v. A l t e n, Die Mineralgerbung, ferner uber denselben Gegenstand A. F.- u. J.-Z. 1881, S. 213.

2) Mit diesen Fragen, sowie mil der ökonomischen Seite des Eichenschälwaldes beschäftigen sieh: $\mathrm{S}$ c h e $\mathrm{n} k$, Die Rentabilität des deutschen Eichenschähwaldes, Darmstadt 1899 . J e $\mathrm{n} \mathrm{s} \mathrm{c} \mathrm{h}$, Der deutsche Eichenschälwald und seine Zukunft, Berlin 1899.

3) Oe. F. 1885. Nr. 44. Ueber die neuere Tanninfabrikation in Slaronien berichtet Forstass. W e r te n in Ztschr. für F. u. J.-Wesen 1900 , Heft 5. 
Von den in Deutsehland heimischen Eichenarten, der Stiel- und der Traubeneiche, gilt die letztere als diejenige, welche eine fleischigere, gerbstoffreichere Rinde gewährt. In Süd- und Westcleutschland überwiegt sie, im Norden und Osten ist die Stieleiche vorherrsehend.

Wichtiger als die Gattung der Eiche ist für die Güte der Rinde der Standort, auf dem das Holz erwïchst, das Zusammenwirken von Boden, Lage und Kilima.

Warmes Klima in Verbindung mit sonniger Lage und einem mineralisch nicht unkräftigen Boden sind die wesentlichsten Faktoren für Erzeugung guter Eichenlohe. $\mathrm{Zu}$ den bekanntesten Eichenschälwaldgebieten Deutschlands gehören die Rhein-, Mosel- und Nahelandsehaften, sowie die Saargegend und der Odenwald, vielfach mit einem Untergrund rou sich stark erwärmendem lockeren Schieferboden, in Odenwald jedoch von buntem Sandstein. Die rheinisehen Rinden sind weltbekanut; nit ilınen treten französische und ungarische Rinden in Wettbewerb.

Die Betriebsform des Eielenniederwaldes liefert insofern die besten Rinden, als mit zunehmendem Alter der Bestände die Güte der Rinde entsehieden abnimnt. Man bezeichnet deshalb auch die niedrigen Umtriebe von 12-16. Jahren als die zweckmäßigsten für den Eichenschälwald.

Infolge des Umstandes, daß für die gute Fintwickelung der Lohrinde starke Einwirkung des Lichtes von besonderem Wert ist, wird das Belassen von Oberholz im Eichensehälwald durehgehends verworfm, ja es werden angemessene Durchforstungen, sowie insbesondere der Aushieb der Weichhölzer (des sog. Raumholzes) einige Jahre vor dem beabsichtigten Abtrieb sehr empfohlen; überhaupt erscheint es geraten, Lohsehläge womöglich in ganz reiner Eichenbestockung zu haben. Was den Einfluß der Durchforstungen anlangt, so gibt Gayer deuselben dahin an, daß die Menge an Holz um 27\%, an Rinde um $20 \%$ erhöht werde; gleichzeitig bewirkt die freiere Stellung der Stockaussehläge eine Zunahme der Rindengüte. Die Unterlassung der Grasnutzung und des Weidebetriebs in Schähwaldungen sollen ebenfalls zur Erhöhung der Rindengüte nicht unwesentlich beitragen.

Neben der Eichenrinde dient die Fiehten rinde als Gerbmaterial. Sie wird für bestimmte Zweeke als notwendig, ja unentbehrlich bezeichnet. Sie wird insbesondere verwendet zur Zubereitung des lialb- und schwachen Pindleders; zur Herstellung starken Sohlenleders ist sie nur in Gemisch mit Eichenlohe oder Ersatzstoffen verwendbar. Besonders im Norden und Osten Deutsehlands, sowie in den Ostseeprovinzen und in Polen findet sie Verwendung.

Man gewinnt die Fichtenrinde besonders in solchen Gebirgslagen, in denen Sommerfällung üblich ist; junge Stämme mit glatter Rinde liefern das beste Iaterial und zwar nieht wegen eines geringeren Gerbstoffgehaltes der starken Borke. sondern wegen eines in letzterer vorhandenen rötlichen Farbstoffes, der das Leder etwas dunkler machen soll.

Lärchenrinde wird in Deutschland wohl kaum zur Gerlserei benützt, hingegen in Rußland, Ungarn, Oesterreich mit Vorliebe verwendet. In den Alpen und Karpathen soll sie sogar der Fichtenrinde vorgezogen werden. Es dürfte die Nichtbeachtung in Deutsehland an ihrem verhältnismäßig seltenen Vorkommen liegen; nach Councler ist ihr Gerbstoffgehalt bedeutend höher als derjenige der Fiehte. Naeh diesem Autor ist auch die IV e i B t a n n e n r in d e nicht so arm an Gerbstoff als gewöhnlich angenommen wird.

In Amerika wird die Rinde der Hemlocktanne (Tsuga canadensis) zur Gerberei benützt. Dieselbe wird auch nach Deutschland ausgeführt.

IV e i d e n r in d e n sollen als Gerbematerial in RuBland namentlich zum Ger- 
ben des Juchtenleders geschätzt werden; in Deutsehland, wo infolge der Verwendung geschälter Weiden zur Kiorbwarenfabrikation viel Weidenrinden zu gewinnen wären, ist dies nicht der Fall, und es soll nach Couneler auch kaum Aussicht vorhanden sein, daß Weidenrinden bei uns zum Gerben benutzt werden. Während das Gerbstoffprozent der Eichenrinde je nach Alter und Güte zwischen $8-12 \%$ beträgt, Fichtenrinde etwa 10\% Gerbstoff enthält, hat Weidenrinde nach Councler nieht mehr als $5-7 \% 1$ ).

Auch Birken rinde gelangt in nordischen Ländern in untergeordnetem Maße bei der Gerberei zur Anwendung. Bei Darstellung des Juchtenleders findet eine Tränkung desselben mit Birłenöl, einem Extrakt aus der obersten weißen Schichte der Birkenrinde, statt.

\section{Gewinnng des Holzes und der Rinde.}

\$ 16. Fäl] ung p l a n. In jedem größeren Forsthaushalt wird die Holznutzung in bestimmten Grenzen der Nachlaltigkeit betrieben. Die Normen für dieselbe liefert die Ertrags- und Betriebsregelung, welche Bestimmung darüber trifft, wie viel allährlich zu schlagen ist und wo und in welcher Weise die Nutzungen zu erheben sind. Damit ist die Art des Vorgehens der Emte am einzelnen Orte bestimmt ${ }^{2}$. Dem wirtschaftenden Beamten liegt die Aufgabe ob, vor Beginn eines neuen Wirtsehaftsjahres einen ins Einzehe gehenden Fällungosplan aufzustellen, der die Nutzungsmassen bestimmt und auf die einzelnen Ernteorte verteilt. Wieser PJan hat alsdann als Richtsehnur für die Hiebsanordnungen des betreffenden Jahres zu dienen.

Der Fällungsplan hat innerhalb der Grenzen der Nachhaltigkeit einen möglichst hohen Ertrag des Waldes anzustreben. Die Hauungen müssen so geleitet werden, daß der herrschenden Naehfrage möglichst entsprochen wird, sie müssen dafür sorgen, daß das in den Jahressehlägen und deren Ergebnissen bestehende Verjaufslager des Forstwirtes nach Möglichkieit alle marktfähigen Sortimente in geeigneter Nenge aufweist; es empfiehlt sich daher, aus jeder der innerhalb eines Revieres vorkommenden Bestandesarten in jedem Jahr einen angemessenen Teil des Massennutzungssatzes zu nutzen und nicht etwa in einem Jahr vorwiegend Hölzer von der einen, im anderen Hölzer von einer anderen Sorte zum Einsehlag und zur Verwertung zu bringen; sofern die Harlitlage es nicht ausnahmsweise wünschenswert macht, von der einen Holzart etwas mehr Masse auf den Markt zu bringen als dies durehschnittlich zulässig ist, wie z. B. bei einer dureh Bauten in der Nähe des Reviers bedingten größeren Nachfrage naeh Bauhołz, bei einer zufälligen Möglichkeit der Verwertung gewisser seltener Sorten, z. B. Schiffsbauhölzer und dergl.

Auch darauf ist zu sehen, daß Endnutzungen und Durchforstungen in nachhaltiger Weise nebenemander betrieben und nieht die eine Nutzungsart zu Ungunsten der anderen in einem Jalire besonders bevorzugt werde. Jedoch sind auch hierbei Ausnahmen nicht nur zulässig, sondern unter Lmständen geradezu geboten. So z. B. wird man die Erfahrung machen, daß Hopfenstangen in einzelnen Jahren ausgezeichnet gut zum Handel zu verwerten sind, in einer ganzen Reihe darauf folgender Jahre hingegen wiederum nicht. Offenbar ist es deshalb geboten, eine solch günstige Marktlage bestmöglich auszunutzen und eintretendenfalls dem Betrieb der Durehforstungen zur

1) Z. f. F. u. J. v. 1881 , S. 551 und das. 1886 , S. 296.

2) Nähеге über diesen Gegenstand, und zwar sowohl bezüglich allgemeiner Erwägungen, wie auch der Betrachtung der einzelnen Betriebsarten vergl. WV a g $n$ e r, , Grundlagen der rãumlichen Ordnung im Walde“", 2. Aufl., S. 252-270 (2. Iiapitel, Die Ernte des Holzes), sowie S. $280-292$. 
Gewinnung der Hopfenstangen selbst unter Zurückstellung von Endnutzungen eine entsprechend große Ausdelnung zu geben.

Einem verfeinerten Betriebe (Kileinflächenwirtschaft) wird eine gewisse Vervielfältigung der Schlagorte zü Gewinnung von möglichst leicher Auswalıl in den Schlagergebnissen und zur Vermehrung der Sortenausbeute in der Regel sehr zu statten liommen.

$\S 17$. F äll u n g z e it. Die allgemeine, von alters her in Geltung befindliche Regel geht dahin, daß die Holzfällungen möglichst außer der Wachstumszeit zu betreiben sind, und diese alte pralitische Erfahrung bestätigt sich auch in den Ergebnissen der wissenschaftlichen Untersuchungen der neueren Zeit und ergibt sich ebenso aus dem inneren organischen Bau und der Zusammensetzung des Holzkörpers aus verschiedenen organischen Stoffen und deren verschiedenen Beschaffenheit in und außerhalb der Vegetationszeit. Jene Periode, vom Laubabfall bis zum Wiederausbruch des Laubes bemessen, nennt man auch die $\mathrm{W}$ a d el z e it oder den IV a d e I. Innerhalb derselben sind namentliclı die Hauungen in Laubholz zu betreiben.

Von größter Wichtigkeit ist dies in Buchenbeständen, deren Verwertung als Nutzholz beabsichtigt ist. Die unangenehmste Eigenschaft des Buchennutzholzes ist die, daß es so leicht reißt und stockig wird; das einzige im großen praktisch anzuwendende Hittel hiergegen ist, das Holz sehr früh im Winter zu fällen und dann so zeitig wie möglich im rohen zu verarbeiten ${ }^{1}$ ).

Was den Einfluß der Fällungszeit auf die anderen Hölzer, namentlich Nadelhölzer anlangt, so nimmt man vielfach an, daß im Sommer gefälltes Holz der Verbreitung des Hausschwammes günstiger sei als das in Winter gefällte ${ }^{2}$ ).

Eine Scheidung lediglich von Som m e r- und W in terfäll u n g, wie üblich, dürfte nicht einwandfrei sein, insofern es sowohl innerhalb wie außerhalb der Vegetationszeit Monate gibt, die der Fällung in Hinblick auf die Güte des Holzes günstig und ungünstig sind. Entscheidend für die Beurteilung der Fällungszeit ist die Güte des Holzes, das aus ihr hervorgeht, und diese hängt, da ja die Holzqualität auf dem Stocke zu allen Jahreszeiten dieselbe ist, in erster Linie von der Witterung

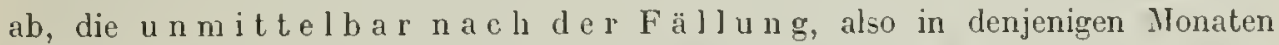
herrscht, wăhrend deren das Holz gefällt und aufbereitet im WValde liegt, um waldtrocken zu werden; dam wohl auch von der Menge und Form, in der die dem Angriffe der Pilze am meisten ausgesetzten Stoffe, Eiweiß, Zucker usw. zur Zeit der Ernte im Holze vorhanden sind. Befinden sich letztere in Ruheform und zeigt die Witterung nach der Fällung noch längere Zeit eine selır niechige Temperatur oder herrscht große Trockenlseit, so daß dem Holze Zeit bleibt, gut auszutrocknen, ehe die Pilze eindringen können, so wird die Holzqualität eine gute sein, andernfalls werden die Schlagprodukte durch Lagerung im Walde leiden.

Gute Fällungszeiten wird darum vor allem der Vorwinter (Olitober bis Januar) aufwejsen, der demgemäß auch für alle Holzarten als beste Fällungszeit gilt, denn hier bleibt den aufbereiteten Hölzern reichlich Zeit, auszutrocknen, ele mit steigender Temperatur die Pilzwucherung beginnt; auch enthält das Holz Eiweiß und Kohlenhydrate in Ruheform. Bedingt wird auch die Zeit des ersten Safts (Mitte Iai bis Mitte Juni) in Frage liommen, da hier, bei günstiger Vitterung wenig-

1) Am besten soll Buchenholz vor dem Reißen zu schützen sein, wenn man die stämme im Winter fāllt, aber mit dem Reisig bis zum Ausbruch des Laubes liegen lāßt, wobei die Schnittfläche des Stammes zu bedecken, längs derselben die Rinde streifenweise zu entfernen ist (B i a 11 a in Oe. F. 1885, S. 2). Das Austrocknenlassen durch die Belaubung ist übrigens uralt.

2) G o p pert, Prof., Der Hausscliwamm, herausgegeben und vermehrt von Prof. Dr. Poleck 1885. Rob. Hartig, Der Hausschwamm 1885. 
stens, rasches Austrocknen stattfindet, das durch volle Entrindung noch beschleunigt wird.

Als schlechte Fällungszeiten werden dagegen Nachwinter und Frühjahr (Januar bis Anfang Mai) und die Zeit des zweiten Safts (Zeit von Mitte Juni ab) zu gelten haben.

Die in Hinsicht auf die verschiedene Dauer der zu verschiedenen Jahreszeiten gefällten Hölzer angestellten Untersuchungen haben noch kieine über alle Zweifel erhabenen Resultate zutage gefördert; nach Professor Bauschinger in München haben Fichten und Kiefern, die im Winter gefällt wurden, 2-3 Monate nach ihrer Fällung geprüft, unter sonst gleichen Lmständen eine un ca. $25 \%$ größere Festigkeit unrl Elastizität ergeben, als solche, die im Sommer geschlagen waren. Ein in Tliarandt gemachter größerer Versuch zur Feststellung der besten Fällungszeit für Nadelhölzer erfolgte so, daß man in jedem Monat Fichten fällen und zerschneiden ließ, hierauf aber die Stöcke von jedem Monat gleichmäßig auf die verschiedenste IVeise behandelte (Aufbewahrung auf luftigem Speicher, in feuchtem Raume, im Freien, unter Dach etc.). Hierbei hat sich keinerlei Gesetzmäßigkeit himsichtlich des günstigeren Einflusses der einen oder der anderen Fällungszeit ergeben, sondern es waren die äußeren Umstände und Einwirkungen, rlenen die Hölzer ausgesetzt waren, für ihre größere oder geringere Dauel" maßgebend ${ }^{1}$ ).

Nach anderen vergleichenden Beobachtumgen fand man die im Vorwinter gefällten Hölzer dauerhafter als die vom Januar an geschlagenen ${ }^{2}$ ).

Trotzden sind Ausnahmen von der Regel der Winterfällung unter gewissen Unständen unvermeidlich. Im rauhen Gebirge, in dem hoher Schneefall die Holzhauerei innerhalb der eigentlichen Wintermonate geradezu unmöglich machen würde, lian diese erst mit dem beginnenden Frühjahr eingeleitet werclen und dauert in der Regel bis spät in den Sommer hinein.' Sie hat es in der Hauptsache mit der Fällung der Nadelhölzer zu tun, und es ist Sommerfällung hier von Vorteil, insofern durch dieselbe die Möglichkeit des Sehälens der Nadelhölzer gegeben ist, was sowohl mit Rücksicht auf die Verwertung der Rinden, als auch wegen des Austrocknens der Hölzer behufs des erleichterten Transportes derselben, insbesondere bei bestehender Flößerei (Trift), endlich auch wegen Abwehr des Nutzholzbohrkäfers (Bostrichus lineatus) und des gewöhnlichen Borkenkäfers (Bustrichus typographus) hier unerläBlich ist.

Der Hieh im ersten Safte mit vollständiger Entrindung hat bei $\mathrm{F}$ i c h $\mathrm{t}$ e und $\mathrm{T}$ a $\mathrm{n} n \mathrm{e}$ den Vorteil, daß infolge des raschen und guten Austrocknens in der Maiund Junihitze das noch wenige Reservestoffe enthaltende Holz s c hön e we i B e Farbe zeigt, also zu Schnittwaren beliebt ist, da Schimmelpilze nicht Zeit hatten, zu wuchem. Doch ist der Erfolg sehr von der Witterung abhängig, auch wirkt das stärkere Reißen des Holzes nachteilig. Sehr ungünstige Eigenschaften zeigt dagegen nach den Erfahrungen des Bearbeiters das Holz aus dem sog. zweiter Safte (um Johanni); dasselbe trocknet schlecht aus, bleibt daher schwer und liefert graugefärbte Schnittwaren.

In Ausschlagwald ist die Periode strengster Winterkälte zur Ausführung der Haunngen unzweekmäßig, weil die Stöcke unter der Einwirkung des Frostes leicht eingehen. Es empfichlt sich also der Nachwinter als zweckmäßigste Hiebszeit belıufs Erlangung guten Stockausschlages, es sei denn, daß man in Brüchern (Erle) wegen der Nässe nur im Winter mit hartem Frost arbeiten kams; in E i c h e $1 \mathrm{~s} \mathrm{chäl-}$ s c h l ä g e n findet die Frühlingsfällung ausschließliche Anwendung, da die Gewin-

1) Tharander Jahrbuch $1879, \$ .53 \mathrm{ff}$.

2) Allg. F.- U. J.-Ztg. 1883, S. 432. 
nung der Eichenrinde an die Periode des Knospen- und Laubausbruches gebunden ist. Nach neueren Erfahrungen empfichlt es sich hier jedoch ganz besonders, mit dem Hieb der Stockausschläge und mit den Schälen derselben nicht länger als unumgänglich nötig zu warten, da cin Rückgang des Gewichtes der Rinde mit dem Fortschrciten der Jahreszeit verbunden zu sein scheint $\left.{ }^{1}\right)$. Auch für Durchforstungen in Laubholzbeständen ist der Vorsommer zweckmäßig, weil dic bei dichtem Stand schlank erwachsenen Stangen, wenn dieselben im Llattlosen Zustand freigestellt werden, dem Schneebruch des WVinters leichter unterliegen, als wenn sie, während der Vegetationsperiode durchforstet, Zeit gehabt haben, noch etwas fortzuwachsen und hierbei zı erstarken.

Lichtende Aushicbe in natürlichen Verjüngungen wird inan hingegen tunlichst im Winter bei Schnce vornelımen, um dem Nachwuchs durch den Fällungsbetrieb und das Anrüclien möglichst wenig Schaden zuzufügen.

Dic Aufarbcitung von Bruclı- und Dürrhölzern pflegt man stets so zcitig als möglich vorzunehmen, um etwaigen Insektenschäden vorzubeugen.

Von besonderer Bedentung ist die frülızeitige Anlage der Hauungen zur Gewinnung der Nutzlölzer. Die Erfahrung lehrt, daß in der Regel bei zeitigem Verkauf die besten Ergebnisse erzielt werden. Namentlich gilt dies für Laubnutzlıolz und hier besonders für Buchen-, Eschen-, Ahornstammholz usw., für Eisenbalınschwellen, sowie für Grubenholz, desgleichen für Hopfenstangen. Es ist eine gewöhnliche Erscheinung, daß die IIolzkäufer Gewicht darauf legen, frühzeitig den Jahresbedarf zu decken, so daß, um in dieser Hinsicht sicher zu gehen, bei den ersten Ankäufen, die sie abschließen, nicht selten höhere Preise von ihnen angelegt werden als später.

Holzhändler, welche Schwellen und andere Hölzer zurichten lassen, liaben namentlich auch mit Rücksicht auf die ihnen während der Wintermonate leichter zur Verfügung stehenden Arbeitermannschaften, sowie auf deren fortlaufende Beschäftigung auf zeitigen Einkauf besonders Bedacht zu nehmen.

In vielen Gegenden, in denen die Holzhauerei nicht das ganze Jalır hindurch betrieben wird, bildet sie eine gerne benutzte Arbeitsgelegenheit für Arbeiter, die während des Sommers in der Landwirtschaft, beim Baugewerbe oder sonstwie beschäftigt sind, so daß die Rücksicht auf rechtzeitige Beschäftigung solcher Arbeiter als Holzhaver dazu auffordert, zoitig in Herbst mit dem Holzhauereibetrieb zu beginnen. $\mathrm{Zu}$ erwähnen ist noch, daß beim Winterfällungshetrieb dann, wenn das Holz fest gefroren ist, die Arbcit eingestellt werden muß, da soust dic fallenden Hölzer leicht zersplittern, bei vorhandenem Nachwuchs auch dieser melı beschädigt wird als bei gelinderer Witterung, und auch für die Arbeiter selbst gesteigerte Gefahr besteht.

$\S 18$. Art des $\mathrm{Holzhauereibetriebs}$ und Anveisung de $\mathrm{r}^{\circ}$ $\mathrm{Hol} \mathrm{z}$ h a u er. In den meisten gröBeren deutschen Forsthaushalten pflegt man es für unzulässig zu erachten, die Holzernte auf dem Stock zu verliaufen und dem Empfänger die Nutzung zu überlassen (Verkauf en bloc), sondern man huldigt dem Grundsatz, die Fällung und Aufarbeitung des Holzes und der Rinde auf Rechnung des WValdeigentümers zu betreiben, mag nun der Verkauf auf dem Stock oder erst in aufbereitetem Zustande erfolgen. In der Tat ist auch im allgemeinen der Verkauf en bloc - ein Verfahren, das in Frankreich noch allgemein herrschend ist und früher auch in Elsaß-Lothringen üblich war, aber nach der Aufnahme dieser Länder ins Deutsche Reich von der deutschen Verwaltung alsbald abgeschafft"wurde - für cine gute Kontrolle der geschätzten Holzmassen ungeeignet; auch begibt man sich dabei der Möglichkeit einer Entscheidung über dic im Wald zu beschäftigenden Arbeiter, so daß die

1) v. Esch we ge in Z. f. F. U. J. 1886, S. 283. 
Möglichkeit des Begehens von Unterschleifen seitens derselben keineswegs ausgeschlossen ist; ferner geht man des Vorteils verlustig, den eine gut gescluulte Holzhauermannschaft, die durch ihre Verwendung im Dienste des Waldbesitzers zu Anhänglichkeit an den Wald erzogen wird, dem letzteren in vielen Fä]len bietet.

Zulässig dürfte das Verfahren der Gewinnung und Aufarbeitung durch den Empfänger oder auf dessen Rechnung bei Stock- und Wurzelholz und bei schwächerem Ausschlagholz sein, das keinen großen Wert hat, und bei dessen Fällung nicht gerade große Mißgriffe zu befürchten sind. Bei Reinigungs- und Durchforstungsmaterial kann man dem İäufer wenigstens die Aufbereitung überlassen.

Wenn man an manchen Orten durch Ueberlassen der Selbstgewinnung verkaufter Hölzer an den Käufer, z. B. auch beim Verkauf von Bauholz im Stehen, bessere Geschäfte zu machen glaubt, als bei Aufarbeitung desselben auf Rechnung der Forstkasse, so kann dies nur dann der Fall sein, wenn der Holzkäufer seine eigene Arbeit nur sehr gering veranschlagt, wie dies bei ländlicher Bevöllierung während der verdienstlosen Zeit des Winters bisweilen der Fall sein mag. In übrigen mögen mancherlei Täuschungen unterlaufen $\left.{ }^{2}\right)$. Der Grund, daß der Holzkäufer, insbesondere wenn es sich um wertvolle Nutzholzstänme handelt, eine vorteilhaftere Ausnutzung derselben herbeiführen werde wie die Forstverwaltung $\left.{ }^{2}\right)$, kann nur dann zutreffen, wenn lie Wirtschaft nicht auf der Höhe der Zeit steht, insbesondere die Sortimentsbildung eine unzweclimäßige ist, so daß die ausgchaltenen Längen nicht den Bedürfnissen des Verbrauchs und llarkts entsprechen, oder wo das Personal nicht entsprechend geschult und zuverlässig ist. In solchen Fällen würde immer noch der Ausweg bleiben, taß zwar der Verkauf des Holzes auf dem Stock vor der Fällung crfolgte, aber nur nach Einheitspreisen, wohingegen die Fällung, sowie die Ablängung der Nutzhölzer auf Rechnung des Waldeigentümers dureh dessen Holzhauermannschaft, aber nach den Angaben des Holzkäufers stattfände ${ }^{3}$ ).

Eher könnte die Aufbereitung der Gerbrinde dureh den Käufer in Ausnahmsfällen gestattet werden, da hier eine rasche Abwiclilung des Geschäftes nötig ist und der Käufer öfters die dazu erforderliche größere Mannschaft leichter zu beschaffen vermag, als dies der Forstverwaltung möglich ist. Hier ist auch die Gefahr ciner Beschärligung stchender Hölzer oder die Möglichkeit der Entwendung nicht verkauften Holzes weniger vorhanden, doch hat sich auch hier die Aufbereitung durch die Verwaltung als zweckmäBiger erwiesen.

Es liommt an manclien Orten vor, daß gewisse Waldnutzungsrechte Abweichungen von der Regel der Aufarbeitung der Forstprodukte auf Rechnung und nach den Verfügungen des Waldeigentümers und seiner Forstverwaltungsorgane bedingen, inden es dem Berechtigten bisweilen zusteht, daß er die ihn gebührende Holzmasse selbst fällen und aufarbeiten darf. Solche Zustände erheischen dringend Ablilfe auf dem Wege der Gesetzgebung, damit der Waldbesitzer in seinem Eigentum auch wirklicher Herr mit unbeschränliter V'erfügung sei.

Die nächste Sorge für geordnete Ausführung der Holzhauerarbeiten im WVege der Selbstgewinnung bildet das Bestreben, eine s t ä $\mathrm{n} \mathrm{d} \mathrm{ige,} \mathrm{gu} \mathrm{t} \mathrm{g} \mathrm{es} \mathrm{c} \mathrm{h} \mathrm{u} \mathrm{l} \mathrm{t} \mathrm{e}$ A r be i te r m a n n e ha f $t$ zu erlangen und zu erhalten. Die hierbei den Forstverwaltungsorganen obliegende Fürsorge und Tätigkeit schägt in das Gebiet der Forstverwaltungslehre ein und wird in demjenigen Teil des Handbuchs besprochen

1) Vergl. B org g r e v e in Forstl. Bt. 1884, S. 321.

2) H a $\mathrm{p} t \mathrm{~g} r \mathrm{u} \mathrm{d}$, den die französische Forstverwaltung für ihr Verfahren geltend macht, vgl. It a r t i n, Forstw. Z.-Bl. 1909, S. 215.

3) Vergl. Ren ne, Verwertung der Holzernte. Z. f. F. u. J. 1883, S. 549. 
werden, der dieser Disziplin gewidmet ist, weshalb wir hier nicht näher auf rieses Gebiet eingehen (rgl. III. Band, XV).

Der örtlichen Anweisung der Holzhauer hat die Verdingung dor renselben zu übertragenden Arbeiten vorauszugehen. Es verdient in den meisten Fällen den Volzug, die Arbeiten niclıt etwa im 'T'aglohn ausführen zu lassen. sondern in Akiord zu geben, da eine genügende Kontrolle guter und vorschiftsmäBiger Arbeit mit Sicherheit und Leichtigkeit wahrgenommen werden kann, mithin seitens des Arbeitgebers kein Bedenken obwaltet, diejenige Art des Arbeitsvertrages zu wälılen, bei welcher der Arbeiter am meisten angespornt wird, seine Kräfte zu entfalten, um in Gestall möglichst hohen Arbeitsverdienstes eine Belohnung für den von ihm betätigten Eifer zu finden.

Es empfiehlt sich hierbei in der Regel, die Holzhauerarbeiten nicht im Wege des öffentlichen Aufgebotes an den Mindestfordernden zu vergeben, sondern aus freier Hand an ständige Holzhauer, die man für eine geordnete Ausfülnrung der ilnen zu übertragenden Arbeiten an allgemeine Holzhauervorschriften bindet.

Es ist zweekmäßig, über diese Alikorde liurz gefaßte sehriftliche Verträge abzuschließen, in denen man namentlich das Zugeständnis durch Namensunterschrift der Arbeiter beliräftigen läßt, daß sie sich verpflichten, nach Ma Bgabe der allgemeinen Vorschriften, die ihnen vorzulesen sind, zu arbeiten; hierbei haben sich dieselben zur Duldung von Abzügen an dem verdienten Arbeitsloln bei Zuwiderhandlung gegen die Vorschriften zu verpflichten. Ebenso empfiehlt es sich, für die Arbeiten in einzelnen die etwa erforderlichen Bestimmungen zu treffen, soweit dieselben nicht sehon in den allgemeinen Vorscliriften enthalten sind.

Ebenso werden in diesem Vertrag die für das Wirtsehaftsjahr gültigen Löhne festgestellt und von den Holzhauern dureh Namensunterschrift anerkannt.

Die Arbeiten der Holzhauer werden denselben nach Absehluß der Akkorde nun örtlich angewiesen; eine zweckmäBige Verteilung der Holzhauer kommt besonders da in Betracht, wo man größere llannschaften in einer Ortsabteilung beschäftigt. Hier handelt es sieh namentlich darum, die ganze Fläche, innerhalb deren der Hieh sich bewegt, in gewisse parallele Streifen einzuteilen und unter die einzelnen Rotten zu verlosen, damit keine derselben die andere in der Arbeit hindert; im gelirgigen Gelände läßt man die Seheidelinien möglichst bergab laufen; auch liann die Rücksieht in Betracht kommen, daß alle Lose auf Wege oder Sehneißen stoßen, an die das gefällte Holz angerüclit wird.

Die Anweisung der zum Fällen bestimmten Hölzer erfolgt bei Kahlsehlägen durch Anplatten der Grenzlinien, auch woll Ansehlagen des Waldhammers an eine Anzahl der an der Innenseite der Grenze stehenden und nicht zum Hieb bestimmten Stämne.

Beim Betrieb natürlicher Y'erjüngung wird die Holzanweisung in der Art vorgenommen, daß der Waldhammer an die zur Fällung bestimmten Stämme angoschlagen wird, damit auch nach der Fällung noeh festgestellt werden kann, ob die Stänme wirklich angewiesen waren. Es ist deshalb das Anschlagen des Hammers a $u$ S t o e k e erforderlich.

Werden nur einzelne Stämme übergehalten, so kann es auch vorteilhaft sein, nur diese auf eine kenntliche und von den Holzhauern nicht leicht naelizuahmende Weise zu bezeichnen.

Die beste Zeit zur Yornahme der Hiebsauszeichnungen ist der Herhst und Vorwinter; insbesondere sollen dieselben in Laubwaldungen so zeitig vorgenommen werden, daß man den Zustand der Wüchse beurteilen und genau erliennen liann, in wel- 
chem Grade Î̈ümmerungszustände derselben vorlıanden sind, die eine größere Lichtstellung erheischen; erfolgt die Auszeichmung später, insbesondere naeh schon eingetretenem Sehneefall, so entscheidet die Kronendiehte der Altholzstämme, indem in der Regel zunächst die Wegnahme der breitkronigen, dichtheasteten Stämme angezeigt erscheint.

Man durchgeht bei diesem Auszeichnen der zu fällenden Stämme unter Zuziehung des Forstschutzbeamten und des Ober'holzhauers die ganze zum Sehlag bestimmte Abteilung in parallelen Streifen, an Bergluängen von unten nach oben, so daß man stets nach derjenigen Seite des Bestandes das Auge gerichtet hat, in der die Auszcichnung bereits elfolgt ist. Jeder angewiesene Stamm wird auf derjenigen Seite, die dem das Geschäft ausführenden Beamten zugekehrt ist, mit einer Platte versehen, die beim Begehen des nächsten parallelen Streifens ins Auge fällt, so daß auch auf weitere Strecken hin erkannt wird, welche Stämme schon zuvor ausgezeichnet wurden. Man pflegt wohl auch die Stämme zu numerieren, sogar ihren Durchmesser zu notieren, um naeh Veranschlagung der Stammkreisfläche unter Multiplikation derselben mit einer einzuschätzenden Formhöhe einen Anhalt darüber zu gewinnen, wieviel Holzmasse angewiesen ist.

Besonders wichtig ist die Auszeichnung des zu hauenden Oberholzes im Mit te lw a 1 d. Hier hat zunächst die Abgrenzung der Schlagfläche und hierauf folgend der Abtricb des Unterholzes zu geschehen, wobei eine besondere Sorgfalt auf die Erhaltumg genügender Laßreidel aus dem Unterholz zu verwenden ist. Es empfiehlt sich hierbei, die WVeisung zu geben, daß alle Kernloden, sowie von jedem Stock derjenigen Holzarten, die im Oberholz begünstigt werden sollen, die beste Ausschlaglode stehen gelassen wird ${ }^{\mathbf{I}}$.

Bei dem naeh beendigtem Abtrieb des Unterholzes erfolgenden Auszeichnen des Oberholzes, das der Wirtschafter nie aus der Hand geben sollte, wird alsdann gleichzeitig Bestimmung darüber getroffen, welche von den etwa zuviel übergehaltenen Laßreideln noch nachträglich entfernt werden sollen.

Die Anweisung der Durchforstungen hann dem Schutzpersonal überlassen werden, wenn unter Anleitung des verwaltenden Forstbeamten zunäehst eine hinlänglich große Fläche als Probestüek ausgezeichnet worden ist; bei den Plenterdurchforstungen wird jedoch die Auszeichnung durch den Virtschafter eine unerläßliche Voraussetzung für sachgemäße Ausführung sein.

In der zeitlichen Aufeinanderfolge der IIauungen muß eine zweckmäßige Ordnung obwalten, indem die dringlichsten Arbeiten vorangestellt werden und die weniger nötigen zuletzt folgen. Hierüber allgemeine Regeln zu geben, ist kaum möglich, da die örtlichen Verhältnisse und Besonderheiten wesentlich von Einfluß auf die zweckmäßigste Reihenfolge der Arbeiten sind. Zu den dringendsten Arbeiten würden die Aufarbeitungen von Wind- und Schneebruchhölzern, von dürren Stämmen, ferner die Lichtungen zur Freistellung besonders bedürftigen Aufschlages bei der natürlichen Verjüngung zu rechnen sein.

§ 19. F äll u n g s b e tri e b. Das Fällen der Bäume erfolgt entweder durch Rodung des stehenden Holzes, d. h. durch Ausgraben mit Stock und Wurzèn, oder aber durch Abtrennen der Stämme mit Axt und Säge oder mittelst eines dieser Werkzeuge allein.

Die Rodung des stehenden Holzes, auch Baumrodung (im Gegensatz zur Stoekrodung) genannt ${ }^{2}$, ist unter allen Fällungsarten die zweck-

1) s. B orggre $\mathrm{re}$, Die Schlagauszeichnung in F,-Bl. 1886, S. 182.

2) K. H e y er, Die Vorteile und das Verfahren beim Baumroden. 1827. D e r s., Ueber denselben Gegenstand, A. F.- U. J.-Z. 1856, S. 122. 
mäBigste, insofem als man hierbei den beim Abschneiden der Stämme in das Stockholz fallenden unteren Teil des Stanmes, besonders bei stärkeren Bäumen, zu erheblich besserem Preis verwerten wird. Dieser finanzielle Vorteil warde für sächsische Verhältnisse von $\mathrm{N}$ e u me is te $\mathrm{r}$ auf $3 \%$ ermittelt. Hicrzu lionmt, daß durch das Belassen eincr Wurzel dem ausgerodeten unteren Stamnstück öfters eine Form gegeben werden kann, die für die Verwendbarlieit desselben z. B. als Schiffsknie, Schlittenkufe etc. ron besonderem Wert ist. Der ausgerodete Stock cines starken Stammes eignet sich nach dem Alschneiden des Stammendes besonders zur Verwendung als Ambos oder Hackblock. Beim Auszug einzelner Stämme aus schon mit Aufwuchs versehenen Naturverjüngungsschlägen ist diese Methode jedoch nicht immer anwendbar, weil durch das Ausgraben zu viele Pflanzen beschädigt werden würden (vgl. dagegen W a g n e r "Der Blendersaumschlag und sein System" S. 50 und 56); auch im Mittelwald findet sic nur eine beschränkte Anwendung.

Daß bei Baunrodung dic sorgfältigste Ausnutzung des Stocli- und Wiurzelholzes nicht eintrete, wird aus Sachsen berichtet, wo man die Erfahrung gemacht zu haben glaubt, daß die Ausgrabung und Benutzung der schwächeren Wurzeln hierbei nicht mit derjenigen Genauigkeit und Sorgfalt betrieben wird, als dies bei Rodung der Stöcke nach vorherigem Abschneiden der Stämme zu geschehen pflegt; bei Baumrodung ist die Gewinnung des Stockholzes mehr llittel zum Zweck und die Aufarbeitung des Stammholzes die Hauptsache; eigentliche Stockrodung hingegen fällt öfters in eine Zeit, in der es an anderer Beschäftigung fehlt und jeder mehr erlangte Raummeter ein Gewinn für den Arbeiter ist. Dieser mangelhafteren Rodung schwacher Wurzeln in Fichtenbeständen wird eine größere Gefahr für Rüsselkäfervermehrung beigemessen und in dieser Erwägung zur Vorbeugung gegen die Gefalır des Rüsselkäfers von der Anwendung der Baumrodung abgeraten ${ }^{1}$ ).

Als letzten Vorteil des Baumrodens läßt sich geltend machen, daß die Stämme nicht so rasch niederstürzen, daher auch nicht so hart auffallen, als über dem Boden abgehauene oder abgesägte und zwar deshalb, weil won dem gerodeten Stamm ein Teil der Herz- und PfahIwurzeln langsam aus dem Boden herausgezogen wird. Deshalb werden auch umgegrabene Nutzholzstämme nicht so leicht zersplittern und wird der Nachwuchs in Licht- oder Abtrielsschlägen weniger beschädigt werden als bei anderen Baumfällungsarten.

Bei Anwendung der Baumrodung wird der zu fällende Stamm zunächst von allen Seiten angerodet, indem die Tagwurzeln bloßgelegt, vom Stamm, und zwar dicht am Stocke abgehauen oder abgesägt und bis zu der noch nutzbaren Stärke vom Stamm auswärts ausgegraben werden. Hierauf werden die Herz- und Pfahlwurzeln, die das Fallen des Baumes noch hindern, abgehauen, was den Stamm zum Fallen bringt.

Bei flachwurzelnden Hölzem gelingt dieses durch einfaches Andrücken der Holzhauer; wirksamer ist die Anwendung besonderer Baumrodewerkzeuge: zu nennen wäre hier als emfachste die $30 g$. Z u g stange, eine leichte Stange von zähem Holz, die an ihren oberen Ende einen Halien trägt, mit dem sic möglichst hoch über dem Boden an einem Ast des noch stehenden Stanmes eingehängt und lieser mittelst der Stange nach und nach umgezogen wird. Die Holzhauer, die zu diesem Behuf an der Stange hin und her ziehen, bringen den Stamm in eine wippende, schaukelnde Bewegung; hierbei wird durch das Hin- und Herschwanken desselben der Ort weiterer Wurzeln festgestellt, die dann bloßgelegt und abgehauen werden; dadurch wird der Stamm wesentlich leichter zu Fall gebracht.

1) v. Oppen in Z. f. F. U. J. 1885, S. 148. 
Diese Stange ist nur bei niedrig beasteten, insbesondere auch schwächeren Stämmen zu verwenden; bei höheren Bäumen findet der sog. S e ilh a k e n Anwendung, d. h. ein eiserner, mit einem Oehr und einem daran befindlichen Ring versehener Haken, bei dessen Gebrauch an dem Ring ein Seil von 20-30 Meter Länge befestigt wird. Der Haken wird in angemessener Höle des Baumes entweder mit. Hilfe einer Stange oder nach Besteigen dessclben an einen stärkeren Ast eingehängt, hierauf der Stamm selbst von den Arbeitern umgezogen.

Das Fallen des Baumes wird dureh Anwendung eines Hebebaums erleichtert, den man mit cinem Ende möglichst tief unter den bereits angerodeten Stack schiebt, während das hintere Ende, nachdem in möglichster Nähe des vorderen der Hebel gehörig unterstützt worden ist, ruckweise zu Boden gedrückt wird. Ebenso hann der Hebel auch untergesteckt und durch eine untergeschobene Wagenwinde gehoben werden.

Fig. 1.

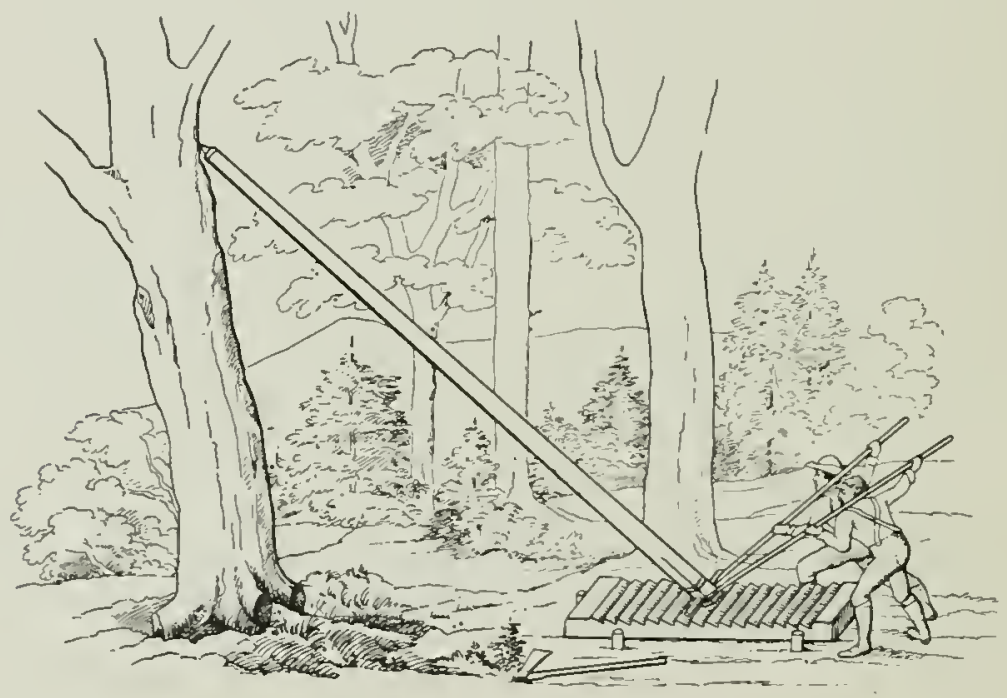

Zur Erleichterung der Arbeit sind weiter noch verschiedene Maschinen erfunden worden, von denen wir folgende erwähnen:

Die $\mathrm{N}$ as a u is che (oder Wohm a n sche) Baumrodemaschine ${ }^{1}$ ) besteht aus einem mit Tierben versehenen 1,75 m langen, $0,30 \mathrm{~m}$ breiten, $0,12 \mathrm{~m}$ dicken Buchenbrett, dem sog. Z w i ckb r e t , auf dem eine oben und unten mit Eisen beschlagene Fichtenstange $(5-6 \mathrm{~m}$ lang, $12 \mathrm{~cm}$ D.), die sog. D r ü c k t a n g e, die mit einer eisernen Spitze in den umzurodenden Stamm eingreift, während das andere Ende in die Kerhen des Zwichbretts gestellt wird, mittelst Brecheisen aus einer lierbe in die andere vorwärts gehoben wird, um den vorher umrodeten und von seinen Wurzeln befreiten Stamm umzudrücken. Die Brecheisen werden unter einem runden eisernen Nagel, der im unteren Ende der Drückstange durchgesteckt ist, hindurch geschoben und finden an diesem Nagel ihre Unterstützungspunlite. Zur Erläuterung diene vorstehende Figur 1.

1) A. F.- U. J.-Z. $1858, \mathrm{~S} .46$ (W o h $\mathrm{m}$ a n $\mathrm{n}) .1864, \mathrm{~S} .369$ und 1870, S. 219 (D r a u d ). 
Die Leistung der Maschine ist am größten, wenn rlie Entfernung von Stammcnde bis zu der Höhe des Stammes, wo das eine Ende der Drückstange eingreift, so grol ist, als die Entfernung vom Stammende his zum unteren Eude der Drückstange. Die Nassauische Rodemaschine wurle in nenerer Zeit dureh $B$ ü $\mathrm{L} t \mathrm{n}$ e $\mathrm{l}$ in zweekmäßiger. Weise abgeänrlert und verbessert - .B ii t t n e r s $\mathrm{B}$ a $\mathrm{um}$ win d e" - vergl. F.Zbl. I904, S. 680 und 1905, S. 144, Zentralbl. f. d. ges. Forstw. 1907 , S. 62. Die "Baumwinde" wird von allen Seiten als selır wirksam bezeichnet.

Eine in der Schweiz erfundene besonders wirksame Rodemaschine ist der IV a I l t e u f I, auch Reutelzerg genannt. Er besteht aus einem starken Hebel, der seinen Stütz- und Drehpunkt an dem einen Ende einer starken Kette hat, die um einen hinreichend starken stehenden Baum oder Stock geschlungen ist. Zu

Fig. 2.

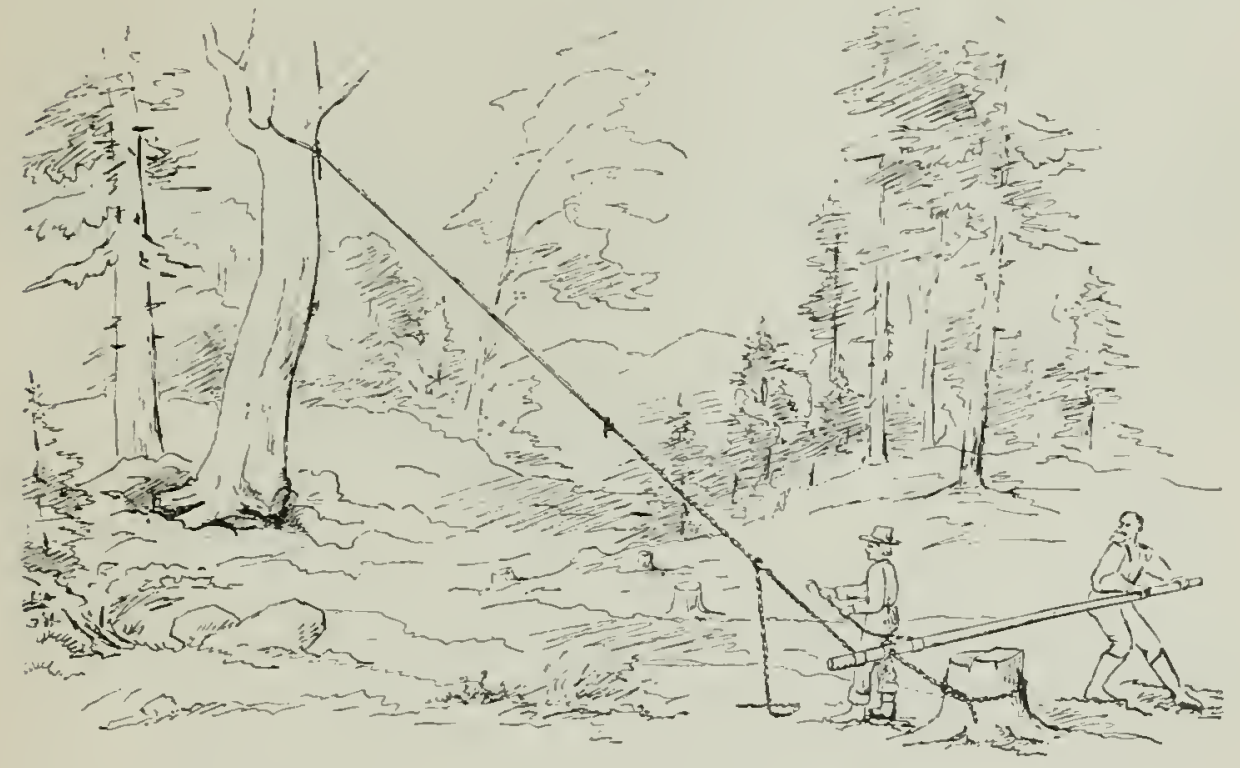

beilen Seiten des Interstützungspunkts sind zwei kurze Hebelketten mit Endhaken befestigt. Eine weitere liette wirl mit einem längeren, um den auszurodenden Stamm geschlungenen Schiffstau oder besser noeh Dralıtseil (denn alles bängt von der Festigkeit dieses Taues ab) verbunrlen, die eine Helelliette in dieselbe straff eingehangen. rler Hebel angezogen und dachurel die zweite Hebelkette so weit dem umzurodenden Baum genähert, daß ein Kettenglied weiter eingelıakt werken kann. Dureh das Hin- und Herbewegen des Hebels wird bald die eine, bald die andere der Ilebellietten vorgeschoben und weitergelıakt. Dureh fortgesetzte Wiederholung wird die am Baum befestigte liette nebst den Tau immer straffer angezogren, so daß der Baum endlich zu Fall kommt. Der Gang der Arbeit wird dureh die vorstehende Zeichnung Figur 2 verilentlicht.

Unter allen Baumrodemaschinen dürfte rler Walılteufel die meiste Beachtung verdienen.

Auch die Nassauische Rorlemasehine in ihrer leichteren, von D r a u il t empfohlenen Form (oder besser noch die B ü t $\mathrm{l}$ n e r sehe Baunwinle), wird greschátzt. 
Diese Maschine, ursprünglich in Nassau angewandt, hat sich auch im Großherzogtum Hessen vielfach eingebürgert.

Eine weitere verbesserte Druckmaschine, angegeben von dem Großh. Hessischen Forstwart Stend a l wird in dem Bericht über die 13. Versammlung des Forstvereins für das GroBherzogtum Hessen (Darmstadt 1901) beschrieben.

Die $\mathrm{H}$ a uptfällungsarten sind jedoch diejenigen mit $\mathrm{Axt}$ u $\mathrm{nd}$

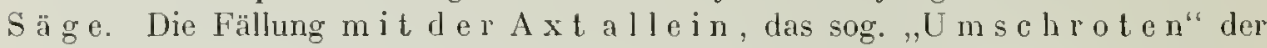
Bäume durch Hauen tiefer Fallkerben auf beiden Seiten des Stamms findet in geordnetem Betriebe nur noch bei Stangenhölzern Anwendung, bei denen man öfters keine glatte Abschnittfläche wünscht, vielmehr Gewicht darauf legt, daß das Stammende schon etwas zugespitzt sei (z. B. bei Hopfenstangen, Bohnenstangen, Zaunpfählen); bei stärkerem Holze dagegen ist mit dieser Methode ein so beträchtlicher Verlust an Iolzmasse verbunden, der gerade am unteren, wertvollsten Teile des Stammes doppelt ins Gewicht fällt, daß man in wolılgeordneten Forsthaushalten von derselben lieinen Gebrauch mehr macht.

Nur wo die Anwendung der Säge ausgeschlossen ist, sei es, daß der Standraum fïr ihre Fïhrung fehlt (auf Felsen, an Steilabstïrzen usw.) oder daß mehrere starke Bäume dicht beisammen stehen, kommt das Umschroten für stärkeres Holz noch in Frage. Hier wird zu möglichster Schonung des untersten Stammteils das sog. "Auskesseln" oder "Aus-der-Pfanne-Hauen" angewendet, d. h. die Fallkerbe wird ringsum, daher weniger tief, gehauen und der Baum dann nach einer Seite gedrüclit.

Die rascheste Arbeit und geringste Holzverschwendung ist mit $\mathrm{A} n \mathrm{w}$ e $\mathrm{n}$ d ung der Säg ge verbunden. Auch sie wird jedoch für sich a ll e in nur bei schwächerem Holze angewendet, weil mit der Stärke der Stänme die Schwierigkeit, die Bäume zu Fall zu loringen, und die Lnsicherheit der Fallrichtung bedeutend steigt.

Die Regel bildet die Fällung m i $\mathrm{A} x \mathrm{t} u \mathrm{n}$ d Säge zu s a m m e n. Zunächst wird auf derjenigen Seite des Baumes, nach welcher derselbe geworfen werden soll, möglichst tief am Stamme eine Fallkerbe (Schrot) von etwa 1/4 des Durchmessers gehauen. Alsdann setzt man auf der entgegengesetzten Seite die zweimännige Waldsäge an und sägt in der Richtung gegen die Fallkerbe wagrecht durch. Zur Erłeichterung des Sägens, und um den Stamm in die Fallrichtung zu treiben, werden hinter del Säge in den Sägeschnitt lieile eingesetzt und nachgetrieben, bis der Stamm zu Fall kommt.

Die Art und Konstruktion der Wraldsägen ist bei diesem Verfahren von wesentlichen Einfluß. Man verfertigt die Sägeblätter in neuerer Zeit vorzüglich aus Tiegelgußstah!. Das Sägeblatt ist eine Stahlschiene, die auf der einen Seite mit Zähnen besetzt ist. Die Zahnlinie bildet zweckinäßig einen Kreisbogen (Bogensägen). Die Zähne hahen in der Regel die Form eines spitzen gleichschenkligen Dreieclis (sog. Wolfszähne); daneben liommt die Form eines großen lateinisclien M vor (sog. M-Zähne), die in Hartholz gut arbeiten sollen. Das Sägeblatt. verjüngt sich von der Zahnlinie gegen den Rücken zu, damit ein Klemmen der Säge vermieden wird.

Wichtig für die Wirksankeit der Waldsägen ist das Maß der Krümmung der Zahnlinie. Lie theoretischen Betrachtungen über das richtige Maß dieser Krümmung sind bisher noch nicht zu einem Abschluß gekommen, doch sind mehrfach Versuche angestellt worden, welche auch zur Konstrulition einer Normalsäge mit bestimmtem Krïmmungsradius der Zahnlinie und bestimmter Bezahnung geführt haben. Die mehr gekrümmten sog. Bauch- orler Bogensägen (Harzer, Thüringer, Steycrische Säge) scheinen in Nadelholz vor den mehr gestreckten Sägen den Vorzug zu ver- 
dienen, wogegren letztere für das Zersehneilen des stärkeren Liubholzes angremessen sein mögen. Jedoch ist eine gewisse kirümmung der Zahnlinie auch hier gegenüber der geraden Linie von Torteil. Bei letzlerer ist die Säge sehwerer zu handlaben und förflert weniger. Her Grund hiesè Erscheinung ist das Klemmen des Sägmehls, auch hat die gerade Zahnlinie aten Nachteil, raß sie durch stärkere Abnutzung der Mitte leicht konkav wird. Bei der Bogensäge ist die Arheit leichter, da immer nur wenige Zähne aufliegen, so daß beiderseits Raum bleibt, in den sich das Sägmehl ansammelt und aus dem es dureh die wiegende Bewegung tes Sägens leicht ausgeworfen wird. Allerdings setzt die Bemutzung der Bogensäge gewandtere Arbeiter voraus, als diejenigen der mehr geraden Sägen. Aus Amerika gelangten vor einer Reihe von Jahren Sägen nach Deutschland, dic eine sehr geringe hrümmung zeigen und sich in Hinsicht auf die Form der Zähne von den gebräuchlichen deutsehen Konstruktionen wesentlich dadureh unterseheiden, daß eine Mehrzahl von Spitzen $(3-4)$ zu einem System vereinigt sind, so daß anstatt der e i n z e I n e n Wolfszähne deren mehrere zusammengefaßt sind. Auf jede solche Zahngruppe folgt wieder ein einzelner

Fig. 3.

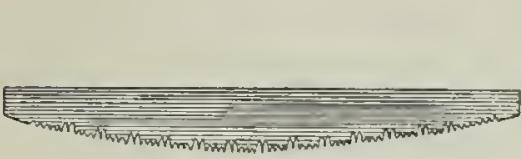

Nonpareil-Schrotsägc.
Fig. 4.

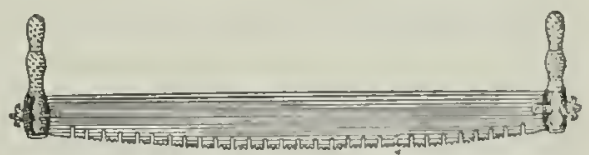

Great Americansäge ${ }^{-}$it abnehmbarem Heft.

Fig 5.

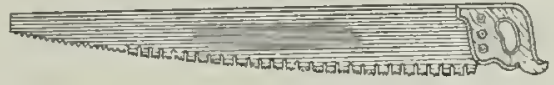

Amerikanische Trummsäge.

spitzer, kürzerer Dreieckszahn (Rammzahn), wic bei der sog. ,No n p a reilSe hrotsäge", und zu beiden Seiten der Rammzähne sind Vertiefungen, die das Sägmehl aufnehmen und ter Säge einen freieren Gang ermöglichen, oder es folgt auf jede Gruppe von Wolfszähnen statt des Raumzahnes ein Hohlraum wie bei der ,Great-Americans äg e" (vergl. die Figuren 3 und 4).

Derartige Sägen sind hinterlocht, $\mathrm{d}$. h. hinter den zwisehen den Zähnen befindlichen Tertiefungen sind Löcher angebracht, die ein leichtes Nachfeilen bei Abnutzung der Zähne ermöglichen. Sie sollen sich in harten Holz vorzüglieh bewähren; in weichem Holz scheint ihnen die Bogensäge überlegen zu sein. Sehr praktisch ist bei beiden die Befestigung der Patentgriffe (s. Fig. 4). Es werden ähnliche Sägen von bester Konstrulition und Besehaffenheit aueh in Deutsehland von der Firma Dominicus und Söhne in Fiemseheir geliefert. Dieselbe hat auch ein besonderes, sehr empfehlenswertes ,Tllustriertes Handbuch über Sägen und Werkzeuge für rle Holzindustrie" herausgegeben. Als hesonders leistungsfähig wird mehrfach die ,Non plus ultra"-Säge dieser Fima bezeichnet.

Bei allen Sägen kommt es darauf an, daß durch eine entsprechende seitliche . Ausbiegung der Zähne dem Schnitt eine solehe Weite gegeben wird, daß tas Sägeblatt, ohne sich zu lilemmen, fortwähend leieht von den beiderseits die Säge handhabenden Arbeitern hin und her gezogen werden kann. Dieses Ausliegen der Zähne, das sog. Schränken, wirl mit einer einfachen Vorrichtung, dem Selıänkeisen 
vorgenommen; auch kann man den sog. Barthschen Schränkschlüssel gebrauchen, und neuerdings wird dazu eine von der Firma Eugen Blasberg u. Comp. in Remscheid erfundene Schränkzange empfohlen. Dieselhe ist durch eine Schraube verstellbar, vermittelst deren die Zange sowohl zum feineren als auch zum gröberen Stellen der Zähne eingrerichtet werden kann. Termittelst dieser Schrauhe erfolgt das Heben bei allen Zälunen vollständig ghleichmäßig. Das Schränken nuß bei Nadedholz stärker sein, als bei Laubholz. Statt des Schüukens wendet man auch, insbesondere in Amerika, das sog. Stauchen der Zälne an, darin bestehend, daß durch einen Schlag die Spitze des Sägezahnes etwas aufgetrieben wird, so daß die Stärke des Blattes dadurch geringer ist, als die Stärke der Sägezahnspitzen, wodurch ebenfalls dem hin- und hergezogenen Blatt ein größerer Spichraum gewälırt wirr.

Die Prüfung der Sägen auf ihre Leistungsfähigkeit hat sich darauf zu erstrecken, daß man untersucht, wieviel Schnittfläche in einer gewissen Zeit geliefert wird, orler wieviel Zeitaufwand man zur Leistung gleicher Schnittflächen braucht. Die Wirkung der Säge ist um so größer, je kürzer die Zeitdauer des Schnittes. Selbstredend muB bei Vergleichung der Leistungen zweier Sägen Gleichheit der Unstände (gleiche Holzart, gleiche stärke der Hölzer, gleiche Leistungsfähigkeit der Holzhaner, gleiche Vertrautheit dersehten mit den Sägen) vorausgesetzt werden. Steile Wolfszähne in ununterbrochener Bezahnung scheinen die besten Schnittleistungen zu liefern ${ }^{1}$ ).

Die Sägen werden nicht nur beim Fällen der Stämme, sondem auch bein Zerschneiden derselben in die dem beabsichtigten Zwecke entsprechenrlen Längen gebraucht. Für die Zerkleinerung schwächerer Hölzer hat man sowohl die gewöhnlichen, in Deutschland allgemein bekannten Handsägen im Gebrauch, als auch neuerdings eine ebenfalls aus Amerika eingeführte Art, die a me rikan is c he T r um m$\mathrm{s} a ̈ \mathrm{~g} e$, die sich am besten als ein vergrößerter Fuchsschwanz, wie ihn die Schreiner zu führen pflegen, beschreiben läßt, und in Fig. 5 abgebildet ist. Die Zahnstelhng ist jedoch hier, wie diejenige der zweimännigen Valdsägen, eine senkrecht (nicht schräg, wie beim Fuchsschwanz) gerichtete. Auch diese lionstruktion bewährt sich vorzüglich. Jie Sägen werden nur von e i n e m Jann geführt, während die Bogensägen zu ihrer Handhabung zwei Arbeiter erfordem.

Die im Walde gebrauchten Aexte sind von verschiedener Form, je nach dem Zwecke, den sie dienen sollen. Man unterscheidet insbesondere die F ä I a x t mit kleinem, und die $\mathrm{S}$ y a $1 \mathrm{tax}$ mit größerem lieilwinkel. Erstere rlent besonders zum schneiden beim Hieb (Hauen der Fallkerbe), letztere insbesondere zum Aufspalten der Trümmer und Treiben der Keile. Vielfach findet man Aexte von mittlerem Bau, die heiden Zwecken gleichzeitig dienen.

Fast jede Gegend liat in Hinsicht der Axtkonstruktion ihre Besonderheiten. Allgemein verlangt man, daß die Schneide gut gestählt, der Anlauf der Sclneideflächen keilförmig, am besten etwas ausgebaucht (gewölbt), die Axt selbst nicht zu schwer und mit einem handlichen Holzstiel (sog. Helm) verseben sei. Wichtig ist eine gute Lage res Schwerpunkts. Auch in bezug auf Aexte scheinen uns die Amerikaner den Vorrang abzulaufen; wenigstens sind seit einer Reihe von Jahren amerikanische Aexte in Gebrauch gekommen, welghe sehr handliche, geschwungene Hehme, sowie stark gewölhte Schneideflächen (Blätter) haben, richtige Lage des Schwerpunkts zeigen, und sich als selı praktisch zu bewähen scheinen ${ }^{2}$ ). In Australien

1) Selur unfassende und beachtenswerte Untersuchungen üher die Leishugsfälinkeit der Waldsägen s. u. a. in Forstw. Zentralblatt $1896 \mathrm{Aug}$-Ok1.-tfeft von Geheinmal Dr. lia ye r und Lr. li a $\mathrm{s} t$.

2) Stoeklia $\mathrm{sen}$ in A. F. U. J.-Z. \*79, S. 115. 
sollen sich Aexte mit rrei breiten Rinnen oder Nuten, die von der Sclmeide zun Rücken frarallel laufen, bewährt haben, da sie leichter ins Itolz eindringen und sich nicht leicht kiemmen können. Zum glatten Ausputzen und Beschlagen der Strinme dienen besondere Breitbeile, nach Art der Zimmernannsixte gebaut; zur Fïlung schwächeren Ausselilaglolzes in Nieder- und Mittelwald benutzt man die sog. H e p p e, ein vorn gekrïmutes starkes Faschinenmesser mit hölzernem Griff.

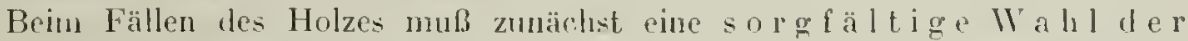

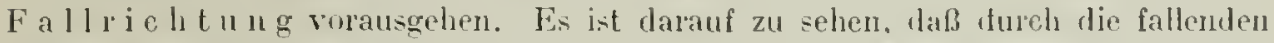
ltölzer werler del ungebende Bestanl noclı der fallende Stanm sellst besehädigt werde. Jan wirft laher die Stämme in Lücken zwischen stchende Bäume, damit diese nicht beschädigt werden und die fallenden Stämme nicht hängen bleiben. Ebenso sucht man hei Naturverjüngung die Stämme in Richtungen zu werfen, in denen sich kein liöherer Anflug oder Aufschlag befindet. Tabei ergeben sich für Schirm- und Blenderschlagbetrieb nieht selten große Schwierigkeiten, tie man durch Abasten der Stämme vor der Fällung zu umgehen sucht $\left.{ }^{1}\right)$. Der Blendersaumschlag sucht diesen Mißstand dadureh zu verneiden, daß er nit seiner Verjüngung in bestimmter Richtung fortschreitet und die Bäume grundsätzlich inmer von Jungwuchse weg gegen das noch unbesamte Altholz wirft, lureh das sie dann auch weggeschafft werden.

Ln die fallenden Stämme vor dem Abbrechen und Zersplittern zu bewahren, vermeidet man femer das Werfen auf Unelsenlreiten des Boders, alte Stöcke, Felsen usw., sowie auf liegenrles Holz.

Bei windigem Wetter nuß mit der Fällung ausgesetzt werden, da man unter solchen Lmständen hinsichtlich der Fallrichtung gar lieine Sicherheit hat.

An Bergwänden läßt man wohl auch sehräg bergauf fällen, da auf diese Weise der Stamm bis zum Aufschlagen auf ren Boclen den kürzesten Weg zurücklegt und mit der geringsten Wucht aufsehlägt, mithin der Gefalır des Zerbrechens an wenigsten ausgesetzt ist. Soll abel der mit dieser "Wurfriehtung verbundene Nachteil, daß der Stamm für das Anrüelien verkelırt zu liegen kommt, vermieden werden, soll viehmehr darauf geselren werden, daß der Stamm so fällt, wie er weggesehafft werden soll, so mub schräg bergab geworfen werden, damit der Stamm mit dem dünnen Ende voran nach abwärts weggeschafft werden kanm.

Durch das Eintreiben von Keilen in ten Sägesclmitt wird dieser offen gehalten, gleichzeitig der Stamm etwas gehoben und nach der gewünschten Fallriehtung hin getrieben. Bei Frost springen rlie Keile leicht zurück, man bestreut alsdam die Seitenflächen zweckmäBig mit Asche orter Sand. Zur Verstärkung der hebenden Wirkung lıat man die Keile anstatt mit geraden Seitenflächen auch mit treppenartig absetzendem Profil (S chn ü ck escher Zahnkeil) hergestellt. Auch wurden Versuche nit einen einzuschraubenden runden, bezw. kegelförmigen Instrument (B less ing scher Schraubenkeil) vorgenommen, jerloch olne Verbesserung der Wirkung. Ferner ist ein sog. Lniversalkeil von Förster Gizek lionstruiert worden, weleher aus :) Schenkeln besteht, die durch Trehung einer spannschraube mehr oder weniger gegeneinander gespreizt werden können (Deutsche Forstzeitung I30 \$. 864).

Besondere Vor-icht ist heim Zufallhringen hängen gebliebener Bäume, sowie bei der Aufarbeitung von Windbruchlıulz geboten, da hiertsei leicht L̈nfälle entstelien. Von Reichsversicherungeant sind Normal-Unfallverhütungsiorschriften für landund forstwirtscliaftliche Betriebe aufgestellt worlen, lie sorgfältig zu beachten sind.

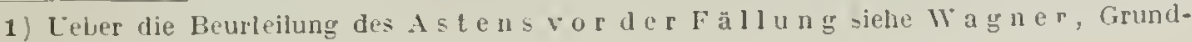
lagen der rüuml. Ordnung 2. Aufl., S. 257 ff. 
Im Interesse der Ordnung ist darauf zu halten, daß die Holzhauer in der Regel nicht mehr Stämme auf einmal zur Fälnng bringen, als im Verlauf der darauf folgenden 2-3 Tage aufgearbeitet werden könmen. Bei Durchforstungen mag diese Regel bisweilen eine Ausnahme erleiden, indem man auf einer größeren Fläche die Fällung beenden und dann erst das Zusammenbringen behufs Aufarbeitung vornelnnen läßt.

$\$ 20$. A us formung und Sortierung der Hölzer. Bei der dem Fällungsbetriebe folgenden Aufbereitung der IIölzer werden zunächst die gefällten Stämme entastet, wobei die Aeste mit dem Beil glatt an Stamme abgetrennt und überdies allc dürren Aststümpfe und Auswüclse weggeputzt werden. Das Kürzen des Derbholzes erfolgt mit der Säge, wobei die Schnitte immer senkrecht auf die Achse des Schaftes geführt werden müssen. Die Ausscheidung derjenigen Stämme und Stammteile, die einen höheren Wert bei der Verwendung zu Nutzholz als zu Brennholz haben, mus als ein Gegenstand bezeichnet werden, der besondere Aufmerksamkeit und Umsicht der Wirtschaftsorgane erheischt.

Jnrch eine gute Sortierung wird der Geldertrag wesentlich gehoben; hierbei kommt der Wirtschaft eine ausgedehnte Kenntnis des Verbrauchs der versehiedenen Holzsortimente seitens des Forstmanns wesentlich zugute.

Hinsichtlich der Sortimente, die im deutschen Reich Geltung haben sollen, sind unter einer Anzahl von Bundesregicrungen gewisse feste Bestimmungen vereinbart worden ${ }^{1}$ ). (Vereinbarung der deutschen Staatsforstverwaltungen von 1875.)

Damach rechnet man zum $\mathrm{Derbholz}$ die oberirdische Holzmasse üher $7 \mathrm{~cm}$ Durchmesser, einschließlich der Rinde gemessen. Zum N i c ht d e r b hol z gehört Reisig (die oberirdische Holzmasse von $7 \mathrm{~cm}$ abwärts) und Stockholz (die unterirdische Holzmasse und die bei der Fällung daran bleibenden Schaftteile). Das $\mathrm{L}$ a $\mathrm{n} \mathrm{g} u \mathrm{u} \mathrm{zh}$ o I z bilden diejenigen Nutzholzabschnitte, die nicht in Schichtmassen aufgearbeitet, sondern kubisch vermessen und berechnet werden. Hiervon sind S t ä $\mathrm{m} \mathrm{m}$ e solche Hölzer, die bei $1 \mathrm{~m}$ oberhalb des unteren Endes über $14 \mathrm{~cm}$, $\mathrm{S} \mathrm{t}$ a $\mathrm{n}$ g e $\mathrm{n}$ hingegen solche, die bis mit $14 \mathrm{~cm}$ Durchmesser halten, wobei unterschieden wird zwischen D e r bstan ge 1 (über 7 bis mit $14 \mathrm{~cm}$ bei $1 \mathrm{~m}$ über dem Abschnitt gemessen) und Reisstange $\mathbf{n}$ (bis mit $7 \mathrm{~cm}$, ebenso gemessen). S c h i c h t$\mathrm{n} u \mathrm{tz} \mathrm{hol} z$ ist das in Schichtmaße oder in Gebunde aufbereitete Nutzholz.

Nutzrinde ist die vom Stamm getrennte Rinde, soweit sie zur Gerberei oder zu sonstigen techischen Zwecken benutzt wird.

Bei Brennlıolz hat man zu unterscheiden: S c lı e it e r, ansgespalten aus Rundstücken von über $14 \mathrm{~cm}$ am obercn Ende, ferner $\mathrm{K}$ n ü p pel oder P r ü g c l üler 7 bis mit $14 \mathrm{~cm}$ am obern Ende, R e is i $\mathrm{g}$ bis mit 7 cm Durchnesser am untern Ende, und zwar R e is pr ü gel (in Schichtmaßc aufgesetzt) oder Well en (Gebunde von 1 m Länge und $1 \mathrm{~m}$ Umfang), endlich $\mathrm{Bren}$ r rind e und S töck e.

Dic Messung des Langnutzholzes soll in der Regel 12 it der Rinde erfolgen, nur dann olme Rinde, wenn das Holz vor der Messung entrindet wird (vergl. weiter unten). Stänme werden auf Grund der gemessenen Längen (in Metern und geraden Dezimetern) und Durchmesser kubisch berechnet, lürzere Blöcke bis mit 5 m Länge können bei Messung des oberen Durchmessers nach lokalen Sätzen berechnet werden. Bei S t a g e n h o l z, das zunächst nach der Stückzahl aufgenommen wird, liamn cbenfalls Berechnung nach Durchschnitts- und Erfahrungssätzen stattfinden.

Die Maß- und Rechnungseinheit für Iolz bei der Absehätzung und Abschätzungskontrulle bildet der liubikmeter fester Holzmasse (Festmeter).

1) J. d. preuß. F. ᄂ. J. 1876, S. $3 \notin 1$. 
Dies führt uns zur Besprechung der A usformung des Hol zes be i I e r Ernte. Nach der Fällung der Bäume landelt es sich zunächst darum, dieselben in für die Verwertung möglichst geeignete Stücke zu zerlegen.

Zunächst können als allgemeine $\lambda$ uf bereitungsgru usätze getten: die gefällten Bäume ju Stücke von transportablen Dimension e n und Formen zu zerlegen; eine solehe 'Teilung vorzunehmen, daß die Teile eine un ö g-

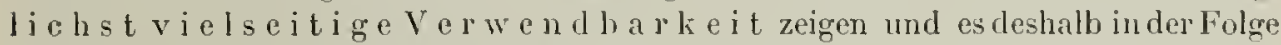
möglich ist, sie derjenigen Verwendungsart zuzuführen, für die sie sich jeweils am besten eignen und zu der sie daher am meisten geschätzt werden; und endlich solche Einheiten zu bilden, die gle i c h a r tige $Q$ u a lit ä t zeigen und daher greichen Wert für die Mlaßeinheit besitzen und zu gleichem Zweck Verwendung finden kiönnen.

Dabei wird man übrigens eben im Interesse möglichst vielseitiger Verwenrbarkeit des einzelnen Stücks die Schäfte zunächst möglichst wenig zerschneiden und die weitere Teilung dem Käufer überlassen.

Wenn z. B. im Eich en holz der untere Teil eines Stammes wertvolles Schreiner- oder sonstiges Starknutzholz gilbt, der Gipfel hingegen nur zu Schwellenholz geeignet erscheint, so wird man zwar eine Bezeichnung der Grenze zwischen Starkholz und Sehwellenholz vornehmen und sodann den Gipfel bis zu dem Minimun der Schwellenholzstärke (in einer Länge, die ein Vielfaches der Schwellenlänge - 2,4 bis $2,5 \mathrm{~m}$ - darstellt) liegen lassen, allein man wird den Stamm auf der Grenze nicht zerschneiden lassen, weil vom Liebhaber vielfach eine noch vorteilhaftere Verwendung ausfindig gemacht wird, an der ihn das vorherige Zerschneiden hindern würde.

Auch bei anderen $\mathrm{L}$ a u b n $\mathrm{n} \mathrm{zh}$ ö $\mathrm{z}$ e r n ist eine Zerstückelung von Stämmen, vielleicht veranlaßt durch Kírümmungen oder Aeste, bisweilen von Nachteil, weil dem Käufer öfters ein Fehlbetrag von dem Bruchteil eines Neters den Stamm zu einer beabsichtigten Verwendung untauglich macht.

$\mathrm{N}$ a delholzstä $\mathrm{mm}$ e läßt man bis zu einer Stärke aushalten, die noch eben zu Nutzholzzwecken brauchbar ist.

In Süddeutschland hat in neuerer Zeit eine Aufbereitung des Nadelholzstämme - als sog. L a n g lo $\mathrm{l}$ z - allgemeine Verbreitung gefunden, welche dic Nutzholzbrauchbarkeit der Schäfte durch Berücksichtigung von $L$ ä $n$ ge und $D$ a $r$ c l $1-$ messer a m d ü n n e $\mathbf{n}$ Ende (Ablaß oder Zopf) in glüclilichster Weise erfaßt. Die Aufbereitung erfolgt nach Kilassen verschiedener Längen und Zopfdurchmesser. Diese Klassenbildung heißt die ,He $\mathrm{I}$ bronner Sortierung ", die, durch Flößerei und Holzhandel nach dem Rheine entstanden I), seit alter Zeit in württenbergischen Schwarzwalde gilt und durch den Heilbronner Holzhandel weiter verbreitet worden ist. (Ueber die Geschichte der Ileilbronner Sortierung vergl. II ä h $n$ l e ,,Sortimentstafeln für Fichtenbestände Württembergs 1905, Einleitung). Die Heilbronner Sortierung bildete früher 5 Langholzklassen, jetzt als Sürldeutscher Tarif 6 Klassen:

I. Kilasse bei mindestens $18 \mathrm{~m}$ Länge wenigstens $30 \mathrm{~cm}$ Ablaß

II. Klasse bei mindestens $18 \mathrm{~m}$ Länge wenigstens $2: 2 \mathrm{~cm}$ Ablaß

III. Irlasse bei mindestens $16 \mathrm{~m}$ Länge wenigstens $17 \mathrm{~cm}$ Ablaß

IV. Kllasse bei mindestens $14 \mathrm{~m}$ Länge wenigstens $14 \mathrm{~cm}$ Ablaß

V. Klasse bei mindestens $10 \mathrm{~m}$ Länge wenigstens $12 \mathrm{~cm}$ AblaB

V1. Klasse alles kürzere und schwächere Langholz.

Neben diesen Langholzklassen geht ein weiteres Sortiment, Sägholz oder Alschnitte genannt, einher, bei dem die Länge keine entscheidende Rolle spielt, das

1) v. Schauen burg, Mandener forstl. Hefte XV-WVII. 
aber, weil weniger wertvoll, nur in geringerem Unfange aufbereitet wird. Die Heilhronner Sortierung hat zuerst in Württemberg (etwa seit 1860) allgemeine Anwendung gefunden und ist in neuerer Zeit von den meisten süddeutschen Staaten übernommen worden. (Baden-reichsländischer ']'arif.)

Die Einführung rerartiger gemeinsaner Grundsätze für verschiedene Verwaltungen ist den Holzhandel selır erwünscht ${ }^{1}$ ). Der deutsche Forstwirtschaftsrat hat sich 1901 und 1904 mit dieser Frage beschäftigt und es als wünschenswert bezeichnet, daß die Nlessung und Sortierung der Handelshölzer, soweit es die Verhältnisse gestatten, in den deutschen Waldungen nach gleichen Grundsätzen erfolge ${ }^{2}$ ).

Es ist nicht immer richtig, daß hei Nadelholzschäften die größere Länge auch dem größeren Kubikinhalt entspricht. Es kommt, insbesondere bei tief herab beasteten und infolgedessen abfälligen Stämmen vor, daß durch Abschneiden von 2-3 Meter an Gipfel der Mittendurchmesser des Stammes um so viel sich erhöht, daß ein höherer Kubikinhalt bei der Berechnung resultiert, als wenn man dem Stanm jenes Gipfelstiicli belassen hätte.

Allgemeine Regeln für vorteilhafteste Entwij,felung der Nadelholzschäfte sind wohl schon aufgestellt worden, haben jedoch in ler Praxis kaum Eingang gefunden.

Grebe schlägt vor, die Ablängung so zu bewirken, daß der obere Durchmesser 1/3 der in Brusthöhe gemessenen Stammstärke betrage; auf diese IVcise soll der Stamm ein gutes Anschen behalten und an Gebrauchsfähigkeit gewinnen ${ }^{3}$ ).

Offenbar spielen hierbei die örtlichen Verwendungsarten, z. T. auch Gewohnluciten die größte Rolle; vor einen zu weit getriebenen Bestreben, die Nutzholzsclıäfte bis in die äußersten Zopfenden als Nutzholz ausformen zu lassen, muß aber entschieder gewarnt werden; dem höheren Nutzholzprozent steht sonst bisweilen ein geringerer Einheitspreis pro Festmeter gegenüber, inden der Käufer die für ihn wertlose Gipfelspitze bei seiner lialkulation und bei Abgabe seines Gebotes für nichts rechnet.

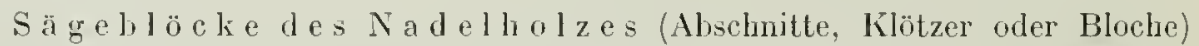
halıen gewöhnlich die durch den Handel gegebenen Normallängen ( $3-4 \frac{1}{2}$ Meter). Bei dem Umstand, daß bisweilen auch Bretter von nicht marktgängigen Längen begehrt werden, empfiehlt es sich, hesomders schöne Schnittlö̈zer in ganzer, zum Bretterschneiden eben noch tauglicher Länge liegen zu lassen, damit der Käufer Gelegenheit hat, ungewöhnliche Blocklängen ausschneiden zu lassen.

Dic Frage, bis zu welchem oberen Durchmesser Nadelholzsägeblöcke auszuhalten sind, beantwortet sich nach der örtlichen Nachfrage.

Zur eigentlichen Brettergewinnung für den Hantel sind Stärken von $30-36 \mathrm{~cm}$ am vorteillaftesten (nornale Breite der Bretter $29 \mathrm{~cm}$ ); für Anfertigung von Kisten, sowic zur Herstellung von Latten, Stollen, Leisten etc. kann man viel weiter (selbst bis $20 \mathrm{~cm}$ ) herabgehen.

Man teilt die Sägeblöcke nach Abstufungen der Mitten-, oder auch wohl (z. B. in Sachsen) der Oberstärke, von 5 zu 5 oder $10 \mathrm{zu} 10 \mathrm{~cm}$ 1)urchmesser in Kilassen ein.

Anbrüclige Alsschnitte finden immer ihre V'erwendung, z. B. zu Kisten-, Ver-

1) Th a t e r. ,Allgem. deutscher Holzklassentarif in sicht". A. F.- u. J.-Z. 1902, S. 365 fr. H of $\mathrm{fm}$ a $u \mathrm{n}$, ,Die Aufslellung gleicher Holzlaxklassen für ganz Deulschland." A. F.- 11. J.-Z. 1903, S. 179 If. E b e r h a r d , ,Aufstellung gleicher Holzlasklassen und Draufholzirage." A. F.11. J.-7. 1906, S. 130 .

2) К schaftsrats).

3) Gr e be, Forstbenulzung, 3. Auflage, S. 131. 
schalungstrettem u. dergl., man muß theselhen nur als solche besomlers bezcichnon und heim Verkanf von her guten Ware sontern, wie es denu uberhaupt als Grund-atz festzulalten ist, laß man dir schadlaften Stellen der Hölzer nicht zu verdechen suchen, sondern dem Küufer offen legen soll, da im ersteren Falle das Vertranen für kïnftige Verkïufe geraubt wird.

Nadelhölzer werden (bei der F i c h t e sehon zorr Gewinnung der Rinde und zur Vorbeugung gegen den Bohrkïfer und Borkenkäfer) meist entrindet; sie trocknen hierbei leichter aus und gewinnen an Transportfähigheit. Zur Verhinderung des: Aufreißens läßt man wohl an len Enden, sowie auch in der llitte Rindenringe stehen.

Eine Ausnahme von der Regel des Schälens machen Hölzer, die zu Brunnenröhren bestimmt sind (Kiefern oder Fichten); dieselben sincl wegen der Gefahr des Reißens unẹtrindet zu lassen und baldmöglichst aus dem Walı und ins Wasser zu seliaffen.

Bezüglich der Aussortierung der geringeren Nutz- und Stangenhölzer lassen sich ins einzehne gohende Vorsehriften nicht wohl erteilen. Die möglichste Ausnützung der Hiebsergebnisse zur Formung soleher Sortimente ist oberster Grundsatz der Forstbenutzung. Selbst wenn die zu erlangenden Erlöse nur wenig über dem gewölınlichen Brennholzpreis stehen, verdient es Beaehtung, daß durch reichliche Ausnülzung der Nutzholzsortinente der Brennlolzanfall vermindert und ladureh die Möglichkeit gegeben wird, selbst geringere Brennhölzer besser zu verwerten.

Bei Ausformung der St a nge n höl z e r (Hopfenstangen, Wagnerhölzer) ist tiefer Aushieb derselben aus dem Boden sowie Beibehaltung der gröBtmöglichen Länge anzustreben; das Entgijfeln ist also in der Regel zu unterlassen. Man legt die Stangen in Haufen, deren Zahl meist auf je 10 abgerundet ist, zusammen.

Bam- und Weinpfähle, Telegraphenstangen, überhaupt solche Sortimente, die in bekannten Längen gebrauclıt werden, läßt man so ablängen, wie es der Begehr fordert.

Auch bei den Narlelstangenhölzem ist das Schälen viclfach üblich und nützlich, teils wegen Erleichterung des Austrocknens, teils als Vorheugung gegen Inselitenbeschädigungen.

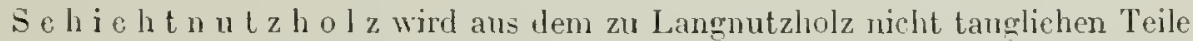
des Einschlages, der sunst nur Bremhliolz liefert, ausgesondert. Es handelt sich hier meist mm astremes, glattspaltiges Holz für Schnitzer, Böttcher, Wagner, Felgenhauer, Drechsler ete. Bei Ausformung desselben ist besonters darauf zu sehen, daß nieht wertwolles und besser bezahltes Langnutzholz in Seheitholz zersclinitten wird, dals vichnehr mur solche Nutzholzabschnitte, dic wegen irgend eines Fehlers in größeren Längen nicht zu benutzen sind, zur Formung des Schichtnutzholzes verwandt werden, letzteres im übrigen aus dem Brennholz ausgeschieden wirl.

$\mathrm{Br}$ en n h o l z zerfält in Scheitholz und Prïgelholz; unter letzterem sind die Rundstücke von über 7 bis 14 em Durchnesser am oberen Enlr zu verstehen; stälicre Hölzer werden behul's leichterer Austrocknung in Scheiter gespalten; bei normal gewachsenen Holze bedient sich der Holzhauer hier nelıen der schweren keilförmignn Spaltaxt des keils; Verwendung finden hölzorne und e is erne Ke ile; erstere haben den Vorzug vor letzteren, daß sie mit dem Rücken der Axt eingetrieben werden können, dagegen den Nachteil größerer Reilıng und daher geringerer Wirlisamkeit. Wer beste und meistverwendete Keil, der die Vorteile lles Holzkeils mit lenen des Stahlkeils verbindet, ist der zusammengesetzte Keil mit eisernem schul und hülzernem Kopf, welch letzterer aus zähem Hainbuchenlwh hergestelt wird und gegen das Breitschlagon dureh einen Eisenring gesichert ist. 
Auch bein Brennholz muß auf eine sorgfältige Sortierung Bedacht gerommen werden; zunächst müssen die verschiedenen Holzarten je nach ihrem Brennwert auseinandergehalten und dürfen beispiclsweise nicht Buchen und Eichen untereinander gesctzt, sondern allenfalls nur solche Holzarten zusammen in einen Stoß gelegt werden, die in ihrer Brenngüte gleichstehen. Es ist forner darauf zu sehen, daß zu gesundem Holz kein anbrüchiges, zu Scheitholz keine schwachen Prügel gelegt werden; knorriges $\mathrm{Holz}$ ist von glattspaltigem zu trennen.

Sortimente, die nur spärlich vorkommen, so daß man aus ihnen keinen vollen Stoß herstellen kann, lege man nicht zu der nächst besseren, sondern zu einer geringeren Klasse; im ersteren Falle wird das Ansehen des guten Holzes geschmälert, im letzteren gewimt die Verkaufsfäligkeit des schlechten durch Beimischung von etwas besserem Holz.

Alle Stöße müssen gut und dicht zwischen fest eingeschlagene Stützen gelegt werden, sie erhalten die richtige Scheitlänge und normale Weite, in der Höhe giht man oft $10 \mathrm{~cm}$ Uebermaß (Darrschicht) zu, wem das Holz bis zur Verwertung voraussichtlich einige Zeit im Walde stehen bleiben muß.

Zur Erlangung guten Sortierens und Aufschichtens der Brennhölzer hat man die Aufstellung besonderer $\mathrm{H}$ o l z s e t z e r vorgeschlagen, derart, daß die gewöhnlichen Holzhaucr das Fällen, Ablängen und Aufspalten besorgen, während das Sortieren und Setzen besonders bevorzugten Holzhauern übertragen wird. Man geht davon aus, daß das Holzsetzen besondere Lebung und Geschicklichlieit erfordere; auch nimmt man an, daß der Holzsetzer, selbst wenn er auch in Akkord arbeitet, doch durch ein lückiges Setzen nur einen geringeren Mehrverdienst habe, als der Holzhaner selbst, da er nur an den geringen Kosten des Setzens, nicht aber an ten Hauplkosten der Aufarbeitung teilhabe, daher kein so großes Interesse an fehlerhafter Arbeit, die ein Mehrergebnis hervorruft, haben könne. - Diese Erwägungen sind ohne Zweifel nicht unrichtig, allein ohne cine eingehende Liontrolle seitens des Wirtschaftspersonals wird auch der Holzsetzer nicht ordentlich arbeiten und eine Erschwerung der Betriebsarbeiten wird mit dieser Einrichtung immerhin verbunden sein; dasselbe scheint daher in der Praxis wenig Eingang gefunden zu haben.

A s t- und $\mathrm{R}$ e is ho $\mathrm{l}$ z wird entwerler mittelst Holzwieden, bezw. dünnem Draht in Wellen gebunden oder in Raummeter zusammengelegt. Bei Sorticrung des Reisholzes in Wellen, wohei die Normalwelle $1 \mathrm{~m}$ Länge und I m Umfang, oder 1,5 m Länge und 0,8 m Umfang haben soll, empfichlt sich zul Beförderung des Austrocknens die Aufstellung derselben in schief gegeneinander dachförnig geneigten Reihen, nicht aber wagrechte Auflagerung; oben auf die Reihe legt man für je 10 Stück eine Welle wagrecht, so daß sofort ersehen wird, wieviel Zehner der StoB enthält. Die stärkeren Knüppel schneidet man bisweilen zweckmäBig als sogenamte $R$ e is $k n$ ü p p e l aus und läßt dieselben ins Raummaß setzen. In holzreichen Gegenden empfiehlt es sich dann üfters, auf das Ausbinden des geringen Reisholzes, gar keine weiteren Kiosten zu verwenden, sondern dasselbe auf Haufen zusammenbringen, zwisehen einzuschlagende Pfähle aufschichten zu lassen und in dieser Form nach dem Raummaß zu verwerten. - Inshesondere erweist sich dieses Verfahren bei Verwertung des Nadehreisigs, das in manchen Gegenden als Streumaterial sehr gesucht ist, nützlich; meist wird dasselbe jedoch einfach auf Haufen gebracht und nach Wellen geschätzt.

S t o e k h o l z gewinnt man entweder mittelst der in 19 beschriebenen Baumrodung oder, nachdem die Stämme nit Axt und Säge gefällt worden sind, dureh hesonderes Ausgraben der in Boden verbliebenen Stöcke. Das Verfahren der Stock- 
rodung nach vorausgegangener Fällung der Stämme mit Axt und Säge ist das weitaus gehrïuchlichste Verfahren.

Auch beim Stockroden werden die Hauptwurzeln vom Stamm getrennt und aus der Erde georahen; den stehengebliebenen Stock zerkleinert man in der Regel mittelst Zerspaltens in einzelne Teile und Herausdrehens derselben nittelst llebestangen; ist der Stock nierlrig, so wird er wohl auch ganz ausgegraben, auf die $\mathrm{Ab}$ schnittsfläche gesetzt und von unten aus gespalten.

An steilen Hängen oder inmitten von Verjüngungen beläßt man wohl auch das Wurzelholz im Boden und spraltet nur den eigentlichen Stock des Baumes ab, indem man möglichst nahe an der Erle einzelne Kerben einlaut und von oben in der entspreehenden Breite des Stammes lieile eintreibt (Abschmatzen, Ausspitzen).

Neben der bloßen Handarbeit unter Benutzung der gewöhnlichen Holzhauerwerkzeuge, sowie von besonderen Stockrodemaschinen (Krupp, Boos...), auf die hier nieht weiter eingegangen werden soll, wird zur Zerkleinerung des Stockholzes auch die Anwendung verschiedener Sprengstoffe (Pulver und Dynamit, Cahäicit usw.) mehrfach empfohlen. Hierbei wird der zu sprengende Stock von der Seite, von oben oder auch unten angebohrt, das Bohrloeh mit Pulver oder Dynamit besetzt und dieses unter Anwendung einer Zündschnur (bei Dynamit derart, daß an der Zündschnur ein Zündlütchen aufgesetzt und in das Dynamit eingefülırt ist) und nach gehörigem Verschluß des Bohrloches zur Explosion gebracht.

Dynamit wirkt kräftiger und zerreißt den Stock mehr als Pulver, bei dem öfter's nur Risse entstehen, die zum weiteren Angriff mit Axt und Keil benutzt werden.

Man hat, insbesondere zur Pulversprengung, besondere Instrumente konstruiert, die zur sicheren Einführung der sprengrpatronen in das Innere des Stockes und zu einem guten Verschluß des Bohrloches dienen. Es sind dies die sog. S p r en $\mathrm{g}-$ se hr a u be $n$; gemeinsam ist ihnen allen eine in das Bohrloch einzuführende holıle Schraube, die auf die Zündmasse aufgeschraubt wird, bezw. diese nebst der Zündungsvorrichtung enthält. Am volliommensten ist die von Forstmeister U ric h erfundene Zündnadelsprengschraube ${ }^{1}$ ), bei der das Pulver durch eine mit einer Spiralfeder verbundene Zündnadel, die in einen Zündspiegel einsehlägt, zur Entzündung gebracht wird, während bei anderen Sprengschrauben, z. B. denjenigen von F I ib o lin, sowie von Preuschen, die Zündung durch Abdrücken einer dem Selılosse eines Gewehres entsprechenden Vorriehtung zu bewirken ist.

Statt der Sprengschrauben hat Oberförster Lang den Śp e ng lifropf zum Verschluß des Bohrloches konstruiert ${ }^{2}$ ), ein kegelförniges Eisenstück, in seiner Achse zur Aufnahme der Zündschnur durchloeht und so eingerichtet, daß es nittelst cines hölzernen Schlegels in das nit Pulver geladene Bohrloch cingetrieben wird. Diese Methode scheint wegen der Billigkeit des Apparates (50 Pfennig pro Stück), die es ermöglicht, daß die Holzhauer sich denselben auf eigene Rechnung beschaflen können, beachtenswert.

In allgemeinen ist die Stockliolzzerkleinerung durch Handarbeit gegenüber der Verwendung von Sprengstoflen bis jetzt wenig zurückgegangen. Es liegt dies vornehmlich daran, dali die Anwendung von Pulver oder Dynamit nur bei dem Baumrodungsverfabren von überwiegendem Vorteil ist, indem die Wirksankeit dieser Sprengstoffe an die Bedingung geknüpft ist, daß der gerodete Stock bereits auBerhalb des Borlens liegt, wogegen, wenn sich der Stock nach Abtrennung des Bammschaftes noch in der Erde befindet, mit den Sprengmitteln ein geringerer Erfolg erzielt wird.

1) Z. f. F. U. Z. 1876, S. 418. Zündnadel-Sprengschraube von Ǔrich.

2) A. G.- U. J.-Z. 1882, S. 68 . Der Sprengpfropf von Lang. 
Was ïlrigens die Vorteile der Anwendung von Sprengmitteln gegenüber der Handarbeit, ausgedrückt in der Verminderung der Gewinnungsksten, anlangt, so liüfte sich dieselbe gewiß bei harten, zähen und vermaserten Stöcken als nennenswert herausstellen ${ }^{1}$ ); bei Fichten hat sich die Handarbeit l,illiger gezeigt, als die Anwendung von Sprengmitteln; auch bei Kiefern stellte sich die Gewinnung von 1 l'm Stockholz billiger durch Handarbeit, als durch Dynanit 2).

Diese letzteren Erfahrungen beziehen sich jedoch $\mathrm{n}$ i $\mathrm{c}$ h t auf Stöcke, die bei der Baumodung gewonnen waren.

Es ist nicht anzunehmen, daß die Mandarbeit durch die Stocksprengung mit Pulver, Dynamit und anderen Stoffen im großen und ganzen verdrängt werden wird; diese Sprengstoffe werden jedoch immerhin als Hilfsmittel Beachtung verdienen, wobei Dynamit wegen der größeren Umständlichkeit des Bezugs und der leichteren Veranlassung zu Unfällen, sowie der Schwierigkeit del Anwendung desselben im Winter (es gefriert schon bei +80 Celsius) gegenüber dem Puver im Nachteil stehen dürfte. Neuesters wird ein neues Sprengmittel, C a h ü c i t, von vielen Seiten angelegentlich empfohlen.

Das zerkleinerte Stockholz wird in Raummeter aufgesetzt. Da dasselbe nie glatt und gerade, sondern immer sperrig und nehr oder weniger gekrümmt ausfällt, sn ist beim Aufsetzen eine besondere Aufsicht auf gutes Legen zu führen; am meisten emprichlt es sich, die Stöße nur in Tiefen von 1’. Meter aufschichten zu lassen, da auf diese Weise Undichtigkeiten und Lücken an leichtesten entdeckt werken.

Auch beim Stockholz ist es geboten, die verschiedenen Holzarten beim Aufsetzen zu sondern; vom Fichtenholz gewinnt man öfters viel anbrüchige Stöcke und Warzeh. Diese müssen von dem gesunden llaterial bei dem Aufsetzen streng geschieden werden.

S21. Nutzung der Rinde. lu Laublolz ist in der Regel nur rlic Gewinnung der E j c h e n r i n d e ron jüngeren Stämmen, insbesondere im Nieder- und vittelwald, Gegenstand der forstlichen Nutzung. $1 m$ Nadehald schält orler räppelt man unter Umständen fast alle Stämme zur leicliteren Austrocknung unc Abwehr von Insektenschärlen, allein eine Nutzung von besonrlerer Erheblichkeit gewährt in den rleutschen Wäldern hierbei nur die Fichte, deren Rinile zur Lohgewinnung dient.

Die Lösbarkeit der Rinde vom Holzkörper ist an die Zeit cles Saftsteigens, die mit dem Kinospenausbruch zusammenhängt, gebunden. Die beste natürliche Schälzeit ist vom Mai bis Enrle Juni, selbst bis Juli. In diese Zeit fällt also die Rindennutzung, da die in Frankreich durch Le Maître erfundene Hethode der Dampfschälung, bei welcher die zu schälenden Hölzer in eine mit Jampf gefüllte Kiste gelegt werrlen und das Schälgeschäft von der Jahreszeit unal,hängig ist, in Deutschland keinen Eingang gefunden hat ${ }^{3}$ ).

Die Schälzeit der Traubeneiche beginnt 8-12 Tage später als die der Stieleiche: die Rinrle löst sich am besten bei warmer und feuchter Lult, insbesondere in den Morgen- und Mbendstunden.

Nach früheren Versuchen nahm man an, daß das Gewicht der Volumeneinheit zu Ende der Schälzeit größer sei als zu Anfang derselben; so z. B. hat Oberförster

1) Nach $H$ e $B$ bezifferten sich die Gewinnungskosten für Buchenstöcke bei Pulversprengung auf $1,02 \mathrm{Ml}$, hei Handarbeit auf 2,33 $\mathrm{ll}$. pr. rm. Es waren dies durch Baumrodung gewonnene Stöcke. F. Z.-BI. 1883, S $1 \pm 7$.

2) Z. f. F. 11. J. 1878, S. 337. S $\mathrm{c}$ h u b e ro, Versuche mit Stockiprengungen. F. Z.-Bl. 1880, S. 99 [f. Lebre Dynamit-Stockiprengver-uche.

3) Z. f. F. u. J. I8io, S. 341 . Die Dampfentrindung von $A$. Be r n hard t. 
R e u $B$ machgewiescn, daß gleich große Gehunde Lohe im Yai geschält IH,I fỉilo, im Juni geschält hingegen 14,7 Kilo wogen I).

Später hat v. Eschwe ge eine Erfalırungr veröfentlicht, nach rler sich umgeliehrt für die frülıer geschälte Lohe ein größeres Gewicht ergibt, als für die słräter geschälte. Rinde, in der Zeit rom 1.-14. Nai 1878 gesclıält, ergab ein Gewicht ron 6,9 Kilo pro Gebund, während gleichgroße Gebunde desselben Standortes, vom 15. bis Enıle Mai geschält, in Durchschnitt nur 5,9 Kilo gewogen haben ${ }^{2}$ ).

Jag num aber die eine oder andere Beobachtung richtig sein, so wird doch jedenfalls der Eichenschälbetricb so f r ü h ze it i g a ls mögli ch einzusetzen haben, schon im Interesse einer rechtzeitigen Beendigming rler Ernte, danu aber auch zur Erziehng eines hesseren Ausschlags von den gehauenen Stöcken, dem noch Zeit zu guter Verholzung bleiben muB.

Das Verfaluren bei der Rindenernte ist folgendes: Zunächst wird schon vor der eigentlichen Schälzeit das sog. Pammholz, d. h. die den Eichenausschlägen beigemischten anderen Holzarten, sowie die nicht schälbaren Eichenloden, gehauen und aus den Schlägen entfernt, sofern dies nicht schon einige Jahre früher geschehen; gleichzeitig werden wohl auch die Wasserreiser von dem Eichenschälholz abgehauen.

Das Schälen selbst erfolgt nach verschiedenen Verfahren. Vielfach angewendet wird das $\mathrm{S}$ chäl e n a m li e gen de $\mathrm{n} \mathrm{Holz}$, inrlem zunächst die Stangen rom Stock getrennt und in $1 \mathrm{~m}$ lange Stücke zerlegt werden. Das Loslösen der Rinde erfolgt hierauf durch Klopfen mit Holzschlegehı auf hölzemer Ĺnterlage. Das Verfahren hat den Nachteil, daß durch das Kḱlopfen sowohl Saft wie Rindenteile verloren gehen, daß die Rinde gequetscht wird, daher leichter schimmelt, und daß endlich besondere Vorrichtungen zum Trocknen rel Rindenrollen notwendig sind.

Ein weiteres Verfahren ist das $\mathrm{S}$ t e he $\mathrm{n} \mathbf{d} \mathrm{s} \mathrm{c}$ h ä $\mathrm{l}$ e $\mathrm{n}$. Hicr werlen nach $\mathrm{Ab}$ hieb der Aeste die stehenden Stangen von unten her geschält, indem man die Rinde zunächst auf einer Seite der Länge nach aufreißt, sie am Fuße der Stange ringsum löst und nach oben abzieht. Zur Loslösung der Rinde berlient man sich besonderer Werkzeuge, der Lohlöffel. Die Loslösung erfolgt bis an die Zweige unter Verwendung von Leitern.

Da die Rinde hierbei am Stamm hängen bleiht, so troclinet sie leicht und rasch. Nachteilig ist, daß die Rinde von den Aesten und Zweigen nicht gewonnen werden kann, auch ist las Verfahren ermüdend.

Eine dritte llethode ist die rles Geknicktschälens. Die Stange wird hierbej von unten im Stelıen bis zu $1 \mathrm{~m}$ Höhe geschält, hierauf nach Einlıuen mit der Axt geknickt, so laß die spitze vom Boden aus erreichbar ist und numehr die liegende Stange mit Leichtigkeit weiter geschält. Zur Gewinnung der Rinde von den Zweigen werden diese geklopft. Die Rinde bleibt auch hier zum Trocknen an Stamme hängen.

Dieses Verfahren ist wohl ras heste. Weil es bequem zur Ausführung zu bringen ist und eine sorgfältige Nutzung der Rinde gestattet.

Wesentlich ist nun weiterhin ein $r$ a $c h e s A u s t r o c k n e n d e r$ Rinde, wobei es darauf ankommt, daß dieselbe nicht beregnet wird, da sie sonst durch Wrasser einen Teil ihres Gerbstoffes verliert.

Damit das Trocknen rasch ronstatten geht und die Rinde lierbei nicht auf dem Borten aufliegt, weil sie dabei leicht schimmlig wird, fertigt man heim Liegendschälen besondere Trockengerüste, indem man 2 Paare von stangen kreuzweise in

1) M. f. F, II, J. $1366, \mathrm{~S}, 450$.

2) Z. f. F. 11. J. 1886, S. 283. ․ E $=$ c ll w e g e, Einfluß der Schälzeil auf das Giewichl der Eichen-Lohrinde. 
Boden befestigt und, nachdem dieselben an dem obersten Teil zusammengebunden sind, in die so entstandene Gabel eine weitere Stange legt, auf der nach dem Borlen in der Fichtung nach der Sommenseite weitere Stangen angelegt werden.

Auf diese Gerüste werden die Rinden dünn ausgebreitet und, nachdem eine Seite abgetrocknet ist, ungewandt ${ }^{1}$ ).

Bei Eintritt von Regen deckt man wohl auch die Rinde mit Tüchern zu. Daß ein solches Verfahren, das in Ungarn allgemein eingeführt ist, in Deutschland nur ausnahmsweise angewandt wird, gehört mit zu den stehenden Ǩlagen der Rindenkïufer.

Nach der Abtrocknung erfolgt das Binden der Rinde in Gebunde. Hierzu benutzt man besondere Böcke, (Rinden-oder Bindböcke), aus kreuzweise in die Erde geschlagenen Prügehn bestehend. Die Gebunde werden mit Wieden oder Stricken gebunder. Thre Länge und Stärke richtet sich nach den ortsüblichen Gewohnheiten und variiert zwischen $1-2$ Veter Länge und $0,6-1,10$ Meter Umfang. Bein Aufbinden wird gleichzeitig sortiert.

Van sortiert entweder nach. J u n g- und A l t r in de, oder schärfer (Sortierung des früheren Heilbronner Rindemnarkts) nach:

G l a n z rin d e (Jung- oder Spiegelrinde) von Loden bis zu $10 \mathrm{~cm}$ Stärke in $1 \mathrm{~m}$ Höhe über dem Boden. Diese Sorte bildet die bestc Qualität, ist glatt und silbergrau, ohne Borkebildung; sie stammt aus bis zu 20jälırigen Schälschlägen.

Pi e itelrind e, von $10-20 \mathrm{~cm}$ starken Stammstücken, hat geringere Qualität, ist rauh (beginnende Borkebildung) und stammt aus Durchforstungen und älteren Schälschlägen.

Grobrinde (Rauls- oder Altrinle) von Stammstüclien und Aesten über $20 \mathrm{~cm}$ Durchmesser, ist starkborkige Rinde und zeigt geringste Qualität.

Da die IRinle gewöhnlich nach dem Gewicht verkault wird, so erfolgt in diesem Fall unnittelbar nach dem Abtrocknen das Verwiegen unil die Lebergabe an den liäufer. An manchen Orten ist der minder sichere Verkauf nach Gebunden im Gebratich.

Auch von älteren Eichenstämmen wird in manchen Gegenden die Rinde als Gerbmaterial gewonnen.

Ilan schält hier meist in Liegen, indem rlie Rinde in meterlange Kränze eingekerbt, mit einem Lohschlitzer aufgerissen und sodann abgelöst wird. Doch ist auch das Verfahren des Stehendschälens im Gebrauch, wobci die geschälten Stämme nicht alsbald nach dem Schälen, sondern crst im folgenden Winter abgehauen werden; dieselben sollen lierbei an Güte und Festigkeit des Holzes gewinnen, indem sie in Gipfel grün werden, auf welche Weise der Saft herausgezogen wird ${ }^{2}$ ).

T)er Verkauf der Alteichenrinde findet in der Regel nach Raummetern statt.

Das Sclıälen der F i h t e $\mathbf{n}$ erfolgt derart, daß die gefällten Stämme und Stangen in Entfernungen von 1-2 Meter ringsum eingekerbt und die Rindenringe meist mittelst hölzemer, harter, zugespitzter Rindenschlitzer abgelöst werden. Diese Rindenringe rollen sich zusammen; sie werden an die liegenden Stämme zum Trocknen angelehnt, nach erfolgter Austrocknung in Raummeter gelegt und diese verwertet. Auch verkauft man wohl die Rinde nach der Stückzahl der Rollen. Bei dem geringeren Wert und Preis der Fichtenrinde ist der Verkauf nach dem Gewicht nicht

1) Etwas abweichende Trockengerüste mit Reisiglecke gegen Regen werden beschrieben von $S e \mathrm{~h} u \mathrm{tz}$ in Z. f. F. U. J. 188I, S. 615.

2) Z. f. 1. U. J. 1880, S.639. B r a u n s, Verfahren, die Eichen stehend zu schälen. 
üblich; hingegen überläßt man wohl auch die Rinden zur Selbstgewinnung an den Lïufer derart, daß ein Liaufpreis je Stamm oder je Stange gezablt wird.

Es ist zu bemerken, daß die Rinde nicht nur von solchen Stämen sich schälen läßt, die zur Saftzeit gefïllt sind, sondern daß mit Eintritt der letzteren die Rinde auch an Stämmen schälbar wird, die schon in Winter geschlagen sind. Woch ist in dicsen Fall die Zeit, während deren das Schälen noch geht, sehr kurz.

Auch Fichtenrinde verliert infolge ron Auslaugen dureh Regen bedeutend an Güte, man verkauft dieselbe meist schon vor der Aufbereitung und übergibt sie dem Käufer alsbald nach Beendigung derselben.

Alte borkige T a n n e n r i u de, die cin gules Brennmaterial abgibt, schält man ebenso wie Fichte.

Die Rinde rom $\mathrm{L}$ in $\mathrm{d}$ e $\mathrm{n} \mathrm{h}$ ol $\mathrm{z}$ ist zur Darstellung des Bastes zu benutzen. Ihre Gewinnung ist in Rußland von Wichtigkeit, in Deutschland ist sie wohl nirgends Gegenstand der regelmäßigen Forstbenulzung. Die geschälte Rinde wird, ähnlich wie Flachs, im Wasser geröstet, und es wird alsdann durch Ǩlopfen die Bastlage von rlem eigentlichen Rindenkürper gelöst ${ }^{1}$ ).

Was die Materialerträge del Gerbrindennutzung, sowie die Volumen-Verhältnisse des Holzes zur Rinde anlangt, so ist darüber folgendes zu sagen:

Im Eichenschälwald hat man je nach dem klimatischen Charakter der verschiedenen Gehiete, sowie der Beschaffenheit, eudlich nach der wirtschaftlichen Bchandlung der Wälder (Untrieb, Bestandespflege etc.) sehr verschiedene Erträge.

Nach $\mathrm{B}$ er $\mathrm{n}$ h a $\mathrm{r}^{\mathrm{d}} \mathrm{t}^{2}$ ) kann man bei kürzeren (12-I7jährigen) Untrieben folgende Zahlen annehmen:

I. Kl. (sehr günstiges Kilima, sehr guter Boden) ein Jahres-Durchschnittszuwachs pro Hektar von 10 Zentnel Kinde und 7 Festmeter IIolz.

II. Kl. (günstiges Klima, guter Borlen) 8 Zentner Rinde und 6 Festmeter Holz.

III. K1. (westdeutsches Bergklima, mittelmäBiger Boden) 5 Zentner Rinde und 5 Festmeter Holz.

IV. KI. (nordwest- und mitteldeutsches Kilima, guter, namentlich frischer und tiefgrünliger Lehmsandboden), $3 \frac{1}{2}$ Zentuer Rinde und \& Festmeter Holz.

V. Kl. (norddeutsches Kilima, friseher Saudboden) 3 Zentner Rinde und 4 Festmeter Holz.

Nach Forstmeister Ost $\mathrm{n}$ e $\mathrm{r}^{3}$ ) ergaben sich im Odenwald folgende Ertragszahlen bei I5jährigem Umtrieb als Durchschnitte pro Jahr und Helitar:

I. schlechte, lüchige Schläge 2,7 Zentner Finde und 1,6 Raummeter Schälholz;

II. mittlere, mäBig geschlossene Schläge 4 Zentner Rinde und 2,4 Raummeter Schälholz;

III. gute, geschlossene Schläge 5,3 7tr. und 3,2 Rm.

IV. sehr gute

V. vorzügliche

VT. ungewöhnliche

Als Höchstbetrag sprechend 15 Zentner Durchschnittsertrag pro Hektar angegeben.

Nach B a rs .,Untersuchungen über die Festgehalte und das Gewicht des

1) A. F.- U. J.-Z. 1873, S. 290 . Verwendung des Lindenbastes in Rußland.

2) Eichenschālwaldkatechismus von A. B f r n li a r d t, 1877, S. 66.

3) Statisclie und statistische Mitteilungen aus dem Eichenschălwald ron $W$ a I $t$ her. Z. F. U. J. 1886, S. 339 . 
Schichtholzes und der Rinde" (IS79) hat man folgende Verlältniszahlen zwischen Volumen und Gewicht der Eichenrinden anzunehmen:

E i c h e $n-A$ It rind e geputzt, waldtrocken 1 Zentner $=0,06.) \mathrm{fm}$ ungeputzt $\quad, \quad=0,06+\mathrm{fm}$

Eichen-Jungrinde

$\begin{array}{rrrl}\text { Spiegelrinde } & \text { I Zentner } & =0,0565 \mathrm{fm} \\ \text { Reitelrinde } & , " & =0,0595 \mathrm{fm} \\ \text { Grolorinde } & , " & =0,0620 \mathrm{fm}\end{array}$

Auf den Raummeter geschälten Holzes kann man nach B a u $\mathrm{r}^{1}$ ) rechmen:

bei jüngerer Stammrinde I,0n Zentner walıltrockene Rinde.

$\begin{array}{lllll}\text { hei älterer Stamminule } & 1.50 & , & , & , \\ \text { hei Astreitelrinde } & 1,30 & ., & ., & , \\ \text { bei Astglanzrinde } & 0.76 & , & , & , .\end{array}$

Die Prozente ler Rinde im Verhältnis zum ungeschälten Holz sind je nach dem Alter, bezw. der Stälke des Holzes verschieden, mit abnehmender Stärie nehmen sie naturgemäß zu. Jan kann nach Baur im Durchschnitt reclmen:

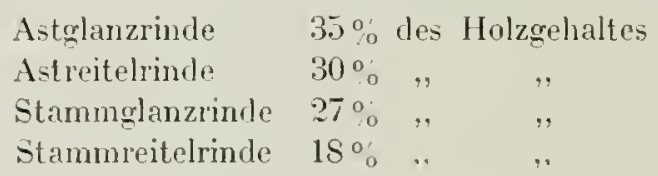

Bei F i ch t e n in de in Rollen kann man nach Baur den Raummeter grün $=0,27 \mathrm{fm}$ und waldtrocken $=0,15 \mathrm{fm}$ ansetzen; das Gewicht pro Raummeter beträgt nach Baur walıtrocken 11 f hilo, grün hingegen ?27 Kilo. Leber rlie Frage nach item Prozentsatz der Pinde in Verhältnis zum Holz liegen bezüglich dieser Holzart in der Literatur bis jetzt weng Angaben ror.

Ueber die in der Sachsen- Jeiningischen Staatsforstverwaltung angestellten Versuche und deren Resultate ist anzuführen, daß die Rindenprozente mit zunehmencter Standortsgïte und Zunahme der Stäken wesentlich abnehmen. Auf geringen Standorten ist die Rinde verhältnismäBig stärker, ebenso an jüngeren, bezw. schwächeren Stanmteilen. Für eine mittlere Ortsgüte von 0,5 ergaben sich folgende Rindenprozente der ganzen Baumschäfte:

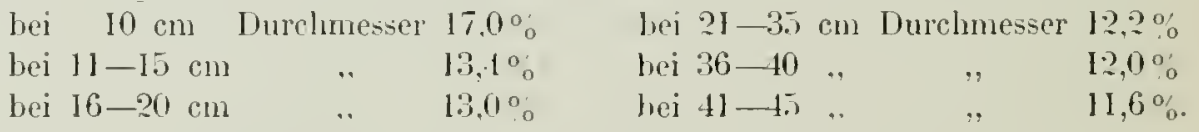

\section{Verwertmug vier Fällumgsergebnisse.}

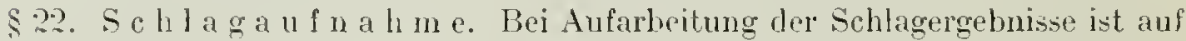
ein geordnetes Anrücken derselben an Wege, Schneisen. Schlagränder behufs elleichterter Uebersicht. sowie zur Schonung der Anwüchse und zur Beförderung des Absatzes zu sehen. Es erfolgt dies bein Brennholz, Reisig und den geringeren Nutzhölzern mittelst Tragens, Fahrens, auf Schiebkarren oder Hanclschlitten, sowie bei stärkrem Holz durch Schleifen, nötigenfalls unter Anwendung von Zugkräften, wobei das Vordergestell eines Wagens zur Aufnahme des zu schleifenden Stammes mit Vorteil benützt wird $\left.{ }^{2}\right)$. An steileren Iängen im Gebirge ist vielfach das,..5 e i-

1) Untersuchungen über Eichengerbrinde von B a u r. .J. f. I. u. J. 1875, S. 241.

2) Eine sehr zwcekmäßige Transportrorrichlung zun Ausrücker ron Langnulzholz be-

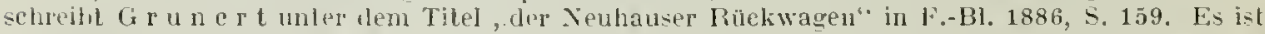
diss ein Käderpaar mit Achse und einer Lenkwiede, an der die Vurrichtung zum Anspannen des Zugviehs sich befindet; die Benutzung geht derarl vol sich, daß die Răder über den Stamm ge- 
len" des Stammholzes üblich, das darin besteht, daß am dicken Stammende mit Hilfe des Lotnagels ein Seil befestigt wird. Dieses Seil wird mehmals um einen stehenden Baum geschlungen und nun der in der Richtung des stärlisten Gefälls und unit dem dünnen Ende nach abwärts liegende Stamm durch Drehen in gleitende Bewegung gesetzt. Diese Abwärtsbewegung wird durch Anziehen und Nachlassen des Seils geregelt und so der Stamm allmählich zu Tal gebracht. (Vergl. II ü ll e r, Schweizer Zeitschr. f. Forstwesen 1905. S. 6.)

Nach erfolgtem Anrücken und Aufsetzen haben die emzelnen Holzhauerrotten die von ilmen aufbereiteten Forsterzeugnisse mit einem Zeichen, am besten einer Nummer zu versehen, die ein für allemal angibt, welche Partie dieselbe aufgearbeitet hat.

Nach Fertigstellung der Hauung erfolgt die Schlagaufnahme. Dieselbe dient zur förmlichen Uebernahme der Hiehsergebnisse seitens der Forstverwaltung von den Holzhauern, sowie zur Verzeichnung derselben in besondere Aufnahmelisten (Nummernbücher) behufs der Verwertung.

Jeder Posten rom Rund-, Werk- oder Brennholz, sowie jeder Haufen Reisig crhält eine Nummer: man wählt getrennte Nummernfolgen für Stammholz, Stangen, Schichtholz, Reisig, Stöcke etc. Das Anschreiben der Nummern erfolgt beim Schichtholz auf die Stirnfläche eines zwechmäßig etwas herausgestoßenen Scheites oder Kinüppels (Nummernscheit), beim Langnutzholz an die untere Abschnittfläche, beim Reisholz auf besonders herausgezogene Prügel. Man bedient sich dazu der gewöhnlichen Rotstifte, oder besonders präparierter Kohlen (Lindenliohle mit Oel getränlit). Wenn die Hölzer längere Zeit bis zur Verwertung bzw. Abfuhr im Walde lagern müssen, so ist es zweckmäßig, die Nummern auf besondere Weise dauerhaft anzubringen. Hierzu kann man Oelfarbe wählen, bei deren Anwendung die Zahlen mit einem Pinsel angeschrieben werden; auch hat man Schablonen von schwachem Blech, mittelst deren ebenfalls unter Anwendung von Oelfarben die Zahlen angebracht werden können.

Außerdem gibt es noch eine Anzahl besonderer Apparate, unter denen die meiste Beachtung der Göhl e r sche $\mathrm{N}$ u m e r i e r s c h l ä g e I verdient ${ }^{1}$ ). Vermittelst desselben werden die Nummem mit Farbe in das Holz eingeschlagen, so daB sie fest und dauerhaft sind. Die Anwendung des Apparates hat die große Annehmlichkeit, daß durch einen einfachen Hebeldruck nach dem Einschlagen einer Nummer die zunächst folgende sich von selbst stellt. Die Nummertypen sind erhaben und werden auf einer Filzplatte, die mit Leinöl und Druckerschwärze getränkt ist, oder mit Hilfe eines Pinscls gesclwärzt. Die Arbeit geht mit diesem Apparat rasch, sicher und sauber von statten. die Zahlen haften grut und sind von weitem erkennbar. Um das Geschäft des Numerierens jedoch nicht umötig für den Forstbeamten aufzuhalten, empfiehlt es sich, die Nummern zunächst mit Rotstift leicht anzuschreiben,

schoben und derselte unter der Achse mit Scherenhaken, am vorderen Teil der Lenkwiede mittelst lietle befestigt wird. Ein großer Vorteil liegt dabei darin, daß die Stamme nicht a $u \mathbf{f}$ dem Wagen, sondern un $\mathrm{L}$ er denselben befestigt werden, so daß ein Iann Stămme von $2 \mathrm{fm}$ allein zu heben und zu regieren imstande ist. Von āhnlicher Einrichlung ist der, A hl bor nsche Blochwagen", beschrieben von Grune $\mathrm{t}$ in F.-Bl. 1887, S. 39. Ferner wurde von Obf. B r ock ein Rückwagen angegeben, der als ein kleiner Wagen mit ganz niedrigen Rādern darzustellen ist, auf den die Stāmme und Abschnilte leicht zu heben sind. Um beide Enden aufliegen lassen zu liönnen. sind zwei Wagen nōtigr; bei Anwendung eines einziğen wird das Stammende geschleift. Zu erwanlunen isl auch der neuestens empfohlene $\checkmark$. M ille r che $\mathrm{B}$ a $u \mathrm{~m}$ e h l e p per, der in leichler und schwerer Ausfūhrung gebaut wird. (Vgl. A. F.- u. J -Z. 1910, S 310).

1) Der sāchsische Vumerierschlăgel ete. von Bernhardt, Z. f. F. u. J. 1874, S. il. Würdigung verschiedener Numeriermethoden von H e 13. - A. F.- U. J.-Z. 1873, S. 142.

Handb. d. Forstwiss. 3. Aufl. II. 
was erheblich rascher zu bewirken ist, als die Arbeit mit dem Hammer, und sodann durch Holzhauer oder Forstaufseher nachträglich das Einschlagen der Nummern bewirken zu lassen.

Der P f itz c n m a e r sche Apparat besteht aus Holzstempeln mit Typen aus Filz, die geschwärzt und mit der Hand aufgedrückt werden. Der I h ri g sche Apparat hat eiscrne Stempel, deren vorderes Ende mit je einer Nummer versehen ist und nach crfolgter Schwärzung mittelst eines Ilammers in das Holz eingeschlagen wird.

In das Nummernbuch wird nunmehr für jede Nummer der nötige Eintrag über das betreffende Sortiment gemacht. Han lıält getrennte Bücher für Stammholz, Stangen und Schichtholz, Reisig und Stöcke.

Beim St a m $\mathrm{m}_{\mathrm{f}}$ ol z erfolgt die Bestimmung des Festgehaits aus Mittenquerfläehe mal Länge ( $\mathrm{H}$ u b e r sche Formel) — als Paraboloid. Es wird somit dic Länge und Vlittenstärke festgestellt und neben der Holzart und nötigenfalls der Sortinentsklasse linter der betreffenden Nummer angegeben.

Bei den Langmutzhölzern wird ron den Holzhauern bei dem Aushalten der einzelnen Stücke die Länge gemessen, hiernach die Mitte örtlich bestinmt und dort die Länge angeschrieben. Die A ufn a hme hat dam die Längenmessung zu prüfen und es erfolgt nummehr die Abnahne des mittleren Durchmessers mit der Kippe; den Durchmesser läßt man zweckmäßig ebenfalls am Stamm selbst ansehreiben.

Zur Feststellung des Raumgehalts der Nadelholzstämme werden in Württemberg seit längerer Zeit sog. Ii u b i c u u gs g b e lm a $B$ e aus Eisen oder Aluminium verwendet, die sich sehr bewähren und immer mehr verbreiten. An der Schiene dieser Gabelmaße kann nicht nur der Lurchmesser, sondern sofort auch der Raumgehałt für verschicdene Längen abgelesen werden, was die Schlagaufnahme ungemein erleichtert.

Die Vermessung erfolgt bei unregelmäßig gewachsenen Stämmen und deren Teilen wohl auch in mehreren Selitionen, namentlich wenn das betreffende Nutzstück infolge seiner Form zweierlei Qualität hat, z. B. an einem Eichenstamm unten ein glattes Stammstück. nach oben ein ästigerer Gipfelteil sich befindet.

Die Abnahme des Durchmessers geschieht bei unregelmäßiger Form des Mittenquerschnitts übers Kreuz unter Vittelung der Ergebnisse. Auf gut konstruierte, solide Kiluppen, die richtiges Maß ergeben, ist streng zu sehen. Fällt die Mitte auf einen Ast oder cine unförmliche Erhöhung, so ist entsprechend am Durchmesser nachzulassen.

Nach der Vereinbarung der deutschen Staatsforstverwaltungen von 1875 ist das Stammholz in der Regel $m$ it $\mathrm{R}$ in d $\mathrm{c}$, wemn es aber entrindet wurde, o lin $\mathrm{e}$ Fi in d e zu nessen. Diese durchaus unzwcclimäBige Vorschrift ${ }^{1}$ ) ist bei den Holzkäufern mit rollem kecht vielfach unbeliebt und daher von vielen Verwaltungen, besonder's in Süddeuischland, dahin abgeändert worden, daß das Stammholz g r u n dsätzlich stets o hne Pindegemessen wird ${ }^{2}$ ). In diesen Falle wird

1) Auf der 1885er Versamn lung deutseher Forstmänner zu Görlitz hat man sich sowohl von holzhändlevischer, als auclı von forstlicher seite für cias Nichtmessen der Rinde ausgesprochen.

2) Da bei Feststellung des Itaterialetats nach vorausgegangener Aufnahme der Holzbestande die Rinde mitgemessen, also der Holzvorrat inklusive Pinde elmittelt ist, so käme es nur darauf an, dureh ausgedehnte Untersuchungen die Rindenprozente der verschiedenen Holzgattungen, je nach deren Stärke, fectzustelten, um alsdann durch gecigneten Zuschlag zu dem rindenirei gemessenen Holz die der ursprünglichen Holzaufnahme entsprechende berindete Holzmasse für den Fällungsnachweis zu finden. In Bayern sind dafür bei Eiche $15^{\circ}$, bei den übrigen Laubhölzern und beim Natelholz hingegen $10 \%$ als Zuschlar festgenetzt, in Wurttemberg für Eiche $20 \%$, für alle ührigen Holzarten (Laubhölzer und Nadelhölzer) $10 \%$. Für Kiffernalthölzer berechnen sjch nach Obf. Sche $1 \mathrm{im}$ Odenwald ebenfalls $15^{\circ}$ (A. F.- 13. J.-Z. 1901, S. 375). 
damn, wo der Stamm nicht entrindet wurde, die Finde an der Meßstelle entfernt. Jene Vorschrilt hat nicht allein den Nachteil der Unsicherheit infolge verschiedener Behandlung der Stammhölzer, je nachılcm sie entrindet wurden oder nicht, sondern sie ist insbesondere auch darum zu verwerfen, weil der Käufer doch wohl $\mathrm{H}$ o l z und nicht Rinde kaufen will und weil somit infolge der weelsselnden Stärke und Borkigkeit der Rinde ein Moment ler Lnsicherleit in die ganze Messung und Bewertung kommt. Diese Unsicherheit bedingt ein Risilio für den Ǩäufer, das der Verkäufer zu büßen hat; denn um ganz sicher zu gehen, wird der Käufer beim Ansatz seines Gebots einen solch hohen Abzug für die nitgemessene Rinde machen, wic er tatsächlich nicht begründet ist.

Ueber den Verlust an Masse und Wert bei der Aufmessung und dem Verkauf des Fichtenholzes in entrindeten Zustande hat $\mathrm{B}$ o $\mathrm{r}$ g $\mathrm{n}$ a $\mathrm{n}$ n interessante Erhebungen gemacht (vergl. Zeitsclur. f. F. u. J. 1910, S. 583).

In einzelnen Forsthaushalten, z. B. bei der K. Sächsischen Staatsforstverwaltung, hat man für dic Kubierung der Nadellılzblöcke, die in gewissen ortsüblichen, denn Handel entsprechenden festen Längen ausgehalten werden, die Mcssung des oberen Durchmessers gevählt, wobei die Bestimmung des Festgehalts der Blöcke mit Hilfe von Tabellen erfolgt, die auf Grund von Erfahrungszahlen aufgestellt sind.

Bei Aufnahme der $\mathrm{s} c \mathrm{~h} w$ ä cheren $\mathrm{R} u \mathrm{nd}$ hol zsortimente, z. B. Wagnerhölzer, Grubenhölzer, verfälırt ınan wohl auch so, daß nicht für jedes einzelne Stück Länge und Stärke erhoben, sondern eine größere Zahl gleicher Länge zu einer Nummer vercinigt und für dieselben e i n gemeinschaftlicher nittlerer Durchmesser ermittelt wird.

Die Stange $\mathbf{n}$ sortime $\mathbf{n}$ te nimmt man nach dem in 1 Vleter über dem Abhieb gemessenen Durchmesser und der mittleren Länge auf. Nan vereinigt auch hier unter einer Nummer eine schon örtich bei der Holzhauerei in passende Haufen zusammengelegte Mclirzalil von Stangen, deren Stïckzahl in der Regel durch 10 teilbar ist.

Vielfach sind bestimmte Klassen für gewisse häufig vorkommende Stangensortimente im voraus festgesetzt, z. B. Bolnenstangen, Hopfenstangen I., II. und III. Kl.. in wclchem Fall nur die Stückzalıl in die betreffende Sortimentsspalte einzutragen ist.

Bei jeder Numerierung und Holzaufnahme lat der das Geschäft besorgende Forstbeamte genau zu prüfen, ob die Hölzer nach Vorschrift aufgearlocitet sind. Beim Langnutzholz muß darauf gesehen werden, daß die Aeste glatt von den Stämmen und Stangen abgelıauen sind; sollten sich anbrüchige Stellen finden, so ist darüber eine Bemerkung im Nummernbuch zu machen, damit die Preisfestsetzung der geringeren Güte entspreehend bewirkt werde.

Beim Sehichtholz und Rejsig wird Güte, Holzart und Sortiment hinter der einzelnen Nummer eingetragen. Beim Schichtholz ist die Richtigkeit der Hlasse zu prüfen, sowie festzustellen, ob die Stöße gehörig dicht und lüclicnlos gesetzt sind; alle in dieser Hinsicht zu stellenden Erinnerungen sind den bei der Schlagaufnahme zugezogenen Holzhauern zur sofortigen Erledigung der Anstände mitzuteilen.

Die Schlagaufnahme wird hinsichtlic $h_{1}$ ihres Ergebnisses mit den Angaben der Holzhauer über das von ihnen Gefertigte verglichen, etwaige Abweichungen werden behoben und dic nötige Cebereinstimmung lıerbeigefülırt.

Der Numerierung folgt die Prüfung des Schlags durch einen Vorgesetzten desjenigen Beamten, der die erste Aufnahme besorgt hat, in der Regel durch den Verwaltungsbeamten, insofern die erste Aufnahme den šchutzpersonal obzuliegen pflegt. 
Dieses Geschäft (Holzabnahme. Kontrolle, Abpostung oder Abzählung genannt), das auch wohl für einzelne Schläge dem Inspektionsbeamten ïbertragen ist, luat den Zweck, festzustellen, ob bei der erstmaligen Aufnahme keine Fehler unterłaufen und ob die ber jener Gelegenheit gerügten Anstände inzwischen heseitigt worden sind. Nit Hilfe des Nummernbuches prüft der kontrollierende Beamte die einzelnen Hiebsergebnisse, indem er Nummer für Nummer die Angabe des Buchs mit dem Befund in Wald vergleicht und sich von der ordnungsmäBigen Beschaffenheit aller Posten überzeugt. Manchen Ortes ist hierbei die Einrichtung getroffen, daß die Rundhölzer an der Stirnseite mit einem besonderen Kontrollehammer angeschlagen werden.

Nach Naßgabe der durch die Schlagaufnahme festgestellten Holzmengen, die von den einzelnen Holzhauerrotten aufbereitet sind, im Zusammenhalt mit den früher vereinbarten Holzhauerlölnen, kann nun die Aufstellung der Lohnrechnung für die beendete Hauung erfolgen.

$\$ 23$. Verka uf s a r te n. Die Abgabe der großen Mehrzalil der Hölzer erfolgt leute seitens iler Forstwirtschaft im Wege des $\mathrm{V}$ e $\mathrm{r}$ k a $\mathrm{u} f \mathrm{~s}$. (Daneben kommen in beschränlitem Unfange vor: Abgabe an Berechtigte und Deckung des eigenen Bedarfs der Verwaltung an Hölzem für den Forstbetrieb selbst, an Besoldungshölzern, für eigene Nebenbetriebe usw.).

Der Erfolg des Verliaufs nun hängt in Ralunen der jeweiligen Marktlage und der Absatzverhältnisse der gegebenen Oertlichkeit wesentlich ab von der Verkaufsart. Zum Verkauf sind versehiedene Wege möglich. Wir kön ne n d i e V e r k a u fsa r ten für die Walderzeugnisse se heiden:

1. nach dem Zustande, in rem sich rer Verkau $\mathrm{I}$ g gegenst a $n$ d zur Zeit des Verkaufs befindet.

A. Verkauf vo r der Fällung (Verkauf ,auf den Stock“).

1. Gesamtverkauf (Verkauf, ,en bloc"), der Schlag wird in Ganzen verkauft.

2. Verkauf nach der Maßeinheit (Verkauf , auf Nachmaß"). Verkauft wird pro Festmeter des sich ergebenden Holzanfalls, gegebenenfalls getrennt nach Sortimenten,

a. mit Gewinnung durch den Käufer:

b. unter Vorbelialt der Fällung und Aufbereitung durch den Verkäufer auf seine Rechnung.

B. Verliauf $\mathrm{n}$ a $\mathrm{c} \mathrm{h}$ der Fällung.

1. in unaufbereitetem Zustand des Holzes - gewöhnlich in Fläclienlosen nach vorausgegangener Füllung durch die Verwaltung.

2. in aufbereitetem Zustand; nach Aufbercitung des ganzen Schlags durch die Verwaltung.

II. Nach der Art und Weise, wie der Vertragsabschluß zustande kommt.

A. freihändiger Verkauf (Verkauf , unter der IIand"); der Waldbesitzer geht mit einzelnen Licblabern einen Kaufvertrag ein.

1. Taxpreisabgabe, d. I. Verkauf zu einer vorher allgemein festgesptzten Taxe;

2. Verkauf zu besonders vereinbarten Preisen (Vertragspreise).

B. Verkauf unter freier Konkurrenz - im Wege des Meistgebots.

I. Oeffentlich mündliches Verfahren.

a. Aufstreichsierkauf (auch Versteigerung, Verstrich, Auktion und Lizitation genannt;

b. Abgebot.

2. Geheimes schriftliehes Verfahren, sog. Submission. 
Jedes in Walde angewandte Verkaufsverfahren bildet num einc Iiombination je cincs der unter I. und unter II. aufgezählten Verfahren.

In einem früheren Paragraphen ist gezeigt worden, daß der Verkanf des a u fbe reiteten Holzes die sicherste und zweckmäßigste Methode sei und daß ihr gegenüber der Verkauf des Holzes im $\mathrm{S}$ te he $\mathrm{n}$ in den meisten Fällen sich weniger empfelıle.

Der Verkauf a u s f r e i e r H a n d , einst allgemein im Gebrauch, hatte seine Berechtigung, solange es möglich war, jedem Verbraucher diejenige Meıge an Forsterzcugnissen zu überweisen, die er nötig hatte. In waldreichen, aber dünn bevölkerten Gegenden, wo das Angebot an Holz die Nachfrage nach solchem übersteigt, ist dieses Verfahren noch heute vollständig begründet. Vit zunehmender Bevölkerung und gesteigertem Anspruch auf Zuteilung von Hölzern, mit der Ausbildung von Holzhandel und Holzindustrie ist jedoch dieses gevissermaßen patriarchalische System nach und nach in den meisten, mehr entwickelten Gegenden in Wegfall gekommen, da cs kaum möglich war, das Ergebnis der Schläge in gerechter Weise unter die einzelnen Empfänger zu verteilen und hierbei die Begünstigung der einen auf Kosten der anderen zu vermeiden. Es ist eine Hauptschattenseite dieses Verfahrens, daß es sich dabei kaum vermeiden läßt, in einer bisweilen unbilligen Weise dem einen Teil der Empfänger Holz in guter Abfuhrgelegenheit zuzuteilen, während ein anderer Teil auf Schläge verviesen werder muB, die eine beschwerlichere und kostspieligere Beförderung der Forsterzeugnisse veranlassen.

Bestehende Berechtigungen gewisser Personen auf den Bezug von Hölzem nach feststehenden Preisen nötigen heute nocl an manchen Orten zur Beibehaltung dieses Verfahrens, das übrigens in der Regel so gehandhabt wird, daß, sofern nicht durch Berechtigung die abzugebende Henge ein für allemal feststcht, die einzclnen Liebhaber an gewissen Terminen Gelegenheit erhalten, ihren Bedarf anzumelden, worauf die Verteilung nach Maßgabe der Anforderungen, gegebenenfalls nach entsprechender Herabsetzung der Bestellungen, erfolgt und jedem Holzempfänger ein Nummernzettel zugestellt wird, auf dem die Holzposten, die er erhalten soll, nach Forstabteilung, Sortiment. Nummer und Preis genau bezeichnet sind. In ähnlicher WVeise sind Holzabgaben um gewisse Tax- oder Tarifpreise nicht ausgeschlossen bei Befriedigung des Bedarfs der Forstbeamten, denen man nicht erlauben darf, in den öffentlichen Verkäufen mitzubieten, ebenso in besonderen Notfällen; ferner wird sich öfters empfehlen, den Holzhauern auf solche Weise ihren Bedarf an Brenmmaterial aus freier Hand zu gewähren, um ihr Interesse für den Wald zu heben und ihre Anhänglichkeit an denselben zu befördernn.

Eine besondere Schwierigkeit bereitet bei dieser Verkanfsart die Festsetzung Ier Taxen, nach denen der Verkauf bewirlit wird, insbesondere dam, wenn der gesamte Verkauf eines Revieres auf diese Weise erfolgt und infolgedessen keine Anhalte darüber vorhanden sind, wie sich die Preise im öffentlichen Marktverkehr stellen.

In der Tat sind auch diese Holztaxen in denjenigen früheren Perioden, in denen der Verkauf ausschließlich nach ihnen bewirlit wurde, meln oder weniger willkürlich aufgestellt worden.

Der öfentlich-mündliche $\mathrm{V}^{\top} \mathrm{er} \mathrm{k}$ a $u \mathrm{f} \mathrm{n}$ a c h de $\mathrm{m}$ II e is $\mathrm{tg}$ e b o t bietct dem Waldbesitzer in der Regel die meisten Vorteile; bei diesem Verfahren werden infolge des vorhandenen Wettbewerbs diejenigen Verliaufspreise erzielt, die den enzelnen Verkaufslosen nach Maßgabe der vorhandenen Absatzgelegenlieiten entsprechen. Es ist Init diesem Verfahren dic größte erreichbare Unparteilichlieit verbunden und der 
den Verkauf leitende Beamte lieinerlei Vorwürfen ausgesetzt, weil das Verfahren sich vor unbeschränkter Oeffentlichkeit abspielt und jede unzulässige Berorzugung des einen Käufers vor den andern ausgeschlossen erscheint.

Der Käufer selbst ist vollständig in der Lage, nach der Beschaffenheit der Ware, deren Abfuhrgelegenheit und ver auf ihre Verwendungsähigkeit für ihn als Verbraucher zu nehmenden Rücksicht sein Gebot abgeben zu können.

Wenn nun auch bei genügendem Wettbewerb die Wirkung von Angebot und Nachfrage in Hinsicht auf die Gestaltung des Verkaufsergebnisses beim AufstreichsVerkauf am besten zur Greltung gelangt, so sind doch bei demselben gewisse Nachteile für den Waldbesitzer nicht ausgeschlossen, wenn das Angebot die Nachfrage übersteigt. In diesem Falle steht dem V'erkäufer lıäufig eine nur beschränkte Anzahl von Kaufliebhabern gegenüber; es ist daher die Möglichkeit vorhanden, daß dieselhen sich verabreden, um durch die Alogabe geringer Gebote und die V'ereinbarung, sich gegenseitig nicht hoehzutreiben, rlie Verkaufspreise niedrig zu halten, und nachher die billig erstandenen Hölzer untel sich zu verteilen $\left.{ }^{1}\right)$.

Es tritt dieses Verhältnis insbesondere in waldreichen Gegenden ein, in denen Industrie und Holzabsatz noch nicht recht entwickelt sind oder einzelne übermächtige Firmen den Markt in der Hand haben. Es muß in solchen Fällen dem Waldbesitzer darauf ankommen, den Ringbildungen entgegenzuarbeiten, insbesondere durch Herbeiziehung auswärtiger Liebhaber und geeignete Wahl der Verkaufsart ${ }^{2}$.

Zuvörderst muß darauf gesehen werden, daß die zu verkaufende Ware in einem dem Holzkäufer zusagenden Zustand ausgeboten wird, daß eine richtige Sortimentsbildung statifindet und daß vor dem Verkauf die Hölzer auf Rechnung der Forstverwaltung an Stellen geschafft worlen sind, an denen sie ohne weiteres aufgeladen und von dem Käufer nach dem Ort ilirer Bestimmung gebracht werden können; dan aber wird sich bei ausreichender Bekanntmachung der Verkäufe ein Wettbewerb bald ron selbst ergeben. AuBerdem empfiehlt es sich im Falle von Verabredungen einer geringeren Anzahl von liäufern sehr oft, ein Verfahren einzuführen, nach dem die Gebote s c h r if $t$ l i c h bei der Forstverwaltung eingereicht werden, so daß die einzelnen Käufer gar nichts von einander wissen. Tat man alsdann wirklich wertvolle Hölzer zu verkaufen, auf deren Besitz gewisse Verbraucher ernstlich rechnen, so ist bestimmt in Aussicht zu nehmen, daf dieselben in der Befürchtung. es könne ein bisher nicht als liäufer beliannter, vielleicht fremder llitbewerber auftreten, ein dem Wert des Holzes angemessenes Gebot einreichen.

Dieses Verfahren, Sub missionsre r a hren genannt, findet neuerdings viele V'ertreter, und es ist nicht in Alırede zu stellen, daß es als ein sehr zweekinäBiges Auskunftsmittel angeschen werden darf.

Freilich läßt dasselbe bei minderwertigen Holzsortimpnten im Stich, indem nur dann ein Käufer Gelote abgeben wird, wenn ilm wirlilich an der Ware etwas gelegen ist.

In solchen Fällen mangehrlen Wetthewerbs, insbesondere beim Verkauf minder wertvoller Sortimente, ist num als eine äuBerst zweckmäßige Form des Verkaufs der Freihandverkauf zu vereinbarten Preisen zu bezeichnen.

Es liandelt sich hierbei neist $u$ bedeutendere Nengen, und es ist diese Ver-

1) Derartige Vereinbarungen dürften, als gegen die guten Sitten verstoßend, nach $\$ \S 134$, 138 des Bürgerlichen Gesetzbuches der Nichtigkeit unterliegen und die Beteiligten nicht binden. (Ausgesprochen in einem Erkentnis vom 1. Zivil-Senal des Oberlandesgerichts in Colmar, s. Zeitschr. Aus dem Walde. 1901, N1. 26.)

2) Verhandungen des Deulschen Forstvereins auf der Xil. Hauptversammlung zu Ulm 1910 , Bericht S. $99 \mathrm{ff}$. 
kaufsart besonders am Platze, wemn die Absicht vorliegt, dic ïber ilen Berlarf der kleinen Abnehmer hinausgelienden Holzmassen an größere Holz verbrauchenı Unternehmungen zu verkaufeu.

Es wird dieses Verfahren beispielsweise den Vorzug verdienen, wenn größere Brennholzmassen an vereinzelt in einer Gegend bestehende Hüttenwerlie orler Fabriken, ebenso wenn Durchforstungshölzer als Grubenholz, als Schleifholz für Holzstoffabriken bei beschränkter Nachfrage verliauft werden sollen, in welchen Fïllen der Verbraucher besonderes Gewieht darauf legen wird. die Sicherheit dafür zu haben, daß sein Holzbedarf gedeclit wird.

Entsteht im Laufe der Zeit ein ausgedehnterer Wettbewerb anch für solche minder begehrte Sortimente, so ist es der Vorsicht angemessen, durch Inberaumung von Versteigerungen odel von öffentlichen Submissionen den Witbewerb auch anderer Liebhaber zu ermöglichen.

Es empfiehlt sich bei solchen Freihandverkäufen öfters der Abschhß schriftlicher Verträge vor dem eigentliehen Holzeinschlag, da auf diese Weise dem Käufer gezeigt wird, daß der Waldbesitzer bei Abgabe ungenügender Gebote nicht in Verlegenheit kommt, weil das Holz noch in Wald steht und bis zur Erlangung eines angemessenen Preises stehen gelassen werden kann.

Eine Abart des öffenthich mündlichen Verfahrens bildet noch das in Frankreich übliche Verfahren des A b g b o ts (Verkauf au rabais), derart, daß auf Grund vorhergehender Schätzung des Verkaufsloses eine Taxe festgestellt und iu Verkaufstermin in sehr erhöhter Summe ausgeboten wird. Während nun der Auslufer immer weiter abwärts gehende Ausgebote ausrůf, muß der Liebhaber den Augenllick benutzen, in dem die Summe niedrig genug erscheint, um dafïr das ausgebotene Los gebrauchen zu können. Er ruft daun einfach: ,.je prends"; nur bei gleichzeitigem Ausruf seitens mehrerer Personen wird das Verliaufslos unter diesen wieder im I u f$g$ e b o t versteigert.

Dieses Verfahren wird in Frankreich bei dem Blockverkauf ganzer Schläge, deren Aufarbeitung Sache des Käufers ist, in Anwendung gebracht.

Die dentsche Forstverwaltung in Elsaß-Lothringen hat als Regel den Aufstreichsverkauf der auf Rechnung der Forstverwaltung aufzuarbeitenden Schlagergebnisse eingeführt. Das große Publikum soll damit, namentlich was den Verkauf des Brennholzes anlangt, zufrieden sein, weil auf die jetzt eingeführte Art die Möglichkeit besteht, daß der einzelne seinen Berlarf kaufen kann, ohne sich an den Holzhändler wenden zu müssen. Dies war früher infolge des en bloc-Verkanfs allgemem üblich, während jetzt jeder unmittelbar und billiger kanft, da der Gewinn des Holzhändlers hinwegfällt. Für große Nutzholzverkäufe ist jedoch der Verkauf an rabais noch in Anwendung; die Neinungen über seine Zweckmäßigkeit sin.l geteilt (vergl. „die Forstrente in Elsaß-Lothringen", Straßburg 1886 S. 46). Eine warme Empfehlung desselben für Nutzhölzer unter geeigneten Voraussetzungen gibt Oberforstmeister $\mathrm{N}$ e y in Zeitschr. "Aus dem Walde" $1901 \mathrm{Nr} .4$ und Forstwiss. Centralbl. 1911 S. 421 . Er empfiehlt ilın auch besonlers gegen Ringbildung.

$\$$ 24. Bildung von $H$ olz t axen. Bei allen Holzverkäufen ist es für den Waldbesitzer von besonderer Wichtigkeit, gewisse Grunısätze für Festsetzung der Preise, nach denen verkauft werden soll ( $\mathrm{H}$ o I z t a $\mathrm{x}$ e $n$ oder T a r i f e), aufzustellen. Am schwierigsten ist die zweckmäBige Bildung dieser Taxen in solchen Wirtschaften, in denen der öfentliche Verkauf um das Meistgebot gar nicht stattfindet. Hier ist, wie bereits bei Würdigung dieser Verkaufsmethode im vorigen Abschnitt angegeben wurde, der Willkür und dem persönlichen Gutdünken der Forst- 
verwaltungen ein gewisser Spielraum gewäht; am zweckmäßigsten wird man noch derart verfalıren, daß man Anhalte aus den Versteigerungsergebnissen solcher Oertlichkeiten zu Hilfe nimmt, in denen der Verkauf ums Meistgebot schon länger besteht, wobei man wegen etwaiger Abgejegenheit der in Frage kommenden Gebiete und der Schwierigkeit der Verbringung des Holzes an solche Verkaufsplätze, in denen sich Mlarktpreise gebildet haben, angemessene Abzüge, die etwa nach der Höhe der Transportkosten zu bemessen sein würden, macht.

Da wo Verkauf im freien Tettbewerb sehon die Regel bildet, sind die Ergebnisse desselben zur Bildung der Taxen zu benutzen. Insofern diese Taxen hauptsäehlich als Anhalte für das Angebot del zur Versteigerung zu bringenden Forsterzeugnisse dienen sollen, empfiehlt es sich nicht, sie genau nach dem Durchschnitt der wirklichen Verkaufserlöse festzusetzen, sondem es ist ein gewisser Abzug von dem wirklichen Durehsehnittspreis zu machen, damit im Falle eines Rückgangs der Preise die Taxe nicht allzuhoch erseheint und den Küufern stets noch ein gewisser Spielraum zur Steigerung bleibt.

Bei Verkäufen in Wege des Aufgebots wird dureh die Wirkung des Wettbewerbs der Käufer ein allenfalls etwas niedriges Angebot in der Regel ohne Nachteil für die Erlöse sein; im Gegenteil kann man behaupteı, daß ein mäßiges Angebot die Lust zum Steigern befördert.

Hingegen wird man Verkäufe aus freier Hand zu vereinbarten Preisen nieht nach derjenigen Angebotstaxe bewirken, die durch einen Abzug von den mittleren Aufgebotspreisen erlangt ist, sondern man wird einen der Marlitlage entsprechenden Aufschlag zugrunde legen, mittelst dessen der Verkaufspreis mindestens die Höhe der Jetzten Durehschnittspreise wieder erhält.

Die Taxen für die Sortimente des örtlichen Markts (für Kleinnutzholz, Brennholz, Reisig usw.) werden in der Regel alljährlich für jedes Revier neu aufgestellt. Für die Sortimente des Grußhandels dagegen (Stammhölzer, Handelsstangen) empfiehlt es sich, die Taxen für größere Gebiete und für eine Reihe von Jahren festzusetzen. An derselben Taxe wird in der Regel so lange festzuhalten sein, bis dieselbe in ein dauerndes Mißverhältnis zu den tatsächliehen Erlösen tritt. Ein solehes längeres Festhalten und eine Gültigkeit der Taxen über größere Landstriehe ist für die Handelshölzer darum zweckmäßig, weil die Taxen dadurch zum festen Maßstab werden, und Verkäufer und Käufer einen Ueberblick über die Preisentwicklung während eines längeren Zeitraums gewinnen und ihnen ein Vergleich versehiedener Oertlichkeiten möglich ist.

Die mittleren Verkaufserlöse, die den Taxen zug!unde liegen, ergeben sich aus s t a t is tis c he n Ermit t l ungen. Für diesen Zweck sind alle in freiem Wettbewerb erzielten Erlöse von Hölzern gleicher Güte und Absatzlage übersichtlich zusammenzustellen und ist aus den Ergebnissen für die einzelnen Sortimente das Mittel zu ziehen.

Eine sichere Erfassung der Werts- und Preisverhältnisse setzt nun aber eine bestimmte $\mathrm{T}$ axklassenbild ung volaus und dann weiterhin den Verkaufder Hölzergetrennt naeh diesen lilassen.

Was zunäelrst die letztere Forderung betrifft, so ist es als besonderer Nachteil der Großschlagwirtschaft, besonders von großen Nadelholzschlägen, zu bezeichnen, laß ein klassenweiser Terliauf des Stammholzes, wo dieses nicht angerückt wurde, vielfach als erschwert oder unmöglich bezeichnet wird, da die Hölzer auf den Sehlägen durcheinander liegen und mit Vorteil nur zusammen weggeschafft werden können.

Im Hinblick auf Feststellung de r T axen bieten Sehich thol z, 
Reisig und Stocklolz der Aufstellung einer nach den früher angegebenen Sorten gegliederten Holzpreisstatistik keine weiteren Schwierigkeiten. Für S t a m mI 0 o $\mathrm{z}$ e r aller Art müssen dagegen er'st T a $\mathrm{x} k \mathrm{l}$ a s s e $n$ gebildet werden, und dies kamn in versehiedener Weise geschehen, entweder nach dem Festge ha l t de $r$ $\mathrm{S} t$ ä $m \mathrm{me}$ oder viel besser nach den deren Gebrauchswert bestimmenden Ausmaßen, dem M it tend u r chmesser oder der Länge und de m Dure hmesser a ul dün ne $n$ Ende.

Die Bildung der Taxklassen und deren Abstufungen nach dem Festgehalt der Abschnitte ist in der Preußischen Staatsforstverwaltung üblich. Hier werden bezeichnet als

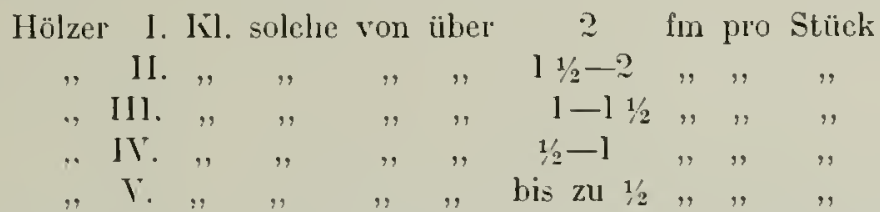

Diese Einteilung wird von verschiedenen Seiten für unzweckmäßig erkiärt, da die den Gebrauchswert des Nutzholzes bestimmenden Faktoren der Stärke, Länge und Form im Festgehalte keinen sicheren Ausdruck finden. Es ist z. B. hierbei möglich, daß durch Belassung eines Zopfstückes, das nur Brennholzwert hat, die Taxe für die Einheit (fm) eine höhere wird, während in Wirklichkeit der spezifische Wert sich verringert; ebenso könuen bei Verteilung der Schlaganfälle in die verschiedenen Taxklassen Hölzer von versehiedenem Gebrauchswerte un richtig in eine Kilasse vereinigt und ebenso Hölzer von gleicher Verwendungsfähigkeit unnötigerweise in mehrere Klassen geschieden werden.

Die den Gebrauchswert bestimmenden Ausmaße sind die 11 it t e ns t.ärke und für gewisse wichtige Gebrauchszwecke die Länge und Form der Stänm e. Zweckmäßige Taxklassen haben sich daher nach diesen Ausmaßen abzustufen.

Eine Taxhlassenbildung, die dieser Forderung genügt, haben wir schon weiter oben bei Besprechung der Aufbereitung in der sog. Heilbron ner Sortie$\mathrm{r}$ u n g für die $\mathrm{Nad}$ e l hol z-L a n g hö $\mathrm{z}$ er kennen gelernt, die insbesondere die Verwendung dieser Hölzer zu Bauholz und Schnittwaren in Auge hat, und bei der somit die Länge und das Maß der Vollholzigkeit, die in sog. Ablaß (Zopfdurehmesser) zum Ausdruck kommt, den Maßstab bilden. Sie gilt in ganz Süddeutschland. Andere Klassenbildungen für Langholz nach ähnlichen Gesichtspunkten finden wir auch noch bei mebreren andern Verwaltungen.

Für $\mathrm{N}$ a d e l h o l z a bs ch i it e (Sägholz, Klötzer), bei denen der Markt bestimmte Längen vorschreibt (3 $\mathrm{m}, 4 \frac{1}{2} \mathrm{~m}$ usw.), bildet der Mittendurchmesser oder auch der Enddurchmesser den Maßstab für die Taxklassen. Der Gebrauchswert eines Sägeblocks ist nämlich bis zu einem gewissen Grade Funktion seiner Mittenstärke. Mit Zunahme derselben steigt die Verwendungsfähigkeit. Während die schnalen Bretter, die aus schwachen Blöcken geschnitten werden, einen verhältnismäBig niedrigen Verkaufspreis haben, und der Abfall bei geringer Stärke des Holzes prozentisch groß ist, können aus stärkeren Blöcken bei verhältnismäßig geringerem Abfalle wertwollere Bretter usw. gesehnitten werden, weshalb ein Ansteigen der Festmeterpleise mit den Durchmesser wenigstens bis zu einer gewissen Stärke eintritt.

Das Gleiche gilt für sämtliches $L$ a u b t a $m \mathrm{~h} \mathrm{ol} \mathrm{z}$, bei den überdies die Länge der Stücke an Bedeutung stark zurücktritt. Hier werden die Taxklassen zweckmäßigerweise $n$ u $\mathrm{n}$ a c $\mathrm{h}$ d e $\mathrm{r} \| \mathrm{i}$ t t e $\mathrm{n}$ s $\mathrm{t}$ ä $\mathrm{r}$ k e gebildet; innerhalb der Stärke- 
klassen aber, da die inuere Güte beim Laubholz besonders große Abweichungen zeigt, noch weiterhin Un terklassen a c h d e r Q u a l i tät aufgestellt.

Diesen WVeg schlägt die aus dem Baden-reichsländischen Tarif hervorgegangene, süddeutsche Sortierung für La ubstam holz ein, die den Gebrauchswert in bester Weise erfaßt und durch die Art ihrer Alstufung gleichzeitig wertvolle Grundlagen für unsere Erkenntnis über den Gang des Wertszuwachses schafft. Dieselbe bildet folgende Klassen:

1. Klasse: Stämme von $60 \mathrm{~cm}$ und mehr Uittenstärlie $\left\{\begin{array}{c}\text { a. ausgesucht schöne, glatte } \\ \text { fehlerfreie Stückie } \\ \text { bewöhliche, nicht mit } \\ \text { erheblichen Fehlern be- } \\ \text { haftete Stücke. }\end{array}\right.$

II. Kilasse: Stämme von 50 bis $59 \mathrm{~cm}$ Mittenstärke

I a. I wie oben.

IIt. Klasse: Stämme von 40 bis $49 \mathrm{~cm}$ Mlittenstärke

1 a.j wie oben.

IV. Jilasse: Stämme von 30 bis $39 \mathrm{~cm}$ Mittenstärke

V. Klasse: Stämme von 20 bis $29 \mathrm{~cm}$ Mittenstärke

VI. Kilasse: Stämme von weniger als $20 \mathrm{~cm}$ Mittenstärke.

Qualitätsunterklassen werden somit nur für die 3 stärksten Ǩlassen gebildet.

Als erhebliche Fehler im Sime des Tarifs werden tiefgehende Fauläste, Rotund Weißfäule, Ringschäle, starlier Drehwuchs, Frostrisse und große Abholzigkeit genamnt. Mit erheblichen Fehlern behaftetes Holz wird als, A u s s c u $B^{\text {" }}$ bei der seinem Mittendurchnesser entsprechenden Klasse abgesondert sortiert und veranschlagt.

Uebrigens ist im Himblick auf die Tarife noch auf eine bemerkenswerte Verschiedenheit zwischen Nadel- und Laubstammholz hinzuweisen. Das Laubstammholz muB, trotz der Taxklassenbildung, immerhin - jedenfalls heute noch - individuell behandelt werden, d. h. der Tarif kamn nur einen Preisrahmen geben, innerhalb dessen jeder der betr. Stärkeklasse zufallende Stamm seinen Besonderheiten gemäß für sich eingeschätzt wird, in Gegensatz zum Nadelholz, das in viel höherem Maße generelle Behandlıng zuläßt. Es rühıt dies daher, daß die Nadelhölzer schon durch den gleichartigen Aufbau ihres Baumkörpers und infolge des Umstands, daß sie zumeist im geschlossenen und gleichwüchsigen Hochwalde erwachsen sind, viel mely. Gleichastigkeit in bezug auf äußere Form und innere Qualität aufweisen, als dies bei den Laubhölzern lıeute der Fall ist, die wir zumeist aus ehemaligen Blender- und Mittel wäldern crnten und die schon ihrer Wuchsform entsprechend große Verschiedenheiten in bezug auf Form und Qualität der Schäfte zeigen. Sobald die Forstwirtschaft später einmal nur melı die Erzeugnisse gleichaltriger und wolılgepflegter Hochwaldbestände ernten wird, dürften sich die Verhältnisse denen des Nadelholzes mehr und melır nähern.

Die Taxen aller Sortimente gelten nur für normale, kaufmannsgute Ware (fehlerfreie oder nur mit geringen, die Verwendbarkeit nicht beeinträchtigenden Fehlem behaftete Stïcke). Alles, was erhebliche Fehler aufweist, erhält als ,A usschu B“ seinen besonderen Preisansehlag außerhalb rler Taxe (s. oben). Vielfach ist die Bezeichmung solcher Objekte durch Kreuze üblich.

Die rationelle Behandlung der Holztaxenbildung ist cin Punlit von großes Vichtigkeit für die geschäftliche Seite der Forstbenutzung und Forstverwaltung. Sie hängt mit ciner sorgfältigen Holzpreisstatistik aufs engste zusammen. Nach 
nnserer Ansicht empfiehlt es sich, am Schlusse eines jeden Wirtschaftsjahres eine statistische Nachweisung der Holzdurehschnittspreise zu beschafien und darans die in Hinsicht auf Beibehaltung oder Aenderung der Holztaxen sich ergebenden Schlüsse zu ziehen.

§ 25. Ausführung der Forstproduktenrerkäufe ${ }^{1}$ ). Bei allen Verkäufen ron Forstprodukten (Holz, Rinden) ist von wesentlichsten Einfluß die Verkaufs z e i t. Vor allem hat man sich bei Wahl derselben nach der allgemeinen M a $\mathbf{r} \mathrm{k}$ z e i f für die einzehnen Walderzeugnisse zu richten. Innerhalb derselben ist es vielfach von Vorteil, so frühzeitig als möglich den Einschlag dem kaufenden Publikum anzubieten. Jeder größere Verbraucher oder Händler wird Gewicht darauf legen, seinen Bedarf frühzeitig zu decken; die Rüclisicht auf eine gewisse Sicherheit dieser Befriedigung des Bedarfs wird ihn dazu bestimmen, bei frülizeitig erfolgenden Verkäufen verhältnismäßig löhere Preise zu bewilligen als spätel.

Von besonderer Wichtigkeit ist dies daun, wenn größere Holzmassen im Stehen ausgeboten und vielleicht vor der Fällung verkauft werden sollen. Die Rücksicht auf einen frühzeitigen Verkauf ist jedoch nicht minder wichtig bei denjenigen Verkäufen, durch welche örtliche Bedürfnisse. insbesondere von Brenn- unl Lileinnutzholz befriedigt werden sollen. Auch hier ist Beschleunigung der Verkäufe zweckmäBig, damit der Käufer in bezug auf Abfuhr und weitere Behandlung der Forsterzeugnisse nicht allzusehr beschränkt ist.

Von wesentlichem Einfhrß auf die Ergebnisse mancher Verkäufe ist die Cr r ö B e

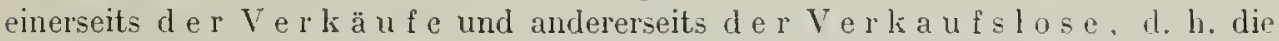
richtige Bemessung der jeweils in e in e $m$ Termin auszubietenden Hengen und die Bildung angemessener Verkaufslose, je nach den Anforderungen und besonderen Wünschen der Holzkäufer.

Hat man einen ausgedehnten und völlig genügenden örtlichen Absatz für seine Erzeugnisse, so empfiehlt sich die Abhaltung $\mathrm{k}$ le i n e Perkäufe und die Bildıng k le iner Verkaufslose, sowohl beim Brennholz als auch bein Nutzholz; anders verhält es sich, wenn dieser örtliche Absatz fehlt und wenn es sich darum lıandelt, auswärtige Verkäufer, vielleicht aus weiterer Ferne herbeizuziehen. Hier müssen g ro ße Verkäufe und innerhalb derselben großeVerkaufslose gebildet werden, damit der größere Abnehmer, der vielfach behufs Abschluß eines Ankaufes eine weite Reise zu machen hat, es auch der Müh wert findet, sich am Wettbewerb der Läufer zu heteiligen. Er tut dies nicht gerne, wenn er genötigt ist, seinen Bedarf durch Ankauf einer Mlenge kleinerer Verkaufslose zu decken, die er öfters nicht einmal in einem einzigen Schlage erwerben kann, wodurch naturgemäß die Aufsicht und der Transport, sowie die weitere Verwendung überhaupt wesentlich erschwert wird. Bei wertvollen, für weitere Ausfuhr in Betracht kommenrlen Hölzerı müßte darauf gesehen werden, daß immer die zu einer vollen Eisenbahnwagenladung nötige Menge in einem Lose ausgeboten wird, weil bei kleineren Posten die Fracht allzusehr verteuert wird.

Zu diesem Zweck wären wertvolle Hölzer (Alıorn, Esche, Elsbeere) nötigenfalls schon aus den Schlägen künftiger Jahre im voraus zu gewinnen, um die erforderliche Nenge zu erhalten, wenn solche aus dem laufenden Schlag nicht anfällt.

Unter Umständen empfiehlt es sich mehr, dem örtlichen Bedarf zunächst durch kleinere Verkaufslose Rechnung zu tragen, sodann aber die Befriedigung größerel Käufer durch Darbietung größerer Verkaufsposten ins Auge zu fassen. Man wird

1) Vergl. St e p h a n i: Einige Betrachtungen über den Holzverkauf aus dem Walde. Forstw. Zentralbl. 1910, 51 - -535. - Ringbildung und Holzverwertung in Bayern. Forstw. Zenlralbl. 1910, S. $316 \mathrm{ff}$. 
vielleicht für den ersteren Zweek Versteigerungen, für den letzteren Submissionen wälılen.

Auch die Zusammenfassung der Holzernte verschiedener Waldbesitzer zum Behuf gemeinsamer Versteigerung ist neuerdings in Anregung gebracht, bezw. angebahnt worden und verdient entschieden alle Beachtung, wenn es sich um den Verkauf von Forstprodukten handelt, die wesentlich für den Großhandel bestimmt sind ${ }^{\mathbf{l}}$ ).

Aus allem bisher Vitgeteilten wird sich ergeben, daß die angemessenste Verkaufsform in der Regel und bei Vorhandensein genügender Nachfrage, insbesondere bei hinlänglichem örtlichem Absatz, die V'ersteigerung sein wird.

Nan hat hierbei darülner gestritten, ob es sich empfiehlt, die Versteigerungen in Freien abzuhalten und dabei jedem Käufer Gelegenheit zu geben, das Holz, auf das el hictet, unmittelbar zu besichtigen. Sicherlich werden auf diese Weise alle etwaigen Beanstandungen abgeschnitten. Allein diese Methode hat doch auch eine Reihe von Uebelständen in Gefolge, namentlich eine erhöhte Unbequemlichlieit für den Verkäufer und für die Käufer, zumal bei Eintritt schlechten Wetters. Bei Versteigerung gr ö $\beta \mathrm{erer}$, im Wald zerstreut stelıender Hölzer ist sie geradezu unausführbar, da es unmöglich, oder wenigstens mit unverhältnismäßigem Zeitverlust verbunden ist, die einzelnen Posten nit den Kaufliebhabern durchzugehen.

Wenn man aber auch bei $\mathrm{k}$ le in e r e $\mathrm{n}$ Verkäufen, namentlich der Bremnhölzer, sicl von der. Methode der W a l f versteiger unge n nicht trennen zu lömnen glaul,t, so ist hier gewiß an vielen Orten noch ein Vormteil vorhanden. Ist es eimmal als fester Grundsatz eingebürgert, daß alle Hölzer im richtigen Maß aufgesetzt, gut sortiert und nach ihrem wirklichen Wert in die Bücher der Forstverwaltung eingetragen werden, ist fernel für gute Wege gesorgt und das Prinzip des Anrückens der Hölzer an die Abfuhrwege allenthalben durehgeführt, so daß in bezug auf die Leichtigkeit orler die Erschwerung der Abfuhr kieine wesentlichen Unterschiede Platz greifen, ist ferner dem Käufer Gelegenheit reboten, das zur Versteigerung gelangende Holz vor Beginn derselben örtlich besichtigen zu können, so wird sich dieser bald daran gewöhnen, an Verkäufen teilzunehmen, die nicht im Walde, sondern in Zimmer abgehalten werden und wird bei näherer Behanntschaft dem letzteren Verfahren den Vorzug geben.

Yon Wichitigkeit für den Erfolg der Verkäufe ist neben anderem auch die WV a lı I e ines passenden V e rsteigerungstages; man sieht hierbei darauf, daß kein Tag gewälılt wird, an dem etwa in der Nachbarschaft Markt ist; gewölınliche Gerichtstage sind auszuschließen, auch wähle man solche Perioden, in denen die Feldarbeiten nicht gerade dringend sind. Verabredungen mit benachbarten Revierverwaltungen behufs Vermeidung etwaigen Zusammentreffens versehiedener Verläufe auf e in en Tag sind geboten.

Alle öfentlichen Verkäufe sind in hinreichend ausführlicher. Weise nach Ort und Zeit, sowie unter Angabe der zu verkaufenden Sortimente öfentlich beliannt zu machen, teils durch Anzeigen in gelesenen Blättern, teils durch anderweite ortsübliche Bekanntmachung (Plakate, Ausschellen ete.). Für Forsterzeugnisse, die Gegenstand des Begelırs für den eigentlichen Holzhandel sind, wie z. B. größere Holzmassen, die den Lokalbedarf ïbersteigen, bei denen es also darauf ankommt, zur Beförderung des Absatzes fremde Holzhändler, bezw. Holzkäufer herbeizuziehen, ist das Aus-

1) S. Vortrag von W i $m$ m e $n$ a u e $r$ in dem Bericht über die XIV. Versammlung deutscher Forstmänner in Görlitz 1885, S. 116. 
schreiben in die Holzverkaufszeitungen, deren jetzt in Deutschland eine ganze Anzahl besteht, meist von großem Vorteil ${ }^{\mathbf{1}}$.

Von wesenthichem Einfluß auf die Ergebnisse der Verkäufe von Walderzeugnissen sind die $\mathrm{Z}$ a h $\mathrm{l}$ u $\mathrm{ng}$ s be d in $\mathrm{g}$ u $\mathrm{n}$ g. e $\mathrm{n}$. In den meisten Staatsverwaltungen bildet die B a r z a h 1 u 11 g die Regel, in Bayem, sowie manchen kleincren Staaten ist die Kreditbewilligung zulässig.

Das Gewähren einer gewissen Zahlungsfrist erscheint mit Rücksicht auf rie dadurch den meisten Käufern bereitete Annehmlichkeit zweckmäßig und dient zur Herbeizichung größeren Wettbewerbs, folgeweise zur Erhöhung der Preise.

Hierbei muß ein Unterschied zwischen großen unil kleinen Verkïufen gemacht werden. Bei geringen Hölzern ist es gewiß nützlich, auf Barzahlung zu sehen, bei größeren nur dann, wenn der Käufer als nicht zahlungsfähig bekannt orler nicht imstande ist, durch Bürgschaft, Hypothek oder Deponierung von Wertpapieren Sicherheit zu bieten.

Letztere Vorsichtsmaßregel, ren Kredit nur gegen Gewähr einer gewissen Sicherheit zu erteilen, empfichlt sich übrigens auch bei größeren Verkäufen ganz allgenein; man wird vielleicht auBerdem the Entrichtung einer Anzahlung (z. B. 10 o' des Kaufpreises) fordern und sich bis zur geleisteten Zahlung das Eigentumsrecht an dem Verliaufsgegenstand vorbehalten.

Auf diese Weise werden bei den Borgsystem Verluste vermieden und es kommen die günstigen Seiten dieses Verfahrens zur Geltung.

Will man an der Barzahlung auch bei dem Großhandel streng festhalten, so schafft man leicht ein Ionopol für wenige, besonders reichlich mit Betriebsmitteln versehene Käufer, während der kleinere Händler von den W' sen ist.

Von Bedeutung für die Ergebnisse der Verkäufe ist noch die Gewähr einer nicht allzu kurz bemessenen Abfuhrfrist, damit der Käufer nicht gedrängt ist und dadurch Gefahr läuft, ungewöhnlich hohe Fuhrlöhne bezahlen zu müssen, um clie vorgeschriebene Abfuhrzeit einhalten zu können.

Auch sollte man die Bearbeitung des Holzes in den Schlägen nicht so allgemein verbieten, wie noch vielfach üblich ist. Bei schwerem Eichenholz erscheint es fast unerläßlich, daß die Stämme behufs Erleichterung des Transportes in Walde zugerichtet werden, insbesondere bei Verwendung zu Eisenbahnschwellen.

Bei jeder Holzversteigerung sind gewisse Formen einzuhalten. Insbesondere werden vor Beginn derselben die Bedingungen bekannt gemacht, unter denen der Verkauf erfolgt. - Man schließt zweckmäßig mit der Zahlung rückständige Käufer aus, bestinmt die Termine für die Abfuhr, gibt die Zahlungsberlingungen bekannt und setzt die Frist fest, bis zu der für das Vorhandensein des Holzes Gewähr geleistet wird.

1) Die wesentlichslen dieser Blätter, welche in der Regel nichı bloße Annoncenblätter sind, sondern auch Abhandlungen und Mitteilungen aus dem Bereiche des Holzhandels und der Holzindustrie, bisweilen sogar zum Teil aus dem ganzen Gebiet des Forstwesens bringen, sind folgende:

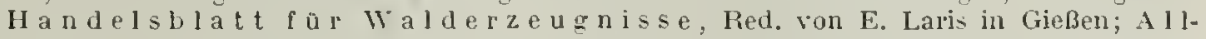
gemeiner Holzrerkaufsanze iger, Red. V. K. Schüßler in Hannover; Allg. Hol z-

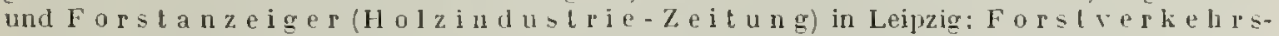

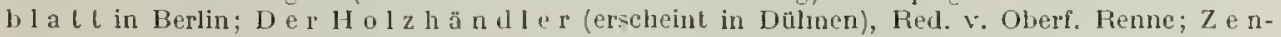

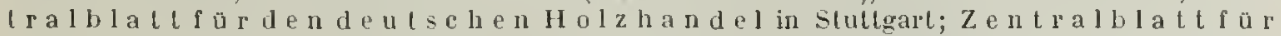

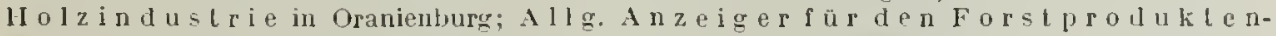

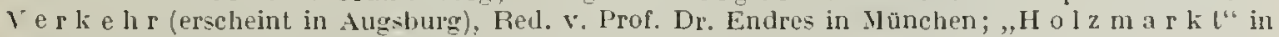
Bu n z l a usw.

Auch erscheint ein Holzrerkaufsanzeiger in $\mathrm{S} l \mathrm{r}$ a $\beta \mathrm{b}$ u $\mathrm{r}$, sowie ein solcher für Sachsen in $\mathrm{Dr}$ es $\mathrm{den}$. 
Die Zuziehung eines Kassenbeamten zu den öfentlichen Verkäufen erscheint zweckmäßig, damit die geforderten Barzahlungen oder Anzahlungen alsbald entrichtet, auch die Frage wegen der Zahlungsfähigkeit der Käufer sofort beantwortet werden liann.

Jeder Käufer erhält einen Holzüberweisungs- oder Holzabfuhrschein, d. h. eine Nachweisung über das von ihm erstandene Holz, die dessen Nummer, die Bezeichnung des Forstortes, den liaufpreis und einen Abdruck der Abfuhrbestimmungen enthält.

Durch die Uebergabe, resp. Annahne dieses Scheines wird der Verkauf abgeschlossen und das Holz steht alsdann auch auf Gelahr des Empfängers im Walde. Höchstens gibt man 24 Stunden Währzeit, innerhalb deren Einwendungen noch erhoben werden können, läßt aber während diesel Frist die Abfuhr noch nicht zu.

Die weiteren Förmlichkeiten der Holzverkäufe sind örtlich sehr verschieden und daher hier nicht weiter zu erörtern. Wesentlich ist in allen Fällen, daß der den Verkauf leitende Beamte sich weniger als solcher fühle. sondern als gewandter Geschäftsmanu auftrete. dessen Bestreben es sein muß, dem Käufer hinsichtlich billiger und berechtigter Wü̈nsche entgegenzukommen.

$\S 26$. B e förderungdes $H$ o $\mathrm{z}$ a b s a tzes. Der von Zeit zu Zeit immer wieder beobachtete Niedergang der Holzpreise, der teilweise auf massenhafte Einfulır fremder Nutzhölzer, bezw. Holzerzeugnisse, z. B. aus Schweden-Norwegen, sowie aus Oesterreich-Ungarn und Rußland, teilweise auf die mehr und mehr sich an Stelle der Holzfeuerung einbürgernde Heizung mit Mineralkolıle, sowie die Verwendung des Eisens statt des Holzes für manche Bauzwecke, in den meisten Fällen jedoch auf geminderte Baulust und Damiederliegen mancher Industriezweige in Zeiten allgemeinen wirtschaftlichen Niedergangs zurückzuführen ist, regt zu Maßnahmen an, die eine Besserung der Zustände und eine möglichste Hebung des Absatzes bezwecken. Wenn wir von den im Gebiet der Geselzgebung und Verwaltung liegenden Maßnahmen (z. B. Holzzölle, Eisenbahntarifgestaltung, Förderung des Transportwesens ete.) absehen und uns darauf beschränken, diejenigen Punkte zu erörtern, die in den eigentlichen Irreis der Forstverwaltung fallen, so finden wir in erster Linje die Notwendigkeit, durch zweckmäBige Tegeanlagen und sonstige Transportmittel die Abfuhr zu erleichtern. Insbesondere tritt mehr und melı die Notwendigkeit heran, durch Ausrïclien der Hölzer an größere Lagerplätze und gutes Sortier'en derselben je nach ihrer Gebrauchsfäligkeit dem Abnehmer den Holzbezug zu erlejchtern, derart, daß derselbe eine gute Lebersicht über das, was zu verkaufen ist, gewinnt und ferner die erkauften Hölzer ohne noclmaliges Umladen direkt dem Orte ihrer Bestimmung zuführen kann.

In den großen zusammenhängenden Forsten der Ebene und des Flachlıügellandes sind ohne Zweifel die Waldeisenbahnen, diese wichtige Errungenschaft der Neuzeit, berufen, hinsichtlich der Annäherung der Holzkäufer an die Forstverwaltungen eine bedeutende Rolle zu spiclen. da durch ihre Benützung jenen Grundsätzen des Verkaufs an größeren Lagerplätzen am leiclıtesten Rechnung getragen werder kann. Immerhin ist die Anlage ron solchen nicht allgemein zweckmäßig, sonderm namentlich an das Torhandensein großer Ueberschüsse von Handelshölzerı über den ürtlichen Bedarf hinaus, sowie an den Absatz nach einer bestimmten Richtung hin, an besten mit Anschluß an große Holzablagen, Eisenbalmstationen oder Wasserstraßen, geknüpft.

Beim Sortieren der Hölzer und dem Ausbieten derselben zum Verkauf ist den veruünftigen und billigen Wünschen des Holzhandels möglichst entgegenzukommen; 
der Forstwirt nuß sich mehr und mehr befleißigen, die technischen Anforderungen, die an Hölzer der versehiedensten Gattungen gemacht werden, und die Verwendungen, denen dieselben dienen sollen, liennen zu lernen; er muß sich genaue Warenkunde aneignen; sehon dadurch wird er viele Wünsche seiner Abnelmer, mit denen er infolge seiner Bestrebungen in einen regeren Verkehr tritt, in Erfahrung bringen.

Die Holztasen sind beweglich zu halten und der jeweiligen Marlitlage tunlichst anzupassen; sie müssen auf Grund genauer Holzpreis-Statistik aufgestellt werden, so daß keinerlei Williür und kein einseitiges Bestreben, die Holzpreise umatürlich in die Höhe zu schrauben, dabei im Spiele ist.

Bei Vermessung der Rundlıölzer walte strenge Unparteiliclıkeit und Gerechtiglicit ob; niemals verfahre man hierbei zu knapp, weder in Hinsiebt auf Längen- noch auf Stärkenbestimmung; geringe Qualitäten bezeichne man als solehe besonders und suche sie nicht als gut zu verwerten. - Beim Sehichtholz gebe man richtiges Maß und sehe auf gutes diehtes Legen, passe sieh aueh etwaigen besonderen, z. B. auf Herstellung ungewölnnlicher längen gerichteten Wünsehen der Käufer an.

Die Verkaufsart sei nicht einseitig gewählt, sondern werde je nach den herrschenden Unständen bestimmt, entweder als Versteigerung, oder Submission, oder Freihandverkauf. Den Verwaltungsorganen sind hinlänglich weitgehende Befugnisse einzuräumen, damit der sehleppende Instanzenweg möglichst abgekürzt wird; in der Firediterteilung und Feststellung der Zahlungsbedingungen, sowie in der Bestimmung der Abfuhrfristen komme man den Käufern möglichst entgegen.

Auf diese Weise wird sich ein auf Vertrauen beruhendes Verlaältnis zwischen den Forstverwaltungen und den Abnehmern bald herausstellen, welehes beiden Teilen zur Zufriedenheit gereichen wird I).

Es ist den Forstverwaltungen manchen Ortes noch die Aufgabe zugewiesen, technische Nebengewerbe zu betreiben, die eine Verarbeitung oder Verfeinerung des Holzes zum Zweck haben.

In der Regel erfordert die Leitung solcher Nebengewerbe, wozu namentlich Sägewerksbetrieb, Schindelfabrikation, Imprägnierung von Hölzern etc. gehört, eine gewisse Summe rein kaufmänniseher Fertigkeiten und Kenntnisse, die den mehr bureaukratisch angelegten Forstverwaltungsbehörden namentlich im Staatsbetriebe zumeist abgehen. Auch bedingen solehe Nebengeschäfte stets ein gewisses Naß von Speliulation, das sich selten mit der im Beamtentum, insbesondere der Staatsverwaltungen, unumgänglich nötigen Kontrolle hefriedigend vereinigen läßt. Auf weiter vorgeschrittenen Stufen des Wirtschaftslebens empfiehlt sich daher derBetrieb technischer Nebengewerbe dureh die Forstverwaltung nicht.

Eine Hauptaufgabe derselben ist es hingegen, in den Fällen ungenügenden Absatzes die private Tätigheit zu wecken. Man liann wohl sagen, daß die letztere in denjenigen Gebieten, in denen überhaupt mit Torteil Geschäfte zu machen sind, leicht einzubürgern ist.

Verbesserung der Terkehrsmittel, Agitation für Straßen- und Eisenbahnbau in rom Verkehr abgesehlossenen Gegenden sind wesentliche Mittel, un die Tätigkeit von Privatunternehmern zu weelien.

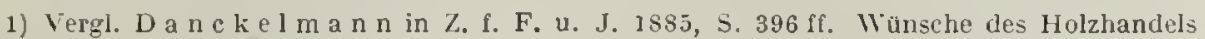
gegenuber der Forstverwaltung.

Bericht uber die XIV. Versammlung deutscher Forstmänner in Gőrlitz, Thena JI: ,Inwieweit sind die Jilagen und Wünsche der Holzhändler bezüglich ungenügender Berücksichtigung ihrer Interessen begründet und in welcher Weice kann berechtigten Einwendungen abgeholfen werden?" Jancherlei beachtenswerte Winke in bezug auf Hebung des Holzabsatzes finden sich

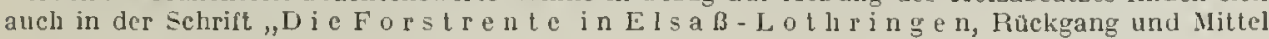
zur Hebung derselben". Straßuurg 1886. 
Die Forstverwaltungen müssen weiter durch Darbietung von Grund und Boden zu angemessenen Preisen, durch Ueberlassung von Wasserkräften, durch Abschluß von Holzlieferungsverträgen auf angemessene Zeiträume dem Privatunternehmer entgegenkommen und ihm den nötigen Mut einflößen, damit er sein Kapital in Unternelimungen steckt, deren Ergebnisse sowohl ihm selbst, als auch der beteiligten Forstverwaltung zugute kommen werden ${ }^{\mathbf{1}}$ ).

\section{Aufbewahrung von Hölzern.}

§ 27. Wenn wir auch mehrfach dem Anrücken der Hölzer zur Erleichterung des Verkaufes derselben das Wort geredet haben, so ist doch im algemeinen unsere Ansicht, daß hierbei eine möglichst zeitige Verwertung derselben in das Auge gefaßt werden muB, damit die Forstverwaltung der Aufsicht und Verantwortlichkeit über dic Hölzer bald überhoben ist und dachurch Verluste vermieden werden.

Ausnahmsweise kann jedoch auch die Aufbewahrung von Hölzern auf besonderen Holzlagerplätzen zur besseren Verwertung derselben nötig werden.

Es liann dieser Fall eintreten:

1. wenn ein durch außergewöhnliche Unstände herbeigeführter, den laufenden Verbrauch weit übersteigender Holzanfall rorhanden sein sollte und man die Preise nicht herabsetzen wollte, was namentlich in Jahren ungewöhnlicher Anfälle, z. B. nach Windbruchbeschärligungen, Insektenverheerungen vorkommen kann, sowie

2. wenn zur Versorgung weit vom Wald abgelegener Verbrauchsplätze, z. B. größerer Städte, und hier insbesondere zur Deckung des Bedarfs von Behörden unu öffentlichen Anstalten Vorratsplätze unterhalten werden müssen.

Ausnahmsweise mag die Bereithaltung kleinerer Mengen Brennholz für Notfälle (z. B. strenge Winter) in Betracht liommen, auch könnte man vielleicht Niederlagen für kleine Nutz- und Geschirrhölzer schaffen.

Man sollte im allgemeinen rlie Aufstapelung auf solche Holzarten und Sorten beschränken, die sich gut halten und nicht leicht verstocken. Vor allem sind trockene, huftige, freie Plätze zu wählen, womöghich etwas erhaben und geneigt. Sie sollen der Zu- und Abfuhr jederzeit zugänglich und gegen Entwendung möglichst geschützt. zum mindesten leicht zu beaufsichtigen sein. Sind derartige Aufstapelungsplätze ständig, so nennt man sie, namentlich soweit es sich um Brennhölzer handelt, wolıl auclı $\mathrm{H}$ ol $\mathrm{z}$ g ä r te n.

Eine Aufbewahrung von Hölzern in Wasser finclet auf manchen Sägewerken statt, wo sich dieselbe namentlich für K̈iefernhölzer empfielılt, da chese im Wasser nicht leicht jene blaue Farbe annehmen, die sich bei Aufbewahrung zu Lande leicht einstellt und das Aussehen der zu gewinnenden Schnittware beeinträchtigt. Für alle IJölzer hat die Aufbewahrung unter Wasser len Vorteil, daß dem Schwinden und Aufreißen vorgebeugt wird; am Rhein liommt es vielfach vor, daß ganze Gebuncle geflöBter Stammhölzer Jahre hindurch ohne jerlen Nachteil für ihre spätere Verwendungsähigkeit im Wasser aufbewahrt werden. Auch im Walde ist mit Erfolg der Versuch gemacht worden, solche Nadelholzstämme, die nicht augenblickich nach ihrem Anfall verkäuflich waren, im Wasser aufzubewahren ${ }^{2}$ ).

Bei der Aufbewahrung zu Lande hat man darauf zu sehen, daß St a m mhö l z e r stets auf U n ter l a g e n zu liegen kommen. Nan wird zweckmäßig sclion mit der Aufstapelung eine gewisse Sortierung der verschiedenen Stärken und Quali-

1) VergI. W e b e r in F.-Z.-Bl. 1883, S, 1 ff. Leber die Bedeutung einiger Holz verarbeitenden Industriezweige.

2) W im m e a u e r in A. F.- U. $\boldsymbol{J}_{*} \cdot$ Z. 1878, S. 443. 
tăten verbinden; einzelne besonders wertvolle Stämme legt man für sich, im übrigen bildet man Haufen, wie sie für die Verwertung zweckmëßig erscheinen. Bei Nadelhölzern ist zur Gesunderhaltung sowie zum Schutz gegen Inselitenangriffe vorgängige Entrindung zu empfehlen. Kleinere Nutzhölzer bewahrt man an besten in Schuppen auf.

Brenn hölzer, die den Hauptgegenstand der Aufbewahrung zu bilden pflegen, gelangen vielfach durch Wassertransport (Trift oder FlöBerei) an die Aufbewahrungsorte; hier ist besonders auf die Gewinnung von solchen Lagerplätzen zu sehen, die hinlänglich hoch üher dem Spiegel des Hochwassers liegen. Brennhölzer läßt man, sie mögen nun zu Wasser oder zu Lande an rlie Lagerplätze befördert worden sein, stets so aufschichten, daß die Stöße in langen geraden Fluchten senkrecht zum herrschenden Luftzug stehen, so daß dieser letztere die Zwischenräune durchstreichen kann. Mlan gibt den Stößen Unterlagen von Holzseheiten, danit das Holz. nicht unmittelbar auf dem Boden liegt, läßt zwischen den Reihen immer 1 Meter Zwischenraum und gibt den Stößen cine Höhe ron 2-3 Meter, damit die Fläche des Lagerplatzes möglichst ausgenutzt wird.

Prügelhölzer werden, damit sie leicht austrocknen und nicht verstocken, möglichst aufgespalten.

Auf großen Holzlagerplätzen hat man noch besondere Aufstapelungsmethoden, vermittelst deren nicht allein eine besondere, das Austrocknen befördernde Schichtung der unteren Lagen der Scheite durch schräge Anordnung derselben, sondern auclr eine Art Berlachung mit schicf gelegten Scheiten zur Ableitung des Regenwassers durehgeführt wird. Diese Methoden lassen sich olnne Zeichnung schwer beschreiben ${ }^{1}$ ).

Besondere Vorsicht ist der Aufbewahrung ungewöhnlich großer Anfälle von Nutz- and Bremhlı̈lzern nach vorgekommenen großen Waldschäden, insbesondere Windbrüchen, Insektenverheerungen (Borkenkäfer- oder Raupenfraß) zu widmen, da derartige Hölzer, insbesondere die dureh Insektenverheerungen zum Absterben gebrachten, leicht verstocken.

Nutzhölzer sind hier stets sofort zu entrinden, Brennhölzer spaltet man alsbald auf, befreit sie ebenfalls von der Rinde und setzt sie nicht eher in Stöße, als bis sie durch den Einfluß der Luft ahgetrocknet sind.

Das minderwertige Reisig bringt bei der Aufbewahrung selten Gewinn; die letztere ist vielmehr meist mit Verlust verbunden, da die Güte des Materials schnell zurückgeht, in der Regel nochmaliges Festbinden der Wellen nötig wird und dadurch besondere Unkosten entstehen.

1) Zu näherer Information vergleiche man: Die Holzbringungsmittel in den ligl. Bayerischen Salinenwaldungen, herausgegeben vom ligl. Bayer. Ministerial-Forstbureau 1860, S. 126. 


\title{
IX. \\ Die Forstbenutzung.
}

\section{Die Nebennutzungen im Walde.}

\author{
Voll
}

Viktor Dielerich.

L i t e r a $t$ u r: bei den einzelnen Abschnitten angegeben. Den ganzen Gegenstaud behandeln die Lehrbücher über Forstbenutzung (G a y e r- Il a y r, 10. Aufl. 1909 bezw. 9. Aufl. 1903, H e B, 2. Aufl. 1901).

\section{Eimleitung.}

$\S$ 1. Der Begriff , $\mathrm{N}$ e be $\mathrm{n} n \mathrm{u} \mathrm{z} u \mathrm{n} g \mathrm{e} n$ " ist mit Bezug auf die neuzeitlichen Verhältnisse in den Iulturländern zu verstehen, wo als Hauptzweck der Forstwirtschaft die Holzzucht und die Holznutzung gilt.

Ueberblicken wir zunächst, um Anhaltspunkte für die Bedeutung der Nebennutzungen zu gewinnen, die forstliche Statistil ${ }^{1}$ ), so finden wir, daß der Anteil derselben am Geldrohertrag aus Waldungen bei den deutschen Staatsforstverwaltungen zwischen 1,5 und 18,0\% schwankt, bei den größeren nur zwischen 1,5\% (EIsaßLothringen) und 5,2\% (Preußen). Aber diese Zahlen bedürfen insofern der Berichtigung, als sie - fälschlicherweise - auch alle die Nutzungen umfassen, welche die einzehnen Forstverwaltumgen aus dem ihnen unterstellten $\mathrm{n}$ i c h t forstlichen Grundbesitz (Wieser, Aecker, teilweise auch Torfriede etc.) bezichen. Andererseits ist zu beachten, daß der Geldwert mancher Nebennutzungen gar nicht oder nicht in scinem vollen Betrag in den Zahlen der Statistik zum Ausdruck kommt; denn einzelne Erzeugnisse finden ummittelbar Verwondung im eigenen Betrieb, bei andern sind die Erlöse nicht durch die Preisgesctze, sondern häufig durch altuistische Hotive bestimmt. Der Schwerpunkt mancher Nebennutzungen liegt überhaupt nicht auf privatwirtschaftlichem, sodern auf volkswirtschaftlichem Gebiete. Man möchte übrigens auch geneigt sein, sie gewissermaßen als Dispositionsfonds in der Hand des Waldbesitzers zu bezeichnen, mit deren Flüssigmachung er als guter Geschäftsmann zur geeigneten Zeit nicht kargen darf rücksichtlich der mittelbaren seinem Entgegenkommen entspringenden Vorteile.

1) Vergl. En d r e s, Forstpolitik S. 123 f. ferner Mitı. d. D. F.-V. 1911 Nr. 3. 
Es fehlt noch an einer einheitlichen Systematili der Nebennutzungen; so wird z. B. die Rindemutzung von manehen unter den Nebenprodukten aufgefülırt, ebenso das Besenreisig, die Christbäune usf. Richtiger dürfte es wohl sein, u n ter die II a p tnutzungalle rjejenigen Walderzeuguisse einzugliedern, welche bei der Abtrennung der einzelnen Holzpflanzen vom Waldboden anfallen, soweitsienicht - wirtschaftliche Ausbeute vorausgesetzt - auch auf andere Weise gewonnen Werden können. Die Rindennutzung usf. wïrde darnach zur Hauptnutzung, dagegen z. B. die Gewinnung der Holzsämereien und des Futterlauhs zu den Nebennutzungen zu rechnen sein.

Dabei empfiehlt sich folgende Einteilung:

I. Die Nutzung der Nebenerzeugnisse vom s te h e $\mathrm{nden} \mathrm{Holz}$, seiner Früchte und dergl. sowie seiner Ahfälle.

II. Die Nutzung der Nebenerzengnisse des $\mathrm{W}$ a l d b o d e n s

a) pflanzliche Nebenerzeugnisse.

b) Mineralien usf.

III. Die Jagd- und Fisehereinutzung.

Auf die letztgenannten Nebemutzungen ist hier nicht weiter einzugehen, da sie Gegenstand besonderer Abhandlungen in diesem Handbuch sind.

Bei allen Nebennutzungen ist der Gesamterfolg der Waldwirtselaft und der Grundsatz der Nachhaltigkeit im Auge zu behalten. Deshalb ist jeweils die Rückwirkung der einzelnen Nebennutzungen auf den Hauptzweck der Waldwirtschaft zu prüfen. Das'strengste Iriterium, das man in dieser Hinsicht anwenden kann, ist der von $\mathrm{A}$ a $\mathrm{y} \mathrm{r}^{1}$ ) aufgestellte Grundsatz, da $B$, je d e $\mathrm{Nutzung}$ im IV a l d e zugleich einen wald ba $\mathrm{l}$ ichen $\mathrm{Z}$ we ck" verfolgen müsse.

\section{Die Nutzung der Nebenerzengnisse vom stehenden Holz.}

\section{Die Baumfrüchte (Holzsämereien).}

L i t e r a $t$ ur: N ob be, Handbuch der Samenkunde. Die waldbautiehen Lehrbüeher von

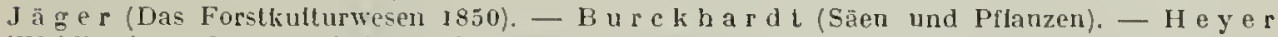
(Waldbau). - G a y e (Waldbau). - M a y $r$ (Waldbau auf naturgesetzlicher Grundlage). Fürst (Pftanzenzucht im Watde). - Ferner die im einzelnen zitierten Arbeiten.

\section{a) Die ökonomischen Gesichispunkte.}

§ 2. Die Nutzung der Waldbaumfüchte erfolgt vorwiegend zum Zweck der Gewinnung von Holzsämereien für die künstliche Bestandesverjüngung und für Neuaufforstungen; die Schweinemast hat nur noolı ganz untergeordnete, örtliche Bedeutung. Gelegentlich finden einzelne Sämereien Verwendung zur Wildfütterung (Eicheln Buchehn, RoBkastanien, Wildolsst u. a.), zur V'erarbeitung in der Lebensmittel- und in der chemischen Industrie (Eichelkaffee, Zichorien, Tinten usf.). Die Früchte der Edelkastanie und der Walmuß seien als GenuBmittel nur nebenbei erwälnt. Eine gewisse Rolle spielt endlich noch die Verwendung der Bucheckern zur SpeiseOel-Bereitung, besonciers geschätzt von der ärmeren Landbevölkerung.

Was nun die Nutzung der zur W a l i z u c h t erforderlichen Sämereien anbelangt, so bildet sie eine beachtenswerte Gelrleinnahmequelle mehr nur beim $\mathrm{K}$ l e inWa l d bes it z: ländliche Privatwaldbesitzer, auch Gemeinden, verpachten das Samenerträgnis teils direkt an Samenhändles und Kilenganstalten, teils an die mit

1) Vorwort zur 10. Auft. der Forstbenutzung 1909. 
Sammeln beschäftigten Personen. Der Waldbevölkerung bringt diese Nebennutzung ${ }^{1}$ ) Arbeitsgelegenheit und Verdienst in den Jabren reicher Samenernte, namentlich wenn bei anderwärts geringen Ergebnissen nur einzelne Gebiete ein gutes Jahr zu verzeichnen haben; die Agenten der Händler kommen dann von weither gereist und suchen durch lebhafte Steigerung den Bedarf ilirer Auftraggeber zu decken. Bei den größeren Forstverwaltungen hat die Nutzung der Waldsamen im Lauf der Zeit verschiedene Wandlungen durehgemacht. Früher stand das Einsammeln für den eigenen Bedarf allgemein in Ueburg; daneben hat allerdings der Samenaustausch und der Bezug von Händlern, besonders in Süddeutschland, schon früh Eingang gefunden ${ }^{2}$ ). Mit dem Ueberhandnehmen der künstlichen Verjüngungsformen sind die Holzsämereien, vor allem die Nadelholzsamen, mehr und mehr Handelsartikel geworden; mit ihrer Gewimung und Verwertung befaßt sich ein besonderer Industrie-Zweig, neben vielen kleinen Betrieben eine Reilie anselmlicher Kilenganstalten. Viele Waldbesitzer baben infolgedessen das Einsammeln und zumal das Ausklengen der Samen aufgegeben oder sich damit begnügt, teils gegen mäßige Geldentschädigung teils gegen Ablieferung bestimmter Mengen Erlaubnisscheine zum Sammeln anszustellen; diese Benutzungsart ist besonders für Laubholz- (vor allem Eicheln und Buchelı) und für Weißtannensamen eingeführt, in geringerem Umfang für die andern Nadelhölzer; denn die Zapfenbrecher galten vielfach als unwilliommene Kunden, die man sich aus Furcht vor Waldbeschädigung und vor Unfallhaftung lieber rom Halse hält.

In der preußischen Staatsforstverwaltung ${ }^{3}$ ) ist an dem Grundsatz der S e l b s tgew in nu $\mathrm{u}$ g von Kiefern- und Fichtensamen festgehalten worden; nach den neuesten bezüglichen Vorsehriften ${ }^{4}$ ) soll die ausschließliche Beschaffung des für Staatswaldungen erforderhichen Saatguts durch die staatlichen Darren mit allen Mitteh angestrebt werder. Aber auch in weiteren forstlichen Kireisen hat sich neuerdings ein Umschwung zugunsten der Selbstbeschaffung des Samens und im Sinn tunlichster Ausmutzung der Samenernten geltend gemacht. Veranlassung hiezu gaben die üblen Erfahrungen, die man mit unreellen Samenlieferungen (Beimischung nicht gewünschter Arten, z. B. Stiel- und Zerr- statt Traubeneicheln, Berghiefer zur gewöhnlichen Kiefer u. a.) mit unsachgemäß behandelten und darum gering keimfähigen Sänereien und nicht zuletzt nit Saatgut ungeeigneter Herkunft ${ }^{5}$ ) vielfach

1) Zu vrrgl. die Sehilderungen $S$ chot ls im F. Zentrallyl. 1904 lf. aber das Sammeln der Kiefernzapfen in Belgien, Frankreich, Ungarn und Pußland.

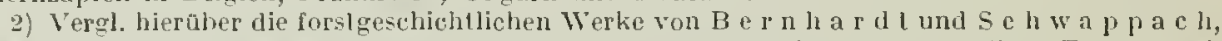

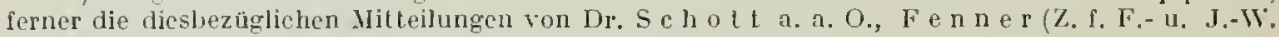
1904, S. 39), J a a c k (M. d. D. F. - T, 1909, Nr. 6, S. 138 f.).

3) Vergl. H a g e n-D o n n er, Die forsllichen Verhälnisse Preußens, 3. Auft. 1894, 1. Bd., S. 283 ff., ferner $S$ e $h 1$ i e e k m a n n, Handbuel der Staalsforstwerw. in Preußen, 1900, S. 628 ff.

4) Vergl. Aufsatz von M ö $\mathrm{l}$ e r, Z. f. F.- U. J.-TF, 1910, S. 694 ff., wo die betr. Verfügungen angegeben sind.

5) Es würde zu weit fülren, die ganze umfangreiche Literalur hier anzugeben, dic in den letzlen Jahren sich über diese Frage verbreitet hat; es dürfle vielmehr genügen, die Namen einiger

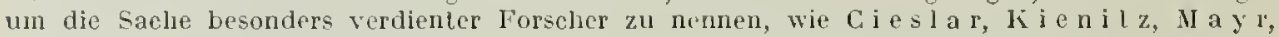

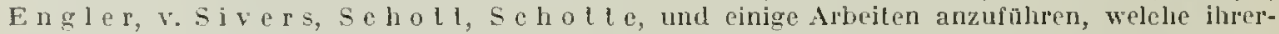
seits eingehende Literaturnachweise enthalten, so $\mathrm{H}$ a a $\mathrm{ek}$ a. a. O., K i e $\mathrm{n} \mathrm{i} \mathrm{z}$, , Formen und Abarlen dergemeinen Kiefer" in Z. f. F.- u. J. 1911, S. 4 ff., Dr. Se hot 1 a. a. O., Sanmel-

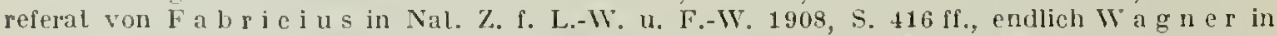
,Die Grundlagen der räumliehen Ordnung in Wald ', 2 . Aufl., S. 21 ff. Uie Provenienzfrage war aueh Beralungsgegenstand bei einer Reihe von wissenschaftlichen Tagungen, so in Inlernationalem Verband forstlicher Versuchsanstalten 1901, 1906 und 1910, beim Internationajen landwirtsel. Kongreß zu Wien 1907; der deutsehe Forstwerein hat sich 1906, der Forstwirtsehaftsrat 1910 mit diesen Gegenstand befaßı. Besonders akluell ist die Frage bezüglich Deutsehlands Hauptholzart, der Isiefer, geworden, deren samen ohmehin sehon lange die wichtigste Rolle im Iilengbetrieb und Samenliandel sjielt. 
gemacht hatte. Gerade dem letzteren Gesichtspunkt mißt man ein gut Teil der Schuld an den vielen Kulturmißerfolgen bei, an dem langsamen Wachstum, dem Vorherrschen schlechter Wuchsformen und der hochgrarligen Empfindlichkeit vieler Jungwüchse gegenüber den Jugendgefahren und Krinderkrankheiten, denen die Saaten von Anfang besonders stark ausgesetzt sind, wenn das Saatgut unter fremile İlima- und Standortsverhältnisse verbracht worden ist. Zur Erklärung dieser Beziehungen hat die Forstwissensehaft die Theorien der Erblichkeits- und Züchtungslehren $\left.{ }^{1}\right)$ beigezogen; durch eingehende Provenienzuntersuchungen ${ }^{2}$ ), die ihrerseits wieder befruchtend auf jenes Gebiet der naturwissenschaftlichen Forschung eingewirkt haben, ist die Verdächtigkeit fremden Saatguts gerechtfertigt worden. Hieraus ergibt sich als Forderung für die Praxis - abgesehen von der natürlichen Verjüngung - sorgfältige Auslese des liultursamens und Gewährleistung für geeignete Herkunft, was an sichersten bei Selbstgewinnung in den einzelnen Revieren oder wenigstens innerhalb der klimatisch abgegrenzten Waldgebiete sich ermöglichen läßt; als andere Benutzungsart ist allenfalls noch die Oeffnung geeigneter Bestände zum Sammeln durch Dritte zu empfehlen unter zuverlässiger Garantie für spätere Lieferung des hieraus gewonnenen Saatguts. Von verschiedenen Forstverwaltungen ist diesen Forderungen praktische Folge ${ }^{3}$ ) gegeben worden. Mit Recht wird der Nutzbarmachung aller Waldhaumfrüchte in Interesse der Waldkultur wieder mehr Gewicht beigelegt, auch wenn in den Hauptbüchern kein nennenswerter Geldertrag aus diesem Nebennutzungsgegenstand erscheint.

\section{b) Die Technik der Samen-Ernte, -Gewinnung und -Aufbewahrung.}

$\$ 3$. Di e Ernte der B a u $\mathrm{fr}$ ü eht e. Nicht jedes Jahr bringt ergiebige Ernten; Vollmasten kehren - je nach Holzart - nit größeren oder kleineren Unterbrechungen wieder. Im allgemeinen nimmt man an $\left.{ }^{4}\right)$, daß die schwerfü̈htigen Holzarten seltener als die leichtfrüchtigen fruktifizieren, ferner daß wärmeres Iilima der Fruchtbildung günstiger sei; besonders warme Sounmer bringen häufig reichliche Eichelmast ${ }^{5}$ ); dagegen scheinen trockene Sommer auf den Samenertrag der Fichte

1) Vergl. Wagner (a. a. O.); Oppermann (Vraenge Boege, C. f. d. g. F. 1909, S. 108); H a u h, Erblichlieil hei Buche und Eiche, C. 1. d. g. F. 1909, S. 333 ; H ess e l m a n (Rassen schwed. Waldbäume, in den Mtt. a. d. Versuchsanstalt Sehwedens, 3. Heft 1907: Z ed e r b a u e (Variationsrichtungen der Nadełhözer - Silz.-Ber. l. K. Ak. f. Wiss. in Wien, Dez. 1907).

2) Die meisten Versuchsanstalten hahen solche in Angriff genommen und z. T. auch schon einige Ergebnisse bekannt gegeben. Vergl. die Rerichle über den Vi. Kiongreß des lnternat. Verbands forstl. Versuchsansla]ten in Brüssel 1910. (C. f. d. g. F. 1910, S. 506 ff.)

3) Vergl. y o jl e r (a. a. O.) betr. Preußen. Die bayrische Slaatsforstverwaltung hat probeweise vor einigen Jahren der $S \mathrm{c}$ l o $t \mathrm{t}$ sehen lilenganstalt ein lieferngebiet in der Jalz zur Zapfenernte geöfnet unler der Berlingung der Lieferung des von dort stammenden Samens für den Bedarf der Staatsforste. (Bericht über die Til. Haupt-Vers. d. D. F.-V. 1906, S. 121 ff.; F ürsl, Pflanzenzucht in Walde, s. 91.) Die Württ. Staatsforstverwaltung läßt Iífernzapfen in ihren Forslbezirken sammeln und durch eine Privatanstalt ausklengen. Dic Hessische Slaatsforstrerwaltung lat i. J. 1904, un einheimischen Samen fü die Domanial und Kommunalwaldungen gewinnen zu kōnnen, cine im Odenwald gelegene lilenganstalt angekauft. (A. F. 11. J.-Z. 1905, S. 318.) Endlich ist auf die vont Deulschen Forstwirtschaftsrat ins Leben gerufene Organisation des Samen- und t'flanzenlandels hinzumeisen, welcle Garantie für Lieferung bezw. Verwendung nur deulschen litefernsamens bielel.

4) Arbeiten über den Samenertrag der WaJdhăume sind ziemlich spāılich; am eingehendsten belıandelt M a y die bezüglichen biologischen Verhâltnisse in , Waldbau auf naturgeselzlicher Grundlage" und in der 10. Aufl. der Forstbenutzung von G a y e r - Il a y r. Speziell für Fichten liegen Arbeiten vor von 0 i e w k i (C. f. d. g. F. 1909, S. 137). W(rtvolles statistisches Material bietet die Irbeit von se ln w p p a e h über die Samenproduktion us. (Z. f. F. u. J. 1895).

3) Vergl. auclı G w i n n e r, M. f. d. W. F. W. 1855, S. 309 (eine parallele mit den Weinjahren ist hiernach nicht nachweisbar). 
nachteilig zu wirken; höhere Sommertemperatur wirkt also bald vorteilhaft, bald nachteilig auf die Entwicklung der Blüten zur Frucht, begünstigt aber jedenfalls die

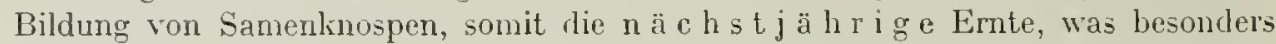
deutlich bei der Buche in die Erscheinung tritt. Die Hoffnung auf ein kommendes Samenjahr, die das Auftreten zahlreicher Blütenlinospen erweckt, wird leider häufig zerstört, indem ungünstige Witterung während des Frühjahrs die Blütenentfaltung, oder ebensolche in Sommer das Austragen der angesetzten Blüten vereitelt. Da Wälme und Lichtgenuß das Samenertrügnis erhöht, kann auch durch Maßnahmen der Bestandeserziehung (Kronenfreihiel)) auf die Häufigkeit und Reichlichkeit der Fruchtbildung eingewirkt werden ${ }^{\mathrm{I}}$ ).

Wenn num freilich ein regelrechter Emtebetrieb nicht jedes Jahr eingeleitet werden kann, so finden sich doch fast immer Früchte an Randbäumen; deren Nutzung erscheint in Fehljahren besonders dringend. In den Samenjahren kann mehr Auswahl getroffen werden; im allgemeinen soll man von mittelalten Bestïnden, von normal und kräftig erwachsenen gesunden Bäumen mit gut ausgebildeter Krone sammeln lassen; dies empfiehlt sich vor allem wegen der Ergiebigkeit der Arbeit, dürfte aber auch am chesten Gewähr für wuchskräftige Pflanzen ${ }^{2}$ ) liefern. Was ferner die Er n te z e it betrifft, so sind hiefür die natürlichen Vorgänge der Reife einerseits und des Abfallens der Früchte bezw. Sämereien andererseits maßgebend. Die Regel ist, daß nur l' e i f e Füühte geerntet werden; denn die weitere Behandlung und die Aufbewahrung nicht ausgereifter. Früchte bietet Schwierigkeiten und wenig Gewähı für befriedigende Saaterfolge. In IIai/Juni beginnen Ulme und Pappel zu reifen, im Juli die Weiden, Juli/August die Birken; Spitzahorn, Eiche und Tanne Ende September, während für die übrigen Waldbäume der Oktober als Reifezeit gelten liann. Der Zeitpunkt des Samenabfalls ist insofern entscheidend, als die schweren und größeren Früchte meist nachher, die leichten und zumal die kleinen vorher eingesammelt werden müssen. Die frühreifen Früchte beginnen schon wenige Tage nach der Reife abzufliegen, die der Ulme von Ende IIai an, Pappel, IVeide im Juniund Juli, Birke Ende Juli; die Eiche und Buche lassen ihre Früchte schon im Oktoher, bald nach der Reife, abfallen, die Weymouthskiefer öfnet ihre Zapfen Anfang Oktober und die Tannenzapfen beginnen häufig schon Ende September abzublättern, wobei die Samen mit den Schuppen zu Boden fliegen. Elwas länger (November bis Anfang Dezember) bleiben an Baume die Früchte des Ahom, der Linde und Hainbuche; Eschen- und Erlensamen fallen den Winter durch ab und überwintern zum Teil an Baume. Die spätesten sind Fichte, Kiefer und Lärche; Fichte und Fiefer lassen von Anfang März ab (teilweise und je nach Vitterung auch schon früher) die Zapfenschuppen sich öffuen und den Samen entfliegen, die Lärchenzapfen werden erst von der vollen Frühjahrswärme im April und Mai ausgeklengt.

Hienach richtet sich die A r t des $\mathrm{E}$ in s a $\mathrm{m}$ m e I n s. Nur bei den größeren ungeflügelten Früchten (der Eiche, Buche, Kastanien, Nußbäume u. a.) lohnt sich das Auflesen am Boden. Die meisten Früchte müssen am stehenden Holz eingeerntet werden, soweit man sie nicht von gefälten Stämmen abnehmen kann. Nach Besteigen

1) Besonders interessant sind die Forschungsergebnisse von A. S o b o l e f (Petersburg) über die Verteilunğ des Samenertrags bei der Fichte nach den Bäumen der $k \mathrm{r}$ a $\mathrm{ft}$ schen Stammklassen. (Die Bäume der ersten drei Klassen liefern beinahe die ganze Samenernte; der Samenertrag hängl sonach in erster Linie von der Hohe des Baums und der .1usbiluung der lirone ab.) Vergl. C. f. d. g. F. 1909 , S. 137.

2) Vergl. die Untersuchungen $G . S \mathrm{c}$ h o $\mathrm{t} t \mathrm{e}$ 's in Stockholn (jüngere und mittelalte Pflanzen ergeben die kräftigsten Pflanzen. N. Z. f. F. u. L. 1906, S. 22 f.). 
der Bäume mittelst Leitern, Steigeisen oder Steigrahmen I) werden die Früchte abgebrochen, abgestreift oder auch dureh Schlagen auf die Aeste (mit Aexten u. a.) zum Abfallen gebracht, um dann auf untergelegten Tüehern aufgefangen zu werden. Die leichten Früchte, wie von Erle, Esehe, Hainbuche, Birke und Ulme, die beim Abstreifen ziemlich weit abfliegen könnten, werden am besten mitsant den Zweigchen abgebrochen; der Sammler muß dann mit einem ungehängten Sack versehen sein, um die Samen alsbald unterbringen zu können. Die Zapfen der Nadelhölzer werden meist mit Haken abgestoßen und unter den Bäumen aufgelesen oder an den mittelst Haken herabgebogenen Zweigen abgestreift.

Mit dem Einsammeln der Früchte ist die Gewinnung der meisten Laubholzsämereien in der Hauptsache erledigt; es sind nur noch die Beinengungen, je nach Umständen mehr oder weniger sorgfältig, zu entfernen, Sproßteile und sonstige Anhängsel loszutrennen, namentlich wenn es sich darum handelt, die Samen zu versenden oder in den Handel zu bringen; bei Gewinnung für den Eigenbedarf ist die Reinheit des Saatguts weniger von Bedeutung. Durch Dreschen, Sieben und Wurfen werden gröbere und feinere Verunreinigungen abgesondert, durch Aufhängen, Trocknen event. auch Kklopfen die in Fruchtständen zusammengeschlossenen Samen (Birke, Erle, Pappeln) befreit; vor allem aber ist für oberflächliches Abtrocknen Sorge zu tragen. Wesentlich mehr Arbeit erfordert die Gewinnung des Samens der meisten Nadelhölzer aus den eingesammelten Zapfen. Die besonderen hiefür zu treffenden Anstalten werden eingehender im nächsten $\$$ besprochen werden.

Es sind hier nur noch einige Regeln für die Gewinnung der wichtigsten Laubholzsamen im einzelnen anzugeben:

Die Eich e I läßt man nach deren Abfall im Oktober auflesen; da dic schadhaften und wurmstichigen Samen zuerst abzufalten pflegen, so wartet man mit dem Sammeln, bis das Abfallen schon etwas allgemeiner ist, um die besten, d. h. sehönsten und vollkonmensten Früchte auswählen zu kōnnen. Jlan läßt, damit sich dieselben nicht erlitzen und zu keimen beginnen,nur an trockenen Tagen sanmeln, wartet auch des. Iorgens, bis der Tau abgetrocknet ist.

Die $\mathrm{B}$ u cheln kann man in ähnlicher Weise auflesen lassen, was allerdings langsam Fonstatten geht, deshalb läßt man wohl auch die Bäume besteigen und durch Anklopfen der Aeste die Bucheln zum Abfallen bringen. Endlich kennt man bei dieser Holzart noch die Methode des liehrens nach crfolgtem Abfall, wobei jedoch das Lauh nitgekehrt wird, weshalb diese Erntewcise weniger zu enpfelılen ist. Durch Wurfen wie bein Getreide werden die Bucheln vor der Aufbewahrung, bezw. Aussaat von den Laub, sowie den tauben Körnern gesondert.

Den $\mathrm{H}$ a in bu chen a m en sammelt man entweder durch Abpflücken der Samenbüschel oder durch $A$ bklopfen des Samens bei windstillem Wetter, an besten nach dem ersten Reif. Von den Flügeln wird er durch Dreschen und Sieben oder Wurfen befreit.

Den B i r k n s a e n gewinnt man, wenn er bräunlich geworden ist, am besten durch Abschneiden der Zweige, welche man alsdann in Büscheln aufhängt und trocknet, worauf die Samen aus den Zäpfehen dureh Abliopfen der Büschel gewonnen werden.

A horn- und Eschensamen, welcher im Oktober und November abfliegt, wird entweder durch Abbrechen von Zweigen, Ibschneiden der Samenbüschel mit der Schere, oder Abstreifen des Samens von den Aesten nach Besteigung der Bāume gesammelt; auch kann man ihn klopfen und auf Tüchern aufrallen lassen.

Der U I m e $\mathrm{s}$ a in e $\mathrm{n}$ soll bald nach der Reife (also etwa Anfang Juni) durch Abstreifen von den Zweigen gesammelt werden; bei windstllem Wetter ist auch AbkJopfen ratsam.

Die Erlenzāpfchen gewinnt man durch Abplücken im Spätherbst, am besten nach den ersten Frösten oder durch Abklopfen auf Tacher; in māßiger Stubenwärme fallen die Samen bald aus; auch das Auffischen des Samens in Frühahr wird für am Wasser stehende Erlen empfohlen; doch ist zu beachten, daß die Keimfähigkeil des so gewonnenen Samens bald verJoren geht.

Das Einsammeln der A s p e n kätzchen ${ }^{2}$ ) geschieht unmittelbar nach der Reife (Ende Mai, Anfang Juni) bei trübem Wetter oder morgens, weil sich die Samenkapseln unter dem

1) F r i e d r c h hat denvon ihm konstruierten Steigapparat auch für diesen Zweck empfoh* len. C. f. d. g. F. 1906, S. 449 .

2) Nach den Versuchen und Ausführungen von Ii. bayr. Forstrat 11 of $\mathrm{m}$ a $\mathrm{n}$ - Rosenheim. F. Centr.-Bl, 1902, S. 360 . 
Einfluß der Sonnenwärme öfnen; in geschlossenen, gegen Luftzug gesicherten Räumen werden die gesammelten Kälzchen dann durch die Luftwärne zum Oeffnen gebracht.

$\S 4$. Die Gewinnung der Nadelholzsamen (Darr-oder Klengbetrieb). Am einfachsten ist das Ausklengen des $\mathrm{S}$ a $\mathrm{m}$ e $\mathrm{n} s \mathrm{~d}$ e $\mathrm{r}$ W e i $\mathrm{B} \mathbf{t}$ a $\mathbf{n} \mathbf{n}$ e $\mathbf{n}$, deren Zapfen Anfang Oktober oder schon Ende September (je nach Gegend und Jahrgang) vom stehenden Holz durch Abbrechen oder von eigens gefällten Samenbäumen entnommen werden. Schon bci mäßigen Wärmegraden öffnen sich die Schuppen. Man breitet die Zapfen auf luftigen Böden aus, stößt sie täglich öfters mit Rechen um, sodaß sie zerfallen und Schuppen nebst Samen sich von den Spindeln lösen; soll das Zerfallen beschleunigt werden, so kann man die Zapfen einer mäßigen Erwärmung aussetzen. Durch Sieben trennt man die Samenkömer von den Schuppen, befreit hiernach mittelst Reiben die Körner von den anhaftenden Flügeln und reinigt den Samen durch Wurfen, Wo Tannensamen zum Selbstgebrauch von Forstverwaltungen gewonnen wird, ist das Abflügeln unnötig.

Auch bei IV e y m o u th s k i e f e $\mathrm{r}$ n zapfen bedarf es keines besondleren künstlichen Klengprozesses, da der Same bald nach der Reife von selbst ausfällt. Die Entleerung der Zapfen wird durch Umstoßen derselben mittelst Rechen befördert.

Höherer Wärmegrade zur Ausklengung bedürfen die von Natur bis ins Frühjahı von den Zapfenschuppen umschlossenen Samenkömer der Fichte, Fiefer und Lärche; es sind deshalb besondere Vorrichtungen nötig, um die Wärme auf dieselben entsprechend einwirlien zu lassen.

Ehe auf die Darr- oder Kilengverfahren eingegangen wird, muß noch bezüglich des Zeitpunkts der Zapfenemte bemerkt werden, daß insbesondere für die Kiefer frühe Ernten zu widerraten sind. Nicht als ob die Zapfen im Oktober und November etwa weniger keimfähige Körner ${ }^{1}$ ) enthielten als die am Baum nachgereiften im Januar und später ${ }^{2}$ ); vielmehr sind die früh geernteten grünen und noch stark wasserhaltigen Zapfen erfahrungsgemäß weniger gut klengbar als die spät gepflückten. „Einmal verlangsant ihre Verwendung das Darrgeschäft und erhöht die dem Samen in der Darre drohenden Gefahren, sodann sind sie . . . für eine längere Lagerung nicht geeignet"; es treten Schimmelbildungen auf, wenn man Uebervorräte von reichen Emtejahren fürs nächste Jahı üherhalten will. Das Pflücken der Zapfen sollte deshalb womöglich nicht vor Dezember beginnen ${ }^{3}$ ) und bis in den Februar und Härz hinein fortgesetzt werden; die zuerst gepflückten sind auch zuerst aufzuarbeiten.

Den besten Samen gewinnt man, wenn das Ausklengen, ebenso wie dies in der Natur erfolgt, durch die Sonnenwärme besorgt wird (Sonnendarren). B u r $\mathrm{k} k \mathrm{~h}$ a r d t führt in ,Säen und Pflanzen" an, daß man von Sonnensamen liamm \%3 der gewöhnlichen Einsaat gebrauche. Diese Methode ist uralt und wird schon in D ö bels Jägerpraktika beschrieben, wo die Bezeichnung ,Buberte“ für Sonnendarre vorkiommt.

Neuere Untersuchungen ) haben diese Erfahrungen der alten Praktiker vollauf bestätigt. Trotzrlem sind die Sonnendarren allmählich fast ganz in Abgang gekommen, weil das Ausklengen etwas langsam vonstatten geht und zu sehr von der Witterung abhängig ist; es dürfte aber zu prüfen sein, ob nicht bei Gewinnung des Revier-

1) Vergl. die Untersuelungen von $\mathrm{H}$ a a c. k, \%, f. l?. u. J. 1905, S. 296 ff.

2) Vergl. H a a e k, M. d. D. F. - V. 1909 , S. 149.

3) Vergl. M ôlle r (a. а. O.); in Preußen sollen später geernlete Zapfen von den Darren höher bezalılt werden; dic Pflücker sind hierdurch zı Vornahme der Ernte erst iın Januar-Mäız.

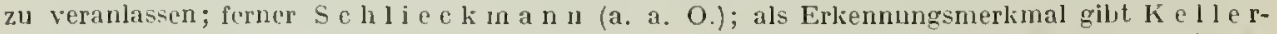
Darmstadl an, der schon länger gepflückte Zapfen trage cinen welken, braunen und abgestorbenen Stiel, der friseh gepllüchle zeige beim Ritzen frisch-grüe Rinde

4) H a a c k in \%. I. F. U. J. 1905, S. $296 \mathrm{ff}$. (in der Sonne gedarrter hatte $99 \%$ Keimfähigheit). 
hedarfs da und dort, wo gecignete Vorrichtungen leicht angehracht werden kömnen, auf jenes hewährte Verfahren zurükgegriffen werden solt. Es sei deshalb die Einrichtung einer Somendarre liurz beschrieben:

An der Sudwand eines Gebăudes errichtet man ein Gerüst mit Wetterdaelı, unler welehem llorden, mit Zaplen geTüllt, etagenweise und in einem solchen Höhenahstand übereinandergestell werden, daB die Sonnenslrahlen auch die hintersten Zapfen riner llorde inmer noch treffen müssen. Unler die untersten Horden bringt man einen Schubkasten mit Leinwandboden an, damit elwaiges Regenwasser clurchdringen und der auf der Leinwancl liogende Samen alsbald wieder abtrocknen kann. Auf die JIorden schütlet man Zapfen, wendel dieselben bei Somnensclıein öfters un, damit dịe Samenkörner ausfallen. Dieselben gelangen dureh die Gillerbőden der Horden von der obersten bis zur untersten hindureb und sammeln sich schlieBlich in dem unlen angebraelilen Schulkasten. Sind die Zapfen auf diese Weise so weit als möglich enfleert, so werden sie noch in einen hohlen, laßartigen Zylinder, das sog. ,Leierfa ${ }^{66}$, gebracht und in demselben dureb Undrelıen so lange erschüttert, bis der Same durch diese Bewegung vollständig ausgelallen ist.

Statt dieser Horden hat man wolı auch nit Deckeln versehene Kiaslen, welche sehräg gegen die Sonne geneigt aufgeslellt werden, in Anwendung gehracht. Diese Deckel, inwendig mit weißer Oelfarbe ges]richen, haben den Zweck, hei Regenwetter dic Kiasten zu versehließen, hingegen in geöffneteru Zusland bei entsprechend sehräger Stellung dic Sonnenstrablen zu refleklieren und auf die Zapfen zu werlen.

Das Oefinen und Schließen des Deckels wird erleichtert durch eine an demselhen angebrachle Schnur, welche über ene hinter dem Kasten an einem Pfosten befindliche Rolle läuft und am herabhängenden Ende mit einem Gewicht beschwert ist, durch dessen Bewegung der Deckel gesenkt oder gehoben werden kann.

Alle andern Klengverfahren bedienen sich künstlieher Wäımequellen. Man unterscheidet zunächst Feuerdarren und Dampfdarren.

Die cinfachste $\mathrm{F}$ e $u$ e r d a r re läBt sich in geheizten Räumen dadurch herrichten, daß man Gestelle über und rings um den Ofen anbringt; auf diese werden die Zapfenhorden eingelegt; die Zapfen kïnmen auch, in Säcke gefüllt, im Zimmer aufgehängt werden. Solche Stubendarren, wie sie vielfach von Privatwaldbesitzern und Fleinhändlern eingerichtet werden, bestehen schon sehr lange, sind aber wegen Lieferung gering keimfähigen Saatguts (infolge Ueberhitzung) in Mißkredit geraten. Bei Vermeidung dieses Hauptfehlers und bei sonst sachgemäßer Behandlung des Samens unter Leitung und Aufsicht des Forstpersonals wird man aber dureh zuverlässige Waldarbeiter oder Angehörige der Forstschutzbeamten die Klengung in dieser einfachen Weise gut vornehmen lassen können, namentlich wenn geeignete, der Forstverwaltung gehörige Räume zur Verfügung stehen und es sich nur um kleinere Quantitäten (für den Eigenbedarf) handelt.

Die Groß-Klengbetriebe lassen die Klengung in besonderen massiven Gebäuden vornehmen, meist unter Anwendung maschineller Vorrichtungen.

Grundsälzlich verschicden ist die Einrichlung der Feuerdarren, je nachdem die Trennung der Samen von den Zapfen im Darraum selbst während des Darrens oder alsbald nach Oeffnung der Zaplen in besonderen Räumen vorgenommen wird ${ }^{1}$ ). Auf ersterem System berulıt die in den meisten preuBischen Iilenganstallen bestehende Einrichtung der E y $\mathrm{t}$ e 1 w e $\mathrm{i}$ n sehen ${ }^{2}$ ) Darre (genanint nach den Erbauer der Eberswalder Darre vom Jahre 1837, Oberbaurat E y $l$ e 1. we $\mathrm{n}$ ): die Zapfen werden in Horden eingeschültet, welche auf hölzernen Gestellen oberhalb (zu beiden Seilen) des im unterslen Stockwerk befindlichen Feuerungsraumes übereinander geschichtel sind. Von der Heizung aus wird heiße Luft durch verschließbare Ocffungen unter die Horden geleitel, auf deren Zapfen sie num, ohne entweichen zu kömnen, cinwirken muß. Die Zapfen werden hier fleißig ungedreht und durchrütelt, so daß der Samen auslinllt; dersclbe fällt von Horde zu Horde und kommt zu unterst (also rechls und links des Feuerungsrauıns) in Iśülıkammern.

Anslatt der Aufschütung der Zapfen auf Horden ist auch die Einfullung derselben in hōlzerne, gillerartige Zylinder, welehe mil eisernen Reifen umgeben sind, ocler in Drahtlromneln

1) Vergl. die Ausführungen des preuß. Landesbauinspektors $v$. P e n $t$ z bei der $1 Y$. Ilauptlers. des Deutseh. Forstvereins zu lỉel 1903. (Bericht S. 35 ff.).

2) Schlieekmann, S. 628 ff. 
im Gebrauch. Diese Trommeln werden durch Kurbeln nach Art der Iraffeebrenner von Zeit zu Zeit gedreht, der Samen entfält in Sammelkanäle und wird aus diesen ausgezogen. Diese öftere Drehung der Zylinder scheint das Klenggeschäfl zu fördern. Die Annaburger Darre, die größte der preußischen Staatsklenganstalten, ist nach diesem System erbaul, die Trommeln werden motorisch gedreht, wie überhaupt der ganze Betrieb maschinell eingerichtet ist.

Auch einige Privatklengbetriebe benützen Trommeldarren. Die meisten bedienen sich aber des andern Systems, kleiner vers $t$ e 11 b a re r Horden, die nach Oeffnung der Zapfen aus der Darrstube herausgenommen und über Gilterböden entleert werden; mittelst Rechen wird hier der Austall des Samens vollends bewirkt; statt dessen bringt man die g e o f f n e $t$ e n Zapfen auch in zylinderfôrmige Leierfässer, sog. "Triller". Diese sind aus Eisendraht hergesleltt und nit Siebwandungen versehen, durch welche nur die Samenkōrner hindurchgehen kōnnen. Durch Drehen wird das Ausfallen des Samens veranlaßt; die leeren Zapfen gleiten aus dem schräg geslellten Triller in einen Seitenraum.

Eine besondere Abart dieses Systems bedeutel die Einrichtung der im Jahre 1896 umgebauten Eberswald er Darre ${ }^{1}$ ). Die Horden sind nicht übereinander gestellt, vielmehr ist der Darraum dureh senlirechte Wände in mehrere Ableilungen gesondert, welche der warme Luftstrom nacheinander durchstreicht; nach Dnrchströmen aller Abteilungen kanir die Darrluft zum Heizkörper zurückgeleitet werden, so daß ein lireislauf entsteht (wie ,Zirkulationsluftung"). Durch klappeneinstellung wird es ermöglicht, die Luftströme bald in der einen, bald in der andern Richtung zu führen, was gleichnıäßige Erwārmung des Raunes und gleichmäßiges Oeffinen der Zapfen befördert.

Wir gehen weiter zur Beschreibung der D a m p f d a r r e n, die statt Heißluft Dampfheizung benutzen, zuerst in der Klenganstalt von II. K e ll er Solın ${ }^{2}$ ) in Darmstadt angewendet, inzwischen auch anderwärts (so bei A p p e l) eingeführt: der in einem Danpfkessel außerhalb res Kilenggebäudes erzeugte Wasserdampl wird unter den IJorden in einem Röhren-System mehrfaels hin- und liergeleitet; zur Abführung des liondensierten Wassers mündet die Leitung wieder in den Dampfkessel aus.

Geringere Feuergefährlichkeit einerseits, raschere Erzielung der erforderlichen Temperaturgrade andererseits werden als Vorzüge der Dampfdarren gerühmt. Es ist hier nicht der Ort, die Vorteile und Naehteile der verschiedenen ${ }^{3}$ ) Verfahren gegeneinander abzuwägen; Voraussetzung für befriedigende Klengelgebnisse ist die Vermeidung schädlicher Hitzegrade; die Gefahr der Ueberhitzung ist größer, wenn früh geerntete stark wasserhaltige Zapfen verwendet werden.

Die vielfach verbreitete Ansicht, daß kurze Zeit wirkende, holse Hitzgrade nicht nachteilig wirken, wenn nur der ausfallende Samen sofort in kühłe Räume verbracht wird, ist durch die Untersuchungen $\mathrm{H}$ a a c ks (a. a. O.) vollständig widerlegt. Mit Rücksicht darauf, daß ,zwischen der noch zulässigen und einer dem Samen schon verderblichen Hitze nur wenige Grade" licgen, empfiehlt es sich, nie die höchst zulässigen I Iitzegrade aufliommen zu lassen; über $45-50^{\circ} \mathrm{C}$. sollte die Temperatur keinenfalls steigen; man wird dabei die Horden so einsetzen, daß an den kühlereu Stellen zunäehst die noch feuchten Zapfen liegen, während an die wärmsten nur die unmittelbar vor dem Platzen stehenden gebracht werden $\left.{ }^{4}\right)$. W i e b e c k e (a. a. O.) empfiehlt auBerdem eine Vordarrung in geeigneten Schuppen bei ca. $25^{\circ} \mathrm{C}$. zur Herabsetzung der eigentliehen Darrzeit und der Darrtemperatur, außerdem eine vorgängige Abtrocknung der Zapfen in besonderen, der Luft und Sonne Zutritt er-

1) ช. Pentz a. a. O.; ferner Z. I. F. u."J. 1900, S. 634.

2) Die Einrichtungen der bekanntesten klenganstalten sind in G a y e $r$ - $\lambda$ a y r, Forstbenutzung, 10. Aufl, angegeben.

3) Noch ein anderes Darrsystem mit verstellbaren Horden schläst Wiebecke vor (Z. I. F. U. J. 1910 , S. 342 f.), nämlich als Darraum $8-9 \mathrm{~m}$ lange, ca. $1,5 \mathrm{~m}$ breite und $2 \mathrm{~m}$ thohe Darrkasale, in welche etwa 10 aneinander gekoppelte, auf schienen laufende Gestelle mit den Horden eingeschoben werden können.

4) Dies der Vorteil bei den Darrkanälen nach W i e b e $\mathrm{k}$ e, in welche von der Richtung der Ausgangstü lier die warme Luft einströnt (а. a. O). 
laubenclen Trockenschuppen; wach Ansicht von Klenganstaltsbesitzern dagegen soll der g r ï $\mathrm{n}$ auf die Horden gebrachte Zapfen besser aufspringen als vorgewärnter.

Eine für die Rentabilität des lilengbetriebs bezw. die Höhe der Kilengliosten wichtige Frage betrift die Wahl des geeigneten Heizmaterials und andererseits die Verwertung der entleerten Zapfen ${ }^{1}$ ). Die Zapfenheizung gibt wenig anhaltende Wärme und erfordert sehr häufiges Nachfüllen; empfohlen wird deshalb eine Mischung von Kohlen und Zapfen. In manchen Gegenden sind die Zapfen als Bremmaterial für Ofenbrand und kleinere gewerbliche Anlagen, ja selbst für Feuerung in Kileinbahnen, begehrt; Fichtenzapfen werden denen der Jüefer bei weitem vorgezogen.

Der ausgeklengte Nadelholzsamen muß nun gereinigt und entflügelt werden. In den größeren Klenganstalten wird diesen Arbeiten peinliche Sorgfalt zugewendet; von Wichtigkeit ist das Entflügeln eigentlich nur zur Erleichterung der Verpackung und Versendung; mit Rücksicht auf bessere Verteilung der Samenkömer wird dagegen gerade die Verwendung b e fl üg elte $n^{2}$ ) Samens empfohlen.

Die Enlflügelung des Ǩiefern- und Fichtensamens isl übrigens (im Gegensatz zur Weißtanne) rechl eintach, da die Flügel mil den Körnern nur lose zusammenhãngen - bei der Fichte löffel-, bei der Kïiefer zangenförmig. Am besten füllt man den Samen in Säeke und läßt diese unler öfterem Unwälzen nit ledernen Dreschflegeln bearbeiten. Viclfach werden auch besondere Maschinen (Bürstenwalzen) oder einfach Fültelsiebe verwendel. Aucl auf nassem Weg läßt sich der Fichten- und Kiefermsamen entflügeln: man breitel den Samen auf geglïtteten Böden aus, übergießt ihn leicht und bearbeilel ihn, naclıdem er eine Nachl durch gelegen hat, mit Dreschflegeln.

Das Reinigen des enlflügellen Saatguts erfolgl init Hilfe von Schüttelsieben, Windfegemühlen oder ähnlichen Gerälen, wobei Flügel und Slaub fortgeweht werden.

Noch ist ein besonderes Wort über die Gewinnung der $\mathrm{L}$ ä r e h e $\mathrm{n}$ s a m e $\mathrm{n}$ zu reden; sie bedürfen zur Ausklengung lange andauernder IVärme, wobei leicht ein Verkleben der Zapfen durch austretendes Terpentin, zumal an ihrer unteren Partie, die Entleerung erschwert. In den Klenganstalten sind deshalb besondere Vorriclitungen zur mechanischen Zerreibung der Lärchenzapfen eingeführt (Tromeh mit gezähnter IIantelfläche oder mit in ihıem Innern sich drehenden Rechenarmen, durch welche die Zapfen stetig durcheinander geworfen werden).

Beim Ausklengen in der Sonnendarre wird empfohlen, die Zapfen, sobald die weitere Entleerung durch Terpentin verhindert wird, in einen Deckelkorb zu füllen und 24 Stunden unter Wasser zu stellen; sind sie dann wieder geschlossen, so setzt man sie wieder im Klengkasten der Besonnung usw. aus. Das läßt sich natürlich nur im Kleinbetrieb machen.

$\$ 5$. Zahlenangaben ïber die Klengergebnisse ${ }^{3}$ ). Die Ausbeute an reinem Samen bei voller Ausklengung läßt sich folgendermaßen in Zahleı angeben:

1. K j e f e r. I Helitoliter Zapfen wiegt, nach dem Frost gepflückt $50 \mathrm{~kg}$, vor dem Frost gesammelt $60 \mathrm{~kg}$ und gil,t $0,75-0,90 \mathrm{~kg}$ abgeflügelten Samen, bei guten Darresultaten wohl auch $1 \mathrm{~kg}$. 1 Kilo Samen (ca. 150000 Körner) ${ }^{4}$ ) füllt etwa 2 Liter; auf $10 \mathrm{~kg}$ Flügelsamen kommen $7 \mathrm{~kg}$ abgeflügelter Samen.

1) Nach B org ma n n können die gesanten Betriebskosten durch den Verkauf der leeren Zapfen gedeckt werden (s. Berichl über die IV. Hauptvers. der Deutsch. Forstvereins zu Kiel 1903 , S. 148 .

2) So von Wrag ne $r$ in ,,1)ie Grundlagen der rãunlichen Ordnung" (2. Aufl. S. 42).

3) Ueber die Ernte erget $n$ isse fellen genaue, auf die Flächeneinheit bezogene Angaben. Soboleff (S. C. f. A. g. F. 1909, S. 137) hat Untersuchungen über den Samenertrag der Fichte angestelll und datei Samenerträge fon $25-90 \mathrm{~kg}$ (Samenkörner) pr. lıa erhallen.

4) Das Gewicht der Samenkörner isl ubrigers nach lilima unı Beslandesalter sehr verschieden, wāmmeres lílima und jüngere Beslände ergebcn schwerere Samen; vgl. die Unlersuchungen Schot tes (N. Z. f. F. U. L. 1906, S. 22). 
2. F i c h t e. I Hektoliter Zapfen wiegt etwa $25-30 \mathrm{~kg}$ und gibt $1,2-1,9 \mathrm{~kg}$ reinen Samen. Auf $10 \mathrm{~kg}$ Flügelsamen kommen $6 \mathrm{~kg}$ Wornsanen. $1 \mathrm{~kg}$ Samen (ca. 120000 Hörner) umfaßt 2,15 Liter.

3. We i $\beta$ t a $n$ ne. I Hektoliter Zapfen wiegt grün $25-30 \mathrm{~kg}$ und liefert 2-3 lig reinen Samen. $1 \mathrm{~kg}$ Samen enthält ca. 24000 Körner, also bei weitem weniger als Kiefer und Fichte und unfaßt ca. 3,5 liter.

4. L ä r e h e. 1 Helstoliter Zapfen wiegt grün ca. $35 \mathrm{~kg}$ und gibt $2-3 \mathrm{~kg} \mathrm{ab-}$ geflügelten Samen. I kg Samen enthält ca. 120000 Körner (soviel als Fichtensamen) und umfaßt ca. 2 Liter. $1 \mathrm{~kg}$ Flügelsamen gibt $0,8 \mathrm{~kg}$ Kornsamen.

Die Kosten des Kilengens sind schwer anzugeben; je nach der Art und Größe des Betriebs sind dieselben verschierlen. In rten preußischen fiskalischen Darren besteht die Einrichtung, daß für das in einer Dartkampagne über $500 \mathrm{~kg}$ gewonnene Samenquantum ein um 5-10 Pf. geringerer Lohn als für die ersten $500 \mathrm{~kg}$ gegeben wird, und daß bei einem Quantum von über $1000 \mathrm{~kg}$ eine weitere Ermäßigung des Darrlohns eintreten liann. Dieser Modus der Bezahlung wird übrigens von Fm. $\mathrm{Se}$ h l i e ckm a $\mathrm{n} n$ a. a. O. insofern gestadelt, als dabei der Darmeister nur ein Interesse an der Gewinnung hoher Gewichtsmengen, ohne Rücksicht auf sorgfältige Ausbeutung der Zapfen und auf hohes Keimfähigkeitsprozent habe.

Ueber die Kosten der Selbstgewinnung sind mit Bezug auf Kiefernsamen dem Bericht über die IV. Versammlung des D. F. V. (Kiel 1903) ff. Zahılen zu entnehmen: Die Hordendarren produzieren gewöhnlich das $\mathrm{kg}$ mit 26-28 Pf. (I hl Zapfen gibt etwa $0,85 \mathrm{~kg}$ Kömer); (der gesamte Selbstkostenpreis der großen älteren preußischen Darren berechnet sich für 1303 auf $4.50 \mathrm{Mk}$. bis $6.30 \mathrm{Mlk}$., für die neue erst kurz zuvor eröffnete Annaburger Trommeldarre zu $7.39 \mathrm{Mk}$. Wenn man demgegenüber bedenkt, daß im selhen Frühjahr 1903 der Samenpreis für $1 \mathrm{~kg}$ Kiefern bei den IJändlern sich auf $6 \mathrm{llk}$. bis $7.30 \mathrm{Mk}$. belief, so rechtfertigt sich die Selbstgewinnung auch vom finanziellen Standpunlit. Die Rechnung fältt alıer noch wesentlich günstiger aus, wenn es auf diese Weise gelingt statt nur $70 \%$ igen 80 -90\%iges Saatgut zu beliommen I).

\$6. Die A u f b ew a h r u g d e r Holzsamen. Es handelt sich entweder nur darum, den im Herbst gesammelten bezw. im Lauf des Winters gewonnenen Samen bis zur Aussaat im Frühjahr zu lagern, oder aber kommt länger dauernde Aufbewahrung über 1 - 2 Jahre und womöglich noch länger in Frage, was bei stark und ständig begehrten Sämereien angesichts der weehselnden Ergiebigkeit der Ernten an sich wünschenswert wäre.

Zunächst sind die Bedingungen genau zu beachten, unter denen die verschiedenen Samen naturgemäß überwintern $\left.{ }^{2}\right)$. Die oben angefülırte Zeit des Samenausfalls gibt hiefür einige Anhaltspunkte. Soll die künstliche Aufbewahrung ohne Schaden für die Ḱeimfähigkeit von statten gehen, so müssen die naturgemäßen Lebensbedingungen dem Samen eingeräunt bleiben; lebensgefährdende Störungen, extreme Zustände bezüglich Temperatur und Feuchtigkeit und vor allem plötzliche Uebergänge sind zu vermeiden; andererseits ist die lieinung des Samens im Interesse des Saaterfolges tunlichst zurückzuhalten. In einzehnen lassen sich ungefähr ff. Regeln aufstellen:

L i e E i c h e ln. Wic alle großen Sämereien vermögen sie ihre Kieimfähigkeit nicht länger als über W'inter zu erhalten; die naturgemäße Ilerbstsaat wäre deshalb

1) Nach den $\mathrm{H}$ a a $\mathrm{c} \mathrm{k}$ schen Lntersuchungen (a. a. O.) ergibt $1 \mathrm{~kg} 85^{\circ}$ oigen lifefernsamens denselben saaterfolg wie $1,7 \mathrm{~kg} 70 \%, 1,4 \mathrm{~kg} 75 \%, 1,2 \mathrm{~kg} 80^{\circ} \%$ und $0,8 \mathrm{~kg} 90^{\circ}$ igen Samens.

2) Vergl. $Z$ e d e r b a e $r$, Versuche über Aufbewahrung von Nadellolzsamereien (C. $f$. d. g. F. 1910 , S. 116 ). 
an sich das Richtige. Mit Rüclisicht auf allerhand Beschärligungen (Mäuse, Wild usf.) empfiehlt sich aber häufig Frühjahrssaat. Trockene und warme Luft bringt die Eicheln zum Abdorren; gegen Frost sind sie dagegen nicht besonders empfindlieh; nach $\mathrm{Z}$ c d e r b a u e r lat sich bei Aufbewahung unter niederer Temperatur und hoher Feuchtigkeit die beste Keimfähigkeit ergeben. Die Aufhewahrung erfolgt vielfach ïber der Erde in kegelförmiger mit Strol oder Noos bedeckten Haufen, die man wohl auch mit Laub und Stroh untermengt. Die Eicheh müssen zuvol" abgetrocknet werden, um vor Schimmelbildung und Erwärmung geschützt zu sein. Daneben wird auch das Einmieten in Gruben empfohlen, am besten nach v. A l e in a n n s Verfahren; da und dort werken die Eicheln, in Körbe oder Säcke gefüllt, unter Wasser (in Bächen oder Brunnen) aufbewalırt ${ }^{1}$ ). Wegen der früh eintretenden Kieimung empfiehlt sich zeitige Aussaat.

$\mathrm{B}$ u c he $\mathrm{I} \mathrm{n}$ : sie sind infolge ihres Oelgehalts gegen Frost kaum empfinulich, müssen aber sorgfältig gegen stockende Feuchtigkeit und Erhitzung ebenso wie gegen Austrocknung geschützt werden. Ausbreiten und Durchlüften hilft am besten gegen Erhitzung, gelegentliches Bebrausen mit kalt Wasser gegen Austrocknung, wenn man in Schuppen und dergl. die Ueberwinterung vornimmt; bei Aufbewahrung in Freien empfiehlt sich neben Schutzmaßregeln gegen Jäusefraß die Durchmengung mit Zwischenschichten frisch eingebrachten Sands sowie Bedeckung init Stroh, Lanb, Moos und eventl. noch Erde.

H a i $\mathbf{b} u$ c he $\mathrm{n}$ - und Es $\mathrm{E}$ he $\mathrm{n}$ s a men, welche beide vor dem Aufgehen ein Jahr überzuliegen pflegen, bewahrt man in grabenförmigen, $30 \mathrm{~cm}$ tiefen Furchen, flach mit Erde bedeckt, bis zum Frühling des 2. Jahres auf.

Birke n s a m e n ist selwer aufubewahren; in Haufen erhitzt er sich leicht, weshalb man zunächst für gutes Ablüften sorgt, worauf man ihn auf dem Speicher flach aufschüttet.

A h o r n s a me n läßt sich leicht in Haufen oder noch besser alsbald in Säcken, die der Mäuse halber wohl auch frei aufgehängt werden, aufbewahreı.

E r l e n s a m e $\mathrm{n}$ ist ähnlich den Birkensamen zu behandeln.

Ul In en s a m e $n$ wird an besten alsbald nach der Reife gesät, da er bei der Aufbewalırung fast stets verdirbt: eventuell müßte er auf luftigem Speicher, aber ja nicht in Säcken zusammengepreßt. aufbewahrt werden.

T a n n e n a m e n verliert leim Aufbewahren seine lieimkraft leicht; man hebt ihn daher mindestens mit den Schuppen oder noch besser in ganzen Zapfen den Winter über auf, falls man nicht die Saat schon im Herbst bewirken kann; letzteres empfiehlt sich am meisten. Nach ten Untersuchungen Z e d e r b a u e r s ist der Tannensamen besonders empfindlich gegen Feuchtigkeitsentzug bei gleichzeitiger Temperatur über $0^{\circ}$.

Ki efern- und Fichten-, sowie Lärchensamen bewaluren ihre lieimkraft ebenfalls am längsten bei Aufbewahrung in ren Zapfen. Andernfalls ist das Belassen der Flügel an ilem geklengten Samen zweckmäBig. Von reinem Kornsamen hebt sich trocken entflügelter besser auf als naß entflügelter. Im Gegensatz zur Tanne können die Fichten-, Kiefer- und Lärchensamen Bodenfeuchtigkeit n i c h t ertragen; niedere Temperatur wirkt günstig aber nicht in Verbindung mit Bodenfeuchtiglieit ( $\mathrm{Z}$ e d e r b a e r a. a. O.).

Neue, wesentlich bessere Nethoden zur Aufbewahrung der Nadelholzsämereien

1) Die Maßnahmen zur Aufbewahrung der Sämereien sind je für die einzelnen IJolzarten gesondert sehr eingehend von $\mathrm{F}$ ü $\mathbf{r} \mathrm{t}$ in, ,Pflanzenzucht im Walde", vierte Auflage, $S$. 269ff. behandelt. 
haben $\mathrm{Ci}$ es la ${ }^{1}$ ) und $\mathrm{H}$ a a $\mathrm{ck}^{2}$ ) gewiesen. Ci es lar empfahl Aufbewalirung in fest verschlossenen gegen Luftzutritt verdichteten Gefäßen. Die $\mathrm{H}$ a a c k'schen Untersuchungen bestätigten vollauf diese Vorschläge. Um die Lebensbetätigung der Samen noch mehr einzuschläfern, empfiehlt er außerdem Lagerung der Samenbeliälter an kühlen Orten, womöglich in Eiskellem. Auf diese Weise gelingt es, den $\mathrm{F}$ i $c h \mathrm{t}$ en - und $\mathbf{K}$ i e $\mathbf{f}$ e $\mathrm{r}$ samen - wie von $\mathrm{H}$ a a $\varepsilon \mathbf{k}$ zuverlässig nachgewiesen wurde - mindestens 3 Jahre lang ohne erhebliche Einbuße an Keimkraft aufzubewahren ${ }^{3}$ ); nach den angestellten Versuchen war das lieimprozent des 3 Jahre lang unter Luftabschluß auf Eis aufbewahrten Samens noch ebenso hoch als bei dem nur 1 Jahr lang I u f ig aufbewahrten. Bei vorübergehender Aufbewahrung genügt natürlich auch die gewöhnliche freie Lagerung auf Speichern in Schuppen mnd dergl., wo die Samen von Zeit zu Zeit umgestoehen werden sollten. Auch wird Aufbewahrung in durchlöcherten Kisten empfohlen. Zum Versand füllt man den Samen in Säcke oder Kisten.

Wertvolle andere Sämereien — meist kleinere Mengen — hebt man in Säcken auf, welche zum Schutz gegen Näuse am besten aufgehängt werden.

\section{Die Nutzung sonstiger Bestandteile des stehenden Holzes.}

\$ 7. Die Gewinnung vongrünen Blätternund Zweigen. Abgeselıen von der Bereitung sog. "Waldwolle", eines Ersatzstoffs für Seegras und Baumwolle, aus den $\mathrm{K}$ i e f e r nadeln und der Herstellung ätherischer Oele aus den $\mathrm{F}$ ich $\mathrm{t}$ e $\mathrm{n}$ - und $\mathrm{T}$ a $\mathrm{n} \mathrm{n}$ en nadeln handelt es sich hier um die Verwendung der jüngsten Sprosse und Sproßteile zur Viehfütterung und zur Einstreu im Stall. Dienen dem ersteren Zweck vorwiegend Laubholztriebe, so beschränlit sich die ,Ast- oder Schneitelstreu"-Nutzung fast ganz auf die Nadelhölzer.

Zur Futterla ubgew in u ng nimmt die landwirtschaftliche Beröllierung in Notjalıren (z. B. IS93) ihre Zuflucht, mancherorts steht sie ständig in Uebung; auch zur Wildfütterung wird gedörrtes Laub empfohlen. Der Futterzweck wird an besten erreicht mit solchen Pflanzenteilen, rlie den höchsten Gehalt an physiologisch wertvollen Stoffen, an Eiweißsubstanzen, gewähren. Deın Grad der Tierbeschädigung nach zu schließen, dürften die einzelnen Holzarten etwa in folgende Reihenfolge vom löchsten zum geringsten Futterwert zu bringen sein: Pappel (besonders kanadische), Esche, Weide, Linde, Eiche, Ahorn, Llme, Buche, Weißtanne, Fichte, Forche, Lärche; die letztgenamnten werden höchstens nocl vom Wild und von der Ziege angenommen. Was den $Z$ e i t $\mathrm{p}$ u $\mathrm{n}$ k $\mathrm{t}$ der Nutzung anlangt, so ergibt sich nach den neuesten Untersuchungen $^{4}$ ), daß der Monat Juli zur Futterlaubernte am geeignetsten ist; zu dieser Zeit haben die B lä $\mathrm{t}$ te I den höehsten Gehalt an Proteinstoffen aufzuweisen, während das Herbstlaub fast keinen Nährwert besitzt. Die Z w e i g e ${ }^{5}$ ) dagegen enthalten im Winter unnittelbar vor dem Austreiben der Kinospen verhältnismäßig am meisten

1) Versuche über Aufbewahrung von Nadelholzsamen unter lufldiehtem Verschluß. C. f. d. g. F. 1897, S. 162 .

2) Z. f. F. U. J. 1909, S. 353 ; It. d. D. F.-V. 1909, Xir. 6.

3) Die preußische Staatsforstverwaltung hal diesen Gedanken bereits mil entspreehenden Anweisungen Folge gegelien (s. M ö] J e r, Z. f. F. U. J.1910, S. 694). Im Tharandter botanischen Institute sind Versuehe mit der Haacksehen Melhode gemacht worden; dabei haben siel nach

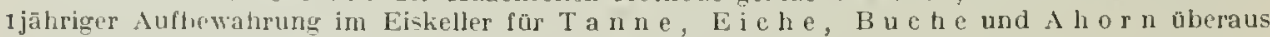
günslige Erfolge ergeben. (N. Z. f. L. 11. F. 1911, S. 402.)

4) Vergl. die Untersuehungen von $B$. S e h u $\mathrm{l} z$ e und $J$. S c h ü $\mathrm{t}$ über die Stoffwandlung in den Laubblattern (Landw. Versuchsstationen, 71. Bd., S. 299); ferner eine Arbeil aus der bayr. Versuchsanstalt von Dr. B a u e r (N. Z. f. F. U. L. 19II, S 409).

5) Vergl. R a m a $n$, Holzfülterung und Reisigfütterung, 1890, S. $15 \mathrm{ff}$. 
Rohprotein. Je schwächer die Triche sind, umso reicher an Stickstoff; unter $1 \mathrm{~cm}$ starke Zweigspitzen sind am besten. Die Futterreisiggewinnung erfolgt dennach an zweckinäBigsten durch entsprechende Verwendung der bei der Holznutzung (Reinigung, I. Durchforstung) anfallenden schwächsten Lieis-Sortimente, während als eigentliche Nebennutzung das Abstreifen oder Abschneilen von Blaittern und blattreichen Zweigen zur Sommerszeit in Frage kommt. Der Nährwert geeigneten Futterlauls kommt dem des Wiesenheus nahezu gleich, übertrift jedenfalls denjenigen des Strohs.

Daß die Futterlaubnutzung infolge Entzugs der Assimilationsträger auf das Holzwachstum nachteilig einwirkt, kann als selbstverständlich gelten, auBerden ist die Gefahr der Waldbeschädigung damit verbunden. Einzelne Betriebsarten, wie Kopfholz- und Schneitelbetrieb, teilweise auch der Niederwaldbetrieb, sind gerade auf diese Nebemutzung zugeschnitten. Im Wirtschaftswald kann sie nur ausnahmsweise und zwar an solchen Bestandesteilen zugelassen werden, die ohnehin zur früheren oder späteren Ausscheidung (Schutzholz, Vorwüclse und dergl.) bestimmt sind. Durch rechtzeitige Ausführung von Reinigungen und Durchforstungen kann dem Bedürfnis nach der besprochenen Nebennutzung vollständig Genüge geleistet werden.

Dasselbe gilt auch für die ,Ast-oder Schneitelstreu"-Gewinnung. Als eigentliche Nebennutzung hat sie keinen Platz in Wirtschaftswald. In waldarmen Gegenden wird die Schncitelstreugewinnung allerdings nicht so bald verschwinden; in Bauernwaldungen sieht man die Nadelholzbäume oft bis nahe unter den Gipfel der Aeste beraubt; wenn diese Verstümmelungen auch nicht zum Absterben fülıren, so schädigen sie doch das Zuwachsvermögen und die technischen Eigenschaften des Holzes. Das Jahr 1893 hat in vielen Waldungen deutliche Spuren der dureh das Aufasten und das Besteigen der Bäune verursachten Holz- und Rindenverletzungen hinterlassen. So sehr sich demnach die Forstwirtschaft der eigentlichen Schneitelstreugewinnung gegenüber ablehnend verhalten muB, so wird sie doch der Aststreunutzung als einer Verwertungsmöglichkeit für das bei der Holzhauerei anfallende Reisigr volle Beachtung zu schenken haben. Der alljährliche Anfall an S t r e u re is ig ist in größeren Nachhaltsbetrieben zumal bei intensiver Bestandespflege reiclılich genug, un weitgehende Bedürfnisse der"umwohnenden Bevölkerung befriedigen zu können. Jan hat von forstwirtschaftlicher Seite schon seit lange den Versuch gemacht, die Bodenstreu durch Aststreu melır und mehr zu verdrängen; leiler nicht überall mit den gewünscliten Erfolg; , wie landwirtschaftliche Bevölkerung zeigt vielfach Abneigung gegen die Reisstreu. Die Zubereitung ist etwas zeitraubend, da jeweils die jüngsten allein verwendbaren Triebe (etwa bis kleinfingerstark) abgehackt werden müssen. In Gegenden, wo die Nadelholzreisstreu eingeführt ist, hört man ihre guten Eigenschaften rühmen: sie bereite ein warmes Lager und besitze hohe Aufsaugungsfähigkeit; wenn nur das schwächste lieisig verwendet wird, zersetzt sich der Reisstreudünger verhältnismäßig rasch und können Beschädigungen der Ackergeräte nicht vorkommen. Der hohe Mineral- und Stickstoffgehalt des schwachen Reisigs ist wissenschaftlich nachgewiesen ${ }^{\mathbf{1}}$ ).

$\$ 8$. Sonstige Nebenerzeugnisse der Wraldbäune. Im tropischen und subtropischen Wald erlangt die Gewinnung von Nebenprodukten des Holzes wie Gunmi, Kautschuk, Wachs, Lack. Farb- und Gerbstoffe (von Rinde abgesehen), Fette, Chinin u. a. geradezu die Bedeutung der Iauptnutzung; die lioloniale Forstwirtschaft wird sich hienit zu befassen haben.

1) $\mathrm{R}$ a $\mathrm{mann}$ a. a. O. 
In den Ländern der gemäßigten Zone spielt eine beachtenswerte Rolle lediglich die Harznutzung. Da dieser Gegenstand in der Technologie behandelt wird, genügt es hier, darauf hingewiesen zu haben; es wird sich ohnehin für den Bereich des IVirtschaftswalds in Zukunft mehr um die Harzgewinnung aus gefälltem Holz bezw. aus den im Boden verbleibenden Stöcken handeln können, als um die früher übliche Anzapfung des stehenden Holzes. Zu erwähnen ist noch die Möglichkeit der Z u c k e rgewinnung aus manchen Alornarten ${ }^{1}$ ).

\section{Die Nutzung der Abfallstoffe des stehenden Holzes.}

§9. Raff- 1 ud Leselıolz. Die dürr gewordenen vom Schaft sich ablösenden Aeste und Zweige werden meist der ärmeren Bevölkerung unentgeltlich überlassen, teilweise, so besonders auch die abgefallenen leeren Nadelholzzapfen, gegen Entgelt in der Form der Ausstellung von Erlaubnisscheinen (sog. „Einmiete"); da und clort ist die Leseholznutzung ein Gegenstand der Berechtigung. In gut bevölkerten Gegenden, z. B. in der L'mgebung von Industrieorten spielt diese Nebennutzung eine sozialpolitisch wichtige Rolle; es sind in der Tat recht erhebliche Geschenke, - man schätzt die Leseholzmengen auf $12-15 \%$ der gesamten Holzmasse - die der Wald in dieser Form den minder bemittelten Volksschichten darbietet. AuBer dem am Borlen liegenden Abfallreisig werden dem Leseholz in einzelnen Gebieten auch die dürren in unschädlicher Weise vom Baum entfernbaren Aeste beigezählt, zum Teil überläßt man auch die dürren Stangen noch den Leseholzsammlerm. So wünschenswert die Entfernung des dürren Ilolzes mit Rücksicht auf Insekten- und Feuergefahr ist, so darf doch auch nicht außer acht gelassen werlen, daß das auf dem Boden zerstreut liegente Reisig einen — je nach Standort - wertvollen Bodenüberzug bildet und in dieser Beziehung bis zu einem gewissen Grad die gleichen Vorteile wie die Laub- und Nadeldecke dem Waldboden bietet. Andererseits mag die unentgeltliche Ueberlassung des Leseholzes als natürliche und gerechte Besitzsteuer erscheinen und zugleich als Iaßregel zur Vorbeugung von Holzentwendungen. Trotzdem erforlert gerarle auch eine ausgedehnte Leseholznutzung aufmerlisame Ueberwachung durch das Forstschutzpersonal, da sie leicht allerhand Waldbeschädigungen und Uebergriffe im Gefolge hat. In clen gröBeren Forstverwaltungen ist deshalb die Leseholznutzung auf bestimmte Wocheritage und Tageszeiten beschränkt; auch sind, um mißbräuchliche Nutzungsüberschreitungen zu vermeiden, besondere Vorschriften bezüglich der zugelassenen Geräte (keine schneidenden Werkzeuge) und der Fortscluafungsmittel (nur Trachten und Handwagen) erlassen.

\section{$\S 10$. Die Laub-und Nadelstreunutzung ${ }^{2}$ ).}

\section{a) Bedeutung und Wert der Laub- uud Nadelstreu als Nutzungsgegenstand.}

Indem man den Blattabfall der Waldbäume, unternischt mit Sproß- und Rindenresten, als Laub- und Nadelstreu bezeichnet, ist der weitaus wichtigste Ver-

1) Wa $11 \mathrm{~h} \mathrm{er}$, A. F. U. J.-Z. 1907, S. 315.

2) Lileratur: W a l z, Waldslreu 1850 und 1870 ; F r a a $s$, desgl. 1856 ; F is c h b a $\mathrm{c} \mathrm{h}$, Beseiligung der Waldstreunutzung 1864 ; Hej $B$, Waldstreufrage $1866 ; \quad$ o n h a $\mathrm{s}$ e $\mathrm{n}$, Raubwirtschaft in den Waldungen 1867 ; $N$ e y, Die natürliche Bestimmung des Waldes und die Strenntzung 1869 ; E b e r m a y e r, Die gesamte Lehre der Waldstreu 1876; $\mathrm{R}$ a $\mathrm{m}$ a $\mathrm{n}$, Die Waldstren und ihre Bedeutung für Boden und Wall 1890; Wolff, J'raktisehe Düngerlehre 1872; derselbe, Aschenanalysen ete., 11. Teil, 1880; $\mathrm{R}$ a m a $\mathrm{n} \mathrm{n}$, Bodenkunde, 2. Aufl. 1905; Il its clierlie h, Bodenkunde 1905; F un ke, Zur landw. Taxation bei der Ablösung der auf Wäldern lastenden Weide- und Streurechte in der Zoitschr. f. d. ges. Staatswiss., 31. Bd.; D a n cke $1 \mathrm{n}$ a $n \mathrm{n}$, Die Ablösung und Regelung der Waldgrundgerechtigkeilen 1888, 111. Teil, 
wendungsweck dieser Nebenprodukte schon angedeutet. Außer zur Einstreu in Stallungen dient das eingesammelte Laub wohl auch zur Füllung von Bettsäclien. zur Herstellung von Isolierschichten, zur Kompostbereitung u. a. Unter den weiteren Begriff "Waldstreu" ist der le bende Bodenüberzug, soweit er zum gleichen Zweck verwendet wird, mit inbegliffen; in den Nadelholzbeständen wird der Nadelabfall zugleich mit der Hoosdccke gewonnen. Trotzdem empfiehlt es sich aus systematischen wie sachlichen Gründen, die Nutzung des Laub- und Nadelabfalls gesondert von der erst in nïchsten Abschnitt zu besprechenden Moos- und Unlirautstreu zu behandeh. Dic gemeinsanen Gesichtspunkte werden gleich hier erörtert.

Die Streunutzung ist cine neucre Eischcinung der Bodenwirtschaft, veranlaßt durch die rasche Bevölkerungszunahme und die intensivere Gestaltung der landwirtschaftlichen Betriebe, insbesondere dureh den Uebergang von der Weide zur Stallfütterung und den immer ausgedehnteren Anbau von Futter- und Handelsgewächsen. Der Hölıpunkt dieser Forstnebennutzung dürfte im großen ganzen übersehritten sein; geht doch die molerne bodenwirtsehaftliche Tendenz dahin, eine möghichst reinliche Abscheidung der verschiedenen Wirtschaftszweige herbeizuführen, und auch ron landwirtschaftlicher Seite wird betont, daß mit zunehmender Betriebsintensität die Bedeutung der Streunutzung mehr und melı abnehmen nüsse ${ }^{1}$ ).

In wirtse haftsgeographis cher Hinsicht ist festzustellen, daß die Waldstreunutzung besunders in den Gegenden üblich ist, wo dic Ungunst des Bodens, des Klimas oder der topographischen Verhältnisse den für landwirtschaftliche Benützung sicheignenden Grund und Borlen sehr knapp bemessen hat und parzellierter Kleinbesitz vorherrscht, namentlich wem dabei die Bevölkerung eine verhältnismäBig dichte ist, wie dies z. B. für Teile des rheinisch-westfälischen Zech- und Hüttengebiets und für manche industriereiche Täler der deutschen Waldgebirge (Sehwarzwald, Vogesen u. a.) zutrifft. Andererseits hat die Streunutzung z. T. gerade auch in minder bewaldeten Gebieten größere Bedeutung erlangt, nämlich da, wo der Anbau von Handelsgewächsen und der Weinbau in größerem Umfang betrieben wird oder wo die höhere Einträglichkeit der Viehzucht und Milchwirtschaft die Haltung eines im Mißverhältnis zur Stroherzeugung stehenden Viehstands veranlaßt hat, so daß cin großer Teil des Strohertrags verfüttert werden nuß. Die Verbesserung der Verkelırsverhältuisse hat allerdings einigermaßen Abhilfe geschaffen, indem sie dic Beschaffung anderer Streuersatzmittel (vor allem der Torfstreu) erleichterte; dazu komnt, daß auch der Bezug künstlicher Düngemittel erheblich billiger geworden ist, ein Lmstand, der seinerseits wieder den Stroh- wie Futterertrag zu steigern vermoclite $\left.{ }^{2}\right)$.

Will man d e n Wert d e r. Wa l d st reun ut z u u g als solcher ermessen,

TafeI XXI-XLIII; Verhandungen der Fachvereine in Fiarlsule 1838, Baden 1841, Darmstadl 1845, Mainz 1849, Passau 1851, licmpten 1856, Würzburg 1862; A r be i l e n des fors 1 lichen Versuchswesens: aus I'reußen: Aufsätze von $\mathrm{S} c \mathrm{~h} w$ a p a $\mathrm{ch}$ in der $\mathrm{Z}$. f. F. u. J., vor allem Jahrg. 1885, 1892, 1896, 1898 und 1900, L a s p e y r s 1898 ; aus Sachsen:

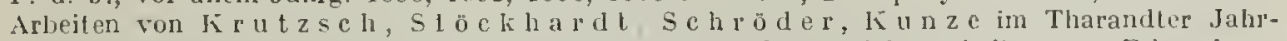
buch, Jahrg. 1850, 1852, 1863, 1869, 1876, 1881; aus Oesterreich: Arbeiten von $\mathrm{R}$ i e $\mathrm{I}$ e $\mathrm{I}^{\circ}$

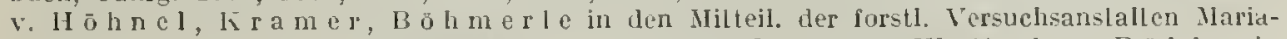
brunn 1879 , 1882, und in C. f. d. II. f. d. F. u. J. 18;6; zahlreiclic Aufsälze von $\mathrm{R}$ a $m$ a $\mathrm{n}$ in der Z. f. F. u. J. (im cinzelnen zilierl).

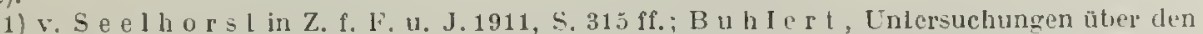
Wert von Wald- und Heidestreu in Landw.-Betrieb (Berichte aus dem physiol. Laboral. und der Versuehsanslall des landw. Instituts der IniversiläL Halle, XY. II., Dresden 1901).

2) In Frantreich, ferner in der Nord. und Ostschweiz ist die Strcunulzung nur sellen üblich (Bop pe e I J olyet, Les forêts 1901; I r ä m e r, Die Landwirlschaft im schweizerischcn Flachland 1897).

IIandb. d, Forstwiss. 3. Auf. II. 
so sind 3 Gesichtspunkte ins Auge zu fassen: 1. die Eignung der Streu als Lager für die Tiere, 2. ilıre Fähigkeit zur Aufsaugung und Festhaltung der tierischen Dungstoffe, und endlich 3. dic Düngerwirkung des betreffenden Streumaterials. Nach allen diesen drei Richtungen steht der Laub- und Nadelabfall hinter anderen Stoffen ${ }^{1}$ ), vor allem dem Stroh, entschieden zurück. Was zunächst den 1. Punkt anlangt, so wären nach Funke, ,um die cinem Gewichtsteil Stroh gleichkommende S t $\mathrm{r}$ e u wirkung zu erzeugen", etwa erforderlich 3,5 Gewichtsteile Laubstreu. Selnr wichtig im Sinn ciner rationellen Stallwirtschaft ist femer der 2. Gesichtspunkt, dic möglichst voll-

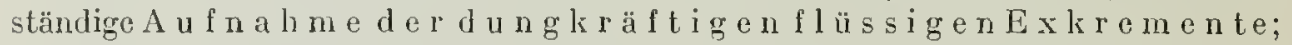
hierfür kann als Anhaltspunlit die Wasscrkapazilät der Streustoffe dienen. Die Untersuchungen ${ }^{2}$ ) von $\mathrm{E}$ b e r m a y e r und W o 1 I n y ergeben, daß Buchenlaub weniger Flüssigkeit als Strol, Moos und Farnkraut aufzunchmen vermag, der Fichten- und Kiefernnarlelabfall aber noch weniger als das Buchenlaub. Bei Benutzung von Laubund Nadelstreu erleidet der Landwirt somit Düngerverluste insbesondere an Stickstoff und Alkalien. Zur Vermeidung dieses Uebelstandes ist empfohlen worden ${ }^{3}$ ), der Laubstreu humose Erde beizumischen; bekanntlich sind die Nutzungsberechtigten nur allzulcicht geneigt, außer der jüngsten Laubschicht auch noch humose Teile zusammenzukratzen. Die D ü $\mathrm{ng}$ e r w i l k u $\mathrm{ng}$ der Streu endlich bemißt sich, abgesehcn von dem eben besprochenen Gesichtspunkt, nach ihrem eigenen Gehalt an wichtigen Pflanzennälırstoffen, nach dem Grad ihrer Zersetzbarkeit und nach der Konsistenz des hieraus gewonnenen Mists. Der Gehalt an Pflanzennährstoffen ist verschieden je nach der Zeit der Nutzung; denn dic begimende Verwesung führt einerseits zur Auflösung der organischen Substanz, andererseits zur Auslaugung der Mineralstoffe. Nach den Untersuchungen vou Eb e r m a y e r, W o l f f $u$, a. ist alic Laub- und Nadelstreu dem Stroh an Stickstoffgehalt überlegen (Nadelstreu noch mehr als Laubstreu), beide stehen aber hinsichtlich Kaliwert zurück, dagegen ist der Phosphorsäuregehalt des Buchenlaubs vieder hölıer als beim Stroh. Ungünstig verhält sich die Laub- und Nadelstreu infolge ilırer $t r$ ä g e $n \mathrm{Z}$ e r s e t z b a r k e i t; die Laubstreu bildet außerdem einen klumpigen, schwer zu verladenden und auszubreitenden llist, der auf strengen Böden ungünstige Humusbildungen veranlaßt. Unter Berücksichtigung all der angegebenen Mtomente hat F u n k e eine Skala für die verschiedenen Streusorten aufgestellt: Einem Gewichtsteil lufttrockenen Winterroggenstrohs sind etwa gleich zu achlen: 3 Gewichtsteile Laubstreu, 1,8 4 Heidelraut, 1,7 Heidelbecre, 1,4 Moos. (Die reine Nadelstreu ist glcich minderwertig wie dic Laubstreu, in Untermischung mit Moos gilt sie aber als besseres Streumaterial).

Hiernach lieBe sich der Gebrauchswer't der Laub und Nadelstreu natürlich auch in Geld ausdrücken, wenn man von einem bestimmten Strohpreis ausgeht und die höheren Wertungs- und Beifuhrkosten der Waldstreu in Abzug bringt. Bei freier Preisbilılung richten sich die tatsächlichen Tauschwerte für Waldstreu ganz nach den Strolipreisen; es wird aber von den größeren Forstverwaltungen unter Ausschaltung der natürlichen Preisgesetze in Notjahren ein crmäßigter Preis angesetzt. Un so wertvoller gestalten sich jene in WVald zur Verfügung stehenden Strohersatzstoffe für den kleineren Waldbesitzer, der hier den Eigenbedarf ausgiebig zu decken nur allzu leicht versucht ist. So kommt es, daß diese Nebennutzung, wie es in 11 a g e n-

1) Verol. Bu h I e r ta. a. O., ferner $\mathbf{C}$ a $\mathbf{r g}$ a $\mathrm{i}$ e o im Jahrbueh des Schles. Forstvereins 1902 , S. 52. Das aus Laub- und Nadelabfall bereitete Lager soll weniger troeken und weniger warm, in einzelnen Fällen auch für die Gesundheit der Tiere weniger zuträglieh sein (s. a. Dr. Giers berg in F. Clul.1906, S. 530).

2) $\mathrm{R}$ a $\mathrm{m}$ a $\mathrm{n} \mathrm{n} 1905, \mathrm{~S} .346$.

3) Wo $1 \mathrm{f} f$, Düngerlelre, S. 81. 
D o $n$ n $\mathrm{r}^{1}$ ) heißt, ,in einigen Landesteilen eigentlich als Hauptertrag bezeichnet werden muB".

Zur Iiennzeichnung des Werts der Nutzung sowolıl für den Waldbesitzer als für die streubedürftige Berölkerung sind noch Angaben über die M a s s e n e r $\mathrm{tr}$ äg c mitzuteilen: Die Blattmenge der einzelnen Holzarten ist schr verschieden. Man hat cine Stufenleiter festgestellt, in welcher Buche, Alorn, Lincle obenan stehen, Esche, Birlie und Aspe den untersten Platz unmittelbar nach den Nadclhölzern einnehmen. Aler auch der Streuertrag der einzelnen Holzart schwankt in zicmlich weiten Grenzen : Bestandesverfassung, Alter, SchluBgrad, Erziehungsweise, hedingen Verschiedenheiten; vor allem aber ist dic Standortsgüte maßgebend. $\mathrm{Zu}$ unterscheiden ist zwischen dem jährlichen Streuanfall und dem jeweils verfügbaren Streuvorrat; auf ersteren ist die Jahreswitterung von größten Einfluß, indem z. B. trockene Jahrgänge wesentlich geringeres Blatterzeugnis (bis zu 60\%. weniger als nasse) aufzuweisen haben; der Streuvorrat andererseits richtet sich außcrdem nach dem Tempo der natürlichen Laubzersetzung und nach dem Streunutzungsbetrieb. So beträgt z. B. nach E b e rm a y e $\mathrm{r}$, ,in vollständig geschonten oder längere Zeit nicht berechten $\mathrm{B}$ u c h e $\mathrm{n}$ beständen" der Gesamtvorrat durchschnittlich die $2 \frac{1}{2}$ fache Menge des jährlichen Blattabfalls, in F i c h $\mathbf{t}$ e $n$ beständen ,fast 4 mal mehr als der jährliche Nadelabfall, in $\mathrm{K} \mathrm{j}$ e f e r beständen im großen und ganzen fast die 5 fache Menge". Es ist aber anzunelımen, daß diese Zahlen je nach Bodenart, Bodenzustand, Kilima usf. recht erheblichen Schwankungen unterliegen. Endlich ist noch zu erwähnen, daß bei fortgesetzter Streuentnahme auch die jälırliche Blatterzeugung melır und mehr abnimmt.

Aus den zahlreiclen Angaben der einschlăgigen Literatur über Streuertrāge mōgen einige Durchschnittszahlen mitgeteill sein:

a) aus $\mathrm{B}$ u $\mathrm{e}$ h $\mathrm{e}$ beständen: Nach den in Bayern ${ }^{2}$ ) angestellen Erbebungen ergab sich ein durehsehnittlicher jährlicher Streuanfall pro lia in tufttrockenen Zusland (d. h. nit ca. $10-15 \%$ Wasser)

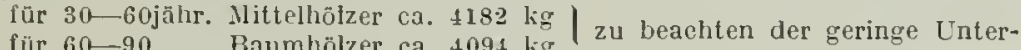

\begin{tabular}{lll|l} 
für $60-90$ & , Baumbölzer ca. $4091 \mathrm{~kg}$ & zu beachten der geringe Unte \\
für $90-130$ &, Althülzer & ca. $4014 \mathrm{~kg}$ & schied der Altersstufen
\end{tabular}

K r $\mathrm{l}$ z se h stellte für einen $50-55$ jähr. Buchenbestand als 8jähriges Mlittel der jährtich angefallenen Laubstreu $\$ 188$ lig fest.

Weiterhin ergab sich nach den bayrischen Untersuchungen in normalen und gut geschłossenen Buchenbestānden
a) ein jährl. Streuanfall pro lıa von $\$ 107 \mathrm{~kg}$
b) ein Bjähr. Streuertrag, ,, , $8160 \mathrm{~kg}$
c) ein 6jāhr. Streuertrag,, , , , $8469 \mathrm{~kg}$
d) ein Forrat in geschonlen Beständen von $10417 \mathrm{~kg}$ (n. K r u t z s h 10488).
$\mathrm{Sch}$ w a p a $\mathrm{ch}$ ermittelte folgende Zahlen auf versehiedenartigen Slandorten:
bei jăhrlicher Nutzung $\quad 3200 \mathrm{~kg}$ bis $6500 \mathrm{~kg}$ (geringer bezw. suler Standort).
bei Nutzung alle 2 Jahre $4800 \mathrm{~kg}$ bis $8700 \mathrm{~kg}$
bei Nutzung alle 4 Jahre $5500 \mathrm{~kg}$ bis $9200 \mathrm{~kg}$
bei Nutzung alfe 6 Jahre $5700 \mathrm{~kg}$ bis $10700 \mathrm{~kg}$

Als einjährigen Ertrag würtlembergischer seit langem berechter Buchenbestande fand $\mathrm{B}$ ü h l er, ausgeschieden nach Landesbonitälen:

$\begin{array}{llllll}\text { bei Bonităl: } & \text { I. } & \text { Il. } & \text { III. } & \text { IV. } & \text { V. } \\ \text { kg luftrocken: } & 3047 & 2213 & 1462 & 1149 & 617\end{array}$

b) Aus $\mathrm{F}$ i c h $\mathrm{t}$ e $\mathrm{n}$ beständen: nack den bayrischen Erbebungen wurde als durchsehnittticher jảlurticher Vadelstreuanfall festgestellt
in Junghölzern unler 30 Jahren $5258 \mathrm{~kg}$
in Mlitlelhỏlzern $\quad 30-60 j a ̈ h r .3964 \mathrm{~kg}$
in Baumhölzern $\quad 60-90 j a ̈ h r .3376 \mathrm{~kg}$
In Althölzerı über 90 Jahre $3273 \mathrm{~kg}$

If $\mathrm{r} u \mathrm{tz}$ s c h ermittelte in einem $15 \mathrm{jäh}$. P'flanzbestand als 4 jähr. Durchsehnitt $5748 \mathrm{~kg}$, in einem ebenso alten Saatbestand $4152 \mathrm{~kg}$. Nach $\mathrm{Se}$ h w a p a c h s Aufnahmen betug der jāhrl. Durchschnittsertrag pro ha im Alter von $61-73 \mathrm{Jahren} 5841 \mathrm{~kg}$, von $73-82 \mathrm{Jahren}+880 \mathrm{~kg}$.

1) Die forstt. Verlaälnisse Preußens, S. 59.

2) Eb e r m a er, a. a. O. S. $44 \mathrm{ff}$. 
Als Streuvorat in geschonten Beständen fanden sich bei den bayrischen Erbebungen durehschnittlich $13857 \mathrm{~kg}$, nach $\mathrm{s} \mathrm{ch}$ w p p a c h bei tjährigem Turnus als Optimum $12581 \mathrm{~kg}$ (in $41-53$ jähr. Besland).

c) aus $K$ i e f e r n beständen: nach den bayr. Erhebungen

in 25 - 50j. Best. $3397 \mathrm{lig}$ durchschn. jährl. Nadelabfall | nach fi r ut z s c h 3913,5 in 50 - $75 \mathrm{j}$. Best. $3491 \mathrm{~kg}$ durchschn. jähr]. Nadelablall in einer $45 \mathrm{j}$. Jiefernsaal, in $75-100 \mathrm{j}$. Besl. $4229 \mathrm{~kg}$ durchschn. jährl. Nadelabfall 3616,2 in 1 I’flanzbestand. im Gesamtclurchschnitt als 6jähiger Streuvorrat $13729 \mathrm{lig}$

als 3 jälıriger Streuvorrat $8987 \mathrm{~kg}$

Die sämtlichen Zahlen beziehen sich auf den 1 u f $t \mathrm{t}^{\circ}$ o c ls e n e n Zustand; zu wissenschaftlichen Untersuchungen und Wertsschätzungen muß dieser Maßstab angelegt werden, weil das $\mathrm{W}$ a $1 \mathrm{~d} g \mathrm{e}$ w i c h t je nach Witterung sich auBerordentlich verschieden gestaltet; fand doch $B$ ï bl 1 e r, daß $100 \mathrm{~kg}$ Laubstreu je nach dem Trockenheitsgrad zwischen 86,1 und $21,2 \mathrm{~kg}$ in lufthockenem Zustand ergaben.

Als pralitische Streumaße sind cbm oder Rm bezw. Fuhren (Fuder) üblich.

Für die oben angegebenen Streuerträge können in großen und ganzen etwa folgende Umrechnungsziffern ${ }^{1}$ ) angegeben werden: 1 ebm luftrockenes $\mathrm{B}$ u $\mathrm{e}$ h e $\mathrm{n}$ laub wiegt rund $60 \mathrm{~kg}$, lei ejnem Wassergehalt von $18 \%$ rund $80 \mathrm{~kg}$, eine zweispännige Fuhre Jufttrocken rund $750 \mathrm{~kg}$. $1 \mathrm{ebm} F$ ic h te n $n$ a d e $1 \mathrm{n}$ bei $15 \%$ Wassergehalt rund $170 \mathrm{~kg}, 1$ desgl. If $\mathrm{i}$ e f e r n nadeln $117 \mathrm{~kg}$, in Unternischung mit Moos und Heide ca. $160 \mathrm{~kg}$. Der durehschnittiche jährliche Streuanfall wird für Buche etwa zu $50 \mathrm{cbm}$, für Fichtennadelstreu zu 20, für Fijefer zu $30 \mathrm{cbm}$ angenommen, der durchschnilliche Streuertrag bei Einhallung einer Umlaufszeit von 6 Jahren in Buchenbestänten zu rund 100 , in Fichten zu 55 , in Fiefern zu 80 clm.

\section{b) Stalik der Laub- und Nadelsireunutzung.}

Geht man von den zuletzt angegebenen Streuerträgen aus und unterstellt die Beschränkung des Betriebs auf die 40-80 jähr. Bestände sowie Einhaltung cines 6 jähr. Turnus, so berechnet sich bei einem crntekostenfreien Erlös von 1 Mk. je cbm ein Reinertrag für Buchenstreunutzung von $100 \mathrm{Mk}$. je 1 ha Nutzungsfläche und von beiläufig $7 \mathrm{llk}$. bezogen auf dic Flächencinheit einer normalen Buchenbetriebsklasse $(u=100)$; diese nieder angesetzten Zahlen dürften angesichts der Tatsache, daß sich in vielen Laubholzrevieren der Reinertrag der Holznutzung nicht über $30 \mathrm{Mlk}$. per ha erhebt, die Streunutzung als nicht zu unterschätzende Eimnalmmequelle erscheinen lassen. Aufgabe der statischen Untersuchung ist es nun, diese scheinbar hohen Nebennutzungserträge in die Gesamtbilanz der Waldwirtschaft einzuglicdern.

Vom privatwirtschaftlichen Gesichtspunk ${ }^{2}$ ) aus werden übermäßige Streunutzungen gelegentlich mit dem Vorwand gerechtfertigt, daß der Wirtschaftszwecli vieler Waldbesitzer in erster Linie auf Streugewinnung, nicht auf llolzerträge, gerichtet sei. Dengegenüber ist zunächst zu untersuchen, ob nicht die Nachhaltigkeit der Streunutzung selbst gefährdet ist. Genauc und einwandfreic Untersuchungen hierüber liegen nicht vor. Immerhin lassen die oben mitgetcilten Zahlen aus württembergischen, seit lang gerechten Buchenbeständen bcin Vergleich mit den Ergebnissen aus anderen früher geschonten Versuchsflächen vermuten, daß langjührige Streunutzung den Streuertrag selbst nachteilig beeinflußt. Wenn man in Berichten über Streudevastation von wipfeldürren absterbenden Buchen mit geringer Bclaubung hört, welche den Boden kaum zur IJälfte mehr decken und so ä., so wird man sich der Annahme nicht verschließen können, daß der streulüsterne Waldbesitzer durch ïbertriebene Streunutzung sich ins eigene Fleisch schncidet. Nehen dem Rückgang des Streumassencrtrags macht sich als Folge länger daueruder Entnahme res Blattabfalls mit der Zeit auch eine Ilerabsetzung des Mineralstoffgehalts und

1) Naeh Eberm a yer, a. a. O. S. 54 ff.

2) Vergl. z. B. Verhandlungen des sächs. Forstvereins über lileinwaldbesilz i. J. 1903. (Bericht über die \pm 7 . Vers. S. $104 \mathrm{ff}$.). 
damit des Düngerwerts der Laubstreu geltend. Wenigstens hat $\mathrm{P}$ a $\mathrm{m}$ a $\mathrm{n}$ n in Buchenstreu-Tersuchsflächen nachgewiesen, daß die Bäume der berechten Fläehe Mangel an Kalk und Kali leiden ${ }^{1}$ ).

Wag der Rückgang der Streunutzung an sich von geringerer und weniger allgemeiner Bedeutung scin, so weist er doch darauf hin, daß durch regelmäBige Entnalme des Blattaballs das $W$ a $l$ d k a $\mathrm{p}$ i a $l$ a $\mathrm{ng}$ e $\mathrm{t}$ a $\mathrm{s} \mathrm{t}$ e $\mathrm{t}$ wird.

Will man dieser Frage auf den Grund gehen, so ist zunächst festzustellen, welche Stoffe eigentlich mit ler Laub- urd Nadelstreu aus dem Wald entführt werden. Hierüber sind schon seit langem eingehende Untersuchungen angestellt worlen. Man unterscheidet in dieser Hinsicht den Gehalt d er Streu an W asser, an organischen und an mineralischen Bestandteilen.

Der II a s serentz ug kann im allgemeinen als ziemlich belanglos bezeichnet werden, zumal wenn die Nutzung erst nach lingerem Liegen erfolgt. E b c $\mathbf{r}$ m a y e schâtzt den Wasaergehalt der frisch abgefallenen Blätter unct Xadeln auf etwa $30-50^{\circ}$, in lufttrockenen Zustand auf $12-14^{\circ}$. In extremen Fällen allerdings hat sich ergeben ${ }^{2}$ ), daß bei der Ueberführung von Laubstreu in den Jufttrockenen Zustand bis zu $78,8 \%$ Wasser verdunstet sind. Im großen Durchschnitt dürfte die mit der Streu dem Vialtboden entzogene Feuchtigkeit einer Jiederschlagsmenge ron hōchstens $1-2 \mathrm{~mm}$ entsprechen.

Was weiterhin dic organ is $\mathrm{c}$ lı $\mathrm{n}$ Bes 1 a $\mathrm{n}$ d teile der Laub- und Nadelstreu anJangt, so macht deren Anteil ctwa $78-83 \%$ des Luftirockengewichts aus; iurch ilire Entfernung werden dem Waldboden die Humus bildenden Suhsianzen entzogen; auf die Bedeutung dieser Tatsache wird unten noch weiter einzugehen sein. Für die Pflanzenernährung sinct von besonderer Becteutung die stickstofflaltigen organischen Bestandteile der Streu (vor allem die Proteinstoffe). Nach $\mathrm{R}$ a $m$ a $\mathrm{n}^{3}{ }^{3}$ ) belrägt der Gesamt-Stickstoffgeliali der Laub- und Nadelstreu nur $0,8-1,4 \%(0,8$ in der libernstreu, rund 1,0 bei Fichte, 1,4 bei Buche); denn im Herbst unmittelbar vor dem Blattabfall hat der Stickstoffgelialt der Blätter den Tiefstand (s. oben S. 526) erreicht. Nach dem Blattabfall ist dersclue bald hōlıer, bald niedriger, je nach dem Grad der Auslaugung einerseits, der Verwesung andrerseits: dazu kommt, daß während des Verwcsungsprozesies atmosphärischer Sticlistoff von der Streu gebunden wird; durch eingehende Lntersucliungen melirerer Forscher ist dieser unter der Einwirkung von Mikroorganismen érfolgende Vorgang naclgewiesen ${ }^{4}$ ). Es ist aber zu betonen, daß die Stickstoff sammelnden Bakterien (so die Gruppe Azotobakter) reichlich Nāhıstoffe und vor allen kalkreiche Böden licanspruchen ${ }^{5}$ ).

Von den wichtigsten A sche $\mathrm{n}$ bestan d teilen der Streu war schon oben bei Erörterung des Düngerwerts derselben die Rede. Nachslehende Uebersicht, aus $\mathrm{E}$ b e r m a y e rs "Maldatreu" cntnommen (S. 116 f.), zeigt die Mineralstoffmengen, welehe durch die jährliche Sireuproduktion in Vergleich zur Holzproduktion und zu den Ernteergebnissen einiger landwirtschaftlicher Gewaachse dem Boden entzogen werden.

In einem Jahresertrag s. durchschn. enth. $\mathrm{kg}$ je lıa

\begin{tabular}{|c|c|c|c|c|c|}
\hline $\begin{array}{l}\text { Gesamt- } \\
\text { Reinasche }\end{array}$ & KOO & $\mathrm{CaO}$ & $\mathrm{IJgO}$ & $\mathrm{PO}_{5}$ & $\mathrm{SiO}_{2}$ \\
\hline 18.5 .54 & 9,57 & 81,92 & $12,2,2$ & 10,45 & 60,36 \\
\hline 29,60 & $\$ .65$ & 14,42 & 3,85 & 2,87 & 2,41 \\
\hline 215,14 & 14,52 & 96,34 & 16,07 & 13,32 & 62,77 \\
\hline
\end{tabular}

1. Buchen hoch wa l d

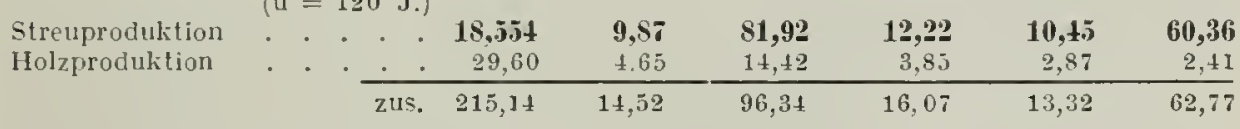

2. Fich ten hoch w a $l$ d

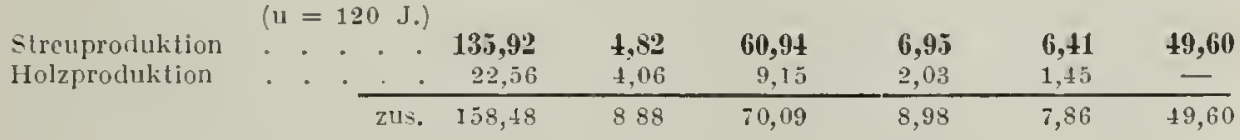

1) Z. I. F. U. J. 1898, S. 295.

2) $\mathrm{B}$ ü h le r a. a. O.

3) Bodenkunde 1905, S. 357.

1) cfr. Hen ry, stickstoff und Streu, in Revuc des eaux et forêts $1908,5.27 t$ und die dort zitierten Forcher $S$ ü $\mathrm{cht}$ ing, $M$ ontemartini, Wiesner, feruer Bur i (schw. Z. f. F. 1904, S. 89), Hornberger, Z. f. F. U. J. 1906, S. 775.

5) $\mathrm{R}$ a $\mathrm{m}$ a $\mathrm{n}$, Bodenkunde $191 \mathrm{I}, \mathrm{S}+2 \mathrm{I}$. 
In einem Jabresertrag s, durchschn. enth. $\mathrm{kg}$ je ha

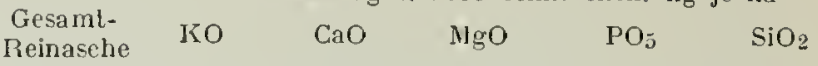

3. Kartof $\mathrm{e} \mathbf{l n}$

Irraul

Kinollen

\begin{tabular}{rrrrrrr}
$\cdot$ & 101 & 21,89 & 32,87 & 16,62 & 7,93 & 4,34 \\
$\cdot \quad$ & 164 & 98,50 & 4,19 & 7,66 & 28,33 & 3,47 \\
\hline zus. & 265 & 120,39 & 37,06 & 24,28 & 36,26 & 7,81
\end{tabular}

4. W e i z e n

Stroh

Körner

\begin{tabular}{|c|c|c|c|c|c|c|}
\hline - & 143 & 19,48 & 821 & 3,53 & 6,85 & 96,21 \\
\hline$\therefore$ & 31 & 9,71 & 1,04 & 3,72 & 14,58 & 0,65 \\
\hline zus. & 174 & 29,19 & 9,25 & 7,25 & 21,43 & 96,86 \\
\hline
\end{tabular}

Man kann aus dieser Uebersicht judenfalls so viel entnelımen, daß bei Nulzung der $f r$ is e h g e f a lle $n$ en Streu eine bedeutende, die Holznutzung weit übersteigende Menge von Hineralstoffen, zumal Kalk, dem Boden entzogen wird. Bleibt die Streu noch längere Zeit an Boden liegen, so läßt sie infolge Auslaugung den obersten Bodensehiehten erhebliche Mengen leicht löslicher Salze (besonders von liali) wieder zugute komnen ${ }^{1}$ ).

Die angeführten Zahlen vermögen jedoeh nur unter der Voraussetzung als Anhaltspunkte für Aufstellung einer $\mathrm{B}$ o d e $\mathrm{n}$ b i l a $\mathrm{n} z \mathrm{zu}$ dienen, daß dureh Analysen der Gehalt eines Bodens an für die Pflanzen zugängliehen Mineralstoffen zuverlässig naehgewiesen werden kann; das ist auch nach dem neuesten Stand der Wissensehaft nur in beschränktem Umfang möglich ${ }^{2}$ ). Außerdem ist zu beachten, daß das $\mathrm{N}$ äh $\mathrm{r}$ to f f be ä $\mathrm{r}$ il is der Pflanzen dureh die Zahlen der Asehenanalyse nicht riehtig widergespiegelt wird, indem die einzelnen Nalurstoffe bezūglich des , A n e i g $n$ u $\mathrm{g} s$ verm ō $\mathrm{g}$ e $n \mathrm{~s}^{6{ }^{3}}$ ) der Pflanze sieh ganz anders zueinander verhalten. Immerhin wird für solehe Verhältnisse, unler denen die obersten Bodensehiehten ausgesproehenermaßen Mangel an einem bestimmten Nährstoff (z. B. Kalk) lejden, das Ergebnis der initgeteilten Asehenanalysen ron Bedeutung sein.

Weiteren Eimblick in das Verhältnis von Streunutzung und W a ld k a p i a l gewährt die Untersuchung der Vorgänge, die sich im IValdboden bei der Streuzersetzung abspielen, bezw. die Beobachtung der Veränderungen, welche ihre Entnahme zur Folge hat. Endlich wird zu prüfen sein, ob gegebenenfalls außer dem Bodenkapital auch das $\mathbf{B}$ estandes kapital (der dermalige Holzrorrat) beeinträchtigt wird.

Es kann sich hier nicht darum handehn, näher auf das erstere Problem einzugehen; handelt es sich doch um nichts anderes als um die Frage der Humusbildung im Boden und um die Bedeutung der Humusstoffe für den Boden. In den neueren bodenkundlichen Schriften sind diese Fragen unter anderen Gesichtspunkten als früher behandelt. Die biołogische Forschung und die Fortschritte der chemischen und physikalischen Wissenszweige (vor allem der Kolloidchemie) haben auch auf die Humuslehre umgestaltend und klärend eingewirkt.

Zum Verständnis der weiteren Ausfülnungen sind einige Bemerkungen über Humusbillung voranzuschicken: Je nach Pflanzenart, klimatisehen und Bodenverhältnissen verläuft die Umbildung des Blatlabfalles verschieden sehnell. $R$ a $m$ a $n$ scheidende Falitoren der Zersetzung ein bestimmtes Maß von Wärme, Anwesenheil von genügend Wasser und Nälrsalzen, Zutritt von Sauerstoff und Abwesenheit pflanzensehädlicher Stoffe (Säuren, Chloride usf.); das sind zugleich die Lebensbedingungen der an der Bodenumgestaltung mitwirkenden pflanzlichen (Bakterien usf.) und tierisehen Lebewesen (Regenwürmer, Tausendfüler). Unter günstigen Zersetzungsverhältnissen entsteht sog., ,milder oder neutraJer" Humus (,ahsorpliv gesättigter" ), d. l. Mull und Moder gleiehmäBig gemiseht mil Ninera]boden unter einer losen Decke des jüngsten Streuselicht. Je mehr einzelne der genannten Faktoren vom Optimum alweichen, sich einem llinimum oder Maximum nähern, um so ungünstiger verläuft der Zersetzungsprozeß; ist die Zersetzung verlangsant, so entsleht eine Ansanmlung von Humusschichten, saurer oder, ,absorptiv ungesättigler" Humus.

1) R a m a n n 1905, S. 359 .

2) S. R a m a n n $1911, \mathrm{~S} .274 \mathrm{ff}$.

3) Vergl. hieruber den Aufsatz von B a u er aber Stoffbildung und stoffaufnahme ete., Nat. Z. f. F. U. L. 1910 , S. 457 ff.; ferner die Arbeiten von V a t e über das Zulangen der Nälrrstoffe im Boden. (Thar. Jahrb. 1909 und 1910; Nal. Z. f. F. U. L. 1910, S. 570.) 
Die Vorteile des aus der Streu hervorgehenden m il d e n H u m us bestehen darin, daß er durch Begünsligung der Kürümelstruktur und durch Erhöhung der Wasserkapazität förderlichen Einfluß auf die plysikalische Bodenbeschaffenheit ausübt und die obersten Schichten mit löslichen Jineralstoffen bereichert. Dagegen erschweren dichte, verfilzte H u m us chich ten (Rohlumus bezw. Trockentorf) die Durchlüftung und Erwärmung des Bodens; trotz scheinbaren Ueberflusses an Feuchtigkeit und Nährstoffen treten Trockenheits- und Hungererscheinungen auf, was sich am besten durch das Ankommen einel xerophyllen und nährstoffscheuen Flora (Heide, Weißmoos, Flechten u. a.) verrät; außerdem vereiteln solche Humusanhäıfungen das Fieimen des natürlichen Samenabfalles und das Anwachsen der jungen Pflänzchen. Da aber auch der saure Humus einen, wenn auch z. Zt. unzugänglichen Vorrat von Mineralstoffen (vor allem Sticlistoff) birgt, kann aus jenen Irrankheitserscheinungen zunächst lediglich der Schluß gezogen werden, daß der Forstwirt durch geeignete Naßnahmen auf die normale Zersetzung der Streu hinarbeiten sollte. Zur Vermeidung ungünstiger Humusformen kann allerdings die Entfernung der Streudecke als einmalige oder vorübergehende Maßregel in Frage kommen; es wird aber mit Recht verlangt ${ }^{1}$ ), daß in solchen Fällen die Einnahme aus der Streunutzung zuvörderst für Gesundung der Humusverhältnisse (Bodenbearbeitung, Düngung) zu verwenden wäre.

Aher abgesehen von den nachteiligen Einwirkungen des sauren Humus auf den Bodenzustand hat die Lehre von der Bedeutung der Bodenstreu auch in andern Stücken Wandelungen erlebt:

Während ältere Forscher allgemein nur nachteilige Folgen der Streuentnahmen bei ihren vergleichenden Bodenuntersuchungen feststellen konnten, ist neuerdings (insbesondere von $\mathrm{R}$ a $\mathrm{m}$ a $\mathrm{n} \mathrm{n}$ ) durch zahlreiche Analysen und durch Untersuchungen ïber das Porenvolumen in gerechten und nicht gerechten Vergleichsflächen der Nachweis erbracht worden, daß unter gewissen Verhältnissen selbst eine längere Zeit ausgeübte Streunutzung bemerkbare Veränderungen im Boden $\mathrm{n}$ i c h t liervorgebracht hat, daß jedenfalls in absehbarer Zeit eine Erschöpfung der reicheren Böden durch Streunutzung nicht zu befürchten sei. Das abschließende Urteil $R$ a m a n $n$ s über die Wirkung der Streunutzung auf den Boden (s. Bodenkunde 1905, S. 365) lautet:

,Jede fortgesetzte und jährich wiederkehrende streunutzung muß früher oder später zu einer Erschöpfung des Bodens an mineralisehen Nährstoffen und zu einer ungüntigen physikalischen Veränderung des Bodens führen. Auf armen Böden, zumal in Sandböden tritt dies am sclnellsten ein, da hier die Bedingungen der ungünstigen Beeinflussung in gesteigertem Maße vorhanden sind. Auf reicheren Bodenarten kann Streuentnahme längele Zeit ohne bemerkbare Veränderung des Bodens stattfinden und bei selten wiederkehrender Streunutzung überhaupt unbenerkbar bleiben."

Die Erschöpfung berechter ärmerer Böden erfolgt weit weniger durch den unmittelbaren Substanzentzug, wie früher angenommen wurde, als vielmehr durch die auswaschende Wirkung der Atmosphärilien ${ }^{2}$ ). Die ungünstige $\mathrm{p}$ h y s i li a lis c he Veränderung aber hängt zusammen mit der Zerstörung der Krüumelstrulitur durch den Mangel löslicher Salze im Boden und ummittelbar durch die schlagende und verschlämmende Wirkung des Regens. Den Niederschlägen gegenüber hat die Laubund Nadelstreudecke noch eine weitere Bedeutung. An Hängen wird das Abfließen des Regen- wie auch des Schneeschmelzwassers durch ihre aufsaugende Wirkung

1) Vergl. diesbezügliche Aeußerungen bei den Verhandlungen des Deutschen Forstvercins über die Humusfrage (Eisenach 1905).

2) Vergl. P a in a n n, Waldstreu S. 63, Bodenkunde 1905, S. 362. 
verlangsamt, die Sickerwassermenge erhöht, die Eodenabschwemmung verhindert und der Uebersehwemmungsgefahr vorgebeugt. Während dieser Vorzug der Streudecke an Hanglagen nach wie vor feststeht, haben bezüglich des Wassergehalts e b en e r Waldfächen neuere Forscher die überkommenen Vorstellungen teilweise berichtigt, so namentlich dureh den Nachweis der Bodenaustrocknung unter stärkeren Humusschichten. Ein Optimum an Bodenfeuchtigheit ergibt die dünne und locker gelagerte Blattabfallschicht, die einerseits dem Obergrund nur wenig Niedersehlagswasser vorenthält, andererseits doch genïgend Schutz gegen die Verdunstung des kapillar aufsteigenden Bodenwassers gewährt. Außer dem V'erdunstungsverlust durch Streuentzug wird als empfindlichster Nachteil der Streunutzung der F e u c h t i gke itswe e hsel empfunden, der allerdings je nach Bodenart (am meisten auf Tonboden), Jahreswitterung wie auch nach dem Zeitpunkt der Nutzung verschieden stark sich geltend maeht; nicht zum wenigsten leiden hierunter die oben erwähnten nützlichen Humusbewohner (Bakterien, Regenwürmer usf.) ${ }^{1}$ ).

Es wird die Aufgabe der ehemischen, physikalisehen und bakteriologisehen Forschung sein, die Waldhumus- und Streu-Frage weiter aufzuklären und die Nachteile des Streuentzıgs festzustellen. In manehen Fällen genügt hierzu schon die Beobachtung des Bodenzustands und des Bodenüberzugs; so sehildert $\mathrm{S}$ c h w a p p a $\mathrm{ch}{ }^{2}$ ), daß die Bodenverhärtung schon beim Gehen über die gerechten Buchenstreu-Versuchsflächen bemerkbar sei: die jährlich und alle 2 Jahre berechten Flächen im preuß. Revier Tronecken waren mit Haftmoosen bedeckt, während auf den geschonten oder nur alle 6 Jahre berechten volle Laubdecke vorhanden war - also unzweideutige Anzeichen der Bodenverhagerung. Bei der Schwierigkeit der Yornahme vergleichender Bodenanalysen sollte in der Praxis gerade auf solehe biologische Veränderungen in Waldboden geachtet werden. Wenn der Bestand selbst schon nachteilige Folgen der Streunutzung äußerlich erkennbar werden läßt, ist das Unheil zu weit vorangeschritten. Bei den meisten Versuchen hat sich gezeigt, daß nachteilige Bodeneinwirkungen viel früher und viel deutlicher wahrnehmbar waren, als etwaige Folgen für die Gesund heit und das W a e h s tum der Be$\mathrm{s} t$ ä n d e. Und doeh kennt man überall llie traurigen Bilder dureh Streunutzung ,devastierter" Bestände: stockendes Wachstum, Verlichtung, künmerliehe, gelblielıgrüne Belaubung, Moos- und Flechtenüberzug an Stamm und Aesten, wipfeldürre Iironen, absterbende Stämme. Solche V'erhältnisse trifft man besonders in L a u bhol z bestänrlen auf an sich armen und flachgründigen Böden bei alljährlicher Nutzung, zum Teil auch bei 2- und mehrjährigem Nutzungs-Turnus. Erhebliche $\mathrm{Zu}$ we h s verluste sind in Vergleichsfächen nachgewiesen worden:

$S c h w a p\left(\mathrm{pach}^{3}\right.$ ) stelle in den oben genannten Buchenbeständen bei jährlicher Nutzung bis zu $55 \%$ Zuwachsminderung wäliend der letzlen Beobaclıtungsperiode fest, $25 \%$ im Durchsehnilt der Versuchsuauer, bei zwejjährigem Turnus elwa die Hälfte, ähnlich bei vierjährigon. während hei sechsjährigem Turnus erst nach längerer Zejt ein Zuwachsverlust eintrat. Auch die Aufnahmen in wütlembergischen und bayrisehen Laubholzbeständen lassen ganz erlieblichen Zuwachsrüchgang erkennen. Weniger aufüllig waren derartige Wachstunssstörungen auf günstigen Böden, so in der sächsischen Buchen-Versuchsfläehe ,Hohe Buchen", wo sich überhaupl kein Zuwachsverlust naehweisen ließ, in Buchenbeständen I. Bonität des

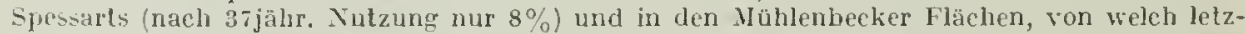
teren $S$ e $h$ w a 1 p a $c$ h bemerkl, da $B$ bei den kräftigen Diluvialbörlen die nachteiligen Folgen des Sireuentzugs sieh sehwächer und langsamer fühlbar machen; bei längerer Dauer komme aber auch hier eine energische Steigerung der ungünstigen Folgen zur Geltung.

1) Yergl. Z. f. F. u. J. 1899, S. 573 (Anzahl und Bedeulung der niederen Organismen im Wald etc.).

2) Z. f. F. U. J. 1892 . S. 524

3) Z. f. F. U. J. 1900 , S. $3+7$. 
Weniger empfindlich als die Buche hat sich die $F$ ic h $\mathrm{l}$ e erwiesen; li u n z e stellte Zuwachs-

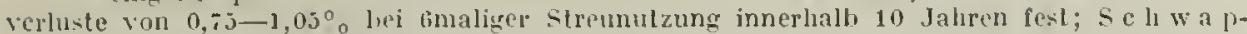
f a $c$ h faßl seine auf diese Holzat bezuglichen Lntersuchungen dahin zusammen, da $B$ in Fichlenbustinden besten Slandorts sich in mitlleren Lebensalter eine Einwirkung des jälurlichen Stretientzugs auf das Wrachstum auch bei längerer Dauer nieht nachweisen lasse, auf ärmetem, flachgrundigem Boden dagegen und in jüngerem Lebensalter wirke die jälurliche Streumutzung sehr schnell und höchst helrächthich. Noch weniger seheint nach $s \mathrm{ch}$ w a p a c h s und L a s p e y res' Untersuchungen die $K$ i e f e r zu leiden; nur für jugendliche Bestänele stellt crsterer entpindlich schĭdigende Wirkungen fest; diese Nltersunterschiede dürflen z. T. Wohl auch dahej rühren, daß es sich in jüngeren kiefernbeständen rorwiegend um die Enntnahme der Nadelstreu liandelt, während in älteren Moos, Gras, Jeide nehr beleiligl sind. Traurige Streudenkmale fincen sich übrigens auch in liefernwaldungen; ein klassischer Zeuge ist der Nïrnberger Reichswald.

Es clürfte als müßiges Unternehnen zu bezeichnen sein, wollte man auf Grund solcher Zuwachsverlustzahlen, deren Entstehung nicht durchweg als einwandfrei bezeichnet werden kann, den Wertsschaden berechnen, den man dem Streunutzungsertrag gegenüberzustellen hätte. Sicher genügt doch vom Standpunkt der Nachlraltigkeit aus die Tatsache, daß im $W$ a 1 d b o d e $n$ nachteilige Veränderungen vor sich gehen, schon vollständig, um über den unmäBig betriebenen Streuentzug das Urteil zu sprechen. Wenn auch bei regelmäBiger oder häufiger Streuentnahme im alten Bestand keine Zuwachsverluste nachweisbar sein sollten, so können sich doch später Wachstums- und Verjüngungsstörungen bemerklich machen.

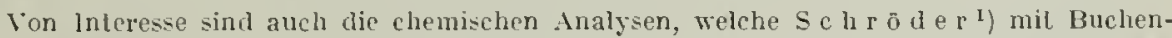
holz von der berechten Vergleichsfläche vorgenommen hat; er fand, da $\beta$ die Reinasche desselben in Mittel nur $70_{0}^{\circ}$ in Vergleich zu dem auf der nicht berechten Flïche slockenden Holz belrug, ohne daß Zuwachsverluste nachweisbar waren; auf Grund der chemischen Untersuchung lasse sich torausselien, daß bei längerer Forlselzung des Rechens über liurz oder lang ein schädlicher Einíluß auf das Wachstum siclı geltend machen werde.

\section{c) Maßs und Art der zulässigen Nutzung.}

Auf Grund der statischen Erwägungen lassen sich Bedingungen für die Zulässigkeit der Nutzung und Regeln für die Art und Weise der Verwertung aufstellen:

1. Die Laub- u. Nadelstreunutzung sollte unterbleiben bei ungünstigen Standortsverhältnissen, die dem Pflanzenwachstum ohnehin Schwierigkeiten bereiten oder eine tote Bodendeclie besonders erwünscht erscheinen lassen, z. B. an steilen und trockenen Hängen, auf flachgründigen und steinrauhen, auf allzu losen und auf streng bindigen Böden. Arme Sandböden sind empfindlicher als Lehmböden, schwere Tonböden bedürfen in besonderem Naß einer lockernden Humusschicht und einer die Feuchtigkeit regulierenden Streudecke, tätige Kalkböden endlich sind olmehin luumusarm und der Verlıagerung ausgesetzt. Ungekehrt wäre bei Streuanläufung, bei beginnender oder schon vorhandener Trockentorfbildung eine einmalige Streuentnahme in Erwägung zu zichen, sofern nicht durch waldbauliche Nittel (Wühlgrubber) die Nachteile des Rohhumus behoben werden können.

?. Die Nutzung des Laub- unr Nadelabfalls sollte in allgemeinen womöglich auf Notjalıre beschränkt bleiben unrl jedenfalls nicht alljährlich, am besten mit Einbaltung eines nicht unter 6 jährigen Turnus vorgenommen werlen, unter ungünstigen Verhältnissen jedenfalls möglichst selten erfolgen. An ehesten können mittelalte Bestände mit lehmigem Boden in ebener Lage geöffnet werden.

3. Als Zeitpunkt für das Einsammeln der Laubstreu ist vom forstwirtschaftlichen Standpunkt aus der Spätsommer oder Herbst am meisten zu empfelılen, d. I. die Zeit unmittelbar vor Beginn oder im ersten Stadium des Laubabfalls; keinenfalls sollte die Nutzung nach Beendigung des Laubabfalls vorgenommen werder, weil

1) Thar. Jahrbuch, Bd. 26, S. 310. 
sonst der Boden zu lange unbedeckt bleibt und die Zuführung der leicht lösbaren Nährstoffe aus der Streu dem Boden vorenthalten wird. Besonders gilt diese Regel für die tätigen Kalkböden; je hunusreicher der Boden ist, um so eher kann von der Regel abgewichen werden.

4. Beim Streurechen darf nur der unverweste Laub- und Nadelabfall entfernt werden, nicht auch die eigentlichen humosen Schichten; es sollen deshalb nur solche Geräte zugelassen werden, welche für Einhaltung dieser Bedingung Gewähr leisten, d. s. hölzerne Rechen (keine eisernen).

5. Während jede unmäßige Streunutzung als für die Waldwirtschaft bei richtiger Bilanzaufstellung verlustbringend verurteilt werden muß, soll diese Nebennutzung überall da erhoben werden, wo sie der Pflanzenvegetation keinen Vorteil bringt, also - abgesehen von dem nur bedingt eingeräumten Fall der Rohhumusbildung innerhalb Bestands - auf Wegen, Linien, in Gräben usf. Um dem Streubedarf der Bevölkerung entgegenzukommen, wie auch aus Rentabilitätsrüclisichten wird der Forstwirt gut daran tun, die nicht bestocliten und nur mit unverhältnismäßig hohen Kosten kultivierbaren Flächen innerhalb Walds zur Streuproduktion (Streuwiesen) heranzuziehen und geeignetenfalls für sonstige Streuersatzstoffe, z. B. durch Reisstreuabgabe oder ev. durch Torfstreugewinnung auf den Riedflächen, Sorge zu tragen.

Betreffend die Verwertung a r t ist noch zu bemerken, daß entweder freihändige Abgabe (z. B. an Waldarbeiter, Revierinsassen) oder Aufstreichsverkauf (in Notjahren ev. unter beschränkter Konkurrenz), nicht aber die Ausstellung von Erlaubnisscheinen (sog. Einmiete) zu empfehlen ist.

Mit Rücksicht auf Einhaltung der oben angegebenen Regeln wäre es an sich ratsam, die Streu nur in Haufen, nach vorheriger Aufbereitung durch die Waldarbeiter, zu verkaufen. Bei Arbeitemangel sowie in Interesse der Käufer wird aber die Aufbereitung durch den Empfänger häufig nicht zu umgehen sein; die bäuerliche Bevölkerung rechnet ja bei solchen Abgaben die eigene Arbeitsleistung gar nicht oder nur sehr nieder ein. Durch strenge Ueberwachung und entsprechende Verkaufsbedingungen muß mißbräuchlicher Nutzungsüberschreitung vorgebeugt werden.

\section{Die Nutzung der Nebenerzeugnisse des Valdbodens.}

\section{Die pflanzliehen Nebenerzeugnisse.}

\section{$\S$ I1. Allgemeines.}

Es handelt sich um diejenigen Gewächse, welche der Waldboden neben seiner bestimmungsgemäßen V'egetation hervorbringt. Dabei ist zunächst zu unterscheirlen zwischen der von Natur sich einstellenden (durch menschliche Eingriffe allerdings möglichenveise heraufbeschworenen) Begleitflora und andererseits den vom Forstwirt selbst angebauten Gewächsen (Waldfeldbau).

Innerhalb der ersteren Gruppe ergibt sich eine weitere Glierlerung nach den. Nutzungszweck, indem jene Nebengewächse Leils zur E i n s t r e u, teils als F u t t e rstoffe, teils in sonstiger IV e is e Verwendung finden. Vorwiegend sind es also Nutzungen zugunsten der Landwirtschaft, von gröBerem Wert im allgemeinen nur für diejenigen Waldbesitzer, welehe die Bedürfnisse der eigenen Landwirtschaft damit befriedigen künnen; im übrigen liegt ihre Bedeutung mehr auf volliswirtschaftlichem Gebiet als auf privatwirtschaftlichem, und soweit letzteres zutrifft; mehr auf dem Gebiet des Waldbaus als auf dem der Forstbenutzung. Faßt man den Gesamterfolg der Waldwirtschaft ins Auge, so sind diese Nutzungen, wie die im vorigen 
Abschnitt besprochenen, vor allem linsichtlich ihrer Rückwirkung auf das Waldboden- und das Waldbestandesliapital zu prüfen. Dies ist umso wichtiger, als es sich bei den mcisten $\mathrm{n}$ i $\mathrm{c} h \mathrm{t}$ um $\mathrm{c}$ in $\mathrm{ze}$ ls $\mathrm{t}$ ä $\mathrm{n} \mathrm{d} \mathrm{i} g \mathrm{e}$, in allgemeinen ziemlich indiffcrcnte Arten handelt, sondern um best a n d es bild en de; soweit solelic eine geschlossene Decke bilden, sind sic, nach $\mathrm{R}$ a m a $\mathrm{n}$ (Bodenkunde 1911, S. 46:2) ,geradezu entscheidend für dic Eigenschaft der Böden". Es sind entweder nützliche Begleitpflanzen, deren Entferuung nicht ungestraft erfolgen kann, oder schädliche, mit deren Bescitigung aber das Uebel meist nicht an der Wurzel gefaßt ist; denn häufig sind sie lediglich die $\mathrm{F}$ o $\mathrm{I} g$ e $\mathrm{n}$ eingetretener Bodenveränderung. Ob einzelne Gewächse schädlich odcr nützlich bezw. unter welchen Vcrlü̈tnissen sie schädlich oder nützlich sind, ist freilich ein noch nicht befriedigend gelöstes biologisches Problem.

Die lebende niedrigwüchsige Bodendecke trägt mit ihren absterbenden Teilen (Wurzeln, Kricchorganen, Blättern usf.) wie die Bäune selbst zur Hunusbildung, leider häufig auch zur Trockentorfbildung bei; insofern übt sie ähnliche Wirkungen wic die Laub- und Nadeldecke aus. Daneben entzieht sie aber dem Boden Feuchtigkeit und Nährstoffe, den jungen Pflanzen durch ihr Wachstum Licht und Wärme, kurz. sie tritt in Nahrungs-Konkurrenz mit den Holzpflanzen. Jc verschiedener die Existenzbedingungen sind, um so unschädlicher ist i. allg. dicse Kónkurrenz; andererseits besteht zwischen manchen Pflanzengesellschaften ein gegenseitiges Hilfeund Schutzverhältnis; in dicscm sinne spricht man von nützlichen Begleitpflanzen.

Entsprechend der oben angegebenen Gliederung ist zunächst die Moos- und die Lnkräuterstreu zu besprechen, hernach die Nutzung der Futterstoffe; hicrbei ist wieder zu unterseheiden die Nutzung der Futterstoffe durch Menschenhand (Grasnutzung) und diejenige durch die Ticre selbst (Waldweide). Hieran reiht sich die Behandlung der sonstigen pflanzlichen Nebennutzungen (Seegras, Beeren, Pilze u. a.) und zuletzt der Waldfeldbaubetrieb.

\$ I2. Die Moosstre unutzung.

Literatur: Die meisten der oben bei $\$ 10$ angegebenen Arbeiten (vor allem $\mathrm{R}$ a $m$ a $\mathrm{In}$, Sc hwappach, Bōhnerle); ferner: Zederbauer: Moose und Flechten in den Versuclıshestănden im großen Fōhrenwald (\$itt. d. k. k. forstl. Versuchsanstalt Mariabrumn) C. . d. g. F. 1906, S. 165; H a m m, Die lloose und die Erhaltung der Waldbodenkräfte, F. Chl. 1906, S. 611.

Rein naturgeschichtlich: Roth, Die europäischen Laubmoose; D e r.s., Die Torfmoose (Enge I m a n n, Leipzig 1906).

Vorauszuschicken ist, daf außer zur Einstreu in Stall einzelne Moose auch als Deck- und Ziermittel für gärtnerische Zwecke usf. abgegeben werden; Polytrichum communc findet Verwendung zur Bürstenfabrikation.

Die Moose finden sich in größercr Menge meist nur in Nadelholzbeständen, vor allem unter Fichte und Tannc, im Laubwald läßt unter normalen Verhältnissen der Laubabfall das Mloos nicht aufkommen. Es würde zu weit führen, alle wichtigeren Moosarten hier aufzuzählen; am bekanntesten sind ron den Laubmoosen i. e. S. Hylo comium splendens, triquetrum, squarrosum, Hypnum Schreberi, purum, cuspidatum u. a., mehrere Polytrichum-Arten, Dicranum scoparium; ferner sind zu mennen die Spliagnaceen oder Torfmoose.

Was nun zunächst den Streuwert der Hoose anbelangt, so ist derselbe ein ziemlicher hoher, um so höher, je trockener die Noose in Verwendung gebracht werden können; die triefenden Sumpfmoospolster dürften darum weniger beliebt sein; wegen größerer Ergiebigkeit sind aber die dichteren Moosdecken rorzuziehen. Hinsichtlich Aufsaugungsfähigkcit wie hinsichtlich Stickstoffgehalt ist die Moosstreu im allgemeinen dem Stroh überlegen, an Lali- und Phosphorgehalt steht sie nur wenig zurück, auch ihre Zersctzbarkeit - zwar verschieden bei den einzelnen Arten - ist im großen 
und ganzen günstig. Funke taxiert den Streuwert der Moose, vergliehen mit Stroh zu $1 / 1,42$. Der Moosstreuertrag ist am löchsten im Schatten leicht durchbrochener Fichten- und Tannenalthöłzer, bei stärkerer SchluBunterbrechung, geht die Noosvegetation zurück; ein lı̈heres $M a ß$ von Luft- und Bodenfenchtigkeit befördert die Hooshildung. Genauere Angaben über die reinen Noosstreuerträge liegen nicht vor, die Moose werden eigentlich nur in Unternengung mit Nadelabfall gewonnen. Bei intensivem Streunutzungsbetrieb ist der Ertrag natürlich wesentlich geringer. B ö hm er le z. B. stellt fest, dab in den alle 5 Jahre berechten Flächen die Moosbildung gering sei, liaum über die Streudecke heranssehe. In den Nadelholzbeständen des württemberg. Schwarzwalds fanden sich bej Probeerhebungen ca. 4500-6 I40 kg lufttrockene Moosstreu ${ }^{1}$ ) (einschl. Nadelabfall) pro ha. Wesentlich größere Mengen ergaben ca. $20 \mathrm{~cm}$ starke Hypnumlager in der Lüneburger Heide, ïber lie A1b e rt i. d. Z. f. F. u. J. I912 S. 2 berichtet: bei radikaler Entfernung der ganzen Moosdecke $85500 \mathrm{~kg}$ Trockensubstanz pro ha. Als Gewicht der lufttrockenen Hoosstreu gibt E berm a y e $17-100 \mathrm{~kg}$ pro cbm an, bei $20 \%$ ca. $104 \mathrm{~kg}$.

Die Frage, ob die Hoosdeche im einzelnen Fall als schädlicher oder nützlicher Bodenüberzug zu betrachten ist, dürfte zunächst weniger nach Moosartes als nach den Standortsverhältnissen und nach der Dichte der Moospolster zu beurteilen sein, sowie nach dem Lustand, ob die Moose von Trockentorfschichten unterlagert sind oder nicht; dieselben Hoosarten können an einer Stelle als günstige, an andern als ungünstige Bodendecke erscheinen; die meisten Hypnumarten - gemeiniglich als A stmoos e bezeichnet - zeigen für gewöbnlich lockere Struktur, cinzelne, wie Hypnum Sctrreberi, kommen aber auch in dichten Polstern und mit Trockentorfbildung vor; die sog. II a f $t$ m o o s e (Polytrichum, Dicranum), vernöge ihrer starken Wurzelhaare an vertärtete Böden mit wechsehrdẹm Wassergelıalt angepaßt, können auch nicht unbedingt als nützliche oder schädliche Bodenpflanzen bezeichnet werden; dagegen weisen die To r f mo o s e meist auf beginnende Vertorfung und auf Nährstoffmangel hin; durch ilıre schwammartigen, oft beinahe undurchdringlich dichten Polster tragen sie noch weiter zur Bodenentartung, Vermoorung oder Trockentoribildung bei; solche Böden zeigen in extremem Mlaß die üblen Folgen der im vorigen Abschnitt besprochenen ungünstigen Humusformen. Was die dichten Moospolster gegenüber den Laub- und Nadelstreuanhäufungen besonders unangenehm macht, ist ihr eigener Wasserbedarf und ilue auBerordentlich hohe Wasserkapazität, vermöge deren sie den unterliegenden Boden und den Pflanzenwurzeln erheblich mehr Fenchtigkeit vorenthalten; sie verdunsten auch viel stärker als clie Laubstren, da sie melı der Luftbewegung ausgesetzt sind. Dazu liommt als weitere Folge del Wärmeentzug, der in Waldgebieten mit an sich rauhem Klima und holıer Niederschlagsınenge für Bodenzustand und Bestandesverjüngung entschieden nachteilig wirken muß. Für die höheren Lagen des Sclıwarzwalds wird diesen Unstand die Hauptschuld an den Yersagen der Tannenverjüngung beigenessen ${ }^{2}$ ); A I b e $\mathrm{r}$ t stellt Wärmemangel zwar auch für die dichten Hoosdecken der Lüneburger Heide fest, fügt aber bei, die biologischen Vorgänge im Boden hätten darunter nicht gelitten. Von vielen Schriftstellem ${ }^{3}$ ) wird die ungünstige Einwirkung der d i h t en Moosdecke auf Boder, Bestandeszuwachs und Bestandesverjüngung als Grund z u r E $\mathrm{n}$ t f e r-

1) Nach Miti. v. B ü hl e r i. d. 2. Aufl. d. Handbuchs.

2) Vergl. S t o l l, i. N. Z. f. F. u. L. 1909, S. 279 ff.

3) So von B öh $\mathrm{merle}$, Z. f. d. g. F. 1906, s. 145, H a m m (a.a.O.), v. B e n t h e i m, Anregungen zur Weiterbilelung der Forstwirtschaft und Forstwiscenscliaft (1901), E be r ll a r d, A. 1*. U. J. Z. 1908, S. 113, R a m m, Die Zuliunft des württ. Schwarzwalds (1911, S. 57), endlich W a g n e r, Der Blendersaumschlag und sein System 1912, S. $109 \mathrm{ff}$. 
nung der Hoosdecke geltend gemacht, und in solchen Fällen die Abgabe des Mooses als Streumittel an die landwirtschaftliche Bevölkerung empfohlen, sei es gegen Geldleistung oder gegen unentgeltliche Uebernahme der Bodeuhearbeitung durch die Abnehmer. Anders verhält es sich mit den l o c k e r auflagernden Moosschichten; R a m a n 12 sagt hierüber (I905 S. 349): „Locker auflagernde Noosschichten bieten dem Boden Schutz gegen die mechanische Gewalt des fallenden Regrens, schwächen Temperaturextreme ab, sind leicht durchlässig für Niederschläge und mäßigen die Wasserverdunstung". Die Wirkung soleler Noosdecken ist also dieselbe, wie die günstiger Laub- und Nadeldecker. A l b e $\mathrm{r} \mathrm{t}^{\mathrm{I}}$ ) konnte auch nit lilfe von Porenvolumen-Bestimmungen feststellen, ,dab durch die radikale Entfernung der Moosdecke ein entschieden ungünstiger Einflu 3 auf den physikalischen Bodenzustand ausgeübt wurde", wie dies auch schon früher auf Streuversuchsfächen beobachtet worden sei. Er erkläl deshalb die radikale Entfernung selbst der starken Moosdecken für bedenklich. Endlich ist auch zu beachten, daß mit dem Noos dem Boden Wasser und Nährstoffe, namentlich Stickstoff entzogen wird. Neuerdings wird ron mehreren Forschern, besonder's M ö 11 e ${ }^{2}{ }^{2}$, die hohe Bedeutung der Rohhumusschichten für die Sticlistoffemährung der Holzpflanzen besonders betont.

Bei Vorkommen dichter und von Trockentorf unterlagerter Moospolster sollte man nicht zögern. die oberste lebende Decke zur Nutzung freizugeben, aber nicht ohne noch humose Schichten dem Boden zu belassen und durch gleichzeitige Bodenbearbeitung für Gesundung der Bodenverhältnisse Sorge zu tragen. In solchen Fällen dürfen auch eiserne Rechen zugelassen werden, denn mit hölzernen kann in dichten Haft- und Torfmoosschichten nicht viel ausgerichtet werden.

Zu erwähnen ist noch, daB auch mit Räcksicht auf die Unschädichnachung mancher im Moos überwinternder Forstschädlinge ${ }^{3}$ ), vor allem der Kífernspanner und Eulen, Moosstreunutzung gefordert wurde; es isl aber mit Recht darauf hingewiesen worden, daß dureh solche Eingriffe nur dann Erfolge erzielt werden können, wenn die humose Schicht, in der die Puppen größtenteils überwintern, mit entfernt wird; auch fand man, daß nur bei Belassung der Streu die nützlichen Schmarotzerinsekten in der wünschenswerten Menge vorhanden waren.

Die Entfernung I o c k e l' e lloosdecken sollte jedenfalls auf Notfälle beschränkt werden. Im großen und ganzen wird man hierfür dieselben Regehn wie bezüglich der Laubstremnutzung aufstellen können. Die Nutzungszeit ist so festzusetzen, daß der Boden in der trockenen Jahreszeit eines schützenden Bodenüberzugs nicht entbehren muß.

\$I3. Die Unkräuterstreunutzung.

In Gegensatz zur "Rechstreu“ (Iloos-, Laub-, Nadeldecke) auch als ,Mähstreu" bezeichnet, umfaßt diese Gruppe eine Anzahl systematisch verschiedenartiger Gewächse, vor allem die Farne, die Beerkräuter, die Heide und den Besenginster. Farne (namentlich Aspidium). Heidel- und Preißelbeere treten schon im Schatten leicht durchbrochener Bestände auf, während Heide und Besenginster ein üppiges Wachstum erst bei höherem Lichtgenuß, an meisten in Freistand, entfalten.

Hinsichtlich ihres St r e $\mathrm{u}$ we r t s verhalten sich diese Pflanzen sehr verschieden: obenan stehen die Farnkräuter; sie können an Streuwirkung, besonders an Aufsaugungsvermögen, wie auch an Nenge und Zersetzbarkeit del organischen Substanzdem Stroh gleichgestellt werden (F u n ke a. a. O. S. 3I); ihr Gehalt an wichtigen Pflanzennährstoffen ist höher als bei den andern Streumitteln; F u n k e schlägt

I) a. a. U.

2) Z. f. F. u. J. 1903, S. 258 f.; diese Fragen wurden auch bei der 1. und VI. Jauptrersaminlung des Deulsehen Forstvereins tehaft bespruchen, s. die Beriehte 1904, S. 33 ff., 1905 S. 164 fr.

3) Vergl. Berieht über die Eisenacher Forstversammlung S. 33 ff. 
deshaib den landwirtschaftlichen Gebrauchswert der Farnkräuter im Vergleich zum Stroh zu 4/3 an; dabei ist natürlich Verwendung in getrocknetem Zustand vorausgesetzt. Geringwertiger als Stroh sind Heide und Beerliäuter, am wenigsten beliebt, aber im Notfall doch auch noch begehrt, ist die grobe Ginsterstreu. F u n k e berechnct den Streuwert der Heicle zu 1/1,84, den der Heiclelbeeren zu 1/1,70 des Strohwerts. Uebrigens bestehen große Untersehiede je nach der Stärke der verwendeten Pflanzenteile; denn je größer der Anteil grober verholzter Sprosse, umso geringer ist das Aufsaugungsvernögen und die Zersetzbarkeit der Streu. Ebenso verschieden ist die Einwirkung der hier zu besprechenden Waldflora a u $f$ e $n$ B o d e $\mathbf{n}$; cntscheidend ist auch hiebei das Maß der Trockentorfbildung. P a $m$ a $n$ n befaßt sich (Bodenkunde 1905, S.351 ff. und 1911, S.469) eingehend mit dieser Frage. Hiernach können die F a r u e (vor allem Pteris aquilina, weniger die Aspidium-Arten) im allgemeinen als Bodenschutzpflanzen gelten, immerhin ist Neigung zu Trockentorfbildung vorhanden. Besenginster äußert dem Baden gegenüber keine nachteiligen Eigensehaften, bildet vielmehr cinen wilkommenen Bodenschutz. Ausgesprochene Pohhumusbildner dagegen sind Heidelbeere, PreiBelbeere und Heide. Die absterbenden Kricchtricbe der Heidelbeere gehen unter einem dich te $\mathbf{n}$ P f l a nzenï b e r z u g in Trockentorf über; noch ungünstiger, weil dichter gelagert, ist der Rohhumus der Preißelbeere; an nachteiligsten ist der Heidehumus, der von einem in speckigen Torf übergehenden Wurzelfilz gebildet wird, unter dem die bekannten Bodenerkianliungen, Ortstein usf. auftreten. Wemn meist auch nur Folgeerscheinung vorhandener Hißstände, trägt der Heidetrockentorf doch zur Bodenverschlechterung noch weiter bei.

Vermöge ihres Längenwachstums wirken diese Bodenpflanzen, vor allem Farne und Ginster, weniger die niedrig bleibende Preißelbeere, verdämmend auf die jungen Pflanzen der Schläge und Unterbauungen ein; ihre Schutzwirkung gegen Frost und Hitze fällt meist weniger ins Gewicht als die Wurzelkonkurrenz und die Vorwegnahrne von Licht und Niederschlagsfeuchtigkeit ${ }^{1}$ ).

Die Entfernung dieser Bodenkräuter ist sonach in vielen Fällen durchaus erwünscht und wird zum Teil mit hohen Kosten bewerkstelligt. Wo dies zutrift, ist es natürlich Aufgabe des Forstwirts, für bestmögliche Verwertung dieser Unkräuter Sorge zu tragen. Im übrigen aber gilt auch hier der Grundsatz, daß den ohnehin armen zur Rohhumusbildung neigenten Waldböden nicht auch die letzte Nährstoffquelle, der Humus, entzogen werden darf, daß vielmehr in erster Linie für dessen. ITeberführung in physilialisch günstigere Formen Sorgo getragen werden muB. Eine fortgesetzte Hcide- und Bcerkrantstreu-Nutzung führt allmählich zur gänzlichen Verörlung des Bodens. Streng verpönt ist mit Recht auch die Gewinnung von Heideplaggen, bei welcher die ganze Humusschicht als Streu mit genutzt wird.

\$14. Die Gras nutzung (Futtergras).

Zur Erhöhung der Nebeneinnahmen sowohl als mit Rüchsicht auf den Bedarf der ärmeren viehhaltenden Bevölkerung sollte jeder Graswuchs auf Wegen, Abteilungslinien, Böschungen und sonstigen holzlos bleibenden Waldflächen genutzt werden ${ }^{2}$ ). Bedenken können aber geltend gemacht werden bezüglich der Nutzung des innerhalb der Bcstände sich einstellenden Graswuchses. Unter Lichthölzern be-

1) Besonders der Besenginster macht sich in manehen Gegenden als äuBerst lästiges lïulturunliraut bemerlich ( $\mathrm{F}$ u n $\mathrm{n} e \mathrm{~b}$ a $\mathrm{u} \mathrm{m}, \mathrm{Z}$. f. F. u. J. 1899).

2) Die Grasnutzung auf ständigen Waldwiesen ist als eine selbständige landwirtsclaftlicbe Nutzung hier nieht zu behandeln. Vergl, hierüber $\mathrm{S} t \mathrm{r}$ e cke $r$, Die Kultur der Wiesen, 2. Aufl. 1906 leei Parey; ferner $\mathrm{K}$ ô $\mathrm{n} \mathrm{g}$, Die Pflege der Wiesen und Weiden 1906 bei Parey; $\mathrm{D}$ ü nkel berg, Der Wiesenbau (Braunselmeig 1907). 
sonders auf tonigen und frischen Böden, sehen wir schon im Stangenholzalter allerhand Gräser sich ansiedeln, auf trockenen Lagen die sog. Angergräser; derselbe Vorgang vollzieht sich bei Durchlöcherung des Bestandesschlusses auch in Schattenholzbeständen; in den Schlägen und Kulturen zeigt sich häufig ein sehr üppiger Graswuchs. Zur Verwendung als Futterstoffe eignen sich am besten die bei vollem Licht erwachsenen breitblätterigen Süß-Gräser frischer, nährstoffreicher Böden; die eigentlichen Angergräser (Agrostis und Festuca-Arten) ehenso wie die Sumpf- und Schilfgräser liönnen als Streumaterial genutzt werden, die letztgenamnten bei Vorlommen in größeren Mengen zum Verkauf an Weißputzer. Ueber den Fntterwert der Waldgräser fehlen genauere Angaben; derselbe ist nach Standort, Bestand, Jahreswitterung usf. verschieden; nur soviel steht fest, daß in vielen Gegenden die Grasnutzung von der Bevölkerung selır begehrt ist. Nach G a y e r - II a y r (Forstbenutzung) kann günstigenfalls eine Waldgrasproduktion von ca. $700-900 \mathrm{~kg}$ Heuwert pro ha gerechnet werden. Noch weitere mittelbare Vorteile bietet diese Nebennutzung durch die lechtzeitige Entfernung des in vielen Beständen lästigen Unkrauts; denn wälrend der Vegetationszeit entzieht ein üppiger Graswuchs den jungen Forstpflanzen Licht, Tau- und Regenfeuchtigkeit und erhöht durch seine lebluafte Verdunstung die Spätfrostgefahr; im Winter bieten die verdorrenden Grasfilze den Iäusen willkommenen Unterschlupf und setzen die kleinen Forstpflanzen dem Ersticliungstod aus; im Spätwinter erlöhen sie die Feuersgefahr.

Diesen vorteilhaften Wirkungen der Grasentnahme stehen allerdings auch manche Nachteile entgegen. In einzelnen Lagen schätzt ithan den Grasüberzug als Schutz gegen die sommerliche Hitze ${ }^{1}$ ). Außerdem befürchtet man nicht mit Unrecht Beschädigung der Pflanzen bei Ausübung der Nutzung sowie Erschöpfung und physilialische Verschlechterung des Bodens. Das einfachste Nittel zur Belsebung aller dieser Bedenken ist die Terhinderung oder wenigstens Beschränkung des Graswuchses durch entsprechende waldbauliche Maßnahmen.

Die Verwertung des Waldgrases erfolgt entweder in der Form der Ausstellung ron Erlaubnisscheinen (sog. Einmiete) oder durch Verliauf der Jalıresuutzung vor der Ernte (Aufstreichsverkauf oder freihändige Abgabe). Die erstere Verwertungsart wird meist für das Gras in Kulturen, die letztere für den Grasanfall auf IVegen usf. gewählt. Abgabe des schon ausgeschnittenen Grases liommt wohl nur ganz ausnahmsweise vor. Auf Wegen, Schneisen usf. erfolgt die Grasgewinnung durch Abmälıen mit der Sense oder Sichel; innerhalb der Irulturen ist der Gebrauch der Sense zu verbieten, höchstens die Sichel zuzulassen, läufig wird auch das Ausrujpen mit der Hand zur Bedingung gemacht. Durch entsprechende Torschriften ist der Pflanzenbeschädigung (Abschneiden, Zusammentreten usf.) vorzubeugen.

$\$$ 15. Die $W$ ald weidenutzung.

Literatur: H u ndesh a gen, Waldweide und Waldstreu 1830; F un ke (s. Y. bei $\S 10$ ); 1 ug o w iz, Wald und Weide in den Alpen, Wien 1908; Ferner forstgesehichtliche Werke und die im einzelnen zitierten Aufsätze.

In weiten Gegenden hat diese Art der Futterstoffnutzung heutzutage nur noch historische Bedeutung, nachdem sie sich infolge der intensiveren Ausgestaltung des landwirtschaftlichen Betriehs überlebt hat. Früher war die Waldweide allgemein üblich, ja meist wichtiger als die Ilolzprodulition. Bei der Siedelung wurde der Wald zur Gewinnung von Weideflächen durch Fener zerstört - wie es heute noch in Amerika

1) Daß die Unkräuter in dieser Hinsicht sich je nach Standort und Bestandesbeschaffenheit den Kulturpflanzen gegenuber sehr verschieden verhalten, zeigten die Verhandlungen des Deutschen Forstvereins i. J. 1905 über das Thema, ,Dic Folgen der vorjährigen Dürre" (Bericht S. $79 \mathrm{ff})$. 
und sonsten vorkommt -; almählich liatten sich mit Rücksicht auf die Weidenutzung besondere Waldformen und Betriebsarten herausgebildet, der Plenterwald, der Mittehwal, die Hutewaldungen, die Myteweiden ${ }^{1}$ ), der Kopfholzbetrieb usf.; auch in Hackwaldbetrieb spielt die Weide eine Rolle. In Gebirgsländern hat sich die Weidenutzung noeh erhalten, sie ist aber auch dort durch den freien Entschluß verständiger Grundbesitzer und durch Polizeivorschriften in maßvolle Schranken zurückgedrängt worden ${ }^{2}$ ). Ueberall besteht das Bestreben, die Waldwirtschaft mit der Weidenutzung auszusölinen teils durch lokale Gebietsabscheidung, teils durch Bannlegung bestimmter W'aldteile während des meistgefährdeten Alters. In solehen Gegenden, die aussehließlich auf Tiehzucht ohne Getreidebau angewiesen sind, hat. der Forstwirt als ,Alpenliultivator" geradezu die Aufgabe, für geregelten und ungestörten Weidebetrieb mit Sorge zu tragen (Lawinenverbauung, Schutzwaldwirtschaft usf.). Anderwärts wird vom Tieheintrieb in die Waldungen nur noels als Notbehelf Gebrauch gemacht, z. B. in Dürrjahren, zugunsten angesiedelter Waldarbeiter, ärmerer Revierinsassen u. dgl. ${ }^{3}$ ); auch als Bereclitigung hat sich der Weidegang noch da und dort erhalten; für Gemeinde- und namentlich Bauernwaldungen spielt diese Nebennutzung unter ärmeren Bodenverhältnissen und parzelliertem Kleinbesitz noch immer eine wichtige Rolle.

Genaue Angaben über den Weideertrag der Waldungen stehen nicht zu Gebot. Die Jenge und Nährkraft des Graswuchses ist verschieden nach Standort, Lichtgrad, Jahreszeit und Jahreswitterung. Vergl. (\$ 14). Im rauheren Kilima drängt sich die Weicleausübung auf kurze Zeit zusammen; der Juni gilt im großen ganzen als die beste Weidezeit. Während das Gras im Genuß vollen Sonnenlichts üppiges Wachstum und höchsten Nährgehalt aufzuweisen hat, sind die Triebe in gedämpften Licht (Nytwälder, Lärchen-Bestände) zarter und dem Weidevieh belömmlicher; auch bietet sich im Bestand Schutz gegen raule Winde.

Den Wert der Waldweide drückt F u n k e (а. a. O. S. 5) aus durch den ,, Süttigungseffelit", den ,relativen" und den ,absoluten Nähreffelit". Unter ersterem Begriff versteht er die zur vollen Sättigung eines bestimnten Lebendgewichts in 1 Tag erforderliche Menge Trockensubstanz, bezogen auf nittleres Wiesenheu ${ }^{4}$ ); Der zweite Begriff bezeichnet die Nahrhaftigkeit eines bestimmten Quantums Weidefutter, verglichen mit derselben Nenge Wiesenheu. Fu n k e schätzt sie auf $2 / 3-1 / 1$ des Wiesenheus, je nach Lichtgrad usf. Der , absolute Nähreffelit" bildet das Produlit der beiden Vergleichsgrößen. Für die Höhe des Pachtgelclertrags, der meist pro Stüch der verschiedenen Viehgattungen und Altersstufen ausgedrückt wird, ist außerdem noch die Entfernung rer Weide vom Wirtschaftshof maßgebend.

Um die Bedeutung des Weidegangs für die $\mathrm{W}$ a I $\mathrm{d}$ wir $\mathrm{t} s \mathrm{c}$ h a $\mathrm{ft}$ darzutun, sind die schädigenden Folgen derselben zu besprechen; Schaden richten das Maul und der Tritt les Weideviehs an: wälrend Schafe und erwachsenes Hornvieh im allgemeinen nur bei Nahrungsmangel die Pflanzen angehen, richtet das Jungvieh und noch weit mehr die Ziege durch Verbeißen erheblichen Scluarlen an; in den Nittelmeerländern ist dem planlosen Weidegang die Entwaldung ganzer Landstriche zu verdanken; vor der Ziege ist keine Holzart, kein noch so steiler oder hoch gelegener

1) V'ergl, hierüber Sthw, Z. 1907, S. 359.

2) S. Geschichle der Oesterrcichischen Forstwirtschaft in der Jubiläumsfes]schift 1898 bis 1902; ferner C i s l a r s Bericht über schweizerisehe Alpenländer i. Z. f. d. g. F. 1910, S. 120; Sc he n c k s Bericht aus Amerika i. d. Suppl. 11. d. A. F. U. J. Z. 1910, S. 131; ebenda S. 119 Vit torios Bericht aus Italien.

3) Vergl. H a g e n-Donner (a. a. O.) S. 70.

4) 1,5-2 $\mathrm{kg}$ Heu auf $100 \mathrm{~kg}$ Lebendgewicht pro Tag. 
Waldteil sicher. Am meisten gefïhrdel sind von den Laubholzarten Esche, Ahorn, Linde, Hainbuche, weniger Eiclıe, Erle, Birke, von den Nadelhülzern am ueisten die Tamme und Lärche. Rindvicls und Pferde schaden ferner durch Untrelen der jungen Pflanzen, durch W'urzelverletzung, was besonders der Fichte verhängnisvoll wird, durch Benagen der Rinde und nicht zuletzt durch Schädigung des Bodens, nämlich durch Abtreten der humosen Schicht an Hang und durch Zerstörung der Krünelstruktur.

Dagegen gewährt der Weidegang dem Wald in manchen Fällen auch gewisse V o r t e il e, so vor allem durch Beseitigung schädlichen Unkrauts und als Maßregel gegen Mäuseschaden; der Schafeintrieb soll speziell auch gegen den Rüsselliäfer helfen. Der Vollständigkeit halber ist noch zu erwähnen, daß der Schweinceintrieb, (der streng genommen nicht hicher, sondem in den Abschnitt über Samemnutzung gehört), neuerdings wieder ganz besonders als Mittel zur Rohhumuslockerung und zur Unterstützung der natürlichen Verjüngung empfohlen wird, auch zur Vernichtung der im Boden überwinternden Eulen-, Spanner- und Blattwesj-Rauper. Nur schade, daß die erforderlichen Schweineherden nieht überall zu haben sind! Als Naßnahme gegen jene Inseliten wäre in diesem Zusammenhang auch noch der Eintrieb von Hühnern ${ }^{1}$ ) in Nadelholzbestände zu erwähnen.

Wo die Waldweide aus volkswirtschaftlichen Gründen oder mit Rücksicht auf die besonderen Interessen des Waldbesitzers oder der Waldbevöllierung nicht zu umgelien ist, sollte sie nur unter solchen Bedingungen zugelassen werden, welche die oben genannten Schädigungen möglichst ausschließen. Die meistgefährdeten Bestände sind zu verbieten und jedenfalls nur solche Kulturen für erwachsenes Hornvieh zu öffnen, die reichlich Gras bieter, und zwar am ehesten noch im Juli, zu welcher Zeit das Gras am nälırstoffreichsten ist, die jungen Holztriebe aber nicht mehr besonders begelırenswert sind. An Hängen und bei nassem Wetter (jedenfalls auf strengen Böden) ist der Weidegang zu untersagen. Endlich muß die Höchstzahl des einzutreibenden Weideviehs festgelegt und die Aufstellung zuverlässiger Hirten, womöglich eines besonderen für jede Viehgattung zur Bedingung gemacht werden. Wo der Weidegang im großen üblich ist, empfiehlt es sich, einen besonderen Weidenutzungsplan aufzustellen.

\$16. Die Nutzungsonstiger wild wachsender Pflanzen.

a) Die Se e grasnutzun $\mathrm{g}^{2}$ ). Sie verdient gesonderte Besprechung, da sie in einzelnen Gegenden, so namentlich im badischen und württembergischen Oberland, im bayrischen Schwaben und in Oberösterreich eine sehr ergiebige Nebeneinnahme darstellt und der ansässigen Bevölkerung reichlich Arbeit und Verdienst bietet.

Das Seegras (carex brizoides) konml in allgemeinen nur auf feuchlen Böden und in niederschlagsreichen Gebieten vor; in Mittelwaldheständen und durchlöcherten Fichten-Althölzern stellt es sich mit Vorliebe ein, un dann jahrelang in den Schlaggen auszuhalten, bis es allmählich von der jungen Waldgeneration wieder verdrăngt wird. Kalıfflächensepgras ist an sich ertragsreicher und wertvoller, aber mehr der Vernichtung durch Spätröste ausgesetzt als das in Schutz des Altholzes stockende. 1 Hektar Altholz-bezw. Kulturfläche vermag je nach Boden- und Bestandesverhältnissen alljährlich 10-75 Ztr. luft trockenes seegras hervorzubringen. Bei guter Ernte werden mit Secgrasrupfen, -Trocknen, -spinnen usf. zalıtrejelue Arbeitskrāfte, meist Kinder und Frauen, beschäligt. Die Erträge sind zum Teil so hoch, daß die Kulturkosten für Fichlenpflanzungen annälıernd gedeckt werden kōnnen. Für 1 Ztr. Trockengewicht kann der Käufer etwa 1 Mk. 50 Pfg. bieten. Das Jahreserzeugnis wirl meist im Juni auf dem Stock verkauft, wenn sich die Erträge anuăhernd beurleilen lassen; nasse Somner

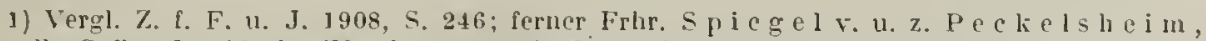
Rationclle Geflügelzucht etc. (Neudamm 1909); d e r. s. i. Z. f. F. u. J. 1903, S. 146.

2) Eingeliend besprochen von Dr. Rebel und Dr. Gossner in der Nat. Z. f. L. u. F. 1907 , S. 249 .

Handb. d. Forstwiss. 3. Auf. II. 
künnen aber den Ertrag noch bedeutend schmālern. Yerarbeitet wird das Seegras zu Geflechten aller Art, zu Läufern, Vorlagen, Seilen usf.

Wegen seiner verdămmenden und in besonders hohem llaß froststeigernden Wirkung empfiehlt sich die Entfernung aus den jungen Saat- und Pflanzbeständen; die Nutzung steht insofern mil den waldbaulichen Rücksichten in Einklang. Bei fortgesetzler Seegrasnutzung - und eine solche läßt sich je nach Art der Wirtschaft his zu 20 ja 30 Jahren in demselben Besland alljāhrlich erheben - wird aber doch eine recht erhebliche llenge von Nährstoffen, besonders Kali, dem Boden entzogen; langdauernde Nutzung lat auch Bodenverdichtung und - Verhärtung zur Folge. Es fragt sich, ob hierdurch nicht ein Nachlassen des Holzzuwachses und weitergehende Schädigungen (Rotfäule) veranlaßt werden. Goss ne v vergleicht die Seegrasnutzung nit der Streuentnahme und berechnet, daß sie bezüglich Nährstoffentzugs einer intensiven Streunutzung gleich zu achten sei. Dabei wird allerdings betont, daß dieses Gewächs überliaupt nur auf guten Böden vorkomnt.

Es wird also auch hier der Ausweg zu empfehlen sein, daß man sich die Einnahme aus dieser Nebennutzung zwar nicht entgehen läßt, aber zugleich durch waldbauliche Maßnahmen (natürliche Verjüngung, Kkleinflächenwirtschaft mit kurzer Verjüngungsdauer) den Seegraswuchs auf möglichst kurze Zeit einzuschränken versucht.

b) Beeren-1) und Pilznutzung.

Die W a $1 \mathrm{~d}$ b e e re $n$ stellen ein sehr geschälztes, alljährlich in beträchtliclien IIengen zu barkt gebrachtes Nahrungs- und Genußmitlel dar. Die wichligeren und in größeren Mengen nutzharen Beeren sind die Erdbeere (Fragaria vesca), die Brombeere (Rubus fruticosus), dic Himbeere (Rubus idaeus), die Heidel- (Vaccinium myrtillus) und die Preißelbeere (Vaccinium vitis ldaea). Ueber den Wert der Beeren-Ernten sind schon wiederholt Schălzungen angestellt worden, so berechnet der preuBische Oberförster $H$ u $\left(t\right.$ e r o $t^{2}$ ) den Wert des in preuBischen Staatsforsten alljährlich genutzten Beerenanfalls zu 15-33 Millionen Mark; von anderer Seite wird er zu 20 Mlillionen veransehlagt.

Es sind also recht hohe Werte, die, ohne dem Waldbesitzer einen nennenswerten Gewinn abzuwerfen, alljährlich aus dem Wald bezogen werden. Dabei darf man nicht übersehen, daß diese Erzeugnisse erst dureh die Emte überhaupt einen Tauschwert erlangen. Während aber die uncntgelliche oder doch nur mit ganz niedriger Zetlelgebühr belegte Ueberlassnng der Beerenernte an die Bevölkerung als Entgegenkommen gegen die ,schwachen Schultern" vom Waldbesitzer gedacht ist, kommt sie mehr den kapitalistischen Internehmern zugute (den Aufkäufern und Händern scheint ein recht erklecklicher Gewinn zu verbleiben). Es wurde auch darauf aufmerksam gemacht, daß durch die Beerenernte der Landwirtschaft wertyolle Irbeitskläfle zu einer Zeit entzogen werden, wo sie am dringendsten erforderlich sind und für das Allgemeinwohl viel ersprießlichere Dienste leisten kōnnten. Lnter diesen Gesichtspunkten wurden schon verschiedentlich Vorschläge ${ }^{3}$ ) zur Regelung der Beerenmulzung gemacht, dic einerseits dem Waldbesitzer einen billigen Anteil an dem Ertrag der Nutzung zusichern, andererseits die Beschäftigung voll arbeitsfäliger Männer mit Beerensammeln hintanzulalten suchten; es sollen gegen tarifmäßige Gebühren Erlaubnisscheine zum Sammeln iıı großen und für den Verkauf von den Forstbehörden ausgestellt werden mit der Beringung, daß nur Finder, Framen und Invaliden hierson Gebrateh machen dürfen. Die Beschränkung der Beerennulzung ist freilich - zumal für den Staat als Waldbesitzer - eine heikle Sache, da im Volksbewußtsein diese frei von der Natur gebolenen Früchte als Geneingut angesehen werden und vielfach langjährige Ausübung als Rechtsgrund gellend gemacht wird. Aber tatsächlich sind in manchen Verwaltungen ziemlich holıe Gebühren (bis zu $7 \mathrm{Mk}$. pro Zettel) eingeführt; die Ansetzung von Gebühren dürfte auch schon deshalb gerechtfertigt sein, weil dem Waldbesitzer bei großem Beerenanfall während der Erntezeit durcl erhöhte Inanspuchelnalıne des Schulzyersonals und durch allerhand Forstbeschädigungen Josten und Nachteile erwachsen. Verhinderung oder Beschränkung des Aufkommens der Beeren durch waldwauliche Maßregeln wäre natürlich wiederum das radikalste Abhilfemittel.

Auch die Nutzung der im Wald vorkommenden e $\beta$ b a $\mathrm{r}$ e $\mathrm{P}$ iJ z e hat weniger Bedeutung für den Waldbesitzer selbst als für die unwohnende Bevölkerung. populäre Schriften $\left.{ }^{4}\right)$ suchen das Verständnis für diese unentgellichen und, wenn gut zuhereitel, delikaten

1) Unsere Beerengewächse, von Dr. P l ï B, 2. Aufl. (Basel-Freiburg 1908).

2) Bericlıl üher die 36. Vers. d. Preuß. F. T. in Stargard 1908, S. 35 ff.

3) Z. f. F. 1. J. 1909 , S. 49 ; 1906, S. 109 ; D. F.-Z. 1909 S. 31, 1906, S. 336, 1905. S. 188; ferner Bayr. 1*. 11. J. Z. 1909, Nr.11 (Erhöhung der Gebühren); Verhandlungen des Pommerschen jorstwereins 1901.

4) Dr J. R ö]l, Unsere eßbaren Pilze in natürlicher Größe mit Angaben ihrer Zubereitung, 7. Aufl. 1908 (bé L a u p p in Tïbingen); Taschenbuch der wichtigeren eßbaren und giftigen Pilze Deutsch]ands, Oesterrcichs und der Schweiz von P. Sydow (Heidelberg bei W in $\mathbf{t}$ e $r$ ); Cleff, Taschenbucl der Pilze (Eßlingen bei Sc hreiber). 
Nahrungsuittel in weitern Kroisen zu verbreiten. Dir bekanntesten unl begehriesten eßlaren schwimme sind Champiguon (Agaricus deliciosus) und Sleinpilz (Bolelus edulis); in der forstlichen Literalur ") finden sich weiterhin Berichte uber die künslliche Aufucht noch anderer guter Speisepilze, so der Vußkralerelle (Cralerellus nucleatus) und des Rustenschwanmes (Pleurolus cornucopioides); II a y 1 versuchle die Einburgerung eines in Japan sehr beliebten pilzes, des Schitake: auch die Speisemorcheln sind noch zu nennen. Fregenstand gewerbsmäBiger Züclılung und kaufmännischer Verwertung seilens des Waldbesizers sind endlich in einzelnen Laublolzgebielen (Pfalz, Baden, Braunselweig, Elsaß-Lolliringen, vor allem aber in Frankreich), die T $\mathbf{r}$ ü f el $\mathbf{n}$, deren wertvollste Art, der Perigord-Trüfel (Tuber melanosporum) aus Frankreich stamml. Die Trüfelzucht erfolgt dureh künslliche Murzelinfelition; beim Aufsuchen bedient man sich abgerichteler Hunde und Schweine. Bei dem hohen l'reis dieser Delikatesse lohnt es sich, im milden Kilima Versuche damit anzustellen ${ }^{2}$ ).

Die ahrigen Pilze werden meist der freien Aneignung überlassen; regenüber gewerbsmăßigen Sammlern kōnnten ăhnliche Maßnahmen wie bei der Beerennulzung in Frage kommen.

Endlich ist der Vollständigkeit halber noeh zu erwähnen das Sammeln offizineller liräuler und die Abgabe seliener Pflanzen (z. B. Orehideen, Stechpalmen elc.) an Gärlner und Pflanzenzüchler gegen Entrichlung einer angemessenen Gebühr.

\$17. Der Wald feld bau.

Literalur: C ol 1 a , Die V'erbindung des Feldhaus mil dem Walduau; H u $\mathrm{n}$ e s h a $\mathrm{g}$ e $\mathbf{n}$, Prüfung der Colt a sehen Baumfeldwirlschaft; $v$. K l i p s $t$ e i n, Der Waldfeldbau 1850; B e r nh a rdt, Haubergswirtschaft in lireise Siegen 1867; Strobecker, Die Hackwaldwirt-

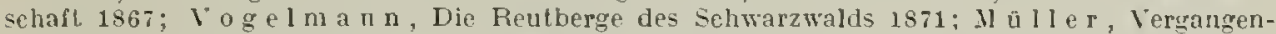
heil, Gegenwart und Zuliunft der Hauberge im Dillkreise (7. f F. 11. J. 1905, S. 96).

11 essely, Die österreichischen Alpenländer und ihre Forsle; mehrere Aufsãlze von Il u h l (A. F. u. J. Z. 1869, S. 121, 1875 S. 369 ; Referat bei der Forstversammlung zu Darmsladt 1886 , A. F. 1. J. Z. 1886, S. 365). Besonders ausführlich in H e y e r s Waldbau, 4. und 5. Aufl. Forstversammlungen in Biberach 1884, Wolfach 1898, Herborn 1901, früher in Poisdam 1839, Brünn 1840, Darnstadt 1845, Freiburg 1846, Mlainz 1849, Stuttgart 1855, Heidelberg 1860.

Zur Orientierung über rein landwirtscliaftslechnische Fragen kann verwiesen werden auf Se hlip f, Populäres Handbuch der Landwirtsehaft, 15. Aufl. (1905); P r o b s $t$, Handbuch

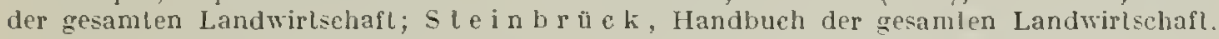

Unter ,Waldfeldbau“ vcrsteht maı die planmäßige Erzengung und Nutzung landwirtschaftlicher Gewächse, vor allem Kartoffeln und Halmfrüchte, auf der Holzbodenfläche entweder zwisclien den Forstpflanzen (Anbau zugleich mit diesen) oder auf der kahlen Waldfläche bei kurzer Unterbrechung der Waldkultur unmittelbar nach Abtrieb des Bestandes. Ein wesentliches Merkmal des Waldfeldbaus war von Haus aus das sog. Hainen, d. i. die Verbrennung des zurückbleibenden Reisigs und Unkrauts und Vermischung der Asche mit dem Boden; erst der sog. , neuere Waldfeldbaubctrieb" (n. H e y e rs Bezcichnung), der von Hessen ausging, hat von dieser Iaßnahme Abstand genommen.

Die Geschichte dicser Nebennutzung wird meist an die ursprüngliche Brandkultur angeknüpft, an die sog. ,wilde Brand- und Feldwaldwirtschaft", die sich als Uebergangsstufe rom Hirten- und Nornadenleben zum geregelten Ackerbau in der Siedelungsgeschichte fast aller Länder und Erdteile darstellt. Zur Begründung dieses Zusammenhangs weist man mit Recht auf Worte wie ,Motten“, ,Reutfeld" u. ä. hin, die sowohl im Sprachgebrauch des Waldfeldbaues wie in Geländenamcn für alte Rodungen vorkommen. Mag sein, daß der geregelte Waldfeldbetricb, so wie er heutzutage in einzelnen Gegenden (Siegener Land, Odenwald, Schwarzwald u. a. a. O.) in Uebung stcht, unmittelbar bis auf jene niederste Stufe der Agrarwirtschaft zurückreicht. A $\mathrm{ch}$ e $\mathrm{n} \mathrm{b}$ a $\mathrm{c} \mathrm{h}^{3}$ ) wenigstens glaubt in der Haubergswirtschaft des Siegener Lands das unmittelbar durch ständigen Gebrauch überkommene Erbe germanischer Vorzeit zu sehen. Vielfach aber wird es als cin bcwußter oder unbewußter Rückfal\} in alte Gebräuche unter dem Druck ungünstiger Wirtschaftsverhältnissc anzusehen sein. Wälırend der Haubergsbetrieb schon Ende des I5. Jahrhunderts durchaus ge-

1) V'ergl. J a n k a, C. f. d. g. F. 1909, S. 415.

2) Vergl. Berichl d. Thür. F.-V. 1905, ferner Aufs. V. Villi. Nat. Z. f. F.u. L. 1912, S. 321 ff.

3) Die Haubergs-Genossenschaften des Sieger-Lands, 1863. 
regelt in genossenschaftlicher Verfassung betrieben wurde, mußten manche Forstordnungen des 16, 17, ja 18. Jahrhunderts noch gegen den Unfug wilden Raubhaus auf gerodeter Fläche sich wenden, da es vorkam, ,daß einige das Land, wenn sie es einige Jahre gebaut und die Geilung herausgezogen haben, wieder liegen lassen "I). Daßs cine planmäßige. durch gesetzhche Vorschriften oder forsttechnische Anweisungen geregelte vorübergehende landwirtschaftliche Benutzung des Waldbodens im 18. Jahrhundert vielfach geübt wurde, geht aus zahlreichen geschichtliehen Leberlieferungen $\left.{ }^{2}\right)$ hervor; als Entgelt war ein Geldzins orler ein Zehnten zu entrichten, vielfach war auch die Wiederaufforstung von dem Pächter zu besorgen. Dabei trat auch sehon der Gesichtspunkt hervor, daß die landwirtsehaftliehe Vornutzung eine Förderung der Waldiultur, eine leichte, sichere und wohlfeile Art der Wiederbestokkung zu bedenten habe. In Vordergrund des Interesses stand aber die Deckung des Bedarfs an Nalıungsmilteln, wofür die besehränkte Feldmarkung in manchen W'Taldgebirgsgegenden häufig nicht ausreichte. In 19. Jahrhundert kam der Waldfeldbau in größerem Linfang zur Einführung, und zwar speziell als Waldkulturmittel, besonders auch in solchen Gegenden, wo eine zahheiche Bevölkerung mit nul geringem Grundbesitz vorhanden war. Es dürfte übrigens keine zufällige Erscheinung sein, daß der Waldfeldhan etwa zugleich mit dem Umsichgreifen des Ii a h l se hl a gbetriebs in weiteren Kreisen Eingang gefunden hat. Verständige Forstwirte wollten mit dem landwirtschaftlichen Vor- und Zwischenlsau wohl in erster Linie den besonderen Nachteilen jener Betriebsart begegnen, vor allen der für die verhältnismäßig armen Waldböden so schädlichen Brache. Die Bedeutung. welche dem Waldfeldbau im 19. Jahrhundert zukam, geht aus den folgenden Zahlen hervol:

Il u h 1 schătzte in Jahre 1886 allon die lurch Waldfeldbetrieb in Beslockung gebrachten Hochwald f lä che n zu 30000 ha ${ }^{3}$ ). Danehen stand diese Virtschaftsform in Vurbin-

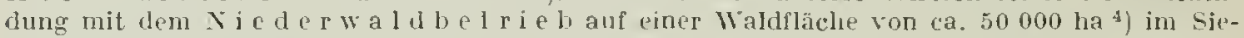
gener-Land als Haubergswirtschaft, auf $58000^{5}$ h ha sog. Reutbergen in Baden, und auf ea. 25000 ha $^{6}$ ) Hackwald im Odenwald in Uehung. Die Reichsslatistik i) von 1883, 1893 mud 1900 gibt als Wallfelder-Fläche an: 18981 bezw. 21468 bezw. 9861 ha; diese ZahIen sind aber wegen ungleicher Aufnahmegrundsătze nicht vergleichbar.

Aus dem bisher Gesagten geht schon hervor, daß der Waldfeldbau alhmählich verschiedenartige Ausprägungen erhalten hatte, je nachden er im Niederwald oder Hochwald (Röderdandbetrieb), als Vor-oder Zwischennutzung, mit oder ohne Hainen betrieben wurde; daneben kamen Zwisehenformen vor, z. B. Tor- und Zwisclienbau; eine weitere Verschiedenheit ergab sich dureh die Art der angebauten Gewächse. die Reihenfolge und Dauel des Anbaus. Vom mehrjährigen Anbau kam man mehr und mehr wieder ab und ging zum 2-, ja zuletzt ljährigen Betrieb über. Neben dieser zeitlichen Einschränkung hat der Waldfeldbaubetrieb neuerdings vielfach gänzliche Einstellung erfahren; der Mangel an Arbeitskiäften auf dem Land, der schon die Bebaung der Felder erschwert, hat ilım bedeutenden Abbruch getan, um in den forstwirtschaftlichen Kreisen ist die einst vorhandene Begeistemng fül diese $\mathrm{Be}-$ trielısform allmählich verraucht.

1) M os e r, Forstökonomie, 2. Teil, Beilagen S. 108.

2) Eidgenössiche Abschiede $7,1,7,2 ; \mathrm{St}$ a hls Forstmagazin 4,$119 ; \mathrm{B}$ u l.g $\mathrm{s}$ d or f , Forsthandbuch 1788, S. $543 ; s$ p e i d e 1 , A. F. U. J. Z. 1888, S. 277.

3) A. F. U. J. Z. 1886, S. 310 .

4) H a $g$ e $n-D$ o $n$ e $r$. Die forstl. Verhältnisse Preußens, S. 27.

5) Das Großherzogtum Baden, S, 416.

6) Mitt. a. d. Forsl- u. Kam.-Verw d. Großherzogtums Hessen 1886, \$. 310.

7) Monatshefle d. Stat. d. D. R. 1884 Heft VIII, Vierteljahrshefte 1894,4 . Hefl, Vierleljahrshefte Elgínzungsheft zu 1903, II. 
Auch der Hackwald- und Hauhergsbetrieb hat, zunächst infolge des Fiaskos der Eichensehäwallwirtschaft, leilweise auch infolge Vermagerung der Waldböden an Geläıde verloren. Endlich dürfte die rückläufige Bewegung, in der sich heutzntage die Kahlschlagwirtschaft befindet, diesen Wandel ler Dinge bis zu einen gewissen Grad mit veranlaßt haben ${ }^{1}$ ). Dafür ist dle landwirtschaftliche Zwischennutzung als sozialpolitische Maßnatume in das Programm der Waldarbeiterfrage aufgenommen wurlen; zur Erlialtung und Ansiedelung ständiger Waldarbeiter in großen, zusammenhängenden Waldgebieten soll Gelegenheit zum Anbau von Kätoffeln und Getreide gegehen werlen; dieser selu beachtenwerte Vorschlag dürfte aber in allgemeinen zweckmäßiger dureh Ausstockung geeigneter Waldflächen zu betätigen sein. Dagegen öfnet sich dem landwirtschaftlichen For- und Zwischenbau ein weites Feld im Gebiet der Heide-, Ried-und Oedlandaufforstung, wo er - vorausgesetzt, daß Arbeitskräfte zur Verfügung stehen und die Emteerzeugnisse nicht mit $2 u$ hohen Beifulnkosten belastet werden - in Verbind ung m it Bodenbearbejtung und D ̈̈ngung als wertrolle Bestockungshilfe und als Gelegenheit zur Erleichterung des Kulturaufwands schätzbare Dienste zu leisten verspricht. Mustergüllig sind in dieser Hinsicht die Aufforstungsversuche in der belgisclien Kampine ${ }^{2}$ ).

Aus den bisherigen Ausfülıungen erhellt, daß dev. Walufeldbau nicht eigentlich mehr als forstliche Nebennutzung, viehmehr fast ausschließlich als Kulturmaßregel, empfohlen werden kasn, abgesehen von örtlichen Gebräuchen, welche auf einer engen Verbindung von Feld- und Waliwirtseliaft beruhen, wie z. B. bei der Siegener Haubergswirtschaft. Wie Erträge des W a ldfeld ba us sind ohnehin vielfacl ganz oder zum überwiegenden Teil als $\mathrm{H}$ ol ze r träg $\mathrm{c}$ anzusehen, wenigstens dort, wo mit dem Waldfeldpacht die Stockholznutzung verbunden ist ${ }^{3}$ ); im württembergischen Oberschwaben geht der Pachtertrag in manchen Waldteilen uberhaupt nicht, im großen Durchschnitt nur sehr wenig über den Vert des Stockholzes hinaus; in geringeren und weiter abgelegenen Waldteilen zeigen sich kaum Liebhaber zur Lebernahme der Waldfeldlose ${ }^{*}$ ). Der Bodenpacht bezw. dic Entschädigung für den Entgangr an Jahreszuwachs ist somit sehr knapp bemessen, es müssen also wohl waldbauliche Rüchsichten zur Beibehaltung maßgebend sein. Speziell die Kartoffelerträge sollen zwar wedel an Nenge noch an Güte den auf Aclierland gebauten nachstehen, auch die Halmfruchternte wird bei nur 1-2jähr. Nutzung den Felderträgen amnähern! gleich geschätzt. Neuere Geld-Ertragsangaben ${ }^{5}$ ) stehen nur in beschränktem Umfang zu Gebot und die älteren sind für heutige Lohn- und Preisverhältnisse nicht mehr zutreffend.

Es erübrigt noch, die Einwirkung des Waldfeldbaus auf den Bodenzustand und das Bestandeswachstum liurz zu erörtern. Daß dem Wallboden durch die Ernten erhebliche Nährstoffmengen entzogen werden, läßt sich durch die Aschenanalysen nachweisen. Diese Tatsache ist aber an sich noch ziemlich belanglos, wenn man bedenkt, daß die jungen Waldpflanzen dieselben bezw. (an Kalk) noch mehr Nährstoffmengen dem Boden entziehen. Der möglichen Beraubung des Bodens steht entgegen die pliysikalische Besserung des Obergrunds durch das Hacken oder die sonstige

1) Selbst in Hessen, den ehemaligen Dorado des Waldfeldbaus, ist man in letzter Zeit mehr und mehr lavon abgekonmen (vergl. H e ye r, Wajdbau, 5. Aufl. $\checkmark$. H E B).

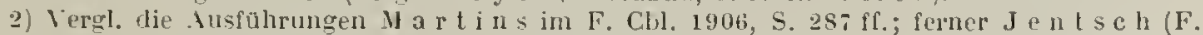

Cbl. 1901, S. 225; L ent (D. F. Z. 1902, Bd. 17).

3) Virrerl. li ó hle r, A. F. U. J. Z. 1898, S. 117.

4) Vach dieshezüglichen privaten Jitteilungen und eigener Erfalırung.

5) Vergl. H $\mathrm{y} \in \mathrm{r}$ a. a. O. 
Bodenbearbeitung ror dem landwirtschaftlichen Anbau. Hierdurch wird eine Vermischung der Humusstoffe mit den mineralischen Boden, eine Steigerung der IVasserliapazität infolge verringerter Kapillarverdunstung und als weitere Folge bessere Aufschließung vorher unlöslicher Verbindungen im Boden (mit Ausnahme der Phosphorsäure) veranlaßt. Außerdem ist zu bedenken, daß an Stelle der landwirtschaftlichen Gewächse inzwischen auch die Unkräuter dem Boden Nährstoffe entzogen und Niederschlagsfeuchtigkeit vorenthalten hätten. $\mathrm{R}$ a $\mathrm{m}$ a $\mathrm{n} \mathrm{n}^{1}$ ) kommt auf Grund spezieller Untersuchungen zu dem Schluß, rlaß lei lesseren Bodenarten eine Erschöpfung nicht anzunehmen sei, d. h. auf solchen, die unter natürlichen Verhältnissen reichlich saftige Gräser tragen. Wenn im Niederwaldbetrieb bei zu häufig wiederkelırenuler landwirtschaftlicher Benutzung einzehe Flächen in ihrem Ertrag geschädigt worden seien, so schließe das den Wert des landwirtschaftlichen Zwischenbaus für viele forstliche Iiulturzweclie nicht aus. Wie Beschränkung des Waldfeldbaus a u f bessere Böden wird im allgemeinen als Grundsatz von den Forstverwaltungen aufgestellt ${ }^{2}$ ). Aus Furcht vor Borlenerschöpfung haben sich schon viele Forstwirte - allerdings olne genaue Bodenuntersuchungen angestellt zu haben der landwirtschaftlichen Zwischennutzung gegenüber überhaupt ablehnend verhalten; Kö h l e r macht vor allem auch auf physikalische Schädigungen aufmerksam, die nach seinen Erfahrungen sonst gute Waldböden bei 2maliger Benutzung erlitten haben, auf die Zerstörung der lírümelstrulitur infolge der meist ungenügenden Bodenbearbeitung zumal beim Anbau von liörnerfrüchten. In der neuesten Auflage des $\mathrm{H}$ e y e rschen Waldbaus ferner wird auf vergleichende Düngungsversuche Bezug genommen, welche 1893-1900 in hessischen Waldfeldern vorgenommen worden seien; daraus habe man die Ueberzeugung gewonnen, daß der Holzboden durch den Anbau von Feldfüchten, insbesondere durch mehrjährigen, in vielen Fällen zu sehr erschöpft werde. Gleichzeitig wird aber aus der Oberförsterei Eberstalt berichtet, daß selbst auf den dortigen geringen Sandböden das Wachstum der Holzpflanzen bei einmaligem Kartoffelbau nicht beeinträchtigt wurde. Alle Bedenken linsichtlich Bodenerschöpfung werden natürlich zerstreut, wenn beim Waldfeldbaubetrieb ein zweckmäßiger Dünger zur Anwendung gelangt (Lupine und Misseraldünger) ${ }^{3}$ ). Es wird sich aber fragen, ob der Betrieb dann noch lohnend ist. Ton den Gegnern des Waldfeldbaus wird auch das Eintreffen der sonst geltend gemachten Vorteile, vor allem des Schutzes der Kinltur gegen Unkraut, in Abrede gezogen, vielmelır sogar die Zunahme mancher Forstschädigungen festgestellt, so des Barfrosts, der Engerlingsplage, der Rotfäule nsf. Eine Schutzwirking für die jungen Pflanzen kann ïberhaupt nur den Z w is c h e $n$ b a u zugut geschrieben werden ${ }^{4}$ ) (z. B. die Haferschutzsaaten). In t r o c k e u e n Sommern wird del Schutz gegen Hitze durch den Wasserentzug der Halmfrucht melir als ausgeglichen.

Ueber den Einfluf des Waldfeldbaubetriebs auf das B es t a ndes wa h st u m liegen keine wissenschaftlich cinwandfreien Messungen vor; man konnte günstige Zuwachsverhältnisse auf ehemaligen Waldfeldern feststellen, alıer vollgültige Beweise für W'Tchsförderung sind nicht erbracht worden, ebensowenig für gegen-

1) Z. f. F. U. J. 1890, S. 655 (Chernisch-physikalische Untersuchungen über Waldfeldbau).

2) Vergl. die Ausführungen in Hagen-Donner $\$ .70$ ff.; auch für die österreichischen Staatswaldungen gilt dieser Grundsalz (s. Geschichte der öslerreich. Forstwirtschaft, Festschrift 1898 lis 1902 ).

3) Vergl. I] a r t in a. a. O. und L e n t a. a. O.

4) Vergl. Va u na n n, Ueber den Ambau des Waldkorns (Johannisstaudenroggen), das zugleich als Schutzsaat und als Acsungsgelegenheit füs Wild gedacht ist (Thar. f. J. 1905, S. 130); ferner $S \mathrm{c}$ h ü $\mathrm{p}$ f e r im $F$. Cibl. 1908, S. 259 über, die Haferschutzsaaten als Pflanzenaufzuchtslätten". 
teilige Einwirkungen, wenngleich solche in manchen Fällen vermutet werden können.

Yom waldbaulichen Standpunkt ist gegen den Waldfeldbau mit Recht auch geltend gemacht worden, daß er der ganzen Wirtschaft eine gewisse Unfreiheit auferlege, sie an einzelne Ilolzarten (Fichte, Eiche, Kiefer) binde und der Erziehung von Mischbeständen entgegenstehe. Wer das Kleinflächenprinzip vertritt und die Bestandesverjüngung unter dem Schutz des Altholzes grundsätzlich durchgeführt wissen will, muß den Waldfeldbau als lästige Nebennutzung über Bord werfen, hezw. er braucht sich dieses Notbehelfs gar nicht zu bedienen. In einzelnen Fällen, so namentlich zur Durchführung der oben angedeuteten Kulturaufgabon, wird diese Betriebsform immerhin noch mit Vorteil zur Anwendung gelangen liönnen.

\section{Mineralisehe Nebennutzungen.}

$\S$ IS. Wo der Waldboden techmisch wertvolle Steine und Erden birgt, die durch Tagbau gewommen werden können, ist der forstwirtschaftliche Betrieb nicht mehr die rentabelste Art der Bodenbenutzung, zumal auf solchen Böden meist nur geringe Bestände stocken. Nur die Rücksicht auf die landschaftliche und allgemein volliswirtschaftliche Bedeutung der Wälder wird in einzelnen Fällen gegen den Abbau geltend gemacht werden können. Die Gewinnung von Steinen und Erden im großen - z. B. Bausteine, Pflastersteine, Schiefer, Kies, Zementmergel, Sand, Lehm u. a. kann aber nicht mehr als forstliche Nebennutzung bezeichnet werden. Das sind selbständige gewerbliche Betriebe, auch wenn der betreffende Grund und Boden einer Forstverwaltung gchört. Immerhin werden derartige Nutzungsgegenstände auch im kleinen, innerhalb des forstlichen Betriebs und ohne flächenweise Ausscheidung eines Steinbruchs, einer lïiesgrube u. dergl. gewonnen. Zu erwähnen ist der Verkauf von Granitblöcken, von Sandsteinquadern, von großen Findlingen, wie sie sich da und dort in der diluvialen Formation vorfinden; ferner kommen Kalksteine von Schutt- und Geröllhalden, Silbersand, Formsand, Töpferlehm, Grobkies für Wegbeschotterung u. ä.zur Verwertung. Soweit solche Nutzungen ohne Beeinträchtigung des forstlichen Betriebs und ohne Schädigung der VIaldkultur sich erheben lassen, wird nichts dagegen einzuwenden sein. Die Abgabe erfolgt entweder gegen Entrichtung bestimmter, nach IIaßen festgesetzter Preise (cbm, Fuliren usf.) oder im Weg der Verpachtung auf bestimmte Zeit, wobei dann natürlich genauc Bestimmungen iiber den Umfang der Nutzungen in den Pachtvertrag aufzunehmen sind.

Der Torf $\mathrm{Tut} \mathbf{z}$ u $\mathrm{ng}$ ist eine besondere Abhandlung in diesem Handbuch gewidmet: als forstliche Nebennutzung im eigentlichen Sinn kommt sie ja kaum in Betracht, vielnelır ist sie auch Gegenstand cines selbständigen Betriebs, oder steht mit der Waldwirtschaft höchstens insoweit direkt in Verbindung, als sie der Riedaufforstung vorangeht. 


\title{
IX. \\ Die Forstbenutzung.
}

\section{Forstlich-Chemische Technologie.}

\author{
Von
}

Franz Schwackhöfer.

Für die 3. Auflage bearbeitet ron J. $\mathrm{Sch} \mathrm{m}$ i d t.

I. Die chemische Zusammensetzung des Holzes, der Rinde und des Korkes, sowie der Gallen.

a) Holz.

\$ 1. Chem iseher Bestand. Das frische, sogenannte, grüne“ Holz, bestelit aus der Holzfaser (Holzskelett) mul aus dem Safte.

Die Holzfaser, welehe die Wandungen der Zellen und Gefäße biłdet, wird aus Zellulose aufgebaut, welche kurz nach erfolgter Bildung eine Veränderung erfährt, die man als Verholzung bezeichnet. Die reine Zellulose besteht aus:

$44,44 \%$ liohlenstoff

$6,17 \%$ Wasserstoff und

$49,39 \%$ Sauerstoff, woraus sich die empirische Formel $\mathrm{C}_{6} \mathrm{H}_{10} \mathrm{O}_{5}$ ergiht. Das verholzte Gewebe ist dagegen kohlenstoffreicher und sanerstoffämer als die Zellulose und enthält überdies noch Stiekstoff und Mineralbestandteile.

Die Elenentar-Zusammensetzung der Holz-Trockensubstanz schwankt zwisehen:

$$
\begin{array}{r}
49,5 \text { und } 51,5 \% \text { Kollenstoff } \\
6,0 \text { und } 6,8 \% \text { Wasserstoff } \\
42,0 \text { und } 44,0 \% \text { Sauerstoff } \\
0,1 \text { bis } 0,3 \% \text { Stickstoff und } \\
0,1 \text { bis } 1,0 \% \text { Asehe. }
\end{array}
$$

Mlan hat sich bisher vorgestellt, da B die Zellulose als solehe unverändert erhalten bleibt und nur von einer kohlenstoffeicheren Substanz eingehült und durehdrungen wird, weleh letztere daher auch inlirustierende Substanz oder $\mathrm{L}$ ig $\mathrm{n}$ in genannt wurde. Neuere Untersuchungen haben jedoch ergeben, daß in der verholzten Zell- 
wand mehere Kohlenhỵthate vou Charakter der Zellulose vorhauden sind, welehe sich durch iln Verhalten gegen verdümnte Ilinera käuren, Aelzalkalien und oxjotierende Agenzien voneinander unterscheiclen. Die widerstandsfähigste ist die DextrosoZellulose (oder eigentliche Zellulose); die an wenigsten widerstandsfahigen sind die Hemizelhulosen. Dazwisehen steht eine Feihe anderer, die man als Mannoso-Galaktoso usw. -Zellulose bezeichnet, je nachdem sie bei der Hydrolisienung dureh verdünnte Ilineralsiuren Dextrose, Mannose oder Galaktose usw. liefern. Ob diesen verschiedenen Zellulosen ein höherer Kohlenstoffgehalt zukommt als der eigentlichen Zellulose, ist allerdings nieht erwiesen.

Neben den Zellulosen findet sieh in ten verholzten Geweben noeh ein anderer Teil, den man auch heute noch als $\mathrm{Lig} \mathrm{n}$ in bezcichnet. Man nimmt an, daß die Ligninstoffe mit den Zellulosen zu ätherartigen Verbindungen vereinigt sind und nemnt diese Ligno-Zellulosen.

Lignin dürfte aller Wahrscheinliehkeit nach ein variables Gemenge von verschiedenen, bisher nicht näher gekamnten Körpern sein. Es gibt eine Reilue charakteristischer Realitionen, welehe dazu benutzt werden, um verholzte Gewebe zu erkenmen. Die gebräuchliehste ist die Wiesnersche Phloroghcin-Reaktion. Eine salzsaure Lösung von Phlorogluein färbt verholzte Gewebe violettrot. Femer färbt bei Gegenwart von Salzsäure: Phenol blaugrün, Naphtol grün, Pyrrhol rot usw.

Nach der Zellulose-Bestinnumgsmethode von Fr. Sehulze besteht die Holztrockensubstanz der Waldbäume aus: 47 his $62 \%$ Zellulose und 38 bis $52 \%$ Lignin.

Diese Zahlen sind aber nur als Yäherungswerte anzusehen, weil nach den Untersichungen Renkers $\left.{ }^{1}\right)$ die Schulze-Hennebergiche Methode sowohl wie auch alle ubrigen zu diesem Zwecke vorgeschlagenen Jethoden und Reagenzien entweder die eigentliche Zellulose-Substanz mehr oder minder stark angreifen oder überhaunt nichl imslande sind, reine, ligninfreie Zellulose aus den stärker verholzlen Pflanzenfasern zu liefern.

Bezūglich der llethoden der Zellulose-Bestimmung sei hier nur kurz erwähnt, daß sie sich prinziniell in zwei Gruppen teilen lassen, und zwar in solche, welche mitlelst hydrolytisch oder oxydierend wirkender Igenzien die Begleitsubstanzen der Zellulose in lösliche Formen überfühen und solche, welche von der Löslichkeit der Zellulose in gewissen Peagenzien Gebraueh maehen.

Die Zellulose findet sich rein in der Natur überhaupt nicht. Relativ am reinsten erscheint sie in Flughaar der Baumwollfrüchte, in Mark gewisser Pflanzen, sowie in den jüngeren Zellen der höheren Pflanzen überhaupt. Bei fortschreitendem Wachstum tritt bei diesen letzteren allmählich jener Prozeß ein, den man - wie schon erwähnt - als Verholzung oder Verkorkung oder liutikularisierung bezeichnet. Der Vérholzungsprozeß ist regelmäßig selıon vor Eintritt des Winters durch den ganzen neuen Jahresring abgeschlossen. Bei einzehnen Holzarten, bezüglich deren dies nicht der Fall ist, bleibt die Zellwand auch im späteren Alter nur unvollständig verholzt.

Die Zellulose ist in reinem Zustande weiB, seidenartig glänzend, durchseheinend, gerueh- und geselınacklos, hygroskopisch und hat eine Dichte von 1,52. Sie besitzt noelı die Form des Pflanzenteiles, aus welchem sie isoliert wurde. Die Zellulose ist in keinem bisher bekannten Agens ohne Zersetzung löslieh ; in Kupferoxyd-Ammoniak quillt sie so stark auf, daß eine scheinbare Lösung entsteht. Aus dieser wird sie dureh Zusatz von Säuren, Salzen und selbst schon dureh starke Verdünnung mit Wasser als strukturlose, flockige oder fadenähnliehe Masse gefällt. Die Lösung erfolgt leichter und rascher, wenn man die Zellulose vorher mit konzentrierter kalter Natronlauge behandelt. Aehnlich wie liupferoxyd-Ammoniak verhält sich auch Chlorzink, nur ist dessen Lösungsvermögen ein geringeres.

Jod färbt die Zellulose gelb bis braun. Wird dieselbe mit Jodlösung getränkt

1) Renker, Ueber Besimmungsmethoden der Zellulose, Berlin 1910. 
und sodann lionzentrierte Schwefelsäure zugegeben, so tritt Blaufärbung ein; desgleichen wenn man Zellulose mit Chlorzinkjod-Lösung betupft. Diese Reaktionen werden zum Nachweis der Zellulose benützt.

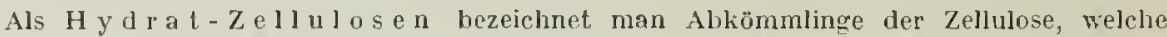
sich von dieser nur durch ihre größere Hygraskopizilät unterscheiden. Schwalbe ${ }^{1}$ ) teilt sie nach der Bildungs- oder Darstellungsweise in folgende Gruppen:

1. Bildung durch mechanische Zerkleinerung bei Gegenwart von Wasser oder durch Trocknung gebleichter Zellulose; im Vegetationsprozeß.

2. Bildung durch Einwirkung von Salzlösungen, Alkalien oder Säuren.

3. Bildung durch Ausscheidung aus Lösungsmitteln oder Estern.

In allen ihren Eigenschaften sind diese Hydratzellulosen noch nieht vollkommen erforscht und charaliterisiert.

1) y drozejlulosen bilden sich durch dic Einwirkung von Säuren verseliedenster lionzentration, von Süuredämpfen, von sauren und neutralen Salzen und beim Erhitzen rter Zellulose. Diese wird dabei hydrolisiert zu einem Produlit, das die Zusammensetzung $\mathrm{C}_{12} \mathbf{H}_{22}$ $\mathrm{O}_{11}$, also dit Aufnalme eines Molekn̈ls Wasser, zeigl. Je nach den Darstellungsbedingungi'u gibt die Zellulose verschiedene Hydrolisierungsstuftn. In reinem Zustande bildet die HydrozelluJose in weißes, leicht zerreibliclıes Pulver von geringer Hygroskopizităt. Gegen kalte verdannte Säuren und Alkalien ist Hydrozellulose sehr beständig; kalte konzentrierte Säuren aber lösen sie, während konzentrierte Alkalilaugen, auch beim liochen, nur von schwacher Wirkung sind. Hydrozellulose mit Essigsäurcanhydrid und wenig konzentrierler Schwefe]säure versetzt löst sich momentan unter heftiger Reaklion; bein Verdünnen mil Wasser fällt das gevildete Aeetat in Form von Flocken aus. 1]it Jodjodlialilösung sowie Chlorzinkjodlösung gibt Hydrozellulose Blaufärbung und reduziert Fehlingsche Lösung; in liupferoxydAmmoniak und Chlorzink ist sie Jeichter löslich als die Zellulose. Reine Hydrozellulose verlrügt Temperaturen über $100^{\circ}$ Cels. ohne Veränderung. IIydrozellulose kann leichter in Glukose übergeführt wrilen als Zellujose.

Durch die Einwirkung von Oxydationsmitteln wird die Zellulose in $\mathrm{O} x \mathrm{yz}$ e J u 1 o se übergeführt, welche reduzierende Eigenschaften zeigt, sich ganz oder tei]weise in verdünnten Alkalien lost und ein stärlieres Aufnahmevermögen fül basisclı Farbstoffe liat als die Zellulose.

Durch Bchandlung der Zellulose mit Wasserstoffsuperoxyd haben Bumelie und Wolffenstein ein Produkt erhallen, das den Oxyzellulosen selü älnlich ist und von ihnen $\mathrm{H}$ y d r a lz ellulose genannt wurde.

Unter den Estern der Zejlulose mit organisclıen Säuren haben namentlich die Z e l I u I os eA e e t a t e ein technisches Interesse, weil sie jöslich sincl, siclı zu strukturlosen, durchsichtigen Platten und fäden von großer Festigkeit und Elastizität formen lassen und nicht explosiv sind.

liochl man Holz oder Zel]ulose mit nicht oxydierenden Jineralsäuren - mit oder ohne Anwendung von Druck - so enlsteht, neben anderen Produkten der Hydrolyse, wie schon erwähnt, Z u c k c r, welcher gärungsfähig ist

IIan luat dieses Verhalten technisch zu verwerten gesucht, um aus Holz Aethylalkohol (Spiritus) zu gewinnen. Erst in der neuesten Zeit aber soll es, nach vielfachen mißglückten Vírsuchen, gelungen scin, das Verfahren praktikabel und rentabel zu gestallen.

Nach R. F. Ruttans Berieht ${ }^{2}$ ) soll in Amerika eine, nach einen von Tomlinson und Ewen abgeăndertcn Classenschen Verfahren arbeitende, liabrik zufriedenstellende Ausbeulen ergeben.

Nach diesem V'rrfahren wird Sägemehl in, nit Chamolte ausgulegten, rotierenden Stahlzylindern vorerst mit $1 \%$ von seinem Trockengewicht gasfömiger, schwefliger Säure behandelt und sodann einem Dampfdruck von $7 \mathrm{Alm}$. ausgesetzt. Nach 40 bis $45 \mathrm{Min}$. ist dic Aufschließung beendel, worauf der, die Terpene, schweflige Säure und Essigsäure enthaltende, Dampf in Absorplionsgefässe abgeblasen und die aufgeschlossene dunke]gefärbte Holzmasse in einc Batterie entleert wird, um hier systemalisch mit heißem Wasser ausgelaugt zu werden. Der saure Extrakt wird mit lialk neutralisiert, filtriert, mit Here versetzt, vergären gelassen und schließlich der Alkohol abdesilliert.

$1 \mathrm{t}(1000 \mathrm{~kg})$ Săgemehl soll 20,5 Gallonen ( 1 Gallone $=3,785$ Liter $)$, somit 77,6 Liter Spiritus ergeben, welcher nach der Peklifikation zu $94 \%$ igem Alliohol, sehr rein, farb- und geruchlos ist und nur spuren von Aldehyd und Furfurol aufweisl.

Auch in Frankreich soll nach G. U. Borde ${ }^{3}$ ) ein in Großbelriebe ausgeführtes, noclifiziertes Classensches Aufschließverfahren, bei dem neben \$lkohol auch noch Essigsäure gewonnen wird, in seinen Erträgen befriedigen. In allen jenen Lïndern, in denen die Spiritusuewinnung aus stärkemelılhalligen Rohmaterialien — im Interesse der Landwirtschaft — durch die steuergeselzgebung geschützt isl, dürfte diese Arl der Nutzbarmaclung von Holzabfällen nicht rentieren.

1) Schwalhe, Die Chenie der Zellulose, Berlin 1910.

2) Journ. Soc. Chem. lnd. 1909.

3) Chen1. News, 1910. 
Wird geraspeltes Ilolz son laubbäumen vorerst mit Ammoniak goreingt und sodann

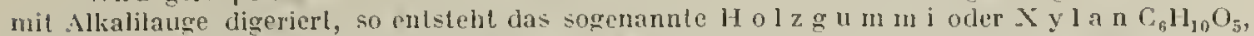
welches bein Erhitzen mil verdunnter Schwefelsaure in $\mathrm{X}$ y los e, $\mathrm{C}_{5} \mathrm{H}_{10} \mathrm{O}_{5}$, cine nicht gärungsfähige Zuelierart (Holzzucker) ühergeht. Das Holz der Coniferen livferl in Verhültnis zu dem der Laubhölzer nur wenig Xylan.

Wird Zellulose mit konzentrierten, kalten Alkalien behandelt, so sehwellen unt sehrumpfen die Fasern, zeigen aber nach leu Auswaschen der Lauge ein besseres Färbungsvermögen, eine höhere Fesligkeit unł Hygroskopizilät, sowie - nach Sehwalbe - eine gesteigerte Rraktionsfähigkeil und leichlere IIydrolyse. IVerden diese geschrumpften Fasern nach der Behandlung gestreckt, so erhalten sie einen holen Glanz. Von diesem Verhalten der Zellulose (Bildung son Iydratzellulose) wird in der Textilindustrie, bein sog. , $1 l$ e r c e r is i e r e $\|^{\prime \prime}$ der Garne ausgiebig Gebrauch gemacht.

Zellulose mit starker Natronlauge behandelt und sodann Schwefolkohlenstoff-Dämpfen ausgesetzt, licfert eine Verbindung, welche als das Nalliunsalz der Alkalizellulose-Xanthogensäure zu bezcichnen ist. Diese Verbindung ist im Wasser löslich; je nach der lionzentration der Losungen sind dieselben melır ofler minder zähflüssig (viskos), woraus sich die Bezeichnung dieser Verbindung, $\mathrm{Y}$ is $\mathrm{k}$ os e, ableitet.

Die wësserigen, meist $10 \%$ Zellulose enthaltenden Lösungen der V'iskose sind gelblich bis brännlich gefärbt und enthalten neben der eigentlichen Zelluloseverbindung noch, ron Nebenreaktionen herrührende, Zersefzungsprodukte des Schwefelkohlenstoffes. Durch schwache Säurcn (Essig-, Nilch-, Kohlensãure u. dergl.), ehenso durch Alkalisalze, Ammoniumelılorid oder starken Alkohol kann lie Zelluloseverbindung inlolge Fällung von diesen Begleitsubstanzen getrennt, d. h. gereinigt Werden. Metalsalze verursachen eine Wechselzersetzung nit der Viskose.

$\backslash$ iskoselösungen liönnen zur Herstellung von Fäden, Häutchen oder plastischen Formen, dann zum Leimen von l'apier, Wasserdichlmachen von Geweben etc. verwendet werden. Dureh Stehenlassen an der Luft, schneller aber dureh Erwärmen, zersetzen sich die Viskoselösungen und es erübrigl schließlich Zellulosehydrat in Forn einer festen, elastischen Masse, die als $V^{\prime}$ is k o i jegliche Bearbeitung durch Sägen, Bohren, Drehen usw. zu verschiedenen Gebrauehs- und Luxusgegenständen rmmöglicht.

Technisch wichtig ist ferner das Verhallen der Zellulose gegen konzentrierte Säuren. Tauchl man ungeleimtes Papier kurze Zeit (5-20 Sekunden) in starke Schwefelsäure und wäscht diese sodann mit Wasser vollständig aus, so geht die Zcllulose in kolloidale Modifikationen, "A n y lo i d und Hyrozellulose" über, welche sich auf und zwischen den Papierfasern niederschlagen und dieselben verkitlen. Derartig präpariertes Papier ist dem animalischen Pergamente ähnlich und wird daher aucluals vegetahilisches Pergament oder P e r g a n e n $t$ p a $p$ i e r bezeichnet. Es ist duchscheinend, stcif, schwer zerreißbar und wird im Wasser geschneidig, ohne dabci wie gewönnliches Papier zu zerfasern. Pergamentpapier wird hauptsächlich zum Verschließen der Gläser von Obstkonserven, als Wursthüllen u. derg̣l., dann aber auch als Iembrane bei der Osmose der Jlassen in der Rübenzuclier-Fabrikation verwendet.

Zur Erzeugung der sog. I u $1 \mathrm{k}$ a $\mathrm{n} \uparrow \mathrm{i}$ b e $\mathrm{r}$ pergamentiert nan ungeleimles Papier statt mit Schwefelsäure, welche schwer auszuwaschen ist, mit Chlorzink, setzl mehrere Lagen solchen Pergaments, eventuell unter Farbzusalz, zwischen geheizten Zylindern einem mäßigen Druch ans, trocknet an der Lufl, wäscht das Chlorzink aus und trockinet schließlich vollends. Dio cinzclnen Lagen verschweißen bei dieser Belındlıng zu Plaften oder Blöcken, in denen lieinerlei Schichtung mehr wahrzunehmen ist und die sich nach dem vollständigen Trocknen wie Melall bearbciten lassen. Harte Vulkanfiber dient vornohnlich als Isoliermaterial für den elektrischen Strom und dann überhaupt zur Erzeugung von Gegenständen, welche, bei einer entsprechenden Elaslizităt, besonders auf Härte und Zïhigkeit beansprucht werden, z. B. Zahnräder für stoßund fast geränschlosen Gang, Bremsen, Stoßringe, Transportgefäße etc. Biegsame Vulkanfiber, durch Tränken der harten nit Glyzerin erhalten, wird als Ersatz für Gummi und Leter zu Dichtungen, Ventilsilzen- und klappen ete. verwendet.

Durch konzentrierte Salpetersâure oder besser noch durch ein Gemiselı von dieser nit lionzentrierter Schwefelsäure (welche als wasserentziehendes Mitlel wirkt) wird die Zellulose (gereinigte Baumwolle oder Holzzellulose) in cin Nitroprodukt oder nach neuerer Auffassung in $\mathrm{S}$ a l petersä u re - Es t e r verwandelt. Je nach dem llengenverinälnis zwischen Salpelersăure, Schwefelsäure und Wasser, sowie nach der Temperatur und Einwirkungsdauer der Säure entstehen verschiedene Verbindungen. Wijd das Molekül der Zellulose mit 12 Atomen C angenommen, so ergibl sich folgende Reihe:

$$
\begin{aligned}
& \text { Zellulose -Dinitrat } \ldots \ldots \mathrm{C}_{12} \mathrm{H}_{13} \mathrm{O}_{8} \quad\left(\mathrm{NO}_{3}\right)_{2} \ldots \ldots, 6,76 \% \mathrm{~N}^{+} \\
& \text {-Trinitral ........ } \mathrm{C}_{12} \quad \mathrm{H}_{17} \mathrm{O}_{7} \quad\left(\mathrm{NO}_{3}\right)_{3} \ldots .9,15, \mathrm{~N} \\
& \text {-Tetranil ral } \ldots \mathrm{C}_{12} \mathrm{H}_{16} \mathrm{O}_{6} \quad\left(\mathrm{NO}_{3}\right)_{4} \ldots \ldots 11,11, \ldots \\
& \text {-Pentanilral } \ldots \mathrm{C}_{12} \mathrm{H}_{15} \mathrm{O}_{5} \quad\left(\mathrm{NO}_{3}\right)_{5} \ldots \mathrm{1}_{5,75}, \mathrm{~N} \\
& \text {, -Hexanitral } \ldots . . \mathrm{C}_{12} \mathrm{H}_{14} \mathrm{O}_{4} \quad\left(\mathrm{NO}_{3}\right)_{6} \ldots \ldots 14,14, \mathrm{~N}
\end{aligned}
$$

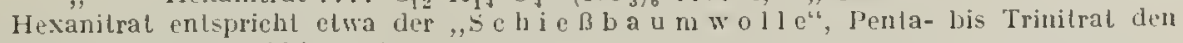
"Collodion pyroxiline n".

Diese lelzteren sind in Alkohol-Acther löslich und fulren allgenein den Namen, ,K o 11 o- 
d i u m w o tle oder lösliches Pyroxilin." Nach clem Verdünsten des Lösungsmittels aus einer solchen Pyroxilinlösung verbleibt das liollodium in Form einer Haut, welehe in der Chirurgie und bei der Herstellung plotographischer Platten und Papiere Verwendung findet.

In newerer Zeit ist die Jiollodiunwolle 11 . a. mit das Hauptrolnnaterial für die Erzeugung der li u n s $\mathrm{s}$ e i de. 1885 nahm Graf Hilaire de Chardonnet sein erstes Patent auf die Herstellung künstlicher Seide aus Pyroxilin, wonacl dieses in Alkohol-Aether unter Erwärmen gelöst und die Lösung zur Beseitigung elwaiger mechanischer Verunreinigungen und behufs gründlicher Misehung unfer Druck filtriert wird. Dieses heiße Filtrat wird mit hohem Druck dureh ein, in einer lialten Flüssigkeit, z. B. Wasser, angeorunetes, enges Munlstück (Spinnorgan) gepreßt, wohei das Lösungsmitlel jom Wasser rasch aufgenommen wird und der austretende sehr dünne liollodiunstrahl an seiner Oberfläche sofort erstart, im lnnern aber noch flüssig bleibt. In diesem Zustand kann man diese Fäden an der Luft zu sehr feinen liokons auszielen, in welcher lorm sie dann leicht vollständig troclinen und erhärten und einen lıohen Glanz aufweisen. Zehn bis zwölf solcher Jiokons zusanmengezwirnt liefern emen verwebbaren Faden, weleher ohne Sehwierigkeit und belicbig gefärbt werden kann. Die aus Nilrozellulose liergestellte liunstseide besitzt aber eine hohe Entzündlichkeit; un ihr dieselbe zı nehmen, wird sie mit versehiedenen Mitteln (Alkali- oder Erdalkalisulfiden- und sulflydraten, Wetallsalzen u. a.) denitriert, d. l. in nahezu reine Zellulose rückverwandelt.

Un dieser Jetzteren Prozedur bei der Íunstseiden-Fabrikalion aus tem Wege zu gehen, hat man, u. $z$ w. mit Erfolg, Versuche untemomen, dieses Produkt aus nicht feuergefährlichen Pohmalerialien herzustellen, als welche zu nennen sind: Lösungen von Zellulose in kupferoxyd-Ammoniak oder Chlorzink, Sulfozellulose, Viskose und in neuester Zeit die Zellulose-Ester organischer säuren, vornehnulich die Zelluloseacetate.

Die Festigkeit der liunstseide ist grring, etwa $t 0$ bis $60^{\circ}$ o von der echten Seide, ihr Glanz aber bei nanehen Fabrikaten höher als der der natürlichen. Sie wird, bei Stofferzeugung nur zum ,,Sehuß", sonst aber hauptsächlich zur Herstellung von Detiorationsgegenständen, Litzen, Borden ete. verwendet.

Ein anderes Fabrikat, weleles aus Nitrozellulose hergestellt wird, ist das $\mathrm{Z}$ e 11 u l o i d, eine innige Jischung von Kollodiumwolle und Kampfer. Diese Mlischung liann ereicht werden dadurch, daß man entweder dje durch Abpressen entwässerte und gemahlene vitrozellulose in schmelzenden liampfer oder in eine alkoholische liampferlösung einrührt und diese llasse in hydrauliselien l'ressen einem holien Druck und einer Temperatur von $130^{\circ}$ Cels. aussetzt, oder auf kaltem Wege, dırch Lösen der liollodiumwolle in einer Lösung von liampfer in Aether, Holzgeist, Aeeton, Eisessig u. dgl. Durch larbenzusälze zu den Rohmaterialipn läßt sich das Zelluloid brlielig färben; in warmen Zustande kann es in versehiedene Formen gepresst oder gewalzt werden unґ behält diese nach dem Erkalten bei. Es ist zäh und elastisclı und besilzt bei $90^{\circ}$ Cels. seine höchste Elaslizität. Bei $140^{\circ}$ Cels. beginnt es sich zu zersetzen, was bei $195^{\circ}$ plötzlich eintritt. Durch Zusätze von hor- und wolframsauren Salzen, A-best, Alaun, Glimmer und versehiedenen anderen Hiteln wird die leiehte Entzündlichkeit des Zelluloids vermindert. liurz erwähnt sei hier nur noch, daß als Ersatz für den teueren und gefährlichen liampfer eine statliche Zahl von llitteln versucht wurde, von denen sich auch einige praktisch bewäht haben (z. B. Borneol, Jsoborneol, Naphtalin, Formanilid etc.).

Zelluloid wirt zu den verschiedenartigsten Gebrauchs- und Luxusgegenständen geformt und dient namentlich zu diversen Imitationen ron Elfenbein, Sehildjati, Horn, Bernstein, Leder (,, Pegamoid" líunstleder, d. ¿. mit Zelluloullösung imprägnierte, sonit wasseruichte Leinen- und Baumwollgewebe) $u$. dgl.

Stärker nitrierte Baumwolle, welche neist ein Genenge der hōchsten Nitrierungsstufen darstellt, heißt - wie schon erwähnt Se hi e $\beta$ b a $u \mathrm{~m}$ w olle. Sie explodiert heftig und wirkt in geschlossenen Röhren (Gewehr- und Geschützläufen) sehr brisant. Durch Befeuchten der Schießbaunwolle mit Aceton und Essigester entsleht eine gelatinöse Masse, welehe in platten gewalzl, sodann in kleine Teile zersehnitten und mit Graphit besläubt das rauchlose, bezw. rauchsehwache Pulver für Gewehre lıefert. Dieses brennt langsamer ab als die Sehießbaumwolle. Für Artilleriezwecke wird kollodiumwolle mit $\mathrm{dmm}$ gleichen Gewichte Vitroglycerin gemengt. Gekörntes, rauchloses Pulver besteht aus Nitrozellulose und Barytsalpeter.

Beim Zusammenschmelzen von zerkleinerten Holze mit Alkalihydrat entsteht $\mathrm{O} x \mathrm{al}$ sä u r e. Diese Art der Darstellung wirl fahriksnäBig betrieben, indem man Sägemehl mit dem gleichen Gewichte detzalkalien $\left(40^{\circ} \%\right.$ liali- und $60 \%$ Natronhydrat $)$ in flachen eisernen Schalen unter fortwährendem Umrüliren bei $240^{\circ}$ C. zosammenschmilzt. Die Schmelze wird in Wasser gelöst, mit Jálimilch gekocht, das dabei entstandene Calciumoxalat mit Schwefe]säure zerlegt und das Filtrat soweit eingedanıft, daß die Oxalsäure auskristallisicrt. Aus $100 \mathrm{~kg}$ Sägemelıl erlıălt man ca. $80 \mathrm{~kg}$ rohe Oxalsäure, welche als solche odel in form von Salzen (Oxalate) in der Färberei und im Zeugdruek ete. Anwendung findet., 1

$\$ 2$. Der Holzsaft. Der Holzsaft besteht aus Wasser, in welehem organische und mineralische Bestandteile teils gelöst und teils suspendiert sind.

Der $W$ a s s e r g e h a $1 \mathrm{t}$ des frischen Holzes ist sehr verschieden und abhängig: 
1. von der Holzart;

2. von dem Aiter des Holzes;

3. von der Jahres- und Tageszeit;

4. von dem Standorte des Baumes und

5. von der Witterung.

In allgemeinen bewegen sich die Schwankungen bei frisch gefälltem Holze zwischen 25 und $50 \%$; ausnahmsweise auch unter 20 bis über $60 \%$.

Ein durchgreifender Unterschied in Wassergehalte zwischen Jartem und weichen Holze ist nicht zu lionstatieren. Im frisch gefällten Holze beträgt der Wassejgehalt durchschnittlich:

hei Hainbuche

"Ahom, Esche und Birke

, Steineiche, Buche, Weißtanne und Fïfer

$2.5-30 \%$

," Erle und Fichte

,, Linde, Lärche und Schwarzpappel . . . . . . 45-50\%

Geflöbles Holz enthält durchschnittlich an 60\% Wasser.

Jüngeres Holz ist stets wasserreicher als das ältere. Diesbezügliche Untersuchungen von R. H a $\mathrm{r}$ i g ergaben:

\begin{tabular}{lcccc} 
& & \multicolumn{3}{c}{ Gewichtsprozente Wasses } \\
Fichtc & Tojährig & 65.2 & Mitte & Kiern \\
Köiefer & 7jährig & 53,9 & 39,0 & 23,7 \\
Rotbuche & S5jährig & 46,9 & 42,1 & 24,7 \\
Eiche & 50 jährig & 44,9 & 42,8 & 36,1
\end{tabular}

NB. Die Bäume wurden im Mai (1881) gefällt und die zur Intersuchung verwendeten Probescheiben aus einer Höle ron 6-8 m über den Boden entnominen.

Der Wassergehalt des Iolzes ist im Frühjahr, zur Zeit der Hauptsafthewegung am größten und im Winter am geringsten. Jedoch nehmen auch Nebcnumstände darauf Einfıß, so daß diese Regel keine allgemeine Gültigkeit besitzt. Der Wassergehalt wechselt sogar in den verschiedenen Tagesstunden und ist in hohem Grarle von der Insolation abhängig. An sonnenhellen Tagen fällt er von früh bis gegen ? Uhr mittags und steigt sodann bis zum nächsten Mlorgen.

Ton dem im Holze enthaltenen Wasser ist nur ein Teil (etwa $1 / 3$ bis $2 / 3$ des Gesamt-Gehaltes) im flüssigen Zustande vorhanden; der Rest ist von den Zellwänden aufgesaugt (Imbibitionswasser). Das Verhältnis zwischen flüssigem und imbibiertem Wasser ist nach der Holzart, Jahres- und Tageszeit sehr bedeutenden Schwankungen unterworfen.

Bleibt frisch gefälltes Holz in zugerichtetem oder wenigstens entrindetem Zustande an der Luft liegen, so verliert dasselbe fortwährend Wasser, bis ein gewisser Gleichgewichtszustand zwischen dem Wassergehalte der Atmosphäre und der Hygroskopizität des Holzes eingetreten ist. In diesem Zustande nennt man das Holz lufttrocken. Dasselbe enthält aber"immer noch 10-18\% hygroskopisches Wasser, welches nur durch Trocknung bei höherer Temperatur $\left(100-110^{\circ} \mathrm{C}\right.$.) vollständig ausgetricben werden hanu.

Die in Molzsafte gelösten oder suspendierten Bestandteile (welche teilweise wohl aueh der Zellwand selhst auruhörn oder Lmwandlungsprodukte derselbon darstellen) sind folgende:

1. Stickstoffsubstanz (Protein).

Der Gehalt an sticlistofl int gering und befrägt in entrindelen Holze etwa $0.1-0.2$ Proz. (entsprechend $0.58-1.16$ Proz. Protein). In jüngeren llolze ist der slickiloffgehalt vin höherer als in älteren. In Winter und Frühjahr int er an geringsten, im Sonmer am höehsten. Der weitaus größte Teil der Stickstoffsubstanz ist im unlösichen Zustande zugegen. Technisch 
erscheint dieselbe nur insolerne von Bedeutung, als sie neben dem Wassergehalte die lauptsächlichste Ursache der Zerselzung des Holzes ist. andere.

2. I o lehydrate und Nächstver and te: Ståke, Zucker, Gummi und

Aus dem Marke der Sagopalnue wird ein Stärkeprodukt, "der echte ostindische Sago", gewonnen, welcher als Nahrungsmitlel in den Handel kommt.

Zucker (Saccharose) findet sich im Safte des Stammes einiger Ahornarten und Palmen in größerer Jlenge, so daß er für lokalen Bedarf technisch gewonnen werden kann.

Als Manna bezeichnet man den eingelrockneten, süßlich schmeckenden Saft der MannaEsche, welcher teils freiwillig, teils durch Einschnitle auslließt und in den südeuropäischen Ländern (Sicilien und Calabrien) gewonnen wird.

Gummi gehört zu den am meisten verbreiteten J'flanzenstoffen und steht den liohlehydraten sehr nahe. Der Hauptbestandteil, ,das Arabin $\left(\mathrm{C}_{12} \mathrm{H}_{22} \mathrm{O}_{11}\right)$ " besitzt den Charakter einer schwachen Säure. Gummi entsteht dureh chemische Mlelamorphose der Zellwände. fummibildung kann sowohl in Holze als auch in der Finde erlolgen. Das beliannteste Prolukt dieser Art ist das Akazjengummi: arabisches Cummi, Senegalgummi usw. Es stammt von mehreren Bäumen und Sträuchern (hauptsächlich von Aeacia V'erch), die in Arika, Oberagypten in den nubischen und arahisehen Tüsten, Ausiralien und Ostindien einheimisch sind. Das Gummi fließt freiwillig aus den Rinden und erhärtet an der Luft. Es kommt in rundliclien, erbsen- bis haselnußgroßen, oft auch länglich gestreckten und verschiedenartig gewundenen, glasartigen, larblos ouler gelb bis braun gefärbten stücken in den Handel. Gummi ist in Wasser leiclıt löslich, wenn es vornelımlich aus Arabin besteht, teilweise löslich, wenn es Cerasin und Bassorin entlält; in Alkolol, Aether u. dgl. ist es unlöslich. Es dieni, wie bekannt, hauptsächlich als Kilehemittel; ferner auch zum Ferdicken der Farben, Beizen, Tinten, Glänzen des Papiers usw. Das natürliche Gummi wird gegenwärtig durch das viel billigere Dextrin, welches aus Irartolfelstärke erzeugt isł, erselzt. Unter den einheinischen Holzarien zeigen namentich die steinobstbäume starke Gummiausscheidungen. Eine dem arabischen Gummi nahestehende Substanz, ,der Traganth" , ist der cingetroclinete Saft mehrerer Astragalus-Arlen

3. Glykoside. Darunter sind alle Körper verstanden, welche durch Einwirkung Fon Enzymen oder chemischen Agenzien in Zueker und irgend eine andere zu den aromal ischen oder Fettkörpern gehörige V'erbindung zerlegt werden. Die Glykoside sind hauptsächlich in den Rinden vertreten, einige davon finden sich aber auch im Holzsalte. Hierher gehörl das Coniferin $\mathrm{C}_{18} \mathrm{H}_{23} \mathrm{O}_{8}$, welches im Cambialsafte aller Coniferen vorkommt; das Fuslin $\mathrm{C}_{36} \mathrm{H}_{28} \mathrm{O}_{14}$ und Fisetin $\mathrm{C}_{15} \mathrm{H}_{10} \mathrm{O}_{6}$, welche beide in Fisetholze (Rhus colinus) vorkommen, und einige andere.

4. P I l a nzens ä uren: Gerbsäure, Oxalsäure, Weinsäure, Zitronensäure, Aepfelsäure, Arabinsäure.

Gerbsäure findet sich ebenfalls hauptsächlich in den Rinden. Es gibt jedoch auch einige Holzarten, welche beträchtliehe IIengen von Gerbsäure aufweisen, so das Quebrachoholz (mit 20-25\% Gerbstoff), das Catechulıolz und das Holz der Edelliastanie, melche als Gerbmaterial verwendet werden.

Auch das Eiehenholz enthält größere Mengen von Gerbsloff. Die übrigen Säuren sind technisch bedeulungrslos.

5. B i t ters $l$ of $f \mathrm{e}$. Diesbezüglich isl namentlich das Quassiaholz, sowie auch dessen Rinde ausgezeichnet und findet als Arzneimittel, zur Herstellung bitterer Liköre u. dgl. Verwendung.

6. Fa rbstoffe. Die meisten Holzarten, speziell die Splint- und Reifholzbäume, besitzen eine helle, weiße bis blaßgrau-gelbe Farbe. Das liernholz mehrerer einheimischer, vornehmlich aber der tropischen Holzarten, zeigt eine lebhafte Färbung.

Bei längrrem Liegen des Holzes dunkelt die Farbe immer nach. Auffallend dunkler wird das llolz durch das Dämpfen.

Manche Holzarten sind sehr reich an Farbsloffen (bezw. Chromogenen) und finden in der Färberei Verwendung.

Solche Farbhölzer sind:

a) Das Blauholz (Canpecheholz), d. i. das Iírnliolz cines auf den Antillen und an der küste von Südamerika, besonders in der Campechebai, wild wachsenden Baumes. Der Splint ist unuranchbar, wird abgeschält und das Kiernholz in etwa $1 \mathrm{~m}$ lange und mehrere Zentimeter dicke seheite zerschnitten. Vor den Gebrathe werden dieselben geraspelt und zermahlen und bleiben im angefeuchtetem Zustante mehrere Wochen liegen, damit sich der Farbstoff durch Oxydation kriftiger entwickell. Das jrische Holz ist an der Oberfläche dunkelrot, im Innern heller. Es ist hart, sehr dicht $(0,9-1,0)$, läßt sich gut polieren und besitzt einen veilchenartigen Geruch.

Das Chromogen, ,IIämatoxylin $\left(\mathrm{C}_{10} \mathrm{H}_{14} \mathrm{O}_{6}+3 \mathrm{aq}\right)^{\circ,}$, ist in reinem Zustande farblos und kristallisiert; die Färbung kommt erst durch Einwirkung von Luft, von Feuchtigkeit und durch Beizmiltel zustande. Das Hämatoxylin ist in einer Menge von 9-12\% in Holze vorlıanden. Das erste Oxydationsprodukt desselben , das $1 \mathrm{Ia}$ mateïn $\mathrm{C}_{16} \mathrm{H}_{12} \mathrm{O}_{6}$ ", ist ein rötliches Pulver 
mit grülichem Metallschimmer. Bei weiter fortscheitinder Oxydalion entslehen hraunscliwarze amorphe Verhindungen.

Je nacl der Art der Beizen wird das Blauholz zun Blan-, Violelt-, Rol-, Grau- und Schwarzfårben verwenulet.

b) Das Rotholz (Fernambuk- oder Brasilienholz) stammt von rerschiedenen Caesalpinien (namentlich Caesalpinia cehieala Lam.), welche in Süamerilia einheimisch sind. Die Zubereitung des Jiernholzes ist ähnlich wie beim Blaulolze. Es kommt in $20-50 \mathrm{~cm}$ dicken Jilölzen in den Handel, hat eine dunkel gellrote Farbe und ist schr dicht, schwerer als Wasser. Das besle Rotlolz komint aus Brasilien.

Ale enthalten das gleiche Chromogen , das Brasilin $\mathrm{C}_{16} \mathrm{H}_{14} \mathrm{O}_{5}+\mathrm{aq}$ ", welches in farblosen Nadeln kristallisierl; an der Luft oxydiert es zu Brasileĩn $\mathrm{C}_{16} \mathrm{H}_{12} \mathrm{O}_{5}+\mathrm{aq}$. Ilit Alkalien wird die Lösung rot.

c) Das Sandellolz, von Plerocarpus santalinus L., eines auf Ceylon und in Oslindien einheimischen Baumes, enthālt etwa $17 \%$ eines rolen Farbstoffes, ,das Santalin $\mathrm{C}_{15} \mathrm{H}_{14} \mathrm{O}_{5}$ ", welches in Wasser unlöslich, in Alkohol und Aether hingegen lüslich ist. Auch in Alkalien löst es sich, wobei die Farbe in violell übergeht.

Dem Sandellolz nahestehend sind: das ostindische Caliatur-Holz, das MadagascarHolz, das afrikanische Barwood und das Camwood.

d) Das Gelbholz. Das ungarische Gelbholz stammt von Perückenbaum (Rlıs colinus L.), das westindische vom Färbernaulbeerbaum (Maclura aurantiaca Muth).

Ersteres enthält ein Glykosid „,das Fustin“, welches ansclieinend an Gerbsäure gebunden ist und bejm Erwärmen mit verdünnter Schwefelsäure in den Gelbfarbsloff ,Fisetin" und in Zucker zerlegt wird:

$$
\mathrm{C}_{36} \mathrm{H}_{28} \mathrm{O}_{1}+4 \mathrm{H}_{2} \mathrm{O}=\underbrace{2 \mathrm{C}_{15} \mathrm{H}_{10} \mathrm{O}_{6}}_{\text {Fustin }}+\underbrace{\mathrm{C}_{6} \mathrm{H}_{14} \mathrm{O}_{6}}_{\text {Rhamnose. }}
$$

Das westindisclie Gelhholz enthält neben dem nicht färbenden Mahlurin $\mathrm{C}_{13} \mathrm{H}_{10} \mathrm{O}_{6}$ den gelben Farbstoff llorin $\mathrm{C}_{15} \mathrm{H}_{10} \mathrm{O}_{7}+2 \mathrm{a}(1$.

Un den Transport zu erleichtern, werden aus den Farblölzern Exlrakle hergestellt. Ton einzelnen kommt uberhaupt nur das eingedickle Extrakt in den Handel, wie z. B. Calcchu, eine spröde, tief dunkelbraun gefärbte Masse, welche aus dem Iiemholze von Acacia Catechu gewonnen wird und neben Gerbsäure einen roten und einen braunen Farbsloff enthält.

Die Farblölzer liaben seit Einfülırung der Teerfarbstoffe an Bedeutung viel verloren.

7. Letherisehe Oele, Harze, Balsame und andere Riechstoffe.

Jedes frische Holz besilzt cinen eigentümlichen, meist schwachen Geruch. Bei manchen Hölzern tritt aber auch im trockenen Zustande der Geruch noch sehr deutlich liervor; so z. B. bei alten Nadelhölzern, bei den Farbhölzern, heim Weichselholz, Cedernholz, Veilchenholz, Nloeholz, Kiampferholz usw.

8. I a u techuk, Guttapereha, Kampfer, Bitterstoffe, Alka10 i de etc. Diese Substanzen sind für gewisse, meist in den Tropen einheimische Holzarten (Stammholz, Wurzeln oder Rinden) charakteristisch. In technischer Hinsicht ist namentlich der liaulschuk von Bedeutung, der sich in dem Nilchsaft (Lalex) mehrerer Iropischer und subtropischer Pflanzen findet. Den meisten und beslen Tiaulschuli liefern die Eujhorliaceen: Hevea brasiliensis und guyanensis. Er kommt unter der Bezeichnung ,Paragummi", nach dem brasilianischen Hafen Para so benannt, in den Handel. Außer diesen gibl es in Brasilien, Zentralamerika, Ostindien und Oslafrika noch eine Reihe anderer Kaulschukbiume, aus der Familie der Artocarpeen, Apocyneen u. a.

Un den llilchsait zu gewinmen, werden entweder die Bäume durch Einschnitte oder Stiche angezapft, oder die Blätter und Stengel der Jaulscliukplanzen ausgepreßt, oder endlich die kaulschukführenden Pflanzenleile getrocknet und dann nit Qucllungsnilteln der Iíautschuk direkt extrahiert.

Der llikhsaft, der eine weißliche, dickflüssige, im frisclien Zustande meist geruchlose, süßschmeckende Flüssigkeit bildet, wird entweder als solcher in Gefäßen gesammelt und aus ilım der Rohkautschuk auf verscliedene Art (Verdunslenlassen, Schlagen, Zentrifugieren, Räuchern, Kochen, starkes Verdünnen mil VIasser, Zusalz von organischen und mineralischen Säuren) zur lioagulation gebrachl, oder das Gerinnen am Baume selbsl veranlaßt und der liautschuk aus den Gerinnsel auf gecigneten Unterlagen glciclısam abgewickelt.

Das auf die eine oder andere Art ausgeschiedene Koagulum ist der Rohkautschuk, welcher den überseeisclien Handelsartike! bildet. Ein Baum liefert pro Jahr etwa 6 Liter Milch, woraus $2,5 \mathrm{~kg}$ Rohkzutschuk gewonnen werden.

Dieser enthäll neben dem eigentlichen oder Reinkautschuli (rund 60\%) beträchtliche Itengen ron Ilarzen, ferner Eiweißkörper, Zucker, Farbstoffe, erdige Bestandteile, Reste des Koagulalionsmittels, Wasser und noch andere Verunreinigungen.

For seiner Weiterverarbeitung wird der Rohkaulschuk einem Waschprozeß nit heißen und haltem Wasser und darauf folgendem grüdlichen Austrockinen unterworlen.

Jischt man so gereiniglen Kautsehuk auf einem Mischwalzwerk nit Schwefel, nebst anderen Zusätzen, und setzt diese Miscliung in einem Dampfliessel oder in einer heizbaren Presse einen Druck bis zu $6 \mathrm{~N}$ lı. aus, so erhält man, je nach der angewendetın Schwefel- 
menge, Höhe und Daumr des Druckes, enlwerler ein wriches elastisches (Weichgummi) oder ein hartes, elaslischen Jrodukt (Harlgummi oder Ebonil), welches gegen Säuren und Alkalien, sowip Quellungsmiltel beständig ist und den allgemeinen Namen ,vulkanisierter Kaulschuk" führt. Weichgummi hehält seine Elastizitäl zwischen - 20 und $+120^{\circ} \mathrm{C}$. und ist an der Luft bestandiger als der Rohkautschuk. Seine Vrrwendung zu den verschiedenen, fä]schlich, Gunmiwaren" genannten Artikedn ist bekannt.

Ebonit repräsentiert eine horn-oder fischbeinartige Masse, welche sich zu den verschiedensten Cebrauchs- und Luxusgegenständen in jeglicher Art bearbeilen läßt.

burch Eintanchen von. geformten liaulschukwarn in ein Bad von geschmolzenem Schwefel vder in eine Lösung von Scliwefelchlortur bezw. durch Behandeln der Gegenstände mil Schwef(ehlorürdämpen erfolgt ebenfalls, wenn auch keine so intensive, Vulkanisierung des Kautschuls (sog. kaltp Vulkanisierung). Ueber die chenische Konstitution des Kautsehuks, dim die Formel $\left(\mathrm{C}_{10} \mathrm{IJ}_{16}\right)$ n zukommt, sowie über die Art der Bindung des Schwefels beim Vulkanisierungsprozeß sind die Ansichten der For -cher noch geteil.

[Der zum Teil von Erfolg gekrönten Versuche, Jautschuk synthetisch herzustellen, sei hier nur Erwälnung gelan.

Eine dem liautschuk ähnliche Sulstanz, "die Gutlajercha", wird aus dem Milchsafte einiger Palaquien-Aplen auf Sumatra und Borneo gewonner. Zu diesem Zwecke wurden früher die Bäume gefäll, jetzl wird aber die Gewinnung auch an lebenden Baume vorgenommen, indem man Einschnite in die Rinde machl. In dissen tritt der Milchsaft aus und gerinnt von selbst sehr rasch, so daß er nil dem Messer ausgeschnilten werden kann. Diese Rohgultayercha wird in ähnlicher Weise gereingt und auch vulkanisicrt wie der Kautschuk.

Einen natürlichen Ersatz für die Gullapercla bildet die .,Balala", der eingetrocknete Milchsaft ron Mimusops Balata, einer in Amerika, Afrika und Australien heimischen Pflanze aus der liamilie der Sapotaceen.

liampler $\mathrm{C}_{10} \mathrm{H}_{16} \mathrm{O}$ jsL das Slearopten aus den âtherischen Oel des liampferbaumes (Cinnamomum Camphora, zur Familie der Lauraceen gehörig), weleher in China und Japan zu Hause ist und auf del lnsel formosa ganz: Wälder hildel. Kampfer ist in allen Teilen des Baumes enthalten; zur Gewinnung werden das Stammholz, die Aeste, die Wurzeln und teilweise anch die Bläler verwendet. Das Holz wird zerklcinerl und der Kampler in printitiven Vorrichlungen mit IIlfe ron Wasserdampl überclestilliert. Aus $100 \mathrm{~kg}$ Holzsjänen resultieren etwa $5 \mathrm{~kg}$ Rohprodulit, aus liampfer und Kampferöl hestehend. Der feste hampfer wird ron dem Oel durch Absickern getrennl, als Roliampler in den Handel gebracht und labriksmäßg durcl sublimation rafliniert.

Jianpfer wirl heule bereits im Großen künsllich hergestell aus Harz als Rohnaterial.

Nach E. J. Pond ${ }^{2}$ ) wird die synthese selbst folgendernaßen ansgefuhrt:

Pinch (aus Terpentinöl) $+\mathrm{HCI}$... Pinenhydrochlorid $+\mathrm{jOH} \ldots$. Camphen $+\mathrm{CH}_{3}$ COOH .... Isoborneolacelat $+\mathrm{H}_{2} \mathrm{O} \ldots$. . Isobolneol $+\mathrm{O}$... Jampfer.

9. il in era ls t of le. Dieselben sind teils im safte und teils in der festen Holzsubslanz abgelagrel. Die Menge der Mineralstoffe macht durchschniltich $0,2-0,6^{\circ}$ o $r o m$ Gewichte des entrindeten, luftrockenen stammholzes aus. Junges Holz ist reicher als älteres.

Die Zusammenselzung der llineralbestandteile wechselt nach der Beschaffenheit des Bodens, auf dem das Holz gewachsen ist. Die Hauplbestandleile sind: liali, lialk, Magnesia und Phosphorsäure Alle anderen Beslandteile treten mehr oder weniger zurück. Der Gelalt an llineralsảuren ist gering. Die Metalloxyde sind zum größten Teil als organisch saure Salze zugegen, welche beim Verirennen des Holzes Carbonale liefern. In der Holzasche herrscht daher die Jiohlensäure ror, die aber dem flolze als solchem nicht angehört. Der Umsland, daß die Holzasche zumeist aus Jiarbonaten bestehl, macht sie zur Gewiunung von Pollasche geeignel.

100 Gewichtstrile Rohasche enthalten:

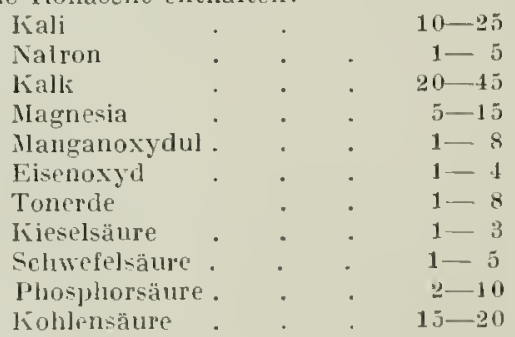

Der jüngste Teil des Iolzes, ..der sogenamule Splint". ist hellfarbig, wasserreich, enthält mehr gelöste Stoffe, namentlich mehr Stickstoffsubstanz. und ist daher auch rascher der Zersetzung unterworfen. Mit zunchmendem Alter zeigt der Splint bei den versehiedenen Holzarten ein ungleiches Verhalten. Bäume, bei welchem der

1) Chemiker Zlng. 190: 
Splint auch in späterem Alter sich nur wenig ändert, werden Splintbäume genannt, wie: Ahorn, Birke, WeiBbuche ete. Entwiekelt sich aus dem Splint allmählich ein wasserärmeres, diehteres und merklich dunkler gefärbtes Holz, so bezeichnet man die Bäume als Reifholzbäume, wic Tamne, Fichte, Linde, Weißdorn, Bimbaum etc. Eine weiter fortsehreitende Veränderung des Splintes findet sich in den Reifholzkernbäumen, wie Rotbuche, Esche, Ulme, Salweide ete., und an weitesten geht die Umwandhung in den Kernholzbäunen, wie: Lärehe, Föhre, Zirbelkiefer, Eibe, Wachholder, Eiche, Kirsche, NuBbaum, Hartriegel, Ebenholz, Mahagoni, Stockholz und allen Farbhölzern.

\section{b) Rinde ${ }^{1}$.}

\$3. In jugendlichen Zustande besteht die Rinde aus der Epidermis, dem primären Rindenparenchym und deın grünen prinären Baste. Bei weiterem Wachstum nimmt die Rinde an Dicke beträelıtlich zu und die in der tiefer liegenden Zone entstehende Korlischichte stößt das äußere, allmählich absterbende Gewebe, ,die sog. Borke", schuppenförmig ab. Der lebende Teil der Rinde, „das Fleisch", ist der sekundäre Bast und dic innerste Kiorkschichte. Vom sekundären Baste entsteht jedes Jahr eine neue Schichte, die sich deuthch von den früheren abhebt.

Die ehemische Zusammensetzung der Rinden ist eine sehr komplizierte und nur zum Teile erforseht. Der wiehtigste Bestandteil, weleher die technisehe Verwendbarlieit gewisser Rinden bedingt, ist der Gerbst of $\mathrm{f}$.

Als Gerbstoffe bezeichnet man eine Reihe schwacher Säuren, welche im Pflanzenreiche sehr verbreitet sind, vorzugsweise in den Rinden und in gewissen pathologischen Gebilden (Galläpfeln und Knoppern) vorkommen, ferner auch in den Blätterm, Samen und anderen Pflanzenteilen. Die Gerbstoffe sind in Wasser leicht, in Alkohol sehwer löslich und in Aether unlöslich. Sie besitzen einen herben, zusammenziehenden Geschmack, geben nit Eisensalzen blauschwarze oder grüne Niederschläge, fällen Eiweiß und Leimlösungen. Mit der tierisehen Haut vereingen sie sieh zu einer gesehmeidigen, fäuhniswiderstehenden Substanz „Leder“. Die Gerbstoffe werden nach den Pflanzen, von welehen sie abstammen, benannt. Als Typus der Gerbstoffe ist das $\mathrm{T}$ a $\mathrm{n} \mathrm{n}$ in oder die Eichenrindengerbsäure $\mathrm{C}_{14} \mathrm{H}_{10} \mathrm{O}_{9}$ zu betrachten. Es ist ein gelblich grauweißes, amorphes Pulver, von der vorhin angegebenen Lösliehkeit. Es bildet mit zwei Aequivalenten der Metalle Salze und fällt viele Alkaloide aus ihren Lösungen.

Einige Gerbstoffe sind Glykoside. Die hauptsäehliehste Verwendung finden die gerbstoffhaltigen Materialien zur Ledererzeugung.

Dem Tannin am nächsten steht die $\mathrm{G}$ a $\mathrm{ll} u \mathrm{ss}$ ä u $\mathrm{r} \mathrm{e}_{7} \mathrm{H}_{6} \mathrm{O}_{5}$; sic ist gewissermaßen das Hydrat des ersteren: $\mathrm{C}_{14} \mathrm{H}_{10} \mathrm{O}_{9}+\mathrm{H}_{2} \mathrm{O}=2 \mathrm{C}_{7} \mathrm{H}_{6} \mathrm{O}_{5}$. Tannin kann durch Wasseraddition in Gallussäure und diese wieder durch wasserentziehende Vittel in Tannin rückverwandelt werden. Die Gallussäure krystallisiert in feinen Nadeln, ist in heißem Wasser leicht löslich und gibt mit Eisenvitriol eine braune Färbung. An der Luft oxydiert sich die Ferroverbindung sehr raseh, wodureh die Flüssigkeit eine tiefschwarze Farbe anninmt. Gallussüure ist in reichlieher Henge in den Galläpfehn vorhanden, ferner findet sie sich in vielen Rinden und in anderen Pflanzenteilen. Ihre Hauptverwendung findet dieselbe zur Erzeugung der Schreibtinte.

Der Gerbstoffgehait der Rinden verschiedener Abstammung variiert in weiten Grenzen. In den einheimisehen Rinden, die als Gerbmaterial Verwendung finden,

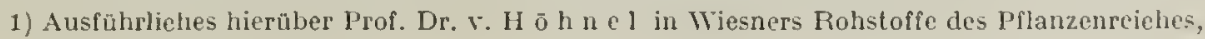
1. Bd. Leipzig 1900 . 
sind im huftrockenen Zustande durchschnittlich 5-15\% Gerbstoff enthalten. Unter den außereuropäischen Rinden gibt es hingegen mehrere, welche einen Gerbstoffgehalt von 20 bis über $35 \%$ aufweisen.

Für Europa ist die E i c he n rind e das wichtigste Gerbmaterial. In Mitteleuropa wird dieselbe vorzugsweise von der Stiel-oder Sommereiche Quercus pedunculata und von der Trauben- oder Wintereiche Qu. sessiliflora gewonnen. Ferner liefern gute Gerbrinde: die Zerreiche Qu. Cerris (Ungarn, liroatien, Slavonien), die Fermeseiche Qu. coccifera; die Grüneiche Qu. Jlex (Südfrankreich und Algier), die Korkeiche Qu. Suber (Italien und Spanien). In Nordamerika ist die Chestnutoakrinde von der Kastanieneiche Qu. Gastanea das wiclutigste Gerbmaterial.

Die Rinde wird entweder von alten Stämmen gewissemaßen nur als Nebenprodukt gewonnen, während das Holz die Hauptnutzung bildet, oder aber es wird die Rinde nur von jungen, 14-20jährigen Stämmen (Stangen) abgeschält und ist das Hauptprodulit (Schälwaldbetrieb). Die Altholzrinde ist borkig, dicker, ärmer" an Gerbstoff und daher minderwertig. Die Jungholzrinde ist dagegen dünn, glatt, borkenfrei und bildet das wertvollere Haterial. Wan unterscheidet 4 Sortimente von Eichenrinden: Dicke.

1. Die Spiegel- oder Glanzrinde, d. i. Junglıolzrinde von Stangen unter $10 \mathrm{~cm}$

2. Die Reitelrinde, von $10-12 \mathrm{~cm}$ dicken Stangen, ein Mittelding zwischen

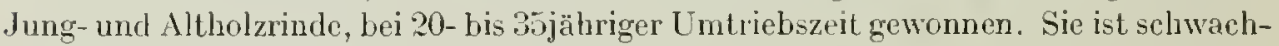
borkig und längsrissig.

3. Die geputzte Altholz- oder Grobrinde, bei welcher die Borlienschichte entfernt wurde.

4. Die ungeputzte Grobrinde oder raube Stammborke, d. i. Altholzrinde, an welcher dic Borke noch vorhanden ist.

Der Gerbstoffgehalt der Rinde nimmt von der Wurzel gegen den Gipfel hin um 3-5\% ab. Nan unterscheidet daher, speziell bei der Glanz- und Reitelrinde: Erd-, Mittel- und Gipfelgut. Das Fleisch der Altholzrinde ist nicht wesentlich ärmer an Gerbstoff als jenes von der Jungholzrinde; der Unterschied liegt hauptsächlich nur in der Borkenbildung. Während das Flciscl einen Gerbstoffgehalt von etwa $12-16 \%$ aufweist, besitzt die Borke weniger als die Iälfte davon. Durchschnittlich enthalten die besten Spiegelrinden 16-20, die Reitelrinden $10-14$, die geputzten Altholzrinden $8-10$ und die ungeputzten $5-8 \%$ Gerbsäure, im luftrockenen Zustande.

Neben der Eichenrinde ist für Deutschland, Oesterreich-Ungarn und die nördlichen Länder Europas überhaupt die F i c h $\mathrm{t}$ e n $\mathrm{r}$ in $\mathrm{d}$ e ein wichtiges Gcrbmaterial. Bäume von 50-80 Jahren liefern die beste Rinde. Die Rinde jüngerer Stämme ist. gerbstoffärmer. Bei Stämmen über 80 Jahren geht der Gerbstoffgehalt zwar nicht. wesentlich zurück, es entsteht aber eine größere Nenge von Farbstoff, welcher die Qualität der Rinde als Gerbmaterial beeinträchtigt. Außer dem Alter kommt aucls die Hölıenlage der Bäume in Betracht. Die aus alpinen Gegenden stamnenden Rinden sind im allgemeinen die wertvolleren. Durchschnittlich enthalten die besseren Sorten der Fichtenrinde 7 bis $9 \%$ Gerbstoff.

Die Schälung der Rinde wird immer erst an den gefällten Stämnen vorgenommen. Fichtenrinde wird hauptsächlich zum Gerben für schweres Unterleder verwendet.

Die T a n n e n r ind e ist gerbstoffarm (etwa $5 \%$ ) und wird nur im Gemenge mit anderen, gerbstoffeicheren Rinden zuweilen als Gerbmaterial verwendet. 
Die Lärch en r i n tl e enthält $10^{\circ}$ o Gerbstoff und noch clarüber, wird aber wegen des relativ seltenen Vorkommens dieser Holzart nu für lokalen Bedarf, vorzugsweise in England unıl Irland, zum Gerben von Schaffellen benützl.

Die Birken rin l e jst selır arm an Gerbstoff (etwa $3 \%$ ), wird aber, hauptsächlich ihrer lıellen Farbe wegen, zum Vorgerben und teilweise wolll auch zum Ausgerben verwendet.

Die Erlen rin de besitzt einen sehr hohen Gerbstoffgehalt, 16 bis $20 \%$, zugleich aber auch sehr viel Farbstoff und kann daher in den Gerbereien nur eine beschränkte Anwendung finden.

Die Weiden rin de $n$ sind für den Norden Europas ein wichtiges Gerbmaterial. Das russische Juchtenleder, sowie das dänische und sehottische Handschulheder wird lauptsächlich mit Weidenrinden gegerbt. Die besten Rinden liefem die stärkeren Ruten, welche einen Gerbstoffgehalt von 8 bis über $13 \%$ aufweisen.

Selten werden verwendet:

Walnuß-, Buchen-, ital. Pappel-, Ulmen- und Roßkastanien-Rinde.

Von den auBereuropäischen Gerbrinden sind namentlich jene von gewissen Akazienarten durch ibren Gerbstoffreichtum ausgezeichnet und werden unter der Bezeichnung W a t $t$ le- oder II i m o s a - Rinden von Australien, Südafrika und Südamerika naclı Eurona importiert. Die besten Sorten enthalten über 35̃, die minderen einige $20 \%$ Gerbstoff. Leberdies werden auch die Fernambukrinde, die Hemlock-Tannenrinde, die Temialia- und die Curtidarinde, sowje melrere andere als Gerbrinde in rlen Handel gebracht.

Sowohl aus den Rinden, als auch aus den gerbstoffreichen Hölzern werden dureb Ausziehen mit Wasser und Konzentrieren der Lösung in Vakummapparate Gerbstoffextrakte hergestellt, welche entwerler als Flüssiglieit $\left(30^{\circ} \mathrm{B}\right)$ orler als feste Substanz in den Handel kommen. Dieser Fabrikationszweig ist namentlich dort von Bedeutung, wo die mangelhaften Verkehrsverhältnisse den Absatz des Rohmateriales sehr erschweren.

Neben Gerbstoff finden sich in den Rinden noeh eine Reile anderer, zum Teile teehniseh verweribarer Stoffe, und zwar:

Ga 11 us ä u re, besonders in der Eichenrinde, in der Rinde der Edelkastanie, Roßhastanie ete.: andere orgaanisehe Säuren, namentlieh Oxalsāure und Pectinsāure. In vielen Rinden sind Oxalatkristalle (nneist Caleiumoxalat) ausgesehieden.

Glykoside. wie: das Quercitrin $\mathrm{C}_{21} \mathrm{H}_{22} \mathrm{O}_{12}$ in der Pinde von Quereus tinetoria, welehe als Farbnaterial eine hervorragende Rolle spielt und die anderen pilanzlichen Gelbstoffe fast gänzlieh verdrängt hat; ferner das Saliein $\mathrm{C}_{13} \mathrm{H}_{18} \mathrm{O}_{;}$in den Weiden und Pappelrinden; das tesculin $\mathrm{C}_{15} \mathrm{HI}_{16} \mathrm{O}_{9}$ in der Rinde der Roßkastanie, das Saponin $\mathrm{C}_{19} \mathrm{H}_{30} \mathrm{O}_{10}$ in der QuillajaRinde, deren Abkochungen gleieh jenen der seifenwurzel zum Waschen von Sehafwolle und diversen Geweben benützl wird; das Populin $\mathrm{C}_{20} \mathrm{H}_{22} \mathrm{O}_{3}+2$ aq in der Papperinde; das Phloridzin $\mathrm{C}_{21} \mathrm{H}_{24} \mathrm{O}_{10}+2$ aq in der Rinde der Obstbãume und noch einige andere.

$\mathrm{S} \mathrm{takke}, \mathrm{Zucker}, \mathrm{Gu} \mathrm{m} \mathrm{m}$. Ein gewisser Stärkegchalt ist in den Gerbrinden erwünscht.

A e the $\mathrm{r}$ ise he $\mathrm{O}$ ele, $\mathrm{H}$ arze, $\mathrm{B}$ a ls a m e. Die Zimtrinde, von Inehreren Cinnamomumarten stammend, dient als Gewūrz, für medizinische Zweeke und zur Erzeugung von Zimtôl.

Die Cascarilla-Rinde wild ihres ätherisehen Oeles wegen in der Parfümerie, in der Medizin, zur Herstellung von Weihrach, Tabakbeizen ele. Verwendet. Leber Harze und ätherische Oele siehe spãter).

B it terstoffe und $t l$ li a lo ide. Den hervorragendsten Platz nehmen in dieser Ilinsieht die Chinarinden ein, welche von Bāumen der insudamerika cinheimischen Cinchona abstammen, gegenwärtig aber auch in mehreren anderen Ländern kulliviert werden. Dip größten Produktionen weisen Ceylon und Java auf. Der Wert dieser Rinden liegt in ihrem Gehalt an Alkaloiden, deren heute 10 verichiedene, gut cliarakterisierte bekannt sind. Die wichtigsten kristallisierbaren China-Nkajoide sind: das Chinin und Chinidin $\left(\mathrm{C}_{20} \mathrm{H}_{23} \mathrm{X}_{2} \mathrm{O}_{2}\right)$, sowie das Cinehonin und Chinchonidin $\left(\mathrm{C}_{10} \mathrm{H}_{22} \mathrm{~V}_{2} \mathrm{O}\right)$. Der . llkaloidgehalt der Ikinden ist auBerordentlieh variabel, von 1 bis 12 l'roz. und auch noch darüber. Die Wurzelrinden sind im algemeinen 
reichhaltiger als die Stamnrinden; auch geben die Rinden von den kultiøierten Bäumen mehr als von den wildwachsenden. Die Alkaloide werden fabriksmäßig aus den Rinden gewonnen und bilden eines der wichtigsten Arzneimittel.

Endlich sind als Rindenbestandteile noeh anzuführen: Zellulose, Lignin, Suberin, Farl.stoffe, Extraktivstoffe, Stiekstoffsubstanz, Hineralbestandteile und Wasser. Der Stiekstoffgehalt der Rinden ist höher als in Holze und beträgt in den älteren Stammrinden $\mathbf{0 . 4 - 0 . 6}$ und in der Reisigrinde 0.6-0.8 Proz. Der Gehalt an Mineralstoffen schwankt von 1.5 bis über 7 Prozent und der Wassergehalt durchschnitlich zwischen 50 und 60 , steigt aber auel bis über 70 Proz. Ein höherer Wassergehalt ist speziell bei den Gerbrinden sehr naehteilig. Auf feuchten Rinden siedeln sich sehr leicht Schimmelpilze (namentlich Pennieillium glaucum) an, welche den Gerbstoff rasch oxydieren. Das inöglichst schleunige Lufthoekenwerden der Rinden ist daher ein Haupterfordernis bei der Rindengewinnung.

\section{e) Kork.}

§4. Die Korkschichte ist, wie schon früher erwähnt, ein Bestandteil der Rinde. Bei den meisten Holzgewächsen ist aber diese Schichte sehr schwach. Nur bei einigen Eichenarten entwickelt sich der Kork so mächtig, daß er gewonnen und technisch verwertet werden kann. In hervorragender Weise ist dies der Fall bei der Forkeiche „Quercus suber", welche in Algier und Marokiso, sowie in Spanien und Portugal zu Jause ist; femer auch bei einer mit der ersteren nahe verwandten Eicherrart, ,Quercus oceidentalis", die im südlichen Frankreich gröBere Bestände bildet. Anch in Italien, Dalmatien und in der Türkei kommt Korkeiche vor, welche jedoch nur mindere Forkqualitäten liefert. Bis zum 3. Jahre bleibt die Epidernis erhalten, dann erst bildet sich Kork. Wenn die Stämme etwa $10 \mathrm{~cm}$ dick geworden sind, wird diese Korkschichte (del sog. männl. Kork) abgenommen. Er ist lart, spröde und zu Stöpsehn oder dergl. unverwendbar. In den folgenden Jahren entsteht der weiche, elastische (sogen. weibliche liork). Nach Verlauf von etwa 8-10.Jahren ist die Korkschichte so dick geworden, daß sie abgeschält werden kann. Die Schähung wird dann alle 8-10 Jahre wiederholt, bis der Baum etwa 150 Jalıe alt geworden ist. Die abgelösten Korkplatten sind $0.3-0.8 \mathrm{~m}^{2}$ groß und von 5 bis zu $20 \mathrm{~cm}$ dick. Sie werden an der Außenseite von den anhaftenden Joosen etc. gereinigt, kurze Zeit in siedend heißes WVasser getaucht, behufs Quellung und Erweichung, sodann flach ausgebreitet. gejpeßt, getrocknet und in Ballen verpackt. Geschicht das Trocknen über freien Feuer, so wird die Außenseite dabei etwas gesenlit; die Ware heißt dann schwarzer Tiork, zum Unterschied von den an der Sonne getrockneten weißen Kork.

Die Außenseite der Korkplatten ist rauh und besitzt Längsrisse, während die Innenseite glatt erseheint und mit radialen Poren (Lenticellen) versehen ist. Je weniger Poren vorhanden sind, desto wertwoller ist der Kork. Am Quersehnitt tritt die Begrenzung der Jahresringe darch dunklere wellige Linien hervor. Die Farbe des Korkes ist grau, gelbrot bis röllich.

Die Korkzellen sind 5 -6seitige, mit Luft gefülte Prismen. Die Zellwand besteht naclt Hölnel aus 5 Lamellen, von welchen die mitlere aus stark verholzter Zellulose, die beiden unmittelbar anschließenden aus Suberin mit renig Zellulose und die beiden äußeren aus schwächer verholzter Zellulose gebildet sind.

Der eharakteristische Bestandteil des Korkes ist das ,Suberin", welehes in einer Menge von 70 bis $80 \%$ vorhanden ist. Es besteht der Hauptsache nach aus einem Gemenge von talgund wachsartigen Stoffen, mit einer niehtfettigen Substanz. Ferner sind im liork vorhanderi: Gerbsäure, Phlobaphen, Phloroghein, $1-3 \%$ Stickstoff und $0.5 \%$ Asche. Luftrockener Kiork enthălt eirca $4-5 \%$ Wasser.

Die wichtigsten Eigenschaften des Kiorkes sinu: seine Elastizität, Undurchlässigkeit für Flüssigkeiten und Gase, Widerstandsfähigkeit gegen äußere Einflüssc, außerordentliche Leichtigkeit und sehr geringes Wärmeleitungsvernögen. Die hauptsächlichste Verwendung findet der Kiork belianntlich für Stöpsel.

Feine liorke für Laboratoriunszwecke, Champagnerflaschen usw. müssen so geschnitlen sein, daß die J'orenkanāle senkreeht zur Stöpselachse stelıen, um einen volliommen dichten Abschluß zu erzielen. Alle anderen Verwendungen (für Schuhsollen, Schwimmgürtel, Fischereiartikel, elastische Unterlagen u. dgl.) sind von geringerem Belang. Dagegen finden die liorli- 
abfille, welche sich beim Zuschneiden der stöpsel ergeben, ausgedehnte Inwendung zur Er-

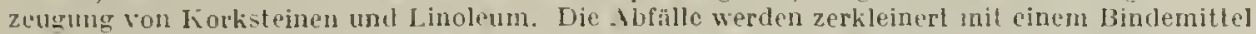
vermengt und in Formen gepreßt. Forkisteine werden als Wärmeschulz-[mbülumgen für lialt- und Warmwasser-Leitungen und Reservoire, für Dampfleitungen, Trockenlegung und Isolierungen für Mauerwände und dgl. verwendet.

Linoleum wird hergestellt, indem man Leino] durch liochen mit Salpelersăure oxydiert, liorhpulver und Farbmaterialien einrührt, die so erhaltene Masse in dünuer Schichte auf cin Gewebe aufträgt und in heißer Luft weiter oxydiert, wobei sie fest wird. Linoleun dient als Fußboden- und Sliegenstufenbelag, ist sehr dauerhaft und läßt sich leicht reinigen. Kanplulikon (liortizin), ebenfalls ein Fußbodentelag, wird bergestellt aus einem Gemenge von liorkabfällen mit liautschuk, Guttapercha oder ringedickten Leinöl, in Form von Platten. ,Spanisch Schwarz", ejne schwarze Farbe, ist Korkliohle.

\section{d) Gallen ${ }^{1}$.}

§5. Die Gallen oder Galläpfel sind krankhafte Gebilde von mehr orler minder liugeliger Gestalt und Erbsen- bis Walnußgröße, die auf Blättern und jungen Zweigen einiger Pflanzengattungen, besonders aber auf Eichen vorkonmen. Sic entstehen durch den Stich der Gallwespe, von welchen es mehrere Arten gibt. Dieselbe durchbohrt mit ihrem Legestachel dic Haut der Blätter oder jungen Pflanzenteile und deponiert in die Stichwunde ein befruchtetes Ei. An dieser Stelle bildet sich durch SaftausfluB und Zellenerweiterung eine Anschwelhung, welche die entstehende Larve umschließt und derselben Nahrung bietet, bis das ausgewachsene Insekt die Hülle durchbolırt und verläßt. Solange das Insekt seine Behausung noch bewohnt, also noch nicht durchbohrt hat, sind die Galläpfel schwärzlich oder blaugrau, höckerig, hart, schwer, sehr gerbstoffreicl und besitzen im Innern eine Höhlung mit der mehr oder minder entwickelten Gallwespe. Die bereits durchbohrten Galläpfel sind blaßgelblichgrau, glatt, schwanmig, leicht, und enthalten weniger Gerbstoff. Denmach werden im Handel schwarze und weike Galläpfel unterschicden.

Der wertvolle Bestandteil der Gallen ist die eisenbläuende Gallusgerbsäure (Tannin), welche beim Kochen init verdünnter Schwefelsäure und Kalilauge Gallussäure liefert:

$$
\frac{\mathrm{C}_{14} \mathrm{H}_{10} \mathrm{O}_{9}}{\text { Tannin }}+\mathrm{H}_{2} \mathrm{O}=\frac{2 \mathrm{C}_{7} \mathrm{H}_{6} \mathrm{O}_{5}}{\text { Gallussäure }}
$$

Gute Galläpfel enthalten im lufttrockenen Zustand gegen $60 \%$ Tannin. Am reichsten sind die chinesischen Gallen, deren Gerbstoffgehalt je nach dem Alter zwischen 59 und $77 \%$ schwankt.

Der Stickstoffgehalt der Gallen ist gering. Als weitere Bestandteile sind zu nennen: Dextrose, Stärke, Gummi, fettes Oel, Chlorophyll, Hineralstoffe und Wasser.

Der Aschengehalt beträgt $1 \frac{1 / 2}{2} \%$. Der Wassergehalt ist in der frischen Galle über 80 , in der lufttrockenen etwa $12 \%$.

Nach ihrer Herkunft werden unterschieden:

1. Die kle in as i a t is chen Galläpfel, von einer straucharligen Eiche (Quercus lusitanica) abstammend, welche kaum $2 \mathrm{n}$ hoch wird. Der Stich rürt von der Wespe ,Cynips gallae tinctoriae" her. Diese Galläpfel sind kugelig bis eifömig, mit mehr oder weniger spitzen Höckern.

Die beste Sorte sind die aleppischen, von $2^{1 / 2} \mathrm{~cm}$ Durchmesser, dunkelgrün bis schwärzlich: Gerbstoffgehalt bis zu 60 Proz. Hindere Sorten sind dic mossulischen von etwas hellerer Farbe, die smyrnaer mit $3-5 \mathrm{~cm}$ Durchnesser, gelblich gefärbt und durchbohrt, Tanningehalt nur 20-30 Proz., und die Bassora-Gallen (oder Sodonıāpfel), von ungefähr $4 \mathrm{~cm}$ Durchmesser, braun gefärbt, sehr leicht und durchbohrt, Tannin-Gehalt im Nittel etwa 27 Proz.

2. Die europäis che $n$ Galläpfel sind hleiner als die vorgenannten und stammen von anderen Eichenarten. Hierher gehören: die Moreagallen von Qu. Cerris, mit circa 30 Proz. Gerbstoff; die Istrianer-Gallen ron Qu. llex, bis zu to Proz. Gerbstoff; die kleinen ungarischen Gallen von Qu. sessiliflora und Qu. pedunculata, nur $1 \mathrm{~cm}$ groß; die großen ungarischen Gallen

1) Ausfühlich behandelt von Dr. W. Figdor in Wiesners „Rohsloffe des Pflanzenreiches". 
von $1 \frac{1}{2}$ bis $3^{1 /}{ }_{2} \mathrm{~cm}$ Durchmesser; die mitteleuropäischen Gallen ron verschiedenen Eichenarten, $1-21 / 2 \mathrm{~cm}$ groß, mil elwa $15 \%$ Gerbstoff.

Eine besondere Art ron Gallen sind die ki n o p e r n. Die echten ungarischen Finoppern sind Auswiuchse, welche durch den Stich der Gallwespe ,Cynips calicis", und zwar an den jungen Früchten fon Quercus pedunculala und Qu. sessiliflora entstehen. Wälurend die Eichel in ihrer Entwicklung zurückbleibl, bilden sich an ihrer Außenseite Auswüchse, welche bisweilen so groß werden, daß sie selbst den Grund der Eichel umschließen. Diese Gebilde sind gelbbraun gefärbt, unfömig, eckig und werden bis zu $4 \mathrm{~cm}$ groß. Sie werden in den Eichenwaldungen Ungarns, Slavoniens und der Bukowina vom August bis Olitober gesammell und bilden ein vortreffliches Gerbmalerial, welches nach Eitner 24-35\% Gerbstoff enthält.

Die levantinischen linoppern oder Valonen sind die becherartig verwachsenen Decklulätter der Früchte einiger in südlichen Europa, lïleinasien und Syrien einhejmischen Eiclicnarten. Ihr Gerbsloffgehalt soll bis zll $45 \%$ betragen.

3. Die $\mathrm{ch}$ in es is $\mathrm{ch}$ e $\mathrm{n}$ Galläpfel stammen nicht von Eichen, sondern von einigen Rhus-Arten und sollen durch den Stich von Blaltläusen hervorgerufen werden. Es sind feste, ziemlich lichte, blasenartige Gebilde von der Größe einer Hasel- bis Walnuß, sehr unregelmäßig geformt und mit Höckem versehen. Sie kommen auf den Blatıstielen, Fiederblätlchen oder Zweigspilzen vor und weisen einen sehr hohen Gerbstoffgehalt, bis zu $7 \%$ \% auf.

Auch auf einigen Pistacia- und Tamaria-Arlen finden sich erbsen- bis nußgroße Gallen, die von Marokko, Algier, Persien, Arabien und Indien aus in den Handel gebracht werden.

\section{Konservierung des Holzes.}

§6. A 1 I g e m e i n es. Das Holz ist verschierlenen nachteiligen Veränderungen ausgesetzt. Dureh Wasser-Abgabe und -Aufnahme erfährt es Gestaltsveränderungen, welche als Schwinden, Werfen und Reißen bezeichnet werden und namentlich im zugerichtelen und fertig bearbeiteten Holze gefürchtet sind. Verschiedene Insekten zerfressen das Holz, bohren Gänge in dasselbe, wobei das sogenannte Wurmmehl entsteht; einige derselben treiben dieses Zerstörungswerk nicht nur im lebenden Baume, sondern setzen es auch noch in den bearbeiteten Holzgegenständen fort.

Mikroorganismen pflanzlicher Natur zersetzen das Holz und veranlassen Fäulnis, Verwesung und Vermoderung desselben, wodurch allmählich eine Lockerung des Gefüges, schließlich aber der gänzliche Zerfall der Holzsubstanz herbeigeführt wird. Endlich wird das $1 \mathrm{Iolz}$ auch von höher organisierten Pilzen befallen und zerstört, unter denen vor allen der echte "Hausschwamm" (Merulius lacrymans) der gefürchtetste ist.

An allen diesen Schädigungen nimnt der Holzsaft, u. zw. sowohl das Wasser wie auch die in demselben gelösten Bestandteile, als Nahrungsstoffe für die tierischen und pflanzlichen Sehärllinge, einen hervorragenrlen Auteil. Aber auch die Bestandteile des Holzskelettes sind als Nährsubstrate für diese Kleinlebewesen niclıt zu ïbersehen, wie ja dies die Vorgänge bei der Zerstörung organischer Substanz in der Natur alltäglich lehren.

W. Omelianski ${ }^{1}$ ) ist es gelungen, die anaëroben (luftscheuen) Erreger der Wasserstoffund Metlan-Gärung der Zellulose in Reinkultur zu züchten, zwei Stäbchen-Baklcrien, welehe sich in ihrem Jugendzustande nur durch ilıe Größe und Form der einzelnen Stäbchen unt'rscheiden, später aber - zur Zeit der Sporenbitdung - dieselbe Gestalt (eines Tromnelschlägels) annehmen. Der Methan-Bacillus isl in allen seinen Abmessungen zarler als der WasserstoffBacillus.

Physiologisch clarakterisieren sie sich dalurch, daß die Methan-Bazillen die Zellulose in Jetlian, liohlensäure und flüchtige organische sãuren (der Hauptmenge nach Essigsäure und Butlersäure) zerlegen, während die Wasserstoff-Bazillen, an Stelle des Jelhans, Wascrlsloff absjallen.

Auch aërobe Bakterien vermögen die Zellulose zu spallen ebenso wie denitrifizierende, welche in Gegrenwart ron Zellulose Nitrate zu Nitrilen reduzieren, die Zellulose selbst aber in gleicher Weise zerselzen, wie die anaëroben. Das Gleiche gilt auch von gewissen schimmeipilzen.

Welcher Art die Einwirkung der Mikroorganismen auf die Zellulose ist, konnle bis mun mit Sicherheil noch nicht festgelegt werden; doch dürten auch hier, wie z. B. bei ter livi-

1) Lafar, IIandb. der techn. Myliologie, 111. Bu. Jena 1904-1906. 
mung del Samen höherer P'flanzen, Zellulose lösende Enzyme (Cytasen oder Zellulasen) die vollsthndige Zerlegung der Zellulose vorbereilen. Auch das Mycel des Ilausschwanmes scheint mittelst einer Cytase die Zellulose zu lösen, un sie dann vielleicht auch als Nahrstoff zı henützen, jedenfalls aber um sich so den Eingang durch die Zellwandungen in das Jolzinnere zul balinen.

Die bekannten Erscheinungen der Trockenfäule, Rotstreifigkeit, des Blau-, Grau- oder Braunwerdens des Rohholzes, ler slaubigen Verwesung drsselben ete. liaben alle ihren Grund in Pilzweherungen oder der Arbeit von Mikrourganisnen überhaupt, deren Erreger zum Teil schon lekannt sind, zum Teil abre noch der Bestimmung harren.

Un num das Holz vor alten den genamnten Schädigungen zu bewahren, wird es für viele Zwecke schon grenügen, den in ihm enthaltenen Ueberschuß an Wasser* soweit abdunsten zu lassen, daß das Holz als gut lufttrocken gelten kann. Soleh trockenes Holz, eventuell noch mit einem dichten Ueberzug versehen, wird sich in trockener Luft, z. B. unter Dach, viele Dezennien hindurch konservieren. Befindet sich dagegen das Holz im Freien, so ist es von geringer Dauer, und am sehnellsten unterliegt es der Zersetzung im Boden, wo es oftmals durchnäßt wird, ohne inzwischen gehörig austrocknen zu liönnen. Anaerobe Bakterien finden hier ein geeignetes Feld und es ist dann in diesem Falle die Entfernung des Wassers resp. Zellsaftes allein nicht ausreichend, sondern bakterizide Nittel, Antiseptika, müssen in Anwendung gebracht werden, wenn man auf eine selbst nur mäßige Dauer des Holzes reflektiert.

Dementsprechend sind denn auch die Methoden und Mittel, welche man zur Holzhonservierung anwendet, dem speziellen Zweek entsprechend versehieden.

Dic Methoden, welche zur Konservierung des Holzes in Anwendung kommen, sind folgende:
1. Das Trocknen;
2. Das Auslaugen;
3. Das Dämpfen;
4. Die Umlıüllung;
5. Die Imprägnierung.

$\S 7$. 1. Das $\mathrm{Trock} n \mathrm{en}$. Es ist dies die einfachste und ganz allgemein angewandte Methode der Holzkonservierung.

Bleibt $\mathrm{Holz}$ in zugerichteten oder wenigstens entrindeten Zustande an der Luft liegen, so verliert es fortwährend an Wasser, bis ein gewisser Gleichgewichtszustand zwischen dem Wassergelialte der Atmosphäre und der Hygroskopizität des Holzes eingetreten ist. In diesem Zustande nennt man das Holz lufttrocken. Dasselbe enthält dam noch 10-IS\% Wasser. Die Zeit, welche das Holz braucht, um lufttrocken zu werden, ist in erster Linie von der Zurichtung abhängig. Die gewöhnlichste Art der Zurichtung des Werkholzes ist die Bretterform, und diese ist für die Trocknung sehr gut geeignet, wenn die Aufschichtung so gesehieht, daß sich die einzelnen Bretter tunlichst wenig berühren und Luft überall frei rhurchstreichen kann. Sind die Bretterstöße im Freien aufgestellt, was in der Regel der Fall ist, so sollen sie durch ein übergreifendes Bretterdach gegen direkte Benässung und gegen Sonnenbrand geschïtzt scin. Auch unter günstigen Bedingungen dauert es aber einige Monate, bis die Bretter lufttrocken geworden sind. Faßholz wird, zu Rohdauben zugeschnitten, in gleicher Weise in Stößen aufgeschichtet, an der Luft getrocknet. Bei Holz von stärkeren Dimensionen, ,Pfosten oder Rundholz", geht die Austrocknung naturgemäß langsamer vonstatten. Das größte Hindernis der Austrocknung des Holzes in ganzen Stämmen ist die Pinde, welche einen fast dichten Abschluß bildet. Berindete stämme werden selbst nach jahrelanger Aufbewahrung nicht lufttrocken und unterliegen schon nach kurzer Zeit der Zersetzung. Ganz besonders ist dies bei sehr wasserreichen Holzarten, wie z. B. Birke der Fal!. 
Un die Trockmung zu beschleunigen, wird zuweilen auch kïnstliche Erwärmung angewendet.

Die Trocknung geschicht in eigenen Trocken-liammen oder -Kanälen, in welchen das zu troclinende Holz liegend und quer auf die Zugrichtung so cingeschichtet wird, daB die Luft zwisehen den einzelnen Stücken ungehindert zirkulieren kann. liammen'n mit direkter Heizung, wobei das zu trocknende Holz nit den Heizgasen in Berührung kommt, sind veraltet und nur für Hölzer, welche keine feinere Zurichtung erfahren, anwendbar. In allen anderen Fällen muß in Kammern mit Dampfoder Heißluftleizung getrocknet werden.

Die Größe des Trockenraumes ist der Länge des Holzes und der geforderten Leistung angepaßt. Schr große Räume sind nicht zweckmäßig, weil dic Erwärmung und Austrocknung keine gleichmäßige ist. Für sehr große Leistungen ist es besser, mehrere Kammern oder Kanäle anzuwenden. Gewöhnlich geht man nicht über 300 bis $400 \mathrm{~m}^{3}$ hinaus, wovon $1 / 3$ auf die $\mathrm{Holz}$ füllung und $2 / 3$ auf den Lufłraum entfallen. Häufig ist aber der Gesamtraum viel kleiner. Die Grundfläche ist länglich viereckig. Die Kanmern sind aus Mauerwerk oder aus Holz hergestellt. Im letzteren Falle muß für gute lsolierung durch Doppelwānde mit schlecht leitendenı Füllnaterial gesorgt seiı.

Bei Dampheizung wird unter dem Lattenfußboden der Fanmer ein Rippenheizrohrsystem gelegt, an welchem die vorüberstreichende Außenluft sich erwärmt und zwisehen den Latten in den Trockenraum aufsteigt. Zur Heizung dient in der Regel Auspuffampf von der Belrielsmaschine und ist durch Einschaltung einer Sicherungsvorrichtung dafür gesorgt, daß ein schädlicher Rücksto $B$ auf die Dampenaschine nicht erfolgt. Das Heizrohrsystem hat ein schwaches Gefälle, damit das Kiondenswasser ablaufen kann. Damptheizung ist nur bei Fabrikanlagen zweckmäßig, in denen man die Wärme des Auspuffdampfes ausnützen will. Häufig reicht aber derselbe für sich allein nicht, so daß auch noch direkter kesseldampf zu Hilfe genommen werden muß, was diese Art der Heizung unökonomisch macht.

Die HeißJuftheizung ist in den meisten Fällen vorzuzichen. Davon gibt es zwei Varianten: die Ofenheizung und die Kanal- oder Rohrheizung.

Bei ersterer wird der Heizapparat (Ofen oder líalorifère) entweder unterhalb oder seitlich neben der Trockenkammer aufgestellt. Die Heizvorrichtung besteht aus den gemauerten Feuerherd, an welchen sich ein gußeiserner Rippenheizkörper anschließt. Die Außenluft streicht an den Heizkörper vorbei und gelangL durch Zugöffnungen in den Trockenraum.

Bei der Jianalheizung ziehen die Heizgase durch einen dünnwandigen Chamottekanal mit daranschließendem Blechrotursystenı. Der Feuerherd liegt außerhalb der Kanmer in dem Boden vertieft, whihrend der Feuerzug unter den Lattenboden des Trockenraumes verläuft und in den liamin einmündet.

Die Ventilation des Trockenraumes muß durch Schicher, Jilappen oder Jalousien regulierbar sein und orfelgt entweder durch den natürlichen Zug oder auf nechanischem Wege. Im ersteren Falle ist ein entsprechend hoher und weiter Dunstschlot erforderlich. Um den Elfekt desselben zu crhöhen, führt man das Rauchrohr, durch welches die Essengase von Heizapparat entweichen, ein. Auch ist es zweckmäBig, eine drehbare llaube mit seillicher Aussl römung und Windfahne auf dem Schlot anzubringen. Diese Haube verhindert einen Rückstau bei windigem Wetler und wirkt immer saugend, gleichgültig von welcher Richtung der Wind auch liommen mag.

Trotz dieser Vorkehrungen ist aber die Ventilation durch den Dunstschlot doch immer von der Temperaturdifferenz zwischen Trockenraum und Außenluft ablängig. Es ist daher dort, wo man eine bewegende Firafi zur Verfügung hat, die Lüftung auf mechanisehem Wege, durch Einblasen oder Absaugen der Luft, vorzuziehen, weil man damit in der Lage ist, die Geschwindigkeit der Luftströmung nach Bedarf zu regulieren.

Es gibt Trockenanlagen für periodischen und solehe für kontinuierlichen Betrieb. Bei ersteren, den Trockenkammern, wird das zu trocknenle Holz cingeschichtet und nach vollendeter Trocknung der Raum abkühlen gelassen und entleert. Bei kontinuierlicher Arbeit, der Kanaltroclinung, wird das Holz auf Rollwagen regelrecht verladen, an der rücliwärtigen Stirnseite des Kanals cingefahren, je nach dem Grade der 'Trockinung allmählich gegen die Richtung des Luftzuges nach der' wärmeren Zone vorgeschoben und an anderen Ende des Kanals ausgefahren. Für jeden herausgerollten Wagen wird an der anderen Stirnseite ein mit frischem Holze beladener eingeschoben, so daß der Kianal immer voll beschickt ist.

Bei der liüstlichen Iolztrocknung sind folgende Nomente zu beachten: 
1. Das Holz darf nur bei mäßiger Temperatur getrocknet werden. Je feuchter das Holz ist, desto langsamer nuß die Trocknung erfolgen. Zu rasches Emärmen hat ein Werfen und Reißen des IIolzes zur Folge. Als Maximaltemperatur gilt 50-60 C.; in der Regel wird aber bei $35-40^{\circ} \mathrm{C}$. fertig getrocknet.

2. Die Ventilation darf lieine zu starke sein; es genügt, wem in etwa 5 Mlinuten die Luft einmal erneuert wird. Uebrigens hängt dies hauptsächlich vom Fenchtiglieitsgelalt der Luft ab. In sehr trockener Luft geht die Terdunstung des Wassers zu rasch von statten und ist ein Rissigwerden des Holzes zu befürchten.

3. Das Holz muß nach der Trocknung noch etwa $10-12 \%$ Wasser enthalten. Vollständig ausgetrocknetes Holz ist spröde, läßt sich schlecht bearbeiten, zieht begierig Feuchtiglieit an und ist dadurch dem Schwinden ausgesetzt.

4. Die Zeitdauer der Trocknung ist verschieden, je nach der Form und Größe der Holzstücke, dem Feuchtigkeitsgehalte und nach der Holzart. Für Bretter und Hölzer von geringem Querschnitt überhaupt können 3-5 Tage, für stärkere Dimensionen $8-10$ Tage gelten.

Nach einen amerikanischen Patente wird dic aus dem Trockenraum kommende, mit. Feuchtigkeit beladene Luft in cinen Jiondensator geleitet, um das Wasser durch Abkühlung nicderzuschlagen. Die teilweise entwässerte Luft kelirt durch den Heizapparat wicder in den Trockenraum zurück, so daß mit ein und derselben Luftmenge die Trocknung zu Ende geführt wird. Anfänglich wird die Luft nur wenig entwässerl, so daß sie noch mit einem bestimmten Feuchtigkeitsgehalt in die liammer cintritt. Je weiter die Trocknung des Holzes fortsehreitet, desto mehr wird auch die Luft entwässert. Es soll dadurch einer zu raschen Trocknung und dem damit verbundenen Schwinden und Reißen des Holzes vorgebeugt werden.

Dieses Verfahren ist nur dort anwendbar, wo große Wassermengen für die Kiondensation zur Verfügung stehen, und hat üherdies noch den Nachteil, daß die Luft stark abgekühlt und dann wieder erwärmt werden muß. Der gleiche Zweck läBt sich einfacher und billiger erreichen, wenn die aus der Ḱamner ahgesaugte, feuehte Luft mit einen gewissen sukzessive steigenden Anteil von frischer Außenluft gemischt wird.

\$ 8. 2. D a s A us la u gen. Es hat den Zweck, den Zellsaft zu entfernen. Auch wird dadurch die hygroskopische Eigenschaft des Holzes abgeschwächt; es wird eher lufttrocken, schwindet weniger und gleichmäßiger. Die einfachste Methode des Auslaugens besteht darin, daß man zugeschnittenes, oder wenigstens von der Rinde befreites Holz längere Zeit, mindestens einige Wonate, in fließendem Wasser liegen läßt. Die Auslaugung kann nur durch Diffusion erfolgen und geht daher auBerordentlich langsan vor sich. Stärkere Stämme müssen sogar mehrere Sommer hindurch unter Wasser liegen bleiben. Zum Auslaugen soll nur frisch gefälltes Holz verwendet werden. Bleibt dasselbe längere Zeit an der Luft liegen, so werden gewisse Saftbestandteile unlöslich. Der Effekt des Auslaugens mit lialtem Wasser ist aber, selbst auch bei frisch gefälltem Holze, kein sehr erheblicher. An eine vollständige Entfernung aller löslichen Bestandteile des Holzes ist nicht einmal bei schwächeren Stücken zu denken.

Besser gelingt die Auslaugung mit kochendem Wasser, welche jedoch nur bei kleineren Holzstücken (Schindehn, Drechsler- und Wagnerholz) anwendbar ist. Als Schutzmittel gegen die Zersetzung des Holzes ist das Auslaugen nur von untergeordneter Bedeutung; dagegen leistet es aber zur Verluinderung des Schwindens und Reißens gute Dienste.

\$ 9. 3. D a s D ä m p f en. In jeder Beziehung effektvoller als das Auslaugen ist das Dämplen des Holzes.

Jlan benūtzt hierzu meist einen starkwandigen Holzkasten von $3-4 \mathrm{~m}$ Länge, $11 / 2-2 \mathrm{~m}$ Breite und Hōhe, welcher mit Eisenspangen und Zugankern zum Nachzielien zusammengehalten wird. Zur Dichlung der Stoßfugen henützt man Hanf-oder Zcllulosepackung. Die beiden Stirnwande sind behufs Beschicliug und Entleerung des Kastens zum Abnehmen eingerichtel und werden durch Eisenschienen mit umlegbaren Schraubenbolzen festgehalten. Die Dichtung 
geschieht in gleicher Weise wie bei den Stoßfugen. Der Kasten ist auf Polsterhölzer, etwas geneigt gestellt und an der tiefsten Stelle mit einem Ablaufhahn für das liondenswasser verselien. Am entgegengesetzlen Ende des liastens mündet das Dampfzuleitungsrohr ein. Um an Dampf zu sparen, muB mögtichst viel Holz in den kasten eingebracht werden, wobei jedoch zu beachten isl, daß sich die Flächøn der einzelnen Holzstüclie tunlichst wenig berühren. Bretter werden hochkanlig cingestellt.

Nachden der Kasten beschickt und verschlossen ist, wird mit der Dämpfung begonnen. In den ersten stadien ist das ablaufende liondenswasser ziemlich lilar und nur wenig gefärbt; später wird es trühe, dunkelgefärbt und besitzt einen eigentümlichen Holzgeruch von den ausgelauglen Extraktivstoffen. Ian setzt las Dämpfen so lange fort, bis das Kiondenswasser klar und farblos abläuft, zun Beweis, daß die Auslaugung, soweit sie ubertıapt hier gelingt, beendet ist. Die Dämpfung nimmt je nach den Dimensionen der Holzstücke $40-80$ Stunden in Anspruch. Ein Ueberdruck kann natürlich in einem Holzkasten nicht angewendet werden, und wäre auch nicht zweckmäßig, weil das Holz dadurch an Festigkeit verliert. Nach dem Dämpten wircl das $\mathrm{Holz}$ an der Luft oder in einem Trockenapparat ausgetrocknet. Statt der Holzkästen verwendet man auch gemauerte oder eiserne Dämpfapparate.

Durch die Einwirkung des Dampfes verändert das Holz seine Farbe und wird im allgemeinen dunkler. Buchenholz wird braun, Eichenholz schwarzbraun, Ahorn rötlich, Kirschbaum gelb bis rot usw. Gedämpftes Holz ist dem Werfen und Reißen weniger ausgesetzt, trocknet rascher und besitzt ein geringeres spez. Gewicht als nicht gedämpftes von gleichem Trockenheitsgrade. In noch warmen, durchfeuchteten Zustande, wie es aus dem Dampfkasten komnt, ist es biegsam und behält die gegebene Form aueh nach dem Erkalten und Trocknen bei. Von diesem Verhalten wird bei der mechanisehen Bearbeitung des Holzes für die Möbelfabrikation, Wagenbau, Sehiffbau, Faßfabrikation etc. die ausgedelnteste Anwendung gemacht.

Eine andere Art der Dämpfung, welche zugleich eine Trocknung des Holzes bewirkt, wurde zuerst in Amerika eingeführt und beruht auf ter Anwendung überhitzlen Wasserdampfes. Das $\mathrm{Holz}$ wird in einen starkwandigen, mit piner Wärmeschutzhülle umgebenen Eisenkessel gebracht und gespannter Dampf eingeleitet. Der Dampf passiert vor dem Eintritt in den Kesiel ein Röhrensystem, in welchem er nicht nur getrocknet, (1). h. von dem mitgerissenen Wasser befreil), sondern auch übertilzt wird. Im Anfang wird der Zellsaft durch den Dampf verdrängt und mit dem Kondensationswasser abgelassen. Bei Jängerer Einwirkung des überbitzten Dampfes kann das Holz auf einen Feuchtigleitsgehalt von $10 \%$ gebracht werden. Dieses Verfahren hat den Vorteil, daß die dem Holze schon vom Walte her antaftenten parasitischen und saprophytischen f’ilze unschädtich gemacht werden, daß ferner ein Rissigwerden des Holzes nicht einiritt. Dagegen aber sind als Nachteile zu bezeichnen: 1. Dio großen Anlagekosten, 2. der unverhältnismäßig große Wärmebedarf, und 3. der Lmstand, daß das IIolz bei diesem Verfahren sehr bedeutend an Festigkeit verliert.

\$10. 4.D i e U m h ü 11 ung des Holzes: a. Dureh Polieren mit Sehelłack oder Wachs; b. dureh Anstrich mit Fimiß, Lack, Teer und Teerpräparaten, sowie das Ueberziehen mit Wasserglas; e. durch Ankohlen.

a. Das Polieren dient mehr zur Verschönerung und nur nebenbei zur Konservierung des Holzes. Die gewölnnliche IIolzpolitur ist eine weingeistige Lösung von Schellack, welehe mit einem zusammengebaltten Lappen auf das vorerst glattgeschliffene IIolz, unter Zugabe von ganz wenig Oel eingerieben wird. Zun Polieren der getäfelten Fußböden (Parketten) dient Wachs, den etwas Terpentinöl zugesetzt ist. Das Einreiben geschicht mit steifen Bürsten. Auch Möbel werden auf diese Art poliert. Die Wachspolitur besitzt weniger Glanz, läBt sich aber leichter auftragen und mit weniger Mühe auffrischen als die Seheltackpolitur.

b. Ther Instrich hat den Zweek, das Holz gegen Feuchtiglieitsaufnahme (und damit auch gegen das Schwinden und Reißen) zu schützen, ferner das Eindringen der Piłze zı verhindern. Häufig beabsichtigt man damit auch noeh, den Holzgegenständen ein gefälligeres Ansehen zu erteilen. Jeder wie immer geartete Anstrich wirkt nur dam konservierend, wenn das Holz zuvor gut lufttrocken geworden ist. Auf feuchtem ITolze ist er geradezu verderblich, weil die Austrocknung dadureh rerhindert wird und das Holz um so schmeller der Verderbnis unterliegt. Die gebräuch- 
lichsten Anstrichmittel sind die Oelfarbenfimisse, welche dureh Zusammenreiben der Farben mit Leinölfirnis hergestellt werden.

Das Leinöl gehört zu den troeknenden Oelen; es besitzt die Eigensehaft, Sauerstoff aus der Luft aufzumehmen, sich dahei zu verdicken und in dünnen Schichten ganz fest zu werden. Die Verdiekung erfolgt viel rascher, wenn man das Leinöl dureh Erwïrnen auf $250^{\circ} \mathrm{C}$. künstlich oxydiert und mit Metallverbindungen verreibt, welche sich darin losen. Es dienen liezu hauptsăchlich Blei- oder Manganverbindungen. Am besten eignen sich die llarzscifen dieser beiden Melalle, die sieh sehon hei weniger hoher Temperatur $\left(130-150^{\circ}\right.$ C. $)$ in Leinöl leicht und vollständig lösen. Diesen Zusałz nennt man Sikkativ; er ist ein geringer, auí Metall berechnet $0,1 \%$ Mangan oder $0,5 \%$ Blıi. Ein clerartig präpariertes Leinöl heißt Firnis. Anstatt Leinb̆l werden zuweilen auch andere trocknende Oele, namentlich Nuß- und Mohnö! verwendet. Die beigemenglen Farben gehen dem Firnis eine größere Konsistenz und Deckf̈̈higkeit. Un das Anstreichen zu erleichtern, setzt man den Firnis etwas Terpentinö zu. Er wird dadurch dünnflüssiger, läßt sich leichter auftragen, trocknet aber langsamer.

Das A n t re ichen m $\mathrm{it} T$ e e $r$ ist nur für roh bearbeitete Holzgegenstande anwendbar und nur dort empiehlenswert, wo dieselben gegen die Einwirliung der direkten Sonnenstrahlen geschützt sind, also hauptsäehlich für Hölzer, welehe in den Boden oder unter Wasser kommen. Bej direkter Beseheinung durch die sonne wird dureh die schwarze larbe des Teers viel Wărne absorbiert und das Holz infolgedessen leieht rissig. Steinkohlenteer eignet sich als Anstrichmittel besser als Braunkohlen-, Torf- oder Holzleer.

Um einen haltbaren, gut deckenden und bald erstarrenden Anstrich zu belommen, muß der Teer in einem liessel soweit eingedielit werden, da $B$ er in der Wärme noch genügend flüssig isi, beim Erkalten jedoch sehr zähe wird und bald erstarrt. Ein geringer Zusatz von gebranntem und zu trackenem Pulver abgelöschten lialk erhöht die lionsistenz des Teeres. Auch ein Zusalz von Zement soll sich gut hewähren.

Der Teeranstrich ist dauerbaft und gewährt einen guten Schutz gegen das Eindringen von Feuchtigkeit; eine wesentlich antiseptische Wirkung ist ihm aber nicht zuzuschreiben. Auch dringl der Teer vermöge seiner schmierigen Beschaffenheit nicht in das Holz ein.

Von Teerpräparaten, welche als Anstreichmittel Verwendung finden, sind vor allem das Karbolineum und das Antinonnin zu nennen.

Karbolineum ist ein Teeröl, welches etwa 10-15\% liresole (pag. 573) enthält; das Uebrige sind indifferente Lohlenwasserstoffe. Es ist licht-bis tiefdunkelbraun gefärbt, riecht stark nach Teer, hat ein spezifisehes Gewicht von 1,13-1,19 und einen Siedepunkt von 250 bis über $360^{\circ} \mathrm{C}$. Es eignet sich als Anstrichmitlel für Pfähle, Zäune, Schleusen, Brủekenhölzer u. dgl. sehr gut. Der Gehalt an Kresolen soll $15 \%$ nicht übersteigen, da sanst die Holzfaser angegriffen wird.

Antinonnin hesteht dem Wesen nach aus Dinilrokresolkalium $\mathrm{C}_{6} \mathrm{H}_{2}\left(\mathrm{NO}_{2}\right)_{2} \cdot \mathrm{CH}_{3} \cdot \mathrm{OK}$ welchem Glyzerin, Seife oder andere Stoffe zlogesetzl sind, $11 \mathrm{~m}$ die Explodierbarkeit, welche den Nitroprodukten eigen ist, zu benehmen. Es kommt als orangfarbige Pasta in den Handel, welche in einer Menge bis zu $5 \%$ in warmem Wasser löslich ist. In der Regel wird eine 2prozentige Losung angewendel und wenn der erste Anstrich tracken geworden ist, ein zweiles und eventuell auch ein drittes Mlal gestrichen. Antinonnin dringt in das Holz ein und wirkt ausgezeichnet antiseptiseh. Es wurde mit großem Erfolge als Schutzmittel gegen die Nonnenraupe angewendet, daher der Name. Gegenwärtig findet es vielfache Anwendung gegen Hausselıwamm, Schimmelpilze und Bakterien. Es werden sowohl Holzwerk als auch Mauerwände damit gestrichen. Letztere überlüneht man noch mit Weißkalk oder mischt die Antinonninlösung gleich der Kalkmilch in einer llenge von $2 \% \mathrm{zu}$.

Der Intinonninanstrich ist vorzugsweise für solche Gegenstände zu enpfehlen, welche sich unter Dach befinden, wîlırend Karbolineun für Holzwerk im Freien sich hesser eignel. Ersteres ist nahezu geruchlos, wird aber leicht ausgewaschen, letzteres hingegen ist widerslandsfähig gegen die Einwirliung von Wasser, lıą aber den Nachteil, daß es einen starken Geruch besitzt, der in gesch!ossenon Räumen unangenehm zur Geltung kommt.

Es gibt noch eine ganze Reihe anderer Präparate, bezw. Mischungen, welche als Anstrichmittel empfohlen werden. Ein liäufig gebrauchtes Mittel dieser Art ist das Mikrosol, eine blaugrüne pastenartige Ilasse, welche aus einer Mischung von phenolsulfosaurem, kieselfhorsaurem und schwefelsaurem Kupfer, nebst indifferenten Beimengungen besteht. Es wird so wie das Antinonnin als 2prozentige Lösung angewendet. Auch Fluorverbindungen, so z. B. das Antipolypin, bestehend aus $\beta-N a p h-$ tol, Natriumliydroxyd und Fluornatriun, das Montanin (Kieselfluoraluminium) и. а. werden für diesen Zweck benützt und in neuester Zeit Casein mit Formaldehyd $\left(\mathrm{CH}_{2} \mathrm{O}\right)$, welches sich für gewisse Holzgegenstände vorzüglich bewährt. 
Für nanche Verwendungen wird das $\mathrm{Holz}$ mit Wasserglas angestrichen. Das Wasserglas ist ein Alkalisilikat, welches sieh in lioehendem Vasser löst und als 33- oder 66\%ige Lösung in den Handel kommt. In dünnen Schichten troeknet diese Lösung an der Luit raseh und gibt einen glasartigen Ueberzug. Das Anstreichen muß 5-bis $6 \mathrm{mal}$, und zwar mit immer stärkerer Lösung wiederholt werden. Der erste Anstrich wird mit etwa 15-und der letzte mit unverdünnter $66 \%$ jger Lösung ausgefürt. Ein neuerlicher Anstrich darf erst dann erfolgen, wenn der nächst vorhergegangene vollkommen trocken geworden ist. Der Wasserglasanstrielı ist nur ein Flammenschutzmittel, aber kein Präservativ gegen Fäulnis und andere Arten von Zersetzungen des Holzes. Das mit Wasserglas üherzogene Holz brennt nicht mit Flamme, sondern verkohlt nur, und auch die Verkohlung geht nur langsam vor sich. Als anderweitiges Konservierungsmittel ist das Wasserglas ganz untauglich, weil es dureh die stark alkalisehe Reaktion die Holzfaser angreilt und überdies den Nachteil hat, daß es unter dem Einflusse der Atmosphärilien leicht verwittert. Das Alkalisilikat wird durch die Kohlensäure der Luft zerlegt, wobei Alkalikarbonat entsteht und Kieselsäurehydrat ausgeschieden wird. Der anfānglieh ganz glatte, glasartige Ueberzug wird rauh, das Alkalikarbonat, welches in Wasser leieht löslich ist, wittert aus, wird dureh das Meteorwasser abgewaschen und in verhältnismäßig kurzer Zeit ist der ganze Ueberzng versehwunden. Bei Gegenständen, die sich unter Dach befinden, hält der Ueberzug etwas länger, fällt aber nit der Zeit auch ab.

Neben Wasserglas gibt es noch diverse andere Präparate, um Holz uuverbrennlieh zu machen. Die meisten derselben haben aber den Uebelstand, daB sie hygroskopiseh sind und aus dem Holze aussehwitzen. Auch genügt ein bloßer Anstrich mit dem Flammensehutzmittel in den seltensten Fällen, sondern es muß eine entsprechende Durehtränkung des Holzes auf dem Wege der Imprägnierung platzgreifen, wenn man mit einer einigermaßen sieheren Wirkung reehnen will.

c. Das A n k h le n wurde früher, namentlich für Seliffsteile, Brückenhölzer, Telegraphenstangen und P[ähle überhaupt häufig benutzt. Gegenwärtig ist man, verschiedener Mißerfolge wegen, mehr davon abgekommen, auf den französischen Schiffswerften und in anderen technischen Etablissements wird aber das Ankohlen (naeh $\mathrm{L}$ e d e b u r) noch in größerem Maßstabe betrjeben. Der Erfolg ist wesentlich von der Ausführung des Verkohlens abhängig. Am besten gelingt das Ankohlen mit einer heißen, spitzen Gebläseflamine, welche stets nur eine kleine Fläche des Holzes auf einmal erhitzt und in alle Spalten und Risse eindringt. Die verkohlte Schichte soll nur ganz schwach, etwa $2-3 \mathrm{~mm}$ dick sein. Wird tiefer gekohlt oder eine größere Flāche auf einnal erlitzt, so entstehen zalilreiche Risse in Holze, welehe das Eindringen der Feuehtigkeit und der Zersetzungsorganismen nur noch mehr begünstigen. Auch würde bei tieferem Kohlen das Holz zu sehr geschwächt. Ein entschiedener Nachteil ist die wasserhaltende liraft der Kohlensehichte, wodurch die darunter befindliche Holzpartje immer feucht gehalten wird und der Zersetzung zugängiger ist. Dieser Umstand wirkt namentlich bei Pfählen und anderen Hölzern, welche im Erdreiche angebracht sind, nachteilig.

\section{Die Imprägnierung.}

\section{a) Imprägnierungsmittel.}

$\$$ I1. Trotz der großen Zahl von Substanzen, welche für diesen Zweek empfohlen und auch versuchsweise verwendet wurden und werden, haben sich doch nur wenige dauernd praktisch bewährt.

Von einem Imprägnierungsmittel verlangt man, daß es:

1. sehr gut konservierend wirkt; 2. tief in das Holz eindringt; 3. der Auslaugung widersteht und 4. billig ist. Allen diesen Anforderungen genügt kein einziges der bisher bekannten Nlittel vollkommen. Relativ am besten haben sich bewährt:

1. das Quceksilberchlorid,

2. das Kupfersulfat (Kiupfervitriol),

3. das Zinkehlorid und andere Zinkpräparate,

4. das schwere Teeröl, und in neuerer Zeit

5. die Salze der Fluorwasserstoffsäure.

Das 2 uecksilberehlorid, $\mathrm{HgCl}_{2}$, besitzt unter allen Metallverbindungen die größte antiseptische Wirkung. Zum Imprägnieren des Holzes wurde dieses Präparat zuerst von dem Engländer $\mathrm{K}$ y a n (1832) in Anwendung gebracht. Es wirkt schon in minimalen Mengen ausgezeichnet konservierend, kann aber: 1. des hohen Preises und 2. der außerordentlichen Giftigkeit wegen nur beschränkte An- 
wendung finden. Man benützt das Quecksilberchlorid heute nur noch auf einigen kleineren Bahnen zum lmprägnieren der Schwellen. Für Hölzer zum Bau von Wohnhäuserı und Stallungen ist es seiner Giftiglieit und für IIölzer zu Wasserbauten der leichten Auslaugung wegen nicht geeignet.

Der K up fervitriol, $\mathrm{CuSO}_{4}+5$ aq, wirkt viel weniger antiseptisch als das Quecksilberchlorid. Er ist zwar lilliger, aber für alle allgemeinere Anwendung noch immer zu teuer, zumal er möglichst rein sein soll. Der Kupfervitriol wurde von den Franzosen B o u li erie (1557) zur Holzimprägnierung empfohlen und wird hauptsächlich zur Imprägnierung von Telegraphenstangen angewendet. Für Bauhölzer, Schwellen u. dgl. ist man davon schon längst abgekommen. Mlit hupfervitriol imprägniertes Holz ist spröde und der Schimmelbildung unterworfen. Fommt derartig präpariertes $\mathrm{Holz}$ in feuchten Zustande mit Eisen in Berülırung (z. B. durchgehende Bolzen oder Schrauben), so erfährt das liupfersalz eine Zerlegung, es bildet sich Eisenvitriol und Kupfer wird ausgeschieden.

$$
\mathrm{CuSO}_{4}+\mathrm{Fe}=\mathrm{FeSO}_{4}+\mathrm{Cu} \text {. }
$$

Das Z in k c h l o r i d, ZnCl +2 aq, steht bezüglich seiner antiseptischen Eigenschaften noch hinter dem Kúpfervitriol, hat aber diesem gegenüber den Vorzug der Billigkeit. Es wird in den Inıpägnierungsanstalten durclı Auflösen von Zinkabfällen oder Zinkasche in Salzsäure dargestellt. Die Lösung darf keine überschüssige Säure und nur Spuren von Eisensalzen enthalten, muß klar sein und soll eine Konzentration von $3^{\circ} \mathrm{B}$. (bei $17,5^{\circ} \mathrm{C}$.) besitzen. Die mit Zinkchlorid imprägnierten Holzgegenstände vertragen Oelanstrich ganz anstandslos, was bei den mit Quecksilberchlorid oder Kupfersalz imprägnierten Hölzern nicht der Fall ist. Auch findet eine Zerlegung des Zinkchlorides durch Eisen unter gewöhnlichen Umständen nicht statt. Ein Uebelstand ist die leichte Löslichlieit des Zinkchlorides. Es wird daher so wie das Quecksilberchlorid aus dem Holze leicht ausgelaugt.

Nach einem Patente von C. B. W i e s e in Hamburg wird anstatt Zinkchlorid eine heiße Lösung von $\beta$-naphtalinsulfonsaurem Zink angewendet. Diese Verbindung ist in der Wärme leicht, in der Kälte lingegen schwer löslich und wird daher bei gewöhnlicher Temperatur weniger leicht ausgelaugt als das Zinkchlorid.

Das s c h we re T e e r öl übertrifft bezüglich seiner antiseptischen Wirkung die beiden letztgenannten Metallverbindungen weitaus und kommit dem Quecksilberchlorid nahe.

Unterwirft man Steinkohlenteer einer fraktionierten Destillation, so werden der Hauplsache nach 5 verschiedene Produkle crhalten:

1. das Leiehlöl (Benzol und scine Homologen);

2. das Mitlelōl (Karbolsâure und Naphtalin);

3. das Schmeröl (Irresol, Chinolin, Naphtalin und Homologc);

5. Pech, als Deslillationsrückstand.

Während man früher den Gehalt eines Teeröles an saueren Bestandteilen (Jiarbolsäure und deren Homologen) für die Holzkonservierung als allein werlvoll ansah, hat Scidenschnur ${ }^{1}$ ) nun durch eingehende Versuche den Bewcis erbracht, daß auch ein von diesen, in Natronlauge löslichen, Körpern hefreites Stcinkohlenteeröl eine hohe desinfizierende und konservierende Vïrkung besitzl. Seidenschnur gewann aus Schwellen, welche mit slark lireosolhalligem Teeröl imprägniert worden waren und nach $16 \mathrm{jahhrgger} \mathrm{Verwendung} \mathrm{im} \mathrm{Geleise} \mathrm{noch} \mathrm{kcine} \mathrm{Spur} \mathrm{von}$ Fãulnis zeigten, durch Exlraktion ein Oel, welches fast nur aus hochsiedenden Anteilen bestand und keinerlei leiehtflüchtige İörper oder sauere und basische Bestandleile enthielt. Da nun diese Schwellen, trolz des Fehlens der als eigentlich wirksam angenommenen Bestandteile des Tceröles, der Fẩnis widerstanden und noch cine Reihe von Jahren zu widerstehen vermocht hätlen, so ergibt sich daraus, daß auch dic neulralen, hochsiedenden Bestandteile des ursprünglich verwendeten Imprägnierungsöles eine vorzügliche anliseplische Wirkung geäußert haben, und im allgemeinen, daß die Wirkung eines gewöhnlichen Teerōles nicht aufhört, wenn đie saueren Beslandleile dessclben dureh Auswaschen oder dgl. entfernl sind.

1) F. Seidensehnur, Zur Frage der Holzkonservierung, Chem. Ztg. 1909. 
Seidenschnur hat nun, veranlaßt durch die antänglichen Mißerfolge, wolche sich beim Ersatz des Teeröles durch rohes Erdōl ergaben, seine Untersuchungen auch auf die sehweren Kohlenwasserstoffe dieses letzteren ausgedehnt und ist dabei zu folgenden Resultaten gegekommen:

1. Die neutralen Bestandteile des Erdöles haben keine Holz konservierende Eigenschaften; Kraft;

2. durch Behandlung (Destillation) mit Schwefel erhalten sie eine hohe antiseptische

3. das fast nur aus neutralen und hochsiedenden Kiörpern bestehende Antlrazenöl ist dem an saucren Bestandteilen reichen Imprägnieröl überlegen, und

4. die antiseptische Kraft des mit Schwefelzusatz destillierten Oeles steht der des gewöhnlichen Teeröles und des Anthrazenöles um 15-20\% nach.

Daraus folgt, daß in Lāndern, welche über ausgiehige Erdölquellen verfügen und die das Teeröl relativ teuer bezahlen oder cinfülren müssen, dieses ,, Schwefelöl" mit Erfolg zur Konservicrung des Holzes verwendet werden kann.

Die öligen Imprägnierungsmittel dringen nur im wamen Zustande gut in das Holz ein, widerstelıen aber der Auslaugung durclı die Atmosphärilien vortrefflieh. Trotz ilhres hohen Preises sind sie heute für die Imprägnierung von in Freien verwendeten Holz, namentlich Schwellen, Leitungsmasten ete. fast ausschließlich in Verwendung.

Da die Zusammensetzung der von den Destillerien auf den Narkt gebrachten Steinkohłen-Teeröle eine ziemlich schwankende ist, so erlassen die Großkionsumenten von mit Teeröl imprägniertem Holz, also in erster Linie die Balınverwaltungen, jeweilig cigene Vorsehriften über die Beschaffenheit des für ihre Zwecke zu verwendenden Imprägnierungsöles.

Die bei den deutschen und ōsterreichischen Bahnverwaltungen derzeit gültigen Vorschriften lauten:

Das Teeröl darf nur aus Steinkolhlenteer erzeugt sein. Der Gelalt an saueren Bestandteilen, welehe in Vatronlauge vom spez. Gew. 1,15 löslich sind, muß mindestens $6 \%$ betragen. Bei der Destillation dürfen, nach reutseher Vorsclırift, bis $150^{\circ} \mathrm{C}$. höchstens $3^{\circ}{ }^{\circ}$, bis $200^{\circ} \mathrm{C}$. höchstens $10 \%$, bis $235^{\circ} \mathrm{C}$. höclıstens $25 \%$ überdestillieren; nach östreichischer Vorschrift däfen höchstens $3 \%$ unter $150^{\circ} \mathrm{C}$., die llauptmenge aber soll zwischen 180 und $350^{\circ} \mathrm{C}$. überdestillieren. DiŁ östrejchisehe Vorsehrift fordert, daß das Imprăgnierungsöl bei der lmprägnierungstemperatur dünnllüssig und frei von ungelösten Stoffen sowi schmierigen Beslandleilen ist, so daß es, auf luftrockenes stimlıolz gegossen, in dasselbe eindringt, ohne andere als ölige Bestandteile zu hinterlassen.

Das spezifisclre Gewicht bei $15^{\circ} \mathrm{C}$. soll zwischen 1,01 und 1,1 liegen, naclı der deutschen Verordnung zwischen 1,04 und 1,15. Nach der letzteren muß das Oel bei $40^{\circ} \mathrm{C}$. klar sein und beim Vermischen mit gleichen Raumteilen Benzol (kristallisierbares) lilar bleiben, olne mehr als Spuren ungelöster liörper auszuscheiden. Zwei Tropfen dieser Nischung sowohl als auch des unvermischten Oeles müssen, auf mehrfach zusanmengefalletes Filtrierpapier gegossen, von diesem vollständig aufgesogen werden, olnte mehr als Spuren, d. h. ohne einen deutlichen Flecken ungelöster Stoffe zu hinterlassen.

In beiden Staaten gültig: Dic liontrolle über die Beschaffenheit des Imprägnicrungsöles sowohl wie auch über die Durchfürung der Imprägnierung selbst, muß den hiefür antlich bestimmten Organen jederzeil gestatlet sein.

Da - wie schon erwähnt - das Teeröl nitunter ein kostspieliges lmprägnierungsmittel ist, so hat man vielfach Versuche unternommen, dasselbe entweder leilweise durelı andere billigere llittel zu ersetzen oder es in fein verteilter Form als sog. E n u ls i o n anzuwenden. Die Enulgierung von Teeröl gelingt leicht, bei Einlualtung ganz bestimmter Bedingungen, mit Alkaliseifen oder nach einem Patente von G. Rütgers mit Anmoniak resp. geeigneten Anmonsalzen.

Praktisch haben sich diese Mittel aber nicht bewäht, und vor allem aus den Grund, weil durch das Sparen an lionservierungsmittel auclı dic Dawer und Wirkung der Iionserviorung beeinlrächtigt wird.

Die Fluorwasserstoff-Säure und ihre Salze sind als Bakteriengifte schon lange bekannt und als solehe zur Immunisierung der verschiedensten Stoffe verwendet worden.

Die Flußsäure (HF) wird durch Erlitzen fon Flußspal oder liryolith mit konzentrierter Selıwelsäure, in Platin- oder Bleirelorten erlatten.

$$
\mathrm{CaF}_{2}+\mathrm{H}_{2} \mathrm{SO}_{4}=\mathrm{CaSO}+211 \mathrm{~F}
$$


Sie tildet ein ramchendes, gifliges, alzendes fas, welches beim dbkülen zu einer farblosen Flüssgleit verdiehttar ist, die bei $19^{\circ} \mathrm{C}$. siedet, bei $-102,5^{\circ} \mathrm{C}$. erstarrt und selır leieht in Wasser lóslich ist. Flußsäure löst alle Metalle, mit Ausnahne von Gold, P'latin und Blei, unter Wasserstoffentwichlung zu ihren Salzen, den F l u o r i d e n. Glas greift sie an und bildet mit dem Iauptbestandteil desselben, dem Silieium, das Silieiumfluorid, weslalh sie nur in Platin-, Blei- oder Hartgummiflaschen aufbewahrt werden kann.

Die Flu o r ide sind, mit Ausmahne derer der Calciumgrupre, alle in Wasser löslich. Sie wirken weniger antiseptisch als die Flußsăure, welche aber als solche praklisch lieine Verwendung finden kanm. Auf die Holzsubstanz wirk"n weder dieso noch jene sehädlich.

Auf die Bedeutung der Fluoride als Holzkonservierungsmittel wurd. zuerst von Malenkovic ${ }^{1}$ ) hingewiesen und von $J$. Netzsch ${ }^{2}$ ) wurden dieselben einer eingehenden Untersuchung unterzogen.

Derzeit stehen hauptsächlich die Fluoride der Alkalien und des Zinks in praktischer Erprobung und aus den bisher gewonnenen Resultaten ergibt sich, daß die Fluoride sowohl betreffs Wirksankieit, wie auch in punkto liosten den übrigen lionservierungsmitteh nicht nachstehen. Als wasserlösliche Substanzen teilen sie natürlich das Schicksal aller ihren gleichen Mittel.

Von den vielen anderen, für spezielle Zwecke mit wechselndem Erfolg angewendelen, Mitteln seien hier nur einige wenige genannt: $\beta$ naphtalinsulfosaures llagnesium, Jiochsalzlōsungen (Salzsole), das Fluorprãparal ,Hylinit", Kiese]fluornatriuıı, Lōsungen von Schwerınetallsalzen und Alialifluoriden, Lösungen von Harz und Harzseifen, Waclıs, Paraffin, Stearinsäure, von Holzteeren mit Pectinsāure und Teeröl in Geniseh, ron Jiresolealcium, Rolıpetroleum ete.

AuBer diesen, hauptsächlich der Jionservierung des Holzes dienenden Mitteln werden noch eine Reihe von Imprãgnierungsflussiglieiten verwendet, welche entweder ein sog. H ả r-

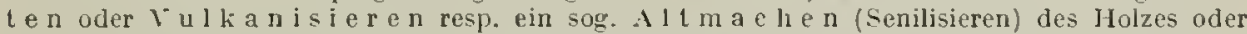
ein $\mathrm{F}$ e ue r sichern a $\mathrm{e}$ he $\mathrm{n}$ des Holzes bewirken sollen.

Nach einem Verfahren von Powell ${ }^{3}$ ) wird frisehes oder auch trockenes Holz mit Zuclierlōsung einige Zeit hindurch gekoclıt und dann auf $35^{\circ} \mathrm{C}$. abkühlen gelassen, wobei dic Zuckerlösung rom Holze begierig aufgesaugh wird. Nach Ablassen der übersehüssigen Zuckerlösung wird heiße Luft eingeblasen und dadurch ein Erstarren und teilweises Karamelisieren des Zuckers sowie Verdampfen des in Holze enthaltenen Wassers hewirkt. Für billiges Holz wird Jelasse, für feine Holzsorten, welche auch eine gute Politur vertragen sollen, wird Zucker besserer Qualität rerwendet. Derart imprägniertes Holz lat eine größere Hărle, Zảhiglieil und Elastizität; es reißt und sehwindet nicht, wirft sich nicht und ist aucl gegen große Temperalurunterschiede nicht empfindlich.

In London hat sich diese Art der Imprâgnierung für Holzpflaster sehr gut bewälrl, welclıes dem mil Teerōl imprägnierten gegenüber noch den Vorzug besitzt, daß es geruelılos ist.

Die Anwendung anderer Härtungsmitte] beruht meist auf der Wechselwirkung zweier oder mehrerer Stoffe, aus denen dahei unlosliche Verbindungen ausgeschieden werden, welche sich auf und zwischen den Holzfasern niedersehlagen und diesen so eine grōßere Festigkeit und Wider'standsfähigkeit verleihen.

Als Flammenschutzmillel dienen vornehmlich die Lōsungen anorganischer Salze, wie z. B.: Wasserglas, Naun, Natrium-Wolframat-Phospliat oder-Aluminal, Ammonium-SulfatPhosphat-Wolframat ohne und mit Borsäure oder wasserlöslichen Zinksalzen im Gemiseh, Gemische der Mineralsäuresalze mit Acelaten oder Formiaten u. a. in.

Endlich sei noch der verschiedenen Mittel zur Imprägnierung des Holzes behufs F ä rb $\mathrm{u} \mathrm{n} \mathrm{g}$ desselben gedacht.

Jan bezweckt damit fast ausschließlich eine Verbesserung minderer Holzsorten für das - Iuge des Beschauers, also eine Verschönerung, wodurch geringerwertige Holzware für spezielle Verwendungsarten namentlich in der Bau- und Möbeltischlerei besser verwertbar wird. Diesem Zwecke dienen Imprägnierungsmittel zweierlei Art. Entweder man verwendet Lösungen von Stoffen, welche erst in Verbindung mit der Holzfaser und durch die Einwirlung de's Sauersloffes der Luft die gewänsehten Nuancierungen hervorufen (hieher gehörig die Chrom-und Eisenbeizen), oder man färbt direkl, dureh Tränken des Holzes mit natürlichen oder künstlichen Farbstoftösungen (Farbholzextrakten oder Teerfarbstoffen).

1) Ialenkovic, Die Holzkonservirung in Hoclbbau, Wien-Leipzig 1907.

2) Velzseh, Die Bedeulung der Fluorverbindungen für die Holzkonservierung. Inauguraldissertation, München 1909.

3) Z. f. angew. Chemie 1906. 


\section{b) Imprägnierungsmethoden.}

Dem Wesen nach stehen 6 versehiedene Nethoden in Anwendung: .

1. das sogenamite Einsumpfrerfahren,

2. das hydrostatische Druckverfahren,

3. das Einpressen mit einer Druckpumpe,

4. das pneumatische Druckverfahren,

5. das Behandeln des Holzes mit Teerölılampf,

6. die Imprägnierung auf elehtrischem Wege.

\$ 12. Das Einsum p fverfahren (oder Kyanisieren). Es ist das einfachste Verfahren, weil es keine besonderen Einrichtungen und kein geschultes Arbeitspersonal voraussetzt. Es kann aber nur für energisch wirkende, wasserlösliche, also leicht in das $\mathrm{Holz}$ eindringende Vittel, wie z. B. das Quecksilberchlorid und die Fluoride, Anwendung finden. Die Lösungen des Imprägniermittels dürfen nur in geringer Konzentration verwendet werden und auch dann ist die vollständige Durchtränkung des Holzes nicht zu erreichen. Das Holz muß gut lufttrocken sein, weil in feuchtes Holz die Lösung überlaupt nicht eindringt, und wird in fertig fassoniertem Zustande der Tränkung übergeben. Eine nachträgliche Zurichtung ist bei Terwendung sehr stark giftig wirkender Mittel von vornherein ausgeschlossen, und außerdem würden dadurch die gerade am besten imprägnierten Partien entfernt werden.

Zum Einsumpfen des Holzes in das Imprägniermittel verwendete man früher vollkommen dichte Kästen aus Eichen- oder Lärchenholz, welche nun fast ausschließlich durch Zisternen aus Zementbeton oder für gewisse Nittel auch aus Eisen ersetzt sind.

Weiches Holz von den Dimensionen der Bahnschwellen soll 8-10, hartes Holz I2-I4 Tage in der Lösung verweilen. Nach der Imprägnierung muß das Holz noch einige Monate an der Luft liegen bleiben, damit sich das Imprägnierungsmittel tiefer in das Holz einsaugt.

\$13. Das liydrostatische Drucliverfahren wurde zuerst von Boucherie in Anwendung gebracht und besteht dem Wesen nach in folgendem:

Auf dem unteren Hirnende des noch mit voller unverletzter Rinde versehenen Stammes wird eine hölzerne Schlußplatte derart angelegt, daß eine schmale (etwa I cm tiefe) dicht schließende Kammer entsteht. Den dichten peripherischen Abschluß bildet ein gefettetes Hanfseil oder besser ein Kautschuckring, gegen welchen die Schußplatte mittelst einer quer üher dieselbe liegenden Holzspange und zwei Schrauben fest angeprelst wird. Diese Kammer steht durch einen Guttaperchaschlauch mit dem Faltrohr eines $10 \mathrm{~m}$ hoch stehenden Reservoirs, welches die Imprägnierflüssigkeit enthält, in Verbindung, so daß ein Flüssigkeitsdruck von ungefälır I Atmosphäre auf die Stimfläche des Stanmes einwirken kann. Infolge dieses Druckes wird der Zellsaft aus dem Stamne verdrängt und durch die Imprägnierungsflüssigkeit ersetzt.

Das für die fmprägnierung bestimmte Holz solf frisch gefällt sein. Bleibt es längere Zeit an der Luft liegen, so nimmt der Saft (namentłich zur Sommerszeit) eine schleinige Beschaffenheit an und läßt sich dann nur sehwierig aus dem Holze verdrängen. Hołz, welches nicht sofort imprägniert werden kann, wird am besten in fließendem Wasser aufbewahrt. Das im Winter gefältte Hotz imprägniert sich feichter ats das Sommerholz; am schwierigsten ist das in der IIauptsafttriebperiode (April und Mai) gefällte Holz zu imprägnieren. Die Tränkungsfähigkeit der vrsehiedenen Holzarten ist eine sehr ungleiche. Die sogenannten Splintbäume, Reifholzbäume und Reifholzkernbäume lassen sich am leichtesten imprägnieren. Viel schwieriger getingt dies bei den sogenannten Kernholzbäumen, bei welchen nur der Splint durehdrungen wird, das liernholz aber fast unberärt bleibt. Vorzugsweise werden die Buche, Fichte und Tanne 
nach dieser Methode imprãgniert. Die Buche eignet sich für diesen Zweck ganz vorzunglictı, zeigt abel nicht selten in der Mitte des Stammes eine Partie von btaßroter bis brauner Farbe, welche der Durchtränkung widersteht. Bei den Vadelhölzern ist ein großer Harzreiehtun fur die 1 mprägnierung nachteifig. Boucherioverwendete als Imprägnierflussigkeit eine $1 \%$ ige Lỏsung von liupfervitriol, und zwar zur lmprignierung von Masten für Telegrapl-- und Teleplionleitungen, welches aber heute fast gänzlich aufgelassen und duretı die wirksameren Fluoride resp. durch das Teeröl verdrängt worden ist. (Die Imprägnierung mittelst des letzteren erfolgt naturlich auf pneumatischem Wege).

Der Verlauf der Imprägnierung nach dem Boucherie-Verfahren gestaitet sich im allgemeinen nun folgendermaßen:

Bereits wenige Minuten nach Beginn des Flüssigkeitsdruckes auf das, durch die liammer eingeschlossene, Stirnende des Holzes tritt an dem freien Stammende Holzsaft aus. Nach und nach hommt eine Mischung des Holzsaftes mit dem Imprägniermittel, welche immer reicher an letzterem wird, bis endich ein gewisser Gehalt an diesem in der ablaufenden Flussigkeit erreicht ist, worauf der Zulaul abgespert wird. Bei der Imprägnierung nit Kiupfersulfat wird der Zulauf der $1 \%$ igen Lösung abgestellt, sobald die austretende liupfertösung $3 / 4^{0} \mathrm{~B}$. zeigt und hierauf mit einer $1 / 2 \%$ igen Lösung nachgewaschen. Diese zweite verdünnte Losung hat nur den Zweck, die bei der ersten Imprägnierung durch Ausscheidung von Kupferhydroxyd frei gewordene Schwefetsäure aus dem Stamme zu verdrängen. Mit der verdünten Lösung wird so lange nachgewasehen, bis die austretende Flüssigkeit nicht mehr sauer reagiert.

Bei der Imprägnierung mit Fluoriden wendet man Laugen in einer Stärke von $3-50^{\circ} \mathrm{B}$. an und stellt den Zulauf des Imprägniermittels ab, wenn der Ablauf $0,5-2{ }^{\circ} \mathrm{B}$. zeigt. Ist die Imprägnierung beendet, so wird die Verschlußkammer abgenommen, der Stamm entrindet und an der Luft getrocknet.

Die Dauer der Imprägnierung ist je nach der Holzart, Fällungszeit, Länge und Stärke des Stammes verschieden und beträgt 18 bis 100 Stunden und darüber.

Der bei Beginn der Imprägnierung aus den Stämmen ablaufende Holzsaft ist merttos und wird nicht aufgesammelt.

Die später nachkommende, Imprägniermittcl-haltige Ffüssigkeit aber gibt man nicht verloren, sondern sammelt sie, um sie, nach entsprechender Reinigung und Ergänzung auf den ursprünglichen Gehaft, wieder zu verwenden. Arbeitet man mit Kupfervitriol, so gewinnt man aus den sehr verdünnten Lösungen das Kupfer durch Fälíng nit Eisen, wảhrend man dỉe $1_{2}^{\circ}{ }^{\circ}$. B. zeigenden Lösungen über Sand filtriert und durch Zugabe von liupfervitriol aul 1\% ergänzt.

Das hydrostatische Druckverfahren ist in der letzten Zeit fast vollständig außer Kurs geraten, da es Anforderungen an das zu imprägnierende Holz stellt, welche nicht lejcht erfüllt werden können. Die Nachteile dieses Verfahrens sinct folgende: 1. muß frisch gefälltes Holz mit möglichst unverletzter Rinde in Anwendung kommen. Alle Bringungsarten, bei welchen eine erhebliche Verletzung der Rinde stattfindet, sowie jeder weitere Transport des Holzes überhaupt, sind unzulässig; 2. können nur solche Hölzer, welche eine weitere Bearbeitung nicht erfordern (also Leitungsmaste und runde Bauhölzer), mit Vorteil imprägniert werden, da bei einer eventuellen Zurichtung die am meisten durchtıänkten Partien des Holzes in Abfall kommen; 3. geht immer ein Teil des Imprägnierungsmittels verlorell, wodurch das Verfahren wesentlich verteuert wird; 4. nimmt die Imprägnierung unverhältnismäßig lange Zeit in Anspruch, und da immer nur wenige Stämme gleichzeitig in Arbeit genommen werden können, so ist dieses Verfahren für Massenproduktion, oder für einen Großbetrieb überhaupt, nicht geeignet.

$\S$ I4. Das Einpressen der I mprägnierungsflüssigkeit mittelst einer D r u ckpumpe nach dem Patente J. Pfister. Im Prinzip stimmt dieses Verfahren mit dem vorgenamnten völlig überein. Der Hauptunterschied der beiden Methoden liegt nur darin, daß Pfister an Stelle des hydrostatischell Drucks den Druck einer Pumpe setzt und diesen somit olne besondere Schwicrigkeiten ad libitum steigern kann. In Rücksicht auf dieses letztere Moment müssen beim Pfisterschen Verfahren entsprechend stark konstruierte Verschlußliammern verwendet werden, welche aus Metall (Eisen oder dgl.) gefertigt sind und durch passende Vorrichtungen gegen den Stamm abgedichtet werden.

Handb. d. Forstwiss. 3. Auf. II. 
Die ursprüngliche Pfislersche V'erschlußhammer bestand aus einer Eisenplafte mit scharfer Stahlschneide, welche in die glatl abgesägle, untere Hirnfläche des Stammes eingelrieben wird. Das Festhalten des Verschlußstücles erfolgte mitlelst cines spannlireuzes, das von Kilammern gehallen wird, welehe außen in den Stamm eingeschlagen nud mil Stellschrauben festgezogen werden. Pfister hat dann seinen Verseh]uß derart abgeänder', daß an die Stelle der Stahtsehneide ein Dichtungsring aus Kautschul oder einem ähnlichen, weichen Dichtungsmaterial tritt, der einen rechtwinkeligen Querschnitt besilzt und leicht jedem Stamnumfang angepaßt werden kann. Die zum Einpressen der Inırägnierflussigkeil dicnende Druckpumpe ist auf einem trag-oder fahrbaren Gestell monliert und wird durch Kautschukschläuche mit den zu inprägnierenden stämmen bezw. Verschlußklammern in Verbindung gesetzt. Der ausgeübte Druck kann - wie schon erwähnt - nach Bedarf bis zu $10 \mathrm{Atmosphären} \mathrm{gesteigert}$ werden. Die Zeildauer der Imprägnierung ist, infolge des viel höheren Druckes, eine sehr kurze und beträgt je nach der Holzart und Länge der Stämme nur wenjge Minulen bis 2 Stunden. Dieses Verfahren erfordert nur ein geringes Anlagekapilal, die Hölzer liönnen unmittelbar nach crfolgter Fällıng gleich an Ort und Stelle imprägniert werden, wodurch eine Beschädigung der Rinde durch den Transport ausgeschlossen und ebenso ein Schlcinigwerden des Saftes infolge lüngeren Liegens des Holzes vor der Imprägnierung vernieden wircl. Dic Fällung kann zu jeder Jahreszeit vorgenommen werden, ohne das Imprägnierungsresultat zu beeinträehtigen.

In entsprechend modifizierier Form, d. h. mit eigens für den Zweck konstruierten VerschluBkammorn, wird dieses Verfahren auch zum Färben des Holzes angewendel ${ }^{1}$ ).

Um eine Imprägnierung des Holzes, durch Einpressen der Imprägnierflüssigkeit mittelst mechanischen Drucks, auch am entrindeten Stamme vornchmen zu können, hat Ing. E. Köpfer eine Art Terschlußkammer konstruiert, welche den ganzen Stamm umschließt und so die natürliche Decke des Baumes (die Rinde) durch eine künstliche ersetzt. Die Einrichtung besteht der Hauptsache nach aus einem druckfesten Rohr, welches, entsprechend der Länge des Holzes, aus mehreren Stücken mit Hilfe von Flanschen, Dichtungsringen und Schrauben zusammengesetzt wird. Das eine Ende des Rohres wir $\}$ mit einem Deckel, das andere mit einem, den Stamm übergreifenden Ting scitlich gegen den Stanm abgedichtet. In dem Deckel und an dem Rohr befinden sich Einlaßöfnungen für Druckluft und Imprägnierflüssigkeit; an dem Rohr auch ein entsprechender Auslaßstutzen. Ist der Apparat fertig montiert, so wird vorerst mit Druckluft der Holzsaft ausgetrieben und sorlann die Imprägnicrflüssigkeit in das Holz (durch den Deckel) und in das Rohr gleichzeitig so lange eingepreßt, bis sie am freien Stanmende austritt.

Durch die Einschaltung entsprechender Dichtungsringe zwischen die Teile des Rohres kann man auch die Möglichkeit schaffen, nur einzelne Partien des Stammes zu imprägnieren.

\$15. Das pneumatische Druekverfahren wurde von Brènt und Payen erfunden, von Burnett, Bethell, Blythe, Rütger's und anderen verbessert. Dasselbe besteht im wesentlichen darin, daß man das fertig zugerichtete Holz (Schwellen, Pfosten, Stangen, Bretter, Schindeln etc.) zuerst dämpft oder trocknet, sorlann einer Luftverdünnung aussetzt und schließlich unter Hochdruck mit der Inprägnierungsflüssiglieit sättigt.

Die hiezu notwendige Apparatur besteht vor allem aus einem horizontalen Imprägnierungszylinder aus Kíesselblech von etwa 9-I2m Länge und $2 \mathrm{~m}$ Durchmesser. Die vordere Stimseite desselben ist nit einem abnehmbaren, luftdichtschließenclen Deckel versehen, welcher mittelst Laufrollen auf einer Hängebahn verschiebbar und um einen Bolzen auf dem Laufwagen drehbar ist. Den dichten SchluB bildet ein in tie Flansche eingegossener Bleiring von schwalbenschwanzförnigem Querschnitt. Zur Zuhaltung dienen entweder scharnierartig umlegbare Schraubenbolzen oder Hackenbolzen. An rler rückwärtigen Stirnwand des Kessels

1) Näheres sirhe: J. Pfister jr., Das Färben des Holzes durch Imprägnicrung. Wien-Leij)zig 1908 . 
sind die nötigen Armaturteile: Probehähne, Lufthahn, Standzeiger, Thermometer, Manometer und Vakmometre angehracht. Her donmartige Aufsatz des Kiessels steht mit der Dampfleitung und mit einer Luftuumpe in Verbindung. An der Unterseite des Kessels sind die Ventile zum Ablassen des Fondenswasser's, sowic für den Eintritt und Auslauf der Imprägnierungsflüssigkeit vorhanden.

Eine Saug- und Druckpumpe stellt dic Verbindung der Bassins, in welchen sich das Imprägnicrmittel befindet, mit dem liessel lier.

Weiter sind erforderlich: cin Dampfliessel, eine Betriebsmaschine, diverse Bottiche mit Mischvorrichtung zur Herstellung der Jmprëgnierungsflïssigheit, Dexelund Hobelmaschinen für die Bearbeitung des Holzes, sowie eine Brückenwage. Soll feuchtes Holz mit cinem öligen Vittel allein imprägniert werden, so muß auch eine Trockenvorrichtung vorhanden sein.

Um die Beschickung und Entleerung des Imprägnierlsessels in einfacher Weise zu bewcrkstelligen, wird das zu inprägnierende Holz auf Bügelwagen verladen und in den Kiessel eingefahren; diese Wagen mit ihrer Ladung sind dem Innenraume des liessels angepaßt. Das Holz wird derart verladen, daß sich die einzelnen Stüelie tunlichst wenig berühren, andererseits aber auch nicht zu große Zwischenräume freilassen. Die Bügel, welche die Holzladung zusammenhalten, sind in Scharnieren zum Lmlegen eingerichtet.

Ein Kiessel von $912 \mathrm{~m}$ Länge faßt 4 und bei $12 \mathrm{~m}$ Länge 5 solche mit Schwellen beladene Wagen. Langhölzer werden auf 2 Wagen verladen.

Die Imprägnierungsanstalten für Bahnschwellen sind entweder stabil oder ambulant. Erstere sind in eigenen Gebäuden untergebracht und naturgemäß auch vollkommener eingerichtet als letztere. Die ambulanten Anstalten sind auf Eisenbahnwaggons aufmontiert, um sie abwechselnd auf bestimmte Stationen des Bahnnetzes bringen zu liönnen. In der Piegel werden von den Balnverwaltungen dic stationären Anlagen den mobilen vorgezogen und diesc letzteren daher auch nur bedingungsweise zugelassen.

Bei der I m prãgn i erung mi l Zi n k chlorid, das hier als Reprâsentant der wasserloslichen Jiltel gellen soll, wird in folgender lieise vorgegangen:

Das $\mathrm{Holz}$ wird nach entspreehender Anarbeitung auf dic Bügelwagen verladen und in die Präparierkessel tingefalıren. Nachdem der Verseblußdechel vorgescboben und lufldielıt verschraubt ist, wird mil der Danmpfung begonnen. Ist alle Lufl dureh den Dampf rerdrängt, wird mindestens eine Slunde hindurcl bei $112^{\circ} \mathrm{C}$. $(=0,5 \mathrm{Alm}$. Leber(lich) gedänpfl und das Kondenswasser von Zeil zu Zeit abgelassen. (In manehen Anslalten wird cin höherer Druck von 1 - $2 \mathrm{Atm}$. angewendet.) Das Dämpfen hat den Zweck, die Auslaugeproulkle aus den Holze zu verdrängen und die Zellen mil Danjlf zu erfüllen. Jollkommen wird dieser Zweek aber niemals erreicht. Wollte man so lange dampfen, lis der Dampf auch in das Innere des Holzes eingelrungen ist, so würde dasselbe selr bedeutend an Fesligkeit verlieren. Es findel Jalier die Auslaugung hauplstehlich nur in der äußeren Sehichte stalt. Aueh soll der Dampfuruck 112. Alm nieht abersteigen. Naeh der Dämpfung wird der Leberdiuck abgelassen, die Luftpumpe in Aktion geselzl und ein Vakuum von nindestens 600 mm erzeugt. Diese Druckverminderung muß in 30 . Jinuten erreieht sein und sodann durell weitere 40 Minuten crhallen hleiben. Das Evatuieren lat den Zweek, die in den Zellrüumen noel vorhandene Luft und den Iampf so weit zu verdünnen, daß die Jmprägnierungsflüssigkeit eindringen kann.

Als dritte Prozedur folgt die eigentliche Imprăgnierung. Zu diesem Behufe wird, unter fortwährender 'Täligkeit der Luflpunpe, die Zinkehloridlösung in den Iensel eingesaugt. Ist der liessel entsprechend gefullt, so wird die Luftpumpe abgestellt, dafür aber die Druckpumpe in Aktion geselzl und so lange Imprägnierungsflüssigkeil nachgepumpt, bis cin Ueberuruck von $7^{1}$ Aln. erreicht ist, was ea. 40 yinuten in Anspruch nimml. In dem llaße, als die Flüssigkeil in das Holz eindringl, sinkl der Druck und muß durch Nachpumpen imner auf 7 : Atm. ergānzl werden. Dic Imprägnierung ist erst dann als beendel zu lulrachten, wenn das Mano-

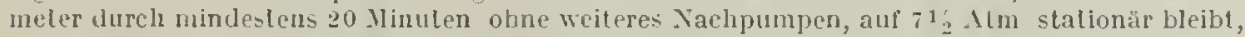
als Beweis, daB ein weileres Eindringen der Flürsigkeit in das $1 \mathrm{Jolz}$ nieht melır slattfindel. lit dies erreichl, so wird die Flüssirkeit aus dem liessel in das Renervoir abgelassen, der Verschlußteckel abgenommen und das 1 lolz ausgefahren. Nach jeder Charge wird der Kiessel gereinigl. 
Die imprägnierten Hözer werden an der Luft getrocknet. Die Zinkchloridlösung wird meist mit einer fionzentralion von $3^{\circ} \mathrm{B}$. genommen. Un an Kosten zu sparen, werden schwächere Lösungen von $1^{1}{ }_{2}-2^{\circ} \mathrm{B}$. verwendel, welche zwal leichter in das $\mathrm{Holz}$ eindringen, aher schwächer konservierend wirken.

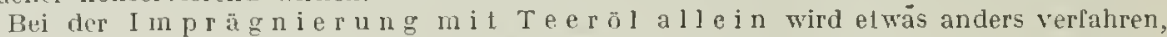
weil hier das Wasser hinderlich ist. An Stelle des Dämplens fritt eine Trocknung, falls nicht vollkommen lufttrockenes Holz zur Imprägnierung vorliegt. Muß liünstlich getrocknet werden, so Cährt man das Holz aus der Trockenkammer, in der man eine Temperalur von $100^{\circ} \mathrm{C}$. durch mehrere Stunden hindurch eingehalten liatte, in noch warmem Zustande in den Iiessel ein und erzengt nun in demselben ein Vakuum von mindestens $600 \mathrm{~mm}$, das 12 Stunde hindurch eingehaIten wird. Unter Einhallung des Vakuums wird das auf mindesteñ $50^{\circ} \mathrm{C}$. vorgewärmte Teeröl eingesaugt und dann mitlelst der Druckpunpe nachgedrückt, bis der liessel voll ist. Man stejgert nun den Druck auf $10 \mathrm{Alm}$. und darüber und hält ihn ${ }_{1}^{1}{ }_{2}-\mathbf{2}$ Stunden ein.

Die I mprägnierung mit einem Gemisch von Zinkehlorid und T e e r o l, welches man früher, um an leuerem Teeröl zu sparen, häulig angewendet hat, gestallet sich ähnlich wie die lmprägnierung mit Zinkchlorid allein. Auch hier kann die Dämpfung entrallen, wenn das Holz gut luftrocken ist; das lmprägniermittel-Gemisch muß aber ebenso, wie bei der Imprägnierung mit Teeröl, vorgewärmt werden.

In neuerer Zeit nun bringt man, un die Imprägnierung mil. Teeröl allein bewerkstelligen und doch an diesem liostspieligen Mittel sparen zu können, eigene Imprägnierungsmethoden, sog. S p a r re $\mathrm{r} f$ a $\mathrm{h} r$ e $\mathrm{n}$ in Anwendung.

Nach einem derseluen, dem Rüpingschen Sparverlahren läßt die preußisch-hessische Eisenbahnverwaltung ihre Schwellen, Masten etc. imprägnieren.

Zur Durehführung dieses Verfahrens muB der Kessel mit dem Oelwärmer durch eine Druclilufteitung in Verbindung slehen. 1st das Holz eingefahren und der Kessel dicht verschlossen, so setzt man auf diesen und den Oelwärmer, je nach der Art und Trockenheit des Holzes, einen Luftdruck von $1 \frac{1}{2}-4 \mathrm{Atm}$, welchen man 5-15 Minuten hindurch aufrecht erhālt. Unter Beibehaltung des Luftclruckes preßt man nun das anf 70-100 $\mathrm{C}$. vorgewärmte Oel aus dem Vorwärmer so lange in den liessel, bis ein Ueberdruck — wiederum je nach der Beschaffenheit des Holzes - von $51 / 2$ bis $8 \mathrm{Atm}$. erreicht ist und hält diesen $30 \mathrm{Mlinuten}$ bis 3 Stunden lang ein. Während dieses Oeld̆ruckes wird der Ijessel mittulst in ihm belindlicher Dampfschlangen geheizt. Nach Abblasen des Ueberdruclis und Entleeren des Oeles erzeugt man im Tiessel ein Vakuum von mindesteıs $600 \mathrm{~mm}$, welehes man während 10-30 Minuten einwirken liiBt. Nach Aulhebung des Vakuums ist die Imprägnierung beendet.

Bei der Imprägnierung von Buchenschwellen wird cine zweimalige Auleinanderfolge des geschilderten Tränkungsvorganges, mit entsprechend bemessenen Zeit-, Druck- und VakuumVerhätnissen eingelualten (sog. Doppelverfahren).

Von der Firma Guido Rütgers-Wien wird ebenfalls ein ihr patentierles Sparverfahren ausgeluhrt, welches densellen Zweck verfolgt, wie das uben geschilderle, diesen aber durch andere Mittel erreicht. Nach diesem Verfahren wird das Holz durch Eintauchen oder, vorteilhafter, in der bereits bekannten VTeise (durch Druck und Vakumm) mit der für jede Holzart, erfahrungsgemä $\beta$ oder versuchsweise ermittelten, für die Konservierung gerade ausreichenden Teerölmenge getränlit, und sodann in heizharen Iiesseln einem Druck von muhreren Almosphären, also heißer Drucliluft, ausgesetzt, wodurch eine gleichmäßige Verteilung des Oeles in der ganzen Holzsubstanz erzielt wird.

Neben diesen beiden genanten Sparverfahren sind noch verschiedene andere Varianten derselben durch Patente geschützt und auch in Ausübung.

Der Zweck aller dieser Sparverfahren ist, wie schon der Name besagt, an Imprägniermittel zu sparen, weil die Erfahrung gelehrt hat, daßes zum Schulze des Holzes geningt, wenn bloß seine lesten'Bestandteile (die Holzfaser) durchtränkt und konserviert sind, die Zellräume aber leer bleiben.

Das pneumatische Druckverfalıren ist gegenwärtig das gebräuchlichste und für den fabriksmäßigen Betrieb auch das zweckmäßigste, weil mit ihm große Holzmengen in relativ kurzer Zeit bewältigt werden können. Die mit diesem Verfahren erzielte Durchtränkung und Konservierung des Holzes kann von keinen der bisher genamnten auch nur annähernd erreicht werden. Die WVahl des Imprägnierungsmittels bietet kine Schwierigkeiten, insolange es sich nicht um Mittel handelt, welche stark korrodierend auf die Apparatur wirken.

Daraus erklärt sich auch, daß diese Vexfahren nicht bloß für die Zwecke der Konservierung, sondern auch zum ,Härten“, Färben ete. des Holzes in vielen, den speziellen Zwecken angepaßten Variationen Anwendung findet.

\$16. Die Imprägnierung mit Teeröldämpfen. Daß Dänpre viel leichter und tiefer in das Holz eindringen als Flüssigkeiten, steht wohl außer Zweifel; nichtsdestoweniger hat dieses Verfahren den Erwartungen doch nicht entsprochen. Bei der österrei- 
chischen Südhahn, wo seinerzeit ein solches Vedfahren eingefuhrt war, wurde dassellse wieder aufgegeben, weil es seh* lompliziert und liostspietig war.

In neuerer Zeit wurde die imprïgnierung mit Lâmpfen wieder aufgenommen und der Berlin--Inhaltischen Maschinenlıat-dkliengesellschaft ein Ferfahren dureli 1). R.-P. Nir. 189232 geschülzl, wonaclı das zu inprăgnierende lloly, in geschlossencn liestiln de linwirlung teerolhaltiger Dimpfe ausgeselzt wird, welele bej der Destillation von llolz, Torf oder Iiohle re-ulticren und nötigenfalls durch verdampftes Teeröl angereichert werden können.

Xach einem weiteren Patenle, Xr. 195878 ex 1906, derselhen Gesellschaft werden keine Gase angewendet, sondern das Imprägniermith wird in kiessel zu einem feinen Nelul verstiubt und dieser dann in das $\mathrm{Holz}$ gedrückt oder gesaugt. Zur Zerstiubung werden entweder Druckluft oder die komprimierten Abgase von hokereien verwendet. Das Gemiseh von Zerstäubungs- und Imprägniermillel sowohl, wie atch dic aus ihm sich riederschlagrende liüssigkeil werden in getrennten Kreisläufen über den liompressor oder die Flüssigkeitspumpe, eventuell unter gleichzeiliger Anwärmung, in den lmprägnierkessel zurüelgelcitet.

In welehem Umfange und nit welchem Resultat diese Patente praktisch ausgenützt werden, darüber fehlen entsprechende Angaben.

In dieser slelle sei auch auf ein Verfahren hingewiesen, welehes F. Druz, 13.-11. Forstbeamler, in einer kleinen Broschüre, ,Buchenholzverwerlung*, , $\mathrm{D}$ ä $\mathrm{m} \mathrm{p} \mathrm{f}$ e $\mathrm{n}$ u $\mathrm{nd}$ I $\mathrm{m} \mathrm{p}$ a a gnicren von Holzern mit Holzverkohlungsdäm nen und Gewinnung des Holzessigs bei der. Jeilenverkofilung", Sarajevo 1911, Leschreibt und das auch in Oesterreich bereits patentiert ist.

Der Rahmen dieses Werlies sestallel leider eine vollinhaliliche Aufnabme der in der Broschüre niedergelegten, namentlich lür den Forstwirt āuBersl interessanten Ausführungen des, in der Hcilenverkolilung bekanten und an einem späleren Orle zitierten Fachmannes nicht und es sei daher hier speziell auf die oben genannte Broschüre verwiesen.

Kurz möge hier nur angeführt werden, daß Denz mil seiner Erfindung die bei der Verkohlung von Abfallholz, in cinem ganz spezifisch gesetzten Jeiler, sich ergebenden flüchtigen Destillationsprodulite mitlelst ciner versetzbaren Rohrleitung auffängt und durch einen Imprägnierkesse] leitel, in welchem Jutzholz, jeglicher Form, je nach der Dauer der Einwirkung der Dämpe, entweder hloß getrocknet oder mit den antiseptischen Anteilen der flüelitigen Destillationsprodukle imprägniert wird. Die aus der Imprägnicrsorrichtung abgesaugten, üherschüssigen Verkohlungsdïmufe werden kondensiert und liefern rohen Holzessig, der nach der Angabe ron Denz selir rein sein soll.

Die für dieses Verfahren nolwendige Anlage ist stahil. Der große Vorteil vorstehender Methode liegl, nach Denz, in den geringen Anlagekosten und der großen Dauerhaftigkeit der einmal erbauten An]age, in der Ersparnis an Heizmateria] und in der Einfachleit des V'erialirens.

$\$ 17$. Die Imprägnierung a u e lektrischem W ege. Diese basiert auf der Tatsache, daß die Geschwindigkeit, mit welcher eine Salzlösung eine poröse llembran durchsetzt, ganz bedeutend vergrößert wird, wenn man gleichzeitig durch diese Membran einen elektrischen Strom leitet.

Zur Durchführung dieses Verfahrens wird das Holz in einem Trog, welcher die Imprägnierflüssigkeit enthält, auf den einen Pol einer Dynamonaschine von 110 Volt Spannung gelegt und über demselben, durch ein Filz- oder Segeltuch-Diaphragna getrennt, in einem gleichen, zweiten Trog, der mit Wasser beschickt ist, der zweite Pol angeordnet.

Nach dem Verfahren von Nodon Bretonneau wird die Imprägnierung mit einer 20\%igen, auf $30^{\circ} \mathrm{C}$. erwårmlen Lösung von Jagnesiumchlorid vorgenommen. Der Sirom wird durch 7-14 Stunden mit variabler Stäke zwischen t und 6 Amp. pinwirken gelassen. Nach dicser Behandlung wird das Holz an der Luft getroeknet. Erfahrungen über die Dauer der naeh diesem Verfahren imprägnierten Hölzer liegen bis jetzl nicht vor.

Ganz ähnlich ist das sogenannte $\mathrm{S}$ e n i l i s i e $\mathrm{r}$ e $\mathrm{n}$ des Holzes, bei dem nur anstatt Magnesiumchlorid eine Lösung von $10 \%$ Borax, $5 \%$ Harzseife, $0,75 \%$ Natriumliarbonal und $84,25 \%$ WVasser angewendet wird. Beide Verfahren sind in Frankreich in Verwendung.

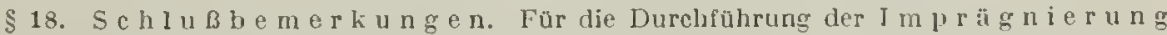
von Eisenbahnsehwellen und Leitungsmasten erlassen die Bahnverwaltungen bestimmte Vorschriften, an welehe sich dic Unternehmer zu halten haben. Diese Vorschriften sind überall fast dic glcichen und unterscheiden sich nur in unwescnlichen Delails. Als Imprägnierungsmiltel wird vornehmlich das schwere Teerö] verwendel. l3ei den ôsterreichischen Bahnverwaltungen lommt aber auch Zinkchlorid, resp. cine Misclung desselhen mil Teerōl oder eine Nacheinandertrinkung mit Zinkchlorid und Tecrōl in Anwendung.

Bei dem ersteren Verfahren (dem sog. genischlen Verfahren) is L das Nischungsverhảltnis der lmprāgnierflussigkeit derart zu rrgeln, daß auf cine Sehwelle durchschnittlich 2 lig Tecröl entfallen und die Trünkung selbst ist so durchzufülren, daß eine Juftrockene licferschwelle 
$\left(0,1 \mathrm{~m}^{3}\right)$ mindestens $30 \mathrm{~kg}$, eine luftroekene Eiehen- und Lärchenschwelle $\left(0,1 \mathrm{n}^{3}\right)$ mindestens $8 \mathrm{~kg}$ Tränkungstoff aufnimmt. Bei der aufeinander folgenden Imprägnierung, welehe mit besonders günstigen Erfolg für Buchenselwellen in Anwendung komml, ist eine Tränliung von $13-15 \mathrm{~kg}$ Teeröl pro Schwelle (von $0,075-0,1 \mathrm{~m}^{3}$ Inhalt) vorgesehrieben.

Für die Gesamtaufnahme an Tränliungsstoffen ist den österreichisehen Balınverwaltungen maßgebend, da $\beta$

1 Rm. luftrockenes Föhren- bezw. Buchenholz mindeslens 300 lig

1 Rill. lufttrockienes Lärchen- bezw. Eichenholz mindestens 80 ," aufnelimen muß.

Dieses Jaß gill bei den österreichischen Bahnverwaltungen auch für die Imprägnierung mit Teeröl allein, welche aber nur in ganz bestimmten Fāllen für Lärchenholz zur Durchïhrung gelangt.

Die preußisch-hessische Eisenbahnverwaltung, welche ilure sämtlichen Hözer nur mit Teeröl imprägniuren läßt, verlangt eine Gewälırleistung der Aufnahme an Teeröl:

\begin{tabular}{|c|c|c|c|c|c|c|c|c|}
\hline $\begin{array}{l}\text { ür } \\
, "\end{array}$ & $\begin{array}{l}\text { eine } \\
, y\end{array}$ & $\begin{array}{l}\text { kicferne } \\
\text { eichene }\end{array}$ & $\begin{array}{c}\text { Schwelle } \\
,,\end{array}$ & $\begin{array}{l}\text { I. 1ิ1. } \\
\text { I. , }\end{array}$ & $\begin{array}{c}\text { jeder } \\
,,\end{array}$ & $\begin{array}{c}\text { Dimension } \\
,,\end{array}$ & ron & $\begin{array}{l}7 \\
5\end{array}$ \\
\hline , & ", & buehene & , & 1. , & , & , & , & 16 \\
\hline ", & $"$ & lieferne & ", & II. , & , & , & , & 6 \\
\hline " & " & cicliene & " & Il. , & ", & " & ", & 4 \\
\hline , & 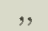 & buchene & ", & Il. & ", & ," & ", & 12 \\
\hline
\end{tabular}

für nach den liubikinlıalt zu bereehnende Hölzer:

$$
\begin{aligned}
& \text { hei Kiefernholz per } \mathrm{m}^{3} \text {. . . . . } 63 \mathrm{~kg} \\
& \text { bei Eichenholz per } \mathrm{m}^{3} \text { - . . . . } 45 \text {, } \\
& \text { bei Buchenholz per } \mathrm{m}^{3} \text {. . . . . 145 " }{ }^{1} \text { ). }
\end{aligned}
$$

Zur Erklärung der eben angeführten Zahlen sei benerht, daß in den österreichisehen Vorschriften ein fast rölliger Ersalz der Gewichtsdifferenz zwischen frisch gefältem und lufttrockenem $\mathrm{Holz}^{2}$ ) durch das Inprägnierungsmittel verlangi wird, während die deutschen Bahnverwaltungen nur eine zur Konservierung des Holzes ausreichende Menge Tränkungsstoff vorsclireiben.

Um letzleres zu creichen, wird die Imprägnierung nach einem modifizierten pneumatischenfDruckverfahren, dem bereits angefühten Rüpingsehen Sparverfahren ausgefürt.

Ueher die Dauer der imprägnierten Schwellen liegen eine Reihe von Angahen vor, jedoch lassen sich daraus lieine zuverlässigen Schlüsse über den Wert der einzelnen Imprägniermittel und Melhoden zichen, weil die mechanische Alnutzung dabei ganz wesentich in Betracht lommt, welche auf den mehr oder minder befahrenen Strecken sehr ungleich ist. Ferner spielt auch die Bodenbeschaffenheit, namentlich aber der Feuchtiglieitszustand, eine sehr wichlige Rolle.

Die Auswechslung der sehwellen erfolgt naturgenäß nur sukzessive, ist innerhalb der ersten füf Jahre sehr gering oder gleich Null und steigert sich sodann von Jahr zu Jahr sehr bedentend. Man kann daher nur von einer annähernden durehschnittichen Dauer sprechen. Nach Angaben von lng. Ziffer beträgt dieselbe bei mil kreosolhaltigem Tecröl imprägnierten Schwellen:

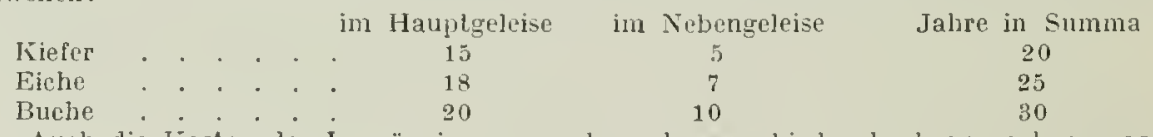

Aueh die Kosten der Imprägnierung werden selır verselieden hoch angegeben, was ja erklärlich ist, da speziell beim Teeröl es nicht gleichgültig ist, ob dasselbe von heimischen Destillerien bezogen werden kann oder importiert werden muB.

Ueber nähare stalistische Daten siehe: Arehiv für Post und Telegrapluie, Berlin 1905 Nr. 16 und 1911 Nr. 8, sowie in den Fachorganen des technischen Eisenbahn-, Post- und Telegraphendienstes überhaupt.

\section{Zellulose- nud Holzstoff-Fabrikation.}

$\$ 19$. A llgeme ines. Unter den Industrie- und Gewerbsweigen, welche sich mit der Verarbeitung des Holzes auf ehemisehen Wege befassen, nimmt die Zellulosefabrikation den ersten Rang ein. Sie ist ein verhältnismäßig junger Industriezweig und hat in den letzten Dezennien einen ganz kolossalen Aufschwung genonmen. Bis Ende der vierziger Jalıre wurden zur Erzeugung des Papier's fast ausschließ-

1) Nach privaten Nitteilungen.

2) Dieser Gewichtsunterschied heträgt: hei der Kijefer rund $350 \mathrm{~kg}$, bei der Lärche $80-140 \mathrm{~kg}$, bei der Eiche $70-100 \mathrm{~kg}$ und bei der Buche $350-450 \mathrm{~kg}$ für den Kiubikmeter. Oeslem. Wochenschrift f. d. öfentlichen Baudienst 1911. 
lich Hadern verwendet. Bei dem stelig steigenden Bedarf an Papier konnte alıer das Hadernmaterial längst nieht mehr genïgen und es inußte an die Heranzielıung von Ersatzmitteln gedacht werden. Unter allen zellulosereichen Roliproduliten ist das Holz das einzige, welches leicht und hillig zu heschaffen ist, große Ausbeuten liefert und sich daher für den Nassenverbrauch am besten eignet. An nächsten lag es wohl, das Holz lediglich auf mechanischem Wege einfach zu zerfasern und den so erhaltenen Holzstoff als Zusatz zu Hadem für die Papierfabriliation zu verwenden. Dieser Ersatz war aber wegen der Kurzfaserigkeil, Steifheit, ungenügenden Verfilzung und Bleichunfähigkeit rler Faser nur ein sehr unvollkommener. Später liam man darauf, daß durch Dämpfen des Holzes ein zienlich langfaseriger Stoff hel'gestellt werden liann, welcher auch olne Hadernzusatz ein genügend festes Papier liefert und für ordinärere Sorten, wie Packpapier, Zeitungs- und Affichenpapier geeignet ist. Damit war der erste große Umschwung in der Papierfabrikation hervolgerufen. Eine zweite, und zwar noch gewaltigere Umwälzung erfolgte durch die Erfindung, Holzzellulose durch Einwirkung chemischer Agenzien von den inkrustierenden Substanzen zu befreien und nahezu rein herzustellen. Dieses so erhaltene Produlit bildet ein vorzügliches Ersatzmittel für Hadern und hat dieselben aus der Papierfabrikation heute fast gänzlich verdrängt.

Als Rohmaterial für die Zellulosefabrikation eignen sich vor allem die Nadelhölzer, welche eine lange, geschmeidige, gut verfilzbare, schwach gefärbte und gut bleichfähige Faser liefem. Minder geeignet sind die weichen Laubhölzer und am wenigsten brauchbar die meisten harten Laubhölzer. Nach ihrer Verwendbarkeit nehmen dic Holzarten folgende Rangordnung ein: I. die Ficlıte (Abies excelsa); 2. die Kiefer (Pinus sylvestris); 3. die Tanne (Abies pectinata); 4. die Lärche (Larix europaea); 5. die Espe (Populus tremula); 6. die Pappel (Populus nigra); 7. die Birke (Betula alba). In der Regel werden aber nur die drei erstgenannten Ilolzarten zur Fabrikation verwendet.

Die 'Herstellung der Zellulose unfaßt folgende Prozeduren:

I. Das Putzen, Zerkleinern und Sortieren des Holzes.

2. Das Aufschließen des zerkleinerten Holzes und die Erzeugung (eventuell Regenerierung) der Lauge.

3. Das Auslaugen, Zerfasern, Sortieren (und eventuell Bleichen) der Rohzellulose, sowie das Entwässern und Trocknen der fertigen Zellulose.

\$20. 1. Das Putzen und Zerkleinerndes Holzes. Das Holz muß von allen zufälligen Verunreinigungen, wie Erde, Sand etc., welche namentlich an den beiden Enden der Scheite und Kílötze zu finden sind, befreit werden. Rinde und Bast müssen abgeschält, die Aeste und Knorren ausgebohrt werden, da dieselben der Aufschließung widerstehen und bleichunfähig sind. Die größte Sorgfalt in der Putzerei ist unbedingtes Erfordernis, weil die Verunreinigungen später nur schwierig zu entfernen sind und das Produlit verderben. Am besten gelingt das Putzen durch Handarbeit, ist aber dafür auch an kostspieligsten. In allen größeren Fabriken verwendet man zum Zerkleinern und Putzen des Holzes eigene Iaschinen. Stärkeres Holz wird zunäclıst mit einer pendelurlen Zirknlarsäge in Klötze von etwa $60-100 \mathrm{~cm}$ Länge zugeschmitten und dabei das liemfaule Holz, welches an der Schnittfläche leicht zu erkennen ist, ausgeschieden. Die Entfernung der Rinde und des Bastes geschicht mit Hilfe der Rindenschälmaschine, welche aus einer rotierenden Scheibe mit 4 lobelartig eingesetzten Jessem bestelıt. Auch Trommeln mit nach innen vorspringenden Schlagleisten werden für diesen Zweck benützt. Durch die Rotation der Trommel werden die in Innem derselben befindlichen Holzliötze abgerieben, 
und die dabei abfallenden Rindenstüclie durch Wasser abgeschwemmt. Da die IIolzklötze immer mehr oder weniger unrund sind, so arbeiten alle Schälmaschinen nur unvolliommen und ist ein wesentlicher Holzverhust damit verbunden.

Viel hesser ist das Schäherfahren mit Dampf. Werden die Holzklötze der Einwirliung von Wasserdampf ausgesetzt, so läßt sich die Rinde samt Bast in ganzen Streifen abzielien und das Holz auf diese Art ganz rein erhalten.

Zum Ausbohren der Aeste benützt man einen rotierenden Löffelbohrer, gegen welchen die Iilötze gedrüclit werden. Auch diese Arbeit ist nur eine unvollkommene, weil man den Verlauf der Aeste in Holze nicht genau verfolgen kann. In manchen Fabriken werden daher die Klötze zuerst zerhackt und dann erst die Aststïcke und sonstigen unreinen Partien auf einem Gurtentransporteur durch Handscheidung entfernt.

Von den Hackmaschinen gibt es zwei Abarten, solche mit auf- und abgehenden und andere mit drehend bewegten Hessern; diese letzteren sind die gebräuchlicheren. Die Hackmaschine zerkleinert das Holz in Späne, unter einem Winkel von 45-600 zur Richtung der Stammachse. Je schwächer dic Späne sind, desto leichter werden sie von der Fochlauge durchdrungen.

Aus der Hackmaschine gelangen die Späne in eine Schleudermühle, wo sie längs der Faserrichtung zerschlagen werden. Schließlich passieren dieselben noch eine Siebtrommel, um einerseits die feinen Verunreinigungen, wie Staub, Holzmeh] und dgl, andererseits aber auch die groben Beimengungen, Aststücke und nicht zerschlagenen Späne wegzuschaffen, während die aussortierten, reinen Späne der Aufschließung zugeführt werden. Der Abgang durch das Putzen, Zerkleinern und Sortieren beträgt bei astarmen, entrindeten Stämmen $5-6$, bei minderen Qualitäten $10-15 \%$, bei berindetem, ästigem Scheitholz 15-20 und bei Prügelholz bis zu $30 \%$.

2. Das Aufschlie Ben des zerkleinerten Holzes. Für diesen Zweck wurden eine Reihe von Agenzien und Verfahren in Anwendung gebracht, von denen aber nur zwei: das Natron- und das Sulfitverfahren in der gioßen Praxis Eingang gefunden und sich dauernd bewälırt haben. Ein drittes Verfahren, ,das elektrochemische", steht demalen nur vereinzelt in Ausübung.

\$21. a) Das $\mathrm{N}$ a tronverfa hre n. Von diesem existieren zwei Abarten: das Soda- und das Sulfatverfahren. Bei ersterem bildet das durch Kaustizieren der Soda erbaltene Aetzuatron und bei letzterem hauptsächlich das durch Feduktion des Natriumsulfates erhaltene Schwefelnatrium das wirlisame Agens.

Das Aetznatron löst in einer Konzentration ron etwa $10^{\circ} \mathrm{B}$., bei einer Temperatur von $160-185^{\circ} \mathrm{C}$. (=5-10 Atm. Ueberdruck) die inlirustierende Substanz des Holzes leicht und vollikommen, so daß die Zellulose nach dem Auswaschen der Lauge sehr rein erhalten wird. Dagegen hat das Aetznatron den Nachteil, daß es sehr teuer ist und nur mit érheblichen Verlusten wieder zurückgewonmen (regeneriert) werden kann, daß es ferner auch die Zellulose sellst angreift und dic Ausbeute daher schmälert.

Schwefelnatrium steht in seiner Wirkung dem Aetznatron nicht nach, im Gegenteil - es löst die inlirustierenden Substanzen besser, greift die Zellulose weniger an und hat zudem noch den Vorzug der Billiglieit. Da es auch auf das im Holze befindliche Eisen lösend wirkt, so resultiert ein hellerer und leichter bleichbarer Zellstoff. Schwefelnatrium braucht nicht eigens dargestellt zu werden, sondern entsteht beim Glühen des dureh Eindampfen der ausgebranchten Laugen erhaltenen Rückstandes von selbst, inden die Holzanslaugeprodukte reduzierend auf das Sulfat einwirken. Der Verlust an Natron liann daher durch Zusatz von Sulfat (Glaubersalz) immer 
wieder ersetzt werden. Als Nachteil ist dagegen anzufülıren, daß - wenn nicht vollkommen richtig zusammengesetzte Laugen und zweckentsprechende Apparate und Verfahren bei der Regenerierung derselben angewendet werden - sowohl heim Tochprozeß als auch bei der Wiederbelebung der Laugen höchst übelriechende Umwandlungsprodulite (Merkaptan, Methylsulfid und andere Sulfoverbindungen) entstehen. Diese verpesten die Luft auf weite Strecken hin, geben infolgedessen zu großen Beschwerden seitens der Nachbarschaft Anlaß und haben schon zu wiederholten Malen die Betriebseinstellung von Fabriken zur Folge geliabt.

Laugenbereitung und Regenerierung.

Bei dem Sodaverfahren wird die Lauge dureh Kaustizierung einer Sodalösung mit Aetzkalk hergestellt. Zu diesem Zwecke dienen eiserne Gefäße, die mit einem Rührwerke und mil einem Schnatterrohr zum Einleiten des Dampfes versehen sind. Für eine Kiaustizierung werden in der Regel $2000 \mathrm{~kg}$ Natriumkarbonat (Soda) und $1100 \mathrm{~kg}$ Aetzkalk (d. s. um rund $2 \%$ mehr als der Theorie nach erforderlich wäre), angewendel. Da der grōßte Teil der Soda aus den gebrauchlen Kochlaugen durch Regenerierung wieder gewonnen werden kann, so ist nur jener Teil, welcher bei der Manipulation verloren gegangen ist, durch neue Soda zu ersetzen.

Die Umselzung erfolgl nach der Gleichung:

$$
\mathrm{Na}_{2} \mathrm{CO}_{3}+\mathrm{CaO}+\mathrm{H}_{2} \mathrm{O}=2 \mathrm{NaHO}+\mathrm{CaCO}_{3} \text {. }
$$

Die Soda-Aełzkalkmischung wird unler fortwährenden Rühren aufgekocht, und sobald die liaustizierung beendet ist, der Dampf abgestell, der Niedersehlag von Calciumkarbonat absitzen gelassen, und die ferlige Lauge abgezogen. Da letzlere nicht vollkommen lilar ist, so muß sie ein Sandfilter (oder eine Filterpresse) passieren, um die feinen suspendierten Schlammteilchen zurückzuhalten. Die filtrierten Laugen müssen alsbald (lăngstens nach 2-3 Tagen) ihrer Verwendung zugeführt werden, da sonst die líaustizitäl wesentlich zurüchgeht. Der Schlamm $\left(\mathrm{CaCO}_{3}\right)$ wird gesammelt und in größeren Partien ausgelaugt, um das darin enthaltene Aetznatron zu gewinnen.

Beim Aufsehließen des Holzes wird die Lauge tief dunkelbraun von den humusartigen Zersetzungsprodukien des Lignins. Um aus dieser ausgebrauchten Lauge das Natron wieder zu gewinnen, wird dieselbe bis zur Trockene abgedampft und der Trockenrüekstand in Flammöfen geglüht, wobei die organische Subslanz verbrennt und das Natron wieder als liarbonat (Soda) zurückbleibt. Es ist notwendig, daß die Soda im Flammofen möglichst weiß gebrannt wird, ohne dabei ganz zu sehmelzen. Die in der Soda verbleibenden, āußersı fein vertcilten Kohlenteilehen sind sehr nachteilig, da sie durch kein Filter zurückgehalten werden, mit in die Zellulose gelangen und derselben einen grünlich-blauen Farbenton erteilen, welelier aucls in der Bleiche nicht weggeschafft werden kann.

Die Regenerierung der Laugen ist eine lāstige und kostspielige Prozedur; der Wärmeverbrauch ist trotzdem, daß die Auslaugeprodukte mitverbrennen, dennoch ein ganz erheblicher, da auf $100 \mathrm{~kg}$ lufttrockener Zellulose elwa $14 \mathrm{hl}$ Lauge entfallen; ferner ist auch der Sodaverlust durch Verflüchligung beim Weißbrennen (Calcinieren) cin bedeutender, etwa $12-15 \%$, und endlich wird auch die Herdsohle durch die sehmelzende Soda stark angegriffen; es sind oftmalige Reparaturen notwendig und die Soda selbst wird durch die Bildung von Silikaten, aus der Chamottemasse der Herdsohte, immer unreiner.

Ein Teil dieser Uebelstände ist vermieden, wenn anstatt Soda das viel billigere Glaubersalz in Anwendung gebracht wird (Palent Dahl). Das Natriumsulfal $\left(\mathrm{Na}_{2} \mathrm{SO}_{4}\right)$ wird, wie bereits erwähnl, beim Glühen des aus den Laugen erhaltenen Trockenrückslandes durch die vorhandene organische Substanz reduziert; es enlsteht hauptsächlich Schwefelnatrium, ferner bilden sich auch schwefligsaures, unlersehwefligsaures und kohlensaures Nalrium. Die so erhaltene Schmelze wird in Wasser gelöst und mit Aetzkalk gekocht, wobei eine teilweise Kaustizierung stattfindet. In allen anderen Details stimmen diese beiden Soda- und Sulfatverfahren vollkommen überein.

Die Kiocher, in welchen die Aufsellließung des zerkleinerlen Holzes vorgenommen wird, sind meist aufrecht slehende Zylinder aus starkem liesselblech, von etwa $10 \mathrm{cbm}$ Fassungsraum. Oben ist die Füllöffnung für das Holz und seitlich unlen die Entleerungsöffnung für die Rohzellulose angebracht. Ferner sind die nōtigen Armaturen für die Einstrōmung und Ausblasung des Damples, Einleitung der frischen und Ablassen der ausgebrauchten Lauge rorhanden. Alle Rōhren und sonstiggen Arınaturleile müssen aus Eisen hergestell sein, da llessing oder andere Legierungen von der Lauge stark angegriffen werden. $1 \mathrm{~m}$ lioeher sind Siebeinsātze vorhanden, welche die Lauge ungehinderl durchlassen, die Holzspäne alıer zurūelihallen. L'm Wärmeverluste nach llöglichkeit zu verhindern, sind die liocher mit einen 1solierungsnaterial umgeben und mit Brelterwänden verschalt. Jeder Kocher steht mit den Laugenvorwärmer und mit dem Dampfkessel in Verbindung. Koeher nit direkter Feuerung sind veraltel.

I'm bei der Entleerung der liocher an Zeit und Arbeitskraft zu sparen, liat nian sie so eingerichlet, daß der gesamte Inhalt (Zellstoff und Lauge) unter schwachem Druck in offene 
oder geschlossene Apparate ausgeblasen werden kann, wobei gleichzeitig eine feine Verteilumg der aufgeschlossenen Holzmasse erreicht wird.

Die Lauge wird von unlen in den Focher eingelassen, un die in der Sclinitzelfüllung befindliche Luft nach oben hin zu verdrängen, und durch tine entsprechende situierung der Heizworrichlung in ständiger Bewegung erhalten. Zuweilen werden zwei oder mehrere Jiacher zu einer Batterie miteinander verbunden, so daß die Lauge von einem Kocher in den nächstfolgenden übersteigen kann, modurch dic Lauge besser ausgenützt und die Rohzellulose reiner wird.

Druck, resp. Temperatur, Kiochdauer und Konzentration der Lauge mủssen dem jeweiligen Rohmaterial angepaßt werden. Am leichtesten ist das Fichtenholz aufzuschließen, dann folgt Föhren- und Lärchenholz und am schwierigsten kocht sich das Tannenholz.

Die Laugen haben gewöhnlich 8-10 B.; die Kochdauer schwankt zwischen 5 und 6 Stunden und der Druck zwischen 5 und 10 Atmosphären. Ieistens halten die Fabrikeı ihre Kochordnung geheim.

Das Natronverfahren ist der Kostspieligkeit und der geringen Ausbeute wegen schon seit einer Reihe von Jahren stark in Abnahme begriffen, wird aber zur Herstellung gewisser Papiersorten, namentlich für weiches, geschmeidiges und gut saugfähiges Papier doch noch angewendet. Für die Erzeugung von Zellstoff aus der schwer aufzuschließenden Kiefer wird es nicht zu umgehen sein, sei es, daß man es hier als solches oder in Kombination mit dem Sulfitverfahren in Anwendung bringt. In Amerika, wo heute noch $75 \%$ der gesamten Zellstoff-Fabrikation ihr Rohmaterial mit harzreichen Nadelhölzern deckt, stelıt das Natronverfahren in Vordergrund. Erwähnt sei hier noch, daß bei der Verarbeitung harzreicher Hölzer nach dem Natronverfahren im ersten Stadium des Aufschließprozesses ohne besondere Sehwierigkeiten das Terpentinöl für sich gewonnen werden liann, wodurch eine, mitunter nicht zu unterschätzende, weil fast kostenlose, Rentabilitätserhöhung des Betriebes erzielt wird.

Unter dem Namen, ,Iraftzelislof" ist in neuerer Zcit ein Zellstoffprodukt stark im Ilandel, welches zur Erzeligung außerordenllich feslel, dunkelfarbiger Papiere (Packpapiere) verwendet wird. Dieser liraftzellstoff stellt ein Halbprodulil dar, das durch unvollstandige Aufschließung von Holz mil aufgefrischlen Ablaugen des Nalionverfahrens und naclifolgendes gründliches Zerfasern in liollergängen oder Holländern erzeugt wird.

$\$ 22$. b) D as Sulfitverf a hren. Dasselbe wurde bereits $1866 \mathrm{dem}$ Amerikaner Tilgham patentiert, 10 Jahıre später von den Schweden Ekman und Prof. Mitscherlich in die Praxis eingeführt, dann mehrfach abgeändert und verbessert; namentlich hat sich Dr. Kellner viele Verdienste in dieser Hinsicht erworben. Ieute ist das Sulfitverfahren weitaus das gebräuchlichste und zweckmäßigste. Es basiert auf der AufschlieBung der Ligninsubstanz des Holzes mittelst Calciumbisulfit $\mathrm{Ca}\left(\mathrm{HSO}_{3}\right)_{2}$ d. i. cine Auflösung von schwefligsaurem Calcium $\left(\mathrm{CaSO}_{3}\right)$ in wässeriger schwefliger Säure $\left(\mathrm{H}_{2} \mathrm{SO}_{3}\right)$. Das wirksame Agens ist die schweflige Säure, während das Calcium gewissermaßen nur als Träger für die erstere zu betrachten ist.

Dił L a ug e n e z e u g u g zertällt in zwei Stadien: 1. in die Erzengung des Schwefeldioxydes $\left(\mathrm{SO}_{2}\right)$, 2. in die Absorption desselben dureh Wasser $\left(\mathrm{SO}_{2}+\mathrm{H}_{2} \mathrm{O}=\mathrm{H}_{2} \mathrm{SO}_{3}\right)$ und Einwirkung der dabei entstehenden schwefligen säure auf Kalkstein $\left(\mathrm{CaCO}_{3}\right)$, wobei Calciumbisulfit gebildet wird und kohlensäure entweicht.

$$
2 \mathrm{H}_{2} \mathrm{SO}_{3}+\mathrm{CaCO}_{3}=\mathrm{Ca}\left(\mathrm{HSO}_{3}\right)_{2}+\mathrm{CO}_{2}+\mathrm{II}_{2} \mathrm{O}
$$

Das scliwefeldioxyd wird entweder durch Verbrennen von schwefel ( $\mathrm{S}+\mathrm{O}_{2}=\mathrm{SO}_{2}$ ) oder durch Rösten von sichwefelkies $\left(2 \mathrm{FeS}_{2}+11 \mathrm{O}=\mathrm{Fe}_{2} \mathrm{O}_{3}+1 \mathrm{SO}_{2}\right)$ in eigens hiefür honstruierten oefen erzengt.

Die Verbrennung nuß bei nur mäßigem Luftäberscluß eine möglichst vollständige sein und darf kein schwefel dabei sublimieren, weil dadulch Verluste und hei der Laugenbereitung und dem Kuchprozeß Schwierigkeiten entstelien. Schwefel, obwohl teuerer, ist dem Schwefelkies vorzuzichen, weil sich der Betrieh einfacher gestaltet, kleincre Oefen ausreichen und kein Abbrand erlalten wird. Vom Schwefellies, weleher als rejuer l'yrit FeS $46,7 \%$ Eisen unel $53,3 \%$ Schwelel enthält, blejben imner $3-50 \%$ Schwefel in den, nie bis ins Innere durchröstenden, Kiesstücken unverbrannt zurücl. Der Abbrand isI somit ein bedeutender, das Cas jst verdünnler (enthäll ca. 9-10 Vol.-Proz, $\mathrm{SO}_{2}$ ) und wird laher auch nicht so leicht und vollständig absorbiert. Ls enthălt immer Flugasche, die sich schon iı den Fülılröhren unangenelın be- 
merlibar macht und bis in den Absorvtionsturm gelangt. Neben selwwefeldoxyd entstelt auch immer etwas Trioxyd $\left(\mathrm{SO}_{3}\right)$ und zwar bei lijes immer meln als bei reinem Schwefel. Diese's Trioxyd ist dia Ursache der lästigen Giphbilung bei der Laugenbereilung. Von 100 Teilen des verbrannten schwefels gohen etwa 2-4 Teile auf Rechnung von Trioxyd.

Eine vorteilhafte Konstruktion der Pyritöfen ist der Kiesröstofen von llereshoff, cin aufrechtstehender Zylinder unit 5 litagen, welche der zu röstende Kïs, infolge der Bewegung von Rohrarmen, langsam von oben nach unten passiert. Dieser Ofen ist speziell für die Erzcugung von Bisulfitlauge selr gut geeignet, weil er ein $\mathrm{SO}_{2}$-reiches Gas liefert und die Bildung von Trioxyd auf rin Minimun reduziert.

Zur Absorption und Finwirkung der schwefligen Säure auf Kalkstein dienen in der Rege! hole Türme, in denen die liakiseinfüllung von oben herab mit Wasser berieselt wird, wälırend die schweflige Sïure von unten whtgegenstreicht. Die Tüme sind meist aus starkem Holzgebälke hergestellt, 20-30 $\mathrm{m}$ hoch und $13 / 2-13 / 4 \mathrm{~m}$ in Geviert. Sic sind mit Brettern verschall, wit Werg oder dergleichen gedichtet und nit Teer gestrichen. Un den Druck der Kalksteinfüllung auszuhalten, müssen starke Eisenreifen angebracht werden. Der IKalkstein ruht auf einem Rost aus starken Eichenbalken; unter demselben mündet das von Schwefel- oder Kiesofen kommende Rolır.

Un möglichst reine und konzentrierte Laugen zu erlalten, muß das Gas vor seinem Eintritt in den Turm, gewaschen" und gekühlt werden. Zu diesen Zwecke passiert es stehende oder liegende Rohrsysteme, die entweder durch die Luft oder durch Wasserberieselung geliülı!t werden.

An der obersten Stelle des Turmes befindet sich ein Wasserreservoir, ans welchem das Wasser mittelst Verteilungsrölren oder Ueberlaufnäpfen durch die Kalksteinfullung, fein verteilt, herabrieselt. Unter dem Reservoir ist eine Gosse zum Nachfullen des lialksteins angebracht.

Die durch die Einwirkung der schwefligen Säure auf den Kallistein entstchende Lauge sammelt sich in einem unter dem Rost befindlichen, gemauerten Behälter und wird durch ein Bleirohr nach außen in Holzkästen abgeleitet. Bei regelrechten Gange der Arbeit zeigt die abfließende Lauge etwa $5-7^{\circ}$ B.; im Winter etwas mehr als im Sommer.

Der durchschnittliche Gchalt an $\mathrm{SO}_{2}$ beträgt ca. $3 \frac{1}{2} \%$, wovon ungefälir $1 / 3$ an $\mathrm{KaJk}$ gebunden und $2 / 3$ im freien Zustande vorianden sind.

Der Wasserzulauf muß so reguliert werden, daß oben am Turm schweflige Säure nur mehr ganz schwach durch den Goruch wahrzunchmen ist, was aber nur bei sehr hohen Türmen gelingt. Un auch nit weniger hohen Türmen rascher arbeiten zu können, und das Entweichen der sehwefligen Säure, welche schädigend auf die Vegelation der Unigubung wirkt, zu verhindern, werden nach dem Patente Dr. liellner zwei Türme so miteinander verbunden, da $\beta$ dic sclweflige Säure, welche oben aus dem ersten Turm entweicht, durch ein Tonrolır nach unten in den zweiten Turm geleitet wird, während die schwache Lauge aus dem zweiten Turn auf den crsten gehoben wird und beim Durchrieseln desselben sich mit der frischen, sehwefligen Säure anreichert. Der lialkstein wird in faust-bis liopfgroßen Stücken in den Turm gefüllt. Er soll porös und dabei doch sehr fest scin, un einerseits eine große Oberfläclle zu bieten, andererseits aber auch den Druck der darüberliegenden Schichten auszuhalten. An gecignetsten ist halktuff. Anstatt lialkstein $\left(\mathrm{CaCO}_{3}\right)$ kann auch Dolomit $\left(\mathrm{Ca} M g\left(\mathrm{CO}_{3}\right)_{2}\right)$ oder Magnesit $\left(\mathrm{IgCO}_{3}\right)$ verwendet werden. Lnreiner, toniger Kalk gibt zu Betriebsstörungen Anla $\mathrm{B}$, weil sich viel schlamm bildet, der die Lauge verunreinigt und auch Verstopfungen im Turm bewirken kann. Bei reinem Kalke kann der Turm Jange Zeit ungestört im Betriebe bleiben; bei unreinem Kalke muß hingegen öfters fin Durehspülen vorgenommen werden, inden man das Wasser stoßweise, in einen starken Scliwall, durch die Kalksteinfüllung fließen läßt.

Die Türme luaben den Nachteil, daß ihre Herstellung kostspielig ist, der Kialkstein und das Wasser hoch gehoben werden müssen, daß ferner die unteren Partien der Kalkfüllung stark korrodieren und durch den Druek der oberen Schichten zerbröckeln; auch üherzieht sich die Oberßäche der lialksteinstücke alsbald mit einer liruste von Gips und Schlamm, welche die weitere Einwirkung der schwefligen Säure verhindert.

Um diesen Uebelständen zu entgelıcı, hat Dr. liellner an Stelle der Türne Gefäßbatterien angewendet. Dicselisen bestehen aus melireren (4-5) stufenförnig aufgestellten Holzbottichen, von denen jeder ${ }^{1}{ }_{3} \mathrm{~m}$ über den vollen Boden einen Lattenboden besitzt auf welchem eine Schichte von lialkstein liegt. Die Bottiehe sind dicht geschlossen, haben im Deckel ein IIannloch zum Einfüllen und seitlieh unlen ein zweites zum Ausräunen des lialksteines. Jeder Bottich ist bis zu $2 / 3$ der IIöhe mit Wasser, bezw. Lauge, gefullt. Das Schwefellioxyd wird inittelst eines liompressors in den zu unterst stehenden Laugenbotticl gepumpt, geht durch ein Uebersteigrohr in den ersten Absorjtionsbotticli, von hier in den zweiten usw. Fort. Aus dem letzten obersten bottich entweichen nur mehr indifferente Gase (Stickstoff, atm. Luft und Kohlensäure), aber keine schwefligsäure. Wasser fließt in den obersten Bottich zu; die hier entstehende sclwache Laure fließt durch ein Ceberlaufsrohr in den nächst untern usw., his sie aus dem untersten Buttich nit der erforderlichen lionzentration in den Laugenbehälter gelangt und von hier abgezogen wird.

Außer diesen Laugenbereitungsapparat gibt es noch diverse andere auch solehe bei 
denen anstatt Jialkstein Kalkmileh in Anwendung kommt. Trotz der mehrfachen Uebelstände, welche den Türmen eigen sind, werden dieselben aber noch am häufigsten verwendet.

Dit li och e r müssen der Einwirkung der schwefligen Säure widerstehen und einen Druck von inindestens $6 \mathrm{Atm}$. aushalten. Diesen Anlorderungen entsprechen am besten zylindrische, eiförmige oder kugelförmige Gefäße aus Flußeisen oder Stahl, welche in Innern mit einem säurefesten Material ausgefütert sind. Die zylindrischen Kocher sind liegend oder stehend; erstere zumeist rotierend, tetztere feststehend. Die Kugelkocher sind immer für Rotation eingerichtet, werden aber in der Regel nur für Strohzellulose-Erzeugung benützt. Als Ausfütterung dienen Bleiplatlen oder porzellanartig gebrannte, säurefeste Ziegel in Zement gelegt oder auch Glaszicgel.

Die modernen Ausileidungen der kiocher werden in der Regel dureh homogene Verbleiung hergestelit.

Einen einfachen, lcicht auszuführenden, billigen und auch sicheren Sehutz der Kiocherwand gegen die schädlichen Säuredämpfe erzielt Brünnger dadurch, daß er, nach Füllung des Kochers mit Sulfitlauge oder Gipslösung, den Focher von außen heizt. Es bildet sich so an der Kocherwandung von selbst eine undurchlässige Kruste, welche jegliche Berührung des Metalls mil der sehwefligen Säure verhindert. Nach Baerwaldt soll sich einc Auskleidung des Kochers mil einer dicken Schicht eines Zement-TTasserglasgemisches, die mit einer BleiglätteKilte gründlich verrieben wird, gut bewähren.

Die Sulfit-liocher haben gewöhnlich einen Fassungsraum von 60 bis $100 \mathrm{~m}^{3}$. Neuerer Zeit baut man auch sehr große Kocher mit mehr als $200 \mathrm{~m}^{3}$ Kapazität. Große Kocher haben den Torteil, daß die Wandfläche im VerhäItnis zum Inhalt geringer ist, ferner bei der gleichen Produktionsmenge auch weniger Armaturstücke erforderlich sind, welche durch die Säure stark angegriffen werden und bald zugrunde gehen. Jeder Koeher ist mit einer Füll- und Entleerungsöfnung versehen, ferner mit den nötigen Armaturen: Ventile für Lauge, Dampf, Gasausströmung. I'robenahme, Sicherheitsventil, Manometer-Thermometer. Die Jeizung geschieht entweder durch direlile Dampfeinströmung oder mittelst Heizschlangen aus Hartbiei, Iupfer oder zinkfreier Bronze, welehe bei stehenden liochern der Kocherwandung angepaßt, bei liegenden als ein Heizrohrsystem im unteren Teil des Kochers angeordnet sind. Auch Mantelheizung mil Dampf oder heißer Luft wird angewendet.

Der Ko c h p ro z e B beim Sulfitverfahren - im Prinzip überall fast gleich wird in seinen Details von den einzelnen Fabriken, je nach der Einrichtung der Fabrik und der Beschaffenheit des Rolmmateriales verschicden durehgeführt. Zunäehst wird der Kocher mit den sortierten Holzspänen so weit gefüllt, daß ein Raum von etwa $40 \mathrm{~cm}$ frei bleibt. Sodan folgt das Dämpfen bei $100^{\circ} \mathrm{C}$., was den Zweck hat, die Luft auszutreiben, damit die Lauge leichter in das Holz eindringen liann; ferner setzt sich auch die Holzfüllung dichter zusammen, so daß eine größere Mlenge eingebracht werden liann. In französischen Fabriken wird auch überhitzter Dampf für diesen Zweck rerwendet. Nachdem das Kondenswasser abgelaufen ist, wird Lauge eingelassen und die Heizung so reguliert, daß die Temperatur allmählich auf $128^{\circ}$ steigt. Temperatur und hochdaucr müssen dem Holzmaterial angepaßt werden. In der Regel kocht man 26-30 Stunden bei $3 \frac{1}{2}-4 \mathrm{Atm}$. oder 60 Stunden bei $21 \% 2$ Atm. Ueberdruek. Temperatur und Druck stehen hier nicht in Relation wie bei einem Dampflessel, weil neben dem Dampfdruck auch noch der Gasdruck, herrührend von der aus der Lauge ausgetriebenen schwefligen Säure, mitwirkt.

Die Sulfitlauge löst die inkrustierende Substanz, ohne rlie Zellulose selbst erheblich anzugreifen.

Ueber die beim Kiochen des Holzes nit Sulfitlauge sich abspielenden eliemischen Prozesse, welche sehr liomplizierter Natur sind, ist man noch im unliaren.

Nach Filein erfolgt durch die Sulfitlauge eine Aufspaltung der Lignin-Zellulose-Ester, als weiche ja das Holz angesehen wird, wobei neben Zellulose das Kiallisalz der Ligninsulfosäure $\left(\mathrm{C}_{18} \mathrm{H}_{19} \mathrm{O}_{8} \mathrm{SCa}^{1}{ }_{2}^{\prime}\right.$ oder $\left.\mathrm{C}_{41} \mathrm{H}_{44} \mathrm{O}_{17} \mathrm{~S}_{2} \mathrm{Ca}\right)$ entsteht. Klason nimmt das Lignin als eine glukosidartige Verbindung an, welche zum Tril aromatischer Natur ist, zum Teil aber aus einer Zuekerart oder Zellulose besteht. Sie enthält eine Oxypropylengruppe CH = CICH ${ }_{2} \mathrm{OH}$, ferner Methoxyl, Hydroxyl und Aldehyd-Gruppen. Beim lioehprozeß lagert sich die Säure an die doppelte Bindung:

$$
\begin{aligned}
= & \mathrm{C} \\
& =\mathrm{CH} \\
= & \mathrm{C}+\mathrm{H}_{2} \mathrm{SO}_{3} \stackrel{\mathrm{C}}{\|} \mathrm{SO}_{3} \mathrm{H}
\end{aligned}
$$

Nach einer anderen Theorie wird jedoch das Lignin unter Bildung aldehydartiger Ver- 
bindungen zersetzt, welche mit. Bisulfit wasserlösliche Reaklionsprodulite geben. Als Nehenprodukte entstehen lexnsen, Jentosen, feruer auch leimälntiche subsiauzen, Gijs, freior Schwefel und schrefelsäure.

Ein Hindernis bei der Aufschließung ist das Harz. Eine Gewinnung des Terpentinöles ist beim Sulfitverfahren nicht möglich, weshalb entweder das Holz vor der Aufschließung oder der Zellstoff bei der Reinigung durch geeignete Vittel entharzt werden muB.

Nach beendeter liochung. was durch eine Probe der Lauge auf ihren Gehalt an $\mathrm{SO}_{2}$ erkannt wird, wird das freigewordene Schwefligsäuregas in einen sog. Uebertreibturm oder eine entsprechende Absorptionsvorrichtung abgeblasen, der Kocherinhalt einigemal mit heißen Wasser ausgewaschen, um den größten Teil der Lauge wegzubringen, und sodann die Rolzellulose entleert.

\$23. c. Das elektrochemische Verfa hren (Patent lielner). Wird liochsalzlösung der Einwirkung eines starken elektrischen Stromes ausgeselzt, so scheidet sich an der Anode das Chlor und an der kathode das Natriun ab; da Wasser zugegen ist, geht ersteres teilweise in mterchlorige Säure und letzteres momentan und vollstandig in Natriumhydrat über. Zur Aufschließung des Holzes verwendet Kellner eine zweiteilige, gemauerte und mit Tonplatien ausgelegte Zisterne, in der jede Abteilung eine EIelitrode enthält. Dadurch, daß man den Strom von Zeit zu Zeit wechselt, wird das Iolz einmal der Einwirlung von Natronlauge, das andereınal aber der von Cluor und unterchloriger Sãure ausgesetzt, auf diese Weise aufreschlossen und gleichzeitig auch gebleicht.

Dieses Verfahren — an sich ausgezeichnet, weil es sehr feste und reine Zellulose liefert komnte sich aber bisher im Großhetriebe nicht einfühen, da die Apparate der Zersetzungszellen, mangels eines geeigneten Materials, ständige und kostspielige Reperaturen erheischen, weIche die Rentabilitat des Verfahrens in Frage stellen.

Die Aufschließung mit Sulfillauge ist dermalen noch immer die rentabelste und wird daher das eleklrochemische Verfahren vorläufig nur zu Bleichzwecken benützl.

S24. 3. Das A us l a u e $\mathbf{n}$, Zerfasern, Sortieren und eventuell Bleichen der Rohzellulose, sowie das Entwässern und Trocknen der fertigen Zellulose. Bei der NatronzelluloseFabriliation handelt es sich um möglichst vollständige Rückgewinnung der ausgebrauchten Lauge. Es ist daher notwendig, daS den Waschen der Rohzellulose eine Auslaugung vorangeht. Un die Lauge dabei nicht zu viel zu verdünnen, muß das Auslaugen systematisch, nach Art des Batteriebetriebes, vorgenommen werden. Man verwendet für diesen Zweck eine Iiombination von mehreren ( $1-8)$ Gefäßen (eiserne Reservoire oder zementierte Zisternen), welche mit Siebböden versehen sind und durch Ueberlaufröhren miteinander kommunizieren. Die Piolnellulose gleitet aus den Kochern über eine rinnenförmige Rutsche direkt in die AuslaugegefäBe. Auf das jeweilig erste Gefäß läuft Wasser zu, durchdringt die Zellulosefüllung, fließt durch den Siebboden ab und steigt durch das Ueberlaufrohr auf das nächstfolgende Gefäß. Dieser Vorgang wiederholt sich von Gefäß zu GefäB. Die Lauge nimmt dabei immer an Fionzentration zu und fließt endlich mit etwa $8-10^{\circ} \mathrm{B}$. aus den jeweilig letzten Gefäß der Batterie ab. Ist der Inhalt des ersten Gefäßes (I) ausgelaugt, so wird der Wasserzufluß auf II gestellt, I entleert, von neuem mit Rohzellulose beschickt und als letztes Gefä $B$ in den Turnus eingeschaltet.

Bei der Sulfitzellulose-Fabrikation, wo man auf eine Wiedergewinnung der Lauge nicht reflektiert, entfällt diese Manipulation.

Die Abwässer aus diesen Fabriken verursachen nicht selten große Falamitäten, da sie in öffentliche Wasserläufe nicht ohne weiteres abgelassen werden dürfen und eine vollkommen befriedigende Peinigungsmethode hierfür nicht existiert. Nur dann, wenn eine entsprechend starke Terdünnung der Ablaugen - nach Klason eine mindestens I000fache, nach Vogel eine jo0fache - im öffentlichen Gerime erfolgen kann, dürfen diese Abwässer denselben direkt zugeführt werden. 
Leber die Zusammensetzung dieser Abfallprodukte (auf Trockensubstanz bezogen) pro 1 L Zellstoff gibt Kilason folgende Bereclınung:

\author{
Lignin \\ Fohlehydrate \\ Protein \\ Ilarz und Fett \\ Sehweflige Säure (an Lignin gebunden) \\ Letzkalk
}

\begin{tabular}{|c|c|c|}
\hline 644 & ode & $600 \mathrm{~kg}$ \\
\hline 311 & ," & 325, \\
\hline 15,5 & $"$ & 15, \\
\hline 73 & 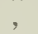 & 30 \\
\hline 235 &, & 200 \\
\hline 102 & . & 90, \\
\hline 1380 & 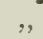 & $1260 \mathrm{~kg}$ \\
\hline
\end{tabular}

Schällich für die Lehewesen in und an den FluBläufen, welche solche Abwässer aufnehmen, ist in erster Linic der Gehalt dorselben an schwefliger Säure, welche weniger vielleicht als direktes, denn als indirektes Fischgift zu bezeiclinen ist. Letzteres aus dem Grunde, weil bei der auBerordentlich raschen Oxydation der schwefligen Säure zu Schwefelsãure, infolge der starken Verdünnung, Sauerstoffmangel im Wasser eintreten kann.

In zweiter Linie sind es die Kohlehydrate und Proteinstoffe, welche, als geeignete Nährsubsirale für Kileinlebewesen, durch ihre Gärungsjurodukte die Wasserläuf verunreinigen und namentlich an den ruhigeren Stellen derselben die Fische von ihren Laichplätzen vertreiben.

Die Ligunstoffe dürten aller Wahrscheinlichkeit nach bei der Selbstreinigung der Flüsse dureh den Sauerstoff und die Lehewesen des Wassers beseitigt werden. ,

Wo ungenügende Wassermengen zur Aufnalime der Abfallprodukte vorhanden sind, muß für eine Unschädlichmachung dieser Vorsorge gelroffen werden. Der Versuche in dieser Richtung giht es zahllose. Die Fällung der schwefligen Säure mit liallimileh zu Monosulfit und die Verwendung der üher dem Niederschlag sich ergebenden Flüssigkeil zur Berieselung von Feldern und Wiesen hat keine befriedigenden Resullate ergeben. Durch Eindampfen die Ablauge in einen festen Rïckstand überzuführen, der als Heizmaterial dienen soll, ist zu kostspielig. Alle übrigen Verwendungsarten der Ablaugen: zu Gerbzweeken, zur Erzeugung von Oxalsäure, eines Dextrin-Surrogates (Dextron gellannt), eines Bindemittels (Zellpech) für pulverige Substanzen bei deren Formung und Brikettierung, als Heilmittel für Lungenkranke (als Lignosulfit in fester Form) usw. sind von untergeordneter Bedeutung.

In neuester Zeit sollen Versuche, die Sulfitablauge - nach Neutralisalion der Säure bis zu dem för die Hefe günstigen Säuregrad-vergären zu lassen und so zur Spiritusgewinnung heranzuziehen, von Erfolg gewesen sein. Aus 100 hl Lauge sollen 60 Liter absoluter Alkohol gewonnen werden können.

Mit Rüeksichl auf die Schwierigheit der Beseitigung der Abfallprodulite einer Sulfitstoff-Fabrik nuß daher schon vor deren Errichlung besonderes Augenmerk auf diesen Umstand gerichtet werden. Die Menge der Abwässer solcher Fabriken ist e ine sehr bedeutende. Von einem liocher mittlerer Größe resultieren elwa $60 \mathrm{~cm}^{3}$ Ablauge, welche beiläufig $5000 \mathrm{~kg}$ organische Substanz und $3000 \mathrm{~kg}$ Kalksalze entlualten.

Die Rohzellulose, wie sie aus dem Kocher, oder beim Natronverfahren aus den Auslaugekästen liommt, besteht der Hauptmenge nach aus Faserbündeln, welche zerteilt werden müssen. Zu diesem Zwecke benützte man früher fast aussch]ießlich die sogen. Holländer, wo durch eine rasch rotierende Trommel mit Grundwerk, welche beide init sclnäggestellten Messerschienen besetzt sind, das Zerfasern der im Wasser verteilten breiartigen Zelhulosemasse erfolgt. Diese Einrichtung hat aber den Nachteil, daß die Faser dadurch stark beschädigt wird. Gegenwärtig benützt man schwach konisch geformte Tronmeln mit durchgehender Welle, welche mit quirlartig gestellten Fingern besetzt ist. Durch die Reibung trennen sich die Faserbündel, während die unaufgeschlossenen harten Teile, die sogen. Knorren unzerkleinert bleiben. Aus dem Zerfaserer gelangt die dünnbreiige Zellulosenasse in eine zweite Trommel, deren Mantel aus Holz-oder Hartgummistäben hergestellt ist. Das feinfaserige Material geht durch dic Schlitzöffnungen des Trommelmantels und wird von Wasser weiter geschwenmt, während die Splitter und Knorren am vorderen Ende der etwas sclıräg liegenden Trommel herausfallen. Der so sortierte Stoff passiert dann noch eine 10-20 m lange Rinne, den sog. Sandfang, wo sich die spez. schwereren Beimengungen, Sand u. dgl., abscheiden. Aus dem Sandfang fließt der Stoff in eine Rührbütte und wird von lier mittelst Schöpfrärlern auf die Entwässerungsmaschine gehoben. Als solche dienen Rund- und Langsiebe. Das Wasser fließt durch die feinmaschigen Siebe ab, wälırend der Stoff darauf zurüclibleibt. Die weitere 
Trocknung geschieht auf langsam rotierenden gußcisernen Zylindern, welche mit Dampf gelıcizt werden. Es resultiert dabei Rollenpapier, welches die gewöhnliche Ilandelsform für Zellulose ist.

Zellulose wird in der Regrel im ungebleichten Zuslande an die l'apieriabrilien geliofert, welche die Bleichung selbst nach Bedarf vornehmen. Fü gewisse Verwendungen speziell als Fillematerial, wird aber gebleichte Ware verlangt. Zum Blichen benulzt man fasi ausschließlich cinen klaren, wässerigen Auszıg von Chlorkalk, dessen wirlisamer Bestandleil das Calciumhypochlorit $\mathrm{CaCl}_{2} \mathrm{O}_{2}$ ist. Sullitzellulase bleicht sich am leichtesten und genügen hierzu etwa $5 \%$ Chlor. Sulfalzellulose erfordert 10-12 und Sodazululose 18-220\% Chlor. Diese Zalten beziehen sich auf trockene Zellulose. Durch die Bleiche verliert die Faser an Festigkeil und Elastizität; es darf daher nicht melı gebleicht werden, als untedingt notwen$\operatorname{dig}$ ist.

5 25. 4. A usbeutc, Beschaffenheit und Verwendung der Z c 11 ulose. Die Ausbeute an Zellulose ist bei den verschiedenen Holzarten, auf das Gewicht bezogen, ziemlich gleich. In allgemeinen gebeı die Nadelhölzer etwas höhere Ausbeuten. Der Hauptunterschied liegt im Putzverlust und in der Art der Aufschließung.

Von $100 \mathrm{lig}$ Juftrockenem Holze werden durchschnittlich beim Natronverfahren $28-34 \mathrm{~kg}$ und beim Sulfitverfahren $45-52 \mathrm{~kg}$ ungcbleichte, lufttrockene Zellulose gewonnen. Auf cin Festmeter reines, gcschältes, astfreies Scheitholz bezogren, lianı man bcim Sulfitverfahren $200-210 \mathrm{~kg}$ luftrockener Zellulose rechnen.

Hinsichtlich der Festigkeit der Faser ist die Natronzellulose mit der Baumwolle und die Sulfitzellulose mit der Leinen- oder Hanffaser zu vergleichen. Nichtsdestoweniger besitzt aber das Zellulosepapier doch eine geringere Festigkeit als das Hadernpapier. Natronzcllulose ist in chemischer Hinsicht reiner als die Sulfitzcllulose, da das Natronhydrat die inkrustierenden Substanzen vollkommener in Lösung bringt, als dies beim Sulfit der Fall ist. Auch ist die Sulfitzellulose in der Regel aschenreicher, indem das beim liochprozeß ausfallende Calciummonosulfit beim Waschen der Rohzellulose nicht volliommen entfernt wird.

Natronzellulose ist weicher und geschmeidiger als Sulfitzellulose.

Die Zellulose soll frei sein von Knotenfaserbündeln und sonstigen Beimengungen; namentliclı schädigen bleichunfähige Verunreinigungen, wie: Pindenfragmente, braune Faserbündel von den Astansätzen, erdige Teile, Abschürfungen von den Treibriemen und dergl. das Produlit in hohem Grade.

Die Hauptverwendung findet die Zellulose in der Papierfabrikation und nur verhältnismäßig geringe Quantitäten dienen dermalen für andere Zwecke, jedoch werden vielfach Anstrengungen gemacht, ein weiteres Verwendungsgebiet zu gewinnen.

So sind z. B. erst in den letzten Jahren durch eine Anzalıl Patente Verfahren geschützl worden, welche die Herstellung von Garnen (Sylvalin, Xylolin etc.) aus Zellstoff bezweclien, einen billigen Ersatz für Baumwolle- und Flachs-Garne. Auch zur Erzeugung von Filz, Watte und Badeschwämnen wird Zellulose verwendet.

Unter den Namen ,Pergamyn" isl ein Surrogal für Pergamentpapier in dem Handel, welches durch andauerndes Mahlen von Sulfitzellsloff in Holländern mit stumpfen Mlesscrn zu einer schleimigen llasse (Hydralzellulose), wolche dann bei der Papierbercitung die unzerhleinerten Fasern einhällt, erhalten wird. Wird dieses Zermahlen des Zellstoffes bis zur Bildung cines gleiclınäßigen, faserfreien Breies fortgeselzt und der Brei durch froiwillges Verdunsten des Wassers oder Erwärmen auf $40^{\circ} \mathrm{C}$. trocknen gelassen, so resultiert schlirßlich cine feste, hornarlige Mlasse, ,Zellulith", welche sich wie Horn, Ebonit u. dgl, bearbeilen und verwenden läßt.

Nicht unbeträchtlich ist der Absatz an Zellulose als Filternaterial. Für diese Art der Verwendung wird die Zellulose in Platten von etwa $50 \mathrm{~cm}$ im Geviert und $5 \mathrm{~cm}$ Dicke gepreßt, un ein bestimmtes Maß für die Filterfüllung zu haben. Diese Platten werden bei ihrer Verwendung in Stücke gebrochen, in Wasser aufgeschlämmt und der so entstehende Faserbrci in das Filter cingefüllt. Fast alle Bierbrauereien 
und Weinkellereien benützen solche Zellulose-Filter. Auch in mehreren anderen Gewerben, wo es sich darum handelt, Flüssigkeiten zu klären, wird Zellstoff als Filtermaterial verwendet.

Von diversen Umwandlungsprodukten der Zellulose wie: Schießbaumwolle, Zelluloir, Kunstseide u. a. war bereits auf Seite 555 und 556 die Rede.

Im Anschlusse an diese Ausführungen über die Gewinnung und Verwendung der Zellulose aus Holz sei hier eine höchst interessante Zusanmenstellung über die Vierlsteigerung des Holzes durch seine Verarbeitung zu Zellulose und weiterhin zu Kínstseide angefüht, welche Dr. O. N. Will in seinem Vorlrage ,Die künstlichen Seiden“ 1909, nach Angaben Dr. M. Müllers, veröffentlichl:

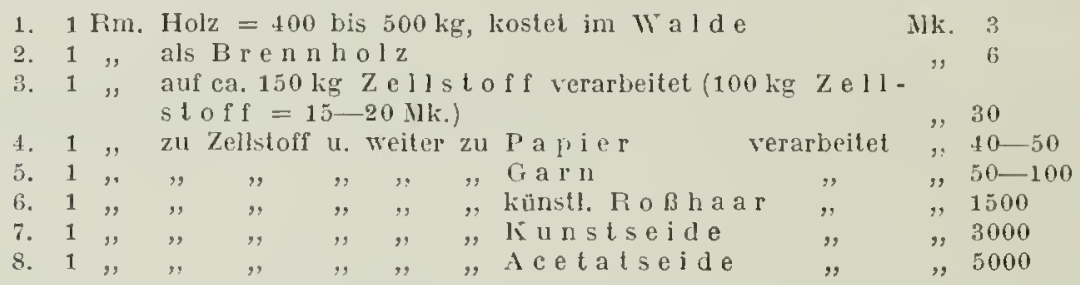

$\$ 26$. Ho lzst of $\mathrm{fg}$ e w in $\mathrm{n} \mathrm{u} \mathrm{g}$. Unter Holzstoff oder Holzschliff versteht man fein zerfasertes Holz. Das Produlit besitzt dieselbe Farbe wie das angewandte Holz und da es nicht bleichfähig ist, so ist zur Herstellung eines lichten Stoffes luellfarbiges Holz erforderlich.

Das hauptsächlichste Material für den Holzstoff bildet die Fichte, weniger häufig wird die Tanne verwendet. Diese beiden liefern hellgelben Stoff von ziemlich langer Faser. Die Föhre schleift sich des großen Harzgehaltes wegen schwierig, gibt zwar eine feine, aber nur kurze Faser von rötlich gelber Farbe. Die Lärche gibt eine gröbere, liurze Faser von rötlicher Farbe. Fölıren- und Tannenstoff dunkeln beim Liegen stark nach und werden matt. Unter den Laubhölzern nimmt die Linde den ersten Rang ein; sie läßt sich am leichtesten schleifen, gibt die größte Ausbeute, liefert einen feinen Stoff, welcher aber beim Liegen stark nachdunkelt und eine schmutziggraue Farbe annimmt. Aspe und Pappel schleifen sich ebenfalls leicht und geben einen sehr weißen Stoff, welcher nicht nachdunkelt. WVeißbuche und Ahorn sind schwer zu schleifen und geben daher nur eine geringe Ausbeute. Die Faser ist hellfarbig und fein. Alle Laubhölzer liefern nur kurzfaserigen Stoff.

Bezüglich der Vorbereitung des Rohmaterials (Entrinden, Spalten und Putzen) gilt das bei der Zellulose-Fabrikation bereits Erwähnte.

Das Holz wird nittelst Kíreis- oder sog. Blocksägen in Kilötze von $35-50 \mathrm{~cm}$ Länge und gewöhnlicher Spaltholzdiclie zugerichtet. Das Zerfasern geschieht auf Schleifsteinen, sog. Defibreurs, mit oder auch ohne Wasserzulauf. Die Schleifsteine müssen aus feinkörnigem, harten Sandstein hergestellt und der ganzen Masse hindurch gleichartig sein. Ungleich harte Stellen bedingen eine ungleiche Abnutzung der Schleiffläche.

Die Steine haben einen Durchmesser von $100-150 \mathrm{~cm}$ und eine Dicke von etwa $50 \mathrm{~cm}$. Sie rotieren entweder in horizontaler, gewöhnlich aber in vertikaler Richtung, mit einer Unfangsgeschwindigkeit von ungefähr $700 \mathrm{~m}$ pro Minute. In der Regel wird auf der Mantelfläche, hier und da aber auch auf der Scheibenfläche geschliffen.

Anstatt die Słeine aus einem Slük herzustellen, werden dieselben auch aus mehreren Segmenten zusammengesetzl, was den Vorteil hal, daß Fehler und Hohlräume im Inneren des Steines leichter entdeckt und beseitigt werden können. Statt der gewöhnlichen Scheibenform werden mitunter auch kegelförmige schleifsteine benüizt. 
In diesen Schleifnaschinen wird das zu schleifende Holz in Einlagkästen, $5-\mathrm{S}$ an der Zahl, mittelst Druekvorrichtungen gegen den rasch rotierenden Stein gepreßt und unter Wasserzulauf zerfasert. Die Andrüeliung des Holzes erfolgt entweder mittelst ciner Gewiclitsbelastung dureli Ketten- oder Seilübertragung, oder dureh ein von der Masehine selbst betätigtes Zahnstangengetriebe, oder bei den neusten Iionstruktionen durch hydraulischen Druck. In jedem Falle muB sie eine gleichmäßige und kontinuierliche sein.

Das Schleifen erfolgt entweder parallel oder senkreeht oder aber sehief zur Faserrichtung des Holzes, und darnach unterseheidet man: Längssehliff, Quersehliff und Diagonalsehliff; der gebräuchlichste ist der Längsschliff. Der Krraftaufwand ist ein beträchtlicher; für je $100 \mathrm{kgg} \mathrm{lufttrockenen} \mathrm{Holzschliff} \mathrm{in} 24$ Stunden sind etwa 6 PS. erforderlich.

Der von den Schleifmaschinen abfließende Faserbrei passiert zunächst einen Splitterfänger, um die gröberen Teile zurückzuhalten und gelangt sodann auf die Schüttelsiebe. Dieselben sind aus geloehtem Kúpferblech hergestellt, haben eine schwache Neigung und werden durch eine Íurbelwelle in sehr rasche Oszillation versetzt. Gewöhnlich sind zwei, mitunter auch drei Siebe von versehieden feiner Lochung übereinander angebracht. Der Faserbrei fließt aus einer Verteilungsrinne auf das obere Sieb, geht durch dasselbe auf das nächst untere und durch das unterste in einen Sammeltrichter, weleher den nunmelır sortierten Stoff auf die Pappenmaschine bringt. Die gröberen Fasern, welehe am vorderen, tiefer liegenden Ende der Rüttelsiebe ausgeworfen werden, gelangen in cine rinnenförmige Rührbütte und werden von hier mit einer Pumpe auf den Raffineur gehoben. Derselbe ist nach Art eines Mahlganges konstruicrt, zerreibt die gröberen Teile, welehe sodann im zerkleinerten Zustande auf die Schüttelsiebe geleitet werden.

AuBer den Schütelsieben werden mitunter auch Zylindersiebe oder aber rotierende Flachsiebe verwendet, bei denen durch die Flichkraft die Sortierung erfolgt. Endlieh giht es auch Apparate, in welchen die Trennung der feinen Fasern von den gröheren Beimengungen durch die verschiedene Schwere gesehicht.

In den Pappenmasehinen wird der sortierte Stoff auf ein feinmasehiges Drahtsieb geleitet, durch welches das Wasser abläuft, während die Fasern auf der Siebfläche zurückbleiben. Der auf solche Art gewonnene Holzstoff entluält $80-90 \%$ Wasser und kann nur an Ort und Stelle verwendet werden. Für die Versendung oder längere Aufbewahrung ist er ungeeignet. Zu diesem Zwecke muß er mindestens durch Druck so weit entwässert werden, daß sein Trockengehalt etwa $50 \%$ beträgt. Eine weitergehende Trocknung ist nur unter Anwendung von Wäme möglich.

Bei der Lagerung des Holzstoffes, der infolge seines relativ hohen Wassergehaltes einen guten Nährboden für Schimmelpilze abgibt, muß man Sorge dafür tragen, daß entweder die Luft keinen Zutritt hat oder eine kräftige Ventilation im Lagerraum statthaben kann; am gefälırlichsten ist stagnierende Luft. Auch die Anwendung verschiedener Immunisierungsmittel chemischer Natur wurde in Vorschlag gebracht.

Der Holzstoff kommt in der bekannten Form der ,Pappe" oder in geringerer Stärke in Rollen oder endlich als sog. Schabstoff, lose in Säcken, milunter auch zu Rollen geformt, in den Handel.

Der Holzschliff hat eine unanselnlielıe Farbe, ist - wie schon erwähnt bleichunfähig und besitzt eine kurze, steife Faser, welche sich schlecht verfilzt. Er ist daher nur für die Erzeugung von Pappe oder ordinären Papiersorten geeignet.

Das Schleifen des Holzes wird wesentlich erleichtert, wenn cin Dämpfen vorangeht. Das unter einem Druck von $4-5 \mathrm{Atm}$, in gußeisernen Kíesseln $8-14$ Stun- 
den lang, gedämpfte Holz schleift sich leicht, gibt eine längere, geschmeidigere und leichter verfilzbare Faser. Durch das Dämpfen wird aber das Holz dunkler und ist daher dieses Verfahren nur zur Herstellung von braunem Stoffe (,B ra u ns c h l if f") verwendbar. Noch leichter gelingt das Schleifen, wenn man das Holz abwechselnd dem Dampfdruck allein und sodann dem unter Dampfdruck stehenden Wasser aussetzt. Der Braunschliff hat in den letzten Jahren eine selır starke Verbreitung gefunden, da er fast ausschließlich rlas Material für die braunen PackipapierSorten, Kartons etc. bildet.

Bemerkenswert ist noch der sog. Hei $\beta$ s ch liff, weleher in Amerika so gut wie allgemein ausgeführt wird und darin besteht, daß man während des Schleifens das Holz nit starkem Druck gegen den Stein preßt und nur wenig oder gar kein Wasser zulanfen läßt, wodurch eine bedentende Emwämung hervorgerufen wirl.

Die Vorteile dieses Heißschliffes gegenüber dem bei uns gebräuchlicheren kaltsehliff mil starken Wasserzulauf sind: großere Leistungsfähigkeil der Schleifmasehinen, geringerer liraftverbrauch (pro $100 \mathrm{~kg}$ lufttrackenem Stoff in 24 Stunden 3-4 PS. statt 6) und eine gründlichere Zerfaserung und Zerquetichung des Holzes, wodurch ein feiner, fast s]litterfreier, geschmeidiger und sehr griffiger Stoff erzielt wird, der ohne Schwierigkeit sich als soleher zu dickeren Pappen verarbeiten läßt.

Aus bescheidenen Anfängen hervorgegangen, hat die Holzstoffindustrie, seit ihner Erfindung durch Keller in Jalue 1840, ebenso wie die Zellstoffindustrie, einen liolossalen Aufschwung genommen, namentlich als man, durch verschiedene Verlıältnisse gezwungen, daran ging, den Holzschleifereien auch Papierfabriken anzugliedern, natürlich nicht zur Erzeugung feiner, sondern billiger Massen-Papiere (Zeitungs-, Affichen-etc. Papiere). Während ursprünglich ausschließlich und auch heute noch für lileinere Untemelımungen Wasserkräfte zum Betrieb von Holzsehleifereien ausgenützt wurden, findet sich in der neueren Zeit bereits eine stattliche Zahl von Holzstoff-Falıriken, welche nur mit Dampfliraft gewaltige Mengen von Holzsehliff rentabel produzieren.

\section{Trockene Destillation des Iolzes.}

\section{(IIolzverkohlung, Teergewinnung, Holzessig- und Holzgeist-Erzeugung.)}

\$27. A llg e me i n e s. Wird Holz unter Luftabschluß oder bei beschränktem Luftzutritt erhitzt, so entweicht bis zu $100^{\circ}$ G. nur das hygroskopische Wasser, die Holztrockensubstanz aber bleibt bis ungefähr $150^{\circ} \mathrm{C}$. unverändert. Erst über diese Temperaturgrenze hinaus beginnt cine Zersetzung des Holzes, wobei Gase, kondensierbare Destillate und ein fester Rückstand entstehen, welche in ihrer llenge und Zusammensetzung verschieden sind, je nachdem ob sie unter völligem Luftabschluß oder bei beschränktem Luftzutritt gebildet wurden. scheiclen:

Bei der trockenen Destillation des Holzes lassen sich im allgemeinen drei Perioden unter-

In der ersten l'eriode (zwischen 150 und $260^{\circ}$ C.) bildet sich hauptsāchliclı wässeriges Destillat. Der wesentliehste Bestandteil desselben ist Viasser. In geringerer Menge sind darin enthalten: Essigsänre $\left.\left(\mathrm{C}_{2} \mathrm{H}_{4} \mathrm{O}\right)_{2}\right)$, Holzgeist $\left(\mathrm{CH}_{4} \mathrm{O}\right)$, Aceton $\left(\mathrm{C}_{3} \mathrm{H}_{6} \mathrm{O}\right)$, Furfurol, Methylamin elc. Verdichtbare liohlenwasserstolfe (Teer) und nicht kondensicrbare Gase trelen nur in beschränktem Maße anf. Die Gesamtmenge der flachtigen Stoffe beträgt rund $60 \%$ vom Gewichte der Holztrockensubstanz. Der Rüekstand $(10 \%)$ hat eine lraune Farbe und kann als Röstholz angesprochen werclen. Der Tïohler bezeichnet diese halbverliohlten Stücke als ,Brände“.

In der zweiten Periode (zwischen 260 und $330^{\circ}$ C.) bildet sich zwar anch noch wässeriges Destillal, jedoch in geringerer Mlenge; dafür treten hauptsächlich liohlenwasserstoffe: Methan (Sumpfgas $\left.\mathrm{C} \mathrm{Il}_{4}\right)$, Actylen $\left(\mathrm{C}_{2} \mathrm{H}_{4}\right)$, Acetylen $\left(\mathrm{C}_{2} \mathrm{H}_{2}\right)$ ete., ferner liohlenoxyd (CO) und liohlensäure $\left(\mathrm{CO}_{2}\right)$ auf. Die geringe Menge stickstoff, wrlche in Holz enthallen ist, verbinelel sicl mit dem Wasserstoff 24 Ammoniak $\left(H_{3} N\right)$ und teils mil liohlenwasserstoff zu llethylamin $\left(\mathrm{CH}_{3} \mathrm{~N}\right)$. Der Gesantrerlust dureh Entweichen der flüchtigen Beslandteile sleigt auf $70^{\circ} \%$, 


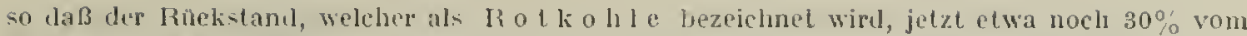
llolzgewichl ausmacht.

In der dritten Periorle (von $330-430^{\circ}$ C.) geht vomehmlich die Teerbilutung vor sieh. Der Teer scheiłpt sich als dunkelhraune, dickllnssige Masse ab und sinkt zum großten Teil im wăserigen Destillat unter. Seine lampthestandleile sind: l'araffin, liresole, liarbolsăure, Benzol, Toluol ete. Als Fase trelen fast nur Melhan und Wasserstoff auf. Der liückstand

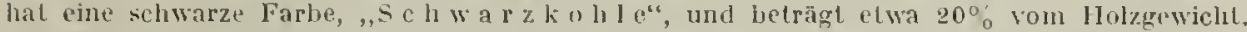
Bei fortgesetzter Steigerung der Temperatur findet zwar noeh eine weitergehende Zepsetzung statt, die aber insofern olne wesentlielien Belang ist, ta in der Praxis so hohe Temperaluren nieht in Anwendung kommen. De' gewöhnliclıe Verkohlungsvorgang ist hei elwa $400-450^{\circ} \mathrm{C}$. als ahgetichlossen zu belrachten.

Nach den Untersuchungin von Klason, v. Ifidenstan und Norlin ") laßBt sieh der bei dieser Tenperatur verlaufene Destillationsprozeß nach folgender Gleichung darslellen:

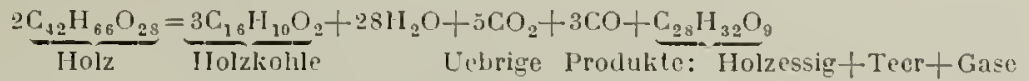

Der Prozeß ist ein exolhermischer Reaktionsvorgang, also einer, bei dem Wăme frei wirl (etwa $6 \%$ von der Verbrennungswärme des Holzes) und bei dem die Zellulose keinen Ietlylalkohol liefert, dieser somit ans dem Lignin gebildet werden nußB.

Aus den Untersuehungen von Violette über tie Vorgänge bei der Verkohlung des Faulhaumholzes (Rhamnus frangula) crgaben sich folgende Zahlen:

\begin{tabular}{|c|c|c|c|c|c|c|c|}
\hline & \multirow{2}{*}{$\begin{array}{l}\text { Tempera- } \\
\text { tursteige- } \\
\text { rung bis } \\
\text { o Cels. }\end{array}$} & \multicolumn{2}{|c|}{$\begin{array}{l}\text { Von } 100 \text { Gewichtsteilen } \\
\text { Holztrockensubstanz wer- } \\
\text { den erhalten: }\end{array}$} & \multicolumn{4}{|c|}{$\begin{array}{l}\text { In } 100 \text { rewichtsteilen des } \\
\text { Rückstandes sind enthalten }\end{array}$} \\
\hline & & $\begin{array}{c}\text { Destillations- } \\
\text { produlite }\end{array}$ & Rüelistände & $\begin{array}{l}\text { Koh- } \\
\text { Ien- } \\
\text { stoff }\end{array}$ & $\begin{array}{l}\text { Was- } \\
\text { ser- } \\
\text { stoff }\end{array}$ & $\begin{array}{l}\text { Sauer- } \\
\text { stoff }\end{array}$ & Asche \\
\hline $\begin{array}{l}\text { Trockenes Holz } \\
\text { Rostholz } \\
\text { Rolkohle } \\
\text { schwarzkohte }\end{array}$ & $\begin{array}{r}150 \\
260 \\
330 \\
+32\end{array}$ & $\begin{array}{l}-- \\
60 \\
68 \\
81\end{array}$ & $\begin{array}{r}100 \\
40 \\
32 \\
19\end{array}$ & $\begin{array}{l}47,5 \\
67,9 \\
73,6 \\
81,6\end{array}$ & $\begin{array}{l}6,1 \\
5,0 \\
4,6 \\
2,0\end{array}$ & $\begin{array}{l}0,1 \\
0,6 \\
0,5 \\
\mathbf{1}, 2\end{array}$ & $\begin{array}{l}46,3 \\
26,5 \\
21,3 \\
15,2\end{array}$ \\
\hline Sehr harle Schwarzkohle & $\begin{array}{l}\text { von etwa } \\
1000 \\
\text { bis über } \\
1500\end{array}$ & - & - & $\begin{array}{l}82,0 \\
96,5\end{array}$ & $\begin{array}{l}2,3 \\
0,6\end{array}$ & $\begin{array}{l}1,6 \\
2,0\end{array}$ & $\begin{array}{r}14,1 \\
0,9\end{array}$ \\
\hline
\end{tabular}

Eine vollkommene Entgasung ist bei den erreiehbaren Temperaturen nieht möglich. Ein kleiner Teil von Wasserstoff und Sauerstoff verbleibt immer noch im Fohlenrückstande.

Verkol J ungs-Methoden. In wesentlichen kann man zwei Hauptarten der Verkohlung unterscheiden: 1) die Verliohlung bei beschränktem Luftzutritt in Meilern, Gruben oder Oefen mit direkter Feuerung und 2) die Verkohlung unter vollständigem Luftabschluß in Oefen mit indirekter Feuerung, Retorten oder liesseln.

Denz ${ }^{2}$ ) unterscheidet seharf zwisehen diesen beiden Iethoden als der eigentliehen "Holzverkohlung" und der ,trockenen Destillation des Holzes", welch letzlere soeben auf Grund genatier Intersuchungen charaklerisicrt wurle. Bei der, ,Holzverkohlung" bedarf es, naeh Denz, bloß einer entsprechenil lohen Initialtemperatur im Neiler - uher $400^{\circ} \mathrm{C}$. durch die Anfeuerung erzielt - damit der Schwel- oder Verkohlungsprozeß in Gang gebraeht wird, sich aber dann von selbst erhält, also nahezu rein exothermisch verläuft.

Mit weit geringeren Temperaturen, als solche bei der trockenen Destillation erforderlieh sind, findet Denz das Au-laugen lei der Meilerverkolılung, da Temperalurmessungen in Meiler prgeben haben, da $\beta$ unler $240^{\circ} \mathrm{C}$. die llolzverohIung zwar noch nicht vor sich geht, alieselbe aber zwischen 240 und $280^{\circ} \mathrm{C}$. regelrceht verläuft. Bei einer Temperatur von $290^{\circ} \mathrm{C}$. wird schon kiohle minderer Qualiläl und Quantitäl gelsildet.

Darnach würde also dır Verkohlungsırozeß in Meiler nielt, wic bisher allgemein an-

1) Iilar, Teelınolorie der Holzsurkullunge. Berlin 1910.

2) Denz, Die Holzverkohlung unt der Köhlereibetrieb, Wien 1910. 
genommen, durch die unvollständige Verbrennung eines Triles des liohlungsmateriales, sondern dureh die Reaktionswirme erhalten werden und mỉßte somit verlustlos verlaufen.

Dureh den in jedem Meiler herrsehenden Zug wird aber so viel Sauerstofi luit der atmosphärischen Luft zugeführt, daß eine, wenn auch nur unvoliständige. V'erbrennung eines geringen Teiles der Ijohlungsmaterie nicht hintanzuhalten ist und somit Wärmeenlwicklung, infolge unvollständiger lerbrennung, slattfinden muB. Ob und in welehem Maße nun diese die trockene Destillation unterhält oder auch nur fördert, mag dahingestellt sein, insolange als Untersuchungen in dieser Richtung fehlen.

Jedenfalls aber bedingt diese Verbrennung einen Holzverlust und je mehr man sie zurückdrälngt, desto höher wiru die Ausbeule an Holzhohle und kondensierbaren Destillationsprodukten. Bei der Verhohlung in geschlossenen Gefäßen sind Verluste zwar auch nicht zu vermeiden, sie sind aber hier anderer Art. Alle Wärne, welche zur Erhaltung des Verkohlungsprozesses notwendig ist, wird dem Holze ron außen zugefürt. Der Wärnebedarf ist in dicsem Falle sogar noch ein erheblich größerer, weil die Gefäßwände und das Mauerwerli mitgeheizt werden müssen und die Feucrgase nit holer Temperatur aus rem Feuerraum ahziehen. Man liat nur den Vorteil, daß zur Feuerung auch geringwertige Maferialien (Torf, Braunohle, Holzabfälle und die Gase von der Verkohlung) angewendet werden können, und daß mehr Deslillationsprodukte aus dem Holze resultielen. Als Nachteil ist dagegen hervorzuheben, daß für diese Art der Yerkohlung eine komplette Fabrikanlage nolwendig ist. während die Mleilerköllerei mit den primitivsten bilfeln im Walde selbst oder an irgend einen anderen Orle, wo das Holz leicht zuzuilringen ist, betricben werden liann.

\section{a) Holzverkohlung.}

\section{Die Meilerköhlerei.}

$\$ 28$. B e grif f. Unter einem Neiler versteht man einen zu dem Zwecke der Verkohlung nacl gewissen Regeln aufgebauten Holzstoß, welcher mit einer diehten, feuerbeständigen Declie ungeben ist. Man unterscheidet ste hende und lie gende 11 e il er. Erstere besitzen die Form eines Paraboloides, in welchem die Hauptmenge des Holzes stehend (respektive schwach geneigt) cingeschichtet ist. Letztere haben im allgemeinen die Form eines liegenden Keiles, dessen Enden senkrecht abgeschuitten oder abgerundet sind. Das Holz wird liegend, quer über die Längsrichtung der Kohlplatte eingelegt. In den stehenden Meilern wird vorwiegend Spaltholz (deutsehe Nethode), in den Alpenländern aber auch Rundholz (italienische Nethode oder Alpenliöhlerei) verkohlt, während in den liegenden Mleilern fast ausschließlich Rundholz in Anwendung kommt.

Abgesehen von der Form des Meiler's unterscheidet man aueh noch W a n d e r oder Wa l d köh lerei und konzentrierte, ständige oder H üt tenkö h l e r e i. Die erstere wird in möglichster Nähe der Holzschläge betrieben, wechselt daher fast alljährlich ihren Standort, während für die konzentrierte Köhlerei ständige Plätze gewählt werden, hauptsächlich dort, wo durch die Trift das Holz zugebracht oder wo die Kohle verbraucht wird, also bei Eisenhütten.

\$29. Vorbem erkungen. A. Terkohlung in stehenden II e ile r n. Zur Verkohhung kann jede Holzart und auch jedes Holzsortiment verwendet werden. Zumeist kohlt man Nadelholz oder Laubholz von geringerem Werte (vorzugsweise Rotbuche). In manchen Distrikten (z. B. in Ober-Ungam, im Banat und Küstenland) wird übrigens fast ausschlieBlich Laubholz (Rotbuche, Eiche, Linde, Aspe etc.) gekohlt. Als Regel gilt es, den Nieiler nur aus ciner Holzart und einem Sortimente aufzurichten, was sowohl hinsichtlich der liohlungsdauer, als auch des verschiedenen Gebrauchswertes der Kohlen erwünscht ist. Ist man gezwungen, Holz von versehiedener Abstammung und Stärie zu verkohlen, so muß das schwerer kohlende Holz in sehwächeren Seheiten melr gegen die Mitte des Meilers gestellt werden, wo schon beim Beginn der liohlung eine höhere Temperatur herscht.

Das Kohlholz soll lufttrocken sein. Bei feuchtem Holze ist der Kohlgang langsamer, unregelmäBiger und die Kiohlenausbeute geringer. 
Das 17 asser, welehes im Ilolze enthalten ist, wird hei der Verkohlung in Dampf verwandelt, und die hierzu notwendige Wärnemenge foir je $1 \mathrm{~kg}$ Wisser rund 630 Calorien $=0,15 \mathrm{~kg} 110 \mathrm{k}$ trocliensubutanz) muß durch Verbremen des llolzes oder der liohle geliefert werden. Ueberdies rroibt sich auch noch ein Verlust durch die binwirliung des Waverdampfes auf die glülyende liohte, wobei Wasserstoff und liohlenoxyd als Endprodukte entstehen:

$$
\begin{aligned}
& \mathrm{C}+21 \mathrm{I}_{2} \mathrm{O}=\mathrm{COO}_{2}+21 \mathrm{l}_{2} \\
& \mathrm{C}+\mathrm{CO}_{2}=2 \mathrm{CO} .
\end{aligned}
$$

Diese l'rozesse sind bei keiner l-lolzverdohlung, mag dieselbe auf was immer für eine Irt geschelen, zu vermeiden. Die liohlenausbeule wird aber um so geringer, je mehr Wasserdampf sich entwickelt, beziehungsweise je feucluter das IIolz ist.

Von Wichtigheit ist ferner die Fom und Stärke des Kohllolzcs. Bei der d e u tschen Verkohlungsmethode wirl vorwiegend Seheitholz verwendet. Stämme über $15 \mathrm{~cm}$ Durchmesser werden einmal, stärkere Stämme mehrmals gespalten. Die Scheitlänge beträgt gewölınlich $1 \mathrm{~m}$. Die Aeste und Zacken müssen scharf abgehauen werden, weil sonst ein dichtes Richten nicht möglich ist und zu viel Irleinholz, welches nur geringwertige Kiohte gibl, zum Ausfülen der Kilüte notwendig wird.

Iin â p pel- und Prügcl holz bleibt ungespalten. Maximallänge $3 / 4-1$ m. Läncere Stücke sind nicht dicht zu stellen. weil sie nur selt en cine regelmäßige Gestalt besitzen.

A este bis zu cinem Minimaldurchmesser von $3 \mathrm{~cm}$ können noeh zur liolnlung verwendel werden. Die Zuriclstung besteht nur in dem Abhauen der lileinen Zweige und Zuschneiden der Aeste auf gleiche Lainge.

$s$ tock- und W u r z e l h o l z erfordert wegen der außerordentlich unregelmäßigen Gestalt eine umständliche, hoslspielige Zurichtung, welche häufig nicht rentiert. Alle vorstehenden Zacken müssen abgesägt und der Stock je nach seiner Stärke in 3,4 und noch mehr Teile gespalten werden.

Bei der Al pen kö hl le re $\mathbf{i}$ wird in der Regel nur Rundholz benützt, meist Fichte, seltener Tanne und Lärche. Nur die stärksten Stämme (über $45 \mathrm{~cm}$ Durclımesser) werden cinmal gespalten. Die Länge des Kiohlholzes beträgt bis zu 2 m, selten darüber. Das Entrinden der Stämme ist zweckmäßig (schon der besseren Austrochnung wegen), geschieht aber nicht immer. Unter allen Umständen gilt es als Regel, nur gesundes Holz zu verwenden. Stockiges oder faules Holz gibt immer eine schlechte, brïchige, und wenn die Zersetzung schon weiter vorgeschritten ist, cine ganz mürbe, unbrauchbare Kohle.

Die Form des stehenden Meilers entspricht einem Paraboloid, dessen Rauminhalt $\mathrm{x}$ durch die Formel:

$$
x=\frac{p^{2} h}{8 \pi}
$$

gefunden wird, worin p die Periplıcrie des Meilers und h dessen Höhe bedeutet. Da die Gestalt des Meilers ron der mathematischen Form des Paraboloides etwas abweicht, so sind von dem berechneten Inhalte 4-6\% in Abzug zu bringen.

Die zwechmäßigste Größe der Neiler hängt von verschiedenen Umständen ab. Nach Denz crgeben deutsche Meiler die besten Ausbeuten, wenn ihr Einsatz: bei der ständigen Tiöhlerci 200-280 Rm. bei der Wanderköhlerei 140-200 Rm. Spaltholz beträgt. Bei der Verarbcitung von minderen Ilolzsortiment (Knüppel-, Ast-, Wurzellolz) nimnt man den Fassungsraum geringer: 60-80-1:0 Rm. Naclel- und weiches Laubholz setzt man in größere Neiler, harte Laubhölzer in kleinere, innerhalb der angegebenen Maße. Bei der Alpenköhlerei wird der Meiler der Form und Stärlie des Kohlholzes wegen viel größer angelegt, bis zu $300 \mathrm{Km}$. und darüber. Jic früher gebräuchlichen, abnorm großen Meiler von $1000 \mathrm{Rm}$. und darüber hat man jetzt allerorts aufgegeben. Große Meiler bensspruchen in Verluältnis zu ihren Inhalte eine geringere Bodenfläche und weniger Deckmaterial. Sic haben ferner den Vorteil, daß die Wärme besser ausgenützt wird, die Kosten für die Arbeit und Uebcrwachung 
pro Gewiehts- oder Volumeinlseit der erzeugten Kohle geringer sind und ein kleinerer Prozentanteil minderwertiger Quandelliolslen gezogen wird. Aber aueh die kleinen Meiler haben gewisse unverkennbare Torzüge und sind nanentlich für dlie Wanderkölılerei sehr geeignet, weil auf unebenem oder sonst ungünstigem Terrain im Walrle ein kleiner Kohljlatz leiehter zu finden und mit geringeren Kosten lierzurichten ist als ein großer. Dic Arbeit des Heileraufbaues ist eine leichtere, der Feuerungsgang läBt sirh sicherer regieren und UnregelmäBigkeiten, welehe dureh ungünstiges Wetter veranlabt werden, können leichter vermieden oder eventuell verbessert werden.

$\$ 30$. Die Arbeit an einem stehenden II eiler umfabt in allgemeinen folgende Operationen:

1. Die Herrichtung der liohlstätte.

2. Der Aufbau des Neilers (das sog. Setzen oder Richten).

3. Das Berüsten und Decken des holzfertigen Meilers.

4. Das Anzünden.

5. Das Regieren des Feuers.

6. Das Nachfüllen.

7. Das Verwahren und Auskülılen des Meilers.

8. Das Ausziehen und Sortieren der fertigen Kohlen.

1. Herielitung der liohlstät e. Bei der Anlage einer neuen Kohlstätte ist darauf Bedacht zu nehmen, daß die Zubringung des Holzes und die Abfuhr der Fohlen lieine großen Sehwierigkeiten und Kosten verursacht, daß Wasser in der Nähe sieh befindet und der liohlplatz gegen Windfall mögliclıst gesehützt ist. Der Boden muß trocken sein. Ist man gezwungen, den Meiler auf sumpfigem Terrain zu errichten, so muß rie betreffende Stelle rlurch Ziehen von Gräben zunächst troeken gelegt werden. Setzt man den Meiler direlit auf die Kíolnlplatte, so darf der Boden werler zu porös, noch zu dicht sein. Auf sehr lockerem Boden ist der Luftzug in Meiler ein zu lebhafter und infolgedessen der Kohllgang ein zu raseher. Auf diehtem Boden werden die flüssigen Destillationsprodulite nicht aufgesaugt und der Verlauf der Kólılung ist wegen ungenügendem Luftzutritt zu langsam. Kiolılplatten der

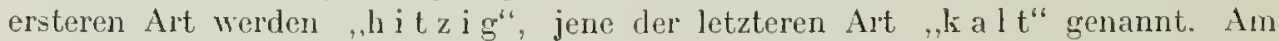
besten eignet sich ein lelıniger Sandboden. Bei Verwendung einer Meilerbrüeke wälılt man einen möglichst undurchlässigen Grund, an besten in einem troekenen Lehmodes Tonboden. Die wesenthichste Bedingung ist die Gleichartigkeit der Kohlplatte. Es dürfen keine Kisse oder Klüfte, ebensowenig aber' auch ganz dichte Stellen (große Steine ete.) vorhanden sein. Der Boden wird zunächst von allem Gestrüjp, Steinen ete. befreit, geebnet und wie ein Gartenbeet bearheitet; sodann zieht man mit einer Selmur einen Ińreis, weleher der Peripherie des Meilers entspricht. Gegen das Zentrun hin wird ein Anlauf von $20-30 \mathrm{~cm}$ Höhe gemacht. Je dichter der Boden ist, desto steiler muß der Anlauf sein. Letzterer lat den Zweck, den Luftzug im Meiler zu vermeliren und die liondensationsprodukte nach außen abzuleiten. SchlieBlieh wird die Kolılplatte festgelreten und bleibt längere Zeit (womöglich äber Winter) unbenutzt. Bevor man die Platte in Gebrauclı nimmt, inüssen etwa vorhandene Sehäden ausgebessert und der Boden dureh Abbrennen von Reisig oberflächlich getrocknet und vorgewärnt werden. Auf einer neuen Platte fällt die Folılenausbeute bei den ersten Kohlgängen immer um 2-5\% geringer aus. Rings um den Kohlplatz muß ein genügend freier Raum (Fegplatz) für die Abladung des Holzes, Unterbringung der Kohlen, Bereithalten des Derlimaterials und Aufstellung der Fïlılerhütte vorlaanden sein. Man traehtet inmer, selhst bei der Waldköllerei, wenn möghich zwei oder melıere Meiler unweit ron einander anzulegen, un an Aufsiehtspersonal zu 
sparen und die Losten für die Herstellung und Erhaltung der Wege zu verminderr. Bei der Hütten- und Lendköhlerei versteht es sich von selbst, daß alle Meiler tunliehst nale aneinander gelegt werden.

2. Der A uf la a oder das Riehten des ll e ilers. Der Aufbau beginnt inmer mit rler Jerstellung des Quandelschachtes. Unter Quandel versteht man den zentralen Raum des Meilers. Der Quandel dient als Feuerschacht und wird aus 3 oder 4 armdicken Pfälılen gebildet, welelıe in einem gegenseitigen Abstand von je $30-10 \mathrm{~cm} \mathrm{im}$ Boden befestigt werden. Thre Höhe entspricht jener des aufzubauenden Meilers. Die Pfähle werden mit Wieden unflochten und bilden so cinen Schacht zur Aufnahme von leicht entzündlichem Brennstoff (Kienholzspäne, trockene Birkenrinde, dürres Reisig, Brände ete.). Ist der Quandelschacht gefüllt, so wird am Fuße desselben ein sogenannter Zündmaterialkegel (bestehend aus dünngespaltenem, troekenem Holze, Bränden, Reisig und dgl.) angelegt und sodann mit dem Ansetzen des Holzes begonnen. Dabei ist als Regel zu beachten, daß unmittelbar an den Zündmaterialkegel schwächeres, dann aber gleich anschließend das stärkste und gegen die Peripherie hin immer schwächeres Holz zu stehen kommt. Die Seheite müssen mit den stärkeren Ende am Boden stehen. Dadurch ergibt sich von selbst cine gewisse Neigung des Holzes gegen den Quandel. Im fertigen Meiler beträgt dic Böschung etwa $60^{\circ}$. Diese Neigung ist notwendig, damit die Declie nicht abrutseht. Ist der Bodenstoß his auf halbem Diameter fertig, so beginnt man mit dem Ansetzen des zweiten Stoßes und fährt dann oben und unten gleichmäßig bis zur Peripherie fort. Schließlich wird die Haube aufgebracht, d. h. das Holz in sehwächeren Scheiten quer gelegt, um die runde Abdachung des Meilers herauszubringen. Das Holz muß zur Vermeidung eines zu starken Zuges im Meiler möglichst dicht gestellt werden und ist daher noch öfter ein nachträgliehes Zuriehten der Scheite (Absägen orter Abhacken der Vorsprünge und Zacken) erforderlich. Alle kilüfte zwisehen den Seheiten müssen mit Spaltholz ausgefüllt werden, namentlich ist dies an der Oberfläche, das sog. Ausschmälen des Heilers, notwendig, um neben dem schon erwähnten Grunde auch noch das Durchrieseln der Decke zu verhindern. Iuß Holz von verschiedenem Feuchtigkeitsgrad gekohlt werden, so setzt man das trockene in den Bodenstoß, das feuchtere aber in die Oberstöße. Verschiedene Holzarten setzt man so ein, daß das Nadelholz nahe an den Quandel, das harte Laubholz gegen die Peripherie des Meilers zu stelien kommt.

3. Das Decken und Berüsten des holzfertigen Meilers. Die Decke besteht bei der deutschen Verkohlungsmethode aus zwei Schichten: zu unterst, als unmittelbare Bedeckung des Holzes, das sog. Raulıdach oder Gründach und darüber das Erddach. Das Raulıdach besteht aus Rasen, Laub, Moos, jungem Nadelholzreisig, Farnkraut, Schilf oder dgl. Es hat den Zweck, der ganzen Decke eine gewisse Elastizität zu verleihen, um dem bei der Kohlung allmählich einsinkenden Meiler nachzugehen, ferner un das Durehrieseln der Erddecke zu verhindern. Das Erddach bildet die äußere, feuerfeste und bis zu einem gewissen Grade auch dichtschließende Umhüllung des Meilers. Dasselbe wird aus einem durehfeuchteten Gemenge von humoser WValderde und Liohlenklein (Stübbe oder Lösehe genannt) hergestellt. Die Mäehtigkeit der Erddecke richtet sich nach der Beschaffenheit des Rauhdaches, nach der Stärke des Kohlholzes, nach der Witterung ete. und schwankt von $5-25 \mathrm{~cm}$. Rasen bedarf die schwäelıste, Reisig die stärkste Erddecke.

Die Unterstützungen zum Halten del Decke werden ,Rüsten“ genannt. Man untersebeidet Unter- und Oberrüsten. Die Unterrüsten (Fußrüsten) werden in der Weise hergestellt, daß man rings um den Neiler in gewissen Abständen kleine, etwa 
$15 \mathrm{~cm}$ hohe Kilötze anbringt und Scheite quer übcrlegt, welche der Decke als Unterstützung dienen. Bei der Verkohlung verbrennen die Scheite teilweise und sind gewöhnlich nur einmal zu gebrauchen. Zuweilen werden auch Steinunterlagen oder eiserne Rüsten, letztere in der Form eines Kreissegmentes, welche an einer Scite einen FuB besitzen, verwendet. Sie sind sehr dauerhaft und geben dem Meilerumfang eine regelmäßige Form, indem sie sich dichter an das Holz bringen lassen, als die geraden Scheite. Unterrüsten sind bei einem jeden Meiler notwendig, nur bei der Reisigdecke lïnnen sie entbchrt werden, weil sich diese niemals so dicht an das Holz legt, daß der Luftzug dadurch gehemmt würde.

Oberrüsten werden nur bei steil gebauten Neilern angebracht oder wenn bei selir trockenem Vetter die Decke nicht halten will.

Alle Meiler, welche nicht im Walde geschützt stehen, brauchen eine Sclsutzwand gegen den Windanfall, den sog. Windsehauer. Derselbe wird aus einigen im Boden befestigten Pflöcken, die mit Schwarten oder Reisig bedechit sind, hergestellt, ist etwas höher als der lleiler und soll, der Feuersgefahr wegen, mindestens $2 \mathrm{~m}$ vom Meilerumfang abstehen.

4. D a s Anzü nde $n$. Der Meiler kann von oben oder von unten in Brand gesetzt werden. Beim Obenanzünden wird an der oberen freien Ilündung des Quandelschachtes ein kleines Feuer angemacht, welches sich allmählich nach abwärts zieht, indem die Quandelfüllung ausbrennt. Beim Anzünden von unten muB schon beim Aufbau des Neilers am Fuße desselben eine Zündgasse, welche von der Peripheric bis in den Quandelschacht reicht, frei gelassen werden. Diese Zündgasse soll hinter Wind liegen. Das Anzünden geschieht durch Einführung einer mit brennenden Ǩienholzspänen versehenen Zündrute. Damit das Feuel nicht erlischt, müssen sowohl beim Oben- als auch beim Untenanzünden Zugöffnungen zwischen den FuBrüsten vorhanden sein. Das Anzünden erfolgt immer vor Tagesanbruch bei windstiller Luft.

5. Das Regieren des Feu ers. Bei jeder Art des Anzlindens brennt zuerst die Quandelfüllung aus, sodann wird der Zündmaterialkegel ergriffen, wobei sich das Feuer um den Quandelschacht herum nach aufwärts zieht und unter der Haube ausbreitet. Bei normalem Gange schreitet die Glutzone in der Form eines mit der Spitze nach abwärts gerichteten Kícgels fort. Dic Nantelfläche desselben breitet sich immer mehr aus und geht endlich in eine Horizontalcbene über, so daß die Glut an dem untersten Rande des lleilers anlangt. Damit ist die liohlung beendet.

Um das gleichmäßige Niedergehen der Glutzone zu ermöglichen, müssen Zugöffnlingen (Rauchlöcher, Register oder Räume genannt) in der Deche angebracht. werden. Die Rauchlöcher werden mit dem Stiel der Schaufel durch beide Decken hindurch bis auf das Holz gestoßen. In den crsten 24 Stunden nach dem Anzünden wird in der Regel blind geliohlt, d. h. ohne Rauchlöcher, und der Meiler auf diese Theise vorgewärmt. Erst nach Ablauf dieser Zeit werden die ersten Rauchlı̈̈lzer rings um den sogenannten Saum oder Wechsel (d. i. jene Stelle, wo der zweite Holzstoß aufhört und die Haube beginnt) gestochen. Der aus diesen Oeffnungen austretende Rauch äıdert seine Beschaffenheit allmählich und daran läßt sich der Gang der Terkohlung beurteilen. Anfänglich tritt fast nur Wasserdampf aus. In dem Maße, als die Verliohlungszone näher rüclit, liommen Produkte der trockencn Irestillation zum Vorsehein; der Rauch wird gelblich-braun, besitzt cinen empyreumatischen, sauren, steehenden Geruch. In weiteren Verlaufe wird der Rauch heller, der stechende Geruch läßt nach und schließlich schlägt eine blaue Flamme (Kohlenoxyd) aus der Oeffnung heraus, als Beweis, daß die Glutzone bei den Rauchlöchern angelangt ist. In diesem Stadium ist die Verkolılung so weit vorgeschritten, daß 
die Kohle zwar schon gebildet, aher noch nicht zur fertigen Schwarzliohle geworden ist. Erst wenn der Rauch sich wieder lichter verfärbt, ist dies ein Zeichen für die Bildung der Schwarzkohle und auch dafür, daß mun die ganze Reihe der Rauchlöcher n11t Lösche geschlossen und nnit der Pättschaufel zugeschlagen werden unuß. Gleichzcitig wird weiter unten cine neue Reihe gestochen. In diescr. Weise wird fortgefahren, bis man an den Fuße des Mcilers angelangt ist. Sollte dic Gut nicht ringsum im ganzen Meiler gleichmäßigr nicdergehen, so muß an jener Scite, wo sic rascher vorschreitet, blind oder an der entgegengesetzten Seite mit stärkerem Zug (durch Vermehren der Fußräume und Rauchlöcher) geliohtt werden. Bei Icilern, welche an cinem Bergabhange stehen, ist der Zug an der Talseite immer größer als an der Bergscite, folglich auch das Niedergehen der Glutzone ein unregehnäBiges, welches in der angedeuteten Weise ausgeghichen werden muß. Eine andere UnrogelmäBigkeit, welche namentlich bei zu raschen Kohlgange auftritt, ist das ., Schütten, Werfen oder Schlagen" des Meilers: darunter versteht man das explosionsartige Abwerfen einzelner Partien der Decke. Sobald die Tcmperatur im IIciler etwas hölser stcigt, cutwickelt sich Wasserdampf aus dem Holze, welcher anfänglich an der kalten Erddecke kondensiert wird. Der Jeiler fängt an zu dunsten und zu schwitzen. Zugleich oder etwas später entweicht auch ein dicker, qualmender Rauch, welcher die Erddecke durchdringt. In dieser Periode liegt die Gefahr des Schüttens sehr nahe. Schließt die Decke zu dicht oder ist das Feuer im Mciler zu lebhaft, so werden mehr Dämpfe entwickelt, als durch die Decke entweichen können; die Fulge davon ist, daß die Dämpfe sich gewaltsam Austritt verschaffen und einen Teil der Decke abwerfen. Außer Wasserdampf können auch noch brembare Gase, vor allem liohlenoxyd und Kohlenwasscrstoffe, in Berührung mit der atmosphärischen Luft knallgasartige Gemenge geben, wclche Explosionen im Meiler veranlassen. Dic Bildung dieser Gase in größerer Mcuge kam durch die Annahme, daB dic Verkohlung ein exothermischer Prozel ist, unschwer erlilärt werden. Beim Beginn der liohlung ist es vorzugsweise der Wasserdampf und in den späteren Stadien sind es die brennbarcn Gase, welche das Schütten des Meilers bewirken. Ganz ruhig verläuft die liohlung niemals, kleine Detonationen sind unvermeidlich, sie dürfen aber niemals so stark werden, daß ein teilweises Abwerfen der Decke und Auseinanderwerfen des Holzes damit verbunden ist. Die durch das Schütten entstandenen Oeffnumgen müssen sofort wieder verschlossen und der Zug in IIeiler muB auf das tunlichste Jinimum reduziert werden.

6. D a s $\mathrm{N}$ a c h $\mathrm{f}$ ü $\mathrm{l}$ e $\mathrm{n}$. Bei der Kohlung entstehen immer Höhlungen im IIeiler, welche mit kurzem Spaltholze, Bränden oder Grösekohlen ausgefüllt werden müssen. Der erste Hohlraum ergiłt sich durch das Ausbrennen des Quandelschachtes; weitere Hohlräume entstehen dann noch durch das ungleichmäßigc Niedergelıen der Kohle. Das Tolumen des Scheitholzes schwindet bei der Verliohlung un $30-10 \%$, hei frischem, wasserreichen Holze auch noch mehr. Durch diese bedeutende Volumverminderung findet nicht nur cin starkes Niedergelıen der Decke, sondern auch ein Verstürzen der Kohle statt, Wodurch notwendigorweise Höllungen in Meiler entstchen müssen. Diese Höhlungen fallen um so größer aus: I. je feuchter das Holz war, 2. jo weniger dicht dasselbe gestellt wurde, 3. je rascher die Kohlung verläuft und 4. je ungleichmäßiger das Feuer niedergeht. Die Ausfüllung des leergebrannten Quandelschachtes nennt man das $H$ a u p $f f u ̈ l l e n$, die Ausfüllung aller übrigen Höhlungen das S c i t e n f ü Il e n. Das Hauptfüllen geschicht schon I2-I6 Stunden nach dem Anzünden des Meilers und muß am 2., 3. und 4. Tage wiederholt werden, weil sich durch dic Verkohlung des Füllmateriales immer wieder 
neue Hohlräume bilden. Die Seitenfüllungen werden nach Bedarf gemacht. Größere Hohlräume geben sich schon an dem örtlich starken Einsinken der Decke zu erkennen. Kúleinere Höhlungen werden durch das Abliopfen des Veilers mit dem sogenannten Wahrhammer (d. i. ein hölzerner Schlegel) ausfindig gemacht. Mindestens eine Stunde vor dem Füllen müssen alle Zugöffnungen ver'sehlossen werden. An der hoht erkannten Stelle nimmt der Köhler die Decke ab, stößt mit einer Stange die losen Kiohlen hinunter, bringt das schon früher vorbereitete Fülhnaterial ein, legt die Rauh- und Erddecke wieder auf mo klopft dieselbe mit dem Hammer fest. Die ganze Manipulation muß möglichst schnell gesehehen, damit die Glut im Meiler nicht zu stark angefacht wird. Durch etwa I2 Stunden nach dem Füllen wird blind geliohlt. Trotz rlieser Vorsichtsmaßregeln verbrennt aber immer ein Teil der liohle und muß daher sehon von vornherein darauf Bedacht genommen werden, alle [mstände zu vermeiden, welche ein oftmaliges Füllen notwendig machen.

7. Das Verwahen und A uskühlen des Meilers. Unu Unregehmäßigkeiten im Kiohlgang vorzubeugen, muß der Köhler jeden Abend die Decke. soweit die Terliohlungszone reicht, mit dem Wahrhammer niederklopfen, etwa vorhandene Risse, sowie die stark eingesunkenen Stellen mit feuchter Stübbe ausgleichen (beschießen) und die nötigen Füllungen machen. Diese Arbeiten nemnt man das V e r w h he n. Ist die Verkohlung bis zur Gare vorgesehritten, so erfolgt das A b k ühle $\mathbf{n}$. Zu diesem Behufe werden die FuBräume verschlossen und damit der Zug im Meiler abgesperrt; die Decke wird streifenweise abgenommen, durchgehackt und sofort wieder aufgebracht. Dabei rieselt die Erde zwischen die Kohlen ein und dämpft die Ghut rasch ab. In diesem Zustande bleibt nun der ,fertig geputzte“ Meiler - ein sog. Kohlstück - 24 bis 48 Stunrten der Abkühlung ïbowlassen.

8. Das Ausziehen und Sortieren der liohlen. Das Ausziehen (auch Langen oder Stören genannt) wird mit einem eisernen, gelirümmten Hacken am Fuße des Meilers vorgenommen. Diese Arbeit wird abends begonnen und die Nacht hindureh fortgesetzt, um die Ghut besser überwachen zu können. Die Ziehöffnumg muß gegen IVindanfall geschützt sein. Mlan zieht nur $2-3 \mathrm{~m}^{3}$ an einer Stelle aus, dann wird die Oeffnung verschlossen und an einer anderen Stelle mit dem Ausziehen begonnen. In dieser Weise fährt man rings um den Meiler fort, bis alle Kohlen ausgezogen sind. Der verbleibende, aus dem Zentrum des Meilers stammende Rest besteht aus Kiohlenklein und Asche und wird behufs Erkaltung ausgebreitet. Die ausgezogenen Kohlen werden nach der Holzart (falls überhaupt gemischtes Holz in Anwendung liam) und nach ihrer Größe sortiert.

Man unlerscheidet folgende Sorimente:

1. Grob- Lese-oder Hüt e nk hle n, d. s. die größten Stucke, welche vorzugsweise für hütlenmännische Zwecke dieß®».

2. S e h m i e d e k o hlen, von Fausigröße und darüber.

3. Zi e h-oder Rechkohlen, von NuB-bis laustgröße.

4. Q u a n delkohlen, die kleinsten leiehten liollen aus der Nähe des Quandelsehaehtes.

Die beiden ersten Sortimente werden durch Handseheidung gewonnen, die beiden lelzteren dureh Gitier aussortiert.

5. $\mathrm{B}$ r ä $\mathrm{n} \mathrm{d} \mathrm{e,} \mathrm{d.} \mathrm{s}$. halbverkohle stüeke, welehe als Fülmaterial Verwendung finden. In der Regel wird nur ein Sortiment, bestehend aus 1,2 und 3 , abgegeben. 4 und 5 , werden an liohlulatz weiter verwendet.

Ton diesem Verfahren, welches gewöhnlich als die the u tsche Verkoh I u n g s meth o de bezeichnet wird, gibt es verschiedene Varianten; eine davon ist die All enk öhle re $\mathrm{i}$ oder it a li en is che Verkohhng. Dieselbe unterscheidet sich ron der deutschen Kohlung durch folgendes: 
1. Wird in der Regel Rundholz, aber auch Spaltholz bis zu 2 in Länge und 's 11 Stïrke angewendet.

2. Die Kiohplatte wird so dicht als möglich genacht und das Kohlholz auf eine spinnennetzartige Meilerbrücke gestellt, un den nötigen Luftzug in Neiler zu veranlassen. Die Heilerbrücke wirt aus eimmal gespaltenen Fohlholzklötzen hergestellt, welelıe teils radial und teils querüber konzentrisch gelegt werten.

3. Muß der Meiler, der größeren Länge des Kiohlholzes wegen, steiler gebaut werden. Der Einfallswinkel beträgt $60-80^{\circ}$. (Bei der deutschen Kohlung hingegen nur $\left.50-60^{\circ}\right)$.

4. Der Fassungsraum des Meilers ist bedeutend größer, bis zu $300 \mathrm{~m}^{3}$.

5. Wird gewöhnlich nur eine Decke, und zwar aus liohlenłösche gegehen, welch* aber viel stärker ist als bei der deutschen liohlung (unten 60 und oben $30 \mathrm{~cm}$ dick). Zum Festhalten der Decke sind bei dem steilen Bau des Neilers komplizierte Rüstungen erforderlich.

6. Das Anzünden geschieht von oben und der Feuerungsgang ist ein rascherer.

Diese VerkohJungsmethode ist eine primitive, stammt aus alter Zeit, hat siel aber bis auf den heutigen Tag erhalten und ist seit dem Rüekgange der konzentrierten höhlerei sogar in Aufschwung begriffen Für die Wanderköllerei ist sie wenig geeignet, weil zun Anmaehen der dicken Lösehdecke viel Wasser erforderlich isl, was nichı überall zur Verfügung steht. Dagegen wird diese llethode in den österreichischen Alpenländern an stăndigen Plälzen häufig betricben. Das Rundholz soll entrindet suin und einen genügenden Trockenheitsgrad lesilzen. Starke Drelılinge, so wie früher, kommen lıeule kaum mehr in Verwendung, da fūr diese zumeist eine bessere Verwendung als Nutzholz zu finden ist. Zuneist kohlt man mur mindere Sortimente. Das Ausbringen ist geringer als bei der deutschen Methode, weil des raseheren Feuerungsganges haber mehr Jiohle verbrennt. Dic kohle selbst ist aber besser durehgeglüh, kohlenstoffreielıer und sauerstoffärmer, weil die Hitze in lleiler eine intensivere ist.

Alle anderen Varianten, welehe sich auf die versehiedene Art des Richtens (stehencle und liegende Stöße abwechselnd), Herstellung des Quandels (Slange anstatl Scliacht), Einlagerung von Grösekohlen (slaviseher Nleiler) oder Ausfüllung aller Zwischenräume durch Kiohlenklein (amerikanischer lleiler) usw. bezichen, sind von untergeordnetem Interesse.

D a u e r d es K o hl g a n ges. Dic Kohlungszeit ist von verschiedenen Umständen: Holzart, Größe und Stärke des Kolılholzes, Feuchtigkeitsgehalt desselben, Größe des Meilers, Leitung des Feuers und von der Witterung abhängig. Ein mäßig beschleunigter Kohlgang gibt die beste Ausbeute, sowohl in bezug auf Qualität, als auch auf Quantität der Kohle. Bei einem stehenden Neiler aus Buchenscheitholz dauert der Feuerungsgang bei $20-40 \mathrm{Rm}$. Inhalt 4-5 Tage, bei $60-80 \mathrm{Rm}$. 7-8 Tage, bei 100-150 Rm. 10-14 Tage. Bei Nadelholz muB der Kohlgang langsamer sein und dauert bei einem Veiler von $20-10 \mathrm{Rm}$. Inhalt $6-8$ Tage, bei 100 bis $150 \mathrm{Rm} .15-20$ Tage. Ungünstige Witterung verzögert den Kíohlgang sehr bedeutend.

$\S 31$. B. Wie Verkohlung in liegenden Me ilern. Diese Methode ist vorzugsweise in Niederösterreich, Steicrmark und im Salzkammergute, ferner auch in Schweden gebräuchlich.

Zur Kohlung dient nur Nadelholz, vorwiegend Schwarzföhre. Das Holz wird in ganzen, möglichst geraden Stämmen von jeder Stärke und gewöhnlich $3-5 \mathrm{~m}$ Länge angewendet. Die Größe der Meiler beträgt $50-300 \mathrm{~m}^{3}$.

Die Herrichtung der Kohlstätte geschieht in kerselben Weise, wie bei stehenden Veilern; mit Vorliebe wählt man ein schwach geneigtes Terrain. Ueber die ganze Länge der Kohılplatte werden gerade Stangen in drei Reihen gelegt, welche dem quer überzulegenden Kiohlholz als Auflager dienen. Beim Aufbau des Veilers ist darauf Pïcksicht zu nehmen, daß die starken Stämme auf halber Höhe und mehr gegen die Rückwand zu liegen kommen, wo sie am längsten der Glut ausgesetzt sind. Oben, unten und an der Vorderwand kommt schwächeres Holz. Alle Zwischenräume müssen 
nit geringerem Holze möglichst dicht ausgefült werden. In der Mitte der Vorderwand wird eine Zündkanmer und von dieser nach beiden Seiten hin, bis an dic Längswände, eine Zündgasse angelegt, un das Feuer über die ganze Meilerbreite leiten zu können. Der holzfertige Jeiler erhält zwei Decken. Als erste dient Reisig, als zweite Lösche gemengt mit feuchter Erde. Un die Decke an den senkrechten Seitenwänden zu halten, werden dieselben mit Brettern oder Schwarten verschalt. In der Regel geschieht dies auch an der Vorderwand, seltener an der Rückwand. Meist wird letztere in einem Winkel von etwa $20^{\circ}$ abfallend gebaut, in gleicher Wrise wie das Dach cingedeckt und durch Rüsten gestülzt. Um den erforderlichen Zug im Meiler herzustellen, werden an den beiden Scitenwänden Fußräume angebracht.

Die Zündkammer und dic Zündgasse werden mit Kienholzspänen gefüllt und in Brand gesteekt. Damit das Feuer gleichmäßig über die ganze Breite des Meiers platzgreift, ist ein öfteres Nachfüllen von Fienholz oder dgl. leicht entzündlicheın Material notwendig. Ist ein Ausgehen des Fevers nicht mehr zu befürchten, so werden die Fußräume geschlossen und am Dache, ungefähr auf ein Drittel der Mcilerlänge, dic ersten Rauchlöcher gestoßen. Dic Glut zicht sich in schräger Richtung von der Vorderwand nach rückwärts, und zwar so, daß die Glutzone am Dache immer um 2-2 1/2 1 weiter vor ist, als am Fuße des Meilers. Sobald sich das Feuer den Rauchlöchern nähert, werden dieselben versehlossen (desgleichen auch die Mündung der Zündkammer) und $1 / 2-1 \mathrm{~m}$ weiter rückwärts neue Räume gestochen. In dieser Weise wird fortgefahren, bis die Flamme am Fuße der Rückwand herausschlägt, als Beweis, daß der ganze Meilerinhalt verkohlt ist. Der Kohlgang nuß möglichst langsan geführt werden, damit einerseits die starken Stämme vollkommen durchkohlen und andererseits nicht zu viel Kohle verbrennt. Die Stübbe am Dach muß anfänglich locker gehalten werden, damit der Wasserdampf entweichen kann. Erst wenn die Kohlung weiter vorgeschritten und die Gefahr des Schüttens vorüber ist, wird die Decke verstärkt.

Das Abkühlen geschieht in derselben Art wie bei den stehenden Meilern, durch stellenweises Abnehmen der Decke am Dache, Einriesehn von trockener Erde und neuerliches Bedecken. Die Seitenwände dürfen dabei nicht angebrochen werden. Dic fertigen Kohlen werden nur an der Vorderwand ausgezogen. Das Ausziehen erfolgt partienweise und wird immer nur so viel ausgenommen, als an einem Tage abgefülnt werden kann. Die Kohlen werden so wie bei den stehenden Meilern sortiert. Am Fuße finden sieh die leichtesten, an der Hinterwand die sehwersten Kiohlen. Häufig wird mit dem Ausziehen schon begonnen, wenn der rückwärtige Teil des Neilers noch im Feucr steht. Dic Kohlenausbeute ist geringer als bei den stehenden Mejlern.

\$32. C. Beurtejlung der Mejlerköblerei. Im allgemeinen ist dieselle stark im Abnelmmen begriffen, was seinen Grund darin hat, daB im Eisenhüttenbetriebe die Holzkohle durch den Koks und die Steinkohle heute schon zum größten Teile verrärngt ist. An Stelle der vielen kileinen Holzkohlenhochöfen sind gegenwärtig riesige Kokshochöfen getreten.

Während früher nur mit Holzkohle vorzügliches Gußeisen und Stahl erzeugt werden konnte, gelingt es seit Einführung des Bessemerprozesses, des Martin- und Thomasverfahrens, auch mit Kolis und auch selbst aus minderen Erzen guten Gußstahl herzustellen und zwar so billig, daß derselbe das Holzkohleneisen in vielen Fällen verdrängen kann. Nach den Angaben des k. und k. Oberforstrates Th. Micklitz ${ }^{1}$ )

1) Geschichte der österr. Land- und Forstwirtschaft und ihrer Industrien. Wien 1899. 
ist der Holzkohlenverbranch in Oesterreich gergenwirtig selıitzungsweise um unin(lestens 12 Mill. IBilogramm per Jahr geringer als vor 3 oder 4 Dezennien.

Obersteiermark allein, wo die llolzliohlenhochı̈fen in grober Zahl vertreten waren, verbratuhte früher jälrlich $5-6$, hente hingegen nur mehr $2-1$ Mill. Wilogramm Holzliohle.

Anch die Oerthehlicit der liohlungsanlagen hat insofern eine Acnderung erfalıren, als die ständige oder konzentrierte köhlerei immer mehr is Abmahme liommt und dafür die $\mathrm{W}$ a u d e r li ö li l e re i zmnimnt. Frülıer trachtete man, liolılstätten möglichst zulionzentrieren und an jene Punlite zu verlegen, wo das Holz auf einfacle und billige Art hingeschafft werden lionnte. Die Trift war die Hauptbringungsmethode und wo es nur immer anging, wurden auch die Hochöfen in nïchster Nähe angelegt, um einerseits an Transportliosten zu sparen, andererseits aber auch den sogenamnten Einrieb (das Abreiben und Zerbreehen der Kohlenstücke wälrend des Transportes) zu vermeiden. Auch melsere andere Torteile waren damit verbunden, wie die fortwährende Benutzung der gleichen, gut vorgerichteten Kinhlplatten, deren Eigentümlichkeiten der Köhler aus jahrelanger Erfahrung genau liennt, die ausgiebigere Íontrolle, bessere Instandhaltung der Wege, Unterbringung des Arbeiterpersonales und dgl. melir.

Die Wanderlï̈llerei, welche dem Holzschlage nachgeht, wurde früher melır vereinzelt, zumeist nur in bäuerlichen Waldungen betrieben. Durch das Auflassen der Zentralkohlungsanlagen liat sie aber an Verbreitung gewonnen.

Das qualitative und quantitative Ausbringen ist dabei allerdings ein geringeres und der Einrieb größer, dafür entfallen aber die Auslagen für die Instandhaltung der Holzriesen und Triftanstalten; auch die Transportkosten für die Kiolıle sind geringer als für das Holz, wodurch die Nachteile wieder ausgegliehen werden.

$\mathrm{S}$ t e h e n d e Y e i l e r haben den liegenden gegenüber den Vorteil, daß nieht nur Stammholz, sundern auch geringere Holzsortimente Verwendnng finden können, daß sich das Feter besser regieren läßt, indem der Meiler ringsum zugänglich ist, daß ferner das quantitative Ausbringen ein höheres und die Qualitïl der Kiohle eine bessere ist. Diese Mlethode ist namentlich für größere ständige Kiohlungsanlagen (Hütten- oder Lendliöhlerei) geeignet. Aber auch die li e genden He iler haben gewisse nicht zu verkennende Vorzüge. In den engen Tälern des Hochgebirges läßt sich für einen liegenden Meiler viel leichter ein geeigneter Platz ausfindig machen, als für einen stehenden rom gleichen Rauminhalte. Das Richten des Meilers ist einfacher, erfordert weniger Sorgfalt und Kraftaufwand; die Führung des Feuers ist leichter; die Witterung hat viel weniger EinfluB, nachdem meist drei Seitenwände des Heilers ganz geschlossen sind und das Dach mit einer starken Decke versehen ist; die lästige und gefährliche Arbeit des Nachfüllens liommt gar nicht vor, weil der Meiler nur nach einer lichtung (von oben nach unten) schwinden liann; das Schütten liann leichter vermieden werden und der dadurch bedingte Schaden liamn niemals solche Dimensionen annehmen, wie bei einem stehenden Neiler. Ueberhaupt erfordern die liegenden Neiler viel weniger Wartung; ein liöhler kann mehrere, auf nicht allzu großen Wegstreeken auscinander liegende Meiler gleichzeitig überwachen. Diese Nethode eignet sieh daher vorzugsweise für die Wanderliöhlerei.

§33. D. Die Grubenköhlere i ist die primitrste Methode der Holzverkohlung und wird gegenwätig nur mehr in vereinzelten Fälen letrielsen. Sie kann nur dann als zulässig gelten, wenn es sich un die Verkohlung geringwertiger Holzsortimente und nebenbei um die. Gewinnung von Teer handelt, letzleres namentlich bei der I erwendungr von harzreichem stoeklolze. Die Grube soll in einem festen, wenig durchlassigen Boden angelegt werden. Die Tiefe beträgt $1-1_{2}^{1} \mathrm{~m}$, der ouere Durchmesser $2-21 \% \mathrm{~m}$, der untere um $12 \mathrm{~m}$ weniger. Die 
Frube wird zuerst mit Reisig̣ gefült und dasselbe angezündet. Sobald der Rauch nachläßt, wird die kohlige Hasse zusammengestoßen und $\mathrm{Holz}$ nachgeworfen und mit Zwischenpausen so weiter verfahren, bis die ganze Grube gefullt ist. Schließlieh wird dieselbe mit Raspn und Erde bedeckt und 1-2 Tage der Ablinhlung äber]assen. Es ist selbstverstindlieh, da $B$ bei dieser Manipulation ein großer Teil der Kohle verbrennt. Viel zweckmäßiger ist es, wenn man die Grube ausmauert oder mit einem dichten Lebmbesehlag versicht, das Holz auf einen Rost stellt und seitlich im Erdreieh Luftzüge anbringt, welche unter dem Roste einmünden. Die regelrecht mit Holz gefällte Grube wird mit Pasen und Erde dicht eingeleckt. An einigen Stellen wird die Decke abgenommen und Fener angemacht. Hat sich das Fener äber die ganze Grube verbreitet, so werden die Oeffnungen wieder zugedeckt und die weitere Fellerleitung durch Rauchlöcher in der Decke bewerksteltigt. Für den Abzug des Teeres ist unter dem Roste ein eigenes Rohr angebracht. Die Grube muß deshalb an einem Bergabhang angelegt werden.

\section{Die Verkohlung in Oefen.}

$\$ 34$. Diese Methode wird vornehmlich dort angewendet, wo es sich neben der Erzeugung von Iolzkohle auch um die Gewinnung der flüssigen Destillationsprodukte (Holzessig, Holzgeist und eventuell Teer) handelt. Dieser Betrieb ist im Gegensatz zur Meilerköhlerei ein rein fabriksmäBiger.

Die hierzu notwendigen Verkolılungs-Apparate weisen die verschiedensten Kionstruktionen auf, sowohł mit Rüeksicht auf deren Form und Größe, wie auch auf Eimrichtung und Leistungsfähigkeit. Aueh bezüglich der Art der Heizung unterscheidet man mehrere Systeme dieser Oefen, teils solche, bei denen, wie bei den Heilem, die Verkohlung dureh eine teilweise Verbrennung des Kohlungsmateriales, andere wieder, bei denen sie durch direkte Fenergase oder Heizelemente (heife Luft) bewirkt wird.

Diese sog. Meileröfen sind in der Regel für die Aufnalıme großer Chargen eingerichtet und auch meist in der Form stehender Meiler gebaut.

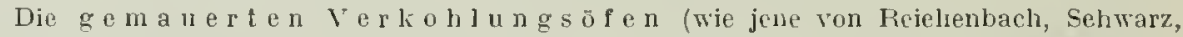
Hahnemann, Scheffer, F. H. Meyer u. a.) stehen aucli heute noch vereinzelt in Verwendung, liaben sich aber doch im großen ganzen uberlebt. Es haftet ihn ler Uebelstand an, daß das Mauerwerk irotz aller Mühe und Sorgfalt nicht dicht zu bringen ist und durch die vielen Fugen namhafte lengen von Destillationsprodukten entwejehen. Ein weiterer Nachteil ist die auBerurdentlich langsame Alokïllung nach Schluß der Verkohlung. Diese selbst geht zwar anstandslos von statten und ist bei Oefen von 80-120 Rm. llolzfullung in 6-8 Tagen beendet. Die Abkühlung der Kohlenmasse aber nimmt mindestens 14-16 Tage in Anspruch, so daß der Ofen eigentlich nur $1 / 3$ der Zeit im Betriebe steht und $2 / 3$ derselben zum Abkühlen erforderlieh ist. Die Leistungsfähigkeit der Oefen ist daher im Verhältnis zu den Ansehaffungs- und Erhaltungskosten eine greringe.

Un diesen Uebelständen abzuhelfen, wurden verschiedene Abänderungen und Verbesserungen angebracht. Es wurden Oefen lionstruiert, bei denen wälrend des Betriebes von unten liohle gezogen und oben Holz nachgefült werden kann. Auch andere kontinuierlich arbeitende Oefen wurden konstruicr, wie z. B. fler von E. F. Ljungherg, welcher, aus vier ringförinig angeordneten Abteilungen besteliend, nach Art eines Ziegel-Ringofens funktionieren sollte; auch er gehört als solcher schon der vergangenheit an.

Auch e iserne, mit Ma uerwerk $11 \mathrm{~m}$ ge bene oefen finden Anwendung. Sie sind aufrecht stelend und haben meist cinen Fassungsian von $40-45$ Rm. Der Eiseneinsatz ruht auf einem Gewölbe, unter welehen die Feuerung angebracht ist. Im Inneren des Ofens hefindet sich eine Anzahl vertikaler föluen, welche von den Heizgasen durchzogen werden und die Holzfüllung zur Verkoblung bringen. Das Holz wird oben eingefüllt und die liohle unten dureh zwei große, geneigt liegende Entleerungsöfnungen ausgezogen.

Transportable $O$ efen haben den Erwartungen nicht entsprochen. Sie sollten dazı dienen, die Verkohlung gleich in der Nähe der Holzsehtäge vornehmen und dabei die flussigen Destillationsprorłule gewinnen zu können. Diese Oefen hatten die Form aufrecht steliender lifssel mit cinem Fassungsraum von etwa 2 Rm. und waren aus melireren ringfömigen Tiilen zusammengesetzt. Diese Teile wurden an Ort und Stelle zusammengepaßt und nit Lehm gedichtet. Hauptzweek dieser Oefen war, an Transportkosten zu sparen, was aber in der Wirklichkeit nicht zutraf.

Als ein Mithlding zwischen den Oefon und den im folgenden liapitel zu besprechind"n

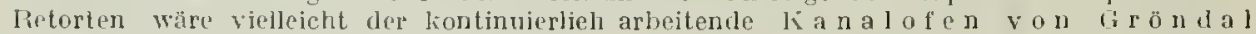
anzuschen. Derselbe ist bis nun auch nur in Forn einer Versuehsanlage in Selıweden und viner Fabrikanlage in Finnland ausgefülirt, aber mit allen bisherigen Errungensclabten aul 
diesem Gebiele ausgestaltel und - vorausgesilz.l, daß alle Einzelprozıluren cinen ungestörlen Terlauf nelimen - fur einen latsächlich kontimuierlichen Belrieb cincrerichtel.

Dieser Verkohlungsaplarat beslcht aus einem langrestrecklon lianal, der in sich in drui

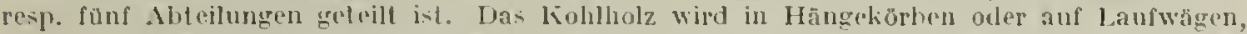

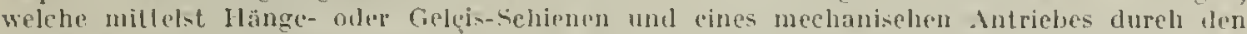
lianal laugsam fortbewegt werlen, vorerst in einen genauerten Vorraum eingeführ, gelangt von lier in einen teils gemauertun, teils ams schmiedeeisen gefertiglen Vortroekenraum, dann in ten eigentlichen, sehniedecistrnen Verkohlungsraum, weleher uil der Kondensationsanlage in Vephindung steht, des weileren in den genauerlen liohlen-Kinhlraum und endlich, zur Aus-

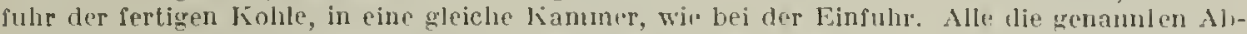
leilungen sind durel gut schließeute Schiebetüren von einander getrenut und elsenso die beiden Endräume nach außen verschließbar. Ein Generalor liefert aus Holzabfallen dio zur Verliolllung notwendigen Heizgase, wolche vor ihrev eigentliehen Verwendung den lïhlram durehzielıen und so die fertige Holzkohle durch Wämeentzug küllen, nach gueislaler Verkohlungsarbeit aber die Trocknung des zu kohlenden IJolzes in Vortrockenraum, hewirlien.

Jede Wagenladung belrågt 3 Rm. Holz; nach je einer Stunte wird cin frischer Wagen eingeführt und einer mit ferliger liohle heraugeschoben.

Die Ausbenten sollen mit diesem Ofen elwas geringere sein, als leci anderen kion-lruklionen, und seine Verwendung wird daher nur bei billigen Holzpreisen renlieren.

\section{b) Holzdestillation.}

\section{Retortenverkohlung.}

\$35. Die rationellste Art der Holzverkohlung, bei möglichst großer Ausbeute an flüssigen Destillationsprodukten, ist jene in Retorten.

Es gibt verschiedene lionstruktionen von Verkohlungs retorten:

1. liegrende;

- 2. stehende, und zwar a) eingemauerte, b) aushebbare.

Die gebräuchlichsten sind die $\mathrm{I}$ i e g e $\mathrm{n}$ d e $\mathrm{n}$ Retorten, aus $10-12 \mathrm{~mm}$ starkem Schmi edeeisen geschweißt hergestellt, von $3 \mathrm{~m}$ Länge und $1 \mathrm{~m}$ im Durchmesser, daher annähernd 2.3 Rm. Fassungsraum. Torne sind sie mit einer gußeisernen Türe verschlossen und an rückwärtigen Ende gelıt das Ronr für die Lestillationsprodulite ab. Je zwei dieser Retorten haben eine gemeinsame Fenerung, welche derart eingerichtet ist, daß die Heizgase vom Roste durch einen Mauerkanal nach rückwärts ziehen und dort erst die Retorte treffen, um die Stichflamme abzuhalten. Von hier gehen sie durch einen Zug nach vorwärts, durch den zweiten nach rückwärts, wobei sie die unterste Hälfte der Retorte umspülen und sodann in den liamin entweichen. Nach der Einrichtung von Bülıler lıat jede Retorte ihre eigene Feuerung, wodurch ein rationelles Heizen und daher auch eine Brennstoffersparnis erzielt wird. Die Destillation kann in 12 Stunden becnrlet sein, besser ist es jedoch, wenn dieselbe auf 16 Stunden ausgedehnt wird. Das Beschicken und Entlecren nimmt etwa cine Stunde in Anspruch. Es muß rasch erfolgen, um den Abbrand der Kohle tunlichst zu reduzieren und die Wärme des Ofens gut auszunützen.

Die Ladung des Holzes geschieht durch Einwerfen der Scheite: es kommen drei Lagen von je $1 \mathrm{~m}$ Länge hintereinander, so daß die Retorte ganz gefüllt ist. Die Scheite müssen regelrecht gelegt sein, um den Raum möglichst auszunützen. lng. Bühler hat eine eigene Ladevorrichtung lionstruiert, welche der IIauptsache nach aus einer auf fahrbarem Gestell inontierten Hülse besteht.

Diese Hülse wird mit Holz beladen in die Retorte eingeschoben und leer herausgezogen, indem eine rorgesetzte Scheibe die Holzfüllung zurückhält. Um đie am Schlusse der Destillation noch schwach roterlühenden Fiohlen rasch auszichen zu können. wird yor dem Eiribringen des Holzes ein eiserner Rechen mit daran befindlicher Stange bis an das rückwärtige Ende der Retorte geschoben und bein Entleeren der liohte vorgezogen. 
Die Kohle konmt sofort in Kühlkästen, die, aus $4 \mathrm{~mm}$ starken Eisenblech hergestellt, dicht verschließbar und zum Fahren eingerichtet sind. Jeder Kühlkasten faßt den Inhalt einer Retorte. Die Ablühlung davert etwa 36 Stunden. Die noch heiße Retorte wird sogleich wieder mit Holz beschickt.

Für die Bewältigung größerer Holzmengen, bei relativ geringem Zeitaufwand, ist eine liegende Retortenanlage von F. H. Meyer, Hannover, konstruiert. Die 15 m lange zylindrische Retorte ist aus Schmiedeeisen und entweder auf der einen oder auf beiden Stimseiten mit Türen dicht verschließbar; sie faßt 4 Waggonets, zu je $7,5 \mathrm{Rm}$. Holz, welche auf Schienen in die Retorte eingefülırt und nach vollzogener Destillation aus dieser gezogen oder geschoben werden. Der Retorte vis-à-vis ist ein ihr gleich großes, eiserner, gleichfalls dicht verschließbarer Zylinder situiert, in den die Waggonets mit den noch glühenden Kohlen durch einen entsprechenden Mlechanismus in wenigen Sekunden zur Ablïhlung befördert werden kiönnen. In die noch heiße Retorte werden sofort nach der Entleerung 4 frisch beschichte Waggonets eingefahren.

Die s tehend eingem a u e r en Retorten haben oben die Füll- und unten die Entleerungsöffnung. Die Feuerung befindet sich seitlich, um die Stichflamme abzuhalten. Die Heizgase umspülen die Retorte spiralförmig nach aufwärts steigend und entweichen oben in den Kamin. Das Abzugrolır für die Destillationsprodukte ist ganz oben unmittelbar unter dem Deckel angebracht.

Bei der Verkohlung verringert sich das Tolumen der Retortenfüllung um etwa $1 / 3$, so daB am Schlusse der Verhohlung die Retorte nur mehr zu $2 / 3$ ilıres Rauminhaltes gefüllt ist. Um den leerwerdenden Raum sukzessive immer wieder auszufüllen, wird nach dem Patente F. Schmidt auf den Retorten ein Aufsatz angebracht, welcher über die Einmanerung frei herausragt, also nicht geheizt wird, und so wie die Retorte selbst mit Holz gefült ist. In demselben Nlaße, als das Volumen der Füllung abnimmt, rutscht Holz, schon entsprechend vorgewärmt, von oben nach und wird auf diese Art der geheizte Raum besser ausgenützt.

Die a us heb b ren Retorten sind meist schwach koniseh, doch auch zylindrisch geformt und sitzen oben mit eimem starken Gußeisenring auf rem Umfassungsmauerwerk auf. Geheizt werten sie von unten, wo ein Gewölbe den Boden der Retorte gegen die direlste Einwirkung der Stichflamme schützt. Die Heizgase gehen durch Oeffnungen, welche ringsum im Manergewölbe angebracht sind, ziehen an den Wandungen der Retorte nach aufwärts und entweichen oben in den Fuchs.

Das Ausheben geschieht nit Hilfe eines Lauflirahnes, welcher die Retorten nach dem Kühlplatz schafft, wo sie durch Oeffnen der Deckel und Umkippen direkt in die Kühlkästen entleert werden. In den frei gewordenen Ofenraum wird sogleich wieder eine andere, schon vorbereitete, mit Holz gefültte Retorte eingesetzt, so daß die Destillation mit nur geringer Unterbrechung fortgesetzt werden kann.

Die aus den Retorten entweichenden Gase und Dämpfe passieren einen Röhrenkühler, wo der kondensierbare Anteil verdichtet wird und als Rohsäure abläuft, während die Gase zu den Fenerungen geleitet werden und nit zur Heizung beitragen. Um das Zurüclischlagen der Gase beim Oeffnen der Retorte zu verhindern, ist das Auslaufrohr für das Destillat geliröpft und anch das Gasrohr mit einem Flüssigkeitsverschluß versehen.

Das Destillat wird in Absatzgefäße geleitet, wo der größte Teil des Teers zu Boden sinkt und die darüber stehende Rohsäure zur Weiterverarbeitung abgezogen gen wird.

Bei primitiver Einrichtung wird die rom Teer getrennte Rohsäure mit Aetz- 
kalk neutralisiert, sodann in einen Destillierkessel gebracht, der Molzgeist abgetrieben und der Destillationsrïekstand zur Trockene verdampft. Der dabei gewonnene essigsaure Kalk (Braunkalk) ist mit Teerprodukten stark verunreinigt.

Un ein reineres Produkt zu gewinnen, wird in allen besser eingerichteten Fabriken die Rohsäure olne vorhergegangene Neutralisation destilliert. Zu dicsem Zwecke werden drei Destillierblasen angewendet, welc he stufenförmig nebeneinander aufgestellt sind. Die Rohsäure kommt in die unterste, größte, mit Dampfheizung versehene Blase und wird hier abdestilliert. Die Säuredämpfe gelangen in die zweite Blase, wo sich verdünnte IKalkmilch befindet, welche die Essigsäure bindet. Die Dämpfe, welche hier entweichen, gehen in die dritte Blase, die ebenfalls verdünnte Kalkmilch enthält und den Rest der Essigsäure aufnimmt. Die von hier abgehenden Holzgeist- und Wasserdämpfe gelangen in einen Iïuhler, wo totale Kondensation stattfindet und roher Holzgeist abläuft, weleher durelı Rektifikation gereinigt wird. Die in der zweiten und dritten Blase befindliche Lösung von essigsaurem Kalk wird behufs Klärung dureh Filterpressen gepumpt und läuft sodann in die Eindampfpfannen ab. Dieselben sind flach konstruiert, haben einen linsenförmigen Boden für Dampfheizung und eine abhebbare Dunsthaube. Der hier bis zur Trockene eingedampfte essigsaure Kalk wird auf geheizten Eisenplatten (Darre) weiter getrocknet und als sogenannter Graukalk in den Handel gebracht. Er bildet das Ausgangsmaterial für die Darstellung der Essigsäure, essigsauren Salze und des Acetons.

Im Ansehluß an die Ausführungen über die trockene Destillation von Holz im allgemeinen sei hier nur liurz speziell der Verkohlung von harzreichen Nadelhölzern Erwähnung getan, bei welcher außer den bereits mehrfach genannten Produkten auch noch die der trockenen Destillation des Harzes gewonnen werden können. Zu diesem Zwecke wird das Holz vor der eigentlichen Verkohlung mit gesättigtem oder überhitztem Dampf destilliert. Nach einem neueren Verfahren von Elfström wird harzreiches Isiefernholz in einer $\mathrm{B}$ a $\mathrm{t} \mathrm{t}$ e r i e von Retorten systematisch mit überhitztem Dampf destilliert, wobei in jeder Richtung bessere Ausbeuten als bei der gewöhnlichen Destillation und außerdem Terpentin von hoher Qualität gewonnen werden sollen.

\section{e) Produkte der Holzdestillation.}

$\S 36.1$. Die $\mathrm{Holzk}$ ohle. Eine gute Holzkohle muß folgende Eigenschaften besitzen:

I. Eine ticfschwarze Farbe nit stahlblauem Anfluge, über Hirn glänzend, ohne abzufärben. Ein brauner Farbenton zeigt unvollständige Verkohlung an. Iiohlen aus morschem Holze sind matt und färben stark ab.

2. Die Holztextur soll deutlich hervortreten; der Bruch muß muschelig sein und die Stücke dürfen nur wenig Risse besitzen. Anbrüchiges Holz liefert texturlose Kohle. War das Holz feucht oder wurde es in zu starken Stämmen angewendet, so resultiert stark rissige Kiohle.

3. Eine große Festigkeit und hellen IKlang. Die Kohle für hüttenmännische Zweeke muß so fest sein, daß sie bei der Verwendung im Hochofen den Druck der darüber liegenden Erz- und Zuschlagschüttung auszuhalten imstande ist. Ueberfeuerte Fiohlen oder fiohlen aus morschem Holze sind leieht zerreiblich und klanglos. Der Iilang der Kohlen läßt sich schon beim Aufschütten deutlich erkennen.

4. Die Kohle muß ohne Rauch verbrennen und darf nur eine kurze, blaue Flamme geben. Nicht ganz durchgekohlte Stücke verbrennen mit langer leuchtender 
Flamme und geben einen bedeutend geringeren Wärme-Effekt. Die Entzündungstemperatur der Holzkohle liegt bei etwa $360^{\circ} \mathrm{C}$. Die Kohle glimmt an der Luft ruhig fort.

Das spezifisclie Gewieht der Holzliohle ist von verschiedenen Umständen ablıăngig. Vor allem ist zu unterscheiden zwischen dem spezifischen Gewicht der liohlensubstanz exklusive J'orenräume (wirkliches spez. Gewicht) und jenem der ganzen liohlenstücke, inklusive der Hohlräume (scheinbares spez. Gewieht). Die Schwankungen beiderseits sind sehr bedeutend. Ersteres variert von 1,4 bis 1,9 und kann im Mittel mit 1,6 angenommen werden; lelzteres ist selbstverständlich viel geringer, 0,14 bis 0,25 , in Nittel 0,20. Für den Kohtenhandel kommt nur das scheinbar spezifische Gewicht in Belracht. Auf dasselbe nehmen folgende Momente EinfluB: 1. D i e $\mathrm{H}_{0} \mathrm{l} \mathrm{z}$ a $\mathrm{r}$ t. Die dichten harten Laubhölzer geben sehwerere Kohle als das weiche Laubholz und die Nadellölzer. 2. D e r F e u c h t i g ke it $\mathrm{s}$ e h a $\mathbf{l t}$ des liollliolzes. Frisclies Ilolz gibt leichtere Fohlen als das gut luftrockerie. 3. D i e Verko h l u g s methode. Die Meilerkohlen sind weniger durchgekoht und daher in allgemeinen schwerer als die Retortenkollen. 4. D e r K o hl g a n g und die Verkohlungst e m p e r a t u r. Je rascher der liohlgang releitet wird, desto leichter fallen die liohlen aus. (Das wirklicle spez. Gewicht steigt aber mit der Verkohlungs-Temperatur.) Violette fand dasselbe bei $310^{\circ} \mathrm{C} .=1,42$, bei $1500^{\circ} \mathrm{C} .=1,87$. Solche dichte kohle ist sehwer entzündlich und bedarf zum Forthrennen einen scharfen Luftzug. Das Heklolilergewicht (in Kübeln oder Körben gemessen) hängt von der JJolzart, von der Größe der hohlenstüeke, von dem spez. Gewichle und von der Art des Einschüttens ab. Es sehwankt in der Regel bei Meilerkohlen aus harten Holze zwischen 18 und $22 \mathrm{~kg}$ und aus weichem Holze zwisehen 115 und $18 \mathrm{~kg}$.

Gut durchgeglühte Meilerkohlen aus hartem und weichem Holze zeigten nach 18 in meinen Laboratorium untersuchten Proben folgende Zusammensetzung:

\section{Fiohlenstoff \\ Wasserstoff \\ Sauerstoff}

Hygroskopisehes IVasser

Asche

Kaloriseher Wert

Minimum
81,3
1,8
4,6
4,5
1,4
6900

Yon diesen 18 Proben wurden 8 auf ihre Festigkeit geprüft und dabei folgende Resultate erhalten:

\begin{tabular}{|c|c|c|c|c|c|c|}
\hline & \multicolumn{6}{|c|}{ Druckfestigkeit in $1 \mathrm{~kg}$ per $1 \mathrm{~cm}^{9}$} \\
\hline & \multicolumn{3}{|c|}{ auf der Hirnfläche } & \multicolumn{3}{|c|}{ auf der Wölbfläche } \\
\hline & Minimum & Maximum & Hittel & Minimum & Mlaximum| & Mittel \\
\hline $\begin{array}{c}\text { liohle aus liartem Holze } \\
, ", \text { weichen , }\end{array}$ & $\begin{array}{r}265 \\
78\end{array}$ & $\begin{array}{l}332 \\
182\end{array}$ & $\begin{array}{l}305 \\
125\end{array}$ & $\begin{array}{l}21 \\
11\end{array}$ & $\begin{array}{l}58 \\
38\end{array}$ & $\begin{array}{l}41 \\
22\end{array}$ \\
\hline
\end{tabular}

Die Ilolzkohle ist ein guter Wärmeleiter. Wird das Leitungsvermögen des Eisens $=100$ gesetzt, so ist jenes der 11olzkohle rund $60-65$.

Beim Liegen an der Luft nimmt die Holzliohle 5-12\% Feuchtigkeit auf. Im frisch geglühten Zustande besitzt die Holzkohle ein beträchtliches Absorptionsvermögen für Gase und Flüssigkeiten, sowie auch für gelöste Substanzen, namentlich Farb- und Riechstoffe. Darauf beruht ihre Anwendung zum Entfuseln des Veingeistes, hier und da auch zum Entfärben von Lösungen, Rieinigen des Trinkwassers etc.

Die hauptsäelılichste Venwendung findet die Holzkohle im Eisenhültenbetriebe, im Schmiedefener und für die Netallgewinnung- und Verarbeitung überhaupt. Frülıer 
war ilıre Anwendung eine viel größere und vielseitigere; heute ist, wie schon erwähnt, die Holzkohle zum großen Teil durch Gasfeuerung verdrinngt.

\$37. 2. Der II olzess jg. Der bei dem primitiven Verfaluren gewonnene rohe Holzessig ist eine rotbraune, trübe Flüssigkeit von stechendem, empyreumatiseliem Geruche und stark sauerer Realition. Sein spezifisches Gewicht selwankt zwischen 1,025 bis 1,050 . Er ist mit Teerprodukten verunreinigt und enthält eine ganze Reihe von Bestandteilen ${ }^{1}$ ), von (lenen aber nur die Essigsäure und der Ilolzgeist verwendbar sind. Bei der verbesserten Destillationsmethode wird überlaupt kein Essig, sondern nur essigsauerer Kalk und einfach destillierter Holzgeist gewonnen.

Darstellugg reinerer Produkte. Um aus dem einfach destillierlen Holz-

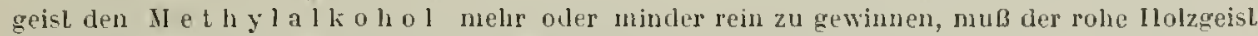
einer fraktionierten Destillation unterworfon werken. Hierzu dienen, ebenso wie bei der Aethylalkohol-Erzeugung in der Spirilusbrennerei, entweder periodisch oder kontinuierlich wirkende Destillierapparate, in denen der rohe Holzgeist, durch wiederholte Destillation (Reklifitation) und teilweise Kondensalion (Dephlegmation), in verschiedene Fraklionen, entsprechend den Siedepunkten der einzelnen Beslandleile, zerlegt und diese nacheinander oder nebeneinander aufgefangen werden können. Bei der periodischen Fraktionierung ergibl jede Rektifikation Produkte, welche entweder schon als solche Verwendung finden können $(z$. B. Denaturjerungsholzgeist, Melhylalkohol für Formalleby-d- und Anilinfarben-Fabrikation (mil $0,03-0,5 \%$ Aceton), zu Parfümeriezwecken (nnit $0,010^{\circ}$ Aceton), oder welche ersl nach weiterer Raffinierung als rein anzusprechen sind. Die kontinuierliche Rektitikation hingegen, in sog. Folonnenapparaten ausgeführt, liefert in ein'm Zuge, ununterbrochen im Zu- und Ablauf, nieht nur Zwischenprodukte (Denaturierungsholzgeist etc.), sondern auch Jelhylalkohol höchsler Grädigkeit.

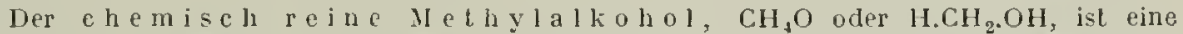
farblose, leicht bewegliche Flüssigkeit von eigentïnlich schwach alkoholisehen Geruch und brennendem Gesehmack. Bei $15^{\circ} \mathrm{C}$. liat er eine Dichte von 0,7984. Sein Siedepunkt liegl bei $66,5^{\circ} \mathrm{C}$. Auf Zusatz von Wasser bleibt er klar (Zeichen der Reinheil), mischt sich in allen Verhältnissen mit Wasser, Alkohol und Chloroform. Fr ist ein Lösungsmittel für IJarze, älherische Oele, Kampfer, Wallrath etc., und kann daher in der Industrie melirfache, bereils erwähnte, Verwendung finden. Er brent mil schwach leuchlender, nichl rußender Flamme. Sein Heizwert betrăgl 5310 Kalorien, ist daher wesentlich geringer als der des Weingeistes (Aethylalkohol), welcher sich auf 7120 halorien stellt. gestellt.

Reine Essigsäure wird enlweder aus dem Calcium-oder Nalriumacetat her-

Der in vorhin angegebener Weise gereinigle essigsaure lialk wird mit Salzsäure zerlegt und die Essigsäure abdestilliert.

$$
\left(\mathrm{C}_{2} \mathrm{H}_{3} \mathrm{O}_{2}\right)_{2} \mathrm{Ca}+2 \mathrm{HCl}=\mathrm{CaCl}_{2}+2\left(\mathrm{C}_{2} \mathrm{H}_{4} \mathrm{O}_{2}\right) \text {. }
$$

Die Salzsăure muß entsprechend verdünt sein und darf kein Ueberschuß davon in Anwendung kommen.

Die Destillation geht zwischen 100 und $120^{\circ} \mathrm{C}$. glatl vonslatten. Das Destillat ist farblos, riechl nur schwach empyremalisch und gibt nil silbernitrat nur eine ganz schwache Trübung. Der schwache Teergeruch kann durch nochnalige Destillation der Sătire unter Zusalz von 2-3\% Kaliumbichromat oder auch durch frisch geglühte Holzkohle beseitigt werden. Der Gehalt des Destillates an Essigsäure soll etwa 35- $10 \%$ betragen, was man durel die Verdannung der zur Zerlegung henülzlen Salzsäure in der Gewalt liat.

Die Zerlegung des escigsauren Kalkes durch Schwefelsåure anstatt Salzsăure lat sieh in der letzten Zeit immer mehr eingehürgerl. Die preisverhãltnisse zwischen den beiden Säuren haben zugunsten der Schwefelsäure entschieden und ebenso auch die Ausbeuten an liöher prozentigen Essigsäure-l'rodukten. Im I'rinzip sind die beiden Methoden gleich; in der $\Lambda$ usführung erfordert aber das Schwefelsäureverfahren mehr Vorsicht und für den speziellen Zweck eingerichtete Destillierapparate.

An Stelle des Calciumacetates wurde früher vielfach das Nalriumacelat, das sog. Rotsalz, in den Holzdestillationeu lergestell und zur Essigsäurefabrikition verwendel. Zu diesem Zweck wird der Holzessig mit Soda neutralisiert; die sich dabei ausscheidenden leerigen Produkte werden entfernt, die Lōsung in den Dentillieraprarat gebrachl und der Holzgeist abgetrieben. Die in der Destillierblase verbleibende Filussigkeil wird in eine flache Pfanne abgelassen und bis auf $27^{\circ} \mathrm{B}$ (heiß gewogen) konzentriert. Diese von din Teerbestandteilen intensiv rot gefärbte Losung komml in noch heißem Zustande in eiserne Kristallisierkästen, wo beim Abkühlen das Valriumacetal austiristallisiert. Die lírislalle werden

1) Aceton (Siedepkt. 56,30 C.), Methylalkohol (Siedeplit. 66,50 C.), Altylalliohol (Siedeplit. $97,0^{\circ}$ C.), Alehyd, Methylacelat, höhere Kelone, Amine, Holzöle und Wass'r. 
in der Zentrifuge von der Mutterlauge getrennt und in einem Kessel gesehmolzen. Zuersu zerfließen die firistalle in ihrem líristallwasser, beim Abdunsten derselben wird die Masse allmählich trocken, staubig und bei weiterer Steigerung der Temperatur beginnt jetzt der eigentliche Fluß. Das Schmelzen wird so lange forlgesetzt, bis eine herausgenomnene Probe mit Wasser eine farblose Lösung gibt. Ist dieser punkt erreicht, so wird die Sehmelze aus dem Kessel entleert, in siedend heißem Wasser gelōst, die Lösung fillriert und zur Krislallisation angestełlt. Die Kristalle werden wieder von der Mutlerlange getrennt, mit Schwefelsäure zerlegt und die Essigsäure abdestilliert.

$$
2\left(\mathrm{C}_{2} \mathrm{H}_{3} \mathrm{O}_{2} \mathrm{Na}\right)+\mathrm{H}_{2} \mathrm{SO}_{4}=\mathrm{Na}_{2} \mathrm{SO}_{4}+\left(\mathrm{C}_{2} \mathrm{H}_{4} \mathrm{O}_{2}\right) \text {. }
$$

Die auf diese Art erzeugte Essigsäure ist nahezu ehemisch rein.

Will man Eisessig, so wird die Zerlegung mit konzentrierter, andernfalts mit entsprechend verdunnter Schwefelsäure vorgenommen.

Die Mutterlaugen, welche von den Kristallisationen resultieren, werden immer wieder eingedampfl, newertich zum Firistallisieren gebracht und so bis auf tinen kleinen Rest, der schon sehr unrein ist, aufgearbeilet.

Die reine, wasserfreie Essigsäure $\mathrm{C}_{2} \mathrm{H}_{4} \mathrm{O}_{2}$ (oder $\mathrm{CH}_{3} \mathrm{COOH}$ ) ist eine farblose Flüssigkeit, welche bei $+16,7^{\circ} \mathrm{C}$. krisiallinisch erslarrt (Eisessig). 1st die Säure wasserhaltig, so liegt die Erstarrungsiemperatur tiefer.

Die Säure besitzl einen sehr scharfen, slechend sauren, zu Tränen reizenden Geruch und wirkt, auf die Haut gebracht, blasenzieliend. Bei $15^{\circ} \mathrm{C}$. ist die Diehte der flüssigen Säure 1,055. Auf Zusatz von Wasser steigt die Dichte und erreiclıt in der 77 bis 80 prozentigen Säure ihr Maximum von 1,075. Der Siedepunkt liegt bei $118^{\circ} \mathrm{C}$, nichtsdestomeniger verdunstet sie aber schon bei gewöhnlicher Temperatur in merklicher Menge. Der Dampf ist brennbar. Die reine Essigsâure mischt sich in allen Verhältnissen mit Wasser, Alkohol und Aelher. Sie löst viele ätherisehe Oele, Kampfer, Harze, Gummi, Kleber etc. Einzelne ätherische Oele, wie z. B. Zitronenöl und Terpentinöl, sind nur in höchst lionzentrierter Essigsäure löslich. Wenn die Säure mehr als $2 \%$ Wasser enthält, so sind die genannten Oele unlöslich; man kann dieses Verhallen dazu benülzen, einen $2 \%$ übersteigenden Vassergehalt in der Säure uachzuweisen. Die Essigsäure ist eine einbasische Säure; die Salze derselben werden Acetale genannt.

Für sich allein kann die Essigsäure, bezw. ihr Dampf, his auf $360^{\circ} \mathrm{C}$. erhitzt werden, ohne eine Veränderung zu erfahren. liommt jedoch Essigsäuredampf mit glühender Kiohle in Berührung, so wird er in Sumpfgas, Kohlenoxyd und liohlensäure zertegt.

$$
2 \mathrm{C}_{2} \mathrm{H}_{4} \mathrm{O}_{2}+\mathrm{C}=2 \mathrm{CH}_{4}+2 \mathrm{CO}+\mathrm{CO}_{2} \text {. }
$$

Dieser Prozeß geht schon bei schwacher Rolglut vor sich, erfolgt daher auch bei der trockenen Destillation des Holzes und verringert die Ausbeule an Essigsâure.

Für die Darstellung ler essig s a re n S a I z e (1eetate) bilelet entweder der assigsaure liatk oder die freie Essigsäure den Ausgangspunlit. Die Acetate finden in der Färberei, Zeugdruckerei, Farbenfabrikalion, ferner für chemische und pharmazeulische Zwecke Anwendung. Die wichtigsten derselben sind:

1. Bleiacetate: das neutrale Salz (Bleizucler) $\left(\mathrm{C}_{2} \mathrm{H}_{3} \mathrm{O}_{2}\right)_{2} \mathrm{~Pb}+3 \mathrm{aq}$, das basische $\mathrm{Salz}$ (Bleiessig) $2 \mathrm{~Pb}\left(\mathrm{C}_{2} \mathrm{H}_{3} \mathrm{O}_{2}\right)_{2} \cdot \mathrm{Pb}(\mathrm{OH})_{2}$.

2. Die Kupferacelate: das neulrale Salz (Grüspan) $\left(\mathrm{C}_{2} \mathrm{H}_{3} \mathrm{O}_{2}\right)_{2} \mathrm{Cu}+\mathrm{aq}$ das zweidrittelsaure Salz $2\left(\mathrm{C}_{2} \mathrm{H}_{3} \mathrm{O}_{2}\right)_{2} \mathrm{Cu}+\mathrm{CuO}+6 \mathrm{q}$, das essiguarseniksaure Kupfer (Schreinfurter Grün) $\left(\mathrm{C}_{2} \mathrm{H}_{3} \mathrm{O}_{2}\right)_{2} \mathrm{Cu}+3\left(\mathrm{As}_{2} \mathrm{CuO}_{4}\right)$.

3. Die Muminiumacetale: das normale Salz $\mathrm{Al}_{2}\left(\mathrm{C}_{2} \mathrm{H}_{3} \mathrm{O}_{2}\right)_{6}$, das basische Salz $\mathrm{Al}_{2}(\mathrm{OH})_{2}$ $\left(\mathrm{C}_{2} \mathrm{H}_{3} \mathrm{O}_{2}\right)_{4}$.

4. Die Eisenacelate: das Oxydulacetat (Eisenbeize) $\left(\mathrm{C}_{2} \mathrm{H}_{3} \mathrm{O}_{2}\right)_{2} \mathrm{Fe}+4 a$, die Oxydacetate: das neuirale Salz $\mathrm{Fe}_{2}\left(\mathrm{C}_{2} \mathrm{H}_{3} \mathrm{O}_{2}\right)_{6}$, das basische Salz $\mathrm{Fe}_{2}(\mathrm{OH})_{2}\left(\mathrm{C}_{2} \mathrm{II}_{3} \mathrm{O}_{2}\right)_{4}$ und direrse andere.

Aus dem essigsauren lalk wird durch trockene Destillation bei $300-100^{\circ}$ C. A $\mathrm{c}$ e $t$ o $n$ gewomen.

$$
\left(\mathrm{C}_{2} \mathrm{H}_{3} \mathrm{O}_{2}\right)_{2} \mathrm{Ca}=\mathrm{CaCO}_{3}+\underbrace{2 \mathrm{CH}_{3}-\mathrm{CO}-\mathrm{CH}_{3}}_{\text {Aceton }}
$$

Das bei der ersten Destillation erhallene Rohaceton wird mit Wasser verdünnt, um die mit übergegangenen Teeröle abzuselıeiden, und sodann unter Zusatz von Alkalien orler alkalischen Erdem, behuls Bindung der flöchigen Säuren und Zerstörung der Aldehyde, dureh fraktionierte Destittation in kontinujertich wirkenden Relitizier-Kolonnen-Apparalen, ebenso wie der Holzgeisi, raffinier

Aus $100 \mathrm{~kg}$ essigsaurem fíalk werden durchsehnittlich $21-25 \mathrm{~kg}$ Rohaceton oder ca. $20 \mathrm{~kg}$ Reinacelon erhalten.

Das Aceton $\left(\mathrm{C}_{3} \mathrm{H}_{6} \mathrm{O}\right)$ ist eine eigentunlich riechende Flüssigkeit von spez. Gewicht 0,792 (bei $20^{\circ} \mathrm{C}$.), siedet luei $56,5^{\circ}$, mischl sich mil Wasser, Atkobol und Aether und kann durch Zusatz von Salzen aus diesen Lösungen wieder abgeschieden werden. Die Acelondämpfe sind brennbar und geben mit Luft ein explosibles Gemiseh.

Die Hauplverwendung findet das Aceton zur Erzeugung von rauchsehwachem Schießpulver, ferner als Lösungsmiłlel für Harzőle, in der Zelluloidindustrie ete. 
$\$ 38$. 3. De r Holz te e r. Die äußeren Eigenschaften des Tecres (Kionsistenz, Farbe, Geruch) sind je nach seiner Abstanmung verschieden.

Der Teer aus Nadelhölzern ist syrupartig, dunkelbraun und besitzt einen empyreumatischen Geruch, der Laubholzteer ist fett-oder talgartig, graubraun bis dunkelbraun und riecht widerlich brenzlich.

Die chemische Zusammensetzung des Teers ist sehr komplizicrt; es sind bis jetzt über 20 verschiedene Bestandteile darin nachgewiesen worden.

Der Holzteer wird zumeist ohne weitere Verarbeitung als Anstreichuittel für Holz, namentlich bei Schleusen-, Brüeken-, Uferschutzbauten, Zäunen und dgl. verwendet.

Unterwirft man den Teer einer fraklionierten Destillation, so können drei verschiedene Produkte daraus gewonnen werden, und zwar:

$$
\begin{aligned}
& 10-15 \% \text { leichles Oel vom spez. Gew. } 0,900-0,97 \% \\
& 15-20 \% \text { sehweres, }, ", 0,1,01 \pm-1,021 \\
& 40-50 \% \text { Pech. }
\end{aligned}
$$

Das auf 100 Felılende ist Wasser mit etwas Essigsãure. Das bei allmăhlich bis zu $160^{\circ} \mathrm{C}$. ansteigender Tenperatur übergehende leichte Oel (Jienöl) besteht vorwiegend aus kiohlenwassersloffen der Reihe $\mathrm{C}_{\mathbf{n}} \mathrm{H}_{2 n}-6$ ' (wie Benzol, Toluol, $\mathrm{Aylol}$, Cynol) und kann, naehdem'es von dem gleichzeitig mit ühergehenden essigsauren Wasser getrennt ist, aIs Beleuchtungsmaterial oder als Lösungsmiftel fūr Fetle, Harze oder dergleichen Verwendung, finden.

Das $\mathrm{z}$ wischen etwa $180-260^{\circ} \mathrm{C}$. übergehende scliwere Oel enthält lireosol nebst diversen Beimengungen. Es kann als lmprägnierungsmitlel für Holz, Erzeugung von Wagenschniere und dgl. benūtzt werden; an vorteilhaftesten ist es aber, das lireosot daraus zu gewinnen. $\mathrm{Zu}$ diesem Zwecke wird es nochmals einer Destillalion unterzogen, nit Wasser gewaschen und mit sodalōsung entsāuert. Die von Waschnittel abgezogenen Kreosotōle werden in einem Mischapparat mit sclnacher Natronlauge systematisch extrahiert, wodurch das Kreosot und auch alle übrigen Phenole in Lösung gelen, die sonstigen Beimengungen aber ungelost zurückbleiben. Durcl Einblasen von Danpt wird die alkalisehe Rohkreosotlösung von suspendierten Bestandteilen befreit und die so geliârte Lösung nun mit Mineralsãure (Selıefel- oder Salzsäure) zerlegt. Das Rohkreosot scheidet sich hierbei als ölige Schichle ab, welche durch Ablassen der Săure von dieser getrennt werden liann. Durch wiederholtes Lôsen dieses Rohkreosots in Natronlauge, Zerselzung der Lösung nit Säure und Destillieren erhält man dann das Reinkreosot.

Das $\mathrm{k}$ reosot ist kein chemisches Individum, sondern ein Gemenge von komplizierter Zusammensetzung. Es bestehl aus:

$$
\begin{aligned}
& \text { Phenol } \mathrm{C}_{6} \mathrm{H}_{5}(\mathrm{OH}) \text {. } \\
& \text { Jireosol } \mathrm{C}_{6} \mathrm{H}_{3}\left(\mathrm{CH}_{3}\right)\left(\mathrm{OCH}_{3}\right)_{-}(\mathrm{OH}) \text {. } \\
& \text { Parakresol } \mathrm{C}_{6} \mathrm{H}_{4}\left(\mathrm{CH}_{3}\right)^{5}(\mathrm{OH}) \text {. } \\
& \text { Phlorol } \mathrm{C}_{6} \mathrm{H}_{3}\left(\mathrm{CH}_{3}\right)\left(\mathrm{CH}_{3}\right)(\mathrm{OH}) \text {. } \\
& \text { Guajacol } \mathrm{C}_{6} \mathrm{H}_{4}\left(\mathrm{OCH}_{3}\right)(\mathrm{OH}) \text {. }
\end{aligned}
$$

Ferner aus den Dimethyläthern: des Pyrogallols, des Methylpyrogallols und des Propylpyrogallols.

Das reine kreosot ist eine farblose, an Lichte jedoch allmăhlich gelb werdende, stark lichtbrechende Flüssigkeit von öliger lionsistenz, rauchartigem Geruch und intensiv brennendem Geschmacke. Auf die Haut gebracht wirkt es ätzend. Es zeigt neulrale Reaktion. Das spezifische Gewicht schmankt zwischen 1,030-1,080; der Siedepunkt liegl zwischen 205 und $220^{\circ} \mathrm{C}$. Bei - $20^{\circ}$ ist es noeh flussig. In alkalischen Laugen, in Alkohol, Aether, Schwefelkohlenstoff ist es leicht, in Wasser schwer löslich.

Ler Destillationsrückstand, ,das sog. P e $\mathrm{c} \mathrm{l}^{\text {ts }}$ erstarrt bein Erlialten zu einer schwarzen, glănzenden Masse von muscheligen Eruch. Es besteht der Hauptnenge nach aus Paraffin $\mathrm{C}_{n} \mathrm{H}_{2 n+2}$ und ähnliehen Verbindungen und findet als. Scliffpecl, als Dichtungsnaterial für Holzstöckelpflaster etc. Verwendung.

Besondere Erwähnung verdient noch der Teer von liarzreichen Nadelhölzern und der Birkenrindenteer. Der erstere, unter den Namen: sclwediseher, Stockholmer, russischer oder finnländischer Teer ein gesuchtes Handelsprodukt, unterscheidet sich in seinem Wert vom Laubholzteer durch seinen Gehalt an Produliten der trockenen Destillation des Harzes, der mitunter kein geringer ist. Sclon bei der Destillation 
des Holzes wird man daher, wie bereits angedeutet, Vorsorge treffen, um diese Produkte mögliehst getrennt vom Teer auffangen zu können und ein Destillat zu erhalten, welches unter der Bezeichnung ,Rohkienöl" mit als Rohmaterial für die Herstellung von Harzdestillations-Produkten dient. Dort wo dies nicht möglich ist, wird der Teer die Hauptmenge der Harzbestandteile enthalten und dieser somit zur Gewinnung des Rohkienöles herangezogen werden.

Durch Destillation, Reinigung auf chemischem Wege und sorgfältige Fraktionierung gelingt es, aus diesem Rohkienöl Raffinate herzustellen, welche den eigentlichen Harzprodukten (hauptsächlich Terpentinöl) zwar nicht völlig gleichkommen, aber sehr wohl als Surrogate für diese Verwendung finden können.

Der B ir k en rindente e r, welcher namentlich in RuBland erzeugt wird, ist dünnflüssig, ölartig, graublau bis schwarzblau, opalisierend, von intensivem, an Steinöl erinnernden Geruch, leicht flüchtig und spezifisch leichter als Wasser. Die Hauptbestandteile sind Toluol $\mathrm{C}_{7} \mathrm{H}_{8}$ (bis zu $50_{0}^{\circ}$ ), Benzol $\mathrm{C}_{6} \mathrm{H}_{6}$ und das sogenannte Eupion (d. i. ein Gemisch von mehreren, dem Benzol homologen liohlenwasserstoffen). Birkenrindenteer dient zur Bereitung des Juchtenleders und zur Darstellung der vorgenannten Produkte, welehe in der Industrie nehrfache Verwendung finden.

A usbeute an Holzkohle, Holzessig, Holzgeist und Teer.

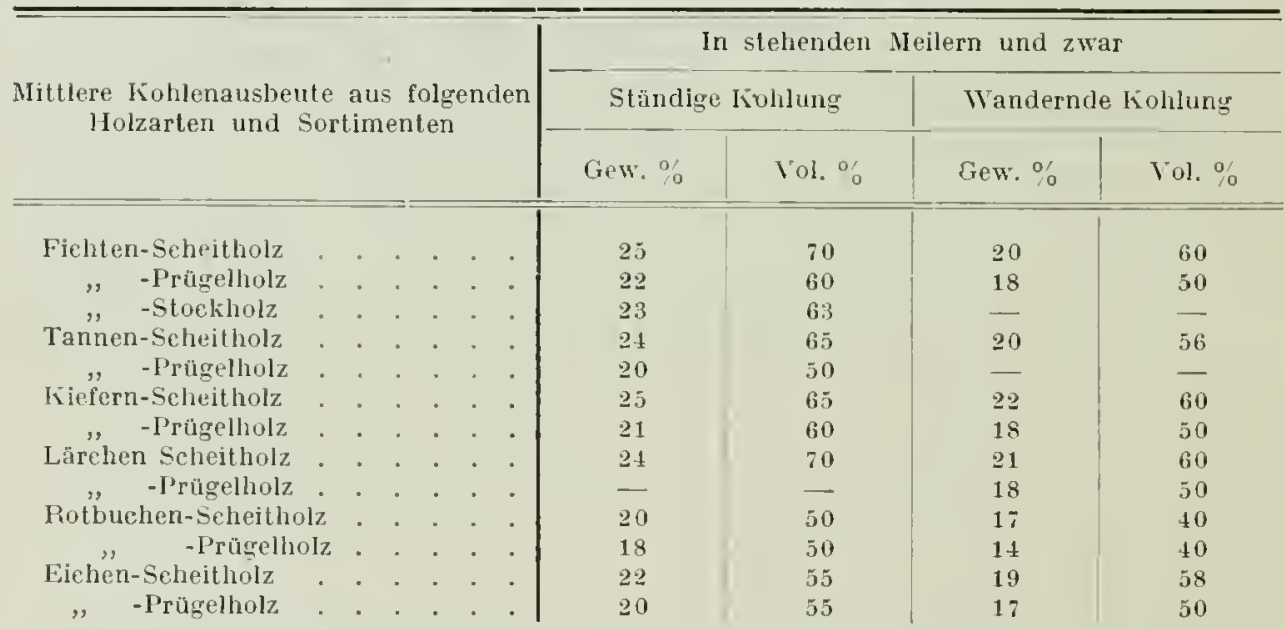

Diese Zahlen sind nur als beiläufige Werte aufzufassen, da die Ausbeute von so vielen Momenten beeinflußt wird, daß sich allgemein gültige Nlittel-oder Grenzwerte gar nieht angeben lassen. Ganz besonders gilt dies von der volumprozentigen Ausbente, wo auch noch die Unsicherheit des Messens dazu kommt. ln großen Durehschnitte werden pro Raummeter vom

we ic ln e $n$ Holze 5 bis 8 im Nittel $6 \frac{1 / 2}{2}$ Hektoliter, li arten , $312,5 \%, \quad, 4 \%$,

Holzkohle gewonnen.

Für die Ausbeute an Essig resp. Graukalk kann nur die Verkohlung in Retorten und Oefen maßgebend sein. Je langsaner die Verkohhung vor sich geht, desto höher ist die Ausbeute an Gesamtrestillat. Entrindetes Holz gibt mehr Säure als solches mit der Rinde; desgleichen gesundes Holz mehr als anbrüchiges; Stammbolz mehr als Astholz und Laubholz mehr als Nadelholz. Von großem Einfhisse ist der Wasserstoffgehalt des Holzes. 
Im fabriksmäßigen Betriebe, bei guter Einrichtung werden aus $100 \mathrm{~kg}$ Buchenlolz (entrindet) erhalten :

$$
\begin{array}{cl}
24-2.5 \mathrm{~kg} & \text { IIolzkohlc, } \\
7-8, " & \text { Graukall, } \\
1-1 / 2, & \text { Ilolzgeist, } \\
7-8, & \text { Teer. }
\end{array}
$$

Diese Zahlen beziehen sich auf Holztrockensubstanz.

Bei Nadellıolz ist die Ausbeute an Grankalk um $2-3 \mathrm{~kg}$ und an Holzgeist um etwa $1 / 2 \mathrm{~kg}$ geringer, jene an Teer hingegen höher. Bei harzreichen Hölzern steigt die Teerausbeute auf $12-16 \mathrm{~kg}$. In der Regel ist aber für den Teer keine entsprechende Verwertung zu finden, so daß er in den Destillationsanstalten verheizt werden Inuß.

Für die Rentabilität des Unternelmens ist der 'Trockenheitsgrad des zur' Verkohlung gelangenden Holzes sehr maßgebend, weil davon der Brennmaterialaufwand abhängt. Man läßt daher das Holz durch längeres Ablagern mögliclıst gut lufttrocken werden oder wendet künstliche Trocknung an durch die von den Retortenheizungen abziehenden Essengase, bei gleichzeitig starker Ventilation in den Trockenräumen.

$\S 39$. Verkohlung von $\mathrm{Hol}$ zab \{äll en. Seit Jahıen schon werden Anstrengungen gemacht, die Holzabfälle von Sägewerken und ähnlichen Holzverarbeitungsstätten, welche dort, wo man keine Gelegenheit hat, sie zu verfeuern, nicht nur ganz wertlos sind, sondern auch noch Kalamitäten bei der Wegschaffung verursachen, zur Verkohlung zu verwenden. Bei der gewöhnlichen Art der Verkohlung resultiert aber nur Kohlenklein oder Pulver, welches erst brikettiert werden muß, um es in eine gebrauchsähige Form zu bringen. Da aber das Holzkohlenpulver, selbst bei starker Pressung, keine genügende Bindigkeit hat, so muß ein Bindemittel (Wasserglas, Teer, Gallerte von Caraghenınoos etc.) zugesetzt werden, was die Fabrikation verteuert. Teer liätte man am billigsten zur Verfügung; solche Briketts müssen aber dann nocl nachträglich wieder bis zur vollständigen Entgasung erhitzt werden, was nicht mehr rentiert. Da ferner die Hauptmenge der Sägewerkisabfälle solche von Narlellı̈lzern sind, welche relativ geringe Ausbeuten an Graukalk und Holzgeist liefern, so gestaltet sich auch mit Rücksicht darauf die Verliohlung derselben nicht rentabel und erklärt sich somit die Erscheinung, daß bis zum heutigen Tage diese Art der Verwertung von Holzabfällen noch nicht im großen eingeführt ist.

Ganz abgesehen von der geringeren Rentabilität der Verkohlung von Abfällen gegenüber der von Holz in jeder anderen Form überhaupt, kommt als weiterer Uebelstand bei dieser Nutzungsart noch hinzu, daß es der Technik trotz der eifrigsten Anstrengungen bis nun nicht gelungen ist, einen für diese Zwecke einwandfrei funktionierenden Apparat zu honstruieren. Die dichte Lagerung des Sägemehls in den Verkohlungsapparaten gewöhnlicher Art verhindert einen freien Durchgang der Gase und Däıpfe, welche die Wärmeübertragung vermitteln sollen, und dementsprechend auch den Abzug der Destillationsprodukte, als deren Folgen sich ergeben: unregelmäßiger Betrieb und ungleichmäßige Produkte. Auch der holıe Vassergehalt der Sägeabfälle bereitet Schwierigkeiten.

Zahlreiche Patente auf Erfindungen, welche diese Schwierigkeiten beheben sollten, wurden genommen, keines aber hat sich über das Versuchsstadium hinaus bewährt.

lurz erwähnt seien daher hier nur die Versuche mit: Retorten mit Rührvorrichtungen, rotierenden Retorten mit oder ohne Rührwerken, Brikettierung der Sägespäne, unter den verschiedensten organischen und anorganischen Zusätzen, 
Verkohlung des Materials in dünner Schicht, auf Horden oder während des langsamen Durchrieselns durch den Verkokungsraum u. a. m.

\section{Das Holz als Heizmaterial.}

$\S 40$. A llgemeines über den $\mathrm{H}$ eizwert der Brennmateri a li en. Der IVert eines Heizstoffes ist abhängig von seiner chemischen Zusammensetzung. Die gewöhnlichen festen Brennstoffe, wie IIolz, Torf, Braunkoble und Steinkohle bestehen aus liohlenstoff, Wasserstoff und Sauerstoff, nebst geringen Nengen von Stickstoff; ferner enthalten alle hygroskopisches Wasser und Mineralbestandteile. In den fossilen Brennstoffen ist auch Schwefel, und zwar vorwiegend als Schwefelkies vorhanden.

Alle fossilen Brennsloffe sind insoferne gleichen Ursprungs, als die Holzfaser das Malerial hierzu geliefert hal. Der ZersetzungsprozeB, welcher dabei statlgefunden hat, wird in seinen ersteren Stadien als Vermoderung und in den späleren Perioden als liarbonisierung bezeichnet. Die gesamle organische Substanz erfährt dabei eine Abnahme, jedoclı schwindet der Sauerstoff und Wassersloff in höherem Maße als der Fohlenstoff. Die Folge davon ist, daß mit zunehmendem Alter, resp. fortschreitender Zersetzung, die Subslanz relativ immer kohlenstoffreicher wird, und zwar läßt sich mit Zugrundelegung der Mittelzahlen folgende Reihe aufstellen:

$\begin{array}{llll} & \text { C } & \text { H } & \text { O } \\ \text { Holzfasern } & 50 & 6,3 & 43,7 \\ \text { Jüngerer Torf (Fasertorf) } & 54 & 6 & 40 \\ \text { Aellerer Torf (Specktorf) } & 60 & 6 & 34 \\ \text { Jüngste Braunkohle (Lignit) } & 62 & 6 & 32 \\ \text { Gemeine Braunkohle } & 70 & 5,5 & 24,5 \\ \text { Felte Steinkohle } & 80 & 5 & \mathbf{1 5} \\ \text { Hagere Sleinkohle } & 88 & 4 & 8 \\ \text { Anthrazit } & 95 & 2 & 3\end{array}$

Dieser Prozeß ist auch in Anthrazil noch niclıt vollig abgeschlossen; das Endprodukt ist reiner liohlenstoff "Graphit".

Obige Zahlenreihe bezieht sich auf wasser- und aschenfreie Substanz; die geringe Menge an Stickstoff ist auBer Achl gelassen. Der Wassergehalt ist im luftlrockenen Torfe und in der Braunkohle in der Regel ein hoher, $10-30 \%$, in der Steinkohle dagegen gering, meist $2-8 \%$. Der Aschengehalt ist in allen fossilen Brennstoffen großen Schwankungen unlerworfen; in den besten Ouanlitäten beträgl er $1-5$, in den milleren $5-10$ und in den schlechten $55 \%$ und darüber.

Die Wärmemenge, welche ein Heizstoff zu entwickeln vermag, kann entweder aus seiner chemischen Zusammensetzung berechnet oder auf kalorimetrischem Wege bestimmt werden.

Für die Berechnung des Heizwertes aus der E $\mathrm{l}$ e $m$ e $\mathrm{n} \mathrm{t}$ a $\mathrm{r}-\mathrm{Z}$ u s a $\mathrm{m} \mathrm{m}$ e nsetzung dienen folgende Zahlen:

Bei der Verbrennung

von $1 \mathrm{~kg}$ Kohlenstoff zu liohlensäure werden rund 8100 Kalorien ${ }^{1}$ )

" 1 "Wasser'stoff "Wasserdampf " ", 29000 "

"1 "Schwefel "Schwefeldioxyd " " 2500 ,

produziert.

Alle anderen Bestandteile sind wärmekonsumierend und setzen dahor den Wert des Brennstoffes herab; namentlich ist dies der Fall beim Wasser. Um $1 \mathrm{~kg}$ Wasser von gewöhnlicher Temperatur in Dampf von $100^{\circ} \mathrm{C}$. zu verwandehn, sind rund 600 Kalorien erforderlich.

Nit Zugrundelegung dieser Zahlen ergibt sich der Heizwert (p) aus der Dulongschen Formel:

1) Unter Kalorie oder Wärmeeinheit ist jene Wärmemenge verstanden, welche notwendig ist, um $1 \mathrm{~kg}$ Wasser um $1^{0}$ C. zu erwärmen. 


$$
\mathrm{P}=\frac{8100 \mathrm{C}+29000\left(\mathrm{H}-\frac{\mathrm{O}}{\mathrm{S}}\right)+2500 \mathrm{~S}-600 \mathrm{WV}}{100}
$$

worin C, H, O, S und IV Prozente Kohlenstoff, Wasserstoff, Sauerstoff, Sehwefel und Wasser bedeuten. Dureh 100 muß dividiert werden, weil hier Prozentzahlen in Rechnung gestellt sind, der Heizwert sich aber auf die Gewichtseinheit $(1 \mathrm{~kg})$ des Brennstoffes bezielit.

Tom Wasserstoff ist nur jener Anteil wärnegebend, welcher verbleibt, wenn aller Sauerstoff in dem Gewichtsverhältnisse $H: O=1: 8$ gebunden erscheint.

Der Ausdruck $\left(\mathrm{H}-\begin{array}{l}\mathrm{O} \\ \mathrm{S}\end{array}\right)$ gibt somit die Nenge des nach der Bindung noch übrig bleibenden Wasserstoffes, weleher als ,disponibel" angesprochen wird.

Hăte eine Steinkolle z. B. folgende prozentische Zusammensetzung:

$70,06 \mathrm{C}, 4,3211 \quad 10,58 \mathrm{O}, 0,93 \mathrm{~N}, 8,42$ hygrosliopisches Wasser und 5,69 Asche (darin $0,43 \mathrm{~S}$ als Schwefelkies angenommen), so berechnet sich der Heizwert nach obiger Formel mit $-\frac{8100 \times 70,06+29000 \times\left(4,32-\frac{10,58}{8}\right)+2500 \times 0,43-600 \times 8,42}{100}=6595$ Kalorien.

Bei der halorimetrischen Heizwertbestimmung wird eine kleine Menge des Brennstoffes (gewölnlieh nur $1 \mathrm{~g}$ ), welche einer unter besonderen Vorsichtsmaßregeln hergestellten Durchschnittsprobe entspricht, in einem eigens hierfür konstruierten Apparat (Kalorimeter) in komprimiertem Sauerstoffgas vollkommen verbrannt. Die dabei entwickelte Wärme wird auf ein gewogenes Wasserquantum übertragen und die Temperaturzunahme desselben bis auf Tausendstel Grade genau ermittelt. Alle Wärmeverluste sind dabei sorgfältig vermieden. Bei den älteren fossilen Brennstoffen (Steinliohle und Braunkohle) stimmen die auf kalorimetrischem Werte mit der dureh Rechnung nach der Dulongschen Formel gefundenen recht gut überein und sind selten Differenzen von melı als $3 \%$ des Heizwertes zu konstatieren. Beim Holze und auch bei jüngerem Torfe hingegen ist dies nicht der Fall und sind die kalorimetrisch bestimmten Heizwerte regelmäBig höher als die berechneten, wie weiter unten erörtert ist.

Dieser theoretisch ermiltelte Heizwert ist in der Praxis nienals erreichbar, weil bei einer jeden Feuerungsanlage, mag sie beschaffen sein wie immer, gewisse Wärmeverluste unvermeidlich sind. Dieselben sind begründet:

1. in dem Entweichen der Verbrennungsprodukte init hoher Temperatur (sogen. Schornsteinverlust);

2. in der unvollkommenen Verbrennung (Entweichen unausgebrannter Gase und Dãıpfe, Rauch- und Rußbildung, unverbrannte Teile in der Asche und Schlacke);

3. Wärmeabgabe nach auBen (Leitungs- und Strahlungsverlust).

Bei den besten Feuerungsanlagen können bis zu $80 \%$ der Wärme ausgenützt werden; in der Regel ist der Nutzeflekt aber viel geringer; bei mittleren Anlagen beträgt er zwisehen 60 und 70 und bei schlecliten sinkt er nicht selten bis unter $50 \%$ luerab.

Die auf die Gewichtseinheit (1 kg) bezogene Wärmemenge wird der absolute und die auf die Volumeinheit (z. B. 1 Rm.) bezogene der spezifische Wärmeeffelit genannt. Neben der Menge kommt unter Umstānden auch die Intensität der Wärme (Verbrennungstemperatur) in Betracht. Diese Zahl wird als pyrometrischer Wärmeeffekt bezeichnet. Unter Verdampfungswert (1) versteht man jene Zahl, welche angibt, wie viele Kilogramm Wasser durch $1 \mathrm{~kg}$ des Brennstoffes verdampft werden können. Die Gesamtwärme G), welehe zur Verdampfung des Wassers beansprucht wird, ergibt sich aus der Formel:

$$
\mathrm{G}=606,5+0,305 \mathrm{~T}-\mathrm{t},
$$

worin $\mathrm{T}$ dic Temperatur des Dampfes und $\mathrm{t}$ die Anfangstemperatur des Wassers bedeutet. Wäre $T=100$ und $t=0$, so ist $G=637$. Diese Zahl wird gewöhnlich auf 630 abgerundet.

Daher $V=\frac{p}{630}$, worin $p$ den absoluten Wärmeeffekt des Brennstoffes bedeutet. 
$\$ 41.11$ e izwert des Holzes im Vergleiche mit de $\mathbf{n}$ foss iI en Brennst of fen. Nach der durchschnittlichen Elementar-Zusammensetzung der gewölnlichen Holzarten berechnet sich der Heizwert der Holztrockensubstanz mit

$$
\frac{8100 \times 49.6+29000 \times\left(6.1-\frac{43.8}{8}\right)}{100}=4200
$$

Kalorien. In Wirklichkeit ist derselbe aber höher und wurde durch kalorimetrische Untersuchungen mit rund 4500 gefunden. Da die Elementar-Zusammensetzung der gewöhnlichen Jolzarten nur in verhältnismäßig engen Grenzen schwankt, so kann diese Zahl als allgemein gültiger Mittelwert angenommen werden. Dagegen ist der Wassergehalt großen Schwankungen unterworfen (pag. 557). Um den Heizwert zu bestimmen, muß daher der Wassergehalt (IV) des Holzes bekannt sein und genügt dam für praktische Zwecke die Formel

$$
\frac{4500 \times(100-W)-600 \mathrm{~W}}{100}
$$

Wäre der Wassergehalt des lufttroekenen Holzes z. B. $12 \%$, so beträgt der Heizwert

$$
\frac{4500 \times(100-12)-600 \times 12}{100}=3888
$$

Kalorien. Diese Zahl bezieht sich auf $1 \mathrm{~kg}$. Das Holz wird aber nicht nach Gewieht, sondern nach Volumen (Raummeter) verkauft. Eine einfache Relation zwisehen Gewicht und Volumen des in Stößen aufgeschichteten Holzes besteht nicht. Das Gewicht eines Raummeters sehwankt je nach der Holzart, dem Holzsortimente, nach der Art des Aufschichtens und dem Trockenheitsgrade des Holzes in weiten Grenzen. Wäre z. B. der Derbgehalt eines Raummeters Fichtenseheitholz $70 \%$ und das Gewicht eines Festmeters $470 \mathrm{~kg}$, so wiegt ein Raummeter $329 \mathrm{~kg}$.

Beträgt der Wassergehalt $15 \%$, so stellt sich der Heizwert des Raummeters auf

$$
\frac{4500 \times(100-15)-600 \times 15}{100} 329=1,228.815
$$

Kalorien. Sollte der Heizwert dieses Holzes in Vergleich gebracht werden mit einer Braunkohle von 3750 kalorien, so ergibt sich, daß I Raummeter $\frac{1228.815}{3750}=327,7 \mathrm{~kg}$ Braunkohle entspricht.

Das Holz kann wohl nur in seltenen Fällen als Heizmaterial mit der Mineralkohle in Konkurrenz treten. Es ist dies nur dort möglich, wo das Holz sehr billig und die Mineralkohle teuer zu stehen kommt oder gar nicht zu beschaffen ist. Auch in solcher lndustriezweigen, wo frïher nur ausschließlieh Holz verwendet wurde, und die Mineralkohlen ihres Gehaltes an Asche, die als Flugasche zum Teile fortgeführt wird, ihrer leichten Rauch- und Rußentwicklung und ihres Schwefelgehaltes wegen nicht unmittelbar zu gebrauchen sind, wie z. B. in der Glas- und Porzellanfabrikation, ist dureh die Einführung der Gasfeuerung das Holz, wenn auch nicht überall, so doch in rlen meisten Fällen verdrängt worden. Am liäufigsten wird das Holz noch in Haushaltungen als Brennstoff benützt, wo es der großen Reinlichlieit, der leichten Entzündbarkeit und der rauchlosen Verbrennung wegen, trotz des höheren Preises, der Mineralkohle vorzuzichen ist. Für industrielle Zwecke kommen zumeist nur die Holzabfälle in Verwendung, welehe mit Rü̈ksicht auf ihre Besehaffenheit auf besonder's konstruierten Feuerungsanlagen (Treppenrosten) verbrannt werden. 
Holz gibt eine lange, nicht rußende Flamme. Der pyrometrische Effekt ist gering. Der Harzgehalt der Nadelhölzer erhöht die leichte Entzündbarkeit unr Langflammigkeit.

Das Flößen übt auf den Heizwert keinen Einfluß aus, vorausgesetzt, daß das Holz wieder lufttrocken geworden ist. Im Wasser liegend nimmt das Holz zwar sehr viel Feuchtigkeit auf (pag. 557 ), es werden dadurch jedoch nur die Saftbestandteile und auch diese nur teilweise ausgelaugt, während das Holzskelett, welches den Heizwert hauptsächlich bedingt, unverändert bleibt.

Zum beilăufigen Vergleiche des Heizwertes von IJolz und den fossilen Brennmaterialien können folgende Zahlen dienen ${ }^{1}$ ):

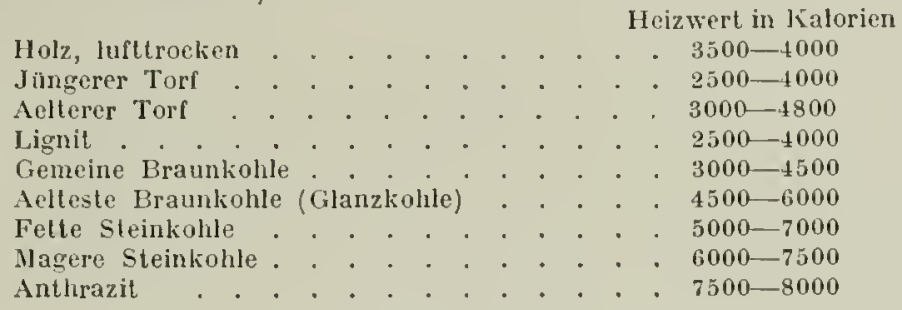

\section{Die Pottasche-Erzengung.}

\$ 42. Bis vor etwa 40 Jahren war die Asche des Holzes und einiger anderer Pflanzen das alleinige Material für die Herstellung der Pottasche und aller übrigen Kalisalze. Gegenwärtig wird Pottasche aus allen drei Naturreichen gewonnen, und zwar:

1. Aus dem Mineralreiche, wo die Staßfurter Abraumsalze, das Kialiumsulfat und Chlorid, das Material hierzu abgeben.

2. Aus dem Pflanzenreiche, die Mclasseasche (als Einäscherungsrüclistand von der Schlämpe der Melassespiritusbrennereien) und die Holzasche.

3. Aus dem Tierreiche, die Schafschweißasche aus der Schafwollwäscherei.

Die größte Henge der Pottasche wird derzeit aus den Staßfurter Abraumsalzen und aus der Melasseasche gewonnen, während die anderen Materialien eine mehr untergeordnete Rolle spielen.

Das sogenannte Aschenbrennen ist zwar die geringste, in manchen Gegenden aber doch nur einzig mögliche Art der Verwertung des Holzes. Im größeren Maßstabe wird Holzpottasche in Ungarn, Siebenbürgen, Galizien und Bukowina, Rul3land, auf Iianada und in den Vereinigten Staaten von Nordamerika erzeugt.

Die Darstellung der Pottasche aus Holz ist sehr einfach und unfaßt folgende Prozeduren :

1. Das Verasehen des Holzes.

2. Das Auslaugen der Asche.

3. Das Versieden der Lauge.

4. Das Kalzinieren der Rohpottasche.

Zum Verasehen werden vorzugsweise moderige, gipfeldürre, kernschälige oder uberhaupt kranke abständige Stämme benutzt. In manchen Lokalitäten muß wohl auch gesundes Holz mit verwendet werden, wenn eine bessere Verwertung nicht zu finden ist. Das Aschenirennen wird in verschiedener Weise ausgefüht. Auf der Herrsehaft Munkács werden nur hohle, moderig gewordene Buchenstämme verascht. Der noch stehende Stamm wird angehauen und in der Oeffnung ein Feuer angemacht. Der lloder und die innere Holzpartie brennen allmählich aus, wobei sich die Asche am Fuße, innerhalb des Stammes, ansammelt.

1) Ausführlicheres hierüber F. Schwackhöfer, „Heizwert der liohlen“. 11]. Auflage.

Wien, Gerold 1912. 
Dieselbe wird von Zeit zu Zeit ausgenommen und das Feuer, wenn nötig, erneuert. Auf solche Art wird die Asche sehr rein erhalten und ist gegen Wind und Regen gesehützt.

In den griech-orient. Religionsfondforsten der Bukowina verascht man nur gefälltes Holz. Zu diesem Behufe wird der liegende Stamm entweder der ganzen Länge nach oder auch nur in gewissen Abständen mit einer $12-15 \mathrm{~cm}$ tiefen und $30 \mathrm{~cm}$ breiten lierbe versehen, welche als Feuerherd dient. Bei einem morschen Stamme genügt eine Feuerstelle am Stockende; gesunde Stämme mussen jedoch melirere Feuerstellen (gewönlich von 6 zu $6 \mathrm{~m}$ Entfernung) erhalten. Der Stamm brennt niemals vollständig aus, sondern es bleiben mindestens Splint und Rinde, nicht sellen aber aucl größere, gesunde Holzpartien zurück. Dieser Rückstand wird zerkleinerl, zu einem St $O \beta$ aufgeschichtet und verbrannt. In gleicher Weise werden auch die Aeste aufgearbeitet. Die Asche wird in Butten gesammelt und in sogen. , $\mathrm{K} \mathrm{o} l \mathrm{i}$ b a" bis zur Abfuhr in die l'ottaschehutle authewahrt. Die lioliba sind cinfache Erdgruben, welche mit Brellerschwarten ausgelegt und eingedeckt werden. Ringsun wird ein Graben gezogen, um das Tagwasser abzuhalten.

Ueber die Aschenmenge und den Káligelıalt der Holzasche gibt die auf pag. 560 angeführfe Tabelle Aufschluß. Dabei ist jedoclı zu bemerken, daß sich diese Zahlen auf Reinasehe beziełien. Die Rohasche enthält aher auch noch kolılige Teile, Kohlensäure und erdige Verunreinigungen. 100 Teile Rohasche entsprechen durchschnittich 75 Teilen Reinasche. Es sind daher alle in dieser Tabelle enthaltenen Zahlen bei der L'mrechnung auf Rolıasche mit dem Faktor 0, 75 zu multiplizieren.

Dic erste Manipulation in der Hütte ist das A u s l a u g e n. Die Auslauggefäße (Aescher genannt) sind nach unten verjüngte Bottiche, welehe einen Doppelboden besitzen. Der untere Boden ist voll, der obere gelocht. Im Zwischenraum ist eine Holzpippe eingeselzt zum Ablassen der Lauge. Auf den Siebboden kommt eine Lage Stroh oder Reisig und darauf die mit Wasser benetzte Holzasche, welche möglichst dicht eingelreten wird. Ein Aescher faßt bis zu $2 / 3$ seiner Höle 120-130 kg Rohasche, welche mit 150-200 Liter Wasser überrossen wird. Im das Wasser gleichmäßig über die ganze Oberfläche zu verteilen, wird die Asche mit einer Schichte Reisig überdeckt. Das Wasser durchdringt die Asche und nimmt die löslichen Salze auf. Nach $4-5$ Stunden wird die erste Lauge abgelassen, neuerlich Wasser aufgegossen und so weiler fortgefahlen, bis die ablaufende Flüsigkeit nur mehr sehr schwach alkalisch reagiert und am Aräometer nahezu Null zeigt. Je nach der Beschaffenheit der Pohasche sind $4-5$ Aufgüsse erforderlich. Die erste Lauge ist die lionzentriertesle, die späler nachkommenden werden immer schwächer und die letzle ist schon so verdünt, daß sie das Eindampfen kaum verlohnt. Viel zweckmäBiger ist die systematische Auslaugung nach Art des Batteriebetriebes. Fünf Aescher werden terrassenförmig übereinander gestellt und mit Asche beschiekt Auf den ersten oberslen \escher wird Wasser gegossen. Naeh 3-4 Stunden wird die Lauge auf den zweiten Aescher abgelassen und der erste neuerlich mit Wasser gefüllt. Nach weiteren 3-4 Stunden wird die Lauge von 2 auf 3 , von 1 auf 2 abgelassen und 1 wieder mit Wasser gefüllt. In dieser Weise wird fortgefahren, bis die konzentrierte Lauge bei 5 zum Abzug gelangt. Der Inhall des Aeschers 1 hat inzwischen 5 Wasseraufgüsse erhalten, ist bereits vollständig ausgelaugt und wird entleert. Der Wasserzulauf wird jetzt auf 2 gestell und 1 mit frischer Rohasche beschickt. Die Lauge geht von 2 auf 3 , von 3 auf 4 , von 4 auf 5 , fließt von 5 in ein Reservoir, wird von hier auf 1 gepumpt und nach 3-4stündiger Einwirkung als konzentrierte Lauge von 1 abgezogen. Der weitere Verlauf der Arbeit ergibt sich aus den Gesaglen von selbst.

Mit warmem Wasser gelingt die Auslaugung sehneller als mit kaltem. Im Winter muB das Wasser unter allen Unständen angewärmt werden.

Der nach vollständigem Auslaugen in den Aeschem verbleibende Rückstand (Aescherich genannt) besteht vorwiegend aus Calciumkarbonat und Phospliat (ca. $8 \% \mathbf{P}_{2} \mathrm{O}_{5}$ in der Trockensubstanz) und kann als Dügemittel verwendet werden. Wenn man auf eine weitere Vurfrach\{ung reftekticrt, so müssen diese Rùckstände an der Luft getrocknet werden, da dieselben sehr viel $(50-60 \%)$ Wasser enthalten.

Zum A b d a m p e n oder Versiede n der Lauge sind gewöhnlich zwei Arten von eisernen Pfanuen vorhanden; die Vorwärmer und die eigentlichen Verdampfpfannen. Erstere sind flach und in der Regel auf dem Kalzinierofen angebracht. Letztere sind entweder ebenfalls flach oder schalenförmig vertieft und hesitzen eine eigene Feuerung. Die frische Lauge liommtizuerst in die Vorwärmer und fließt von hier aus in einem dünnen Strahl auf die Verdampfpiannen.

Das Eindampfen wird unter Zufluß von vorgewārmter Lange so lange fortgesetzt, bis eine herausgenommene Probe beim Erkalten erstarrt. Ist dieser Punkt erreicht, so wird der weitere Zufluß der Lauge abgestellt und das Feuer unterbrochen. Beim Ablíhlen scheiden sieh an den Wänden der Pfanne Salzkrusten ab, welche allmählich stärker werden, bis endlich die Masse erstarrt. Diese Krusten werden mit Hammer und Mleisel losgeschlagen. Das so er-

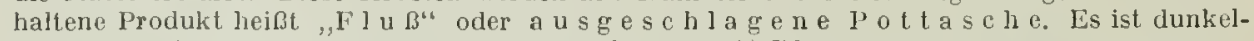
graubraun bis grauschwarz gefärbt und enthält $10-15 \%$ Wasser.

Diese Methode des Versiedens hat den Nachteil, daß die Pfannen durch das Losmeißeln der Salzlirusten sehr stark in Anspruch genommen werden und oftmaligen Reparaturen unterliegen. 
Zwecknảßiger wird in der Treise rorgegangen, daR man, sol,alu die Ausselieidung beginnt, das Feuer mïBigt und die Lauge ununterbrochen rührt. Narh vollstäsdigem Abdampfen linterbleibl in der Pfanne die polı Pottascle als lockere, krümliche Masse, welche nach denı Abliuhlen der Pfanne ausguschaufell wirl Dieses J'rodukt heißt, g e r a h r t e l'o $\mathrm{t} t$ a s c he", ist schwarzbran gefül, und enthalt noch 6-10\% Wasser. For das erstere Verfahren sind sehalenformige und für das letztere flache Pfannen nolwendig.

Die lelzle Operation ist das $\mathrm{K}$ a 1 \% i n i e r e n. Es brzweckit dic vollstândige Entwăsserung und las Weißbrennen der Poltasche. Die Vorrichtung hierfü ist ein Flamruofen mit einem oder zwei Feuerherden. Der lialzinierram ist aus fenerfestem Material hergestelit und überwölbt. Das Gewölbe darf von der Sohle, worauf die Potlasche zu liegen kommt, nicht melir als $3 /$, n abstehen, damit die J'lamme niedergehallen wird und die Pottasclie beslreicht.

Zuerst wird der Ofen so lange goheizl, bis der lialzinierraum glühend geworden ist, sodann die rohe Pottasche cingeworf'n und anf der twas vertieften Solle ausgehreitet. Jeim Iialzinieren muß die Jottasche mit einer eisernen lirücke oftmals durchgerülrt und gewendet werden, danit immer neue Teile an dic Oberiläche gelangen. Dio Trmperatur darf anfangs nur mäßig sein und wird allmählich bis zur Iıllen Rolglut gesteigert. Ein Schmelzen der Pottasche darf dabei nicht eintreten, weil sonst die kohligen Teile eingesehlossen und an der Verbrennung gehindert werden. Beim Schmelzen wird auch die Herdsohle stark angegriffen"und die Pottasche kieselsäurehaltig. Nach Verlauf von 2-3 Stunden ist die Mlasse weiß gebrannt. Um sich von der Gahıe zu überzeugen, werden einige Stïcke ausgezogen und nach dem Erkalten zersehlagen. Erscheinen diuselben bis in das Innere weiß, so ist genügend geglüht. Die Pottasche wird nun ansgezogen, erkalten gelassen und sodann ohne Verzug in Fässern eingestampft. Bleibt diesclbe lange an der Luft Jiegen, so zieht sie Feuchtigkeit an, backl zu Klumpen zusammen und wird endlich ganz zerfließlich. Beim Kalzinieren ergibt sich je nach der Qualitat der Rohpoltasche ein Gewichtsverlust von 10-20 Prozent.

Die kalzinierte Pottasclıe ist eine krümelig-blasige, zusammengesinterte Masse. Die Farbe ist selten rein weiß, sondern besitzt meist einen Stich ins graue (von sehr feinen Kohleteilchen). Zuweilen crscheint sie rötlich (durch Eisenoxyd), bläulich oder grünlich (durch Kaliummanganat). Sie schmeckt laugenhaft, ist stark hygroskopisch, in Wasser leicht löslich, in Alkohol hingegen unlöslich. Kalzinierte wasserfreie Pottasche enthält:

$$
\begin{gathered}
80-85 \% \text { Kaliumkarbonat } \mathrm{K}_{2} \mathrm{CO}_{3} \\
6-9 \% \text { Natriumkarbonat } \mathrm{Na}_{2} \mathrm{CO}_{3} \\
6-9 \% \text { Kaliumsulfat } \mathrm{K}_{2} \mathrm{SO}_{4} \\
0,5-4 \% \text { Kaliumchlorid } \mathrm{KCl}
\end{gathered}
$$

nebst geringen Mengen von Eisenoxyd, Tonerde, Manganverbindungen, Magnesia und Iileselsäure (resp. Alkalisilikate).

Durch fraktionierte Iŕristallisation kann man die Salze voneinander trenuen, und das Kaliumkarbonat fast rein erhalten; das ist aber eine komplizierte Prozedur, wclche sich nur für chemische Fabriken verlohnt. Auch ist die Pottasche von obiger Zusammensetzung für die meisten Zwecke ohne weiteres geeignet.

Die Verwendung der. Pottasche war in früherer Zeit vicl ausgedehnter und vielseitiger. Gegenwärtig ist dieselbe durch die weit billigere Soda zum größsten Teil verdrängt. Nur in einigen Industriezweigen kann man die Pottasche nicht entbehren; es ist dies namentlich der Fall bei der Fabrikation des Kristallglases und der scliwer schmelzbaren Glassätze überhaupt, der Schmierseife, des Blutlaugensalzes und diverser chemischer Präparate.

\section{Die Harze, deren Gewiunung und Verarbeitung ${ }^{1}$ ).}

\section{Vorkommen, Entstehung und allgemeine Charakteristik der Harze.}

$\S 43$. Die Harze gchören zu den am meisten verbreiteten Pflanzenbestandteilen und finden sich in allen Organen mit Ausnahme des Cambiums. Sie bilden

1) Literatnr über Harze: Wiesner, Rohstoffe des Pflanzenreiches, Wien 1900; Tschirch, Die Harze und Harzbehälter, Leipzig 1906; Nayr, Das Harz der Nadelhölzer, Berlin 1891; Andés, Die Harzprodukte, Wien-Leipzig 1905; Schweizer, Die Destillation der Harze, Wien-Leipzig 1905; Damner, Chem. Technologie der Neuzeil, Stuttgart 1911, u. a. 
entweder einen Teil der Zellwand oder des Zellinhaltes; zumeist sind sie jedoch in eigenen interzellularen Sekretbehältern (Harzgängen) angesammelt. Dieselben sind in clen Rinden aller Abietineen, nicht selten aber auch im Holze selbst vorhanden.

Nach den Untersuchungen von Mayr wird das Harz aus den oberen Teilen des Baumes allmählich nach unten geleitet. Der harzreichste Teil ist das Wurzelholz, sorlamn folgt die untere Partie des Stammes bis zu etwa 2 m über dem Boden, weiter das Astholz, damn der bekronte Teil des Stammes, der astlose Gipfel und endlich die Rinde. Warmer, sonniger Standort erhöltt den Harzertrag. Die Harzmenge nimmt mit dem Alter des Baumes zu.

Ueber die Art und Weise, wie die Harzbildung erfolgt, sind die Ansichten geteill. Nach Wiesner, Iiarsten und anderen sind die Harze Produkte ler rückschreitenden Stoffmetamorphose und entstehen entweder direkt oder durch intermediäre Bildung von Gerbstoff aus der Zellulose odel' aus Stärlie. Nach neueren Forschungen von TEehirch ist jedoeh die Harzbildung kein pathologischer, sondern ein physiologiseher Proze $B$, welcher in einer bestimmten Partie der Zellwand erfolgt, die sich als Schleimschichte entwickelt. Diese Schleimmembran sondert Oel, bezw. Harz ab. Als Zwischenprodukt wird Phloroglucin angesehen. Daß die harzbildende Schichte unter Unständen teilweise oder auch ganz resorbiert wird, soll nach Tschirch mit der Sekretbildung selbst nicht zusammenhängen.

Außer in normalen Pflanzengeweben entsteht Harz auch in nicht normalen Gebilden, welche dureh Verwundungen hervorgerufen werden, wie die Narbengewebe der Coniferen oder die mit IIarz erfüllten Lernholzrisse bei der Lärche oder die sogenannten Harzgallen, d. h. abnormale, flache Harzbehälter im Nadelholze, welche durch eine Art von innerer Verletzung (hervorgerufen durch Druckdifferenzen im Splintgewebe) zustande kommen.

Die Harzbehälter münden nirgends frei nach außen und es kann daher auch ein spontaner Harzausfluß nicht erfolgen. Jeder Harzaustritt ist ein pathologischer Vorgang. Unter natürlichen Bedingungen ist der Ausfluß aber stets nur gering und hat seinen Grund in dem Vertrocknen der äußeren, der Luft ausgesetzten Gewebsschichte. Werden hingegen Verwundungen angebracht, wie dies bei der Harznutzung gesehieht, die Rinde stellenweise abgesehält oder der Stamm angebohrt, so vermeht sich der Harzausfluß sehr bedeutend.

Da die Harzgänge außerordentlich feine Kíapillarräume sind und das Harz sehr zähflüssig ist, so kann ein freiwilliges Ausfließen infolge der Schwere niemals stattfinden und ist viehmehr ein bedeutender Druek notwendig, um das Harz auszupressen. Dieser Druck geht von den umliegenden Saftgeweben (Splint) aus und pflanzt sich in Baume fort, so daß das Harz auch aus entfernteren Partien in den Kanä]en bis zur Ausflußstelle geleitet wird.

Das austretende Harz besitzt entweder Tropfenform orler es, ist zu unförmigen Knollen oder stalaktitischen Gestalten vereinigt. Gharakteristisch ist die zuerst von Wiesner beobachtete, miliroskopische Oberflächenbesehaffenheit. Beim Festwerden schrumpft das Harz ein, wodurch die Oberfläclı ein feinkörniges, chagriniertes Aussehen annimmt. Bei längerem Liegen an der Luft verwittert das Harz und zeigt sodamn an der Oberfläche Spalten und Rißlinien.

Lie Grundsubstanz der Harze ist immer amorph; häufig sind jedoch kristallinische Einschlüsse in derselben vorhanden. Im gemeinen Coniferenharz sind so vicle Kiristalle von Abietinsäure ausgeschieden, daß die ganze Mlasse trüb erscheint.

Die meisten Harze sind gelb bis braun gefärbt, glasartig glänzend, durchsichtig bis durehseheinend, oder auch ganz undurehsichtig. Nur einzelne Harze sind farblos oder zeigen verschiedene Nuancen von rot, grün bis schwarz. Bei längerem Aufbewahren thukeln alle Harze nach. Viele derselben besitzen einen sehr angenehmen, aromatischen Geruch (Coniferenharz), einige sind geruchlos (Copale), andere hingegen riechen höchst widerlich (Asa foetida). Jer Geschmack ist zumeist bitter. Die harten Harze sind spröde, brechen glasartig oder muschelig; ihre Härte liegt 
zwischen Steinsalz und Gịs; andere sind weich bis zälıflüssig. Bei längerem Liegen an der Luft gehen die Weichharze in Hartharze über.

Der Schmelzpunkt der festen Harze ist sehr verschieden; Siambenzoe schmilzt schon bei $73^{\circ}$, die harten Copale hingegen erst über $300^{\circ} \mathrm{Cels}$. Die Dichte der Harze ist nahe an 1 (Ausnahmen von 0,9 bis 1,3 ).

Die Harze sind keine chemischen Individuen, sondern Gemenge von meist sehr komplizierter Zusammensetzung. Man lıat zunächst zu unterscheiden: den eigentlichen Harzkörper und die alizessorischen Bestandteile oder Begleitsubstanzen.

Den eigentlichen Harzkörper bilden:

Resine, Resinotannole, Resinole, Resinolsäuren und Resene. In keinem Ilarz sind alle diese Substanzen enthalten, bald herrseht die eine, bald die andere vor oder fehlt auch gänzlich.

Resine sind esterartige Verbindungen der Harzalkohole. In den Harzen kommen sowohl flüssige als auch feste Ester (d. h. zusammengesetzte Aether) vor.

Resinotannole und Resinole sind Harzalkohole, von denen die ersteren gefärbl erscheinen und die Gerbstoffeaktion geben, wăhrend dies hei letzteren nicht der Fall isl. Sie gehören sămllich der aromatischen Reihe an.

Resinolsã u ren (Harzsiuren) sind Oxysauren, welche teils in freien Zustande. leils als Ester vorhanden sind und den Hauptbestandleil vieler Harze bilden. Hierher gehören: Abielinsãure, Pimarsăure, Zimmtsãure, Benzoësâure und mehrere andere. Die beiden lełzlgenannlen sind charakteristisch för eine ganze Gruppe von Harzen (Perubalsam, Tolubalsam, Storax, Benzoë, Drachenblut und Santhorrhoëaharz), während sie in einer anderen Gruppe (Terpenlin und gemeines IJarz, Mekkabalsam, Copaivabalsam, Gurjunbalsam, Elemi, Maslix, Sandarak, Dammar, Copal, Guajalilarz und Gummilack) fehlen (Wiesner).

Besonders hervorzuheben isl die Abietinsäure, als Hauplbestanteil der Coniferenharze. Die A bientinsã u re- $-\left(\mathrm{C}_{10} \mathrm{H}_{28} \mathrm{O}_{2}\right)$ bildet im reinen Zustande farblose, welzsleinfômige líristalle von versehiedener Größe, bis $2110,22 \mathrm{~mm}$. Sie ist unlöslich in Wasser, dagegen leicht löshich in Alkohol, Aether, Aceton, Chloroform, Schwefelkohlenstoff, Benzol, Eisessig und in alkalischen Flüssigkeiten. Jhr Schmelzpunlit liegt Lei 153-15. Cels. Sie lenkt die Polarisalionsebene nach links ab, $(x) \mathrm{D}=-66,7$. Mit der Pimarsüure, mil welcher sie früher oft verwechsell wurde, hal sie nichts gemein.

Die Pimarsäure, welche neben der vorgenannten in vielen Harzen vorkommt, ist ein Gemenge von 3 isomeren Säuren $\left(\mathrm{C}_{20} \mathrm{H}_{30} \mathrm{O}_{2}\right)$.

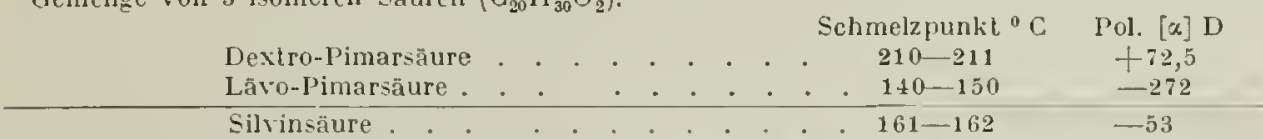

Als Resene bezeichnet Tschirch gewisse Harzbestandteile, welche noch nichl näher studiert sind, sich sehr widerslandsfähig erweisen und wahrscheinlich der aromatischen Reihe angehören dūrften.

Begleitsubstanzen der eigentlichen Ilarze sind: ätherische Oele, Gumni, Gerbstoff, Bitterstoffe, Farbstoffe und diverse mechanische Verunreinigungen.

Besonders wichtig sind die beiden erstgenannten. Harze, welche größere Mengen ätherisches Oel, speziell Terpentinöl, enthalten, werden Terpentine genannt. Es gibt flüssige, halbweiche und feste Terpentine. Erstere heißen Balsame, die beiden letzteren gemeines Harz. Die feinen Balsame sind honigdick, klar, farblos oder blaßgelb bis braun gefärbt. Ist eine schwache Trübung vorhanden, so rührt dieselbe nur von eingeschlossenen Luftbläschen oder Wassertropfen her und verschwindet, wenn man den Balsam in dünner Schichte stehen läßt oder schwach erwärmt. Die ordinären Balsame hingegen sind immer mehr oder minder getrübt, von ausgeschiedenen Iiristallen der Abietinsäure, und lassen sich durch Erwärmen nichtklären, sondern werden im Gegenteil noch trüber. Sie bilden den Uebergang zun gemeinen halbweichen Harz.

Der feinste Terpentin ist der von Abies balsamea abstammende Tianadabalsam. Er ist vollkommen klar, im frischen Zustande farblos und wird bei längerer Aufbewahrung hellgelb, besitzt ein starkes Lichtbrechungsvermögen und wird laauptsächlich für optische Zwecke verwendet. Er hat einen aromatischen Geschmack. In 
absolutem Alkohol ist er nur teilweise löslich. Zu den feinen Terpentinen zählen ferner auch das Lärchenharz oder venetianiseher Terpentin und das Tannenharz oder Straßburger Terpentin. Die übrigen Coniferenharze gehören zum gemeinen Harz.

Die Gummiharze (Gummigutt, Asa foetida, Galbanum und Ammoniakgummi) sind dureh ihren Gelialt an Gummi charakterisiert, welches durchschnittlich in einer Menge von 12 bis $25 \%$ darin vertreten ist.

Die Harze sind durehwegs kohlenstoffreich, sauerstoffarm und frei von Stickstoff. In Wasser sind sie unlöslich, dagegen lösen sich die meisten in Alkohol, Aether, Schwefelkohlenstoff, Terpentinöl, Benzol, Petroleum usw. Von Gummiharzen lösen die genannten Mittel nur das Harz, während das Gummi ungelöst bleibt. Chloralhydrat löst jedoch beide Substanzen. In konzentrierter Schwefelsäure lösen sich viele Harze ohne Zersetzung und werden auf Zusatz von Wasser unverändert gefällt.

Gegen schmelzendes Kalihydrat erweisen sich manche Harze sehr widerstandsfähig, während andere energisch oxydiert werden, wobei regelmäßig die gleichen Produkte, nämlich: Protocatechusäure, Paraoxybenzoesäure, Phloroglucin und Resorein entstehen (Hlasiwetz).

Die Verbindungen mit llelalloxyden werden Resinale genannt. Die Alkaliresinale sind in Wasser löslich, bilden slarken Schaum und werden H a r z s e i e n genannt. Von den gewöhnlichen Fettsāureseifen unterscheiden sie sich dadurch, daß ihre Lösungen beim Konzentrieren keinen Seifenleim liefern und auf Zusatz von Kochsalz keine Seife ausscheiden. Die Harzseifen der alkalischen Erden sind in Wasser schwer löslich, jene der Sehwermetalle unjöslich. Durch Säurezusatz werden alle Harzseifen zerlegt, wobei sich das Harz ausscheidet.

Die Verseifungsiähiglieit der verschiedenen Harze ist eine sehr ungleiche, bei ein und demselben Harz aber innerhalb gewisser Grenzen konstant und kann daher neben anderen llerkmalen zur Bestimnung der Reinheit dieser Produkte verwendet werden.

Unter Verse if $u \mathrm{ng} \mathrm{g} \mathrm{z}$ a h l versteht man lilligramme Kali, welche $\mathbf{l} \mathrm{g}$ Harz beim Koehen mit a b e r s e h üs sige r alkoholiseher lialilauge bindet.

Die Sà u reza hl sind Nilligramme kiali, welche zur Sätligung von $1 \mathrm{~g}$ Harz in alkoholiseher Lösung heansprueht werden.

Die Es terzahl isl die Differenz zwischen Verseifungs- und Säurezahl.

\section{Harzgewinnung.}

$\S 44$. a. Allgemeines. Trotz der außerordentlich weiten Verbreitung der Harze ist die Zahl der Pflanzen, bei denen die Harznutzung verlohnt, doch nur eine beschränkte. Untel den in Europa einheimischen Waldbäumen sind es folgende: Die Schwarzfölure (Pinus Larieio), die Strandliefer (Pinus maritima oder P. Pinaster), die Fichte (Picea excelsa) und die Lärclıe (Larix europaea).

Von untergeordneter Bedeutung sind die harzreicheren Spielarten der Tanne (Abies pectinata) und die Kiefer (Weißföhre) (Pinus silvestris), ferner die Krumholzliefer (Pinus pumilio) und die Zirbelkiefer (Pinus eembra).

Im größten Maßstabe wird die Harzung bei der Sehwarzföhre und Strandkiefer betrieben, welche unter den Vorgenannten auch die größte Harzergiebigkeit aufweisen.

Viel Harz (bezw. Kolophonium) wird aus Nord- und Südamerilia importiert und macht der einheimisehen Produktion ganz gewaltige Konkurrenz. Das meiste amerikanische Harz wird aus Pinus australis und Pinus taeda gewonnen, neben denen noch eine Anzahl anderer Bäume zur Harzuutzung herangezogen wird. Unter diesen verdient besondere Erwähnung Abies balsamea, welche das feinste Harz liefert. Von den asiatischen Harzbäumen sind vor allem Pinus Merkusii und Pinus Khasiana wegen ihres Harzreichtums zu nennen.

Die verschiedenen anderen Harze, welche ebenfalls importiert werden und teils technisehe, teils medizinische Verwendung finden, sind für den vorliegenden Zweck insofern bedeutungslos, als sie durchweg von außereuropäischen Pflanzen abstanmen und mit den in Europa gewonnenen IIarzen nicht in Konkurrenz treten. 
Die Gewinnungsmethode ist verschieden, je nachdem die IIauptmenge des Harzes in Splint und in der Rinde oder in Hohlräumen des Kernholzes sich befindet. In wesentlichen können folgende Methoden unterschieden werden:

1. Das stellenweise Abnehmen der Rinde (das sogen. Lachtenreißen), und zwar a) das Aufsammeln des ausfließenden Harzes in einer napfö̈migen Vertiefung am untern Ende der Lachte (Schwarzföhrenharzung oder österr. Methorle). b) Aufsamnlung des Harzes in der Nähe der Ausfußstelle, mittelst angehängter Gefäße (Strandkieferharzung oder fianzösische Methode). c) Erhärtenlassen und Abscharren des Harzes aus der Lachte (Fichtenharzung).

2. Das Anbohren des Stammes nahe ïber dem Boden (Lärchenharzung).

3. Anschneiden der Harzbeulen in der Rinde (Tannenharzung).

4. Einfaches Aufsammeln des abtropfenden Harzes.

$\S 45$. b) Sch wa rz föh ren- $\mathrm{H}$ a rzung. Die Schwarzföhre wird vorzugsweise in Niederösterreich, u. zw. in der Umgegend von Möding, Baden, Wiener-Neustadt, Pottenstein, Pernitz, Hernstein ete., ferner auch in Frankreieh und auf liorsika zur Harzgewinnung benutzt. Der Vorgang dabei ist folgender: Die erste Arbeit ist die Herstellung des Grandels, d. i. einer napfformigen Vertiefung an der Südseite des Stanınes, ungefāhr $1 / 3 \mathrm{~m}$ über dem Boden, zun Aufsammeln des später abfließenden IJarzes. Das Grandel umfaßt etwa $1 / 4$ bis $1 / 3$ des Stammes. und hat eine Tiefe ron 7 bis $8 \mathrm{~cm}$. Diese Arbeit heißt das Schroten. Zu beilen Seiten des Grandels wird eine in schräger Richtung aufsteigende Einkerbung gemacht, woran sich die Lachte (auch Lache, Lasehe oder Plätzstreifen genannt) schließt. Diese letztere wird durch Abdechseln der Rinde und des jüngten 2-4jälırigen Holzes hergestellt. Ein tieferer Eingriff wăre zweeklos, weil das Harz nur aus dem Splinte und der Rinde ausfließt, aus dem liernholze aber niemals. Das Dechsel ist eine kleine gebogene Hacke mit einer 6 cm breiten Sehneide, welche zum Stiel rechtwinhelig steht. Anfänglich wird die Lachte nur wenige Zentimeter hoch gemacht und dann allmählich nach aufwärts verlängert, so daß sie nach einer Jahresperiode die Höhe von 35 bis $40 \mathrm{em}$ erreieht hat. Das allmähliehe V'erlängern des Laehte nennt man das Plätzen. Es hat den Zweel, die Harzhanäle offen zu halten. Im ersten Jahre wird alle 8 prage, in den späteren Jahren atle $4-5$ Tage einmal geplätzt. Wird diese Arbeit in längeren Zwischenpausen vorgenommen, so ist der Ertrag geringer, weil sich das Harz an der Ausflußstelte verdiekt und Irrusten bildet, wetehe den weiteren Harzaustritt verhinderm. In dieser Weise wird etwa 3-12 Jahre hindureh fortgefahren und die Lachte von Jahr zu Jahr un $35-10 \mathrm{~cm}$ erhöht. Die Breite derselben bleibt aber immer gleieh und darf $2 / 3$ des Stanmumfanges nicht übersteigen. Die Harzungsarbeit (das Plātzen) wird in dè zweiten Hältte April begonnen und bis Anfang oder Mitte Oktober fortgesetzt. In ersten Jalire, wo die Lachte noch keine beträchtliche Höle erreicht hat, fließt das meiste Harz in das Grandel ab (Rinnharz), auf der Lachte bleibt nur wenig. Später hingegen, wenn das Harz einen längeren Wieg zurūckzulegen hat, verdunstet viel Terpentinöl, das Harz verdickt sich, bleibt zun großen Teil auf der Lachte sitzen und muß abgeschart werden (Scharrharz). Un die Verdunstungsobirfläclıe zu verringern, låßt man das Harz nieht über die ganze Breite der Lachte lierabfließen, sondern leitet dasselbe in der Nāhe der Ausflußstelle so zusammen, daß es in Form eines sehmalen Streifens in das Grandel abfließt. Zu diesem Zwecke werden von beiden Sciten sehräg gegen die Hitte der Lachte zulaufende Einhiebe (sog. Iilaffen) gemacht und llotzspäne (sogen. Selırten, Vorlegseheiter oder Leitspäne) eingesteckt, welehe dem ausfließenden Harze die gewünshte Pichtung geben. Alle 14 Tage wird das Harz aus den Grandeln ausgesehöpft und in Bottichen, welche am Harzungsorte in den Boden vertieft sind, bis zur lleiterverwendung aufbewahrt. Der auf der Lachte festgewordene Teil des Harzes wird in Hurbste mit einem gekrūnmten Eisen abgescharrt. Zur Harzung sollen die Bäume erst 10-20 Jahre vor dem Abtrieb, also in 60.-80., keinesfatls aber vor dem 40. Lehensjahre lierangezogen werden.

Stärkere stämne werden nicht selt'n von zwei Seiten geharzt. Naehden die Lachte auf der einen seite eine Hōhe von + bis $5 \mathrm{~m}$ crreicht hat, wird sie aufgelassen und an der entgegengesetzten Seite eine neue Lachte gemacht, so daß nur zwei ganz schmale Rindenstreifu zwischen beiden Lachten stehen bleiben.

Ueber Harzertrag, Kíosten der Harzung ete. lat k. k. Oberforstrat W. Stöger, in dem Werke "Geschichte der österr. Land- und Forstwirtschaft", 1899 seh" wertvolle Angaben gemacht, aus welehen nachstehendes im Auszuge entnommen ist.

Auf den Harzertrag nehmen Einfluß: der Borlen, die Jahreswitterung, die Stärke des Stammes, die Zeit und Dauer der Harzung, sowie die Geschicklichkeit der Arbeiter.

Handb. d. Forstwiss. 3. A uf. II. 
Der Ertrag eines Stammes nimmt um so mehr ab:

1. je seichter, trockener und durchlässiger der Boden ist,

2. je rauher das Klima ist,

3. je geringer die Stammstärke und Benadelung und je dichter der Bestandesschluß ist.

Der Harzertrag ist Ende Juni am höchsten und nimmt dann stetig ab bis gegen Ende des Sommers. In den ersten 2 oder 3 Jahren, sowie aueh gegen Schluß der Harzungsperiode ist der Ertrag geringer. Bei den stärkeren Stämmen wird im 7. bis 9., bei den schwächeren im 4. bis 6. Jahıre der Höchstertrag erreicht. Auch die Qualität des Harzes ist in den ersten Jahren geringer als später. Die Harzungsperiode geht selten unter 8 Jahre herab und steigt in der Regel nicht über 12 bis 15 Jahre. Das Plätzen darf weder bei andauernder Sommerhitze, nach auch bei zu niederer Temperatur vorgenommen werden; beides ist nachteilig für den Harzertrag und es liann selbst der Stamm eingehen; günstig für den Ertrag sind Wärme mit abwechselnder Feuchtigkeit, freier, sonniger Standort, Süd- und Ostlagen. Kiennzeichen eines ertragreichen Stammes ist eine gelbrote Farbe des Plätzstreifens.

Die im harzungsfähigen Alter stehenden Stämme werden nach Stöger in 2 Ḱlassen gesehieden: I. Kilasse über $30 \mathrm{~cm}$, II. Ǩlasse von 25 bis $30 \mathrm{~cm}$ Brustjahresdurchmesser. Der Harzertrag in $\mathrm{kg}$ per Stamm und Jahr stellt sich während einer 10 jährigen Periode:

\begin{tabular}{lrr} 
& \multicolumn{2}{c}{ bei der } \\
auf Konglomelat & $4,3-4,9$ & I1. Kl. \\
" Dolomit & $3,3-4,2$ & $2,4-2,8$ \\
" Hallstädter lialk & $2,6-3,7$ & $1,4-2,6$ \\
& & $1,5-2,2$
\end{tabular}

Das gewonnene Harz seleidet sich in Rinnharz und Scharrharz. Das Scharrharz entlıält bedeutend weniger Terpentinöl, ist mit Holzspänen vermengt und erzielt daher meist nur zwei Drittel des Preises vom Rimharz. Die Menge des Seliarrharzes hängt zumeist von dem Flächeninhalt der Lachte ab, ferner auch von der Lufttemperatur im Herbste. Herrscht im September und Oktober warmes Wetter, so wird weniger Seharrharz und dafür mehr Rinnharz gebildet.

Von je $100 \mathrm{lig}$ des gewonnenen Harzes entfallen auf Scharrharz bei der

I. Iil. II. Kl.

$\begin{array}{ccc}\text { auf Konglomerat } & 42,1-45,8 & 53,8-62,8 \\ , \text { Dolomit } & 41,9-53,7 & 41,9-68,9 \\ \text { " Ilallstädter Kalk } & 28,6-60,4 & 31,8-58,6\end{array}$

Vährend der Harzungsdauer ergibt sich immer ein Verlust an Stämmen teils durch Niederbruch und teils durch Vertrockmen. In Prozenten ansgedrückt stellt sich dieser Verlust

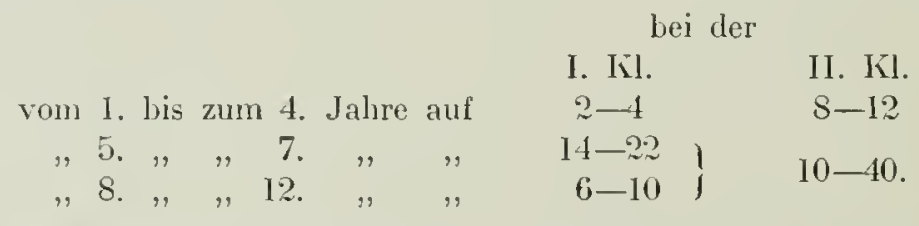

Ueberdies werden $3 \%$ Eintrockmungsverlust des Rohstoffes beim Lagern und 5-6\% Einsud beim Raffinieren vom Käufer in Abzug gebracht. Im Frühjahr ist der Preis des Rohproduktes um 9-10\% höher als im Herbste. 
Durch die Harzung erleidet der Höhenzuwachs eine Einbuße von rund $3 \%$; der Rindenverlust betrïgt 10-66\% und der Holzverlust $20-43 \%$. Dagegen wirl das Holz knorriger und gewinnt an Qualität als Bau- und Nutzloolz.

\$ 46. c. Strandkjefer-Harzung. Die Strandkiefer gedeilit nur in wärmeren Jilimaten und wird hauptsächlich in Frankreich, in dem Departement, des Landes", zwischen Bayonne und Bordeaux, wo sie grőßere Bestände bildet, ferner in Spanien und J'urtugal (Provinz (Estremadura), sowie an den nordafrikanisehen lüsten gepflanzl. Die Harzgewinnnng künnte in der gleichen Weise geschehen, wie hei der Schwarzfohre; jedoch ist in Frankrpich eine Methode des Lachtenreißens ${ }^{1}$ ) (System fl ugues) in Uehung, welche zweclimäBiger ist, als die ōslerreichische. Da Pinus maritima sehr schncllwachsig ist, so ist sie schon sehr jung (mil etwa 15 Jahren) zur Harznulzung reif, doch setzt diese in der Regel erst Lei Stämnen von 25-30 Jahren ein, welche nach der dort bestehenden Forstordnung einen Stammumfang ron ca. 1,1 m besitzen solten. Je nach dem Beginn der Harznutzung wird dieselbe bis zum 45. auch 80., ja sogar bis zum 125. Lebensjahre des Baumes fortgesetzt. Ende Februar oder Anfang März wird die runzelige Rinde an jener Stelle, wo spăter die Lachte gemacht werden soll, auf einer Höhe von elwa $60 \mathrm{~cm}$ und einer Breite ron $10-12 \mathrm{~cm}$ mit einem Schabeisen so weit versclnwächt, daß der Splint nur noch mit einer dünnen, glatten, rötlich erscheinenden Rindenschichte ledeckt bleibt. Dies hat den Zweck: 1. zu T-erhinderu, daß Rindenstücke in das Harzammelgefä $\beta$ fallen, 2. die Werkzeuge bei der Herstellung der Lachle zu schonen und 3. dem Verlaufen des Harzes in der rauhen, rissigen Rinde vorzubergen.

Die zweite Prozedur, welche in die erste Hälfle März fällt, ist die Herslellung der Lachle. Zu diesem Behufe wird an der geschāllen Stelle, etwa $1 / 3 \mathrm{~m}$ ïber dem Boden ein Einschnit von $10 \mathrm{~cm}$ Breite, $3 \mathrm{~cm}$ Höhe und $1 \mathrm{~cm}$ Tiefe gemacht. Auf dieser Föhe sickert das lJarz in Tröpfchenform aus, wird von cinem rinnenförmig gebogenen Zinkblechstreifen aufuenonmen und in den Sammeltopf abgeleilet. Letzterer ist aus glasierlen Ton hergestellt und nit einen Nagel an dem Stanme befestigl. Sein Fassungsraum beträgt etwa $1 / 2$ Liter. Die Blechrinne ragt über die ganze Breite der Lachte und steht $3^{1 !} \mathrm{cm}$ vor. Zur Befestigung der Blechrinne wird mit einem geschärften Vorschlageisen eine Einkerbung gemacht, die Rinne mittelst des sogenannten Sleckeisens testgehallen und mil einem Hammer eingeschjagen. Die Lachte wird anfänglich jede Woche, und in den späteren Monaten von je 5 zu 5 Tagen, nach oben hin auf einer Länge von $10-12 \mathrm{~cm}$ anfgefrischt. Dabei darf immer nur eine äuBerst dünne Schichte abgenommen werden, so daß der Eingriff in den Splint $1 \mathrm{~cm}$ Tiefe niemals übersteigt. Diese Anffrischung wird in Laufe eines Jahres 40-45mal wiederholt und erfurdert die meiste Geschicklichkeit. Die Lachte erreicht dabei in erslen Jahre eine Hŏhe von $55 \mathrm{~cm}$, in 2., 3. und 4. Jahre wird sie um je 75 und in 5. Jahre un $100 \mathrm{~cm}$ erhöht, so daß sie am Schhuß des 5 . Jahres die Totalhöhe von $3,8 \mathrm{~m}$ erreicht hat. Die Breite bleibt aber inmer dieselbe und soll $9 \mathrm{bis} 10 \mathrm{~cm}$ nicht ubersteigen. In den Maße, als die Lachte nach aufwärts vorrinckt, wird anch die Rinne und der Sammeltopf gehohen. Darin liegl ein entsehiedener Vorzug gegenüber der österr. Methode. Das Harz hat niemals einen langen Weg zurückzulegen, um in das Samnelgefãß zu gelangen, es verdunstel viel weniger Terpentinöl, man erhält weniger Scharrharz und dafür mehr Rinnharz. Auch ist das Harz reiner, weil die Töpfe gedeckt sind. Alle 15-20 Tage wird deren Inhalt in einen líubel entleert und in die Sammelbottiche gebracht. Das Scharrharz wird zweimal im Jalıre und zwar in Juni und Novenber eingesammelt. Auf ein FaB Finnharz (gemme) $=235 \mathrm{~kg}$ dürfen nicht mehr als $50 \mathrm{~kg}$ Scharrharz (barras) entfallen, d. s. 17,9\% der Gesamtproduktion, gegen ca. $50^{\circ}$ a bei der österr. Methode.

Bezüglich des weiteren Verlaufes der Harzung untcrscheidet man zwei Arten: 1. gemmage à mort und 2. gemmage à vic. Das erste Verfahren wendet man bei solchen Stämmen an, welche entweder bchufs Lichtung gefält werden mussen, oder welche schon am Ende der Nutzungsarbeil stehen. Da es untel diesen Uniständen angezeigl ist, so viel Harz als mōglich zu gewinnen, so werden je nach der Stärke des Stamnes $2-6$ Lachten gleichzeilig in Angriff genominen.

Das zweile Verfahren wird nur bei jenen Bäumen in Anwendung gebracht, welche man eine Reihe von Jahren hindurch nutzen will. Zu diesem Zwecke darf niemals mehr als eine Lachte auf einmal geöfnel werden. Wenn nach Verlauf von 5 Jahren die erste Lachte cine Höhe von $3,8 \mathrm{~m}$ erreicht hat, Jäßt man den Baum mchrere Jahre hindurch ausruhen. Sodann wird in einem Abstande von $15-20 \mathrm{~cm}$ von der aufgelassenen Lachte eine neue greoffnet, wieder 5 Jahre geharzt und so weiter verfahren, bis der Rundgang um den ganzen Slamm gemacht ist.

Ceber die Ausheute pro Stamm und Jakr sind in der vorzitierten Abhandlung präzise Angaben nicht zu linden; es heißt nur, daß in den jüngeren (30-35jăhrigen) Beständen 240

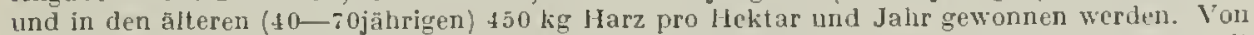
anderer Seite wird die jăhrliche Ausbeute pro Stamn in Mittel von jüngeren Bäumen mit

1) Den Grundzügen nach entnommen aus der Notice sur je gemmage du pin maritime par .1. Croizette Desnoyer, garde général de forèts; nberselzt vom Forstmeister W. S $\mathrm{t}$ g e r in den . Mitteilungen d. $\dot{n}$. ö. Forstrereins II. Heft 1886. 
etwa $3 \mathrm{~kg}$. bei $60-70 j a ̈ h r i g e n ~ S t a ̈ m m e n ~ m i t ~ 6-8 \mathrm{~kg}$ angegeben, weJcher Ertrag sich bei der gemmage à nort bis zu $11 \mathrm{~kg}$ steigern kann.

In Spanien und Portugal wird die Seestrandkicfer wach tinem Verfahren genutzl, das ungefähr die Mitle zwischen der österreichischen und französischen Methode lıălt. Breite Laclten, von denen das Harz über ein Traufblech in ein Getäß abrinnt, charakterisieren kurz diese Methode.

$\S 47$. d. Fie hte $\mathrm{n}-\mathrm{H}$ ar zung. Die Fichte ist zwar sehr verbreitet, wirt aber ihre geringen Ergiebigkeit wegen doch nur noch selten geharzt. Die Harzgewinnung beschränkt sich hauptsächlich auf einige Distrikte in Böhmen, sowie im Thüringerwald und im Großherzog. tum Baden (Schwarzwald).

Das Fichlenharz hal die Eigenschaft, an der Luft sehr bald fest zu werden. Auf ein freiwilliges Abfließen ans der Lachle sowie bei der Schwarzföhe oder Slrandkiefer ist hier nicht in dem Maße zu rechnen, und muß daher eine andere Gewinnungsmethode befolgt werden. Im Nai oder Juni werden gleichzeitig 2 Lachten von je 1-11's m Höhe und $3-6 \mathrm{~cm}$ Breite an den entgegengeselzten Seilen des stammes aufgerissen. Dic Lachlen werden mit einem eigenartig gekrümmlen Messer scharfiantig ausgeschnillen und reichen bis in den Splint. Sie sollen unten spitz zulaufen, damit kein Wasser in densethen stagnieren kann. Im Laufe des ersten Jahres ïberziehen sich die hloßgclegten Stellen mit Harz, welches allmählich erhärtet und in Juli des nächsten Jahres abgescharrt wird. An den Lachtenrändern bi]det sich mit der Zeit rine Leberwallung, welche den Harzauslrilt beeinträchtigt und endlich ganz verhindern würde. Es müssen daher alle 2-3 Jahre die Lachtenränder erneuert werden, eine Arbeit, welche man das Flußscharren nennt. In einigen Gegenden wird das Flußscharren jährlich vorgenommen und die Lachte dabei immer um einige Zenlimeler erweilert, so daß nach ciner Rejhe von Jahren nur mehr zwei schmaJe Rindenstreifen zwischen den beiden Lachlen slehen bleiben. Die Emeuerung der Lachtenränder soll im Sommer vorgenommen werden, damit sich dieselben noch vor Eintritt des Winters mit Harz uberziehen können und der Stamn dadurch geschützt ist. An anderen Orten macht man zuerst zwei schmale Lachten, nach zwei Jahren werden diese aufgelassen und zwischen denselben zwei neue Lachten gerissen usw. so daß auch hier schließlich nur mehr gauz sehmale Rindenstreifen zwischen den einzeluen Lachten stehen bleiben. In der Regel wird die Harzung 10-15 Jahre hindurch fortgesetzt. Die Ausheute pro Stamm und Jahr beträgt in Nittel 0,5 kg Baum- oder Bruchharz und 0,2 kg Fegespäne, sogen. Pickharz.

Das aus der Lachte ausgescharrte Harz ist an reinsten, während das über die Lachte herabgeflossene, sowie das beim Flußscharren gewonnene stets verunreinigt und daher geringwertiger ist.

Aus der in Vorhergehenden angeführten Beschreibung der praktisch geühten Methoden der Harznutzung durch das sog. Lachtenreißen ergibt sicl ohne weiteres, daß ein großer Teil (bis zu $50 \%$ ) gerade der wertvollen, leicht flüchtigen Bestandteile des Harzes (das Terpentinöl) durch Verdunsten verloren geht. Zudem liommt noch, daß die rlureh die Lachten erzeugten Wunden des Baumes nur sebwer oder auch gar nicht heilen und das freigelegte Holz leicht, infolge Austrocknung, Risse erhält, in denen sich tierische und pflanzliche Parasiten ansetzen, zum Scluaden rles Baumes.

Dr. H. Mayr hat daher, um diesen Uebelständen möglichst aus den Wege zu gehen, ein Verfahren in Vorschlag gebracht, das für alle Jolzarten, welche dureh Lachlenreißen auf Harz genutzt werden können, gleich gut anwendbar sein soll und das nur der Erprobung durch die Praxis harrt.

Nach diesem Verfahren wird der Baum, an seiner Südostseite, im Frühjahr, etwa $30 \mathrm{~cm}$ über dem Boden, nitlelst eines Zentrumbohrers schräg aufwärls ansteigend bis ins Holz angebohrt. Yon diesen Loche aus wirt nit einer $A x t$ cin ca. $50 \mathrm{~cm}$ langer Einschnith bis zun Cambium geselılagen und zu beiden seilen dieses Schnittes die Rinde mittelst des, beim Sehalen der Fichte üblichen, Schäleisens in Herzform rom Holze losgelöst, ohne hiebei aber die Rinde zu zerreißen. Etwaige Weichholzpartien, zwischen Rinde und Holz, werden bei dieser Prozedur abgeschabi. Durch Einschieben $\bigwedge$ förmig gefalteter Blechstreifen, wale durch entsprecheucte Biegen dem Stammunfange angepaßt werden können, wird ein Verwachsen der Rinde mil den Holze vermieden und durch die schräg nach außrn und unten gerichtete Stellung rler Blechstreifen, das austretende Harz gegen die Peripherie unt nach der Spitze der Herzform geleitet. Dort wird das Harz beiderseits von nach anfwäts gerichteten V-Blechrinnen aufgenommen und piner in das Bohrloch eingeführten, hallorunden Blechrinne zugefülrt. Aus dieser lropit es in ein knapp unter der Rinne angebrachtes Gefäß, welches, um Verdunstung des Terpentinöles und Verunreinigung des Harzes möglichst zu verueiden, mit einem kleingelochten, trichterförmigen Deckel verschlossen ist. Durch tie eingeschobenen Blechstreifen wird dic linde ausgefuckelt und so das Regenwasser, eventuell noch durch Ziehen entsprechen- 
der Rillen in ter Rinde, ahgeleitet. Bei stark horkigen Kiefern, Lïrelıen oder Douglastannen wird man turelı, , Anröten" die Rinde für diese llethode genüg(nd elastiseh machen.

In jedem weiteren Nulzungsjahre wircl diese, natirliel gedeekte Lachte in gleielur Weise nach oben verlangert und das Sammelgefill naehgerackt, währond dic aufgelassenen Partien dureh Festnageln der Rinde relativ rasch der lleilung zugeführl werten, ohne stark zu verkienen.

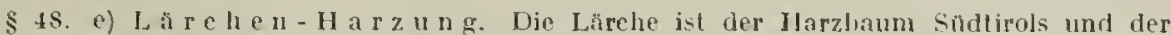
italienischen Alpen. Diese Harzung wird vornehmlich in der Umgebung von Bozen, Meran und Trient, in Nals, ferner um Bricancon und in Tale St. Martin betrieben.

Der Hauptsitz des Harzes befindet sich lei der Lärehe im liernholze. Nach II i s n e r sind in den Markstrahlen der Lärebe zwej harzfühende interzeljularäume vorhanden. Der Lärehenschaft ist sehr häufig kernsehälig und zuweilen auch frostrissig. In diesen spalten des Holzkörpers sammell sich das llarz. Lin dasselbe zu gewinnen, werlen din stamme in Frühjahr etwa $1 / 3 \mathrm{~m}$ über dem Roden in etwas schräg nach aufwirts steigender Richtumg anrebohrt. Das BohrJoch hat ea. $3 \mathrm{~cm}$ Lichte, reicht bis in das Zentrum und wird mit einem Holzstöpsel verschlossen. Bis zum llerhst fült sich die Bohröffnung mit Harz, welches sodann mil llilfe eines halbzylindrischen Hohleisens (Räumer), ausgeslochen wird, wobei man den ganzen Harzzylinder herauszieht und die Oeffnung wieder verstopft. Ein einziges Bohrloch genügt für die ganze Jarzungsdater, welele bis zu 30 Jahren ausgedehnt werden kann. Die Biume sollen mindestens 80 Jahre alt sein, bevor sie zur llarzung henützt werden. Bäump mit starker Borke geben erfahrungsgemä $B$ die beste Ausbeute. Der Harzertrag ist vor allem davon abhanngig, ob durch das Anbohren cine oder mehrere Harzspallen getrofien wurden oder nicht; fermer auch clavon, ob in tiner Periode nur einmal oder ob mehrmals das Jarz ausgeslochen wird oder ob, wie es in manchen Gegenden Brauch ist, das Bohrloch elwa vom Frülijalır bis zum Herbst offen bleibt. Die Ausbeule variiert dann von 0,1 bis über 0,5 lig per Stamm und Jahr. Bei einzelnen slarken Stämmen und offengehallenem Bohrloch soll der Jlarzertrag bis zu $+\mathrm{kg}$ steigen. Das feinste. Harz ist das ausgestochene; das bei offenen Bohrloche frei auslaufende Harz ist unreiner und enthäll ach weniger 'lerpentinōl, flafür int aber das quantitative Erträgnis ein bedeutend höheres. Trotz der durclischnitlich doch nur geringen Ausbeule ist die Larchenharzung doch rentabel, weil sie sehr wenig Arbeit erforderl, das Harz hoch im Preise sleht und die slämme keinerlei Verunslallung erfahren.

Alle anderen europüischen Harzbăume sind, wie schon erwaihnt, von untergeordneter Bedeutung. Die Tanne ist im allgemeinen ein llarzarmer Baum und wird nur im Elsaß und auch dort nur noch vereinzelt auf Harz genulzt. Der Hauplsitz des Harzes ist in der Rinde, wo Harzbeulen entslehen, die man dureh Anschneiden offnet und das ausfließende Harz in eigens geformten Gefäßen aufsammelt. Durch Anschneiden der Rinde wird in den liarpathenJändern aus der Zirbelkiefor, ferner in Galizien und in Rußland aus der liefer (Weißföhre) Harz gewonnen. Das von der lirumholzkiefer, sowie von jungen Fiehten und Föhren abtropfende Harz wird in Gestalt von kleinen körnchen einfach am Maldboden gesammelt.

Das Schwarzföhen-, Strandkiefer- und Fichtenharz gehören zu den gemeinen Terpentinen. Die beiden ersteren sind habllüsig und schejden bei längerem ruligen stehen einen kristallinischen Bodensatz von Dhjetinsäure ab, über welchem die kları, gelb bis rotbraun gefärble, honigdicke Flüssigkeit. sleht. Bein Strandkieforharz isl der weitaus größte Teil flüssig und klar; beim Schwarzöhrenharz hingegen der größere Teil krislahlinisch. Das Fichtenharz ist fest, hallweich und gelb bis braun gefärbt.

Lårchen- und Tannenharz zählen zu den feinen Terpenlinen; sie sind, abgesehen von mechanischen Verunreinigungen (hauptsächlich Luỉtbläschen und Wasserlröpfchen), klar, frei von kristallinischen Ausscheidungen. Das Lärchenharz ist dickflüssig und geht unter der Bezeichnung ,venetianischer Terpentin" in den Handel; das Tannenharz ist dünnflüssiger und führt den Namen , Slraßburger Terpenlin“. Diese beiden besitzen einen sehr angenehmen, lerpentinartigen, an Zil ronen erinnernden Geruch und bitteren Geschmack. An der Luft. wird der Straßburger Terpentin rascher fest als der venetianische.

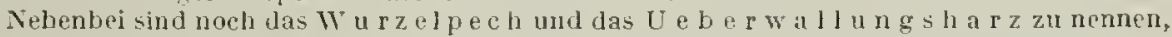
welche beide zum gemeinen Harz gehören. Ersteres findel sich in Form ron J'latlen zwisehen Rinde und Holz dicker Wurzeläste der Fichle und wird in einzelnen Gegenden Bönens gesammelt. Es ist harl, spirōde und ron schwefelgelber Farhe. Das Ueberwallungsharz wurde zuerst von Wiesner studiert. Es bildel sich an den Wundstellen verletzter Nadelhölzer aus dem Narhengewebe. Das Ueberwallungsharz der Schwarzöhre liesteht aus dünnen Ku justen oder knollenfömigen, mehrere Zentimeter yroßen Stücken, von bernsteinartigen Ansehen. Jenes von der Fichte isl konglomeratarlig, weiß, gelh bis braun. Das Lärehenuberwallungsharz hildet halbkugel-oder plattenfömige Stücke von bernsteingelber Farbe. Es erhärlet wegen seines hohen Gelıaltes an Terpentinöl nur selır langsam.

\section{Verarbeitung der Harze.}

$\S 49$. Das Rohharz findet als solches nur beschränkte Verwendung; es dient hauptsächlich nur für medizinische Zwecke, zur Herstellung von Verbandstoffen 
und Pflastern. Die weitaus größte Menge des Rohharzes wird auf Harzprodukte verarbeitet. Die wichtigsten derselben sind: Terpentinöl und Kolophonium. Aus letzterem werden sodann durch trockene Destillation verschiedene $\mathrm{Harzöle}$ hergestellt. Wird das Terpentinöl ganz abdestilliert, so verbleibt im Rückstand Kiolophonium. Wird hingegen nur ein Teil des Terpentinöles abgetrieben, so hinterbleibt eine dickflüssige Masse, welche als gemeiner Terpentin in den Handel geht.

In den primitiv eingerichteten Pechhütten wird die Destillation in kupfernen Kesseln mit abnehmbarem Helm über freiem Feuer vorgenommen. Um das Terpentinöl leichter zu trennen. wird in das gesehmolzene Harz Wasser eingerührt, welches beim Verdampfen das Terpentinöl mit fortreißt. Die Destillationsprodukte werden durch einen Kühler geleitet und in einer Vorlage (nach Art der Florentinerflaschen) aufgesammelt, wo sich das Terpentinöl vom Wasser trennt. Nachdem das Terpentinöl abgetricben ist, verbleibt in Kessel das sogenannte IV a s s e har z oder W e i B pech. Dasselbe enthält noch eine beträchtliche llenge Wasser in Form sehr kleiner Tröpfchen und bildet beim Erstarren eine trübe, hellgelb bis braun gefärbte Massc. Es dient zum Leimen des Papiers und als Dichtungsmittel für Fässer, aber nicht als Brauerpech. Um Kolophonium daraus darzustellen, muß das Wasser vollständig verdampft werden. Zu diesem Behufe wird der Helm abgenommen und der Kesselinhalt so lange erhitzt, bis er durchsichtig geworden ist. Sodann hebt man den Kiessel aus dem Feuerherd heraus und gießt das Kolophonium durch Draht- oder Strohhürden in Fässer oder Kisten. Die mechanisch beigemengteı Verunreinigungen, namentlich Holzspäne und Rindenstücke, bleiben auf den Hürden zurück. Die schwereren, erdigen Verunreinigungen finden sich in der Schmelze als Bodensatz, welcher separat ausgestoßen und, wenn eine größere Partie vorhanden ist, dureh Umschmelzen und Abseihen gereinigt wird.

Dieses T'erfahren eignet sich nur zur Erzeugung von ordinärem, dunkelgefärbtem Kolophonium, weil die Erhitzung des Kesselinhaltes eine sehr ungleichmäßige ist. An den überhitzten Kesselwänden wird immer ein Teil des Harzes zersetzt und dic ganze Masse dadurch trüb und tief rlunkelbraun gefärbt. Leberdies ist auch die Ausbeute an Terpentinöl eine geringere.

Bei rationeller Arbeit wird das Rohharz zunächst geschmolzen und durch cin Sieb filtriert. Das Filterreservoir ist doppelwandig für die Dampfheizung und mit cinem aushebbaren Sicbeinsatze versehen. Es ist mit dem Destillierkessel durch ein Rohr verbunden, so daß das filtrierte Rohharz im warmen flüssigen Zustande direlit in den Destillierkessel gelangt. Derselbe ist aus Eisenblech hergestellt, mit einem Dampfmantel und überdies auch noch mit direkter Dampfeinströmung verschen. Der Boden ist trichterförmig vertieft, damit das Kolophonium leicht und vollständig abgelassen werden kann. Die Destillation wird am vorteilhaftesten unter Druekverminderung vorgenommen, welehe ein Dampfstrahlgcbläse bei der Einmündung des Helmrohres in den Kondensator veranlaßt. An Stelle des Sehlangenkühlers ist ein Kondensator mit mehreren ineinander gesteckten zylindrischen Einsätzen angebracht, zwischen denen das Küühlwasser zirkuliert. Vorlauf und Hauptdestillat können separat aufgesammelt werden. Mit Hilfe dieser Vakuum-Einrichtung wird nicht nur die Filtration des Rohharzes wesentlich beschleunigt und das Einfüllen in den Kiessel erleiehtert, sondern auch dic Ausbeute an Terpentinöl erhöht und ein reineres Produkt crhalten, weil die Destillation bei niedrigerer Temperatur erfolgt.

Dic Ausbeute an Terpentinöl und Kolophonium ist sehr verschieden, je nach der Abstammung und Qualität des Rohharzes. Gewöhnlich werden zwisehen $15-30 \%$ Terpentinöl und $65-75 \%$ Kolophonium erhalten; 5 bis $10 \%$ sind Ver- 
unreinigungen (Wasser, Rindenstücke, erdige Teile etc.) und Verlust. Nach der Ausbeute an Terpentinöl nehmen die in Europa gewonnenen Harze folgende Rangordnung ein: Tannen-, Lärchen-, Strandkiefer-, Schwarzföhren- und endlich Fichtenharz als das ärmste.

\section{Harzprodukte.}

$\$ 50$. a. Das $\mathrm{T}$ e r p e n t i n $\vec{l}$ besteht aus einem Gemenge von Kolnlenwassersloffen; der Hauptbestandeił ist das Pinen $\mathrm{C}_{10} \mathrm{H}_{16}$. tm rohen Produk1, welches durch Destillation über freiem Fener erhalten wurde, finden sich auch Zersetzungsprodukte des Kïolophoniums (Retinnaphta $\mathrm{C}_{8} \mathrm{H}_{8}$, Siedepunkt $108^{0}$, Retinyl $\mathrm{C}_{8} \mathrm{H}_{12}$, Sdpt. $150^{\circ}$, Retinol $\mathrm{C}_{8} \mathrm{I}_{8}, \mathrm{Sddp}_{\mathrm{p}} 180^{\circ} \mathrm{C}$.), ferner llarzsāuren etc. Um das Del zu reinigen, wird es mit Kalkwasser vermiseht und nochmal mit Dampfheizung destilliert (rektifiziert). Aber auch das so gereinigte oel besitzt je nach seiner Abstammung noch versehiedene Eigenschaften.

Frisch dargestellt ist das Terpentinöl farblos, dünnflüssig und von eigentümlichen Geruch. Das franzosische Oel riecht nach Wachloolder, das amerikanische kolophoniumartig. Die Dichte bei gewōhnlicher Temperatur variiert von $0,855-0,886$. Es polarisiert teils nacli rechts und teils nach links. Der Siedepunkt liegt zwisehen 150 und $165^{\circ} \mathrm{C}$; ; trotzdem verdunstet es aber docl schon bei gewöhnlicher Temperatur ganz merklich. Der restierende Teil nimmt Sauerstoff aus der Luft auf und bildet sich ein Aldehyd $\left(\mathrm{C}_{10} \mathrm{H}_{16} \mathrm{O}_{3}\right)$ von scharfem Geruch. Bei weiter fortschreitender Oxydation verdickt es sich, wird nach und nach ganz fest, spröde, kolophoniumartig, schwach gelb und zeigt eine saure Reaktion. Der absorbierte Sauerstoff wird in Ozon verwandelt und leicht auf andere Substanzen überlragen, so daß das Terpentinöl in Lack- und Firnisanstrichen nicht nur als Verdünnungsmittel, sondern auch als Oxydationsmitlel wirkt. Dureh die Gegenwart von Wasser wird die Oxydation beschleunigt. Terpentinöl und seine Dāmpfe sind leicht brennbar und verbrennen mil roter, stark rußender Flamme. Terpentinōl ist in Wasser unlöslich, dagegen lōslich in Alkohol, Aether, Scliwefelkohlenstoff, Benzol, Petroleumāther etc. Unter der Einwirkung von Sonnenlicht und Luft resp. Sauerstoff bildet sich aus feuchtem Terpentinöl Pinolhydrat $\mathrm{C}_{10} \mathrm{H}_{16} \mathrm{O}_{2}$, ein je nach den angewendeten Lösungsmitteln in Blättchen oder Nadeln kristallisierender Körper, welcher auch in einigen Pinusarten vorgefunden wurde. IIit Chlorwasserstoffgas giht es eine weiche, knetbare Verbindung $\mathrm{C}_{10} \mathrm{H}_{16} \mathrm{HCl}$ - Pinenhydrochlorid - , aus welcher, wie schon erwāhnt, der künstliche liampfer erzeugt wird.

Terpentinöl isl ein gutes Lōsungsmittel für viele Harze, Wachs, Felte, liautschuk, Schwefel und Phosphor. In der Industrie findet es vielfache Verwendung, namentlich zur Lack- und Firnisbereitung. In der Medizin dient es für innerlichen und äußerlichen Gebrauch. Nicht selten benützl man das Terpentinöl auch als Verfälschungsmittel für diverse ätherische Oele.

$\S 51$. b. Das Kolop ho n i m zeigt je nach der Art der Darslellung sehr verschiedene Eigenschaften. Es ist entweder volliommen durchsichtig, durehscheinend oder fast undurchsichtig. Das Klarwerden der geschmolzenen Masse basiert auf der L'mwandlung der kristallisierten Abietinsăure in das amorphe Anhydrid derselben. Die Farbe geht von blaßsgelb, goldgelb, rotgelb durch alle Nuancen bis in tief dunkelbraun, fast schwarz. Auch bezüglich der Hårte des Kolophoniums gibt es verschiedene Abstufungen. Vanche Sorten sind so weich, daß sie den Eindruck mit dem Fingernagel annehmen; die meisten hingegen besitzen cine solehe Hārte, daß sie erst mit Eisen gerizt werden können. Das harte Isolophonium ist fast geruch- und geschmacklos, glasartig glänzend, sehr spröde, läßt sich leicht pulvern. Bei $70^{\circ} \mathrm{C}$. wird es weich, zwisehen 100 und $135^{\circ} \mathrm{C}$. schmilzt es. Das spezifische Gew icht betrāgt $1,045-1,108$ bei $15^{\circ} \mathrm{C}$. Hinsichtlich der Löslichkeit steht das Kolophonium ungefähr auf gleicher Stufe wie das Harz. Nach den Untersuelungen von Perrenaud enthäll das amerikanische Kolophonium aus dem Stammharze von Pinus strobus und P. picea, sorie jenes aus dem Wurzelharze von P. sylvestris Abientisäure, während das fiolophonium aus dem Stammliarze von P. sylvestris und aus dem Galipol Pimarsāure enthält.

Das Kiolophonium als solches dient zur liitt-, Siegellack- und Firniserzeugung, als Geigenharz, zur Herstellung von Harzseifen und Brauerpech; ferner werden, wie sehon erwähnt, verschiedene Harzōle daraus dargestellt.

Besondere Erwảhnung verdienen die beiden letzlgenannten Produlite, da deren Herstellung mit der Harzgewinnung unmittelbar zusammenhängt und die eigentliche Harzindustrie bildet.

§5. c. Das Br a u e r pech dient zum Auspichen der Bierfässer. Der innere Pechūberzıg ist notwendig, um das Faß vollkommen zu dichten, dem Austreten der liollensãure und Eindringen der Luft vorzubeugen und ferner eine grüdliche Reinigung vornehmen zu kōnnen. In einem unausgepichten Fasse jürde das Bier in das Holz eindringen und einen Holzgeschmack annehmen. Beim Ausschmelzen des alten und Ersalz desselben durch neues Pech wird hingegen eine so gründliche Reinigung erzielt, wie sie auf anderem Wege gar nicht zu bewerkstelligen ist. Das Kolophonium als solches ist zum Auspichen nicht ohne weiteres geeignet, weil es zu sprōde ist und von den Faßwānden abspringt. Un es geschmeidiger zu 
machen, wird es mit gewissen Znsälzen versehen und dieses Produkt heißt Brauerpech. Als Zusätze werden Harzöl, Leinől, liotlonöl, Paraffin, reiner Preßtalg und dgl. verwendet und zwar in einer Menge von elwa 8-10\%. Das kolophonium wird in einem offenen liessel geschmolzen und der Zusalz eingerührt, so daß eine gleichmäßige Mlischung entsleht. Dic Fabrikation ist also sehr einfach.

Gutes Brauerpech muß nahezu geruch- und geschmacklos sein, der Schmelzpunkt sol] zwischen $40-50^{\circ} \mathrm{C}$. hegen; es darf beim Schmelzen nichl schäumen und nach dem Erkalten weder zu weich noch zu sprōde sein. In $4 \%$ igem Weingeist muß es unlöslich und in absolutem Alkohol voljständig Jöslich sein. Der Aschengehalt darl $0,3 \%$ nicht übersteigen. Die Farbe ist verschieden von goldgetb bis liefbraun und an sich bedeutungs]os, nur dürlen Farbstolfzusätze nicht vorhanden sein. Die hellen Pechsorlen sind in der Regel ganz durehsichtig (sog. Transparentpech), die dunkleren durchscheinend bis undurchsichtig. Doeh isl auch diese Eigenschaft [ür den Gebrawchswert g]eichgültig; das wichtigste isl, daß das Pech keinen Geruch oder Geschmack an das Bier ahgibt, was sich durch eine ganz einfache Probe konstalieren läßi. Zwei oder drei gul gereinigte und vollkommen ausgetrocknete Bierflaschen werden im angewärmten Zustande mit Pcch ausgegossen, so daß nur eine ganz dünne Schichte desselben an der Glaswand halten bleibt. Nach dem Erkalten werden diese Flaschen mil geschmaekreinen Bier gefüll, verkorkt und mehrere Tage bei Zimmertemperatur oder im Eiskasten stehen gelassen. Da hier eine relativ große j'echoberflache mil dem Bier in Berülıung konmt, so läßt sich bei der liostjrobe sehon nach 3 oder 4 Tagen jeder, auch der geringste Geruch-oder Geschmackstehter deutlich erkennen. Des Vergleiches wegen muß auch immer eine Probe desselben Bieres in einer nicht ausgepiehten Flasche mit in Beobachlung genommen werden.

§53. d. Ats Ha r zöle bezeichnet man meltrere ölartige Flüssigheiten, welche durch trockene Destillation aus liolophonium erhalten werden.

Die Destillationseinzichtung bestand früher aus einem gußeisernen Destillicrkessel von zylindrischer Gesta]t mil schalenförmig vertieftem Boden, gewölblem Deckel mit Abzugrohr (Rüssel) für die Oeldämpfe, welches mil einem Schlangenkondensator verbnnden ist. Die Heizung erlolgte mit direktem Feuer, wozu man neben kohle und eventuell Holzablällen auch die Destillationsgase nit verwendete.

Heute wird in allen rationell arbeitenden Fabriken die Destillation des Kolophoniums in Apparaten ausgeführt, welche entweder ausselließlich mit Dampf (direkt oder indirekt), auch überhitztem Dampf, oder mit Dampf und Fevergasen geheizt werden. Die Destillationsgase werden aus dem Apparat abgesaugt und mit als Heizmaterial verwendet, wodurch sie erstens cinmal für die Nachbarschaft unschädlich gemacht werden, dann aber auch eine nicht zu unterschätzende Brennstoffersparnis erzielen lassen. Die Apparate sind für periodischen ader liontinuierlichen Betrieb und zur Vorwärmung des Kolophoniums, sowie zur Fralitionierung und Rektifikation der Destillationsprodukte eingerichtet.

Von Kíräner und Flammer wurde ein Apparat konstruiert, in welehem die Destillation durch überhitzten Dampf, Feuergase und Vakuum betrieben wird, durch welch letzteres eine raschere Destillation und bessere Qualität der Produlite erzielt wird, weil man mit geringeren Temperaturen das Auslaugen findet. Die Einrichtung der Dampfdestillations-Anlagen stinmt dem Wesen nach mit der für direkte Feuerung überein. Sie besteht sonit aus Destillierblasen und Kondensiervorrichtungen, welche aber je nach der Art der Feuerung, Durchfülırung des Betriebes und Qualität der Produkte etc. entsprechend ausgestattet sind ${ }^{\mathbf{1}}$ ).

Die Vorteile der Dampfdestillation lassen sieh kurz folgendermaßen zusamnenfassen:

1. Einfacher und rationeller Betrieb.

2. Präzise Temperatur-Regulierung.

3. Holıe Qualität der Produlite.

4. Rasche Destillation.

5. Leichte Ueberwachung des Ganges der Destillation.

6. Vermeidung von Feuers- und Explosionsgefahr.

7. Schonung der Destillierapparate.

1) Năheres in: Andés, Die Harzprodukle, Sc ł weize r, Die Destillation der Harze u. a. 
Behufs Durchführung der Destillation wurde bei den alten Apparaten mit Feuerkochung das Kolophonium durch die Füllöffnung in den Destillierkessel, bis zu $3 / 4$ max. $4 / 5$ von dessen Fassungsiaum, eingebracht und zunichst bei offenem Mannloch geschmolzen, un ein starkes Schäumen und Steigen der Masse beobachten und nötigenfalls durch Abschöpfen verhindern zu können. War die Masse in ruhigem FluB (ca. $140^{\circ} \mathrm{C}$.), so wurde das Mannloch verschlossen und init der Destillation begonnen.

Bei den Apparaten mit Dampfheizung wird das Kolophonium in Vorwärmer, welcher mit der unter ihm liegenden Destillierblase durch ein Rohr in Verbindung steht, durch Anheizen des ganzen Apparates geschmolzen und in diesem Zustande dem Destillierkessel nach Bedarf zugeführt.

Der Beginn der Destillation des Harzes gibt sich durch ein eigentümlich prasselndes Geräusch zu erkennen, hervorgerufen durch den Wasserdampf, welcher sich aus dem dem Harze anhaftenden Wasser bildet und durch die flüssige Masse Bahn bricht.

Zuerst geht bei einer allmählich bis zu $270^{\circ} \mathrm{C}$. ansteigenden Temperatur der sogenannte Vorlauf über, d. i. Sauerwasser mit Pinolin. Ist der Vorlauf zu Ende, so wird die Temperatur gesteigert und es beginnt die Oeldestillation. Das von etwa $290^{\circ} \mathrm{C}$. aufwärts übergehende Oel ist trūb, dunkelbraun und besitzt einen scharfen, durchdringenden Geruch. Nach dem trüben Oel folgt klares, wasserhelles bis schwach gelbgefärbtes Oel von mildem, angenehmem Geruch, ,sog. Mittel- oder Blondol". Bei fortgesetzter Temperaturerhöhung folgt das Blauöl und schließlich, über $350-360^{\circ} \mathrm{C}$, das Crünöl. In Destillierkessel verhleibt ein hoksartiger Rückstand.

Die Ausbeuten betragen:

$$
\begin{aligned}
6-8 \% & \text { Vorlauf } \\
4-5 \% & \text { trübes Oel } \\
50-55 \% & \text { helles Oel } \\
15-20 \% & \text { Blauŏl } \\
6-7 \% & \text { Grünöl }
\end{aligned}
$$

Das auf 100 fehlende ist lioks und sind die Gase, welche entweichen.

Der Vo $\mathrm{l}$ l a $\mathrm{f}$ besteht ungefähr zur Hälfte aus Sauerwasser und zur Hälfte aus leichtem Harzól (Pinolin). Ersteres enthät verschiedene organische Säuren, vornehmlich Essigsäure, wird aber in der Regel nicht weiter verwertet. Bein Stehenlassen scheidet sich das leichte Oel an der Oberflächc $a b$ und wird durch Abziehen vom Sauerwasser getrennt. Das Rohpinolin ist braun gefārbt und riecht sehr unangenehm. Behuf́s Reinigung wird es mit Natronlauge gemischt, um die Săure zu neutralisieren, sodann mit Wasser gewaschen und nochmals destilliert. Un ein ganz reines Produkt zu erhalten, muß die Destillation mit direkter oder indirekter Dampfheizung geschehen und wird zuweilen auch Holzkohle zugegeben, welche den Rest der unangenetm riechenden Beimengungen aufnimmt. Derartig raffiniertes Pinolin ist wasserbelt, riecht mild aromatisch, hesitzt eine Dichte ron $0,860-0,900$ und stetıt in seinem Gebrauchswert auf gleicher Stufe mit dem Terpentinö. Es hommt unter der Bezeichnung ,Harzsprit" oder "Harzessenz" in den Handel.

Das zweite Produlit, ,d a s t r u be o e l" ist ein Gemisch von Harzöl mit Vorlauf. Eine seharfe Trennung dieser beiden ist bei der erstmaligen Destillation jedoch nicht möglich. Auch bleibt hei der Rektifikation des Pinolins mit Dampfheizung immer etwas Harzöl im Rückstande. Bei der Aufarbeitung wird dieses Gemisch mit Lauge und Viasser gewaschen und dient dann entweder für sich allein oder mit Blauöl gemischt zur Wagenfetterzeugung oder zur Bereitung von Kalkseife.

Das dritte Produkt, das helle Oel o d e r Blon d öl ist das wertrollste und wird auch in größter Henge erhalten. Es kann schon in rohen Zustande zur Wagenfetterzeugung und als Sefnieröl verwendet werden; vorteilhafter ist es aber, dasselbe einer Raffination zu unterziehen, wodurch sein Gebrauchswert bedeutend erhöht wird.

Das rohe Blondōl muß im frischen Zustande, womöglich unmittelbar nach der Destillation, raffiniert werden. Zu diesem Zwecke wird das Rohōl zunächst mit heißem IIasser gewaschen, nach scheidung der beiden Schichten abgezogen, dureh Einleiten von direkten Dampfe zum gleichmāBigen Aufwallen gebracht und so viel Vatronlauge zugesetzt, als zur vollständigen Bindung der Harzsäure notwendig ist. Sobald die Verseifung (res]'. Entharzung) erfolgt ist, was man an der lilärung und setharfen Trennung des Oeles in einer herausgenommenen Probe erkennt, muß die Waschflüsigkeit sofort abgezogen werden, da sich sunst wieder etwas von der Seife löst und das Oel dunkel färbt. Es wird mit Wasser, unter Zubilfenalıme von direkter Dampfeinströmung, wiedertıolt gewaschen und sodann in den Oxydationsapparat 
abgelassen. Hier wird das Oel in einer 80 bis $100 \mathrm{~cm}$ hohen Schichte durch Einblasen von Lull, unter gleichzeitigem Anwärmen, mehrere Stunden hindurch oxydiert, wobei es den blauen Schimmer verliert. Ein Zusatz von 10-15\% Salzwasser während des Oxylationsprozesses ist vorteilhaft, weil dieses die entstehenden Brandharze aufnimmt. Das raffinierte Oel ist harzfrei, Follständig blank, blaßgelbgrün und nahezu geruchlos. Die Fluoreszenz ist aber nicht ganz wegzubringen. Das Rohöl fluoresziert blau und das raffinierte grün. Die Dichte ist bei $15^{\circ} \mathrm{C}$. $=0,960-0,965$; der Flammpunkt liegt bei $135-140^{\circ} \mathrm{C}$.; der Brennpunlit bei $180-185$. Bei $300^{\circ} \mathrm{C}$. destilliert es fast vollständig uber. Es trocknet rasch, riß-und klebfrei und findet vielfaclıe Verwendung zur Firnis- und Lackfabrikation, namentlich zur Herstellung von Druckerschwärze, Eisenlack, Holz- und Mauerglasur, ferner als Schmiermittel, zur Herstellung ron Ledersalbe, medizinisehen Salben, künstlichem Tran, zur Erzeugung von Linolcum, Isoliermassen für elcktrische Leitungen, als Zusatz für Brauerpech, Seife und Parfümerieartikel usw.

Als Nebenprodukt bei der Raflinierung wird die Harzseifenlauge gewonnen, aus welcher durch Aulkochen mit Dampf und Einleiten von Kohlensäure einc zähllüssige Harzmasse, sogen. ,Dicköl" abgeschieden werden kann, welches zur Wagenfeltfabrikation dient. Die durch Zersetzung der Seife entstehende Sodalauge kann neuerlich kaustiziert und wieder benutzt werden.

Wird die Oxydation nicht in offenen Gefäßen, sondern in geschlossenen Reservoiren vorgenommen, so können auch die dabei entweicherden leichten Oeldämpfe abgesaugt und kondensiert werden.

Sehr praktische Einrichtungen für diesen Zweck, sowìe auch fōr die Destillation des Iarzes und Raffinjerung der Harzole liat F. Boleg konstruiert und in der Chem. Revue über Fett- und Harzindustrie 1897 beschrieben.

Das $\mathrm{B}$ l a u öl kann in gleicher Weise raffiniert werden, wie das Blondöl.

Das G r ü n öl, welches als letztes Produlit äbergeht, wenn die Destillation bis auf Verbleiben eines Koksrückstandes fortgesetzl wird, kann ebenlalls zur Wagenfetterzeugung verwendet werden. Da aber dieser lioks nahezu wertlos ist und sich selbst zur Feuerung nicht gut eignet, wird die Destillation in der Regel nicht bis zum Schluß fortgesetzl, sondern unterbrochen, sobald das Blauöl übergegangen ist. Es verbleibt sodann im Destillierkessel eine sehwarzbraune, matt bis glänzende, beim Erkalten spröde werdende Masse, das sog. ,Pech". Dasselbe wird im heißen, flüssigen Zustande aus dem Kiessel abgelassen, in Holzkübel oder Lehmformen gegossen und findet zur Herstellung von Schmiede-, Schuster-, Bürten- und Schilfspech Verwendung. 


\title{
Sachregister zu Abschnitt VI bis IX.
}

\author{
Die Zablen bezeichnen die Seilen.
}

Abgebot 503.

Abies concolor 31 .

Shistum 6.

Ableger 118. 139.

Abnutzbarkit (des Holzes) 426.

Abscheerfestigkcit 387.

Absenker 84. 139.

Aezkalk 125.

Ahoru (Betriebsart und Verjüngung) 146 .

Ailanthusholz 399.

Akkumulation 298.

Alkaloide 563.

Altmachen des Holzes $\mathbf{5 7 5}$.

Alpenköhlerei 597.

Amaranthholz 362 .

Ammoniak, schwefelsanres 125.

Amyloid 55 .

Anbaufāhigkeit 29.

Anbauwürdigkeit 29.

Anbrüchige Hānge (Befestigung durch Vegelationsdecke) 307 .

Angriffshiebe 76 .

Ankollen 572.

Anrūcken 496.

Anschlämmen der Pflänzlinge 128 .

Anstrich 570 .

Anzündholz 466 .

Arbeitskapazität des Holzes 129.

Arbeitsplan für Holzprüfung 389.

Aspenbockkäfer 259.

Aststreu 527.

Astungen 193.

Aufastungen 193.

Aufastungssägen 195 .

Aufbewahrung von Hölzem 512 .

Aufforstungen gegen Lawinen 339. gegen Wildbäche 329 .

Aufstapelung von Hölzern 512.

Aufstreichsverkauf 502 .

Ausformung des Holzes 487 . Ausgleiclısgefälle 303.
Ausheben der Pflānzlinge 128. Ausjütungen 162 .

Auskesseln 182.

Ausländische llolzarten (Einfuhrung) 28 .

Ausläuterungen $160,162$.

Auslaugen 569 .

Auslaugung des Holzes in Süß- und Salzmassel 427. Auslichtungsstadium 74 .

Aussaat 112.

- im Forstgarten 126.

Ausschlagholzhetriebe 38 .

Aussehlagvermögen 79.

Ausschlagwald 42.50 .

AusschuBhölzer 506 .

Auszugshauungen 159.

Axt 484.

Bachverlauf, Einteilung 296.

Balata 560 .

Balken 447.

Balkensperren 315 .

Ballenpflanzung 118. 136 .

Bankskiefer 31

Barfrost 270.

Barzahlung 509.

Bastliäfer 232.

Bauholz +45 .

- Elastizităt und Fostigkeit (Tetmayer) 402

Baumfrüchte $\mathbf{5 1 5}$.

Baumrodemaschine

- Nassauische 180.

- Wohmannsche 480 .

- Stendalsche 482.

Baumwinde, Buttners 481 .

Bauschreinerei 460 .

Beerennutzung 546 .

Bekanntmachung (der Verkãufe) 508 .

Berauhwehre 327.

Bergban 452 .

Beschädigungen, Verhalton der Holzarlen gegen 13.

Beschneiden der Pflinzlinge 128.

Bestandesbegründung 61 .

- bei den cinzelnen Holzarten 140 .
Bestandesbegründung liủnstliche 62,81 .

- natürliche 62,66 .

Bestandeserziohung 158.

Bestandesmalerial 4.

Besteck 91.

Bestraucliung 91.

Betriebsarten 36.

- bei den einzelnen Holzarten 140 .

- Grundformen 37. 38.

- Uebergangsformen 37. 52.

- Zwischentormen 37.52.

Betriebsumwandlungen 57.

Bewässerung 198.

Biegeversuche 389 .

Biegsankieit 385. 427.

Bildsamkeit 428 .

Bindigkeit des Bodens 10.

Binnensand (liultur und Bindung) 90 .

Birke (Betriebsart und Verjüngung) 147.

Birkennestspinner 264.

Birkenrinde $4: 2$.

Birkenrindenteer 614 .

Bitlerstoffe 558. 563.

Blattiäfer 260.

Blauwerden des Kiefernholzes 362.

Blendersaumschlag 40.48 .

Blitzschlag 279.

Blockiausbau 446 .

Blockwandspercen 315.

Bockliäfer 259.

Boden, Ertaltung des 197.

- physikalische Eigenschatten des 8.

Bodenbearbeitung, wiederholte 126.

Bodenfeuer 208.

Bodenfrische 197.

Bodenlockerhoit 197 .

Bodenlockerung 110.

Bodenpllege 197 .

Bogensägen $\downarrow 82$.

Borkenkiter 229.

Boule--Irbeit 358.

Brandfruchlbau 98.

Brauerpech 631. 
Braunsehliff 594.

Brennholz 466.

Brucherscheinungen 431 .

Bruchmodut 384.

Brückenbauhölzer 457.

Buche als Bauholz 449 .

- Betriebsart und Verjüngung $1+0$.

Bucheckernöl 515.

Bucheln 519. 525.

Bucliengallmüclie 266.

Buchenhocluwaldbetrieb, nodifizierter (v. Seebach) 189.

Buelenkeimlingspilz 287.

Buchenspinner 261 .

Buehenspringrüsselkäfer 260 .

Buchenwollaus 267.

Büsehelpflanzung 118. 119.

Bubnen 324

Buhnenpfăhte 458 .

Buttlar-Eisen 138.

Cahūeit 492.

Carya alba 31.

Castanetum 6.

Chamaecyparis Lawsoniana 31.

Chilisalpeter 125.

Cieslars Keimkasten 108.

Coldewes litimapparat 108.

Dämpfen des Jlokes 569 .

- der Rotbuche 362.

Darrbetrieb 520 .

Darrgewicht des IIolzes 372.

Darrtemperatur 522.

Darrverfahren 520. 521. 522.

Darriorrichtungen 520 .

Datler des Nadellolzes 411.

Deforma1ion des Juolzes 381 .

Deformitä1 enerzeuger 265 .

Denudation 298

Dichte des Jolzes 371 .

Douglasie 31 .

Dreiecksverhand $\mathbf{1 1 8 .}$

Drewitz, Sämaschine von 116 .

Druckversuch 389.

Dủnensand, Bindung und

Kultur 91.

Düngung 121.

- Auslührung der 125.

Duft 278 .

Dunkelschlagwirtschaft 40 .

Durchtorstung

- Beginn der 169.

- Begriff 161.

- dänisehe 177.

- He c ks freie 177.

- Posteler, nach v. Salisch 178.

- Stärlie der 170.

- Wiederlolung 170 .

- Zweck der 165.

Durchhiehe 165.

Ebenliolz 361.

Eclaircie par le liant 177.

Edelkastanie 148.
Eggen 111.

Eiche (Betriebsart und Verjüngung) 143.

Eicheln 519. 524.

Eichenbockkäfer 259.

Eichenmehlau 288.

Eichenniederwald 80.

Eichenrinde 492.

EichensehäIrinde 470 .

Eichenschälwald 80 .

Eichensehälwaldertrag 495.

Eichenwickler 265.

Eichenwurzeltöter 289.

Eichhörnchen 221.

Einsumpfverfahren 576.

Einzelpflanzung 118.

Eisenbahnsehwellen 454 .

Eisenhahnwagen 462 .

Eisklüfte 270.

Elastizität des Holzes 383 . 381.

- verschiedener Nadelhölzer 412.

- von Fichten- und kiefernholz 407 .

Engerlingsehaden 244.

Entel, lieimapparat von 108.

En1flügelung des Samens 523.

Entwässerung 198.

Entwässerungsanlagen 325 .

Entwässerungsarbeiten 88 .

Entwässerungsgrälien 326 .

Erdfeuer 208.

Erdfloh 261.

Erle (Betriebsart und lerjüngung) 147 .

Erlenniederwald 82.

Erosion 299.

Esche (Betriebsart und Vorjüngung) 146.

Eschenbastkäfer 258.

Eschenholz (technische Eigenschaften) 425 .

Essigsäure

- Darstellung 611.

- Eigensehaften 612.

Exoten 28.

Exposition 7.

Extensiv'system 12.

Fachmerkbau 446 . Fagelun 6.

Fällungsbetrieb 478 .

Fällungsplan 472 .

Fällungsze it 473 .

- Einfluß auf die Daner des

Fichtenholzes 400 .

Färbung des Holzes 575.

Faltrichtung 485 .

Falschkern 361.

Familiengånge 230 .

Fangbäume 231.

Fangbüschel 242 .

Fanggrähen 241.

Fangkloben 242 .

Fangrinde 242

Farbe des Holzes 357.

Farbstoffe in Holz 558
Farbverănderung 361 .

Faschinen 458 .

Faschinenwerke 324

Feinheit des Holzes 365 .

Femelbetrieb 38. 45 .

Femelschlagbetrieb $39,46,75$.

Festigkeit des Holzes 383 . 384,385 .

Festigkeit des Fichten- und liefernholzes 407.

- der verschiedenen Nadelhölzer 412.

Festigkeitsänderung beim Nadellolz nach der Fällung 411.

Festigkeitskoëffizient 425 .

Fesiigkeilsmaschinen 388 .

Fenchtigkeit 10.

Feversichermachen des Holzes 575.

Fichte (Betriebsart und Verjüngung) 152.

- Beziehung zwischen Jahrringbreite und technisehen Eigensehaften 422 .

Fichtenbastkäfer 239.

Fichtenbockkäfer 259.

Fichtenborkenkäfer 232.

Fichtengespinstblattwespe 257

Fichtenholz

- Alter der Stämme 424.

- Astreinheit 424

- Jahrringe (Gleiclınäßig keit) 424

- Kern- und Splintholz 422.

- technisclse Eigenschaften 419.

Ficlutennadelrost 288.

Fichtennestwickler 254.

Fichtenrinde 471. 494 .

Fichtenrindenlaus 266 .

Fichlenrindenwickler 254.

Flader 367 .

Flecht faschinenwerke 324.

Fliege, spanische 261.

Flugsand 90 .

Fölireneule 251.

Föhrenspanner 252.

Formbarkeil des Holzes 385. Formen, klimatiscle 101.

Forstdüngung 199.

Forstrevel 206

Forslgärten, Bodenbearbeilung 123 .

— ständige 121.

- unständige 121 .

Forstgartenhetrieb 121.

Forstinseliten 223.

Forstunkräuter 267 .

Fraxinus alba-americana 31 .

Freihandverkauf j01.

Frost 269

Frosthöhe 271.

Frostlöcher 271.

Frostrisse 270 .

Frostspanner 264.

Fruhfrost 270 . 
Frülijahrsfrost 269.

Fruklifikation 13.

Funfverband 118.

liutterlaubgewimung 526 .

Irutterreisig 5ะ?.

Galläp[ul ehinesisehe 566.

Gallen 565.

Gallussăure 561 .

Gallwespen 266.

Garlensaalmaschine, Hak-

liers 127.

Gegenfeuer 211.

Gerbrinden 562.

Gerbstolf 561.

Ceruch des Holzes 368 .

Geschiebe, Herkommen der 299.

Gespinstblattwespe 257.

Gipfeldurre 285.

Gipifelfeuer 208.

Gips 125.

Gitterwalze 131.

Glanz des Holzes 364 .

Glaserholz 461 .

GlashüL.ıen 466.

Gleiclıgewiclıtsgefälle 305.

Gletscherlawinen 331.

Glykoside 558. 563.

Fölıren, Sämaschine 116.

Goldafter 264.

Grasnulzung 542 .

Grauholzverfahren 363.

Gienzzeichen, Sicherung 204.

Grobrinde 494 .

Crubber 111.

Grubenholz 452 .

Gründigkeit 10.

Gründüngung 124.

Grünfäule 362.

Grüngewicht des Holzes 372.

Grünwald, Ijeimapparat von 108.

Grundbestand 22 .

Grundlawinen 331.

Crundschwellen (Wilubach-

verbauming) 318 .

Gruppenhiebe 76 .

Cuajaholz 361.

rummi 558.

Cutlapercha 560 .

\section{Hacken 110.}

Hackfilanzungen 136.

Hackwald 548 .

Iackwaldwirtschaft 56. 57.

IIärte de's Holzes 385. 436.

IIärteskala 441.

IIagel 279.

Jainbuche (Betriebsarl und Verjünung) 145 .

I Iaintก 5ั 547 .

I Ialbschalt tenhölzer 18.

Hallinaseh 288.

Janderillmaschine $\mathbf{1 1 6}$.

Ilandsaat 100.

Ilannemannsche Keimplatte 108.
Harzbaีแแme 624 .

liarzbildung 622 .

Harze (Ciewinnung und Verarloitung) 621.624 .629 .

I Larzgalienwickler 254.

Harznulzung 528.

Harzprodukte 631.

IJarzrūsselkäfer $2 \pm 3$.

Harzung

- der Schwarzöhre 625.

- Strandkiefer 627.

- Fichte 628.

- Lärche 629 .

- Tanne-829.

IIarzungsmethode von $\mathrm{M}$ a y r 628.

IIaselmâuse 221.

Haubergswirlschaft $56 . \quad 57$. 547.548 .

Hauptbestand 167 .

Hanplfällungsarten 182 .

Hauplnutzung, Verhätnis $\mathrm{zu}$ den Nebennutzungen 444 .

Haupfnutzungsbetriebe 56 .

Heideböden 94.

Heidelbeerhumus 97.

Heilbronner Sortierung 487.

Heißschliff 594.

Heizwert des Holzes 616. 619.

Herbstfrost 270 .

Hickory, weiße 31.

Hitze 273.

Hochbaus, Holzarten des 448 .

Hochdurchlorstung 171. 177.

Hochwald 44 .

- Burclihardts zweialtriger 189.

Hochwaldbetrieb, femelartiger 52.

- zweihiebiger 53. 55.

Hochwaldformen 38.

Hohenentwicklung 12.

Hohlbohrer von li. ILeyer 132.

ILhlspaten 132.

Holz, äußere Erseheinung 357 .

- Iärlen desselben 575.

- als Heizmaterial 616.

- Iionservierung 566.

- lulttrockenes 557.

- Troclinung, künslliche 568 .

- Trochnung, natûrlielıe 567.

- Wassergehalt 556.

Holzabrälle (Verkohlung) 615.

Holzahsalz 510

Holzanweisung 477.

IIolzart, Verbreitungsgebiet 6 .

- Wahl derselben 4.

Holzarten und Boden 15.

- waldbauliche Eigensehaften 4.

Iolzartenwechsel 27 .

Iloizbaten (an Wirdbach) 309.

IIolzil'sillation 607 .

llolzdraht 460 .

Holzessig 611.

Ilolzlaser 552.

IIolzıărten 512 .
11olz-Grundschwellen 318.

llolzhatereibetriel, 475 .

llolzhauermannschaft 476 .

IIolzkohle, Eigenscliaften 609.

- Zusamnensetzung 610 .

Holzkohlensortimente 602.

Jolzp[laster 456 .

Holzsaft 556 .

Holzsamen 515.

- Aufhewahrung der 524.

Holzschliff 592.

Holzsehuhe 463.

Holzsetzer 490 .

Holzstifte 460.

Holzstoff 463.592 .

IJolzstoffgewinnung 592.

Holztaxen 503.

Holztexr 613.

lolztrockensubstanz (Zusanmensetzung) 552 .

Holzverkaufsarten 500 .

Holzverkohlung 596 .

IHolzverwendung nach $\mathrm{Holz}$ arten und Sorlimenten 467 .

Iolzweberei 429 .

Holzwolle 464.

Holzzucker 555.

Ionigpilz 288.

Hopfenstangen 465 .

Horizontalgrảben 198. 275. 327.

Jlornbaum (Belriebsarl und Verjüngung) $1 \pm 5$.

Hïgelpillanzung 138.

Hilltenkỏhlerei 596.

Ilumusformen 535.

Humus, unfruelitbarer 97.

Humusvorral, Erlialtung des 199.

Hygroskopisches Wasser 375.

I] yroskiopizität 379.

Iclineumonen 226 .

Imbibitionswasser 37.

Imprägnierung von Eisenbahnschwellen und Leilungsmasten (Vorschuriften) $\mathbf{5 8 1 .}$

Jmpräguierung, anf elektrisehem Wege 581.

- Suarverfahren 580.

- mil Teeröl 580.

- mit Teeröldämı́fen 580.

- mit Zinkehlorid 579.

Jmprägnierungsmethoden 576 . 580.

Jmprägnierungsmittel 572.

Imprăgnierungsōl (Vorschriften über die Beschaffung) 574.

lmprägnierungsverfahren

- liydrostalisches 576 .

- P'islersches 57.

- premetisches 578 .

lnseklenherde 225.

lutensirsystem 12.

Jälepflug, Roth-Gerhardscher 117. 
Jugenderziehung, Schiffels freiwulchsige 173.

Juglans nigra 31 .

Kältegrenze 6 .

liahlschtag mit Randbesamung 50. 67 .

Iiahlschlagbetrieb 41,48 .

Krainit 125 .

Iílidüngung 125 .

Kalkdüngung 125.

Kiampfer 560 .

Karbolineum 571.

Iiastanienniederwald 81 .

liautschuk 559.

Tegelbohrer von Ed. Heyer 132.

lieil 489

Keilspaten 138.

Keimapparate 108.

lieimbett 109.

Keimfähigkeit 524 .

Keimprobe 107 .

hieimung 11.

- Beförderung der 114.

Keimungsenergie 106.

Fieimzah! 106

Kernpflanzen 84. 118.

Kernrisse 382.

Kernschãle 290.

liiefer (Betriebsart und Verjüngung) 154.

Kiefernbastkäfer 238.

liefernbaumscliwamm 290.

Kiefernblattwespe 255 .

Kiefernborkenkäfer 235.

Kiefernmarlikāfer 236.

Iief ernritzenschorf 288 .

liefernspinner 246 .

Kiefernstangen-Rüsselkäfer 213.

Kieferntriebwickler 253.

Kinderspielnaren 463 .

Kistenfabrikation 461 .

IileinbestandswaId, IIayrs 190.

Kilemmpflanzungen 136. 137. Kilengbetrieb 520 .

Kilengergebnisse 523.

Kitengkosten 524.

Kinima 5

Knopjern 566.

Iīöhlerei 596.

Iiohlehydrate 558.

Fohlenausbeute (bei Holzver. kohiung) 614.

Kollodiumwolle 555 .

Iiolophonium 631.

Kopfholzuetrieb 42. 51. 83.

liorbflechterei 429.

hork 564 .

hotsackblattwespe 257.

Krafts Stammklassen 171.

Kraftzellst off 586 .

Krankheitserscheinungen am Holz 361 .

Kreditbewilligung 509 .

Kronenfeuer 208.
Kubierung 498 .

liubierungsgabeimaße 498 .

Fufissendurchforstung 178 .

Kulissenhiebe 67 .

Kulturen, Reihenfolge 66 .

Kulturerde 112.

Kuiturfläche, Herrichtung der 133.

Iulturgerăte, Spitzenhergsche 131.

Kufturverfahren von lioześnik und von Spettstōßer 137.

Trunstseide 556 .

Tiupfervitriol 573 .

Kiyanisieren 572. 576.

Lachtenreißen 625.

Lärche 157 .

- japanische 31.

Lärchenkrebspilz. 290.

Lärchenmotte 255.

Lärchenrinde 471.

Lãrchensamen 523 .

Lafetten 462.

Lage, geographische 4 . örtiche 7 .

Landwirtsehaftlicher Holzverbrauct 465 .

Langhōizer 505.

Langholzsortierung 487 .

Laricetum 6.

Larix leptolepis 31.

Laßreißer, Laßreitel 42.

Laubhözer (Verwendung) $46 \overline{6}$.

Laubholzborkenkãfer 258.

Laubholzrüsselkäfer 259.

Laubholzsamen 519 .

Laubstamuholz 505 .

- Sortierung für 506 .

Laubstreu 528.

Lauffeuer 208.

Lauretum 6.

Lawinen, Abbau im Anbruchgebiete 333 .

- Ursachen und Einteilung 331.

Lawinenbauten, zur Ableitung 340.

Lawinenstatistik 341 .

Lawinenverbauung 331. 333.

Lawsonszypresse 31.

Lebende Werke 318.

Leguminosen, Anbau von 124.

Lehnenbindungen 327.

Leitergänge 230.

Leitungsstangen 458 .

Leseholz 528.

Lichthölzer 17. 25. 26.

Lichtungrsetrieb 181. 185.

Lichtwuchsbetrieb 55.

- Von Vog t 191.

- von Wagener 190.

Licfitwuchsdurehforstung v. Borgmann 178.

Lignin $5 \mathbf{5 3}$.

Linde (Betriebsart und Verjüngung) 147 .

Löcherpitze 289.
Löfiersaat 100. 101.

Lochpflanzungen 136.

Loshiebe 282.

Lotgänge 230 .

Luftrockengewicht des Holzes 372.

Luxuswagen 462 .

Mähstreu 541 .

Māuseschaden 220.

Nagersteins lieimapparat 108.

Maikäfer 244.

Markstrahien 365 .

Maschinensaat 100 .

Maserung 367 .

Massenerzeugung 32 .

Massivbau 416.

Maslen 458.

Maulwurfsgrille 257.

Mechanische Eigenschaften des Holzes 383.

Meereshöhe 7 .

Meiler 596.

- Arbeit an einen stehenden 598.

- Verkohlung im liegenden 603.

Meilerköhlerei 596.

- Beurteilung der 604.

Meiłeröfen 606 .

Meistgebotsverkauf 501 .

Mennigepulver 130.

Mergel 125.

Methylalkohol, (Darstellung u. Eigenschaften) 611.

Mineraldünger 124 .

Mineralstoffe 560 .

Mischbestände 19. $15 \%$.

- Vorzüge 20 .

Mischungen 19.

Misteln 269.

Mittelwald 51 .

Mittelwaldbetrieb 38.42 .

Vöbelschreinerei 460 .

lloore 98.

Moorflāchen, flüchtige 99 .

Moosdecke 540 .

Hoosdeckung 130.

Moosstreu 539 .

Mosaikarbeit 358.

Mullwehen 99.

Juttergang 230.

Nachbesserungen 117.

Vachverjüngungsbetriebe 38 .

Nadelhōlzer (Verwendung) 469.

Vadelnolzabsctinitte 505.

Nadeholzsamen 520 .

Nadelstreu 528 .

Nährstoffgehait, Erhaitung des 199.

Nässe 275.

Nalronverfahren 584.

Vebenbestand $16 \%$.

Nebenholzarten 22.

Nebennutzungen 514.

- mineralisetse 551 . 
Yebennutzungsbetriebe 56.

Neigungsrichtung 7 .

Veigungswinkel 8.

Niederdurchforstung 171.

Niederwald 50.

- Verjüngung in 79.

Niederwaldschlagbetrieb 42.

Noobescher lieimapparat 108.

Nonne 249.

Niunmerierschlägel 497 .

Nulzholz und Brennholz 445 .

Vutzholz, Verwendungsarten 445.

Nutzholz-Borkenkäfer 235.

Nutzholzwirtsehaft, Homburgsche 189.

Ohenaufpllanzungen 136. 138. Oberflächengestaltung 8 .

Oberholz 42 .

Oberlawinen 331.

Oherständer 42.

Oedlandsaufiorstung 99.

Oele, aetherische 559. 563.

Optinum, klinatisches 6 .

Ortstein 92.

Oxalsäure 556.

Palmetum 6.

Papierfabrikation 463 .

Papjel 118.

- lianadische 31.

Pappelbock 259.

Parallelbauten (Wildbach) 322.

Patenthohlbohrer von Janka 132.

Pechkiefer 31.

Pergamentpapier $\mathbf{5 5 5 .}$

Pfilzenmayers Keimkasten 108.

Pflanziveil 138.

Pflanzdoleh 138.

Pflanzen, Aufbewahren 132.

-_ Ausheben 132.

- Besclnneiden 132.

- Transport 132.

Pflanzenbeete in Forstgarten 127.

Pflanzenbeschaffung 120.

Pflanzendünger 124.

Pflanzenhalter, Rebmannscher 137.

Pflanzenkrankheiten 283.

P’lanzenlade, Bromberger 133.

- Spitzenbergsche 133.

Pflanzenmenge 135.

Pflanzenprozent 107.

Pflanzensäuren $5 \overline{5} 8$.

Pflanzenstichel, Grünewalds 138.

Pflanzenverband 128 .

Pflanzenzahl 135.

Pflanzgartendünger 124.

Pflanzholz 138.

— nit Wühlspitze $v$. Spitzenberg 138.

Pflanzhämpe 121.
Pflanzlanze 138.

Pflanzmalerial, Eigenseliaflen 119.

Pflanzschnabel, Barths 132,

pflanzschulen 121.

Pflanzspaten, $v$. Alemanns 138.

Pflanzung, Arten der 118.

- mit ballenlosen Pflanzen 136.

- geregelle 118.

- ungeregelte 118.

- Vollzug der 134.

Pflanzverband 118.

Pflanzverbände, geregelte 134.

Pilanzverfahren 136.

Pflanzweite 135.

Pflanzzeit 134.

Phosplıorsãuredüngung 125.

Picea silelensis 31 .

Picetum 6.

Pilze 5.46.

Pinus Bankiana 31.

Pinus rigida 31.

Pinus strobus 31.

Plaggenpilanzung 138.

Plattensaat 100 .

Plenterbetrieb 38. 45.

Plenterdurehforstung, Borggreves 178.

Plentersehlagbetrieb 39. 46 .

Polieren 570.

Pollacks Waldsämaschine 116.

Populus canadensis 31 .

Porzellanfabrikation 467 .

Poltasche, Erzeugung 619.

Prachtkäfer 260.

Prozessionsspinner 262.

Prunus serotina $\mathbf{3 1}$.

Pseudotsuga Douglasii 31.

Pulver, ranchseliwaches 556 .

Pulverfabrikation 466.

Puntisaat 100. 101.

Quadratverband 118. Qualităt des IIolzes 418 . Quebrachoholz 470 .

Quecksilberchlorid 572 .

Quellen des Holzes 371.379.

Quercus rubra 31.

Rabatienpilanzung 138.

Rahattierung 94.

Raffholz 528.

Räuher (Insekten) 226.

Rãuchern des Holzes 363 .

Rahmen (Bauholz) 446.

Raseneisenstein 92.

Rasenhügelpflanzung 138.

Rauchschäden 211.

Raulubamsperre 315.

Rauhreif 278.

Raupenfliegen 226 .

Rechteclisverband 118.

Reife aus Holz 459 .

Reilınverband 118.

Reinigungshiebe 160 .

Reißen des Holzes 382.
Reisstreu 527.

Resonanzhol7. 459 .

Retorten 607. 608.

Retortenverkohlung 607 .

Riegellıŏlzer 417.

Rillenpflug 129.

Rillensiat 127.

Rillensảmaschine von Fehate 127.

Rillenzielier (Spilzenberg) 127.

Rinde 561.

- Verwendung 469 .

Rindenbrand 27.

Rindennutzung 492 .

Rindensortierung 494 .

Ringelspinner 264.

Robinie 148.

Robinienniederwald 81 .

Rochs Samaschine 116.

Rodung des stehenden Holzes 478.

Roderlandbetrieb 56. 548 .

Rohliumus 535. $5+1$.

Rostbauten 45.4 .

Rolbuchenholz, rücliwirkende Festigheit 397.

Roteiche 31.

Rotfäule 362.

Rotschwanz 261.

Rüsselkäfer, brauner 239.

Rundes Sämaschine 116.

Saat und Pilanzung, Wahl zwischen 81. 100.

Saat, stellenweise 100,115 .

- Durchrujfen zu dichter 130.

- Durchselineiden zu dichter 130.

Saatarten 100.

Saatbedecker 131.

Saatbretter 127.

Saatflinte 116.

Saatkämpe 121.

Saalkulturen, Pflege der 117.

Saatmaterial 101.

Saatpflanzen 118.

Saatillenwalze (von Holl, Zwinger) 127.

Saatschulen 121.

Saattrichter, Harzer 116.

Saalzeit 112.

Säapparate 116.

Säapparat von Hörmann 127.

Sågeblöcke 488.

Sähorn 116. 127.

Sälatle von Esslinger 127.

Sämasehinen 116.

Sãmaschine von Sack 116.

- von Schneider 127.

— von Spitzenberg 127.

Samien, Anquellen 114.

- Beschaffung 101.

- Ernte und Aufberahrung 105.517.

- Herkunft 101.

- Selbstgewinnung 101. 516.

- Unterbringen und Bedeliken 116. 
Samenabfall 518.

Samenertrag 517.

Samenlolzbetriebe 38 .

Samenjalir 518.

Samenmenge 113.

Samenprüfung 105.

Samenprüfungsanstalt 108.

Samenreife 518.

Samenselilag 73 .

Sandgras 91.

Saudgrasplanzung 91 .

Saumplenterschläge 47.

Saumschirmschläge 47 .

Saumschlagbetrieb 40.47 .

Saumsehlagbetrieb nach Wagner 77.

Schälen des Wildes 216 .

Schälrinde 470 .

Schälverfahren 493.

Schalenbauten 324.

Schaltenliölzer 17. 24. 25.

Selienk von Schnitisburgs

Waldsamensãmaschine 116.

Scherenbohrer von Mnhlmann 132.

Schießbaunwolle รう6.

Schiffuatholz 450 .

Sclindelfabrikation 459 .

Schirmschlagbelrieb 40.47 .71 .

Schläfer 221.

Schlagaufnahme 496 .

Schlagauszeichnung 477 .

Sclılagbetriebe 39.

Schlagpflanzen 118.

Schlujfwespen 226.

Schmarotzer 226.

Schmarotzergewächse 269 .

Schmoren 57.

Schnee 276.

Sclineebruel $27 \%$.

Schneebrüken und Schneefänge 335 .

Selıneedruek $27 \%$.

Schneidelholzbetrieb 42.51 . 84.

Selunitzerei 463.

Seluränken der Sägen $\$ 83$.

Sehreinerei 460 .

Sehrotsäge 483 .

Sehönjahns Keinapparat 108. Schütte 286 .

Schulpflanzen 118 .

Sehutlahlagerung (Wildbach) 298.

Schuttkegel (Wildbach) 295.

- Schutzvorriehtungen am 308.

Schuttkegelversicherungen 328.

Sehulzholz 163.

Scliwammspinner 264

Schweinerinlrieb 216. 545 .

schweinemast. 515 .

Schwellen (Eisenbahnschwellen) 446 .

- Datuer der imprägnierten 582 .

Sclıwellenlıölzer 454.
Sehwinden $371.37 \% .379$.

Sebwindmaß 377. 378.

Schwindrisse 382.

Seebachselier Betrieb 189.

Seegras 545

Seilen 496.

Seilhaken 480 .

Sengen 57.

Senilisieren des Holzes 575 . 581.

Setzholz 129. 138.

Setzreiser 139.

Setzstangen 118. 139.

Siehwerfen des Holzes 382.

Sickergräben 198.

Silbertanne, amerikanische 31 .

Sinkwalze 322.

Sitkafichle 31.

Sodaverfahren 584 .

Sohlenerosion 303 .

Somnerfällung 473 .

Sommerhänge $;$.

Sortierung der IIōzer 486.

Sortimentsbildung 486 .

Spätfrost 270 .

Spaltbarkeit 385.432.

Spaltholz 458.

Spalipflanzungen 136. 137.

Spaltschneider von Spitzenberg 138.

Spaltwaren 435 .

Sparren 447 .

Spezifisches Gewicht des Holzes 371 .

Spiegelflächen 365 .

spiegelrinde 470 .

Spielwarenfabrikation 463 .

spiritus aus Holz 554.

Splintkäfer 232.

Sprengpfropf 491.

sprengschrauben 491.

stainers lieimapparat 108.

Slammfeuer 208.

Stamnklassenbildung 171.

Standort 4.

Standortsansprüche 4 .

Standorts-Varietälen 101.

Stauberde 97.

Staublawinen 331.

Stecklinge 84. 139.

Steckreiser 118.

Steinbau (Holzverwendung) \pm 46 .

Steinbauten (an Wildbach) 309.

Steingrundscliwelle 318.

Steinkastensperren 315 .

Sterngänge 230 .

Stieksloffdünger 125.

Sticksloffsubstanzen 557 .

Stieleistn, Wartenbergs 138.

Stockholzgewinnung $\mathbf{4 9 0}$.

Slocliselulagbetriebe 80 .

strahlenrisse 382.

Straßenpflasterung $\$ 56$.

Strauchzäune 91

Streifen, Abstand der 112.

- Breile der 112.
Streifen, Herstellung der 112. Streifensaat 100. 101.

- Richtung der 111.

Streuertrãge 531.

Streunutzung 529. 537 .

Streurechen 538 .

Streureisig 527.

Streuwert 530. 540.541 .

Stummelpflanzen 84. 118 .

Sturm 280.

Submissionsverfahren 502 .

Sümpfe, Behandlung 88.

Sulphatverfahren 584.

Sulphitverfahren 586 .

Superphospliat 125.

Tachinen 226.

Talsperren 311 .

- aus Stein 312 .

- aus Holz 31 .

Tanne (Betriebsart und Verjûngung) 149.

Tannenborkenkāfer 234 .

Tannenkrebs 290.

Tannenrinde 495.

Tannin 561.

Taxklassenbildung 504 .

Taxpreisverliauf 501.

Teakholz 398.

Teeröl, schweres 573 .

Terpentin 623, 629 .

Terpenlinöl 631.

Textur 366.

Thomasmell 125.

Thonelsches Verfahren 428 . 461.

Thuja gigantea 31 .

Tischlerei 460.

Tole Werke 320.

Tränkbarkeil des Holzes 375 .

Tränken des IHolzes 375 .

Tränkungssloffe, Aufnahme soleher 582.

Tragkraft von Balken 446 .

Tragmadul 384 .

Traubenkirsche, spätblülıenele 31.

Traversen 324

Treibholz 163.

Trockene Destillation des IIolzes 594.

Trockiengewicht des Holzes 372.

Trockienrisse 382.

Trockentorf 97. 535. 540.542.

Troeknen der Rinde 493.

Trüffeln 547 .

Trummsãge 484.

Ueberlälter, Rảumung 159.

Ueberhalthetrieb 53.

Ueberhaltform 53.

Ueberwurfkultur von Grollmann 137.

Ulme (Belriebsart und V'erjüngung) 146 .

Ulmenblatllaus 266.

Ulmensplintkäfer 259. 
Umrandungshiebe 76 .

Umschroten 482 .

Umzêunungen, tole 129 .

Unlirāulerstreu 541 .

Unterbau 181.

Interbaubetrieb 55 .

Unterholz $\$ 2$.

Unterwùlung 299.

Urbarmachung 88 .

Varietäten,physiologische oder kimatische 101.

Verbande, geregelle (für Pflanzung) 119.

Verbautungsprojekte 310.

Verbaunngsysteme 329. 330.

Verbeißen 218.

Verdünnung der Jungwūchse $11 \bar{\gamma}$.

Verfahren, elektrochemisches 589.

Verjüngung, natürliche durch Ausschlag 79.

- natürliche durch Samen 67.

Verjüngungszeitraum 39.71 .

Verkaufsarten 500 .

Verkaufslose 507 .

Verkaufsvollzug 507 .

Verkohlung des Holzes 467 .

Verkohlungsmethoden 595 .

Verkohlungsmethode, deutsche 597.

Verkohlungsöfen 606 .

Verkohlungsretorten 607. 608 .

Vermarkung 204.

Verpfählungen (gegen Lawinen) 331.

Verschulen 127

Verschulungsapparate 129.

Verwitterung 299.

Viskoid 555.

Viskose 555.

Vollsaat 100. 115. 127.

Volumenveränderlichkeit des Holzes 377 .

Volumenveränderung 371.

Vorbereitungshiebe 76 .

Vorbereitungsstadiun 71 .

lordüne 91.

Vorkeimen der Samen 115.

Vornutzungen 167.

Vorratsdūngung 126.

Vorverjüngungsbetriebe 38 .

Yorwüchse, Aushieb derselben 160.

Vulkanisieren des Holzes 575.

Wadelzeit 473 .

Wärneansprüche der Holzarten 5.
Wärmegrenze 6.

Wärmeleitungsfāhigkeit des

Holzes 370

Wagegänge 230 .

Wagenbau 462.

Viagneriolz $\$ 61$.

Waldbau 1.

Waldbeeren $5 \$ 6$.

Waldboden, Herstellung eines kulturfāhigen 88 .

Valdbrïnde 208.

Waldfeldbau 56. 547 .

Waldgärtner 236.

Waldgras 543.

Waldköhlerei 596.

Waldhorn 117.

Maldmantel 282.

Valdpfluge 111.

Waldsägen 482 .

Waldstreu 529 .

Waldteufel $\$ 81$.

Waldversteigerung 508 .

Waldweide 215. 543 .

Waldwolle 526.

Waldzonen 6 .

Walnuß, scliwarze 31 .

Wanderforstöarten 121.

Warnfähigkeit des Holzes \pm 32 .

Warthenbergsches Eisen 138.

Wasserbauhölzer 457 .

Wasser-Eichenholz 362

Wassurgehalt des Holzes 374.

Wasserglasanstrich 572.

Wegbauhölzer 454.

Weide $1+8$.

Weideertrag 544.

Weidenniederwald 82.

Weidenrinden 471 .

Weideliere 213.

Weinpfähle 46 5.

Weißesche 31.

WeiBfăule 362.

Weißpunktrüsselkäfer 242.

Weißtannenrinde $\$ 71$.

Werfen des Holzes 382.

Wertserzeugung 32.

Weymouthskiefer 31 .

Wiener Nöbel 428 .

Wildbāche, der Berg- und Hügelländer 307.

- Charakteristik und Einteilung 292.

- Reinhaltung von Wildholz 308 .

- Unterwühlende Wasserwirkung der 306

Wildbachverbauung 292.

- allgemeine Regeln 308 .

- Aufsicht der 309.
Wildbachverbauung fernere Erhaltung der 310.

- System der 302 .

- die technischen Mlittel der 310 .

- Ursachen der 301.

- die wirtschaftlichen Maßnahuen 330.

Wildfilterung 515. 526.

Wildlinge 118.

Wildsehaden 216.

Wind 280.

Windbrüche 281.

Windwüre 281.

Winkelbänder (beim Hochbau) 446.

Winlerfällung 173 .

Winterfrost 269.

Winterhānge 8.

IVölfe 160 .

Wuclisverhăltnisse des einzelnen Baums 11.

Wühlrechen 131.

Wühlspaten, Spitzenbergscher 131. 137.

Wundfäule 284.

Wurzelfüule 285.

Wurzelkonkurrenz 17.

Wurzelschneidemesser liaisers 129.

Wurzelschwann 289.

Wurzelsystem 11.

Xylan 555.

Zähigkeit des Holzes 385 . 427. 428 .

Zahlungsbedingungen 509 .

Zangenbock 259.

Zangenbohrer 137.

Zapfenernte 520 .

Zelluloid 556.

Zellulose 463 .

- Ausbeute der 591.

- Beschaffenleit der 591.

- chemische Formen der 554 .

- Eigenschaften der 553.

- Verwendung der 591.

Zelluloseacetate $55 \pm$.

Zellulosefabrikation 464, 582.

— \bพässer 589.

- Rohmaterial 583.

- Verfahren 583.

Zinkchlorid 573 .

Zirbenholz 361.

Zitnys Plattensier 116.

Zuckergewinlung 528 .

Zugslange 479.

Zwischennutzungen $16 \%$ 

Verlag der 5. Lsaup p'sthen Buchhandlung in Cübingen.

\section{Aus Württemberg. \\ Unsere Forstwirtschaft im 20. Jahrhundert.}

In zwanglosen Heften herausgegeben von C. Wagner. I.

Allgemeine forstökonomische Betrachtungen

Professor C. Wagner in Tübingen.

8. 1909. MI. -.80 .

Betrachtungen über den forstlichen Unterricht und das Einrichtungswesen

Professor C. Wagner in Tübingen.

8. 1910 . M. 1.20 .

III.

Kritische Betrachtungen über die württembergische

Gemeindewaldwirtschaft

von

Rudolf Schleicher, K. Oberförster in Ebingen.

8. 1910. M. 1.20 .

IV.

Die zweckmässige Grösse der Forstbezirke in Württemberg von

Dr. Paul Wörnle, K. Oberförster in Giengen a. B.

8. 1911. M. 1.20 .

$\mathrm{v}$.

Die Elemente der Wertsmehrung in der Waldwirtschaft von

Dr. Victor Dieterich, Forstamtmann in Stuttgart.

Mit 2 Kurven. 8. 1911. M. 3.20.

V1.

Die waldbauliche Zukunft des wïrttembergischen Schwarzwalds von

Dr. Sigmund Ramm, K. Oberförster in Calmbach.

Mit 8 Abbildungen. 8. 1911. M. 2.60.

VII.

Die Kiefer des württembergischen Schwarzwaldes.

Von

Dl. Wilhelm Harsch, Kgl. Forstmeister in Hirsau.

8. 1912. M. 2.40 .

Derlag oon Э. e. B. Illohr (Paul Siebed) in Cübingen.

Wald und Jagd

zu Anfang des 16. Jahrhunderts und die Entstehung des Bauernkrieges.

Rede gehalten am Geburtsfest Seiner Majestät des Königs Wilhelm II von Württemberg an 25. Februar 1911 im Festsaal der Aula der Universität Tübingen.

Von Professor Dr. Anton Buhler.

Gross $8^{\circ}$. 1911. M. -.80 . (Universität Tübingen 2.) 
Dr. C. Wagner,

Professor der Forstwissensctalt an der Universitåt $\tau_{\text {L̆bingen. }}$

\section{Die Grundlagen der räumlichen Ordnung im Walde.}

Zweite, vermehrte und verbesserte Huflage.

Mnit 60 Figuren im $\tau$ ext und einer farbigen $\tau_{a f e l}$

Lsex. 8. 1911. II. 9.-. Gebunden M. 11. - .

"Das Werk zeigt uns den Verfasser als einen Mann ron staunenswerter Literaturkenntnis und als wohlbewandert in den rerschiedensten Zweigen forstlichen Wissens. Scharfsinnig und kritisch im Denken, bat er auf manche Mifsstände in der forstlichen Produktion und in dem forstlichen Betrieb anfmerksam gemacht und wird durch sein tiefgriindig geschriebenes Buch sicherlich mancherlei wertvolle Anregungen geben, welche dem Wald zum Segen gereichen werden. Möge das empfehlenswerte Buch eine recht weite Verbreitung und die seinem Wert angemessene Beachtung finden."

(H. Stoetzer in der Allgemeiu. Forst- und Jagdzeitung, 1907, Dezember.)

\section{Der Blendersaumschilag und sein System.}

mit 73 Figuren im Text und zwei farbigen Taieln. Lex. $8^{0}$. 1912. M. 10. - Gebunden $\mathrm{M} .12 .-$.

Das Buch bildet in gewissem Sinne die Fortsetzung und Ergänzung der im Jahr 1907 erschienenen Schrift desselben Verfassers über „Die Grundlagen der räumlichen Ordnung im Walde" (2. Aufl. 1911), denn der Verfasser setzt sich hier die Aufgabe, durch A ufstellnng eines räumlichen B etriebssystems für die Forstwirtschaft die Ergebnisse der in jener Veröffentlichung niedergelegten kritischen Untersuchungen ihrer praktischen Verwirklichung näherzubringen. Die Vorschläge jener "Grundlagen" haben in der forstlichen literatur und Wirtschaft in besonderem Maße Anklang und Anwendung gefunden.

\section{Die Verdrängung der Lsaubwälder durch die Madelwälder in Deutschland.}

Don

Fans Bernhard Эacobi.

Gró̉ 8.

$=$ Unter der Presse. 




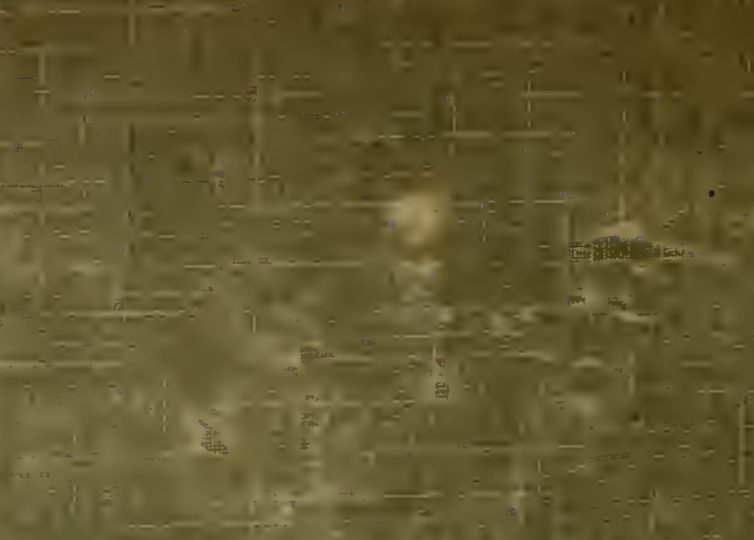

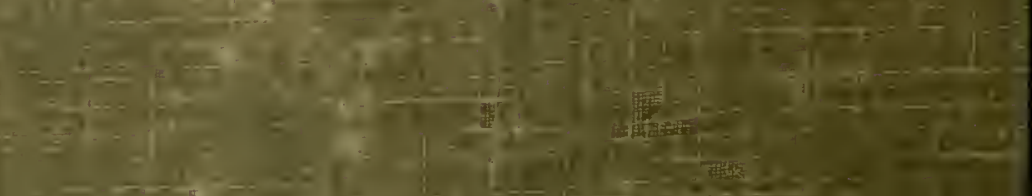

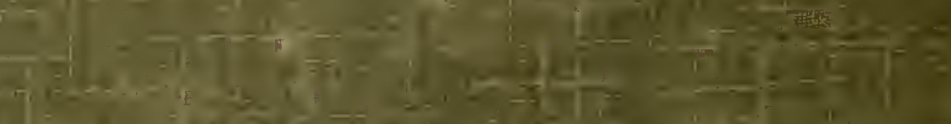

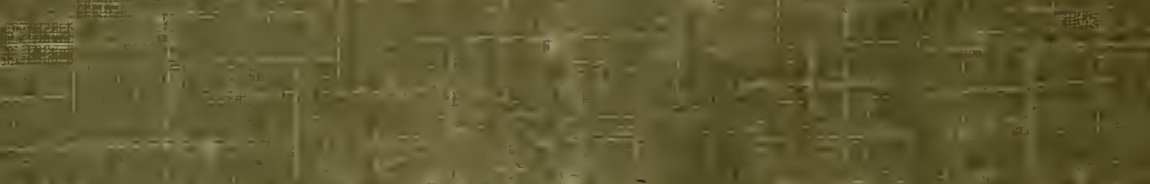

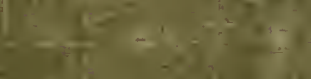
f. $3 x^{2}=2$ (1)

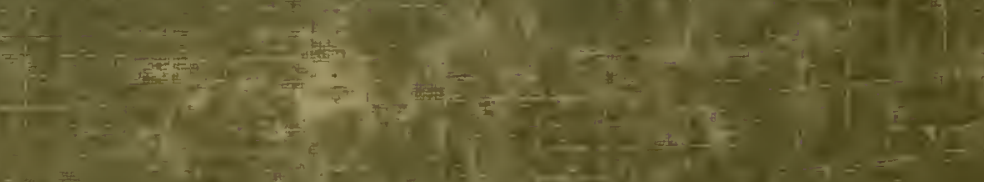

